UNIVERSIDADE DE SÃO PAULO

FACULDADE DE FILOSOFIA, LETRAS E CIÊNCIAS HUMANAS

DEPARTAMENTO DE SOCIOLOGIA

PROGRAMA DE PÓS-GRADUAÇÃO EM SOCIOLOGIA

\title{
ELISA KLÜGER
}

\section{Meritocracia de laços:}

gênese e reconfigurações do espaço dos economistas no Brasil

(Versão corrigida) 


\title{
UNIVERSIDADE DE SÃO PAULO \\ FACULDADE DE FILOSOFIA, LETRAS E CIÊNCIAS HUMANAS \\ DEPARTAMENTO DE SOCIOLOGIA \\ PROGRAMA DE PÓS-GRADUAÇÃO EM SOCIOLOGIA
}

\author{
ELISA KLÜGER
}

\section{Meritocracia de laços: \\ gênese e reconfigurações do espaço dos economistas no Brasil}

(Versão corrigida)

Tese apresentada ao Programa de Pós-graduação em Sociologia da Faculdade de Filosofia, Letras e Ciências Humanas da Universidade de São Paulo, para obtenção do título de Doutor em Sociologia.

Área de concentração: Sociologia

Orientadora:

Profa. Dra. Sylvia Gemignani Garcia

São Paulo 
Autorizo a reprodução e divulgação total ou parcial deste trabalho, por qualquer meio convencional ou eletrônico, para fins de estudo e pesquisa, desde que citada a fonte.

Catalogação na Publicação

Serviço de Biblioteca e Documentação

Faculdade de Filosofia, Letras e Ciências Humanas da Universidade de São Paulo

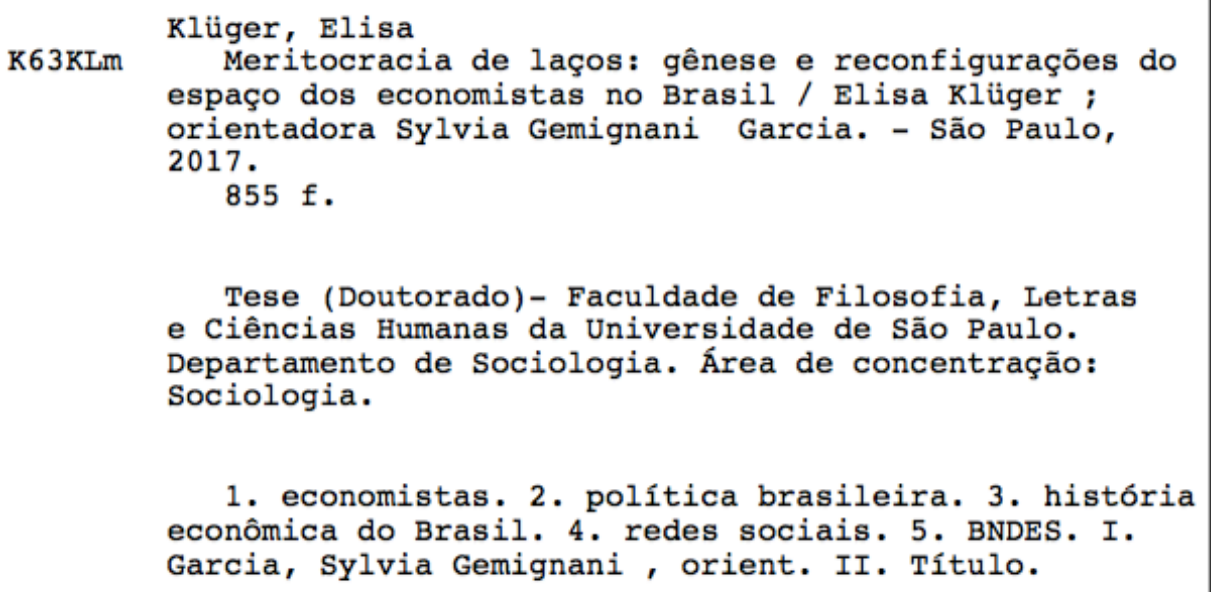

1. economistas. 2. politica brasileira. 3. história econômica do Brasil. 4 . redes sociais. 5. BNDES. I. Garcia, Sylvia Gemignani, orient. II. Título. 
Nome: KLÜGER, Elisa

Título: Meritocracia de laços: gênese e reconfigurações do espaço dos economistas no Brasil

Tese apresentada ao Programa de Pós-graduação em Sociologia da Faculdade de Filosofia, Letras e Ciências Humanas da Universidade de São Paulo, para obtenção do título de Doutor em Sociologia.

Aprovada em:

Banca Examinadora:

Prof. Dr.

Instituição:

Julgamento:

Assinatura:

Prof. Dr.

Instituição:

Julgamento:

Assinatura:

Prof. Dr.

Instituição:

Julgamento:

Assinatura:

Prof. Dr.

Instituição:

Julgamento:

Assinatura:

Prof. Dr.

Instituição:

Julgamento:

Assinatura: 
Dedico esta tese aos meus avós Anna e Hugo Klüger e Clara e Marcelo Kochen, inspiração e exemplo. 


\section{Agradecimentos}

A escrita de uma tese acerca dos laços que formam a trama do espaço dos economistas fez com que me tornasse ávida leitora do gênero "agradecimentos de dissertações e teses”, que tantas informações essenciais aportaram à pesquisa. Dedico-me agora a proferir meus próprios agradecimentos aos indivíduos e organizações que compõem a extensa rede social que viabilizou subjetivamente e pragmaticamente a redação desta tese:

Em primeiro lugar, agradeço a Aluysio Antonio da Motta Asti, Ana Célia Castro, André Franco Montoro Filho, André Pinheiro de Lara Resende, Andrea Sandro Calabi, Armando Mariante Carvalho, Beatriz Azeredo, Carlos Kawall Leal Ferreira, Carlos Lessa, Darc Antonio da Luz Costa, Darlan Dórea, Demian Fiocca, Edmar Lisboa Bacha, Eduardo Bunker Gentil, Eduardo Rath Fingerl, Eleazar de Carvalho Filho, Elena Landau, Elvio Gaspar Lima, Fernando Perrone, Fernão Bracher, Francisco Vidal Luna, Frederico Mazzucchelli, Guido Mantega, Helio Blak, Isac Roffé Zagury, João Carlos Ferraz, João Sayad, José Luiz Osorio de Almeida Filho, José Mauro Mettrau Carneiro da Cunha, José Pio Borges de Castro Filho, Julio César Ramundo, Laura Passos Domingues, Luciano Galvão Coutinho, Luis Stuhlberger, Luiz Carlos Bresser-Pereira, Luiz Carlos Mendonça de Barros, Luiz Eduardo Melin de Carvalho, Luiz Fernando Linck Dornelles, Luiz Gonzaga Belluzzo, Luiz Orenstein, Marcio Henrique Monteiro de Castro, Maurício Borges Lemos, Otávio Castello Branco, Paulo Hartung, Persio Arida, Philippe Reischstul, Regis Bonelli, Roberto Timóteo da Costa, Roberto Zurli Machado, Sérgio Besserman Vianna e Wallim Vasconcelos. Entrevistados que, com imensa generosidade, concederam precioso tempo de suas repletas agendas e ofereceram densos relatos de suas vidas. Agradeço a grande confiança que em mim depositaram ao descrever em detalhes suas experiências acadêmicas, profissionais e políticas, discorrer sobre suas preferências estéticas, amizades, raízes familiares e vasculhar distantes memórias para responder às tantas perguntas que lhes foram endereçadas.

Em segundo lugar, agradeço enfaticamente a Afrânio Garcia, Bernardo Parnes, Clara Kochen, Eduardo Fagnani, Fabiana Rocha, Felipe Teixeira Gonçalves, Gilda Montoro, José Orenstein, Maria Mazzucchelli, Raphael Padula, Renato Boschi e Ricardo Abramovay que se prontificaram a estabelecer contato com especialistas em economia 
que conheciam viabilizando, deste modo, a realização da tese. Sou grata igualmente aos tantos entrevistados que auxiliaram na tarefa de contatar seus colegas e amigos, permitindo que fluísse através de suas redes, ampliando o universo retratado na pesquisa. Sou grata igualmente a Werner Baer, Monica Balanda, filha de Anníbal Villela e Jacques Kerstenetzky, filho de Isaac Kerstenetzky por responder prontamente os e-mails com esclarecimentos sobre suas trajetórias e de seus familiares.

A tese aqui apresentada era, inicialmente, um estudo acerca dos altos quadros do Banco Nacional de Desenvolvimento Econômico e Social que, aos poucos, foi convertido em uma tese sobre o conjunto do espaço dos economistas. As entrevistas com os dirigentes do BNDES e o largo material coletado nos arquivos do Banco foram, não obstante, ponto de partida e fio condutor da pesquisa. Agradeço, pois, a larga solicitude dos funcionários do BNDES que me receberam sempre com grande cortesia, coletando com empenho e rapidez a profusão de material que solicitei nos últimos anos.

Sou também grata às bibliotecárias da Comissão Econômica para a América Latina que passaram uma semana inteira buscando toda sorte de documentos e aos funcionários das bibliotecas das faculdades de economia, que visitei repetidamente em busca de livros e teses. O Centro Celso Furtado de Políticas para o Desenvolvimento e o Centro de Pesquisa e Documentação de História Contemporânea no Brasil, responsável pela elaboração do Dicionário Histórico Biográfico Brasileiro e depositário de vasta coleção de entrevistas, também foram essenciais para a realização da pesquisa.

Os estudos que deram origem ao doutorado foram realizados em três diferentes estruturas institucionais: a Université de Picardie Jules Verne, a University of California at Berkeley e a Universidade de São Paulo. Permito-me variar o idioma para os respectivos agradecimentos.

Je voudrais remercier mon directeur de thèse en France, Frédéric Lebaron, de m'avoir généreusement reçue au Centre Universitaire de Recherches sur L'Action Publique et le Politique - Epistémologie et Sciences Sociales (CURAPP-ESS), laboratoire de recherche qu'il dirigeait à Amiens, et de m'a avoir invitée à suivre ses cours d'analyse de correspondances multiples et de statistique et le cours de la professeur Diane Delacourt à propos de l'usage des logiciels statistiques. Je suis heureuse d'avoir eu des opportunités de discuter ma recherche avec vous; elles ont été essentielles. Je remercie aussi Afrânio Garcia, coordinateur du groupe de Réflexions sur le Brésil Contemporain, 
que je suivais heureusement chaque mercredi, de m'avoir invitée à présenter ma recherche pour la première fois. Alice Yassa, Adriana Balducci, Adriana Tillous, Andrea Fülöp, Erick Tjong et Thais Joi sont les responsables pour apporter des couleurs aux jours vécus en France, merci beaucoup.

I am extremely thankful to professor Marion Fourcade, who supervised my work at Berkeley, invited me to follow her classes and seminaries, recommended new literature and offered valuable comments on my work. I am much obliged as well to professors Ann Swidler, John Lie, Neil Fligstein and Loïc Wacquant who allowed me to follow their excellent classes. My life at Berkeley wouldn't have been so great if it weren't for my colleagues at the sociology department, who were so kind and welcoming, and for my Ihouse friends: Ari Cukierman, Beate Soldberg, Emilio Corea, Giovanni Zenati, Gunar Sveinsson, Jan Schattner, Kate Doherty, Kristina Sep, Loes Kengen, Meghana Ravikumar, Nicolás Giordano, Sunwoo Yoo, Tina Erbert, among many others, that made life happier. The enriching experience of studying at Berkeley was enabled by the scholarship granted by the CAPES/PSDE program.

Por onze anos a Universidade de São Paulo foi fulcral espaço de aprendizagem teórica, política e social. A graduação no Instituto de Relações Internacionais foi marcada pelo notável empenho de professores como Maria Hermínia Tavares de Almeida, coordenadora do curso, e Modesto Florenzano, aos quais agradeço. A participação no Centro Acadêmico Guimarães Rosa foi das mais venturosas vivências da universidade. Sou longamente grata aos amigos das gestões "Veredas", "Terceira Margem", "Sete de Ouros" e aos queridos colegas de gestão "Meio da Travessia": André Mattana, Anita Stefani, Daniela Lopes, Daniel Marechal, Elisa Evangelista, Franz Buhr, Jônatas de Paula, Melina Rombach, Paulo Guerra, Rafael Vidal e Vitor Oliveira. O curso de Relações Internacionais presenteou-me também com as caras amizades de Bárbara Frossard, Camila Curado, César Albuquerque, Iuri Codas, Laura Calasans, Leonardo Rodarte, Lilian Krohn, Marcella Brandimarti, Marília Ramos, Nicolle Konai, e por extensão, Martim e Gabriel Leicand e Yurika Akemi, além dos colegas da vizinha Faculdade de Economia e Administração.

O trabalho, ainda na graduação, no Grupo de Pesquisa em Políticas Públicas de Acesso à Informação da Escola de Artes Ciências e Humanidades, integrado por amigos como Ana Paula Anjos, José Paulo Guedes, Maria Carlotto e Pablo Ortellado, foi essencial no 
despertar do apreço pelo trabalho coletivo e empírico de pesquisa. Sou grata a todos participantes do estudo sobre direito autoral e propriedade intelectual, com os quais tanto aprendi.

À equipe da biblioteca da Faculdade de Arquitetura e Urbanismo da Universidade de São Paulo e aos amigos Ana Paula Anjos, André Goldfeder, Camila Rosatti, Fernando Rossine, José Henrique Bortoluci, Juliana Froehlich, Kim Hoffmann, Leandro Leão, Lilian Krohn, Marcelo Pacheco, Marianna Boghosian, Paula Gorenstein Dedecca, Rafael Frajndlich, dentre tantos outros, agradeço a capacidade de tornar o frio concreto armado um lugar acolhedor para os anos de exercício diário da atividade intelectual.

A transferência para a Faculdade de Filosofia, Letras e Ciências Humanas, na pósgraduação, foi indubitavelmente efeito das aulas memoráveis da professora Sylvia Gemignani Garcia. Profunda gratidão tenho pelo incomensurável amparo teórico, prático e pessoal com o qual me presenteou nos seis anos em que orientou a elaboração dessa tese. Ana Paula Hey, presente desde os primeiros passos da pesquisa, ofereceu sempre essenciais conselhos, disponibilizou sua rede de contatos e incentivou o profundo mergulho na atividade de pesquisa, razões pelas quais sou-lhe amplamente grata. O Grupo de Pesquisa em Sociologia da Educação, Cultura e Conhecimento, por elas dirigido, provou-se um espaço frutífero para o debate teórico e o escrutínio detalhado dos projetos e produção escrita dos participantes. Sou grata a todos pela disposição para, mais de uma vez, ler e comentar trechos de meu trabalho.

O grupo Corte e Cultura, além de espaço de intercâmbio de referências e confluência de atentos leitores, foi responsável por alegres reuniões de pessoas com interesses e questões comuns. Às turmas de mestrado e doutorado da FFLCH, e aos amigos Camila Gui Rosatti, Eduardo Bonaldi, João Ivo Guimarães, José Muniz Jr., Laura Chartain, Lidiane Rodrigues, Maria Carlotto, Mariana Toledo, Ricardo Crissiuma e Stefan Klein, só tenho a agradecer, pela cumplicidade e apoio nestes anos todos.

Agradeço aos funcionários do departamento de sociologia, sempre solícitos e aos professores Alvaro Comin, Antonio Sergio Guimarães, Brasílio Sallum, Fernando Pinheiro, Flávio Pierucci, Glauco Arbix, Gustavo Venturi, José Guilherme Magnani, Luiz Carlos Jackson, Marcia Lima, Nadya Guimarães, Paula Marcelino, Ricardo Musse e Ruy Braga cujas aulas foram momentos extremamente importantes de formação intelectual. As disciplinas oferecidas por Ricardo Abramovay, na Faculdade de Economia, e 
Alexandre Barbosa, no Instituto de Estudos Brasileiros, foram valiosas contribuições da pós-graduação. Agradeço a Maria Jardim, da UNESP de Araraquara e Roberto Grün da Universidade Federal de São Carlos pelos convites e produtivo intercâmbio. Finalmente, não saberia como expressar minha gratidão aos professores Ana Paula Hey, Alvaro Comin, Graziela Perosa e Alexandre Barbosa que aceitaram participar da banca tese, dispondo-se a ler atentamente e comentar largos volumes.

À Maria Alice Delitti e Márcia Britto, agradeço os anos de incentivo e atenção.

Aos amigos do IRI, da FAU, da FFLCH, da França, de Berkeley, aos meus primos e às amigas de mais longa data: Diana Stuhlberger, Flora Leite, Heloísa Baldin, Ilana Blankfeld, Lina Cadamuro, Maísa Gaiarsa e Silvana Forsait, agradeço pela enorme paciência com a qual, por anos a fio, ouviram falar dessa pesquisa e, mais do que isso, pelo dom de criar momentos de alegria nos quais a tese pudesse ser o mais distante dos pensamentos.

Em uma família de imigrantes recentes, cresci ouvindo que se há uma coisa que pode ser carregada com você para qualquer lugar é o conhecimento adquirido. Agradeço a Maurício Vaena pela biblioteca de excelência com a qual me presenteou. À minha família do Rio de Janeiro, Clarinha e Marcos Zagury, Lena, Alfredo, Ruth e Jonas Epstein, sou grata pela grande hospitalidade e apoio, mais do que essenciais nos meses vividos no Rio. O contínuo incentivo ao estudo, o carinho e o amparo para atravessar toda sorte de obstáculos devo às famílias Bain, Issler, Klüger, Kochen e Parnes, principalmente aos meus pais Miriam e David Klüger e a meu irmão Michel Klüger. Muito obrigada por tudo, sempre. 
Esta pesquisa foi financiada pelo Conselho Nacional de Desenvolvimento Cientifico e Tecnológico (CNPQ) e pela Coordenação de Aperfeiçoamento de Pessoal de Nível Superior (CAPES), Programa de Doutorado Sanduíche no Exterior (PDSE-CAPES). 
"Poderíamos continuar a buscar uma a uma as relações múltiplas, de proximidade e de distância, de afinidade e aversão, de simpatia e antipatia que se estabelecem entre diferentes categorias de patrões; as relações de vizinhança sendo, evidentemente, tão importantes quanto as relações de oposição, porque as afinidades de estilo de vida que elas exprimem são sem dúvida as condições permissivas, senão necessárias, ao estabelecimento das vínculos de todas as ordens, oficiais ou informais ou até mesmo clandestinos, como os casamentos, a participação em conselhos de administração, os clubes ou os grupos de amigos (de antigos alunos), a frequência aos mesmos salões, aos mesmos jantares, às mesmas classes etc., as "ligações" amorosas ou os acordos. Poderíamos, de fato, supor que é por meio da orquestração imediata dos babitus e da homogeneidade dos estilos de vida que se realiza tudo aquilo que, no campo, não é possível ocorrer sem o intermédio das relações pessoais, como as trocas de informações, de serviços (entre outros financeiros), as operações de cooptação e, em particular, a escolha de sucessores" 
KLÜGER, Elisa. Meritocracia de laços: gênese e reconfigurações do espaço dos economistas no Brasil. 855p. Tese (Doutorado em Sociologia). São Paulo: Faculdade de Filosofia, Letras, Ciências Humanas, Universidade de São Paulo, 2017.

Resumo: Este estudo propõe enraizar histórica e socialmente o espaço dos economistas no Brasil, abordando os laços entre os agentes em concorrência para estabelecer as fronteiras e os princípios de legitimidade de seu conhecimento e sua atuação. A tese consagra-se ao exame do trânsito de especialistas em economia entre a academia, o Estado e o setor privado e entre o espaço nacional e o internacional, enfatizando a convergência de dois recursos no acesso às posições de poder e prestígio: os vínculos com pessoas e instituições e as credenciais especializadas. A tese percorre o período que vai do final dos anos 1930 ao início dos 2000, mostrando de que maneira o espaço dos economistas foi se adensando e que configurações e fracionamentos prevaleceram em cada ponto do tempo. Para tanto, extraiuse de entrevistas e fontes secundárias os dados relativos às origens sociais e trajetórias dos agentes, enfatizando a confecção dos laços que os unem ao longo do tempo. Dados sobre os vínculos sociais foram utilizados para desenhar as redes, apresentadas ao final de cada capítulo. Marcadores de propriedades sociais foram acrescentados às redes para caracterizar cada ponto do espaço, revelando que os laços tendem a formar-se entre pessoas que têm afinidades sociais decorrentes da proximidade estrutural. O oximoro "meritocracia de laços" caracteriza uma história na qual, malgrado a valorização progressiva da qualificação especializada para o exercício de funções de prestígio na área econômica, conserva-se a importância do capital social como rota de acesso ao poder.

Palavras chave: economistas, política brasileira, história econômica do Brasil, redes sociais, BNDES

KLÜGER, Elisa. Meritocracy of ties: genesis and reconfigurations of the space of economists in Brazil. 855p. PhD Dissertation. São Paulo: Faculdade de Filosofia, Letras, Ciências Humanas, Universidade de São Paulo, 2017.

Abstract: This study proposes to historically and socially embed the space of the economists in Brazil, addressing the ties between competing agents in order to establish boundaries and legitimacy principles of their knowledge and practice. The dissertation is dedicated to the study of economy experts who are in transit between the academy, the State, the private sector as well as between national and international spaces, emphasizing the convergence of two resources in accessing prestige and power positions: relationships with people and institutions and specialized credentials. Covering the period from the end of the 1930s to the beginning of 2000, the dissertation shows how the economists' space has become denser and which configurations and fragmentations prevailed at each point in time. Therefore, in order to emphasize the creation of ties over time, the analysis draws upon the interviews and secondary sources used to draw a network, which are presented at the end of each chapter. Data on social origins as well as professional careers was used to characterize each point of the system, revealing that bonds tend to be created between individuals who are socially similar, caused by structural proximity. The oxymoron "meritocracy of ties" features a study in which, despite the progressive appreciation of specialized qualification for the exercise of prestigious roles in economy, the importance of social capital as a route to access power is preserved as fundamental.

Keywords: economists, Brazilian politics, economic history of Brazil, social networks, BNDES. 


\section{Lista de gráficos}

Gráfico I - Admissão por concurso de economistas, engenheiros, contadores e advogados no BNDE(S) - 1952-2012

Gráfico II - Recursos do BNDE(S) em dólares por ano

Gráfico III - Peso das disciplinas na grade horária da EPGE em 1966

Gráfico IV - Número de disciplinas por área na grade do IPE (1966 a 1969)__ 384

Gráfico $V$ - Desembolsos do BNDES por setor entre 1990 e $2014 \_688$

Gráfico VI - Desembolsos em reais por ano de 1952 a 2014

732

\section{Lista de tabelas}

Tabela I - Trajetórias das principais personagens da Abertura

Tabela II - Trajetórias das principais personagens do Primeiro Movimento_ 203

Tabela III - Trajetórias, cronologia da circulação pelo Chile e ocupações no Chile de personagens do Intermezzo

Tabela IV - Trajetórias das principais personagens do Intermezzo que não circularam pelo Chile

Tabela $V$ - Trajetórias das principais personagens do Segundo Movimento__ $\quad 486$

Tabela VI - Trajetórias das principais personagens do Terceiro Movimento__ 634

Tabela VII - Percentual da trajetória profissional dos diretores de cada gestão dividia entre vínculos com o Estado, o mercado e a academia 758

Tabela VIII - Bibliografia dos concursos para o BNDES 1997-2008_

Tabela XIX - Trajetórias das principais personagens do Quarto Movimento 770

\section{Lista de imagens}

Mapa I - Órgãos estatais da área econômica $\quad 52$

Figura I: Escala de cores das redes

Rede I - Rede da Abertura, data final 1964

Rede II - Rede do Primeiro Movimento, data final $1967 \ldots 214$

Rede III - Rede do Intermezzo, data final 1973

Rede IV - Rede do Segundo Movimento, data final 1979_ 501

Rede $V$ - Rede do Terceiro Movimento, data final 1990_ $\quad 647$

Figura II - As dimensões da visão 2005

Rede VI - Rede do Quarto Movimento, data final 2003

\section{Siglas}

AI-5: Ato Institucional No 5

AID: Act of International Development

ALN: Ação Libertadora Nacional

ALPRO: Aliança para o Progresso

ANPEC: Associação Nacional de Centros de Pós-Graduação em Economia

ANPES: Associação Nacional de Programação Econômica e Social

ANPOCS: Associação Nacional de Pós-Graduação e Pesquisa em Ciências Sociais

AP: Ação Popular

ARENA: Aliança Renovadora Nacional

BANERJ: Banco do Estado do Rio de Janeiro

BANESPA: Banco do Estado de São Paulo 
BB: Banco do Brasil

BCB: Banco Central do Brasil

BID: Banco Interamericano de Desenvolvimento

BM: Banco Mundial

BNDE: Banco Nacional de Desenvolvimento Econômico

BNDES: Banco Nacional de Desenvolvimento Econômico e Social

BNDES-EXIM: BNDES-Export-import

BNDESPAR: BNDES Participações S.A.

BNH: Banco Nacional da Habitação

CAE: Centro de Aperfeiçoamento de Economistas da FGV-RJ

CACEX: Carteira de Comércio Exterior do Banco do Brasil

CAPES: Coordenação de Aperfeiçoamento de Pessoal de Nível Superior

CAVC: Centro Acadêmico Visconde de Cairu da FEA-USP

CEBRAP: Centro Brasileiro de Análise e Planejamento

CEDEC: Centro de Estudos de Cultura Contemporânea

CEDEPLAR: Centro de Desenvolvimento e Planejamento Regional

CEMIG: Companhia Elétrica de Minas Gerais

CENDEC: Centro de Treinamento para o Desenvolvimento Econômico e Social

CEPAL: Comissão Econômica para a América Latina (atual Comissão Econômica para a América Latina o Caribe)

CEPAL-BNDE: Centro CEPAL no Brasil em associação com o BNDE

CESIT: Centro de Estudos de Sociologia Industrial e do Trabalho

CES: Centro de Estudios Sociales del Colegio de México

CESO: Centro de Estudios Sociales da Facultad de Economía da Universidad de Chile

CEXIM: Carteira de Exportação e Importação do Banco do Brasil (depois CACEX)

CIA: Central Intelligence Agency

CIES: Conselho Interamericano Econômico e Social

CIESP: Centro das Indústrias do Estado de São Paulo

CMBEU: Comissão Mista Brasil-Estados Unidos

CNE: Conselho Nacional de Economia

CNI: Confederação Nacional da Indústria

CNPIC: Conselho Nacional de Política Industrial e Comercial

CNPQ: Conselho Nacional de Pesquisas (atual Conselho Nacional de Desenvolvimento Científico e Tecnológico)

CO-USP: Conselho Universitário da USP

COBEC: Companhia Brasileira de Entrepostos e Comércio

CODENO: Conselho de Desenvolvimento do Nordeste

CONEP: Comissão Nacional de Estabilização de Preços

CONSULTEC: Sociedade Civil de Planejamento e Consultas Técnicas Ltda.

COFECON: Conselho Federal de Economia

COPAG: Comissão do Plano de Ação do Governo

COPPE-UFRJ: Instituto Alberto Luiz Coimbra de Pós-Graduação e Pesquisa de Engenharia

CORECON: Conselho Regional de Economia

CPC: Centro Popular de Cultura

CSN: Companhia Siderúrgica Nacional

CVM: Comissão de Valores Mobiliários

DASP: Departamento Administrativo do Serviço Público

DEPE: Departamento de Economia e Planejamento Econômico da UNICAMP

DEPLAN: Departamento de Planejamento do BNDES 
DHBB: Dicionário Histórico Biográfico Brasileiro do Centro de Pesquisa e Documentação de História Contemporânea do Brasil

DIEESE: Departamento Intersindical de Estatística e Estudos Socioeconômicos

DIVESP: Distribuidora de Valores e Títulos Mobiliários do Estado de São Paulo

DNOCS: Departamento Nacional de Obras Contra as Secas

DNPM: Departamento Nacional de Produção Mineral

DOPS: Departamento de Ordem Política e Social

ECOSOC: Conselho Econômico e Social da ONU

ECOTEC: Consultoria Engenharia Econômica

EAESP-FGV: Escola de Administração de Empresas de São Paulo da FGV

EBAP-FGV: Escola Brasileira de Administração Pública da FGV

ECAFE: Comissão Econômica para a Ásia e o Extremo Oriente

EHESS: École des Hautes Études en Sciences Sociales

ELAS: Escuela Latinoamericana de Sociología

ELACP: Escuela Latinoamericana de Ciencia Política

ELSP: Escola Livre de Sociologia e Política

EMBRAMEC: Mecânica Brasileira S.A.

EME: Estado-Maior do Exército Brasileiro

EPEA: Escritório de Pesquisa Econômica Aplicada

EPGE: Escola de Pós-Graduação em Economia da FGV-RJ

ESALQ: Escola Superior de Agricultura Luiz de Queiroz

ESCAP: Comissão Econômica e Social para a Ásia e o Pacífico

ESCOLATINA: Escuela Latinoamericana de Economía de la UC

ESG: Escola Superior de Guerra

EUA: Estados Unidos da América

FACE: Faculdade de Ciências Econômicas e Administrativas de Minas Gerais (atual

Faculdade de Ciências Econômicas da UFMG)

FAO: Organização das Nações Unidas para a Alimentação e a Agricultura

FAPESP: Fundação de Amparo à Pesquisa do Estado de São Paulo

FAT: Fundo de Amparo ao Trabalhador

FAU: Faculdade de Arquitetura e Urbanismo da USP

FCEA-USP: Faculdade de Ciências Econômicas e Administrativas da USP (atual FEA-USP)

FCEARJ: Faculdade de Ciências Econômicas e Administrativas do Rio de Janeiro

FD-USP: Faculdade de Direito da USP

FEA-USP: Faculdade de Economia e Administração e Contabilidade da USP

FEA-UFRJ: Faculdade de Economia e Administração da UFRJ

FECAP: Fundação Escola de Comércio Álvares Penteado

FED: Federal Reserve System

FEI: Faculdade de Engenharia Industrial

FEMIG: Federação das Indústrias de Minas Gerais

FFCL: Faculdade de Filosofia Ciências e Letras da USP

FFLCH: Faculdade de Filosofia Letras e Ciências Humanas da USP

FGV-RJ: Fundação Getúlio Vargas do Rio de Janeiro

FGV-SP: Fundação Getúlio Vargas de São Paulo

FIBASE: Insumos Básicos S.A.

FIESP: Federação das Indústrias do Estado de São Paulo

FINAME: Financiamento para a Aquisição de Máquinas e Equipamentos Industriais

FINAMEX: Programa de Financiamento à Exportação de Máquinas e Equipamentos

FINEP: Fundo de Financiamento de Estudos de Projetos e Programas (atual Financiadora de Estudos e Projetos) 
FINSOCIAL: Fundo de Investimento Social

FIPE: Fundação Instituto de Pesquisa Econômica

FIPEME: Programa de Financiamento às Pequena e Média Empresas

FLACSO: Faculdade Latino-Americana de Ciências Sociais

FMI: Fundo Monetário Internacional

FMRI: Fundo de Modernização e Reorganização Industrial

FNCE: Faculdade Nacional de Ciências Econômicas da UB

FNDCT: Fundo Nacional de Desenvolvimento Científico e Tecnológico

FRE: Fundo de Reaparelhamento Econômico

FUMCAP: Fundo de Desenvolvimento de Mercado de Capitais

FUNAR: Fundo Agroindustrial de Reconversão

FUNDEPRO: Fundo de Desenvolvimento da Produtividade

FUNESPE: Financiamento de Estudos e Pesquisas Técnicas

FUNTEC: Fundo de Desenvolvimento Técnico-Científico

GEIA: Grupo Executivo da Indústria Automobilística

GTDN: Grupo de Trabalho sobre o Desenvolvimento do Nordeste

GTM: Grupo de Trabalho de Minério

GTS: Grupo de Trabalho de Siderurgia

IAPI: Instituto de Aposentadorias e Pensões dos Industriários

IBESP: Instituto Brasileiro de Economia, Sociologia e Política

IBGE: Instituto Brasileiro de Geografia e Estatística

IBRASA: Investimentos Brasileiros S.A.

IBRE: Instituto Brasileiro de Economia

IDEPLAR: Instituto de Desenvolvimento e Planejamento Regional

IDESP: Instituto de Estudos Econômicos, Sociais e Políticos de São Paulo

IDORT: Instituto de Organização Racional do Trabalho

IED: Investimento Externo Direto

IE-UNICAMP: Instituto de Economia da UNICAMP

IEI-UFRJ: Instituto de Economia Industrial da UFRJ

IE-UFRJ: Instituto de Economia da UFRJ

IEPE-UFGRS: Centro de Estudos e Pesquisas Econômicas da UFRGS

IERJ: Instituto de Economistas do Rio de Janeiro

IFCH: Instituto de Filosofia e Ciências Humanas da UNICAMP

ILADES: Instituto Latino-Americano de Doutrina e Estudos Sociais

ILPES: Instituto Latinoamericano de Planificación Económica y Social

IMPA: Instituto Nacional de Matemática Pura e Aplicada

INCRA: Instituto Nacional de Colonização e Reforma Agrária

INFRAERO: Empresa Brasileira de Infraestrutura Aeroportuária

INPES: Instituto de Pesquisa do IPEA

INSS: Instituto Nacional de Seguro Social

INTERBRÁS: Petrobrás Comércio Internacional S.A.

IPE-USP: Instituto de Pesquisas Econômicas da USP

IPEA: Instituto de Pesquisa Econômica Aplicada

IPES: Instituto de Pesquisas e Estudos Sociais

I PND: Primeiro Plano Nacional de Desenvolvimento

II PND: Segundo Plano Nacional de Desenvolvimento

IPT: Instituto de Pesquisas Tecnológicas

ISEB: Instituto Superior de Estudos Brasileiros

ITA: Instituto Tecnológico da Aeronáutica

IUPERJ: Instituto Universitário de Pesquisas do Rio de Janeiro 
JEC: Juventude Estudantil Católica

JUC: Juventude Universitária Católica

LSE: London School of Economics

MAPU: Movimiento de Acción Popular Unitaria

MASP: Museu de Arte de São Paulo

MDB: Movimento Democrático Brasileiro

MDIC: Ministério do Desenvolvimento, Indústria e Comércio

MIR: Movimiento de Izquierda Revolucionario

MIT: Massachusetts Institute of Technology

MOBRAL: Movimento Brasileiro de Alfabetização

MRE: Ministério das Relações Exteriores

NYU: New York University

OBAN: Operação Bandeirante

ODEPLAN: Oficina de Planificación Nacional

OEA: Organização dos Estados Americanos

OEB: Ordem dos Economistas do Brasil

OIT: Organização Internacional do Trabalho

ONU: Organização das Nações Unidas

OPA: Operação Pan-Americana

OPENO: Operação Nordeste

ORM-POLOP: Organização Revolucionária Marxista - Política Operária

ORTN: Obrigações Reajustáveis do Tesouro Nacional

OSB: Orquestra Sinfônica Brasileira

PAI: Programa de Ação Imediata

PASEP: Programa de Formação do Patrimônio do Servidor Público

PAEG: Plano de Ação Econômica do Governo

PCB: Partido Comunista Brasileiro

PDC: Partido Democrata Cristão

PED: Plano Estratégico de Desenvolvimento

PEM: Programa de Estabilização Monetária

PET: Programa de Educação Tutorial

PFL: Partido da Frente Liberal

PIB: Produto Interno Bruto

PIMES: Programa de Pós-Graduação em Economia da UFPE

PIS: Programa de Integração Social

PMDB: Partido do Movimento Democrático Brasileiro

PNUD: Programa das Nações Unidas para o Desenvolvimento

POC: Partido Operário Comunista

POLI: Escola Politécnica da USP

POLOP: Organização Revolucionária Marxista - Política Operária

PPM: Partido Progressista Mineiro

PSB: Partido Socialista Brasileiro

PSD: Partido Social Democrático

PSDB: Partido da Social Democracia Brasileira

PT: Partido dos Trabalhadores

PTB: Partido Trabalhista Brasileiro

PUC-RJ: Pontifícia Universidade Católica do Rio de Janeiro

PUC-RS: Pontifícia Universidade Católica do Rio Grande do Sul

PUC-SP: Pontifícia Universidade Católica de São Paulo

RBE: Revista Brasileira de Economia 
SABESP: Companhia de Saneamento Básico do Estado de São Paulo

SAGMACS: Sociedade de Análise Gráfica e Mecanográfica Aplicada aos Complexos Sociais

SCIENCE PO: Institut d'études politiques de Paris

SENEPESP: Secretaria do Planejamento do Estado de São Paulo

SENFESP: Secretaria de Estado dos Negócios da Fazenda do Estado de São Paulo

SEPLAN: Secretaria de Planejamento da Presidência da República

SNI: Serviço Nacional de Informações

SPHAN: Serviço do Patrimônio Histórico e Artístico Nacional

SPTRANS: São Paulo Transportes S.A.

SUDENE: Superintendência do Desenvolvimento do Nordeste

SUMOC: Superintendência da Moeda e do Crédito

UB: Universidade do Brasil (atual UFRJ)

UBA: Universidad de Buenos Aires

UC: Universidad de Chile

UCC: Universidad Católica de Chile

UCLA: University of California - Los Angeles

UDN: União Democrática Nacional

UEE: União Estadual dos Estudantes

UEG: Universidade do Estado da Guanabara

UERJ: Universidade do Estado do Rio de Janeiro

UFBA: Universidade Federal da Bahia

UFC: Universidade Federal do Ceará

UFES: Universidade Federal do Espírito Santo

UFF: Universidade Federal Fluminense

UFJF: Universidade Federal de Juiz de Fora

UFMG: Universidade Federal de Minas Gerais

UFPE: Universidade Federal de Pernambuco

UFPR: Universidade Federal do Paraná

UFRGS: Universidade Federal do Rio Grande do Sul

UFRJ: Universidade Federal do Rio de Janeiro

UFSCAR: Universidade Federal de São Carlos

UMG: Universidade de Minas Gerais

UNAM: Universidad Nacional Autónoma de México

UNB: Universidade de Brasília

UNE: União Nacional dos Estudantes

UNECE: Comissão Econômica para a Europa

UNESCO: Organização das Nações Unidas para a Educação, a Ciência e a Cultura

UNESP: Universidade Estadual Paulista Júlio de Mesquita Filho

UNICAMP: Universidade Estadual de Campinas

URSS: União das Repúblicas Socialistas Soviéticas

USAID: Agência Norte-Americana para o Desenvolvimento Internacional

USP: Universidade de São Paulo

VAR-Palmares: Vanguarda Armada Popular Revolucionária Palmares

VPR: Vanguarda Popular Revolucionária 


\section{Sumário}

PRELÚDIO

1 ABERTURA: Em busca de um pensamento autóctone: batalhas diplomáticas por uma Comissão Econômica para a América Latina (CEPAL) e as rotas de ingresso do pensamento cepalino no Brasil (1948-1964)

1.1 Hernán Santa Cruz e a criação de uma Comissão Econômica para a América Latina 33

1.2 Raúl Prebisch e o Manifesto Latino-Americano 38

1.3 Celso Monteiro Furtado do DASP à CEPAL 47

1.4 Cleantho de Paiva Leite, Ignácio de Mourão Rangel, Rômulo de Almeida e Jesus Soares Pereira na Assessoria Econômica de Getúlio Vargas

1.5 Maria da Conceição Tavares, Carlos Lessa e Antonio Barros de Castro no escritório CEPAL-

BNDE 62

1.6 Rede da Abertura 90

2. PRIMEIRO MOVIMENTO: Política externa Brasil-Estados Unidos e a gênese dos especialistas em economia no Brasil (1931-1966)

2.1 Eugênio Gudin e Octavio Gouvêa de Bulhões: pontes entre o Brasil e os Estados Unidos 104

2.2 Roberto Campos, a Comissão Mista Brasil-Estados Unidos e a origem do BNDE 125

2.3 Lucas Lopes e o Plano de Metas 140

2.4 Mario Henrique Simonsen: CONSULTEC e CAE-FGV 158

2.5 João Paulo dos Reis Velloso: USAID, Fundação Ford e a criação do EPEA

2.6 Rede do Primeiro Movimento 206

3. INTERMEZZO: Militância e exílio (1964-1973) 215

3.1 Herbert José de Souza e os bolsistas: economistas, sociólogos e militantes mineiros 224

3.2 José Serra e Luiz. Carlos Mendonça de Barros: a militância politécnica

3.3. Fernando Henrique Cardoso e os cientistas sociais no Chile 275

3.4 As heterodoxias na ESCOLATINA: Ana Célia Castro, Frederico Mazzucchelli e Paulo

Renato Costa Soura 310

3.5 Vânia Bambirra, Theotônio dos Santos e Ruy Mauro Marini: teoria e práxis 327

3.6 Rede do Intermezzo 349

4. SEGUNDO MOVIMENTO: Visões matematizadas ciência econômica (19671979)

4.1 Roberto Cochrane Simonsen: a economia politica dos industriais 361

4.2 Antonio Delfim Netto: a FCEA-USP e o exercicio do poder 368 
4.3 Pedro Malan e Regis Bonelli na Missão Califórnia 394

4.4 Arnold Harberger e Carlos Geraldo Langoni: Chicago no Brasil 416

4.5 Marcos Vianna: Brasil Potência-BNDE Potência 441

4.6 Edmar Bacha, Chico Lopes, Dionísio Dias Carneiro, Persio Arida e André Lara Resende: disputas na FGV e origens da PUC-RJ 458

4.7 Rede do Segundo Movimento 491

5. TERCEIRO MOVIMENTO: A frente de oposição no governo (1979-1990) 503

5.1 Luiz Carlos Bresser Pereira e Yoshiaki Nakano: a EAESP-FGV

5.2 Luciano Galvão Coutinho, Luiz Gonzaga Belluzzo e João Manuel Cardoso de Mello: a construção da pós-graduação em economia na UNICAMP 526

5.3 Guido Mantega: a PUC-SP e as raizes da intelectualidade petista 546

5.4 O MDB no governo do Estado de São Paulo: André Franco Montoro Filho, Andrea Calabi e

João Sayad

5.5 Francisco Gros: do mercado financeiro ao BNDES 594

5.6 O Plano Cruzado e a reconfiguração do espaço dos economistas na Nova República 614

5.7 Rede do Terceiro Movimento 642

6. QUARTO MOVIMENTO: O BNDES dos governos Collor, Itamar e FHC (1990-2003) 649

6.1 O BNDES da Integração Competitiva 656

6.2 O BNDES e a Privatização $\quad 670$

6.3 O BNDES em meio à estabilização econômica 693

6.4 O BNDES entre neoliberais e liberais-desenvolvimentistas $\quad 721$

6.5 O segundo governo FHC e a aliança do BNDES com o mercado de capitais 746

6.6 A transição para o governo Lula: invertendo o sinal 763

6.7 Rede do Quarto Movimento $\quad 778$

$\begin{array}{ll}\text { FINALE } & 785\end{array}$

$\begin{array}{ll}\text { REFERENCIAS } & 793\end{array}$ 


\section{PRELÚDIO 1}

Meritocracia de laços: gênese e reconfigurações do espaço dos economistas no Brasil é um estudo que pretende enraizar histórica e socialmente os laços entre os agentes em concorrência para estabelecer as fronteiras e os princípios de legitimidade vigentes no espaço dos economistas brasileiros, considerando suas propriedades objetivas e disposições subjetivas. A tese consagra-se ao estudo do trânsito de especialistas em economia entre a academia, o Estado e o setor privado e entre o espaço nacional e o internacional, enfatizando a convergência de dois recursos no acesso às posições de poder e prestígio: os vínculos com pessoas e instituições e as credenciais especializadas.

O espaço dos economistas, objeto central da tese, é composto tanto pelo campo relativamente autônomo da ciência econômica - com suas escolas, revistas, associações e demais instâncias de formação, regulação e consagração - quanto pelas instituições da área econômica do Estado e pelas empresas e o setor financeiro privados. Ao acompanhar a gênese e as reconfigurações do espaço dos economistas no Brasil, é possível verificar, historicamente, a luta travada por um conjunto de agentes que mobiliza capitais científicos, sociais, simbólicos e políticos para construir as fronteiras que separam os agentes competentes e credenciados para as tarefas de gestão racional da economia, no setor público e privado (BOURDIEU, 2000, p. 244; BOURDIEU, 2003, p. 22; LEBARON, 2000; LEBARON, 2006a; FOURCADE, 2009; LOUREIRO, 1997a; NEIBURG, 2004; BABB, 2003; MONTECINOS, 2009).

A leitura histórica permite assim acompanhar o processo de reconhecimento e ascensão dos economistas no campo do poder, espaço onde as frações dominantes de diversas esferas de atividade, tendo acumulado grande volume de capitais de espécies diferentes, lutam para estabelecer a legitimidade e o valor relativo de cada espécie de recurso e conquistar poder sobre os diferentes poderes, influenciando a própria conformação da disputa (BOURDIEU, 2011, pp. 126-127; BOURDIEU, 1989, p. 216; DENORD et al., 2011, p. 26). Ao trabalhar com dados sobre as origens e trajetórias de

\footnotetext{
${ }^{1}$ Prelúdio: "trata-se de uma peça destinada a um instrumento solista (raramente voz ou orquestra), que tem por função introduzir uma outra peça de caráter composto" É ademais fruto das improvisações introdutórias dos músicos quando testam e afinam seus instrumentos (VIGNAL, 1999, p. 678, tradução minha). Bem como no prelúdio musical, seguem-se passagens introdutórias que têm por objetivo preparar e apresentar os conceitos que funcionarão como instrumentos da análise.
} 
agentes que conquistam posições de poder, em uma determinada época e sociedade, acompanha-se a variação dos atributos sociais e visões de mundo dos grupos dominantes; e dos princípios de legitimação por eles mobilizados para justificar sua posição (BOURDIEU, 1989, pp. 168, 378; SAINT-MARTIN, 2008, p. 67).

A narrativa da gênese e das reconfigurações do espaço dos economistas no Brasil será apresentada em quatro Movimentos e um Intermezzo, precedidos de uma Abertura. Os quatro movimentos possuem elementos comuns, pessoas e instituições que perpassam os diversos momentos da narrativa, surgindo, a cada movimento, novos elementos e variações que dão origem a novas configurações. Cada movimento é definido por uma estrutura de encadeamentos e polarizações entre os agentes presentes nas intersecções dos espaços dos economistas e do poder político, em permanente tensão entre as lógicas de cooperação e conflito. O Intermezzo e a Abertura introduzem e caracterizam sujeitos que estarão presentes nos movimentos que a eles se seguem, enfocando os efeitos de afastamentos do espaço nacional sobre a tessitura de laços e incorporação de novas visões de mundo, que se retraduzirão ao ingressar no espaço nacional (DEZALAY e GARTH, 2002; GARCIA, 2005; FOURCADE, 2009).

A Abertura ocupa-se das batalhas diplomáticas transcorridas no período de formação da Comissão Econômica para a América Latina (CEPAL), da apresentação de ideias centrais da Comissão e de suas rotas de entrada no Brasil, abrigando eventos que ocorrem do final dos anos 1930 ao início da década de 1960. O Primeiro Movimento situa-se no mesmo período cronológico, enfocando o processo de montagem de um conjunto de escolas de economia e órgãos públicos voltados à gestão econômica no Brasil, com destaque para o efeito da diplomacia econômica Brasil-Estados Unidos nesse processo. O Intermezzo, que começa no início da ditadura no Brasil, ponto no qual se encerra o Primeiro Movimento, e vai até 1973, concentra-se no deslocamento de um conjunto de economistas e cientistas sociais críticos do governo militar para o Chile, país onde entraram em contato com ideias econômicas que por ali circulavam e teceram laços que teriam impacto na reconfiguração do espaço dos economistas nos anos seguintes. $\mathrm{O}$ Segundo Movimento apresenta a coalizão de especialistas em economia que domina a gestão econômica durante o governo militar e indica a formação de grupos de oposição integrados por aqueles que permaneceram no país, ressaltando a tendência à matematização da ciência econômica observada no período. O Terceiro Movimento 
descreve a formação, nos últimos anos da ditadura, da frente de oposição que participará do primeiro governo da Nova República, integrada tanto pela oposição que permaneceu no país quanto por aqueles que regressavam do exílio. O Quarto Movimento, por fim, abarca o período que vai da primeira eleição direta para a presidência da República à transição do governo Fernando Henrique Cardoso para o governo de Luiz Inácio Lula da Silva. O trabalho se encerra com um Finale dedicado à análise das características prosopográficas elementares do grupo social estudado, enfocando as variações geracionais observadas.

Em todos os movimentos destaca-se o papel exercido pelo Banco Nacional de Desenvolvimento Econômico e Social (BNDES). De fato, esta pesquisa começou como uma investigação sobre as posições, disposições e tomadas de posição daqueles que ocuparam a direção do Banco nos anos noventa e dois mil, enquadramento que definiu o conjunto de entrevistas feitas para a tese. Dada a perspectiva teórica adotada, o recorte do objeto foi se ampliando de modo a cruzar as instâncias de atuação dos agentes no campo da política, da política econômica e das escolas de economia.

De acordo com a abordagem estrutural que orientou a construção do objeto, a formação das disposições e visões de mundo dos agentes dá-se a partir da sucessão de suas posições no decorrer de uma trajetória traçada a partir do núcleo familiar, passando pelas instituições educacionais, interações sociais e experiências profissionais. Assim, uma trajetória só faz sentido quando localizada na estrutura social relacional, entendida como matriz das relações objetivas entre as diferentes posições. A partir dessa matriz torna-se possível comparar trajetórias similares e distintas, revelando possíveis fatores sociais de explicação das práticas e visões de mundo de indivíduos e grupos (BOURDIEU 1986; BOURDIEU, 1989; BOURDIEU 2005; BOURDIEU, 2008).

Com o objetivo de enquadrar socialmente as transmutações atravessadas pelo BNDES, associadas à variação do conjunto de especialistas em economia ocupando as posições dirigentes da instituição, a pesquisa construiu relacionalmente os agentes e o espaço, constantemente reestruturado, em meio ao qual se formaram e se deslocaram. O BNDES aparece, portanto, imerso nessa trama que se converteu no eixo central da investigação. Apenas no Quarto Movimento, tendo sido apresentadas quase todas as escolas e órgãos econômicos, a narrativa centra-se decisivamente nos jogos transcorridos 
no interior do BNDES, sempre imersos nas estruturas e vistos como produto de um conjunto de relações em constante mutação.

Às quarenta e uma entrevistas com ex-diretores do Banco feitas para a pesquisa, foram acrescentadas entrevistas com nove outros agentes centrais na história narrada. Todas elas foram feitas entre 2012 e 2015 nas cidades de Rio de Janeiro, São Paulo, Vitória e Paris, seguindo um questionário padronizado com perguntas sobre origens sociais, práticas culturais e estilos de vida, trajetória acadêmica e profissional, orientação política, opiniões acerca da condução do BNDES e origem dos laços sociais com outros economistas, tendo sido apenas parte do material utilizada na tese.

A mais elementar inquietação que se colocou nas etapas de desenho e planejamento da pesquisa era referente à viabilidade de estabelecer contato com aqueles que se pretendia entrevistar ${ }^{2}$. O quadro de diretores do BNDES no período abarcado pela pesquisa foi composto por especialistas em economia que ocuparam e ocupam numerosas funções proeminentes no setor público e privado. Além de diretores e ex-diretores do Banco, os entrevistados foram e são professores universitário, conselheiros empresariais, gestores de fundos, ministros, banqueiros, dirigentes de outros órgãos dos governos Estadual e Federal etc.

No início cogitamos enviar cartas timbradas da universidade, assinadas por minha orientadora, aos dirigentes que ainda atuavam como professores acreditando que, caso aceitassem conceder as entrevistas, poderíamos pedir-lhes indicações para contatar outros diretores. Não foi uma estratégia efetiva. Um dos entrevistados, que aceitou dar a entrevista após telefonema de um colega de Banco anteriormente entrevistado, explicoume que havia recebido a carta, mas que recebe tantas demandas que não tem meios de triar quais são relevantes e quais não são. Descartada a via institucional, passei a mobilizar elos, em geral fracos 3 , da minha rede social; professores, colegas, parentes próximos e

\footnotetext{
${ }^{2}$ Além de pensar como entrar em contato com os entrevistados, deveria prever que o tempo de que disporiam seria limitado. Um pré-teste do questionário foi feito com prestigiado especialista em economia do setor privado, para avaliar a consistência das perguntas, experimentar a situação de pesquisa e avaliar o tempo necessário para percorrer o questionário. Após o teste, decidimos que na carta de apresentação enviada àqueles que pretendia entrevistar deveria constar uma hora e meia como o tempo previsto da entrevista. A média do tempo das entrevistas resultou, no entanto, ser efetivamente de duas horas e meia. Em alguns casos tive que parcelar a entrevista, tendo feito algumas em 2 ou 3 encontros.

${ }^{3}$ Mark Granovetter (1973), em sua pesquisa sobre a procedência das informações que levam as pessoas a encontrar novos empregos, cunhou a expressão força dos elos fracos para exprimir a situação na qual os contatos relevantes para obter informações sobre novas oportunidades estariam em geral na periferia da rede social do ator, pois a informação que circula em sua rede próxima tende a ser redundante com aquela possuída pelo próprio indivíduo.
} 
distantes, vizinhos e amigos de amigos. A partir das entrevistas iniciais e contando com grande disposição dos entrevistados para ajudar no contato com seus pares, foi possível alcançar mais informantes. A reflexividade central ao exercício sociológico convida a pensar em que medida a pesquisa mobilizou a própria meritocracia de laços que estuda, ao valer-se simultaneamente de credenciais acadêmicas e de vínculos pessoais para percorrer a trama de laços dos entrevistados.

A maior parte dos informantes solicitou, antes de concordar em conceder a entrevista, o resumo ou o projeto da pesquisa, o plano de trabalho, as questões centrais do estudo e o teor e a natureza das perguntas. Em um caso soube que a secretária do entrevistado pesquisou minha inserção na universidade, a identidade de minha orientadora e do orientador da minha orientadora, nome que abriu portas por ser reconhecido como "sério". Tão logo fiz as primeiras entrevistas, passaram a me recomendar aos amigos, qualificando a entrevista de interessante e mesmo divertida, garantindo, assim, nas entrelinhas, que não havia assuntos indesejáveis.

Característica previsível, considerando que a maior parte da amostra é composta por mestres e doutores, muitos dos quais professores universitários, foi o interesse que os informantes demonstraram pela construção da pesquisa. Em situação de entrevista perguntavam como eu iria estabelecer relações entre os itens das diferentes partes do questionário, indagavam acerca das hipóteses da investigação e alguns chegaram mesmo a tentar prever que resultados eu iria encontrar. Outra peculiaridade decorrente dessa mesma característica foi a entrevista converter-se, em alguns momentos, em uma aula ou uma quase reunião de orientação, na qual me ofereciam sugestões de leituras, recomendações de métodos de análise e outras indicações de caráter acadêmico.

Além das entrevistas, a pesquisa utiliza vasto conjunto de fontes secundárias, entre as quais biografias e autobiografias, depoimentos autobiográficos, dicionários históricobiográficos, livros e DVDs comemorativos elaborados por faculdades de economia ou encomendados por órgãos econômicos do próprio Estado, jornais e revistas, currículos disponíveis online e livros, teses e artigos acadêmicos. Cabe destacar que parte significativa das fontes foi produzida pelos sujeitos que são objeto do estudo, em esforço perpetrado por eles mesmos de produção da história e da memória dos economistas. A inserção no contexto sócio-histórico dos depoimentos permite, não obstante, que se transcenda a reconstrução de uma sequência de fatos por eles oferecida. A análise dos 
depoimentos não se presta, desse modo, a uma busca objetiva da verdade, mas à compreensão do que a narrativa revela sobre o narrador: sua posição, seu habitus, suas crenças e os modos de enquadramento das disputas nas quais está inserido (LEVI, 1989, pp. 1327-9; FERREIRA, 2000, pp. 7-11; POLLAK, 1992, p. 204; BOURDIEU, 1986, pp. 69-71; CELLARD, 2008, p. 299).

Com os dados das entrevistas e das fontes secundárias, construiu-se a narrativa histórica que compõe o núcleo de cada capítulo. Na narrativa, são enfatizadas a origem social dos economistas, a formação de vínculos entre eles - sendo destacadas as similaridades e contrastes entre indivíduos e grupos, no que concerne às suas propriedades sociais e às suas visões de mundo -, o surgimento e as transformações das instituições do espaço dos economistas e a teia de conexões internacionais em que os agentes e instituições estão imersos. Além disso, a história desenrola-se segundo transformações na política, na economia e na sociedade que dão sentido às lutas e polaridades observadas. Ao final de cada capítulo, os dados sobre os vínculos são utilizados para desenhar redes sociais e os dados morfológicos sobre os agentes, sintetizados nas tabelas I, II, III, IV, V, VI e XIX, são empregados para caracterizar áreas da rede, com o objetivo de explicitar o caráter socialmente estruturado das clivagens nela observadas.

As redes sociais, construídas com auxílio de um software de análises de rede ${ }^{4}$, são representações simplificadas de emaranhados de vínculos sociais duráveis (que podem ser de interconhecimento, de trocas, de amizade, de lealdade, de parentesco, profissionais etc.) entre unidades (indivíduos, instituições, famílias, grupos etc.) que assumem uma determinada forma e estrutura (dependendo dos padrões de conexão entre as unidades) e que operam como canais de transferência e troca de bens materiais (mercadorias, dinheiro, presentes etc.) e elementos imateriais (como ideias, informações, afeto etc.). A estrutura de rede, as transformações que ela experimenta ao longo do tempo e a posição que cada unidade elementar nela ocupa (sua centralidade, o número de vínculos, o tipo e a força dos vínculos que os conecta a outros etc.) são determinantes do tipo e do volume de bens materiais e imateriais que se colocam ao alcance das unidades. A estrutura da rede tem, também, influência sobre a constituição das lealdades, das obrigações e dos pertencimentos, tendo, consequentemente, efeito sobre o comportamento dos indivíduos

\footnotetext{
${ }^{4}$ Todas as redes da tese foram feitas com o software Gephi, disponível em https://gephi.org/.
} 
e/ou grupos (LAZEGA, 1998, pp. 6, 13; MARQUES, 2007, p. 159; SMITH-DOERR e POWELL, 2005, pp. 380-390).

As análises de redes possibilitam estudar os sistemas concretos e contínuos de relações e interações entre agentes supondo, via de regra, as relações e interações sociais como a unidade básica da sociedade. Caberia ao cientista social, no caso, investigar os padrões e as variações nas estruturas de relações e interações entre os atores presentes na rede, vista como representação simplificada de um sistema social, de modo a contextualizar a ação social, criada e recriada nas próprias interações (EMIRBAYER, 1997; MARQUES, 2007; WATTS, 1999; GRANOVETTER, 2007, p. 8, LAZEGA, 1998, p. 6).

Pierre Bourdieu e seus seguidores criticam a premissa interacionista subjacente à análise de redes, indicando ser limitada a reconstrução de uma trama de relações empiricamente observáveis entre agentes atemporais e indiferenciados, visto ignorar a existência de estruturas sociais que precedem, ultrapassam e condicionam a trama constituída pelos vínculos concretos. De acordo com eles, as redes, em si, são capazes de retratar padrões de vinculação entre os agentes mas não de oferecer elementos para interpretar as razões do estabelecimento de tais vínculos. O sentido da trama revelar-se-ia apenas à luz do conjunto de relações de força constitutivas dos espaços sociais hierarquizados - nos quais os agentes possuem diferentes dotações de capitais econômicos, culturais, simbólicos, políticos etc., estando posicionados uns em relação aos outros de acordo com os recursos e caraterísticas herdados e acumulados em suas trajetórias - que tornam mais ou menos prováveis as vinculações entre os agentes, dependendo de suas propriedades sociais, ou seja, do grau de semelhança de seus habitus (BOURDIEU, 2000, pp. 238-244; DENORD, 2003, p. 240; DENORD, 2015, p. 62; LEBARON, 2008, p. 127).

Para que o estudo dos laços efetivos não seja desprovido de uma moldura estrutural, seria preciso situar os agentes e os próprios vínculos relacionalmente, posicionando-os em espaços sociais hierarquizados. O enquadramento, no espaço social, dos laços e do capital social e prestígio decorrentes da posição ocupada por um agente na teia de vínculos permite que as redes não sejam tomadas como resultado de interações fortuitas entre agentes indiferenciados, mas decorrentes, via de regra, da proximidade entre agentes cujas propriedades objetivas e disposições subjetivas são objetivamente 
convergentes. Verificar-se-ia, assim, que nem todos os laços teriam igual probabilidade de concretização, sendo, em teoria, maior a chance de aproximação entre indivíduos com babitus afinados (BOURDIEU, 1986; LEBARON, 2008, p. 127; DENORD, 2015, pp. 66$71)$.

Não é nova a intenção de testar de que modo o espaço social interage com os vínculos efetivos, tendo sido conduzidos, nos últimos anos, alguns projetos em que a sociologia calcada na construção de espaços sociais estruturados compatibiliza-se com a análise de redes (DENORD, 2003; 2005; MACH, DAVID e BÜHLMANN, 2011; ANHEIER, GERHARDS e ROMO, 1995; SAPIRO, 2006). No caso, propõe-se que a análise de redes seja usada, não como ferramenta voltada ao estudo de uma ordem social dinâmica, constantemente criada e recriada nas interações, como sugere o interacionismo, mas como um método capaz de iluminar os padrões de efetivação, nos laços, da estrutura social relacional como apregoado por Pierre Bourdieu e seus discípulos.

A epígrafe da tese expressa justamente a busca, nas afinidades decorrentes da orquestração ${ }^{5}$ dos habitus e na homogeneidade dos estilos de vida, dos fundamentos dos vínculos subjacentes à ação observada que cria e recria as estruturas, sendo ao mesmo tempo por ela condicionadas. Ao observar a relação entre os especialistas em economia na academia, as indicações para as posições centrais no governo e a tessitura de vínculos afetivos ressaltar-se-á, portanto, o conjunto de disposições dos agentes e as afinidades e diferenças em suas trajetórias que poderiam impactar na formação dos laços, por meio dos quais ocorrem as cooptações e nomeações, agindo sobre a própria reconfiguração do espaço (BOURDIEU e SAINT-MARTIN, 1978, p. 37).

A solução metodológica adotada para promover a imersão dos vínculos pessoais no espaço social estruturado, de acordo com as proximidades e distâncias de propriedades sociais objetivas desigualmente distribuídas, começa pelo desenho de redes que expressam os padrões de repulsão entre esferas que representam indivíduos e instituições. A distância entre dois pontos na rede é reduzida quando são conectados, fazendo com a forma do espaço e a estrutura de polarizações nele visível altere-se de acordo com o número e o padrão de vínculos entre os agentes. O segundo passo consiste em sobrepor à

\footnotetext{
${ }^{5} \mathrm{O}$ uso das nomenclaturas musicais na denominação dos capítulos é tanto uma referência à orquestração dos habitus como fundamento da aproximação entre os agentes quanto à ideia de que a estrutura do espaço social movimenta-se e reconfigura-se, sendo as posições relativas das unidades alteradas em função da inclusão de novos elementos e do reposicionamento dos precedentes.
} 
estrutura da rede resultante dos laços reportados na narrativa histórica marcadores que indicam: período de nascimento dos agentes, profissão, região de origem, visão de economia, dentre outras propriedades sociais e disposições.

Combina-se, deste modo, dados sobre os vínculos com informações acerca das distâncias entre as propriedades sociais que representam diferenças estruturais objetivas entre os agentes, dadas pela posse desigual de trunfos sociais, que independem das interações face a face ${ }^{6}$. Ressalta-se que, por ser um método de representação geométrica baseado atração e repulsão entre agentes, a análise de redes é semelhante, em sua premissa fundamental, à análise de correspondências múltiplas, procedimento relacional que expressa geometricamente distâncias entre propriedades sociais, desenvolvido por Jean Paul Benzécri e adotado correntemente por Pierre Bourdieu e seus discípulos por expressar polarizações decorrentes da distribuição desigual de recursos que estariam na raiz das lutas travadas para determinar os princípios de dominação dominantes (NOOY, 2003; LEBARON, 2010, p. 103).

Ao caracterizar cada área da rede e detectar os princípios estruturais de aproximação e oposição dos agentes associados em frações no espaço e os condicionantes das disputas e lealdades que estabelecem entre si, torna-se possível observar os fundamentos sociais estruturais das vinculações por intermédio das quais ocorrem as trocas de bens, de informações e aproximações pessoais, sendo destacadas na tese as afinidades sociais subjacentes à aproximação e distanciamento pessoal, profissional e político entre os especialistas em economia e as cooptações subjacentes à montagem das escolas de economia e das equipes econômicas de cada governo.

As redes apresentadas ao final dos capítulos incluem tanto indivíduos quanto instituições, sendo representados não apenas os vínculos concretos do período histórico retratado no capítulo, mas também o conjunto de pertencimentos do agente ao longo de sua trajetória, visto considerar-se a trajetória como um processo contínuo de socialização, acumulação de propriedades objetivas e de capitais e formação de disposições subjetivas. Os marcadores de propriedades sociais aparecem posicionados no ponto médio

\footnotetext{
${ }^{6}$ Para testar se a convêrgencia de princípios entre os métodos resulta em representações geométricas semelhantes, Wouter de Nooy desenha uma rede com base nos pertencimentos dos agentes mencionados no Homo Academicus de Pierre Bourdieu e avalia que as clivagens entre instituições e indivíduos que nela se expressam é bastante semelhante àquela delineada na análise de correspondências do Homo Academicus (BOURDIEU, 2008a, p. 73), visto ser o pertencimento às instituições superiores, retratadas na rede, elemento fortemente determinante da estrutura do espaço social apresentado na análise de correspondências original (NOOY, 2003, p. 314).
} 
aproximado da região do espaço que reúne aqueles agentes que partilham a característica destacada. Linhas guia e/ou formas geométricas foram utilizadas, adicionalmente, para enfatizar as clivagens observadas nos espaços representados. Os agentes e as instituições aparecem nas redes representados por círculos, sendo o tamanho e a coloração de cada um deles indicadores de seu grau de conectividade simples, ou seja do número de agentes com os quais um ponto se conecta. A escolha do grau de conectividade como parâmetro para a observação da centralidade e prestígio dos agentes baseia-se na ideia de que quanto mais vasta a rede de laços, maior o capital social do agente e mais ampla sua capacidade de ação (LAZEGA, 1998, pp. 45-47).

A sucessão das redes apresentadas ao final de cada capítulo é concebida como uma sucessão de fotografias do espaço dos economistas em que se registra sua configuração em cada momento do tempo. A comparação das fotografias permite tecer considerações acerca da mudança de posição dos agentes e do tipo de clivagens observadas em cada retrato. Evidentemente o enquadramento e o foco de cada foto variam em função da narrativa. Retratos diferentes dão destaque a sujeitos, grupos e regiões distintos, recaindo a ênfase sobre as particularidades e o papel específico que desempenham naquele momento. Visto ser a narrativa construída a partir de um conjunto limitado de relatos não se tratando de representações completas do universo, resultantes de experimentos em que se tem a resposta sim ou não para qualquer par de vínculos - há uma tendência a que os agentes que são centrais na narrativa ganhem destaque na rede. A escolha dos agentes em foco decorre, não obstante, das propriedades sociais que fazem deles agentes centrais, seja por ocupar posições de visibilidade e poder no interior do espaço dos economistas ou no campo do poder, seja por sua capacidade de atuar como intermediário entre diversos grupos.

No Finale, os dados proposopográficos elementares dos principais agentes abordados na tese, sintetizados nos quadros apresentados ao final dos capítulos, são analisados com a intenção de comparar sistematicamente as propriedades sociais do grupo retratado, iluminando mudanças de caráter geracional e a existência de homogeneidades e dissimilaridades que condicionam a coesão ou o conflito entre as frações dos grupos investigados (CHARLE, 2001; LEBARON, 2006, p. 39; MICELI 2001, pp. 347, 355; STONE, 2011). 


\section{ABERTURA7: Em busca de um pensamento autóctone: batalhas diplomáticas por uma Comissão Econômica para a América Latina (CEPAL) e as rotas de ingresso do pensamento cepalino no Brasil (1948-1964)}

A Abertura da tese, que antecede o estudo dos movimentos do espaço dos economistas no Brasil, faz um desvio cronológico e geográfico em direção ao Chile com o objetivo de expor brevemente o processo de criação e consolidação da Comissão Econômica para a América Latina e o Caribe $^{8}$ (CEPAL). Esse desvio justifica-se pela centralidade que a instituição teve na irradiação, pelo continente, de uma análise do desenvolvimento econômico, historicamente e geograficamente situada, que, em sua busca pela compreensão dos efeitos específicos da inserção periférica no sistema internacional, contrapõe-se a alguns constructos centrais da teoria econômica canônica. Além de fornecer um enquadramento teórico e conceitual para pensar a relação centroperiferia, a Comissão funcionou como um polo agregador de especialistas em economia de diversos países da América Latina interessados na busca de caminhos para romper a condição periférica. Por fim, como agência vinculada à Organização das Nações Unidas (ONU), a CEPAL conferia legitimidade às políticas de desenvolvimento e às experiências de planejamento que os especialistas por ela formados começaram a ensaiar nos países latino-americanos (LOVE, 1996, p. 207; MONTECINOS, 2009, p. 147; BIELSCHOWSKY, 1997, p. 97; COLISTETE, 2007, p. 27).

Parte substantiva das reflexões acerca do desenvolvimento econômico cultivadas no Brasil, a partir dos anos 1950, esteve ancorada nos constructos cepalinos. A circulação de pessoas e de ideias entre o Brasil e Santiago é, certamente, peça fundamental na configuração da ciência econômica e da política econômica no Brasil. Além de promover uma breve incursão na história da CEPAL, a Abertura deverá expor as principais rotas de aproximação entre a CEPAL e o espaço composto pelos economistas, escolas de economia e órgãos de Estado encarregados da gestão econômica no Brasil e oferecer subsídios para que se compreenda porque a vinculação ao ideário da CEPAL, ou a oposição a ele, transformou-se em um eixo central de fracionamento desse espaço.

\footnotetext{
${ }^{7} \mathrm{O}$ termo abertura foi escolhido por referir-se precisamente a um trecho que, apresentado antes que se abra a cortina para iniciar a representação, introduz elementos que permearão o espetáculo que se segue (VIGNAL, 1999, p. 636).

${ }^{8}$ Até 1984 chamava-se apenas Comissão Econômica para a América Latina.
} 
A narrativa da Abertura, que cobre o período que vai do final dos anos 1930 à metade dos anos 1960, é costurada pela apresentação das trajetórias, ou seja, dos deslocamentos no espaço social, dos especialistas em economia que desempenham os papéis principais nos episódios narrados. A escolha de agentes singulares como ponto fulcral das tramas não incorre numa ilusão biográfica, visto que os dados biográficos são discutidos dentro de um contexto histórico e social que dá sentido aos personagens, aos episódios e aos entroncamentos de trajetórias descritos (BOURDIEU, 1986; GARCIA, 1998, p. 52). A maior parte dos envolvidos nos eventos descritos na Abertura desempenharam papel na história da construção do espaço dos economistas e das instituições econômicas brasileiras, razão pela qual busca-se, desde já, situá-los socialmente, apontando quais vínculos pessoais, institucionais e circulações foram estratégicos para que acumulassem os trunfos, o poder e o prestígio de que se valem em sua atuação no universo dos especialistas em economia.

O texto da Abertura inicia-se (item 1.1) com a apresentação do cenário geopolítico do final dos anos 1940, momento no qual Hernán Santa Cruz apresentou à ONU a proposta de criação da CEPAL. Como se explicitará adiante, o contexto descrito é semelhante àquele no qual o Banco Nacional de Desenvolvimento Econômico (BNDE) brasileiro é gestado. Ambos foram fruto de negociações com os Estados Unidos que ocorreram entre o final da Segunda Guerra Mundial e a estruturação da Guerra Fria. Em seguida (item 1.2), será esboçada a trajetória do mais conhecido economista da CEPAL, Raúl Frederico Prebisch Linares, com o intuito de situar historicamente a gênese das principais ideias cepalinas e apresentar as premissas por ele desenvolvidas, oferecendo pistas para explicar porque, via de regra, elas foram recebidas com grande entusiasmo na periferia e com certa ojeriza no centro.

A partir da trajetória de Celso Monteiro Furtado (item 1.3), será abordada a transferência das ideias cepalinas para o Brasil já que ele, além de ter sido o primeiro representante brasileiro na CEPAL, traduziu e conseguiu publicar no Brasil o 'Manifesto' cepalino, participou de encontros e palestras que divulgaram no Brasil o pensamento da Comissão, assumiu a coordenação das atividades do grupo misto CEPAL-BNDE, ocupou o cargo de diretor do BNDE, criou e dirigiu a Superintendência do Desenvolvimento do Nordeste (SUDENE) e foi Ministro Extraordinário do Planejamento; tecendo um denso emaranhado de elos entre a CEPAL e o Brasil. A 
apresentação do itinerário de Celso Furtado nestes anos iniciais de sua atividade como economista permite, ademais, fazer considerações acerca do surgimento, em 1938, do Departamento Administrativo do Serviço Público (DASP), que pode ser definido como marco inicial do processo de formação de uma burocracia especializada no Brasil (PEREIRA, 2008, pp. 50-51). Se o DASP foi uma primeira iniciativa do presidente Getúlio Dornelles Vargas em direção à racionalização da atividade administrativa do Estado, a montagem, em seu segundo governo, de uma Assessoria Econômica vinculada diretamente à Presidência da República e encarregada do planejamento econômico, constitui um segundo avanço do processo de racionalização da gestão pública. A trajetória de Cleantho de Paiva Leite, amigo de infância e colega de DASP de Celso Furtado, e de três outros nordestinos, Ignácio de Mourão Rangel, Jesus Soares Pereira e Rômulo de Almeida, representantes da Assessoria de Vargas, conduzirão o leitor aos embates pela consolidação da CEPAL que ocorreram em 1951 (item 1.4). Por fim, ingressarão na narrativa Antonio Barros de Castro, Carlos Lessa e Maria da Conceição Tavares (item 1.5), três funcionários do escritório CEPAL-BNDE, que ajudarão a difundir o pensamento cepalino no Brasil.

No trecho final da Abertura (item 1.0), será apresentada e descrita a primeira rede social, construída a partir dos vínculos mencionados no capítulo, enfatizando os princípios de polarização do espaço social e a conexão entre propriedades e disposições dos agentes e as posições por eles ocupadas na rede.

\subsection{Hernán Santa Cruz e a criação de uma Comissão Econômica para a América} Latina

O surgimento da CEPAL deve ser compreendido dentro do panorama econômico e geopolítico do pós-Segunda Guerra Mundial, no qual os países latino-americanos, especialmente aqueles que colaboraram militarmente com os Aliados, esperavam poder contar com auxílios econômicos para reparar os danos provocados pelos anos de isolamento e compensar a colaboração no esforço de guerra. A resposta que habitualmente recebiam era: o destino prioritário do auxílio internacional deve ser o conjunto de países diretamente danificados pela guerra, ou seja, os países europeus e 
asiáticos que sediaram o conflito, devendo a América Latina esperar ou buscar outras fontes de financiamento para promover o seu desenvolvimento econômico.

O Conselho Econômico e Social da ONU (ECOSOC) já havia autorizado a instalação de duas comissões econômicas regionais - uma para a Europa (UNECE) 9 outra para a Ásia e o Extremo Oriente (ECAFE) ${ }^{10}$, ambas criadas em março de 1947 quando o delegado permanente do Chile junto à Organização das Nações Unidas, o advogado e diplomata Hernán Santa Cruz Barceló (1906-1999), propôs que se criasse uma Comissão Econômica para a América Latina. Santa Cruz era neto, por parte de pai, de Joaquín Santa Cruz Vargas, senador, filólogo e historiador, e, por parte de mãe, de José María Barceló Carvallo, parlamentar, ministro da Justiça e Presidente da Suprema Corte chilena. Seu pai era advogado e funcionário do Ministério das Relações Exteriores, tendo exercido os cargos de Auditor Geral de Guerra e prefeito da comuna de Ñuñoa. Foi através dele que Santa Cruz, ainda estudando direito na Universidade de Chile, ingressou no serviço público chileno, indo trabalhar na Auditoria de Guerra quando esta era controlada por seu pai (ORELLANA, 2014, pp. 82-83). Além dos trunfos advindos de

\footnotetext{
${ }^{9}$ A UNECE era dirigida por Karl Gunnar Myrdal (1898-1987). "Myrdal nasceu na província de Dalarna, na Suécia em 1898 e cresceu no campo [...] Ele estudou inicialmente direito na Universidade de Estocolmo. Logo mudou para economia e, em 1927, completou a sua tese de doutorado sobre o problema da formação de preços em condições de mudança econômica, com destaque para o papel das antecipações. [...] Myrdal foi, inicialmente, um teórico econômico "puro", mas envolveu-se profundamente em debates sobre política econômica. A princípio Myrdal foi um economista ortodoxo, trabalhando na tradição neoclássica, fascinado por modelos matemáticos abstratos [...]. A transição de Myrdal de economista ortodoxo para economista político e social começa em 1929, com a atribuição da Bolsa Rockefeller para que Myrdal e sua esposa Alva estudassem nos Estados Unidos. Lá, Myrdal confrontou a posição da economia institucional e testemunhou a tensão racial, as favelas, pela primeira vez, e os efeitos do crash da bolsa. Ele moveu-se na direção de uma perspectiva multidisciplinar (o que se reflete em seus escritos do início dos anos $1940 \mathrm{em}$ diante), descrevendo-se como um institucionalista. Ao longo de sua carreira, Myrdal trabalhou os "grandes problemas", consciente da natureza multifacetada dos problemas econômicos e sociais e da necessidade de uma pesquisa cuidadosa. Depois de passar um ano nos Estados Unidos como um Rockefeller Fellow, em 1929 Myrdal fez um levantamento dos problemas monetários e cambiais da Suécia. Ele tornou-se um conselheiro do novo governo socialdemocrata em 1932, e membro do Parlamento em 1935. Myrdal estava fortemente engajado em mostrar os possíveis benefícios de uma política fiscal expansionista, desempenhando um papel pioneiro no desenvolvimento de um quadro teórico para a análise da política fiscal (1934). [...]. De 1933 a 1939, ele foi professor de economia política na Universidade de Estocolmo. Ele envolveu-se ativamente na vida política sueca na década de 1940, retornando ao Parlamento e sendo nomeado Diretor do Banco Central, Presidente da Comissão de Planejamento e Ministro do Comércio (1945-1947). Ele tornou-se secretário executivo da Comissão Econômica das Nações Unidas para a Europa em 1947, cargo que ocupou por dez anos". Além disso recebeu o premio Nobel de Economia em 1974" (SAWYER, 2000, pp. 424-425, tradução minha). Cabe ressaltar a existência de similaridades com a carreira de Raúl Prebisch, primeiro diretor da Comissão para a América Latina. Ambos começaram suas carreiras como economistas de viés ortodoxo até serem confrontados com os efeitos da crise econômica de 1929, que fez com que notassem a importância da intervenção do Estado na condução da política econômica. Se Myrdal teve que ir até os Estados Unidos para entrar em contato com a crise social e econômica gerada pelo crash, Prebisch vivenciou isso em seu próprio país, no Banco Central, como será discutido no próximo item. Myrdal segue sendo um economista de prestígio em seu país onde tem a oportunidade de aconselhar partidos e governos. Prebisch, ao contrário, passa a vida como um apátrida com prestígio internacional, pois os sucessivos ditadores argentinos viam-no com extrema desconfiança.

${ }^{10}$ Atualmente Comissão Econômica e Social para a Ásia e Pacífico (ESCAP).
} 
sua origem social privilegiada, da rede política de seus antepassados e do diploma adquirido na Faculdade de Direito, Santa Cruz costurara seus próprios laços no universo político chileno, que seriam essenciais para que ele obtivesse cargos de confiança como a representação do Chile na ONU e para que tivesse poder para propor e sustentar um projeto como a CEPAL.

$\mathrm{Na}$ Faculdade de Direito, Santa Cruz aproximou-se de vários políticos de sua geração, entre os quais os futuros presidentes Gabriel González Videla (1989-1980), Eduardo Frei Montalva (1911-1982) e Salvador Allende Gossens ${ }^{11}$ (1908-1973) posicionados no espectro da esquerda chilena: Partido Radical, Democratas Cristãos, Comunistas, Socialistas e a Frente Popular -, que frequentavam assiduamente a casa de sua família ${ }^{12}$. Santa Cruz havia sido designado secretário geral do Instituto ChilenoBrasileiro de Cultura e, nessa condição, foi convidado, em 1944, a passar quatro meses no Rio de Janeiro, onde aproxima-se do embaixador chileno no Brasil, Gabriel González Videla. Dessa amizade resultou a cooperação intensa de Santa Cruz na elaboração do programa de governo de Videla, especialmente no que dizia respeito à temática internacional. Videla foi eleito Presidente da República Chilena em 1946 e designou Santa Cruz para o cargo de primeiro embaixador do Chile na ONU, valendo-se de sua fluência em francês, língua franca de seu tempo, pois até então não havia estudado inglês. Em 1947 Santa Cruz foi eleito vice-presidente da sessão do Conselho Interamericano Econômico e Social (CIES). Em uma das reuniões do CIES, que tinha como pauta o desenvolvimento latino-americano, Santa Cruz tomou a iniciativa, sem ter recebido qualquer instrução de seu governo, de propor a criação de uma Comissão Econômica para a América Latina. Apresentada em 14 julho de 1947, a proposta foi rapidamente endossada por todos os países latino-americanos (ORELLANA, 2014, pp. 83-87; CRUZ, 1966, p. 12; CRUZ, 2008, pp. 1-2).

O projeto foi baseado na noção de que a América Latina havia entrado em uma grave crise econômica decorrente do esforço para defender a causa das Nações Unidas na guerra, e nas perturbações que ela causou na economia global; e que era necessário "desenvolver a indústria dos países da América Latina e utilizar ao máximo seus enormes recursos naturais para elevar o padrão de vida dos seus habitantes, para ajudar a resolver os problemas econômicos de outros continentes, alcançar um melhor equilíbrio na construção econômica global e intensificar o comercio internacional". A Comissão deveria "estudar as medidas

\footnotetext{
${ }^{11}$ Eduardo Frei Montalva, presidente de novembro de 1964 a novembro de 1970, e Salvador Allende, presidente de novembro de 1970 a setembro de 1973, serão alvo de considerações no terceiro capítulo.

${ }^{12}$ A proximidade com a esquerda chilena faz com que, após o golpe de 1973, Hernán Santa Cruz deixe suas funções diplomáticas e permaneça exilado no exterior por quase dez anos (CRUZ, 2008, pp. 3-4).
} 
necessárias para facilitar uma ação conjunta destinada a promover o progresso económico dos países da América Latina e elevar o nível de atividade econômica desses países, bem como para manter e fortalecer os laços econômicos que os conectam entre si e também com o resto do mundo" e, também "participar da execução dessas medidas" (CRUZ, 1966, p. 14, tradução minha $\left.{ }^{13}\right)$.

Uma vez que as comissões econômicas para a Europa e para a Ásia haviam surgido com o intuito de promover a reconstrução dos países no pós-guerra, a questão imediatamente endereçada à Santa Cruz foi: por que haveria de se criar uma comissão econômica para a América Latina se ela não foi palco da guerra? O Reino Unido, o Canadá e a União das Repúblicas Socialistas Soviéticas (URSS) argumentavam que as comissões econômicas eram instituições temporárias, destinadas tão somente a ocupar-se da recuperação das sociedades devastadas pela guerra, razão pela qual a criação de uma comissão semelhante para a América Latina seria despropositada. Por sua vez os Estados Unidos da América (EUA) argumentavam que já havia um foro legítimo para tratar dos problemas econômicos da América Latina, o CIES, de modo que a criação de uma nova comissão econômica para a região seria uma ação redundante que só resultaria em desperdício dos parcos recursos internacionais. Os latino-americanos não desistiram do projeto, já que consideravam ter sido atingidos pela guerra, ainda que indiretamente, e que não encontravam respaldo para suas aspirações no CIES, que julgavam ser um órgão com pouca influência na vida diplomática sem capacidade para fazer política econômica para a região, logo deslocado para dentro da Organização dos Estados Americanos (OEA), orientada fundamentalmente para as questões políticas e de segurança internacional e amplamente dominada pelos interesses norte-americanos (PERLOFF, 1969, p. 9).

Com ajuda de seu irmão Alfonso Santa Cruz Barceló14 (1907-1990), funcionário das Nações Unidas que acabara de concluir sua pós-graduação em Harvard, Hernán Santa Cruz conseguiu recolher dados para convencer os membros do ECOSOC que:

nossa região, ainda que não tenha sido devastada por uma catástrofe como a que assolou a Europa, vivia em um estado de atraso e necessidades tais que se justificava, por parte das Nações Unidas, uma atenção especial como a que foi dada aos continentes que haviam experimentado os horrores da guerra. Mencionei, em seguida, a contribuição decisiva da América Latina para a vitória dos aliados ao fornecer-lhes petróleo, cobre e outros minerais, açúcar, café,

\footnotetext{
${ }^{13}$ Todas as traduções das citações em língua estrangeira que aparecem no texto são de minha responsabilidade e foram feitas em conjunto com Iris Kochen a quem agradeço enormemente.

${ }^{14}$ Rodrigo Santa Cruz conta que "Alfonso Santa Cruz, irmão do meu pai, era colaborador próximo do Dr. Prebisch. O tio Alfonso foi secretário da Comissão [CEPAL], diretor do escritório mexicano e secretário executivo adjunto da CEPAL até que em 1964 o presidente Frei [Montalva] nomeou-o embaixador do Chile em vários países da Europa e da Comunidade Econômica Europeia" (CRUZ, 2008, p. 3).
} 
algodão, lã, nitratos, etc., a preços congelados em baixos níveis, enquanto as manufaturas, incluindo bens de capital que não puderam ser adquiridos durante o período bélico alcançavam, em 1947, preços mais altos a cada dia. Salientei que a conflagração mundial também havia prejudicado gravemente a América Latina, ao impedi-la de renovar seu maquinário industrial, que agora estava se esgotando e ao distorcer o sentido e o ritmo de sua industrialização incipiente (CRUZ, 1966, p. 16).

Os latino-americanos argumentavam, ademais, que o desenvolvimento econômico da América Latina deveria ser um tema abordado em escala global e não restrito ao âmbito regional como propunham os estadunidenses (POLLOCK, 1978, pp. 58-59).

Hernán Santa Cruz destaca a importância do ex-ministro da economia francês - e futuro primeiro ministro da França -, Pierre Mendes France (1907-1982), para a vitória da proposta latino-americana. Mendes France disse a ele que, caso fossem incluídas na comissão a França, a Holanda e a Grã-Bretanha, que possuíam também territórios na região, ele conseguiria reunir votos favoráveis das nações europeias para a proposta de Santa Cruz. Ele argumentava, inclusive, que não seria salutar manter a polarização América Latina-Estados Unidos verificada nos demais organismos panamericanos, razão pela qual lhe parecia vantajoso incluir a Europa na Comissão. A entrada dos europeus na Comissão ocorreu, apesar da oposição dos Estados Unidos, que via seu grau de influência sobre a nova organização diminuído. A CEPAL foi formalmente instituída em 25 de fevereiro de 1948, tendo sido a proposta apoiada por 15 dos 18 membros do ECOSOC. Registraram abstenções: Estados Unidos e Canadá, e a URSS, que teve seu pedido de ingresso na Comissão rejeitado, cisto que o critério adotado foi que a nova comissão seria aberta a todos os países das Américas, incluindo os europeus que tinham territórios no continente. Decidiu-se, também, que a sede da entidade seria instalada em Santiago, no Chile, que era, afinal, o país que apresentara a proposta (CRUZ, 1966, pp. 19-20, 27-29; CRUZ, 1988, pp. ix-xii; POLLOCK, 1978, p. 59; PREBISCH, 2001, p. 13$)^{15}$.

Os primeiros anos de existência da CEPAL foram marcados por repetidas ameaças à continuidade dos trabalhos da instituição. Uma das condições acordadas no momento do estabelecimento da Comissão era que seu trabalho fosse avaliado três anos depois, para determinar se os objetivos propostos foram alcançados e julgar se havia necessidade de que ela continuasse ativa. As objeções da diplomacia norte-americana à CEPAL não cessaram, o que inquietava os defensores da organização que previam um desfecho

15 Ver: http://memoria.bn.br/DocReader/DocReader.aspx?bib=089842_05\&PagFis=40314. Consultado em $16 / 01 / 2016$. 
amargo na reavaliação de 1951, caso a produção da instituição não se notabilizasse (CRUZ, 1966, pp. 31-32; GONÇALVES, 2011, pp. 27, 54). Se o descontentamento dos Estados Unidos com a Comissão decorria, no princípio, da simples rejeição de qualquer ingerência das Nações Unidas sobre a América Latina ${ }^{16}$, que consideravam ser área de sua exclusiva influência, com o passar do tempo, o confronto passou a dever-se, cada vez mais, à visão econômica e à concepção de desenvolvimento que a CEPAL adotou, sob a liderança do economista argentino Raúl Prebisch.

\subsection{Raúl Prebisch e o Manifesto Latino-Americano}

O economista argentino Raúl Frederico Prebisch Linares (1901-1986) teve influência determinante na constituição de uma ciência econômica orientada para as nações periféricas e engajou-se pessoalmente na implantação de estruturas econômicas basilares na Argentina e na América Latina. Prebisch ocupou sucessivas posições de destaque nacional e internacional, podendo ser considerado um protótipo do moderno economista do setor público. Ele nasceu na província argentina de Tucumán, e era, diz ele, produto de "velho sangue espanhol e bom sangue alemão" (Raúl Prebisch apud DOSMAN e POLLOCK, 1993, p. 15). Era filho de Albin Prebisch, alemão protestante, nascido em aldeia próxima a Dresden, e de Rosa Linares Uriburu, católica proveniente de família argentina tradicional e distinta da região de Salta, da qual saíram governadores de província, generais, senadores e até presidentes da república. Seu avô materno, Segundo Linares, que era senador e vivia em uma mansão em Jujuy com largos pátios e uma imensa biblioteca com janelas voltadas para os Andes, teve grande influência sobre Raúl, despertando seu interesse pelo estudo dos assuntos públicos. O pai de Prebisch, por sua vez, tinha uma origem modesta, o que fez com que a família materna demorasse a aceitar o casamento e que a "sociedade argentina" nunca visse os rebentos do casal como legítimos membros da elite. Ao chegar à Argentina Albin trabalhou como carteiro e mensageiro, complementarmente, lecionava inglês em uma universidade de Tucumán. Posteriormente conseguiria abrir sua própria gráfica que cresceu até se tornar um dos maiores estabelecimentos do gênero na região. Em seguida expandiu os negócios abrindo

\footnotetext{
${ }^{16}$ Santa Cruz argumenta que essa luta pelo controle da região poderia ser entendida como uma extensão da doutrina Monroe para a área econômica (CRUZ, 1966, p. 31).
} 
uma serraria e uma livraria em Tucumán. Ainda que fosse protestante, ele concordara em educar seus oito filhos ${ }^{17}$ no catolicismo, tendo sido Prebisch enviado a uma escola de padres franceses na qual aprendeu a dominar, desde cedo, os idiomas francês e inglês, além do espanhol. O alemão não lhes foi transmitido por seu pai, para que os filhos fossem tidos como legitimamente argentinos. Depois de participar de uma greve na escola, Raúl foi expulso do colégio católico e enviado para o Colegio Nacional de Jujuy, onde estudou também italiano (LOPÉZ, 2008, pp. 1-2; DOSMAN, 2011, pp. 31-35; DOSMAN e POLLOCK, 1993, pp. 15-16).

Em 1918, Prebisch transferiu-se para a casa de sua tia Luisa Uriburu no elegante bairro de Belgrano, em Buenos Aires, com o intuito de estudar Economia na Facultad de Ciencias Económicas da Universidad de Buenos Aires (UBA), criada em 1913, que funcionou, até 1945, em um andar da Escuela Superior de Comercio Carlos Pellegrini ${ }^{18}$. Raúl Prebisch diz ter sido mais autodidata do que aluno na Universidade: frequentava poucos cursos, em compensação, lia os clássicos, revistas e manuais de economia por conta própria, tendo tido um excelente desempenho acadêmico. Ainda que flertasse com o socialismo, ele era, à época, um economista ortodoxo: franco adepto do padrão ouro e do livre mercado que sonhava em seguir seus estudos em Harvard ou em alguma universidade inglesa. Sonho que não pode concretizar posto que sua família não podia financiar a continuidade de sua formação e que não havia, à época, bolsas de estudos disponíveis (PREBISCH, 2002, pp. 540-542; DOSMAN, 2011; LOPÉZ, 2008, pp. 2-4).

Depois de graduado, Prebisch começou a dar aulas na UBA e na Universidad de la Ciudad de La Plata, ocupando, simultaneamente, posições públicas e privadas de destaque. Foi estatístico da Sociedad Rural Argentina e da Oficina Nacional de Estadísticas, diretor da divisão de estudos econômicos no Banco de la Nación, fundador da Revista Económica, subsecretário da Fazenda (1930-1932), assessor do Ministério de Agricultura e Fazenda (1933-1935) e, finalmente, criador e diretor geral do Banco Central Argentino (1935-1943). Além disso teve, entre 1932 e 1933, sua primeira experiência internacional: passou quase um ano na Europa, movendo-se entre Genebra e Londres

\footnotetext{
${ }^{17}$ Alguns dos irmãos de Prebisch também ocuparam posições de destaque intelectual na sociedade Argentina: Julio Prebisch foi reitor da Universidade de Tucumán e Alberto Prebisch foi arquiteto e construiu, dentre outras coisas, o obelisco de Buenos Aires, marco arquitetônico da cidade. O que indica o grau de prestígio de que a família desfrutava em seu país, malgrado o casamento da mãe com um homem de origem modesta (LÓPEZ, 2008, p. 2; DOSMAN e POLLOK, 1993, p. 16).

${ }^{18} \mathrm{O}$ nascimento das faculdades de economia como anexos das escolas de comércio ocorreu também no caso brasileiro, tema que será discutido adiante (itens 2.1 e 3.1).
} 
para participar dos trabalhos preparatórios da conferência monetária internacional da Liga das Nações, onde diz ter percebido o papel marginal desempenhado por seu país no cenário internacional, malgrado ser a Argentina a oitava economia mundial do período. Prebisch relata que, primeiramente como subsecretário da Fazenda e depois como dirigente do Banco Central, tentou prescrever remédios ortodoxos para abrandar os efeitos deletérios que atingiam a economia argentina na esteira da crise de 1929. Mediante o fracasso desse receituário, acabou por adotar terapias econômicas heréticas: desvalorizar o câmbio, elevar tarifas de importação e dar incentivos para que a indústria se expandisse. Ele conta que o sucesso do comportamento heterodoxo levou-o ao abandono da crença no livre mercado, o que, juntamente com a percepção da condição subordinada de seu país no cenário internacional, deu início à sua reconversão teórica e à sua produção voltada ao entendimento das especificidades da inserção latino-americana no cenário internacional (PREBISCH, 2002, pp. 532-42; DOSMAN e POLLOCK, 1993, pp. 18-21).

Ao final de 1943, os militares, liderados por Pedro Pablo Ramírez e Edelmiro Farrell, assumiram o poder na Argentina. Eles consideravam Prebisch um sujeito "poderoso demais, independente demais e próximo demais da embaixada americana" (DOSMAN, 2011, pp. 205-6), razão pela qual o teriam demitido. Ao deixar o Banco Central, é convidado por diversos países latino-americanos para falar da experiência que ali tivera. A respeito do episódio acima, Víctor Urquidi, funcionário do Banco de México, faz o seguinte comentário:

Em 1943 eu trabalhava no Departamento de Estudos Econômicos do Banco do México, quando soube que o Dr. Raúl Prebisch, Gerente do Banco Central da Argentina, tinha sido forçado a renunciar. O Diretor do Banco do México, Eduardo Villaseñor, a pedido de Daniel Cosío Villegas, logo o convidou para fazer uma visita de cerca de três semanas, para dar palestras sobre sua experiência como banqueiro central. Confesso que não tinha ideia de quem ele era, mas conhecíamos no Departamento de Estudos Econômicos publicações financeiras argentinas, em particular os relatórios anuais do Banco Central. Eu tive oportunidade de conversar com Don Raúl sobre suas experiências na Liga das Nações, no Ministério da Fazenda, no Banco de la Nación e no Banco Central [...]. Em 1944, Raúl Prebisch foi convidado outra vez pelo Banco do México para oferecer um curso a funcionários, economistas e pessoal de Banco e das finanças públicas. Fui nomeado seu contato e acompanhante, e pude me beneficiar de longas conversas com ele; Além disso, o Sr. Raúl foi convidado para várias viagens no interior México com funcionários. Também apresentou no Colegio de México, em um seminário sobre América Latina, um trabalho, já clássico, sobre a vulnerabilidade econômica dos países da América Latina (URQUIDI, 1998, [online]). 
Depois de um período viajando para falar sobre o Banco Central, Prebisch retornou à vida universitária, sendo readmitido na UBA, malgrado suas divergências com o governo (DOSMAN, 2011, pp. 205-6). Ele havia recusado convites para lecionar nos Estados Unidos e ofertas para ocupar posições de direção em burocracias econômicas de outros países da América Latina, pois esperava que a situação política nacional se revertesse, permitindo que voltasse à direção da política econômica de seu país. Suas esperanças esvaíram-se quando o sucessor de Farrell, Juan Domingo Perón, decidiu que o Banco Central deveria estar sob seu comando e a seu serviço, mantendo Prebisch inteiramente afastado. Mesmo assim, ele continuou recusando os convites que recebia, alegando que precisava continuar na Argentina e que estava adoentado. Um deles foi feito pelo especialista em economia brasileiro Eugênio Gudin, com quem teve, em maio de 1947, cordial encontro em Buenos Aires. Gudin escreveu pouco depois, convidando-o “a passar dois meses na Fundação Getúlio Vargas, em um seminário sobre políticas bancárias e monetárias”. Prebisch alega estar doente, propõe reduzir a estadia a um mês e ao final desiste, para decepção dos brasileiros que admiravam seu trabalho no Banco Central Argentino e que ansiavam por seus conselhos para criar uma instituição semelhante no Brasil ${ }^{19}$ (DOSMAN, 2011, pp. 257-8).

No início de 1948, Prebisch também recebeu convite para ser o secretário executivo recém-criada CEPAL.

A notícia da criação da Cepal havia sido recebida por Prebisch com indiferença e
não parecia lhe interessar. Lembrava-se da velha e fracassada Liga das Nações de
seus dias em Genebra e do papel marginal que os países em desenvolvimento
como a Argentina desempenhavam em suas deliberações. O título de "secretário
executivo" também sugeria um papel fraco em uma agência subordinada, distante
do poder em Nova York, com responsabilidade meramente administrativa. Ele
achava que a Cepal não teria nem poder nem influência em uma instituição
dominada por Washington (DOSMAN, 2011, p. 264).

Após a recusa de Prebisch, os criadores da CEPAL chegaram a cogitar o nome de Víctor Urquidi (1919-2004), que tinha uma formação acadêmica considerada de excelência: estudou economia na London School of Economics (LSE) em um momento no qual quase nenhum mexicano estudava fora do país. Lecionou na Faculdade de Economia da Universidad Nacional Autónoma de México (UNAM) e no Centro de Estudios Sociales (CES) do Colegio de México. Além de colaborar intensamente com as

\footnotetext{
${ }^{19}$ A trajetória de Eugênio Gudin e a criação da Fundação Getúlio Vargas serão alvo de considerações adiante (item 2.1).
} 
traduções do Fondo de Cultura Económica, editora mexicana especializada em economia, Víctor tinha uma vivência de quase dez anos na gestão econômica, primeiro no departamento econômico do Banco de México e depois no Banco Mundial. Urquidi era visto como um prodígio, foi, por exemplo, dos mais jovens delegados de Bretton Woods. Possuía vastos trunfos sociais que alavancaram sua rápida ascensão e fácil trânsito nos círculos da expertise econômica internacional: possuía um inglês perfeitamente fluente e modos de gentleman que adquirira em sua excepcional trajetória (URQUIDI, 1998; HODARA, 2008, pp. 50-51; BABB, 2003, p. 116; SÁEZ, 2009, pp. 17-18).

Víctor era neto de ingleses. O seu avô materno trabalhava na tripulação de cruzeiros internacionais e acabara por estabelecer-se em Melbourne, onde nasceu a mãe de Víctor, Beatriz. Após alguns anos, decidiu mudar com a família para a costa da Nicarágua, onde estava sendo construído um canal transoceânico. Depois de ter feito os estudos básicos com a própria mãe, Beatriz foi enviada a Nova York para seguir o curso superior de enfermagem. Lá conheceu e casou-se com o engenheiro mexicano Juan Francisco Urquidi, que se exilara nos Estados Unidos, em 1913, por apoiar os governos democráticos contra a junta militar que se instalara no poder. Em 1917, foi restaurada a constitucionalidade no México. Juan retorna ao seu país e é nomeado para a representação diplomática mexicana em Washington. Na sequência, transfere-se para o serviço exterior em Paris, nascendo seu filho Víctor no abastado subúrbio parisiense de Neuilly. A família só retornou à América Latina em meados dos anos vinte pois Francisco assumiu, em sequência, a representação mexicana na Colombia, em El Salvador e no Uruguai. Em 1935, retornaram à Europa pois o pai foi trabalhar na embaixada do México em Madrid. No ano seguinte, Víctor iniciou sua graduação em economia na LSE concluída em 1940, ano no qual, finalmente, irá viver e trabalhar no México (URQUIDI, 1998; HODARA, 2008, p. 50).

Para a precocidade da ascensão de Urquidi no serviço público contribuiu decisivamente o cosmopolitismo adquirido nos sucessivos deslocamentos de sua família, o vasto domínio de idiomas estrangeiros e a especialização em economia, incomum entre os profissionais mexicanos de seu tempo, advinda de seus estudos na Inglaterra. Chegou a ser sondado para ocupar a posição de secretário executivo da CEPAL, mas não se mostrou interessado e tinha apenas 30 anos, sendo considerado demasiado jovem para o posto. O secretário adjunto para assuntos econômicos da ONU, David Owen, nomeou 
outro economista mexicano para a posição: Gustavo Martínez Cabañas ${ }^{20}$ (1911-2003), nascido na Cidade do México, pós-graduado em administração pública na American University of Washington e graduado em direito e economia na UNAM, escola onde lecionava, além de trabalhar no setor público mexicano (DOSMAN, 2011, p. 274; FURTADO, 2014, p. 59).

Em outubro de 1948, Cabañas voltou a convidar Prebisch para colaborar com a instituição, pedindo a ele que fosse a Santiago para elaborar uma introdução ao Estudo Econômico sobre a América Latina, relatório que pretendiam apresentar na primeira reunião geral da organização. Em decorrência da radicalização das polarizações políticas na Argentina e do endurecimento do regime peronista, Prebisch fora informado que, caso não deixasse seu posto na UBA, ele seria sumariamente demitido. Neste interim, fora incentivado por seu amigo mexicano Víctor Urquidi a candidatar-se para uma posição no Fundo Monetário Internacional (FMI), tendo sua nomeação rejeitada porque suas ideias econômicas começavam a desagradar os Estados Unidos ${ }^{21}$. Totalmente isolado e sem rumo, aceita, por fim, o convite para atuar como consultor da nova organização internacional por 4 meses. Suas atividades em Santiago tiveram início em março de 1949 e deveriam terminar no mesmo ano, o que não ocorreu pois a CEPAL fez dele um homem internacionalmente notável e ele fez dela uma instituição de prestígio (LOVE, 1996 p. 218; PREBISCH, 2001, pp. 10-11; DOSMAN, 2011, pp. 256-257, 270).

O texto El desarrollo económico de América Latina y sus principales problemas, que resultou do período de consultoria de Prebisch à CEPAL, ficou conhecido como 'Manifesto pela industrialização latino-americana' ou 'Manifesto' da CEPAL - termo que teria sido cunhado por Albert Hirschman 22 (GARCIA, 2005, p. 540; LOVE, 1996, p. 228; PREBISCH, 2002, p. 532). Ele sintetiza as ideias que Prebisch concebera no período que transcorreu de sua experiência no Banco Central à ida para Santiago e contém alguns dos principais elementos pelos quais a CEPAL se faria conhecida.

O texto convida aqueles que pretendem pensar o desenvolvimento latinoamericano a romperem - como ele fizera anos antes - com a ortodoxia econômica,

\footnotetext{
${ }^{20}$ Ver: http://www.cepal.org/cgi-bin/getprod.asp?xml=/noticias/paginas/6/14296/P14296.xml\&xsl=/tpl-i/p18fst.xsl\&base=/tpl-i/top-bottom.xsl e http://biblio.juridicas.unam.mx/libros/7/3308/29.pdf. Consultados em $29 / 10 / 2105$.

${ }^{21}$ Edgar Dosman, biógrafo de Prebisch, sustenta hipótese segundo a qual Octavio Gouvêa de Bulhões (item 2.1) teria feito oposição à nomeação para o FMI (DOSMAN, 2011, p. 207).

${ }^{22} \mathrm{O}$ texto é chamado também de Manifesto Singer-Prebisch, por aqueles que veem uma influência decisiva dos estudos de Hans Singer, acerca do declínio das relações comerciais dos países subdesenvolvidos, na formulação de Prebisch (DOSMAN, 2011, pp. 278-9).
} 
argumentando que existiriam especificidades históricas de cada região que deveriam ser observadas com lentes apropriadas. Ele rejeita o receituário do livre comércio e declara que os países da região não poderiam superar sua condição periférica caso permanecessem produtores de bens primários para o comércio internacional - o que defendiam aqueles que acreditavam que o mercado distribuiria automaticamente as riquezas se cada um se especializasse na produção de bens em relação aos quais desfrutasse de vantagens comparativas naturais. O Manifesto sustentava que o comércio internacional não repartiria automaticamente os frutos do progresso técnico entre o centro especializado em artigos manufaturados e a periferia produtora de bens primários $^{23}$. Consequentemente, as diferenças acentuadas nos níveis de vida no centro e na periferia subsistiriam enquanto não fosse implementada uma política ativa para a superação do atraso econômico dos países periféricos, que consistia, essencialmente, na promoção planejada da industrialização. A crise e as guerras, explica, "indicaram positivamente o caminho da atividade industrial" aos países da América Latina, apresentando-se como "único meio de que dispõem para ir captando uma parte do fruto do progresso técnico e elevando progressivamente o nível de vida das massas”, porquanto ofereceria trabalho a pessoas desempregadas ou mal empregadas, incrementando a produtividade do sistema e, assim, elevando a renda nacional (PREBISCH, 2011).

Após clamar pela industrialização, Prebisch sinaliza que essa não é incompatível com o incremento da produção primária orientada para o mercado internacional, até porque esta forneceria os recursos necessários para a importação dos bens de capital necessários tanto à industrialização quanto à modernização da agricultura. Ademais, afirma que a redução das importações por parte dos países periféricos seria saudável ao próprio sistema internacional, já que permitiria que estes reduzissem seu déficit e pudessem honrar seus compromissos financeiros com os países credores. Finalmente, o autor destaca que investimentos estrangeiros bem encaminhados poderiam contribuir para o aumento imediato da produtividade da periferia e, consequentemente, para a melhoria das condições econômicas e de vida, razão pela qual os países da América Latina clamavam por ajuda financeira externa (PREBISCH, 2011).

\footnotetext{
${ }^{23}$ Isso ocorre porque, em momentos de crise, os bens primários teriam seus preços mais fortemente reduzidos do que os bens industriais, dado o baixo grau de organização dos trabalhadores da periferia para a defesa de seus salários - decorrente, em parte, do excesso de mão de obra desocupada que pressiona para baixo os salários e inibe os protestos - que fazem com que os preços na periferia possam declinar mais velozmente quando comparados com os preços dos bens produzidos em nações onde os trabalhadores têm maior força política para a defesa de seus ganhos (PREBISCH, 2002, pp. 533-534).
} 
Cabe analisar porque esses argumentos funcionaram como uma poderosa peça retórica no contexto em que foram lançados. Em primeiro lugar, postula-se que há um centro e uma periferia e que o desenvolvimento econômico dos dois polos não seguiria um trajeto idêntico e natural, posto que, por razões históricas e sociais, os dois foram levados a produzir bens que se comportam de modo distinto no mercado internacional.

Em segundo lugar, afirma-se que, caso fosse mantido o status quo, não ocorreria uma transferência automática do progresso técnico do centro para a periferia, permanecendo esta pobre e estagnada. Razão pela qual o desenvolvimento das nações periféricas requereria ação deliberada dos governos latino-americanos em favor da industrialização. A política em prol da industrialização não era, pois, uma mera afronta protecionista $^{24}$ à boa conduta econômica - como argumentavam os defensores do livre comércio - e sim um caminho legítimo a ser trilhado para a melhoria das condições de vida de seus cidadãos.

Em terceiro lugar, argumenta-se que não apenas aos países latino-americanos caberia a responsabilidade pela redução das desigualdades, devendo o centro colaborar através da concessão de ajuda econômica.

Finalmente, ele diz que essa orientação não seria uma barreira ao comércio internacional, já que era preciso exportar bens primários para adquirir os bens de capital necessários para a implantação da industrialização, e que ela seria, inclusive, favorável aos países desenvolvidos por ajudar a reduzir o déficit dos países da periferia reinstaurando o equilíbrio financeiro do sistema.

Essa abordagem justificava, igualmente, a existência de uma Comissão Econômica para a América Latina que seria necessária por ser capaz de analisar o desenvolvimento da região em suas especificidades e propor soluções sob medida para os problemas dos países do subcontinente. Prebisch relata que escreveu, assinou e enviou o informe às Nações Unidas.

Alguns dias mais tarde, New York enviou-me o telegrama mais longo que havia visto em minha vida [...]. Nesse telegrama faziam uma série de considerações que

\footnotetext{
24 "Nas circunstâncias criadas pelo comportamento da economia internacional, na fase do predomínio do novo centro principal, a propagação do progresso técnico à periferia requer ação deliberada, pois a dinâmica do sistema é insuficiente para impulsá-la. Se por um lado a absorção de sobra de mão-de-obra requer medidas protecionistas, por outro a tendência ao desequilíbrio externo exige a aplicação de critérios seletivos de importação. A conjunção dessas duas conclusões de caráter normativo conduziria à doutrina da industrialização orientada para a substituição de importações" (FURTADO, 1997a, p. 177). A conjunção dessas duas orientações, protecionismo e ação intervencionista, consideradas hereges pela boa doutrina, estaria na raiz da industrialização por substituição de importações.
} 
terminavam da seguinte forma: "O relatório é um documento de grande conteúdo. Mas fala do desenvolvimento, da industrialização, da relação de preços de intercâmbio e muitas outras questões que não competem à CEPAL. A CEPAL não tem autoridade para resolver estes problemas. No entanto, como o documento é um documento sério e responsável, sugerimos [a Martínez Cabañas] apresentá-lo como uma introdução assinada pelo autor, a fim de atribuir a responsabilidade a ele e não à organização". Lembro-me que Martínez Cabañas veio ver-me muito preocupado, pensando que eu me enfureceria. Eu disse: "Gustavo, eu nunca imaginei que assinaria o documento. Eu coloquei nele minhas ideias pessoais. Não as dilui. Portanto, estou plenamente de acordo" Acredite que a acolhida que o documento teve na Conferência da CEPAL em Havana pelos países latino-americanos foi simplesmente incrível. Elogios por toda parte. Por outro lado, também houve reações convencionais dos Estados Unidos, assim como do Reino Unido, e um pouco melhores da França (PREBISCH, 2001, p. 11).

“O Manifesto criou sensação na imprensa latino-americana e consternação entre os representantes oficiais mais graduados de Washington, que perceberam a sua força" (DOSMAN, 2011, pp. 284-5). Prebisch era um homem dotado do carisma, da oratória e dos requintes nos modos exigidos à elite latino-americana cosmopolita, ou seja, dispõe das propriedades simbólicas que são pré-requisitos para fazer-se legítimo representante das aspirações das frações modernizadoras e nacionalistas das elites latino-americanas. Imbuído da crença na verdade de sua pregação e na sua missão crítica, condição de sua eficácia simbólica, transforma-se em um profeta contestador das ideias da velha igreja. Sua heresia, anunciada como revelação, ecoa porquanto oferece a um grupo de crentes pronto a negar a igreja, uma resposta à fratura social que estão experimentando em um contexto de crise (BOURDIEU, 1971, pp. 317 ss.).

O período de guerras, que desestruturou o arranjo político e econômico vigente, era precisamente esse contexto propício à aparição de profetas que conseguissem nomear as transformações em curso e expressar a posição dos descontentes. A experiência de ruptura percebida pelas frações modernizadoras das elites periféricas, no período que vai da Primeira Guerra Mundial, passando pela Crise de 1929 e chegando ao pós-Segunda Guerra, é retoricamente articulada no discurso deste que anuncia sistematicamente a possibilidade de conduzir autônoma e ativamente o desenvolvimento econômico, usando medidas amplamente condenadas pelos cânones para criar sua própria rota de progresso. Prebisch é assim aquele capaz de fazer coincidir a "revolução com ela mesma, operando a revolução simbólica que conclama a revolução política” (BOURDIEU, 1971, p. 334). Furtado chega a brincar com a ideia do missionário religioso ao comentar com Jorge Ahumada que "nós, sem o saber, constituímos uma Ordem, a dos pregadores da fé no 
Desenvolvimento. Ele riu e disse: o pior é que os jesuítas começaram a concorrer conosco e eu não sei o que vai sair de tudo isso" (FURTADO, 2014, p. 407).

O que desagradava à igreja da teoria econômica ortodoxa nesse discurso era que ele clamava por intervenções estatais voltadas para a industrialização dos países da América Latina, prevendo medidas protecionistas que bloqueavam seu fluxo de exportações para a periferia. Argumentava-se que, caso tivesse sucesso, a industrialização da periferia poderia levar, no médio prazo, a uma supressão da dependência da região em relação aos capitais externos e aos bens importados do centro, alterando o status quo político e econômico do sistema internacional.

A vasta repercussão do Manifesto apresentado em Havana convenceu Prebisch da potência do organismo regional como foro de discussão e contraponto às nações centrais, levando-o a prolongar suas atividades na CEPAL. Ele assume inicialmente a direção de um centro de pesquisas, convidando para trabalhar diretamente com ele o jovem economista brasileiro Celso Furtado, que ingressara na CEPAL poucas semanas antes do início do seu período como consultor. Em maio de 1950, Prebisch substitui Martinez Cabañas na Secretária Executiva da CEPAL, posição que ocupou até julho de 1963.

\subsection{Celso Monteiro Furtado do DASP à CEPAL}

O pensamento cepalino repercutiu rapidamente no meio acadêmico, no mundo empresarial e no plano governamental brasileiro. Ele chegou ao Brasil por múltiplas vias: carregado por aqueles que na CEPAL estudaram e trabalharam; por meio da publicação em revistas nacionais de textos seminais da teoria cepalina, como $O$ desenvolvimento da América Latina e seus principais problemas, de Raul Prebisch, traduzido por Celso Furtado e publicado em setembro de 1949 na Revista Brasileira de Economia, que era, à época, dirigida por Eugênio Gudin; através do grupo misto CEPAL-BNDE e do Escritório da CEPAL no Brasil que aqui oferecia cursos de treinamento. De todos os elos que ligavam a CEPAL ao Brasil, provavelmente, o principal tenha sido o economista Celso Furtado, que ajudou a transpor as ideias da CEPAL para a academia e para os vários organismos de governo que ajudou a criar e solidificar, como o Ministério do Planejamento, a SUDENE e o BNDE. A análise da trajetória de Celso Furtado permite reconstituir algumas das rotas de entrada das premissas cepalinas no Brasil. 
Celso Monteiro Furtado ${ }^{25}$ (1920-2004) ${ }^{26}$ nasceu na cidade de Pombal, no sertão da Paraíba. Sua mãe, Maria Alice Monteiro, provinha de família de proprietários de terras da região que fora muito afetada pelas fortes $\operatorname{secas}^{27}$ dos anos de 1915 e 1919. O pai, Maurício de Medeiros Furtado, era membro de uma família de magistrados e, como seus antepassados, foi advogado, juiz e desembargador. Ele era, ademais, maçom e tinha uma grande biblioteca - que foi determinante na formação de Furtado e no despertar de sua paixão pela literatura, atividade à qual acreditava que se dedicaria - e acabou sendo eleito membro do Instituto Histórico e Geográfico Paraibano e da Academia Paraibana de Letras $^{28}$. Furtado diz ter sido ateu desde muito jovem e ter flertado com o positivismo quando adolescente. Influência que foi acrescida do contato, ainda no ginasial, com os escritos de Karl Marx e com a sociologia norte-americana, em especial com a antropologia da cultura, via Gilberto Freyre (FURTADO, 1997, pp. 12-16).

Após cursar os estudos secundários em Pernambuco, Celso Furtado transferiu-se para o Rio de Janeiro, onde frequentou a Faculdade Nacional de Direito, diplomando-se advogado em 1944. Interessou-se por temas ligados à economia apenas nos dois últimos anos da graduação e diz: "o que fiz por conta própria, sem qualquer supervisão. Tivera em anos anteriores dois cursos de economia que me haviam deixado a impressão de que esta era uma ciência menor, para gente sem imaginação” (FURTADO, 1997, p. 19).

Como era regra na época, minha formação de economista era de um autodidata, facilitada pelo estupendo fluxo de publicações com que nos brindava o Fondo de Cultura Económica do México, e apoiada na minha formação jurídica e em estudos especializados de organização e finanças públicas. Mas considerava a economia como um instrumento para penetrar no social e no político, e avançar na compreensão da história, particularmente quando esta ainda se exibia como presente a nossos olhos (FURTADO, 2014, p. 27).

Ao mesmo tempo que começou a estudar economia por conta própria, mergulhou na sociologia, lendo Max Weber, Ferdinand Tönnies, Hans Freyer, Georg Simmel, Henri

\footnotetext{
${ }^{25}$ As datas e eventos da trajetória de Celso Furtado podem ser consultados no site do Centro Celso Furtado no endereço: http://www.centrocelsofurtado.org.br/geral.php?ID_M=478. Consultado em: 16/01/2015.

${ }^{26}$ Informações extraídas de: http://www.centrocelsofurtado.org.br/geral.php?ID_S=64 e http://www.ihgp.net/mauricio.htm. Consultados em 30/10/2015.

${ }^{27} \mathrm{Na}$ carreira de Furtado no Estado o tema das secas será privilegiado. Uma grande seca motivará Juscelino Kubitschek a encarregar Furtado da criação da Superintendência do Desenvolvimento do Nordeste (SUDENE). Imbuída do planejamento para a economia da região a organização tentará repactuar as políticas para a seca, antes atribuída ao Departamento Nacional de Obras Contra as Secas (DNOCS), conhecido como "órgão da indústria da seca" por não investir o suficiente em obras que protegessem sistematicamente a região e por privilegiar as terras pertencentes aos "coronéis" nordestinos (item 2.3).

${ }^{28}$ Informações extraídas de: http://www.centrocelsofurtado.org.br/geral.php?ID_S=64 e http://www.ihgp.net/mauricio.htm. Consultados em 30/10/2015.
} 
Pirenne, Werner Sombart e outros. Segundo ele, essa formação multifacetada fez com que a economia não fosse mais do que um instrumental para entender a história e a sociedade, razão pela qual diz nunca ter podido "compreender a existência de um problema estritamente econômico". No início de 1940 já havia começado a trabalhar como periodista, atividade que exercerá por anos em paralelo a seus empregos principais ${ }^{29}$ (FURTADO, 1997, pp. 19-20).

Em 1943, Furtado foi aprovado no concurso do DASP, órgão de Estado criado em 1938, dirigido pelo engenheiro agrônomo Luiz Simões Lopes (1903-1994). Homem de confiança de Vargas, Simões provinha de uma família importante na vida política gaúcha ${ }^{30}$. Seu avô paterno, João Simões Lopes Filho, era um estancieiro que chegou a exercer a presidência da província do Rio Grande do Sul e seu pai, Idelfonso Simões Lopes, era engenheiro e foi Deputado Federal pelo Rio Grande do Sul por quase vinte anos, Ministro da Agricultura entre 1919 e 1922, e um dos articuladores da Aliança Liberal de Getúlio Vargas. Assim que a Aliança fez-se vitoriosa, Luiz Simões foi nomeado oficial-de-gabinete do novo presidente. A partir desse posto, encarregou-se de dirigir o processo de reforma administrativa do setor público que deu origem ao DASP, cuja missão era organizar, modernizar e centralizar o controle do serviço público brasileiro. Razão pela qual é possível dizer que sua criação é um marco inicial ${ }^{31}$ da história da racionalização da administração pública no Brasil (DHBB, verbete Luiz Simões Lopes; LOPES, 2003, p. 36).

Com o intuito de otimizar os processos burocráticos, o DASP procurava promover divisões claras de tarefas entre os departamentos e racionalizar os processos de trabalho da burocracia. Ele passou, igualmente, a organizar o recrutamento de quadros para o funcionalismo, estabelecer planos de carreira e promover atividades de aperfeiçoamento de pessoal. Para tanto, elevou o número de burocratas concursados de 140, em 1947, para 17.345, ao final de 1950. Passou também a oferecer bolsas para que os funcionários públicos frequentassem universidades e repartições no exterior com o objetivo de estudar as ciências da administração e adquirir competências especializadas (LOPES, 2003 p. 22; SILVEIRA, 2009, pp. 42-43). Ao modernizar os procedimentos de

\footnotetext{
${ }^{29}$ Furtado escreveu, por exemplo, para a Revista da Semana, o semanário Panfleto e O Observador Econômico e Financeiro (FURTADO, 2014, p. 27).

${ }^{30}$ Luiz Simões Lopes era primo de segundo grau de Lucas Lopes, que será alvo de considerações adiante (item 2.3).

${ }^{31}$ Outro marco foi a criação do Instituto de Organização Racional do Trabalho (IDORT), fundado em 1931, apresentado adiante (item 4.1).
} 
trabalho, profissionalizar o recrutamento dos burocratas e incentivar a especialização, o DASP prenuncia a criação de cursos universitários voltados para o aprendizado da técnicas de gestão e dos princípios econômicos, fomenta a entrada no governo de especialistas em economia e cria as condições para a constituição, nos anos 1950 e 1960, das ditas ilhas de eficiência burocráticas, entre as quais o BNDE(S) (EVANS, 1995).

Em seu livro de memórias A fantasia organizada, escrita entre a metade dos anos 1980 e o início dos 1990, Furtado aproxima o DASP da descrição de uma burocracia weberiana e reporta uma desconfiança semelhante à de Weber $^{32}$ em relação a ela quando diz que o órgão

simbolizava, na opinião geral, o espírito do período ditatorial que havia pouco se encerrara: preocupação máxima com a eficiência e mínima com os fins últimos perseguidos. Tutelada por essa instituição, a máquina burocrática fora levada a extremos de racionalização, dentro dos critérios da chamada organização científica do trabalho. [...] Ora, essa engrenagem administrativa tão bem azeitada não perseguia nenhum propósito claro. Nunca houve um plano de governo, nem definição de diretrizes, tudo permanecendo nas dependências de ocasionais iniciativas de ministros que eram escolhidos em função da composição de forças políticas estaduais em que se apoiava o ditador. $\mathrm{Na}$ ausência de uma orientação global, nada assegurava a coerência das ocasionais iniciativas ministeriais, muitas vezes meritórias. A única lógica era a da reprodução do sistema de poder, tudo devendo convergir para reforçar a posição do ditador. Desaparecido este, o DASP fora em grande parte esvaziado (FURTADO, 2014, pp. 54-55).

Celso Furtado argumenta que, malgrado seu insucesso em caminhar em alguma direção política nítida, o DASP legou ao serviço público brasileiro uma estrutura administrativa sem a qual não teria sido possível conceber os planos econômicos das décadas seguintes, a começar pelo pioneiro, ainda que muito limitado, Plano Salte do governo Eurico Gaspar Dutra (BASTOS, 2010, pp. 308, 314).

No ano em que diplomou-se em Direito, Furtado foi convocado para a Força Expedicionária Brasileira, embarcando para a Itália com aspirante a oficial. Pouco depois do término da guerra, decide afastar-se por um tempo do DASP e retornar à Europa, diz ele, "para observar de perto o drama europeu", "a cena social e humana que aí se armara", o "laboratório social" do pós-guerra. Furtado, que falava bem o francês e o inglês, planejava viajar livremente pela Europa e cultivava especial interesse pelo Leste

\footnotetext{
${ }^{32}$ Weber percebera os riscos decorrentes da organização burocrática racional quando submetida ao desígnios de políticos que poderiam ser escolhidos não com base em valores e competências mas simplesmente por seu carisma. Ele reconhecia também que o emprego burocrático da racionalidade em direção a fins constrangedores da liberdade humana poderia levar os homens racionalmente a um futuro sombrio. Temores que se concretizaram, por exemplo, na Segunda Guerra Mundial, que ocorreu quase duas décadas após seu falecimento (JAY, 2008, p. 171;WEBER, 2011, pp. 78-79).
} 
Europeu, mas foi dissuadido de seu plano de visitar a URSS dada a dificuldade política de acesso à região. A alternativa pragmática que encontrou foi assegurar sua renda com os artigos que continuava escrevendo para os periódicos brasileiros e fixar-se em Paris onde conseguiu um vínculo universitário que assegurava a sua permanência no continente (FURTADO, 2014, pp. 26-7; O LONGO AMANHECER - CINEBIOGRAFIA DE CELSO FURTADO).

Maurice Byé (1905-1968), um dos professores convidados pelo Ministro da Educação e da Saúde Gustavo Capanema para juntar-se à missão francesa que viria ao Brasil para lecionar na Faculdade Nacional de Filosofia do Rio de Janeiro (FÁVERO et al., 1991, p. 66), foi quem o aconselhou a inscrever-se no curso de doutorado da Faculdade de Direito e Ciências Econômicas da Sorbonne. Furtado conta ter frequentado, além dos cursos de economia, o Instituto de Ciências Políticas, onde leu Marx sistematicamente. Sob a direção de Byé, que era especialista em comércio internacional e discípulo de um discípulo de Joseph Schumpeter, Furtado defendeu, em 1948, a tese L'économie coloniale brésilienne, uma leitura do comércio internacional feita por meio da análise do caso da economia do açúcar brasileira no período colonial. O trabalho foi viabilizado pelas excursões de Celso à coleção brasiliana da biblioteca do Musée de l'Homme de Paris, da qual tomou conhecimento através do futuro crítico de cinema, Paulo Emílio Sales Gomes (FURTADO, 2014, p. 37).

De volta ao Brasil, Furtado voltou ao DASP e ligou-se à revista Conjuntura Econômica, editada pela Fundação Getúlio Vargas do Rio de Janeiro (FGV-RJ), que publicava diagnósticos sobre a economia brasileira e indicadores econômicos de curto e médio prazos. Tanto o DASP quanto a edição da revista ficavam alocados em salas do recém-inaugurado prédio do Ministério da Fazenda, na esquina da Avenida Almirante Barroso com a Avenida Presidente Antônio Carlos. A proximidade espacial dos diversos órgãos encarregados da gestão econômica do Estado propiciava a circulação de conhecimentos e informações entre eles, o que foi determinante na trajetória de Furtado. 


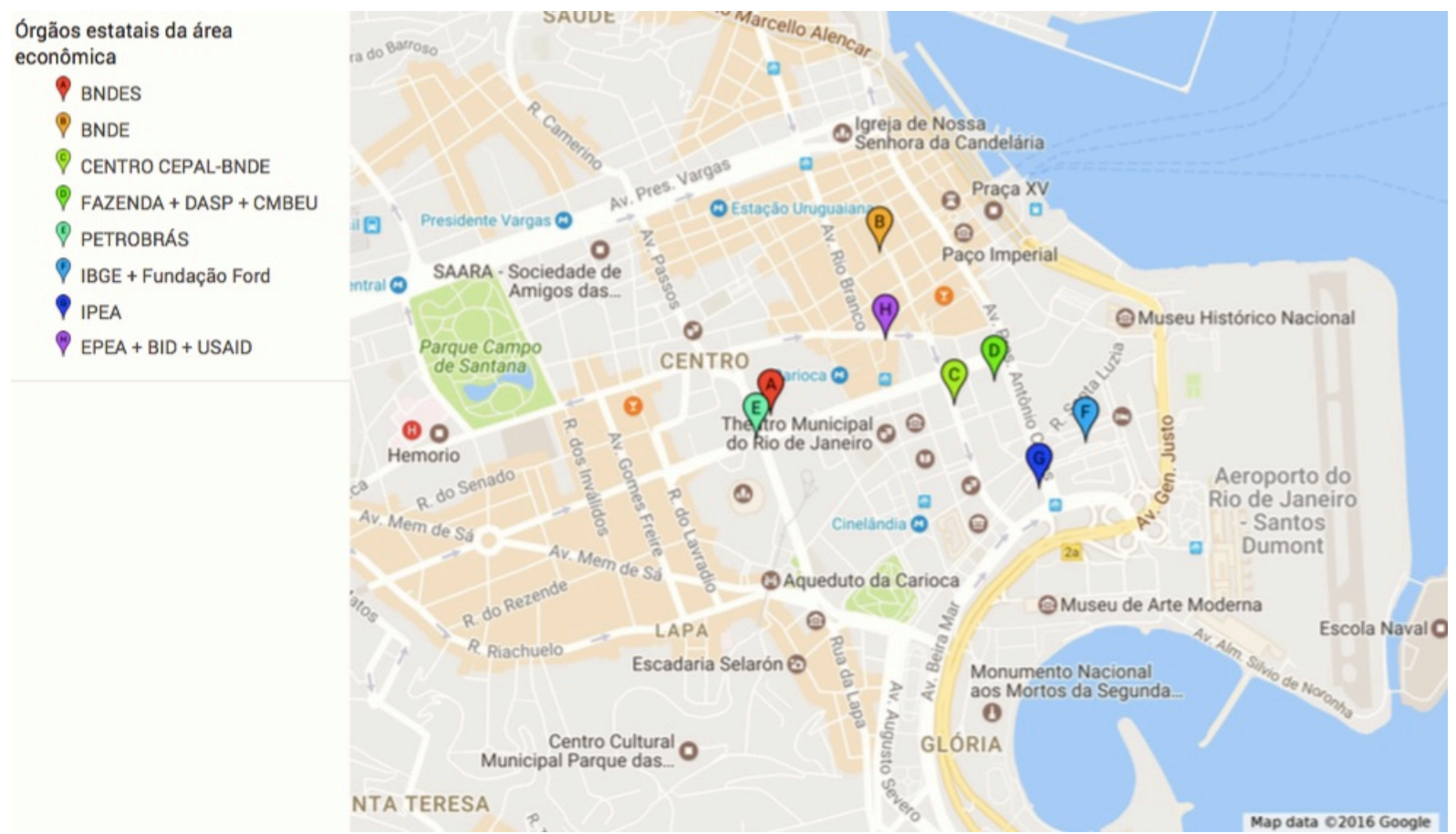

Mapa I: Órgãos estatais da área econômica. Fonte: Google Maps. Elaboração própria

Ele conta que um dia chegou ao gabinete do Dr. Octavio Gouvêa de Bulhões ${ }^{33}$, que à época chefiava a Divisão de Estudos Econômicos e Financeiros do Ministério da Fazenda,

a informação de que buscavam um economista para servir na nova Comissão Econômica para a América Latina (CEPAL), das Nações Unidas, que se instalava em Santiago do Chile [...] quando falei ao Dr. Bulhões [que tinha interesse na vaga] ele se mostrou surpreendido. A Fundação Getúlio Vargas oferecia enormes possibilidades, observou-me. Éramos poucos, os economistas brasileiros, e tudo estava por ser feito no país, mas percebendo que eu tinha opinião formada, disse noutro tom: "Bem, o Secretário Executivo da Comissão, o Dr. Martinez Cabañas, chegará ao Brasil em poucos dias. Peço-lhe que o receba em meu nome, conduza-o ao Copacabana Palace e tome as providências do caso" (FURTADO, 2014, pp. 55-56).

No dia 11 de fevereiro de 1949, Furtado apresentou-se na sede da CEPAL, em uma casa no bairro da Providencia em Santiago do Chile na qual se reunia o staff da organização que até então não passava de dez pessoas, o que corrobora a hipótese de Prebisch quanto a provável fraqueza do órgão. Pouco tempo depois chegou a Santiago Raúl Prebisch que, nas palavras de Furtado, era "sem lugar a dúvida o único economista latino-americano de renome internacional" (FURTADO, 2014, p. 63). O sucesso de Prebisch e de seu Manifesto na Segunda Conferência da CEPAL, realizada na cidade de

\footnotetext{
${ }^{33}$ A trajetória de Octavio Gouvêa de Bulhões será alvo de considerações adiante (item 2.1).
} 
Havana ${ }^{34}$, conferiu credibilidade à produção da Comissão, mitigando o risco de desligamento da instituição, ao término do período experimental, por alegação de ineficiência ou irrelevância. Em contrapartida, a repercussão internacional das ideias da CEPAL era, mais do que nunca, incômoda aos olhos dos países do centro e a sobrevivência da instituição não estava de modo algum assegurada.

$\mathrm{Na}$ Conferência de 1951, realizada na Cidade do México, na qual deveria ser definido o destino da organização, os EUA voltaram a afirmar que havia redundância entre as atividades da CEPAL e aquelas conduzidas pelo CIES, agora incorporado à OEA, criada em 1948, constituindo um espaço no qual os Estados Unidos estavam muito bem posicionados para influenciar as decisões. Depois de entender que não conseguiriam desfazer a Comissão, visto que ela havia tido retumbante sucesso nos últimos dois anos e ganho franco apoio de quase todos latino-americanos ${ }^{35}$, os EUA, representados pelo embaixador Merwin Bohan ${ }^{36}$, engajaram-se na tentativa de fazer com que a as reuniões dela coincidissem com as do CIES-OEA, desprovendo as conferências centrais da CEPAL de sua autonomia. Proposta que também foi rejeitada pelos países da região, satisfeitos com a atual estrutura. Para manter laços estreitos com a América Latina e garantir o apoio político e o abastecimento de bens primários de que necessitavam, especialmente porque eclodia a Guerra da Coréia, a diplomacia norte-americana aceitou, ao final, que a CEPAL preservasse sua independência (DOSMAN, 2011, pp. 308-311; GONÇALVES, 2011, pp. 46-56).

\footnotetext{
34 As primeiras conferências da CEPAL foram realizadas nas cidades de: Santiago (1948), Havana (1949), Montevideo (1950), Cidade do México (1951) e Petrópolis (1953).

${ }^{35}$ À exceção do México e o Panamá que, ao que tudo indica, estavam prontos para negociar com os Estados Unidos uma solução de conciliação, em troca de vantagens bilaterais (ALMEIDA, 2009b, p. 40; DOSMAN, 2011, p. 309; FURTADO, 2014, p. 107; GONÇALVES, 2011, p. 52).

${ }^{36}$ Merwin Bohan (1899-1975) cresceu na Cidade do México e em Dallas e trabalhou como representante comercial nas embaixadas de Havana, da Guatemala, de San Salvador, de Honduras, no Peru, Ecuador, Chile, Colômbia e Bolívia e conseguiu ser promovido a Counselor of Embassy for Economic Affairs em Buenos Aires. Posteriormente serviu em diversas missões especiais no Brasil e no México. (https://www.trumanlibrary.org/oralhist/bohanm.htm. Consultado em 16/01/2016). Bohan teve sucessivos desentendimentos com Prebisch ao longo de suas carreiras. Quando fora representante para assuntos econômicos da embaixada dos EUA na Argentina, retaliou Prebisch duramente quando o Banco Central argentino afastou-se das políticas ortodoxas. Chegou ao ponto de dizer que a Argentina estava retirando-se da comunidade das nações ocidentais e anunciou que a Argentina não obteria mais licenças comerciais dos EUA se continuasse com suas políticas defensivas. Na sequência, os EUA negaram o visto de Prebisch, na ocasião das reuniões de preparação do FMI. Depois que Bohan aceitou a independência da CEPAL na conferência mexicana, os conflitos com Prebisch minguaram e ele passou, inclusive, a ser visto como um aliado (DOSMAN, 2011, pp. 183-190, 206, 308-310, 323).
} 


\subsection{Cleantho de Paiva Leite, Ignácio de Mourão Rangel, Rômulo de Almeida e Jesus Soares Pereira na Assessoria Econômica de Getúlio Vargas}

Tanto Prebisch quanto Furtado ressaltam o papel desempenhado pela diplomacia brasileira na defesa da CEPAL. O carioca Miguel Álvaro Osório de Almeida (1916-1999) era um dos diplomatas que integrara a representação do Brasil ${ }^{37}$ no encontro do México. Filho de um médico-fisiologista e cientista de prestígio, Miguel Osório de Almeida graduou-se em direito na Faculdade Nacional, onde foi aluno de San Thiago Dantas, e ingressou no Itamaraty em 1942. Alocado em Nova York para integrar a missão brasileira junto à ONU, aproveitou para especializar-se em economia frequentando classes na New York University (NYU), em Columbia e na New School for Social Research (ABREU e LAMARÃO, 2007, pp. 11-14; ALMEIDA, 2009b, pp. 3-4). Seus vínculos com o mundo universitário norte-americano colocavam-no em boa posição para negociar com os Estados Unidos pois, frequentemente, seus interlocutores eram pares da vida acadêmica. Nas palavras do diplomata: "o mais engraçado é o seguinte: na maioria das vezes, eu estava sentado no lugar do delegado brasileiro e o delegado americano, sentado do outro lado, era o meu professor de economia na Columbia. E, sentado atrás dele, como assessor, na quinta cadeira lá atrás, era o lecturer da matéria, também na universidade" (ALMEIDA, 2009b, p. 4). Tal coincidência entre os produtores de conhecimento econômico e os operadores da política e da diplomacia econômica é também verificada no caso brasileiro e em outros países da América Latina, sendo um indicador da profunda vinculação da ciência econômica ao campo do poder (LEBARON, 2000, pp. 42-45).

$\mathrm{Na}$ condição de representante do Brasil junto à ONU, Miguel Osório de Almeida foi convidado a participar da reunião da CEPAL. Ele e Celso Furtado estavam alarmados pois acreditavam que os Estados Unidos estavam preparados para liquidar as atividades da Comissão e buscavam uma estratégia para manobrar, a seu favor, o silêncio das relações exteriores brasileiras que não haviam enviado nenhum posicionamento oficial ou instrução de como a representação deveria proceder no encontro. Osório de Almeida teve a ideia de contatar um conhecido seu que trabalhava na Assessoria Econômica de Getúlio

\footnotetext{
${ }^{37}$ Furtado diz que é nessa ocasião que encontra o diplomata Roberto Campos (item 2.2) pela primeira vez e conta que eles tinham muitos pontos de vista comuns tendo tecido boas relações. Campos estava escrevendo um memorando favorável à manutenção CEPAL e elogiava suas realizações (FURTADO, 2014, p. 106). A autobiografia de Campos, escrita nos anos 1990, quando ele já havia mudado radicalmente de opinião em relação às teorias cepalinas, não menciona o evento.
} 
Vargas, Cleantho de Paiva Leite, com quem havia trabalhado no secretariado brasileiro das Nações Unidas, para que solicitasse diretamente ao presidente um documento oferecendo expresso apoio do governo brasileiro à CEPAL. A declaração de Vargas ajudou a agregar outros países em torno do projeto, elevando o custo político que os EUA experimentariam caso insistissem em desarticular a Comissão (ALMEIDA, 2009b, pp. 39-43; FURTADO, 2014, pp. 106-112, GONÇALVES, 2011, p. 49).

Cleantho de Paiva (1921-1992), nascido na Cidade da Paraíba (hoje João Pessoa), era filho de um casal de professores e colega e amigo de Furtado dos tempos de Liceu Paraibano. Cleantho estudou na Faculdade de Direito de Recife e, como Furtado, escrevia para jornais para complementar a renda. Em 1942, quase no final da graduação, foi aprovado no concurso do DASP, um ano antes de Furtado, e transferiu-se para o Rio de Janeiro, concluindo na Faculdade Nacional de Direito os últimos exames para a obtenção do bacharelado. Bem como Furtado, Cleantho teve a oportunidade de estudar economia na Europa. Foi bolsista do British Council na LSE e, após concluir sua pós-graduação, trabalhou para o Conselho de Tutela da Organização das Nações Unidas ${ }^{38}$, de 1945 a 1951, onde se familiarizou com os jogos que ocorriam nos foros internacionais, razão pela qual era o aliado ideal para implementar o plano de Osório de Almeida (DHBB verbete: Cleantho de Paiva Leite). Após a conferência, Furtado contatou seu amigo de infância para:

fazer-lhe um relatório do que se passara no México, e transmitir-lhe o desejo de Prebisch de apresentar pessoalmente às autoridades brasileiras o reconhecimento da secretaria da Cepal pelo apoio que nos haviam dado. [...] Cleantho informouse bem da data de chegada de Prebisch e ficou de telefonar para ver que se podia fazer. Poucos dias depois, chamou-me e disse: "Consegui abrir espaço na agenda do Dr. Getúlio para que ele receba vocês. Ele mostrou curiosidade”. [...] Vargas nos recebeu na grande sala de despachos e nos convidou a sentar. [...] Era evidente que Cleantho o havia posto a par do essencial, e ele estava contente. [...] Prebisch aproveitou a oportunidade para relatar o que havia ocorrido e enfatizar o quão decisivo havia sido o apoio do governo brasileiro. Vargas ouviu, imperturbável, e, como se desejasse abreviar um ponto sensível passou a perguntar sobre a natureza dos trabalhos que vinha produzindo a comissão. Prebisch aproveitou para fazer uma daquelas sínteses magistrais, que lhe dão um tremendo poder de convencimento. [...] Vargas ouviu com inequívoco interesse. Ele havia sido o homem da industrialização, mas tateando, lutando contra a "boa doutrina ${ }^{39} "$ dos mestres da época. Agora, ouvia uma demonstração lapidar de que havia feito a escolha certa. Interessou-se em ter cópia desses trabalhos e Cleantho

\footnotetext{
${ }^{38}$ Conselho da ONU que visava auxiliar no processo de conversão dos territórios sob controle colonial em países independentes, podendo o conselho ocupar-se diretamente da administração dos novos países nos períodos de transição (SANTOS, 2011b, pp. 61-62).

${ }^{39}$ Prebisch usa o termo "boa doutrina" quando se refere às crenças econômicas que afirmavam que o cumprimento dos compromissos financeiros externos e o bom funcionamento monetário apenas dependeriam do cumprimento das regras do jogo (PREBISCH, 2011, pp. 98-99).
} 
intercedeu, informando que inclusive já eram disponíveis em português, em traduções feitas por mim, e que se encarregaria de pô-los à disposição do presidente (FURTADO, 2014, pp. 115-116).

A Assessoria Econômica da Presidência da República, da qual Cleantho fazia parte, foi criada logo no início do segundo governo Vargas e pode ser considerada uma segunda iniciativa do governo em direção à racionalização da administração pública, visto ser um órgão específica e inteiramente encarregado do planejamento econômico nacional. Ao conferir a uma assessoria técnica a tarefa de planejar, Vargas lograva isolar a tomada de decisão econômica ${ }^{40}$ das querelas partidárias, dos olhares publicitários e da opinião pública, além de agilizar os trabalhos e manter uma continuidade no planejamento da industrialização, mesmo em um cenário de fortes conflitos políticos (D’ARAUJO, 1992, pp. 152-154, 131; MOT'TA, 2005; SOLA, 1998, p. 96).

A Assessoria havia sido organizada por Rômulo de Almeida (1914-1988), baiano de Salvador que era filho de um caixeiro-viajante e de uma dona de casa. Como um primo seu era dono de um dos colégios de elite de Salvador, o Ginásio Ipiranga, ele pode ali estudar malgrado a falta de recursos da família nuclear. Ele ingressou na Faculdade de Direito da Bahia. Foi diretor do Centro Acadêmico e adquiriu o diploma de advogado em 1933. Rômulo explica que como era de uma família muito pobre, ficando na Bahia não teria a menor chance de conseguir emprego. O Rio oferecia fascínio e oportunidades para essa geração de nordestinos letrados e sem vínculos com a elite política e econômica local, que se sentiam deslocados em seus universos de origem, percebidos como impenetráveis à modernização. Com o objetivo de fazer algum tipo de pós-graduação, transferiu-se para a capital, onde lecionou como professor substituto na Faculdade de Ciências Econômicas e Administrativas do Rio de Janeiro (FCEARJ), de 1933 a 1934. Chegou a ingressar na Universidade do Brasil (UB) mas não conseguiu seguir o curso de ciências sociais por “problema de emprego" (ALMEIDA, 1988, p. 2). Mudou-se para o Acre em 1940 onde trabalhou no escritório de advocacia de San Thiago Dantas de 1941 a 1945 e (item 2.1) (ALMEIDA, 1988, pp. 1-4; BARBOSA e KOURY, 2012, pp. 1077-1081; BARBOSA, 2014, pp. 305-306; VIANA, 1988, pp. 11-32).

Em 1944, Rômulo ingressou no DASP por concurso e logo foi designado para trabalhar no Ministério do Trabalho, Indústria e Comércio. Ele foi o responsável pelo parecer favorável do Ministério ao relatório que o dirigente da Federação Estadual das

\footnotetext{
${ }^{40}$ Filosofia semelhante se manifesta na criação da administração paralela de Juscelino Kubitschek (item 2.3).
} 
Indústrias do Estado de São Paulo (FIESP), Roberto Cochrane Simonsen, apresentou ao Conselho Nacional de Política Industrial e Comercial (CNPIC) (item 4.1). Logo tornou-se assessor pessoal de Roberto Simonsen e, por indicação dele, passou a ser o economista responsável pela organização do departamento econômico da Confederação Nacional da Indústria (CNI), função que exerceu de 1945 a $1950^{41}$ (BARBOSA e KOURY, 2012, pp. 1077-1081; BARBOSA, 2014, pp. 305-306; VIANA, 1988, pp. 11-32).

Rômulo de Almeida filiou-se ao Partido Trabalhista Brasileiro (PTB) em 1950 e foi convidado por Getúlio Vargas para redigir a Mensagem Presidencial ao Congresso. Ele o faz combinando um nacionalismo de feições getulistas com um pleito pela industrialização do país. Em 1951, Rômulo foi encarregado da montagem da Assessoria Econômica de Vargas: um grupo de técnicos silenciosos e discretos que trabalhavam "todos os dias, com o presidente e para o presidente" (LEITE, 1959, p. 47. Grifo no original). Para integrá-la Rômulo convocou, além de Cleantho, o positivista ${ }^{42}$ Jesus Soares Pereira (19101974) e o marxista Ignácio Mourão Rangel (1914-1994).

Jesus Soares era cearense, filho de um telegrafista e de uma professora primária falecida precocemente e sequer chegou a frequentar o ensino superior. Ingressou no serviço público através da amizade que mantinha com alguns dos positivistas que circulavam pelo governo, passando por diversos órgãos como o Ministério da Agricultura, o Departamento Nacional de Produção Mineral (DNPM), a Secretaria Estadual de Agricultura e o Conselho Federal de Comércio Exterior antes de ingressar na Assessoria. Jesus ficou encarregado dos assuntos ligados à política energética, trabalhando intensamente nos projetos de criação da Petrobrás e do Fundo Nacional de Eletrificação (DHBB, verbete Jesus Soares Pereira).

Ignácio de Mourão Rangel era maranhense, natural da cidade de Mirador. A família Rangel possuía um engenho e o pai, o avô e o bisavô de Ignácio eram magistrados de província. Mudou-se para São Luís para cursar o ginasial e, seguindo o curso da família, ingressou na Faculdade de Direito do Maranhão. Na juventude, Rangel foi militante da Aliança Nacional Libertadora e do Partido Comunista Brasileiro (PCB). Participou de movimentos e greves operários e estudantis, e inclusive de ensaios de guerrilha, razão pela

\footnotetext{
${ }^{41}$ http://www2.senado.leg.br/bdsf/bitstream/handle/id/91414/Homenagem\%20a\%20Romulo\%20de\%20Almeida. pdf? sequence $=2$. Consultado em 30/10/2015.

${ }^{42}$ Jesus Soares Pereira foi um dos muitos desenvolvimentistas nacionalistas de sua geração a ter sido influenciado pelos positivistas. O próprio Rômulo de Almeida havia sido formado nessa tradição (BARBOSA e KOURY, 2012, p. 1078).
} 
qual foi preso aos 21 anos. Permaneceu dois anos na cadeia no Rio de Janeiro e oito anos sem poder sair de São Luís. Quando começou a colaborar com seu primo e colega de Faculdade de Direito, Ewaldo Correa Lima, e com Rômulo de Almeida no departamento econômico da Confederação Nacional da Indústria, Rangel já estava rompido com o PCB, pois ao sustentar que era possível industrializar o Brasil sem fazer a reforma agrária, discordava da cartilha do líder nacional do partido, Luís Carlos Prestes (FARO e SINELLI, 2014, pp. 47-48; FERNANDES, 2011; PAIM, 1998, p. 59; RANGEL, 1991/1992; RANGEL, 2009, p. 126; RANGEL, 2012, pp. 552-553). Sobre sua entrada na Assessoria Vargas, Rangel relata:

Fui chamado por Getúlio Vargas para um fim específico: redigir uma lei sobre o babaçu. Fui, então, trabalhar na redação da tal lei e me integrei à equipe, depois não houve mais meio de eu me descolar dela. Fizemos boas amizades, Rômulo [de] Almeida, Jesus Soares Pereira, pessoas assim, e são amizades que ficaram para o resto da vida e que me enriqueceram enormemente. Então trabalhei com o Getúlio, é difícil saber se o presidente sabia que eu não era getulista e se apesar disso ele queria que eu fosse trabalhar com ele. O fato é que o presidente mandou me dizer que me sentisse em casa, de aduladores ele não precisava tinha muito bons - ele precisava e de gente que tivesse coragem de dizer que ele estava errado, e eu era desse tipo que dizia quando ele estava errado. Então fiquei, me integrei à equipe (RANGEL, 1991/1992, pp. 128-129).

O depoimento de Rangel aponta para a tese de que a escolha dos assessores não decorria de considerações de ordem político-partidária, já que não havia nenhuma homogeneidade na composição ideológica da Assessoria que comportava técnicos de orientação trabalhista, marxistas, positivistas e ex-integralistas. Para integrar a Assessoria era preciso ter competência econômica e afinidade com o projeto de ampliação da infraestrutura com vistas à industrialização. Deles não era exigida afiliação ao getulismo, apenas lealdade ao Presidente, traço característico de um governo no qual o poder apresenta fortes traços personalistas, sendo associado diretamente ao chefe autoritário, mescla de protetor e pai (D’ARAUJO, 1992, pp. 151-153, 188; FAORO, 2001, pp. 792793). A Assessoria reunia ainda entre seus colaboradores: João Neiva de Figueiredo, engenheiro do DNPM; Tomaz Pompeu Accioly Borges, engenheiro cearense comunista que trabalhava no Departamento Nacional de Obras Contra as Secas (DNOCS) e era editor da revista Conjuntura Social; Américo Barbosa de Oliveira, engenheiro civil com especialização na Sorbonne, editor das revistas Conjuntura Econômica e Conjuntura Social e funcionário do BNDE. Ottolmy Strauch, advogado gaúcho que trabalhava no DASP, e 
Mario Abrantes da Silva Pinto, engenheiro e geólogo carioca do DNPM (item 2.4) (LIMA, 2013, pp. 176, 240).

Coube aos "boêmios cívicos" da Assessoria Vargas - alcunha dada por Getúlio por trabalharem madrugada adentro ${ }^{43}$ - o diagnóstico da situação econômica do país e o planejamento econômico de setores estratégicos, fundamentalmente energia e transportes. A Assessoria esteve envolvida na elaboração da política para o setor energético que deu origem à Petrobrás, ao Fundo de Eletrificação, à Eletrobrás e ao Plano Nacional do Carvão e participou do desenho da indústria automobilística, que ganharia força no governo Juscelino Kubitschek. Formulou também políticas agrárias e de crédito rural, criou o Banco do Nordeste, além de outras iniciativas, todas destinadas a acelerar o crescimento brasileiro e viabilizar a ascendente industrialização (BARBOSA e KOURY, 2012, p. 1078; D’ARAUJO, 1992, p. 152; GOUVÊA, 1994, p. 118; LEOPOLDI, 1992, pp. 87-88; MOTTA, 2005; SOLA, 1998, p. 99).

Celso Furtado e os principais membros da Assessoria formavam o grupo dos técnicos ditos "nacionalistas" (SOLA, 1998) ou "desenvolvimentistas do setor público" (BIELSCHOWSKY, 2000) por enfatizar de sobremaneira o papel do Estado e do capital nacional no processo de desenvolvimento. Defendiam, em linhas gerais, que o Estado deveria encarregar-se da distribuição do capital que ingressava e do direcionamento dos incentivos econômicos para áreas estratégicas, assumindo, quando necessário, a produção em setores pouco atraentes ou demasiado complexos para depender da iniciativa privada (SOLA, 1998, p. 99).

À exceção de Jesus Soares Pereira, os nacionalistas da Assessoria Vargas provinham de famílias tradicionais do nordeste que, em um cenário de decadência da economia açucareira da região, passaram a depender da aquisição do título de bacharel em direito para assegurar sua posição social. Os rebentos desses grupos, formados em direito no nordeste ou na capital, mudavam para o Rio de Janeiro onde estavam as principais oportunidades para essa classe de profissionais, integrando-se à sociedade carioca através do ingresso no serviço público. Cleantho, Furtado e Rômulo de Almeida começaram sua

\footnotetext{
${ }^{43}$ Essa ideia, daqueles que dedicam a vida ao trabalho, patrioticamente, sem noção de horário, capazes de intensos investimentos de energia, repete-se nas narrativas dos técnicos desenvolvimentistas do período como, por exemplo, "trabalhar com Juscelino era uma tarefa estimulante e ao mesmo tempo cansativa. Fustigava-me, querendo apressadamente o desdobramento das metas. [...]. Ele não tinha grande noção de horário de trabalho $\mathrm{e}$ era capaz de despertar na tecnocracia singular devoção, levando-a a uma espécie de voluntariado patriótico em tempo de trabalho" (CAMPOS, 1994, p. 294) e "nós, trabalhando em Santiago dez ou mais horas por dia, renunciando a férias, convencidos de que cumpríamos uma missão útil e de valor reconhecido" (FURTADO, 2014, p. 104).
} 
vida profissional no DASP, onde vivenciaram o processo de formação de uma burocracia profissional no Brasil. Jesus Soares Pereira e Ignácio Rangel integraram-se ao serviço público através de seus contatos pessoais. Soares Pereira inseriu-se na capital com ajuda de seus colegas positivistas e Ignácio Rangel foi trabalhar com seu primo Ewaldo Correa Lima e Rômulo de Almeida na CNI. Quando Rômulo foi convidado para montar a Assessoria, ele compôs sua equipe recrutando esses homens que tinham vínculos familiares e de amizade uns com os outros e trajetórias sociais e experiências de migração bastante semelhantes (BARBOSA e KOURY, 2012, pp. 1079-1080; LOUREIRO, 1997a, p. 47).

Após o suicídio de Vargas, Rômulo de Almeida assumiu o posto de Deputado Federal pela Bahia. Em 1958, chegou a lançar-se como candidato a vice-governador de seu Estado mas perdeu a disputa. Cleantho de Paiva, que havia sido indicado por Vargas para o Conselho Administrativo do BNDE, tornou-se diretor do Banco, posição que ocupou até 1962. Jesus Soares Pereira retomou seu posto no Ministério da Agricultura e de lá circulou pelo Banco do Nordeste, pela assessoria do Ministério de Viação e Obras Públicas, pelo Conselho Nacional do Petróleo, continuando a colaborar com os projetos que gerira na Assessoria. Ignácio Rangel foi indicado para trabalhar no BNDE, posição que assegurou ao ser aprovado no primeiro concurso público do Banco, realizado em 1955. Para concorrer à vaga de economista do BNDE era preciso ter um diploma de economia ou uma habilitação para exercício da profissão. Rangel, advogado de formação, não tinha nenhum dos dois. Conta ele que:

na hora em que foi organizada a profissão de economista, eu não podia me inscrever como economista pela porta normal, que era a porta do curso, porque eu não era formado em economia. Eu também não podia me inscrever como economista alegando ter assessorado o governo em entidades paraestatais por cinco anos no mínimo, porque eu tinha assessorado todas elas, mas por períodos menores do que cinco anos. Então, a única porta aberta era a chamada porta do notório saber. Eu tinha que escrever um livro e requerer na fé desse livro o posicionamento como economista. Esse livro [Dualidade básica da economia brasileira] foi escrito em talvez quatro fins de semana, porque durante toda a semana eu não tinha tempo absolutamente de voltar para isso. Eu estava trabalhando na assessoria do Presidente Vargas, inclusive na lei que desembocaria na Eletrobrás e aos sábados e domingos eu ia para minha casa, porque durante a semana eu ficava na cidade, e aí trabalhava. Em quatro semanas, quatro fins de semana saiu o livro que foi lançado e com base no qual eu fui reconhecido como economista. Com base nele também eu tive a bolsa de estudos para as Nações Unidas (CEPAL, Santiago do Chile) (RANGEL, 1991/1992, p. 116). 
A bolsa que Ignácio Rangel obteve permitiu que fosse, em 1954, passar 8 meses em Santiago para seguir o curso de capacitação em desenvolvimento da CEPAL ${ }^{44}$, dirigido pelo chileno Jorge Ahumada ${ }^{45}$ (1915-1965), engenheiro agrônomo formado na Universidade do Chile com pós-graduação em economia em Harvard e experiência no FMI, que

coordenava a divisão de treinamento da CEPAL que criou [em 1952] um centro de treinamento onde "jovens economistas promissores dos governos de toda a região receberiam 24 semanas de treinamento básico em análise econômica, contabilidade social, sociologia, teoria do desenvolvimento econômico e planejamento de projetos. A esse treinamento básico seguiam-se dezesseis semanas extras de trabalho em pequenos grupos, centradas em tópicos especiais como administração do setor público, planejamento orçamentário e desenvolvimento de recursos humanos. Junto com seu 'curso básico' anual, a divisão de Ahumada oferecia cursos intensivos e seminários especiais por toda a região, por solicitação de governos e em colaboração com universidades e institutos" (DOSMAN, 2011, p. 320).

Segundo Rangel, foi na CEPAL que ele foi "metodicamente informado sobre as teorias do desenvolvimento econômico, e que encontrei também contradita sábia e fecunda, dessas que apuram o espírito e o animam a prosseguir” (RANGEL, 1990, pp. 67). O fato de ter sido aluno da CEPAL não fez de Rangel um cepalino modal. Parte de seus conceitos e de suas ideias fundamentais foram desenvolvida antes de sua ida ao Chile, aparecendo no livro Dualidade básica da economia brasileira (RANGEL, 1991/1992, p. 116). Mais do que isso, ele contestou algumas ideias que estavam em voga na agência internacional da ONU. Essa posição crítica de Rangel, inclusive face a alguns dos argumentos mais largamente difundidos nos grupos nacionalistas, é uma das singularidades que fizeram com que fosse, a vida toda, um "ilustre marginal" (TAVARES, 2009, p. 173). Se nas aulas que compõem o seu livro Introdução ao desenvolvimento econômico

\footnotetext{
${ }^{44}$ No relatório administrativo do BNDE de 1954 consta: "Valendo-se, por isso mesmo, de oportunidades surgidas no correr do ano, a Diretoria, com a aprovação do Conselho de Administração, autorizou afastamento de sete servidores para efetuar cursos de especialização e estágios de treinamento em Porto Rico e nos Estados Unidos, mediante aproveitamento de bolsas de estudo oferecidas dentro do programa de assistência técnica do governo americano. Designou-se, também, oficialmente, um economista para estagiar junto à Comissão Econômica para América Latina, em Santiago do Chile [Ignácio Rangel], assim como se concederam facilidades para que outro economista [Juvenal Osório] gozasse de bolsa de estudo proporcionada pela Organização das Nações Unidas e seguisse curso regular na Universidade de Londres" (BNDE, 1954, p. 35).

${ }^{45}$ Ahumada é considerado o antípoda de Furtado na CEPAL. Nas palavras de Dosman: "um comunicava novas ideias enquanto outro as criava. Mas também eram ideologicamente distintos: o grupo de Furtado era conhecido como a "divisão vermelha". O chileno Ahumada era um democrata cristão intimamente envolvido na política chilena [próximo de Frei Montalva]. Eles se equilibravam" (DOSMAN, 2011, p. 320). Furtado afirma que Ahumada tinha "excessivo respeito o pensamento dominante nas grandes universidades norte-americanas". Considerava-o, não obstante, um homem com legítimos dotes para o ensino, área da qual se encarregou na CEPAL (FURTADO, 2014, p. 77).
} 
brasileiro ele se posiciona de modo francamente favorável ao planejamento econômico, também contesta a maneira como a CEPAL concebia a programação econômica:

no Brasil e na América Latina há uma ilustre escola de planejadores que pretende planificar - ou, para usar sua expressão favorita: programar - o desenvolvimento, sem o controle de tais alavancas. Ao invés de decidir quanto se vai inverter na indústria de cimento, procura, pela construção de complicado edifício matemático, dizer quanto se deveria inverter, admitidos certos supostos — demasiado numerosos por sinal [...]. A beleza da construção — suas linhas geometricamente sóbrias, a singeleza da concepção conquista cada vez mais adeptos a esse estilo de planejamento. Não obstante, quando estudamos mais de perto e atentamente o edifício, não tardamos a descobrir que ele é uma pirâmide assente sobre o vértice - posição que, evidentemente, não convém a uma pirâmide. Que razão teríamos nós, com efeito, para começar o planejamento supondo certo crescimento da renda nacional? Por que não relacionamos antes os recursos disponíveis, em função do efetivo comando que tenhamos sobre eles, para depois, como coroamento do nosso trabalho, chegarmos à previsão de certo aumento da renda nacional, se esses recursos são usados de certo modo e não de outro? A programação estilo "pirâmide invertida" necessita de supor demasiadas coisas além do poder efetivo de realizar as coisas programadas (RANGEL, 1990, pp. 108-110).

Em seu retorno ao Brasil, Rangel procurou aplicar sua visão de planejamento no departamento econômico do BNDE. Em sua carreira no Banco, ele passará por todos os cargos técnicos, nunca chegando à diretoria. Aposentou-se em 1975, mas continuou colaborando com o Banco até o fim de sua vida, em 1994, transmitindo às novas gerações suas interpretações sobre o Brasil, notavelmente seu entendimento acerca da privatizaçãoe (item 6.1) (RANGEL, 2009, p. 125; RANGEL 1991/1992, pp. 103-6).

\subsection{Maria da Conceição Tavares, Carlos Lessa e Antonio Barros de Castro no escritório CEPAL-BNDE}

Em 1956, o curso que Rangel fizera no Chile passou a ser oferecido diretamente no Brasil sob o nome de Curso de Treinamento em Problemas do Desenvolvimento Econômico. O interesse pelos cursos oferecidos pela divisão da CEPAL coordenada por Ahumada foi tão grande

que se fez necessário organizá-los nos próprios países, de forma intensiva, deslocando-se o corpo de professores por tempo limitado e fazendo-se apelo a especialistas locais para ministrar certas matérias. A esses cursos pelos quais passaram muitas centenas de estudantes deve-se a difusão continental do pensamento desenvolvido pela CEPAL (FURTADO, 2014, p. 126). 
A circulação do pensamento da CEPAL pelo Brasil ampliara-se consideravelmente após a consolidação da instituição na reunião do México de 1951. Quando da visita de Furtado e Prebisch ao Presidente Vargas, pouco após a conferência, eles também encontraram-se com empresários, industriais, jornalistas, acadêmicos, especialistas em economia, estudantes e autoridades como os Ministros da Relações Exteriores, da Fazenda e da Agricultura, diretores do Banco do Brasil (BB) e membros de diversas comissões e conselhos econômicos. A publicação do Manifesto em português tornara Prebisch bastante conhecido no país e despertara a curiosidade que garantiu amplo público aos eventos dos quais participou no Rio de Janeiro e em São Paulo. Neles apresentou as teorias da CEPAL e respondeu questões acerca das políticas de industrialização, falando sobre os tipos de substituição de importações, o nível de intervenção governamental, o papel da política monetária e cambial na industrialização etc. Depois dessa viagem, o idioma português foi convertido em uma das línguas oficiais da CEPAL. E sua quinta conferência, realizada em 1953, foi sediada no Brasil, ocorrendo no hotel Quitandinha, em Petrópolis (DOSMAN, 2011, p. 321).

Nela foi celebrado um acordo de cooperação entre a Comissão e o recém-criado BNDE, tendo a CEPAL cedido Celso Furtado e Regino Boti ao Brasil para coordenar o Grupo Misto CEPAL-BNDE46. À época Furtado chefiava a divisão de desenvolvimento da Comissão, que era o "centro do pensamento sobre teoria do desenvolvimento e planejamento na organização". Ela acabou conhecida como a "divisão vermelha" da CEPAL, integrada por marxistas autodeclarados, como Regino Boti e Juan Francisco Noyola que se tornariam, respectivamente, Ministro da Economia de Fidel em Cuba e fundador da Junta Central de Planificação e principal assessor de Che Guevara no Banco Central Cubano (DOSMAN, 2011, pp. 222, 228 320, 400; FURTADO, 2014, p. 312).

Juan Francisco Noyola Vazquez (1922-1962) nasceu em San Luís Potosi, no México, em uma família muito católica por parte de mãe, tendo chegado a militar na Ação Católica. Seu pai, Juan Noyola Barragán, era engenheiro e seu tio, Luís Noyola Barragán, foi Procurador de Justiça do Estado, Secretário Geral do Governo e Reitor da Universidad de Potosí. As famílias Barragán e Vazquez eram ligadas à elite política mexicana e descendentes do imperador asteca Moctezuma II. Sua avó paterna era

\footnotetext{
${ }^{46}$ A conferência de Petrópolis e o convênio CEPAL-BNDE serão retomados no próximo capítulo (item 2.2), pois é preciso antes inserir na narrativa agentes, instituições e eventos do período para discutir em detalhe os episódios assinalados.
} 
descendente da família de Miguel Barragán que foi Presidente da República mexicana. Juan Francisco foi enviado pelos pais para estudar no colégio franco-inglês na cidade do México, uma escola particular onde os pais inscreviam os filhos para que estivessem protegidos do ateísmo e das ideias revolucionárias que circulavam nas escolas públicas. Depois de ter flertado com as ciências naturais e com a medicina, ele passou ao estudo das relações humanas, cursando economia na Escuela Nacional de Economía da UNAM e ciências sociais no CES do Colegio de México, onde foi aluno de Víctor Urquidi e José Medina Echevarría (item 3.3) (ESCAMILLA e MANRIQUE, 1991, pp. 19-20, 26-27).

Noyola foi convidado por seu professor Jesús Silva Herzog (1892-1985) historiador econômico, economista autodidata, marxista, editor do Fondo de Cultura Económica, diplomata e defensor da produção de teorias econômicas autóctones, que foi o mais importante dos fundadores do primeiro programa de economia mexicano na UNAM (BABB, 2003, pp. 1, 43-44) - para colaborar com ele no Comité de Aforos y Subsidios del Comercio Exterior. Na sequência, deixou o México para trabalhar na divisão latinoamericana de pesquisa econômica do FMI. Ao retornar, em 1948, foi assessor e depois funcionário da direção de estudos financeiros da Secretaria da Fazenda e, em 1949, defendeu seu doutorado intitulado Desequilibrio fundamental y fomento económico de México, bastante crítico da ortodoxia econômica, em uma banca dirigida por Jesús Herzog. Entrou para a CEPAL pouco depois ${ }^{47}$.

Regino Boti Léon (1923-1999) nasceu na cidade de Guantánamo, filho de Regino Eladi Boti, destacado poeta cubano, doutor em direito civil e em filosofia e letras pela Universidad de Habana, e neto de um imigrante catalão, tendo sido enviado à Barcelona, terra de seus antepassados, para fazer parte de seus estudos. Cursou a Faculdade de Direito da Universidad de Habana, como quis seu pai, mas não tinha vocação literária nem desejo de seguir a carreira de advogado. Ao graduar-se, recebeu de Eladi os recursos necessários para cursar a pós-graduação em economia em Harvard. Lá integrou a mesma turma que Jorge Ahumada e estudou com nomes de destaque como Wassily Leontief, Joseph Schumpeter e Gottfried Haberler, especializando-se em comércio (DOSMAN, 2011, p. 304). Na sequência ingressou na CEPAL, fazendo parte do primeiro grupo de

\footnotetext{
${ }^{47}$ Ver: http://www.cepal.org/es/search?as_q=semblanza\%20biografica\%20noyola. Consultado em 17/01/2015.
} 
funcionários da Comissão ${ }^{48}$. Era "um socialista declarado, obcecado pelos Estados Unidos, que tinha estudado em Harvard e dizia que nunca tinha lido nem uma página de Marx; havia sido contratado, com recomendação da ONU, por suas habilidades estatísticas” (DOSMAN, 2011, pp. 292-293).

Boti León aproximou-se fortemente de Furtado e foi por ele convidado a acompanhá-lo na missão do grupo misto CEPAL-BNDE, que funcionou de 1953 a 1955, sendo encarregado da realização de um conjunto de diagnósticos sobre a economia brasileira que deveria servir de subsídio a um planejamento econômico extensivo. Os documentos produzidos pelo grupo misto foram aproveitados no governo Juscelino Kubitschek que os utilizou para embasar parte de seu Plano de Metas (item 2.3). Concluído esse trabalho, Furtado retornou à CEPAL. O fim do convênio e a partida de Furtado não resultaram, entretanto, em um desmanche dos vínculos entre as duas organizações já que, em 1956, as duas viriam a estabelecer novo convênio que instalaria no Brasil os cursos de formação oferecidos pela CEPAL.

O primeiro Curso de Treinamento em Problemas do Desenvolvimento Econômico oferecido pela CEPAL com apoio do BNDE teve início em setembro 1956, no Rio de Janeiro. Ele tinha o objetivo de:

a) familiarizar funcionários públicos, profissionais e professores, cujo trabalho está de algum modo relacionado com o desenvolvimento econômico, com os problemas fundamentais que este suscita e a técnica moderna para sua solução; b) expor as técnicas modernas de preparação e análise de projetos de desenvolvimento econômico; c) dar elementos de apreciação e técnicas que possam ser utilizados na elaboração e coordenação da política econômica requerida pelo desenvolvimento; e d) apresentar uma visão coordenada dos problemas econômicos do país a longo prazo e das perspectivas de desenvolvimento (BNDE, 1957).

Na sessão inaugural, o Presidente Juscelino Kubitschek ressaltou a importância da CEPAL e do curso dizendo que:

A Comissão Econômica para a América Latina, órgão regional das Nações Unidas, já prestou inestimáveis serviços a este continente. De inicio foi este o órgão que procurou formular uma interpretação viva dos fatos econômicos e humanos da América espanhola e portuguesa, e que buscou reformular as doutrinas econômicas tradicionais em face de uma realidade nova, que circunstâncias históricas, geográficas e políticas marcaram de originalidade e dinamismo surpreendentes. Não permaneceu, entretanto, no altiplano das especulações teóricas, procurando extrair de suas investigações os ensinamentos corretos para a ação política que objetiva acelerar o ritmo do desenvolvimento

\footnotetext{
${ }^{48}$ Ver: http://www.acn.cu/deportes/2757-cuba-con-equipos-completos-de-taekwondo-a-lid-centrocaribena, http://www.encaribe.org/es/article/regino-boti-leon, http://www.cubaliteraria.cu/autor/regino_boti/vidaobra/vidaobra.htm. Consultados em 10/01/2015.
} 
econômico de todo o continente. Mais ainda, tem-se empenhado em assistir os países da América Latina na criação dos instrumentos necessários à execução dessa política de desenvolvimento. Uma estreita associação entre os nossos órgãos de promoção do desenvolvimento econômico, como o Banco de Desenvolvimento, e a CEPAL é mais que uma conveniência, é uma necessidade. [...]. A importância do curso ora iniciado consiste em atacar um dos problemas mais graves e mais subestimados do Brasil, assim como de outros países que ainda não alcançaram o seu pleno desenvolvimento: é o da escassez de pessoal habilitado em técnicas de programação e de planejamento [...]. Cada vez mais me convenço, na base da experiência de governo, de que as limitações de recursos humanos são tão sérias quanto as dificuldades financeiras e materiais. Um governo só pode promover eficazmente o desenvolvimento econômico se nos vários escalões da administração puder contar com homens conhecedores das dificuldades e dos métodos de solucionar problemas de desenvolvimento, possuídos de entusiasmo, dotados de espírito realista e noção de prioridades, desejosos de programar, planejar e executar (KUBITSCHEK, 1956).

O curso oferecido em 1956 tinha duração de dois meses, era ministrado em tempo integral e composto por um núcleo básico com as disciplinas: Contabilidade Social, oferecida pelo professor Manoel Balboa; Programação do Desenvolvimento Econômico, ministrada pelo coordenador do curso Jorge Ahumada, Elaboração e Avaliação de Projetos, sob a direção de Julio Melnick; e Financiamento do Desenvolvimento Econômico, com o professor Carlos Oyarzún. Além das aulas oferecidas pelos quadros advindos da CEPAL, especialistas em economia brasileiros proferiram também uma série de conferências. Celso Furtado falou sobre as Perspectivas do Desenvolvimento Econômico, Rômulo de Almeida sobre os Problemas Regionais e Rômulo de Almeida e Cleantho de Paiva Leite discutiram Problemas Administrativos. Além deles, foram responsáveis por comunicações alguns especialistas que terão importante papel no próximo capítulo: Roberto de Oliveira Campos: Caraterísticas do Desenvolvimento Brasileiro, Juvenal Osório Gomes: Problemas Industriais, José Garrido Torres: Instrumentos de Comércio Exterior, João Batista Pinheiro: Política de Comércio Exterior, Casimiro Ribeiro: Problemas Monetários. Até Eugênio Gudin, que em 1956 já era notório adversário da CEPAL, colaborou ministrando a lição: Orientação da Programação do Desenvolvimento Econômico (BNDE, 1957).

Em 1957 o BNDE já cogitava instalar um escritório permanente da CEPAL no Rio de Janeiro. Esse órgão seria composto por uma pequena equipe de economistas que deveria coordenar os convênios entre a agência internacional e entidades brasileiras, organizar o curso de treinamento em problemas do desenvolvimento econômico, assegurar a assistência técnica a organizações nacionais e preparar a documentação sobre o Brasil que se fizesse necessária para a CEPAL. A instalação de um núcleo permanente 
no Brasil foi aprovada nas sessão da CEPAL de 1957, mas o Centro de Desenvolvimento Econômico CEPAL-BNDE só passaria a funcionar plenamente em 1960, assumindo a responsabilidade pelos cursos de treinamento ${ }^{49}$ que atraiam, ano a ano, maior número de alunos dispostos a dedicar quatro meses em tempo integral para obter o certificado. A criação do Centro CEPAL-BNDE viabilizou a difusão de cursos de treinamento para outras partes do país, pois até então só eram administradas classes no Rio de Janeiro e na SUDENE em Recife. Entre 1963 e 196750, foram oferecidos também cursos nas cidades de: Aracaju, Belém, Belo Horizonte, Brasília, Curitiba, Florianópolis, Fortaleza, Porto Alegre, Salvador, São Paulo e Vitória. Foram alunos dos treinamentos que a CEPAL ofereceu no Brasil os economistas e cientistas sociais: Pedro Malan, Régis Bonelli, Luiz Gonzaga Belluzzo, João Manuel Cardoso de Mello, Paulo Renato de Souza, Marcelo Abreu, Theotônio dos Santos, Vânia Bambirra, Eduardo Kugelmas, Francisco de Oliveira, Wilson Cano, Gilberto Dupas, Flavio Tavares de Lyra, Antônio Bezerra Baltar, Helga Hoffmann, dentre outros que aparecerão nos próximos capítulos (BNDE, 1957, pp. 185-186; BNDE, 1962, p. 108, BNDE, 1963, p. 56, BNDE, 1964, pp. 76-81, BNDE, 1965, pp. 51-55; BNDE, 1966, pp. 49-53; BNDE, 1967, p. 45).

Para encarregar-se dos cursos e dos trabalhos de pesquisa conduzidos pelo Centro CEPAL-BNDE foi montada uma equipe mista, composta por alguns técnicos enviados de Santiago e por especialistas em economia radicados no Brasil. O primeiro diretor do Centro foi o economista Osvaldo Sunkel (1929). Nascido em Puerto Montt, Sunkel era descendente por parte de pai e de mãe de alemães ${ }^{51}$. Seu avô materno transferiu-se para o Chile com o objetivo de assumir a posição de pastor na igreja luterana da pequena cidade de Osorno, onde nasceu sua mãe Elena. Seu avô paterno, também imigrante alemão, chegou ao Chile na infância e tornou-se agricultor. Seus pais desenvolviam atividades comerciais. Em casa Sunkel aprendeu o alemão e o espanhol e estudou francês no colégio. Mais tarde incorporaria ao seu repertório de idiomas o inglês e o português (SUNKEL, 2006; WANDERLEY, 2015, p. 309).

Osvaldo Sunkel estudou economia e administração na Universidad de Chile, onde teve como professor Aníbal Pinto Santa Cruz. Quando estava cursando o último ano da

\footnotetext{
49 Ver: http://memoria.bn.br/DocReader/DocReader.aspx?bib=089842_07\&PagFis=13210. Consultado em $10 / 11 / 2015$.

${ }^{50}$ Em 1967, o BNDE encerra unilateralmente seu convênio com a CEPAL e a CEPAL passa a ter um convênio com o Instituto de Pesquisa Econômica Aplicada (IPEA) que dá origem ao Escritório CEPAL-Instituto LatinoAmericano de Planificação Econômica (ILPES) brasileiro, eventos que serão discutidos adiante (item 4.3).

${ }^{51}$ Ver árvore genealógica em: http://www.genealog.cl/Alemanes/S.html\#SUNKEL. Consultado em 10/11/2015.
} 
graduação candidatou-se a uma vaga para estudar administração pública no Rio de Janeiro. A seleção para a bolsa era feita por Jorge Ahumada que, depois de escolhê-lo, foi obrigado a rever a decisão pois o governo chileno decidiu enviar um funcionário de Estado para o Brasil. Ahumada ofereceu, em retorno, uma bolsa para que Sunkel participasse do Curso de Capacitación en Problemas de Desarrollo Económico, ministrado pela CEPAL, pela primeira vez, entre 1952 e 1953, orientando-o pessoalmente na redação de sua dissertação final, que versava sobre estrutura da poupança (SUNKEL, 2006; SUNKEL, 1998, pp. 183-184). Na sequência, Sunkel obteve uma bolsa para estudar economia na LSE, mudando para a Europa em 1954. Ele conta que:

O diretor [da LSE] era ninguém menos que Lionel Robbins. Entrevistou-me para perguntar, entre outras coisas, o que eu ia estudar lá. Eu respondi que estava interessado no tema do desenvolvimento econômico. Foi como se o tivesse insultado, ou se tivesse sido picado por uma vespa. Ele pulou em sua cadeira, bateu fortemente na mesa com as duas mãos e perguntou com veemência, "and what is that?!!!” Ele tinha estado aqui no Brasil, acho que convidado pela Fundação Getúlio Vargas, para dar umas palestras. Também vieram Viner e Haberler ${ }^{52}$. Acho que foi para neutralizar a influência insalubre da CEPAL à teoria do comércio internacional e outras ideias convencionais. Em suma, ele recomendou estudar as Teorias da População, porque o problema dos países pobres era para ele o crescimento demográfico excessivo! Obviamente [sic] não levei a sério, mas fui estudar os modelos macrodinâmicos, que então eram moda. Havia essa enorme resistência ideológica à temática do desenvolvimento, Robbins dirigia um seminário dedicado precisamente para destruir os poucos trabalhos que existiam sobre o assunto: os de [Paul] Rosenstein-Rodan, de [Kurt] Mandelbaum (depois [Kurt] Martin) de [Hans] Singer e Prebisch. Então tive que escrever e apresentar em inglês pela primeira vez um trabalho para criticar o mais ferozmente possível a [Walt] Rostow, cujo livro acabara de sair. Esse era o clima na LSE (SUNKEL, 1998, p. 187).

Em 1955, Ahumada, que partia para a Colômbia para realizar um estudo para a CEPAL, escreveu a Sunkel convidando-o a assumir a coordenação dos cursos de treinamento. No mesmo ano obteve uma posição de professor na Universidad de Chile (SUNKEL, 2006). No final de 1955, Sunkel, recém-incorporado na “divisão vermelha" que estava desfalcada pois Boti licenciou-se da CEPAL temporariamente para organizar a primeira escola superior de economia de Cuba, na Universidad de Oriente - foi designado para trabalhar com Celso Furtado e Juan Noyola em um estudo sobre a situação econômica mexicana, feito a partir do escritório subregional da CEPAL no México, dirigido por Urquidi desde março de 1952. O estudo sobre o México fazia críticas profundas à gestão econômica do país, apontando efeitos concentradores de

\footnotetext{
${ }^{52}$ Essas conferências de Viner, Haberler e Robbins feitas na FGV-RJ a convite de Eugênio Gudin serão alvo de considerações no Primeiro Movimento (item 2.1).
} 
renda e falando sobre a dependência externa. Apresentado em 1957, o texto El Desequilibrio Exterior de México não foi bem recebido pelos governantes mexicanos. A versão para publicação com introdução de Urquidi foi rejeitada por Prebisch, que decidiu não editar o livro. O desgaste provocado por esse episódio foi determinante para que Urquidi e Furtado se afastassem da CEPAL. Urquidi foi trabalhar na Secretaría de Hacienda Mexicana. Furtado partiu para Cambridge onde escreveu entre 1957 e 1958 seu estudo clássico Formação Econômica do Brasil. Regressou ao Brasil em agosto de 1958, sendo designado diretor do BNDE e depois coordenador da criação da SUDENE (FURTADO, 2014, pp. 167-173; HODARA, 2008, p. 53; SUNKEL, 2006).

Sunkel retornou à CEPAL e algum tempo depois foi convidado a ser o primeiro diretor do Centro CEPAL-BNDE, posição que ocupou entre 1960 e 1961. Sobre o episódio conta a seguinte história:

O cubano Regino Boti ia encarregar-se deste escritório, mas veio a Revolução Cubana e voltou ao seu país. O venezuelano José Antonio Mayobre iria em seu lugar, mas quando ele estava prestes a partir, chamaram-no da Venezuela e ele regressou. Depois de ficar no México nos anos 1956-1959, voltei para Santiago. Então fui encarregado de organizar o escritório do Brasil. Fui trabalhar com Furtado. Era recém criado o Conselho de Desenvolvimento do Nordeste (CODENO), que mais tarde se tornou a Superintendência do Desenvolvimento do Nordeste (SUDENE). Depois de desenvolver um programa de treinamento muito grande para a SUDENE, permaneci no Rio de Janeiro para organizar o escritório do Brasil. Fiquei três anos. Um dia Prebisch nos visitou no Brasil e me pediu para ir a Santiago de criar o Instituto de Planejamento Econômico e Social (ILPES). O ILPES foi criado em Santiago, em julho de 1962, como resultado da Aliança para o Progresso (ALPRO) que promovera John Kennedy ao tomar posse na presidência dos EUA. Na verdade, a ALPRO adotou grande parte da filosofia da CEPAL ${ }^{53}$. O ILPES foi responsável pela formação de pessoal de diferentes países para desenvolver diagnósticos, projeções e planos e programas setoriais e outras tarefas que eram conteúdo necessário para obter recursos através da ALPRO. [...] Ao longo do tempo, o Instituto foi orientado para dar apoio aos escritórios de planejamento do setor público, planejamento setorial, elaboração de orçamento por programa nos escritórios do orçamento. Em muitos países foram criados ILPES nacionais (SUNKEL, 2006).

O Instituto de Planificación Económica y Social (ILPES), diz Prebisch, era uma ideia que vinha cultivando para quando se aposentasse da CEPAL. Em março de 1960, Paul Hoffman, representante dos EUA na ONU, fez uma visita à CEPAL. Hoffman, que havia sido administrador do Plano Marshall na Europa e ajudado a planejar o Mercado Comum Europeu, via com bons olhos os estudos de Prebisch sobre a integração latinoamericana. Pouco tempo depois convidou Prebisch a visitar Nova York, onde comunicou

\footnotetext{
${ }^{53}$ O CODENO, a SUDENE e a Aliança para o Progresso serão objeto de considerações no próximo capítulo (itens 2.3 e 2.4).
} 
que poderia aprovar os recursos para a criação de um instituto de planificação ligado à CEPAL. A Bolívia, o Brasil, o Chile, a Colômbia e a Venezuela manifestaram apoio à criação de um instituto de planificação aos cuidados da CEPAL, o que legitimou a proposta de criação da instituição irmã da CEPAL, que com ela dividiria, a partir de 1966, a nova sede da Comissão (item 3.2). Além do financiamento da ONU, o ILPES passou a contar com recursos do Banco Interamericano de Desenvolvimento (BID) e com o apoio da Aliança para o Progresso, que convidara os governos da região a estabelecerem institutos de planejamento do desenvolvimento em seus países (DOSMAN, 2011, pp. 423-425; FRANCO, 2013, pp. 109-116; PREBISCH, 2001, p. 21).

Quando questionado acerca da validade de criar outra burocracia para fazer parte do que a CEPAL já realizava, Raúl argumenta que era preciso ter autonomia e distância das demandas burocráticas, para que a vitalidade da instituição no início dos anos 1950 fosse reascendida (DOSMAN, 2011, pp. 423-425). Mesmo que fosse uma justificativa retórica para a consecução do seu projeto de aposentadoria, não se pode deixar de pensar que algum distanciamento do sistema ONU seria produtivo na medida em que os entraves políticos à publicação dos resultados das pesquisas fossem menores. O próprio Prebisch menciona, segundo ele, "cometendo uma indiscrição", a censura que havia enfrentado da Organização, que não permitiu a publicação de seu Manifesto em nome da CEPAL (PREBISCH, 1962, p. 3). Ele afirma pouco depois:

Em matéria de desenvolvimento econômico, devo confessar, mais uma vez, que
as exigências de ação prática nos levaram a praticamente desmantelar a nossa
Divisão de Desenvolvimento Econômico, e interromperam - muito para o nosso
pesar - a natureza sistemática da nossa pesquisa. O Instituto permitirá retomar
esse caminho e explorar novos aspectos, bem como avançar no domínio
econômico e no terreno social, porque apenas por razões metodológicas é
possível distinguir estes dois aspectos da realidade viva da América Latina
(PREBISCH, 1962, p. 4).

Se ele pudesse cometer uma indiscrição mais grave, deveria dizer que o que desmontou a "Divisão Vermelha" foi o bloqueio da publicação de relatórios e textos técnicos por ela elaborados que desagradaram governos da região, considerados como muito radicais para estarem associados ao nome da Comissão. O que fez com que a CEPAL perdesse parte significativa de seus mais notórios colaboradores. Seria possível aventar que a radicalidade da crítica dependentista elaborada sob a égide do ILPES (item 3.3) só foi possível por haver esse distanciamento em relação ao centro do poder da 
ONU, permitindo que os funcionários internacionais assinassem textos que na CEPAL possivelmente teriam sido alvo de resistências.

Ao montar o ILPES, Raúl vai buscar Sunkel, um dos poucos remanescentes da equipe vermelha, para organizar a coordenação dos cursos de treinamento concebidos por seu professor Ahumada. Devido à grande demanda, os treinamentos sobrecarregavam a Comissão, razão pela qual sua transferência para o ILPES era vista com bons olhos. Os participantes passaram a receber bolsas da ONU e da OEA para ir a Santiago e lá se instalar por 8 meses para fazer o curso que, além do treinamento básico em análise econômica, técnicas de planificação, política econômica e financeira, administração, contabilidade e preparação e avaliação de projetos, passou a oferecer especializações em indústria, agricultura, obras públicas e técnicas de planejamento do desenvolvimento econômico, e mesmo seminários complementares, voltados para as áreas de saúde e de educação (FRANCO, 2013, pp. 130-132).

Quando Sunkel voltou a Santiago para coordenar o ILPES, foi substituído no Centro CEPAL-BNDE por Aníbal Pinto Santa Cruz (1919-1996). Santa Cruz estudou direito na Universidad de Chile e, como Sunkel, obteve bolsa para estudar economia na LSE. Quando retornou ao seu país, no início dos anos 1950, tornou-se professor de economia no Instituto de Economia da Universidad de Chile e pouco depois na Escuela Latinoamericana de Economía de la Universidad de Chile (ESCOLATINA), que oferecia cursos de pós-graduação na área. Aníbal Santa Cruz foi descrito por discípulos seus como "um aristocrata de esquerda" (Liana Aureliano apud CORTEZ, 2003, p. 273) e é igualmente lembrado por seu largo capital cultural, "amor à música e profundo conhecimento da musicalidade mundial e latino-americana; prazer com as conversas longas, inteligentes, do salão ao bar; leveza no dançar; prazer em comer e em falar de comida; fascínio pela literatura” (LESSA, 1998, p. 10).

Santa Cruz pertencia a uma família chilena muito tradicional e nuclearmente inserida na vida política de seu país: bisneto de Francisco Antonio Pinto, presidente do Chile de 1827 a 1829, neto de Aníbal Pinto Garmendia, advogado, ministro da Guerra e da Marinha e presidente do Chile de 1876 a 1881, e filho de Francisco Antonio Pinto Cruz, advogado, ministro da Guerra e da Marinha, ministro da Justiça e da Instrução 
Pública, diplomata e político ${ }^{54}$. Os Pinto Santa Cruz tinham laços próximos com o fundador da CEPAL, Hernán Santa Cruz, sendo que um tio de Hernán era casado com uma tia de Aníbal. A familiaridade precoce com o poder e a rede extensa de contatos no mundo político dava a esses homens trunfos culturais, sociais, materiais e simbólicos que os ajudavam a transitar nacional e internacionalmente e sustentar suas ideias heréticas sem que elas fossem interpretadas como ameaças à ordem social.

Aníbal Pinto Santa Cruz chegou ao Brasil em 1960 e permaneceu no Rio de Janeiro até 1965. Em sua equipe do Centro CEPAL-BNDE estavam Antonio Barros de Castro, Carlos Lessa e Maria da Conceição Tavares, três amigos que eram economistas em início de carreira. Carlos Lessa foi o primeiro a ingressar no escritório. Ele conta que era estagiário do Ministério da Fazenda, em uma equipe dirigida pelo fiscalista Gerson Augusto da Silva, que estava trabalhando na preparação do tratado de Montevidéu (1960), o qual daria origem à Associação Latino-Americana de Livre Comércio.

Nessa ocasião eu lidei com muita gente da divisão de comércio exterior da CEPAL. E eles deram indicação ao Osvaldo Sunkel, que vinha para o Brasil abrir o escritório CEPAL-BNDE, de que eu era um brasileiro interessante para recrutar para a organização [...]. Aí eu comecei a minha carreira como vice-diretor do centro CEPAL-BNDE. O Sunkel era o diretor e eu era o vice-diretor. Pouco tempo depois Aníbal Pinto Santa Cruz substituiu o Sunkel e aí o escritório cresceu por agregação de Castro, Conceição, de uma porção de jovens economistas que depois fizeram carreira, muitos deles na Universidade de Campinas (Entrevista de Carlos Lessa à autora, 2012).

Carlos Lessa conta que já conhecia Maria da Conceição Tavares e Antonio Barros de Castro antes da reunião dos três no Centro CEPAL-BNDE. Lessa conheceu Castro no Colégio Padre Antonio Vieira, uma das principais instituições de formação dos rebentos masculinos de famílias tradicionais católicas da elite brasileira. Cabe aqui uma observação sobre as escolas católicas de grande prestígio, onde os jovens da elite cresciam e eram educados em meio a seus pares. Essas instituições, juntamente com as famílias, incutiam a crença na excelência e excepcionalidade, naturalizando a ideia de que seus alunos poderiam vir a ocupar os postos de direção da sociedade. Ajudavam, ademais, a criar as afinidades culturais, sociais e políticas a partir das quais se teciam os laços de amizade que uniriam os futuros dirigentes nacionais (CHAVES, 2008, p. 3).

A Igreja Católica, ao ocupar-se da educação privada dos descendentes de grande parte das elites nacionais, procurava manter sua influência sobre os grupos dominantes de

\footnotetext{
${ }^{54}$ Ver: http://historiapolitica.bcn.cl/resenas parlamentarias/wiki/Francisco_Antonio_Pinto_Cruz e http://www.genealog.cl/Chile/P/Pinto/\#PintoGarmendia,Anibal. Consultados em 10/11/2015.
} 
uma sociedade que se laicizava. Em uma relação de mutualismo, a Igreja e seus colégios conquistavam prestígio atraindo as famílias mais antigas e destacadas da sociedade para seus preceitos. As famílias de elite, por sua vez, acumulavam os capitais conferidos pela frequência a esses estabelecimentos antigos, consagrados e reservados. As elites cristãs encontravam nos colégios confessionais ambientes controlados e protegidos, nos quais os filhos não apenas seriam criados de acordo com a moral e os valores vigentes em suas casas, mas também e talvez sobretudo, permaneceriam entre soi, estando em contato com seus semelhantes. Essa circunscrição das relações era parte importante da estratégia de multiplicação do capital social das famílias de classe dominante. O custo do envio dos moços e moças para os colégios particulares era, portanto, um investimento de capital econômico na reprodução dos capitais social, cultural e simbólico e no aprendizado dos modos e da moral adequados ao mundo social no qual deveriam inserir-se (CHAVES, 2010/2011; PEROSA, 2004, pp. 63-72; PINÇON e PINÇON-CHARLOT, 1989, pp. 141-146; PINÇON e PINÇON-CHARLOT, 2006, p. 115).

As famílias de Lessa e de Castro, contemporâneos de Colégio Padre Antônio Vieira, têm origem nas elites católicas "quatrocentonas" - termo cunhado pelas classes dominantes que se reivindicam antigas, enraizadas e autênticas para distinguir-se dos imigrantes que começavam a instalar-se à sua volta (SEVCENKO, 1992). Carlos Lessa (1936) declarou em entrevista ser "um oligarca de família tradicional” (LESSA, 2010, [online]). Ao ser indagado sobre a razão que o levou a usar tal expressão para definir suas origens, ele responde:

O lado de minha mãe é pernambucano, muito antigo no Brasil. O lado do meu pai, que é predominantemente português, é muito antigo no Brasil também. Vem do século XVIII [...]. Economicamente a família de minha mãe esteve ligada, obviamente, ao açúcar, e o patrimônio da família de meu pai esteve ligado, basicamente, à economia do café. Agora, tem assim, digamos, caminhos laterais dessa árvores, que me remetem, por exemplo... eu sou descendente do Gomes Freire de Andrade, que foi vice-rei do Brasil, né. De quem eu sou descendente? Sou descendente do filho dele. Do segundo filho dele e o segundo filho dele foi quem projetou o Paço Imperial. Foi o arquiteto que projetou os passeios da Lapa. Durante muito tempo foi considerado o autor do primeiro livro publicado no Brasil [...]. Vamos simplificar, eu sou da elite brasileira de muitas gerações. Ponto. [...] se você pegar os meus avós, os mais imediatos, o meu avô Theodoro, que é o pai de minha mãe, foi um grande advogado e ele foi filho do José Higino Duarte Pereira da Silva, que foi o autor da Lei do Ventre Livre. Se você pegar pelo lado do meu pai, o meu avô, Carlos Oscar, médico. Foi lente no Pedro II de física, química e biologia que é, na época, digamos, a vanguarda científica. Esse meu avô era botânico, estudou profundamente a reprodução das orquídeas, aprendeu árabe clássico. Eu sou de uma família muito, como posso dizer, durante muito tempo urbana e durante muito tempo, é uma expressão idiota, mas vamos dizer, culta. O irmão de meu pai, por exemplo, foi ser diplomata de 
carreira com 17 anos, porque na época era direto o concurso. Ele foi primeiro lugar em um concurso de duas vagas. O meu pai foi para a faculdade de medicina com 15 anos. O meu pai, quando foi para a faculdade de medicina, já tinha dez anos de cello e dez anos de piano. Era considerado com ouvido absoluto. O meu tio tinha ouvido absoluto, foi considerado o melhor violinista da geração dele [...]. Quer dizer, eu tenho uma família que é urbana, o que é relativamente raro, urbana de Rio de Janeiro, que é mais raro ainda, por três gerações ou quatro. Três com absoluta certeza, que são todos acadêmicos (Carlos Lessa, entrevista à autora, 2012).

Sobre as mulheres da família, diz ele que não estudaram, mas conta que a avó tinha “o culto à cultura". "Ela forçava o meu pai e o meu tio a estudar doze horas por dia. Eles não foram para colégio, tiveram preceptores individuais”. Quanto à mãe, diz que ela era um personagem panglossiano ${ }^{55}$ : "dedicava dois dias por semana para tecer casaquinho de tricô para crianças órfãs" e estava envolvida com obras sociais pontifícias na favela que ajudavam a "salvar gente que estava doente, arranjar emprego, arranjar profissão, resolver problemas de toda natureza". Lessa fala também daqueles que chamava de "os pobres de minha mãe", pessoas que ela alimentava no jardim de sua casa todos os dias. Segundo ele, na juventude, os vizinhos favelados eram seus heróis porque "jogavam futebol muito melhor e também contavam aventuras sexuais reais e imaginárias que nós não tínhamos nada para contrapor". A contiguidade espacial com a favela e a devoção de sua mãe ao trabalho social, argumenta, tiveram grande influência sobre o seu olhar para os problemas brasileiros (Carlos Lessa, entrevista à autora, 2012).

Toda a família de Lessa era católica. Ele diz, no entanto, não ser "praticante da formalidade" embora se considere "um cristão verdadeiro" - a ponto de encerrar seu discurso de posse na presidência do Banco Nacional de Desenvolvimento Econômico e Social (BNDES) dizendo: "que a razão nos ilumine e que Deus nos ajude e proteja" (LESSA, 2003). Além da educação cristã masculina e tradicional, o Colégio Padre Antônio Vieira ensinava latim, francês e inglês. À formação recebida no colégio somavam-se as lições da preceptora alemã, contratada por sua avó, que teria sido a responsável por fazer com que ele achasse o estudo de idiomas “a coisa mais chata do planeta”. Declara ler "com facilidade inglês, francês, italiano e com muita dificuldade eu consigo entender algumas coisas do alemão, e espanhol obviamente" e completa: “talvez a única coisa que

\footnotetext{
${ }^{55}$ Panglossiano "relativo ao Doutor Pangloss, personagem de Cândido, romance satírico de Voltaire [...] que lembra o otimismo dessa personagem. Otimista" (Dicionário Aurélio Buarque de Hollanda Ferreira, $2^{\mathrm{a}}$ Edição, 1986, p. 1256).
} 
eu consegui ser fluente falando foi portunhol, versão própria" (Carlos Lessa, entrevista à autora, 2012).

O relato de Lessa explicita a crença na excepcionalidade da trajetória de seus antepassados, que procura associar ao cultivo cultural, apresentado como a razão meritória de tamanha proeminência. Não há, em seu relato, qualquer tentativa de ocultar a relação direta entre seu sucesso e o de seus antepassados e o privilégio usufruído por sua família. Ele procura, entretanto, associar a vivência proporcionada pelas ações benevolentes da mãe ao despertar de sua consciência crítica. Em outros momentos da entrevista, ele dirá que outras pessoas teriam sido desviadas desse caminho crítico ao ceder à "sedução do bezerro de ouro". Assim sugere que a sua condição privilegiada e a boa administração das "pequenas heranças" que recebeu faziam com que ele não corresse esse risco, podendo assim sustentar suas convicções contra as tentações do dinheiro. "Eu nunca passei pelo problema do dilema do bezerro de ouro. Mas eu consigo compreender que exista esse dilema. Eu não posso nem condenar as pessoas que cedem a esse dilema. Posso apenas deplorar" (Carlos Lessa, entrevista à autora, 2012).

Antonio Barros de Castro (1938-2011) estudou no Padre Antônio Vieira e também em outros dos mais tradicionais colégios católicos do Rio de Janeiro: o Notre Dame, o Santo Agostinho, o Santo Inácio e o São Bento. Sua mãe, Adelina, era católica fervorosa e deu a ele o nome de Antonio cumprindo promessa que fizera para Santo Antonio, a quem rezara para engravidar e dar a luz a um segundo filho homem (CASTRO, 1978, p. 55-56). Adelina era bisneta do Barão de Itu, Bento Paes de Barros, que por sua vez era irmão do Barão de Piracibaba, Antônio Paes de Barros. Ela era neta de um

jovem paulistano formado em direito e adepto de valores republicanos em plena
Monarquia: Raphael Aguiar Paes de Barros. Na década de 1970, o pai do jovem -
o Barão de Itu - enviou o filho para uma viagem europeia, e foi neste contexto
que Raphael conheceu as corridas de cavalo, habituais na Inglaterra. De volta ao
Brasil, decidiu reunir amigos da elite paulistana a fim de angariar capital e
agremiar sócios, em ações que resultaram na fundação do "Club de Corridas
Paulistano" em 1875 (MANCINI, 2013, p. 184).

Adelina descendia de famílias proprietárias de terras do Estado de São Paulo que casavam entre si para não partilhar seu patrimônio. Essas elites tinham sua matriz econômica associada à terra, não obstante, faziam investimentos escolares para que seus filhos adquirissem a cultura cosmopolita e o título de bacharel que funcionavam como marcadores de aptidão social para o exercício do poder, em um universo no qual a 
competência técnico-administrativa não tinha ainda grande importância. A educação que ofereciam a eles seria tanto melhor quanto mais próxima dos padrões culturais europeus. Assim aqueles que podiam enviavam seus filhos para estudar e viajar pela Europa, considerada o berço da "civilização" e da "cultura" e o modelo de sociedade a ser importado para que o Brasil pudesse combater o atraso. Foi o que fez o Barão de Itu ao enviar o avô de Adelina, Raphael Aguiar Paes de Barros, para o velho continente. Aqueles que de lá retornavam traziam consigo signos cosmopolitas que funcionavam como trunfos nos jogos de poder e distinção nacionais e importavam as modas e modos dos europeus, como ilustra a história da criação do Club de Corridas Paulistano que mimetizava o turfe, tão valorizado em países como a França e a Inglaterra (CARVALHO, 2013; DEZALAY, 2004, p. 6; DEZALAY e MASDEN, 2008, pp. 5-15; HOLANDA, 2006, p. 172; KLÜGER, 2015a; MARTINS, 1987, pp. 65-87; MICELI, 2001, pp. 79, 114; NEEDELL, 1993, p. 72).

$\mathrm{O}$ avô materno de Castro era engenheiro construtor de estradas de ferro e morreu precocemente. Sua avó, viúva, voltou a residir com a família, primeiro com a bisavó Cândida e depois na casa do avô Raphael, um palacete na rua Brigadeiro Tobias que serviria, anos depois, como Tribunal de Justiça do Estado de São Paulo (CAMPOS, 2005, pp. 37-38; CASTRO, 1978, pp. 8-9). Como muitas moças de elite de seu tempo, Adelina estudou no Colégio Sion. "Como os pés das meninas chinesas, o corpo e a alma das pequenas alunas de Sion eram progressivamente enfaixados desde seus primeiros passos no colégio, através de práticas que ordenavam seu tempo, sua inscrição no espaço, seus gestos, sua voz, sua escrita e até mesmo seus pensamentos”. Assim incutia-se o sentimento permanente de culpa que compelia as mulheres à obediência e à submissão a Deus, às autoridades e aos maridos, próprias ao destino social que para elas era projetado (BRITO, 2009, p. 46; BRITO, 2010). O Sion preparava as moças para ter os conhecimentos úteis à vida das mulheres da alta sociedade: o francês, o piano e os modos que lhes permitiriam circular pelos salões e atrair um matrimônio adequado. Adelina assim refere-se ao Sion em suas memórias:

Achei o francês uma língua fácil e expressiva e tanto foi meu gosto que em 3 meses já não tinha dificuldade em seguir as aulas e ter ótimas notas, sendo que quase todas as matérias eram dadas em francês. Nessa língua é que ouvia falar sobre a Criação do Mundo, o Povo de Deus, entusiasmando-me pelas histórias de José, Moisés, o rei David e outros personagens. Apegava-me à História Universal, ao heroísmo dos tempos remotos, mas onde mais vibrei foi na classe [...] em que estudávamos a História da França [...] estudávamos bastante matemática, quase todas as matérias do atual currículo e tínhamos bons 
professores para o português e a História do Brasil que era estudada com muita atenção. Todas as alunas estudavam piano [...] as aulas de piano eram dadas em um grande salão onde se tocava em 5 pianos; e assim, em conjunto, apresentávamos nossas músicas em dias de festa (CASTRO, 1978, p. 15).

Depois de concluir os estudos, "aos domingos não faltava à missa e às quintasfeiras tomava parte na costura para os pobres no Sion onde encontrava antigas colegas e trocávamos novidades". Com suas tias frequentava os espaços de lazer pelos quais circulava a elite: teatros, óperas, o cinema, os concertos da Sociedade Cultura Artística, da qual sua tia era associada, e o Jockey Club, fundado por seu avô (PINÇON e PINÇONCHARLOT, 1989, p. 114; NEEDELL, 1993, pp. 100-110). No casamento de uma de suas primas, Adelina conheceu o futuro marido Euclydes José Coelho de Castro, um carioca proveniente de famílias também tradicionais, os Coelho de Souza e os Castro do Maranhão. O avô paterno de Antônio Barros de Castro, Armando, era veterinário e médico diplomado pela Faculdade Nacional de Medicina. O pai, Euclydes, estudou engenharia, foi contador na Estrada de Ferro Central do Brasil, trabalhou em uma firma de automóveis, em uma companhia de seguros e na Seção Comercial da Rádio Ipanema (CASTRO, 1978, pp. 6-7, 17; Entrevista de Ana Célia Castro à autora, 2014).

Quando Antonio Barros de Castro nasceu seus pais residiam no Rio de Janeiro, no bairro de Ipanema. Pouco tempo depois, o pai decidiu comprar uma fazenda na região de Parnaíba do Sul para tentar produzir café. Por 13 anos tiveram a fazenda e a família passou a dividir o seu tempo entre o Rio de Janeiro e o interior. Situada em uma região na qual a produção cafeeira declinava velozmente, a fazenda foi afetada por geadas e aftosa, dando, a cada ano, maiores prejuízos à família. Os descaminhos econômicos dos Barros de Castro criam uma situação contraditória na qual eles viviam na casa adquirida em meio à área rica de Ipanema, mas contrapunham-se aos dois mundos dos quais se avizinhavam: as famílias riquíssimas do Rio de Janeiro, às quais já não pertenciam, e os moradores das favelas que cercavam o bairro, fonte de seus mitos da infância, como os de Lessa. Os Barros de Castro eram amigos de crianças muito ricas, como os filhos do banqueiro e ministro Clemente Mariani, mas não tinham mais o capital requerido para integrar-se plenamente a esse universo. Antonio conta que chegaram a atravessar momentos em que não havia dinheiro suficiente para manter o estudo dos sete filhos e comprar vestimentas adequadas. Segundo ele os altos e baixos da economia familiar despertaram seu interesse e 
o de seus dois irmãos para as "restrições orçamentárias", levando os três moços a estudar economia (CASTRO, 1978; CASTRO, 1999, p. 155).

Carlos Lessa e Antonio Barros de Castro foram colegas novamente na Faculdade Nacional de Ciências Econômicas (FNCE) da Universidade do Brasil ${ }^{56}$, onde ingressaram em 195657. Castro dá o seguinte depoimento sobre sua vida na universidade:

\begin{abstract}
Cursei, no Rio de Janeiro, a antiga Faculdade Nacional de Economia, na mesma turma de Carlos Lessa, amigo inseparável de muitos anos. Era uma boa escola, apesar de extremamente conservadora. As figuras marcantes eram: Octavio Bulhões, Roberto Campos, Antônio Dias Leite e San Thiago Dantas. Eram quatro notáveis professores [...] o grande problema da nossa escola era o insulamento. Que eu me lembre jamais foi mencionado o debate Roberto Simonsen versus Eugênio Gudin ${ }^{58}$. A CEPAL também não era referida. A publicação do Formação Econômica do Brasil de Furtado teve repercussão nula. Como disse, era uma escola extremamente conservadora, mais do que isso: uma redoma (CASTRO, 1999, p. 156).
\end{abstract}

A opinião de Lessa sobre a escola não é diferente. Ele também reclama da falta de diversidade dos conteúdos ministrados, afirmando que não havia sequer uma referência a Keynes e que o Brasil nunca foi tratado como uma economia com especificidades. Ainda assim, ele julga sólida a formação recebida: "nós tínhamos um conjunto de professores praticamente todos conservadores, mas muito bem preparados. Figuras assim, estelares, tipo Eugênio Gudin [...] San Thiago Dantas era uma figura fantástica. Deslumbrante! Talvez o melhor professor que eu vi em toda a minha vida. Roberto Campos era um homem extremamente culto" (Carlos Lessa, entrevista à autora, 2012). "Meu curso de economia foi um curso muito curioso para os padrões atuais, pois eu li os grandes autores neoclássicos e suas obras originais [...]. Ora, o pensamento liberal em sua melhor versão leva à discussão conceitual. Coisa que o manual anglo-saxão atual não leva” (LESSA, 1981, p. 165). Tanto Castro quanto Lessa sustentam que só assumiram posturas críticas em relação ao pensamento econômico produzido e ministrado na FNCE depois de formados.

Como Lessa, Castro e outros dois colegas, David Langier e Ruy Formosi, trabalharam, durante a graduação, no Conselho de Política Aduaneira, com Gérson Augusto da Silva. Castro o considerava como um "pai intelectual" que despertou seu interesse pela política econômica. Ao final da graduação, Barros de Castro recebeu a

\footnotetext{
${ }^{56}$ A Faculdade Nacional de Ciências Econômicas da Universidade do Brasil será objeto de consideração no próximo capítulo (item 2.1).

${ }^{57}$ Lessa havia ingressado antes na engenharia mas rapidamente trancou o curso e passou à economia.

${ }^{58} \mathrm{O}$ debate entre Roberto Simonsen e Eugênio Gudin será tematizado adiante (item 4.1).
} 
medalha Visconde de Cairu por seu desempenho acadêmico e obteve uma bolsa da Fundação Rockefeller para complementar seus estudos no exterior. Castro, que já dominava o inglês e o francês, optou inicialmente pela Inglaterra, para onde foi também seu colega e amigo Langier. Ele ingressou na LSE em 1960. Lá estudaria com o mesmo Lionel Robbins que dirigira os estudos de Sunkel anos antes, mas diz ele: "estudei só marginalmente economia. Eu me interessava mesmo era pelo curso de Filosofia da Ciência e sobretudo pelo seminário do [Karl] Popper, que foi a maior experiência intelectual da minha vida". Depois de um ano em Londres, Castro mudou-se para Paris onde estudou matemática e estatística no Centre d'Études des Programmes Économiques. Nele lecionava Edmond Malinvaud ${ }^{59}$, economista que, como Gerard Debreu $^{60}$, integrava o grupo de jovens que se congregava ao redor de Maurice Allais, economista com formação em matemática, diploma de politécnico e experiência na administração de Estado ${ }^{61}$, tendo sido pioneiros na construção da visões matematizadas

\footnotetext{
59 "A trajetória de Edmond Malinvaud ilustre imbricação de «ciência econômica» fonte de um prestígio propriamente intelectual, e do acesso a postos públicos voltados, inicialmente, para a produção e difusão de informações estatísticas com finalidade de racionalização das políticas econômicas. Descendente da burguesia togada provincial - seu pai era advogado -, nascido em Limoges, [...]. Ele descreve seu direcionamento para a economia como resultado de uma vocação nascida da crise, das dificuldades da guerra e da vontade de agir contra as consequências nefastas do desconhecimento da economia que se manifestam publicamente nos anos 1930. Ele descobriu essa disciplina enquanto fazia a graduação em direito, conforme a tradição familiar. Recebeu [treinamento] na Escola Politécnica e completou sua formação lendo livros de economia. Ao sair da faculdade, dirigiu-se ao corpo de administradores do INSEE, onde entrou aos 25 anos, ao final da guerra [...]. Dois anos depois ele obteve uma bolsa Rockefeller para ir para Chicago, nos Estados Unidos, integrar um formado por jovens pesquisadores provenientes de todos os país (a Cowles Comission). Ele volta maravilhado por um mundo pouco conhecido na França, mas a opção por uma carreira de pesquisador the parece demasiado "arriscada", mesmo que se tenha sido oferecida a ele a possibilidade de construir o sistema nacional de informações estatísticas, continuando, por outro lado, a conduzir pesquisas e a importar, progressivamente, o modelo descoberto na Cowles Comission. Desde esta época, ele mobiliza os laços intelectuais, frequentemente com europeus, tecidos nos Estados Unidos, para participar do desenvolvimento de um "ambiente de pesquisa" internacional, particularmente europeu (LEBARON, 1997, p. 18). Mesmo sendo de um país central a circulação internacional é essencial para que este, até então, economista prático e autodidata tivesse contato com a fronteira do conhecimento em nível internacional que, à época, era a economia e a econometria de Chicago e da Cowles Comission, que serão discutidas adiante (item 4.4).

${ }^{60}$ Debreu "era primariamente um matemático graduado na Ecole Normale Supérieure na França. Como muitos de seus colegas europeus, ele entrou na academia estadunidense pouco depois da guerra, graças a bolsas da Fundação Rockefeller. Em 1951, ele foi convocado para a Cowles Comission e lá trabalhou por onze anos antes de juntar-se ao departamento de economia de Berkeley [...]. Debreu era produto de um ambiente social e intelectual muito particular. Durante sua juventude na França, ele foi fortemente influenciado pelo método axiomático do coletivo matemático que chamava a si mesmo de "Nicolas Bourbaki." Ele também familiarizou-se com a síntese do equilíbrio geral de Maurice Allais, em cujo tratado econômico (publicado como Traité d'économie pure) tropeçou em 1946 e cujo seminário viria posteriormente a integrar em Paris, aprofundando, assim, suas conexões com o mundo da engenharia. [...]. Ele via economia como uma ciência puramente dedutiva que deveria abracar os princípios Bourbaki de absoluto rigor matemático, simplicidade e generalidade. Não surpreendentemente, ele um dia ajudaria a fundar o Journal of Mathematical Economics" (FOURCADE, 2009, pp. xii-xiii).

${ }^{61}$ Ver: http://www.nobelprize.org/nobel_prizes/economic-sciences/laureates/1988/allais-bio.html. Consultado em $22 / 05 / 2016$.
} 
da economia (item 4.4) (Ana Célia Castro entrevista à autora, 2014; CASTRO, 1999, p. 156-158; MALINVAUD, 2003, p. 183).

Enquanto Castro estudava na Europa, Lessa fazia o curso de aperfeiçoamento ministrado pelo Conselho Nacional de Economia (CNE). Ao concluí-lo, Lessa passou a lecionar no Instituto Rio Branco e trabalhar no próprio CNE, a convite de Juvenal Osório. O Conselho enviou-o para o Nordeste para fazer um diagnóstico sobre a economia da região metropolitana de Recife. Sobre a ocasião diz:

\begin{abstract}
Eu visitei as favelas do Recife. Visitei Nova Brasília e fiquei em um estado de revolta com a elite brasileira. Como que deixam que as pessoas vivam nessas condições desumanas. Como que tem apartamentos de luxo na Barra, na praia da Boa Viagem, por trás essas favelas pútridas, curtas, com pessoas pigmeus, envelhecidos, imundos. A sociedade está errada. Então eu passei por uma posição crítica em relação à sociedade sem ter sido doutrinado por nenhum grupo propriamente. Foi, digamos assim, um resultado, digamos assim, da minha maneira romântica de ver as favelas do Rio e o choque de ver a favela de alagado. Depois que eu conheci a favela dos alagados de Salvador, aí virei obcecado pelo tema favelas, estudei o tema favelas obstinadamente (Carlos Lessa, entrevista à autora, 2012).
\end{abstract}

As favelas e a leitura de Celso Furtado foram, na opinião de Lessa, os estopins de sua orientação crítica. Pouco tempo transcorreu até que sua orientação encontrasse eco no pensamento e ação da CEPAL, onde diz ter mergulhado "de cabeça na agenda brasileira e na agenda latino-americana" (LESSA, 1981, p. 166). Quando Castro retorna de Paris, já encontra seu colega Lessa e uma economista que era da turma seguinte da UB, Maria da Conceição Tavares, trabalhando no recém-criado Centro CEPAL-BNDE. Eles apresentaram Castro ao novo chefe, Aníbal Pinto Santa Cruz, que o convida a juntar-se à equipe em dezembro de 1962 (CASTRO, 1999, p. 159).

Ao falar de Maria da Conceição Tavares (1930) é preciso ressaltar, desde já, a excepcionalidade da posição por ela desfrutada naquele momento. É ela a única mulher a ter destaque no espaço dos economistas por quase dez anos. É possível indagar se a singularidade de Tavares não estaria diretamente relacionada, em primeiro lugar, ao fato de ser estrangeira e ter chegado ao Brasil com uma perspectiva da inserção social da mulher já transformada pelas experiências que teve junto a grupos sociais contestadores e, em segundo lugar, à posse de um grande domínio da matemática avançada, tão raro e cada vez mais caro àqueles que estavam tentando ensinar economia e esboçar uma administração econômica racional. 
Conceição nasceu no povoado de Anadia, próximo a Coimbra, em Portugal. Sua mãe, Maria Augusta, descendia de uma família católica de realistas miguelistas ${ }^{62}$ e o pai, Fausto Tavares, de uma família republicana de comerciantes pequeno-burgueses. Fausto e Maria mudaram-se para Lisboa logo após o nascimento de sua filha Maria da Conceição, pois havia uma cisão entre as famílias dos dois, motivadas por divergências políticas. $\mathrm{O}$ avô paterno de Conceição, Manuel Tavares, era um negociante português próspero que deixou a mulher e os filhos para aventurar-se na exploração da borracha que prosperava na Amazônia, na passagem do século. Com o colapso da economia seringueira no início do século XX, Manuel retorna a Portugal sem nada, razão pela qual seu filho, Fausto, desiste do sonho de estudar engenharia para ajudar no sustento da família (CARICATURA FAUSTO RODRIGUES TAVARES, 1949; MELO, 2012, pp. 206-207; TAVARES, 2008, pp. 14, 17; TAVARES, 2010).

Fausto começou trabalhando a terra, passou por uma fábrica de azeite, por uma serraria e, por volta de 1924, foi para Lisboa trabalhar na Vinícola D’Amadora. Diz ele: “Ali iniciei a minha vida de trabalhos e descobri que, só usando muita força, sem ajuda de ninguém, um homem pode chegar até o alto. E foi isso que comecei a fazer. A lutar. A lutar sozinho. Com as minhas próprias mãos e nada mais”. Quando casou com Maria Augusta Caiado de Almeida, em 1928, Fausto já era um dos principais sócios da vinícola e exportadora. Em meados dos anos 1940, em férias no Brasil com a família, recebe proposta para participar de uma sociedade que iniciava empreendimento de fabricação de bebidas no Rio de Janeiro, para onde transferiu-se em 1947 (CARICATURA FAUSTO RODRIGUES TAVARES, 1949) ${ }^{63}$.

A fábrica de cerveja e refrigerantes, que começou na Praça da Bandeira e depois transferiu-se para um enorme galpão em Bonsucesso, recebeu o nome de Companhia Cervejaria Cayru em homenagem a José da Silva Lisboa, o Visconde de Cairu: homem de confiança da corte portuguesa no Brasil, envolvido com a política joanina de abertura dos portos. Partidário do livre cambismo e do livre mercado, Cairu é tido como o primeiro economista político brasileiro. Ele traduziu e publicou no Brasil Os Princípios de Economia

\footnotetext{
62 "Os miguelistas eram adeptos de Dom Miguel, irmão de Pedro I do Brasil e Pedro IV de Portugal. Incentivado por sua mãe, Dona Carlota Joaquina, Dom Miguel ocupou e perdeu o trono português e, nos anos de 1832 a 1834, Portugal sofreu uma guerra civil entre absolutistas adeptos de Dom Miguel e liberais, comandados por Dom Pedro [...]. A vitória dos liberais assegurou o controle do Estado português mas não a concorde, e essa divisão ainda estava presente na sociedade portuguesa no início do século XX" (MELO, 2012, p. 222).

${ }^{63}$ Ver: http://memoria.bn.br/docreader/DocReader.aspx?bib=348970 04\&PagFis=56990 http://www.jusbrasil.com.br/diarios/2274803/pg-70-secao-1-diario-oficial-da-uniao-dou-de-08-021949/pdfView. Consultados em 15/11/2015.
} 
Política, de Adam Smith e foi convidado, por D. João, para oferecer uma Aula Pública de Ciência Econômica com o objetivo de preparar os vassalos da corte que tivessem interesse no exercício da profissão ${ }^{64}$ (FARIA JÚNIOR, 2008, pp. 123-140; ROMA, 2011, p. 331; VIEIRA, 1981, pp. 351-352).

A escolha do nome Cayru para a fábrica procurava "assinalar que um brasileiro e um português (este rei; aquele estadista) haviam harmonizado em tempos idos suas ideias a fim de que os benefícios do comércio atingissem os países amigos com a abertura dos portos. Pois a cervejaria Cayru demonstrava, como demonstra, a mesma compreensão de portugueses e brasileiros em obra destinada a favorecer os consumidores em geral" 65 . No início dos anos 1950, Fausto vendeu sua cervejaria para o grupo Scarpa, dono da Cervejaria Rio Claro. Pouco depois, começou outro empreendimento similar, agora no Paraná: a Cervejaria Londrina, que anos depois também foi vendida para o grupo Scarpa, que se associou ao grupo europeu Skol66. Com o dinheiro que acumulou, Fausto fez investimentos na construção civil e adquiriu propriedades no Mato Grosso e em Goiás nas quais mantinha atividades pecuárias (FARIA JÚNIOR, 2008, pp. 123-140; ROMA, 2011, p. 331; VIEIRA, 1981, pp. 351-352).

Maria da Conceição Tavares declara, em diversas entrevistas, que o pai, apesar de burguês, era anarquista e conta que ele e um tio comunista abrigaram os refugiados da Guerra Civil Espanhola. Foi através deles que Conceição teve seu primeiro contato com as leituras clássicas da esquerda. Ela relata também que foi politicamente influenciada por sua mãe que lutava pelos direitos das mulheres, ajudando as prostitutas de Lisboa. Maria da Conceição nasceu, pois, nessa síntese contraditória: tinha uma família em parte realista, em parte republicana, incapaz de conciliar-se. A mãe, extremamente católica, era progressista no que concerne à valorização das mulheres. O pai era um grande capitalista que, ao mesmo tempo que professava o anarquismo-marxismo, deu à sua fábrica o nome de um expoente do pensamento liberal e retratava-se como um self made man que venceu depois de muito "lutar sozinho, com as minhas próprias mãos e nada mais" (MELO, 2012, pp. 206-207; TAVARES, 2008, pp. 14, 17; TAVARES, 2010; CARICATURA FAUSTO RODRIGUES TAVARES, 1949).

\footnotetext{
${ }^{64}$ As aulas públicas de Cayru não chegaram a ser implementadas. Caso contrário teriam sido as primeiras aulas oficiais de economia no país.

Citação extraída da reportagem: http://memoria.bn.br/docreader/DocReader.aspx?bib=348970_04\&PagFis=56990. Consultado em 15/11/2015.

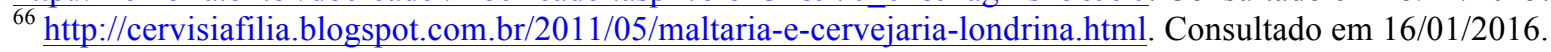


Fausto mudara para o Brasil sem a família. Maria da Conceição, em Portugal, foi aprovada no Instituto Superior Técnico de Lisboa para estudar engenharia químicoindustrial. Ao final do primeiro ano, decidiu transferir-se para a Faculdade de Matemática da Universidade de Lisboa, concluindo a graduação em 1953. Conceição afirma que "do ponto de vista intelectual, a influência mais importante, em Portugal, foi a do professor Bento de Jesus Caraça, matemático de esquerda e produtor cultural das mais brilhantes enciclopédias do país. Além disso, era militante do Partido Comunista Português, ilegal, dando aulas para trabalhadores que organizavam o jornal A Voz Operária"67 (TAVARES, 2010; MELO, 2012, p. 207). Tavares refere-se aos seus anos de estudante em Portugal sob o salazarismo como um período de pânico, no qual não importava o conteúdo do seminário que se fizesse, podia ser filosofia pura ou qualquer outra coisa, era ilegal. Ela, como muitos dos matemáticos marxistas portugueses, imigrou para o Brasil almejando trocar a "ditadura selvagem, irrespirável" de Salazar por uma democracia. A ilusão não durou muito. Mal chegara ao país, o presidente Getúlio Vargas suicidou-se, fazendo com que ela indagasse "onde foi amarrar o seu cavalo" (Maria da Conceição Tavares apud DURÃO e TOTTI, 2012 [online]).

Conceição chegou ao Rio de Janeiro em pleno carnaval de 1954 acompanhada de seu marido, o engenheiro hidráulico Pedro José Serra Ribeiro Soares e grávida de sua primeira filha. Pedro conseguiu um emprego em uma empresa que realizava obras na Lagoa Rodrigo de Freitas. Ela acreditava que aqui conseguiria tornar-se professora de matemática, mas não obteve a equivalência de diploma requerida para lecionar e tampouco encontrou emprego em empresas privadas. Conceição conta que:

De 1954 a 1957 foi o meu período de ciências exatas. Eu já tinha desistido de dar aula, pois como não me reconheciam o diploma, eu não podia entrar na universidade. Consegui um emprego, não como matemática, mas como estatística, no Instituto Nacional de Colonização, que vem a ser hoje o INCRA, da reforma agrária. E comecei minha profissão fazendo tabelas sobre a questão agrária (TAVARES, 1986).

Ela diz que foi lá que começou a "conhecer os números [do Brasil] e perceber quanto é grande e desigual. Foi a desumana distribuição de renda que me levou a estudar economia" (Maria da Conceição Tavares apud DURÃO e TOTTI, 2012).

\footnotetext{
${ }^{67}$ Ver: Papo UFRJ com Maria da Conceição Tavares

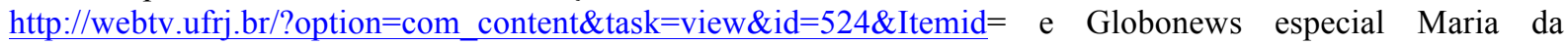
Conceição Tavares 80 anos: https://youtu.be/K_qunKjZf4U. Consultados em 15/11/2015.
} 
A Fundação Getúlio Vargas, para mim, era quase um mistério, eu nem sabia que existia. Só conheci nessa época o Mario Henrique Simonsen porque ele era engenheiro e amador de matemática. Nos encontramos no IMPA (Instituto de Matemática Pura e Aplicada), ele explicando para que servia o modelo simplex, de programação linear, nervoso, fumando o giz e escrevendo com o cigarro, aquelas coisas do Mario... Ele era amigo do meu marido, de modo que pudemos nos aproximar. Concluímos os dois, com sinceridade, que a matemática que se usava em economia era muito vagabunda, não servia para nada. Depois ele continuou usando a matemática para enrolar o pessoal, e eu tive a sorte de desejar fazer economia porque logo me dei conta de que não adiantava nada só saber matemática; o que eu fazia com ela eram tabelas, correlações e coisas assim. Em 1957 entrei para a escola de economia e fui trabalhar como analista matemática no BNDE (Banco Nacional de Desenvolvimento Econômico), com o Jessé Montello, que àquela altura era uma pessoa séria, e com o Miguel Osório. Precisavam montar umas equaçõezinhas econométricas que fizessem simulação da distribuição de renda e que usavam a lei de Pareto. Eu me lembro, jovem matemática, discutindo com eles estatística, que servia mais para esse tipo de coisa. Era fascinante o contraste entre o que a gente falava com o Jessé, tudo muito chato, e o que o pessoal do Departamento Econômico do Banco falava. Estes sim eram assuntos estimulantes, eles estavam discutindo tudo: a questão agrícola, a lei do capital estrangeiro, as reformas econômicas - e eu ali, com o olho arregalado (TAVARES, 1986 [online]).

No BNDE Conceição trabalhou nos cálculos necessários para a formulação do Plano de Metas e aproximou-se de Inácio Rangel, do Departamento Econômico, que foi quem a aconselhou a ler os pioneiros das teorias do imperialismo de Vladmir Lenin e Rudolf Hilferding, que falavam sobre o capital financeiro, tema que teria importante papel em sua obra (TAVARES, 2010).

O período das ciências exatas termina quando Conceição ingressa na Faculdade Nacional de Ciências Econômicas em 1957, uma turma depois de Castro e de Lessa. Ao mesmo tempo, passou a ser assistente do professor Octavio Gouvêa de Bulhões que, ainda que fosse conservador, dava liberdade para que ela ensinasse coisas diferentes. Podia falar de monopólio, oligopólio, o que quisesse, desde que ensinasse também o conteúdo por ele determinado. Nesse sentido, argumenta, ele era um verdadeiro liberal (TAVARES, 1996, pp. 128-129). Ela conta que:

como eu sabia matemática, fazia as contas e os gráficos para o velho, que não era muito familiarizado com essa parte. Na verdade, a matemática só me serviu para ser aceita como assistente na escola, já que sabia fazer equações, gráficos e umas estatisticazinhas sem a menor importância [...] Eu fui fazer economia para ser uma economista matemática. Por sorte, durante a minha formação, o próprio Bulhões não sabia nada de matemática e me mandou ler todos os clássicos: "Começa no Adam Smith, segue com o Ricardo, depois pega o Marx" - mandou a gente ler o Marx - "o Böhm-Bawerk, o Vicksell..." Ele só não gostava do Keynes. De outro lado, o Eugênio Gudin tinha uma apostila sobre economia monetária, que é um ótimo livro. Eu aprendi economia com o livro do Gudin, que não tinha nenhum modelo matemático. Os clássicos também não tinham nenhuma equação. Você pode imaginar a surra que levei. En passant, eu fazia um 
seminário de filosofia com o grupo do Ratisbona, um velho meteorologista que juntava em torno de si todo mundo da filosofia. Tal era a consciência da minha ignorância profunda para ler os clássicos - sim senhor, porque para isso a matemática não ajudava nada - que meu primeiro seminário sobre eles foi com filósofos. Li o Smith, o Ricardo e $O$ Capital marcando as partes histórico-filosóficas. Aí é que começou de verdade a coisa de aprender economia. Porque senão seria tudo uma xaropada. Economia se aprendia na Fundação Getúlio Vargas. A Margareth Hanson Costa ensinava, o Isaac Kerstenetzky ensinava, o Julian Chacel foi meu professor... Eles é que deram minha formação teórica, coisas de economia aplicada, aquelas curvinhas. Minha formação ideológica, do ponto de vista do desenvolvimento econômico, foi no BNDE, e minha formação humanística vinha dos meus colegas matemáticos. Acho muito simpático isso, o progressismo que tinha do lado das ciências exatas [...]. Esses são os primórdios da minha profissão. Tive a sorte de ter professores de todas as tendências, porque o pessoal da Fundação me ensinava na escola e o pessoal do BNDE me ensinava no Banco. Depois que terminei o curso, fiz a CEPAL, fui aluna do Furtado e do Prebisch, tirei o primeiro lugar e me convidaram para ficar lá. Peguei uma prática fantástica: eu era monetarista pela manhã - porque era assistente do Bulhões na escola - e estruturalista à tarde, na CEPAL (TAVARES, 1986 [online]).

Depois de concluir a graduação, em 1960, de conquistar o prêmio Visconde de Cairu de melhor desempenho acadêmico e de concluir o curso da CEPAL, Maria da Conceição Tavares foi convidada para juntar-se à equipe de seu colega de faculdade Carlos Lessa no Centro CEPAL-BNDE. Pouco depois, Antonio Barros de Castro voltou ao Brasil e foi também integrado ao Centro. Castro, Lessa e Tavares formaram, então, um trio que percorreu, por muitos anos, caminhos teóricos e políticos semelhantes. Além deles, o escritório incorporou, em 1964, um estudante de economia de nome Francisco de Almeida Biato que trabalhou dois anos no Centro e depois foi para a sede da CEPAL estudar no ILPES. Aníbal Pinto contratou também, entre 1962 e 1963, o sociólogo Herbert José de Souza (1935-1997), o Betinho (item 3.1), também conhecido como "o irmão do Henfil". Ele permaneceu pouco tempo no escritório pois estava totalmente imerso na militância política (Francisco de Almeida Biato in: D'ARAÚJO et al., 2005, p. 8368; SCHUMAHER e BRAZIL, 2000, p. 377; TAVARES, 2001, pp. 57-61).

Aníbal Pinto Santa Cruz, o segundo diretor do Centro CEPAL-BNDE, tornou-se uma espécie de mentor dos jovens economistas brasileiros que enxergavam nele "um homem sábio", “com grande capacidade institucional”, “antidogmático”, "com uma tendência à iconoclastia" e “engajado na luta pela transformação social”. Sob a direção de Aníbal Pinto, Conceição começou a escrever o livro Auge e declínio do processo de substituição

\footnotetext{
${ }^{68}$ Para indicar o entrevistado e o autor da coletânea onde consta a entrevista utilizo o marcador in.
} 
de importações no Brasil69 e Lessa preparou o Quinz̧e anos de política econômica no Brasil. Além de guiar as pesquisas de Conceição e Lessa, Aníbal Santa Cruz encomendou a Castro e Lessa, um manual para ser usado nos cursos intensivos da CEPAL no Brasil, que deveria ser adequado para ensinar pessoas com as mais diversas formações e experiências profissionais. O resultado foi o livro Introdução à economia: uma abordagem estruturalista ${ }^{70}$ (1967), também conhecido como o "Castro-Lessa", que empregava a perspectiva sistêmico-estrutural adotada pela CEPAL para discutir os problemas econômicos específicos da realidade brasileira, ressaltando o poder de transformação do planejamento e das políticas de desenvolvimento (Ana Célia Castro, entrevista à autora, 2014; CASTRO, 2000, p. 823; Carlos Lessa, entrevista à autora, 2012; CRUZ, 1977, p. 9; LESSA, 1998, pp. 8-9; SERRA, 2010; TAVARES, 2010).

O Introdução à economia foi dedicado à Gerson Augusto da Silva, que fora importante influência na vida dos dois autores. No livro há também um agradecimento a Tavares que, "ao longo dos quatro anos em que essa obra se desenvolveu [...] nos oferecia ela críticas e sugestões e se algum rigor o trabalho apresenta deve-se, em grande medida, ao seu aguçado espírito crítico e ao seu incansável desejo de cooperar" (CASTRO e LESSA, 1977, p. 17). Quando o manual ficou pronto e foi lançado, Lessa já havia deixado

\footnotetext{
69 "Auge e declínio do processo de substituição de importações, meu primeiro trabalho como economista da CEPAL, apresento quatro caminhos possíveis para o desenvolvimento. Destes, um, o que todos nós queremos, a via da autonomia e da igualdade, continua não sendo possível. Todas as formas de acumulação capitalista inventadas neste país são desequalizadoras. Não é só o estatuto colonial, a origem escravista que produz essa cultura miserável dos senhoritos [sic]. O problema é o modelo de acumulação, é a modalidade da inserção do país no capitalismo, que sempre foi dinâmica mas excludente. O Brasil sempre esteve inserido no contexto internacional e submetido a ele, desde que nasceu até hoje, embora só há pouco tempo tenha se constituído, mal e mal, como um mercado capitalista unificado. Daí a sua heterogeneidade estrutural (um conceito trabalhado por Aníbal Pinto). Em 1962, eu já dizia que o processo de substituição de importações não cumpriria o ideal progressista. Aliás, o meu livro é uma crítica à tentativa de descrever por meio da categoria 'substituição de importações' uma espécie particular de desenvolvimento industrial numa situação periférica. Industrialização, desenvolvimento das forças produtivas, nada disso resolve, pois nunca se transforma em um processo endógeno autossustentado. Enquanto isso vale a tese de Prebisch que é o cerne da tese do capitalismo dependente. Por isso, somado à impossibilidade de concorrer no mercado internacional em igualdade de condições, sem tecnologia própria, tampouco teremos uma moeda conversível e o Estado sempre será usado para criar 'moedas podres'. Por fim, como explico no ensaio sobre capitalismo financeiro, o capital financeiro nunca se junta com o capital industrial de forma orgânica, o que nos condena a ter sempre um capitalismo patrimonialista, especulativo, de quinta categoria" (TAVARES, 1997a, p. 7).

${ }^{70}$ Aníbal Pinto explica a abordagem estruturalista dizendo tratar-se de uma abordagem sistêmica, ou seja, da análise de um conjunto de fenômenos sociais inter-relacionados que deve ser apreciado em sua totalidade, que se contrapõe a uma visão atomística da economia que separa a economia do conjunto de fenômenos da vida social e cria microentidades dissociadas que interagem segundo leis míticas como a "livre concorrência", a "concorrência imperfeita". Na abordagem sistêmica a economia está inserida em uma estrutura social e global, histórica e geograficamente situada, de onde provém "os fatores e relações que condicionam objetivamente sua realidade e comportamento" (CRUZ, 1977, p. 10). Estes são estruturais quando sua influência é relativamente estável em um período determinado. $\mathrm{O}$ estruturalismo latino-americano buscou detectar quais fatores da economia global condicionariam sua condição subdesenvolvida (CRUZ, 1977, pp. 10-12).
} 
o Brasil para fugir da repressão que se alastrara após o golpe. Ele conta que, logo após a instalação do governo militar, deu um curso "meio rebelde", "caindo de porrada" nos militares. "Um aluno chegou perto de mim e disse: ô professor, os militares estão ficando incomodados com o senhor, já tem denúncias”. Foi quando as Nações Unidas “acharam que era melhor me retirar do Brasil, porque se criava uma situação complicada" na qual sua segurança poderia ser ameaçada (Entrevista de Carlos Lessa à autora, 2012). Aníbal Santa Cruz providenciou que Lessa fosse transferido para a sede da CEPAL no Chile. Chegou ele a Santiago em 1964.

Conceição Tavares destaca o papel que Aníbal Pinto desempenhou tanto na montagem de uma escola cepalina no Brasil quanto na integração dos brasileiros oficialmente exilados e auto-exilados no Chile. Quando do falecimento de Aníbal Pinto, Conceição escreve:

Sei que prantearam a sua morte, pelo muito que lhe devem, muitos amigos em várias partes do mundo, que seguiram, no entanto, por caminhos distintos. Mas falo hoje apenas pelos brasileiros, onde fez um grande número de discípulos na direção do Centro CEPAL-BNDE, de 1960 a 1964. Creio que represento a todos, por ter sido neste país, juntamente com Carlos Lessa e Antonio Barros de Castro, uma das suas discípulas mais antigas e fiéis. Ensinou-nos os fundamentos da economia política e, com a paciência, o entusiasmo e a generosidade que o caracterizavam, guiou os nossos primeiros ensaios sobre economia brasileira. Mais do que isso, ajudou, por meio dos cursos CEPAL-BNDE, a formar dezenas de economistas originários das burocracias públicas, da universidade e da política. Os mais ativos na política de resistência à ditadura acabaram no exílio e vários deles se reencontraram no Chile, onde, na CEPAL, na ESCOLATINA [Escuela Latinoamericana de Economía de la Universidad de Chile] e na FLACSO [Faculdade Latino-Americana de Ciências Sociais], continuaram desenvolvendo, junto com o mestre, seu pensamento econômico e social em forma mais rigorosa. Os que ficaram no Brasil criaram vários centros de ensino e pesquisa, o mais notório dos quais foi o Departamento de Economia da Universidade de Campinas. Como núcleo de resistência e pensamento econômico independente, grupos de economistas da UFRJ [Universidade Federal do Rio de Janeiro], da Universidade Fluminense, continuaram como puderam o seu trabalho [...]. Da sensibilidade humana de Aníbal Pinto, ao incorporar aos seus discípulos gente jovem e exilada no Chile de toda a América Latina, muitos poderiam dar testemunhos. No Brasil, temos vários casos, mas creio que o mais notável foi o de José Serra, que, sendo engenheiro e exilado, iniciou sua carreira como economista, no Chile, sob a proteção intelectual e afetuosa de D. Anibal [Pinto Santa Cruz] (TAVARES, 1996, pp. 5-6).

Por motivos distintos - fugir do regime militar, antecipar-se à perseguição, buscando um ambiente de maior liberdade intelectual, ou em busca de qualificação profissional - Carlos Lessa, Antonio Barros de Castro, Maria da Conceição Tavares, Francisco Biato e Herbert de Souza do Centro CEPAL-BNDE foram para o Chile, respectivamente, em 1964, 1969, 1968, 1966 e 1972. O exílio dos brasileiros no Chile, a 
relação que eles estabelecem com a CEPAL e com os outros órgãos internacionais lá situados será tematizada no terceiro capítulo, no qual serão retomadas as trajetórias dos funcionários do Centro CEPAL-BNDE.

\begin{tabular}{|c|c|c|c|c|}
\hline Personagem & Cronologia & Local de nascimento & Formação & Filiação \\
\hline $\begin{array}{l}\text { Raúl } \quad \text { Frederico } \\
\text { Prebisch Linares }\end{array}$ & $1901-1986$ & Tucumán - Argentina & $\begin{array}{l}\text { Graduação em economia } \\
\text { (UBA). }\end{array}$ & $\begin{array}{l}\text { Avós maternos provenientes } \\
\text { de família tradicional ligada à } \\
\text { política. Avô materno } \\
\text { senador. Pai imigrante } \\
\text { alemão que na Argentina foi } \\
\text { carteiro, mensageiro e } \\
\text { professor de inglês até } \\
\text { montar uma grande gráfica e } \\
\text { em seguida uma serraria e } \\
\text { uma livraria. }\end{array}$ \\
\hline Luiz Simões Lopes & 1903-1994 & Pelotas - RS & Engenheiro agrônomo. & $\begin{array}{l}\text { Avô paterno, João Simões } \\
\text { Lopes Filho, estancieiro, } \\
\text { exerceu a presidência da } \\
\text { província do Rio Grande do } \\
\text { Sul. Pai, Idelfonso Simões } \\
\text { Lopes, engenheiro, deputado } \\
\text { federal pelo Rio Grande do } \\
\text { Sul, Ministro da Agricultura e } \\
\text { articulador da Aliança } \\
\text { Liberal. }\end{array}$ \\
\hline $\begin{array}{lll}\text { Hernán } & \text { Santa } & \text { Cruz } \\
\text { Barceló } & & \end{array}$ & 1906-1999 & Santiago - Chile & $\begin{array}{l}\text { Graduação em direito } \\
\text { (UC) e diplomata. }\end{array}$ & $\begin{array}{l}\text { Avôs: Joaquín Santa Cruz } \\
\text { Vargas, senador, filólogo e } \\
\text { historiador, e José María } \\
\text { Barceló Carvallo, } \\
\text { parlamentar, ministro da } \\
\text { Justiça e Presidente da } \\
\text { Suprema Corte Chilena. Pai } \\
\text { advogado, funcionário do } \\
\text { Ministério das Relações } \\
\text { Exteriores, Auditor Geral de } \\
\text { Guerra e prefeito da comuna } \\
\text { de Ñuñoa. }\end{array}$ \\
\hline $\begin{array}{lll}\text { Alfonso } & \text { Santa } & \text { Cruz } \\
\text { Barceló } & & \\
\end{array}$ & $1907-1990$ & Santiago - Chile & $\begin{array}{l}\text { Graduação em direito } \\
\text { (UCC). Pós-graduação } \\
\text { em economia (Harvard) } \\
\text { e diplomata. }\end{array}$ & $\begin{array}{l}\text { Avôs: Joaquín Santa Cruz } \\
\text { Vargas, senador, filólogo e } \\
\text { historiador, e José María } \\
\text { Barceló Carvallo, } \\
\text { parlamentar, ministro da } \\
\text { Justiça e Presidente da } \\
\text { Suprema Corte Chilena. Pai } \\
\text { advogado, funcionário do } \\
\text { Ministério das Relações } \\
\text { Exteriores, Auditor Geral de } \\
\text { Guerra e prefeito da comuna } \\
\text { de Ñuñoa. }\end{array}$ \\
\hline Jesus Soares Pereira & $1910-1974$ & Assaré - CE & Sem ensino superior. & $\begin{array}{l}\text { Pai taquígrafo e mãe } \\
\text { professora primária. }\end{array}$ \\
\hline $\begin{array}{ll}\text { Gustavo } & \text { Martínez } \\
\text { Cabañas } & \end{array}$ & $1911-2003$ & $\begin{array}{l}\text { Ciudad de México - } \\
\text { México }\end{array}$ & $\begin{array}{lr}\text { Graduação em direito e } \\
\text { economia (UNAM). Pós- } \\
\text { graduação } & \text { em } \\
\text { administração } & \text { pública } \\
\text { (American } & \text { University } \\
\text { Washington). } & \\
\end{array}$ & s.d. \\
\hline Rômulo de Almeida & 1914-1988 & Salvador $-\mathrm{BH}$ & $\begin{array}{l}\text { Graduação em direito } \\
\text { (Faculdade de Direito da } \\
\text { Bahia). }\end{array}$ & $\begin{array}{l}\text { Pai caixeiro-viajante e mãe } \\
\text { dona de casa. }\end{array}$ \\
\hline Mourão & 1914-1994 & Mirador - MA & 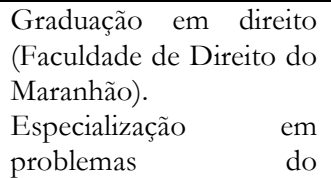 & $\begin{array}{l}\text { Pai, avô e bisavô juízes, } \\
\text { família havia sido } \\
\text { proprietária de engenho. }\end{array}$ \\
\hline
\end{tabular}




\begin{tabular}{|c|c|c|c|c|}
\hline & & & $\begin{array}{l}\text { desenvolvimento } \\
\text { (CEPAL). }\end{array}$ & \\
\hline Ewaldo Correia Lima & $1915-1992$ & s.d. - PI & $\begin{array}{l}\text { Graduação em direito } \\
\text { (Faculdade de Direito do } \\
\text { Maranhão). }\end{array}$ & s.d. \\
\hline Jorge Ahumada & $1915-1965$ & s.d. - Chile & $\begin{array}{l}\text { Graduação } r \text { em } \\
\text { engenharia agrônoma } \\
\text { (UC) Mestrado em } \\
\text { economia (Harvard). }\end{array}$ & s.d. \\
\hline $\begin{array}{ll}\text { Miguel } & \text { Osório } \\
\text { Almeida } & \end{array}$ & 1916-1999 & Rio de Janeiro - RJ & $\begin{array}{l}\text { Graduação em Direito } \\
\text { (Faculdade Nacional de } \\
\text { Direito). Especialização } \\
\text { em economia (NYU, } \\
\text { Columbia, New School } \\
\text { of Social Research) e } \\
\text { diplomata. }\end{array}$ & $\begin{array}{l}\text { Pai médico fisiologista e } \\
\text { cientista de grande prestígio. }\end{array}$ \\
\hline $\begin{array}{lll}\text { Aníbal Pinto } & \text { Santa } \\
\text { Cruz } & & \\
\end{array}$ & 1919-1996 & Santiago - Chile & $\begin{array}{l}\text { Graduação em direito } \\
\text { (UC). Graduação em } \\
\text { economia (LSE). }\end{array}$ & $\begin{array}{l}\text { Bisneto do presidente do } \\
\text { Chile de } 1827 \text { a } 1829, \\
\text { Francisco Antonio Pinto, } \\
\text { neto do advogado, Ministro } \\
\text { da Guerra e da Marinha e } \\
\text { Presidente do Chile de } 1876 \\
\text { a 1881, Aníbal Pinto } \\
\text { Garmendia, e filho do } \\
\text { advogado, Ministro da } \\
\text { Guerra e da Marinha, } \\
\text { Ministro da Justiça e da } \\
\text { Instrução Pública, diplomata } \\
\text { e politico, Francisco Antonio } \\
\text { Pinto Cruz. }\end{array}$ \\
\hline Victor Urquidi & 1919-2004 & Neuilly - França & $\begin{array}{l}\text { Graduação economia } \\
\text { (LSE). }\end{array}$ & $\begin{array}{l}\text { Avô materno inglês, membro } \\
\text { de tripulação de cruzeiros } \\
\text { internacionais. Mãe } \\
\text { enfermeira e pai engenheiro, } \\
\text { ambos educados nos Estados } \\
\text { Unidos. Pai designado para a } \\
\text { representação diplomática } \\
\text { mexicana, viveu longos } \\
\text { períodos no exterior }\end{array}$ \\
\hline $\begin{array}{ll}\text { Celso } & \text { Monteiro } \\
\text { Furtado } & \end{array}$ & $1920-2004$ & Pombal - PB & $\begin{array}{l}\text { Graduação em direito } \\
\text { (Faculdade } \\
\text { Dacional de } \\
\text { Direito). Doutorado em } \\
\text { história } \\
\text { (Sorbonne). }\end{array}$ & $\begin{array}{l}\text { Pai juiz e desembargador, } \\
\text { mãe de família de } \\
\text { proprietários de terra. }\end{array}$ \\
\hline $\begin{array}{l}\text { Cleantho de } \quad \text { Paiva } \\
\text { Leite }\end{array}$ & 1921-1992 & Cidade da Paraíba - PB & $\begin{array}{l}\text { Graduação em direito } \\
\text { (Faculdade de Direito de } \\
\text { Recife). Pós-graduação } \\
\text { em economia (LSE). }\end{array}$ & Pais professores. \\
\hline $\begin{array}{l}\text { Juan Francisco Noyola } \\
\text { Vazquez }\end{array}$ & $1922-1962$ & $\begin{array}{l}\text { San Luis Potosí - } \\
\text { México }\end{array}$ & $\begin{array}{l}\text { Graduação em economia } \\
\text { (UNAM). Graduação em } \\
\text { ciências sociais (CES). }\end{array}$ & $\begin{array}{l}\text { Pai Juan Noyola Barragán, } \\
\text { engenheiro, e tio Luís } \\
\text { Noyola Barragán, } \\
\text { Procurador de Justiça do } \\
\text { Estado, Secretário Geral do } \\
\text { Governo e Reitor da } \\
\text { Unviersidad de Potosí. As } \\
\text { famílias Barragán e Vazquez } \\
\text { eram ligadas à elite política } \\
\text { mexicana e descendentes do } \\
\text { imperador asteca Moctezuma } \\
\text { II. Avó paterna descendente } \\
\text { da família de Miguel } \\
\text { Barragán, que foi Presidente } \\
\text { da República mexicana. }\end{array}$ \\
\hline Regino Boti Léon & 1923-1999 & Guantanámo - Cuba & $\begin{array}{l}\text { Graduação em direito } \\
\text { (Universidad } r \text { de } \\
\text { Habana). Pós-graduação } \\
\text { em economia (Harvard). }\end{array}$ & $\begin{array}{l}\text { Filho de Regino Eladi Boti, } \\
\text { destacado poeta cubano, } \\
\text { doutor em direito civil e em } \\
\text { filosofia e letras pela } \\
\text { Universidad de Habana, e } \\
\text { neto de imigrante catalão. }\end{array}$ \\
\hline
\end{tabular}




\begin{tabular}{|c|c|c|c|c|}
\hline Osvaldo Sunkel & 1929 & Puerto Montt - Chile & \begin{tabular}{lr}
\multicolumn{3}{l}{ Graduação em economia } \\
e administração & (UC). \\
Especialização & em \\
problemas & do \\
desenvolvimento & \\
(CEPAL). & Pós- \\
graduação em economia \\
(LSE).
\end{tabular} & $\begin{array}{l}\text { Avôs pastor e agricultor e } \\
\text { pais comerciantes. }\end{array}$ \\
\hline $\begin{array}{l}\text { Maria da Conceição } \\
\text { Tavares }\end{array}$ & 1930 & Anadia - Portugal & $\begin{array}{lr}\text { Graduação } & \text { em } \\
\text { matemática } & \\
\text { (Universidade } & \text { de } \\
\text { Lisboa). Graduação } & \text { em } \\
\text { economia (FNCE). } & \end{array}$ & $\begin{array}{l}\text { Pai, em Portugal, chefiava a } \\
\text { Companhia Vinícola } \\
\text { Amadora Ltda., no Brasil, } \\
\text { fundou a Companhia } \\
\text { Cervejaria Cavru. }\end{array}$ \\
\hline Carlos Lessa & 1936 & Rio de Janeiro - RJ & $\begin{array}{l}\text { Graduação em economia } \\
\text { (FNCE). Especialização } \\
\text { em economia (CNE). }\end{array}$ & $\begin{array}{l}\text { Descendente de Gomes } \\
\text { Freire de Andrade, vice-rei } \\
\text { do Brasil. Avô materno } \\
\text { advogado e filho de José } \\
\text { Higino Duarte Pereira da } \\
\text { Silva. Avô paterno médico, } \\
\text { botânico e professor no } \\
\text { Pedro II. Pai médico. }\end{array}$ \\
\hline $\begin{array}{lll}\text { Antonio } & \text { Barros } & \text { de } \\
\text { Castro } & & \end{array}$ & $1938-2011$ & Rio de Janeiro - RJ & 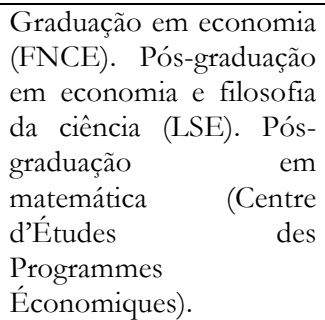 & $\begin{array}{l}\text { Mãe bisneta do Barão de Itu } \\
\text { - irmão do Barão de } \\
\text { Piracibaba - e neta de } \\
\text { Raphael Aguiar Paes de } \\
\text { Barros. Avô paterno médico } \\
\text { e veterinário de família } \\
\text { tradicional do maranhão. Pai } \\
\text { engenheiro, foi funcionário } \\
\text { público e fazendeiro. }\end{array}$ \\
\hline
\end{tabular}

Tabela I: Trajetórias das principais personagens da Abertura. Elaboração: própria.

\subsection{Rede da Abertura}

Para além de apresentar a CEPAL em um conjunto de eventos e personagens, o relato precedente traz embutido - como é suposto que ocorra nas Aberturas - temas que se repetirão nos movimentos seguintes. A análise da rede derivada da narrativa feita na abertura permitirá tratar de algumas temáticas que serão centrais no curso da tese, como o padrão de relações do espaço dos economistas no Brasil com universidades, centros de pesquisa e economistas de outros países; ou a relação entre a origem regional e as posições nas redes, ou ainda o poder em forma de capital social derivado do grau de conectividade dos agentes e de sua capacidade de fazer ligações entre diversos subgrupos. Sendo a rede decorrente da narrativa e dependente das entrevistas, biografias, relatos, documentos e outras fontes encontradas, é evidente que não se trata de uma rede social completa, ou seja, capaz de esmiuçar presença ou ausência de conexão para todos os agentes. A rede funciona, neste caso, primordialmente como um aparato de representação parcial de um conjunto de propriedades e padrões de vínculos detectados na narrativa, que ajuda a contextualizar as ações dos agentes. 
A conexão entre a abordagem histórica - com ênfase na caracterização social dos indivíduos e na análise da gênese das conexões entre eles e deles com as instituições - e a representação dos vínculos nas redes permite trabalhar os padrões de conectividade segundo a premissa de que as relações sociais se formam em espaços estruturados, nos quais os agentes possuem conjuntos dissimilares de capitais (econômico, simbólico, cultural, político, militante, religioso etc.) acumulados em suas trajetórias, sendo a tessitura de vínculos dependente da dotação de recursos e das clivagens observáveis no espaço social. Assim sendo, procura-se mostrar quais propriedades objetivas e disposições subjetivas tornam provável que um agente ocupe determinada posição no espaço. Como já exposto na introdução, a distância entre dois pontos na rede corresponde à distância das posições que estruturam o espaço constituído e reproduzido pelas disputas em torno dos princípios de hierarquização e de legitimação de visões de mundo e formas de produção de conhecimento (BOURDIEU, 1996, p. 190; DENORD, 2003, p. 240; DENORD, 2015, p. 62, 2005, p. 74-79; LEBARON, 2008, p. 127; MATTEDI-RAUD, 2005, pp. 74-79; RAUD, 2007, p. 205).

Nas redes apresentadas ao final de cada capítulo, o tamanho e a coloração dos círculos indicam o número de conexões de cada agente ou instituições. Quanto maior o número de vínculos de um ponto na rede, maior será sua circunferência e mais próxima da coloração magenta da escala abaixo. Quanto menor o número de vínculos de um ponto na rede, menor sua circunferência e mais próxima do amarelo. A escolha do grau de conectividade como parâmetro para a observação da centralidade e prestígio dos agentes baseia-se na ideia de que quanto mais vasta a rede de laços um ator, maior o capital social do agente e mais ampla é sua capacidade de ação ${ }^{71}$ (LAZEGA, 1998, pp. 4547). Além dos elementos gráficos da própria rede, são utilizados marcadores de propriedades sociais, sintetizados nas tabelas que aparecem ao final do capítulo, indicando período de nascimento dos agentes, profissão, região de origem, dentre outras propriedades e disposições, além de marcadores que denotam a visão de economia, e são situados no ponto médio aproximado da região do espaço que reúne os que são

\footnotetext{
${ }^{71}$ Outros parâmetros como a centralidade, baseada na média de vínculos que é preciso percorrer para alcançar qualquer outro agente no sistema, ou a capacidade de intermediar relações entre grupos que de outro modo não se conectariam poderiam também ter sido utilizados como parâmetros para mensuração de poder e centralidade. A opção pelo grau de conectividade como principal parâmetro justifica-se pela consideração de que há agentes particularmente ativos em seus subsistemas sem que sejam, entretanto, agentes de intermediação entre polos afastados ou indivíduos com maior conectividade média (LAZEGA, 1998, pp. 45-48).
} 
caracterizados pelo marcador. Finalmente, a representação de cada rede contem uma linha guia utilizada que enfatiza as clivagens observadas.

Figura I: Escala de cores das redes. Amarelo: menor número de vínculos; magenta: maior número de vínculos. Elaboração: própria.

Conforme anunciado no título da Abertura, a proposta do capítulo é analisar as condições sociais de formação da Comissão Econômica para a América Latina e as vias de entrada do pensamento ali produzido no Brasil. A rede ilustra alguns padrões que esclarecem o processo social observado. Em primeiro lugar, constata-se que aqueles que propuseram e defenderam na ONU a criação da Comissão, os Santa Cruz, tinham conexões com indivíduos largamente dotados de trunfos políticos. Eram descendentes de presidentes e famílias centrais da elite chilena, tendo precoce familiaridade com o poder e extensa rede de contatos no mundo político. Acumulavam a tradicional formação em direito e o cosmopolitismo requerido para que se fizessem ouvir internacionalmente, tornando-se interlocutores de burocratas, cientistas e políticos dos países centrais (DEZALAY, 2004, p. 6; DEZALAY e MADSEN, 2008, pp. 5-15; KLÜGER, 2015a; PINÇON e PINÇON-CHARLOT, 2006, pp. 123-150; WAGNER, 2003, pp. 33-34; WAGNER, 2007, pp. 10-14).

A origem social privilegiada e o vasto conjunto de trunfos econômicos, culturais e simbólicos dos quadros que criaram e consagraram a CEPAL permitiam que transitassem nacional e internacionalmente e que tomassem iniciativas até mesmo sem o imediato respaldo de seus governos, já que eram pessoas com autoridade e prestígio próprios. A ausência de constrangimentos materiais de primeira ordem dá a essa elite periférica dotada de referências culturais supranacionais e quase sempre com vivências internacionais que ajudavam a estabelecer contrapontos entre as nações e enxergar o percurso dissimilar de desenvolvimento econômico e social - a liberdade para flertar com a heterodoxia, fazer ecoar sua tese sobre a exclusão de seus países de origem e arriscar-se ao rechaço. O contato com as últimas tendências do pensamento econômico, adquirido na vivência internacional, fazia, ademais, com que as análises por eles propostas estivessem ajustadas metodológica e tematicamente ao conhecimento em economia produzido naquele momento nos países centrais, legitimando-as nos cenários nacional e internacional. 
A atuação de Alfonso Santa Cruz é representativa do poder decorrente da mobilização de dados e cálculos como parte da argumentação por maior atenção à América Latina. Alfonso é um pioneiro na conjugação da tradicional formação em direito com pós-graduações em economia. Tal perfil marca a geração de 1915-1925, integrada por seu primo Aníbal Pinto, Celso Furtado, Cleantho de Paiva, Miguel Osório de Almeida, Víctor Urquidi, Juan Noyola e Regino Boti, que tiveram a possibilidade de, no pós-guerra, especializar-se em economia em universidades norte-americanas e europeias de prestígio. Como os Santa Cruz, são eles agentes que ocupam posições privilegiadas em seus países de origem e tornam-se intermediários entre as elites de seus países e o sistema internacional. Miguel Osório de Almeida e Cleantho de Paiva Leite exemplificam o poder resultante dessa conexão nos episódios em que, como agentes diplomáticos e representantes do Brasil nas organizações internacionais, conquistaram apoio político local para suas posições nas disputas internacionais, ao mesmo tempo que acumulavam mais prestígio local em função dos postos ocupados nessas instituições.

Tal qual Cleantho e Miguel Osório, Celso Furtado desempenhará papel de intermediário entre o nacional e o estrangeiro. É a figura mais ao centro no plano e aquela que maior número de vínculos apresenta, ao lado da própria CEPAL. É possível argumentar que a razão de ser dessa posição resulta de sua perspectiva ter sido adotada para narrar diversos episódios, ficando suas conexões em evidência. Não obstante, há um sentido social na posição observada, visto ser Furtado, ao mesmo tempo, o primeiro e o principal elo entre o Brasil e a CEPAL, precisamente, um dos temas que o capítulo propõe abordar, e um indivíduo largamente provido de trunfos que lhe permitiam transitar com fluidez no universo analisado. Possuía, ao mesmo tempo, a velha formação em direito e a nova formação em economia, a formação superior no espaço nacional e a pós-graduação no exterior, a origem nordestina e a vivência carioca e internacional. Estudou na Europa, viajou numerosas vezes pelos EUA e trabalhou no Brasil e no Chile, tendo vínculos com as várias localidades em consideração no espaço. Nascido em 1920, situa-se também em ponto intermediário no espectro geracional em consideração.

No grupo daqueles nascidos ao redor de 1935, representado neste capítulo por Osvaldo Sunkel, Maria da Conceição Tavares, Carlos Lessa e Antônio Barros de Castro, não se nota, no caso brasileiro, menor segurança social e disponibilidade de capitais culturais. Lessa e Castro descendem de tradicionais elites brasileiras com sólidos laços 
com a vida política. Ainda que Castro tenha experimentado o declínio econômico de sua família, a educação sólida e cosmopolita dos grandes colégios e a tradição familiar deixaram marcas profundas em seu habitus. Tavares também cresceu em meio à segurança material de uma família burguesa industrial-exportadora de sucesso, o que deu a ela condições de investir em sua formação intelectual. No caso chileno, diversamente, encontram-se descendentes de imigrantes de camadas médias em ascensão econômica, caso de Osvaldo Sunkel, aqui apresentado, e de Enzo Faletto, que pertence à mesma geração e será apresentado adiante (item 3.3). A formação em economia dos brasileiros tanto quanto dos chilenos dessa geração apresenta uma conjugação entre instituições nacionais e a CEPAL, que à época começava a implementar seus cursos de formação e abrir ramificações em outros países.

Se a primeira geração de especialistas em economia brasileiros, representada na rede por aqueles agregados ao redor de Getúlio Vargas e sua Assessoria, era composta majoritariamente por engenheiros e advogados formados em escolas brasileiras de prestígio; e a segunda geração, de Celso Furtado e Cleantho de Paiva, combinava a formação local em engenharia ou direito com a especialização em economia no exterior; aqueles que se sucedem terão, via de regra, formação em economia não apenas no exterior, mas também nas escolas criadas por autodidatas em economia como Eugênio Gudin e Octavio Gouvêa de Bulhões (item 2.1), que adquiriram experiência na área ao conduzir instituições de administração econômica nacionais, razão pela qual são considerados economistas práticos (LOUREIRO, 1997a, pp. 23-24). A capacidade de conhecer economia como autodidata estava condicionada à possibilidade de acessar um conhecimento, até então, quase inteiramente produzido no exterior, o que exigia tanto o domínio de idiomas quanto a posse de bibliotecas particulares e de recursos econômicos para adquirir obras raras - sobretudo no caso das obras, ainda não canônicas, que avançavam a fronteira dos conhecimentos da área.

No período analisado na Abertura, as instituições de formação em economia e os órgãos econômicos do Estado brasileiro têm elos entre si, ficando próximas no espaço representado tanto quanto, como vimos, no espaço físico, com o DASP e a Conjuntura Econômica, revista da da Fundação Getúlio Vargas, alojados no Ministério da Fazenda. Esses foram criados por um conjunto de agentes que, ainda que pudessem ter orientações econômicas e posicionamentos políticos distintos, sobrepujavam suas diferenças em prol 
da valorização da visão econômica, segundo a qual era preciso empregar a racionalidade instrumental para promover a modernização nacional. A frase de Octavio Bulhões, "éramos poucos, os economistas brasileiros, e tudo estava por ser feito no país" (FURTADO, 2014, pp. 56), indica que se colocavam na posição de missionários dos novos princípios de gestão econômica, projetando uma identidade específica capaz de fazê-los agir cooperativamente na elevada missão de transformar o Estado e o país. No próximo capítulo, que se ocupa do mesmo período histórico e transcorre em meio ao mesmo cenário geopolítico, mas é centrado no Brasil, será observada a transição, no final da década de 1950, para um arranjo no qual se intensificam os conflitos entre os especialistas em economia que se distanciam progressivamente no espaço. 


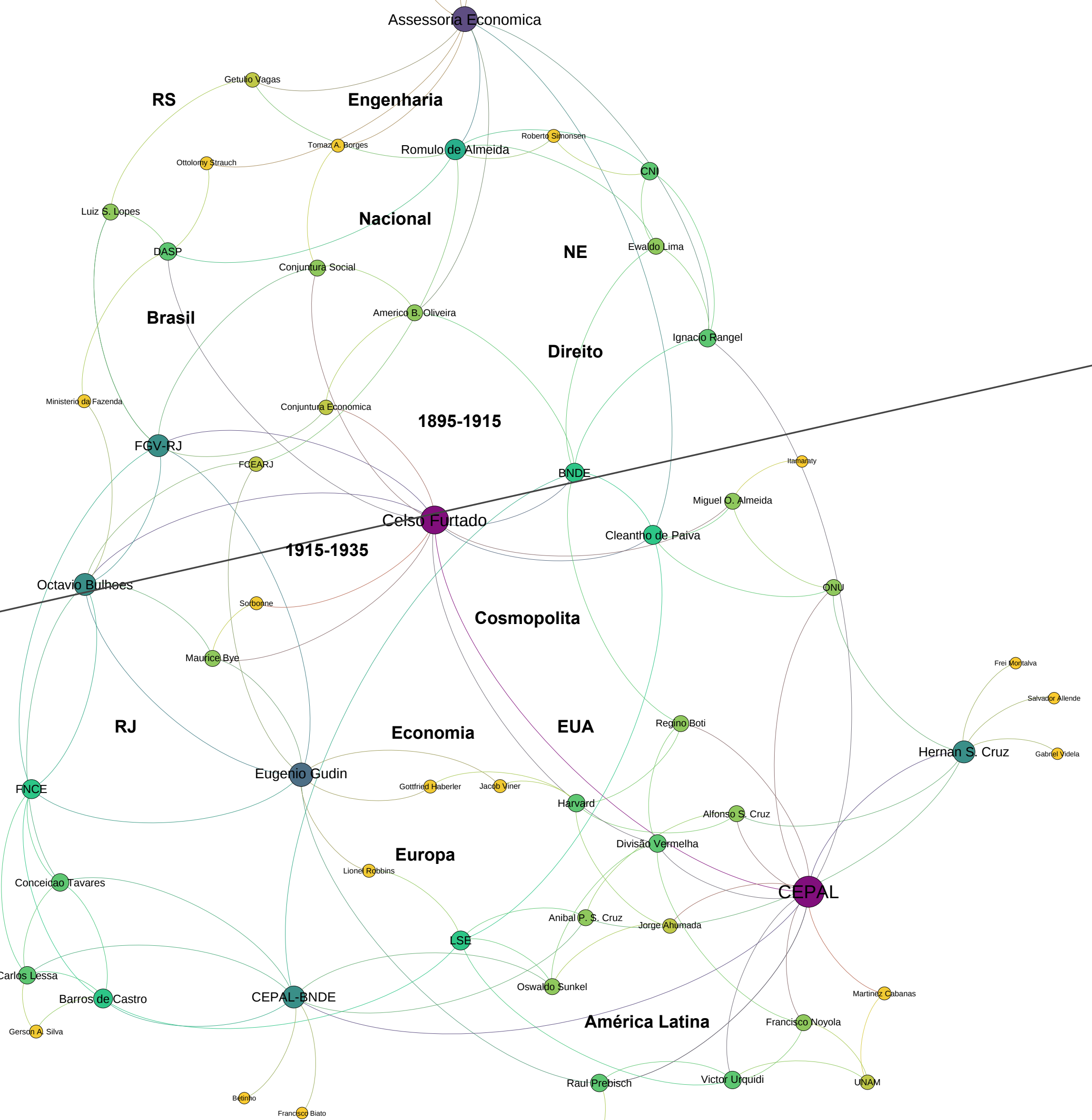

Rede da Abertura, data final 1964 


\section{PRIMEIRO MOVIMENTOO ${ }^{72}$ : Política externa Brasil-Estados Unidos e a gênese dos especialistas em economia no Brasil (1931-1966)}

No primeiro movimento quatro histórias são apresentadas de maneira articulada:

1) A primeira delas é uma história da política externa Brasil-Estados Unidos. A justificativa para a adoção da perspectiva internacional reside no fato de que tanto o fluxo de expertise quanto a criação de instituições econômicas no Brasil estiveram associadas às trocas de saberes, pessoas e dispositivos entre os dois países. Ademais, a história do espaço dos economistas no Brasil articula-se à das relações econômicas exteriores, na medida em que os primeiros especialistas em economia tiveram contato com a teoria econômica e com as modernas técnicas de gestão nos múltiplos episódios, comissões e negociações internacionais dos quais participaram no pós-guerra. Na vivência internacional adquiriram conhecimentos e criaram vínculos determinantes de seus engajamentos subsequentes e da moldagem da expertise econômica no Brasil. Cinco são os principais momentos das relações Brasil-Estados Unidos que serão analisados neste capítulo:

O primeiro deles (item 2.1) corresponde ao período da Segunda Guerra Mundial, no qual os Estados Unidos buscavam colaboração para os esforços de guerra e portanto posicionavam-se favoravelmente ao estímulo à industrialização brasileira. A participação na Guerra trouxe esperança aos brasileiros, que passaram a acreditar que a aliança com os Estados Unidos (EUA) traria a ajuda externa necessária ao desenvolvimento econômico. O segundo período (item 2.1) é o da frustração dessas expectativas, uma vez que o auxílio econômico do pós-guerra foi direcionado, prioritariamente, à recuperação europeia e asiática, sendo recomendado ao Brasil que procurasse atrair capitais privados e que usasse as reservas que acumulara durante a guerra para reaparelhar sua economia e elevar o bem estar de sua população.

O engajamento explícito dos Estados Unidos no combate ao comunismo é o marco inicial do terceiro período (item 2.2). Prevendo a necessidade de preservar em sua área de influência aliados que pudessem fornecer recursos e apoio para as ações militares

\footnotetext{
${ }^{72}$ Movimentos são as partes independentes e contrastadas de uma composição que, em conjunto, constituem uma sonata, uma sinfonia ou qualquer outra peça instrumental análoga (VIGNAL, 1999, p. 574).
} 
da Guerra Fria, o presidente democrata Harry Truman ensaia atender algumas reivindicações dos países alinhados aos EUA. O Act of International Development por ele promulgado abre um canal de cooperação técnica que objetiva tornar os benefícios dos avanços científicos e do progresso industrial disponíveis para os países subdesenvolvidos. Resulta desse programa a criação de uma Comissão Mista BrasilEstados Unidos (CMBEU), composta por técnicos brasileiros e norte-americanos. A Comissão engajou-se no desenho de projetos de desenvolvimento que deveriam ser financiados com um misto de capital externo e brasileiro, legando ao Brasil a expertise necessária para formulação e análise de projetos de investimento e o Banco Nacional de Desenvolvimento Econômico (BNDE), órgão criado para administrar as verbas que seriam alocadas nos projetos selecionados pela Comissão.

O quarto estágio (item 2.3) tem início em 1953, quando os republicanos assumem o governo dos EUA, com Dwight Eisenhower, que entra em choque com o presidente Getúlio Vargas encerrando as atividades da CMBEU e bloqueando as verbas previstas para o financiamento dos projetos por ela aprovados. A guerra da Coréia havia terminado e os republicanos tinham pouca disposição para levar adiante acordos de cooperação econômica que implicassem o envio de fundos para áreas do globo não consideradas geopoliticamente estratégicas. A América Latina não estava na lista das prioridades, tida pelos americanos como uma zona fora da linha de risco de expansão comunista. A política dos EUA para a região foi, por esse motivo, caracterizada por uma negligência cordial durante quase todo o governo republicano.

A postura dos Estados Unidos em relação à América Latina muda novamente (itens 2.4 e 2.5) após uma viagem do Vice-Presidente dos EUA, Richard Nixon, ao continente, no qual é execrado pela população dos países que visita, mostrando aos estadunidenses que um forte antiamericanismo difundia-se pela região. Juscelino Kubitschek aproveita o incidente para propor uma política multilateral para a América Latina, lançando a Operação Pan-Americana (OPA). A vitória do democrata John F. Kennedy e a aproximação de Cuba com a União Soviética levam os Estados Unidos a voltar sua atenção para a região. Kennedy lança o programa Aliança para o Progresso, que incorpora várias reivindicações que estavam presentes na OPA de JK e prevê tanto a concessão de fundos para os países subdesenvolvidos quanto o envio de técnicos e equipamentos modernos para a região. A United States Agency for International 
Development (USAID), criada para gerir os financiamentos da Aliança, e algumas organizações não governamentais norte-americanas, como a Fundação Ford e a Fundação Rockefeller, passam a veicular recursos para o desenvolvimento científico da região. Eles tornam viável a atração de professores estrangeiros para a América Latina e permitem equipar o ensino superior e suas insitituições de pesquisa, o que foi fundamental para a consolidação da ciência econômica no Brasil. As bolsas de estudos concedidas por essas organizações criaram também canais através dos quais os brasileiros puderam intensificar sua circulação acadêmica internacional.

2) A segunda história presente neste capítulo é a da institucionalização do ensino e da pesquisa em ciência econômica e da multiplicação dos órgãos encarregados das políticas econômicas. No período contemplado neste movimento multiplicaram-se: as instituições que ofereciam treinamento em economia, as agências governamentais da área econômica e o contingente de profissionais especializados na área. Nesse momento, houve uma grande coincidência das pessoas que ocupavam as principais funções nos órgãos governamentais encarregados da gestão econômica e nas escolas de economia, isso porque aqueles que detinham o saber especializado eram poucos e as tarefas a eles atribuídas eram crescentes. Houve, igualmente, uma coincidência do espaço físico ocupado pelas instituições da área econômica. A maior parte das novas comissões e agências governamentais econômicas e mesmo as revistas e equipes que produziam os indicadores econômicos alojavam-se, ao menos inicialmente, no Ministério da Fazenda. Essa coincidência foi fundamental para o fluxo de informações e de pessoas que propiciaram a formação de laços e as articulações necessárias para a criação de uma série de organizações da área econômica.

Surgiram, nesses anos, os já apresentados (itens 1.3 e 1.4) Departamento Administrativo do Serviço Público (DASP) (1937) e Assessoria Econômica Vargas (1951), aos quais se agregaram a Superintendência da Moeda e do Crédito (SUMOC), em 1945 (item 2.1), o Banco Nacional de Desenvolvimento Econômico, em 1952 (item 2.2), o Conselho de Desenvolvimento responsável pelo Plano de Metas, em 1956 (item 2.3), a Superintendência do Desenvolvimento do Nordeste (SUDENE), em 1960 (item 2.3), o Ministério do Planejamento, em 1962 (item 2.5), o Escritório de Pesquisa Econômica 
Aplicada (EPEA), em 1964 (item 2.5), e o Banco Central do Brasil (BCB), no final de 1964 (item 2.5).

A institucionalização do ensino e da pesquisa em economia, por sua vez, tem início em 1931, com a primeira legislação que permite conferir o grau de bacharel em ciências econômicas. Até então, a economia estava marginalmente presente em algumas outras áreas, seja nos cursos prestigiosos de engenharia e de direito - nos quais titularamse a maior parte dos primeiros especialistas em economia - que ofereciam cursos de economia política e de ciências das finanças como parte da formação geral de seus alunos $^{73}$, seja nas pouco renomadas escolas de comércio que se ocupavam da transmissão de instrumentos e técnicas comerciais, contábeis e atuariais. Essas escolas não podiam conferir o grau de bacharel e via de regra ofereciam cursos no período noturno, atraindo alunos provenientes de estratos sociais médios e baixos que necessitavam conciliar os estudos com trabalho em período integral.

O movimento de descolamento da economia das outras especialidades tem início com a instalação dos primeiros cursos superiores especificamente voltados ao ensino de economia a partir dos anos 1930. Em 1932 foi criada a Faculdade de Ciências Econômicas de São Paulo da Escola Álvares Penteado (item 4.1), à qual se seguem: em 1938, a Faculdade de Ciências Econômicas e Administrativas do Rio de Janeiro (FCEARJ) (item 2.1), em 1945 a Faculdade de Ciências Econômicas e Administrativas de Minas Gerais (FACE) da Universidade de Minas Gerais (UMG, futura UFMG) (item 3.1) e, em 1946, a Faculdade Nacional de Ciências Econômicas (FNCE) da Universidade do Brasil (UB, futura UFRJ), o Núcleo de Economia da Fundação Getúlio Vargas (FGV-RJ) (item 2.1) e a Faculdade de Ciências Econômicas e Administrativas (FCEA) da Universidade de São Paulo (USP) (item 4.2), às quais se somariam várias outras.

\footnotetext{
${ }^{73}$ Os professores das cadeiras de economia política do direito e da engenharia ajudaram a tornar o corpo de saberes da área acessível aos brasileiros traduzindo livros clássicos para o português. O primeiro catedrático de economia política da Faculdade de Direito de Pernambuco, Pedro Autran da Mata, traduziu Elementos de economia política de James Mill e escreveu seu próprio manual de economia política: o livro Preleções de economia politica, de 1959. O professor José Luís de Almeida Nogueira, da Faculdade de Direito do Largo São Francisco publicou o seu Curso didático de economia política. Na Escola Politécnica do Rio de Janeiro, foram professores de economia política personalidades como José Maria da Silva Paranhos, Visconde do Rio Branco e Vieira Souto. Na Escola Politécnica de São Paulo lecionaram Calos Alberto Vanzolini e Ruy Aguiar da Silva Leme, que terá importância na montagem da Faculdade de Economia da Universidade de São Paulo. Diferentemente das escolas de direito que cultivavam uma perspectiva mais filosófica sobre os problemas econômicos, as escolas politécnicas abordavam a economia de forma aplicada, tratando dos problemas de produção interna, comércio internacional, incorporação de tecnologia e previsão das tendências de oferta e demanda (CANABRAVA, 1984, p. 38; CASTRO, 1991, pp. 5-6; COFECON, 2012, pp. 19-20; MOTTA, 1994, p. 85; PRADO, 2007, p. 7; VIEIRA, 1981, p. 357).
} 
Surgem também nesse período os primeiros cursos de especialização para graduados, oferecidos pelo Conselho Nacional de Economia (CNE), pelo Centro de Aperfeiçoamento de Economistas da Fundação Getúlio Vargas (CAE-FGV) (item 2.4) e pelo Centro CEPAL-BNDE, formado em cooperação pela Comissão Econômica para a América Latina (CEPAL) e pelo BNDE (item 1.5). Os cursos de mestrado e doutorado, por sua vez, só surgirão em 1966, o que será discutido no quarto capítulo, que se inicia, precisamente, nesse ano com a apresentação do Encontro de Itaipava que reuniu os responsáveis pelas escolas de economia para um exercício de reflexão sobre os rumos da ciência econômica no país (ítem 4.2).

Vinte anos transcorreram entre a oficialização do diploma de bacharel em ciência econômica, em 1931, e a regulamentação da atividade profissional do economista por meio de um decreto do Presidente Getúlio Vargas, assinado em agosto de 1951. As organizações de classe criadas após o decreto, o Conselho Federal de Economia $(\mathrm{COFECON})$ e suas representações regionais (CORECON), buscavam organizar e valorizar a categoria, passando a pleitear que os concursos reservassem o acesso às posições de gestão econômica àqueles que tivessem diplomas ou habilitações válidas para a atuação na área (CASTRO, 1991, p. 3; CASTRO, 2001, p. 15). O primeiro edital de seleção de economistas para o BNDE, de 1955, por exemplo, já mostra reflexos dessa política ao exigir que aqueles que desejassem concorrer às vagas de economista apresentassem diploma ou habilitação oficial para o exercício da profissão (BNDE, 1955), como foi possível ver no depoimento de Ignácio Rangel (item 1.4), aprovado nesse concurso.

\section{3) A terceira história é a da criação e evolução do BNDE em seus primeiros} anos. Ela tem início com a ativação da CMBEU, em 19 de julho de 1951, que desenha uma série de projetos que deveriam ser financiados com capital brasileiro e estrangeiro a ser gerido por uma nova instituição: o BNDE. Em 1953 as atividades da Comissão são encerradas pelo presidente republicano Eisenhower e o Banco passa a funcionar exclusivamente com os recursos do Fundo de Reaparelhamento Econômico (FRE), criado para assegurar a contrapartida brasileira aos empréstimos norte-americanos. As primeiras equipes de dirigentes do BNDE foram compostas por alguns dos profissionais que integravram a CMBEU: Roberto Campos, Glycon de Paiva, Ary Torrres e Lucas 
Lopes. Esse grupo, dos chamados técnicos desenvolvimentistas cosmopolitas ou não nacionalistas, deixou a instituição depois de entrar em conflito com o superintendente do Banco indicado por Getúlio Vargas, José Soares Maciel Filho, que consideravam ser um político sem a qualificação necessária para figurar na direção do BNDE. Eles retornam após o suicídio de Vargas e ocupam-se da consecução dos projetos de energia e transportes previstos pela Comissão Mista (itens 2.2 e 2.3).

No governo JK, o BNDE ganha estrutura e proeminência por liderar, na figura de seu presidente Lucas Lopes, o Conselho de Desenvolvimento, encarregado de conceber e coordenar o Plano de Metas. JK reúne, no Banco e no Conselho, os desenvolvimentistas não nacionalistas da CMBEU e os desenvolvimentistas nacionalistas da Assessoria Vargas. Quando, em 1958, Lucas Lopes foi convocado para o Ministério da Fazenda o Banco passa por uma alteração, sendo seu superintendente, Roberto Campos, alçado à presidência. No final do governo JK, Campos entra em sucessivos atritos com o Presidente da República e com os desenvolvimentistas nacionalistas, deixando o Banco após a ruptura do Brasil com o Fundo Monetário Internacional (FMI). Ficou então encarregado de dirigir o BNDE o Ministro de Viação e Obras, Lúcio Meira (item 2.3).

Nos governos Jânio Quadros e João Goulart, o Banco volta a ser dirigido por dois homens de confiança dos presidentes visto como pessoas com maiores pretensões políticas do que qualificação técnica para a gestão da economia: Vicente Faria Lima, que se tornou prefeito de São Paulo, e Leocárdio Antunes, um deputado gaúcho aliado de Leonel Brizola. Nessas duas gestões o Banco passa por um período de crise institucional, experimentando declínio do volume de recursos e ausência de uma diretriz clara de ação. Expressão dessa crise é a ausência de nomeação de um substituto quando o presidente Leocárdio Antunes deixa o Banco. O superintendente Genival Santos, técnico e professor ligado à FNCE e à FGV-RJ, exerce interinamente a presidência até o golpe militar de 1964 (item 2.5).

A última etapa da história do Banco narrada neste capítulo corresponde aos eventos que se seguem à ida de Roberto Campos para o Ministério do Planejamento e de Octavio Bulhões para o Ministério da Fazenda. Nela o Banco diversificou sua área de atuação em direção ao setor industrial, em especial à siderurgia, e começou a verter seus empréstimos para o setor privado. Além disso, criou uma série de fundos especiais: o Financiamento para a Aquisição de Máquinas e Equipamentos Industriais (FINAME), o 
Fundo Agro-Industrial de Reconversão (FUNAR), o Fundo de Desenvolvimento Técnico-Científico (FUNTEC), o Programa de Financiamento às Pequena e Média Empresas (FIPEME), o Fundo de Financiamento de Estudos de Projetos e Programas (FINEP) e o Fundo de Desenvolvimento da Produtividade (FUNDEPRO). A criação desses fundos enquadra-se na lógica de um projeto que Roberto Campos havia apresentado para o BNDE anos antes, propondo que o Banco fosse desvinculado do orçamento da União, passando a funcionar como um fundo que pudesse receber capital privado e internacional, além de remunerar os investidores com os lucros derivados do retorno dos financiamentos. Os anos de Campos no Ministério e de José Garrido Torres, um monetarista do grupo de Octavio Bulhões, na presidência do BNDE são marcados também pelo agravamento da perda da função de concepção de planos de desenvolvimento que o Banco já vinha experimentando desde o fim dos anos JK, sendo a criação do EPEA para desempenhar esse papel a mais clara expressão disso (item 2.5).

4) A quarta e última das histórias centrais é a das transformações do perfil social e das trajetórias educacionais dos especialistas em economia. Como na Abertura, a descrição dos eventos em curso vincula-se à apresentação das trajetórias dos principais especialistas em economia envolvidos na trama.

A princípio, a condução da economia era feita essencialmente, por engenheiros, advogados e diplomatas autodidatas que se tornaram especialistas em economia por meio da atuação que tiveram nos órgãos e comissões econômicas, razão pela qual podem ser chamados de economistas práticos (LOUREIRO, 1992, pp. 49-50). Esses bacharéis eram, via de regra, provenientes de famílias bem inseridas social e politicamente, frequentemente interligadas. Muitos deles tinham pais profissionais liberais: advogados, diplomatas, engenheiros e médicos e mães fluentes em língua e modos franceses que se ocupavam exclusivamente da gestão doméstica. Esses homens - somente homens puderam frequentarar bons colégios que reforçavam a educação cosmopolita e refinada que recebiam em suas casas. Enquadram-se nesse primeiro perfil, por exemplo, Eugênio Gudin, Octavio Gouvêa de Bulhões (item 2.1), Lucas Lopes, Octávio Dias Carneiro (item 2.3), Mario Henrique Simonsen (item 2.3), Celso Furtado (item 1.3), Miguel Osório de Almeida e Ignácio Rangel (item 1.4). Esse grupo pode ser bifurcado em dois: o primeiro formado por aqueles que acessaram os primeiros postos que ocuparam por concurso, 
como Furtado, Rangel e os diplomatas Dias Carneiro e Osório de Almeida, e o segundo composto por aqueles que em suas vidas só ocuparam cargos de confiança, como Eugênio Gudin, Octavio Gouvêa de Bulhões, Lucas Lopes e Mario Henrique Simonsen.

Um segundo grupo é dos rebentos de famílias menos privilegiadas que ascenderam socialmente por intermédio da igreja. A possibilidade de receber uma boa formação nas instituições educacionais católicas abriu portas a pessoas como João Paulo dos Reis Velloso (item 2.5), filho de pai telegrafista e mãe costureira, e Roberto Campos, cuja mãe passou a trabalhar como governanta e costureira após o precoce falecimento do pai (item 2.2). Para esses homens o ensino cristão gratuito e o concurso público apresentaram-se como vias de estabelecimento e elevação da posição social. O estudo da economia, em suas trajetórias, não resultou do autodidatismo desinteressado e precoce daqueles que se acreditavam vocacionados. Diversamente foi, resposta a desafios enfrentados nas áreas de trabalho para as quais foram designados, no Banco do Brasil e no Itamaraty respectivamente, que os motivaram a fazer cursos de especialização em economia. O cosmopolitismo e a alta cultura tampouco eram-lhes familiares. Os dois mencionam ter tido dificuldades para incorporar o inglês e revelam gosto antes pelo cinema, a diversão popular de seu tempo, do que pela musica clássica e a ópera, apreciadas por descendentes da elite como Gudin, Bulhões e Simonsen que chegaram, inclusive, a presidir a Orquestra Sinfônica Brasileira (OSB).

Aos poucos, começa a delinear-se um terceiro tipo: o daqueles que se especializam precocemente, seja cursando a graduação em economia, como Anníbal Villela, Genival Santos, Julian Chacel, Isaac Kernstenetszy (item 2.1), Dênio Nogueira, Paulo Lira, Casimiro Ribeiro, Ernane Galvêas (item 2.5), Maria da Conceição Tavares, Carlos Lessa, Antonio Barros de Castro (item 1.5) e Juvenal Osório. Esse é o perfil da maior parte dos especialistas em economia que serão estudados partir do terceiro capítulo.

\subsection{Eugênio Gudin e Octavio Gouvêa de Bulhões: pontes entre o Brasil e os Estados Unidos}

Os primórdios do ensino de economia no Brasil remontam ao início do século XIX, quando foram ensaiadas duas iniciativas voltadas ao ensino de técnicas de comércio. A primeira delas, que não passou de um anúncio de D. João, foi a Aula Pública do 
Visconde de Cairu (item 1.5). A segunda, que datava de 1809, as Aulas de Comércio da Corte, curso de dois anos no qual os participantes deveriam aquirir noções de geografia, história, cálculo, geometria e conteúdo voltado ao exercício da atividade comercial: juros, seguros, câmbio, arrumação de livros de registros etc. Em 1856, as Aulas de Comércio dão origem ao Instituto Comercial do Rio de Janeiro, que acrescentaria ao currículo cadeiras de contabilidade, escrituração mercantil, estatística comercial, direito mercantil e economia política aplicada. O Instituto não logrou sequer garantir assiduidade dos alunos (CANABRAVA, 1984, p. 24; CASTRO, 1991, pp. 1, 6; CASTRO, 2001, pp. 20-21; CONFECON, 2012, pp. 18-20).

Em 1902, o Instituto Comercial é substituído pela Academia de Comércio instalada no prédio da Escola Polítécnica do Rio de Janeiro, no Largo São Francisco. Em 1905 o Presidente Rodrigues Alves sanciona um decreto tornando a Academia entidade de utilidade pública. Ele reconhece os diplomas por ela concedidos e faz de seu currículo o parâmetro para a outorga do grau superior em comércio. Esse diploma habilitava seus portadores para o exercício de funções consulares, atuariais, contabilísticas e de relações exteriores. A necessidade de preparar os alunos para o exercício diplomático fez com que fossem incluídos no currículo cursos de direito internacional, diplomacia, história dos tratados, idiomas, ciência política das finanças e correspondência diplomática. Em 1909 a Academia de Comércio passou a abrigar uma Faculdade de Ciências Políticas e Econômicas, a primeira a conceder o diploma de ciências econômicas no Brasil. Esse diploma, reconhecido em 1926, não equivalia a um bacharelado e a formação oferecida aos alunos da Faculdade não diferia substancialmente daquela dos contadores e comerciantes (CANABRAVA, 1984, p. 29; CASTRO, 1991, p. 10; CASTRO, 2001, p. 22; GAROFÁLO e RIZZIERI, 2007, p. 178).

Getúlio Vargas aprovou em 1931, o curso de Administração e Finanças que tinha duração de três anos e conferia o grau de bacharel em ciências econômicas. Essa formação era acessível apenas àqueles que já tivessem diplomas técnicos da área comercial, não podendo ser cursado pelos egressos do ensino médio regular, o que reduzia o prestígio das ciências econômicas pois os descendentes das famílias de elite seguiam preferencialmente o ensino regular, que era aquele que dava acesso às carreiras de advogado, médico e engenheiro. O programa do curso incluía disciplinas de contabilidade e administração voltadas para a gestão privada e cadeiras orientadas para a atuação na 
esfera pública, dentre as quais a economia política e as lições de direito (comercial, internacional, público, civil, constitucional, administrativo, industrial e operário e consular). Os cursos da área de direito ocupavam metade da grade, o que é coerente com a tradição de valorização da formação jurídica vigente na sociedade brasileira e com o fato de que grande parte do corpo docente era composto por bacharéis em direito (CASTRO, 2001, pp. 19, 25-26; CONFECON, 2012, pp. 22-26;).

Em outubro de 1932, foi criado o Instituto da Ordem dos Economistas do Rio de Janeiro e em 1937 a Sociedade Brasileira de Economia Política. Estes deram origem em dezembro de 1938 à Faculdade de Ciências Econômicas e Administrativas do Rio de Janeiro. Esta era uma organização privada que teve incessantes dificuldades financeiras, razão pela qual passou a ser administrada, em 1945, pela Fundação Mauá. No ano seguinte a FCEARJ foi incorporada à Universidade do Brasil ${ }^{74}$, alterando seu nome para Faculdade Nacional de Ciências Econômicas. Entre os primeiros professores da FCEARJ e da FNCE estavam personalidades como San Tiago Dantas, Afonso Arinos de Melo Franco e Eugênio Gudin. Este último era vice-presidente da Sociedade Brasileira de Economia Política e responsável pela cátedra de Moeda e Crédito (COFECON, 2012, p. 30; DHBB, verbete Eugênio Gudin).

Eugênio Gudin (1886-1986) era neto de comerciantes franceses da linhagem dos Orleans que se instalaram no Brasil em 1839 e aqui abriram uma casa de modas parisienses. Seu pai, educado na França, trabalhava na bolsa de valores e era comerciante. A mãe de Gudin faleceu jovem e seu pai casou-se em segundas núpcias com a filha de um banqueiro de grande fortuna, também educada na Europa. Eugênio Gudin teve, portanto, uma educação cosmopolita, alinhada aos padrões culturais europeus dominantes em seu tempo (DHBB verberte Eugênio Gudin; GUDIN, 1980; SCALERCIO e ALMEIDA, 2012).

Guarda Eugênio Gudin nítidas reminiscências da sua primeira viagem à Europa, aos sete anos de idade, num vapor das Messageries Maritimes. O encontro com Paris marcou-o para sempre, impregnando-lhe a beleza da cidade. Levado pela mão do seu avô, andou pelas margens do Sena; caminhou pelas ruas e praças que retraçam o curso da civilização. Deste tempo recorda-se ainda da silhueta de Verdi, quando conversava com seu avô à porta do Grand-Hôtel. Associou sempre essas lembrança ao gosto pelas criações do ilustre compositor, principalmente pelas obras Aída, Otelo e Falstaff' [...]. Tornou-se desde cedo um fervoroso admirador de Wagner, conservando-se inalteravelmente fiel às suas

\footnotetext{
${ }^{74}$ A Universidade do Rio de Janeiro, criada em 1920, converteu-se, em 1937, na Universidade do Brasil, reunindo diversas das instituições de ensino superior da Capital. Em 1965, a UB teve seu nome alterado para Universidade Federal do Rio de Janeiro.
} 
criações. Nada o detém diante da possibilidade de ouvir uma representação da Walkyria! O culto de Wagner não impede porém que em sua discoteca se multipliquem as sinfonias de Mozart e de Beethoven, as composições de Bach, os concertos de Haendel e de Brahms [...] assiste com seus pais à inauguração do Teatro do Champs Elysées. Inicia-se na música russa e entusiasma-se por Stravinsky, que acabava de compor o Le Sacre du Printemps" (CARNEIRO, 1979, pp. 2-3).

A descrição romanceada da vida de Gudin oferece elementos para analisar a socialização das elites brasileiras que procuravam fazer-se à imagem e semelhança europeia, transpondo os saberes, estilos de vida, modos, modas e bibelôs encontrados nos países do velho mundo que exerciam a hegemonia cultural (FREYRE, 2003, p. 461; KLÜGER, 2015a; NEEDEL, 1993; SCHWARZ, 1992, p. 17; SEVCENKO, 1992; VASCONCELOS, 2007). Gudin vivia nesse eixo Paris-Rio de Janeiro, sendo sua família assídua frequentadora do circuito cultural europeu. Ele colecionava quadros que adquiria em suas viagens pela Europa e fez cursos de história da pintura no Louvre. De frequentador do circuito musical nacional e internacional passou à presidência da OSB, que exerceu nos anos de 1966 e 1967.

Gudin nasceu no Rio de Janeiro e foi interno no Colégio Brasileiro-Alemão, em Petrópolis, dirigido pelo educador alemão Hans Heilborn. De lá seguiu para a Escola Politécnica do Rio de Janeiro, onde obteve, com menos de 20 anos, o diploma de engenheiro e a medalha Gomes Jardim de melhor aluno. Depois de formado, trabalhou como engenheiro em diversas companhias estrangeiras ou de controle acionário estrangeiro, como Light, Dodsworth \& Cia., Pernambuco Tramways and Power Company, Great Western of Brazil Railway Company, Western Telegraph and Co., tendo coordenado obras dessas companhias no Rio de Janeiro, no Ceará e em Pernambuco, o que permitiu que conhecesse um pouco melhor o seu país. O cosmopolitismo ${ }^{75}$ precoce aliado à capacitação técnica faziam dele um valioso ativo para as companhias estrangeiras instaladas no Brasil pois ele ajudava a construir pontes entre os dois mundos (GUDIN, 1980; DHBB verberte Eugênio Gudin).

Gudin é o tipo ideal do economista prático e autodidata. Estudou sozinho os clássicos ingleses Adam Smith, David Ricardo e Alfred Marshall e aventurou-se na leitura de economistas norte-americanos e europeus de seu tempo, como seus diletos Jacob Viner e Gottfried Haberler. Como muitos de seus contemporâneos, escreveu para jornais,

\footnotetext{
${ }^{75}$ Seus casamentos atestam tal cosmopolitismo, já que sua primeira esposa era francesa, a segunda americana e a terceira brasileira (SCALERCIO e ALMEIDA, 2012, p. 286).
} 
tendo sido diretor do periódico O Jornal de Francisco de Assis Chateaubriand, e colaborador da área econômica do Correio da Manhã. Além disso, participou de alguns dos primeiros conselhos e comissões econômicas instalados no Brasil (DHBB verberte Eugênio Gudin; GUDIN, 1980).

Em 1944 Gudin, que acabara de publicar seu livro Princípios da Economia Monetária, foi escolhido para ser delegado brasileiro na Conferência de Bretton Woods, convocada com o objetivo de reorganizar o sistema monetário que se desestruturara com o declínio do padrão-ouro e de buscar "arranjos que dessem estabilidade às taxas de câmbio com a finalidade específica de dar sustentação ao estabelecimento de um sistema de comércio durável” (EICHENGREEN, 2000, p. 129). Na ocasião foram criados o FMI e o Banco Mundial (BM) "para monitorar as políticas econômicas nacionais e oferecer financiamento para equilibrar os balanços de pagamentos de países em situações de risco" (EICHENGREEN, 2000, p. 131). Além de Eugênio Gudin, estiveram presentes na Conferência o secretário da embaixada brasileira Roberto Campos e os delegados do governo brasileiro: o Ministro da Fazenda Arthur de Souza Costa, Valentim Bouças e Otavio Gouvêa de Bulhões.

Octavio Gouvêa de Bulhões (1906-1990), também nascido no Rio de Janeiro, era filho do diplomata Godofredo de Bulhões e sobrinho neto de Leopoldo Bulhões que fora ministro da Fazenda dos governos de Rodrigues Alves e de Nilo Peçanha. Octávio também teve uma socialização cosmopolita precoce. Viveu até os 8 anos de idade na Europa, tendo residido na França e na Áustria. No Brasil passou a morar com os avós e com os tios em Copacabana e foi matriculado no Colégio Aldrigde, ${ }^{76}$ dirigido inicialmente pelo educador inglês Alfred Aldrigde, e depois por seu filho Walter Aldrigde, cuja esposa era francesa. Nesse colégio, a língua oficial era o inglês, mas o francês também fazia parte do cotidiano dos alunos. A educação nos estabelecimentos privados e socialmente homogêneos da elite, como aqueles frequentados por Gudin e Bulhões, era um instrumento essencial de transmissão do gosto, dos modos e dos idiomas da "civilização" europeia, razão pela qual importavam de lá os professores, manuais e métodos de ensino (PINÇON e PINÇON-CHARLOT, 1989, pp. 141-146; PINÇON e PINÇON-

\footnotetext{
${ }^{76} \mathrm{O}$ colégio Aldrige, que funcionara inicialmente em São Gonçalo, transferiu-se em 1917 para um edifício em Botafogo. Durante o Estado Novo, vivendo o Brasil um momento de extremado nacionalismo, os estrangeiros tiveram sua permissão para ensinar cassada. Quando a família Aldrigde foi obrigada a abandonar o ensino, Luiz Simões Lopes, presidente do DASP, que também havia sido aluno do colégio, decidiu comprar o edifício e todo seu equipamento, instalando ali, em 1945, a Fundação Getúlio Vargas (D’ARAÚJO, 1999, pp. 16, 27).
} 
CHARLOT, 2006 p. 115). Bulhões também conta ser grande apreciador de música clássica. Gostava de Beethoven, Mozart e Respighi e ia frequentemente ao Teatro Municipal para “ouvir boa música”. Ocupou a presidência da OSB entre 1968 e 1987, como Gudin fizera antes dele e Mario Henrique Simonsen fará na sequência (item 2.4) (BULHÕES, 1990, p. 9; DHBB, verbete Octavio de Gouvêa Bulhões;).

Em 1926, Octavio Bulhões ingressou no serviço do Imposto de Renda por indicação de seu tio-avô Leopoldo. Lá trabalhou enquanto estudava direito na Faculdade Nacional do Rio de Janeiro. Poucos anos depois, o Imposto de Renda foi incorporado ao Ministério da Fazenda. Bulhões propôs a criação de uma seção de Estudos Econômicos e Financeiros no Ministério, para a qual se transferiu em 1939. Foi lá que conheceu Eugênio Gudin, que o "injetaria” como professor na FCEARJ"7 (GUDIN, 1980, p. 91). Bulhões conta que mesmo antes de atuar na área econômica já havia se interessado pelo tema e explorado as numerosas obras de economia disponíveis na biblioteca de seu tio, especialmente Adam Smith e David Ricardo. Bulhões considera que a primeira pessoa com quem pode debater as suas ideias sobre economia foi Eugênio Gudin, seu "grande orientador" (BULHÕES, 1990, p. 5).

O tema principal de nossas conversas era que, com a taxa de câmbio que o governo insistia em manter valorizada, a economia ficava muito prejudicada. Inclusive a economia particular do próprio Eugênio Gudin, que tinha uma grande plantação de laranjas em Nova Iguaçu. Ele exportava para a Inglaterra mas não obtinha bons resultados porque a taxa de câmbio não permitia que recebesse o mil-réis em proporção equivalente à depreciação da moeda (BULHÕES, 1990, p. 35).

Bulhões foi uma das pessoas que Luiz Simões Lopes enviara para o exterior ${ }^{78}$ no programa de qualificação de funcionários públicos financiado pelo DASP (item 1.3). Ele fez alguns cursos de economia na American University, em Washington, onde teve aulas com Harry White, criador do Plano White ${ }^{79}$, que chefiou a delegação estadunidense na

\footnotetext{
${ }^{77}$ Gudin diz: "quando fui diretor [da FCEARJ] peguei três elementos bons e botei lá dentro: Octavio Bulhões, Dias Leite e Jorge Kingston. Eram três elementos de primeira ordem, injetei-os na faculdade, fazendo concurso" (GUDIN, 1980, p. 91). Fica ambíguo na explicação dada por Gudin se ele indicou aos três a possibilidade de fazer um concurso para a posição ou abriu vagas específicas para eles.

${ }^{78}$ Quando indagado sobre o destino das pessoas que enviava para o exterior Luiz Simões Lopes respondeu dizendo que os Estados Unidos eram o destrino prioritário porque concluiu, observando os sistemas de gestão pública de vários países, que a administração americana era a mais moderna (LOPES, 2003, p. 22).

${ }^{79}$ Harry Dexter White, do lado americano, e John Maynard Keynes, do lado britânico, foram os principais responsáveis pela elaboração dos documentos preparatórios para a conferência de Bretton Woods que visava reorganizar o sistema monetário internacional. "A diferença entre os planos de Keynes e de White estava nas obrigações que eles impunham aos países credores na flexibilidade das taxas de câmbio e na mobilidade do capital por eles admitidas. O Plano Keynes teria permitido aos países modificar suas taxas de câmbio e adotar restrições cambiais e comerciais, conforme necessário para compatibilizar o pleno emprego com o equilíbrio no
} 
conferência de Bretton Woods. Foi ele que pediu ao Ministro da Fazenda brasileiro, Souza Costa, que enviasse Bulhões às seções preparatórias de Bretton Woods. Na casa de White, Bulhões conheceu o professor de Chicago, Jacob Viner, com quem ele e Gudin estabeleceriam laços de amizade que resultariam, inclusive, em convites para palestrar no Brasil. Viner, que fora professor de Paul Samuelson e Milton Friedman em Chicago (item 4.4), teve grande influência sobre Bulhões e Gudin.

No período que passou nos Estados Unidos, Bulhões aproximou-se do modelo de ensino de economia norte-americano que tomou como inspiração e molde para a organização das escolas brasileiras da área. As trajetórias de Eugênio Gudin e Octavio Bulhões mesclam-se e confundem-se com a história da institucionalização da ciência econômica no Brasil. Sempre em trânsito entre as escolas e o Estado, os dois faziam uso dos trunfos sociais e políticos, do prestígio e do reconhecimento que acumularam na vida pública para solidificar o ensino de economia e separá-lo das outras disciplinas. Eles transpuseram as experiências de gestão da economia que tiveram no setor público para a sala de aula e levaram gerações de alunos para o governo, colaborando, desse modo, para criar especialistas em economia que se equilibrassem entre o Estado e academia (SILVEIRA, 2009).

Depois de Bretton Woods, o engenheiro e o advogado convertidos em economistas decidem enviar ao Ministro da Educação e Saúde Gustavo Capanema um projeto de reforma do ensino de economia. A inspiração para o novo currículo teria vindo da visita que Gudin e Bulhões fizeram a Harvard durante a conferência de Bretton Woods (BULHÕES, 1990, pp. 65-66).

21 de agosto de 1944. Meu caro Ministro, depois da Conferência de Bretton Woods, seguimos, o Dr. Octavio Bulhões e eu, para Boston, em visita à Faculdade de Economia da Universidade de Harvard. Fômos ali muito bem recebidos, tendo tido ocasião de tratar com os maiores professores que são os mais eminentes economistas da América, do programa da futura organização de nossa projetada Faculdade de Economia. Escrevi na pedra o programa e o projeto de curriculum que lhe recomendamos, para submetê-lo à critica de todos e para receber as sugestões dos Mestres. Tenho a satisfação de comunicar-lhe que, depois de fazerem várias perguntas e de pedir esclarecimentos, todos os professores de Harvard acharam o programa excelente, dizendo que nada havia a modificar. Perguntamos também sobre a conveniência ou não de separar as duas Faculdades, a de Economia e a de Administração. Eles nos levaram à janela para

balanço de pagamentos. O Plano White, em contraste, previa um mundo livre de controles e paridades fixas sob a supervisão de uma instituição internacional com poder de veto sobre as mudanças nessas paridades" (EICHENGREEN, 2000, p. 135). Octavio Bulhões e Eugênio Gudin, tal qual White, defendiam a liberação dos mercados como via para a eficiência econômica, pleiteando redução do nível de controles adotados em nome do pleno emprego. 
mostrar-nos, do outro lado do rio, a Faculdade de Administração, admiravelmente instalada aliás, e nos recomendaram que se não tivéssemos um rio, abríssemos um canal... para separar as duas Faculdades. Conversamos também sobre a possibilidade de eles nos fornecerem alguns professores para a Faculdade de Economia, o que eles acham perfeitamente possível, logo após a guerra na Europa. As duas dificuldades são a língua e a remuneração. Quanto à remuneração, conversei com os Chefes do Departamento Cultural do Departamento de Estado em Washington, que acham perfeitamente possível a cooperação financeira desse Departamento para que os professores americanos possam aceitar os padrões de remuneração que usualmente podemos oferecer. Quanto à língua, teremos, no princípio, de aceitar lições em inglês, como aceitamos o francês, no caso dos professores franceses. Queira o meu iluste amigo receber minhas cordiais saudações com meus votos para que a Reforma do Ensino superior seja, muito breve, transformada em lei e para que ela tenha o sucesso que é de se esperar. De seu muito atencioso apreciador, Eugênio Gudin (GUDIN, 1979, p. 39).

Nessa passagem fica claro que o modelo que Bulhões e Gudin buscavam mimetizar no novo currículo era o de Harvard, escola onde estavam aqueles professores que chama de "os maiores da América". Apoiados na experiência norte-americana, pleiteavam que o ensino da economia fosse separado das faculdades de Administração e Contabilidade, áreas que consideravam menos nobres. Sugeriam, por fim, que economistas americanos fossem convidados a lecionar no Brasil, mencionando as missões francesas como exemplo de sucesso da importação de professores e da viabilidade do ensino em outras línguas. Colaborou com eles na elaboração desse projeto de reforma do ensino de economia Maurice Byé, o orientador francês de Furtado, que à época integrava a missão francesa da Faculdade Nacional de Filosofia do Rio de Janeiro. Finalmente, a reforma diminuía a carga das disciplinas jurídicas na formação do economista e aumentava a dose da teoria econômica de matriz quantitativa, fortemente apoiada na matemática e na estatística, em geral aportada por professores engenheiros (Antônio Dias Leite in: ALBERTI et al., 2002, pp. 46-47; CHACEL, 1979, pp. 29-30; LEFEBVRE, 1990; SCALERCIO e ALMEIDA, 2012, p. 74).

Finalmente em 1945, o ingresso na Faculdade de Ciência Econômica deixou de ter como requisito a passagem prévia por um curso técnico de comércio, elevando o prestígio e a origem social dos frequentadores dos cursos de economia. O curso de Administração e Finanças de Getúlio Vargas foi substituído por dois cursos separados, um de Ciências Econômicas e um de Ciências Contábeis e Atuariais, exatamente como pleiteavam Gudin e Bulhões. O novo currículo também modificava o peso das diversas disciplinas no programa que passava a ter a maioria dos cursos dedicados ao ensino da economia e dos métodos e técnicas quantitativos a ela associados, remanescendo uma parte menor da 
formação dedicada às áreas de geografia econômica, história econômica, sociologia e direito (CASTRO, 2001, p. 19; CONFECON, 2012, pp. 29-35).

Em 1946, ainda antes da regulamentação da profissão de economista, Gudin e Bulhões participaram da criação de uma segunda instituição que ajudaria a estabelecer os pilares da ciência econômica no Brasil: o Núcleo de Economia da FGV-RJ. Luiz Simões Lopes conta que, durante o período em que fora presidente do DASP, teria ficado mal impressionado com o fraco desempenho dos candidatos nos concursos de recrutamento para o setor público que organizou, razão pela qual empenhou-se na criação de uma instituição destinada a oferecer treinamento em administração.

Comecei então a imaginar a criação de uma entidade destinada a melhorar o nível intelectual dos brasileiros no campo das ciências sociais, com preponderância para a administração, pública e privada, e para outra coisa que está muito ligada à administração, e que era muito necessária, porque na época praticamente não existia no Brasil: a economia (Luiz Simões Lopes in: D’ARAÚJO, 1999, p. 13).

Criada por decreto-lei em julho de 1944, a FGV era uma instituição imersa em contradições. Foi criada pelo Estado mas sua administração e funcionários eram escolhidos privadamente pelos membros de sua assembleia. A instituição era privada e podia receber investimento particular mas dependia totalmente das subvenções anuais do governo e funcionava, inicialmente, dentro de um prédio que pertencia ao Ministério da Fazenda. Seu principal expoente, o professor Gudin, era feroz anti-estatista mas dirigia uma instituição privada que dependia do governo para sobreviver. A instituição criada pelo presidente Getúlio Vargas levava seu nome mas abrigava vários anti-varguistas, notadamente o diretor Gudin ${ }^{80}$ (LOPES, 2003, p. 73; SILVEIRA, 2009, pp. 51-57).

No início a FGV oferecia cursos de nível médio, como o treinamento para secretariado. Só depois é que foram criados os cursos superiores de administração e economia. Simões Lopes diz que para organizar o curso de economia trouxe "um economista [que havia] no Brasil, que era o Gudin" e pegou a "escola onde estava o Bulhões, outros etc. e trouxe para a Fundação" (LOPES, 2003, pp. 29-30). A FNCE e o Núcleo de Economia da FGV tinham em comum mais do que as figuras de Gudin e

\footnotetext{
${ }^{80}$ Luiz Simões Lopes relata: "Eu trouxe essa gente toda, inclusive adversários dele em bom número, Gudin, por exemplo, entre outros. Tanto eles acharam que era justo botar o nome Getúlio Vargas - porque sem ele não haveria Fundação -, que no dia da votação do nome, foi unânime. Não houve nenhum voto contra". E explica: "ele fez muito, por um lado, porque assinou esse decreto-lei, deu o primeiro dinheiro e incluiu a Fundação no Orçamento da República” (LOPES, 2003, pp. 73-74). É possível supor que ao dar o nome do presidente buscavam também a benevolência futura e a manutenção das verbas.
} 
Bulhões. A Faculdade Nacional de Ciências Econômicas instalou-se na sede da Fundação, no terreno onde funcionara o colégio Aldrige em Botafogo. As duas escolas repartiam, além do espaço físico, os professores e funcionários, as verbas e custos e os alunos que estudavam em uma das escolas recebiam bolsa da outra. Era "no mínimo difícil perceber onde começa uma entidade e onde termina a outra" (FLORES, 1998, p. 6; MOTTA, 1994, p. 100; SILVEIRA, 2009, p. 61, 70-72). Nota-se um amálgama entre uma escola pública e outra privada mas dependente do governo, mostrando a permeabilidade entre público e privado e a indistinção institucional.

Outros membros fundadores do Núcleo de Economia estavam ligados à Universidade do Brasil. Era o caso dos professores da Faculdade Nacional de Engenharia, Antônio Dias Leite e Jorge Kafuri, e de Jorge Kingston, da Faculdade Nacional de Filosofia (SILVEIRA, 2009, pp. 36, 61; VIEIRA, 1981, p. 358). Alguns alunos deles na FCEARJ e na FNCE, como Julian Chacel $^{81}$, Genival Santos ${ }^{82}$ e Maria da Conceição Tavares (item 1.5), Anníbal Villanova Villela ${ }^{83}$, Isaac Kerstenetzky ${ }^{84}$, Margareth Hansen

\footnotetext{
${ }^{81}$ Julian Alfonso Magalhães Chacel (1928) tinha vínculos próximos com a família de Eugênio Gudin. Nasceu no Rio de Janeiro mas passou parte da primeira infância na Espanha, tendo aprendido a falar primeiro o espanhol. Era filho do comandante espanhol Julian Chacel Norma, que servia no Brasil e na Argentina, e de Maria Beatriz Magalhães, filha de Fernando Augusto Ribeiro de Magalhães, professor e diretor da Faculdade de Medicina do Rio de Janeiro, deputado da constituinte de 1934 e membro da Academia Nacional de Medicina e da Academia Brasileira de Letras. Seu bisavô, Nuno Ferreira de Andrade, também médico, foi presidente da Academia Imperial de Medicina, Reitor da Universidade do Brasil e era conselheiro do Imperador Dom Pedro II. Chacel conta que antes de ingressar na FNCE já tinha vínculos com Gudin pois ele era amigo de sua avó e de sua tia e frequentava jantares na casa de seus pais. Tinha laços também com a família de Mario Henrique Simonsen, pois seu avô era colega do avô de Simonsen na Faculdade de Medicina e seu pai era amigo de Hermano Simonsen, irmão de Mario Simonsen, o pai de Mario Henrique. Ainda aluno da FNCE, Chacel foi convidado por Gudin para ser estagiário da FGV encarregado de ajudar na elaboração da revista Conjuntura Econômica. Em 1950 Chacel é enviado para cursar um doutorado em economia na Faculdade de Direito da Universidade de Paris. Ao retornar passa a lecionar na FNCE além de colaborar com a FGV (Julian Chacel in: ALBERTI et al., 2002, pp. 81-82; CHACEL, 1979, p. 27; CHACEL, 2012, pp. 20-24; MOTTA e ROCHA, 2008, p. 28).
}

Ver: http://www.dichistoriasaude.coc.fiocruz.br/iah/pt/pdf/andnunfer.pdf,

http://www.academia.org.br/academicos/fernando-magalhaes/biografia e

http://camara.fgv.br/sites/camara.fgv.br/files/file/Curriculo\%20Vitae\%20Julian\%20Chacel.pdf. Consultados em $10 / 01 / 2016$.

${ }^{82}$ Genival Santos (1920-2002) nasceu em Guabira, na Paraíba. Mudou-se para o Rio de Janeiro aos 17 anos, com a intenção de estudar medicina. Conseguiu um emprego de auxiliar de atendimento no Hospital Central de Acidentados e chegou a tornar-se chefe do Raio X. Ao invés de seguir a carreira médica, decidiu estudar economia, ingressando em 1942 na FCEARJ. Em 1946, Genival transladou-se para Paris com a intenção de realizar o doutorado em ciências econômicas na Faculdade de Direito de Paris. Quando retornou ao Rio de Janeiro passou a lecionar na FNCE e ocupou, simultaneamente, as posições de coordenador da equipe encarregada da elaboração dos indicadores de renda nacional do Instituto Brasileiro de Economia e diretor da divisão de comércio exterior do CNE. Em 1961 Genival deixou o CNE para chefiar o departamento econômico do BNDE. Em 1963 foi promovido a superintendente do Banco e no ano seguinte assumiu interinamente como presidente (item 2.5) (CENTRO INTERNACIONAL CELSO FURTADO DE POLÍTICAS PARA O DESENVOLVIMENTO, 2009, pp. 345-346; DHBB, verbete Genival Santos).

${ }^{83}$ Annibal Villanova Villela (1926-2000), nascido no Rio de Janeiro, era filho de Adhemar Villela dos Santos, general de brigada que vinha de Minas Gerais e era filho de Francisco Villela dos Santos, tesoureiro dos Correios do Estado de Minas. Neto por parte de mãe do carioca Annibal de Azambuja Villanova, também general de brigada. Anníbal Villela estudou no externato São José, no bairro da Tijuca, onde nasceu e cresceu. 
Costa ${ }^{85}$ e Dênio Nogueira (item 2.5) começaram também a trabalhar próximos a seus professores na FGV e logo foram enviados a estudar no exterior. Chacel e Genival foram fazer o doutorado em economia na Faculdade de Direito da Universidade de Paris. Anníbal Villela estudou em Estocolmo e na LSE. Dênio Nogueira foi para a Universidade de Michigan. Isaac Kerstenetzky para as universidades McGill no Canadá e Haia na Holanda. Tavares não foi estudar no exterior nessa época, já que ingressou no BNDE e depois no Centro CEPAL-BNDE (item 1.5).

Vinculados ao Núcleo de Economia surgem, em 1947, duas revistas especializadas: a Revista Brasileira de Economia (RBE), voltada ao debate teórico, que publicava artigos de professores estrangeiros e era dirigida por Gudin, e a Revista Conjuntura Econômica, informativo que publicava os índices de renda nacional, de preços e os balanços de pagamentos, sendo dirigida por Richard Lewinsohn, judeu polonês, médico e cientista político de formação, que havia sido contratado pelo DASP86 (CHACEL, 2012, pp. 2024). Em 1950, surgiu também a revista Conjuntura Social, dirigida por Accioly Borges, um

Tornou-se um homem religioso e tinha grande interesse no aprendizado de idiomas, chegando a falar 6 línguas estrangeiras: inglês, francês, espanhol, sueco, alemão e russo, tendo sido autodidata em quase todas elas. Graduou-se em economista na FNCE em 1949. Ao concluir a graduação passou a trabalhar junto a seus professores Bulhões e Gudin na FGV. Na primeira metade dos anos 1950 foi enviado para a Europa, com uma bolsa concedida pelas Nações Unidas para cursar a pós-graduação em economia na Stockholm School of Economics e na London School of Economics. De volta ao Brasil, além de lecionar no CAE e na especialização em engenharia econômica, foi chefe do Setor de Estudos Monetários do Departamento Econômico do BNDE e depois chefe do Departamento Econômico da CNI, especializando-se nas áreas de economia industrial e planejamento econômico (CENTRO INTERNACIONAL CELSO FURTADO DE POLÍTICAS PARA O DESENVOLVIMENTO, 2009, pp. 308-309; Informações concedidas por Monica Balanda, filha de Anníbal Villela, por email em $2016 \mathrm{e}$

http://memoria.bn.br/DocReader/DocReader.aspx?bib=175102\&PagFis=18169.

http://memoria.bn.br/DocReader/DocReader.aspx?bib=175102\&PagFis=18459

http://memoria.bn.br/DocReader/DocReader.aspx?bib=178691_04\&PagFis $=44683$

http://memoria.bn.br/DocReader/DocReader.aspx?bib=175102\&PagFis=8583 Consultados em 16/01/2016, http://www.bibliotecacelsofurtado.org.br/interna.php?ID_M=44. Consultado em 09/01/2016.

${ }^{84}$ A trajetória de Isaac Kerstenetzky (1927-1991) foi bastante distinta. Nascido em Vila Isabel, no Rio de Janeiro, era filho de imigrantes judeus da Europa Oriental. Seus pais eram mascates, comercializavam objetos de pequeno valor à prestação, de porta em porta. Isaac estudou no Colégio Pedro II e bacharelou-se em economia pela FNCE, em 1946. No mesmo ano em que concluiu a faculdade, começou a trabalhar na FGV, sendo recrutado por Genival Santos para integrar a equipe do Centro de Contas Nacionais, que elaborava as estatísticas nacionais. Entre 1952 e 1953, Kerstenetzky, que falava inglês, francês e espanhol, teve a oportunudade de cursar uma pós-graduação em economia na McGill University, em Montreal, no Canadá, e outra em Haia na Holanda em 1960, onde foi aluno do Prêmio Nobel Jan Tinbergen (FARO, 1991, p. 333; IBGE, 2006, pp. 155-156; Informação concedida por Jacques Kerstenetzky, filho de Isaac, por email em 2016).

${ }^{85}$ Sobre Margareth Hansen Costa, a única mulher além de Maria da Conceição Tavares mencionada nos depoimentos, pouquíssima informação pode ser encontrada, o que é sintomático do baixíssimo grau de prestígio das mulheres na área.

86 "Quando acabou a guerra, Richard Lewinsohn resolveu voltar para a Europa. Garrido Torres estava nos Estados Unidos e tinha muito bom contato com a Fundação. Com a saída do Lewinsohn, foi convidado para ser diretor da revista, e aí veio Denio Nogueira como redator-chefe. Jesus Soares Pereira e Thomaz Pompeu foram coisas transitórias; efetivo mesmo foi o Américo, seguido pelo Dênio Nogueira. [...]. Jesus e Thomaz saíram da Fundação quando fechamos a Conjuntura Social' (Jorge Oscar Flôres in: D’ARAÚJO, 1999, p. 70). 
dos homens ligados à Assessoria Econômica de Vargas (item 1.4), que contava com a colaboração de outros membros da Assessoria e de Celso Furtado. Jorge Oscar Flôres, da FGV-RJ, acreditava que a Conjuntura Social era um antro de socialistas. Chacel conta que "Gudin, com sua visão liberal, antiestatista, não gostava do tom da Conjuntura Social', achava que não se coadunava com a parte econômica. Um dia foi ao Simões Lopes, deu um basta, e essa gente toda foi expelida" (Jorge Oscar Flôres in: D’ARAÚJO, 1999, pp. 69-70; Julian Chacel in: D’ARAÚJO, 1999, p. 71). Essa ocorrência mostra que, ainda que predominasse nesse período a convivência cordial e a colaboração entre economistas com diferentes posições políticas, já havia manifestações das contradições e conflitos que se acirrariam no final dos anos 1950 e início dos 1960.

Em 1951, o Núcleo de Economia foi transformado no Instituto Brasileiro de Economia (IBRE). A Comissão Diretora do Instituto incluía, além de Bulhões, Gudin e Kingston, o diplomata e economista Roberto Campos e Alexandre Kafka (1907-2007) ${ }^{87}$, que havia estudado Direito, Relações Internacionais e Economia e que, por ter raízes judaicas, decidiu refugiar-se no Brasil durante a Segunda Guerra Mundial. Tornou-se professor da Escola Livre de Sociologia e Política (ELSP) de São Paulo e consultor econômico da Federação das Indústrias do Estado de São Paulo (FIESP), a convite de Roberto Cochrane Simonsen (item 4.1). Em 1949, tornou-se representante do Brasil no FMI e, depois de ter passado dois anos em Washington, Gudin convidou-o para ser diretor de pesquisa do $\mathrm{IBRE}^{88}$, posição que ocupa até 1966, quando volta a ser o representante brasileiro no FMI (CHACEL, 1997, p. 368; KAFKA, 1998, pp. 35-47, 5557; MOT'TA e ROCHA, 2008, p. 388). No período em que esteve no IBRE, Kafka ocupou também a posição de conselheiro da SUMOC, convidado pelo superintendente da época, Walter Moreira Salles, que o havia conhecido em reunião do FMI em

\footnotetext{
${ }^{87}$ Nascido em uma família judia de Praga, Alexandre era filho de Bruno Kafka, primo do escritor Franz Kafka, que descendia de uma linhagem de juristas. Bruno doutorou-se em direito e tornou-se professor, diretor e reitor da Universidade Alemã de Praga. Atuou também na política, tendo sido eleito deputado. Sua mãe, em contraposição, descendia de uma linhagem de industriais e engenheiros. Alexandre seguiu a tradição familiar inscrevendo-se na Faculdade de Direito em Praga. No terceiro ano da faculdade fez cursos da pós-graduação em Relações Internacionais do Institut Universitaire de Hautes Études Internationales de Genebra. Retornou à Praga para concluir a graduação e logo foi obrigado a deixar seu país por conta das perseguições aos judeus. Mudou-se para Oxford onde fez estudos em Philosophy, Politics and Economics (GREY et al., 2005, p. 152; KAFKA, 1998, pp. 19-29;).

${ }^{88} \mathrm{Kafka}$ conta que quando começou a montar sua equipe de pesquisa logo tomou a iniciativa de convidar Celso Furtado, que recusou a proposta porque queria continuar no Chile (KAFKA, 1998, p. 62).
} 
Washington. Em seu período nos Estados Unidos, Kafka ficou amigo de Albert Wolf89, que trabalhava na Fundação Ford, a quem viria a recorrer para conseguir verbas para financiar estudos da FGV ${ }^{90}$ (Alexandre Kafka in: D’ARAÚJO, 1999, pp. 54-57; KAFKA, 1998, pp. 61-65).

Além dos colaboradores estrangeiros residentes no Brasil, como Lewinson e Kafka, que para cá vieram por causa da guerra, a FGV recebeu, através de uma missão acordada com as Nações Unidas, economistas da França, África do Sul, Alemanha, Bélgica e Holanda, o que fazia com que a FGV parecesse uma torre de Babel. Posteriormente, passaria a contar com a cooperação de organismos norte-americanos para financiar a ida de seus professores e alunos para o exterior e a vinda de professores estadunidenses para o Brasil. Aos poucos, os professores e pesquisadores estrangeiros foram sendo substituídos pelos brasileiros que regressavam das universidades norteamericanas. Gudin costumava, ainda, convidar professores estrangeiros para ficar um ou dois meses na Fundação. Eles davam conjuntos de palestras e ajudavam os brasileiros a incorporar técnicas mais modernas de pesquisa e elaboração de estatísticas. Dentre os professores convidados estiveram Lionel Robbins da LSE, Gottfried Haberler de Harvard, Ragnar Nurkse de Columbia/Princeton e Jacob Viner de Chicago (Luiz Simões Lopes In: D’ARAÚJO, 1999, p. 21; Jorge Oscar de Mello Flôres In: D’ARAÚJO, 1999, p. 31; KAFKA, 1979, p. 45).

A passagem de Jacob Viner pelo Brasil, na metade de 1950, é citada nos depoimentos de Prebisch, Furtado, Chacel e Kafka. Ela é tida como um marco da adoção, pelos professores da FGV, de uma posição crítica à CEPAL. Chacel relata:

À época, princípio dos anos 50, Gudin estava encantado pelas ideias de Raúl
Prebisch, por quem nutria grande respeito, desde os tempos em que este ocupara
a presidência do Banco Central da República Argentina. Jacob Viner, que tinha
vindo ao Rio de Janeiro para dar um ciclo de conferências, refutou, um a um, os
argumentos de Prebisch sobre a deterioração secular das relações de troca e
conquistou em definitivo a mente lógica de Gudin. [...] É muito possível que a
influência de Viner sobre ele explique porque o Instituto Brasileiro de Economia
da Fundação Getúlio Vargas tenha sido imune ao proselitismo que, desde
Santiago do Chile, a CEPAL fazia sobre toda a América Latina (CHACEL, 1979,
p. 32).

\footnotetext{
89 "Ex-alto funcionário público nas gestões Truman e Roosevelt, o primeiro homem forte do programa latinoamericano da Fundação Ford, liberal simpático às instituições acadêmicas e à pesquisa científica" (MICELI, 1993, p. 38).

${ }^{90}$ A oitava maior doação da Fundação Ford para o Brasil foi destinada à FGV no ano de 1960. Essa é a mais antiga das 50 maiores doações da Ford para o Brasil e destinava-se a "programas de pesquisa econômica aplicada relacionada com problemas de desenvolvimento econômico" (BROOKE e WITOSHYNSKY, 2002, p. 42).
} 
Furtado, ao comentar o episódio, diz que depois de publicar o Manifesto latinoamericano de Prebisch na RBE, Gudin convidou os amigos Viner e Haberler a enviarem comentários sobre o texto. Werner Baer, que foi aluno de Haberler em Harvard, conta que em seu curso de economia internacional Gottfried "atacava as teorias do Prebisch/CEPAL" de maneira "veementemente" (BAER, 1998, p. 768). Jacob Viner, quando veio ao Brasil, dedicou uma de suas conferências inteiramente a desdizer as "heresias" de Prebisch. Isso era parte, segundo Furtado, de "um esforço para restabelecer a verdade em pontos essenciais da teoria [ortodoxa], particularmente no que respeita à teoria do comércio internacional", caracterizando uma "cruzada de purificação ideológica". Furtado diz ainda que Viner era um "homem de superior formação intelectual e grande argúcia" e elogia longamente sua capacidade de fazer "teoria pura, mundo de construções rigorosas em que tudo se explica dedutivamente, a partir de premissas ascépticas”. Furtado argumenta que o método de Viner consistia em dizer "ignoremos o mundo real e observemos uma caixa vazia. E começava a descrever essa caixa”, enquanto Prebisch procurava fazer o contrário, descrever o mundo real ao invés de fazer demonstrações de puro rigor lógico. Nisso divergiam inevitavelmente (FURTADO, 2014, pp. 128-129).

A divergência na interpretação do episódio é reveladora dos conflitos que começavam a estruturar o espaço dos economistas: Chacel, discípulo de Gudin e professor da FGV, conta que seu mestre tinha apreço pela figura de Prebisch - sobretudo pelo Prebisch ainda ortodoxo que criara o Banco Central -, com quem ele havia trocado cartas e a quem fizera repetidos convites para lecionar na Fundação. A simpatia inicial de Gudin pela produção de Prebisch teria sido, na interpretação de Chacel, desfeita pela argumentação de Viner, resultando em uma rejeição de seu proselitismo latinoamericanista. Furtado, ao contrário, considera que rejeição da teoria cepalina era um a priori, tendo sido os professores estrangeiros convidados precisamente para reforçar as convicções ortodoxas contra as novas e hereges ideias.

De acordo com Furtado não poderia haver confirmação ou refutação das teses de Prebisch por Viner, já que os dois falavam de coisas inteiramente diferentes. Viner tomava a teoria pura e testava a adequação das descobertas de Prebisch aos princípios lógicos estabelecidos por seu modelo. Enquanto Raúl observava uma situação econômica concreta que procurava explicar com as ferramentas da teoria econômica que melhor se 
prestassem a isso, mesmo que se desviassem do conjunto de premissas da teoria ortodoxa. Não apenas seus métodos divergiam, mas também as premissas subjacentes às suas teorias. Prebisch estava em busca de uma teoria para explicar o caso específico da América Latina e afirmava que o desenvolvimento da região não alcançaria os padrões de vida existentes no centro sem uma política ativa em favor da industrialização. Viner, ao contrário, era defensor da liberdade de atuação na economia e "muito severo no que diz respeito aos desequilíbrios orçamentários, à falta de controle dos meios de pagamento. Era favorável a um intercâmbio mundial. Seus livros tratavam muito mais de comércio internacional do que de problemas nacionais" (BULHÕES, 1990, pp. 20-21).

A perspectiva de Gudin e Bulhões era bastante semelhante à de Viner, ocupando lugar privilegiado em seus estudos a estabilidade monetária e o incentivo à expansão do comércio internacional. Nesse sentido havia grande afinidade entre as preocupações da dupla quanto aos tópicos que estiveram discutindo em Bretton Woods e o posicionamento teórico e político dos norte-americanos com os quais dialogavam. É possível argumentar, portanto, que ainda que tivessem admiração pela figura de Prebisch, as críticas de Viner teriam sido alegremente acolhidas pelos professores da FGV, posto que restauravam as certezas fundamentais desses economistas ditos ortodoxos e/ou (neo)liberais ${ }^{91} \mathrm{e} /$ ou monetaristas.

Malgrado a existência de grande afinidade teórica e política entre Eugênio Gudin e Octavio Bulhões é possível dizer que existiam algumas dessemelhanças em seus pontos de vista. Gudin partia da noção liberal clássica de divisão internacional de trabalho e considerava que não cabia ao Brasil adotar políticas de industrialização baseadas em medidas protecionistas, devendo o país ater-se às suas vantagens comparativas atuais, o que na prática equivaleria a defender a sua vocação primário-exportadora. É possível sugerir que seu apreço pela economia de exportação e pela abertura ao comércio internacional estaria, de alguma forma, vinculado à sua própria experiência com a agricultura de exportação. Gudin dizia, ainda, que a herança que o Brasil tinha de um

\footnotetext{
91 “Todas as versões da teoria neoclássica partiram da suposição de que a economia é formada por um conjunto de agentes econômicos, e que estes são possuidores, de um lado, de preferências ou escalas de utilidade e, de outro, de dotações de fatores, dentre as quais se incluem determinadas 'quantidades de capital'. A tarefa, então, de todas elas foi a de mostrar como o 'mecanismo de mercado', por meio da produção, da circulação e da repartição, faz um casamento ótimo ou quase ótimo entre o emprego dos fatores e a satisfação dos consumidores" (PRADO, 2007, p. 6). Os neoliberais diferem dos liberais por admitir a necessidade de alguma intervenção, vistas as imperfeições de mercado (BIELSCHOWSKY, 2007, pp. 305-6).
} 
capitalismo de Estado colocava-o no caminho dos totalitarismos ${ }^{92}$ (CARNEIRO, 1979, p. 8; GUDIN, 2010; PEREIRA, 1997, p. 24). Bulhões, por sua vez, considerava o processo de industrialização irreversível, aprovando inclusive a política keynesiana do imediato pósguerra. Via de regra, opunha-se à ação direta do Estado na economia mas aceitava que fossem adotadas medidas de incentivo aos empreendedores, desde que não causassem desajustes econômicos e desequilíbrios monetários (BIELSCHOWSKY, 1997, p. 77; BULHÕES, 1990, pp. 22-24; SARETTA, 2007, pp. 322-324).

Suas posições eram afinadíssimas no que concerne à estabilização monetária. Todas as vezes que ambos estiveram no governo empenharam-se incansavelmente em aprovar políticas rigorosas de estabilização. Roberto Campos afirma que Eugênio Gudin "sempre foi um monetarista ortodoxo, acreditando intransigentemente no valor da estabilidade como pré-condição fundamental para qualquer outra coisa. Sempre foi um defensor da austeridade fiscal. Advogava a abertura em matéria de comércio internacional, acentuando a necessidade de se dar mais atenção às vantagens comparativas" (CAMPOS, 1996, pp. 37-38). Bulhões, por sua vez, diz que ele próprio não fez "outra coisa na vida senão falar em combater a inflação", "sem dó nem piedade” (BULHÕES, 1990, pp. 3233).

Foi essa obsessão com a estabilização monetária que levou Bulhões a propor ao Ministro da Fazenda, Souza e Cruz, de quem era chefe de gabinete, que se criasse uma Superintendência da Moeda e do Crédito com o objetivo de preparar o advento de um Banco Central. Seguindo a onda de reformas dos sistemas financeiros propulsionada por Bretton Woods (1944), propôs-se a criação de uma autoridade monetária independente que deveria controlar a moeda, dar assistência ao setor bancário e executar a política de moeda e crédito, tarefas antes outorgadas ao Banco do Brasil (BB). Na opinião daqueles que defendiam a criação da nova instituição, o BB não poderia exercer simultaneamente as funções de banco comercial e de autoridade monetária, já que controlar a si mesmo não seria adequado técnica ou eticamente (LAGO93, 1982, pp. 6-7; RAPOSO, 2011, p. 43).

\footnotetext{
${ }^{92}$ Os posicionamentos de Gudin serão apresentados de maneira mais detalhada no quarto capítulo, quando for tematizada a controvérsia que ele sustentou com Roberto Simonsen (item 4.1).

${ }^{93}$ A dissertação de Pedro Aranha Corrêa do Lago sobre a SUMOC, orientada por Pedro Malan, chega quase a advogar em prol da causa do Banco Central independente. Uma de suas principais fontes de dados, o funcionário da SUMOC e do BCB, Casimiro Ribeiro, foi, ao mesmo tempo, objeto de estudos e membro da banca de defesa da dissertação.
} 
A criação de uma autoridade monetária independente favorecia o Ministro da Fazenda, na medida em que a SUMOC seria colocada sob seu controle, dando-lhe maior poder sobre a política econômica. Bulhões estava "ciente de que, se tentasse arrancar do Congresso uma lei, não sairia. Havia sempre oposições”, especialmente do BB (RIBEIRO, 1981, p. 11). Para fugir dos conflitos, resolveram aprovar a nova instituição por decreto. O Presidente Vargas assinou o decreto-lei redigido por Bulhões sancionando a criação da SUMOC em 2 de fevereiro de 1945. As negociações que levaram à criação da SUMOC não foram, entretanto, capazes de torná-la tão autônoma quanto almejavam seus criadores já que, por não ter caixa própria, continuava sendo, na prática, dependente do $\mathrm{BB}$ que, ademais, fornecia os funcionários para a SUMOC e tinha grande peso em seu conselho administrativo. O novo órgão era, portanto, no máximo um estágio transitório para a criação de um Banco Central (GALVÊAS, 1990, p. 11; LAGO, 1982, pp. 16-17, 65; RAPOSO, 2011, pp. 42-45).

A SUMOC, em seus vinte anos de existência, foi um "polo de aglutinação de um grupo de técnicos e estudiosos de economia formados pelos mestres Eugênio Gudin e Octavio Bulhões para lidar com os aspectos monetário, creditício e cambial da economia. Questões privilegiadas pelo pensamento liberal, do qual Gudin e Bulhões são expoentes no Brasil" (LAGO, 1982, p. 5). Os quadros da SUMOC eram quase todos funcionários concursados do BB selecionados pelo advogado Herculano Borges da Fonseca - filho do tesoureiro geral do BB, Homero Borges da Fonseca - para integrar a SUMOC e depois enviados ao exterior para fazer cursos de aprofundamento em economia ${ }^{94}$. Desse grupo, referido na literatura como "sumoqueano" ou "monetarista", fizeram parte Celso Silva, Herculano Borges da Fonseca, Sidney Lattini, Guilherme Pegurier, Eduardo Silveira Gomes, Basílio Martins e algumas pessoas que depois assumiriam posições importantes no futuro Banco Central do Brasi1 ${ }^{15}$. Era o caso de Dênio Nogueira, primeiro presidente

\footnotetext{
${ }^{94}$ Herculano Borges da Fonseca "trouxe gente nova do Banco do Brasil para trabalhar com ele: Casimiro Ribeiro, Sidney Lattini, Guilherme Pegurier, e um grupo... Paulo Pereira Lira [...]. O Herculano teve uma visão muito ampla de todos esses acontecimentos, em relação ao que seria o trabalho da Sumoc, e mandou muita gente estudar fora. Ele estimulou muito as pessoas a irem fazer cursos no exterior. O Guilherme Pegurier foi para o Fundo Monetário fazer curso de balanço de pagamentos; o Sidney Lattini foi para o Fundo Monetário fazer curso de balanço de pagamentos... Casimiro Ribeiro foi para a Inglaterra. [...] Havia um curso de 'Teoria e política monetária', no México, que muita gente ambicionava fazer. Era um curso de oito meses, no México, no CEMLA, no Centro de Estudos Monetários Latino-Americano" que ele frequentou (GALVÊAS, 1990, pp. 12${ }_{95}^{13) .}$

95 Para dados sobre a composição do $\mathrm{BCB}$ ver: http://www.bcb.gov.br/pre/historia/comp_historica_BCB_area.pdf; http://www.bcb.gov.br/pre/historia/comp_historica_BCB_estrutura.pdf; http://www.bcb.gov.br/pre/historia/comp_historica_BCB_gestao.pdf. Consultados em 04/11/2015.
} 
do BCB, de 1965 a 1967; Ernane Galvêas, presidente de 1968 a 1974 e de 1979 a 1980; Aldo Batista Franco, diretor de 1965 a 1967; Antônio Abreu Coutinho, diretor de 1966 a 1967; Casimiro Ribeiro, diretor de 1965 a 1967; Paulo Hortênsio Pereira Lira, diretor de 1968 a 1974 e presidente de 1974 a 1979; além de José Garrido Torres que foi superintendente da SUMOC em 1958 e presidente do BNDE de 1964 a 1967 (GALVÊAS, 1990, pp. 12-13; GOUVÊEA, 1994, p. 80).

O debate acerca da criação de um Banco Central no Brasil não era novo. O inglês Sir Otto Ernest Niemeyer, representante do Bank of England e membro do Comitê Financeiro da Liga das Nações, em missão de aconselhamento financeiro ao Brasil em 1931, havia defendido veementemente a criação de um Banco Central independente. A missão, organizada por pressão dos banqueiros Rothschild, tinha o objetivo de avaliar a capacidade brasileira de saldar as dívidas que decorreriam dos empréstimos internacionais que o Brasil solicitava. Sir Otto Niemeyer era um dos muitos Money Doctors que circularam pela América Latina no século XX. Esses especialistas financeiros estudavam as conjunturas locais e ofereciam fórmulas econômicas e institucionais para tornar a economia dos países subdesenvolvidos mais estável, aberta e organizada, de modo a poder honrar seus compromissos financeiros (DRAKE, 1994, p. xii). O relatório Niemeyer, por exemplo, dizia que:

a confiança no futuro do Brasil dependerá basicamente da confiança, interna e externa, na estabilidade e eficiência do sistema monetário. É para criar e alimentar tal confiança que praticamente todos os países mais importantes estabeleceram um sistema baseado em um banco central de reservas. Não é suficiente que um país organize um banco central. Deve ser um banco central autêntico operando exclusivamente como banco central... e não fundamentalmente como um banco comercial cumprindo apenas algumas funções de um Banco Central (Otto Niemeyer apud ABREU, 1974, p. 16).

A ideia de que a nova instituição deveria separar as funções comerciais da função de Banco Central referia-se, precisamente, à situação mista do BB. Niemeyer recomendava que se afastasse o Banco Central do controle do Estado e que ele fosse aberto aos interesses privados cosmopolitas, aceitando, inclusive, a presença de diretores não-brasileiros (ABREU, 1974, p. 17). As recomendações feitas por Niemeyer não redundaram na aprovação de nenhum projeto de Banco Central naquele período e os 14 anos que separam a sua missão da criação da SUMOC coincidem com o processo de transição da influência econômica inglesa para a estadunidense (DRAKE, 1994, p. xiii). O modelo de Banco Central que Bulhões e Gudin tinham como referência primordial não 
era aquele que decorrera das recomendações britânicas e sim o Federal Reserve System (FED), no qual os diretores eram nomeados para mandatos fixos que atravessassem as gestões governamentais, para evitar que fossem sujeitos às conjunturas da vida política nacional. Alinhados ao projeto hegemônico das finanças internacionais pós-Bretton Woods, os sumoqueanos passariam a representar o Brasil junto ao FMI e ao BM (LAGO, 1982, p. 8; RAPOSO, 2011, p. 43).

A partir dos anos quarenta os estadunidenses passaram a enviar os próprios Money Doctors para o Brasil ${ }^{96}$. No período da Segunda Guerra, os doutos em economia norteamericanos deixam de enfocar a capacidade do país de honrar os seus empréstimos e passam a concentrar-se na avaliação das condições de apoio material e político às suas iniciativas bélicas. Eles atrelavam a vaga promessa de colaboração econômica ao alinhamento político e adesão do Brasil aos Aliados, o que implicava no fornecimento estável e em preços fixos dos suprimentos de que necessitassem para seus esforços de guerra.

Um conjunto de 4 missões econômicas norte-americanas foi enviado ao Brasil entre os anos 1940 e 1950. Antes da guerra, o Brasil recebeu a missão Taub em 1941 e a missão Cooke em 1942. Sobre a missão chefiada por Alex Taub, que contava com uma equipe de aproximadamente dez engenheiros, pouco se sabe, já que o relatório final não foi publicado. Consta apenas haver proposto um programa decenal para dobrar a produção industrial do Brasil ${ }^{97}$. A missão coordenada por Morris Llewellyn Cooke contava com 12 técnicos norte-americanos que eram acompanhados por uma equipe de brasileiros, composta por diplomatas, entre os quais Miguel Osório de Almeida, por técnicos como Ary Torres e Glycon de Paiva Teixeira e por colaboradores ligados às representações industriais da Confederação Nacional da Indústria (CNI), do Centro das Indústrias do Estado de São Paulo (CIESP) e da Federação das Indústrias do Estado de

\footnotetext{
${ }^{96}$ O Brasil e a Argentina foram os últimos países latino-americanos a transicionar para a órbita de influência dos EUA. Os demais já haviam recebido especialistas financeiros norte-americanos entre 1890 e 1920 . O mais famoso deles foi Edwin Kemmerer, para quem foi cunhado o termo Money Doctor, também descrito como "oneman IMF [FMI de um homem só]" por ter sido convidado a reformar os sistemas financeiros do México, da Guatemala, do Chile, da Bolívia, da Polônia, da China, do Peru, do Equador, da Colômbia e da África do Sul. Para todos os países Kemmerer oferecia a mesma receita: combater inflação e cortar gastos governamentais (DRAKE, 1994, p. xxviii). Os Money Doctors atuaram, assim, como agências de rating [agências de classificação de risco de concessão de crédito] avant la lettre.

${ }^{97}$ No livro de MALAN et al., 1980, o relatório consta como não publicado. Até hoje nada sobre a missão Taub consta no site do U.S. Department of State: Office of the Historian, que abriga, por exemplo, a troca de correspondência da missão Abbink. https://history.state.gov/historicaldocuments, consultado em 18/08/2015.
} 
São Paulo. A Missão Cooke teve duração de dez semanas e ocorreu entre setembro e dezembro de 1942, durante a Segunda Guerra Mundial.

A intenção dos EUA era tecer alianças e integrar a economia brasileira no esforço de guerra em curso, de modo a garantir acesso aos minérios estratégicos e às bases navais e aéreas brasileiras estrategicamente posicionadas. A Missão Cooke manifestou-se em favor da promoção da industrialização por substituição de importações, ocupando-se do estudo e da proposta de medidas voltadas para a racionalização da indústria brasileira e para a transferência de tecnologia, a fim de que pudessem incrementar a produtividade e ampliar a gama de bens produzidos nacionalmente. A industrialização reduziria a dependência externa brasileira, o que era essencial em um contexto no qual os países centrais não podiam suprir as necessidades da periferia por estarem suas economias inteiramente voltadas para a guerra. A Missão Cooke diferira radicalmente, pois, do receituário de controle financeiro e abertura do comércio internacional, repetidamente propalado pelos Money Doctors (MISSÃO COOKE NO BRASIL, 1949, pp. 21-22; MALAN et al., 1980; MALAN, 1984, p. 60; OLIVEIRA, 2003, pp. 64-71).

Ao final da guerra, o pêndulo da política externa econômica dos EUA para o Brasil oscila, sendo a ideia de uma industrialização latino-americana abandonada face à prioridade dada à reconstrução dos países arruinados pela guerra e à contenção da expansão soviética. Retorna-se aqui ao contexto descrito no episódio de criação da CEPAL, no qual os países da América Latina buscavam, sem sucesso, garantir sua participação nos programas de ajuda externa e nos projetos de desenvolvimento do pósguerra (item 1.1).

Tendo entrado ao lado dos EUA na Segunda Guerra Mundial, o Brasil esperava, em contrapartida, poder contar com a colaboração norte-americana para seu desenvolvimento econômico e social. O presidente brasileiro no imediato pós-guerra, Eurico Gaspar Dutra, alinhava-se abertamente à política internacional ditada pelos EUA. Adotou, no início de sua gestão, a política de estabilização e de liberalização preconizada pelos estadunidenses, acreditando que obteria, como recompensa pela participação do Brasil na guerra e por seus esforços de adequação econômica, os empréstimos necessários para modernizar sua infraestrutura e estimular o desenvolvimento nacional. Suas repetidas tentativas foram vãs e as suas esperanças sucessivamente frustradas (BASTOS, 2010, pp. 292-294; MALAN, 1984, pp. 62-66). 
Em setembro de 1947, Eurico Gaspar Dutra e Harry Truman encontraram-se no Rio de Janeiro por ocasião da Conferência Interamericana sobre a Defesa do Continente, da qual resultou o Tratado Interamericano de Assistência Reciproca, que propunha medidas para assegurar coletivamente a segurança dos países do continente contra agressões de outras nações. O diálogo entre os dois ocorreu em um contexto no qual, do lado americano, a doutrina Truman ${ }^{98}$ clamava pelo envolvimento direto do governo dos EUA no combate ao comunismo e, do lado brasileiro, a crise cambial e as sucessivas negativas aos pedidos de auxílio econômico ${ }^{99}$ compeliam o governo Dutra ao abandono de suas posições ultraliberalizantes. Resultou dessas conversas a criação de outra missão econômica para discutir os problemas brasileiros, A missão Abbink, dirigida pelo americano John Abbink e pelo brasileiro Octavio Bulhões, escolhido por sua proximidade com o universo norte-americano. Ao invés de reconquistar o governo brasileiro, oferecendo recursos para o desenvolvimento, a missão Bulhões-Abbink assolou uma vez mais as ilusões brasileiras ao negar qualquer sorte de apoio econômico.

A missão Abbink-Bulhões foi responsável pela produção de dados e diagnósticos sobre os problemas econômicos brasileiros e dividiu-se em uma série de subcomissões voltadas para a elaboração de diagnósticos para setores específicos: "comércio, desenvolvimento agropecuário, combustíveis, exploração mineral, desenvolvimento industrial, meios de transporte, eletrificação e mão-de-obra" (DHBB, verbete Octavio Bulhões). Destacam-se no relatório final da missão Bulhões-Abbink, a adesão às doutrinas do livre comércio e da estabilidade monetária, acompanhadas do juízo de que as necessidades de capital poderiam ser supridas pelo uso dos recursos internos brasileiros, inclusive das divisas acumuladas durante a guerra e pelos investimentos externos diretos (IED), que seriam naturalmente carregados pelas empresas privadas norte-americanas, caso houvesse harmonia econômica (MALAN et al., 1980, pp. 29-33; SOLA, 1998, p. 83).

As cartas trocadas entre John Abbink e o Secretário de Estado dos EUA deixam ver que a missão não estava autorizada a oferecer nenhuma declaração que comprometesse seu governo a enviar fundos para o Brasil. Na correspondência, Abbink acusava o Brasil de manter-se fechado ao capital estrangeiro por razões políticas e emocionais, especialmente no caso do petróleo. Ele acompanhava, naquele momento, a

\footnotetext{
98 Sobre a doutrina Truman: https://history.state.gov/milestones/1945-1952/truman-doctrine, consultado em18/08/2015.

${ }^{99}$ Para uma discussão acerca das razões da crise cambial ver: BASTOS, 2004, pp. 122-125 e MALAN, 1984, pp. 64-67.
} 
eclosão da campanha nacionalista "O Petróleo é Nosso", o que deve ter causado sobre ele grande impacto. Abbink informava o Secretário de Estado que nacionalistas e comunistas desconfiariam da Missão e que era pressionado, dentro e fora do governo, a ceder capitais para o Brasil. É igualmente ressaltada no relato a importância dos investimentos agrários para evitar agitações entre a população rural que poderiam ameaçar a estabilidade social do país ${ }^{100}$. Bulhões, por sua vez, quando indagado acerca do trabalho com os americanos da missão Abbink responde dizendo que era muito fácil trabalhar com eles porque: "Eles não trouxeram ideias novas, apenas reforçaram as ideias que nós já tínhamos” (BULHÕES, 1990, p. 58) e por "nós já tínhamos" entenda-se ele e o seu grupo monetarista, já que havia ampla desavença quanto aos propósitos da Missão, em diversos segmentos da vida política nacional e mesmo entre os especialistas em economia com afinidade com os EUA.

\subsection{Roberto Campos, a Comissão Mista Brasil-Estados Unidos e a origem do BNDE}

O pêndulo da política externa norte-americana oscila outra vez com o avanço da Guerra Fria. Os EUA passam a demandar novamente apoio político e suprimentos, agora para os esforços de contenção do avanço do comunismo. Em 1949, o presidente Harry Truman, no ponto IV do discurso inaugural de sua gestão, argumenta que os Estados Unidos deveriam embarcar em um programa para tornar os benefícios dos avanços científicos e do progresso industrial disponíveis para os países subdesenvolvidos. Ele pondera que os recursos materiais que poderiam oferecer eram limitados, mas os conhecimentos tecnológicos, em constante crescimento, são inexauríveis e poderiam ser oferecidos aos países livres e amantes da paz para ajudá-los a concretizar suas aspirações. Diz que esperava poder contar com a cooperação de outras nações para juntos oferecerem capital para os investimentos nas áreas não desenvolvidas, com o objetivo de aumentar a prosperidade e a segurança geral. Finalmente sustenta que "o velho imperialismo - exploração para benefício estrangeiro - não teria lugar em nossos planos.

\footnotetext{
${ }^{100}$ Carta de John Abbink para o Secretário de Estado dos EUA. Document 347 - Foreign Relations of the United States, 1949, The United Nations; The Western Hemisphere: Volume II - Historical Documents. Disponível em: https://history.state.gov/historicaldocuments/frus1949v02/d347. Consultado em 09/01/2016.
} 
O que buscamos é um programa de desenvolvimento baseado no conceito de justiça democrática"101.

O ponto IV, lançado face ao avanço do comunismo, inaugura um segundo momento de maior disposição dos EUA a colaborar com os países subdesenvolvidos. Em 5 de junho de 1950, logo antes da eclosão da Guerra da Coréia, foi promulgado o Act of International Development ${ }^{102}$ (AID) que dava continuidade à iniciativa de cooperação anunciada no ponto IV. Dentre outras coisas, o AID viabiliza a criação de comissões econômicas bilaterais para organizar projetos de ajuda econômica e prover assistência técnica aos quadros de Estado dos países subdesenvolvidos. Em seguida o Itamaraty negocia com os Estados Unidos a criação de uma comissão mista para organizar a cooperação econômica dos dois países (LEOPOLDI, 1992, p. 82; TAVARES, 2010a, pp. 16-17).

A Comissão Mista Brasil-Estados Unidos, que se instalou no Brasil em 19 de julho de 1951, era chefiada, do lado americano, por Merwin L. Bohan ${ }^{103}$ (item 1.3), que veio ao Brasil acompanhado de peritos nas áreas de transporte ferroviário, marítimo, fluvial, energia elétrica, metalurgia, construção naval, agricultura e indústria básica (CAMPOS, 1994, p. 160). Do lado brasileiro, a comissão foi liderada por: Ary Frederico Torres, Valentim Bouças, Glycon de Paiva Teixeira, Lucas Lopes e Roberto Campos.

Ary Frederico Torres (1900-1973) era natural de Porto Alegre e filho de Cristiano Torres, um grande comerciante exportador de fumo de folha. Na infância passou um ano estudando na Suíça e de volta ao Brasil iniciou os estudos secundários no colégio público Júlio de Castilhos em Porto Alegre. Em 1914 transferiu-se para São Paulo onde estudou no colégio Anglo-Brasileiro. Jovem, ingressou na Escola Politécnica de São Paulo (POLI), onde obteve o melhor desempenho de sua turma, recebendo em 1925 bolsa para passar um ano na Europa. Ele viajou pela França, Alemanha, Áustria, Itália, Bélgica e Suíça com o objetivo de cursar uma especialização e visitar e trabalhar em laboratórios de pesquisas

\footnotetext{
101 Ver: http://www.trumanlibrary.org/whistlestop/50yr_archive/inagural20jan1949.htm Consultado em: 09/01/2016.

${ }^{102}$ http://trumanlibrary.org/publicpapers/index.php?pid=781\&st=\&st1 e

https://history.state.gov/historicaldocuments/frus1950v01/d304. Consultados em 3/11/2015.

103 Ver entrevista com Merwin Bohan em https:/www.trumanlibrary.org/oralhist/bohanm.htm. Consultada em 3/11/2105. Nos itens 50 a 52, ele conta a história da sua vinda ao Brasil e corrobora a versão de Lucas Lopes, segundo a qual: "A Comissão Mista não chegou a ser muito formalizada do lado americano [...] Como o representante americano inical morreu na viagem de navio para o Brasil, eles tiveram que improvisar um segundo representante, e designaram o embaixador Merwin Bohan, que não estava preparado [...] eles ficaram durante algum tempo desorganizados na formação da equipe. Recorreram à contratação individual de pessoas ligadas tanto a firmas privadas como ao próprio governo americano" (LOPES, 1991, p. 118).
} 
técnicas de universidades mais avançadas eem desenvolvimento tecnológico. Em 1927 volta à Europa com a missão de coletar o equipamento necessário para aparelhar o Gabinete de Resistência de Materiais da POLI, do qual tornou-se diretor. Em 1928, Torres monta o Laboratório de Ensaios de Materiais que, em abril de 1934, passa a ser uma autarquia com autonomia administrativa em relação à Escola Politécnica, o Instituto de Pesquisas Tecnológicas (IPT). Torres é escolhido seu primeiro diretor, algum tempo depois torna-se também professor da POLI. Em paralelo às suas atividades acadêmicas e de pesquisa, Ary Torres assumiu os negócios de exportação do pai, ajudou a trazer a companhia norte-americana Tubize Chatillon Co. Hopewell da área de nitroquímica para o Brasil e foi presidente da Associação Brasileira de Cimento Portland. Foi também secretário de Viação em Obras públicas em São Paulo e participou de diversas comissões durante o governo Vargas: Comissão Executiva do Plano Siderúrgico Nacional, Comissão Técnica de Estudos de Matérias-Primas, Comissão de Defesa da Economia Nacional, tendo sido assistente responsável pelo setor da produção industrial da Coordenação da Mobilização Econômica e vice-presidente da Companhia Siderúrgica Nacional (CSN), dentre outros (DHBB, verbete Ary Torres; VARGAS, 1979, pp. 337-339) ${ }^{104}$.

Valentim Bouças (1981-1964) nasceu em Santos, filho de um empregado da Companhia Docas de Santos. Diplomou-se na recém-criada Academia de Comércio José Bonifácio de Santos e iniciou sua vida como office boy da companhia onde seu pai trabalhava. Depois de ter sido vendedor e representante comercial de algumas firmas estrangeiras que operavam em sua cidade, em 1917 passou a ser representante no Brasil da Computing Tabulating Recording Company, depois chamada de International Business Machines (IBM). Em 1924 consegue autorização para instalar uma subsidiária brasileira da IBM, que alugava as máquinas de contagem e processamento de dados Hollerith, especialmente para o setor público. Através dos serviços prestados por sua empresa ao Estado conheceu o Ministro Oswaldo Aranha que o convidou, em 1931, para integrar-se à equipe encarregada da gestão econômica. Bouças passa, então, a participar de comissões econômicas e negociações internacionais, tornado-se um dos conselheiros econômicos pessoais de Getúlio Vargas. Bouças também escrevia artigos econômicos

104 Ver: http://www.ipt.br/institucional/campanhas/26-personalidades_ipt_ary torres.htm, consultado em $03 / 11 / 2015$. 
para periódicos e foi o fundador da revista O Observador Econômico e Financeiro ${ }^{105}$ (DHBB, verbete Valentim Bouças; ESPINA, 1998, pp. 45-47).

Glycon de Paiva Teixeira (1902-1993) era mineiro de Uberaba, filho de uma professora primária e de um engenheiro agrônomo formado no Instituto Zootécnico de Uberaba, que faleceu quando ele tinha apenas um ano. Glycon estudou no Ginásio Marista Diocesano de sua cidade, instituição católica, fundada no início do século XX, que adquirira grande prestígio. Depois de diplomar-se em engenharia na Escola de Minas de Ouro Preto, tornou-se geólogo do Departamento Nacional de Produção Mineral (DNPM), tendo chefiado o serviço de produção mineral da mobilização econômica para a Segunda Guerra Mundial. Tomou parte em comissões nacionais voltadas para as áreas de exploração de recursos minerais e foi enviado como delegado brasileiro para diversas conferências internacionais (DHBB, verbete Glycon de Paiva; RICIOPPO, 2007, p. 225).

Tal qual Glycon, Torres e Bouças, Lucas Lopes (item 2.3) e Roberto Campos participaram, de alguma maneira, do esforço brasileiro na Segunda Guerra Mundial. Os três primeiros fizeram parte da Comissão de Mobilização Econômica, que funcionou de setembro de 1942 a dezembro de 1945, o quarto participou da mobilização mineira e o diplomata Roberto Campos havia sido enviado para Washington para reforçar o serviço da embaixada brasileira na área econômica intensificado pelas múltiplas solicitações relacionadas à guerra.

Roberto Campos (1917-2001) já foi mencionado em três episódios: no encontro que Furtado relata ter tido com ele na conferência da CEPAL no México (item 1.4), na posição de diretor do IBRE e em sua passagem por Bretton Woods (item 2.1), momento em que conheceu Bulhões e Gudin - aquele que diz ser talvez sua maior influência profissional (CAMPOS, 1996, p. 37). A trajetória familiar de Campos é bastante díspar das de Bulhões e Gudin. Ele não era um carioca nascido em berço de ouro e educado no mais alto cosmopolitismo. Campos define-se como um "menino do Pantanal, que se tornou teólogo no claustro, diplomata na guerra e na paz, economista presente à criação

\footnotetext{
${ }^{105}$ Revista mensal publicada entre 1936 e 1962, “o Observador atuou principalmente como órgão de manifestação de demandas e posições representadas através de um núcleo de técnicos de crescente destaque na esfera do planejamento. Integrado pelo próprio Valentim Bouças e por Octavio Gouvêa de Bulhões, Ignácio Tosta, Ary Frederico Torres, Rômulo de Almeida e Edmundo de Macedo Soares, esse núcleo seria responsável pela redação dos textos mais afinados ao projeto editorial da revista, cujo objeto primordial era o debate dos temas econômicos" (CORRÊA, 2011a, p. 7).
} 
da arquitetura econômica do pós-guerra, passando depois a tecnocrata, administrador e político" (CAMPOS, 1994, p. 20).

Nascido em Cuiabá, era filho de Valdomiro de Oliveira Campos, um professor paulista que foi para Mato Grosso em missão de ajuda de São Paulo à reforma do ensino no Oeste tornando-se diretor de um grupo escolar. Ali casou-se com Honorina, nascida em São Luiz de Cáceres e filha de um escriturário de uma fazenda da região que, ao fim da vida, havia conseguido juntar algum gado e terra. Eles voltaram para São Paulo pouco depois de seu nascimento, estabelecendo-se no Oeste Paulista onde Valdomiro deveria assumir outro grupo escolar. Sua morte precoce deixa Honorina sem herança e com dois filhos para criar. Ela retorna ao Mato Grosso e por algum tempo vivem em Nhecolândia, como os "primos pobres" na fazenda de uma irmã de sua mãe que era casada com um fazendeiro, membro de uma família de grandes proprietários de terra. Incomodada com a dependência imposta pela posição de agregada, Honorina muda para São Paulo onde trabalha como governanta e estuda corte e costura, terminando por abrir sua própria academia de corte e costura em Guaxupé, Minas Gerais (CAMPOS, 1994, pp. 121-125, 135).

Roberto Campos, depois de ter cursado o primário em um colégio de padres italianos em Corumbá, decide entrar no seminário em Guaxupé. Conta que acreditava ter vocação religiosa e acrescenta: o ensino era gratuito. Passa seis anos no internato estudando humanidades e filosofia. Ali aprende diversos idiomas latinos, mas não tem contato com o inglês. Em 1934 vai estudar teologia no seminário de Belo Horizonte, onde toma lições de direito canônico. Campos terminou o seminário cedo demais para fazer os votos de obediência e de castidade. Ele começou a dar aulas em ginásios de padres em Batatais mas, incerto sobre sua vocação mística, decide transferir-se para o Rio de Janeiro, em 1938, onde passa a viver em um quarto partilhado em uma pensão e dar aula para receber uns trocados (CAMPOS, 1994, pp. 135-142, 25, 28).

Sua situação no Rio de Janeiro era muito precária. Em busca de um emprego mais estável do que aulas eventuais, inscreveu-se no concurso organizado pelo DASP para o Itamaraty. Nesse período dobrou seus afazeres: lecionava durante o dia e estudava à noite para o concurso. O seminário dera a ele um bom treinamento em humanidades e direito canônico, dominava bem o francês e o italiano e tinha treinamento em latim e grego, mas não falava nem uma palavra de inglês, idioma obrigatório no exame para a carreira 
diplomática. Campos explica que decidiu então estudar inglês por conta própria com auxílio de gramáticas e dicionários. Acreditava que seu grande problema seria a prova oral e conta que, para treinar o ouvido, "metia-me horas no cinema, de olhos fechados, resistindo à tentação de ler as legendas" (CAMPOS, 1994, p. 29). Cinema que muito despertava seu interesse, como demonstram os capítulos de suas memórias dedicados à estadia em Los Angeles (CAMPOS, 1994, pp. 213-221). Campos diz ter continuado com péssima pronúncia por alguns anos e revela que, durante sua primeira estadia em Washington, tinha imensa dificuldade com o inglês coloquial. Sua ascensão até esse momento deve-se à combinação da formação cultural - incluindo o domínio linguístico que a Igreja procurava oferecer aos seus futuros quadros com a possibilidade de ascensão social aberta pelo concurso público.

Ao explicar sua conversão para a economia, Campos conta que, após ser alocado duas vezes na divisão comercial, nos "secos e molhados" da diplomacia, primeiro no Brasil e depois no EUA - isto por não ter amigos e aparentados que o carregassem para posições mais nobres - "concluí ser inútil pelejar contra o destino. Decidi-me a estudar economia nos cursos noturnos da George Washington University". Assim, teria virado “economista não por vocação e sim por resignação” (CAMPOS, 1994, p. 48). Na George Washington ele obtém o Master of Arts, em 1947, com o texto “Algumas inferências sobre a propagação internacional dos ciclos". Trabalho que era fortemente influenciado por seu ídolo intelectual da época Joseph Schumpeter, estudioso dos ciclos econômicos, do empresariado e da inovação, que adota uma perspectiva institucional em suas análises. Campos relata que conheceu nessa época Gottfired Haberler, de quem se tornou amigo por intermédio de Eugênio Gudin (CAMPOS, 1994, p. 49). Transferido para a Organização das Nações Unidas (ONU), em Nova York, Campos passa a frequentar a University of Columbia, ao mesmo tempo que seu colega diplomata Miguel Osório de Almeida. Ele relata que lá teve aulas com Ragnar Nurske e que uma das personalidades mais interessantes em Colúmbia à época era o sociólogo e antropólogo da economia Karl Polanyi, que procurou fazer uma análise da economia social e historicamente enraizada. Nos sete anos que passou no exterior Campos, autodenominado "um tímido bugre de Mato Grosso", começou a tomar contato com a cultura cosmopolita da qual dispunham desde nascença seus predecessores Gudin e Bulhões. 
Segundo ele seus estudos de economia nos EUA fizeram que quase detivesse o monopólio dos assuntos econômicos dentro do Itamaraty - junto com Osório de Almeida, Octavio Dias Carneiro, João Batista Pinheiro e alguns poucos mais. A especialização era cada vez mais requisitada pela intensidade da diplomacia econômica no pós-guerra, uma das razões propulsoras da profissionalização dos economistas (CAMPOS, 1994, pp. 119, 53; CANABRAVA, 1984, p. 29). Depois de retornar ao Brasil, no final de 1949, e de passar um ano e alguns meses entre uma comissão de acordos comerciais e a Carteira de Exportação e Importação do Banco do Brasil (CEXIM), à época chefiada por Luiz Simões Lopes (item 1.3) e integrada também por José Garrido Torres e Casimiro Ribeiro da SUMOC, Campos foi convidado a participar da CMBEU.

Como tantos outros órgãos econômicos, a Comissão Mista começou suas atividades em salas emprestadas no edifício do Ministério da Fazenda. No princípio operavam em uma mesa de dois metros na sala do Valentim Bouças, depois o Ministro da Fazenda Horácio Lafer ${ }^{106}$, que era amigo próximo de Ary Torres, passou a ceder o salão nobre do ministério para as reuniões. A CMBEU não tinha recursos próprios. Seus diretores não eram remunerados e, como mantinham outros trabalhos em paralelo, não se encontravam com regularidade, reuindo-se apenas para tomar grandes decisões. $\mathrm{O}$ que a direção da Comissão fazia era receber os projetos que eram enviados pelos técnicos especialistas em cada setor e analisar os valores, a rentabilidade e o cronograma de gastos. Deveria julgar se os projetos estavam bem elaborados ou se novas pesquisas deveriam ser feitas e recomendar ou não aos ministros e embaixadores que concedessem o financiamento solicitado (LOPES, 1991, pp. 118-120).

Por dois anos a Comissão Mista trabalhou na elaboração de diagnósticos das condições econômicas brasileiras e no desenho de planos de investimento "conducentes a eliminar os obstáculos mais graves ao desenvolvimento econômico do Brasil”. Ela

\footnotetext{
${ }^{106}$ Horacio Lafer (1900-1965) nasceu na cidade de São Paulo e era descendente de imigrantes judeus da Lituânia. Seu pai havia fundado, com seus três primos de sobrenome Klabin, a oficina tipográfica e depois fábrica de papel Klabin Irmãos e Cia. Horácio estudou no colégio Anglo-Brasileiro e no Ginásio São Bento e depois ingressou na Faculdade de Filosofia São Bento e na Faculdade de Direito do Largo São Francisco. Formado, mudou-se para a Alemanha onde fez cursos de especialização em economia e finanças e estudou na Faculdade de Filosofia de Berlim. De volta ao Brasil, passou a trabalhar na indústria de seu pai e ajudou a formar a CIESP, da qual tornou-se diretor. Em 1928 Lafer assessorou o ministro das relações exteriores participando de conferências da Liga das Nações, sua primeira experiência junto à diplomacia, que se estenderá ao longo do primeiro governo Vargas. A partir de 1943, Lafer passou a integrar também o conselho técnico de economia e finanças do Ministério da Fazenda. Foi deputado, líder da maioria, presidente da comissão de financas da Câmara e relator do orçamento durante o governo Dutra, especializando-se na gestão econômica do Estado. Em 1951 Vargas designa-o para o Ministério da Fazenda, posto que ocupou até agosto de 1953 (DHBB, verbete Horácio Lafer).
} 
aprovou, no total, 41 projetos, especialmente nas áreas de transporte e energia elétrica. O investimento previsto para a implementação desses projetos era de aproximadamente US\$ 390 milhões, que deveriam ser emprestados pelo governo dos Estados Unidos e por instituições econômicas multilaterais ${ }^{107}$. Em contrapartida, o Brasil facilitaria o envio de matérias-primas estratégicas como manganês, urânio, bertilo, tântalo, colúmbio e areias monazíticas para os Estados Unidos, negociaria o estabelecimento de limite de preços para o café e cooperaria com as operações de combate ao comunismo (CAMPOS, 1994, p. 558; CMBEU, 2008, p. 285; D’ARAÚJO, 1992, p. 162; GONÇALVES, 2011, p. 50; SOLA, 1998, p. 95; VIANA, 1981, pp. 22-23).

Os trabalhos da Comissão previam a criação de um banco de desenvolvimento no Brasil para conceder crédito em montante equivalente àquele concedido pelos empréstimos estrangeiros. Ele deveria, ademais, gerir os recursos advindos das fontes internas e externas e responsabilizar-se pela implementação dos projetos aprovados pela Comissão (GOUVÊA, 1994, p. 116). O BNDE seria, pois, um "órgão de contrapartida, com características bancárias" e uma "instituição de análise de rentabilidade e viabilidade de projetos" (CAMPOS, 2009, pp. 43-44).

O Ministro Horácio Lafer responsabilizou-se pela tramitação do projeto de lei referente à criação da nova instituição financeira e pela aprovação de recursos para o financiamento dos projetos da Comissão. Havia um clima de otimismo no executivo e no legislativo quanto à cooperação financeira internacional, o que facilitou a criação do BNDE, em 20 junho de 1952, e a aprovação do Plano Lafer, que definia o montante de recursos que o Brasil investiria nos projetos de desenvolvimento e criava o Fundo de Reaparelhamento Econômico, destinado a captar, por meio de um adicional sobre o imposto de renda, os recursos da contrapartida brasileira aos empréstimos estrangeiros ${ }^{108}$ (CENTRO INTERNACIONAL CELSO FURTADO DE POLÍTICAS PARA O DESENVOLVIMENTO, 2008, pp. 10-11).

Criado o BNDE, o ministro Horácio Lafer preparou um plano do organograma da instituição que atribuía a escolha da direção do Banco à Presidência da República. Não

\footnotetext{
${ }^{107}$ Campos alega que as instituições multilaterais financiadoras insistiam em dizer que os projetos definidos pela CMBEU não seriam automaticamente aprovados por elas, devendo passar pela avaliação padrão e estar sujeitos, como de praxe, ao comportamento macroeconômico saudável (CAMPOS, 1994, p. 160).

108 Sobre as negociações que levaram à instituição do FRE, vide: MARTINS, 1976, pp. 383-386. A propósito das razões para a adoção do modelo de financiamento por adicional do imposto de renda ver CAMPOS, 1994, p. 191.
} 
obstante, Lafer permitiu-se encaminhar a Getúlio Vargas uma lista de suas sugestões para a composição da primeira diretoria do BNDE ${ }^{109}$. Encabeçada por Eugênio Gudin, a lista continha os nomes de três membros da CMBEU: Ary Torres, Roberto Campos e Glycon de Paiva. Vargas rejeita apenas a indicação de Gudin, notório crítico de seu primeiro governo, cuja orientação econômica liberal era tida como incoerente com o projeto econômico de industrialização intensiva e, provavelmente, com a própria instalação de um banco de desenvolvimento (BASTOS, 2004, pp. 10-11; LEOPOLDI, 1992, p. 85; SOLA, 1998, pp. 115-116).

Os técnicos da CMBEU incorporados ao BNDE com o apoio de Horácio Lafer formaram o grupo hegemônico no período de constituição do Banco. Eles faziam parte do segmento dos especialistas em economia que recebeu na literatura as seguintes denominações: desenvolvimentistas ${ }^{110}$ cosmopolitas ${ }^{111}$ (SOLA, 1998), técnicos internacionalistas (LEOPOLDI, 1992), desenvolvimentistas do setor público não nacionalistas (BIELSCHOWSKY, 2000a), popularmente conhecidos como "entreguistas" (TAVARES, 2009, p. 167). Essas designações procuram ressaltar um traço distintivo: a simpatia à cooperação internacional, que remonta à própria origem do grupo, posto que ele provém diretamente do esforço de cooperação bilateral da Comissão Mista. Ele contrastaria com o grupo dos desenvolvimentistas nacionalistas (SOLA, 1998) ou desenvolvimentistas do setor público nacionalistas (BIELSCHOWSKY, 2000a), que enfatizavam o papel do Estado e do capital nacional no processo de desenvolvimento, do qual faziam parte Celso Furtado e os membros da Assessoria Econômica apresentados na Abertura (itens 1.3 e 1.4).

A postura favorável à cooperação internacional dos cosmopolitas redunda em uma posição mais flexível no que concerne à participação de recursos e empresas estrangeiras no esforço de desenvolvimento nacional. Esses especialistas buscavam ressaltar as

\footnotetext{
${ }^{109}$ De 1952 a 1956 a diretoria do BNDE era composta por um presidente, um superintendente e dois diretores (DIAS, 1996, pp. 87-88).

$110 \mathrm{O}$ termo desenvolvimentistas foi cunhado pelos analistas, não sendo nativo do vocabulário dos economistas da geração de cinquenta. "Celso Furtado, Ignácio Rangel e até mesmo o Roberto Campos da primeira metade dos anos 1950 não se diziam desenvolvimentistas, mas sim, nacionalistas" (BARBOSA e KOURY, 2012, p. 1076).

${ }^{111} \mathrm{O}$ termo cosmopolita, tal qual empregado por Lourdes Sola, refere-se a um grupo de especialistas em economia que mantinha laços fortes com os Estados Unidos, visível na rede do Primeiro Movimento (item 2.6). Os desenvolvimentistas nacionalistas também eram cosmopolitas, mas seus vínculos principais dirigiam-se a outras regiões do globo, notavelmente a América Latina e a Europa. Não obstante, há um sentido no uso do termo cosmopolita para caracterizar o primeiro grupo, dado por sua defesa do não fechamento aos fluxos econômicos internacionais, nesse sentido preconizando uma economia cosmopolita em contraponto a um arranjo econômico nacionalista.
} 
convergências dos interesses brasileiros e norte-americanos e argumentavam ser a cooperação internacional uma "condição sine qua non - juntamente com uma política agressiva de exportações — para superar, em condições de estabilidade econômica, as restrições cambiais ao desenvolvimento do país" (SOLA, 1998, p. 141). A inserção de três membros da Comissão Mista na primeira diretoria do Banco, além de favorecer a aproximação com capital internacional, ajudou a transferir para o BNDE os conhecimentos técnicos e os projetos desenhados pela Comissão.

A política externa norte-americana para o Brasil oscila novamente em 1953. A Guerra da Coréia terminara e os republicanos, que conquistaram a presidência dos EUA com Dwight Eisenhower, não tinham a mesma boa vontade diplomática para com a América Latina. Eram declaradamente privatistas e decidem acabar com a Comissão Mista, um projeto da gestão anterior que não consideravam prioritário. Para tanto, sugerem ser a decisão uma retaliação às medidas, "de cunho nacionalista" que Vargas adotou para conter a crise cambial: desvalorização da moeda, mudanças nas taxas de câmbio, restrições à repatriação dos lucros de capital estrangeiro e instituição do monopólio do petróleo ${ }^{112}$. Desfrutando novamente de uma situação geopolítica estável, os EUA não apenas deixam de socorrer o Brasil no que concerne ao problema cambial, como, ao contrário, optam por reforçar a antiga tese de que o Brasil deveria atrair o IED e não receber aporte de capital governamental. Devido à suspenção das linhas de crédito previstas no acordo de cooperação e à redução dos montantes já acordados para o período, pouco daquilo que a Comissão planejou chegou a ser implementado no prazo previsto (BASTOS, 2012, p. 19; MALAN et al., 1980, pp. 32-35; MARTINS, 1976, pp. 389-390; SOLA, 1998, pp. 79, 112-113; TAVARES, 2010a, p. 20; VIANA, 1981, p. 23).

Apesar de não ter concretizado parte significativa do que almejara, a CMBEU deixou legados que teriam efeitos duradouros: ela aportou ferramentas de planejamento e análise econômica que o Brasil desconhecia, contribuiu para a formação de técnicos

\footnotetext{
112 Existe uma controvérsia para definir se foi a virada nacionalista de Vargas ou a entrada de Eisenhower no governo o fator definitivo para o encerramento das atividades da CMBEU. A entrevista de Merwin Bohan aponta para a segunda hipótese quando diz: "I think the Joint Commission was completely a project of the Truman administration. It was through during the early days of the Eisenhower administration, because of the dislike of the new administration for anything that smacked of planning, particularly by Mr. [George] Humphrey the Secretary of the Treasury". (Itens 52 e 53 da entrevista com Merwin Bohan, 1974. Disponível em https://www.trumanlibrary.org/oralhist/bohanm.htm. Consultada em 3/11/2105,). Sérgio Besserman Vianna também rejeita a interpretação segundo a qual a finalização do convênio resultaria da postura nacionalista de Vargas, argumentando serem as causas principais da inflexão: a mudança do presidente dos EUA; o conflito de competências e interesses que opunha o Banco Mundial ao Eximbank; e a tentativa do Banco Mundial (BM) de exercer tutela sobre os países que solicitassem crédito (VIANNA, 1987, pp. 87-91).
} 
especializados e os diagnósticos que elaborou sobre a economia brasileira puderam ser aproveitados no Plano de Metas de Juscelino Kubitscheck. Finalmente, dela resultou a criação do Banco Nacional de Desenvolvimento Econômico que não foi desmontado com a Comissão pois havia interesses nacionais capazes de defender a necessidade de que se desse seguimento à política de investimentos operada pelo Banco, independentemente da cooperação norte-americana (GONÇALVES, 2011, p. 50; LOPES, 2009, pp. 11-12).

O BNDE assumiu então a tarefa de executar os projetos legados pela Comissão, usando os recursos do FRE. Aos poucos passou a conceder crédito de longo prazo para outros projetos e segmentos seguindo as diretrizes políticas nacionais vigentes. Para tanto, empregava as técnicas de análise de custos e benefícios e de cálculo de rentabilidade que herdara da CMBEU. Apoiava-se também nas noções de pontos de estrangulamento e de pontos de germinação para definir quais áreas deveriam ser alvo prioritário de investimentos. Os estrangulamentos seriam as demandas insatisfeitas, principalmente nas áreas de infraestrutura e bens de capital, que barravam o crescimento econômico. Os pontos de germinação, por sua vez, seriam investimentos capazes de produzir externalidades positivas em cadeia, colaborando para a propulsão da economia (CABRIA, 2012, pp. 138, 154; CAMPOS, 1994, pp. 163, 316-317; LAFER, 1975, p. 35).

No início, o BNDE funcionava nas salas do Ministério da Fazenda utilizadas pela CMBEU e não tinha um grupo de funcionários próprio. Ele só contava com os "responsáveis por alguns cargos de chefia, auxiliados por servidores da CMBEU ou prestadores de serviços". Em agosto de 1953, o Banco recrutou, sem ter feito um concurso, 6 advogados, 10 economistas, 12 engenheiros, 31 assistentes técnicos e 91 auxiliares administrativos. Em setembro de 1953, mudou-se com os seus primeiros 150 funcionários para um edifício de sete andares na rua Sete de Setembro, número 48, no centro do Rio de Janeiro (BNDES, 2002, p. 31).

Nesse mesmo ano o BNDE faz acordo com a CEPAL por meio do qual somaria aos conhecimentos adquiridos junto à CMBEU um segundo conjunto de saberes e técnicas de planejamento e financiamento do desenvolvimento. Em seu relatório administrativo de 1952, publicado no início de 1953, o Banco explica:

Os projetos elaborados pela Comissão Mista Brasil-Estados Unidos inegavelmente encerram valiosa documentação sobre diferentes aspectos da vida econômica nacional. Esses estudos entretanto se ativeram a projetos individuais e concretos, compreendidos apenas naqueles setores que podem ser considerados obviamente prioritários na estrutura econômica brasileira. Desse ponto de partida, deve-se agora marchar para pesquisas que permitam ao governo 
enquadrar, numa planificação geral, medidas destinadas a apressar o ritmo do desenvolvimento econômico do país. [...]. O levantamento em causa terá seu êxito condicionado, em apreciável parcela, à seleção e à formação de uma equipe ética e tecnicamente qualificada. É provável que se consiga recrutar economistas e estatísticos dotados de base suficiente para iniciar uma pesquisa de tal magnitude. A inexperiência, entretanto, dos servidores assim selecionados nessa modalidade de trabalho talvez viesse a exigir um período de afeiçoamento ao problema e de realização de tentativas, inconveniente ao desempenho do plano que se tem em mira pôr em execução. $O$ problema equacionado no duplo aspecto da imprescindibilidade da pesquisa e da preparação de pessoal para a sua realização vinha preocupando a direção do Banco, quando surgiu oportunidade de encaminhar a sua solução, em bases bastante satisfatórias. Discutido o problema com a Comissão Econômica para a Amércia Latina (CEPAL), o citado órgão das Nações Unidas mostrou-se interessado na execução do projetado levantamento e assegurou a possibilidade da sua cooperação para a consecução do objetivo. A CEPAL está realizando estudos sobre modelos de desenvolvimento econômico aplicáveis à América Latina [...]. A colaboração da CEPAL se afigurou, por isso mesmo, muito útil, o que levou o Conselho de administração do Banco do Desenvolvimento a examinar o assunto e a autorizar um acordo para a concretização dos entendimentos oficiosamente estabelecidos. Firmou-se, posteriormente, um convênio, no texto do qual se assentaram as seguintes providências:

a) A criação, na sede do Banco, no Rio de Janeiro, de um Grupo Misto de Estudos, constituído de servidores do Banco e da CEPAL, especialmente destinado a estudar a aplicação, na economia brasileira, dos métodos de planejamento estrutural já adotados pela referida organização internacional; b) a colocação, pela CEPAL, à disposição do Banco, pelo prazo de um ano ou o julgado necessário, de elementos qualificados para cooperar com o Grupo Misto de Estudos; c) a designação, pelo Banco, de economistas do seu quadro técnico para operar com o pessoal da CEPAL, colocando-se também à disposição do Grupo Misto de Estudos os elementos de pesquisas e os recursos de expediente e secretaria que forem necessários; d) a aprovação do programa de trabalho do Grupo de Estudos, em bases provisórias e compreendendo a coleta e análise de dados com o objetivo de avaliar o crescimento econômico do Brasil; a determinação da natureza do problema de desenvolvimento econômico brasileiro; o delineamento de um esquema básico de dados que permitam traçar perfis dos programas de desenvolvimento econômico para o Brasil; e) elaboração de relatório conclusivo expositivo; sob a responsabilidade conjunta das partes convencionantes.

Complementarmente previu o acordo o estreitamento das relações entre as duas entidades, mediante troca de dados e informações de intercâmbio de pessoal e aplicação conjunta de recursos de pesquisa. O início dos trabalhos objeto do acordo deverá dar-se nos primeiros dias do mês de maio de 1953, isto é, após o encerramento do Quinto período de sessões da CEPAL. Constituirá, sem dúvida, o projetado levantamento, tarefa de grande envergadura e de promissores resultados (BNDE, 1953, pp. 30-32).

A exposição permite verificar que o BNDE, em seus anos iniciais, flertava com a ideia de implementar no Brasil uma planificação geral, no modelo preconizado pela CEPAL, razão pela qual busca estabelecer um acordo com a agência internacional. Não havia, até então, uma desconfiança por parte dos desenvolvimentistas não nacionalistas em relação à CEPAL e à ideia de planejamento integral que, ao longo dos anos 1950, passou a ser mal vista por aqueles que se alinhavam aos EUA por serem associadas à 
economia soviética. Com o tempo, a própria CEPAL passaria a utilizar a "palavra " programação' para não falar de planejamento, que era muito perigoso nos anos da 'caça às bruxas' anticomunista nos EUA" (SUNKEL, 1998, p. 184).

No início dos anos 1950, as posições favoráveis à cooperação externa não eram tidas como incompatíveis com a adoção de uma política de desenvolvimento ativamente planejada e dirigida pelo Estado, sendo plenamente aceito que os recursos captados junto aos organismos internacionais fossem geridos pelo Estado. Em texto redigido em 1952, Roberto Campos, talvez o mais conhecido dos cosmopolitas, comenta que "a intenção de planejar passou a ser um datum político e sociológico, não restando aos economistas outro recurso que aplicar o seu instrumental analítico ao desenvolvimento de uma técnica planificadora" (CAMPOS, 1963, p. 13). Era possível discutir em que escala seria feito o planejamento e em que medida o Estado deveria participar diretamente do esforço de desenvolvimento, mas planejar ou não planejar não era algo que estivesse em questão naquele momento. É em busca de expertise em planejamento que o BNDE na figura de Campos $^{113}$ procurará aproximar-se da CEPAL e de Celso Furtado (KLÜGER, 2014, p. 67).

Seguem as histórias da criação do Grupo Misto CEPAL-BNDE como contadas por Campos e por Furtado:

Visitei Santiago do Chile, em janeiro de 1953, como diretor do BNDE, para solicitar a assistência técnica da CEPAL para o planejamento brasileiro, indicando expressamente a Raúl Prebisch o desejo de contarmos com Celso Furtado como chefe do grupo da CEPAL. A metodologia nos foi exposta na $5^{a}$ Sessão da CEPAL, no Rio de Janeiro, em 1953, quando Prebisch acordou em enviar ao Brasil Celso Furtado e Regino Boti (economista cubano de grande criatividade que depois ocuparia posição de relevo no início do governo Fidel Castro), para formarem a Seção cepalina do grupo misto CEPAL/BNDE (CAMPOS, 1994, p. 164).

\footnotetext{
113 “É possível argumentar que Roberto Campos teve suas convicções econômicas consideravelmente alteradas ao longo de sua trajetória de vida. Aos 80 anos Campos logra publicar um livro de memórias, A lanterna na popa, no qual narra em retrospecto sua carreira, comentando quais teriam sido suas orientações em momentos decisivos. É interessante comparar as opiniões de Campos nesse momento e aquelas que formulara nos textos da década de 1950, publicados no livro Economia, planejamento e nacionalismo. Se o Campos da década de 1950 defende fortemente o planejamento, reconhece a eficácia do planejamento sob o socialismo, defende a originalidade da Cepal e apenas critica a negligência da Cepal em relação à inflação e à agricultura, o Campos dos anos 1990 diz ter tido apenas uma curiosidade em relação à Cepal e afirma que sua intuição de que o planejamento não funcionaria estava certa. 'Eu estava certo em minha intuição. A metodologia da Cepal nunca foi aplicada com êxito na América Latina. Os experimentos chilenos (sob Salvador Allende) e peruano (sob o general Velasco Alvarado), que mais se aproximaram do modelo cepalino, foram rotundos fracassos. $\mathrm{O}$ planejamento integral era ilusório, sem o autoritarismo socialista. E o autoritarismo socialista provou-se, no correr dos anos, um misto de tirania política e ineficiência econômica' (CAMPOS, 1994, p. 165). Assim sendo é essencial situar as opiniões de Campos no tempo para evitar imputações anacrônicas" (KLÜGER, 2014, p. 67). É o que faz Celso Furtado em A fantasia organizada onde afirma que Campos era um homem totalmente estranho às preocupações que levaram à criação do BNDE (FURTADO, 2014, p. 155).
} 
Quando se criou o BNDE, Roberto Campos foi a Santiago do Chile, vindo de Nova York, me convidar para participar da primeira diretoria do Banco. (...) eu não disse sim nem não, disse apenas: "vamos conversar com Prebisch", que era secretário executivo da CEPAL, muito amigo meu e conhecia também o Roberto Campos. Prebisch saiu-se com uma solução salomônica: "aqui temos apenas um economista brasileiro, que é o Celso, e não podemos nos privar dele nessa fase, mas podemos trabalhar conjuntamente, CEPAL e BNDE, pois temos o mesmo objetivo, que é o desenvolvimento do Brasil e da América Latina; por que então não fazemos um programa conjunto?" E daí nasceu a ideia do Grupo Misto BNDE-CEPAL. No quadro desse grupo misto, disse Prebisch, eu poderia ir para o Brasil, com uma missão de um ano renovável, para dirigir o grupo a ser constituído dentro do próprio BNDE (FURTADO, 2009, p. 103).

Esse convênio foi oficializado por Getúlio Vargas na quinta Conferência da CEPAL, realizada em abril de 1953, no hotel Quitandinha, em Petrópolis. Faziam parte da delegação brasileira os já citados Eugênio Gudin, Valentim Bouças, Roberto Campos, Rômulo de Almeida, Cleantho Paiva Leite, Octavio Gouvêa de Bulhões e Miguel Osório de Almeida. No evento inaugural da Conferência, Vargas elogiou o trabalho da CEPAL dizendo que ela tinha muito a oferecer aos governos latino-americanos. Prebisch, por sua vez, procurou incitar os latino-americanos a pensar a industrialização em bases regionais, exortando os presentes a incrementar comércio entre os países subdesenvolvidos. As cinzas da polêmica que Jacob Viner criara quando estivera no Brasil ainda estavam ardentes quando a conferência de Petrópolis ocorreu e os meses que se seguiram a ela foram repletos de debates suscitados pelos artigos de Gudin e Bulhões, criticando a CEPAL, e pelas réplicas de Furtado e Prebisch aos ataques por eles deferidos ${ }^{114}$ (GONÇALVES, 2011, p. 67).

Malgrado o agravamento das controvérsias com os economistas do grupo ligado a Eugênio Gudin, a influência da CEPAL no Brasil intensificar-se-ia substancialmente com o estabelecimento do Grupo Misto CEPAL-BNDE, ainda no primeiro semestre de 1953. Furtado veio ao Brasil com seu companheiro de divisão vermelha da CEPAL, o

\footnotetext{
114 Gudin publica 5 artigos no Correio da Manhã intitulados A mística do planejamento, em 29 de maio e 2, 6, 9 e 11 de junho de 1953, exalando suas desavenças habituais em relação à CEPAL, às teorias "autóctones" e à intervenção econômica (item 4.1). Ao que Prebisch responde em seu artigo A mística do equilíbrio espontâneo da economia dizendo que: "Naturalmente este esforço de integração teórica requererá mais de uma modificação de algumas das teorias vigentes e mesmo a rejeição de certas entre elas. Mas este fato não poderia escandalizar o Dr. Gudin num campo como o da teoria econômica, que ainda se encontra em incipiente elaboração. Sinto-me inclinado a pensar, por outro lado, que a investigação sistemática dos fenômenos da periferia poderia contribuir vantajosamente a introduzir elementos dinâmicos nas teorias vigentes, sem os quais seguiriam elas um tanto afastadas da realidade" (PREBISCH, 1953). A controvérsia Prebisch-Gudin pode ser lida como uma edição avançada no plano teórico da controvérsia que Gudin tivera com Roberto Simonsen dez anos antes, que será retomada adiante (item 4.1 ).
} 
economista cubano Regino Boti. Os dois eram auxiliados pelo Setor de Renda e pelo Serviço de Estatística e Documentação do Banco que prestavam assistência e forneciam dados para eles pudessem elaborar um diagnóstico acerca da situação econômica que permitisse embasar as projeções de longo prazo necessárias para fazer um planejamento amplo e sistemático para o Brasil. A equipe do Grupo Misto instalou-se no Setor de Renda Nacional do Departamento Econômico do BNDE que era dirigido por Américo Barbosa de Oliveira, com quem Furtado já havia trabalhado nos tempos de Conjuntura Econômica e eram assessorados diretamente pelo funcionário José Pelúcio Ferreira ${ }^{115}$ (BNDE, 1954; FURTADO, 2014, p. 156).

Américo e Pelúcio fariam parte do grupo que Furtado recrutou para formar o Clube dos Economistas, que se instalou no edifício do BNDE - reforçando a tese da concentração espacial da área econômica (Mapa I). O acirramento das controvérsias entre o grupo da CEPAL e o grupo de Gudin, visível no episódio da conferência de Petrópolis, levou Furtado a criar em 1954 uma associação própria, o Clube dos Economistas e uma revista alternativa à RBE, a Revista Econômica. Nessa iniciativa reuniram-se a ele os organizadores da revista Conjuntura Social que haviam sido banidos por Gudin: Accioly Borges, Jesus Soares Pereira e Américo Barbosa de Oliveira. O grupo não se restringiu, entretanto, aos seus colegas desenvolvimentistas nacionalistas. Diversos dos jovens sumoqueanos fizeram parte em algum momento do Clube, interessados também na consolidação de uma posição social para a carreira, e mesmo nomes que viriam a ser importantes no período ditatorial ali publicariam como Mario Henrique Simonsen e Ernane Galvêas. Ainda que aberto a outros segmentos do espaço dos economistas, predominavam no Clube e na Revista ideias e textos associados à orientação da CEPAL e do grupo nacionalista que ali era hegemônico. A revista publicou textos de Prebisch, Noyola, Ahumada, Sunkel, Aníbal Pinto e Boti, da CEPAL, além de textos de teóricos de outros países com posições próximas como Gunnar Myrdal, Joseph Grunwald, Maurice Dobb, Oscar Lange e Nicholas Kaldor, que eram inspiração para a própria produção da CEPAL (ANDRADA et al., 2015, pp. 3-6, 11, 17).

Quando o Clube e a Revista estavam instalando-se Furtado retorna à CEPAL, o que enfraqueceu a iniciativa. Em maio de 1955, ele e sua equipe concluem sua tarefa no Brasil, entregando ao Banco o volume "Esboço de um programa preliminar de

\footnotetext{
${ }^{115}$ Pelúcio Ferreira será alvo de considerações adiante (itens 4.5 e 5.5).
} 
desenvolvimento da economia brasileira (período 1955-62)”. Furtado partiu para o México acompanhado de Francisco Noyola e Osvaldo Sunkel para lá realizar diagnóstico semelhante (item 1.5). Os estudos de Celso sobre o Brasil não foram imediatamente aproveitados como guias para o planejamento econômico. O conturbado final do governo Vargas e o interlúdio monetarista, que vai do suicídio de Vargas em agosto de 1954 até a posse de Juscelino Kubitschek em fim de janeiro de 1956, fizeram com que o texto e as propostas de matriz cepalinas gestadas no Grupo Misto ficassem no ocaso até o surgimento do Plano de Metas de JK.

\subsection{Lucas Lopes e o Plano de Metas}

Nos anos finais de seu segundo governo, com grande instabilidade política e econômica, o presidente Vargas fez, em junho/julho de 1953, uma reforma ministerial que afastou os industriais paulistas Horácio Lafer e Ricardo Jafet, respectivamente do Ministério da Fazenda e do Banco do Brasil, com o objetivo de arrefecer os ânimos das oposições (D’ARAÚJO, 1992; LOPES, 1991, p. 210). No período que se segue ao seu suicídio houve uma radicalização da reversão da política econômica intervencionista e pró-industrial, até então liderada pela Assessoria Vargas. Café Filho, tão logo empossado, designa Eugênio Gudin para o Ministério da Fazenda. Como ministro, Gudin procurou conter a expansão dos meios de pagamento e restaurar o equilíbrio orcamentário. Ele desejava liberar inteiramente o mercado cambial, reduzir os subsídios e dominar a inflação ${ }^{116}$ (BULHÕES, 1979, pp. 67-70).

$\mathrm{Na}$ reforma ministerial feita por Vargas, Ary Torres havia sido substituído na presidência do BNDE por Válder Lima Sarmanho (1901-1987), irmão da primeira dama Darcy Vargas, um homem da inteira confiança do presidente. Sarmanho também era gaúcho, nascido em São-Borja e filho de grande estancieiro. Ele estudou engenharia na

\footnotetext{
116 Pode-se argumentar que a exceção em direção contrária à liberalização econômica anti-industrial era a instrução 113 da SUMOC. Promulgada em janeiro de 1955 por Eugênio Gudin, a instrução 113 favorecia a entrada em massa de capitais externos na forma de máquinas e equipamentos ao autorizar licenças de importação sem cobertura cambial para bens que antes eram de difícil importação dada a escassez de divisas externas. Os investimentos privados externos atraídos no governo de $\mathrm{JK}$, especialmente aqueles vinculados à indústria automobilística, fizeram largo uso dessa instrução. Grandes campanhas nacionalistas foram feitas contra a instrução 113, considerada uma ameaça ao desenvolvimento por aqueles que viam com maus olhos o domínio da produção brasileira por estrangeiros (BENEVIDES, 1976, p. 238; CAMPOS, 1994, p. 297; LOPES, 1991, p. 211).
} 
Escola Politécnica do Rio de Janeiro e trabalhou com Vargas desde o início de seu primeiro governo em 1930, tendo sido oficial-de-gabinete, inspetor do Ministério da Fazenda, consultor informal do Presidente e representante diplomático, entre os dois governos de Vargas (DHBB, verbete Válder Sarmanho). O grupo de homens ligados ao Presidente, mais próximo do polo nacionalista ${ }^{117}$, passou a ocupar, naquela ocasião, todas as posições de direção do Banco, já que além de Sarmanho, eram próximos de Vargas o superintendente José Soares Maciel Filho e os diretores Francisco Antunes Maciel e Cleantho de Paiva Leite, que substituíram Glycon e Campos na direção do Banco.

José Soares Maciel Filho118 (1904-1975), outro conselheiro informal de Getúlio, era um jornalista carioca pró-Vargas que foi nomeado superintendente do BNDE em 1952, passando a ocupar a mesma posição na SUMOC em 1953. O diretor Francisco Antunes Maciel (1881-1966), por sua vez, era um advogado formado pela Faculdade Nacional de Direito. Nascido em Pelotas, provinha de uma família de longa trajetória política no Rio Grande do Sul. Seu pai havia sido ministro do Império, seu irmão foi interventor do Mato Grosso no início dos anos 1930 e ele secretário da fazenda do Rio Grande do Sul (DHBB, verbetes José Soares Maciel Filho e Francisco Antunes Maciel). Cleantho de Paiva Leite (item 1.4), que não tinha uma trajetória na política como os outros, fora designado conselheiro do BNDE enquanto atuava na Assessoria para reportar ao Presidente os detalhes sobre a atuação do Banco. Na reforma de 1953, Cleantho deixou o conselho para exercer a função de diretor.

Nos primeiros anos de funcionamento do Banco são reportados conflitos entre os "políticos" de Vargas e os "técnicos" da CMBEU, em especial aqueles que se entendiam como técnicos. Tanto Campos como Furtado tecem críticas à escolha de José Soares Maciel Filho para a superintendendência ${ }^{119}$ do Banco, o que consideram ter sido o estopim da primeira crise institucional vivida pelo BNDE:

\footnotetext{
${ }^{117}$ É razoável ponderar, quando fala-se de nacionalismo, em que medida este não é, antes de tudo antiamericanismo. Durante o período de Saramenho como presidente, o BNDE estabeleceu acordos de colaboração econômica para o desenvolvimento com a Alemanha e a França, assinados em 1953 e 1954, respectivamente. Nesse sentido é possível pensar que talvez o anti-americanismo predominasse em relação ao nacionalismo como uma defesa purista da atuação brasileira. Disponível em http://www.brasil.diplo.de/contentblob/2700970/Daten/780338/1953_investitionen_pt.pdf e em http://daimre.serpro.gov.br/atos-internacionais/bilaterais/1954/b_7/at download/arquivo. Consultados em 25/08/2015.

${ }^{118}$ Supõe-se que teria sido ele a datilografar a carta-testamento de Vargas.

119 "Pelo estatuto do banco, o superintendente tinha poder decisório até um certo limite de financiamento. A partir daí, as decisões teriam que ser levadas a conselho. Havia na verdade três degraus: um em que o superintendente podia decidir sem discutir com ninguém; outro em que ele convocava a diretoria para decidir, e um terceiro, em que o presidente do Banco era consultado". (LOPES, 1991, pp. 173-4).
} 
Logo que houve uma oportunidade, ele [Vargas] reafirmou seu domínio político, nomeando José Soares Maciel Filho para diretor-superintendente. Este era um homem de sua confiança pessoal, mas não tinha nenhuma vivência técnica do problema, não tinha participado na criação do Banco. Essa foi a primeira grande crise institucional! (CAMPOS, 2009, p. 42).

Dizia-nos ele, de vez em quando, que estávamos enganados ao pensar que o BNDE era uma organização exclusivamente técnica. $\mathrm{Na}$ realidade, dizia, inexistem no governo organizações estritamente técnicas. É inevitável a injeção de motivações políticas no próprio BNDE, pois se trata de um instrumento de governo e o dr. Getúlio Vargas assim quer usá-lo (CAMPOS, 1994, p. 194).

Getúlio tenta um compromisso e faz uma diretoria complicada, isto é, põe Campos como diretor e, ao mesmo tempo, como superintendente, Maciel Filho, que não tinha nada a ver com o espírito daquele grupo que pensava o desenvolvimento. Ele era um homem que vinha do Rio Grande do Sul, ligado aos interesses mais diretos do grupo Vargas, que podiam ser legítimos e indispensáveis, mas nada tinham a ver com o desenvolvimento e as técnicas que se exigiam, nem com, como se dizia, o espírito novo que era como que a matriz do espírito tecnocrata que emergia (FURTADO, 2009, p. 106).

Campos, o homem que havia aprendido inglês tardiamente indo ao cinema, ultrapassa a crítica ao despreparo técnico dos aliados de Vargas quando aproveita para rebaixá-los socialmente ridicularizando-os por não dominarem idiomas estrangeiros. Ele conta ter presenciado uma "humilhante conversa demonstradora de nosso supino grau de subdesenvolvimento econômico" que Maciel Filho teve com o embaixador americano, em um "portunhol de província"120 (CAMPOS, 1994, p. 194) e afirma que, como Sarmanho "não conhecia inglês, ficava a meu cargo todo o trabalho de redação e contatos com as autoridades americanas" (CAMPOS, 1994, p. 222).

No limite, a rejeição da figura de Maciel Filho simbolizava a ascensão de uma fração técnica e ilustrada da elite, a intelligentsia, "que absorve as técnicas do capitalismo industrial, preocupada com a eficiência da modernização econômica e social" (FAORO, 1975, p. 743), da qual fazem parte os especialistas em economia: homens que se julgavam credenciados a tomar decisões econômicas em bases racionais por terem treinamento técnico, adquirido através do estudo da economia ou da gestão dos órgãos econômicos, frequentemente amplificado por suas vivências e aprendizados internacionais. Ela se opõe a outra fração mais antiga da elite, composta pelos políticos tradicionais, de matriz

\footnotetext{
${ }^{120}$ Campos relata que, em tal conversação, Maciel tentava assegurar que o Brasil obteria os recursos necessários para oferecer a contrapartida aos empréstimos americanos. Em sua versão do ocorrido, Maciel teria falado a Bohan: " "Ne se preocupen ustedes por el problema de la contrapartida en cruzeiros. Es que el doctor Getúlio Vargas me ha nombrado al miesmo tempo para ser el diretor ejecutivo de la SUMOC e el presidente del BNDE. Así tendré em mis manos el control de la moneda. Si hubiera la necessidad de proveer la contrapartida em cruzeiros me cabe el poder de emitir moneda en la SUMOC.' O embaixador Bohan olhou-me, e a Maciel Filho, com olhos esbugalhados, imaginando o que ocorreria ao processo inflacionário brasileiro se um homem com essa percepção das coisas continuasse por algum tempo na SUMOC” (CAMPOS, 1994, p. 194).
} 
oligárquica, credenciados por seus nomes, posses e vínculos e pelos homens que eram por eles convocados com base em sua lealdade ao dirigente. A intelligentsia desdenhava essa velha elite vista como de "simples agitadores, ignorantes, incapazes, corruptos", que não poderiam orientar a vida econômica da nação (FAORO, 1975, p. 743).

Os conflitos com os homens de Vargas provocaram a renúncia de Roberto Campos, Glycon Paiva e do diplomata carioca Otávio Dias Carneiro (1912-1968)121, provavelmente o primeiro brasileiro a obter um $\mathrm{PhD}$ em economia, que chegara há poucos meses para chefiar o departamento econômico, trazendo para o Banco as mais modernas técnicas econômicas - como a matriz input-output - das quais se interara em seu doutorado no Massachusetts Institut of Technology (MIT). Com a saída dos três Furtado diz ter ficado praticamente isolado em sua missão de produzir o relatório do Grupo Misto CEPALBNDE, já que Maciel Filho não compreendia ou valorizava seu trabalho (CARNEIRO, 2005, pp. 6-14; DHBB, Verbete Octávio Dias Carneiro; LOPES, 1991, p. 222).

A hegemonia dos políticos ligados a Vargas no BNDE acabou pouco tempo depois do suicídio do Presidente. Em março de 1955, Glycon de Paiva foi apontado para a presidência e Roberto Campos retornou como superintendente. No mesmo ano há o lançamento do primeiro edital de seleção por concurso para o Banco, assinado por Roberto Campos e homologado em 1956. Além de um conjunto de assistentes para as áreas de administração geral, contabilidade, biblioteconomia, cálculo e estatística, desenho, taquigrafia, datilógrafos, operadores de telefone e mimeógrafo, foram contratados 8 economistas e 19 engenheiros ${ }^{122}$, dentre os quais estavam Juvenal Osório, Ignácio Rangel, José Pelúcio de Ferreira e Roberto Saturnino Braga ${ }^{123}$.

\footnotetext{
${ }^{121}$ Dias Carneiro era filho de um Capitão da Marinha com uma descendente do Barão de Santa Cruz nascida na França. Ele tentou inscreveu-se na Escola Naval pois desejava seguir os passos do pai mas teve que se afastar da Marinha por ter uma doença cardíaca que o incapacitava para o serviço. Decidiu então estudar Belas-Artes na Universidade do Brasil. Pouco depois transferiu-se para a Escola Nacional Superior de Belas-Artes da Universidade de Paris, onde chegou a esboçar um mestrado sobre o gótico inglês. Dias Carneiro ingressou no Itamaraty em 1940. Seis anos depois foi designado para a embaixada do Brasil em Washington. Aproveitou a ocasião para cursar o Master of Arts de ciências políticas e econômicas na George Washington University, concluindo-o no início de 1949 com a apresentação do texto Some theoretical aspects of price-quantity fixing and intergovernmental commodity agreements. Carneiro conseguiu um afastamento da embaixada para cursar o doutorado em economia no MIT e sua tese, A study on the theory of international economic organization (1951), foi orientada por Charles Kindelberg e Paul Samuelson (CARNEIRO, 2005, pp. 6-14; DHBB, Verbete Octávio Dias Carneiro).

${ }^{122}$ Por que o Banco não contrata advogados em seu primeiro concurso? Porque os advogados contratados provisoriamente conseguem entrar na justiça para suspender o concurso e permanecer em seus cargos (BNDE, 1955). Somente em 1959 há a admissão de 2 auxiliares para a área de direito e em 1960 uma seleção interna para advogados, tamanho o poder da categoria de verter a lei a seu favor.

${ }^{123}$ Consta que Rangel e Pelúcio já trabalhavam para o Banco antes do concurso em posições provisórias. Juvenal Osório estava entre os primeiros formados em economia da FNCE. Saturnino hava estudado engenharia na UB e
} 


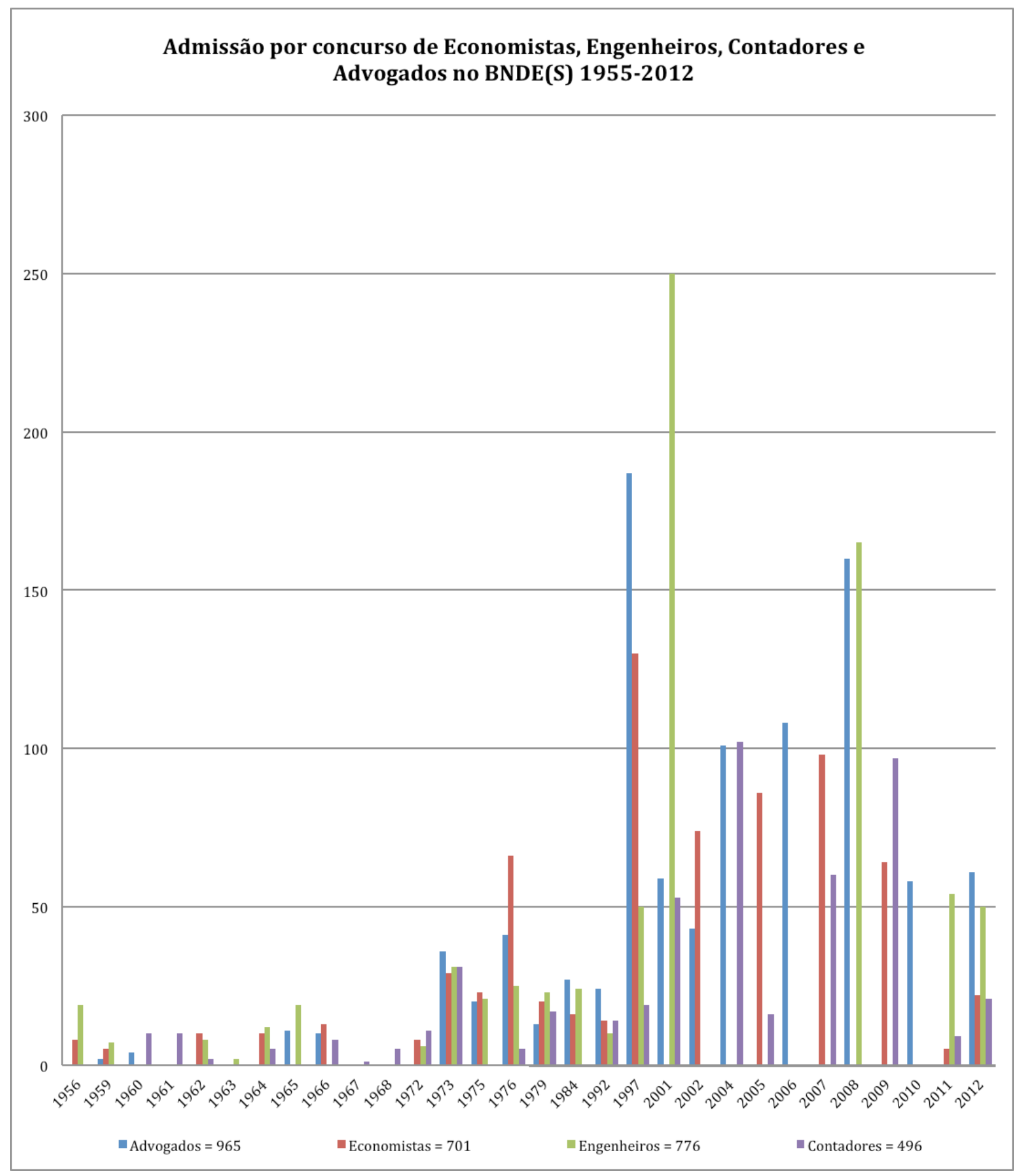

Gráfico I: Admissão por concurso de economistas, engenheiros, contadores e advogados no BNDE(S) 1952-2012. Fonte: Editais de seleção e listas de admissão para o BNDE(S) de 1955 a 2012 fornecidos pelo Serviço de Informação ao Cidadão do BNDES. Elaboração: própria ${ }^{124}$ (publicado em KLÜGER, 2015c, p.

havia trabalhado na Companhia Nacional de Álcalis antes de ingressar no BNDE. José Pelúcio era estatístico de formação e vinha do IBGE (TAVARES, 2010a, p. 257-258).

${ }^{124}$ Notas sobre a construção do gráfico: 1) Em alguns anos só há informações sobre o número de vagas abertas e sobre os candidatos habilitados, não sendo possível dizer, portanto, se os candidatos habilitados foram convocados em momentos posteriores, já que alguns concursos são válidos por mais de um ano. Em outros casos consta a data na qual a pessoa ingressou efetivamente no Banco ou há anotações que indicam que o candidato foi convocado em momento posterior, solucionando esse problema. 2) A contagem do número de admissões não inclui aqueles que entraram no Banco através dos prêmios BNDES, os profissionais requisitados de outros órgãos governamentais, aqueles que entraram através das subsidiárias do Banco ou por qualquer outro canal que não a admissão por concurso nos anos assinalados. Desse modo, os números apresentados estão longe de ser um retrato do número total de profissionais dessas carreiras que passaram pelo Banco. 3) No ano de 1976 a seleção 
85).

Furtado conta que Maciel Filho, além de não ter experiência e não acreditar em planejamento, considerava que o Banco não deveria ser dirigido somente por técnicos ${ }^{125}$. A ele, diz Furtado, era atribuída a seguinte frase: "Concurso para a seleção de técnicos leva sempre à escolha de comunistas" (FURTADO, 2009, p. 106). Ironicamente, de fato, vários dos especialistas recrutados por concurso para o BNDE foram acusados de serem comunistas. Notavelmente Ignácio Rangel, Juvenal Osório e Saturnino Braga. É a lógica do contraponto entre o "técnico" e o "político" que opera quando Campos rejeita a exigência de atestado ideológico do Departamento de Ordem Política e Social (DOPS), que barraria os presumidos comunistas, alegando que a posição política não poderia ser adotada como critério de seleção em um concurso técnico (TAVARES, 2010a, p. 43; Roberto Saturnino Braga in: TAVARES, 2010a, p. 257).

Para concorrer às vagas de economista era preciso apresentar um diploma de ciências econômicas ou título de habilitação na área. Dada a recente formalização do bacharelado em ciências econômicas, caso a habilitação não fosse aceita seriam pouquíssimos aqueles que poderiam concorrer às vagas da carreira de economista. Os engenheiros, por sua vez, deveriam apresentar um diploma de bacharel em engenharia. $\mathrm{O}$ processo de seleção de economistas em 1955-1956 consistia em exame escrito de conhecimentos específicos de economia e uma prova de monografia, na qual o candidato deveria apresentar, até 90 dias depois do encerramento das inscrições, uma dissertação inédita e original, que seria avaliada por escrito e arguida oralmente, e que deveria versar sobre um dos seguintes tópicos:

1) Teorias sobre o desenvolvimento econômico; Formação de capital. 2) Teorias sobre poupança, investimento e relação capital-produto. 3) Métodos de financiamento do desenvolvimento econômico. Fontes de poupança pública e privada e métodos para incrementá-la. 4) Política fiscal e desenvolvimento econômico. 5) Desenvolvimento econômico espontâneo e programado; métodos de influenciar o ritmo e direção do desenvolvimento. 6) Técnicas de elaboração de projetos de investimento. 7) Desenvolvimento industrial e desenvolvimento agrícola. 8) Problemas de industrialização. 9) Inflação e desenvolvimento econômico. 10) Produtividade. 11) Critérios para seleção de investimentos prioritários. 12) Investimentos estrangeiros. 13) Balanço de pagamentos. 14)

foi dividida por área de atuação e não por título universitário. Há, pois, uma dificuldade para diferenciar os economistas dos engenheiros" (KLÜGER, 2015c, p. 85-86).

${ }^{125}$ Campos concorda quando diz que: "nem mesmo o princípio do concurso público de provas e títulos parecia importante para Maciel Filho. Dizia-nos que concordava que o recrutamento fosse mantido à base de concurso, para cerca de $80 \%$ do pessoal. Mas seria necessário que lhe reservassémos uma quota de apadrinhamento político de 20\% (CAMPOS, 1994, pp. 193-195). Não obstante, o relatório administrativo do Banco de 1954, sob Maciel, informa estar estudando soluções para o processo de seleção e ter aprovado diretrizes gerais para elaboração do primeiro concurso (BNDE, 1954). 
Intercâmbio comercial e relações de troca. 15) Cooperação econômica internacional. 16) Política anticíclica. 17) Coordenação da política econômica e fiscal em sistemas federais de governo. 18) Economia dos transportes e da energia. 19) Economias regionais. 20) Estruturas do mercado e progresso econômico.

Já no caso dos engenheiros havia um exame escrito de conhecimentos técnicos de análise econômica e financeira de investimentos e domínio dos temas de organização racional do trabalho e da indústria. Ao qual seguir-se-ia uma avaliação prática que consistia na elaboração de um roteiro de análise e de um relatório técnico avaliando um projeto de financiamento na área de transportes ou energia ou indústria.

Há uma convergência entre o papel de desenhista de rotas para o desenvolvimento brasileiro desempenhado pelo BNDE nesses anos e o modelo de seleção adotado. O grande número de pontos voltados aos problemas do desenvolvimento e a exigência de uma monografia em formato similar à requerida para obtenção de um título acadêmico sugere que, à época, desejava-se atrair profissionais que dominassem teoria e fossem capazes de analisar a situação econômica, fazer projeções amplas sobre os rumos do desenvolvimento brasileiro e elaborar um planejamento geral para o país. Complementarmente, buscava-se recrutar engenheiros capazes de analisar a viabilidade técnica e econômica de projetos de investimento, sobretudo nas áreas de transportes e energia, que responderam por 69,1\% do capital investido pelo Banco de 1952 a 1963 (BNDE, 1955; KLÜGER, 2015c, pp. 87-89; LIMA, 2006, pp. 52, 58, 67).

A partir de 1956, o papel desempenhado pelo Banco na concepção de políticas voltadas ao desenvolvimento brasileiro e no financiamento da energia e dos transportes, expresso no modelo de seleção adotado, só viria a reforçar-se. Com a eleição de Juscelino Kubitschek, Lucas Lopes assume a presidência do BNDE ${ }^{126}$, Campos continua na superintendência e Cleantho de Paiva e Francisco Antunes Maciel continuam sendo diretores. A eles somar-se-ão, no início de 1957, João Batista Pinheiro e Ewaldo Correia Lima (DIAS, 1996, p. 143).

João Batista Pinheiro (1914-2001) nasceu em São Miguel do Veado (atualmente Alegre) no Espírito Santo. Cidade da qual seu pai, Genaro Pinheiro, foi prefeito antes de eleger-se Senador da República. João Batista bacharelou-se ciências jurídicas e sociais pela Faculdade de Direito de Niterói e foi aprovado, com 25 anos, no concurso para a carreira

\footnotetext{
${ }^{126}$ Inicialmente JK havia convidado Glycon para permanecer à frente do BNDE mas muda de ideia e aponta Lucas Lopes para a posição. Isso gera desentendimentos entre os dois por anos (LOPES, 1991, p. 281), levando, segundo Roberto Campos, ao fim dos "três mosqueteiros" (Campos, Lopes e Glycon) (CAMPOS, 1994, p. 293).
} 
diplomática. Designado vice-cônsul e depois cônsul em São Francisco, teve a oportunidade de estudar no departamento de economia da University of California Berkeley, obtendo o título de mestre em 1948. No governo do presidente Juscelino Kubitschek, Batista Pinheiro foi alocado no Ministério da Fazenda, ficando à disposição do BNDE. Ewaldo Correia Lima (1915-1992), por sua vez, nasceu no Piauí e estudou na Faculdade de Direito do Maranhão com seu primo Ignácio Rangel (item 1.4). Lima integrou o grupo dos desenvolvimentistas nacionalistas, sendo o principal economista do Instituto Superior de Estudos Brasileiros (ISEB) e fazendo parte do grupo de assessores que Rômulo de Almeida reuniu para trabalhar na Confederação Nacional da Indústria, tendo colaborado também com a Assessoria Vargas (DHBB, verbete João Batista Pinheiro; CENTRO INTERNACIONAL CELSO FURTADO DE POLÍTICAS PARA O DESENVOLVIMENTO, 2009, p. 337; FARO e SINELLI, 2014, pp. 47-48).

Com JK tem fim o interlúdio monetarista dos anos que se seguiram ao suicídio de Vargas. A intervenção do Estado na economia e o esforço ativo de industrialização fortalecem-se com a implementação do Plano de Metas, que adota os projetos da CMBEU e as projeções do grupo misto CEPAL-BNDE como seus principais subsídios para a elaboração de uma programação econômica de larga escala. Os técnicos da CMBEU e do Grupo Misto engajam-se diretamente na formulação e na implementação do Plano de Metas, transferindo suas técnicas e conhecimentos para o Conselho de Desenvolvimento e para o BNDE.

O coordenador geral do Plano de Metas era o presidente do BNDE e membro da CMBEU, o engenheiro Lucas Lopes, assessor pessoal de JK com longa vida de técnico ligado ao Partido Social Democrático (PSD) mineiro. De acordo com Bulhões, Lucas era o "braço direito e esquerdo de Juscelino" (BULHÕES, 1990). Aos laços políticos entre JK e Lopes somavam-se vínculos familiares, pois a esposa de Lucas Lopes, Esther, era prima da esposa de Juscelino, dona Sarah, e um dos filhos de Lucas e Esther, o empresário Rodrigo Lopes, casou-se com umas das filhas de Juscelino e Sarah, Maria Estela (LOPES, 2006, pp. 216-218).

Lucas Lopes (1911-1994) nasceu na cidade de Ouro Preto. Seu avô fora vereador e coronel no Rio Grande do Sul, tendo sido agraciado com o título de barão. Seu pai, Francisco Antônio Lopes, deixou o Sul jovem, partindo para a capital com o objetivo de ingressar na Escola Naval do Rio de Janeiro. Por conta de um surto de febre amarela, 
acabou desviando sua rota e indo para Minas Gerais, onde residia um tio seu que o aconselhou a cursar engenharia na Escola de Minas de Ouro Preto. Durante os estudos Francisco viveu com o dinheiro do aluguel das propriedades que seu pai deixou no Rio Grande do Sul. Na metade da graduação resolveu transferir-se para a Escola Politécnica de São Paulo - onde conheceu Roberto Simonsen (item 4.1), que o convidaria a supervisionar as obras de sua empresa em Minas. O interlúdio paulista foi breve. Logo Francisco Antônio regressou a Minas Gerais e, depois de obter o diploma da Escola de Minas de Outo Preto, foi trabalhar na Estrada de Ferro Noroeste. Nos anos seguintes foi diretor de obras da prefeitura de Belo Horizonte, historiador e colaborador do Serviço do Patrimônio Histórico e Artístico Nacional (SPHAN). A mãe de Lucas Lopes, Maria da Conceição Mosqueira, havia estudado no Sion de Petrópolis (item 1.5), falava francês fluente e recitava em italiano. Sua avó materna era uma mulher respeitada na sociedade mineira e muito bem relacionada, que hospedava em Ouro Preto políticos de todas as afiliações.

Lucas Lopes foi interno do Colégio Arnaldo em Belo Horizonte que, dirigido por padres alemães verbitas, abrigara diversas personalidades da política mineira, como Milton Campos, que foi governador de Minas Gerais e Ministro da Justiça, Gabriel Passos, que foi Ministro de Minas e Energia e Procurador Geral da República, e Gustavo Capanema, Ministro da Educação e da Saúde (CANÊED, 2002, p. 90). Conta ele que "o Colégio Arnaldo tinha uma disciplina germânica, horários rígidos: sete da manhã banho frio, missa, depois aquela vida típica de colégio rigoroso, mas bom. Com uma pequena falha: os professores de algumas cadeiras não falavam bem português” (LOPES, 1991, p. 28). Nesse colégio estudou inglês mas, como seu professor era alemão e não dominava inteiramente o idioma, o aprendizado foi muito precário. Essa falha seria corrigida no período em que Lopes trabalhou para uma companhia elétrica que era subsidiária da American and Foreign Power, pois "foi obrigado a falar e escrever relatórios em inglês". Lá familiarizou-se também com a "análise financeira de custos, o que veio a completar a minha formação de engenheiro acrescentando o lado do planejamento econômico" (LOPES, 1991, p. 52). Lopes registra a influência em sua formação do primeiro livro que leu depois das cartilhas escolares, um folheto intitulado Sê perfeito em tudo o que fizeres, que ganhara de seu pai (LOPES, 1991, p. 37), expressão exemplar das disposições que as elites modernizantes procuram incutir em seus rebentos (KHAN, 2011, p. 15). 
$\mathrm{Na}$ escola de engenharia de Belo Horizonte consegue uma indicação para trabalhar no jornal Estado de Minas. Pouco tempo depois é indicado para o posto de desenhista na Estrada de Ferro Oeste de Minas, envolvendo-se na elaboração de um programa de racionalização para a Rede Mineira. Lucas Lopes não tinha formação de economista e começou a ler de forma "muito autodidata e primitiva" textos sobre organização racional do trabalho: fordismo e taylorismo ${ }^{127}$. Por conta desse programa, entrou em contato com grupos de técnicos e engenheiros que debatiam os problemas de racionalização das estradas de ferro, ocasião em que conheceu Ary Frederico Torres, que liderava o IPT de São Paulo (LOPES, 1991, pp. 48-49, 98).

Mais ou menos por essa época ofereci-me ao Israel Pinheiro, que era amigo do meu pai e estava como secretário de Agricultura do governo [Benedito] Valadares, para ajudá-lo a criar um instituto de Pesquisa Tecnológica em Minas. Eu sentia que um dos entraves ao desenvolvimento econômico de Minas era a inexistência de um órgão de pesquisa tecnológica [...] Acontece que depois de ter me oferecido para ajudar o Israel, surgiu a oportunidade de eu vir para o Rio de Janeiro, esqueci o assunto e ele também. Mas algum tempo depois, quando ele deixou a secretaria, sugeriu ao Valadares que eu o substituísse, especialmente porque eu havia conversado muito com ele sobre o problema do desenvolvimento da tecnologia (LOPES, 1991, p. 51).

Lucas Lopes passou alguns meses em Vitória ajudando Israel Pinheiro' ${ }^{128}$, que havia sido nomeado presidente da nascente Companhia Vale do Rio Doce, a instalar a Estrada de Ferro Vitória-Minas. Os Lopes e os Pinheiro eram amigos dos tempos de Ouro Preto. Segundo Lucas "Israel era um homem de grande brilho, formado na Escola de Minas de Ouro Preto, onde obteve a medalha de melhor aluno" (LOPES, 1991, p. 65). Na sequência Lopes foi convidado pelo governador mineiro Bendito Valadares, cuja filha era casada com um cunhado seu, para ocupar a Secretaria de Agricultura e Indústria ${ }^{129}$. Era então prefeito de Belo Horizonte o médico Juscelino Kubitscheck, que se ligara a Valadares em 1932, no episódio da defesa do túnel Mantiqueira contra os revolucionários paulistas. Foi então que Lopes começou a conviver com Juscelino, que descreve como "um homem aberto, que tinha visitado a Europa, falava francês e tinha muitas relações. Como prefeito, mobilizou muito a vida social de Belo Horizonte. Ao contruir Pampulha,

\footnotetext{
${ }^{127}$ Anos depois, por volta de 1947-1948, Lucas Lopes lecionaria geografia econômica na Faculdade de Ciências Econômicas e Administrativas de Minas Gerais (FACE) (item 3.1) (LOPES, 1991, p. 98; LOPES, 2006, p. 55).

${ }^{128}$ Israel é pai da Helena Pinheiro, esposa do jornalista Otto Lara Resende, e avô de André Pinheiro de Lara Resende, que será presidente do BNDES de abril de 1998 a novembro de 1998. As trajetórias dos membros da família Pinheiro serão reconstruídas adiante (item 4.5).

${ }^{129}$ Durante seu período como Secretário de Agricultura e Indústria foi criada a Coordenação da Mobilização Econômica, momento em que reencontrou Ary Torres, então envolvido com a promoção da substituição de importações (LOPES, 1991, p. 74).
} 
levou para lá Oscar Niemeyer, Lúcio Costa, Burle Marx, Portinari. Modernizou a cidade” (LOPES, 1991, p. 67). Quando se tornou governador, em 1951, Juscelino centrou sua atuação no binômio energia e transportes, criando a Companhia Elétrica de Minas Gerais (CEMIG) e posicionando Lucas Lopes na direção ${ }^{130}$.

\begin{abstract}
Naquela época, o Brasil começou a se preparar para a IV reunião de Consulta dos Ministros das Relações Exteriores das Repúblicas Americanas, que seria realizada em Washington em março de 1951. [...]. O Itamaraty precisava preparar um documento básico sobre alguns aspectos da economia brasileira para levar para essa reunião, mas, como seu Departamento Econômico não tinha informações especializadas sobre energia elétrica no Brasil, fui convidado a escrever um paper sobre o assunto. Esse meu paper foi encaminhado, e algum tempo depois fui surpreendido com a notícia de que tinha sido criada a Comissão Mista Brasil-Estados Unidos, para a qual haviam sido designados, como presidente, Ary Torres, e como membros, Valentim Bouças, Roberto Campos, Glycon de Paiva e Lucas Lopes. Fui chamado lá e me disseram: "Você foi nomeado para a Comissão Mista" (LOPES, 1991, p. 116).
\end{abstract}

Lopes trabalhou simultaneamente na CEMIG, na CMBEU e no conselho do BNDE, viajando de Minas ao Rio e voltando no mesmo dia com alguma frequência. Depois do suícido de Vargas, foi nomeado Ministro de Viação por Café Filho, segundo ele porque interessava nomear alguém ligado ao PSD que não tivesse intenções políticas conflitantes com as do presidente (LOPES, 1991, p. 161). Ao deixar o governo, começou a trabalhar no programa básico da campanha de JK, escrevendo as Diretrizes gerais do Plano Nacional de Desenvolvimento, que dariam origem ao Plano de Metas. A ideia de adotar um planejamento econômico não era nova para Kubitschek. Já como governador havia apostado na elaboração de um plano para desenvolver as áreas de eletrificação e transporte que tivera boa repercurssão. Ele não acreditava na tese da vocação agrícola do Brasil e propunha um planejamento setorial voltado à industrialização como estratégia para elevar o nível da população (LAFER, 1975, p. 33).

Antes mesmo da posse de JK, Lucas Lopes mobilizou os quadros técnicos que participaram de experiências anteriores de planejamento na CMBEU, na Assessoria Vargas, na CEPAL e no BNDE para fazer um diagnóstico sobre o estado da produção

\footnotetext{
${ }^{130}$ Em suas memórias, Lucas Lopes diz ter lido muito sobre planejamento. Conta que era grande entusiasta do planejamento de Roosevelt do New Deal e que foi influenciado pelos planejadores russos. Não obstante, nega adesão ao planejamento integral da economia, dizendo que se ocupava sobretudo de um planejamento geográfico das obras e construções. Afirma também que pouco sabia de "planjamento econômico no estilo moderno, implicando decisões macroeconômicas e monetárias" e argumenta que naquele período dava pouco importância à questão de quem deveria ser o agente econômico. "Lamentávamos muito que não existisse iniciativa privada para produzir energia elétrica em Minas, mas nem por isso cruzávamos os braços esperando que ela surgisse". Era preciso recorrer ao Estado para capitalização "mas nem por isso éramos socialistas" (LOPES, 1991, pp. 80$82,114)$. Essas considerações são próprias dos debates sobre os tipos e os limites do planejamento que aparecem em tantos outros relatos.
} 
econômica no país e definir e quantificar as metas de governo. Resultaria desses estudos preliminares a definição de um plano que abarcava cinco setores: energia, transportes, alimentação, indústrias de base e educação ${ }^{131}$ e que se desdobrava em 30 metas que fariam o Brasil avançar 50 anos em 5, às quais veio a somar-se a meta-síntese: Brasíliai32 (LAFER, 1975, p. 35).

A formulação macroeconômica [do Plano] estava sendo feita por Celso Furtado, em acordo com a CEPAL. Esse trabalho do Celso Furtado era de conhecimento da maior parte dos economistas, mas não do meu conhecimento, pois nunca fui macroeconomista, sempre fui engenheiro. Era um trabalho paralelo, que não tinha influência na elaboração específica do Programa de Metas [133]. Mais tarde, na medida em que foram se desenvolvendo as várias metas, cada programa se baseou em projeções e naturalmente foi buscar seus índices nas projeções econométricas da CEPAL [134] (LOPES, 1991, pp. 168-9).

131 O setor da educação teria sido incluído pelo Ministro da Educação e da Saúde, Clóvis Salgado (LOPES, 1991, p. 201). Os especialistas em economia brasileiros não estavam então envolvidos com a temática educacional, da qual só passarão a ocupar-se com intensidade a partir do golpe de 1964, fortemente influenciados pelas reflexões norte-americanas sobre o capital humano (item 4.6) (ALMEIDA, 2008, pp. 168169).

${ }^{132}$ Uma representação da convergência das políticas do Plano de Metas com o ideário cepalino é gravada no cimento do prédio da CEPAL, projetado pelo arquiteto Emilio Duhart e inaugurado em 1963. Ao longo da escada externa, em caracol, do auditório central que dá acesso ao topo do prédio, há uma sequência de imagens que representam a América Latina em seus vários estágios de desenvolvimento. "O percurso de subida aparece, assim, como uma espécie de espiral da história, desde a Caverna de Fell, em território patagônico, até Brasília" (OYARZÚN, 2012, p. 43), representada por seu eixo monumental e pela catedral de Niemeyer. Duhart, que havia trabalhado com Gropius em Harvard e com Le Corbusier em Paris, ajudando inclusive no desenho dos edifícios de Punyab e Chandigarh, dedicou o edifício da CEPAL - que segue o receituário "pilotis", "planta livre", "janelas contínuas", "fachada livre" "jardim entre muros" (ACAYABA, 2011, p. 16) e pode ser considerado um marco da arquitetura brutalista (BRUNA, 2011) - a seu mestre Corbusier (BERGDOLL, 2012, p. 28). Niemeyer, arquiteto das obras de JK em Belo Horizonte e Brasília e da Fundação Getúlio Vargas no Rio, teve três encontros decisivos com Corbusier: em 1936 no Rio de Janeiro na colaboração para a construção do Ministério da Educação e Saúde de Capanema; em 1947, quando o desafio era criar uma sede para a ONU em Nova York; e em 1955, em Paris, tendo, neste último encontro, travado conhecimento com o projeto de Corbusier para Chandigarh (QUEIROZ, 2007). Os jardins da CEPAL, por sua vez, foram criados pelo mesmo Roberto Burle Marx que desenhou os jardins dos edifícios da Petrobrás e do BNDE, órgãos basais do desenvolvimentismo brasileiro. É possível observar, pois, que as afinidades políticas e teóricas subjacentes aos projetos desenvolvimentistas do Brasil de JK e da CEPAL desdobram-se nas afinidades estéticas das vanguardas que projetavam a arquitetura, o urbanismo e o paisagismo do desenvolvimento latino-americano, dando forma a um ideal de modernização.

${ }^{133}$ A posteriori Campos reconstrói sua posição em relação à denominação do plano: “ 'Lucas pediu-me sugestões sobre a denominação possível para o programa de governo de Kubitschek. Respondi-lhe que um termo extremamente popular na literatura desenvolvimentista da época era 'metas' (targets)'. Sugeri que o programa se chamasse 'Programa de Metas'. A expressão 'programa' seria preferível a 'plano'. Escrevi a Lucas, em 2 de maio de 1955, uma carta em que explicava minha alergia à palavra 'plano', nos seguintes termos: 'Prefiro de longe a expressão mais modesta 'programação'. Isso porque a idéia de planejamento é tecnicamente associada a várias coisas que não são praticáveis estatística e administrativamente no Brasil como, por exemplo, (a) Delimitação de metas quantitativas de produção; (b) O escalonamento temporal das realizações; (c) Escolha do agente executivo (iniciativa privada, pública etc.); e (d) O contingenciamento de recursos através de controles diretos (controle de câmbio, racionamento de matérias-primas, alocação de meios de transporte etc). Dado que nossa iniciativa privada não é de todo estagnada, que o nosso regime jurídico-constitucional é o de democracia liberal e, finalmente, que nos faltam dados técnicos para qualquer planejamento de modelo socialista, seria mais realístico (e no fundo mais útil) pensarmos em termos de 'programação'." (CAMPOS, 1994, pp. 266-267). Mais uma vez há uma negação de seu passado de defensor do planejamento.

${ }^{134}$ É estratégico dizer que a responsabilidade pela parte macroeconômica era de Furtado e da CEPAL e que ele nada sabia disso, já que se exime de responsabilidade pelo aspecto mais criticado do Plano de Metas, que foram as consequências inflacionárias. 
Juscelino Kubitscheck institui, em 15 de março de 1956, o Conselho de Desenvolvimento, órgão centralizador das decisões do Plano de Metas que era formado "por todos os ministros, os chefes da Casa Civil e Militar, o presidente do Banco do Brasil e o presidente do BNDE, que era o secretário do órgão" (LOPES, 1991, p. 170). O Conselho de Desenvolvimento reunia-se em um andar do mesmo edifício no qual estava localizado o BNDE. “As secretárias eram requisitadas ao BNDE para fazer serviços de datiligrafia ou de pesquisa, o conselho pedia ao BNDE que contratasse estatísticos para fazer levantamentos, e assim por diante. O BNDE naquela época ainda estava numa fase inicial, não tinha muito dinheiro para aplicar, não tinha muitos projetos a fazer, de modo que houve uma fusão interessante: o BNDE e o Conselho de Desenvolvimento formaram uma unidade" (LOPES, 1991, p. 172).

Os técnicos que trabalharam no Plano de Metas vieram de todos os órgãos de governo que tinham quadros na área econômica, reunindo-se ao grupo da CMBEU. Roberto Campos trouxe com ele quadros do Itamaraty que tinham treinamento em economia: Miguel Osório de Almeida, Otávio Dias Carneiro e João Batista Pinheiro. Da SUMOC vieram Casimiro Ribeiro e Dênio Nogueria. Da Assessoria Vargas, Ignácio Rangel e Cleantho de Paiva Leite. Do BNDE participaram os funcionários José Pelúcio Ferreira e Juvenal Osório. Havia um advogado, José Luís Bulhões Pedreira, que cuidava da adequação jurídica da documentação. Vários outros quadros do BB, da CAXEC e de outras burocracias governamentais reuniram-se à equipe (LOPES, 1991, pp. 172-175; LOPES, 2006, pp. 142-143).

O Conselho de Desenvolvimento e o BNDE deram origem a diversos grupos de trabalho e grupos executivos que se responsabilizaram por setores específicos do Plano, podendo ter duração mais ou menos longa, ser menores ou maiores, mais ou menos institucionalizados. Dentre os mais de trinta grupos estavam o Grupo Executivo da Indústria Automobilística (GEIA) coordenado por Lúcio Meira ${ }^{135}$, o Grupo de Trabalho de Minério (GTM) dirigido por Glycon de Paiva e o Grupo de Trabalho de Siderurgia (GTS), coordenado por Octávio Dias Carneiro (LOPES, 2006, pp. 128-141; LOPES,

\footnotetext{
${ }^{135}$ Lúcio Meira (1907-1991), natural de Petrópolis, filho de militares, e ele mesmo militar formado na Escola Naval do Rio de Janeiro, na Escola Nacional de Engenharia e na Escola de Aviação Naval, já havia trabalhado no grupo da Comissão de Desenvolvimento Industrial de Getúlio Vargas que era responsável pela implantação da indústria automobilística (DHBB, verbete Lúcio Meira). Nesse sentido, a política de JK para o setor dá continuidade ao projeto da era Vargas, tendo sido, inclusive, entregue ao mesmo responsável.
} 
1991, p. 172). Os órgãos externos à administração regular do Estado, formados com a intenção de levar adiante o Plano de Metas sem que houvesse intervenção política do Congresso e do clientelismo, ficaram conhecidos como Administração Paralela ${ }^{136}$ (BENEVIDES, 1976, pp. 224-227; LAFER, 1975, pp. 38-40).

As estruturas paralelas contornavam, ao invés de confrontar, os problemas da burocracia brasileira. À exceção de alguns órgãos que passaram a ser conhecidos como bolsões de eficiência - com funcionários altamente especializados, carreiras prestigiosas, bem conectadas aos setores estratégicos da sociedades e que, na área econômica, atuariam no sentido de viabilizar investimentos produtivos de longo prazo, fornecendo capital e direcionando racionalmente a alocação dos recursos (EVANS, 1995, pp. 44-48) - como o BNDE, a SUMOC e o Itamaraty, o recrutamento da burocracia estatal existente dava margem ao personalismo e ao clientelismo característicos da política oligárquica. Diante dessa visão os grupos modernizantes criaram novos espaços, pretensamente isolados da "irracionalidade" da vida política nacional, nos quais os técnicos teriam autonomia para tomar decisões "racionalmente": planejar, financiar e implementar projetos, sobretudo nas áreas voltadas à definição de políticas econômicas (EVANS, 1995, p. 61; GEDDES, 1990, p. 225; GOUVÊA, 1994, p. 117; NUNES, 1984, pp. 137-138).

O Conselho de Desenvolvimento e os grupos executivos de JK requisitaram funcionários dos "bolsões de eficiência" e reuniram, entre 1956 e 1961, especialistas convidados para desenhar o Plano de Metas e coordenar sua implementação. O BNDE controlava parte substantiva da concessão dos financiamentos ${ }^{137}$ previstos, pelo que aumentou seu nível de atividade e fortaleceu sua posição no conjunto das burocracias de Estado. Ele geria os recursos: 1) do FRE ${ }^{138}$ com os quais financiava empresas públicas e privadas ${ }^{139}$ em diversas áreas; 2) de fundos especiais com finalidades específicas, como o

\footnotetext{
136 Estruturas semelhantes já existiam na era Vargas. Exemplos delas são a Assessoria Vargas e os numerosos conselhos ligados ao Poder Executivo que se ocupavam das políticas econômicas e sociais em seu segundo governo (BENEVIDES, 1976, p. 227; DIAS, 1996, p. 78).

137 “Do início do programa de metas, em fevereiro de 1956, até dezembro de 1960, o BNDE firmou contratos para o financiamento de 133 projetos, comparados aos 47 contratos firmados entre 1952 e 1955, sob o Programa de Reaparelhamento Econômico. Neste mesmo período, as operações autorizadas, mas que permaneceram sem contrato, foram destinadas a 31 projetos, e as participações acionárias envolveram 13 projetos, dentre os quais os da Cosipa e da São Paulo Light. As operações de investimento direto das companhias de seguro e capitalização financiaram, ao todo, mais outros 40 projetos. Foram firmados 80 contratos avalizando empréstimos em moeda estrangeira, quantidade bem superior aos nove contratos firmados entre 1952 e 1955" (DIAS, 1996, p. 138).

${ }^{138}$ O FRE incialmente havia sido aprovado para os cinco primeiros anos do Banco. Em 1956, depois de longas discussões no Congresso, ele foi renovado por mais dez anos.

${ }^{139}$ Nos anos JK, o BNDE dirigia $84,5 \%$ de seus empréstimos para o setor público e $15,5 \%$ para o setor privado. Os empréstimos ao setor privado só passaram a ser majoritários em 1968 (NAJBERG, 2002, p. 353).
} 
Fundo de Eletrificação, o Fundo Portuário Nacional, o Fundo de Renovação e Melhoramento das Ferrovias e o Fundo de Pavimentação; e 3) os financiamentos obtidos no exterior (DIAS, 1996, pp. 80, 95; LAFER, 1975, pp. 38-42).

A captação de recursos externos continuava sendo a faceta mais delicada do programa pois o Brasil seguia extremamente dependente de bens de capital e de tecnologia importados. Mesmo que as negociações para a concessão de recursos externos tivessem sido retomadas ao final do governo de Vargas, a disposição do republicano Eisenhower para colaborar com o Brasil não aumentara substantivamente. De acordo com Kubitschek, os estadunidenses não se entusiasmaram com o Programa de Metas, já que estavam mais preocupados com o combate à subversão nos países que julgavam estar ameaçados pela inflitração comunista (Juscelino Kubitschek apud BENEVIDES, 1976, p. 237).

Tão logo eleito, JK viajou para os EUA e para a Europa com a intenção de discutir o financiamento de seu Plano de Metas. Em seguida, em fevereiro de 1956, Eisenhower enviou o vice-presidente Richard Nixon para a posse de JK. Ele visitou Volta Redonda, anunciou um empréstimo destinado à ampliação da usina e carregou para os EUA detalhes dos planos de desenvolvimento propostos pelo novo presidente brasileiro ${ }^{140}$. Em seguida, o vice-presidente brasileiro João Goulart fez uma visita de reciprocidade aos EUA, acompanhado de João Batista Pinheiro, dando continuidade às negociações de financiamentos para as obras do Plano de Metas. Finalmente, Lucas Lopes e os diplomatas Roberto Campos, Otávio Dias Carneiro e João Batista Pinheiro vão aos EUA negociar a restauração dos financiamentos para os projetos da CMBEU. Lopes relata a argumentação que adotaram na ocasião:

\begin{abstract}
Não temos nada a apresentar além dos projetos que os senhores já conhecem, encaminhados pela Comissão Mista Brasil-Estados Unidos. O que queremos é uma decisão: vocês vão financiar os projetos aprovados pela Comissão Mista? Depois nós apresentaremos outros. Eles ficaram realmente encurralados, porque não poderiam dizer que não conheciam aqueles projetos, se já os haviam estudado (LOPES, 1991, p. 181).
\end{abstract}

Assim, os primeiros projetos a receber aportes do Exim-Bank foram aqueles dos setores energéticos, de ferrovias e do reaparelhamento de portos que há anos aguardavam os recursos externos prometidos. Um pouco depois, o Banco Mundial aprovaria o

\footnotetext{
${ }^{140}$ Ver: 
financiamento para a construção da usina hidrelétrica de Furnas (CAMPOS, 1994, pp. 303-307; DIAS, 1996, pp. 42, 55).

Neste momento, a reconstrução europeia já estava em estágio avançado e a prioridade geopolítica dos EUA voltava-se para o bloqueio do avanço comunista, especialmente na Ásia e no Oriente Médio. A América Latina continuava não sendo contemplada com volumes significativos de empréstimos, já que os estadunidenses acreditavam que esses países não estavam sujeitos a ameaças comunistas diretas. Continuava prevalecendo, portanto, a máxima da missão Abbink, segundo a qual a região deveria ser alvo de investimentos privados e não de ajuda externa governamental, indicando que para favorecer a atração desses investimentos era preciso liberalizar os sistemas cambiais e reduzir o protecionismo. Parte substantiva do capital externo empregado no Plano de Metas foi obtida através da entrada de empresas estrangeiras no Brasil e do ingresso de capital privado ${ }^{141}$ na forma de máquinas e equipamentos, viabilizada pela instrução 113 da SUMOC, o que convergia com a orientação que os EUA defendiam para a América Latina (PINHO, 1996, pp. 11-22).

A recuperação europeia e japonesa ampliava o espectro dos países com os quais o Brasil podia negociar empréstimos e investimentos. Esses países voltavam a competir com os Estados Unidos nos mercados internacionais, passando a poder exportar bens de capital e instalar fábricas e franquias de suas empresas no exterior. Essa diversificação fez com que o Brasil deixasse de depender somente do investimento norte-americano, logrando atrair outros empréstimos e empresas para implementar seu plano de industrialização.

Tomando-se, por exemplo, os países ou as empresas internacionais que concorreram à execução do Plano de Metas, verifica-se que a participação inicial de empresas do país capitalista hegemônico — os Estados Unidos - era irrisória: elas não estiveram presentes na indústria de construção naval, que se montou com capitais japoneses, holandeses e brasileiros, na indústria siderúrgica, que se montou basicamente com capitais nacionais estatais (BNDE) e japoneses (Usimimas), nem sequer tinham participação relevante na própria indústria automobilística, que se montou com capitais alemães (Volkswagen), franceses (Simca) e nacionais (DKW, Mercedes-Benz); as empresas norte-americanas que já estavam aqui desde há muito, como a General Motors e a Ford, não se interessaram pela produção de automóveis de passeio senão depois de 1964, e a empresa americana que veio para aqui, a Willys-Overland, era não somente uma empresa marginal na produção automobilística dos Estados Unidos, como basicamente montou-se com capital nacional, público (do BNDE) e privado (através do lançamento de ações ao público e associação com grupos nacionais como

\footnotetext{
${ }^{141}$ Campos relata que JK não tinha grande preocupação em avaliar de onde vinha o capital, a ele interessava saber onde seria a fábrica e assegurar que o capital fosse produtivo e não especulativo (CAMPOS, 1994, pp. 287, 297).
} 
o Monteiro Aranha). A posição do capitalismo internacional, principalmente a do capitalismo do país hegemônico, era, muito ao contrário, amarrada à antiga divisão internacional do trabalho, em que o Brasil comparecia como produtor de bens primários de exportação. Assim, é difícil reconhecer uma estratégia do capitalismo internacional em relação à aceleração da industrialização brasileira; foi nas brechas do policentrismo, com a reemergência dos países do Mercado Comum Europeu e a do Japão, que a estratégia nacional encontrou viabilidade (OLIVEIRA, 1972, pp. 44-45).

Entre as consequências do relaxamento das restrições externas e da entrada em massa de capitais externos privados estavam a deterioração no balanço de pagamentos e o crescimento do endividamento. Os créditos privados eram mais caros e tinham um tempo de maturação inferior àquele dos créditos governamentais e multilaterais, o que resultou em uma situação de rápida fragilização externa (BENEVIDES, 1976, pp. 237-238; DIAS, 1996, p. 134; PINHO, 1996, pp. 17-22). A delicada situação externa somada à inflação e à queda do preço do café142 enfraqueceram decisivamente o Ministro da Fazenda, José Maria Alkmin, que era alvo de incessantes críticas do Ministro da Guerra, o General Henrique Lott, que o acusava de ser responsável pelo agravamento da crise financeira e o recriminava por ter reatado relações comerciais com a URSS por conta dos interesses dos cafeicultores. Alkmin exonerou-se da Fazenda na metade de 1958, alegando que iria concorrer a deputado. Lucas Lopes foi designado, em junho de 1958, para substituí-lo, tendo a específica missão de estabilizar as finanças e conter a inflação (BENEVIDES, 1976, p. 183; LOPES, 1991, p. 13).

Lucas Lopes transfere, então, a presidência do BNDE para Roberto Campos, João Batista Pinheiro passa a ser superintendente do Banco e Celso Furtado, que havia deixado o Brasil em outubro de 1955, ao fim dos trabalhos do Grupo Misto CEPAL-BNDE, é convidado a retornar ao Banco como diretor. Convite que aceita em setembro de 1958, com a condição de poder dedicar-se exclusivamente ao tema do desenvolvimento do Nordeste. Ele passa a integrar o Grupo de Trabalho sobre o Desenvolvimento do Nordestes (GTDN) mas, percebendo que este não avançava no ritmo que desejava, decide que seria melhor conduzir seus trabalhos de maneira autônoma a partir do próprio BNDE, onde trabalhava com um grupo pequeno de assessores, entre os quais estavam Jader de Andrade, para a economia agrícola, Juarez Farias, que atuava nos estudos da indústria, e Pelúcio Ferreira (item 4.5). Foi preciso que uma grande seca devastasse o Nordeste naquele ano e abalasse a oferta de alimentos para que JK, que já era duramente

\footnotetext{
${ }^{142}$ Sobre a queda do preço do café, vide: MALAN, 1984, pp. 80-82.
} 
acusado pela oposição de negligenciar a região, ficasse alarmado e visse que a solução não sairia nem do GTDN nem do Departamento Nacional de Obras Contra as Secas (DNOCS), dominado pelas oligarquias latifundiárias regionais (CAMPOS, 1994, p. 342; DIAS, 1996, pp. 41-43; FURTADO, 2014, pp. 229-233; TAVARES, 2010a, p. 259).

Em janeiro de 1959, JK decide reunir em Petrópolis seus conselheiros para discutir a questão nordestina. Furtado foi convidado a juntar-se ao grupo. Cleantho de Paiva, que sabia que ele estava estudando a questão nordestina, sugeriu que ele fosse o primeiro a falar. A ideia de Furtado era instigar JK a promover um projeto de desenvolvimento para a região que fosse tão grande que não pudesse ser interrompido pela gestão seguinte. Ele apresentou os resultados dos estudos preliminares que fez no BNDE e ganhou a confiança do Presidente, sendo encarregado do esboço de um plano de ação para a região que ganhou o nome de "Operação Nordeste" (OPENO), que deveria ser apresentado aos governadores da região dentro de um mês. Furtado entregou ao Presidente relatório intitulado Uma política de desenvolvimento econômico para o Nordeste com base no qual JK justificou a instalação, em março de 1959, de um Conselho de Desenvolvimento do Nordeste (CODENO), com sede em Recife, que deveria gerir a OPENO até que fosse aprovada a criação da SUDENE, o que ocorreu em dezembro de 1959 (FURTADO, 2014, pp. 234-274).

Doravante, a SUDENE seria encarregada de elaborar e conduzir um planejamento plurianual para o Nordeste que objetivava reduzir as disparidades regionais. A SUDENE era uma autarquia análoga ao BNDE e pretendia, como ele, ser capaz de formar um corpo de técnicos de excelência, no caso especializados em Nordeste. Furtado transferese do BNDE para a presidência do novo órgão onde começa custosa batalha contra os poderes arraigados da região. Integram sua equipe na nova organização: o economista agrícola mineiro Jader de Andrade (1924-1998), o agrônomo especializado em irrigação Estevam Strauss, o sociólogo Francisco de Oliveira, o engenheiro Ulrich Hoffmann, o economista Flávio Tavares de Lyra (item 3.2) e outros, quase todos ex-alunos dos cursos de Treinamento em Problemas de Desenvolvimento. Em parceria com a SUDENE, os cursos do Centro CEPAL-BNDE passam a ser oferecidos também em Recife. Eles foram adaptados para tratar da questão nordestina, ajudando a alimentar a organização com quadros especialmente treinados para pensar o Nordeste dentro do enquadramento estrutural e para utilizar as técnicas de planejamento cepalinas para propor soluções para 
os problemas da região (FURTADO, 2014, p. 208; WANDERLEY, 2015, pp. 199-200).

Enquanto Furtado ocupava-se do Nordeste, Lucas Lopes e Roberto Campos cooperaram na tentativa de desenvolver um plano de estabilização financeira. Lopes conta ter chegado a tentar nomear Bulhões para a diretoria da SUMOC, com o objetivo de aproximar-se de seus monetaristas, experientes nos problemas relativos à inflação. Juscelino não aceitou a indicação. Eles optam, então, por indicar outro sumoqueano, José Garrido Torres, que tinha uma aceitação mais ampla e era menos associado ao signo da ortodoxia (LOPES, 1991, p. 226).

Havia, pois, uma tensão na gestão da política econômica que resultava da contradição entre as duas orientações, a de JK, que pretendia dar continuidade ao seu acelerado plano de investimentos e inaugurar Brasília no tempo previsto, independente dos efeitos inflacionários, e a dos responsáveis pelas finanças que tentavam implementar cortes nas linhas de crédito e medidas de contenção de gastos e de emissões que acabariam por retardar os planos do presidente. Alimentavam essa tensão os protestos nacionalistas de estudantes e trabalhadores contra os "entreguistas", os ministros do grupo desenvolvimentista cosmopolita, que visava a estabilização e tinha maior tolerância à participação estrangeira na economia. Em junho de 1959, Lucas Lopes tem um ataque cardíaco e afasta-se do governo. Poucos dias depois, JK rompe com o FMI, que exigia que o Brasil adotasse uma série de medidas ortodoxas para liberar os empréstimos prometidos. Um mês depois, Roberto Campos deixa sua posição no BNDE, substituído pelo ex-Ministro da Viação e coordenador do GEIA, Lúcio Meira, próximo de JK e disposto a dar sequência ao programa previsto no Plano de Metas (DIAS, 1996, p. 45; PINHO, 1996, pp. 17-22).

\subsection{Mario Henrique Simonsen: CONSULTEC e CAE-FGV}

Afastados do centro do poder, os “desenvolvimentistas não nacionalistas" Roberto Campos e Lucas Lopes organizam uma consultoria que pode ser considerada como um dos primeiros think tanks brasileiros: a Sociedade Civil de Planejamento e Consultas Técnicas Ltda (CONSULTEC), visto haver um caráter coeso, estratégico e normativo nas orientações políticas da consultoria, subjacente mesmo ao funções habituais: fazer business plans, estudos macroeconômicos, análises de mercado e projetos para empresas privadas 
que desejavam obter financiamento junto a bancos de fomento (Augusto Jefferson Lemos in: ALBERTI et al., 2002, p. 61). Para tanto, transferiram os conhecimentos e as técnicas que adquiriram em suas experiências governamentais, especialmente na CMBEU, no BNDE e no Plano de Metas, para o setor privado e passaram a usar o conhecimento que tinham da máquina governamental em prol de seus clientes. Lucas Lopes admite que a empresa cresceu rapidamente com base no prestígio acumulado por eles no governo (LOPES, 1991, p. 277). Assim encontramos na CONSULTEC uma manifestação do fenômeno que recebe em francês o nome de pantouflage, o êxodo de quadros de elite do setor público para o setor privado, no âmbito do qual se legitimam pelo renome e pelos contatos adquiridos nas instâncias estatais (BOURDIEU e SAINT-MARTIN, 1976, p. 52 ; CHARLE, 1987, p. 1115).

Criada em 26 de setembro de 1959, a CONSULTEC tinha como primeiros sócios acionistas: Lucas Lopes, Mario Abrantes da Silva Pinto, engenheiro e colega próximo de Glycon Paiva no DNPM que havia sido convidado por Roberto Campos para chefiar o departamento de projetos do BNDE, e Jacinto Xavier Martins, da divisão de transportes do BNDE. O único que nunca fez parte do BNDE foi Jorge Oscar de Melo Flôres, funcionário do DNPM que era professor da Faculdade Nacional de Engenharia e da FGV, amigo pessoal do grupo (LOPES, 1991, p. 269). Atribui-se a ideia de formar a consultoria a Lucas Lopes e a montagem da equipe a Roberto Campos, que incorporou diplomatas e quadros do BNDE que eram leais a ele.

Na saída do BNDE, acompanharam-me vários colegas do Itamaraty - Miguel
Osório de Almeida, Geraldo Holanda Cavalcanti e Lindenbergh Sette $\left[{ }^{143}\right]-$ que
eu havia atraído para o banco e para o Conselho do Desenvolvimento, pelo
interesse que tinham em planejamento econômico. Passaram a enfrentar
problemas de sobrevivência, ao perderem as gratificações que suplementavam os
magros salários do Itamaraty. Isso, e mais o desejo que tínhamos, Lucas Lopes e
eu, de manter unido e coeso esse núcleo de talentos, que aliavam conhecimentos
de planejamento econômico e experiência internacional, levaram-nos à criação da
CONSULTEC, uma consultoria privada para investidores e planejadores. Seria
um ganha-pão comercial e não um órgão de complôs tecnocráticos (CAMPOS,
1994, p. 379).

Mario da Silva Pinto conta que:

Quando eu fui me despedir do Roberto Campos no Banco Nacional do

\footnotetext{
${ }^{143}$ Vale notar que Campos não menciona Ótavio Dias Carneiro, que descolou sua carreira do grupo dos diplomatas da área econômica reunidos ao redor de Campos. Permanecendo ligado a San Tiago Dantas, Carneiro atuou no governo Jango como Ministro da Indústria e Comércio e como diretor da SUMOC (CARNEIRO, 2005).
} 
Desenvolvimento Econômico, ele me disse assim: "Não se preocupe, Mario. Nós vamos continuar juntos. Vamos fazer aí uma firma de consultoria, com a qual é possível que a gente ganhe dinheiro, e que vai evitar que muita gente o perca." Eu digo: "Estou às suas ordens, Roberto." Ele levou uns dez, 15 dias, e fez junto comigo o quadro das pessoas que iriam trabalhar conosco (PINTO, 1988, p. 93).

A dupla motivação que Campos e Lucas Lopes alegam ter tido para a criação da consultoria era trazer os seus jovens aliados que teriam perdido seus salários complementares ao acompanhá-los na saída do governo e manter unido o grupo de "economistas tecnocratas" que tinham conseguido consolidar (Roberto Campos in: ALBERTI et al., 2002, p. 66). A citação de Campos, acima, revela que ele reafirma a simples necessidade econômica pessoal dos envolvidos, em busca de maiores rendimentos, contra a interpretação da iniciativa em termos estratégicos mais amplos, de um grupo que pretendia continuar interferindo na vida econômica do país, mantendo-se apto a retornar ao poder governamental, neste sentido podendo ser considerado um think tank. De fato, a manutenção da unidade da equipe na consultoria permitiu que Campos, uma vez designado ministro extraordinário do planejamento pelo general Humberto de Alencar Castello Branco, recrutasse ali mesmo sua equipe.

A escolha de Campos para o Ministério do General Humberto Castello Branco é uma das razões pelas quais a CONSULTEC é frequentemente associada ao golpe de 1964. A segunda razão é a participação de alguns membros da consultoria, como Jorge Oscar Flôres e Roberto Campos, no Instituto de Pesquisas e Estudos Sociais (IPÊS), que forjou a aliança entre empresários, militares e técnicos contra o governo de João Goulart ${ }^{144}$. Uma pessoa chave no IPÊS era Glycon Paiva, amigo de DNPM e de BNDE dos sócios da CONSULTEC (LOPES, 1991, p. 281). A terceira razão é que em 1960 a CONSULTEC foi contratada pelo professor da universidade de Harvard, Lincoln Gordon, para produzir estudo que ajudou a subsidiar o programa norte-americano para a

\footnotetext{
144 “A idéia de criação do IPÊS surgiu de uma série de reuniões informais de homens de negócios do Rio de Janeiro, realizadas a partir do início de 1961. A renúncia do presidente Jânio Quadros, em agosto daquele ano, e a subseqüente posse de João Goulart — vista com desconfiança pelo empresariado devido às suas ligações com o movimento sindical - deram uma nova dimensão aos encontros que vinham sendo mantidos. Preocupados com a inflação, com a falta de planejamento econômico do governo e, sobretudo, com a crescente influência de radicais comunistas e o aumento da intervenção estatal, os empresários resolveram intensificar suas articulações". "Fundada oficialmente em 2 de fevereiro de 1962, com o objetivo de 'defender a liberdade pessoal e da empresa, ameaçada pelo plano de socialização dormente no seio do governo João Goulart', através de um 'aperfeiçoamento de consciência cívica e democrática do povo'. Após o triunfo do movimento militar de março de 1964, de cuja preparação participou ativamente, reduziu suas atividades, desaparecendo completamente em 1972". Tomaram parte nas atividades do IPÊS Ôscar Mello Flôres, Glycon de Paiva, Israel Klabin, Dênio Chagas Nogueira, Helio Beltrão, Alexandre Kafka, Julian Chacel e José Garrido Torres (DHBB, verbete IPÊS; RAMÍREZ, 2005, pp. 616-628).
} 
América Latina batizado "Aliança para o Progresso". Gordon foi embaixador dos EUA no Brasil de 1961 a 1966, posição que lhe rendeu atuação destacada na promoção do apoio norte-americano ao golpe de 1964 (Carlos Ivan Simonsen Leal in: ALBERTI et al., 2002, p. 56; DHBB, verbete Lincoln Gordon; GREEN e JONES, 2009).

A associação da CONSULTEC com o golpe na obra do cientista político René Dreyfuss, 1964: a conquista do Estado: ação política, poder e golpe de classe, provocará reações de Campos e vários outros membros da consultoria. Eles empenham-se em desqualificar a interpretação segundo a qual teriam trabalhado intensamente pelo golpe. Por exemplo:

A CONSULTEC não foi uma célula conspiradora, foi um núcleo de pessoas que foram importantes para aquilo que, a meu ver, foi um movimento de modernidade. Havia ali uma reunião de pessoas inteligentes, preparadas, ligadas no Brasil, querendo um país moderno e mais justo econômica e socialmente, e o movimento de 64 veio buscar essas pessoas [...] [ela] nunca teve nada de entreguista, foi uma nacionalista com $\mathrm{N}$ imenso, mas que queria desesperadamente plugar o país na modernidade (Luiz Fernando da Silva in: ALBERTI et al., 2002, pp. 54, 63).

Roberto Campos classifica de "fantasiosas" as interpretações da CONSULTEC como um anel de "poder burocrático empresarial", servindo de "think tank" para projetos conspiratórios de conquista do poder. Segundo ele:

Essa suspicácia foi alentada pelo fato acidental que vários dos participantes da
CONSULTEC, como eu próprio, Mario Simonsen e Mauro Thibau [...], nos
tornamos ministros de Estado, em diferentes períodos da Revolução, enquanto
outros vieram a ocupar cargos de destaque na administração. Isso não resultou de
nenhum projeto político, e sim do simples fato de que alguns dos melhores
cérebros tecnocráticos da época, imbuídos do espírito de 'racionalidade
capitalista', foram recrutados pela CONSULTEC para a análise de projetos
específicos. O que era um 'bico' financeiro para funcionários mal-pagos passou a
ser interpretado, dentro da paranóia ideologizante da época, como uma semente
de conspiração técnico-burocrática[145] (CAMPOS, 1994, pp. 379-380).

Já Lucas Lopes desqualifica tal acusação dizendo que "a CONSULTEC merece um ensaio sobre sociologia do boato" (LOPES, 1991, p. 281).

A CONSULTEC funcionava no mesmo prédio que a empresa Klabin, na Avenida Rio Branco. Roberto Campos tinha sido o primeiro patrão de Israel Klabin, que fora trabalhar com ele depois de terminar o curso de engenharia, por indicação de seu tio, Horácio Lafer. Klabin cedeu os móveis e um de seus funcionários, Vítor da Silva, que passou a ser secretário executivo da consultoria. Para Israel, eles formavam "um pequeno grupo com base cultural idêntica e uma responsabilidade social, econômica, financeira e

\footnotetext{
${ }^{145}$ Ironicamente, Campos usa Dreyfuss como obra de referência ao falar do ISEB em suas memórias (CAMPOS,
} 1994, p. 301). 
ideológica muito grande" (Israel Klabin in: ALBERTI et al., 2002, pp. 65-66; PINTO, 1988, p. 131). Os Klabin frequentavam muito a casa de Eugênio Gudin e lá encontravam recorrentemente os Simonsen. Gudin era primo de Mario Simonsen ${ }^{146}$, pai do então jovem Mario Henrique Simonsen (Luiz Fernando da Silva Pinto in: ALBERTI et al., 2002, p. 66). Ao falar sobre os laços entre os Gudin, os Chacel e os Simonsen, Julian Chacel declara: "o Rio de Janeiro era pequeno, e as famílias se conheciam. No fundo eram todos um bando de aristocratas, de uns tempos que não voltam mais" (Julian Chacel in: ALBERTI et al., 2002, pp. 82-83).

No livro Mario Henrique Simonsen: um bomem e seu tempo (2002), que reúne depoimentos de homenagem e reconstrução de sua trajetória (diversamente de tantos de seus pares sociais ele morreu sem deixar um largo depoimento biográfico), sua figura é recoberta por uma salva de adjetivações com sentidos que remetem à inteligência. São usadas no livro as caracterizações: "Aluno excepcional"; "Nunca deixou de tirar o primeiro lugar onde quer que entrasse"; "Se tornou um mito no Santo Inácio por saber antes do ano começar tudo que seria ensinado"; "Ganhou vários prêmios de excelência acadêmica". "O melhor aluno que eu tive"; "Ele era la jeunesse dorée, o garoto prodígio, tinha uma cabeça muito bem arrumada, um talento quantitativo, uma facilidade de trabalhar com matemática"; "Matemático nato"; "Memória, raciocínio lógico límpido e excepcional"; "De longe o melhor projetista"; "Rapidez fantática [de raciocínio]"; "Estrela absoluta"; "Intelectual formidável”; "Aristocrata do pensamento"; "Sabidamente brilhantíssimo"; "Talvez o único verdadeiro gênio que eu conheci”; “"O mais brilhante de todos"; "Cabeça privilegiada"; "Cérebro privilegiado"; "Tinha memória absoluta"; "Pessoa realmente superdotada"; "Genialmente inteligente"; "Nunca convivi com uma pessoa mais inteligente do que ele"; "Muito arguto"; "Ele era fulminante" (ALBERTI et al., 2002).

Sobre seu estilo de vida dizem os depoimentos que "era guloso, almoçava de maneira exagerada, fumava de maneira exagerada, bebia de maneira exagerada" (Lindolpho de Carvalho Dias in: ALBERTI et al., 2002, p. 39). "Mario era uma figura excepcional. Agora, do ponto de vista físico, saúde, tudo errado. Quatro maços de

\footnotetext{
${ }^{146}$ Dionísio Dias Carneiro conta que “a primeira vez que ouvi falar do Mario Henrique foi pelo Inácio Rangel, e com referência ao Gudin. Naquele seu jeito, o Inácio virou-se para mim e disse assim: 'Rapaz, conheci um sobrinho do Gudin que parece avô do Gudin! Tem idéias mais antigas que as do Gudin! Prefiro o Gudin...' Tempos depois é que me dei conta de que aquele era o Mario Henrique..." (CARNEIRO, 2002, p. 109).
} 
cirgarro por dia. Mario era caracterizado por ser o homem dos excessos. Trabalhar, era trabalhar muito. Na hora de sentar numa mesa para jogar qualquer coisa, lá na casa dele, jogava muito. Ficavam até de madrugada, ele e a Iluska jogando. Tudo ele fazia em excesso" (Arlindo Lopes Corrêa in: ALBERTI et al., 2002, p. 76). "Mario fumava muito, punha fumaça pelo nariz, se agitava muito, conclusão: era o Dragão. Eu o chamei a vida inteira de Dragão, ou então Drago" (Luiz Fernando da Silva Pinto in: ALBERTI et al., 2002, p. 76). "Fumava que nem um condenado, tinha alguns ataques de nervos para botar as equações no quadro e às vezes escrevia com o cigarro e fumava o giz" (Maria da Conceição Tavares in: FARO e GATTO, 1994, p. 64), sendo atribuído aos inúmeros cigarros o tumor que causou sua morte aos 61 anos.

Cabe interpretar seus traços de personalidade na configuração social na qual estava inserido (ELIAS, 1995). A pergunta que deve ser colocada é pois, qual inflexão no espaço brasileiro dos economistas Mario Henrique representava? Os muitos adjetivos a ele dirigidos associam sua inteligência à matemática e ao raciocionio lógico. Seu grande mérito como professor talvez tenha sido, precisamente, difundir uma versão matematizada da economia para seus alunos e para aqueles que estudaram com suas apostilas. Nisto ele acompanhava a tendência internacional de aproximação da economia com a matemática encarnada na Cowles Comission que doravante viria a dominar a produção da ciência econômica (item 4.4). Sua dita genialidade anunciava, assim, um deslocamento da configuração na qual se encontrava. Seus alunos, ao estudar no exterior, iam ao encontro da mesma matematização com a qual entraram em contato nas preleções de Mario Henrique, preparando-se para consolidar o modelo que ele lutara para propagar.

Corrobora a ideia de que a matematização da economia era o ideal de Simonsen, a lista de suas constatações sobre as principais fontes de debilidade do ensino e a lista das disciplinas que considera ideiais para a formação de economistas. Em ambos os casos nota-se que a matemática, a estatística e o raciocínio lógico aparecem em primeiro lugar:

De um modo geral, os defeitos mais freqüentes são: a) falta de conhecimento básico de matemática e estatística; b) dificuldade de raciocínio lógico e incompreensão do método científico: a maioria dos economistas recém-saídos das faculdades não sabe o que é e o que pretende ser um modêlo; isso lhes torna bastante difícil manipular a análise econômica (ou qualquer ciência); c) conhecimento desintegrado de análise econômica: a maioria das faculdades dá aos alunos idéias mais ou menos vagas sôbre economia, que talvez consigam familiarizar os economistas com o jargão da profissão, mas que raramente são apresentadas como um sistema integrado; como conseqüência, os economistas ficam quase sem possibilidade de usar êsses conceitos em problemas práticos; $d$ ) falta de informação institucional: a maioria dos economistas sai das escolas sem 
conhecer o funcionamento dos instrumentos de política econômica adotados no Brasil - sistema fiscal, sistema financeiro, sistema cambial, órgãos de fomento, etc. (SIMONSEN, 1966, p. 20).

Ele julgava que as disciplinas de matemática, estatística e econometria, microeconomia e macroeconomia deveriam constituir o núcleo fundamental do curso, exigido em caráter obrigatório de todos os alunos (SIMONSEN, 1966, p. 26). Encarnava, assim, a nova economia, sendo capaz de divulgar no Brasil padrões em ascensão no espaço global da ciência econômica, sem nunca ter estudado ou lecionado fora do país (João Paulo dos Reis Velloso in: ALBERTI et al., 2002, p. 70). Cabe indagar quais as condições sociais teriam permitido que ele prefigurasse a nova ciência econômica?

Segundo o sobrinho de Mario Henrique Simonsen, Carlos Ivan Simonsen Leal, atual presidente da Fundação Getúlio Vargas, o avô de Simonsen era médico, com doutorado em Paris. Foi um dos primeiros psiquiatras brasileiros, professor catedrático na Faculdade de Medicina no Rio de Janeiro, além de atuar como clínico particular de membros das elites cariocas. Até Mario Simonsen, pai de Mario Henrique, todos os Simonsens estudaram na Europa e teriam sido poliglotas. Ele foi o primeiro a estudar no Brasil, bacharelou-se em direito mas nunca exerceu a profissão pois deixou-se levar por sua vocação comercial e financeira, envolvendo-se com o comércio internacional. Mario Henrique cresceu cercado por médicos e engenheiros, pelos literatos amigos de seu pai e por uma excelente biblioteca (Carlos Ivan Simonsen Leal in: ALBERTI et al., 2002, pp. 22-25).

Diz-se de Mario Henrique que jogava xadrez e que "gostava de música clássica de modo geral, especialmente de ópera, sabia óperas inteiras de cor" (Lindolpho de Carvalho Dias in: ALBERTI et al., 2002, p. 39). Vivia no municipal e decorava óperas mesmo em línguas que não conhecia, como o russo. Simonsen ocuparia a presidência da Orquestra Sinfônica Brasileira de 1988 a 1997, sucedendo Octavio Bulhões que, por sua vez, sucedera Eugênio Gudin. A caracterização que Carlos Ivan faz do tio é similar às dos professores que o antecederam na presidência da orquestra: Gudin e Bulhões. Também Simonsen descendia de uma família com profundas raízes na elite brasileira, recebera uma educação cosmopolita de elite em casa e na escola que nutrira seu gosto pelo estudo e pela música clássica. Simonsen foi aluno do Colégio Santo Inácio. Um de seus colegas da época oferece o seguinte depoimento acerca da escola:

Fui aluno do Santo Inácio, depois fui reitor, e trabalhei também como diretor no 
colégio dos jesuítas em São Paulo, o São Luís. O Santo Inácio sempre teve menos concorrentes do que o São Luís. Havia no Rio o São Bento, que é um colégio tradicional, muito bom, o Santo Antônio Maria Zacaria, e só depois vieram o São Vicente, nas Laranjeiras, e o Santo Agostinho, que também é muito bom. Durante muito tempo o Santo Inácio teve um destaque muito grande, praticamente imperou. Além disso, o Rio era a capital do país. Logo o colégio tinha muitos filhos de ministros, de senadores, de deputados, que continuaram, muitos deles, na política. Eu até assisti uma vez a uma entrevista do presidente Sarney na televisão, em que ele dizia que uma das grandes frustrações que tinha na vida era não ter sido aluno do Colégio Santo Inácio, porque todo mundo de destaque na sociedade era ex-aluno de lá. E ainda é. Por exemplo, quando fui reitor, o colégio tinha netos de cinco ex-presidentes da República. Tenho colegas que venceram na vida e que dizem que devem isso à disciplina do Santo Inácio, que os formou para estudar e para levar a vida a sério. A disciplina era um pouco rígida naquele tempo, agora está bem mais aberta. Por exemplo, naquele tempo a missa no domingo era obrigatória. A gente tinha uma caderneta em que se marcava presença nos dias de aula e também na missa de domingo. Nas missas mais solenes, usávamos farda branca; nas outras, farda cáqui. Usar farda no calor exige disciplina. No Santo Inácio também havia uma interesse muito grande pelo esporte. Existe aquela máxima, que é antiga, mas que também é atribuída à pedagogia dos jesuítas: mens sana in corpore sano" (Dom Aloysio José Leal Penna, in: ALBERTI et al., 2002, p. 25).

A educação rígida sob a tutela dos padres é semelhante àquela presente na descrição que Lucas Lopes faz do Colégio Arnaldo de Belo Horizonte. A diferença do Santo Inácio é que ele era um dos principais colégios de católicos da capital, o que fazia com que abrigasse os filhos da elite política e vários dos futuros membros da classe dirigente. Quando Mario Henrique concluiu o ensino secundário, em 1952, a Pontifícia Universidade Católica do Rio de Janeiro (PUC-RJ), fundada em 1946, ainda não tinha tradição no ensino de engenharia. Um colega conta que a opção de Simonsen e dele pela Faculdade Nacional de Engenharia do Rio de Janeiro advinha também de um desejo de conhecer o "mundo real" fora dos domínios controlados da Igreja nos quais cresceram (João Reynaldo Pereira da Costa in: ALBERTI et al., 2002, p. 29).

Os professores da Escola Nacional de Engenheria Jorge Kafuri e seu cunhado Antonio Dias Leite, membros do primeiro grupo recrutado por Gudin para compor o corpo de professores da FGV e da FNCE, promoveram a introdução do treinamento em economia na formação dos estudantes de engenharia. Intencionavam formar engenheiros que fossem capazes de fazer business plans: lidar com orçamentos, estatísticas, obras públicas, planejamento etc. Eles criaram uma especialização em engenharia econômica, com duração de quatro horas por noite, cinco noites por semana, 32 semanas. Kafuri lecionava economia geral; Dias Leite, macroeconomia e Genival Santos, contabilidade social. O curso de engenharia econômica da UFRJ, inclinado para o ensino das técnicas de administração para engenheiros, surgiu ao mesmo tempo que as primeiras 
especializações em engenharia de produção, na segunda metade dos anos 1950, momento no qual "as empresas multinacionais começam a se instalar com maior peso e os seus departamentos já possuíam cargos específicos para os industrial engineers" (MARTINS, 2015, pp. 88-89). Mario Henrique Simonsen ingressou no curso de engenharia econômica e foi convidado por Dias Leite para trabalhar na consultoria que ele dirigia, a Engenharia Econômica ECOTEC (Antonio Dias Leite in: ALBERTI et al., 2002, p. 46; Augusto Jefferson Lemos in: ALBERTI et al., 2002, p. 59; Carlos Ivan Simonsen Leal in: ALBERTI et al., 2002, p. 41; Luiz Fernando da Silva Pinto in: ALBERTI et al., 2002, p. $53)$.

Os colegas de Simonsen contam que ele, desde o colégio, tinha especial interesse e facilidade no estudo de matemática. "A formação em matemática foi o que o distinguiu, porque a maior parte dos economistas não sabia - e alguns ainda não sabem - matemática e têm dificuldade para fazer certas análises que demandam um certo arcabouço matemático e estatístico" (Lindolpho de Carvalho Dias in: ALBERTI et al., 2002, p. 41). Durante a graduação em engenharia Simonsen frequentou um seminário de aprofundamento em matemática pura, oferecido por dois professores que depois criariam o Instituto Nacional de Matemática Pura e Aplicada (IMPA). O grupo era frequentado também por Lindolpho de Carvalho Dias, que se tornou colega de estudos e amigo próximo de Mario Henrique. Lindolpho era cunhado de Mario da Silva Pinto e viviam as duas famílais na mesma casa. Depois de desentender-se com os sócios da ECOTEC, Simonsen procurou Lindolpho e pediu que o indicasse para Mario da Silva Pinto. Foi assim que chegou à CONSULTEC ${ }^{147}$ (Luiz Fernando da Silva Pinto in: ALBERTI et al., 2002, pp. 54).

O filho de Mario da Silva Pinto, Luiz Fernando da Silva Pinto, conta que um dia foi procurar o pai na CONSULTEC e encontrou casualmente com Mario Henrique, amigo de seu tio, que ofereceu a ele um estágio na consultoria. Eram estagiários na CONSULTEC naquele momento, Arlindo Correa, colega de colégio de Carlos Eduardo da Silva Pinto, o outro filho de Mario da Silva Pinto, e Augusto Jefferson de Oliveira Lemos, sobrinho de Roberto Campos. Seu pai, Tito de Oliveira Lemos, casado com a irmã de Roberto Campos, era dentista, fez uma especialização em economia do setor de

\footnotetext{
${ }^{147}$ Na graduação em engenharia já havia sido aluno de outro sócio da CONSULTEC, Jorge Ôscar Mello Flores.
} 
papel e celulose e tornou-se funcionário concursado do BNDE ${ }^{148}$. Tito saiu com Campos do governo, chegou a passar pela CONSULTEC, mas como especialista da área de papel e celulose foi pouco depois chamado para trabalhar com os vizinhos Klabin (Augusto Jefferson Lemos in: ALBERTI et al., 2002, pp. 59-60; Luiz Fernando da Silva Pinto in: ALBERTI et al., 2002, pp. 54-56). Entre 1965 e 1966 estagiou também na CONSULTEC Francisco Lopes, o segundo filho de Lucas Lopes que, em 1968-1969, passaria a ser aluno de Mario Henrique Simonsen na Fundação Getúlio Vargas (item 4.0).

Além de trabalhar na consultoria, Mario Henrique formou, em sociedade com Julio Bozano $^{149}$, a administradora financeira Bozano, Simonsen \& $\mathrm{Cia}^{150}$, uma das primeiras do gênero no país (Luiz Fernando da Silva Pinto in ALBERTI et al., 2002, p. 78; Julio Bozano in: ALBERTI et al., 2002, p. 79). Ao mesmo tempo, lecionava em quatro lugares: no curso de engenharia econômica da Nacional de Engenharia; no IMPA; no curso de especialização em economia do Conselho Nacional de Economia e na Fundação Getúlio Vargas, no Centro de Aperfeiçoamento de Economistas. Os dois últimos foram, juntamente com os cursos oferecidos pelo Centro CEPAL-BNDE, os embriões da pósgraduação em economia no Brasil.

Em 1959, a FGV-RJ havia começado a enviar egressos do curso de economia aos Estados Unidos e à Inglaterra com o apoio da Rockefeller Foundation ${ }^{151}$. Chacel conta que Simões Lopes, Gudin e ele estavam interessados em transformar essa experiência pioneira em um programa mais amplo e sistemático. Procuraram então o diretor do ponto IV no Brasil com a intenção de pedir financiamento para o projeto de instalação, no IBRE, de um Centro de Aperfeiçoamento de Economistas para os egressos das faculdades de economia. Chacel se encarregou do projeto e solicitou a ajuda do professor

\footnotetext{
${ }^{148}$ Nas listas de aprovados dos concursos do BNDE de 1955, 1956 e 1959 não há nenhum candidato com sobrenome Oliveira Lemos. Não foram encontradas no BNDES informações sobre outros concursos naquele período.

${ }^{149}$ Simonsen conhecera Bozano no Centro de Instrução de Oficiais da Reseva da Marinha (Julio Bozano in: ALBERTI et al., 2002, p. 78).

${ }^{150}$ Simonsen "montou todo o programa de capitalização da financeira. Quer dizer, as tabelas que os sujeitos usam para dizer quanto é que você vai pagar de prestação, ele montou aqui, na sala da EPGE, num computadorzinho em que eu... - ou um pré-computador, vamos chamar aquilo de um pré-computador -, em que eu e o Chico programávamos... Não era nem furando cartão, eram cartões magnéticos. Era uma Olivetti, um computador Olivetti que era uma desgraça para programar, e que eu e o Chico é que ficávamos fazendo coisas ali. E ele montou todo o programa de capitalização do Banco Bozano Simonsen - do que viria a ser o Banco Bozano Simonsen em cima daquilo" (CARNEIRO, 2003, pp. 20-21).

${ }^{151}$ De acordo com texto mimeografado de Ney Coe de Oliveira, sete economistas da FGV teriam recebido essa bolsa da Fundação Rockefeller. No período do CAE, de 1961 a 1964, diz ele, outros nove bolsistas teriam ido estudar no exterior (Ney Coe de Oliveira apud D'ARAÚJO, 1999, p. 178). Entre os nove bolsistas do CAE estariam, provavelmente: João Paulo dos Reis Velloso, Hamilton Tolosa, Jorge Vianna Monteiro, Alkimar Moura, Claudio de Moura Castro, Clóvis Cavalcanti, Flávio Versiani e Edmar Bacha.
} 
Ney Coe de Oliveira para organizar o novo centro. De acordo com ele:

\begin{abstract}
De início, o propósito do curso era fazer com que o egresso da Faculdade de Economia pudesse obter uma bolsa e chegasse aos Estados Unidos com um conhecimento de inglês suficiente, o que a gente chama de reading knowledge; era também reduzir o hiato de conhecimento de teoria econômica que nós tínhamos em relação aos alunos americanos e ingleses que iam fazer a pós-graduação [...]. O CAE começou a funcionar em 1960, e havia o problema de constituir um corpo docente. Foi nesse momento que veio o Mario Henrique (Julian Chacel in: ALBERTI et al., 2002, pp. 84-85).
\end{abstract}

Simonsen juntou-se ao CAE em 1961, segundo Chacel por indicação de Roberto Campos, com quem trabalhava na CONSULTEC. Julian declara que Gudin haveria perguntado se isso não soaria a nepotismo, já que Mario Henrique era filho de seu primo (Julian Chacel in: ALBERTI et al., 2002, p. 81). Mario Henrique tornou-se rapidamente o principal professor do novo Centro. Contam seus alunos que ele dava aula de tudo: microeconomia, macroeconomia, matemática, economia internacional, finanças públicas. O cursinho do Mario Henrique, como apelidavam o CAE, era uma escola tão artesanal que funcionava em uma "casinha lá no fundo do estacionamento da Fundação que também podia cair a qualquer momento" e que não tinha ar-condicionado, só uns ventiladores barulhentos (Augusto Jefferson Lemos in: ALBERTI et al., 2002, p. 101). O quadro-negro, sustentado por um cavalete, caía quando se escrevia com muita força e quando chovia o próprio Simonsen "botava lá uns baldinhos" para evitar inundações (José Luiz de Carvalho in: D’ARAÚJO, 1999, p. 195).

Além de Simonsen, eram professores no CAE: Maria da Conceição Tavares, Jessé Montello, Margareth Hansen Costa e Isaac Kerstenetzky. Simonsen convidou também para lecionar na FGV seus colegas de CONSULTEC, Jefferson Lemos e Luiz Fernando da Silva Pinto, que deveriam encarregar-se do ensino de elaboração e análise de projetos, que tinha a intenção de "ancorar o curso no chão". Alguns anos depois, Fernando convidou o pai, Mario da Silva Pinto, para ser professor também. Ele passou a ocupar-se dos cursos de treinamento em Economia Aplicada, apelidados de "cursinho Walita", por “abrandar consideravelmente a frustração dos estudantes reprovados [nos cursos de matemática e economia pura], dando-lhes importante instrumental prático para a vida profissional” (João Paulo dos Reis Velloso in: ALBERTI et al., 2002, pp. 87-89; José Luiz de Carvalho in: D’ARAÚJO, 1999, p. 196; Julian Chacel in: ALBERTI et al., 2002, p. 81; Luiz Fernando da Silva Pinto, in ALBERTI et al., 2002, pp. 102-103; BACHA, 2014, p. 7; SIMONSEN, 1966, p. 29). 
Foram alunos do CAE o Ministro João Paulo dos Reis Velloso, que foi para Yale cursar o mestrado, Hamilton Tolosa, que foi fazer pós-graduação na Universidade da Pensylvannia, e Hélio João Soares, que não foi para o exterior. Os três farão parte dos primeiros quadros do EPEA. Clóvis Cavalcanti, que também foi para Yale, tornou-se funcionário da SUDENE e professor da Universidade Federal de Pernambuco (UFPE). Jorge Vianna Monteiro, que foi aluno da UFRJ, tornou-se professor da PUC-RJ. Além deles havia um grupo de mineiros formados na Economia da UFMG: Edmar Bacha, que foi estudar em Yale, Flávio Versiani, que foi para Vanderbilt, Alkimar Moura, que esteve em Berkeley e Stanford, e Claudio de Moura Castro, que passou por Yale, Berkeley e Vanderbilt.

Edmar Bacha (1942), nascido em Lambari, Minas Gerais, é neto, por parte de pai, de comerciantes libaneses. Seu avô libanês veio para o Brasil com um primo em busca de melhores oportunidades de vida e, uma vez estabelecido, voltou para o Líbano para buscar a esposa. O pai de Edmar, Felício Bacha, só estudou até o ginasial, foi comerciante e trabalhou também como secretário da prefeitura de Lambari, tendo também parentes envolvidos na vida política das cidades de Lambari e de Cambuquira. Pelo lado materno Edmar era descendente de uma família de políticos petebistas. Seu avô, João de Almeida Lisboa, era dono de uma farmácia e foi eleito prefeito de Lambari e deputado federal. João Lisboa Júnior, o irmão mais velho de sua mãe, era médico e foi prefeito de Lambari, seguindo os passos do pai. A mãe de Edmar, Maria de Jesus Lisboa Bacha, estudou no colégio Sion de Campanha, onde as filhas da elite aprendiam francês e boas maneiras, e lecionou no curso primário do colégio João Bráulio Júnior, em Lambari. A família era afeita à literatura: duas das irmãs de Maria foram eleitas para a Academia Mineira de Letras: a poetisa Henriqueta Lisboa e a professora emérita da UFMG, Alaíde Lisboa de Oliveira. Um dos irmãos, José Carlos Lisboa, também escritor e membro da Academia Mineira de Letras, era Bacharel em Direito pela Universidade do Brasil e foi professor na UFMG e na UFRJ (DHBB, João de Almeida Lisboa; Entrevista de Edmar Bacha à autora, 2012).

Felício Bacha faleceu quando Edmar Bacha tinha 9 anos. A mãe decidiu então transferir-se com seus 7 filhos para Belo Horizonte. Na capital Bacha passou a estudar no Colégio Santo Antônio, dirigido por franciscanos holandeses. Ele conta que a mãe e as irmãs eram religiosas praticantes, que rezavam o terço todos os dias, mas nega ter sido 
influenciado pelo catolicismo em sua trajetória de vida. No Colégio Santo Antônio estudou francês - com ajuda da mãe, que era fluente no idioma - e teve aulas particulares de inglês na casa de um professor em Belo Horizonte. O espanhol conta ter aprendido na vida (Entrevista de Edmar Bacha à autora, 2012).

Bacha conta que todos os colegas do Colégio Santo Antônio queriam ser engenheiros. Diz que “a escolha óbvia em Belo Horizonte era engenharia mecânica; cheguei a fazer um vestibular para engenharia, mas não passei na primeira rodada" (BACHA, 1996, p. 232). Ele conta que a família "presumia que eu ia fazer engenharia desde sempre. Quando eu disse para a minha mãe que eu não ia fazer a segunda época do vestibular [de engenharia], ela falou: o seu pai gostaria tanto que você fosse engenheiro. Aí que eu soube que tinha influência dos pais" (Entrevista de Edmar Bacha à autora, 2012). Segundo ele, "Eu estava insatisfeito de ter que seguir uma carreira de engenharia, porque gostaria de ter algo que fosse mais 'político', mas também não queria ir para a sociologia, porque era muito pouco 'científico'” (Edmar Bacha in: ALBERTI et al., 2002, p. 94). A economia tinha a vantagem de contemplar o interesse pela política, adquirido no ambiente familiar, visto que além dos diversos parentes que ocuparam cargos públicos na vida política mineira, Edmar foi influenciado por seu cunhado, Guy de Almeida, jornalista ligado ao PCB, intensamente envolvido com a política, que se exilou durante o governo militar. A desvantagem da opção pelas ciências econômicas advinha do baixo grau de reconhecimento social da profissão. Bacha declara "eu sofri muito por não estar fazendo uma profissão nobre, né?” (Entrevista de Edmar Bacha à autora, 2012).

Em 1960 ingressou na FACE, onde integrou o grupo dos bolsistas (item 3.1), alunos que recebiam um salário mínimo para dedicar-se integralmente aos estudos universitários. Sobre a sua experiência na faculdade, comenta que gostava das áreas de matemática, estatística e comércio internacional e que seus escritos da época teriam sido influenciados por Ignácio Rangel, João Paulo de Almeida Magalhães e Roberto Campos. Não considera ter tido nenhum professor marcante nesse período. Segundo ele, influente mesmo foi Mario Henrique Simonsen, no CAE. Quando Edmar Bacha concluiu a graduação, em 1963, o curso de pós-graduação do Centro de Desenvolvimento e Planejamento Regional (CEDEPLAR) ${ }^{152}$ ainda não existia. Ele só foi criado, como

\footnotetext{
${ }^{152}$ Nos anos 1960 começaram a entrar na grade da FACE disciplinas voltadas para o estudo da economia regional, que serão marca importante da pesquisa em economia feita na UFMG. "Da criação do CEDEPLAR participaram professores da FACE/UFMG, que também eram técnicos do BDMG, Banco de Desenvolvimento
} 
Instituto de Desenvolvimento e Planejamento Regional (IDEPLAR), em 1967. As opções para dar continuidade dos estudos em economia que existiam eram o CAE, a especialização do CNE e a da CEPAL. O prospecto de seguir do CAE para os Estados Unidos funcionava como um fator de atração dos mineiros para o curso de Mario Henrique, no Rio de Janeiro (BACHA, 1996, p. 232; BACHA, 1998, pp. 197-198. Entrevista de Edmar Bacha à autora, 2012). Claudio de Moura Castro foi o primeiro dos mineiros da FACE a ingressar na pós-graduação da FGV no Rio de Janeiro. Ele conta:

Eu tinha a oportunidade, quando me formei, de fazer o concurso para o CAE,
no Rio, mas não quis me inscrever, porque tinha ganho uma bolsa, via USAID,
para fazer o MBA nos Estados Unidos, em Michigan [item 5.1] - lembremo-nos
de que aquele foi o período de abundância das bolsas americanas. A inscrição
para o concurso do CAE já tinha terminado, havia uma quota limitada de
candidatos, mas na última hora uma colega que estava inscrita desistiu. Resolvi
fazer o concurso na vaga que se abriu e passei. Mas continuei na dúvida se fazia
pós-graduação em economia ou em administração: em Michigan seria
administração e no CAE seria economia. Meu avô, Marcos Carneiro de
Mendonça, foi então comigo à casa do Simões Lopes, fundador e presidente da
Fundação Getúlio Vargas, e disse: "Este moço aqui tem uma bolsa de
administração e tem a possibilidade de estudar com o Mario Henrique" - que era
conhecido da minha família. Todo domingo, um dos comensais do jantar na casa
do meu avô era o Edgar Simonsen, tio do Mario Henrique. O pai dele, eu
conheci mal, mas também era amigo da família. A referência a Mario Henrique
Simonsen era portanto muito próxima. Meu avô perguntou: "O que ele deve
fazer?" Simões Lopes respondeu: "Vá estudar economia com o Mario" (Claudio
de Moura Castro in: ALBERTI et al., 2002, pp. 89-90).

Bacha, Flavio Versiani, Alkimar Moura, José Carlos de Oliveira e Denise Wiliamson seguiram o mesmo caminho em 1964, com a intenção de adquirir as "tinturas de micro, macro, matemática, estatística e inglês" (BACHA, 1998, p. 198) que os levariam para os EUA.

O envio dos alunos para o exterior, parte fulcral da proposta do CAE, foi facilitado por uma nova inflexão da política dos EUA para a América Latina que ocorreu no início dos anos 1960, quando a política externa norte-americana é revista após uma série de incidentes político-diplomáticos. As manifestações anti-estadunidenses que ocorreram na visita que o vice-presidente Richard Nixon fez à América Latina em 1958, a

de Minas Gerais, como Fernando Roquete Reis e Élcio Costa Couto e Álvaro Fortes Santiago, e então jovens professores da FACE como Paulo Haddad, José Alberto Magno de Carvalho e Carlos Maurício Carvalho Ferreira. Esta busca de relações entre teoria e política, entre teoria e planejamento tem marcado a vida do CEDEPLAR. De fato, tanto pela ênfase nos estudos regionais, urbanos e ambientais, quanto por abrigar um dos mais importantes centros de ensino e pesquisa em demografia do hemisfério Sul, o CEDEPLAR optou por valorizar temáticas e perspectivas, que têm sido pouco consideradas pelo mainstream, com prejuízos importantes para a compreensão da nossa realidade socioeconômica marcada por desigualdades regionais e pesados déficits sociais" (PAULA, 2006, p. 340-341). 
entrada do governo revolucionário cubano de Fidel Castro na órbita soviética e o episódio da malograda invasão da Baía dos Porcos, em 1961, fazem com que os EUA percebam que a América Latina, que acreditavam orbitar ao seu redor, não estava imune à sedução da União Soviética, razão pela qual decidiram contrabalançar a influência comunista com um programa de concessão de ajuda externa direta ao países da região: a Aliança para o Progresso.

Até o final dos anos 1950, prevalecera a negligência cordial dos EUA em relação à América Latina. Além dos encontros nos foros multilaterais, os EUA procuravam manter uma série de visitas diplomáticas do primeiro escalão do governo aos países do continente. Os latino-americanos, por sua vez, continuavam a frustrar-se com a incompatibilidade entre a promessa simbólica oferecida pela condição de aliados e a sua não realização material que resultava do constante adiamento dos almejados programas voltados ao desenvolvimento da região.

A tensão decorrente das expectativas divergentes fez-se notar de maneira explícita nas repetidas injúrias de que Richard Nixon foi alvo em sua excursão diplomática pela América Latina. No início de 1958, Nixon compareceu à posse do presidente Arturo Frondizi na Argentina e aproveitou para visitar o Uruguai, o Paraguai, a Bolívia, o Peru, o Equador, a Colômbia e a Venezuela, com o intuito de mostrar a boa vontade dos EUA em relação aos latino-americanos. O Secretário de Estado, John Foster Dulles, esteve no Brasil e o próprio presidente Eisenhower tinha visitas programadas à região. O forte sentimento anti-estadunidense que ecoava na América Latina fez com que Nixon fosse hostilizado em todos os pontos do roteiro, chegando a ser apedrejado e esputado. No Peru e na Venezuela, sua visita foi marcada por protestos populares tão fortes que os EUA chegaram a aventar uma operação militar para resgatar o vice-presidente, caso necessário (RIBEIRO, 2006, p. 47; SCHLESINGER, 1966, p. 194; SILVA, 1992, p. 16).

Nesse contexto de relações diplomáticas desgastadas pelas sucessivas negativas às solicitações de apoio econômico e pelas ingerências norte-americanas na política nacional em diversos dos países da região, JK apresentará uma proposta de cooperação regional nomeada Operação Pan-Americana. Após a viagem de Nixon, JK envia carta a Eisenhower na qual se declara solidário ao vice-presidente dos EUA e propõe uma revisão da política para o continente como estratégia para desfazer os atritos que geraram o incidente experimentado pelo vice-presidente dos EUA. Eiseinhower responde a JK 
concordando com o projeto mas exigindo um plano detalhado para a colaboração panamericana (MALAN, 1984, p. 87; RIBEIRO, 2006, p. 48).

A proposta, que teve início com a troca de cartas entre os presidentes, foi estudada por quadros do Itamaraty ${ }^{153}$ próximos de JK, como Miguel Osório de Almeida e Araújo de Castro, sendo oficializada em 20 de junho de 1958 em um discurso feito aos embaixadores das repúblicas americanas que foi transmitido por rádio e televisão para o país todo. No discurso de lançamento da OPA, JK procurava associar subdesenvolvimento e ameaça à estabilidade política, de modo que a harmonia social estaria vinculada à melhoria das condições sociais da população e esta, por sua vez, dependia da disponibilidade de recursos materiais e técnicos para atender às necessidades essenciais de seus povos. Argumentava ainda que a ausência de boas condições de vida deixava o continente vulnerável às promessas de justiça social feitas pelo comunismo, o que ameaçava as nações ocidentais. Seria, pois, necessária a cooperação dos países do continente para erradicar o subdesenvolvimento, difundir o ideal democrático e afastar o perigo soviético (ALMEIDA, 2009b, p. 60; SILVA, 1992, pp. 16-19).

A acolhida do governo Eisenhower à proposta de JK é fria. Na linha que predominava até então, os EUA procuravam evitar compromissos com qualquer iniciativa que implicasse em ajuda econômica à região. Alguns meses depois do lançamento da proposta, o secretário de Estado dos Estados Unidos, John Foster Dulles, em sua visita ao Brasil, após longas negociações, assina declaração conjunta com JK, na qual enfatizam a necessidade de combater o comunismo e o subdesenvolvimento, como dois lados de uma mesma política de segurança para as Américas. Em resposta ao rechaço experimentado na visita de Nixon, os americanos sinalizam favoravelmente à ampliação do diálogo com os países do sul e admitem, inclusive, a possibilidade de criação de uma instituição financeira interamericana, o futuro Banco Interamericano de Desenvolvimento (BID). As propostas da OPA foram, não obstante, tratadas com morosidade, especialmente no que diz respeito à proposta de cooperação econômica, já que os EUA preferiam negociar a ajuda externa bilateralmente, vinculada à sujeição dos países a

\footnotetext{
${ }^{153}$ As iniciativas de JK não transitaram por dentro do Ministério das Relações Exteriores, o que gerou ressentimento e protestos por parte de alguns dos diplomatas. A preferencia de parte da diplomacia, inclusive do Ministro era pelas relações bilaterais com os EUA e achavam inclusive que a OPA poderia prejudicar a diplomacia brasileira com os EUA. No mesmo período das outras reformas ministeriais JK substitui o Ministro das Relações Exteriores, nomeando Negrão de Lima, uma pessoa mais próxima dele que aderiu ao novo projeto de política externa. Quando Horácio Lafer assume o ministério em 1959 a orientação pró-OPA e a proximidade com o presidente se mantém (SILVA, 1992, pp. 20-21, 35).
} 
programas de estabilização e à adesão a um programa para a região como um todo ${ }^{154}$. A criação do BID, negociada em abril de 1959, foi a única vitória explícita dos latinoamericanos no período.

Uma mudança efetiva da política dos EUA para a América Latina só ocorreu após a aproximação da Cuba revolucionária de Fidel Castro com a URSS, pondo por terra a visão de que a região não deveria receber ajuda prioritária por estar distante do front de avanço comunista. De um lado, os Estados Unidos buscavam apoio dos latinoamericanos para sancionar e isolar economicamente Cuba, de outro, procuravam estabelecer medidas para evitar que outros países da região passassem para a órbita soviética. Surge a percepção de que a revolução não teria ocorrido se os EUA não tivessem sido tão prepotentes e negligentes em suas relações com a América Latina corroborando, portanto, as teses que JK havia apresentado pouco antes, vinculando a segurança do hemisfério à adequação das condições socioeconômicas.

As mudanças na política externa norte-americana tem lento despertar no final da gestão Eisenhower, em parte como resposta às criticas feitas pelos democratas na disputa eleitoral. Em visita ao Brasil em fevereiro de 1960, o Presidente dos EUA declara apoio inconteste à OPA e propõe que o ministro das Relações Exteriores, Horácio Lafer, visite os EUA para dar continuidade às negociações. Em julho de 1960, os EUA falam, pela primeira vez, na criação de um Fundo de Progresso Social na América Latina a ser administrado pelo BID e concordam em adotar uma série de medidas de assistência técnica e financeira para o desenvolvimento social e econômico da região, como proposto pela OPA. Lafer, em viagem aos EUA, defende: 1) a elevação do montante de recursos destinados ao desenvolvimento econômico da região; 2) a criação de programas de apoio técnico e financeiro para o desenvolvimento agrícola e industrial; 3) medidas para estabilização de preços dos bens primários; 4) um programa de cooperação técnica e financeira na área de educação; 5) a criação de uma agência interamericana na área tecnológica para estimular o desenvolvimento industrial e a produtividade (SILVA, 1992, pp. 36-37).

Com a vitória do democrata John F. Kennedy na eleição presidencial americana de 1960, a mudança da política externa toma forma no programa intitulado Aliança para o

\footnotetext{
${ }^{154}$ Recordando que foi precisamente nesse momento que o Brasil rejeitou a submissão aos programas de estabilização impostos, rompeu com o FMI e reatou relações comerciais com a URSS.
} 
Progresso, que é anunciado pelo novo presidente em março de 196155. Ele consistia em um plano de ajuda externa econômica e de cooperação técnica que deveria aplicar na América Latina 20 bilhões de dólares em dez anos, com o objetivo de promover o desenvolvimento econômico, social e político da região - e, obviamente, de evitar o surgimento de novas Cubas. A Aliança para o Progresso era calcada na ideia já presente no plano de JK segundo a qual o desenvolvimento econômico e as reformas sociais trariam estabilidade política para a região, legitimando os estados democráticos e prevenindo o avanço comunista, e seus procedimentos eram muito semelhantes aos propostos por Lafer. A melhoria das condições de moradia, educação, saúde e a redução da desigualdade social eram consideradas prioritárias pois, argumentava-se, são os alicerces da dignidade humana necessária ao desenvolvimento democrático. A Aliança para o Progresso combinava a ajuda externa voltada ao desenvolvimento econômico e à melhoria das condições materiais com um conjunto de reformas sociais, entre as quais incluía-se a reforma agrária, destinada a alterar a estrutura de propriedade da terra, atacando aquela que talvez fosse a mais crucial fonte de desigualdades em muitos dos países do continente, estando, pois, no cerne dos conflitos sociais que ali ecoavam ${ }^{156}$ (RIBEIRO, 2006, pp. 17-18; SMITH, 1993, pp. 71-73).

As ideias que fundamentaram o programa da Aliança para o Progresso já circulavam no universo acadêmico estadunidense nos anos 1950, sendo dois de seus principais propositores os $\mathrm{PhDs}$ em economia da University of Yale, Walt Rostow e Robert Millikan. Os dois economistas participaram de projeto financiado pelas Fundações Ford e Rockefeller e pela Central Intelligence Agency (CIA), conduzido pelo Center for International Studies do MIT, que procurava avaliar de que modo os EUA poderiam agir para promover a democracia e o desenvolvimento econômico dos países periféricos. Os estudos por eles realizados são peças centrais do que veio a ser nomeado de "teoria da modernização", uma interpretação do desenvolvimento fortemente influenciada pelos escritos de Max Weber, lidos via Talcott Parsons (RAMOS, 2006, pp. 30-32; RIBEIRO, 2006, pp. 19, 26, 54-56, 63; SMITH, 1993, p. 77; WIARDA, 1988, p. 103).

A teoria da modernização, que teve origem no Department of Social Relations de Harvard, e dali espalhou-se para outros centros de pesquisa, notavelmente para o MIT,

\footnotetext{
${ }^{155}$ Disponível em: https://legacy.fordham.edu/halsall/mod/1961kennedy-afp1.asp. Consultado em 4/1/2016.

${ }^{156}$ Nesse sentido, a Aliança para o Progresso era mais radical que o Plano Marshall, que procurava apenas reconstruir as condições econômicas sem promover transformações nas estruturas sociais (SMITH, 1993, p. 73).
} 
assumia que todos os povos poderiam desenvolver-se social e economicamente nos moldes capitalistas-ocidentais e postulava que a ajuda externa seria valiosa auxiliar na tarefa de promover a prosperidade, a democracia e a liberdade, através da difusão tecnológica, da melhoria das condições de vida e da educação. Independentemente das especificidades sociais, políticas e culturais de cada país, a estratégia para a promoção da modernização a partir do modelo econômico busca a conquista das elites locais para sua versão da modernidade da qual eram profetas, convencendo-as de que as mudanças sociais que propunham eram necessárias - inclusive, à preservação de seus privilégios (RAMOS, 2006, pp. 30-32; RIBEIRO, 2006, pp. 19, 26, 54-56, 63; SMITH, 1993, p. 77; WIARDA, 1988, p. 103).

A verba das universidades para os estudos do mundo subdesenvolvido foi elevada a partir da percepção do fracasso da linha de ação da política externa norte-americana para a periferia. Os textos produzidos pelos teóricos da modernização eram especialmente críticos da passividade dos anos republicanos, entendida como a principal responsável pelo crescente antiamericanismo e pela infiltração das ideias comunistas em áreas antes tidas como seguras, como a América Latina. Na era Kennedy, o poder dos economistas acadêmicos foi notavelmente ampliado (FOURCADE 2009, p. 107), tornando-se os formuladores da teoria da modernização importantes consultores e assessores de seu governo que buscava, precisamente, de uma nova linha de ação externa que pudesse atacar os problemas do subdesenvolvimento e da instabilidade da periferia.

Já na campanha presidencial, Rostow e Millikan colaboraram com Kennedy na formulação do programa de ajuda externa que daria origem à Aliança para o Progresso. Além deles integravam a equipe outro pesquisador do MIT, Rosenstein-Rodan, e quatro assessores provenientes de Harvard: o economista democrata de matriz keynesiana, John Kenneth Galbraith, o historiador Arthur M. Schlesinger, o advogado Richard Goodwin e o economista Lincoln Gordon. O grupo ficará conhecido como "Charles River School”, já que o MIT e Harvard encontram-se lado a lado ao longo do Charles River (CAMPOS, 1994, pp. 463, 531; RIBEIRO, 2006, pp. 56-59, 76-77; SCHLESINGER, 1966, p. 176; SMITH, 1993, p. 77).

Gordon fizera o PhD em economia na Universidade de Oxford concentrando seus estudos na área de desenvolvimento. Ao regressar aos Estados Unidos tornou-se professor em Harvard, conduzindo estudos sobre o desenvolvimento na América 
Latina $^{157}$. Transferiu-se para o Rio de Janeiro no final dos anos 1950, para coordenar pesquisa de Harvard sobre o Brasil. $\mathrm{Na}$ ocasião estabeleu convênios com economistas brasileiros como Octavio Bulhões, Miguel Osório de Almeida e com a equipe da CONSULTEC, onde estabeleceu o escritório a partir do qual coordenava os estudos encomendados por Harvard. Em 1961, Lincoln Gordon foi indicado para a posição de embaixador americano no Brasil, posto que ocupou até 1966. Sua missão inicial era implementar os projetos da Aliança para o Progresso ${ }^{158}$, tendo escrito o livro de divulgação, O progresso pela Aliança. Nele, Gordon aceita que "a ideia central da Aliança tenha tido origem, principalmente, na proposta da Operação Pan-Americana, do exPresidente Juscelino Kubitschek", chegando a sugerir que a proposta do Presidente Kennedy deveria ter sido chamada de "Operação Aliança” (GORDON, 1962, p. VII, 1). Desse modo, procurava conquistar a simpatia dos brasileiros e remediar as acusações de que o programa estadunidense era um plágio da proposta de JK sem o devido reconhecimento, caracterizando-o como desdobramento de uma iniciativa brasileira e não como uma imposição imperialista (GREEN e JONES, 2009, p. 72; LOPES, 1991, p. 272; RIBEIRO, 2006, pp. 132-133).

A Aliança para o Progresso ganha maior definição após a desastrosa invasão da Baía do Porcos, em 17 de abril, episódio que estremeceu, ainda mais, a relação dos EUA com a América Latina. Ali explicitou-se que a luva diplomática da ajuda externa ao desenvolvimento dos Kennedy não estava dissociada da possibilidade de emprego do cassetete militar e da ameaça à soberania nacional caso os países da região desafiassem a potência hegemônica. Seria esse lado militar da política da Guerra Fria que viria a interferir na política da região de maneira mais violenta nos anos 1960 e 1970, promovendo treinamentos anti-guerrilha, auxiliando no combate aos líderes de oposição e oferecendo suporte à instalação dos regimes militares de viés anticomunista (SMITH, 1993, pp. 76-77).

Como resposta ao episódio da Baía dos Porcos, o grupo que defendia o uso da diplomacia econômica como instrumento de política externa procurou acelerar a

\footnotetext{
${ }^{157}$ Segundo ele "as diversas formas de arte, literatura e filosofia latino-americanas devem ser bem vindas, mas não deve haver uma 'ciência econômica latino-americana', assim como também não deve haver uma física ou uma matemática latino-americanas" (Lincoln Gordon apud CRUZ, 1977, p. 13).

${ }^{158}$ Gordon, embrenhado na lógica da guerra fria, chegou a oferecer apoio militar e logístico aos conspiradores de 1964, expressando temer os possíveis desdobramentos da crise governamental que poderia levar à um golpe de matriz comunista (GREEN e JONES, 2009). O envolvimento de Gordon com a instauração da ditadura é, como dito anteriormente, uma das razões pelas quais a CONSULTEC é associada ao golpe militar.
} 
implementação do programa da Aliança, razão pela qual foi convocada, em maio de 1961, reunião extraordinária do Conselho Interamericano Econômico e Social da Organização dos Estados Americanos (CIES-OEA), em Punta del Este. A proposta final da Aliança anunciava o apoio às nações democráticas na busca pelo desenvolvimento econômico e social que seria alcançado por meio de uma melhoria na distribuição de renda e diversificação da matriz produtiva dos países da região via industrialização. Falava-se em incentivar a produtividade agrícola, se necessário promovendo reformas agrárias que melhorassem a estrutura e distribuição da propriedade da terra e ajudassem na estabilização dos preços dos bens agrícolas. A Aliança propunha que se trabalhasse para erradicar o analfabetismo e melhorar as condições de saúde da população, através da instalação de sistemas de tratamento de água e esgoto e da construção de habitações para populações de baixa renda. Por fim, ressaltava a importância do controle macroeconômico e da integração comercial para proteger os países latino-americanos dos efeitos deletérios da inflação, mas deixava claro que o crescimento econômico deveria ser a prioridade e não a estabilização econômica (LOUREIRO, 2011, p. 1; RIBEIRO, 2006, pp. 81-85; SILVA, 1992, p. 39).

Combinavam-se, na Aliança para o Progresso, as tradições desenvolvimentistas da América Latina e a intenção dos norte-americanos vinculados à teoria da modernização de adotar uma nova estratégia de influência na região. Aproximava-se bastante dos pontos que Lafer havia apresentado aos Estados Unidos quando viajara aos EUA um ano antes para falar sobre a OPA e transformava o BID, considerado a maior vitória da política externa de JK, em importante veículo do projeto. Além disso, a Aliança para o Progresso respondia diretamente às críticas de Prebisch e da CEPAL, contemplando a estabilização dos preços agrícolas e a industrialização como duas ferramentas para o desenvolvimento da região adotando assim o planejamento econômico como estratégia de ação política para a região ${ }^{159}$. Prebisch foi convidado a colaborar com a equipe do governo Kennedy

\footnotetext{
${ }^{159}$ Em seu relatório de atividades de 1962, a aprovação da Carta de Punta del Este, que oficializou o programa da Aliança para o Progresso, o BNDE credita as mudanças representadas pela Aliança à CEPAL dizendo: "coube, inegavelmente, à agência regional da Organização das Nações Unidas - a Comissão Econômica para a América Latina (CEPAL) - papel preponderante na luta contra o subdesenvolvimento econômico nos países latino-americanos. Os seus estudos sobre a natureza e causas do fenômeno, e as variantes próprias de cada país, levaram-na a uma campanha pertinaz pela mobilização total dos povos latino-americanos contra a estagnação econômica e a consequente miséria social. Somente através desta arregimentação total, e, ainda, com a participação consciente de toda população, seria viável lograr-se um ritmo satisfatório de desenvolvimento econômico. Um esforço global, como o exigido pelo combate ao subdesenvolvimento, impunha por sua vez aos governos nacionais uma participação enérgica no processo de crescimento econômico, incompatível com a
} 
para a América Latina, tendo redigido, com outros colegas latino-americanos, as recomendações que deram origem a oito dos dez pontos do discurso de JFK. Ele foi escolhido coordenador do "comitê de nove sábios" que deveria aconselhar aqueles que pretendiam solicitar financiamentos, mudando-se para Washington (DOSMAN, 2011, pp. 407-409).

Celso Furtado à frente da SUDENE também foi de alguma forma envolvido no programa. Uma parte da equipe de Kennedy, inclusive Arthur Schelisnger e Richard Goodwin, visitaram o Nordeste, onde as ligas camponesas de Francisco Julião tomavam o campo e flertando com os comunismos de Fidel e de Mao Tsé-Tung. "Os auxiliares de Kennedy mereceram o melhor de minha atenção, como se comprova lendo o livro de Schlesinger sobre os Mil dias de Kennedy. Deram-se conta que o quadro nordestino era grave, mas também de que os problemas estavam sendo enfrentados com realismo e, principalmente, de que a SUDENE contava na região com ampla credibilidade" (FURTADO, 2014, pp. 302). Furtado foi convidado a ir a Washington em julho de 1961 para acertar, com a cúpula do governo Kennedy, os detalhes do programa para o Nordeste, chegando a ser recebido pelo próprio presidente que, assim como seus auxiliares, demonstrou grande interesse nos planos apresentados. Enquanto isso a SUDENE recrutava mais e mais técnicos e desenvolvia amplo plano de reformas para o Nordeste, estando Furtado convencido de que receberia o apoio prometido em Punta del Este (FURTADO, 2014, pp. 303-309, 323).

Mas o romance entre a heterodoxia latino-americana e a Aliança não duraria muito. Prebisch não ficou nem um ano em Washington. Seu comitê era meramente consultivo e não conseguia que os EUA ou os países da América Latina seguissem suas recomendações. Os ditos "Falcões da Defesa", quadros do alto escalão do Estado que privilegiavam o uso da força como solução para os conflitos internacionais, fortaleciam-se com o acirramento dos tensões na região, ficando as soluções da diplomacia econômica dos acadêmicos keynesianos de Kennedy relegada ao segundo plano. Quando acharam

atitude abstencionista tradicional, calçada nos princípios do "laissez-faire". Para ser, porém, bem sucedido, o Estado deveria submeter a sua ação à disciplina de um programa consequente de desenvolvimento, através do qual se induzisse o setor privado a comportar-se de acordo com as diretrizes do plano. A longa batalha travada pela CEPAL, em que buscava o reconhecimento do desenvolvimento econômico como problema básico de governo em tôda a América Latina, e a aceitação das suas consequências, isto é, da necessidade de cada país de mobilizar-se em torno de um programa pode agora ser considerada como vitoriosa. A Carta de Punta del Este [que sistematizou o programa da Aliança para o Progresso] representa, a êste respeito, a consagração continental das teses tão vivamente defendidas pela CEPAL” (BNDE, 1962, p. 10). 
que a Argentina poderia recair em um regime comunista, depois da derrubada de Arturo Frondizi, fizeram um grande empréstimo aos novos militares argentinos sem consultar a Aliança e sem exigir qualquer planejamento para uso da verba concedida. $\mathrm{Na}$ sequência Kennedy foi forçado a esquivar-se da promessa de estabilização dos preços agrícolas, porque o Congresso dos EUA que se preocupava-se com déficit e desemprego começou a criar sucessivas barreiras protecionistas que impediram a concretização do programa previsto (DOSMAN, 2011, pp. 415-421).

As boas relações entre a Aliança e a SUDENE também não duraram muito. Novamente a linha dura do Departamento de Estado, que pensava o comunismo como uma ameaça a ser imediatamente erradicada e não algo que pudesse ser prevenido a médio prazo com reformas sociais, prevaleceu em relação aos assessores acadêmicos de Kennedy. O Departamento de Estado considerava a SUDENE e a ala progressista da Igreja Católica que com ela colaboravam simpatizantes do comunismo. Suas desconfianças levaram a Aliança a operar através dos governos locais em ações emergenciais que deixassem visível o apoio dos EUA para conseguir conquistar a opinião pública com velocidade e arrefecer as ligas camponesas: instalaram chafarizes nas zonas insalubres, perfuraram poços, construíram habitações para os trabalhadores, forneceram filmes educacionais, criaram unidades móveis de saúde. Ao trocar o planejamento da SUDENE pelos políticos locais, a Aliança acabou reforçando as lideranças tradicionais do nordeste, que não aceitariam a reforma agrária ou outra transformação estrutural de maior alcance (FURTADO, 2014, pp. 323-327; SMITH, 1993, p. 81).

Como a gestão Kennedy, que apostava de um lado na força e de outro na transformação social através da solidificação, pela via econômica, da democracia, a Aliança era ambígua. Ainda que falassem em reformas amplas, estabilização dos preços e ajuda aos planos de desenvolvimento, seus efeitos foram limitados e pouco articulados. Ela não seguiu as recomendações dos especialistas que haviam formulado as políticas e não se ateve a financiar projetos que atendiam às regras ao programa, priorizando o combate emergencial ao comunismo à transformação social duradoura.

A parte da Aliança que se voltava à cooperação científica, também oscilava entre as duas lógicas. De um lado procurava fomentar o desenvolvimento da ciência, por outro oferecia resistência a grupos vistos com suspicácia por suas orientações políticas críticas. As políticas da Aliança para o fomento da ciência econômica nos países 
subdesenvolvidos, que visava atualizar sua capacidade administrativa oferecendo ferramentas de gestão dos recursos materiais e humanos, tiveram grande impacto no espaço dos economistas dos diversos países que foram contemplados pelas verbas, bolsas de estudo e programas de intercâmbio de professores e consultores. Entre esses países estava o Brasil que recebeu recursos tanto do governo quanto de fundações privadas de cooperação científica dos EUA.

\subsection{João Paulo dos Reis Velloso: USAID, Fundação Ford e a criação do EPEA}

Para implementar o programa da Aliança para o Progresso foi criada, em novembro de 1961, a United States Agency for International Development, agência vinculada ao Departamento de Estado dos Estados Unidos que seria responsável pelo direcionamento da assistência de matiz econômico e humanitário. Assim a verba de financiamento dos programas de assistência foi separada da verba militar voltada à contenção do comunismo (RAMOS, 2006, pp. 46-47). Um dos destinos da assistência econômica provida pela USAID foi o financiamento de atividades de cooperação científica com universidades e institutos de pesquisa dos países da periferia. Às atividades de intercâmbio científico promovidas pelo governo dos Estados Unidos somavam-se iniciativas semelhantes financiadas por fundações privadas, notavelmente a Fundação Rockefeller (1913) e a Fundação Ford (1936).

A ação da Fundação Rockfeller no Brasil orientou-se predominantemente para as ciências biológicas, tendo apoiado a expansão da medicina, da biologia, da saúde pública e da genética. Manteve também alguns projetos nas áreas de agricultura, demografia e educação. A Fundação Ford, por sua vez, instalará um escritório no Rio de Janeiro, em 1962, e apoiará as áreas de engenharia, agronomia e ciências sociais, incluindo a administração pública, a administração de empresas e a economia. Ela ajudou a criar e sustentar instituições como o Instituto de Estudos Econômicos, Sociais e Políticos de São Paulo (IDESP), a Associação Nacional de Pós-Graduação e Pesquisa em Ciências Sociais (ANPOCS) e o Centro Brasileiro de Análise e Planejamento (CEBRAP) (item 5.3) (BROOKE e WITOSHYNSKY, 2002, p. 13; FARIA e COSTA, 2006; MICELI, 1993, p. 40). 
Ainda que a Fundação Rockefeller tenha provido algumas das primeiras bolsas para que economistas brasileiros fossem aos Estados Unidos (item 2.4), o apoio norteamericano à pesquisa e formação em Ciências Econômicas foi provido, fundamentalmente, pela USAID e pela Fundação Ford. "A década inaugural das operações latino-americanas [da Fundação Ford] foi toda ela centrada no atendimento prioritário às áreas de economia e administração, e em menor escala às ciências naturais e engenharia, através da concessão de bolsas a estudantes latino-americanos com formação universitária nos Estados Unidos ou, então, por conta de doações feitas a universidades e institutos de pesquisa" (MICELI, 1993, p. 42). Ela financiou, por exemplo, a publicação de revistas nas áreas de economia e administração, contribuiu com o programa de história oral e documentação histórica em ciências sociais organizados pela FGV e apoiou a compra de equipamentos e a montagem da biblioteca do Instituto de Pesquisa Econômica da USP (item 4.2), sempre com o objetivo de promover o desenvolvimento de competências científicas e administrativas que se desdobrariam em eficiência nas políticas públicas e, consequentemente, em crescimento, democracia e segurança (MICELI, 1993, p. 43).

Como a Ford, a USAID financiava o envio de professores brasileiros para os Estados Unidos e de professores estrangeiros para o Brasil. Ela foi responsável pela missão acordada com a Universidade de Vanderbilt, baseada em Nashville-Tennessee, que enviou professores para a FGV e para a Universidade de São Paulo e recebeu estudantes dessas universidades em seus cursos de pós-graduação. Ela financiou, ademais, a construção do prédio, desenhado por Oscar Niemeyer, da FGV no Rio de Janeiro e a vinda de missões de cooperação técnica para auxiliar órgãos governamentais. Caso paradigmático dessa vinculação com o governo foi a missão financiada pela USAID e coordenada pela Universidade da Califórnia - Berkeley, enviada em 1965 para o nascente Escritório de Pesquisa Econômica Aplicada (item 4.3), dirigido pelo economista João Paulo dos Reis Velloso, ele mesmo produto da cooperação científica com os Estados Unidos, já que foi um dos primeiros estudantes do CAE a tornar-se aluno do programa de mestrado da Universidade de Yale.

Reis Velloso (1931) nasceu em Parnaíba, no Piauí, em família residente na pequena cidade de Buriti dos Lopes. Seus pais eram piauenses e, segundo ele, o status social da família era maior que o econômico: o pai telegrafista era respeitado pelos empresários da 
cidade por ser o mais antigo funcionário dos Correios e Telégrafos. Os Velloso moravam com seus tios e primos em um sobrado. O tio de João Paulo era tabelião e, com renda maior do que a de seus pais, ajudava a arcar com as despesas da família. Sua mãe, que faleceu quando ele tinha 17 anos, mantinha um ateliê de costura no qual copiava os modelos franceses e da capital. Velloso diz que a mãe tinha hábitos mais sofisticados que os de seu pai, atribuindo a ela seu gosto pela leitura, que o levará no futuro, entre outras propriedades, a tornar-se membro da Academia Parnaibana de Letras. Ao falar da infância, comenta a molecagem de rua, o gosto pelo futebol e a convivência com a diversidade étnica e socioeconômica no microcosmo social que era a sua vizinhança. Revela que não havia o costume de escutar música clássica em casa na infância, ainda que um dos seus irmãos tivesse o nome do meio, Wagner, em homenagem ao compositor. Ele expõe longamente em suas memórias a paixão pelo cinema e pelas tramas de ação e aventura dos filmes, livros e quadrinhos (João Paulo dos Reis Velloso in: D’ARAÚJO e CASTRO, 2004, pp. 11-23).

Como no caso de Roberto Campos, a força decisiva para que experimentasse uma inflexão em sua trajetória foi a educação oferecida pela Igreja Católica, da qual pode desfrutar ao obter uma bolsa para cursar o ginásio no colégio católico privado São Luís Gonzaga. Apesar do costume de comparecer à missa todo domigo, a família não tinha, segundo ele, grande convicção religiosa. Foi então no São Luiz Gonzaga que, aos doze anos, aderiu fortemente ao catolicismo. Começou a frequentar a casa do diretor do Ginásio, com quem discutia Alceu Amoroso Lima, Leonel Franca e Jacques Maritain. Tornou-se um católico politicamente engajado, alinhado à democracia cristã, e não à tendência católica que se associou ao integralismo. Ele declara que, na época, era antigetulista porque conhecia muita gente que tinha sido presa durante o Estado Novo (João Paulo dos Reis Velloso in: D’ARAÚJO e CASTRO, 2004, pp. 24-36).

Ao mesmo tempo em que cursava o ginasial, João Paulo trabalhava em uma exportadora de cera de carnaúba redigindo a correspondência de exportação. Ao concluir o colégio, Velloso fez três anos de curso de comércio na Escola Técnica do Comércio União Caixeiral, pertencente à associação dos lojistas da cidade, não havendo ensino médio regular em Parnaíba. Foi então que começou a pensar em transferir-se para outra cidade para trabalhar e estudar. Através da Academia de Letras e da militância católica conseguiu contatos no Rio de Janeiro para onde foi em 1951. Os católicos indicaram-no 
para o deputado recém-eleito Jorge Lacerda ${ }^{160}$, que lhe ofereceu emprego de secretárioassessor. Nessa função, passava o dia no trabalho e estudava à noite para o exame do curso de medicina. Após um ano de trabalho junto ao deputado, Velloso prestou concurso para o Instituto de Aposentadorias e Pensões dos Industriários (IAPI) ${ }^{161}$ onde trabalhou como administrador e escriturário até ser convidado para integrar a assessoria da presidência do IAPI, por influência de Jorge Lacerda. Visando, segundo ele, um bom salário, uma boa perspectiva de carreira e uma boa aposentadoria, João Paulo fez, como “todo piauiense pobre, naquele tempo," concurso para o Banco do Brasil em 1954 e em 1955 foi enviado para trabalhar em São Paulo, onde permaneceu por dois anos. Ao retornar ao Rio de Janeiro tornou-se assessor da presidência do BB (João Paulo dos Reis Velloso in: D’ARAÚJO e CASTRO, 2004, pp. 45-66).

No período em que esteve no BB dedicou-se aos estudos formais de economia, não por vocação, conforme declara, mas por já estar nesse rumo.

Comecei em São Paulo [em 1957], na Faculdade Alvares Penteado (o curso da USP era diurno) [162], e, quando vim para o Rio, transferi-me para a Universidade do Estado da Guanabara (UEG), porque a UFRJ também não tinha curso noturno. Trabalhava na presidência do Banco do Brasil durante o dia, na rua Primeiro de Março, onde hoje é o Centro Cultural Banco do Brasil, e à noite ia para a UEG, atual UERJ, em São Cristóvão (João Paulo dos Reis Velloso in: D'ARAÚJO e CASTRO, 2004, p. 63).

Entre janeiro e março de 1960, Velloso participou com outros 19 estudantes brasileiros de um seminário na Universidade de Illinois, organizado pelo Departamento de Estado dos EUA. Ele conta que o seu inglês era bem ruim, mas diz ter conseguido entender o suficiente para constatar que não sabia nada de economia, ou quase nada, já que tinha tido alguns poucos bons professores na UEG, "que eram, por exemplo, do BNDE, e esses sabiam teoria econômica" (João Paulo dos Reis Velloso in: D’ARAÚJO, 1999, p. 178; João Paulo dos Reis Velloso in: D’ARAÚJO e CASTRO, 2004, p. 66). Ele atribui a essa passagem pelos EUA a decisão de seguir estudando economia. Após a mudança do BB para Brasília, em maio de 1960, Velloso consegue uma autorização do presidente do Banco para cursar a pós-graduação do CNE, em 1961, e a do CAE-FGV em 1962.

\footnotetext{
${ }^{160}$ Jorge Lacerda tornou-se governador de Santa Catarina em 1956 mas faleceu em 1958 em acidente aéreo.

${ }^{161}$ Trabalhava também no IAPI, naquele momento, Hélio Beltrão, que viria a ser Ministro do Planejamento no Governo Costa e Silva, do qual Reis Velloso tornar-se-ia secretário-geral.

${ }^{162}$ De fato a FCEA oferecia cursos noturnos desde 1950 (PINHO, 1984, p. 44).
} 
Tanto no CNE quanto no CAE Velloso foi aluno de Mario Henrique Simonsen. Comenta que ele era "um sujeito completamente sem ritmo, desengonçado, sem dar bom dia, vai para o quadro e o enche de equações" (João Paulo dos Reis Velloso in: D'ARAÚJO, 1999, p. 179). Sobre os dois cursos realizados declara:

O objetivo do curso de pós-graduação do Conselho Nacional de Economia era dar ao aluno aquele mínimo de que ele precisava para ser um profissional. O da Fundação já era diferente: sempre foi orientado para preparar alunos que iriam para o exterior fazer mestrado ou doutorado, e havia um esquema de bolsas de estudo. Quem tivesse uma boa colocação já tinha a sua bolsa garantida, principalmente pela USAID, em boas universidades, porque os próprios professores da Fundação recomendavam o aluno. A Fundação se relacionava bem com várias universidades estrangeiras, e você tinha completa liberdade de escolher para onde ir (João Paulo dos Reis Velloso in: D’ARAÚJO, 1999, p. 179).

No curso do CAE, além de aprimorar sua formação em economia, Velloso fez estudos sistemáticos de inglês, idioma obrigatório para os alunos que pretendiam ir para o exterior. Em setembro de 1962, ele recebeu uma bolsa da USAID para passar 18 meses em Yale fazendo o curso de mestrado. Conseguiu ainda financiamento para 6 meses de cursos complementares permanecendo, no total, dois anos no exterior. O contato com Yale havia sido estabelecido por Alexandre Kafka, que conhecia o chairman do Departamento de Economia e escreveu a carta de apresentação ao diretor do Economic Growth Center ${ }^{163}$, que tinha um curso com vagas reservadas para estudantes estrangeiros. Sobre a sua experiência nos Estados Unidos, João Paulo diz que tinha duas grandes desvantagens em relação aos estudantes locais: a língua, obviamente, e o fraco treinamento em matemática, estatística e métodos quantitativos, que ainda estavam sendo introduzidos nas escolas de economia brasileiras, sob a influência decisiva de Mario Henrique Simonsen. "Além dos cursos obrigatórios de teoria econômica e métodos quantitativos, estudei as matérias que interessavam, referentes à minha carreira, como política econômica e comércio internacional e política de desenvolvimento" (João Paulo dos Reis Velloso in: ALBERTI et al., 2002, pp. 87-89; João Paulo dos Reis Velloso in:

\footnotetext{
163 Kafka conhecia Llyod Reynolds, que havia sido diretor do programa da Fundação Ford para países subdesenvolvidos e fundador, em 1961, e diretor, até 1967, do Economic Growth Center de Yale. Kafka havia estado com ele ao menos uma vez: em 1958, em uma conferência organizada pelo National Bureau of Economic Research. É possível que ele conhecesse também o dean de Yale, William J. Fellner, também judeu proveniente do Leste Europeu (Budapeste), especialista em teoria monetária e inflação, temas caros a Kafka (KAFKA, 1998). Ver:

http://economics.yale.edu/about-us/past-chairmen, http://bea.gov/scb/pdf/BEAWIDE/2001/0401imrr.pdf e http://www.nber.org/nberhistory/FindingAid.pdf, consultados em 02/09/2015. http://www.yale.edu/opa/arcybc/v33.n27/story15.html, consultado em 01/10/2015.
} 
D’ARAÚJO e COSTA, 2004, p. 68).

Ao final dos dois anos de mestrado em Yale, Velloso via algumas opções a sua frente. Ele poderia passar mais dois anos nos Estados Unidos para fazer mais cursos e escrever a tese de doutorado. Ele comenta que à época não havia grande preocupação com a obtenção do título de doutor, principalmente entre aqueles que já trabalhavam para órgãos públicos brasileiros e não pretendiam tornar-se professores, como era o seu caso $^{164}$. A outra opção era trabalhar em algum órgão internacional como o BID, o Banco Mundial ou o FMI pois, diz ele, havia déficit de brasileiros nessas instituições. Em seu retorno ao Brasil, abrem-se várias possibilidades de trabalhar para o governo. Ele relata ter sido chamado por Paulo Hortênsio Lira, chefe da assessoria do presidente do Banco do Brasil, para voltar a sua burocracia de origem, ter recebido convite de Garrido Torres, presidente do BNDE, para ser chefe do departamento econômico e outro convite, de Roberto Campos, para trabalhar no Ministério do Planejamento (João Paulo dos Reis Velloso in: D’ARAÚJO, 1999, p. 179; João Paulo dos Reis Velloso in: D’ARAÚJO e COSTA, 2004, pp. 70, 85-86).

Em maio de 1964 vim ao Brasil e, quando cheguei, encontrei em casa, à minha espera, um telegrama de Roberto Campos, que pouco antes tinha assumido o cargo de Ministro do Planejamento, convidando-me a ir conversar com ele. Eu o tinha visto uma vez, quando ele foi a Yale dar um seminário num curso que havia no Departamento de Economia Latino-Americana. Assisti ao seminário e, à noite, no Faculty Club, o clube dos professores, por coincidência sentei-me à mesa diante dele. De repente ele se voltou para mim: "você é o Velloso, não é?" Eu disse: "Sou". Simonsen ou o Isaac Kerstenetzky tinham falado com ele a meu respeito. Em função disso, ele me requisitou para o Ministério do Planejamento, e resolvi aceitar. Nos primeiros dias no ministério, eu não sabia o que iria fazer. Disseram que eu ficasse numa sala no gabinete do ministro, peguei uns livros de economia e fiquei lendo. Até que fui chamado pelo Campos, que disse: "Você vai criar o EPEA". Era ainda Escritório de Pesquisa Econômica Aplicada, ele não queria que fosse Instituto: "Instituto parece coisa de serviço público, escritório parece mais serviço privado. Fica melhor EPEA" 165 (João Paulo dos Reis Velloso in: ALBERTI et al., 2002, pp. 69-70).

Além de dar início à montagem do EPEA, Velloso foi convidado por Simonsen para dar aulas de economia brasileira no CAE. Ele lecionou na FGV até virar ministro do planejamento em 1969, retomando a atividade docente após a saída do governo em 1979.

\footnotetext{
${ }^{164}$ Velloso afirma que esse era também o caso de Paulo Hortênsio Lira, da SUMOC, que teria ido para Harvad por um ano para fazer os cursos da área de política monetária e comércio internacional e voltado sem nenhum diploma (João Paulo dos Reis Velloso in: D’ARAÚJO, 1999, p. 180).

${ }^{165}$ Em fevereiro de 1967, o EPEA muda seu nome para Instituto de Pesquisa Econômico-Social Aplicada (IPEA), nome que é alterado novamente em janeiro de 1969, passando a ser Instituto de Planejamento Econômico e Social (IPEA). O nome é alterado uma vez mais, em maio de 1990, quando o órgão passa a chamar-se Instituto de Pesquisa Econômica Aplicada (IPEA) (D’ARAÚJO et al., 2005, pp. 23, 24, 301, 440).
} 
A ideia da criação do EPEA, gestada na metade de 1964, é mais um capítulo da multiplicação e especialização das instituições da área econômica. Segundo Velloso, o Escritório deveria ser um órgão de reflexão econômica ligado ao governo mas independente da rotina administrativa, responsável por fazer pesquisa orientada para o planejamento das políticas econômicas de médio e longo prazo (João Paulo dos Reis Velloso in: D'ARAÚJO et al., 2005, p. 21). A primeira tarefa à qual o EPEA dedicou-se foi a redação do planejamento setorial do Programa de Ação Econômica do Governo Castello Branco (PAEG). Octavio Bulhões havia sido designado Ministro da Fazenda do primeiro governo do período militar e Roberto Campos, Ministro Extraordinário do Planejamento e Coordenação Econômica.

O PAEG era um plano com duas faces: a primeira delas, prevalecente, era a política de estabilização monetária gradualista ${ }^{166}$ que dava continuidade à luta do ministro da Fazenda Bulhões contra a inflação e a segunda era aquela que procurava compatibilizar o ajuste com aumento dos investimentos e retomada do crescimento econômico. Quanto à primeira, o diagnóstico do qual partiam para desenhar a política de estabilização monetária gradualista era que o desequilíbrio macroeconômico e a inflação decorriam do déficit público e de um excesso de demanda que, por sua vez, resultava do clientelismo, do populismo, da pressão sindical e da incompetência administrativa dos governos anteriores (RAPOSO, 2011, p. 93; RESENDE, 1990, p. 225; TAVARES, 2010a, pp. $112-$ 113).

Para acabar com o déficit público adotaram as seguintes medidas: reajuste das tarifas dos serviços de utilidade pública, reforma tributária; venda de títulos públicos para poder equilibrar as contas sem novas emissões; constrição monetária; corte de subsídios à importação e de créditos para o setor produtivo; controle do balanço de pagamentos para evitar que a capacidade para importar fosse ameaçada; consolidação da dívida externa; estimulo à entrada de capitais estrangeiros na forma de investimentos e de ajuda financeira externa; e uma política salarial draconiana com redução do salário mínimo real e do salário na indústria de transformação que visava reduzir a pressão inflacionária advinda do excesso de demanda e forçar a poupança para investimento. A concentração da renda nas classes altas era viabilizada pela supressão das liberdades democráticas e

\footnotetext{
${ }^{166}$ A estratégia gradualista opõe-se a um choque ortodoxo, como a suspensão de reajuste salarial ou o corte abrupto de gastos, que gerariam recessão imediata. Nesse sentido é possível dizer que alguma preocupação com o crescimento econômico subsistia.
} 
repressão dos movimentos sindicais, que tolhiam a capacidade de protesto e reivindicação daqueles que eram desfavorecidos pelo plano (RAPOSO, 2011, p. 95; RESENDE, 1990, p. 217; TAVARES, 2010a, pp. 112-118).

Além disso, foram promovidas numerosas reformas institucionais, sobretudo alterações na estrutura tributária e bancária aliada à criação da fórmula de correção monetária ${ }^{167}$, que procuravam fomentar o surgimento de um mercado de crédito e capital privado que permitiria que o Estado fosse afastado progressivamente da atividade econômica.

Em meados de 1965, a lei 4.728 traçou todo o desenho institucional do sistema financeiro delimitando as funções dos bancos comerciais, bancos de investimentos e de desenvolvimento, sociedades de crédito e financiamento, sociedades corretoras e distribuidoras de títulos e valores, sociedades de crédito imobiliário, entre outras. O desenho do arcabouço básico de um sistema financeiro moderno, associado à correção monetária nos contratos e títulos financeiros de médio e longo prazos, permitiu a captação da poupança privada voluntária e sua canalização para o financiamento tanto do Tesouro quanto do investimento privado. Com relação ao setor externo as reformas institucionais passaram pela simplificação e unificação do sistema cambial, pela modernização e dinamização das agências do setor público ligadas ao comércio exterior, e pela maior integração com o sistema financeiro internacional como fonte de acesso a créditos de médio e longo prazos (RESENDE, 1990, p. 229).

A reforma institucional, além de ter promovido um redesenho do setor bancário privado, criou o Banco Nacional de Habitação (BNH), em agosto de 1964, e remodelou os programas de seguridade social, criando o Programa de Integração Social (PIS) e o Programa de Formação do Patrimônio do Servidor Público (PASEP), que captavam poupança de maneira forçada - eles tornar-se-ão, em 1974, as principais fontes de financiamento do BNDE. Finalmente, em dezembro de 1964 implantou-se uma das principais mudanças previstas no PAEG: a criação do Banco Central do Brasil e do Conselho Monetário Nacional que assumiram funções que antes eram exercidas pela SUMOC e pelo BB, centralizando o controle sobre a moeda ${ }^{168}$. Com Bulhões, o homem

\footnotetext{
167 “A correção monetária - criada no Governo Castello Branco com a intenção de compensar a desvalorização sofrida pelos títulos da dívida pública -, transformou-se, depois, em problema para a estabilidade monetária, pois passou a indexar e reproduzir automaticamente os preços dos principais produtos, serviços e contratos do país, perpetuando um processo de reajuste desses preços. Essa indexação só será extinta com a adoção do Plano Real, nos governos Itamar Franco (1992-1995) e Fernando Henrique Cardoso (1955-1999 e 1999-2002)” (RAPOSO, 2011, p. 101).

168 “A SUMOC era o órgão normativo das políticas monetárias e cambial sem, entretanto, autoridade executiva. $\mathrm{O}$ Banco do Brasil acumulava às suas funções de banco comercial e de fomento duas funções de Banco Central: a de banqueiro do Tesouro e a de banqueiro do sistema bancário através da Carteira de Redesconto e da Caixa de Mobilização Bancária. Apesar de não ter levado até o fim a desvinculação do Banco do Brasil do papel de Autoridade Monetária, pois o Banco do Brasil permaneceu tendo acesso automático e discricionário aos fundos do Banco Central, a criação do Banco Central foi um enorme avanço no sentido da modernização do sistema financeiro e da condução da política monetária" (RESENDE, 1990, p. 228).
} 
que idealizou a SUMOC, na Fazenda, apoiando a montagem da nova instituição, e sem contestação, visto que as liberdades democráticas estavam suspensas, foi possível criar o $\mathrm{BCB}$ nos moldes desejados, sem necessidade de arranjos que contemplassem diversos interesses e partidos - cabe recordar que também a SUMOC havia sido criada de maneira autoritária para evitar reações adversas do Banco do Brasil e de outros atores prejudicados pela reforma (LIRA, 1990, p. 10; RAPOSO, 2011, p. 97; RESENDE, 1990, pp. 228-229).

$\mathrm{O}$ controle do $\mathrm{BCB}$ foi entregue aos sumoqueanos que, sob a liderança de Bulhões e Gudin, já vinham sendo treinados para assumir o Banco Central há duas décadas. Revezaram-se na direção da instituição membros do grupo monetarista como Dênio Nogueira ${ }^{169}$, Paulo Pereira Lira ${ }^{170}$, Casimiro Ribeiro ${ }^{171}$, Ernane Galvêas ${ }^{172}$. Os quatro

${ }^{169}$ Dênio Nogueira (1920-1997) nasceu no Rio de Janeiro. O pai era militar e inscreveu o filho no Colégio Militar do Rio de Janeiro. Ao concluir o secundário, Dênio foi trabalhar no Conselho Nacional de Águas e Energia, sob a chefia de Jorge Oscar de Melo Flôres. Matriculou-se na FCEARJ e pouco antes de diplomar-se foi nomeado estatístico do Ministério da Educação. Em 1949, obteve bolsa de pós-graduação na School of Graduate Students, na Universidade de Michigan. Lá produziu texto sobre as causas da inflação brasileira que chamou a atenção de Bulhões que o convidou para chefiar a divisão de finanças do Departamento Econômico do CNE. Pouco depois torna-se editor chefe da revista Conjuntura Econômica. Em 1963 associa-se ao IPÊS. Em 1964 foi nomeado superintendente da SUMOC, com a tarefa de preparar a transição do órgão para o $\mathrm{BCB}$, do qual virá a ser o primeiro presidente (DHBB, verbete Dênio Nogueira).

${ }^{170}$ Paulo Hortênsio Pereira Lima (1930) nasceu no Rio de Janeiro. O pai, José Pereira Lira, natural da Paraíba, formou-se advogado na Faculdade de Direito de Recife. Em 1922, mudou para o Rio de Janeiro onde ingressou no Ministério Público e lecionou na Faculdade Nacional de Direito. Foi também deputado constituinte, primeiro secretário da Câmara dos Deputados e chefe do gabinete civil da presidência de Gaspar Dutra. Paulo Hortênsio ingressou na FNCE em 1950 e no mesmo ano começou a trabalhar no BB. Em 1953 transferiu-se para a equipe de Herculano Borges da Fonseca na SUMOC. Fez pós-graduação em Harvard e lecionava economia no CNE e na FNCE. De 1961 a 1964, trabalhou na ECOTEC, com seus professores Dias Leite e Kafuri. Depois de ter sido chefe da assessoria do presidente do Banco do Brasil em 1964-1965 e Diretor-executivo adjunto do Brasil junto ao FMI em 1966-1968, tornou-se diretor da área externa do Banco Central (DHBB, verbetes Paulo Hortênsio Lira e José Pereira Lira; LIRA, 1990).

${ }^{171}$ Casimiro Ribeiro (1922) é descendente de alemães radicados no sul do Brasil. Ele nasceu em Joiville mas cresceu em Porto Alegre, onde viveu até a adolescência quando foi completar os estudos no Rio de Janeiro, nos colégios São Bento e Anglo-Brasileiro. O pai de Casimiro ficou órfão muito cedo, mas recebeu do pai uma herança destinada a financiar seus estudos na Europa. Como fora alfabetizado em alemão, pode estudar engenharia na Universidade de Charlottenburg na Prússia. De volta ao Brasil trabalhou como engenheiro e dedicou-se à exportação de minérios. Foi representante comercial de várias firmas inglesas e ficou amigo de muitos britânicos. Admirava a Inglaterra, planejando o envio do filho para estudar em Oxford ou Cambridge. Mas, ao concluir o ensino secundário, em 1942, Casimiro ingressa no BB, para trabalhar na área de estatística e estudos econômicos, e na Faculdade Nacional de Direito. Somente em 1955 fará curso de pós-gradução de um semestre em economia na LSE. Em 1951 foi convidado a trabalhar na CEXIM sob a direção de Luis Simões Lopes, que reuniu em sua equipe Garrido Torres e Roberto Campos. No final de 1952 foi convocado por Walter Moreira Salles para trabalhar na SUMOC, passando a integrar a equipe de Herculano Borges da Fonseca (RIBEIRO, 1981; RIBEIRO, 1990).

${ }^{172}$ Ernane Galvêas (1922) nasceu em Cachoeiro de Itapemirim no Espírito Santo, descendente de portugueses por parte de pai e de mãe. O pai, dentista, faleceu cedo, deixando dez filhos e quase nenhum patrimônio. A prole foi entregue aos cuidados de parentes dispersos pela região, indo Ernane viver com um tio vendedor de café em Mimoso do Sul no Espírito Santo, tornando-se depois interno no Colégio Bittencourt, em Campos no Rio de Janeiro. Influenciado pelo cunhado, Galvêas, sem ter cursado o ensino superior, faz o concurso para o BB, nele ingressando como escriturário em 1942, designado para a agência do Banco no Méier, onde permaneceu por dez anos. No início de sua carreira no banco vai estudar contabilidade na Escola Vera Cruz, no período noturno. No início dos anos 1950 matriculou-se no curso de economia da Escola Amaro Cavalcanti (UEG, depois UERJ). Em 1952 é convidado por Herculano Borges da Fonseca, filho do tesoureiro geral do BB, Homero Borges da 
eram filhos de profissionais liberais e, mesmo que nascidos em cidades diferentes, todos completaram os estudos e cursaram o ensino superior no Rio de Janeiro. Antes mesmo de iniciar a faculdade todos ingressaram em burocracias públicas, os três primeiros aprovados em concursos para o BB, de onde foram levados para a SUMOC por Bulhões e Herculano Borges da Fonseca. Dênio Nogueira passou pelo Conselho Nacional de Águas e Energia e foi estatístico do Ministério da Educação. Depois de fazer uma pósgraduação em economia em Michigan foi convidado por Bulhões para trabalhar com ele no CNE. Os outros três também receberam treinamento complementar em problemas monetários e tiveram a chance de fazer cursos de especialização em economia no exterior. Paulo Lira fez pós-graduação em Harvard, Casimiro na LSE e Galvêas no México e em Yale. Os novos dirigentes do BCB estavam alinhados a seu mentor Bulhões e com ele colaboraram na elaboração e execução da primeira face do PAEG, a da estabilização econômica.

A segunda face do PAEG era aquela que procurava compatibilizar o ajuste com aumento dos investimentos e retomada do crescimento econômico para atenuar os desequilíbrios setoriais e regionais da produção. Esse foi o lado da fórmula de menor sucesso, tendo o crescimento industrial caído, provocando a falência de numerosas empresas, sobretudo de pequenos negócios, e elevando os níveis de desemprego. Esse lado do plano exigia um planejamento setorial da produção industrial, do qual ocupou-se o EPEA, e o financiamento da diversificação da produção, do qual encarregou-se o BNDE. Assim, o planejamento e a aplicação da política de desenvolvimento e elevação da produtividade passaram a ser feitos em dois órgãos distintos, sem uma coordenação central.

O principal redator do PAEG foi o sócio de Roberto Campos na CONSULTEC, professor Mario Henrique Simonsen. Jefferson Oliveira Lemos declara que era possível assistir a gestação do PAEG dentro da Consultoria. Segundo ele, Simonsen e José Luiz Bulhões Pedreira, responsável pela dimensão jurídica do Plano de Metas e do PAEG, faziam a maior parte do trabalho e seu tio, Roberto Campos, a partir do Ministério do

Fonseca, de quem seu cunhado era o braço direito, para ir com ele para a assessoria da SUMOC como seu datilógrafo. Já na SUMOC Galvêas fará curso de teoria e política monetária, com duração de oito meses, no Centro de Estudos Monetários Latino-Americano no México (GALVÊAS, 1990, pp. 12-13). Por seu desempenho nesse curso ganha bolsa da Fundação Ford para cursar pós-graduação nos EUA. Escolhe ir para Yale e, ao retornar, passou a lecionar no CNE e foi assessor do Ministério da Fazenda de 1961 a 1963 e 1965 a 1966. Atuou durante um ano e meio como diretor da Carteira de Comércio Exterior do Banco do Brasil (CACEX) sendo então nomeado presidente do BCB por Costa e Silva (DHBB, verbete Ernane Galvêas; GALVÊAS, 1990, p. 16). 
Planejamento, orientava e depois revia os resultados no final (Jefferson de Oliveira Lemos in: ALBERTI et al., 2002, p. 62).

A equipe do EPEA somou-se aos esforços iniciados na CONSULTEC para a elaboração do Plano. Vítor da Silva ${ }^{173}$ vai da Consultoria para o EPEA e, algum tempo depois, um dos estagiários deles, Arlindo Corrêa, passa também a trabalhar no Escritório. De acordo com Velloso, Simonsen já tinha preparado os capítulos de macroeconomia do PAEG, cabendo ao EPEA a elaboração dos planos setoriais. Para tanto, recebiam documentos que correspondiam aos setores que deveriam ser incluídos no plano e, com base neles, criavam as diretrizes para cada setor (Arlindo Corrêa in: ALBERTI et al., 2002, p. 62; João Paulo dos Reis Velloso in: ALBERTI et al., 2002, p. 70).

É cabível indagar porque Campos teria optado pela criação de um órgão novo para a elaboração do PAEG ao invés de aproveitar a expertise acumulada pelo BNDE no Plano de Metas. Ainda que não haja uma resposta inequívoca para a questão, é pertinente analisar o contexto no qual Roberto Campos deixou o BNDE para elencar possíveis razões para o enfraquecimento da instituição. Retoma-se, para tanto, o cenário no qual ocorreu o afastamento de Roberto Campos do BNDE no final do governo JK. Três eventos situados entre 1958 e 1959 podem ter contribuído para abalar a relação dele com o Banco e com os setores desenvolvimentistas nacionalistas.

O primeiro deles é a rejeição de um projeto por ele proposto para alterar as regras de financiamento do BNDE, que terá eco nas reformas pelas quais o Banco passará durante o período do PAEG. Quando ele e Lucas Lopes traçaram o Programa ${ }^{174}$ de Estabilização Monetária (PEM) do governo JK, no segundo semestre de 1958, uma das propostas que apresentaram era de uma mudança na estrutura do capital do BNDE. Campos advogava em favor da desvinculação do orçamento do Banco do Tesouro Nacional e dos empréstimos compulsórios. Acreditava que o Banco poderia levantar seus

\footnotetext{
${ }^{173}$ Marcia Cunha chama atenção para o sumiço, na documentação historiográfica, de um primeiro presidente do EPEA, que teria sido precisamente Vítor da Silva Alves Filho, companheiro do ministro Campos na Comissão Mista Brasil- Estados Unidos nos anos 1950, diretor executivo do Conselho de Desenvolvimento de março de 1958 a julho de 1959, com passagem também pelo BNDE. Já Roberto Campos e Lucas Lopes mencionam, nas respectivas memórias, que ele ajudou a fundar a revista Análise e Perspectiva Econômica, que foi gestada dentro da CONSULTEC. No livro em homenagem a Mario Henrique Simonsen, consta também que o secretário emprestado pelos Klabin à CONSULTEC era o mesmo Vítor Silva que esteve no EPEA até ir para o BID (Arlindo Lopes Correa in: ALBERTI et al., 2002, p. 68; Israel Klabin in: ALBERTI et al., 2002, p. 65; CAMPOS, 1994, p. 625; CUNHA, 2012, p. 29; LOPES, 1991, p. 272).

${ }^{174}$ Roberto Campos, em suas memórias, oscila entre chamar de Plano de Programa Estabilização Monetária. Refaz-se, assim, a contraposição dos termos "plano" e "programa", que aparece no caso do Plano de Metas (item 2.3).
} 
próprios recursos no mercado através da concessão de certificados de participação aos investidores que fornecessem capital ao BNDE, que passaria a financiar exclusivamente investimentos privados. Para tanto, seria criado um

\begin{abstract}
"Fundo de Investimentos Industriais", destinado a prover recursos para investimentos em empreendimentos privados nos setores básicos da economia. O capital desse fundo variável seria dividido em duas partes: a) capital do BNDE e b) capital constituído pela subscrição das quotas de participação em circulação. Segundo o mecanismo proposto, o BNDE incorporaria sua parcela de capital no fundo mediante a transferência, pelo valor nominal, das ações recebidas em contrapartida aos financiamentos industriais que concedesse. [...] o certificado de participação no "Fundo de Investimento da Indústria" do BNDE dava ao titular das quotas o direito a um dividendo mínimo e cumulativo de $8 \%$ ao ano, em moeda corrente, garantido pelo BNDE. Mas, além disso, daria também direito de participação no lucro líquido apurado anualmente pelo fundo, que excedesse esse dividendo mínimo. Assim a remuneração do comprador teria dois componentes, um de renda fixa e um de renda variável, representado este pela participação no lucro líquido apurado pelo fundo em suas aplicações (CAMPOS, 1994, pp. 349-350).
\end{abstract}

Eles propunham que esse fundo tivesse uma administração paritária, com quatro membros do setor privado escolhidos entre os acionistas do fundo e cinco do setor público: o diretor-superintendente do BNDE, o diretor do BNDE encarregado do Fundo de Investimentos Industriais, o diretor da Carteira de Crédito Agrícola e Industrial do Banco do Brasil e um membro do conselho de administração do BNDE, sendo chefiado pelo presidente do Banco, que teria o voto de desempate. Ainda que se convertesse em um modelo misto de banco de investimento, o BNDE continuaria tendo uma face pública, pois receberia fundos do Tesouro para os investimentos em infraestrutura (CAMPOS, 1994, p. 350). Campos desapontou-se com o fraco interesse despertado por sua proposta. Ele deixou a presidência do Banco pouco tempo depois, ficando a ideia congelada por alguns anos.

Em janeiro de 1959, o episódio dos Acordos de Roboré desgasta novamente as relações de Roberto Campos com o governo JK e com o ideário de desenvolvimentismo por ele representado. Em 1938 o Brasil havia adquirido o direito à exploração de petróleo em uma região da Bolívia que permaneceu intocada até 1958. Pressionado pelo governo boliviano a ocupar-se da área e ajudar a desenvolvê-la, o Brasil decidiu estudar como investir naquele território. Revisados os acordos originais, definiu-se que a área que cabia ao Brasil seria reduzida mas que, em contrapartida, as empresas de exploração não precisariam mais ser empresas mistas Brasil-Bolívia, podendo ser empresas privadas exclusivamente brasileiras. $\mathrm{Na}$ opinião de Campos era impossível realizar tal empreitada sem ajuda de capitais externos que estivessem dispostos a correr risco. Decidiu, então, 
pela criação de uma holding de maioria de capital nacional que controlaria as empresas de exploração. Estas, por sua vez, poderiam ter participação majoritária estrangeira, entendase estadunidense, já que foram articulados inclusive incentivos fiscais especificamente desenhados para atrair os norte-americanos. O BNDE foi encarregado da execução do acordo, o que incluía a parte de licitação das empresas em concorrência para a exploração (CAMPOS, 1994, p. 366).

A interpretação segundo a qual empresa privada exclusivamente brasileira poderia ser uma holding de maioria brasileira que controlasse empresas de participação majoritária norte-americana não foi bem recebida pelo exército, pelos estudantes e pelos nacionalistas em geral, que passaram a atacar o "entreguismo" de Campos em artigos, passeatas e até mesmo inquéritos. Os estudantes fizeram passeatas em 29 de janeiro e 6 de fevereiro de 1959. Plantaram-se na frente do BNDE onde promoveram enterro simbólico de Roberto Campos ${ }^{175}$, sendo duramente reprimidos pela polícia. Campos conseguiu que até o notório conservador Carlos Lacerda ficasse contra ele nesse episódio, alinhando sua posição à da UNE! Foi quando Roberto Campos, autodenominado "bugre do Mato Grosso", ganhou a alcunha de "Bob Fields, o entreguista", consagração profundamente ambígua de seu cosmopolitismo e, em termos mais amplos, das possibilidades locais de mobilidade social e simbólica que permitiram que "o bugre" fosse também "Bob".

O grupo de trabalho encarregado da execução dos acordos de Roboré era integrado por seus colegas e futuros sócios de CONSULTEC e de PAEG, Mario da Silva Pinto, geólogo, e Bulhões Pedreira, advogado. Quando a controvérsia estabeleceu-se, eles já tinham selecionado as empresas que se encarregariam da exploração petrolífera e não estavam dispostos a rever o processo, mesmo sob tamanha pressão. O impasse foi resolvido pelo presidente $J K$, que rejeitou publicamente a interpretação do BNDE, dizendo que os técnicos encarregados da execução dos acordos foram pessimistas, o que os levou a desviar da diretriz presidencial que determinara que aquela área deveria ser de exploração exclusivamente brasileira. Era a palavra de JK contra ele ${ }^{176}$. O desgosto de Campos aumentou ${ }^{177}$.

\footnotetext{
${ }^{175}$ Ver:

http://memoria.bn.br/DocReader/docreader.aspx?bib=089842_06\&PagFis=101860 e http://memoria.bn.br/DocReader/docreader.aspx?bib=089842_06\&PagFis=102144. Consultados em 17/10/2015. ${ }_{176}$ Ver: http://memoria.bn.br/DocReader/docreader.aspx?bib=089842_06\&PagFis $=101318$. Consultado em 17/10/2015.

${ }^{177}$ Resultou desse episódio, também, a dissolução das relações de Campos com o diplomata Otávio Dias Carneiro: "Uma de minhas mágoas é que meu dileto colega do Itamaraty, o ministro Otávio Dias Carneiro,
} 
A ruptura do Brasil com o FMI foi o ponto culminante da sequência de malogros de Campos no final do governo JK. Ele já estava ressentido pelo abandono do presidente no caso do petróleo da Bolívia e Lucas Lopes estava afastado pelo enfarto quando JK resolveu ouvir seus ministros acerca da reforma cambial e adequação às solicitações do FMI. Depois de falar separadamente com os diversos assessores econômicos, convocou, para um almoço no Palácio do Catete, Campos, Amaral Peixoto e Walther Moreira Salles, os dois últimos embaixadores do Brasil em Washington. Ao chegar ao Palácio, os três perceberam que ali estavam também Celso Furtado, Cleanto de Paiva Leite e Ewaldo Corrêia Lima (itens 1.3 e 1.4), que sustentavam uma posição contrária à austeridade econômica e favorável à ruptura do Brasil com o FMI, o que coadunava com a vontade de JK de seguir "a todo motor” para Brasília. As relações com o Fundo foram rompidas em 17 de junho de 1959 e Campos caiu em 21 de julho de 1959. Ele relata: "senti que em face da radicalização nacionalisteira de Juscelino, tinha me tornado um incômodo no governo. Dispus-me a pedir exoneração do BNDE, atitude que sabia ser bem recebida" (CAMPOS, 1994, pp. 359-360, 377). JK, por sua vez, declarou aos jornais que a substituição do ministro estava prevista mas foi acelerada por pressão dos nacionalistas que "queriam a cabeça de Campos"178.

Ainda que, como visto anteriormente, os "técnicos" desenvolvimentistas nacionalistas e cosmopolitas tivessem trabalhado amistosamente no BNDE nos primeiros 5 anos de existência da instituição, opondo-se essencialmente aos "políticos", nesse momento suas visões desalinharam-se entre uma vertente nacionalista e outra cosmopolita ou não nacionalista. Eles divergiram nos três casos. Cabe mencionar que estavam entre os mais influentes funcionários e dirigentes do BNDE do período técnicos que se alinhavam à vertente nacionalista que teve origem na Assessoria Vargas, como Juvenal Osório, Saturnino Braga, Inácio Rangel, Cleantho de Paiva e Ewaldo Corrêia Lima. Roberto Campos saiu do BNDE levando com ele vários altos quadros da instituição, que viveria, nos 5 anos seguintes, período de estagnação e declínio, com recursos e funções reduzidos. Ao ser designado Ministro do Planejamento em 1964,

amigo e compadre - que eu havia trazido para o BNDE, e a quem havia designado para 'representar-me no Conselho Nacional de Petróleo' - acabou aderindo ao irrealismo nacionalisteiro do relator da matéria no CNP, Jesus Soares Pereira [item 1.4], um ideólogo de esquerda, ingênuo em sua sobrestimação da eficácia de soluções estatizantes" (CAMPOS, 1994, p. 369).

${ }^{178}$ Ver:

http://memoria.bn.br/DocReader/docreader.aspx?bib=089842_06\&PagFis=107188

http://memoria.bn.br/DocReader/docreader.aspx?bib=089842_06\&PagFis=108575. Consultados em 17/10/2015. 
Campos, que havia sido fundador, superintendente e presidente do BNDE, mantém o Banco - e seus técnicos concursados identificados ao desenvolvimentismo nacionalista afastado do núcleo de planejamento, criando nova instituição destinada ao estudo e à concepção das políticas econômicas e de desenvolvimento: o Escritório de Pesquisa Econômica Aplicada.

O EPEA, por ser uma fundação pública que funcionava como uma empresa sujeita ao regime Consolidação das Leis do Trabalho e não como uma autarquia regida pelas normas do DASP, tinha um regime de pessoal próprio que permitia recrutar livremente seus quadros e remunerá-los de maneira flexível, razão pela qual pode oferecer salários bastante atraentes em comparação com os vigentes no resto da administração pública ${ }^{179}$. O deslocamento do locus do planejamento expressava a alteração da própria concepção do que se entendia por planejamento. Não se tratava mais de fazer um plano integrado da economia nacional, como propunha a CEPAL, e sim de "disciplinar os investimentos públicos e racionalizar a ação do governo, construindo assim uma moldura dentro da qual a iniciativa privada poderia operar com segurança”, como expõe Roberto Campos em sua posse no Ministério da Fazenda (CAMPOS, 1994, p. 570; João Paulo dos Reis Velloso in: D’ARAÚJO et al., 2005, p. 23; Ricardo Luís Santiago in: D’ARAÚJO et al., 2005, p. 256).

O deslocamento do papel de planejador do BNDE para o Ministério do Planejamento e para o EPEA era um dos sinais da perda de centralidade experimentada pelo BNDE, a qual havia começado ainda antes do governo militar. A dotação de recursos do Banco que havia subido de 32.841 mil dólares, no início do Plano de Metas em 1956, para 173.328 mil dólares em 1961, teve declínio constante durante os anos seguintes. Desceu para o patamar de 150.000 mil dólares nos anos de 1962 e 1963 e regrediu a 133.772 mil dólares em 1964 (PROCHNIK, 1995, pp. 161-162).

\footnotetext{
179 "Era a forma possível de trazer gente com salários competitivos. Várias pessoas famosas da área econômica pertenceram aos quadros do IPEA enquanto exerciam atividades na administração federal: Andrea Calabi, Carlos Viacava, Afonso Celso Pastore. João Batista de Abreu, ex-ministro do Planejamento, Everardo Maciel, Murilo Portugal, entre inúmeros outros, foram funcionários do IPEA, mas nunca foram pesquisadores e nem chegaram a ser lotados na casa. Já tivemos ministro-chefe da Casa Civil e vice-presidente do Banco do Brasil, todos exfuncionários do IPEA. Até hoje, há mais de 100 técnicos cedidos à administração federal. Mas depois da Constituição de 88 não se contratou mais ninguém sem concurso" (Marcelo de Piancastelli Siqueira in: D'ARAÚJO et al., 2005, p. 301).
} 


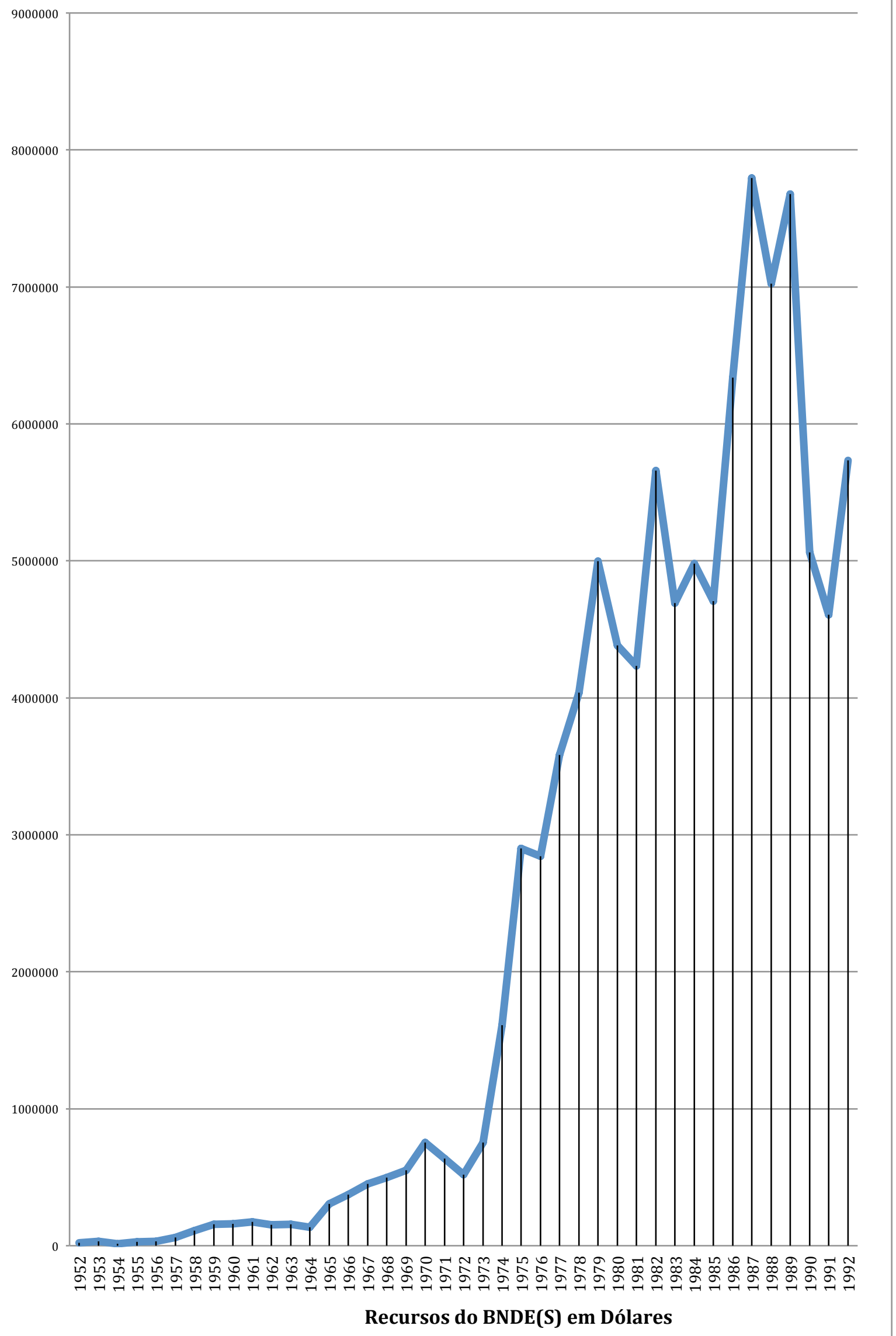

Gráfico II: Recursos do BNDE(S) em dólares por ano. Fonte: PROCHNIK, 1995. Elaboração própria. 
Os presidentes do Banco também passaram a ser homens de menor projeção nacional, intimamente ligados aos políticos em exercício e com pretensões político-eleitorais próprias. Aproximavam-se, pois, do "tipo político" de José Soares Maciel Filho e Válder Sarmanho e não do "tipo técnico", ao qual pertenceriam diretores como Celso Furtado, Cleantho de Paiva Leite, Lucas Lopes, Glycon de Paiva e Roberto Campos.

Durante o governo Jânio Quadros esteve à frente do Banco José Vicente de Faria Lima (1909-1969). Carioca filho de imigrante português que travalhava no arsenal da Marinha, Faria Lima fez carreira na Aviação Militar cursando a Escola de Aviação Militar do Campo dos Afonsos e um ano de aprofundamento na Escola de Engenharia Aeronáutica de Paris. Foi diretor do Campo de Marte, o Parque de Aeronáutica de São Paulo, presidente da Viação Aérea São Paulo (VASP) e secretário de Viação da Prefeitura de São Paulo a convite de Jânio. Faria Lima, que depois seria eleito prefeito de São Paulo, não tinha experiência na administração de órgãos ligados à gestão econômica ou qualquer participação na elaboração de políticas de desenvolvimento até assumir o BNDE, em 1961 (DHBB, verbete Vicente Faria Lima). Logo que João Goulart assumiu a presidência, tornou-se presidente do BNDE Leocádio de Almeida Antunes (1915-1999), um gaúcho de Alegrete, ligado ao Partido Trabalhista Brasileiro (PTB). Era contador formado na Escola de Comércio Fontoura Illa e diplomado em direito, ciências políticas e econômicas na Pontifícia Universidade Católica do Rio Grande do Sul. Depois de formado trabalhou como guarda-livros e escriturário até eleger-se deputado estadual em 1958. Licenciou-se do posto para ser Secretário Estadual de Economia do governador Leonel Brizola (DHBB, verbete Leocádio Antunes).

Quando assumiu o BNDE em 1961, Leocádio passou a ocupar concomitantemente os cargos de presidente e diretor-superintendente. Acumulou, assim, todo o poder de comando da instituição em suas mãos até março de 1963, mês em que nomeou para a superintendência o chefe do departamento econômico do Banco, professor da Faculdade Nacional e pesquisador do IBRE, Genival de Almeida Santos. Ele ficou na presidência do BNDE até junho de 1963, quando se tornou embaixador do Brasil junto à Associação Latino-Americana de Livre Comércio, organização criada em 1960 para promover zona de comércio sub-regional (BARRAL e BOHRER, 2010, p. 92) ${ }^{180}$. A crise no BNDE, e na

\footnotetext{
${ }^{180}$ Ver:

http://memoria.bn.br/DocReader/DocReader.aspx?bib=089842_07\&PagFis=47883

http://memoria.bn.br/DocReader/DocReader.aspx?bib=089842_07\&PagFis=37396. Consultado em 13/05/2016.
} 
economia como um todo, era tamanha que sequer foi nomeado um substituto oficial para Leocádio. Ensaiou-se a nomeação de Lelivaldo Brito que, mais do que agrônomo, era cunhado do governador da Bahia, Lomanto Júnior, e administrador da fortuna de sua família ${ }^{181}$. Como a nomeação foi rejeitada pelo PSD, Genival de Almeida Santos, que era superintendente do Banco, exerceu interinamente a Presidência por quase um ano, de junho de 1963 até o golpe militar em abril de 1964182 .

No primeiro governo Castello Branco é indicado para o BNDE um ex-diretor da SUMOC, José Garrido Torres (1915-1974). Nascido no Rio de Janeiro, fez graduação na FCEARJ no início dos anos 1940. Na sequência tornou-se funcionário do Escritório de Expansão Comercial brasileiro em Nova York, onde fez graduação e mestrado em economia na New York University (NYU), passando a representar o Brasil em diversas conferências internacionais. De volta ao país no começo dos anos 1950, Garrido foi convidado para trabalhar na CEXIM, com Luiz Simões Lopes, e para dirigir a revista Conjuntura Econômica. Nessa última posição escolheu para ser o redator-chefe Dênio Nogueira, do CNE, órgão onde Torres passaria também a atuar, chegando a ser presidente entre 1957 e 1958, quando foi nomeado diretor da SUMOC. Suas boas relações internacionais fizeram com que fosse indicado para o posto de consultor brasileiro no BID em 1960. Além de afinidade com os sumoqueanos e trânsito internacional, Garrido Torres tinha proximidade com os militares, tendo cursado, em 1954, a ESG e sido membro atuante do IPÊS (CENTRO INTERNACIONAL CELSO FURTADO DE POLÍTICAS PARA O DESENVOLVIMENTO, 2009, p. 358; DHBB, verbete Garrido Torres; FARIAS, 2012, p. 11; RIBEIRO, 1981, p. 10).

O início do governo militar representa a transição do predomínio dos desenvolvimentistas nacionalistas e cosmopolitas para o exercício do controle da economia pelos monetaristas da SUMOC. Sem ter que fazer concessões partidárias o Ministro Bulhões conseguiu montar uma administração econômica bastante coesa, tendo

\footnotetext{
Este período se segue ao fracasso do Plano Trienal de Celso Furtado - feito com apoio dos técnicos do BNDE e da SUDENE, que pretendia conciliar estabilização e reformas estruturais (BNDES, 2012, p. 39) - e à substituição no Ministério da Fazenda de San Thiago Dantas por Carvalho Pinto.

${ }^{181}$ Ver:

http://memoria.bn.br/DocReader/DocReader.aspx?bib=089842_07\&PagFis=40833, http://memoria.bn.br/DocReader/DocReader.aspx?bib=089842_07\&PagFis $=40912$ http://www.carloscastellobranco.com.br/sec_coluna_view.php?id=4753. Consultados em 5/01/2015.

${ }^{182}$ Ver: http://memoria.bn.br/DocReader/DocReader.aspx?bib=089842_07\&PagFis=41262 http://memoria.bn.br/DocReader/DocReader.aspx?bib=089842_07\&PagFis=36870 Consultados em 17/10/2015.
} 
representantes de seu grupo não apenas no BNDE (Garrido Torres) e na SUMOC-BCB (Dênio Nogueira), mas também na Carteira de Redesconto (Casimiro Ribeiro) e na Carteira de Comércio Exterior do Banco do Brasil (CACEX) (Aldo Franco) (MOTTA, 1994, p. 112). Campos, que fora a princípio desenvolvimentista cosmopolita, indentificava-se cada vez mais com os monetaristas, aderindo à diretriz da estabilização como requisito para um desenvolvimento sustentado por capitais privados e, portanto, ao combate à inflação e à reestruturação institucional. Até então eram considerados conservadores aqueles que, como os membros da CMBEU, não fossem nacionalistas, ainda que pleiteassem que a economia fosse planejada e que o Estado interviesse quando necessário. A partir do golpe o grupo torna-se, mais do que cosmopolita em sua perspectiva de abertura à integração econômica internacional, antiestatista, antiprotecionista e monetarista, tomando por mestres, Gudin e Bulhões.

Além de retirar do BNDE a função de planejar o desenvolvimento econômico, transferida para o EPEA e para o Ministério do Planejamento, alguns desenvolvimentistas nacionalistas afirmam que Campos planejava desmontar o BNDE, fragilizado desde o início dos anos 1960, teria abafado as vozes nacionalistas e estatizantes que ali estavam e substituido o BNDE por bancos de investimento privados (OSÓRIO, 2009, p. 155; TAVARES, 2009, p. 176). A versão por eles sustentada atribui a Garrido Torres a inciativa de manter o Banco redirecionando-o para o setor privado. Maria da Conceição Tavares, por exemplo, argumenta que:

No caso do Garrido, ele veio com o fim explícito de mudar a ideologia do Banco. Veio
fazer do BNDE um banco operativo, uma espécie de "banco de investimento". A ideia
do FINAME é dele. Era para tornar o Banco um agente operador financeiro para o setor
privado já instalado [...] Na verdade, o Banco criou uma agência para financiar o setor
privado, mas como este não demandava recursos, o FINAME ficou obrigado a usar
recursos para os setores "estatizados". Buscou recursos no EXIMBANK [Export-Import
Bank], no Banco Mundial e no Tesouro para financiar a indústria do aço, que ficou toda
em cima dele. Como se não bastasse, acabou a cota japonesa da USIMINAS. Então, 50\%
dos recursos daquele período pós-crise, que vai até metade dos anos 1970, foi para o aço
(TAVARES, 2009, p. 176).

É possível sustentar que as mudanças ideológicas que Garrido Torres pretendia promover estavam alinhadas ao projeto de reforma que Campos aventara para o BNDE em 1958, no qual o Banco deveria deixar progressivamente o orçamento da União, devendo captar seus próprios recursos no mercado e dirigir-se prioritariamente ao financiamento do setor privado. Logo foram instaurados os fundos que Campos propunha para "prover recursos para investimentos em empreendimentos privados nos 
setores básicos da economia” (CAMPOS, 1994, pp. 349-350).

Em 1964 criaram-se três fundos: o FINAME que, marcando a transição do Banco em direção ao setor industrial, destinava-se a financiar a aquisição de máquinas e equipamentos industriais de produção nacional, o que incentivava a produção nacional de bens de capital. O Fundo Agro-Industrial de Reconversão (FUNAR) tinha seus recursos oriundos do Fundo Nacional de Reforma Agrária e de empréstimos contraídos no país e no exterior e o "objetivo era financiar projetos de desenvolvimento agropecuário e agroindustrial, desde que adequados aos critérios estipulados pelo BNDE e pelo Ministério do Planejamento" (TAVARES, 2010a, pp. 120-121). O Fundo de Desenvolvimento Técnico-Científico (FUNTEC), finalmente, buscava financiar o ensino e a pesquisa tecnológica para formar técnicos de nível superior qualificados e promover pesquisas técnico-científicas em áreas de fronteira. Os recursos do FUNTEC foram direcionados inicialmente para a formação de programas de pós-graduação em áreas como engenharia, química e física e para programas de pesquisas tecnológicas em setores industriais de ponta. Este fundo recebeu grandes aportes do BID e da USAID que apoiaram a instalação da pós-graduação e também ofereceram bolsas para que brasileiros estudassem no exterior (BAER e VILLELA, 1980, pp. 430-431; CENTRO CELSO FURTADO DE POLÍTICAS PARA O DESENVOLVIMENTO, 2009, p. 342; TAVARES, 2010a, pp. 120-121).

Em 1965 e 1966 foram adicionados à lista de novos fundos o FIPEME e o FUNDEPRO. O primeiro, financiado com recursos do BID e do Kreditanstalt für Wiederaufbau alemão, ocupava-se da instalação ou reequipamento de pequenas e médias empresas. Funcionava através do financiamento para aquisição de máquinas e equipamentos, apoio à construção civil e instalação de equipamentos em empresas de setores industriais como têxtil, metal, celulose, papel, madeira, plásticos, automóveis e outros. O segundo usava os recursos do BNDE para financiar pesquisas que fizessem diagnósticos de produtividade para propor medidas que pudessem promover incrementos na produtividade industrial (BAER e VILLELA, 1980, pp. 430-431; BNDES, 2002; CENTRO CELSO FURTADO DE POLÍTICAS PARA O DESENVOLVIMENTO, 2009, p. 349; TAVARES, 2010, pp. 120-123).

Em 1965 criou-se também o FINEP, que usava recursos do BNDE, do BID e da USAID para conceder empréstimos a projetos e programas em áreas de pesquisa e 
desenvolvimento. À FINEP cabia avaliar a viabilidade dos projetos e recomendar o financiamento daqueles que fossem exequíveis e prioritários. Em 1967 o FINEP será desligado do BNDE, tornando-se uma empresa separada do Banco, a Financiadora de Estudos e Projetos S.A. (FINEP), subordinada ao Ministério da Ciência e Tecnologia, que passou a ser gerida por Pelúcio Ferreira, que havia assessorado Furtado no Grupo Misto CEPAL-BNDE e era membro do Clube dos Economistas (BAER e VILLELA, 1980, pp. 430-431; BNDES, 2002; TAVARES, 2010, pp. 120-123).

Há alguns indícios de que o surgimento dos novos fundos de 1964 a 1966 fosse um passo na direção proposta por Campos em seu projeto de reforma de 1958:

O primeiro deles reside na origem dos recursos dos fundos. Grande parte deles fora criada com capital não proveniente dos tributos arrecadados pelo governo, usando, por exemplo, recursos do BID, da USAID, de bancos estrangeiros ou os repasses dos Acordos do Trigo (BNDES, 2012, p. 54; CABRIA, 2012, p. 90). A necessidade de negociar os financiamentos internacionais fez com que o BNDE passasse a ter uma representação fora do Brasil, instalada na embaixada brasileira em Washington (BNDES, 2012, p. 55). A busca de fontes externas indica que se caminhava em direção à desvinculação do Banco do orçamento da União, como defendera Campos no fim dos anos 1950.

O segundo deles é a transformação em 1966 do FINAME $^{183} \mathrm{em}$ uma sociedade mista, da qual o BNDE seria o principal acionista, exatamente como fora proposto por Campos em seu projeto de 1958. Há igualmente uma alteração na forma de financiamento que visa estimular o surgimento do mercado financeiro, sendo a parcela de empréstimos concedida em troca de ações ampliada, chegando em 1965 a um terço das operações do Banco (BAER e VILLELA, 1980, pp. 430-431).

Finalmente houve um aumento progressivo da parcela de recursos do Banco destinados ao setor privado. Até 1964 em média 15,5\% dos financiamentos iam para o setor privado, no início do governo militar a média subiu para 36,5\% da colaboração financeira oferecida pelo Banco e no segundo governo militar passa a 59,5\%, sendo 1968 o primeiro ano em que o setor privado recebeu mais recursos do que o público (NAJBERG, 2002, p. 353). A possibilidade de destinar cada vez mais recursos do BNDE para o setor privado havia sido ampliada pela criação de empresas públicas especialmente

\footnotetext{
${ }^{183}$ O FINAME passa por uma segunda modificação em 1971, quando se torna empresa pública subsidiária do BNDE. (item 4.5).
} 
encarregadas do financiamento de alguns dos serviços de utilidade pública dos quais o Banco se ocupava até então, como a Rede Ferroviária Federal (1957), a Eletrobrás ${ }^{184}$ (1962) e a Embratel (1965). A criação dessas empresas permitiu ao Banco diversificar sua área de atuação depassando o binômio energia e transportes, com o qual havia se ocupado predominantemente em seus primeiros anos (TAVARES, 2010a, pp. 127-128). Em sintonia com o novo perfil, a partir de 1963, além dos segmentos de transportes e energia e indústria em geral, as provas de seleção do BNDE passaram a contemplar, no exame prático, os setores de agroindústrias e armazenagem, mineração e metal, elétrica e mecânica e química e petroquímica (KLÜGER, 2015c).

Ainda que o BNDE tenha sido destituído do papel de cérebro do planejamento econômico, não se pode dizer que tenha perdido sua função de financiador do crescimento como indica a ampliação da dotação orçamentária do Banco. Em 1965, o capital do Banco passou de 133.772.000 dólares para 304.310 mil dólares e continuou subindo para 373.181.000 em 1966 e 450.187 .000 em 1967. A quase totalidade deste incremento deveu-se à vinculação ao BNDE de novos fundos que responderam por quase metade do orçamento do Banco naqueles anos, passando de 23.275.000 dólares em 1964 para 137.359.000, 182.027.000 e 205.618.000 dólares nos anos seguintes (Gráfico II) (PROCHNIK, 1995, p. 162).

Assim, se de um lado o primeiro governo militar fortaleceu o poder de investimento do BNDE ao ampliar seu orçamento e atribuir a ele o financiamento dos investimentos setoriais previstos pelo PAEG, de outro enfraqueceu-o ao desprover o Banco da função de planejador do desenvolvimento e iniciar uma transição em direção à transformação do Banco em um fundo misto de investimentos para o setor privado que pudesse ser desvinculado do orçamento brasileiro, rendendo frutos para os acionistas privados nacionais e internacionais como qualquer outro banco de investimento. Estando, ademais, previsto para 1967 o fim do repasse automático do FRE para o Banco, considerava-se que os investimentos privados e a ajuda externa internacional poderiam começar a assumir o financiamento de longo prazo, desonerando a União, o que coadunava com a percepção dos monetaristas da necessidade de redução do déficit público imposta pelo

\footnotetext{
${ }^{184}$ A Eletrobrás e o Plano Nacional de Eletrificação, propostos há mais de uma década pela Assessoria Econômica Vargas, eram combatidas pelos desenvolvimentistas cosmopolitas que, ou advogavam, como Campos, por um modelo mais descentralizado - e se possível privado - de gestão do setor energético (CAMPOS, 1994, pp. 331-332); ou acusavam, como Lucas Lopes, a Assessoria de não ter experiência em elaboração projetos e, portanto, pensar a eletrificação de maneira demasiado téorica (LOPES, 1991, p. 152).
} 
lado estabilizador do PAEG.

\begin{tabular}{|c|c|c|c|c|}
\hline Personagem & Cronologia & Local de nascimento & Formação & Filiação \\
\hline $\begin{array}{l}\text { Francisco Antunes } \\
\text { Maciel }\end{array}$ & $1881-1966$ & Pelotas - RS & $\begin{array}{l}\text { Graduação em direito } \\
\text { (Faculdade Nacional de } \\
\text { Direito). }\end{array}$ & $\begin{array}{l}\text { Neto do Barão de Butuí. Pai } \\
\text { ministro do Império e irmão } \\
\text { interventor no Mato Grosso. }\end{array}$ \\
\hline Eugênio Gudin & $1886-1986$ & Rio de Janeiro - RJ & $\begin{array}{llr}\begin{array}{l}\text { Graduação } \\
\text { engenharia }\end{array} & \text { em } \\
\text { Politécnicala } \\
\text { Janeiro). }\end{array}$ & $\begin{array}{l}\text { Avô francês, dono de casa de } \\
\text { modas no Rio de Janeiro, } \\
\text { comercializava artigos de } \\
\text { luxo importados. Pai } \\
\text { educado na Europa, } \\
\text { comerciante e operador da } \\
\text { bolsa de valores. A mãe } \\
\text { faleceu precocemente. Foi } \\
\text { criado pela madrasta, } \\
\text { educada na Europa, filha de } \\
\text { banqueiro de grande fortuna. }\end{array}$ \\
\hline Valentim Bouças & $1891-1964$ & Santos - SP & $\begin{array}{l}\text { Formação técnica em } \\
\text { comércio (Academia de } \\
\text { Comércio José } \\
\text { Bonifácio de Santos). }\end{array}$ & $\begin{array}{l}\text { Pai empregado da } \\
\text { Companhia Docas de Santos. }\end{array}$ \\
\hline Ary Frederico Torres & $1900-1973$ & Porto Alegre - RS & $\begin{array}{lr}\text { Graduação } & \text { em } \\
\text { engenharia } & \text { (POLI- } \\
\text { USP). } & \\
\end{array}$ & $\begin{array}{l}\text { Pai grande comerciante } \\
\text { exportador de fumo de folha. }\end{array}$ \\
\hline Horácio Lafer & $1900-1965$ & São Paulo - SP & $\begin{array}{l}\text { Graduação em filosofia } \\
\text { (Faculdade de Filosofia } \\
\text { São Bento). Graduação } \\
\text { em direito (FD-USP). } \\
\text { Especialização em } \\
\text { economia e finanças } \\
\text { (Faculdade de Filosofia } \\
\text { de Berlim). }\end{array}$ & $\begin{array}{l}\text { Pai judeu imigrante lituano, } \\
\text { fundou com os primos } \\
\text { Klabin a tipografia e } \\
\text { indústria de papel Klabin. }\end{array}$ \\
\hline Valdér Sarmanho & 1901-1987 & São Borja - RS & 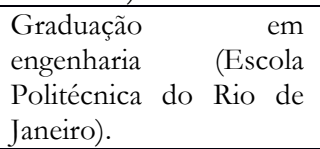 & $\begin{array}{l}\text { Pai grande estancieiro e } \\
\text { diretor do Banco São-Borja. }\end{array}$ \\
\hline $\begin{array}{lll}\text { Glycon } & \text { de } & \text { Paiva } \\
\text { Teixeira } & & \end{array}$ & $1902-1993$ & Uberaba - MG & $\begin{array}{l}\text { Graduação } \quad \text { em } \\
\text { engenharia (Escola de } \\
\text { Minas de Ouro Preto). } \\
\text { Geólogo. }\end{array}$ & $\begin{array}{l}\text { Pai engenheiro agrônomo, } \\
\text { formado no Instituto } \\
\text { Zootécnico de Uberaba, } \\
\text { faleceu precocemente. Mãe } \\
\text { professora primária. }\end{array}$ \\
\hline $\begin{array}{l}\text { José Soares Maciel } \\
\text { Filho }\end{array}$ & 1904-1975 & Rio de Janeiro - RJ & $\begin{array}{l}\text { Jornalista com estudos } \\
\text { de filosofia na Itália. }\end{array}$ & s.d. \\
\hline $\begin{array}{l}\text { Octavio Gouvêa de } \\
\text { Bulhões }\end{array}$ & 1906-1990 & Rio de Janeiro - RJ & $\begin{array}{l}\text { Graduação em direito } \\
\text { (Faculdade Nacional de } \\
\text { Direito e cursos } \\
\text { complementares na } \\
\text { American University - } \\
\text { Washington). }\end{array}$ & $\begin{array}{l}\text { Pai diplomata. Tio-avô } \\
\text { financista e advogado } \\
\text { formado na Faculdade de } \\
\text { Direito do Largo São } \\
\text { Francisco, foi político e } \\
\text { Ministro da Fazenda. }\end{array}$ \\
\hline $\begin{array}{l}\text { Mario Abrantes da } \\
\text { Silva Pinto }\end{array}$ & 1907-1999 & Santa Cruz - RJ & $\begin{array}{llr}\text { Graduação } & & \text { em } \\
\text { engenharia } & \text { civil e de } \\
\text { minas } & \text { (Escola } \\
\text { Politécnica do Rio de } \\
\text { Janeiro). Geólogo. }\end{array}$ & $\begin{array}{l}\text { Pai médico, inspetor de } \\
\text { higiene de abate de animais e } \\
\text { professor da Faculdade de } \\
\text { Medicina. Mãe professora } \\
\text { primária. }\end{array}$ \\
\hline Lúcio Meira & $1907-1991$ & Petrópolis - RJ & $\begin{array}{l}\text { Graduação } \\
\text { engenharia } \quad \text { em } \\
\text { naval e Escola } \\
\text { de Engenharia). }\end{array}$ & $\begin{array}{l}\text { Pai comerciante, tornou-se } \\
\text { capitão do exército. }\end{array}$ \\
\hline Alexandre Kafka & $1907-2007$ & $\begin{array}{l}\text { Praga - Império Austro- } \\
\text { Húngaro }\end{array}$ & $\begin{array}{l}\text { Graduação em direito } \\
\text { (Praga). Pós-graduação } \\
\text { em relações } \\
\text { Internacionais (Institut } \\
\text { Universitaire de Hautes } \\
\text { Études Internationales } \\
\text { Genebra) e graduação } \\
\text { em filosofia, política }\end{array}$ & $\begin{array}{l}\text { Família paterna todos } \\
\text { juristas. Pai Bruno Kafka, era } \\
\text { doutor em direito e professor } \\
\text { de direito na universidade } \\
\text { alemã de Praga. Foi também } \\
\text { político, eleito deputado. } \\
\text { Faleceu quando Alexandre } \\
\text { tinha } 14 \text { anos. Mãe era de }\end{array}$ \\
\hline
\end{tabular}




\begin{tabular}{|c|c|c|c|c|}
\hline & & & and economia (Oxford). & $\begin{array}{l}\text { família de engenheiros e } \\
\text { industriais. }\end{array}$ \\
\hline $\begin{array}{lll}\text { José } & \text { Vicente } & \text { Faria } \\
\text { Lima } & & \end{array}$ & 1909-1969 & Rio de Janeiro - RJ & $\begin{array}{l}\text { Militar - Aeronáutica } \\
\text { (Escola de Aviação } \\
\text { militar do Campo dos } \\
\text { Afonsos e Escola de } \\
\text { Engenharia Aeronáutica } \\
\text { de Paris). }\end{array}$ & $\begin{array}{l}\text { Pai imigrante português que } \\
\text { trabalhava no arsenal da } \\
\text { marinha. Um de seus irmãos } \\
\text { foi presidente da Petrobrás e } \\
\text { governador do Rio de } \\
\text { Janeiro durante o governo } \\
\text { militar. }\end{array}$ \\
\hline Lucas Lopes & 1911-1994 & Ouro Preto - MG & 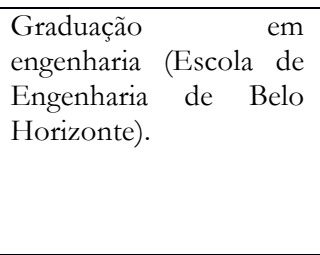 & $\begin{array}{l}\text { Avô vereador e coronel no } \\
\text { Rio Grande do Sul, agraciado } \\
\text { com um título de Barão. Pai } \\
\text { engenheiro, diretor de obras } \\
\text { da prefeitura de Belo } \\
\text { Horizonte, historiador e } \\
\text { colaborador do SPHAN. }\end{array}$ \\
\hline Octavio Dias Carneiro & $1912-1968$ & Rio de Janeiro - RJ & 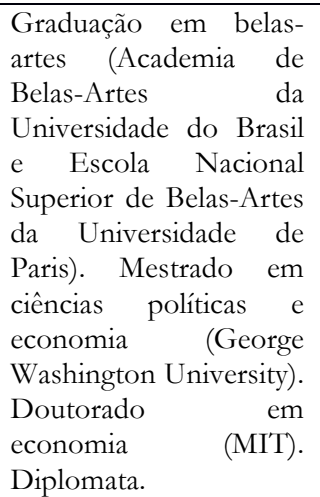 & $\begin{array}{l}\text { Pai capitão da Marinha. Mãe } \\
\text { francesa, descendente do } \\
\text { Barão de Santa Cruz. }\end{array}$ \\
\hline João Batista Pinheiro & 1914-2001 & $\begin{array}{l}\text { São Miguel do Veado } \\
\text { (Alegre) - ES }\end{array}$ & $\begin{array}{l}\text { Graduação em direito } \\
\text { (Faculdade de Direito } \\
\text { de Niterói). Mestrado } \\
\text { em } \\
\text { (Berkeley). Diplomata. }\end{array}$ & $\begin{array}{l}\text { Pai, Genaro Pinheiro foi } \\
\text { prefeito de Alegre e Senador } \\
\text { da República. }\end{array}$ \\
\hline José Garrido Torres & $1915-1974$ & Rio de Janeiro - RJ & $\begin{array}{l}\text { Graduação } \\
\text { economia (NYU). Pós- } \\
\text { graduação em economia } \\
\text { (NYU). }\end{array}$ & s.d. \\
\hline $\begin{array}{l}\text { Leocádio de Almeida } \\
\text { Antunes }\end{array}$ & 1915-1999 & Alegrete - RS & $\begin{array}{lr}\text { Graduação } & \text { em } \\
\text { contabilidade } \text { (Escola } \\
\text { de Comércio Fontoura } \\
\text { Illa). Graduação em } \\
\text { direito, ciências políticas } \\
\text { e econômicas (PUC- } \\
\text { RS). }\end{array}$ & s.d. \\
\hline Roberto Campos & $1917-2001$ & Cuiabá - MT & $\begin{array}{lr}\text { Seminário } & \text { (Belo } \\
\text { Horizonte). Mestrado } \\
\text { em economia (George } \\
\text { Washington University). }\end{array}$ & $\begin{array}{l}\text { Pai professor primário. Mãe } \\
\text { governanta e costureira. }\end{array}$ \\
\hline Dênio Nogueira & 1920-1997 & Rio de Janeiro - RJ & $\begin{array}{lr}\text { Graduação } & \text { em } \\
\text { economia } & \text { (FCEARJ). } \\
\text { Pós-graduação } \quad \mathrm{em} \\
\text { economia } \\
\text { Graduate } & \text { (School of } \\
\text { University of Michigan). }\end{array}$ & Pai militar. \\
\hline $\begin{array}{lll}\text { Genival de Almeida } \\
\text { Santos }\end{array}$ & $1920-2002$ & Guarabira - PB & $\begin{array}{lr}\text { Graduação } & \text { em } \\
\text { economia } & \text { (FCEARJ). } \\
\text { Doutorado } & \mathrm{em} \\
\text { economia } & \text { (Universidade } \\
\text { de Paris). } & \\
\end{array}$ & s.d. \\
\hline Casimiro Ribeiro & 1922 & Joinville - SC & $\begin{array}{l}\text { Graduação em direito } \\
\text { (Faculdade Nacional de } \\
\text { Direito). Pós-graduação } \\
\text { em economia (LSE). }\end{array}$ & $\begin{array}{l}\text { Descendente de alemães. Pai } \\
\text { formado engenheiro na } \\
\text { Universidade } \\
\text { Charlottenburg na Prússia. } \\
\text { Dedicou-se à exportação de } \\
\text { minérios. Foi representante }\end{array}$ \\
\hline
\end{tabular}




\begin{tabular}{|c|c|c|c|c|}
\hline & & & & $\begin{array}{l}\text { comercial de várias firmas } \\
\text { inglesas. }\end{array}$ \\
\hline Ernane Galvêas & 1922 & $\begin{array}{l}\text { Cachoeiro } \\
\text { Itapemirim - ES }\end{array}$ & $\begin{array}{lr}\text { Graduação } & \text { em } \\
\text { contabilidade } & \text { (Escola } \\
\text { Vera } & \text { Cruz). } \\
\text { Especialização } & \text { em } \\
\text { teoria e } & \text { política } \\
\text { monetária } \quad \text { (Centro de } \\
\text { Estudos Monetários } \\
\text { Latino-Americano } \\
\text { México). Mestrado } \\
\text { economia (Yale). }\end{array}$ & $\begin{array}{l}\text { Pai descendente de } \\
\text { portugueses era dentista e } \\
\text { faleceu precocemente. Foi } \\
\text { criado na casa de um tio que } \\
\text { era comprador de café. }\end{array}$ \\
\hline $\begin{array}{l}\text { Juvenal Osório } \\
\text { Gomes }\end{array}$ & 1924-2002 & $\begin{array}{l}\text { Santa Isabel do Rio } \\
\text { Preto - RJ }\end{array}$ & $\begin{array}{lr}\text { Graduação } & \text { em } \\
\text { economia } & \text { (FNCE). } \\
\text { Pós-graduação } & \mathrm{em} \\
\text { economia } & \text { (LSE). } \\
\text { Especialização } & \mathrm{em} \\
\text { demografia (Instituto de } \\
\begin{array}{l}\text { Estudos Demográficos } \\
\text { em Paris). }\end{array}\end{array}$ & s.d. \\
\hline $\begin{array}{l}\text { Anníbal } \quad \text { Villanova } \\
\text { Villela }\end{array}$ & $1926-2000$ & Rio de Janeiro - RJ & $\begin{array}{lr}\text { Graduação } & \text { em } \\
\text { economia } & \text { (FNCE). } \\
\text { Especialização } \quad \mathrm{em} \\
\text { economia (Universidade } \\
\text { de Estocolmo e LSE). }\end{array}$ & $\begin{array}{l}\text { Pai Adhemar Villela dos } \\
\text { Santos, general de brigada } \\
\text { que vinha de Minas Gerais e } \\
\text { era filho de Francisco Villela } \\
\text { dos Santos, Tesoureiro dos } \\
\text { Correios do Estado de } \\
\text { Minas. Neto de parte de mãe } \\
\text { do carioca Annibal de } \\
\text { Azambuja Villanova, } \\
\text { também general de brigada. }\end{array}$ \\
\hline Isaac Kerstenetzky & 1927-1991 & Rio de Janeiro - RJ & $\begin{array}{lr}\text { Graduação } & \text { em } \\
\text { economia } & \text { (FNCE). } \\
\text { Pós-graduação } & \text { em } \\
\text { economia } & \text { (McGill, } \\
\text { Canadá } \\
\text { Holanda). }\end{array}$ & $\begin{array}{l}\text { Filho de imigrantes judeus da } \\
\text { Europa Oriental que se } \\
\text { tornaram mascates no Rio de } \\
\text { Janeiro. }\end{array}$ \\
\hline $\begin{array}{l}\text { Julian Alfonso } \\
\text { Magalhães Chacel }\end{array}$ & 1928 & Rio de Janeiro - RJ & $\begin{array}{lr}\text { Graduação } & \mathrm{em} \\
\text { economia } & \text { (FNCE). } \\
\text { Especialização } & \mathrm{em} \\
\text { economia (Universidade } \\
\text { de Paris). }\end{array}$ & $\begin{array}{l}\text { Pai comandante espanhol } \\
\text { Julian Chacel Norma que } \\
\text { servia no Brasil e na } \\
\text { Argentina. Mãe Maria Beatriz } \\
\text { Magalhães, filha de Fernando } \\
\text { Augusto Ribeiro de } \\
\text { Magalhães, professor e } \\
\text { diretor da Faculdade de } \\
\text { Medicina do Rio de Janeiro, } \\
\text { deputado da constituinte de } \\
\text { 1934 membro da Academia } \\
\text { Nacional de Medicina e da } \\
\text { Academia Brasileira de } \\
\text { Letras. Seu bisavô Nuno } \\
\text { Ferreira de Andrade, também } \\
\text { médico, foi presidente da } \\
\text { Academia Imperial de } \\
\text { Medicina, Reitor da } \\
\text { Universidade do Brasil e era } \\
\text { conselheiro do Imperador } \\
\text { Dom Pedro II }\end{array}$ \\
\hline $\begin{array}{ll}\text { Paulo Hortênsio } \\
\text { Pereira Lira }\end{array}$ & 1930 & Rio de Janeiro - RJ & $\begin{array}{lr}\text { Graduação } & \text { em } \\
\text { economia } & \text { (FNCE). } \\
\text { Pós-graduação } & \text { em } \\
\text { economia (Harvard). }\end{array}$ & $\begin{array}{l}\text { Pais mudaram da Paraíba } \\
\text { para o Rio de Janeiro. Pai era } \\
\text { advogado pela Faculdade de } \\
\text { Direito de Recife, passou a } \\
\text { lecionar na Faculdade } \\
\text { Nacional de Direito, foi } \\
\text { deputado constituinte em } \\
\text { 1934, primeiro secretário da } \\
\text { câmara dos deputados, chefe } \\
\text { do gabinete civil da } \\
\text { presidência de Dutra. }\end{array}$ \\
\hline $\begin{array}{l}\text { João Paulo dos Reis } \\
\text { Velloso }\end{array}$ & 1931 & Parnaíba - PI & 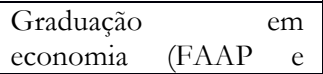 & $\begin{array}{l}\text { Pai telegrafista e mãe } \\
\text { costureira. }\end{array}$ \\
\hline
\end{tabular}




\begin{tabular}{|c|c|c|c|c|}
\hline & & & $\begin{array}{l}\text { UEG). Especialização } \\
\text { em economia (CNE e } \\
\text { CAE). Mestrado em } \\
\text { economia (Yale) }\end{array}$ & \\
\hline $\begin{array}{ll}\text { Mario } & \text { Henrique } \\
\text { Simonsen } & \end{array}$ & 1935-1997 & Rio de Janeiro - RJ & $\begin{array}{lr}\text { Graduação } & \text { em } \\
\text { engenharia } & \text { (Faculdade } \\
\text { Nacional } & \text { de } \\
\text { Engenharia). } & \\
\text { Especialização } & \text { em } \\
\text { engenharia econômica } \\
\text { (Faculdade Nacional de } \\
\text { Engenharia) }\end{array}$ & $\begin{array}{l}\text { Avô médico das elites } \\
\text { políticas brasileiras, fez } \\
\text { doutorado em Paris e foi um } \\
\text { dos primeiros psiquiatras } \\
\text { brasileiros e era professor } \\
\text { catedrático na Faculdade de } \\
\text { Medicina no Rio de Janeiro. } \\
\text { O pai Mario Simonsen } \\
\text { bacharelou-se em direito, não } \\
\text { exerceu a profissão, } \\
\text { envolveu-se com o comércio } \\
\text { internacional. }\end{array}$ \\
\hline
\end{tabular}

Tabela II: Trajetórias das principais personagens do Primeiro Movimento. Elaboração: própria.

\subsection{Rede do Primeiro Movimento}

A rede tecida a partir dos vínculos narrados neste Primeiro Movimento expressa a diferenciação do espaço brasileiro dos especialistas em economia, ocorrida ao longo do período que vai dos anos 1940 ao final do primeiro governo militar. Por diferenciação entende-se tanto a multiplicação das escolas de economia e das estruturas institucionais governamentais, que se especializaram em diferentes áreas da administração econômica, quanto o distanciamento relativo entre grupos com visões econômicas divergentes. No princípio do Movimento, predominava a tendência à cooperação de todos aqueles engajados na valorização do saber econômico e na missão de transformá-lo em instrumento fundamental de racionalização das práticas do Estado, de modo que as equipes econômicas eram integradas por membros de diferentes grupos e as escolas e institutos de pesquisa publicavam trabalhos e abrigavam pessoas com diversas orientações econômicas. Ao final do período, depois de uma série de episódios conflituosos, como o caso dos acordos de Roboré, a ruptura de JK com o FMI e o encontro da CEPAL em Petrópolis, o espaço assume uma configuração na qual há visíveis polaridades entre grupos com ideias contrapostas no que concerne aos princípios da boa gestão econômica, à ação do Estado na economia e à forma legítima de produção do conhecimento econômico.

As polaridades detectadas no período dispõem-se na rede em uma estrutura triangular cujos vértices correspondem aos grupos monetarista, desenvolvimentista nacionalista e desenvolvimentista não nacionalista ou cosmopolita. Desenhada sobre a 
rede há uma linha guia que divide o espaço no que concerne às conexões internacionais. $\mathrm{Na}$ parte de baixo observa-se predominantemente vínculos com a Europa e a América Latina e na parte de cima com os Estados Unidos, havendo variações nos segmentos do espaço dos economistas estadunidenses com os quais cada fração dos brasileiros estabelece contato.

O polo desenvolvimentista nacionalista coincide, em grande parte, com aquele apresentado na rede da Abertura, desenhada em função da análise das relações entre o Brasil e a CEPAL. Nele estão situados, além da Assessoria Vargas e da CEPAL, apresentados anteriormente, a SUDENE e, principalmente, o Clube dos Economistas, agregação que reunia funcionários de burocracias econômicas de Estado, os antigos assessores de Vargas e os editores da Conjuntura Social que foram afastados da Fundação Getúlio Vargas. É possível ver o destaque de Celso Furtado neste ponto do espaço, resultante do exercício de funções de liderança na CEPAL, na SUDENE, no BNDES, na Conjuntura Social e no Clube dos Economistas, além de vínculos diretos com diversos indivíduos, em função de relações pessoais e deslocamentos institucionais no espaço nacional e internacional.

A região do espaço na qual localizam-se os desenvolvimentistas nacionalistas comporta, como na parte superior da rede apresentada no capítulo anterior, o Nordeste, de onde provém a maior parte da Assessoria Vargas e da SUDENE, e o Rio Grande do Sul, estado do qual são oriundos diversos quadros de confiança de Getúlio Vargas e João Goulart, casos de Valder Sarmanho, Francisco Antunes Maciel e Leocádio Antunes. O núcleo nacionalista inclui também a maior parte dos advogados, formação partilhada tanto pelos "técnicos" ligados a burocracias econômicas de Estado, localizados na área do vértice inferior ao BNDE, quanto pelos "políticos" de Vargas e Jango. As duas subpartições correspondem a idades diferentes, aqueles nascidos no início do século XX acima, próximos dos políticos e quase sem contatos com o exterior, e, abaixo, os nascidos entre os anos 1920 e 1935, mais próximos dos órgãos econômicos de Estado e dos centros de formação de economistas, abrigando os que tiveram oportunidade de especializar-se em economia, via de regra na Europa ou na América Latina, em instituições como a CEPAL e a LSE, representadas neste ponto do plano, casos, por exemplo, de Cleantho de Paiva e Ignácio Rangel. 
Movendo-se do desenvolvimentismo nacionalista ao monetarismo não nacionalista, encontram-se aqueles cuja formação inicial foi adquirida nas escolas de economia nacionais, a FCEARJ e a FNCE, e os que mantiveram vínculos com a FGV-RJ, núcleo central do vértice monetarista. Esse polo se caracteriza pela proximidade com o Rio de Janeiro e pelo aumento do número de anos dedicado à formação especializada em economia. A área da rede correspondente ao monetarismo abriga diversos economistas nascidos entre 1920 e 1935 que frequentaram as primeiras escolas de economia e ligaramse à SUMOC ou à FGV, como Dênio Nogueira e Julian Chacel. Muitos dentre eles foram alunos de Eugênio Gudin e Octavio Gouvêa de Bulhões, as duas figuras com maior número de laços nesse ponto do espaço.

Gudin e Bulhões apresentam notável multiposicionalidade, ocupando numerosas posições dirigentes (BOLTANSKI, 1973, pp. 24-25), e, simultaneamente, vasto conjunto de laços pessoais com economistas reconhecidos internacionalmente, que atraíam para falar em suas escolas e publicar em suas revistas, sendo, na contrapartida, por eles convidados para participar, como representantes brasileiros, de conferências e negociações internacionais na área econômica, como a participação de Bulhões no Plano White.

Segmentos diferentes do espaço representado na rede estão vinculados a pontos distintos do espaço dos economistas norte-americanos. Os laços de Gudin e Bulhões foram majoritariamente tecidos com grupos que partilhavam a visão econômica que privilegiava a ação dos mercados, o controle da emissão de moeda e rejeitava a intervenção do Estado e do planejamento estatal para a promoção do desenvolvimento. Gottfried Haberler e Jacob Viner, críticos das teorias cepalinas e do protecionismo, aparecem como os mais importantes contatos de Gudin e Bulhões no exterior. Viner, especialmente, foi figura importante na formação de Milton Friedman e outros alunos seus que, nesse período, estavam constituindo em Chicago um departamento de economia que ficaria célebre por sua orientação monetarista (item 4.4).

Ainda que Bulhões tenha feito curto estágio nos EUA, a maior parte dos vínculos dele e de Gudin com o exterior decorreram do renome adquirido como os primeiros representantes da moderna economia no Brasil. Os vínculos institucionais entre o espaço dos economistas no Brasil e o exterior foram sendo tecidos a posteriori, em parte como fruto da atuação de Gudin e Bulhões, que intermediam convites para palestrantes, que 
recebem a carta de convocação que levou Furtado à CEPAL, que negociam os acordos de cooperação científica, que atraem para a FGV Alexandre Kafka, um dos elos com o exterior etc. As disposições sociais dos dois, como o cosmopolitismo precoce e a familiaridade com a "alta cultura", adquiridos no ambiente familiar, nas viagens ao exterior, no estudo em colégios dirigidos por estrangeiros e no trabalho junto a companhias internacionais, além das incursões autodidatas na economia, favoreciam a costura de laços, tanto no plano internacional quanto em meio às elites da então capital do país. Bulhões era sobrinho de influente Ministro da Fazenda e filho de diplomata e a família de Gudin conectava-se com os Chacel, os Simonsen, os Klabin e outras influentes famílias cariocas.

Mario Henrique Simonsen e Julian Chacel, nascidos em famílias do círculo social de Eugênio Gudin, foram por ele influenciados na entrada no universo da economia. Mario Henrique Simonsen, nome de destaque no período, aparece no espaço em posição intermediária entre o núcleo do monetarismo e o desenvolvimentismo não nacionalista, atuando nas duas organizações centrais da área da rede que abriga o desenvolvimentismo não nacionalista, isto é, o CAE-FGV e a CONSULTEC. O CAE, escola dirigida por Simonsen que estabeleceu diversos convênios com instituições de ensino e pesquisa em economia no exterior e que se transformaria, ao final do período contemplado no Primeiro Movimento, em um dos dois primeiros mestrados em economia do país (item 4.2), é o centro a partir do qual a geração mais jovem de economistas (1935-1945), formada sobretudo por mineiros e cariocas, será enviada para as universidades de Yale, Vanderbilt e Berkeley - em acordos intermediados, notavelmente, por Alexandre Kafka e Werner Baer (item 4.2), figuras que circulavam entre o Brasil e os Estados Unidos com ampla gama de laços.

Os acordos internacionais de cooperação científica e técnica dos EUA com a América Latina multiplicaram-se com o lançamento do Ponto IV e cresceram ainda mais na época da Aliança para o Progresso. Não se tratam mais de vínculos intermediado por indivíduos, mas de convênios institucionais. Simonsen atuou como interlocutor privilegiado na aproximação de sua escola com os EUA, capacitado por suas conexões com a elite local e por sua formação cosmopolita em escolas de prestígio, mas sobretudo por personificar a lógica abstrata da economia matematizada. Conforme a matemática conquista o polo dominante no espaço global da ciência econômica (item 4.4), seu curso, 
pioneiro na conjugação da economia com a matemática e a estatística, tornou-se importante elo para o estabelecimento dos convênios que permitiram aos seus alunos formarem-se em prestigiadas universidades norte-americanas.

Além dos convênios de cooperação científica, o contato com a especialidade econômica cultivada nos Estados Unidos passou, nesse período, pelo núcleo de diplomatas que teve a oportunidade de frequentar universidades no exterior, incluindo João Baptista Pinheiro, Roberto Campos e Octávio Dias Carneiro; pelos acordos de cooperação técnica, como visto no caso da CMBEU de Lucas Lopes, Ary Torres, Roberto Campos, Glycon Paiva e Valentim Bouças; e pela ponte entre Lincoln Gordon, professor de Harvard e assessor de Kennedy, que se tornou embaixador dos Estados Unidos no Brasil, com a CONSULTEC, consultoria privada formada por "técnicos" que deixavam o governo em um movimento de pantouflage em direção ao setor privado (BOURDIEU e SAINT-MARTIN, 1976, p. 52 ; CHARLE, 1987, p. 1115).

Roberto Campos e Lucas Lopes, sócios-fundadores da CONSULTEC, são os indivíduos com maior grau de conexão nessa área da rede por sua multiposicionalidade institucional e capacidade de transitar entre a política, o setor público e o setor privado. Ainda que as conexões familiares com membros da elite política continuem rendendo dividendos importantes, funcionando como via de acesso ao poder, como, por exemplo, no caso de Lucas Lopes, esses não são mais os trunfos de maior destaque nesse ponto do espaço, que se define pela competência "técnica" especializada, em oposição àqueles dotados apenas de laços políticos, como o grupo dos gaúchos de Vargas. Roberto Campos sequer era um homem dotado de laços familiares com o universo da política, órfão de pai provindo de família de origem média. Sua inserção social deveu-se ao acesso a ensino religioso de qualidade, essencial para a aprovação no concurso público. Caso semelhante ao de João Paulo dos Reis Velloso, que também ascendeu socialmente graças a vínculos estabelecidos na comunidade católica. Para ambos, a aproximação da economia é uma opção pragmática visando a ascensão profissional nas carreiras que trilhavam na burocracia, Campos, no departamento comercial do Itamaraty; Reis Velloso, no Banco do Brasil.

À CONSULTEC agregaram-se especialistas em economia da geração seguinte (1935-1945), como o próprio Mario Henrique Simonsen e seu grupo de estagiários composto por Fernando Silva Pinto, Arlindo Corrêa e Jefferson de Oliveira. O caráter 
bigeracional dessa área da rede é evidenciado pela presença de filhos e sobrinhos, caso de Mario e Fernando Silva Pinto, de Lucas e Chico Lopes e de Roberto Campos e Jefferson de Oliveira. Os estagiários da CONSULTEC e Simonsen ainda partilhavam com a maior parte do grupo mais velho (1905-1920) a formação inicial em engenharia; somente os alunos deles no CAE serão formados integralmente em economia, seguindo a maior parte deles para a pós-graduação no exterior e vários deles ligando-se ao EPEA ao retornar. Além da confluência entre duas gerações, esse ponto do espaço é marcado pela aproximação dos cariocas do CAE e da Faculdade Nacional de Engenharia com os mineiros de JK e da FACE.

Os desenvolvimentistas cosmopolitas, tal qual os desenvolvimentistas nacionalistas, até este momento consideravam, via de regra, válida a ação planejadora sobre a economia. Adquiriram, nos programas de cooperação técnica, domínio sobre instrumentos de planejamento e avaliação de projetos, que utilizaram no Plano de Metas do governo de Juscelino Kubitschek e que seriam empregados pela CONSULTEC em seus serviços de consultoria ao setor privado. Não acreditavam, entretanto, que as soluções para os problemas econômicos nacionais passassem pelo protecionismo e fechamento das fronteiras ao capital estrangeiro, o que os diferenciava dos nacionalistas e aproximava-os dos monetaristas. No centro da área da rede recoberta pelos não nacionalistas encontra-se o IPÊS, agregação de empresários que incluía, entre seus membros, diversos especialistas em economia, vários dos quais ligados à FGV, ao lado da qual aparece na rede. A presença, nessa região do espaço, de vários participantes do golpe leva diversos não nacionalistas ao governo militar, notavelmente os ministros Bulhões e Campos, acompanhados de Dênio Nogueira e Garrido Torres, monetaristas do grupo da SUMOC e membros do IPÊS, que se tornam presidentes, respectivamente, do BCB e do BNDE.

O BNDE ocupa na rede ponto intermediário entre o desenvolvimentismo nacionalista e o desenvolvimentismo cosmopolita. A interpolação dos dois grupos na direção da instituição caracteriza o período que vai do início do segundo governo Vargas ao final do governo JK. Entre 1953 e 1954 houve um pequeno interlúdio, mais nacionalista, resultante do afastamento do grupo dos "técnicos" desenvolvimentistas cosmopolitas decorrente do conflito com os “políticos” nomeados por Getúlio Vargas. 
Os técnicos não rejeitavam que o Banco tivesse orientações políticas que funcionassem como balizas para a definição de um projeto de país. O conflito primordial expresso na oposição dos termos "técnica" e "política" decorre da contraposição entre os "técnicos" modernos especializados e os "políticos" tradicionais, desprovidos de certificações escolares. Para os técnicos, a certificação era fundamental para uma política racional, vendo em seus oponentes falta de "vivência técnica" (CAMPOS, 2009, p. 47), despreparo para julgar o "mérito intrínseco dos projetos" (LOPES, 2009, p. 28) e uma “irracionalidade temperamental” (CAMPOS, 2009, p. 54). Assim, a oposição entre a técnica e a política não significa aqui uma visão das duas como esferas distintas, regidas por lógicas diversas, mas uma afirmação dos títulos escolares como requisito inescapável da atuação legítima, na técnica e na política. Trata-se de uma perspectiva que busca a racionalização da política reivindicando que ela seja feita por aqueles que detêm competências de natureza técnico-científica (KLÜGER, 2015b, pp. 82-83). Ao apresentar suas decisões como racionais, neutras, técnicas e eficazes, os "técnicos" buscavam converter suas crenças e visão de mundo em princípios universais legitimadores de seu poder, desqualificando aqueles não pertencentes à "classe universal" modernizadora (BOURDIEU, 1989, pp. 537, 555-558).

Jânio Quadros trouxe para o BNDE um militar de seu círculo pessoal, sem vínculos com o universo dos especialistas em economia. Jango voltou a escolher um advogado do Rio Grande do Sul, leal a ele e a Vargas, também sem vínculos com o universo dos economistas. O período de crise econômica, declínio do planejamento, crise política e conflitos sociais teve efeitos sobre o Banco que perdeu recursos, prestígio e reduziu suas operações. De junho de 1963 até o golpe o BNDE ficou nas mãos do superintendente Genival Santos, que ocupava posição intermediária entre o desenvolvimentismo e o monetarismo. O primeiro governo militar trará para a presidência do Banco Garrido Torres, próximo ao grupo monetarista, com vínculos com a SUMOC e o IPÊS, tendo, portanto, além de graduação e pós-graduação na NYU, vasto conjunto de vínculos com membros influentes do novo governo. Conquanto o BNDE matenha vínculos sólidos com a área nacionalista do espaço na qual situam-se seus funcionários de carreira, a direção do Banco transita em direção ao polo menos favorável ao planejamento e à intervenção estatal, voltando o Banco para o fortalecimento do setor 
privado em lugar da realização de planos abrangentes de ação do Estado e das empresas públicas sobre a economia, aderindo à perspectiva não nacionalista.

Antes de dar sequência à narrativa e análise da transmutação das estuturas do espaço dos economistas, há um Intermezzo com um novo deslocamento da narrativa para o Chile, com o objetivo de apresentar um conjunto de personagens que desempenharão papel essencial no Terceiro Movimento, que se ocupará da redemocratização. 


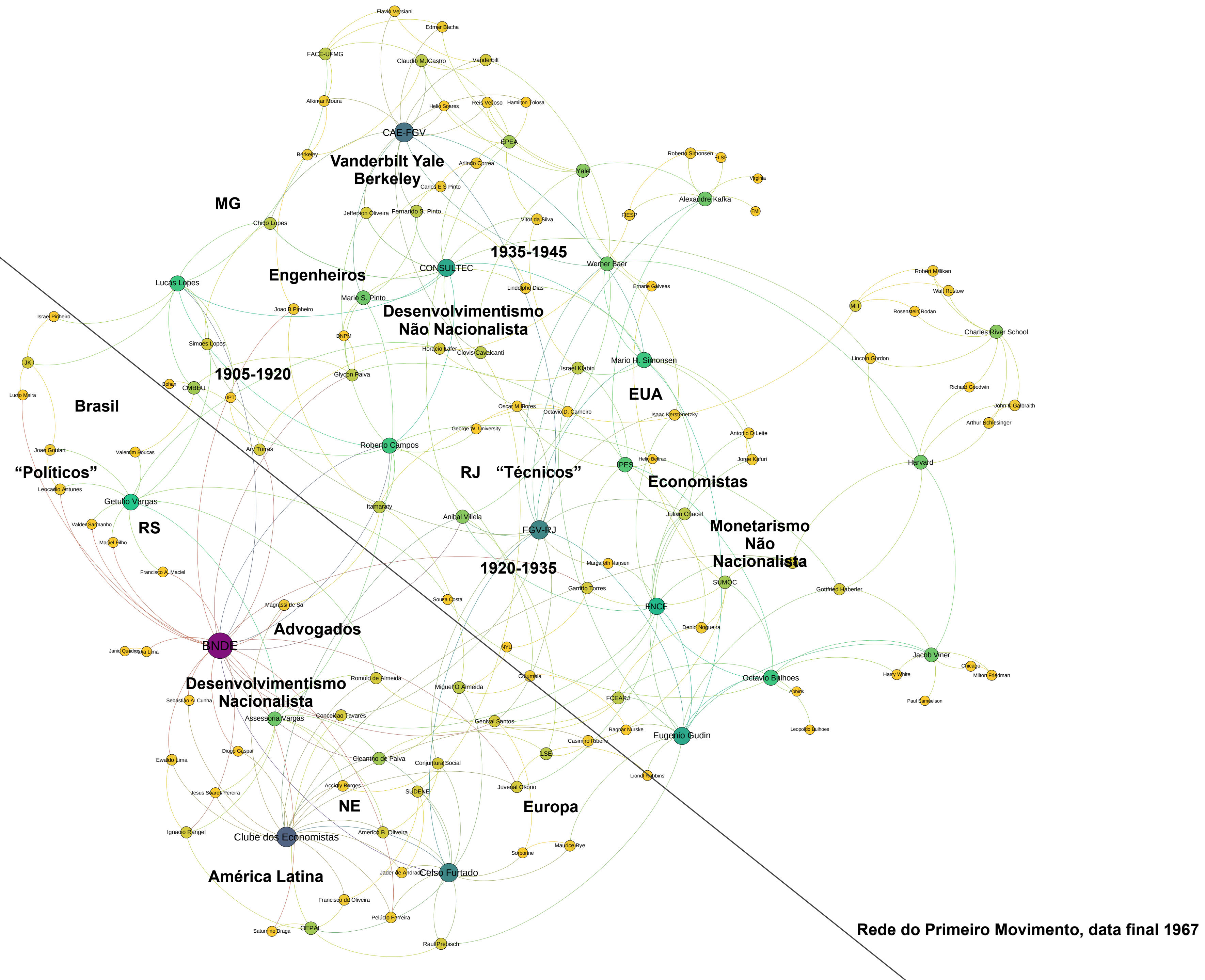




\section{INTERMEZZO'185: Militância e exílio (1964-1973)}

O cenário no qual se passa o Intermezzo é a Santiago dos exilados brasileiros, de 1964 a 1973. A narrativa é, assim, uma continuação da Abertura, posto que retorna à Comissão Econômica para a América Latina (CEPAL) e à luta pela produção de um pensamento latino-americano. A interrupção da exposição propriamente voltada aos movimentos do espaço dos economistas no Brasil objetiva introduzir grupos de intelectuais e ativistas que irão ocupar posições centrais no campo do poder político e da administração e ciência econômica na Nova República. A incorporação na análise de estudantes, militantes, cientistas sociais e outros agentes não é, portanto, um descaminho do estudo das conexões entre o espaço dos economistas e o campo do poder.

O Intermezzo ocorre entre dois momentos da narrativa acerca da formação e transmutação do espaço dos economistas no Brasil:

O Primeiro Movimento, que se encerra com o governo Castello Branco, cuja administração econômica é dominada por alguns dos principais personagens apresentados ao longo do capítulo dois. Octavio Bulhões e Roberto Campos (itens 2.1 e 2.2) tornam-se os mais poderosos ministros. Discípulos sumoqueanos de Eugênio Gudin e Bulhões, como Garrido Torres, Dênio Nogueira e Casimiro Ribeiro (itens 2.1 e 2.5) espalham-se pela administração do Banco Central Brasil (BCB), do Banco do Brasil (BB) e do Banco Nacional de Desenvolvimento Econômico (BNDE). Mario Henrique Simonsen (item 2.4) escreve parte substantiva do Plano de Ação Econômica do Governo (PAEG), complementado pelos estudos econômicos setoriais, tarefa entregue a um aluno de Mario Henrique recém-chegado dos (EUA), João Paulo dos Reis Velloso (item 2.5).

O Segundo Movimento, que tem início no segundo governo militar e se arrasta até as vésperas da redemocratização, introduzirá um novo grupo de especialistas em economia. O foco desvia-se do Rio de Janeiro para São Paulo, que doravante será celeiro de parte substancial dos economistas que chegarão à cúpula da gestão econômica nacional. O deslocamento para São Paulo é acompanhado de uma transição no perfil social daqueles que chegam ao poder, havendo uma alguma abertura para descendentes de

\footnotetext{
${ }^{185}$ Nos séculos XIX e XX o termo intermezzo designa um interlúdio musical, com cortinas fechadas, separando dois atos ou cenas de uma ópera (VIGNAL, 1999, p. 418). No caso, trata-se de um capítulo que ocorre entre os movimentos em curso no Brasil e que apresenta elementos essenciais para a compreensão dos reposicionamentos dos agentes ao voltar ao cenário principal.
} 
imigrantes em trajetória de ascensão social, cujo exemplo mais paradigmático é Delfim Netto, “o Czar" da economia brasileira no período (item 4.2). O Segundo Movimento é também marcado pela transição de um estágio no qual a administração econômica é predominantemente praticada por diplomatas, advogados e engenheiros com especializações práticas ou com pós-graduações em economia cursadas no exterior, para um momento em que criam-se os primeiros cursos de mestrado e doutorado, cresce o número de escolas de economia no país e os economistas formados no Brasil alcançam postos de direção no Estado.

O Intermezzo apresenta trajetórias de agentes que, entre o final do primeiro movimento e o início do segundo, foram deslocados da vida política nacional pelo governo militar. A trajetória de vida desses opositores é inexoravelmente marcada pela experiência de desvio do destino projetado, em decorrência das perseguições promovidas pela ditadura. Eles interrompem suas carreiras acadêmicas, suspendem as aspirações políticas, escondem-se, deixam as famílias e muitos deles são obrigados a partir tendo que reconstruir a vida no exterior. Nos países que receberam grandes contingentes de exilados, constituíram-se comunidades que reuniam brasileiros de todas as regiões do país, promovendo encontros que a priori seriam geograficamente improváveis. Os laços tecidos nesses espaços e o pensamento crítico ali formulado serão, na época da anistia, deslocados para o cenário nacional, funcionando como referência para a ação política daqueles que se inserem nas lutas políticas da redemocratização.

Santiago é central na modelagem do pensamento político e econômico crítico e das redes daqueles que governarão países latino-americanos em processo de redemocratização. Ela abrigou numerosos intelectuais do espectro de esquerda, muitos dos quais lograram inserir-se de maneira profícua em uma capital que transitava de uma democracia cristã, que propunha reformas sociais sem precedentes no país, ao experimento de instalação do socialismo por via democrática. A vasta presença de organizações internacionais, como a CEPAL, a Organização das Nações Unidas para a Alimentação e a Agricultura (FAO) e a Organização Internacional do Trabalho (OIT), e o surgimento de escolas de pós-graduação voltadas à formação de quadros latinoamericanos e ao estudo da realidade socioeconômica da região, notavelmente a Faculdade Latino-Americana de Ciências Sociais (FLACSO) e a Escuela Latinoamericana de Economía de la Universidad de Chile (ESCOLATINA), criaram oportunidades para que 
os brasileiros pudessem inserir-se na vida intelectual de Santiago. Além do grande contingente de latino-americanos ali reunidos, havia tantos outros estrangeiros que circulavam pelas representações internacionais, criando um universo aberto a trocas cosmopolitas.

O período abarcado por este capítulo é justamente aquele que separa o golpe militar no Brasil, em abril de 1964, do golpe chileno em setembro de 1973. No Chile, esse período corresponde às experiências de governo democráticas e progressistas, o reformismo de Eduardo Frei Montalva e o ensaio de socialismo de Salvador Allende, que foram suprimidas com a instauração da ditadura de Augusto Pinochet. No plano das ciências econômicas há o surgimento de versões da análise do desenvolvimento latinoamericano ainda mais heterodoxas do que a da CEPAL, que passaram a conjugar a análise econômica com o estudo das condições sociais e políticas das nações do subcontinente. Caso, por exemplo, da teoria da dependência na versão de Fernando Henrique Cardoso e Enzo Falleto e da crítica à política econômica ao governo militar brasileiro elaborada por Maria da Conceição Tavares e José Serra. Em alguns casos, com acentuada inspiração marxista, como na teoria marxista da dependência de Vânia Bambirra, Theotônio dos Santos, Ruy Mauro Marini e André Gunder Frank. Simultaneamente, estavam adentrando o Chile as ideias neoliberais de Chicago, carregadas por Arnold Harberger e seus seguidores, conhecidos como os Chicago Boys, que assumiriam o controle da política econômica da ditadura de Pinochet, fazendo do Chile um pioneiro caso de radical modelagem da política econômica de acordo com as ideias neoliberais de Milton Friedman e seus colegas da Escola de Chicago, grupo que será alvo de considerações no próximo movimento (item 4.4).

Como nos capítulos anteriores, os eventos narrados serão costurados pela apresentação das trajetórias de alguns dos principais envolvidos na trama, com o objetivo de caracterizar indivíduos e grupos, descrever seu processo de socialização e compreender como foram tecidos os laços entre eles. Ainda que a comunidade de brasileiros exilados seja extensa e abrigue muitos grupos além dos intelectuais, a análise vai se restringir à apresentação daqueles com conexões importantes com as personagens que conduzem a narrativa e às instituições nas quais reúnem-se os cientistas sociais e economistas brasileiros. Portanto, pouca atenção será dada à formação das células militantes no exterior, a grupos que não se integram na vida chilena pois se ocupam primordialmente 
da preparação da revolução no Brasil e a outras camadas sócioprofissionais, como os profissionais médios e aqueles que se transformam em mão-de-obra não qualificada.

Posto que a vida política de oposição, que leva à perseguição e ao exílio, é central para a construção da trama, ao longo da narrativa serão apresentadas algumas organizações posicionadas no espectro da esquerda brasileira dos anos 1960, sobretudo agremiações que reúnem jovens universitários dispostos a lutar contra o governo. Em lugar do Rio de Janeiro, foco dos eventos até agora apresentados, terão centralidade neste capítulo grupos de mineiros, paulistas e pernambucanos. O Intermezzo começa com a apresentação da Faculdade de Ciências Econômicas de Minas Gerais que agregou jovens de oposição que terão papel de destaque no movimento estudantil e que, por caminhos diversos e em momentos distintos, circularão pelo no Chile.

O capítulo principia pela trajetória do mineiro Herbert José de Souza (item 3.1), o Betinho, mencionado no primeiro capítulo em sua brevíssima experiência como sociólogo do Centro CEPAL-BNDE. A partir dela, serão apresentados a Faculdade de Ciências Econômicas da Universidade de Minas Gerais (FACE-UFMG) e o grupo dos bolsistas dos cursos de Economia e de Ciências Sociais. Betinho foi um dos principais líderes dos movimentos estudantis ligados à esquerda católica. Seu caminho da Juventude Católica (JEC/JUC) à Ação Popular (AP), versão laica, socialista e revolucionária da JUC, ilustra a experiência de tantos outros que ingressaram na vida política por meio de grupos de jovens ligados aos setores progressistas da igreja, que lutavam em prol da transformação social, equiparando o pecado religioso à inação face às injustiças sociais. No acirrar dos conflitos sociais e políticos do princípio dos anos 1960, essas agremiações transitaram para a esquerda, passando a associar-se com militantes e grupos socialistas laicos do movimento estudantil. Como outras facções majoritariamente jovens da esquerda surgidas naqueles anos, a AP procurava apresentar uma alternativa ao Partido Comunista Brasileiro (PCB), considerado demasiado hierarquizado, pouco radical e lento em sua luta política. A AP logo conseguiu posição de destaque entre os estudantes. Passou a ocupar posição hegemônica no movimento estudantil, logrando eleger sucessivamente os presidentes da União Nacional dos Estudantes (UNE). De 1962 a 1963, foi presidente da organização um colega de Betinho de FACE e de militância, Vinícius Caldeira Brant. No ano seguinte, a AP conseguiu novamente eleger seu candidato, desta vez o paulistano José Serra. 
Acompanhar a trajetória de José Serra (item 3.2) torna possível narrar o processo de constituição da AP em São Paulo e observar a formação de um núcleo de ativistas na Escola Politécnica da Universidade de São Paulo (POLI-USP), muitos dois quais continuarão próximos entre si até o governo Fernando Henrique Cardoso. A ele pertenceram, dentre outros, os ministros de FHC, das Comunicações, Sérgio Motta e da Casa Civil, Clóvis Carvalho, e Luiz Carlos Mendonça de Barros, presidente do BNDES de 1995 a 1998 (item 6.4). O golpe de 1964 e o incêndio da UNE fazem com que Serra, visado por ser um líder da esquerda estudantil, esconda-se na embaixada da Bolívia e deixe o país. Depois de uma primeira experiência no exílio, com passagens pela Bolívia e pela França, e de uma breve tentativa de viver como clandestino em São Paulo, José trilha o caminho até Santiago de Chile, onde integra a primeira onda de intelectuais brasileiros exilados, muitos dos quais conseguiram inserir-se no ambiente político e acadêmico chileno.

A partir deste trecho começam a reaparecem diversos personagens da Abertura, especialmente os quadros da CEPAL com os quais os exilados passarão a interagir. Os membros do Centro CEPAL-BNDE (item 1.5) dos quais se falou anteriormente vão se transferir, um a um, para Santiago, estabelecendo vínculos com José Serra. Carlos Lessa apresentará Serra a Aníbal Pinto Santa Cruz, que o ajuda a ingressar no Instituto LatinoAmericano de Planificação Econômica (ILPES) e na ESCOLATINA, fazendo dele seu assistente pessoal. Serra vai morar com Francisco de Almeida Biato, que fora estagiário do Centro CEPAL-BNDE, e com um colega dele de Universidade Federal do Rio de Janeiro (UFRJ), Cláudio Salm. Nessa casa conhece Maria da Conceição Tavares, de quem se tornou parceiro de pesquisa, escrevendo em conjunto o texto Além da estagnação: uma discussão sobre o estilo de desenvolvimento recente do Brasil (1970), no qual analisam o modelo de crescimento econômico com concentração de renda que se produzira no governo militar. Serra e Conceição, além disso, atuarão lado a lado na assessoria econômica do governo Salvador Allende. Antonio Barros de Castro, que chegou pouco depois, juntou-se a Serra na coordenação de um seminário de leituras do Capital de Karl Marx. Betinho, finalmente, chegará a Santiago no começo dos anos 1970, sendo recebido e abrigado por seu antigo companheiro de AP e passando também a colaborar com o experimento de socialismo democrático chileno. 
Depois de dividir casa com Biato e Salm, Serra vai morar com dois outros companheiros de AP, Vilmar Faria e Regina Faria, que como Betinho fizeram parte do grupo dos bolsistas mineiros, e com Carlos Estevam Martins, que ele conhecia do Centro Popular de Cultura (CPC). Serra estudava no ILPES, os Faria e os Martins na FLACSO. Todos eles tinham aulas com Fernando Henrique Cardoso, sociólogo da USP que chegou ao Chile na leva que deixou o Brasil quase imediatamente após o golpe. Fernando Henrique será próximo dos três por bastante tempo. Com Serra atuará na política no Movimento Democrático Brasileiro (MBD) e no Partido da Social Democracia Brasileira (PSDB). Com Vilmar Faria e Carlos Estevam Martins pesquisará no Centro Brasileiro de Análise e Planejamento (CEBRAP). Faria será um de seus principais assessores quando presidente, assim como Serra, seu Ministro do Planejamento, Ministro da Saúde e, por fim, candidato à sua sucessão pelo PSDB.

A trajetória de FHC passa, então, a ser o condutor da narrativa (item 3.3). Seguindo seus passos será explorada a interface da economia com as ciências sociais, narrando a entrada dos sociólogos na CEPAL e os efeitos dessa conjugação sobre a análise dos processos de desenvolvimento. Percorrer-se-á o caminho feito por Fernando Henrique e sua esposa Ruth Cardoso de suas infâncias até a Faculdade de Filosofia Ciências e Letra da Universidade de São Paulo (FFCL-USP), destacando as conexões de FHC com a Faculdade de Contabilidade Administração e Economia (FEA-USP), que será sistematicamente apresentada no próximo capítulo, e sua entrada na vida política da universidade através do Conselho Universitário (CO).

Os laços das ciências sociais da USP com a França têm impacto sobre a carreira do casal Cardoso, que será encarregado da recepção de diversos estrangeiros, dentre os quais Simone de Beauvoir, Jean Paul Sartre e Alain Touraine, que será o responsável por atrair os Cardoso para Paris. Cardoso vai trabalhar com Touraine no Laboratoire de Sociologie Industrielle enquanto Ruth frequenta o seminário de Claude Lévi-Strauss. A circulação entre o velho e o novo mundo feita eles e por outros colegas seus vai impactar a produção de conhecimento feita na FFCL, posto que os jovens professores passarão a analisar o Brasil com auxílio de Marx e das vanguardas críticas europeias com as quais tiveram contato no exterior. Touraine colaborará com FHC no estabelecimento do Centro de Estudos de Sociologia Industrial e do Trabalho (CESIT), uma versão tropical de seu laboratório francês. Pouco antes do encontro com Cardoso no Brasil, Touraine 
havia estado no Chile, onde fez pesquisas de campo sobre a condição operária e contribuiu para fomentar a sociologia do trabalho, que difundia em suas aulas na recémcriada FLACSO.

O primeiro sociólogo da CEPAL e primeiro diretor da FLACSO, José Medina Echevarría, que havia tido contato com FHC quando lhe solicitou um relatório sobre o Brasil para uma das conferências da CEPAL, foi quem o convidou para trabalhar em Santiago, ao saber que ele havia deixado o Brasil. Cardoso parte com um colega da Sociologia, Francisco Weffort, que também estava sendo vigiado pelas forças da repressão. No Chile, Fernando Henrique inicia colaboração acadêmica com um discípulo de Echevarría, que também havia trabalhado com Touraine, Enzo Falleto. Escrevem juntos o livro Dependência e desenvolvimento na América Latina (1969) que "visava estabelecer um diálogo com os economistas sobre desenvolvimento na América Latina, para salientar a natureza social e política daquele processo", mostrando "como se dá esta relação e que implicações derivam da forma de combinação que se estabelece entre economia, sociedade e política em momentos históricos e situações estruturais distintos" (CARDOSO e FALLETO, 1970, p. 7).

O Dependência e desenvolvimento já estava quase pronto quando FHC recebeu convite de Touraine para deixar o Chile e ir lecionar com seus colegas franceses em Nanterre. Antes de partir, Fernando Henrique propôs aos sociólogos Vilmar Faria e Carlos Estevam Martins que passassem a trabalhar como seus assistentes quando ele regressasse à USP. Não previa que seu direito de lecionar seria cassado tão logo conquistasse a cátedra. Não se transformaram em catedrático e assistentes e sim em parceiros de pesquisa no CEBRAP, organização que abrigou largo segmento da intelectualidade crítica que havia sido tolhida do acesso à universidade pelos militares. Carlos Martins partiu na sequência. Foi fazer o doutorado nos Estados Unidos, não se afeiçoou à universidade e acabou transferindo-se para a Universidade de Essex, na Inglaterra, para onde também havia mudado Weffort. Vilmar e Regina Faria partiram um pouco depois para Harvard.

José Serra casou-se com a chilena Monica Allende, transferindo-se para uma casa no bairro da Providencia, que ficava próximo ao edifício modernista que a CEPAL ocupava desde 1966. Eram vizinhos agora do filósofo Ernani Maria Fiori, muito amigo do educador Paulo Freire. Serra apresentou o filho de Ernani, José Luís Fiori, a Carlos Lessa, que o ajudaria a inserir-se no meio universitário chileno. Pouco depois, José Luís 
conheceria outra amiga de Serra, Conceição Tavares, com quem colaboraria intensamente nos anos seguintes. José Luís, por sua vez, apresentou Serra a um colega dele da Universidade Federal do Rio Grande do Sul (UFRGS) e de militância na AP, Paulo Renato Costa Souza, que chegara ao Chile para dar sequência a seus estudos de economia na pós-graduação da ESCOLATINA. Tornar-se-iam amigos e passariam a fazer parte do mesmo núcleo político. Paulo Renato, como Serra e outros amigos da AP, será nomeado ministro no governo FHC.

Paulo Renato e Fiori eram só alguns dos muitos jovens universitários que acabaram reunidos na ESCOLATINA (item 3.4), instituição que havia sido criada em 1957, com apoio das Fundações Ford e Rockefeller e sob a coordenação do professor de Columbia, Joseph Gunwald. Por ela passaram também os brasileiros Liana Aureliano, Ana Célia Castro, José Carlos Braga, Adhemar Kyotoshi Sato, Carlos Alonso Barbosa de Oliveira, Frederico Mazzucchelli, Paulo Baltar, Eduardo Kugelmas, Lourdes Sola, Sulamis Dain, dentre tantos outros. Muitos deles reuniam-se periodicamente com seus professores brasileiros e alguns funcionários da CEPAL/ILPES, como José Serra, Antonio Barros de Castro e Jader Andrade, para realizar seminários de leitura do Capital, uma das muitas atividades intelectuais que reuniam os exilados para estudar e pensar a política.

Os conflitos políticos que se alastravam pela sociedade chilena no início do governo Allende tiveram eco na Universitad de Chile (UC). Parte significativa dos professores da graduação em economia e da ESCOLATINA acabaram deixando a academia para colaborar com o governo. Os que ali restaram acabaram cindindo-se em duas diferentes escolas. A do campus Occidente, que era formada por professores que sustentavam uma formação no modelo clássico de ensino da economia, seguindo a matriz norte-americana, e a escola do campus Norte que passou a advogar em prol de um ensino de economia centrado na noção de Economia Política e diretamente voltado à luta pela transformação social e reorganização da sociedade em bases coletivistas. A influência do marxismo nessa escola é indisfarçável, sendo parte essencial do programa da faculdade calcado no ensino do Capital. Passaram a lecionar no campus Norte uma série de brasileiros exilados, notavelmente alguns ex-alunos da ESCOLATINA e os professores do Centro de Estudios Sociales ligado à Facultad de Economía da Universitad de Chile (CESO), autores de uma versão declaradamente marxista da teoria da dependência que passou a ser intensamente divulgada na nova escola, sendo especialmente popular entre 
os jovens militantes por assegurar que a única saída possível para o subdesenvolvimento seria a revolução (item 3.5).

Dentre os principais elaboradores da vertente marxista da teoria da dependência estavam os bolsistas de Minas Gerais, Theotônio dos Santos e Vânia Bambirra, militantes da Organização Revolucionária Marxista-Política Operária (ORM-POLOP), grupo marxista-leninista que sustentava uma via revolucionária de massas para o socialismo, rejeitando a ideia, dominante no $\mathrm{PCB}$, segundo a qual era preciso constituir uma sociedade burguesa antes do advento da revolução. Além deles integrava o grupo Ruy Mauro Marini, também mineiro e militante da POLOP, que havia feito seus estudos no Rio de Janeiro e em Paris, ao lado do qual seguiriam na vida acadêmica e na política. No início dos anos 1960 os três deslocaram-se para a Universidade de Brasília (UNB), onde aproximaram-se de André Gunder Frank, professor universitário norte-americano, também influenciado pelo marxismo. Após o golpe os quatro deixariam o Brasil. Vânia e Theotônio foram diretamente para o Chile, tendo solicitado ajuda a FHC para encontrar uma ocupação no universo acadêmico chileno. Marini e Frank passaram pelo México e depois reuniram-se a antigos companheiros em Santiago. A esse grupo agregaram-se Emir Sader, Marco Aurélio Garcia e outros cientistas sociais de matriz marxista.

O Chile também contava com organizações políticas que lutavam à esquerda do governo Allende, como o Movimiento de Izquierda Revolucionario (MIR) de inspiração guevarista e o Movimiento de Acción Popular Unitaria (MAPU), dissidência da Democracia Cristã, que pleiteava a revolução armada liderada pelos trabalhadores (AGGIO, 1993, pp. 50-51). Alguns jovens exilados aproximaram-se dos grupos revolucionários chilenos. Para eles a tarefa não se restringia a fazer a revolução no Brasil, mas por toda parte. Havia alguma identificação de militantes da AP, que transitavam da democracia cristã ao socialismo, com o governo Allende, que anunciava a conciliação de socialismo e humanismo, promovendo uma transição de modelo social por via democrática. Aproximavam-se do polo revolucionário grupos que também no Brasil lutavam pela tomada do poder pelos trabalhadores, como a POLOP.

Não só à esquerda havia radicalização no início dos anos 1970. A eleição de Salvador Allende alarmou a direita chilena que, com o apoio dos grupos da administração norte-americana que acreditavam que a única maneira de combater a subversão era com armas, lutou arduamente para desmoralizar, combater e por fim derrubar o governo 
socialista. Com a instauração da ditadura de Pinochet, os brasileiros exilados são obrigados a partir para segundos exílios. Mudam-se para a França, o México, a Itália, o Canadá, os Estados Unidos e onde mais fossem recebidos. Aqueles que eram ligados às organizações internacionais e tinham maior autonomia diplomática ajudaram a deslocar aqueles que precisavam de refúgio. O capítulo encerra-se com a narrativa da dispersão daquela mini-sociedade de exilados e indica de que modo os vínculos ali tecidos serão reestruturados no regresso ao Brasil, assunto a ser retomado no Terceiro Movimento.

\subsection{Herbert José de Souza e os bolsistas: economistas, sociólogos e militantes mineiros}

A Faculdade de Ciências Econômicas e Administrativas da Universidade Federal de Minas Gerais descende de um Curso de Administração e Finanças, criado em Belo Horizonte em 1941, que concedia o título de bacharel em ciências econômicas ${ }^{186}$. Em 1945, o ensino de economia passou por reformulação, sendo criada a Faculdade de Ciências Econômicas e Administrativas de Minas Gerais. Da direção da Faculdade ficou encarregado, de 1946 a 1960, Yvon Leite de Magalhães Pinto, advogado que lecionava na cadeira de economia política da Faculdade. Bem inserido socialmente, Yvon era descendente de políticos que atuaram no Império e na Primeira República, ligado ao Banco Hipotecário de Minas Gerais, além de ter feito parte do grupo de fundadores da União Democrática Nacional (UDN) de Minas. O diretor usava sua rede de relações e seus trunfos pessoais para obter recursos para solidificar a instituição e conferir-lhe prestígio, conseguindo apoio das elites agrárias das quais provinha e dos financistas e empresários em ascensão. O envolvimento de tais grupos com a constituição de uma faculdade de ciências econômicas e administrativas expressa a tentativa dessas elites de aproximarem-se dos padrões modernos de gestão racional, evitando que Minas Gerais ficasse atrasada em relação a outras áreas do país que já investiam nesta formação (ARRUDA, 1989, pp. 251-254; CANÊDO, 2009, p. 44; PAULA, 2006, pp. 330-338). Em

\footnotetext{
${ }^{186} \mathrm{O}$ curso adequava-se à legislação de Vargas de 1931, que havia instituído a modalidade de ensino de Administração e Finanças (item 2.1).
} 
1948, a FACE foi integrada à Universidade de Minas Gerais (UMG) ${ }^{187}$ e em 1953 incorporou um curso de sociologia e política.

O diretor Magalhães Pinto avaliava que em seus primeiros anos de funcionamento a Faculdade tinha dois principais problemas: o primeiro era a falta de um espaço adequado, pois ocupava apenas um andar de um edifício na Rua Curitiba, no centro de Belo Horizonte. Este seria rapidamente solucionado com a mudança da FACE, em 1954, para um prédio de 13 andares na mesma rua, edifício que a faculdade ocupou até 2008, quando transferiu-se para o campus da UFMG, mais distante do centro da cidade ${ }^{188}$. O segundo problema era a falta de professores especializados que fossem capazes de conduzir o ensino da moderna teoria econômica e social. A solução para esse desfalque só pode ser oferecida depois que começaram a ingressar no corpo docente, em meados de 1960, os primeiros diplomados em economia e ciências sociais. Uma iniciativa do diretor para acelerar o processo de formação de novos professores dessas disciplinas foi a instauração, também em 1954, de sistema de concessão de bolsas de estudo para os melhores alunos que os obrigasse a dedicarem-se integralmente ao curso (PAULA, 2006, pp. 330-338).

As bolsas eram custeadas com verba da própria faculdade e com doações privadas que Yvon angariava através de sua rede de relações nos altos círculos mineiros. A lógica subjacente ao sistema de bolsas era a seguinte: a remuneração funcionaria como incentivo para que os melhores alunos não trabalhassem, podendo consagrar parcela maior do seu tempo aos estudos. A exigência de dedicação exclusiva alongava o preparo dos alunos e ajudava a forjar uma elite estudantil com disposições ascéticas, que favoreciam a transição para a pós-graduação e o ingresso no universo acadêmico. Essa experiência foi replicada em escala nacional através do atualmente denominado Programa de Educação Tutorial (PET), criado por um ex-bolsista da FACE, Claudio de Moura Castro, quando diretor geral da Coordenação de Aperfeiçoamento de Pessoal de Nível Superior (CAPES), entre os anos de 1979 e 1982. Moura Castro conta que o sistema criado e atentamente supervisionado por Yvon Magalhães selecionava "os cinco ou seis melhores em cada turma e coloca-os também em salinhas de estudos, em tempo integral, com presença rigorosamente controlada. Para tal, recebem uma bolsa modesta (por volta de um salário

\footnotetext{
${ }^{187}$ A UMG federalizou-se em 1949 e em 1965 passou a chamar Universidade Federal de Minas Gerais (UFMG).

${ }^{188}$ Ver: https://www.ufmg.br/boletim/bol1598/4.shtml. Consultado em 20/01/2016.
} 
mínimo)" (ARRUDA, 1989, pp. 258; CASTRO, s.d.; CORREA e LEMOS, s.d.; KEINERT, 2011, p. 114).

Como o ensino da ciência econômica funcionava junto com o de ciências sociais, estiveram, entre os bolsistas alunos de economia, como Claudio de Moura Castro (1938), Paulo Roberto Haddad ${ }^{189}$ (1939), Edmar Lisboa Bacha ${ }^{190}$ (1942), Alkimar Ribeiro Moura ${ }^{191}$, Flavio Versiani, Rogério Ladeira Furquim Werneck e Dorothea Fonseca Werneck (1948), Eustáquio Reis e José Marcio Camargo, e também alunos do curso de sociologia e política, como Herbert José de Souza (1935-1997), Ivan de Otero Ribeiro (1936), Theotônio dos Santos (1936), Antonio Octávio Cintra, Fábio Wanderley Reis (1937), Simon Schwartzman (1939), José Murilo de Carvalho (1939), Vânia Bambirra (1940), Vinícius Caldeira Brandt (1941-1999), Vilmar Faria (1941-2001), Amaury de Souza (1942-2012), Bolívar Lamounier (1943) e Elisa Reis (1946) (CASTRO, s.d.; SCHWARTZMAN, 2010, pp. 4-5). A bolsa ajudava alunos menos privilegiados e estudantes que migravam do interior para a capital a conseguir recursos para manter-se durante o estudo. Mas nem todos os bolsistas tinham origens sociais modestas, posto que o critério para receber a bolsa não era socioeconômico, dependendo exclusivamente do desempenho escolar.

O grupo dos bolsistas era fortemente heterogêneo. Incluía descendentes de elites políticas locais, como Vinícius Caldeira Brant que tinha dois tios-avôs deputados, um dos quais foi também secretário de finanças de Minas e diretor do BB, Paulo Roberto Haddad (item 6.3), cujo pai era vereador e os irmãos chegaram a ser vereadores, prefeitos e deputados, ou Edmar Bacha, que, como relatado anteriormente, tinha um avô que fora prefeito e deputado e um tio prefeito (item 2.4). Estavam representados igualmente filhos de quadros médios, como José Murilo de Carvalho, filho de um dentista e pequeno proprietário de terras, Ivan Otero Ribeiro, filho e sobrinho de militares comunistas que participaram do levante de 1935, Elisa Reis, de pai técnico em contabilidade e também fazendeiro, herdeiro de uma parte da grande propriedade agrícola que o avô tinha no interior, Bolívar Lamounier, filho de um pequeno fazendeiro da região de Dores do

\footnotetext{
${ }^{189}$ Paulo Haddad será Ministro do Planejamento de outubro de 1992 a janeiro de 1993 e Ministro da Fazenda de dezembro de 1992 a março de 1993.

${ }^{190}$ Bacha não era bolsista em tempo integral. Ele obteve permissão para conciliar os estudos financiados pela bolsa com o emprego de redator de anais e documentos parlamentares que tinha na Assembleia Legislativa de Minas Gerais (BACHA, 1998, p. 197; Edmar Bacha entrevista à autora, 2012).

${ }^{191}$ Alkimar Ribeiro Moura foi diretor do Banco Central da área de dívida pública e mercado aberto de janeiro de 1987 a janeiro de 1988, da área de política monetária de março de 1994 a março de 1996 e da área de normas e organização do sistema financeiro de março de 1996 a setembro de 1997.
} 
Indaiá e de uma professora primária em área rural, e Dorothea Werneck cujo pai era bancário. Havia por fim rebentos das classes médias baixas e baixas, como Vilmar Faria, cujo pai era alfaiate, e Simon Schwartzman, filho de judeus imigrantes, sem instrução superior, que no Brasil trabalhavam como mascates (CANÊDO, 2009, p. 42; DHBB, verbetes Paulo Roberto Haddad, Vinicius Caldeira Brant, Dorothea Werneck; LAMOUNIER, 2013, p. 2-3; REIS, 2010, p. 2; SCHWARTZMAN, 2010, pp. 2-3; SCHWARTZMAN, 2014, p. 48).

As ciências econômicas e sociais funcionavam, por um lado como veículo de ascensão social e de deslocamento do campo para a cidade de grupos dominados (CANÊDO, 2009, p. 47; KEINERT, 2011, p. 113), por outro constituiam estratégia de reconversão das elites políticas tradicionais, até então primariamente apoiadas em seus recursos econômicos e nos vínculos locais de parentesco, amizade e obrigações sociais, em elites modernas que se legitimam com base no mérito acadêmico e profissional.

A sociabilidade entre os bolsistas era favorecida pela partilha do espaço físico e pela grande quantidade de tempo que dispendiam conjuntamente especialmente no caso dos estudantes provenientes do interior ${ }^{192}$ do estado que tinham que refazer seu universo social ao chegar a Belo Horizonte, como atesta o depoimento de Elisa Reis:

\begin{abstract}
Vivendo sozinha na cidade grande, sem laços afetivos tradicionais, fazia da Faculdade "minha casa": entrava às sete da manhã quando as portas se abriam e ia embora quando por volta das 11:30 da noite a biblioteca fechava. Ali se exercia grande parte de minha vida intelectual e afetiva. Era ali que eu estudava, encontrava amigos, fazia minhas refeições. Em uma das duas amplas salas de leitura disponíveis tinha mesa cativa. Naquela mesa me sentei diariamente, durante quatro anos, para ler, discutir questões teóricas, existenciais e estéticas, comentar os filmes, quase sempre vistos na própria universidade, fazer planos para o futuro, sonhar (REIS, 1998, p. 8).
\end{abstract}

Nesse ambiente universitário costuraram-se amizades duradouras, como a de Lamounier e Bacha, e começaram a ser tecidas também as relações que levariam aos matrimônios de Eustáquio e Elisa Reis, de Rogério e Dorotea Werneck, de Flávio e Teresa Versiani e de Theotônio dos Santos e Vânia Bambirra.

Além da proximidade intelectual e dos laços afetivos, muitos bolsistas vivenciavam conjuntamente a política universitária que eclodia na FACE. Na militância, os bolsistas dividiam-se, predominantemente, entre a POLOP, da qual fizeram parte Simon Schwartzman, Fábio Wanderley, Theotônio dos Santos, Vânia Bambirra e Amaury de

\footnotetext{
${ }^{192}$ Nasceram no interior, por exemplo, Bolívar Lamounier, Edmar Bacha, Elisa Reis, Herbert José de Souza, José Murilo de Carvalho, Paulo Haddad, Amaury de Souza e Theotônio dos Santos.
} 
Souza; e a JUC/AP, integrada por Vinícius Caldeira Brant, Herbert José de Souza, Paulo Haddad, Vilmar Faria, Antonio Octávio Cintra, José Murílo de Carvalho e Bolívar Lamounier ${ }^{193}$. Brincando com o fato de ser um dos poucos a não pertencer a nenhuma das correntes políticas da época, Edmar Bacha diz que Claudio de Moura Castro e ele tinham sua própria sigla, "a JUD, que era a Juventude Universitária Depravada" (Entrevista de Edmar Bacha à autora, 2012). Em alguns casos, a militância levava à opção pelas ciências sociais, vistas como ferramentas para a transformação social. Em outros, o meio universitário da FACE levava à militância. Os dois bolsistas que maior visibilidade nacional ganharam com sua militância estudantil foram Vinícius Caldeira Brant e Herbert José de Souza (BAMBIRRA, 1991, p. 11; CANÊEDO, 2009, p. 42; CARVALHO, 1998, p. 364; KEINERT, 2011, pp. 8, 121, 148, 207-208; LAMOUNIER, 2013, p. 10; RIDENTI, 2010, p. 35).

Betinho era mineiro de Bocaiúva, cidade da qual seu pai, Henrique, chegou a ser prefeito. Henrique havia sido padeiro e dono de cinema antes de passar pela prefeitura. Ele era muito amigo do político mineiro José Maria Alkmin, que não só era de Bocaiúva mas também era primo de sua esposa, Maria da Conceição Figueiredo, também prima do general e depois presidente João Batista Figueiredo. Alkmin, que se tornaria Ministro da Fazenda de JK e vice-presidente do governo Humberto Castelo Branco, havia estudado na infância com Juscelino Kubitschek e sido aprovado com ele em concurso público para funcionário dos telégrafos. Ele foi convocado para o serviço militar em 1922 e serviu no mesmo regimento onde estava Castello Branco, à época tenente. Na sequência Alkmin estudou direito na Faculdade de Direito de Belo Horizonte e, no início dos anos 1930, ingressou na vida política, primeiro no Partido Progressista Mineiro (PPM) e depois no Partido Social Democrático (PSD). Em 1935 Alkmin renuncia a um de seus mandatos de deputado para assumir o Tribunal de Contas de Minas Gerais e depois a Secretaria do Interior e Justiça. A partir da Secretaria criou a Penitenciária Agrícola de Neves e convidou Henrique para geri-la. Em 1938 Alkmin dirigiu a Santa Casa de Misericórdia de Belo Horizonte, designando Henrique, para trabalhar na funerária (ARAÚJO, 2001, pp. 88-89; DHBB, verbete José Maria Alkmin).

\footnotetext{
${ }^{193}$ Segundo Vânia Bambirra os métodos stalinistas e burocráticos do Partido Comunista Brasileiro não puderam conquistar aquela geração, tão influenciada pela revolução cubana e pelos movimentos que traziam os signos da "irreverência de pensamento e ação" (BAMBIRRA, 1991, p. 11). Um dos poucos membros do PCB no grupo dos bolsistas da FACE era Ivan Ribeiro, filho e sobrinho de militares que eram ativistas comunistas, estiveram envolvidos nas revoltas de 1935 e foram presos (DHBB, verbetes Ivan Ramos Ribeiro e Francisco Leivas de Otero).
} 
Ao mudar para Belo Horizonte com o pai, Betinho passa a estudar no tradicional Colégio Arnaldo, da Congregação do Verbo Divino (item 2.3), mas é obrigado a interromper seus estudos por conta de uma tuberculose que o confinou por 3 anos. Não bastasse a tuberculose, herdou da mãe a hemofilia. Do lado materno vieram também a religiosidade e o conservadorismo das camadas mais tradicionais de Minas. A angústia gerada pelas doenças fez com que se apegasse profundamente à religião. Betinho passou a atribuir à fé e à castidade de seus pensamentos a cura da tuberculose, que lhe permitiu retomar a convivência social e os estudos, agora no Colégio Estadual. Durante o científico passou a integrar a Juventude Estudantil Católica (JEC), braço da Ação Católica ${ }^{194}$ no secundário. O então encarregado da JEC e da Juventude Universitária Católica ${ }^{195}$ (JUC) ${ }^{196}$ de Belo Horizonte era Frei Mateus Rocha, que havia estudado na França, alinhava-se à moderna teologia francesa e era apaixonado por Fiódor Dostoievski, que considerava retratar tão bem os dilemas e sofrimentos humanos. A nova catequese $\mathrm{c}^{197}$ que Frei Mateus equiparava Cristo à revolução, considerando pecado permitir a fome e a agonia do semelhante e chamando a atenção dos jovens para as desigualdades sociais brasileiras (BETTO, 2001, p. 71). Essa vertente da igreja procurava orientar a Ação Católica para a prática política, já que considerava que, para lutar por igualdade, não bastava investir na evangelização e liturgia dos jovens, era preciso prepará-los para a

\footnotetext{
194 "A década de 30 assistiu à consolidação de novas orientações desse contencioso célebre [entre o catolicismo tradicional e a sociedade moderna], que iriam levar finalmente à Constituição Pastoral Gaudium et Spes do Concílio Vaticano II. Dois episódios históricos merecem ser aqui lembrados: 1. no plano pastoral a organização ampliada e o fortalecimento da Ação Católica, lançada por Pio X, estimulada e apoiada por Pio XI, e cuja diretriz fundamental era a presença dos leigos católicos nas estruturas da sociedade moderna; 2 . no plano teórico a proposição, em torno da idéia de um humanismo cristão, de um novo paradigma de presença humanizadora e civilizadora da tradição cristã e da Igreja no mundo pós-medieval. A repercussão dessas duas iniciativas renovadoras no Catolicismo europeu fez-se sentir desde logo no Catolicismo brasileiro, tendo a recebê-las e propagá-las, no plano pastoral, a ação do Cardeal-Arcebispo do Rio de Janeiro, Dom Sebastião Leme, e do episcopado em geral. Desse apoio da hierarquia eclesiástica procede a importância da Ação Católica na vida da Igreja sobretudo nas décadas de 40 e 50 e início da década de 60" (VAZ, 1998, pp. 324-325).

${ }^{195}$ Até este momento a JUC era a representação oficial da igreja no meio universitário, que se contrapunha ao movimento estudantil laico e procurava espalhar a mensagem divina e a adesão à igreja entre os estudantes do ensino superior. Alinhada ao catolicismo tradicional, procurava aprofundar a fé e a espiritualidade dos participantes, que "tendiam a compor uma elite acadêmica católica. A visão de mundo que deu origem à JUC estaria ancorada na doutrina medieval da Igreja: a tarefa do homem na Terra seria espelhar a ordem divina ideal, tanto em sua alma quanto na sociedade. Assim, a predisposição seria valorizar a ordem e a harmonia social, acatar as estruturas e as instituições existentes, cujos eventuais problemas estariam nas falhas das pessoas que as compõem" (RIDENTI, 1998, p. 3).

${ }^{196}$ A JUC fora até os anos 1950 separada em dois grupos, a JUC e a JUCF, respectivamente, para rapazes e moças (SOUZA, 1984, p. 87).

${ }^{197}$ A JEC e a JUC incorporavam à brasileira a vertente francesa moderna do catolicismo, de Emmanuel Mounier, Jacques Maritain, George Bernanos, Louis-Joseph Lebret e Pierre Teilhard de Chardin, e baseava-se em experiência que "se desenvolvera na França, na Bélgica e no Canadá, a partir das primeiras experiências do Padre Cardjin, na Bélgica, com a [Juventude Operária Católica] JOC" (GONTIJO, 1998, p. 54; RIDENTI, 1998, p. 6; SOUZA, 1984, p. 86).
} 
missão de conduzir a mudança social (BETTO, 2001, p. 72; GONTIJO, 1998, p. 54; RIDENTI, 1998, p. 6; SOUZA, 1976, pp. 70-71; SOUZA, 1984, p. 86).

Carlos Alberto Libâno Christo, o Frei Betto (1944), outro discípulo de Frei

Mateus, relata:

Em 1959, conheci Betinho na JEC (Juventude Estudantil Católica), em Belo Horizonte. Ele ingressava na JUC (Juventude Universitária Católica), aprovado no vestibular de sociologia, enquanto seu irmão Henriquinho - mais tarde, Henfil - e eu atuávamos entre os secundaristas, aprendendo com Frei Mateus e Frei Chico que cristão rima com revolução, sexo não é pecado e Deus tem sabor de justiça. Todas as tardes nós nos encontrávamos no "chá das seis", como era conhecido o encontro dos militantes cristãos à porta da igreja São José, no centro da capital mineira. Ali conspirávamos e debatíamos as estratégias para mudar a sociedade pela força da fé: Vinicius Caldeira Brant, Hugo Amaral, Paulo Haddad, Marcelo Guimarães, Nassim Mehedeff, Tomás Aroldo da Mota Santos, Humberto Pereira, José Alberto Fonseca, Rafael Guerra, Jair Ferreira de Sá e tantos outros. Enquanto a missa não tinha início, analisávamos a conjuntura do mundo, do Brasil, de Minas, até a hora de entrar no templo para receber a comunhão. Betinho era o líder, o mais perspicaz, o mais sagaz. Muito magro, com um sorriso esperto, sobressaía-se por sua inteligência. Era o estrategista de nossas lutas estudantis. Nunca chegou a presidente da UNE, mas levou ao cargo Vinicius Caldeira Brandt, Aldo Arantes e José Serra. No Rio, no início dos anos 60, costumava hospedar-se no apartamento em que eu morava, na esquina das ruas Laranjeiras com Pereira da Silva. Era uma república de estudantes, todos militantes cristãos, que dividiam o pequeno espaço: Osmar Fávero, Luiz Eduardo Wanderley, Paulo Eduardo Arantes[198], José Roberto Soeiro[199], Júlio Olímpio [Fusaro] Mourão Filho[200], Celso Guimarães e outros (BETTO, 1997).

Ao concluir o científico Herbert de Souza cogita ir para a Faculdade de Direito mas acaba optando pelo curso de Sociologia e Política da FACE-UMG, onde ingressa em 1959, logo passando a integrar o grupo dos bolsistas. Transfere-se da JEC para a JUC, assumindo a face política com cada vez maior nitidez. Diz ele que a JUC deixava progressivamente a visão de mundo cristã para entrar na visão de mundo marxista, mantendo, entretanto, “a mesma mística que havíamos vivido na religião, a mesma perspectiva de compromisso, a mesma pureza, responsabilidade, auto-renúncia” (SOUZA, 1976, p. 71). A virada para a esquerda da JUC começou a gerar polêmica dentro da própria igreja católica que, nas camadas superiores, passou a denunciar a aproximação

\footnotetext{
${ }^{198}$ Paulo Arantes mantinha forte diálogo com o Padre Henrique Vaz, que era muito amigo de Ernani Maria Fiori, seu futuro sogro, pai de Otília Fiori Arantes e José Luís Fiori. Os Fiori serão alvo de considerações adiante (item 3.4). Betinho também tornou-se muito próximo de Henrique Vaz (BETTO, 2001, p. 73; SERRA, 2014, p. 62; ARANTES, 2005, p. 7).

${ }^{199}$ Que se tornará funcionário do BNDE e ocupará posto de superintendente do BNDE em 2003.

${ }^{200}$ Que se tornará funcionário do BNDE e será superintentende de destaque nos anos 1980 (item 6.1).
} 
dos estudantes católicos com o marxismo, com o discurso a favor do socialismo e com a defesa da reforma universitária e da escola pública, em detrimento da tradicional educação católica sustentada com verba pública, piamente defendida pela cúpula da igreja (LIMA e ARANTES, 1984, p. 30; SOUZA, 1976, p. 73).

A JUC começou a ganhar força no movimento estudantil pois a estrutura nacional da igreja dava a ela meios para a difusão por toda a Federação de suas ideias e projetos e porque ela conseguia atrair uma parcela dos estudantes antes alinhados ao conservadorismo nacionalista, com um discurso no qual o marxismo era o ponto de chegada decorrente de uma crítica nacionalista e pleito pela igualdade social e não o ponto de partida da militância. A entrada na política estudantil fez com que a JUC tivesse que assumir um programa político mais definido. Em seu congresso de "10 anos, realizado em 1960, no Rio de Janeiro, a JUC aprova um documento intitulado 'Diretrizes Mínimas Para o Ideal Histórico do Povo Brasileiro', onde faz a opção por um 'socialismo democrático' e pelo que chama de 'revolução brasileira'." (LIMA e ARANTES, 1984, p. 28). Nele reivindicavam o papel de agentes da transformação social, encarada como uma execução da providência divina que libertaria as massas humanas da opressão. Logo na sequência, a JUC elege pela primeira vez um presidente para a UNE: Aldo da Silva Arantes, goiano e bolsista do curso de direito da Pontifícia Universidade Católica do Rio de Janeiro (PUCRJ), cuja gestão é marcada pela difusão nacional do movimento estudantil, através da criação da UNE Volante e da incorporação e estruturação do Centro Popular de Cultura $^{201}$. Juntos, o CPC e a UNE Volante levavam os debates e a crítica social pela via artística para todo o país, com o objetivo de conscientizar e engajar as massas na luta política (DHBB, verbete Aldo Arantes; LIMA e ARANTES, 1984, p. 31; RIDENTI, 1998, p. 4; SOUZA, 1976, pp 74-75).

Nesse período a ala mais à esquerda da JUC começava a separar a política da religião - motivada em parte pela rejeição, por parte da igreja, dos novos rumos adotados pela juventude e em parte pela vontade de agregar setores não católicos à sua luta - e expandir-se para além do meio universitário, procurando constituir um movimento de

\footnotetext{
${ }^{201}$ O CPC foi uma iniciativa que Oduvaldo Vianna Filho, o Vianinha, que tinha pertencido ao teatro Arena, articulou junto com Carlos Estevam Martins, que era próximo do Instituto Superior de Estudos Brasileiros (ISEB). O CPC era uma organização independente, fundado com o objetivo de valorizar a cultura brasileira e levar a arte às ruas. Era influenciado pela estética do Teatro de Arena, e pelos diversos segmentos da esquerda, sobretudo a esquerda nacionalista do PCB e do ISEB. A UNE oferecia a eles o espaço de sua sede e recursos para as atividades. Integraram o Centro artistas como Arnaldo Jabor, Cacá Diegues, Eduardo Coutinho, Ferreira Gullar, Leonzinho Hirszman e outros (GARCIA, 2004a, pp. 131-135; RIDENTI, 2014).
} 
massas alternativo à política do $\mathrm{PCB}$ e à própria JUC, considerados demasiado reformistas. O novo grupo, batizado de Ação Popular, pretendia engajar-se na construção do socialismo com humanismo, uma forma de socialismo democrático, não calcado na ditadura do proletariado, que se voltasse para a transformação social através da ruptura da condição de subdesenvolvimento. A AP procurava também afastar-se das práticas políticas do PCB, que consideravam hierarquizadas e rígidas, adotando uma organização mais flexível e voltando o debate político às questões contemporâneas do cenário nacional (ARANTES, 2005, p. 14; LIMA e ARANTES, 1984, pp. 35-37; SOUZA, 1976, p. 75). Setores progressistas da igreja, liderados por religiosos como Frei Mateus Rocha (1923-1985) de Belo Horizonte, Padre Henrique Cláudio Vaz (1921-2002) do Rio de Janeiro e Célia Sodré Dórea, a Madre Cristina (1916-1997) 202, de São Paulo, aderiram à nova corrente, migrando, com seus adeptos, para a AP. Madre Cristina expõe:

A Igreja tinha de participar desse movimento, porque ela existe para transformar o universo. Não pode ficar à margem. Então, comecei a puxar a JUC. Nossa Senhora, foi um escândalo! Diziam que eu estava profanando a JUC, que achava que oração não valia... Eu não estava dizendo que oração não valia, e sim que não resolvia ficar rezando o dia inteiro, sem fazer nada. Porque eles não faziam nada. A JUC não participava da política universitária. Mais ou menos 1958. Mais tarde, a JUC caminhou um pouco para a esquerda. Mas estou falando de uma primeira etapa. Depois, juntamos o nosso grupo de São Paulo com o de Minas, do Betinho. E nasceu o Grupão. Então, a gente fazia reuniões para estudar. Queríamos uma mudança, mas não sabíamos para onde, nem como. Depois, esse Grupão se transformou na AP (Ação Popular). Sempre fui contra um socialismo com orientação do exterior. Era minha grande briga com eles. Em vez de procurar o socialismo de origem brasileira, começavam a ver o que estava

\footnotetext{
${ }^{202}$ Madre Cristina, provinha da tradicional família Sodré. O governador de São Paulo do período 1967-1971 era parente de sua mãe. Seu pai não era político mas a casa onde viviam era um espaço onde homens e mulheres discutiam política. Nasceu em Jaboticabal mas estudou em São Paulo, como interna no tradicional Colégio des Oiseaux, a escola de meninas "mais refinada da época". Depois entrou para a congregação. Ao ser indagada sobre sua vocação religiosa, Cristina diz: "Eu sempre achei que Cristo se encarnou para construir a Terra. Senão, ele teria fícado no céu. Ele foi um revolucionário. Acho que a Igreja ou é revolucionária ou não é cristã" (DÓREA, 1989, [online]). Matriculou-se na faculdade Sedes Sapientiae, criada pelas irmãs que dirigiam o colégio, as cônegas de Santo Agostinho. Ao mesmo tempo matriculou-se na Escola Normal Caetano de Campos. Formada, tentou criar um curso de psicologia, que até então não existia. Aprendia-se um pouco nas escolas normais e um pouco nos cursos de pedagogia e filosofia. "Em 1940, quando me formei, tentei transformar o Curso de Pedagogia em Curso de Psicologia. A gente esvaziava o currículo mínimo e colocava todas as cadeiras de Psicologia - da personalidade, social, diferencial, testes, diagnósticos. Começamos a criar realmente um curso de Psicologia, e nesse mesmo ano já tínhamos a primeira Clínica Psicológica do Sedes. O próprio nome, Clínica Psicológica, foi um escândalo na época, ninguém sabia o que era. Naturalmente dizíamos que não era para atender nem para prestar serviços, era um local para aprendermos. [...]. Precisei viajar e estudar na Europa e Estados Unidos para me sentir menos insegura. O primeiro curso foi, então, proposto assim: vamos ser honestos, reunir o pessoal que está interessado e ser ao mesmo tempo aluno e professor. Dessa forma montamos, em 1953, o curso de Psicologia Clínica, com duração de 3 anos, para os formados em pedagogia ou filosofia" (DÓREA, 1984, p. 41). A clínica do Sedes na rua Caio Prado passou a ser um local de encontro das organizações de esquerda, arquivo de sua produção intelectual, estrutura da clandestinidade e ponto de apoio psicológico para os militantes. A familiaridade com a elite política paulistana ajudava a dar proteção sem ser perseguida. Cristina afirma que várias vezes ligou para o governador Abreu Sodré para reclamar, perguntando se ele não tinha vergonha de matar a juventude (DÓREA, 1989).
} 
acontecendo na China, na Albânia. Eu dizia: "Esses modelos não interessam. Interessam para ver como eles fazem, mas nós temos de encontrar uma coisa nossa, porque nós somos brasileiros" (DÓREA, 1989, [online]).

A recém-criada AP passou a ser coordenada nacionalmente por Herbert de Souza e contar com o apoio de políticos já estabelecidos como Almino Afonso 203 (1929), do Partido Trabalhista Brasileiro (PTB), Plínio de Arruda Sampaio (1930-2014) (item 3.2), do Partido Democrata Cristão (PDC), que havia sido presidente nacional da JUC, e Paulo de Tarso Santos 204 (1926), do PDC, Ministro da Educação ${ }^{205}$ de João Goulart de junho de 1963 a outubro de 1963, de quem Betinho tornou-se assessor ${ }^{206}$. Além disso, a AP conseguiu que seus candidatos fossem sucessivamente eleitos para a presidência da UNE. O presidente de 1962-1963 foi o colega de Betinho de JUC e AP mineiras e de graduação em sociologia na FACE, Vinícius José Nogueira Caldeira Brant (1941-1999), com larga

\footnotetext{
${ }^{203}$ Almino Monteiro Álvares Afonso (1929) nasceu em Humaitá, na Amazônia. Descendia de famílias seringalistas do norte do país, envolvidas na política local. Seu pai foi prefeito de Porto Velho e o avô paterno, deputado constituinte e senador. Almino começou a militar no movimento estudantil ainda no ginásio. Frequentou a Faculdade de Direito do Amazonas, da qual transferiu-se para a Faculdade de Direito da USP. Participou do movimento estudantil no Centro Acadêmico XI de Agosto e foi escolhido secretário de cultura da União Estadual dos Estudantes (UEE) de São Paulo, na gestão de Fernando Gasparian. Na sequência foi eleito presidente da UEE. Em 1958 foi eleito deputado pelo estado do Amazonas e designado líder da bancada do PTB na Câmara a partir de 1961. Reelegeu-se em 1962 e foi indicado por João Goulart para o posto de Ministro do Trabalho e Previdência Social, posição que exerceu até junho de 1963. Volta então à Câmara, onde permanece como líder do PTB até o golpe. Partiu para o Chile, onde trabalhou na OIT e foi professor da Universidad Católica de Chile. Depois do golpe de Pinochet tornou-se diretor da Escuela Latinoamericana de Ciencia Política (ELACP) da FLACSO na Argentina (DHBB, verbete Almino Afonso).

${ }^{204}$ Paulo de Tarso Santos (1926) nasceu em Araxá, estudou na Faculdade de Direito da USP e trabalhou no Bradesco. Pouco depois filiou-se ao PDC, elegendo-se vereador de São Paulo em 1955, deputado federal em 1958 e, em 1961, foi nomeado prefeito do Distrito Federal por Jânio Quadros. Retornou à Câmara depois da renúncia do Presidente e foi reeleito em 1962. Fez pressão pela implementação das reformas de base e acabou sendo convocado para assumir interinamente o Ministério da Educação e Cultura, em junho de 1963, posto do qual demitiu-se em outubro. Tem seus direitos e o seu mandato de deputado cassados no golpe e é preso, exilando-se no Chile, onde trabalha no Programa das Nações Unidas para o Desenvolvimento (PNUD) e na FAO (DHBB, verbete Paulo de Tarso Santos).

${ }^{205}$ Enquanto ocupava o Ministério da Educação, Paulo de Tarso trouxe, de Recife, Paulo Freire para coordenar o Plano Nacional de Alfabetização.

${ }^{206}$ Além de Betinho que assessorava Paulo de Tarso em Brasília, trabalhavam com o ministro Luiz Alberto Gómez de Souza e Ferreira Gullar. Depois de assessorar Paulo de Tarso, Betinho e Luiz Alberto Gómez de Souza passam a trabalhar com o Diretor de Estudos da Superintendência da Reforma Agrária, Francisco Whitaker Ferreira (1931). Whitaker nasceu em São Carlos e era descendente de imigrantes portugueses. Seu pai era contador e dono de uma serraria e a mãe oriunda de tradicional família da região. Francisco estudou na Faculdade de Arquitetura e Urbanismo da USP e sucedeu Plínio de Arruda Sampaio na presidência da JUC. Tornaram-se muito amigos. Depois de formado conseguiu bolsa para fazer intercâmbio na Universidade de Hamburgo, na Alemanha. Diz ele: "Aprendi a falar alemão "na marra”. Fiquei por lá uns dois semestres. Passei mais outro semestre na França, estudando arquitetura gótica e românica" (FERREIRA, 2011, [online]). Na volta ao Brasil, em 1957, ligou-se à Sociedade de Análise Gráfica e Mecanográfica Aplicada aos Complexos Sociais (SAGMACS), onde teve contato com o Padre Lebret e com o engenheiro Antonio Bezerra Baltar. Pouco depois de voltar ao Brasil foi convidado por Plínio para participar da elaboração e gestão do Plano de Ação do governo Carvalho Pinto e, na sequência, foi por ele indicado para trabalhar na Superintendência da Reforma Agrária, posto que ocupava quando ocorreu o golpe. Depois de ter sido preso partiu com a família primeiro para Roma, depois para Paris e por fim morou 4 anos no Chile trabalhando na CEPAL (SOUZA, 2001, pp. 50-51; FERREIRA, 2002; FERREIRA, 2011).
} 
história familiar de ligação com a política. O presidente seguinte, de 1963-1964, o último antes da ditadura, era, diversamente, paulista de originário de camadas médias, sem laços com o universo da política, que estreara na militância somente um ano antes de tornar-se presidente da UNE, José Serra.

\subsection{José Serra e Luiz Carlos Mendonça de Barros: a militância politécnica}

José Serra (1942) é neto, por parte de pai, de um italiano de Corigliano, na Calábria, que era produtor de oliva. Seu pai, Francesco, chegara ao Brasil com 30 anos em busca de melhores condições de vida. Sua mãe, Serafina, também era filha de italiano de Corigliano que vendia frutas no mercado da Cantareira. A avó materna de José era descendente de napolitanos, nascida na Argentina, razão pela qual Serra transitava desde a infância pelo italiano e pelo espanhol, sendo capaz de ler francês. O inglês só foi aprender muitos anos depois, primeiro ouvindo um curso em long-plays, quando preso na Embaixada da Itália, depois, quando exilado nos Estados Unidos, estudando na escola de idiomas Berlitz e assistindo os late movies e late late movies com o objetivo de acelerar o aprendizado do idioma para conseguir acompanhar a vida acadêmica da University of Cornell, onde fez doutorado (SERRA, 2014, p. 229, 222; SERRA, 2002, p. 29). Ele conta que no exílio não tinham "dinheiro para ir muito ao teatro ou acompanhar concertos. Mas eu sempre me mantive ligado ao que eu mais gosto, que é o cinema" (SERRA, 2002, p. 130; PINHEIRO, 2009).

Serra nasceu em uma vila operária no bairro da Mooca, então predominantemente habitado por imigrantes. Seu pai mantinha a família com o dinheiro que ganhava na barraca de frutas que, como o sogro, mantinha no mercado da Cantareira. José começou a ser alfabetizado na pré-escola Dom Bosco, dos padres Salesianos, depois estudou por dois anos no colégio particular São Judas Tadeu e, finalmente, transferiu-se para o colégio público Firmino de Proença, onde completou seus estudos. No científico passou a estudar no período noturno, para dar aulas de matemática durante o dia. Foi como juntou dinheiro para pagar o cursinho preparatório para o vestibular de engenharia da Escola Politécnica da USP e, ao ser aprovado, em 1960, tornou-se o primeiro membro da família a cursar o ensino superior (RETRATOS DO SERRA, 2010, [online]; FURTADO e FRIEDLANDER, 2002 PINHEIRO, 2009; SERRA, 2002, pp. 41-42; SERRA, 2014). 
Na faculdade, Serra participava do Grupo Teatral Politécnico e do Jogral da POLI. Acompanhou o começo do Teatro Oficina e chegou, em 1962, a fazer o papel principal da peça de Zé Celso Martinez Corrêa, Vento forte para papagaio subir. Segundo ele, foi com desgosto que largou o teatro para dedicar-se exclusivamente à política (SERRA, 2014, pp. 150-152). José havia começado a participar de debates dos estudantes sobre a reforma universitária e interessou-se pela greve nacional liderada pela gestão Aldo Arantes da UNE, que ocorreu em junho de $1962^{207}$. Aproximou-se então das lideranças paulistas da JUC, José Carlos Seixas, presidente do centro acadêmico da Medicina da USP, e Walter Barelli (1938), um dos diretores do Centro Acadêmico Visconde de Cairu (CAVC) da Faculdade de Economia da USP. Seixas conta que Serra lhe pediu a indicação de textos que o ajudassem a conhecer melhor as reivindicações dos estudantes e logo voltou a entrar em contato, dizendo que lera o material e que gostaria de conversar sobre o tema. Seixas ficou bem impressionado e achou que ele poderia ser um bom nome para concorrer à União Estadual dos Estudantes de São Paulo (UEE-SP) pela JUC, ainda que não tivesse afiliação oficial com o movimento. Isto porque Barelli, que seria o mais provável candidato da JUC à posição, tinha uma mãe viúva e não podia largar o emprego no BB que lhe permitia complementar a renda da família 208 (BARELLI, 2006; FURTADO e FRILANDER, 2002; SERRA, 2014, p. 71).

Serra foi eleito para a presidência da UEE-SP. Seguindo a diretriz da UNE, implementou em São Paulo a UEE-Volante que organizava caravanas para levar ao interior os debates políticos e as vanguardas artísticas críticas. Na política estudantil colaboram com ele, dentre outros, os estudantes de engenharia da Faculdade de

\footnotetext{
${ }^{207}$ Conhecida como greve do $1 / 3$, o movimento reivindicava, dentre outras coisas, a participação paritária dos estudantes nos conselhos das universidades. Em alguns lugares os estudantes passaram a ter alguma representação, mas não em toda parte, razão pela qual o $1 / 3$ segue sendo até hoje pauta do movimento estudantil em diversas universidades brasileiras.

${ }^{208}$ Walter Barelli nasceu em São Paulo. Seu pai, que trabalhava como mecânico de manutenção na Nitroquímica e na fábrica de papel e papelão dos Matarazzo, morreu precocemente. Para sustentar a família sua mãe trabalhava como tecelã e passadeira. Depois de estudar em colégios públicos, Barelli entrou para o seminário de São Roque, onde viveu de 1951 a 1956. Ao deixar o seminário fez "um curso de Administração Racional do Trabalho, no IDORT [Instituto de Organização Racional do Trabalho (item 4.1)] para ver como se trabalhava em uma empresa. Aí descobri que tinha faculdade de administração. Fui atrás da GV [Fundação Getúlio Vargas], mas era muito cara. Não tinha dinheiro para pagar a mensalidade. $\mathrm{O}$ que eu ganhava como bancário era pouco. Aí me falaram: 'Olha, tem a Faculdade de Economia da USP'. Aí fui para Economia. Fiz o vestibular e passei" (BARELLI, 2006, [online]). Ao concluir a faculdade fez a pós-graduação na Sociologia sob a direção de Octavio Ianni. Em 1966 foi contratado pelo Departamento Intersindical de Estatística e Estudos Socioeconômicos (DIEESE), a partir de onde participou da crítica à concentração de renda e denunciou a manipulação de índices por parte do Governo Federal nos anos 1970. Passou a lecionar economia na PUC e na FGV e foi nomeado Ministro do Trabalho de Itamar Franco, posição que ocupou de 1992 a 1994, sendo secretário do trabalho do governo estadual de Mário Covas em 1995 e deputado federal a partir de 2005 (BARELLI, 2006; DHBB, verbete Walter Barelli).
} 
Engenharia Industrial (FEI), Benedito Nicotero, que o sucedeu na presidência da UEE, e Egydio Bianchi (1940), que ele conhecia dos tempos de colégio e do bairro da Mooca. Além deles recrutou Sérgio Motta (1940-1998), que vivia em outro bairro imigrante, o Brás, sendo descendente de portugueses, filho de funcionário público operador de raio-x. Motta, ao contrário dos outros colegas, estudou em colégios particulares de prestígio, como o São Bento e o Bandeirantes. Foi no cursinho Anglo Latino da Rua Tamandaré que foi apresentado a Serra por um amigo comum: o vizinho de José, Adroaldo Wolf (GAVIÃO, 2007, p. 161; PRATA et al., 1999, p. 39, 47-49; SERRA, 2008).

Em 1963, Wolf e Motta se tornaram sócios na Livraria Cultura e Arte Popular, que vendia literatura marxista e revolucionária, além de distribuir o material da UNE e da UEE. O grupo manteve-se próximo durante muito tempo. Mais de 30 anos depois, Sergio Motta seria coordenador e tesoureiro das campanhas de Fernando Henrique Cardoso e Bianchi e Wolf, seus operadores. Durante o primeiro governo tucano, Sérgio Motta, que dividia uma fazenda com FHC, tornar-se-ia Ministro das Comunicações. Bianchi foi nomeado presidente dos Correios, Serra, Ministro do Planejamento e da Saúde e Nicotero, seu assessor no Ministério. Além disso, Nicotero era sócio, no bar O Paulistano, de Wilma Motta, tesoureira de sua gestão na UEE, que viria a esposar Sérgio (GAVIÃO, 2007, p. 161; PRATA et al., 1999, p. 39, 47-49; SERRA, 2008). Nos anos seguintes, ingressariam no grupo três politécnicos de famílias muito católicas do interior de São Paulo com passagem pela JUC: Gilberto Dupas ${ }^{209}$ (1943-2009), Clóvis de Barros Carvalho (1938) 210 e Luiz Carlos Mendonça de Barros (1942).

\footnotetext{
${ }^{209}$ Gilberto Dupas (1943-2009) nasceu em Campinas, filho de fiscal de rendas do Estado e neto de dono de serraria em Araras e de um francês que veio para o Brasil sozinho em um porão de navio e tornou-se dono de uma vendinha, em uma fazenda no interior de São Paulo. Dupas era de família católica, estudou a vida toda em colégio público e fez cursinho para prestar POLI. Ingressou na JEC no secundário e, na POLI em 1962, passando a integrar a JUC, então mobilizada em torno das greves pelo $1 / 3$. Depois de formado fez o curso do Centro CEPAL-BNDE e pós-graduação na Delft University. Trabalhou no Instituto de Pesquisa Econômica Aplicada e no Banco Mundial, além de ocupar posições no setor privado. Nunca passou da JUC para a AP, mas seria convidado a colaborar com Serra no governo estadual de Franco Montoro, sendo vice-presidente do BANESPA, presidente da Nossa Caixa e secretário da Agricultura (DUPAS, 2009; ALMEIDA, 2009a, p. 126; SERRA, 2009).

${ }^{210}$ Clóvis de Barros Carvalho (1938) nasceu em Franca, em família muito católica, fillho de promotor público que, nas palavras do irmão, Paulo Gustavo, era "reacionário". Estudou em escolas públicas em São José do Rio Preto e em Campinas, passando a integrar a JEC. Transferiu-se para o Rio de Janeiro, onde tornou-se seminarista nas escolas católicas Santo Inácio e Anchieta, em Nova Friburgo, de 1958 a 1962. Estudando letras e filosofia, foi aluno do Padre Henrique Vaz. Clóvis voltou para São Paulo e ingressou, em 1964, na POLI e logo na Ação Popular. O irmão, Paulo Gustavo de Barros Carvalho (1943), que cursou medicina na Federal do Paraná, também fez parte da JUC e depois da AP (ARANTES, 2005, p. 14; DHBB, verbete Clóvis Carvalho). Ver depoimento de Paulo Carvalho para a ONG Direitos Humanos para a Paz: http://www.dhpaz.org/dhpaz/depoimentos/detalhe/63/depoimento-para-a-historia-a-resistencia-a-ditaduramilitar-no-parana. Consultado em 21/11/2015.
} 
Luiz Carlos nasceu em São Paulo, em família inteiramente brasileira. Seu avô paterno era um industrial que fabricava xaropes e remédios em Campinas, proveniente de uma das famílias fundadoras da cidade de Pouso Alegre, em Minas Gerais. Possuíam ali o Colégio Mendonça, dirigido por um tio-avô de Luiz Carlos, o padre Antônio Francisco Furtado de Mendonça, também conhecido como Monsenhor Mendonça. Foi ele quem educou o pai de Luiz Carlos, Leovigildo Mendonça de Barros²11, que cursou a Faculdade de Medicina Nacional do Rio de Janeiro e tornou-se um dos primeiros cardiologistas do Brasil. Para Luiz Carlos, o pai, que oferecia cursos de especialização nas associações de medicina, "era um professor nato". Além disso "ganhava dinheiro traduzindo coisas do alemão. Não me pergunte por que ele estudou alemão”. A mãe de Luiz Carlos era normalista mas nunca lecionou. Provinha de Campinas e era filha de funcionário da Companhia Mogiana de Estradas de Ferro (Entrevista de Luiz Carlos Mendonça de Barros à autora, 2012).

Mendonça de Barros diz provir de família inteiramente católica. Ainda que hoje não seja praticante, recebeu educação religiosa à qual imputa a moldagem dos valores pelos quais procura conduzir sua vida: “eu sempre falo, o próximo para mim era uma coisa importante, e isso veio principalmente do [Colégio] Santa Cruz, que tinha uma educação muito caracterizada pelo se portar com o próximo". Além da moldagem dos valores, o ambiente católico possibilitou a entrada na JUC, onde conheceu sua esposa e de onde vai para a militância na AP. No Santa Cruz começou a estudar francês, mas o domínio do idioma veio depois, em aulas particulares com uma senhora francesa. O cultivo do francês assim como do italiano são associados ao gosto pelas viagens. Chegou a tomar lições de alemão tardiamente, mas desistiu. O inglês somente aprendeu "lá para os 25, 26 anos”, por razões profissionais (Entrevista de Luiz Carlos Mendonça de Barros à autora, 2012).

Sobre a escolha da carreira de engenheiro diz que "na época, o Brasil estava se industrializando e, realmente, era a grande a demanda que se tinha". Segundo conta, em episódio exemplar de sua socialização, o pai queria que ele

fosse engenheiro metalúrgico, que ele achava que na época era o melhor, mas eu entrei muito bem classificado na POLI e quando eu fui fazer a matrícula, eu vi bastante gente querendo saber o que é que eu queria ser. Quando eu falava que

\footnotetext{
${ }^{211}$ Ver:

http://www.tvuai.com.br/pousoalegre/pa153/familias6.html.

http://www1.folha.uol.com.br/fsp/dinheiro/fi1412200109.html. Consultados em 22/11/2015.
} 
eu queria fazer o curso de metalurgia os caras falavam: oba! Aí no terceiro oba, eu resolvi perguntar: por que oba? Porque todo mundo aqui quer fazer produção e é muito pouca gente. Então quando um sujeito bem classificado escolhe metalúrgica... Aí eu peguei e escolhi produção [risos], e deu certo. Como diz um amigo meu, por ter muito comprador já é um sinal de mercado [risos]. O duro foi explicar para o meu pai depois, porque eu não tinha a menor ideia do que fazia o engenheiro de produção (Entrevista de Luiz Carlos Mendonça de Barros à autora, 2012).

Mendonça diz que teve dois professores marcantes na POLI: Ruy Aguiar da Silva Leme $^{212}$ (1925-1997), da área de engenharia de produção, que se tornaria presidente do Banco Central, "foi quem me ensinou a pensar", e o professor Oswaldo Fadigas"213, da cadeira de planejamento da produção, que ministrava o curso de estatística. Até ser contratado para o posto de professor regular da Politécnica, Fardigas lecionava na Fundação Getúlio Vargas em São Paulo (FGV-SP), na Economia da USP e na Faculdade Mauá de engenharia. Ao deixar as outras faculdades procurou substitutos, indicoando Mendonça para lecionar estatística na FGV, curso que ministrou em 1967 e 1968.

Indagado sobre as áreas de estudo de preferência na graduação, ele conta como entrou na política:

$\mathrm{Na}$ graduação eu comecei a fazer política... mas a minha área sempre foi matemática. Eu sempre fui muito bom aluno de matemática. Tinha muita facilidade. Mas a POLI eu fui levando meio aos trancos e barrancos, porque eu comecei a fazer política muito cedo. Lá no primeiro ano... no segundo ano eu já comecei a fazer política. Depois no terceiro eu fui eleito para a UEE. Aí o que me salvou foi a prisão. Depois da prisão eu comecei a estudar porque eu não podia fazer mais nada [...]. Eu fui escolhido para a UEE por uma razão muito simples. Eu tinha um colega meu o Adroaldo [Wolf] que era um sujeito que era para ser o representante da POLI na chapa da UEE. Só que ele estava muito mal na escola e o pai dele proibiu. Eles tiveram que encontrar alguém para substituir e aí as coincidências, né... na hora em que [...] o Sérgio [Motta] estava com esse problema, eu entrei em uma sala e o Adroaldo falou: pô, aí, o Mendonça! E me

\footnotetext{
${ }^{212}$ Ruy Aguiar da Silva Leme (1925-1997) nasceu em São Paulo. Seu avô paterno, Luiz Gonzaga da Silva Leme era advogado formado na Faculdade de Direito de São Paulo e engenheiro formado no Instituto Politécnico de Rensselaer, em Troy em Nova York. No Brasil ajudou a projetar as estradas de ferro do estado de São Paulo. Seu pai, Hildebrando da Silva Leme era também advogado pela Faculdade de Direito de São Paulo. Ruy estudou no Colégio Bandeirantes e fez cursinho da Escola Politécnica para entrar na USP, onde estudou de 1944 a 1948, fazendo pós graduação em estatística na própria universidade em 1954. Começou a lecionar na engenharia da USP em 1949, ensinava economia política, estatística aplicada e organização administrativa e fundou o curso de engenharia de produção. Tornou-se diretor da Faculdade de Contabilidade, Economia e Administração da USP no final dos anos 1950 e lá também lecionou desde 1965. Foi professor também na Faculdade de Arquitetura e Urbanismo, na Engenharia de São Carlos, além de ter dado aulas na FEI, na PUC e em outras instituições privadas. Ruy foi um dos responsáveis pela parte econômica do Plano de Ação do governador Carvalho Pinto, além de diretor do Banespa. Ademais disso trabalhou em companhias privadas como a Hidroservice e a Fiação Rayon e integrou o conselho da Aço Villares. Assumiu a presidência do Banco Central de 1967 a 1968 durante a gestão de Delfim Netto, que havia sido aluno seu, no Ministério da Fazenda (CANABRAVA, 1984a, pp. 263264; DHBB, verbete Ruy Leme e http://www.arvore.net.br/Paulistana/Lemes 8.htm. Consultado em $03 / 02 / 2016)$.

${ }_{213}$ Ver: http://www.poli.usp.br/pt/a-poli/historia/galeria-de-diretores/203-prof-dr-oswaldo-fadigas-fontestorres.html, Consultado em 22/11/2015.
} 
pegaram. Mudou a minha vida. É engraçado o acaso, né? (Entrevista de Luiz Carlos Mendonça de Barros à autora, 2012).

Quando Mendonça chegou na UEE, José Serra já havia mudado para a UNE no Rio de Janeiro e só aparecia na POLI vez ou outra para fazer alguma prova. Serra, que mal acabara de ingressar no movimento estudantil, tornou-se o candidato da AP à presidência da UNE porque José Carlos Seixas, aquele que o recrutara, havia sido indicado pela direção nacional para concorrer, mas estava quase formado e decidiu sugerir, uma vez mais, o nome de Serra para o pleito. Madre Cristina, amiga e conselheira de Serra por muitos anos, relata: "nós descobrimos que era inteligente e que, se déssemos uma engomada nele, ele toparia. Então, a gente pegou o Serra e disse: 'Você vai ser o presidente da UNE'.” (DÓREA, 1989, [online]).

Como presidente da UEE-SP, Serra havia circulado em congressos de estudantes pelo país e participado da estruturação da AP. Começou a fazer campanha nas viagens que fazia para participar de reuniões e seminários do movimento estudantil. Nas eleições para a UNE, acabou sendo beneficiado pelo tamanho da delegação paulista, que contava com quase $20 \%$ dos presentes no encontro de Santo André, elegendo-o contra o candidato baiano, Sérgio Gaudezini (SERRA, 2014, pp. 23, 76). Na direção da UNE, continuou sustentando as pautas de seus antecessores para a educação, como a reforma e a expansão universitárias e a campanha de alfabetização; acompanhou a construção do teatro do CPC, que a ditadura queimou sem ter sido inaugurado; e integrou a Frente de Mobilização Popular, ao lado do presidente João Goulart, alertando a população para a conspiração de direita em curso. Não teve efeito.

A sede da UNE na Praia do Flamengo foi incendiada e Serra acabou escondido na Embaixada da Bolívia, onde permaneceu cerca de oitenta dias sem conseguir salvoconduto para deixar o país. No meio de 1964, partiu finalmente para La Paz, onde ficou cerca de um mês antes de viajar para Paris. Tinha uma carta assinada pelo padre dominicano Louis-Joseph Lebret que lhe garantia uma bolsa para estudar no Institute International de Recherche et de Formation en vue du Développement Harmonisé. Chegou na França em meados de agosto e reencontrou colegas da AP também exilados, como Vinicius Caldeira Brant, que o ajudaram a instalar-se. Com eles discutia política, marxismo, Brasil, Althusser, a revolução cubana, etc. Foi nesse momento que começou a aventurar-se em leituras sobre economia. Diz ter passeado por obras de Furtado, pelo 
Manifesto de Prebisch, leu o manual de introdução à economia de Paul Samuelson, algo de Henri Guitton e Albert Hirschman (SERRA, 2002, pp. 89-95; SERRA, 2014, pp. 106, 120-125).

Ainda que tivesse um vínculo formal que assegurava sua permanência na França, Serra não conseguia largar a ideia de regressar ao Brasil. "Era um misto de desejo de continuar na luta política e, quem sabe, voltar à vida normal [...] pensava reconquistar a namorada e concluir o meu curso de engenharia, o que era difícil de fazer no exterior. Tudo utopia, evidentemente” (SERRA, 2002, p. 92). Em janeiro de 1965, embarcou em direção ao Chile com um passaporte falso. Passou por Santiago, por Mendoza, por Buenos Aires e por Montevidéu, onde estavam muitos exilados brasileiros, como as lideranças da AP, Aldo Arantes e Betinho. Ficou no Uruguai um mês até que fosse organizado o seu regresso para o Brasil: a instalação na casa de um amigo de Brizola, a travessia da fronteira e o transporte até Pelotas e dali para São Paulo (SERRA, 2002, pp. 89-95; SERRA, 2014, pp. 106, 120-125).

De volta à sua cidade de origem, Serra escondeu-se, primeiro, na casa de Maurício e Beatriz Segall214 e depois na casa de um casal belga. A ilusão de que poderia retomar sua vida regular foi rapidamente desfeita. Ele visitou regularmente Madre Cristina e seus antigos companheiros de AP, José Carlos Seixas, Sérgio Motta e Egydio Bianchi, que agora lideravam clandestinamente o movimento. Queria retomar as atividades políticas junto a eles, mas foi veementemente desaconselhado pelos colegas. Em março de 1965, Sérgio Motta, Egydio Bianchi, Luiz Carlos Mendonça de Barros e Paulo Gustavo de Barros Carvalho (1943), irmão do Clóvis Carvalho que estudava medicina na Federal do Paraná, foram presos e permaneceram no Departamento de Ordem Política e Social (DOPS) por pouco mais de uma semana. Sérgio Motta escreveu para a família dizendo que a prisão era parte do caminho que tinha abraçado na "luta consciente, que irá colaborar para que tenhamos no mundo tudo aquilo que Cristo pregou: liberdade, igualdade, fraternidade e vida integral para todos os homens" (Sérgio Motta Apud PRATA

\footnotetext{
${ }^{214}$ Maurício Klabin Segall (1926) nasceu em Berlim e é filho do pintor russo radicado no Brasil, Lasar Segall, e da escritora Jenny Klabin Segall. Estudou Ciências Políticas e Sociais na Escola Livre de Sociologia e Política de São Paulo e tornou-se professor assistente da cadeira de ciência da administração da USP. Era ligado inicialmente ao PCB, depois transitou para a Ação Libertadora Nacional (ALN). Durante os primeiros anos da ditadura ajudou a esconder e tirar pessoas do país e, depois, a fazer esquemas de segurança de altos quadros da ALN. Chegou a ser preso duas vezes. Junto com a esposa, a atriz Beatriz Segall, trabalhou em vários empreendimentos artísticos. Recuperou o Teatro São Pedro, onde organizava produções artísticas de resistência, e tornou-se diretor do Museu Lasar Segall, que abriga a obra de seu pai (CANABRAVA, 1984a, p. 225; RIDENTI, 2014, pp. 146, 298-299).
} 
et al., 1999, p. 51). O apelo ao cristianismo ensaiava dar legitimidade perante suas famílias beatas à militância política em que estavam engajados.

A prisão e a transição da Ação Popular em direção ao maoísmo e à guerrilha fez com que todo esse grupo acabasse afastando-se da militância. Paulo Carvalho, o único que engajou-se na luta armada, foi capturado no Uruguai e enviado para o Brasil, onde foi preso e torturado. Sérgio Motta e Luiz Carlos Mendonça de Barros deixaram a militância, mas seguiram fazendo política no teatro. Fundaram uma empresa de produção cultural, a Difusão, que tentava se esquivar da censura e montar peças com conteúdo político. Tornaram-se cada vez mais próximos e, além da empresa, acabaram comprando, em sociedade, terreno em Porto de Galinhas, ao qual se seguiram casas vizinhas em Iporanga.

A maior parte do grupo de politécnicos inseriu-se, pincipalmente, no emergente mercado financeiro. Clóvis Carvalho trabalhou no departamento de ações do Banco Safra, na corretora Bansulvest e no departamento de fundos de investimento do Unibanco. Mas foi também superintendente da Companhia de Gás de São Paulo, gerente financeiro do Metrô de São Paulo e trabalhou por mais de dez anos na administração da Indústria Villares (DHBB, verbete Clóvis Carvalho). Gilberto Dupas começou a trabalhar em planejamento para o governo e acabou ingressando no Instituto de Pesquisa Econômica Aplicada (IPEA). Quando da mudança do IPEA para Brasília recebeu convite, via "Roberto Campos, que era conhecido de um conhecido de um conhecido, e que teve referência de mim e tal", para entrar no mercado financeiro. Começou reestruturando a área de investimentos do Banco Arnaud e chegou a ser vice-presidente no Banco Brascan de Investimentos. Trabalhou em mais alguns grupos financeiros e na área de seguradoras (DUPAS, 2009, [online]) $)^{215}$.

Mendonça também foi trabalhar no mercado financeiro a convite de Roberto Campos, com quem tinha algum parentesco. Começa no Investbanco de Campos e depois trabalharia em diversas outras financeiras: a corretora Patente, o banco de investimentos Planibanc, o Banco Matrix e a Quest investimentos. Assim converte-se de engenheiro de produção em economista especializado em mercado de capitais. A especialização em produção favorecia esta transição, já que combinava a formação em engenharia com disciplinas das áreas de economia, estatística, contabilidade, finanças,

\footnotetext{
${ }^{215}$ Os dois iriam reencontrar seus companheiros de movimento estudantil no governo Franco Montoro. Depois disso Dupas migraria para a vida acadêmica e Clóvis Carvalho passaria a trabalhar junto ao Partido da Social Democracia Brasileira, com todos os membros da AP de São Paulo mencionados: Serra, Mendonça de Barros, Sérgio Motta, Walter Barelli, José Carlos Seixas, Benedito Nicotero, Egydio Bianchi e Adalberto Wolf.
} 
marketing e administração. Como muitos dos engenheiros que se converteram à economia, Mendonça menciona ser sua afinidade prioritária com a matemática. Diz que entre seus melhores professores estava justamente aquele que ensinava Estatística e que o convidou a lecionar na FGV. É esse domínio da matemática e da lógica abstrata que torna os engenheiros de produção candidatos extremamente atraentes para o mercado, facilitando a conversão dos politécnicos para um setor de mais alta remuneração (MARTINS, 2015, p. 283).

Sérgio Motta, o único deles que seguiu atuando como engenheiro, comprou uma empresa de engenharia de projetos hidráulicos, a Hidrobrasileira, onde empregou diversos perseguidos políticos e parentes de presos das mais diversas tendências da esquerda, como Clara Charf, viúva de Carlos Marighella, da Ação Libertadora Nacional (ALN), Ulrich Hoffmann, do PCB, irmão de Helga Hoffmann (item 4.6), que depois seria secretário do governo do estado de Serra, Aldo Arantes, da AP, seu colega Adroaldo Wolf e tantos outros. A Hidrobrasileira faria também diversos contratos de pesquisa com o CEBRAP, que abrigava numerosos intelectuais da oposição (Entrevista de Luiz Carlos Mendonça de Barros à autora, 2012; PRATA et al., 1999, p. 63).

Com a prisão de seus colegas de militância, em março de 1965, José Serra desiste da clandestinidade no Brasil para ir para Santiago, que se transformava na capital latinoamericana dos exilados brasileiros.

Em novembro de 1964 havia tomado posse no Chile o presidente democrata cristão Eduardo Frei Montalva - adepto da mesma teologia francesa que a AP tinha como referência (PINTOR, 1977, p. 131) - cujo governo reformista orientou-se pela busca de uma terceira via comunitária entre o capitalismo laissez-faire e o socialismo, arrogando-se o lema Revolución en libertad. Dentre suas bandeiras estavam a integração entre o público e o privado, a promoção da distribuição de renda e a autogestão dos espaços de trabalho. Propunha, inclusive, a nacionalização do controle sobre os recursos minerais chilenos, em especial o cobre, e a reforma agrária (FALCOFF, 1982, pp. 324). Seu governo contava com franca simpatia e apoio da vertente norte-americana que dera origem à Aliança para o Progresso, pois realizava exatamente aquilo que a Aliança ambicionava: promover reformas sociais progressistas que trouxessem melhoria das condições de vida e aprofundassem a democracia, o que entendiam ser o caminho para a estabilidade política e para o enfraquecimento do comunismo. O resultado, no entanto, foi contrário às 
previsões estadunidenses, desembocando na eleição de um proposta de perspectiva socialista para ampliar as reformas iniciadas pelos democratas cristãos.

O socialismo de Salvador Allende explicitava que "as transformações econômicas - de caráter anti-imperialista, antioligárquico e antimonopolista - que se deveriam operar na base da sociedade chilena teriam o claro sentido de abrir caminho para a implantação do socialismo, sem a necessidade de uma ruptura da institucionalidade democrática vigente no Chile" (AGGIO, 1993, p. 19). Os experimentos sociais em curso no período, a ascensão do humanismo cristão com Frei Montalva e depois a via chilena ao socialismo

\begin{abstract}
atraíram um número cada vez maior de intelectuais de todo o mundo e de todos os matizes teóricos e ideológicos que foram transformando Santiago de Chile numa verdadeira universidade aberta e pública, um verdadeiro caldeirão de ideias, uma experiência intelectual única, que talvez já tivesse ocorrido em algumas cidades europeias dos séculos XIX e XX, mas que não tinha havido, nem nunca mais ocorreu na América do Sul [...]. depois da vitória do Allende multiplicaramse os seminários e as conferências sobre a "transição para o socialismo", sobre "socialismo e democracia", "revolução e reforma", "literatura e revolução"... isso tinha em toda esquina (FIORI, 2015, p. 30).
\end{abstract}

O Chile era o país inegavelmente de maior mobilização e politização da América Latina [...] foi um curso intensivo de ciências políticas em dois anos. Aí você vai descobrir o que é massa, o que é luta de classes, o que é partido. Aí você vai descobrir o que é ser liderança e o que é não ser liderança, como é que se desenvolve o nível político, qual a relação entre economia e política, qual o peso da conjuntura, das decisões tomadas, como se toma decisão política. Aí você sai de uma situação sem política, ou apolítica, para uma situação de Política com P maiúsculo, a política em dimensão de massa (SOUZA, 1976, p. 95).

A abertura e intensidade da vida política e o caráter progressista das transformações sociais propostas pelos governos de Frei Montalva e Allende despertavam especial interesse entre os brasileiros que haviam deixado o país por combater uma ditadura militar que se instaurara justamente para conter os projetos socialistas e reformistas, vista como repressora das reivindicações sociais, constrangedora da liberdade de expressão e concentradora de renda. Santiago reuniu uma miríade de intelectuais, lideranças estudantis e políticas, artistas, pessoas ligadas aos sindicatos, à luta pela reforma agrária, jornalistas e acadêmicos de diversas áreas, unidos por suas desavenças com a ditadura. "Dos 80 ou 100 da primeira leva, saltamos para mais de 5 mil. O Chile transformou-se na Meca da Esquerda Mundial. Exilado ou não, esquerdista que não passasse por lá, pelo menos por curto período, perdia um pouco de seu status" (RABÊLO e RABÊLO, 2001, p. 75). 
Sérgio Motta, que acabara de sair da prisão, levou José Serra até o porto de Santos. De lá Serra viajou de navio até Buenos Aires e então de trem para o Chile, onde inseriu-se socialmente graças à rede de laços que tinha no mundo dos brasileiros expatriados. Como é típico em fenômenos de migração, aqueles que já estavam posicionados na nova sociedade funcionaram como canais de informação e apoio para o estabelecimento da rede migratória. Assim, as teias de relações transferidas para o exílio permitiam que os recém-chegados conseguissem hospedagem, assistência e inserção nos mesmos espaços de trabalho e estudo desbravados pelos primeiros a chegar (SOARES, 2003, p. 40).

Os brasileiros que estavam há mais tempo no Chile criaram estruturas de solidariedade para ajudar os recém-chegados. Eles mantinham uma "caixinha", fundo de coleta e redistribuição de renda que contava com a colaboração financeira daqueles que já estavam bem inseridos no exílio e de simpatizantes, para garantir a sobrevivência daqueles que chegavam no "Chile sem trabalho, sem emprego, sem nada e isso era importante na manutenção destes brasileiros" (Entrevista de Ana Célia Castro à autora, 2014; RABÊLO e RABÊLO, 2001, p. 82). Os já estavelmente posicionados ajudavam também na busca de trabalho e de vínculos estudantis, o que era facilitado pelo clima de abertura do Chile de Frei e de Allende e pela larga presença de organizações internacionais que concediam bolsas de estudo para os exilados. A rede dos brasileiros conseguiu articular-se ao redor de organizações como a OIT, a FAO, a CEPAL, o ILPES, a ESCOLATINA, a FLACSO, o CESO, a UC e a Universidad Católica de Chile (UCC) que permitiram que aos poucos reestruturassem suas vidas, ao oferecer oportunidades para que estudassem, trabalhassem, fizessem política e produzissem conhecimento.

Aos poucos os exilados foram também criando seus espaços de sociabilidade, festas com feijoada, grupos de amigos, relacionamentos afetivos. Mantinham estruturas de formação política e trocas de informações, como os seminários sobre o Brasil contemporâneo, um grupo de leitura do Capital, os comitês nos quais produziam material para divulgação internacional das violações aos direitos humanos perpetradas pelo regime militar, os grupos de edição dos jornais que circulavam na comunidade, como o Frente Brasileño de Informaciones que ocupava-se da divulgação de "dados sobre o Brasil que haviam sido encobertos pela censura, revelando à comunidade internacional e de exilados o que 'de fato' ocorria" e o Campanha que "voltava-se à concretização da ação revolucionária, divulgando e debatendo projetos da esquerda. Com o lema 'Fazer do 
exílio uma campanha de luta'.", objetivava "unir toda a comunidade dos exilados num movimento internacional de construção da vanguarda revolucionária” (CRUZ, 2010, p. $50)$.

A comunidade de brasileiros cresceu em ritmo regular de 1964 a 1968. Chegaram novos membros, alguns voltaram ao Brasil, outros trocaram o Chile por outras localidades. José Maria Rabêlo, jornalista mineiro exilado, descreve a estrutura social ali instaurada da seguinte maneira:

O exílio no Chile caracterizou-se por dois momentos marcantes. O primeiro, quando chegaram os pioneiros, aqueles companheiros que saíram do Brasil no período seguinte ao golpe. Eram, como vimos, pessoas com experiência e formação profissional acima da média - ministros, deputados, médicos, advogados, professores, economistas, jornalistas - que encontraram certa facilidade para empregar-se. $O$ segundo momento coincidiu com $O$ endurecimento do regime militar, a partir de 1968. A leva que então aportou no Chile, integrada por gente mais jovem, principalmente um grande número de estudantes, operários, militares, que, em sua maioria, tiveram alguma participação na luta armada, iria enfrentar obstáculos muito maiores na busca de trabalho [...]. De maneira superficial, mas bem próxima da realidade, poderíamos dizer que aquela minissociedade se dividia em três níveis: os funcionários internacionais, que constituíam a burguesia do exílio; a classe média, com os que trabalhavam em repartições do governo chileno, nas universidades, nas empresas estatizadas, nos organismos internacionais não oficiais [...] e, por fim, o proletariado, reunindo os estudantes, os empregados de empresas privadas e os companheiros mantidos pela caixinha (RABÊLO e RABÊLO, 2001, pp. 81-83, grifos no original).

Além da hierarquia de classe e ocupação, havia na comunidade brasileira três status em relação ao modo de chegada no Chile ${ }^{216}$ : havia os exiliados, os autoexilados e aqueles que lá estavam por outras razões. Os exilados eram os que deixaram o país por causa de perseguições ou prisões, com ou sem tortura. Os autoexilados eram aqueles que teriam saído do Brasil antes de combater, sem ter sofrido perseguição direta, ou seja, sem feitos revolucionários que lhe rendessem dividendos simbólicos entre os militantes. Outros tantos por lá passavam para estudar, fazer projetos de cooperação científica e desenvolver outras atividades. Estes podiam transitar entre países sem medo de perseguição. Para muitos dos exilados engajados na luta revolucionária os outros eram "o pessoal da colônia" brasileira, "aqueles que não pertenciam ao punhado de siglas de organizações

\footnotetext{
${ }^{216}$ Outra clivagem existente no grupo era entre os que optaram por dar continuidade à militância no Chile, engajando-se nos partidos revolucionários ou socialistas locais como o MIR e o MAPU por considerarem que o projeto da revolução era internacional; os que mantinham atividades ligadas somente à política brasileira revolucionária; aqueles que apoiavam a luta produzindo jornais de divulgação das torturas e participando dos comitês de debate sobre os rumos do país; e aqueles que não mantinham atividades políticas sistemáticas. Muitos dos militantes ligados aos movimentos revolucionários brasileiros optavam deliberadamente pela não inserção na sociedade para a qual partiam, pois deviam estar prontos para deixar tudo a qualquer momento e voltar ao país para lutar.
} 
armadas, sinônimo de sofrida, penada, trágica resistência ao regime [...]. Eram as pessoas que trabalhavam, tentavam se integrar profissionalmente no país, ou simplesmente faziam a cabeça por aí, sem se dispor a passar a vida em reuniões, pontos, aparelhos, informes, lutas ideológicas e rachas" (SIRKIS, 1982, pp. 39-40). Eram aqueles que não tinham capital militante a ostentar (MATONTI e POUPEAU, 2004, pp. 5-7; SIRKIS, 1982, p. 39).

A primeira onda de exilados, composta majoritariamente por conhecidos intelectuais, políticos, professores e artistas, teve mais facilidade para inserir-se no novo país, já que eram qualificados profissionalmente e possuíam bons contatos (ROLLEMBERG, 1999, p. 50).

\begin{tabular}{|c|c|c|c|c|c|c|c|}
\hline $\begin{array}{l}\text { Personagem, } \\
\text { Cronologia e } \\
\text { Local de } \\
\text { Nascimento }\end{array}$ & Formação & Filiação & $\begin{array}{l}\text { Data(s) } \\
\text { de } \\
\text { entrada } \\
\text { no Chile }\end{array}$ & $\begin{array}{l}\text { Data(s) } \\
\text { de saída } \\
\text { do } \\
\text { Chile }\end{array}$ & $\begin{array}{l}\text { Próximo } \\
\text { destino }\end{array}$ & $\begin{array}{l}\text { Ocupações } \\
\text { no Chile }\end{array}$ & $\begin{array}{l}\text { Ocupação } \\
\text { anterior }\end{array}$ \\
\hline \multicolumn{8}{|c|}{ Anterior ao Golpe de 1964} \\
\hline $\begin{array}{l}\text { Celso Furtado } \\
\text { (1920-2004) } \\
\text { Pombal - PB }\end{array}$ & $\begin{array}{l}\text { Graduação em } \\
\text { direito } \\
\text { (Faculdade } \\
\text { Nacional de } \\
\text { Direito). } \\
\text { Doutorado em } \\
\text { história } \\
\text { econômica } \\
\text { (Sorbonne). }\end{array}$ & $\begin{array}{ll}\text { Pai juiz } & \text { e } \\
\text { desembargador, } & \\
\text { mãe de família de } & \\
\text { proprietários } & \text { de } \\
\text { terra. } & \end{array}$ & $\begin{array}{l}1949, \\
1955,1964\end{array}$ & $\begin{array}{l}1953, \\
1957, \\
1964\end{array}$ & $\begin{array}{l}\text { Brasil, } \\
\text { Estados } \\
\text { Unidos, } \\
\text { França e } \\
\text { Inglaterra }\end{array}$ & $\begin{array}{l}\text { Funcionário } \\
\text { da CEPAL e } \\
\text { Professor } \\
\text { ILPES }\end{array}$ & $\begin{array}{l}\text { Ministro do } \\
\text { Planejament } \\
\text { o, } \\
\text { Superintend } \\
\text { ente da } \\
\text { SUDENE }\end{array}$ \\
\hline $\begin{array}{l}\text { José Medina } \\
\text { Echevarría } \\
(1903-1977) \\
\text { Castellón de la } \\
\text { Plana - } \\
\text { Espanha }\end{array}$ & $\begin{array}{l}\text { Graduação em } \\
\text { direito } \\
\text { (Universidade } \\
\text { de Valência). } \\
\text { Doutorado em } \\
\text { filosofia } \\
\text { (Universidade } \\
\text { Central de } \\
\text { Madrid/Unive } \\
\text { rsidade de } \\
\text { Paris) }\end{array}$ & $\begin{array}{l}\text { Pai era funcionário } \\
\text { do Ministério da } \\
\text { Fazenda. Avô } \\
\text { paterno era um } \\
\text { tenente-coronel da } \\
\text { Marinha. }\end{array}$ & 1952 & 1974 & Espanha & $\begin{array}{l}\text { Funcionário } \\
\text { CEPAL, } \\
\text { professor } \\
\text { ILPES, } \\
\text { diretor } \\
\text { FLACSO }\end{array}$ & $\begin{array}{l}\text { Professor de } \\
\text { Sociologia } \\
\text { em Porto } \\
\text { Rico. }\end{array}$ \\
\hline $\begin{array}{l}\text { Joseph } \\
\text { Grunwald } \\
\text { (1920-1997) } \\
\text { Viena - } \\
\text { Áustria }\end{array}$ & $\begin{array}{l}\text { Graduação em } \\
\text { economia } \\
\text { (Johns } \\
\text { Hopkins). } \\
\text { Doutorado em } \\
\text { Economia } \\
\text { (Columbia) }\end{array}$ & $\begin{array}{lr}\text { Família } & \text { judia } \\
\text { austríaca } & \text { que } \\
\text { mudou } & \text { para } \\
\text { Baltimore } & \text { em } \\
1938 . & \end{array}$ & 1954 & 1961 & $\begin{array}{l}\text { Estados } \\
\text { Unidos }\end{array}$ & $\begin{array}{l}\text { Professor da } \\
\text { UC. } \\
\text { Organizador } \\
\text { e diretor da } \\
\text { ESCOLATI } \\
\text { NA }\end{array}$ & $\begin{array}{l}\text { Aluno de } \\
\text { doutorado } \\
\text { da } \\
\text { University of } \\
\text { Columbia }\end{array}$ \\
\hline $\begin{array}{l}\text { Nuno } \\
\text { Fidelino Lobo } \\
\text { da Costa } \\
\text { Figueiredo } \\
\text { (1923- ) } \\
\text { Lisboa - } \\
\text { Portugal }\end{array}$ & $\begin{array}{l}\text { Graduação em } \\
\text { economia } \\
\text { (Universidade } \\
\text { de Lisboa). } \\
\text { Doutorado em } \\
\text { Economia } \\
\text { Política } \\
\text { (FFCL-USP) }\end{array}$ & $\begin{array}{l}\text { Pai Nuno Fidelino } \\
\text { Figueiredo, } \\
\text { português exilado } \\
\text { no } \\
\text { historiador, } \\
\text { escritor, crasil, } \\
\text { literário, professor } \\
\text { de literatura, } \\
\text { membro } \\
\begin{array}{lr}\text { Academia } \\
\text { Brasileira }\end{array} \\
\text { Letras. }\end{array}$ & 1957 & 1969 & Brasil & $\begin{array}{l}\text { Funcionário } \\
\text { da CEPAL }\end{array}$ & $\begin{array}{l}\text { Professor } \\
\text { FCEA e } \\
\text { FFCL-USP }\end{array}$ \\
\hline $\begin{array}{l}\text { Thiago de } \\
\text { Mello (1926) }\end{array}$ & $\begin{array}{l}\text { Graduação } \\
\text { incompleta em }\end{array}$ & $\begin{array}{lr}\text { Avó } & \text { materna } \\
\text { provinha } & \text { de }\end{array}$ & 1961,1968 & $\begin{array}{l}1965, \\
1973\end{array}$ & $\begin{array}{l}\text { Argentina, } \\
\text { França, }\end{array}$ & $\begin{array}{l}\text { Adido } \\
\text { cultural }\end{array}$ & $\begin{array}{l}\text { Poeta, editor } \\
\text { e jornalista }\end{array}$ \\
\hline
\end{tabular}




\begin{tabular}{|c|c|c|c|c|c|c|c|}
\hline $\begin{array}{l}\text { Barreirinha - } \\
\text { AM }\end{array}$ & $\begin{array}{l}\text { medicina } \\
\text { (Faculdade } \\
\text { Nacional de } \\
\text { Medicina). } \\
\text { Escritor, } \\
\text { Poeta, Editor. }\end{array}$ & 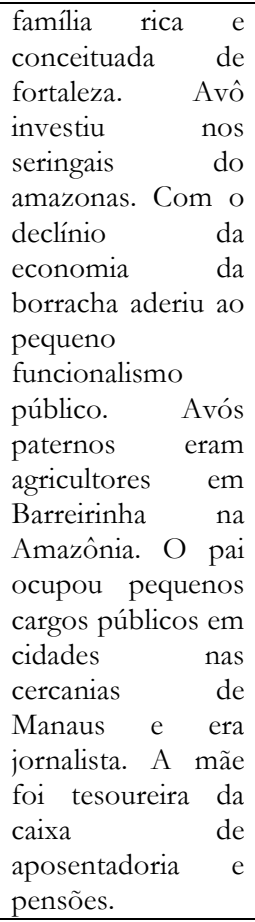 & & & $\begin{array}{l}\text { Portugal , } \\
\text { Alemanha } \\
\text { e outros }\end{array}$ & $\begin{array}{l}\text { Brasil em } \\
\text { Santiago, } \\
\text { poeta, } \\
\text { tradutor e } \\
\text { depois } \\
\text { diretor de } \\
\text { comunicaçõe } \\
\text { s do } \\
\text { Instituto de } \\
\text { Reforma } \\
\text { Agrária } \\
\text { durante o } \\
\text { governo } \\
\text { Allende }\end{array}$ & \\
\hline $\begin{array}{l}\text { Antonio } \\
\text { Otávio Cintra }\end{array}$ & $\begin{array}{l}\text { Graduação em } \\
\text { ciências sociais } \\
\text { (FACE). } \\
\text { Mestrado em } \\
\text { ciências sociais } \\
\text { (FLACSO). } \\
\text { Doutorado em } \\
\text { ciência política } \\
\text { (MIT) }\end{array}$ & s.d. & 1962 & 1963 & Brasil & $\begin{array}{l}\text { Aluno da } \\
\text { FLACSO }\end{array}$ & $\begin{array}{l}\text { Aluno de } \\
\text { graduação da } \\
\text { Sociologia e } \\
\text { Política da } \\
\text { FACE }\end{array}$ \\
\hline $\begin{array}{l}\text { Fábio } \\
\text { Wanderley } \\
\text { Reis } \\
(1937)\end{array}$ & $\begin{array}{l}\text { Graduação em } \\
\text { ciências sociais } \\
\text { (FACE). } \\
\text { Mestrado em } \\
\text { ciências sociais } \\
\text { (FLACSO). } \\
\text { Doutorado em } \\
\text { Ciência } \\
\text { Política } \\
\text { (Harvard) }\end{array}$ & s.d. & 1962 & 1963 & Brasil & $\begin{array}{l}\text { Aluno da } \\
\text { FLACSO }\end{array}$ & $\begin{array}{l}\text { Aluno de } \\
\text { graduação da } \\
\text { Sociologia e } \\
\text { Política da } \\
\text { FACE }\end{array}$ \\
\hline $\begin{array}{l}\text { Simon } \\
\text { Schwartzman } \\
(1939)\end{array}$ & $\begin{array}{l}\text { Graduação em } \\
\text { ciências sociais } \\
\text { (FACE- } \\
\text { UFMG). } \\
\text { Mestrado em } \\
\text { ciências sociais } \\
\text { (FLACSO). } \\
\text { Doutorado em } \\
\text { ciência política } \\
\text { (Berkeley). }\end{array}$ & $\begin{array}{lr}\text { Mãe palestina } & \text { de } \\
\text { família de judeus } \\
\text { poloneses. } & \text { Pai } \\
\text { descendente } & \text { de } \\
\text { judeus } & \\
\text { provenientes } & \text { de } \\
\text { aldeia } & \text { na } \\
\text { Bessarábia. } & \\
\text { Instalados no } \\
\text { Brasil trabalhavam } \\
\text { comor mascates. } \\
\text { Ambos rem } \\
\text { instrução superior. }\end{array}$ & 1962 & 1963 & Brasil & $\begin{array}{l}\text { Aluno da } \\
\text { FLACSO }\end{array}$ & $\begin{array}{l}\text { Aluno de } \\
\text { graduação da } \\
\text { Sociologia e } \\
\text { Política da } \\
\text { FACE }\end{array}$ \\
\hline $\begin{array}{l}\text { Flávio Tavares } \\
\text { de Lyra } \\
(1937) \\
\text { Garanhus - } \\
\text { PE }\end{array}$ & $\begin{array}{l}\text { Graduação em } \\
\text { economia } \\
\text { (UFPE). } \\
\text { Especialização } \\
\text { em Problemas } \\
\text { do } \\
\text { Desenvolvime } \\
\text { nto (CEPAL- } \\
\text { BNDE). Pós- } \\
\text { graduação em } \\
\text { economia } \\
\text { (ILPES) }\end{array}$ & $\begin{array}{l}\text { Avô } \\
\text { Tavares de Lyrânio } \\
\text { recifense da família } \\
\text { do político } \\
\text { Augusto Tavares } \\
\text { de Lyra. Avó } \\
\text { paterna de família } \\
\text { de pequenos } \\
\text { agricultores na } \\
\text { zona da mata de } \\
\text { Pernambuco. Avô } \\
\text { materno dono de }\end{array}$ & 1963,1970 & $\begin{array}{l}1963, \\
1973\end{array}$ & $\begin{array}{l}\text { Brasil, } \\
\text { Argentina, } \\
\text { Peru }\end{array}$ & $\begin{array}{l}\text { Aluno de } \\
\text { pós- } \\
\text { graduação } \\
\text { do ILPES e } \\
\text { depois } \\
\text { funcionário } \\
\text { do ILPES e } \\
\text { professor de } \\
\text { ciências } \\
\text { econômicas } \\
\text { da UCC }\end{array}$ & $\begin{array}{l}\text { Economista } \\
\text { e } \\
\text { funcionário } \\
\text { da } \\
\text { SUDENE. }\end{array}$ \\
\hline
\end{tabular}




\begin{tabular}{|c|c|c|c|c|c|c|c|}
\hline & & $\begin{array}{ll}\text { pequena } & \\
\text { propriedade } & \\
\text { agrícola } & \text { em } \\
\text { Pernambuco. } & \text { Pai } \\
\text { marceneiro. } & \\
\end{array}$ & & & & & \\
\hline $\begin{array}{l}\text { Gerson } \\
\text { Gomes }\end{array}$ & $\begin{array}{l}\text { Graduação em } \\
\text { economia } \\
\text { (UEG). } \\
\text { Especialização } \\
\text { em problemas } \\
\text { do } \\
\text { desenvolvimen } \\
\text { to (CEPAL- } \\
\text { BNDE). Pós- } \\
\text { graduação em } \\
\text { economia } \\
\text { (ILPES) }\end{array}$ & s.d. & 1963 & 1972 & Itália & $\begin{array}{l}\text { Aluno do } \\
\text { ILPES, } \\
\text { curso de } \\
\text { treinamento } \\
\text { em } \\
\text { Economia e } \\
\text { Planificação } \\
\text { Agrícola e } \\
\text { funcionário } \\
\text { da FAO e da } \\
\text { CEPAL }\end{array}$ & $\begin{array}{l}\text { Graduação } \\
\text { em } \\
\text { economia } \\
\text { UEG e } \\
\text { curso de } \\
\text { treinamento } \\
\text { em } \\
\text { problemas } \\
\text { do } \\
\text { desenvolvim } \\
\text { ento CEPAL }\end{array}$ \\
\hline \multicolumn{8}{|c|}{ Primeira onda de brasileiros no Chile } \\
\hline $\begin{array}{l}\text { Almino } \\
\text { Afonso } \\
(1929) \\
\text { Humaitá - AM }\end{array}$ & $\begin{array}{lr}\text { Graduação } & \text { em } \\
\text { direito } & \\
\text { (Faculdade } & \text { de } \\
\text { Direito } & \text { do } \\
\text { Amazonas } & \text { e } \\
\text { FD-USP) } & \end{array}$ & 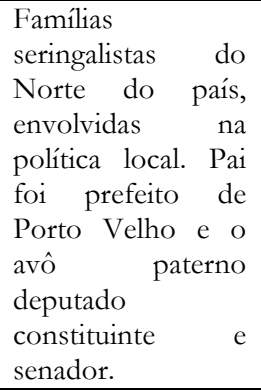 & 1964 & 1973 & Argentina & $\begin{array}{l}\text { Funcionário } \\
\text { da OIT e } \\
\text { professor da } \\
\text { UCC }\end{array}$ & $\begin{array}{l}\text { Deputado } \\
\text { federal pelo } \\
\text { estado do } \\
\text { Amazonas. } \\
\text { Foi ministro } \\
\text { do Trabalho } \\
\text { e da } \\
\text { Previdência } \\
\text { Social até } \\
\text { junho de } \\
1963 \text {. }\end{array}$ \\
\hline $\begin{array}{l}\text { Carlos Lessa } \\
(1936) \\
\text { Rio de Janeiro } \\
\text { - RJ }\end{array}$ & $\begin{array}{l}\text { Graduação em } \\
\text { economia } \\
\text { (FNCE). } \\
\text { Especialização } \\
\text { em economia } \\
\text { (CNE). }\end{array}$ & $\begin{array}{l}\text { Descendente de } \\
\text { Gomes Freire de } \\
\text { Andrade, vice-rei } \\
\text { do Brasil. Avô } \\
\text { materno advogado } \\
\text { e filho de José } \\
\text { Higino Duarte } \\
\text { Pereira da Silva. } \\
\text { Avô paterno } \\
\text { médico, botânico e } \\
\text { professor no } \\
\begin{array}{ll}\text { Pedro II. Pai } \\
\text { médico. }\end{array} \\
\end{array}$ & 1964 & 1968 & Brasil & $\begin{array}{l}\text { Funcionário } \\
\text { da CEPAL, } \\
\text { professor } \\
\text { ILPES e } \\
\text { professor }\end{array}$ & $\begin{array}{l}\text { Funcionário } \\
\text { do centro } \\
\text { CEPAL- } \\
\text { BNDE e } \\
\text { professor de } \\
\text { economia } \\
\text { CNE/UFRJ }\end{array}$ \\
\hline $\begin{array}{l}\text { Cláudio } \\
\text { Leopoldo } \\
\text { Salm }\end{array}$ & $\begin{array}{l}\text { Graduação em } \\
\text { economia } \\
\text { (IEI-UFRJ). } \\
\text { Pós-graduação } \\
\text { em economia } \\
\text { (ESCOLATIN } \\
\text { A). Doutorado } \\
\text { em economia } \\
\text { (IE- } \\
\text { UNICAMP). }\end{array}$ & s.d. & 1964 & 1967 & $\begin{array}{l}\text { Inglaterra } \\
\text { e Brasil }\end{array}$ & $\begin{array}{l}\text { Aluno de } \\
\text { pós- } \\
\text { graduação } \\
\text { ESCOLATI } \\
\text { NA }\end{array}$ & $\begin{array}{l}\text { Estudante da } \\
\text { graduação } \\
\text { em } \\
\text { Economia } \\
\text { da UFRJ e } \\
\text { funcionário } \\
\text { da } \\
\text { SUDENE }\end{array}$ \\
\hline $\begin{array}{l}\text { Elza Maia } \\
\text { Costa Oliveira } \\
\text { Freire } \\
(1916-1986) \\
\text { Recife - PE } \\
\end{array}$ & $\begin{array}{l}\text { Normalista } \\
\text { (Instituto } \\
\text { Pedagógico) }\end{array}$ & $\begin{array}{l}\text { Pai guarda-livros e } \\
\text { mãe dona de casa. }\end{array}$ & 1964 & 1969 & $\begin{array}{l}\text { Estados } \\
\text { Unidos e } \\
\text { Suíça }\end{array}$ & $\begin{array}{l}\text { Dona de } \\
\text { casa }\end{array}$ & $\begin{array}{l}\text { Professora, } \\
\text { alfabetização } \\
\text { popular }\end{array}$ \\
\hline $\begin{array}{l}\text { Estevam } \\
\text { Strauss }\end{array}$ & $\begin{array}{l}\text { Engenheiro } \\
\text { agrônomo }\end{array}$ & s.d. & 1964 & 1973 & s.d. & $\begin{array}{l}\text { Funcionário } \\
\text { CEPAL }\end{array}$ & $\begin{array}{l}\text { Funcionário } \\
\text { da } \\
\text { SUDENE }\end{array}$ \\
\hline $\begin{array}{l}\text { Fernando } \\
\text { Henrique } \\
\text { Cardoso } \\
(1931) \\
\text { Rio de Janeiro } \\
\text { - RJ }\end{array}$ & $\begin{array}{l}\text { Graduação em } \\
\text { ciências sociais } \\
\text { (FFCL-USP). } \\
\text { Doutorado em } \\
\text { sociologia } \\
\text { (FFCL-USP). }\end{array}$ & $\begin{array}{lr}\text { Bisavô } & \text { paterno } \\
\text { Felicíssimo do } \\
\text { Espírito Santo } \\
\text { Cardoso, foi o } \\
\text { primeiro } \\
\text { presidente } \\
\text { republicano do } \\
\text { estado de Goiás, } \\
\text { senador deputado } \\
\text { e governador. Avô } \\
\end{array}$ & 1964,1973 & $\begin{array}{l}1967, \\
1973\end{array}$ & Brasil & $\begin{array}{l}\text { Funcionário } \\
\text { CEPAL, } \\
\text { professor } \\
\text { ILPES e } \\
\text { FLACSO }\end{array}$ & $\begin{array}{l}\text { Professor } \\
\text { assistente de } \\
\text { Sociologia } \\
\text { FFCL-USP }\end{array}$ \\
\hline
\end{tabular}




\begin{tabular}{|c|c|c|c|c|c|c|c|}
\hline & & 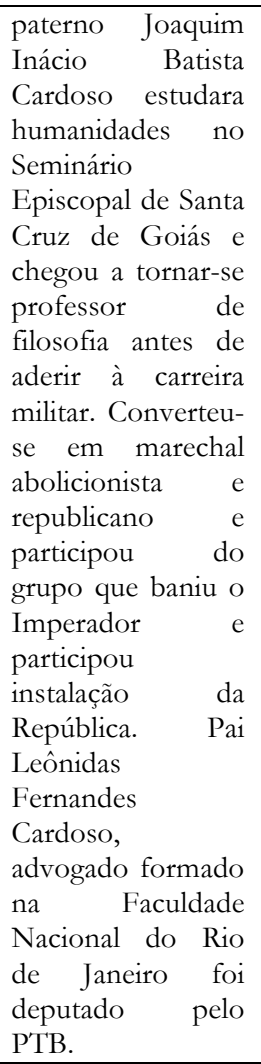 & & & & & \\
\hline $\begin{array}{l}\text { Francisco de } \\
\text { Oliveira } \\
\text { (1933) } \\
\text { Recife - PE }\end{array}$ & $\begin{array}{l}\text { Graduação em } \\
\text { ciências sociais } \\
\text { (UFPE). } \\
\text { Especialização } \\
\text { em Problemas } \\
\text { do } \\
\text { Desenvolvime } \\
\text { nto (CEPAL- } \\
\text { BNDE) }\end{array}$ & $\begin{array}{l}\text { Pai farmacêutico } \\
\text { prático não } \\
\text { diplomado. }\end{array}$ & 1964 & 1964 & $\begin{array}{l}\text { Brasil, } \\
\text { Guatemala } \\
\text {, México }\end{array}$ & $\begin{array}{l}\text { Assessor } \\
\text { CEPAL }\end{array}$ & $\begin{array}{l}\text { Funcionário } \\
\text { da } \\
\text { SUDENE, o } \\
\text { segundo na } \\
\text { hierarquia da } \\
\text { Superintend } \\
\text { ência depois } \\
\text { de Celso } \\
\text { Furtado. }\end{array}$ \\
\hline $\begin{array}{l}\text { Francisco } \\
\text { Weffort } \\
(1937) \\
\text { Quatá - SP }\end{array}$ & $\begin{array}{l}\text { Graduação em } \\
\text { ciências sociais } \\
\text { (FFCL-USP). } \\
\text { Doutorado em } \\
\text { ciência política } \\
\text { (FFCL-USP) }\end{array}$ & $\begin{array}{l}\text { Pai dono de } \\
\text { oficina mecânica } \\
\text { em Quatá. }\end{array}$ & 1964 & 1968 & Brasil & $\begin{array}{l}\text { Funcionário } \\
\text { da CEPAL, } \\
\text { professor } \\
\text { ILPES e } \\
\text { FLACSO }\end{array}$ & $\begin{array}{l}\text { Professor } \\
\text { FFCL-USP }\end{array}$ \\
\hline $\begin{array}{l}\text { Jader de } \\
\text { Andrade } \\
\text { (1924-1998) } \\
\text { Sete Lagoas - } \\
\text { MG }\end{array}$ & $\begin{array}{l}\text { Graduação em } \\
\text { economia } \\
\text { (UFPE) }\end{array}$ & s.d. & 1964 & 1973 & Equador & $\begin{array}{l}\text { Funcionário } \\
\text { da CEPAL }\end{array}$ & $\begin{array}{l}\text { Diretor de } \\
\text { Agricultura e } \\
\text { abasteciment } \\
\text { o da } \\
\text { SUDENE. }\end{array}$ \\
\hline $\begin{array}{l}\text { Liana } \\
\text { Aureliano } \\
(1942) \\
\text { s.d. - PE }\end{array}$ & $\begin{array}{l}\text { Graduação em } \\
\text { economia } \\
\text { (UFF). } \\
\text { Mestrado em } \\
\text { economia } \\
\text { (ESCOLATIN } \\
\text { A). Doutorado } \\
\text { em economia } \\
\text { (UNICAMP). }\end{array}$ & $\begin{array}{l}\text { Pai médico e } \\
\text { intelectual de } \\
\text { esquerda de família } \\
\text { bastante católica. }\end{array}$ & 1964,1972 & $\begin{array}{l}1966, \\
1973\end{array}$ & Brasil & 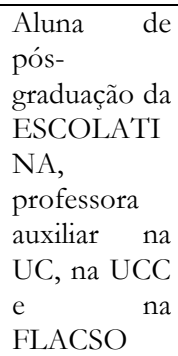 & $\begin{array}{l}\text { Aluna de } \\
\text { graduação da } \\
\text { economia da } \\
\text { UFRJ }\end{array}$ \\
\hline $\begin{array}{l}\text { Paulo Reglus } \\
\text { Neves Freire } \\
(1921-1997) \\
\text { Recife - PE }\end{array}$ & $\begin{array}{ll}\text { Graduação } & \text { em } \\
\text { direito } & \\
\text { (Faculdade } & \text { de } \\
\text { Direito } & \text { de } \\
\text { Recife). } & \\
\text { Doutorado } & \text { em } \\
\text { filosofia } & \text { e } \\
\text { história } & \text { da } \\
\text { educação } & \\
\text { (Faculdade } & \text { de }\end{array}$ & $\begin{array}{l}\text { Pai faleceu quando } \\
\text { tinha } 13 \text { anos. A } \\
\text { família } \\
\text { experimentou } \\
\text { situações } \\
\text { privação } \\
\text { econômica. }\end{array}$ & 1964 & 1969 & $\begin{array}{l}\text { Estados } \\
\text { Unidos e } \\
\text { Suíça }\end{array}$ & $\begin{array}{l}\text { Assessor do } \\
\text { Ministério } \\
\text { da Educação } \\
\text { e consultor } \\
\text { da } \\
\text { UNESCO, } \\
\text { trabalhando } \\
\text { na } \\
\text { formulação } \\
\text { do Plano de }\end{array}$ & $\begin{array}{l}\text { Educador, } \\
\text { organizador } \\
\text { do } \\
\text { Movimento } \\
\text { de Cultura } \\
\text { Popular do } \\
\text { governo de } \\
\text { Pernambuco } \\
\text { de Miguel } \\
\text { Arraes, }\end{array}$ \\
\hline
\end{tabular}




\begin{tabular}{|c|c|c|c|c|c|c|c|}
\hline & $\begin{array}{l}\text { Filosofia, } \\
\text { Ciências e } \\
\text { Letras da } \\
\text { Universidade } \\
\text { do Recife). }\end{array}$ & & & & & $\begin{array}{l}\text { Educação } \\
\text { em Massa do } \\
\text { governo Frei } \\
\text { e no } \\
\text { programa de } \\
\text { alfabetização } \\
\text { de adultos } \\
\text { conduzido } \\
\text { pelo } \\
\text { Instituto de } \\
\text { Reforma } \\
\text { Agrária }\end{array}$ & $\begin{array}{l}\text { idealizador } \\
\text { do plano de } \\
\text { alfabetização } \\
\text { nacional do } \\
\text { Ministério } \\
\text { da Educação }\end{array}$ \\
\hline $\begin{array}{l}\text { Paulo de } \\
\text { Tarso } \\
(1926) \\
\text { Araxá - MG }\end{array}$ & $\begin{array}{l}\text { Graduação em } \\
\text { direito (FD- } \\
\text { USP) }\end{array}$ & s.d. & 1964 & 1971 & Brasil & $\begin{array}{l}\text { Funcionário } \\
\text { PNUD e } \\
\text { FAO }\end{array}$ & $\begin{array}{l}\text { Deputado } \\
\text { Federal. } \\
\text { Havia sido } \\
\text { Ministro da } \\
\text { Educação de } \\
\text { junhor a } \\
\text { outubro de } \\
1963 .\end{array}$ \\
\hline $\begin{array}{l}\text { Plínio de } \\
\text { Arruda } \\
\text { Sampaio } \\
\text { (1930-2014) } \\
\text { São Paulo - SP }\end{array}$ & $\begin{array}{l}\text { Graduação em } \\
\text { direito (FD- } \\
\text { USP). } \\
\text { Mestrado em } \\
\text { Desenvolvime } \\
\text { nto } \\
\text { Econômico } \\
\text { (Cornell). }\end{array}$ & 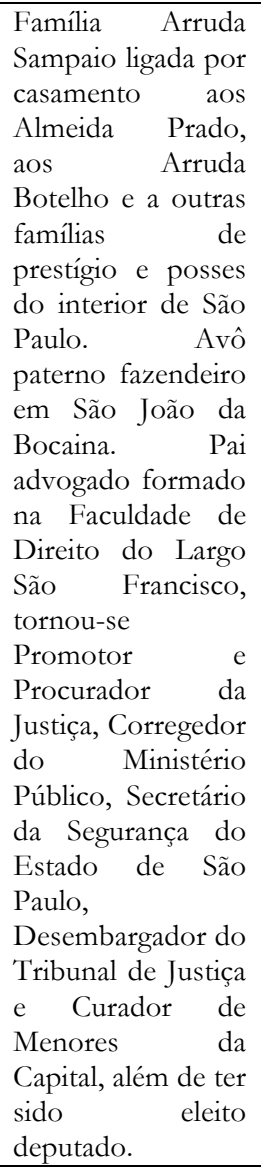 & 1964 & 1970 & $\begin{array}{l}\text { Estados } \\
\text { Unidos }\end{array}$ & $\begin{array}{l}\text { Trabalhou } \\
\text { no } \\
\text { Departamen } \\
\text { to de } \\
\text { Administraç } \\
\text { ão de } \\
\text { Reforma } \\
\text { Agrária do } \\
\text { Instituto de } \\
\text { Capacitación } \\
\text { e } \\
\text { Investigació } \\
\text { n en } \\
\text { Reforma } \\
\text { Agraria }\end{array}$ & \begin{tabular}{l}
\multicolumn{2}{l}{ Deputado } \\
federal do \\
PDC eleito \\
por $r a ̃ o$ \\
Paulo.
\end{tabular} \\
\hline $\begin{array}{l}\text { Ruth Cardoso } \\
\text { (1930-2008) } \\
\text { Araraquara - } \\
\text { SP }\end{array}$ & $\begin{array}{l}\text { Graduação em } \\
\text { ciências sociais } \\
\text { (FFCL-USP). } \\
\text { Mestrado em } \\
\text { ciências sociais } \\
\text { (FFCL-USP). } \\
\text { Doutorado em } \\
\text { antropologia } \\
\text { (FFCL-USP) }\end{array}$ & $\begin{array}{lr}\begin{array}{lr}\text { Avô } \\
\text { educador }\end{array} & \text { e } \\
\text { professor } & \text { de } \\
\text { matemática. } & \text { Mãe } \\
\text { farmacêutica } & \text { e } \\
\text { professora } & \text { no } \\
\text { ginasial e } & \text { na } \\
\text { Faculdade } & \text { de } \\
\text { Farmácia } & \text { e } \\
\text { Odontologia. } & \text { Pai } \\
\text { era guarda-livros. }\end{array}$ & 1964 & 1967 & Brasil & $\begin{array}{l}\text { Professora } \\
\text { de sociologia } \\
\text { na UCC }\end{array}$ & $\begin{array}{l}\text { Professora } \\
\text { de } \\
\text { antropologia } \\
\text { na USP }\end{array}$ \\
\hline
\end{tabular}




\begin{tabular}{|c|c|c|c|c|c|c|c|}
\hline $\begin{array}{l}\text { Wilson } \\
\text { Cantoni } \\
\text { (1926-1977) } \\
\text { Franca - SP }\end{array}$ & $\begin{array}{l}\text { Graduação em } \\
\text { Ciências } \\
\text { Sociais (FFCL- } \\
\text { USP). }\end{array}$ & s.d. & 1964 & 1973 & Costa Rica & $\begin{array}{l}\text { Diretor da } \\
\text { Unidad de } \\
\text { Investigacio } \\
\text { nes del } \\
\text { Fondo de } \\
\text { Educacional } \\
\text { y Extension } \\
\text { Sindical do } \\
\text { Ministério } \\
\text { do Trabalho } \\
\text { do Chile, } \\
\text { Pesquisador } \\
\text { OIT/Profes } \\
\text { sor da } \\
\text { FLACSO }\end{array}$ & $\begin{array}{l}\text { Professor de } \\
\text { Sociologia } \\
\text { na } \\
\text { Faculdade de } \\
\text { Filosofia, } \\
\text { Ciências e } \\
\text { Letras de } \\
\text { São José do } \\
\text { Rio Preto. }\end{array}$ \\
\hline $\begin{array}{l}\text { Álvaro Vieira } \\
\text { Pinto } \\
\text { (1909-1987) } \\
\text { Campos - RJ }\end{array}$ & $\begin{array}{l}\text { Graduação em } \\
\text { Medicina } \\
\text { (Faculdade } \\
\text { Nacional de } \\
\text { Medicina). }\end{array}$ & $\begin{array}{l}\text { Pai comerciante. } \\
\text { Família de classe } \\
\text { média baixa. }\end{array}$ & 1965 & 1968 & Brasil & $\begin{array}{l}\text { Colaborador } \\
\text { do programa } \\
\text { de educação } \\
\text { popular, do } \\
\text { Ministério } \\
\text { da } \\
\text { Educação. } \\
\text { Pesquisador } \\
\text { do Centro } \\
\text { Latino- } \\
\text { Americano } \\
\text { de } \\
\text { Demografia }\end{array}$ & $\begin{array}{l}\text { Professor da } \\
\text { Faculdade } \\
\text { Nacional de } \\
\text { Filosofia e } \\
\text { diretor do } \\
\text { ISEB }\end{array}$ \\
\hline $\begin{array}{l}\text { Antônio } \\
\text { Bezerra Baltar } \\
(1915-2003) \\
\text { Recife - PE }\end{array}$ & $\begin{array}{l}\text { Graduação em } \\
\text { economia UC. } \\
\text { Mestrado em } \\
\text { economia } \\
\text { (UNICAMP). } \\
\text { Doutorado em } \\
\text { economia } \\
\text { (UNICAMP). }\end{array}$ & $\begin{array}{lr}\begin{array}{l}\text { Filho } \\
\text { engenheiro }\end{array} & \text { do } \\
\text { urbanista, } & \\
\text { professor } & \text { das } \\
\text { Faculdades } & \text { de } \\
\text { Engenharia } & \text { e de } \\
\text { Arquitetura } & \text { e } \\
\text { Urbanismo da } & \text { dFPE, vereador e } \\
\text { senador Antônio } \\
\text { Bezerra Baltar. }\end{array}$ & 1965 & 1977 & Canadá & $\begin{array}{l}\text { Funcionário } \\
\text { da CEPAL }\end{array}$ & $\begin{array}{l}\text { Professor de } \\
\text { Engenharia e } \\
\text { Arquitetura } \\
\text { e Urbanismo } \\
\text { na UFPE. } \\
\text { Senador até } \\
1961\end{array}$ \\
\hline $\begin{array}{l}\text { Carlos } \\
\text { Estevam } \\
\text { Martins } \\
\text { (1934-2009) } \\
\text { Rio de Janeiro } \\
\text { - RJ }\end{array}$ & $\begin{array}{l}\text { Graduação em } \\
\text { filosofia (UB). } \\
\text { Mestrado em } \\
\text { ciência política } \\
\text { (FLACSO). } \\
\text { Doutorado em } \\
\text { ciência política } \\
\text { (North } \\
\text { Caroline/Esse } \\
\text { x) }\end{array}$ & $\begin{array}{lr}\text { Avô } & \text { materno } \\
\text { médico } & \mathrm{e} \\
\text { fazendeiro } & \mathrm{em} \\
\text { Minas } & \text { Gerais. } \\
\text { Descendentes } & \text { de } \\
\text { membro da } & \text { missão } \\
\text { francesa } & \text { do } \\
\text { império re } & \text { da } \\
\text { família } & \text { do } \\
\text { Brigadeiro } & \text { Luís } \\
\text { Antônio. } & \text { Avô } \\
\text { paterno advogado. } & \text { Pai comerciante. } \\
\end{array}$ & 1965 & 1967 & $\begin{array}{l}\text { Estados } \\
\text { Unidos e } \\
\text { Inglaterra }\end{array}$ & $\begin{array}{ll}\text { Aluno } & \text { do } \\
\text { ELACP } & \end{array}$ & $\begin{array}{l}\text { Pesquisador } \\
\text { do ISEB e } \\
\text { do IUPERJ }\end{array}$ \\
\hline $\begin{array}{l}\text { José Luís Fiori } \\
\text { (1945) } \\
\text { Porto Alegre - } \\
\text { RS }\end{array}$ & $\begin{array}{l}\text { Graduação em } \\
\text { ciências sociais } \\
\text { (UC). } \\
\text { Mestrado em } \\
\text { economia } \\
\text { (ESCOLATIN } \\
\text { A). Doutorado } \\
\text { em ciência } \\
\text { política } \\
\text { (FFLCH-USP) }\end{array}$ & $\begin{array}{lr}\text { Pai Ernani } & \text { Fiori, } \\
\text { filósofo } & \mathrm{e} \\
\text { professor } & \\
\text { universitário. }\end{array}$ & $\begin{array}{ll}\text { Final de } \\
1965\end{array}$ & 1973 & Brasil & $\begin{array}{l}\text { Aluno de } \\
\text { graduação } \\
\text { em Ciências } \\
\text { Sociais na } \\
\text { UC, aluno } \\
\text { de pós- } \\
\text { graduação } \\
\text { em } \\
\text { economia da } \\
\text { ESCOLATI } \\
\text { NA }\end{array}$ & $\begin{array}{l}\text { Aluno de } \\
\text { graduação } \\
\text { em } \\
\text { economia da } \\
\text { UFRGS }\end{array}$ \\
\hline $\begin{array}{l}\text { José Serra } \\
\text { (1942) } \\
\text { São Paulo - SP }\end{array}$ & $\begin{array}{l}\text { Graduação } \\
\text { engenharia } \\
\text { incompleta } \\
\text { (POLI-USP). } \\
\text { Pós-graduação } \\
\text { economia } \\
\text { (ILPES). }\end{array}$ & $\begin{array}{l}\text { Pai vendedor de } \\
\text { frutas no mercado } \\
\text { da Cantareira. Avô } \\
\text { paterno pequeno } \\
\text { produtor de olivas. } \\
\text { Avô materno } \\
\text { vendedor de frutas }\end{array}$ & $\begin{array}{ll}\text { Abril de } \\
1965\end{array}$ & $\begin{array}{l}\text { Maio de } \\
1974\end{array}$ & $\begin{array}{l}\text { Itália e } \\
\text { Estados } \\
\text { Unidos }\end{array}$ & $\begin{array}{l}\text { Aluno do } \\
\text { ILPES, } \\
\text { aluno da } \\
\text { pós- } \\
\text { graduação da } \\
\text { ESCOLATI } \\
\text { NA. }\end{array}$ & $\begin{array}{l}\text { Aluno de } \\
\text { graduação da } \\
\text { POLI-USP. } \\
\text { Presidente } \\
\text { da UNE }\end{array}$ \\
\hline
\end{tabular}




\begin{tabular}{|c|c|c|c|c|c|c|c|}
\hline & $\begin{array}{l}\text { Mestrado em } \\
\text { economia } \\
\text { (ESCOLATIN } \\
\text { A). Doutorado } \\
\text { em economia } \\
\text { (Cornell) }\end{array}$ & $\begin{array}{l}\text { no mercado da } \\
\text { Cantareira. }\end{array}$ & & & & $\begin{array}{l}\text { Professor do } \\
\text { ILPES, da } \\
\text { ESCOLATI } \\
\text { NA e da } \\
\text { FLACSO. } \\
\text { Assessor } \\
\text { econômico } \\
\text { do governo } \\
\text { Allende. }\end{array}$ & \\
\hline $\begin{array}{l}\text { Leon } \\
\text { Hirszman } \\
(1937-1987) \\
\text { Lins de } \\
\text { Vasconcelos - } \\
\text { RJ }\end{array}$ & $\begin{array}{l}\text { Graduação } \\
\text { incompleta em } \\
\text { engenharia } \\
\text { (Nacional de } \\
\text { Engenharia). } \\
\text { Cineasta. }\end{array}$ & $\begin{array}{l}\text { Pais imigrantes } \\
\text { judeus da Polônia. } \\
\text { Pai foi vendedor } \\
\text { ambulante e } \\
\text { depois teve uma } \\
\text { loja de sapatos. }\end{array}$ & 1965 & 1966 & Brasil & Cineasta & $\begin{array}{l}\text { Cineasta, } \\
\text { vinculado ao } \\
\text { CPC-UNE }\end{array}$ \\
\hline $\begin{array}{l}\text { Luiz Alberto } \\
\text { Gomes de } \\
\text { Souza }\end{array}$ & $\begin{array}{l}\text { Graduação em } \\
\text { direito (PUC- } \\
\text { RS). Mestrado } \\
\text { em ciências } \\
\text { sociais } \\
\text { (FLACSO). } \\
\text { Doutorado em } \\
\text { sociologia } \\
\text { (Paris- } \\
\text { Sorbonne) }\end{array}$ & s.d. & 1965 & 1973 & Itália & $\begin{array}{l}\text { Funcionário } \\
\text { da CEPAL, } \\
\text { aluno do } \\
\text { ELACP e } \\
\text { depois } \\
\text { professor do } \\
\text { ELACP }\end{array}$ & $\begin{array}{l}\text { Secretário } \\
\text { Geral da } \\
\text { Juventude } \\
\text { Estudantil } \\
\text { Católica } \\
\text { Internaciona } \\
1 \text { em Paris. } \\
\text { Assessoria } \\
\text { do } \\
\text { Ministério } \\
\text { da } \\
\text { Educação. }\end{array}$ \\
\hline $\begin{array}{l}\text { Paulo } \\
\text { Eduardo de } \\
\text { Andrade } \\
\text { Baltar }\end{array}$ & $\begin{array}{l}\text { Graduação em } \\
\text { Economia } \\
\text { (UC). } \\
\text { Mestrado em } \\
\text { Economia } \\
\text { (UNICAMP). } \\
\text { Doutorado em } \\
\text { Economia } \\
\text { (UNICAMP) }\end{array}$ & $\begin{array}{lr}\begin{array}{lr}\text { Filho } \\
\text { engenheiro }\end{array} & \text { do } \\
\text { urbanista, } & \\
\text { professor } & \text { das } \\
\text { Faculdades } & \text { de } \\
\text { Engenharia } & \text { e de } \\
\text { Arquitetura } & \text { e } \\
\text { Urbanismo da } \\
\text { UFPE, vereador e } \\
\text { senador Antônio } \\
\text { Bezerra Baltar. }\end{array}$ & 1965 & 1973 & Brasil & $\begin{array}{l}\text { Aluno de } \\
\text { graduação } \\
\text { em } \\
\text { economia na } \\
\text { UC }\end{array}$ & s.d. \\
\hline $\begin{array}{l}\text { Regina Marta } \\
\text { Barbosa Faria }\end{array}$ & $\begin{array}{l}\text { Graduação em } \\
\text { ciências sociais } \\
\text { (FACE). } \\
\text { Mestrado em } \\
\text { ciências sociais } \\
\text { (FLACSO). } \\
\text { Doutorado em } \\
\text { saúde pública } \\
\text { (USP) }\end{array}$ & s.d. & 1965 & 1970 & $\begin{array}{l}\text { Estados } \\
\text { Unidos }\end{array}$ & $\begin{array}{l}\text { Aluna da } \\
\text { FLACSO }\end{array}$ & $\begin{array}{lr}\text { Aluna de } \\
\text { graduação da } \\
\text { Sociologia e } \\
\text { Política da } \\
\text { UFMG }\end{array}$ \\
\hline $\begin{array}{l}\text { Ulrich } \\
\text { Hoffmann } \\
(1940)\end{array}$ & $\begin{array}{l}\text { Engenharia } \\
\text { aeronáutica } \\
\text { (ITA) }\end{array}$ & s.d. & 1965 & 1973 & Costa Rica & $\begin{array}{l}\text { Engenheiro } \\
\text { e depois } \\
\text { chefe da } \\
\text { OPEE - } \\
\text { Oficina de } \\
\text { Planificación } \\
\text {, Evaluación } \\
\text { y Estudios } \\
\text { do Servicio } \\
\text { de } \\
\text { Cooperación } \\
\text { Técnica, } \\
\text { organismo } \\
\text { dedicado ao } \\
\text { fomento das } \\
\text { pequenas e } \\
\text { médias } \\
\text { indústrias e } \\
\text { do } \\
\text { artesanato }\end{array}$ & $\begin{array}{l}\text { Funcionário } \\
\text { da } \\
\text { SUDENE }\end{array}$ \\
\hline $\begin{array}{l}\text { Vilmar Faria } \\
(1941-2001) \\
\text { Belo }\end{array}$ & $\begin{array}{l}\text { Graduação } \\
\text { sociologia } \\
\text { política }\end{array}$ & Pai alfaiate. & 1965 & 1969 & $\begin{array}{l}\text { Estados } \\
\text { Unidos }\end{array}$ & $\begin{array}{l}\text { Aluno de } \\
\text { pós- } \\
\text { graduação da }\end{array}$ & $\begin{array}{l}\text { Aluno de } \\
\text { graduação da } \\
\text { Sociologia }\end{array}$ \\
\hline
\end{tabular}




\begin{tabular}{|c|c|c|c|c|c|c|c|}
\hline $\begin{array}{l}\text { Horizonte - } \\
\text { MG }\end{array}$ & $\begin{array}{l}\text { (FACE). } \\
\text { Mestrado em } \\
\text { ciências sociais } \\
\text { (FLACSO). } \\
\text { Doutorado em } \\
\text { ciência política } \\
\text { (Harvard) }\end{array}$ & & & & & $\begin{array}{l}\text { FLACSO, } \\
\text { depois } \\
\text { pesquisador } \\
\text { do ILPES }\end{array}$ & $\begin{array}{l}\text { Política da } \\
\text { UFMG, } \\
\text { envolvido } \\
\text { com a } \\
\text { política de } \\
\text { alfabetização } \\
\text { do } \\
\text { Ministério } \\
\text { da Educação } \\
\text { conduzida } \\
\text { por Paulo } \\
\text { Freire. }\end{array}$ \\
\hline $\begin{array}{l}\text { Clélia Bacha } \\
\text { de Almeida } \\
\text { (1931) } \\
\text { Lambari - MG }\end{array}$ & $\begin{array}{l}\text { Colégio Sion } \\
\text { de Campanha. }\end{array}$ & $\begin{array}{lr}\text { Família } & \text { de } \\
\text { comerciantes } \\
\text { libaneses do lado } \\
\text { paterno. } \\
\text { comerciante, } \\
\text { trabalhou rai } \\
\text { secretário romo } \\
\text { prefeitura } \\
\text { Lambari. Um do do } \\
\text { seus tios foi } \\
\text { prefeito } \\
\text { Cambuquira. Do } \\
\text { lado materno era } \\
\text { descendente da } \\
\text { elite política local. } \\
\text { A mãe era } \\
\text { normalista. O avô } \\
\text { materno, João de } \\
\text { Almeida Lisboa } \\
\text { era farmacêutico } \\
\text { de formação e foi } \\
\text { eleito prefeito de } \\
\text { Lambari r e } \\
\text { deputado federal. } \\
\text { Duas das irmãs de } \\
\text { sua mãe foram } \\
\text { eleitas para a } \\
\text { Academia Mineira } \\
\text { de Letras. }\end{array}$ & 1966 & 1970 & Peru & s.d. & $\begin{array}{l}\text { Funcionária } \\
\text { pública no } \\
\text { Instituto de } \\
\text { Previdência } \\
\text { dos } \\
\text { Servidores } \\
\text { do Estado } \\
\text { de Minas } \\
\text { Gerais. }\end{array}$ \\
\hline $\begin{array}{l}\text { Ernani Maria } \\
\text { Fiori } \\
\text { (1914-1985) } \\
\text { Porto Alegre - } \\
\text { RS }\end{array}$ & $\begin{array}{ll}\text { Faculdade } & \text { de } \\
\text { Ciências } & \\
\text { Jurídicas } & \text { e } \\
\text { Sociais } & \\
\text { (Faculdade } & \text { de } \\
\text { Direito } & \text { de } \\
\text { Porto Alegre) }\end{array}$ & $\begin{array}{l}\text { Pai imigrante } \\
\text { italiano. } \\
\text { Trabalhava como } \\
\text { alfaiate. }\end{array}$ & 1966 & 1973 & Brasil & $\begin{array}{l}\text { Funcionário } \\
\text { do Instituto } \\
\text { de } \\
\text { Educación } \\
\text { Rural (IER), } \\
\text { órgão } \\
\text { católico } \\
\text { engajado na } \\
\text { reforma } \\
\text { agrária e } \\
\text { professor de } \\
\text { filosofia e } \\
\text { vice-reitor } \\
\text { da UCC }\end{array}$ & $\begin{array}{l}\text { Professor } \\
\text { filosofia } \\
\text { UFGRS e } \\
\text { UNB. }\end{array}$ \\
\hline $\begin{array}{l}\text { Francisco } \\
\text { Biato de } \\
\text { Almeida }\end{array}$ & $\begin{array}{l}\text { Graduação em } \\
\text { economia } \\
\text { (IEI-UFRJ). } \\
\text { Pós- } \\
\text { Graduação em } \\
\text { economia } \\
\text { (ILPES). } \\
\text { Doutorado em } \\
\text { economia } \\
\text { (University } \\
\text { College } \\
\text { London) }\end{array}$ & s.d. & 1966 & 1967 & Brasil & $\begin{array}{l}\text { Aluno de } \\
\text { pós- } \\
\text { graduação } \\
\text { do ILPES. }\end{array}$ & $\begin{array}{l}\text { Estagiário } \\
\text { do Centro } \\
\text { CEPAL- } \\
\text { BNDE }\end{array}$ \\
\hline $\begin{array}{l}\text { Guy de } \\
\text { Almeida } \\
\text { (1932-) }\end{array}$ & $\begin{array}{l}\text { Graduação } \\
\text { incompleta em } \\
\text { sociologia e }\end{array}$ & $\begin{array}{lr}\text { Pai } & \text { funcionário } \\
\text { público } & \text { da } \\
\text { imprensa } & \text { oficial. }\end{array}$ & 1966 & 1970 & Peru & $\begin{array}{l}\text { Departamen } \\
\text { to de } \\
\text { documentaç }\end{array}$ & $\begin{array}{l}\text { Jornalista. } \\
\text { Assessor do } \\
\text { Deputado }\end{array}$ \\
\hline
\end{tabular}




\begin{tabular}{|c|c|c|c|c|c|c|c|}
\hline $\begin{array}{l}\text { Belo } \\
\text { Horizonte - } \\
\text { MG }\end{array}$ & $\begin{array}{l}\text { política } \\
\text { (FACE) }\end{array}$ & $\begin{array}{l}\text { Mãe normalista, } \\
\text { dona de casa. }\end{array}$ & & & & $\begin{array}{l}\text { ão da } \\
\text { agência } \\
\text { inter-press }\end{array}$ & \begin{tabular}{l}
\multicolumn{2}{l}{ Tancredo } \\
Neves do \\
PTB que \\
fazia \\
campanha \\
para o \\
governo de \\
Minas \\
Gerais.
\end{tabular} \\
\hline $\begin{array}{l}\text { Theotônio } \\
\text { dos Santos } \\
(1937) \\
\text { Carangola - } \\
\text { MG }\end{array}$ & $\begin{array}{l}\text { Graduação } \\
\text { sociologia e } \\
\text { política } \\
\text { (FACE- } \\
\text { UFMG). } \\
\text { Mestrado em } \\
\text { ciências sociais } \\
\text { (UNB). } \\
\text { Especialização } \\
\text { em problemas } \\
\text { do } \\
\text { Desenvolvime } \\
\text { nto (CEPAL- } \\
\text { BNDE) }\end{array}$ & s.d. & 1966 & 1973 & México & $\begin{array}{l}\text { Professor e } \\
\text { pesquisador } \\
\text { do CESO }\end{array}$ & $\begin{array}{l}\text { Mestrando e } \\
\text { assistente de } \\
\text { ensino na } \\
\text { UNB }\end{array}$ \\
\hline $\begin{array}{l}\text { Vânia } \\
\text { Bambirra } \\
(1940-2015) \\
\text { Belo } \\
\text { Horizonte - } \\
\text { MG }\end{array}$ & $\begin{array}{l}\text { Graduação } \\
\text { sociologia e } \\
\text { política } \\
\text { (FACE- } \\
\text { UFMG). } \\
\text { Mestrado em } \\
\text { ciências sociais } \\
\text { (UNB). } \\
\text { Especialização } \\
\text { em problemas } \\
\text { do } \\
\text { desenvolvimen } \\
\text { to (CEPAL- } \\
\text { BNDE) }\end{array}$ & $\begin{array}{lr}\text { Pai alfaiate } & \text { e } \\
\text { militante } & \\
\text { comunista. } & \text { Mãe } \\
\text { herdeira } & \text { de } \\
\text { tradicional } & \text { família } \\
\text { mineira. } & \end{array}$ & 1966 & 1973 & México & \begin{tabular}{l}
\multicolumn{2}{l}{ Funcionária } \\
do Instituto \\
de Pesquisa \\
de Opinião \\
de Eduardo \\
Hamuy e \\
professora e \\
pesquisadora \\
do CESO
\end{tabular} & $\begin{array}{l}\text { Instrutora na } \\
\text { UNB e } \\
\text { assistente de } \\
\text { pesquisa de } \\
\text { uma } \\
\text { companhia } \\
\text { de } \\
\text { publicidade }\end{array}$ \\
\hline $\begin{array}{l}\text { André } \\
\text { Gunder Frank } \\
(1929-2005) \\
\text { Berlim - } \\
\text { Alemanha }\end{array}$ & $\begin{array}{l}\text { Graduação em } \\
\text { economia } \\
\text { (Swarthmore } \\
\text { College). } \\
\text { Doutorado em } \\
\text { economia } \\
\text { (Chicago) }\end{array}$ & $\begin{array}{lr}\text { Pai } & \text { escritor, } \\
\text { proveniente } & \text { de } \\
\text { uma } & \text { família } \\
\text { modesta } & \text { do } \\
\text { interior } & \text { da } \\
\text { Alemanha. } & \end{array}$ & 1968 & 1973 & Alemanha & $\begin{array}{l}\text { Professor } \\
\text { UC e } \\
\text { pesquisador } \\
\text { no CESO }\end{array}$ & $\begin{array}{l}\text { Professor } \\
\text { UNB e na } \\
\text { UNAM }\end{array}$ \\
\hline $\begin{array}{l}\text { Ayrton José } \\
\text { da Fonseca } \\
\text { Fausto } \\
(1943) \\
\text { Fortaleza - } \\
\text { Ceará }\end{array}$ & $\begin{array}{l}\text { Graduação em } \\
\text { ciências } \\
\text { jurídicas e } \\
\text { sociais } \\
\text { (Faculdade } \\
\text { Nacional de } \\
\text { Direito) } \\
\text { Graduação em } \\
\text { sociologia } \\
\text { (PUC-RJ). } \\
\text { Mestrado em } \\
\text { ciências sociais } \\
\text { (FLACSO). } \\
\text { Diplôme } \\
\text { d'Etudes } \\
\text { Approfondies } \\
\text { (EHESS). }\end{array}$ & $\begin{array}{lr}\text { Pai médico } & \text { do } \\
\text { Ministério } & \text { da } \\
\text { Saúde. } & \text { Avô } \\
\text { materno } & \\
\text { funcionário do BB. }\end{array}$ & 1968 & 1973 & $\begin{array}{l}\text { Argentina, } \\
\text { França e } \\
\text { Equador }\end{array}$ & $\begin{array}{l}\text { Aluno } \\
\text { FLACSO, } \\
\text { professor da } \\
\text { ESCOLATI } \\
\text { NA e depois } \\
\text { pesquisador } \\
\text { da FLACSO }\end{array}$ & $\begin{array}{l}\text { Ajudante de } \\
\text { pesquisa na } \\
\text { UFRJ e } \\
\text { professor na } \\
\text { Faculdade de } \\
\text { Economia, } \\
\text { Filosofia e } \\
\text { Letras da } \\
\text { UFF. }\end{array}$ \\
\hline $\begin{array}{l}\text { Edmar Bacha } \\
\text { (1942) } \\
\text { Lambari - MG }\end{array}$ & $\begin{array}{l}\text { Graduação em } \\
\text { Economia } \\
\text { (FACE). Pós- } \\
\text { graduação em } \\
\text { Economia } \\
\text { (CAE-FGV). } \\
\text { Mestrado em } \\
\text { Economia } \\
\text { (Yale) }\end{array}$ & $\begin{array}{lr}\text { Família } & \text { de } \\
\text { comerciantes } \\
\text { libaneses do lado } \\
\text { paterno. } \\
\text { comerciante, } \\
\text { trabalhou } \\
\text { secretário } & \text { como } \\
\text { prefeitura } & \text { da } \\
\text { Lambari. Um } & \text { dos }\end{array}$ & 1968 & 1969 & Brasil & $\begin{array}{l}\text { Pesquisador } \\
\text { do convênio } \\
\text { Yale- } \\
\text { ODEPLAN }\end{array}$ & $\begin{array}{l}\text { Aluno de } \\
\text { doutorado } \\
\text { em Yale }\end{array}$ \\
\hline
\end{tabular}




\begin{tabular}{|c|c|c|c|c|c|c|c|}
\hline & $\begin{array}{l}\text { Doutorado em } \\
\text { Economia } \\
\text { (Yale). }\end{array}$ & 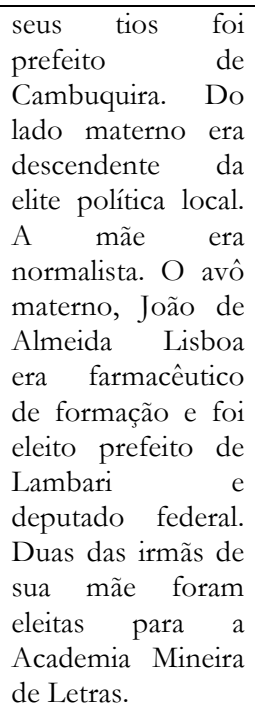 & & & & & \\
\hline $\begin{array}{l}\text { Elisa Maria da } \\
\text { Conceição } \\
\text { Pereira Reis } \\
\text { (1946) } \\
\text { Araxá - MG }\end{array}$ & $\begin{array}{l}\text { Graduação em } \\
\text { sociologia e } \\
\text { política } \\
\text { (FACE). } \\
\text { Licenciatura } \\
\text { em sociologia } \\
\text { do } \\
\text { desenvolvimen } \\
\text { to (ILADES). } \\
\text { Mestrado em } \\
\text { ciência política } \\
\text { (IUPERJ) } \\
\text { Doutorado em } \\
\text { ciência política } \\
\text { (MIT). }\end{array}$ & $\begin{array}{l}\text { Avô paterno } \\
\text { grande } \\
\text { latifundiário, } \\
\text { analfabeto. Todos } \\
\text { os tios moravam } \\
\text { em fazendas. Pai } \\
\text { cursou o } \\
\text { secundário. A mãe } \\
\text { normalista. }\end{array}$ & 1968 & 1969 & Brasil & $\begin{array}{l}\text { Aluna do } \\
\text { programa de } \\
\text { licenciatura } \\
\text { em } \\
\text { Sociologia } \\
\text { del } \\
\text { Desarollo do } \\
\text { ILADES }\end{array}$ & $\begin{array}{l}\text { Aluna de } \\
\text { graduação da } \\
\text { FACE- } \\
\text { UFMG }\end{array}$ \\
\hline $\begin{array}{l}\text { Maria da } \\
\text { Conceição } \\
\text { Tavares } \\
(1930) \\
\text { Anadia - } \\
\text { Portugal }\end{array}$ & $\begin{array}{l}\text { Graduação em } \\
\text { matemática } \\
\text { (Universidade } \\
\text { de Lisboa). } \\
\text { Graduação em } \\
\text { economia } \\
\text { (FNCE). }\end{array}$ & 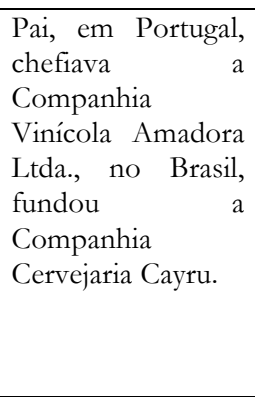 & $\begin{array}{l}\text { Setembro } \\
\text { de } 1968\end{array}$ & $\begin{array}{l}\text { Março } \\
\text { de } 1973\end{array}$ & Brasil & $\begin{array}{l}\text { Funcionária } \\
\text { da CEPAL, } \\
\text { Professora } \\
\text { do ILPES, } \\
\text { da } \\
\text { ESCOLATI } \\
\text { NA e } \\
\text { assessora } \\
\text { econômica } \\
\text { do governo } \\
\text { de Allende }\end{array}$ & $\begin{array}{l}\text { Funcionária } \\
\text { do centro } \\
\text { CEPAL- } \\
\text { BNDE e } \\
\text { professora } \\
\text { de economia } \\
\text { UFRJ }\end{array}$ \\
\hline \multicolumn{8}{|c|}{ Segunda onda de brasileiros no Chile } \\
\hline $\begin{array}{l}\text { Antonio } \\
\text { Barros de } \\
\text { Castro } \\
\text { (1938-2011) } \\
\text { Rio de Janeiro } \\
\text { - RJ }\end{array}$ & $\begin{array}{l}\text { Graduação em } \\
\text { economia } \\
\text { (FNCE). Pós- } \\
\text { graduação em } \\
\text { economia e } \\
\text { filosofia da } \\
\text { ciência (LSE). } \\
\text { Pós-graduação } \\
\text { em matemática } \\
\text { (Centre } \\
\text { d'Études des } \\
\text { Programmes } \\
\text { Économiques). }\end{array}$ & 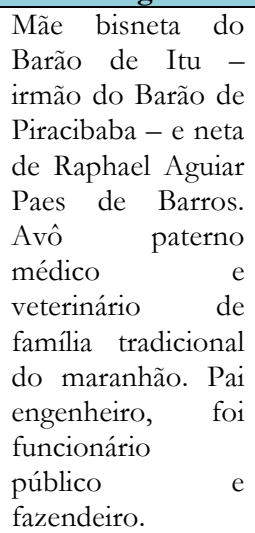 & 1969 & 1973 & Inglaterra & $\begin{array}{l}\text { Funcionário } \\
\text { da CEPAL, } \\
\text { professor } \\
\text { ILPES e } \\
\text { professor }\end{array}$ & $\begin{array}{l}\text { Funcionário } \\
\text { do centro } \\
\text { CEPAL- } \\
\text { BNDE e } \\
\text { professor de } \\
\text { economia } \\
\text { UFRJ }\end{array}$ \\
\hline $\begin{array}{l}\text { César Maia } \\
(1945) \\
\text { Rio de Janeiro } \\
\text { - RJ }\end{array}$ & $\begin{array}{l}\text { Graduação } \\
\text { incompleta em } \\
\text { engenharia } \\
\text { (UFOP). } \\
\text { Graduação em } \\
\text { economia } \\
\text { (UC) }\end{array}$ & $\begin{array}{l}\text { Pai engenheiro, ex- } \\
\text { diretor da Casa da } \\
\text { Moeda. Lavosier } \\
\text { Maia, um de seus } \\
\text { primos foi } \\
\text { governador do Rio } \\
\text { Grande do Norte, }\end{array}$ & 1969 & 1973 & Portugal & $\begin{array}{l}\text { Aluno de } \\
\text { graduação } \\
\text { em } \\
\text { economia na } \\
\text { UC }\end{array}$ & $\begin{array}{l}\text { Estudante de } \\
\text { Engenharia } \\
\text { na UFOP }\end{array}$ \\
\hline
\end{tabular}




\begin{tabular}{|c|c|c|c|c|c|c|c|}
\hline & & $\begin{array}{ll}\text { deputado } & \text { e } \\
\text { senador. } & \\
\end{array}$ & & & & & \\
\hline $\begin{array}{l}\text { Ivan de Otero } \\
\text { Ribeiro } \\
(1936-1987)\end{array}$ & $\begin{array}{l}\text { Graduação } \\
\text { sociologia } \\
\text { política } \\
\text { (FACE). }\end{array}$ & $\begin{array}{lr}\text { Avô } & \text { paterno } \\
\text { militar que } \\
\text { participou da } \\
\text { revolta tenentista } \\
\text { de 1922. Pai militar } \\
\text { da aviação, filiado } \\
\text { ao PCB e } \\
\text { participou da } \\
\text { revolta comunista } \\
\text { de 1935. Tio } \\
\text { militar comunista, } \\
\text { foi deputado } \\
\text { estadual. Outro tio } \\
\text { foi secretário } \\
\text { particular de } \\
\text { Getúlio Vargas. }\end{array}$ & 1969 & s.d. & $\begin{array}{l}\text { Polônia e } \\
\text { Itália }\end{array}$ & s.d. & $\begin{array}{l}\text { Estagiário da } \\
\text { Eletrobrás }\end{array}$ \\
\hline $\begin{array}{l}\text { Lourdes Sola } \\
\text { (1942) } \\
\text { São Paulo - SP }\end{array}$ & $\begin{array}{l}\text { Graduação em } \\
\text { ciências sociais } \\
\text { (FFLCH- } \\
\text { USP). } \\
\text { Mestrado em } \\
\text { sociologia } \\
\text { (FFLCH- } \\
\text { USP). } \\
\text { Mestrado em } \\
\text { economia } \\
\text { (ESCOLATIN } \\
\text { A) Doutorado } \\
\text { em ciência } \\
\text { política } \\
\text { (Oxford/Cam } \\
\text { bridge). }\end{array}$ & $\begin{array}{l}\text { Pai imigrante } \\
\text { espanhol de } \\
\text { origem proletária, } \\
\text { tornou-se } \\
\text { próspero } \\
\text { comerciante, dono } \\
\text { da Leiteira Campo } \\
\text { Belo e proprietário } \\
\text { de imóveis. Mãe } \\
\text { descendente de } \\
\text { italianos. }\end{array}$ & 1969 & 1973 & Inglaterra & $\begin{array}{l}\text { Professora } \\
\text { da FLACSO } \\
\text { e aluna de } \\
\text { pós- } \\
\text { graduação da } \\
\text { ESCOLATI } \\
\text { NA }\end{array}$ & $\begin{array}{l}\text { Professora } \\
\text { assistente de } \\
\text { Sociologia } \\
\text { USP e } \\
\text { pesquisadora } \\
\text { do CESIT }\end{array}$ \\
\hline $\begin{array}{l}\text { Ruy Fausto } \\
\text { (1935) } \\
\text { São Paulo - SP }\end{array}$ & $\begin{array}{l}\text { Graduação em } \\
\text { filosofia } \\
\text { (FFCL-USP). } \\
\text { Graduação em } \\
\text { direito (FD- } \\
\text { USP). } \\
\text { Doutorado em } \\
\text { filosofia (Paris } \\
\text { VIII). }\end{array}$ & $\begin{array}{l}\text { Família de judeus } \\
\text { do Império } \\
\text { Austro-Húngaro } \\
\text { da parte de pai e } \\
\text { da Turquia da } \\
\text { parte de mãe. Avô } \\
\text { paterno e pai } \\
\text { comerciantes. Mãe } \\
\text { faleceu } \\
\text { precocemente. }\end{array}$ & 1969 & 1972 & França & $\begin{array}{l}\text { Professor de } \\
\text { Filosofia na } \\
\text { UCC }\end{array}$ & $\begin{array}{l}\text { Professor } \\
\text { FFCL }\end{array}$ \\
\hline $\begin{array}{l}\text { Paulo Renato } \\
\text { Souza } \\
(1945-2011) \\
\text { Porto Alegre - } \\
\text { RS }\end{array}$ & $\begin{array}{l}\text { Graduação em } \\
\text { economia } \\
\text { (UFRGS). } \\
\text { Especialização } \\
\text { em problemas } \\
\text { do } \\
\text { desenvolvimen } \\
\text { to (CEPAL- } \\
\text { BNDE) } \\
\text { Mestrado em } \\
\text { economia } \\
\text { (ESCOLATIN } \\
\text { A). }\end{array}$ & $\begin{array}{l}\text { Pai advogado, } \\
\text { funcionário } \\
\text { público da polícia } \\
\text { civil. Foi vereador } \\
\text { pelo PTB. }\end{array}$ & 1969 & 1977 & Brasil & $\begin{array}{l}\text { Aluno de } \\
\text { pós- } \\
\text { graduação da } \\
\text { ESCOLATI } \\
\text { NA, } \\
\text { professor na } \\
\text { FLACSO e } \\
\text { na UCC. } \\
\text { Economista } \\
\text { da CEPAL. } \\
\text { Trabalhou } \\
\text { na OEA e } \\
\text { no Programa } \\
\text { Regional de } \\
\text { Emprego da } \\
\text { OIT }\end{array}$ & $\begin{array}{l}\text { Assessoria } \\
\text { de } \\
\text { planejament } \\
\text { o do } \\
\text { governador } \\
\text { Ildo } \\
\text { Meneghetti } \\
\text { do PSD, } \\
\text { depois } \\
\text { secretário da } \\
\text { bancada do } \\
\text { PSD na } \\
\text { Assembleia } \\
\text { Legislativa } \\
\text { do Rio } \\
\text { Grande do } \\
\text { Sul e na } \\
\text { sequência } \\
\text { técnico da } \\
\text { Assembleia. }\end{array}$ \\
\hline $\begin{array}{l}\text { Ruy Mauro } \\
\text { Marini } \\
\text { (1932-1997) } \\
\text { Barbacena - } \\
\text { MG }\end{array}$ & $\begin{array}{l}\text { Graduação } \\
\text { incompleta em } \\
\text { direito } \\
\text { (Faculdade } \\
\text { Nacional de } \\
\text { Direito). }\end{array}$ & $\begin{array}{lr}\text { Avô } & \text { paterno } \\
\text { costureiro } & \text { em } \\
\text { Gênova. } & \text { Avó } \\
\text { paterna camponesa } \\
\text { da região } \\
\text { Calábria. }\end{array}$ & $\begin{array}{l}\text { Novembro } \\
\text { de } 1969\end{array}$ & 1973 & $\begin{array}{l}\text { Alemanha } \\
\text { e México }\end{array}$ & $\begin{array}{l}\text { Professor } \\
\text { CESO }\end{array}$ & $\begin{array}{l}\text { Professor } \\
\text { UNB } \\
\text { funcionário } \\
\text { do IAPI }\end{array}$ \\
\hline
\end{tabular}




\begin{tabular}{|c|c|c|c|c|c|c|c|}
\hline & $\begin{array}{l}\text { Graduação em } \\
\text { administração } \\
\text { (EBAP). Pós- } \\
\text { graduação em } \\
\text { ciências sociais } \\
\text { (Sc. Po) }\end{array}$ & $\begin{array}{lr}\text { descendia } & \text { de } \\
\text { latifundiários } & \\
\text { decadentes } & \text { de } \\
\text { Minas Gerais. } & \text { Pai } \\
\text { lecionava } & \\
\text { matemática } & \text { na } \\
\text { escola agrícola. Fez } \\
\text { faculdade } & \text { de } \\
\text { Direito e do } \\
\text { concurso público } \\
\text { para inspetor de } \\
\text { impostos. } \\
\text { Vinculou-se aos } \\
\text { círculos do Estado } \\
\text { Novo e do PSD. }\end{array}$ & & & & & \\
\hline Sulamis Dain & $\begin{array}{l}\text { Graduação em } \\
\text { economia } \\
\text { (UFRJ). } \\
\text { Mestrado em } \\
\text { economia } \\
\text { (ESCOLATIN } \\
\text { A). Doutorado } \\
\text { em economia } \\
\text { (UNICAMP/ } \\
\text { University of } \\
\text { London) }\end{array}$ & s.d. & 1969 & 1974 & Brasil & $\begin{array}{l}\text { Aluna de } \\
\text { pós- } \\
\text { graduação } \\
\text { em } \\
\text { Economia } \\
\text { ESCOLATI } \\
\text { NA }\end{array}$ & $\begin{array}{l}\text { Concluíra a } \\
\text { graduação } \\
\text { em } \\
\text { economia na } \\
\text { UFRJ e era } \\
\text { funcionária } \\
\text { do EPEA }\end{array}$ \\
\hline $\begin{array}{l}\text { Adhemar } \\
\text { Kyotoshi Sato } \\
(1942) \\
\text { São Paulo - SP }\end{array}$ & $\begin{array}{l}\text { Graduação em } \\
\text { economia } \\
\text { (FEA-USP). } \\
\text { Graduação em } \\
\text { direito (FD- } \\
\text { USP) } \\
\text { Mestrado em } \\
\text { economia } \\
\text { (FEA-USP). } \\
\text { Mestrado em } \\
\text { ciências sociais } \\
\text { (FFCL-USP). } \\
\text { Mestrado em } \\
\text { economia } \\
\text { (ESCOLATIN } \\
\text { A). Doutorado } \\
\text { em economia } \\
\text { (UNICAMP). }\end{array}$ & $\begin{array}{lr}\text { Pai agricultor } \\
\text { nasceu no interior } \\
\text { paulista e era } \\
\text { descendente de } \\
\text { japoneses. Mãe } \\
\text { japonesa de família } \\
\text { tradicional } \\
\text { decadente. }\end{array}$ & 1970 & 1973 & Brasil & $\begin{array}{l}\text { Aluno de } \\
\text { pós- } \\
\text { graduação da } \\
\text { ESCOLATI } \\
\text { NA. } \\
\text { Professor na } \\
\text { UC, trabalho } \\
\text { na } \\
\text { Corporación } \\
\text { de Fomento } \\
\text { de la } \\
\text { Producción } \\
\text { do Governo } \\
\text { Allende. }\end{array}$ & $\begin{array}{l}\text { Professor } \\
\text { FEA-USP }\end{array}$ \\
\hline $\begin{array}{l}\text { Ana Celia } \\
\text { Castro } \\
(1950) \\
\text { Rio de Janeiro } \\
\text { - RJ }\end{array}$ & $\begin{array}{l}\text { Graduação em } \\
\text { economia } \\
\text { (IEI-UFRJ e } \\
\text { UC). Mestrado } \\
\text { em economia } \\
\text { (IE- } \\
\text { UNICAMP). } \\
\text { Doutorado em } \\
\text { economia (IE- } \\
\text { UNICAMP). }\end{array}$ & $\begin{array}{l}\text { Pai romeno e mãe } \\
\text { ucraniana. Não } \\
\text { fizeram estudos } \\
\text { formais, o pai } \\
\text { trabalhou como } \\
\text { operário, mascate, } \\
\text { operador de bonde } \\
\text { até que junto com } \\
\text { o cunhado dele } \\
\text { abriu um pequeno } \\
\text { comércio no qual } \\
\text { trabalhava também } \\
\text { sua esposa. }\end{array}$ & 1970 & 1973 & Inglaterra & $\begin{array}{l}\text { Aluna de } \\
\text { mestrado da } \\
\text { ESCOLATI } \\
\text { NA }\end{array}$ & $\begin{array}{l}\text { Aluna de } \\
\text { graduação da } \\
\text { Economia } \\
\text { da UFRJ }\end{array}$ \\
\hline $\begin{array}{l}\text { Carlos Alberto } \\
\text { Afonso } \\
\text { (1945) } \\
\text { Presidente } \\
\text { Prudente - SP }\end{array}$ & 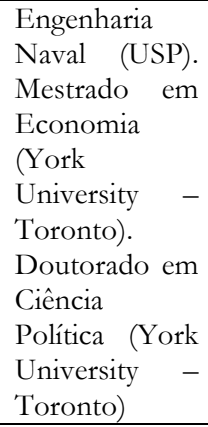 & s.d. & 1970 & 1973 & $\begin{array}{l}\text { Panamá, } \\
\text { Canadá }\end{array}$ & $\begin{array}{l}\text { Funcionário } \\
\text { da área de } \\
\text { projetos } \\
\text { industriais } \\
\text { da } \\
\text { ODEPLAN }\end{array}$ & $\begin{array}{l}\text { Aluno da } \\
\text { Escola } \\
\text { Polítécnica. }\end{array}$ \\
\hline Eder Sader & Graduação em & libanês & 1970 & 1973 & França & Pesquisador & Professor \\
\hline
\end{tabular}




\begin{tabular}{|c|c|c|c|c|c|c|c|}
\hline $\begin{array}{l}\text { (1941-1988) } \\
\text { São Paulo - SP }\end{array}$ & $\begin{array}{l}\text { ciências sociais } \\
\text { (FFCL-USP). }\end{array}$ & $\begin{array}{lr}\text { comerciante } & \text { de } \\
\text { roupas. } & \text { Avô } \\
\text { materno } & \\
\text { comerciante } & \text { de } \\
\text { café. Mãe pianista } \\
\text { e comerciante } & \text { de } \\
\text { roupas. } & \text { Tio } \\
\text { professor } & \text { na } \\
\text { FFCL-USP. }\end{array}$ & & & & CESO & $\begin{array}{l}\text { Ciências } \\
\text { Sociais USP }\end{array}$ \\
\hline $\begin{array}{l}\text { Eduardo } \\
\text { Kugelmas } \\
(1946-2006) \\
\text { São Paulo - SP }\end{array}$ & $\begin{array}{l}\text { Graduação } \\
\text { direito e } \\
\text { ciências sociais } \\
\text { (FD/FFCL- } \\
\text { USP). } \\
\text { Mestrado em } \\
\text { sociologia } \\
\text { (EHESS). } \\
\text { Doutorado em } \\
\text { ciência política } \\
\text { (USP). }\end{array}$ & 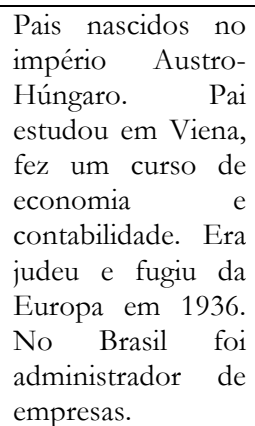 & 1970 & 1973 & França & $\begin{array}{l}\text { Aluno de } \\
\text { pós- } \\
\text { graduação da } \\
\text { ESCOLATI } \\
\text { NA }\end{array}$ & $\begin{array}{l}\text { Pesquisador } \\
\text { do } \\
\text { departament } \\
\text { o de Ciência } \\
\text { Política da } \\
\text { USP. }\end{array}$ \\
\hline $\begin{array}{l}\text { Elisabeth de } \\
\text { Souza Lobo } \\
\text { Garcia } \\
\text { (1943-1991) } \\
\text { Porto Alegre - } \\
\text { RS }\end{array}$ & $\begin{array}{l}\text { Graduação em } \\
\text { letras } \\
\text { (UFRGS). } \\
\text { Doutorado em } \\
\text { sociologia } \\
\text { (Paris 8) }\end{array}$ & s.d. & 1970 & 1973 & França & $\begin{array}{l}\text { Professora } \\
\text { na UC }\end{array}$ & $\begin{array}{l}\text { Aluna de } \\
\text { graduação } \\
\text { em Letras na } \\
\text { UFRGS. }\end{array}$ \\
\hline $\begin{array}{l}\text { Emir Sader } \\
(1943) \\
\text { São Paulo - SP }\end{array}$ & $\begin{array}{l}\text { Graduação em } \\
\text { filosofia } \\
\text { (FFCL-USP). } \\
\text { Mestrado } \\
\text { filosofia } \\
\text { (FFCL-USP) } \\
\text { Doutorado em } \\
\text { ciência política } \\
\text { (FFCL-USP) }\end{array}$ & $\begin{array}{lr}\text { Pai libanês } \\
\text { comerciante } \\
\text { roupas. } \\
\text { materno } \\
\text { comerciante } \\
\text { café. Mãe pianista } \\
\text { e comerciante de } \\
\text { roupas. } \\
\text { professor } \\
\text { FFCL-USP. }\end{array}$ & 1970 & 1973 & $\begin{array}{l}\text { França e } \\
\text { Argentina }\end{array}$ & $\begin{array}{l}\text { Pesquisador } \\
\text { no CESO }\end{array}$ & $\begin{array}{l}\text { Aluno de } \\
\text { mestrado e } \\
\text { professor } \\
\text { Ciências } \\
\text { Sociais USP }\end{array}$ \\
\hline $\begin{array}{l}\text { Francisco } \\
\text { Whitaker } \\
\text { Ferreira } \\
(1931) \\
\text { São Carlos - } \\
\text { SP }\end{array}$ & $\begin{array}{l}\text { Graduação em } \\
\text { arquitetura } \\
\text { (FAU-USP). }\end{array}$ & $\begin{array}{l}\text { Pai descendente de } \\
\text { imigrantes } \\
\text { portugueses, era } \\
\text { contador e dono } \\
\text { de uma serraria e } \\
\text { mãe descendente } \\
\text { de tradicional } \\
\text { família do interior } \\
\text { de São Paulo. }\end{array}$ & 1970 & 1973 & $\begin{array}{l}\text { Argentina } \\
\text { e Brasil }\end{array}$ & $\begin{array}{l}\text { Funcionário } \\
\text { da CEPAL }\end{array}$ & $\begin{array}{ll}\text { Diretor de } \\
\text { Estudos da } \\
\text { Superintend } \\
\text { ência da } \\
\text { Reforma } \\
\text { Agrária }\end{array}$ \\
\hline $\begin{array}{l}\text { José } \\
\text { Guilherme } \\
\text { Cantor } \\
\text { Magnani } \\
\text { (1944) } \\
\text { s.d. - PR }\end{array}$ & $\begin{array}{l}\text { Graduação em } \\
\text { Ciências } \\
\text { Sociais } \\
\text { (UFPR). } \\
\text { Mestrado em } \\
\text { Ciências } \\
\text { Sociais } \\
\text { (FLACSO). } \\
\text { Doutorado em } \\
\text { Antropologia } \\
\text { (USP) }\end{array}$ & $\begin{array}{l}\text { Avós maternos } \\
\text { donos de um hotel } \\
\text { em São Mateus do } \\
\text { Sul, no Paraná. } \\
\text { Mãe professora. }\end{array}$ & 1970 & 1973 & Brasil & $\begin{array}{l}\text { Aluno de } \\
\text { pós- } \\
\text { graduação da } \\
\text { FLACSO }\end{array}$ & $\begin{array}{l}\text { Aluno de } \\
\text { graduação da } \\
\text { Sociologia } \\
\text { da UFPR }\end{array}$ \\
\hline $\begin{array}{l}\text { Maria } \\
\text { Hermínia } \\
\text { Tavares de } \\
\text { Almeida } \\
\text { (1942) } \\
\text { São José do } \\
\text { Rio Preto - SP }\end{array}$ & $\begin{array}{l}\text { Graduação em } \\
\text { ciências sociais } \\
\text { (FFCL-USP). } \\
\text { Mestrado em } \\
\text { Ciências } \\
\text { Sociais } \\
\text { (FLACSO). } \\
\text { Doutorado em } \\
\text { ciência política } \\
\text { (FFCL-USP) }\end{array}$ & Pai advogado. & 1970 & 1973 & Brasil & $\begin{array}{l}\text { Aluna de } \\
\text { pós- } \\
\text { graduação da } \\
\text { FLACSO }\end{array}$ & $\begin{array}{l}\text { Aluna de } \\
\text { graduação da } \\
\text { FFCL }\end{array}$ \\
\hline $\begin{array}{l}\text { Marco Aurélio } \\
\text { Garcia }\end{array}$ & $\begin{array}{ll}\text { Graduação } & \\
\text { direito } & \mathrm{e}\end{array}$ & $\begin{array}{lr}\text { Pai } & \text { advogado e } \\
\text { mãe } & \text { funcionária }\end{array}$ & 1970 & 1973 & Brasil & $\begin{array}{l}\text { Pesquisador } \\
\text { no CESO e }\end{array}$ & $\begin{array}{lr}\text { Aluno } & \text { de } \\
\text { filosofia } & \mathrm{e}\end{array}$ \\
\hline
\end{tabular}




\begin{tabular}{|c|c|c|c|c|c|c|c|}
\hline $\begin{array}{l}(1941) \\
\text { Porto Alegre - } \\
\text { RS }\end{array}$ & $\begin{array}{l}\text { filosofia } \\
\text { (UFRGS). } \\
\text { Pós-graduação } \\
\text { (EHESS). }\end{array}$ & pública. & & & & $\begin{array}{l}\text { professor na } \\
\text { FLACSO }\end{array}$ & $\begin{array}{l}\text { direito na } \\
\text { UFRGS. } \\
\text { Aluno de } \\
\text { pós- } \\
\text { graduação } \\
\text { EHESS. }\end{array}$ \\
\hline $\begin{array}{l}\text { Paulo } \\
\text { Henrique } \\
\text { Ribeiro } \\
\text { Sandroni } \\
\text { Rio de Janeiro } \\
\text { - RJ }\end{array}$ & $\begin{array}{l}\text { Graduação em } \\
\text { economia } \\
\text { (FNCE/USP). } \\
\text { Pós-graduação } \\
\text { em ciências } \\
\text { sociais } \\
\text { (FFLCH- } \\
\text { USP). }\end{array}$ & $\begin{array}{l}\text { Descendente, por } \\
\text { parte de mãe de } \\
\text { uma família } \\
\text { brasileira de } \\
\text { Guaxupé-MG e, } \\
\text { por parte de pai, } \\
\text { de imigrantes } \\
\text { italianos } \\
\text { Toscana. Seu pai } \\
\text { era contador de } \\
\text { formação } \\
\text { tornou-se } \\
\text { empresário, } \\
\text { transferindo-se } \\
\text { com a família para } \\
\text { o Rio de Janeiro. }\end{array}$ & 1970 & 1973 & Colômbia & $\begin{array}{l}\text { Professor } \\
\text { economia } \\
\text { UC }\end{array}$ & $\begin{array}{l}\text { Professor } \\
\text { economia } \\
\text { FEA PUC- } \\
\text { SP, pós- } \\
\text { graduação } \\
\text { em ciências } \\
\text { sociais } \\
\text { FFCL e } \\
\text { colunista da } \\
\text { Folha de São } \\
\text { Paulo. }\end{array}$ \\
\hline $\begin{array}{l}\text { Teodoro } \\
\text { Buarque de } \\
\text { Hollanda } \\
\text { (1946) } \\
\text { Rio de Janeiro } \\
\text { - RJ }\end{array}$ & $\begin{array}{l}\text { Graduação em } \\
\text { engenharia } \\
\text { civil (PUC-RJ). } \\
\text { Mestrado em } \\
\text { ciências sociais } \\
\text { (FLACSO). }\end{array}$ & 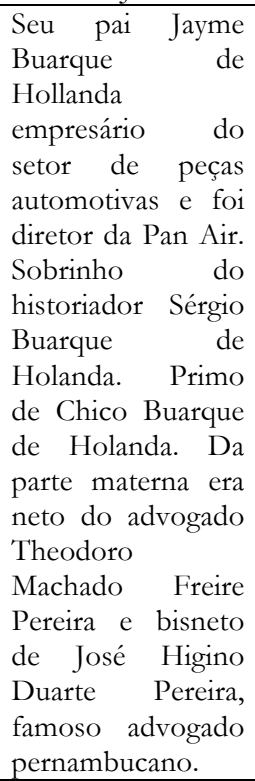 & 1970 & 1973 & Costa Rica & $\begin{array}{l}\text { Aluno da } \\
\text { FLACSO }\end{array}$ & $\begin{array}{l}\text { Aluno de } \\
\text { graduação da } \\
\text { Engenharia } \\
\text { Civil da } \\
\text { PUC-RJ }\end{array}$ \\
\hline $\begin{array}{l}\text { Darcy Ribeiro } \\
(1922-1997) \\
\text { Montes Claros } \\
\text { - MG }\end{array}$ & $\begin{array}{l}\text { Graduação em } \\
\text { medicina } \\
\text { incompleta } \\
\text { (UMG). } \\
\text { Graduação em } \\
\text { ciências sociais } \\
\text { (ELSP). }\end{array}$ & $\begin{array}{l}\text { Avô materno } \\
\text { comerciante e } \\
\text { dono de cartório. } \\
\text { Pai gerente de uma } \\
\text { fiação. Mãe } \\
\text { normalista. Avô } \\
\text { paterno prefeito e } \\
\text { presidente da } \\
\text { câmara da cidade. }\end{array}$ & 1971 & 1972 & Peru & $\begin{array}{l}\text { Assessor } \\
\text { especial } \\
\text { Salvador } \\
\text { Allende e } \\
\text { professor do } \\
\text { Instituto de } \\
\text { Estudos } \\
\text { Internaciona } \\
\text { is da } \\
\text { Universidade } \\
\text { do Chile }\end{array}$ & $\begin{array}{l}\text { Reitor da } \\
\text { UNB, } \\
\text { Ministro da } \\
\text { Educação e } \\
\text { Chefe da } \\
\text { Casa Civil de } \\
\text { Jango. }\end{array}$ \\
\hline $\begin{array}{l}\text { Herbert José } \\
\text { Souza } \\
\text { (1935-1997) } \\
\text { Bocaíuva - } \\
\text { MG }\end{array}$ & $\begin{array}{l}\text { Graduação } \\
\text { sociologia } \\
\text { política } \\
\text { (FACE). }\end{array}$ & $\begin{array}{lr}\text { Pai prefeito } & \text { de } \\
\text { Bocaiuva } & \text { e } \\
\text { administrador } & \text { da } \\
\text { penitenciária } & \text { de } \\
\text { Neves e } & \text { da } \\
\text { funerária da Santa } \\
\text { Casa por indicação } \\
\text { do político Maria } \\
\text { Alkmin. }\end{array}$ & 1971 & 1973 & Canadá & $\begin{array}{l}\text { Professor da } \\
\text { FLACSO e } \\
\text { assessoria } \\
\text { política a } \\
\text { Joan Garcés, } \\
\text { na } \\
\text { ODEPLAN } \\
\text { durante o } \\
\text { governo } \\
\text { Allende. }\end{array}$ & $\begin{array}{l}\text { Aluno de } \\
\text { graduação da } \\
\text { Sociologia e } \\
\text { Política da } \\
\text { UFMG }\end{array}$ \\
\hline $\begin{array}{l}\text { Raúl Carrion } \\
(1945) \\
\text { Porto Alegre - } \\
\text { RS }\end{array}$ & $\begin{array}{l}\text { Graduação } \\
\text { incompleta em } \\
\text { engenharia } \\
\text { química } \\
\text { (UFRGS e }\end{array}$ & $\begin{array}{lr}\text { Pai } & \text { Francisco } \\
\text { Machado Carrion } \\
\text { era advogado, } \\
\text { professor } \\
\text { Faculdade da } \\
\text { de }\end{array}$ & 1971 & 1973 & Argentina & $\begin{array}{l}\text { Aluno da } \\
\text { graduação na } \\
\text { faculdade de } \\
\text { química da } \\
\text { UCC }\end{array}$ & $\begin{array}{l}\text { Aluno de } \\
\text { Engenharia } \\
\text { Química da } \\
\text { UFRGS. }\end{array}$ \\
\hline
\end{tabular}




\begin{tabular}{|c|c|c|c|c|c|c|c|}
\hline & $\begin{array}{l}\text { UCC). } \\
\text { Graduação em } \\
\text { história } \\
\text { (UFRGS). }\end{array}$ & $\begin{array}{lrr}\text { Economia e } & \text { da } \\
\text { Faculdade } & \text { de } \\
\text { Filosofia } & \text { da } \\
\text { UFRGS e foi } \\
\text { secretário de } \\
\text { educação de Porto } \\
\text { Alegre. A mãe era } \\
\text { educadora, filha de } \\
\text { um político que } \\
\text { fora deputado } \\
\text { estadual e prefeito } \\
\text { de Nova } \\
\text { Hamburgo. }\end{array}$ & & & & & \\
\hline $\begin{array}{l}\text { José Carlos } \\
\text { Braga }\end{array}$ & $\begin{array}{l}\text { Graduação em } \\
\text { economia } \\
\text { (UFRJ). } \\
\text { Mestrado em } \\
\text { economia } \\
\text { (ESCOLATIN } \\
\text { A/UNICAMP } \\
\text { ). Doutorado } \\
\text { em economia } \\
\text { (UNICAMP). }\end{array}$ & s.d. & Pós 1970 & 1973 & s.d. & $\begin{array}{l}\text { Aluno de } \\
\text { pós- } \\
\text { graduação da } \\
\text { ESCOLATI } \\
\text { NA }\end{array}$ & $\begin{array}{l}\text { Graduação } \\
\text { UFRJ }\end{array}$ \\
\hline $\begin{array}{l}\text { Frederico } \\
\text { Mathias } \\
\text { Mazzucchelli } \\
\text { (1947) } \\
\text { São Paulo - SP }\end{array}$ & $\begin{array}{l}\text { Graduação em } \\
\text { economia } \\
\text { (FEA-USP). } \\
\text { Mestrado em } \\
\text { economia } \\
\text { (ESCOLATIN } \\
\text { A/UNICAMP } \\
\text { ). Doutorado } \\
\text { em economia } \\
\text { (UNICAMP). }\end{array}$ & $\begin{array}{l}\text { Avós maternos } \\
\text { eram libaneses. O } \\
\text { Avô } \\
\text { comerciante } \\
\text { vendia café. Avós } \\
\text { paternos e o pai } \\
\text { eram italianos. O } \\
\text { Avô advogado e o } \\
\text { pai tornou-se } \\
\text { industrial, criando } \\
\text { no Brasil um } \\
\text { laboratório } \\
\text { farmacêutico. Irmã } \\
\text { de seu pai era } \\
\text { casada com } \quad \text { o } \\
\text { crítico de arte } \\
\text { Giulio } \\
\text { Argan. Carlo }\end{array}$ & 1972 & 1973 & Brasil & $\begin{array}{l}\text { Aluno de } \\
\text { pós- } \\
\text { graduação da } \\
\text { ESCOLATI } \\
\text { NA }\end{array}$ & $\begin{array}{l}\text { Aluno de } \\
\text { graduação } \\
\text { FEA-USP e } \\
\text { pesquisador } \\
\text { do CEBRAP }\end{array}$ \\
\hline $\begin{array}{l}\text { Luciano } \\
\text { Coutinho } \\
(1946) \\
\text { Recife - PE }\end{array}$ & $\begin{array}{l}\text { Graduação em } \\
\text { Economia } \\
\text { (USP). } \\
\text { Mestrado em } \\
\text { Economia } \\
\text { (USP-Cornell). } \\
\text { Doutorado em } \\
\text { economia } \\
\text { (Cornell) }\end{array}$ & 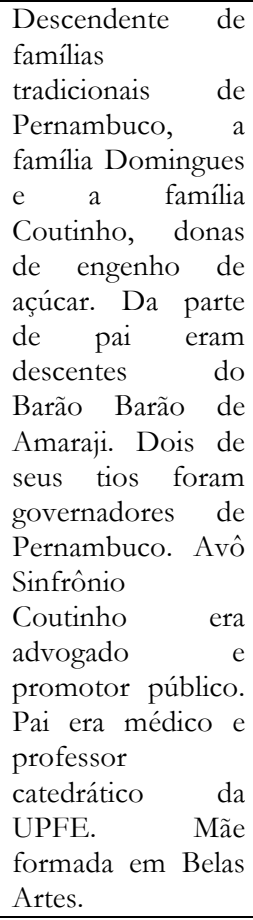 & 1971 & 1971 & $\begin{array}{l}\text { Estados } \\
\text { Unidos }\end{array}$ & $\begin{array}{l}\text { Férias de } \\
\text { verão do } \\
\text { doutorado } \\
\text { que cursava } \\
\text { em Cornell. } \\
\text { Consegue } \\
\text { uma bolsa } \\
\text { para ir para } \\
\text { o Chile onde } \\
\text { frequentou } \\
\text { informalmen } \\
\text { te cursos na } \\
\text { ESCOLATI } \\
\text { NA e no } \\
\text { ILPES }\end{array}$ & $\begin{array}{l}\text { Doutorado } \\
\text { em Cornell }\end{array}$ \\
\hline $\begin{array}{l}\text { Sonia Miriam } \\
\text { Draibe } \\
(1943)\end{array}$ & $\begin{array}{l}\text { Graduação em } \\
\text { pedagogia } \\
\text { (USP). }\end{array}$ & s.d. & 1972 & 1974 & Brasil & $\begin{array}{l}\text { Aluna de } \\
\text { pós- } \\
\text { graduação da }\end{array}$ & $\begin{array}{l}\text { Professora } \\
\text { de Pedagogia } \\
\text { PUC-SP }\end{array}$ \\
\hline
\end{tabular}




\begin{tabular}{|c|c|c|c|c|c|c|c|}
\hline & $\begin{array}{l}\text { Mestrado em } \\
\text { ciências sociais } \\
\text { (FLACSO). } \\
\text { Doutorado em } \\
\text { ciência política } \\
\text { (FFCL-USP) }\end{array}$ & & & & & FLACSO & \\
\hline $\begin{array}{l}\text { Carlos Alonso } \\
\text { Barbosa de } \\
\text { Oliveira }\end{array}$ & $\begin{array}{l}\text { Graduação em } \\
\text { economia } \\
\text { (FEA-USP e } \\
\text { UC). Mestrado } \\
\text { em economia } \\
\text { (UNICAMP). } \\
\text { Doutorado em } \\
\text { economia } \\
\text { (UNICAMP). }\end{array}$ & s.d. & Pós 1968 & 1973 & Brasil & $\begin{array}{l}\text { Aluno de } \\
\text { graduação } \\
\text { em } \\
\text { economia na } \\
\text { UC, aluno } \\
\text { de pós- } \\
\text { graduação da } \\
\text { ESCOLATI } \\
\text { NA }\end{array}$ & s.d. \\
\hline $\begin{array}{l}\text { Silvério Soares } \\
\text { Ferreira } \\
(1947) \\
\text { São Paulo - SP }\end{array}$ & $\begin{array}{l}\text { Graduação em } \\
\text { economia } \\
\text { (FEA- } \\
\text { USP/UC) }\end{array}$ & s.d. & Pós 1968 & 1973 & França & $\begin{array}{l}\text { Aluno de } \\
\text { graduação } \\
\text { em } \\
\text { economia }\end{array}$ & $\begin{array}{l}\text { Aluno de } \\
\text { graduação } \\
\text { em FCEA- } \\
\text { USP }\end{array}$ \\
\hline $\begin{array}{l}\text { Reinaldo } \\
\text { Carcanholo } \\
(1945-2013) \\
\text { Sorocaba - SP }\end{array}$ & $\begin{array}{l}\text { Graduação em } \\
\text { economia } \\
\text { (USP e UC). } \\
\text { Mestrado em } \\
\text { economia } \\
\text { (ESCOLATIN } \\
\text { A). Doutorado } \\
\text { em economia } \\
\text { (UNAM) }\end{array}$ & s.d. & Pós 1968 & 1973 & $\begin{array}{l}\text { Costa Rica } \\
\text { e México }\end{array}$ & $\begin{array}{l}\text { Aluno de } \\
\text { Pós- } \\
\text { graduação da } \\
\text { ESCOLATI } \\
\text { NA }\end{array}$ & $\begin{array}{l}\text { Aluno de } \\
\text { Graduação } \\
\text { FEA-USP }\end{array}$ \\
\hline $\begin{array}{l}\text { Jorge Eduardo } \\
\text { Levi Mattoso } \\
\text { (1949) } \\
\text { Porto Alegre - } \\
\text { RS }\end{array}$ & $\begin{array}{l}\text { Graduação } \\
\text { interrompida } \\
\text { em economia } \\
\text { (UFRGS). } \\
\text { Graduação em } \\
\text { economia } \\
\text { (Instituto } \\
\text { Universitário } \\
\text { de Estudos do } \\
\text { Desenvolvime } \\
\text { nto em } \\
\text { Genebra). Mes } \\
\text { trado em } \\
\text { economia } \\
\text { (Paris- } \\
\text { Sorbonne. } \\
\text { Doutorado em } \\
\text { economia } \\
\text { (UNICAMP). }\end{array}$ & s.d. & 1972 & 1973 & $\begin{array}{l}\text { Suíça, } \\
\text { França }\end{array}$ & $\begin{array}{l}\text { Aluno na } \\
\text { UC }\end{array}$ & $\begin{array}{l}\text { Aluno de } \\
\text { Graduação } \\
\text { da Faculdade } \\
\text { de } \\
\text { Economia } \\
\text { da UFRGS }\end{array}$ \\
\hline $\begin{array}{l}\text { Maria Lygia } \\
\text { Quartim } \\
\text { Moraes }\end{array}$ & s.d. & 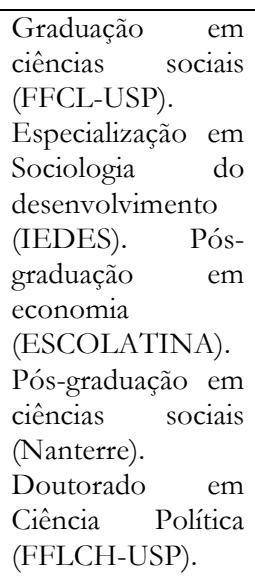 & 1972 & 1973 & França & $\begin{array}{l}\text { Aluna de } \\
\text { Pós- } \\
\text { graduação da } \\
\text { ESCOLATI } \\
\text { NA }\end{array}$ & $\begin{array}{l}\text { Graduação e } \\
\text { pós- } \\
\text { graduação } \\
\text { em ciências } \\
\text { Sociais } \\
\text { FFCL. } \\
\text { Especializaç } \\
\text { ão em } \\
\text { sociologia } \\
\text { do } \\
\text { desenvolvim } \\
\text { ento } \\
\text { IEDES. }\end{array}$ \\
\hline $\begin{array}{l}\text { Andrea } \\
\text { Sandro Calabi } \\
(1945) \\
\text { São Paulo - SP }\end{array}$ & $\begin{array}{l}\text { Graduação em } \\
\text { economia } \\
\text { (FEA-USP). } \\
\text { Mestrado em } \\
\text { economia } \\
\text { (USP- }\end{array}$ & $\begin{array}{l}\text { Família italiana, o } \\
\text { pai nasceu em } \\
\text { Verona, a mãe em } \\
\text { Modena. Avô } \\
\text { paterno era } \\
\text { engenheiro }\end{array}$ & 1973 & 1973 & $\begin{array}{l}\text { Estados } \\
\text { Unidos }\end{array}$ & $\begin{array}{l}\text { Férias de } \\
\text { verão do } \\
\text { doutorado } \\
\text { que cursava } \\
\text { em Berkeley. } \\
\text { Conseguiu }\end{array}$ & $\begin{array}{l}\text { Aluno de } \\
\text { doutorado } \\
\text { em Berkeley }\end{array}$ \\
\hline
\end{tabular}




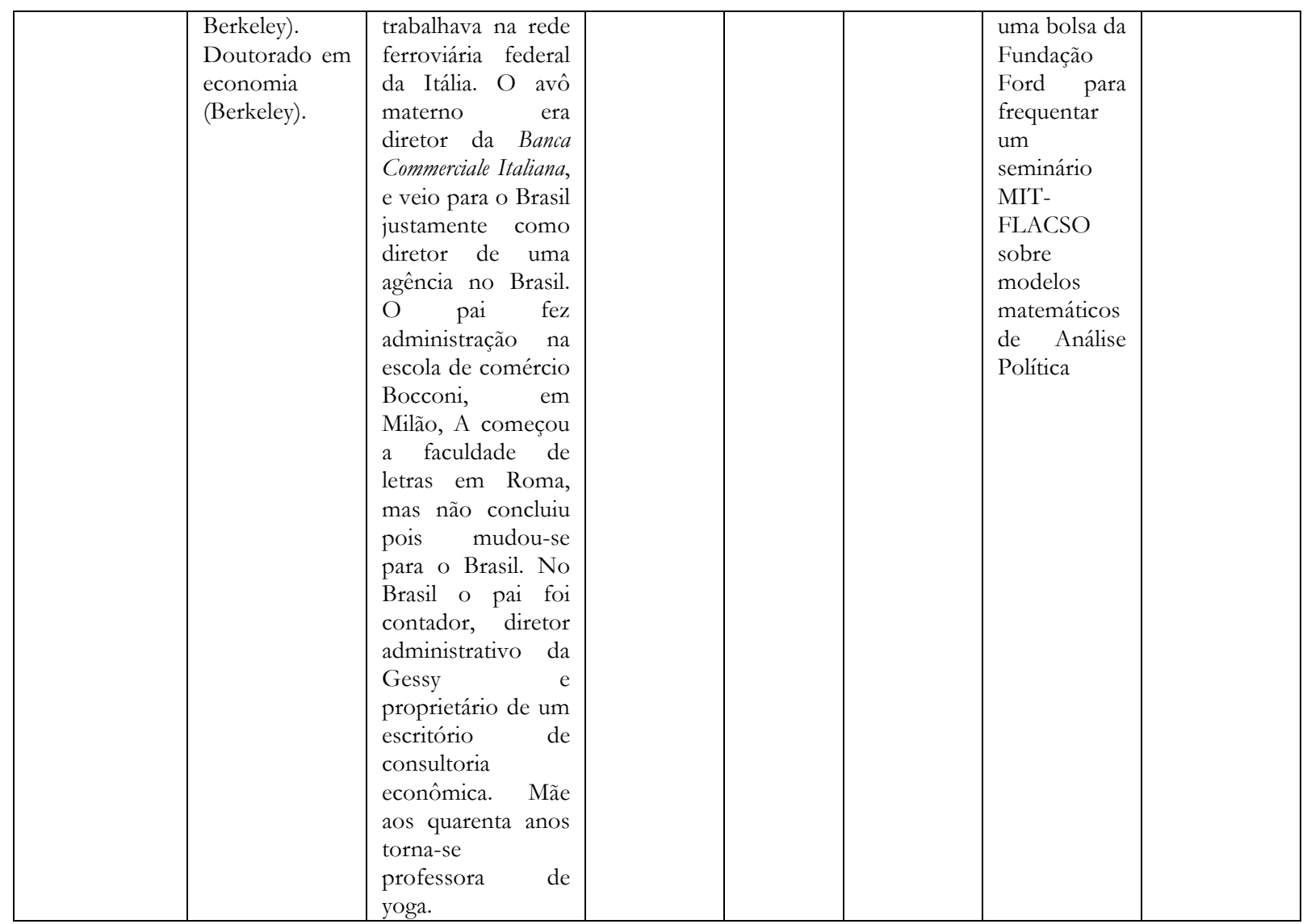

Tabela III - Trajetórias, cronologia da circulação pelo Chile e ocupações no Chile de personagens do Intermezzo. Elaboração: própria.

A principal referência daqueles que chegram ao Chile na primeira leva era o adido cultural brasileiro Amadeu Thiago de Mello ${ }^{217}$ (1926). Poeta conhecido e apreciado pelos chilenos, Mello vivia em La Chascona, casa que seu amigo Pablo Neruda construíra no Cerro San Cristóbal para viver com sua amante Matilde. Além de promover festas

\footnotetext{
${ }^{217}$ Amadeu Thiago de Mello (1926) nasceu em Barreirinha, à margem do Amazonas. Seus avôs maternos eram de Fortaleza. A avó provinha de família rica e conceituada, herdeira de diversas casas que o avô vendeu quando foi tentar a sorte nos seringais do Amazonas. Com o declínio da economia da borracha passaram por dificuldades até que ele conseguisse se estabelecer como funcionário público em postos de confiança. Os avós paternos viviam em Barreirinha trabalhando em atividades de agricultura e extração. O pai, Pedro Thiago, começou a vida como secretário de superintendências e depois ocupou outros cargos públicos em cidades nas cercanias de Manaus, trabalhando simultaneamente como jornalista. A esposa, Maria, era tesoureira da caixa de aposentadoria e pensões. Amadeu Thiago queria estudar medicina então um amigo dos pais falou com o governador que concedeu uma bolsa para que fosse para a capital. Ele ingressou na Faculdade Nacional de Medicina, que trancou no final do quarto ano (MELO, 1983), voltando-se para o jornalismo, a literatura e a poesia. Funda a editora Hipocampo, que publica grandes poetas nacionais. Em 1961, é designado adido cultural brasileiro no Chile, onde é hospedado por Pablo Neruda. Em 1965, ao retornar é preso imediatamente, voltando a viver em Santiago em 1968. Eleito Allende, seu amigo, passa a trabalhar como diretor de comunicação no Instituto de Reforma Agrária. Após o golpe perambula por Argentina, França, Portugal e outros países (Ver: http://simaopessoa.blogspot.com.br/2015/10/thiago-de-mello-poesia-servico-da-vida-1.html. Consultado em 22/01/2015).
} 
memoráveis ${ }^{218}$, Thiago dedicava-se a "receber refugiados brasileiros e pô-los em contato com personalidades chilenas que pudessem ser-lhes de alguma utilidade. Ele gozava de extraordinário prestígio no mundo cultural chileno e suas múltiplas relações foram de grande valia para muitos dos que aportavam sem maiores conexões locais" (FURTADO, 2014, p. 403).

Celso Furtado, que fora caracterizado pelas elites conservadoras do Nordeste do Brasil como um "astuto economista empenhado em bolchevizar o Nordeste" (FURTADO, 2014, p. 260), foi um dos primeiros cassados pela ditadura, sendo a Superintendência do Desenvolvimento do Nordeste (SUDENE), por ele dirigida, imediatamente atingida pela repressão militar. Os coronéis - que se beneficiavam do controle privado das reservas d'água, da largueza de suas terras, do baixo custo da mão de obra e de outros aspectos desigualdade social reinante na região - desgostavam da interferência que a SUDENE exercia sobre os territórios que controlavam há gerações.

Os estadunidenses foram críticos à supressão dos direitos de Celso Furtado ${ }^{219}$. Por mais que apoiassem o golpe e desconfiassem da SUDENE, Furtado era um homem com ampla circulação e prestígio internacional. Havia sido recebido na Casa Branca por John Kennedy, acumulara diversos convites para lecionar em universidades americanas e tinha seu nome associado a organizações internacionais. Não seria conveniente, pois, classificálo como comunista por mais subversivo que julgassem ser. Exilado, Celso Furtado voltou para a órbita da CEPAL. Passou a trabalhar no ILPES, Instituto para o qual Prebisch havia se deslocado um ano antes, e começou a organizar um seminário de releitura dos clássicos da Comissão à luz da perda de dinamismo das economias latino-americanas. Este contava com a participação de Osvaldo Sunkel, José Medina Echevarría e outros

\footnotetext{
218 "Festas [que] iriam estender-se até a manhã, alimentadas por maravilhosos frutos do mar, finos queijos franceses, e não pouco vinho e pisco. O bom brandy chileno. Celebridades tanto do Brasil quanto do Chile passavam por ali, incluindo o próprio Neruda" (CARDOSO, 2006b, p. 90).

${ }^{219}$ Lincoln Gordon envia, em 20 de abril, o telegrama: "Presidente [Castello Branco] observou então que a reação da imprensa americana ao seu discurso tinha sido favorável, mas claramente existia preocupação nos EUA quanto a eventuais excessos revolucionários. Ele entendeu que a retirada de direitos políticos [de] Celso Furtado tinha sido especialmente mal recebida. Eu respondi que houve de fato tal inquietação, não por desacordo quanto aos fins básicos da revolução, mas porque medidas repressivas poderiam ser arbitrárias ou excessivas [...]. Ademais, o dito caso Furtado era especialmente sensível, tendo em conta a sua associação ao internacionalmente renomado CIAP [Comitê Internacional da Aliança Para o Progresso], e eventual convite de uma universidade americana como professor visitante. $\mathrm{O}$ presidente disse que em seu entendimento Furtado havia designado muitos comunistas à SUDENE, o que eu reconheci, mas eu então expus com detalhes a nossa própria avaliação de Furtado. Presidente ouviu atentamente a esta exposição. "Relações Exteriores dos Estados Unidos, 1964-1968, XXXI volume, a América do Sul e Central; México, documento 212. telegrama da Embaixada no Brasil para o Departamento de Estado. Rio de Janeiro, 20 de abril de 1964, 23:00, por Lincoln Gordon". Disponível em: https://history.state.gov/historicaldocuments/frus1964-68v31/d212. Consultado em $22 / 01 / 2015$.
} 
quadros da CEPAL, além de dois professores brasileiros recém-chegados que com ele passaram a morar, Francisco Weffort e Fernando Henrique Cardoso (FURTADO, 2014, pp. 410, 423).

$\mathrm{Na}$ primeira onda de exilados que chegara ao Chile, além de Furtado, estavam diversos dos seus colaboradores na SUDENE: Jader de Andrade 220 (1924-1998), economista formado na Universidade Federal de Pernambuco (UFPE) que havia trabalhado com Furtado desde seus tempos de diretor do BNDE, muito próximo também do governador pernambucano cassado Miguel Arraes; o engenheiro formado pelo Instituto Tecnológico da Aeronáutica (ITA), Ulrich Hoffman 221 (1940); Estevam Strauss, engenheiro agrônomo, professor da Universidade Rural de Pernambuco e diretor de recursos naturais da SUDENE, onde conduzia os projetos da área de irrigação; Francisco Cavalcanti de Oliveira, cientista social que havia trabalhado no Banco do Nordeste 222 e era "o número dois" da SUDENE, tendo enfrentado sessenta dias de prisão antes de conseguir partir para Santiago; e Cláudio Salm, economista formado pela UFRJ. Tempos depois ainda chegariam outros, como Flavio Tavares de Lyra ${ }^{223}$, economista pela UFPE que havia feito o curso de treinamento em Problemas do Desenvolvimento no Rio de Janeiro e especialização no ILPES em 1963, que voltou ao Chile em 1970. Com apoio de Furtado, quase todos acabaram inserindo-se na CEPAL, no ILPES, na

\footnotetext{
${ }^{220}$ Ver: http://docvirt.com/docreader.net/DocReader.aspx?bib=hemerolt\&pagfis=3787\&pesq=\#. Consultado em $01 / 02 / 2016$.

${ }^{221}$ Ulrich Hoffmann vai se aproximar do grupo de militantes politécnicos paulistas ligados a Serra. Trabalhará depois do exílio no governo Montoro junto a Serra e Sérgio Motta. Será diretor da Hidrobrasileira, empresa de Sérgio Motta, e assumirá a presidência da São Paulo Transportes S.A. (SPTRANS), com Serra na Prefeitura de São Paulo. Ver: http://saopaulo.pps.org.br/helper/printData/136838 e http://pressclub.com.br/exibeNoticia.asp?id=8127\&key=. Consultados em 01/02/2016.

${ }^{222}$ Francisco Cavalcanti de Oliveira (1933) nasceu em Recife, em família de classe média. Seu pai era farmacêutico não diplomado e a mãe dona de casa. Francisco estudou no Colégio Salesiano e cursou ciências sociais na Universidade do Recife, tornando-se funcionário concursado do Banco do Nordeste. Foi ali que leu Keynes, foi treinado em economia contemporânea e teoria das contas nacionais, teve aulas com Anníbal Villela e outros professores do Rio de Janeiro e trabalhou com Jader de Andrade. Estagiou por algum tempo na Superintendência da Moeda e do Crédito (SUMOC) e foi trabalhar na Comissão de Desenvolvimento Econômico de Pernambuco, tendo sido enviado para o curso de treinamento da CEPAL, no Rio de Janeiro em 1957. Ele afirma que esse curso promoveu um "giro de $180^{\circ}$ " em sua cabeça. Conta que "a bibliografia do curso era a da CEPAL. Mas o curso do Celso era tão original que não tinha bibliografia capaz de nos informar. A bibliografia era Celso Furtado, ele mesmo". Pouco tempo depois foi ao BNDE para falar com ele, à época diretor do Banco, pois ouvira dizer que ele estava montando um órgão econômico para o Nordeste e tinha interesse em trabalhar na nova organização. Furtado solicitou que fosse a Recife para ser entrevistado por aqueles que selecionavam os candidatos. Aceito, tornou-se um dos primeiros funcionários da SUDENE (OLIVEIRA, 2009, pp. 147-153; Francisco de Oliveira in: BIAZO, 2014, p. 33).

${ }^{223} \mathrm{O}$ avô paterno de Flávio, Antônio Tavares de Lyra, era recifense da família de Augusto Tavares de Lyra, advogado e político no Rio Grande do Norte. A avó paterna provinha de família de pequenos agricultores da zona da mata de Pernambuco. O avô materno era dono de pequena propriedade agrícola na cidade de Correntes em Pernambuco. A mãe foi dona de casa e o pai, marceneiro (LYRA, 2007, pp. 23-27).
} 
ESCOLATINA ou em outros órgãos conexos (FURTADO, 2014, pp. 423-424; LYRA, 2007, pp. 133, 183).

Deslocou-se para a CEPAL também Antônio Bezerra Baltar ${ }^{224}$ : engenheiro, urbanista e fundador do Centro de Estudos de Planejamento Urbano e Regional que havia sido contratado pela SUDENE, com recursos da Agência Norte-Americana para o Desenvolvimento Internacional (USAID), para elaborar um planejamento físico-urbano para as cidades do Nordeste (PONTUAL, 2011, p. 154). Ele partiu para o Chile acompanhado do filho, Paulo Baltar e lá reencontrou, em 1970, o arquiteto Francisco Whitaker Ferreira, com quem trabalhara na Sociedade de Análise Gráfica e Mecanográfica Aplicada aos Complexos Sociais (SAGMACS) na elaboração de planos de urbanização para as cidades de São Paulo e Belo Horizonte. Os dois eram muito ligados ao humanista cristão Louis-Joseph Lebret diretor da SAGMACS. Balizado pelo axioma "o pecado mais grave é a omissão diante da miséria no subdesenvolvimento", Lebret e a SAGMACS voltaram-se ao estudo da miséria urbana, coordenando pesquisas sobre as favelas no Rio de Janeiro, as condições de vida em Pernambuco e sobre necessidades e possibilidades de desenvolvimento da bacia Paraná-Uruguai (FERREIRA, 2011, [online]).

Plínio de Arruda Sampaio, amigo próximo de Whitaker, também adepto do humanismo cristão francês, chegou a Santiago pouco antes de Bezerra Baltar e foi trabalhar no Departamento de Administração de Reforma Agrária do Instituto de Capacitación e Investigación en Reforma, ligado à FAO. Os outros dois políticos apoiadores da AP, Almino Afonso e Paulo de Tarso, chegaram na mesma leva e também incorporaram-se a órgãos do sistema ONU. Almino, que fora Ministro do Trabalho, foi

\footnotetext{
${ }^{224}$ Antônio Bezerra Baltar (1915-2003) nasceu em Recife. De família católica, estudou em colégios confessionais toda a infância. Seu pai era médico e diretor da Saúde Pública em Pernambuco, mas faleceu precocemente de gripe espanhola. Órfão aos 3 anos de idade, foi viver com o avô materno, José Bezerra Cavalcanti, advogado que assumiu o escritório de José Higino Duarte Pereira da Silva, bisavô de Carlos Lessa e de Theodoro Buarque de Hollanda, "que teve possivelmente o maior escritório de advocacia daqui de Pernambuco naquele tempo". Foi também procurador e senador (BALTAR, 1995, p. 30). Em 1932 Baltar ingressa na Escola de Engenharia da Universidade do Recife. Depois de formado trabalhou como engenheiro do Instituto de Previdência dos Servidores do Estado de Pernambuco, na Associação Brasileira de Cimento Portland, no Departamento Nacional de Estradas de Rodagem e, junto ao Padre Lebret, na SAGMACS, especializando-se em urbanismo. Lecionou nos curso de arquitetura da Escola da Belas-Artes de Pernambuco e na Escola de Engenharia de Recife. Fez o curso de treinamento do Centro CEPAL-BNDE e fundou um Centro de Planejamento Urbano e Regional ligado à Universidade. Além disso fazia parte dos grupos à esquerda da política pernambucana, sendo próximo de Miguel Arraes, Pelópidas Silveira (1915-2008) e de catedráticos progressistas como Maurício e Amaury Coutinho (item 5.1). Foi vereador de Recife pelo Partido Socialista por dois mandatos e trabalhou próximo a Pelópidas Silveira na prefeitura de Recife. Foi eleito suplente de senador em 1958 e passou a ocupar o posto em junho de 1960, quando o titular foi convocado por JK para o Ministério da Agricultura. Em 1964 foi cassado, partindo para o Chile pouco depois (BALTAR, 1995; PONTUAL, 2011, pp. 151-154; DHBB, Antônio Bezerra Baltar).
} 
admitido na OIT e Paulo de Tarso, Ministro da Educação, trabalhou na FAO e no Programa das Nações Unidas para o Desenvolvimento (PNUD). José Serra conta que fazia boas refeições nas casas deles. Passou a frequentar também a casa dos educadores recifenses Paulo Reglus Neves Freire (1921-1997) e Elza Freire (1916-1986), ${ }^{225}$ responsáveis pelo desenvolvimento de um método de alfabetização e formação crítica, que eram pais de sua namorada, Madalena, também educadora, que acabaria se casando com Francisco Weffort (NAKANO e ROITMAN, 2001; SERRA, 2002, p. 98; SERRA, 2014, pp. 169).

Naquele primeiro período também passaram pelo Chile os membros da Assessoria Vargas: Jesus Soares Pereira e Cleantho de Paiva Leite, que trabalhava para o BID no Chile. Os deputados cassados Arthur da Távola (Paulo Alberto) e Márcio Moreira Alves, Anísio Teixeira, sogro de Arthur da Távola, que lutava reorganizar o sistema educacional brasileiro e que à época ocupava-se da fundação e direção a Universidade de Brasília, visitava-os com frequência. Darcy Ribeiro ${ }^{226}$, companheiro de Anísio na formação da UNB, que estava exilado no Uruguai, chegaria ao Chile em 1971, para trabalhar como assessor pessoal do Presidente Salvador Allende, que conhecera no Uruguai quando Allende foi fazer uma visita a João Goulart (RIBEIRO, 1997, pp. 413-414).

Professores como Álvaro Vieira Pinto, Wilson Cantoni, Fernando Henrique Cardoso, Francisco Weffort, Ruth Cardoso, Ernani Fiori, com filho José Luís Fiori, e tantos outros não tardaram a mudar para lá. Conseguiram todos, com alguma rapidez, obter posições nas universidades e instituições de pesquisa chilenas, no que a solidariedade local em relação aos brasileiros ajudava.

$\mathrm{Na}$ leva que antecedeu o AI-5 chegaram alguns jovens militantes. Parte deles próximos ao PCB, como Leon Hirszman, sua namorada Liana Aureliano e Carlos Estevam Martins. Outros ligados à POLOP, como Theotônio dos Santos e Vânia

\footnotetext{
${ }^{225}$ Paulo Freire (1921-1997) nasceu em Recife. Perdeu o pai precocemente e foi morar com a mãe em Jaboatão, vivendo em dura privação. Volta ao Recife para estudar no colégio particular católico, Oswaldo Cruz, como bolsista. Ingressa depois na Faculdade de Direito e torna-se doutor em filosofia e história da educação pela Faculdade de Filosofia, Ciências e Letras da Universidade do Recife. Integrou-se aos círculos progressistas pernambucanos trabalhando ao lado de Pelópidas da Silveira e Miguel Arraes e conduzindo os projetos de educação e de cultura popular de seus governos. Durante a presidência de Jango, colaborou com Paulo de Tarso no Ministério da Educação para elaborar um plano de alfabetização de alcance nacional. Depois de ter que responder a inquéritos policiais da ditadura militar, exilou-se chegando ao Chile em setembro de 1964 (FREIRE, 1996, pp. 27-42). Elza também trabalhava como educadora, sendo parceira em muitos de seus projetos (SPIGOLON, 2009, pp. 65, 71).

${ }^{226} \mathrm{O}$ avô materno de Darcy Ribeiro era comerciante e dono de cartório e a mãe, normalista. O avô paterno fora prefeito e presidente da Câmara da cidade e o pai era gerente de uma fiação que pertencia a um irmão (RIBEIRO, 1997, pp. 24-29).
} 
Bambirra. Quadros da AP, como Luiz Alberto Gomes de Souza, Vilmar e Regina Faria, Ayrton Fausto e José Serra e membros de outras organizações de esquerda. Os primeiros militantes a chegar foram mais facilmente amparados pela rede de solidariedade e pelos contatos com os intelectuais mais velhos. Tornou-se mais complicado alocar o contingente de jovens mal egressos das universidades após o AI-5, de dezembro de 1968, quando a comunidade cresceu em maior velocidade do que a capacidade de apoio à inserção dos recém-chegados 227 .

Nos primeiros oito meses no Chile, Serra não conseguiu trabalho ou vínculo estudantil fixo. Tentou retomar a engenharia, mas a duração da faculdade era de seis anos e para obter o diploma deveria prestar exames de todas as matérias que já havia cursado no Brasil. Acabou seguindo voluntariamente algumas das aulas de microeconomia oferecidas na escola de engenharia, com o objetivo de dar continuidade aos estudos iniciados na França. Foi quando conheceu e tornou-se amigo do economista do escritório CEPAL-BNDE Carlos Lessa, que chegara pouco antes dele a Santiago. Lessa fora transferido para a sede da CEPAL no Chile para não correr perigo no Brasil e passou a lecionar no ILPES e na ESCOLATINA (item 1.5). Ele conta que quando o Zé Serra apareceu no Chile "ficou muito amigo nosso" (Entrevista de Carlos Lesa à autora, 2012). Serra, por sua vez, diz que Lessa “ajudou muito do ponto de vista afetivo e acadêmico. É uma figura humana notável". Recebeu-o "como um velho amigo, embora nem nos conhecêssemos" e "por pura generosidade (e talvez curiosidade a meu respeito)" ofereceu um seminário:

sobre um livro do Paul Sweezy, Teoria do desenvolvimento capitalista, até hoje uma das melhores exposições sobre a economia marxista. Sweezy era formado em Harvard, fora discípulo de Schumpeter e dominava a economia convencional. Aderiu plenamente ao marxismo quando já era um economista de enorme respeito. Nossas reuniões semanais e noturnas, foram inesquecíveis em mais de um sentido. A cada capítulo, cada conceito, alongávamo-nos horas em discussões. Lessa fumava como um turco e eu não tinha a petulância de reclamar. Em todos os encontros, havia uma pausa para um magnífico jantar. Eu absorvia conhecimento e nicotina, alimento e amizade. Ele me deu de presente um livro de Schumpeter, o fascinante Capitalismo, socialismo e democracia, que me serviu de introdução ao economista mais refinado do século XX, o que melhor captou a essência do desenvolvimento no capitalismo: inovação, destruição criadora e instabilidade cíclica no curto, no médio e no longo prazos (SERRA, 2014, p. 168).

\footnotetext{
${ }^{227}$ Se a estimativa que havia 5 mil brasileiros no Chile, essencialmente em Santiago, em 1973 estiver correta, calcula-se que estes representassem $0,175 \%$ da população da cidade em 1970 , e correspondessem a $0,53 \%$ do crescimento que a grande Santiago teve de 1970 a 1973 (ROLDAN, 1975, pp. 65 e 68).
} 
Lessa foi fundamental na trajetória de Serra. Foi ele quem o apresentou a Aníbal Pinto Santa Cruz (item 1.5), com quem trabalhara no centro CEPAL-BNDE no Rio de Janeiro, que havia retornado ao Chile em 1965. Serra explica que Aníbal Pinto, que também era professor no ILPES e na ESCOLATINA, procurou ajudá-lo a inserir-se no universo acadêmico chileno,

\begin{abstract}
mas o curso do ILPES começara havia dois meses e não dava para acompanhá-lo nem como ouvinte. O mesmo quanto ao curso de economia da universidade, e ele achava que não valia a pena começar do primeiro ano. Sugeriu que assistisse às suas aulas sobre desenvolvimento da América Latina no ciclo preparatório da ESCOLATINA, um programa de pós-graduação do Instituto de Economia da Universidade, e que o ajudasse a preparar aulas, gráficos e tabelas (SERRA, 2014, pp. 166-167).
\end{abstract}

Graças a Aníbal Pinto, em 1966, Serra conseguiu se matricular no curso do ILPES, que "durava um ano. Um terço era de introdução à economia. Um terço era de política econômica e o restante era de especialização. Escolhi a especialidade de planejamento industrial" (SERRA, 2002, p. 100). Como não tinha bolsa para manter-se durante o curso, porque não fora indicado pelo governo brasileiro para a vaga, ele passou a trabalhar para Don Aníbal. Ministrou, a convite dele, curso introdutório de matemática para economistas do próprio ILPES, afinal era engenheiro e sabia matemática. "Recebi um ótimo salário durante quatro meses, suficiente para manter-me o resto do ano. Além disso, ganhava algo na ESCOLATINA, como assistente de Aníbal. Eu organizava seminários para repassar as aulas e quando o mestre viajava substituía-o”. Nos anos seguintes, assumiria os cursos Estruturas e modelos de desenvolvimento da América Latina e História do pensamento econômico, que Aníbal ministrava no Programa de Mestrado em Economia da Universidade do Chile (SERRA, 1998, p. 7; SERRA, 2002, p. 101; SERRA, 2014, pp. 179-180, 188).

Quando começou seus estudos no ILPES, Serra passou a dividir um apartamento com dois estudantes brasileiros: o estagiário e depois economista do centro CEPALBNDE, Francisco Biato, que havia ido para o Chile em 1966 com o objetivo de fazer o curso de especialização do ILPES, e um economista que chegara em 1964 para cursar a pós-graduação na ESCOLATINA, Cláudio Leopoldo Salm, formado na UFRJ e que estava trabalhando na SUDENE quando ocorreu o golpe 228 (Francisco de Almeida Biato in: D'ARAUJO et al., 2005, p. 83; SALM, 2011, p. 168; SERRA, 2014, p. 180). Na casa

\footnotetext{
${ }^{228}$ Ver currículo Lattes: http://lattes.cnpq.br/2441573248845179. Consultado em 21/01/2015.
} 
deles viveu também por algum tempo Liana Aureliano (1942), que namorava o cineasta do CPC, Leon Hirszman (1937-1987).

Liana é pernambucana, filha de médico e intelectual de esquerda, de família bastante católica e progressista no que concerne às questões sociais. O catolicismo socialmente engajado e a intensa discussão política em sua casa levaram-na a ingressar no PCB aos 15 anos. Frequentou o movimento secundarista e universitário. Em 1964 passou logo a ser procurada pois era militante conhecida. Depois de repetidas aparições da polícia em sua casa e da breve prisão de seus irmãos e pai em seu lugar, Liana fugiu para o Rio de Janeiro e pediu asilo à embaixada do Chile, para onde partiu em 1965 (CORTEZ, 2003, p. 128; GOUVEIA, 2003, pp. 118-120). Ao chegar em Santiago, Aureliano contatou Aníbal Pinto Santa Cruz.

\begin{abstract}
Embora ele não a conhecesse, ao saber que se tratava de asilada política vinda do Brasil, procurou ajudá-la e, ao tomar conhecimento de que não tinha meios para se manter, providenciou para que fizesse seleção para o mestrado na Escola Latino-Americana para Economistas para ter direito à bolsa de estudo, mesmo sem ter concluído o curso de Economia. Liana saiu-se muito bem na prova de Teoria do Desenvolvimento, mas nada conhecia da segunda, a de Microeconomia. Os professores da disciplina, ao perceberem sua dificuldade, passam-lhe uma "cola" com as questões da prova resolvidas [...] "e assim eu tirei nota máxima naquela matéria, o que me permitiu entrar na escola. Mas fiz só o ciclo básico e interrompi. Por isso o meu currículo é completamente louco. Tenho créditos de mestrado antes de ter terminado a graduação" (CORTEZ, 2003, p. 274; Liana Aureliano apud CORTEZ, 2003, p. 274).
\end{abstract}

De regresso ao Rio de Janeiro retomou os estudos de economia, na Universidade Federal Fluminense (UFF), concluindo a graduação em 1969. Entre 1970 e 1971, foi professora auxiliar na UFF, na PUC-RJ e professora na Escola Superior de Desenho Industrial do Estado da Guanabara. Retornou ao Chile em 1972, para dar sequência ao mestrado na ESCOLATINA e passou a trabalhar como professora auxiliar na UC, na UCC e na FLACSO, além de participar dos empreendimentos cinematográficos do marido. Chegou a ser convidada para trabalhar formalmente no Chile, mas recusou o convite visto estar desassossegada em razão das movimentações que anunciavam o golpe. Deixou o país em agosto de 1973, pouco antes da tomada do poder pelos militares (CORTEZ, 2003, pp. 206-207, 279) ${ }^{229}$.

Também na casa de Biato e Salm, Serra foi apresentado a Maria da Conceição Tavares, que havia sido professora deles na Universidade do Brasil (UB) e trabalhado com

$229 \quad$ Ver: Currículo Lattes, disponível $\quad$ em:

http://buscatextual.cnpq.br/buscatextual/visualizacv.do?id=K4788925T4. Consultado em 12/01/2016. 
Biato no Centro CEPAL-BNDE. Conheceram-se quando estava de passagem pelo Chile em 1966, em uma das viagens que fazia como funcionária internacional. Em setembro de 1968, quando Lessa retornava ao Brasil, Conceição transferiu-se para a sede da CEPAL, passando também a lecionar na ESCOLATINA. Deixou o Rio de Janeiro pouco antes do AI-5, razão pela qual não chegou a ser formalmente cassada. Serra e Conceição travaram longa amizade e profícua colaboração acadêmica. Consideravam-se ambos discípulos de Aníbal Pinto, reconhecido como inspiração e estímulo essenciais para que escrevessem o ensaio Além da estagnação: uma discussão sobre o estilo de desenvolvimento recente do Brasil (1970) (item 3.5).

Concluídas suas especializações, Biato e depois Salm deixaram o Chile e foram trabalhar no IPEA. Salm passou pela Inglaterra, concluindo sua dissertação de mestrado no Institute for Development Studies, na University of Sussex. José Serra, que terminara o curso do ILPES, fez exames para ingressar na ESCOLATINA, pela qual obteve seu mestrado em ciências econômicas. Conseguiu bolsa de estudos e mantinha o salário complementar que recebia de Aníbal Pinto e de Osvaldo Sunkel, de quem também tornou-se assessor (SALM, 2011, p. 1969; SERRA, 1998, p. 7; SERRA, 2002, p. 101; SERRA, 2014, pp. 179-180, 188).

Nestes anos, Serra passou a dividir um pequeno apartamento com Vilmar Evangelista Faria e Regina Marta Barbosa Faria, um casal de cientistas sociais de Minas Gerais que estava, como outros bolsistas da FACE antes deles, cursando a pós-graduação na FLACSO. Vilmar e Regina integraram a turma de 1966-1967 da Escuela Latinoamericana de Sociología (ELAS). Seus colegas mineiros Antonio Octavio Cintra, Fabio Wanderley Reis e Simon Schwartzman haviam sido da turma da ELAS de 19621963. Vilmar (1941-2001) foi, como Serra, militante da AP e havia apoiado sua candidatura para a presidência da UNE. Entre 1963 e 1964 passou algum tempo no Rio de Janeiro ajudando Paulo Freire no desenho do Plano Nacional de Alfabetização. Lá hospedava-se na casa de outro colega de AP, Ayrton Fausto 230 (1943), que faria a pósgraduação da FLACSO em turma posterior a sua e seria, dali em diante, parte do quadro

\footnotetext{
${ }^{230}$ Ayrton Fausto (1943) nasceu em Fortaleza. Seu pai era médico e trabalhava no Ministério da Saúde e o avô materno era funcionário do Banco do Brasil. Fez a graduação em Ciências Jurídicas e Sociais na UB ao mesmo tempo que a graduação em Sociologia na PUC-RJ. Na véspera do golpe trabalhava com o sociólogo Luciano Martins em projeto de pesquisa sobre empresários desenvolvido na UB e lecionava na UFF e na Gama Filho. Deixou o Brasil em 1968, ingressando na FLACSO.

Ver: http://ayrtonfausto.com.br/wp/curriculo/, http://memoria.bn.br/DocReader/DocReader.aspx?bib=107670 03\&PagFis=20794 e http://memoria.bn.br/DocReader/DocReader.aspx?bib=089842_06\&PagFis=53795. Consultados em 02/02/2016.
} 
da FLACSO em diversos países (FAUSTO, 2002, p. 8; FRANCO, 2007, pp. 74, 180-182; SERRA, 2001; SERRA, 2002, p. 102).

Por alguns meses morou ainda com eles o filósofo carioca Carlos Estevam Martins (1934-2009 $)^{231}$, do CPC, que estava terminando seus estudos na Escuela Latinoamericana de Ciencia Política (ELACP) da FLACSO e quase partindo para os EUA para fazer o doutorado. Eram todos amigos dos tempos de movimento estudantil. Martins não era, como os outros dois, membro da AP. Ele e um colega seu da Faculdade de Filosofia da Universidade do Brasil, Wanderley Guilherme dos Santos (1935) ${ }^{232}$, aproximaram-se do PCB no início da graduação. Wanderley foi presidente do diretório dos estudantes e Carlos Estevam participava ativamente. Os dois tornaram-se assistentes de Álvaro Vieira Pinto $^{233}$, professor de filosofia antiga e encarregado da área de filosofia do Instituto Superior de Estudos Brasileiros (ISEB), órgão que reunia parte da intelectualidade carioca nacionalista-desenvolvimentista (MARTINS, 2012, pp. 158-159; SANTOS, 2011a, p. 16; MIGLIOLI, 2005, p. 63).

O Instituto Superior de Estudos Brasileiros (ISEB) resultou de uma série de encontros de intelectuais que começaram a divulgar suas ideias em 1949, em um suplemento no Jornal do Commercio. Ampliado, o grupo passou, em 1952, a reunir-se no Parque Nacional de Itatiaia, a meio caminho entre São Paulo e Rio de Janeiro, tendo sido o local dos encontros providenciado por Rômulo de Almeida, à época chefe da Assessoria Vargas. Os paulistas abandonaram a iniciativa logo depois e os cariocas acabaram por instalar-se no Rio de Janeiro. Criaram o Instituto Brasileiro de Economia,

\footnotetext{
${ }^{231}$ Carlos Estevam Martins (1934-2009) nasceu no Rio de Janeiro. Seu avô materno, médico e fazendeiro em Minas Gerais, era descendente de um membro da missão francesa do império e da família do Brigadeiro Luís Antônio, tendo estudado no Rio de Janeiro. $\mathrm{O}$ avô paterno era advogado e o pai não fez estudos superiores, sendo comerciante de representação. Martins estudou como interno no colégio marista São José. No final do científico começou a trabalhar em uma empresa de contabilidade, estudava na Cultura Inglesa e na Aliança Francesa e frequentava o colégio à noite. Ingressou na Faculdade de Direito, que frequentou por dois anos, depois transferiu-se para a Faculdade de Filosofia da Universidade do Brasil (MARTINS, 2012, pp. 176-177).

${ }^{232}$ Wanderley Guilherme dos Santos nasceu no bairro de Catumbi no Rio de Janeiro. Seu pai faleceu quando ele tinha 6 anos de idade. Foi morar em Vila Isabel com tios-avôs e a mãe, que passou a trabalhar para sustentar a família. Wanderley formou-se em Filosofia na Faculdade Nacional de Filosofia e anos depois cursou o doutorado em Stanford (SANTOS, 2011a, pp. 2-3).

${ }^{233}$ Álvaro Borges Vieira Pinto (1909-1987) nasceu em Campos, no Rio de Janeiro e era filho de um comerciante de ascendência portuguesa. Mesmo advindo de uma família de classe média baixa, pode estudar no tradicional colégio jesuíta Santo Inácio no Rio de Janeiro, onde aprendeu grego e latim. Depois de viver um ano com a família em São Paulo lendo literatura, filosofia e frequentando os cafés nos quais reuniam-se os intelectuais, ingressou na Faculdade Nacional de Medicina no Rio de Janeiro. Depois estudaria também física e matemática. Na universidade acabou envolvendo-se com a Ação Católica e com o movimento Integralista adquirindo tinturas nacionalistas. $\mathrm{O}$ catolicismo e o integralismo foram fundamentais em sua trajetória pois foram dois integralistas católicos, Alceu Amoroso Lima e Roland Corbisier, que, respectivamente, levaram-no a lecionar na Faculdade Nacional de Filosofia e a trabalhar no ISEB (FREITAS, 1998, pp. 46-48, 50-52 e http://www.alvarovieirapinto.org/referencias/cronologia-obras/. Consultado em 18/02/2016).
} 
Sociologia e Política (IBESP), mantido com recursos dos próprios membros, que oferecia cursos e editava a revista Cadernos de Nosso Tempo, com artigos de opinião dos participantes. Esta fase durou de 1953 até o final de 1955 (PEREIRA, 2005, pp. 253-256).

A impossibilidade de sustentar economicamente o instituto fez com que procurassem o governo. Passaram a receber o apoio de Anísio Teixeira, que naquele momento era coordenador da Campanha de Aperfeiçoamento de Pessoal de Nível Superior. Com recursos governamentais, o agora ISEB instalou-se em um casarão na Rua das Palmeiras no valorizado bairro do Botafogo e passou a operar como um centro de estudos e pesquisas que oferecia cursos e promovia debates sobre os rumos do país. De 1956 a 1958, o Instituto foi coordenado, na seção de Economia, por Ewaldo Correia Lima - que se tornaria diretor do BNDE -, na sociologia por Guerreiro Ramos, em ciência política por Hélio Jaguaribe, na história por Cândido Mendes, a filosofia passou a ser conduzida por Álvaro Vieira Pinto e logo Nelson Werneck Sodré passou a lecionar história Brasileira (MIGLIOLI, 2005, pp. 74-75; PEREIRA, 2005, p. 255).

Em 1958 houve uma disputa entre Guerreiro Ramos e Helio Jaguaribe, que coincidiu com a crise de Roberto Campos no BNDE e girou em torno do mesmo tema: o uso do capital estrangeiro na exploração de recursos estratégicos sob controle brasileiro (item 2.5). Narra Jaguaribe que seu livro, ainda incompleto, teria sido divulgado por Ramos para a UNE, que passou a execrá-lo como um defensor do capital estrangeiro. Ramos foi internamente condenado pela ação e os dois acabaram se afastando (JAGUARIBE, 2005, pp. 36-37). Após um breve período de reestruturação, Álvaro Vieira Pinto assumiu a direção do ISEB, em 1962, tendo início uma segunda fase da vida da instituição que vai até seu fechamento e depredação em abril de 1964.

A segunda fase é caracterizada por uma ascensão da esquerda, resultante da identificação do Instituto com várias das teses sobre o desenvolvimento nacional defendidas pelo PCB e com as propostas de reforma de base do governo Goulart. O Instituto tentou neste período aproximações com segmentos populares, lecionou para os trabalhadores, apoiou os projetos do CPC, identificava-se com o programa educacional de Paulo Freire que se tornou amigo pessoal e interlocutor de Vieira Pinto, e acabou atraindo diversos jovens recém formados na Faculdade Nacional de Filosofia para auxiliar na condução das atividades. Ingressaram no ISEB nesse período alguns alunos de Vieira 
Pinto, entre os quais Wanderley Guilherme dos Santos, Carlos Estevam Martins, Helga Hoffmann (item 4.0) e Jorge Miglioli234 (item 5.2) (MIGLIOLI, 2005, pp. 71-76).

Ao terminar a graduação, Wanderley continuou ao lado de Álvaro Vieira no ISEB enquanto Carlos Martins passou a dar aulas de filosofia em colégios particulares e tornouse o principal ideólogo do CPC da UNE. Concluído seu mandato como dirigente do CPC, Martins afastou-se da organização e foi enviado para o Recife, onde residiu 6 meses com dois objetivos: montar um curso de reciclagem para o funcionalismo público e avaliar a experiência do Movimento de Cultura Popular e as iniciativas de Paulo Freire e seus colegas junto ao governo de Miguel Arraes. Foi organizando o curso de reciclagem que conheceu Fernando Henrique Cardoso, Caio Prado, Carlos Lessa, Maria da Conceição Tavares e outros intelectuais que lá estiveram para lecionar. Todos aceitavam, diz ele, "porque o governo Arraes era a coqueluche do momento". Findos os 6 meses, Martins voltou ao ISEB, passou a lecionar no Colégio Pedro II e a trabalhar no Ministério da Educação com Paulo de Tarso. A instauração do regime militar tolhe-o de todos os seus vínculos empregatícios (MARTINS, 2012, p. 168).

Foi nessa ocasião que Cândido Mendes, neto do fundador da Universidade Cândido Mendes e doutor em direito, que havia sido membro fundador do ISEB e visto com pesar a dissolução da instituição pelos militares, convocou alguns jovens isebianos, entre os quais Wanderley e Carlos Martins, e alguns alunos da PUC-RJ para integrar o Instituto Universitário de Pesquisas do Rio de Janeiro (IUPERJ). Aos poucos o IUPERJ atraiu jovens cientistas sociais que retornavam do exterior, como Bolívar Lamounier, Amaury de Souza 235 e Simon Schwartzman, do grupo dos bolsistas de Minas Gerais, que regressavam de seus doutorados na University of California - Los Angeles (UCLA), no

\footnotetext{
${ }^{234}$ Miglioli permaneceu até 1963 no ISEB, ano em que partiu para a Polônia para estudar planejamento econômico em um grupo no qual estavam também Lenina Pomeranz, Arthur Ribeiro Candal e Ignacy Sachs (SACHS, 2004).

${ }^{235}$ Como alunos de graduação Amaury de Souza e Bolívar Lamounier viajaram aos EUA por um mês e meio, em programa do Departamento de Estado do governo Kennedy, parte da estratégia para a América Latina. Bolívar narra: "o que eu acho que essa viagem me proporcionou, basicamente, foi a percepção não estereotipada dos Estados Unidos [...]. De repente, nós vamos para a universidade americana e descobrimos o seguinte: 'Olha, é simplesmente impressionante isso aqui'. Cada universidade daquelas tinha um campus extraordinário; aqueles departamentos super bem povoados de professores competentes; bibliotecas espetaculares; e discussões francas, sem teias ideológicas nem nada". Ele diz que a vida em Minas Gerais havia mudado radicalmente com o advento do governo militar. Conta que chegou a ser preso em sua própria casa e depois disso decidiu que iria partir. Entrou em contato com conhecidos na University of California Los Angeles (UCLA) e foi admitido na pósgraduação em 1965, com bolsa da própria universidade. Faz o mestrado e o doutorado em Los Angeles, onde estudou comportamento político. Concomitantemente, Amaury de Souza foi, com Antonio Octávio Cintra, para o MIT, onde concluíram o doutorado em 1967, e Fábio Wanderley Reis foi para Harvard, todos como bolsistas da Fundação Ford (LAMOUNIER, 2013, p. 11).
} 
Massachusetts Institute of Technology (MIT) e em Berkeley respectivamente (MARTINS, 2012, p. 166; SANTOS, 2011a, pp. 29-31; SANTOS, 2011, pp. 2-3).

Cândido Mendes estabeleceu acordo com a Fundação Ford em 1967, que financiou a instalação da pós-graduação e viabilizou a atração de um grupo cada vez maior de professores que regressavam prontos para trazer para o Brasil a nova ciência social de feições quantitativas que vigorava nos EUA e na FLACSO. Como faz notar Elisa Reis - uma das bolsistas de Minas Gerais que se juntara à instituição como aluna de mestrado depois de voltar de um período de estudos no Instituto Latino-Americano de Doutrina e Estudos Sociais (ILADES) no Chile - nada mais explícito do que a revista ligada ao IUPERJ chamar-se Dados (REIS, 1993, p. 119; SANTOS, 2011a, p. 30; pp. 2-3).

Enquanto o IUPERJ estava ainda em fase de estruturação, Cândido Mendes, que estava sobrecarregado, pediu a Carlos Martins que desse aulas em seu lugar no curso de Administração Pública da FGV, de onde foi demitido por imputações de comunismo. Mesmo que pudesse permanecer no IUPERJ sob a proteção de Cândido Mendes, Carlos Estevam parte para o Chile ao final de 1965. Seu colega Wanderley parte pouco depois, indo para Stanford em 1967 e só regressaria em 1970, reaproximando-se do IUPERJ (MARTINS, 2012, pp. 166-167). No Chile, Martins ingressou na ELACP, curso que a FLACSO inaugurara um ano antes de sua chegada, especificamente voltado para as áreas de Ciência Política e Administração Pública. Lá conheceu Vilmar Faria que seguia o curso da ELAS no mesmo período. Foram morar juntos e adquiriram seus diplomas de mestrado em 1967.

$\mathrm{Na}$ FLACSO, Martins e os Faria foram alunos do sociólogo Fernando Henrique Cardoso, que fora também professor de Serra enquanto ele frequentara o ILPES. Fernando Henrique diz recordar do dia e das circunstâncias em que ele e Serra falaram-se pela primeira vez. Conta que havia um "estudante que causou impacto em mim desde o primeiro segundo em que o vi. Eu sempre me lembrarei da imagem dele, sentado no fundo da sala de aula com estes enormes olhos de falcão, absorvendo cada palavra. Após o fim da palestra, ele desceu os degraus da sala de aula e se apresentou como um jovem exilado brasileiro chamado José Serra” (CARDOSO, 2006b, p. 91). 


\title{
3.3. Fernando Henrique Cardoso e os cientistas sociais no Chile
}

Cardoso, que havia chegado ao Chile na primeira leva, já com convite para integrar-se à CEPAL, diz que para ele o Chile não foi particularmente um exílio amargo. Passou ali 4 anos com sua esposa e filhos e argumenta que foi lá que

\begin{abstract}
eu alcancei um grau de reconhecimento internacional com o meu trabalho e fui promovido. Recebi um salário considerável e meu status diplomático permitiume importar um Mercedes sedan, um belo símbolo de status na época. Meus filhos mais jovens aprenderam a falar espanhol e Inglês [...], estávamos nos tornando cidadãos do mundo, adquirindo um ponto de vista mais global e de mente aberta (CARDOSO, 2006b, pp. 87-88).
\end{abstract}

O tal despontar de uma carreira internacional de prestígio não era, entretanto, de modo algum descolado da trajetória prévia do sociólogo. Cardoso provém de uma família com profundas raízes na história política brasileira. Raízes estas que penetraram seu imaginário e fomentaram suas próprias ambições políticas.

Um de seus bisavôs paternos, Felicíssimo do Espírito Santo Cardoso, foi o primeiro presidente republicano do estado de Goiás “com o título honorífico de brigadeiro, Comendador da Ordem da Rosa, senador estadual, deputado, governador duas vezes da província” (CARDOSO, 2012a, p. 20). Seu avô paterno Joaquim Inácio Batista Cardoso estudara humanidades no Seminário Episcopal de Santa Cruz de Goiás e chegou a tornar-se professor de filosofia antes de aderir à carreira militar. Converteu-se em marechal abolicionista e republicano e integrou o grupo que baniu o Imperador Dom Pedro II em 1889, participando da instalação da República. Seu tio-avô Augusto Inácio do Espírito Santo Cardoso chegaria a ser Ministro da Guerra da ditadura Vargas (19321933) e o filho dele, Ciro do Espírito Santo Cardoso, Ministro da Guerra do governo de Vargas eleito (1952-1954). Joaquim Inácio era muito próximo de Floriano Peixoto, tendo morado no Palácio do Itamaraty com o Presidente. Eurico Gaspar Dutra, que se tornaria presidente em 1946, fora, na juventude, seu ajudante-de-ordens (CARDOSO, 1998, pp. 340-341; DHBB, verbetes Augusto Inácio do Espírito Santo Cardoso e Ciro do Espírito Santo Cardoso; GARCIA, 2004, pp. 287-289).

O avô Joaquim Inácio e o pai de FHC, Leônidas Fernandes Cardoso (1889-1965), advogado formado na Faculdade Nacional do Rio de Janeiro e militar, participaram da revolução de 1922 e depois da revolução de 1930. A família unida até 1930 dividiu-se em 1932 quando alguns apoiaram São Paulo e outros permaneceram fiéis a Vargas. Leônidas 
apoiou São Paulo, embora trabalhasse no gabinete de seu tio Augusto Inácio, no Ministério da Guerra, que chegou a prender um dos sobrinhos, aliado dos paulistas. Nas palavras de FHC: “a briga política em casa era intensa” (CARDOSO, 1998, pp. 340-341; CARDOSO, 2012a, p. 20; DHBB, verbete Leônidas Fernandes Cardoso).

Fernando Henrique cresceu neste mundo onde todos "tinham uma enorme paixão pela pequena história: Fulano fez tal coisa. Não, foi Sicrano. Naquele dia foi assim. Não, não foi. Fulano foi preso. Beltrano caiu. Essas discussões eram, na minha casa, o cotidiano". "Preencheram o meu imaginário, na infância". "Esses personagens, para mim, não eram de ficção. Eram pessoas. Eu fui, digamos, socializado, treinado, nesse ambiente de revisão permanente dos fatos políticos, e muitas vezes em oposição ao governo" (CARDOSO, 1998, pp. 341-342). Assim a grande história nacional era narrada em sua casa como pequena história, prosaica porquanto considerada história familiar, relatos em meio aos quais as novas gerações eram educadas. Governar não parecia, pois, uma atividade excepcional no imaginário juvenil do futuro presidente.

Fernando Henrique Cardoso (1931) nasceu em Botafogo no Rio de Janeiro, bairro onde na época vivia a maior parte da elite carioca. Era o filho mais velho de Leônidas Cardoso e Nayde Silva. A mãe tinha raízes distintas da família do pai, não provinha do fulcro do mundo político. Nascera no Amazonas porque o avô materno de FHC, descendente de espanhóis, homem ilustrado e maçom que trabalhava no comércio, decidira aventurar-se no surto da borracha. A avó materna descendia de uma família tradicional de Alagoas, os Costa Rêgo, que exerciam também atividades comerciais. Nayde fora educada em colégio de freira, a diferença entre a socialização em sua família e os padrões da família do marido fez com que tivesse alguns atritos com a sogra, com quem moraram por alguns anos no Rio de Janeiro (CARDOSO, 2012a, p. 19; LEONI, 1997, p. 42).

Em 1940 a família de Fernando Henrique transferiu-se para São Paulo. Estabeleceram-se em Higienópolis - bairro com localização privilegiada, “assentado numa encosta a certa distância da cidade, circundada de abundante vegetação, mas também por seu arruamento regular, pela densa arborização das ruas e pelas belas e luxuosas casas que estavam sendo levantadas - todas isoladas no meio dos lotes, conforme o tipo mais recente de implantação" (CAMPOS, 2005, p. 50) - para o qual se deslocou parte da elite agrária, que com a decadência do café deixava suas fazendas e mudava-se para palacetes 
na capital do Estado. Higienópolis e seus arredores abrigavam vários colégios católicos de elite paulistanos, como o Sion, o Des Oiseaux e o São Luís (PEROSA, 2004, pp. 65-66).

O Ginásio Perdizes, onde FHC estudou ao chegar em São Paulo, ficava na rua Cardoso de Almeida, também na região. Foi lá que conheceu Plínio de Arruda Sampaio, com quem conviveria na política brasileira e no exílio. Fernando Henrique deu sequência aos seus estudos no Colégio São Paulo, situado na rua Doutor Gabriel dos Santos, na confluência de Perdizes, Pacaembu em Higienópolis. Ali iniciou suas atividades políticas, sendo, sucessivamente, diretor, vice-presidente e presidente do grêmio dos estudantes. Conta um amigo próximo que ele "já manifestava um gosto bastante pronunciado pela política", coerentemente com suas origens e com a socialização experimentada no meio familiar (CARDOSO, 2006, pp. 71, 77; GARCIA, 2004, p. 289, 291; LEONI, 1997, p. 32).

Além do aprendizado escolar, Fernando Henrique dispunha de uma professora particular de francês, língua da elite cosmopolita de seu tempo. O forte domínio do francês render-lhe-ia altos dividendos no futuro, pois foi instrumento essencial para que se aproximasse de figuras como Georges Friedmann e Alain Touraine, que teriam grande influência sobre seu percurso acadêmico. Garantiu-lhe também papel de destaque na recepção e entretenimento dos intelectuais franceses que visitavam São Paulo, como o casal Sartre e Simone de Beauvoir que aqui esteve em 1960. O inglês de FHC era até então deficiente. Conta que tinha que esforçar-se mesmo para conseguir ler no idioma. Alguns anos depois, enquanto lia O Capital com seus colegas da Faculdade de Filosofia, começaria a estudar alemão, mas com cinco anos de lições não conseguiu sequer aprender a ler com fluência (CARDOSO, 2006, pp. 71, 77; GARCIA, 2004, p. 289, 291; LEONI, 1997, p. 32).

Quando estava concluindo os estudos secundários, Fernando Henrique fez uma viagem de férias à Estação de Águas de Lindóia com alguns colegas. Lá encontrou-se casualmente com o português Nuno Fidelino Figueiredo, historiador, escritor, crítico literário, professor de literatura e membro da Academia Brasileira de Letras, que viveu exilado no Brasil entre 1938 e 1951. Figueiredo, que lecionava na FFCL-USP, teve forte influência sobre sua decisão de fazer o exame de admissão para a Faculdade de Filosofia. Cardoso conta que Figueiredo estava

lendo um livro na varanda do hotel e eu estava muito curioso para saber que livro era aquele. Nós começamos a conversar e o professor Fidelino viu que eu estava 
interessado em literatura e na crítica social. Naquela época havia um movimento cultural grande em São Paulo ligado a uma grupo de pessoas com um pensamento social progressista, e eu estava interessado em me aproximar deles. O professor Fidelino me disse para passar no gabinete dele (CARDOSO, 2006a, p. 96).

Ao visitá-lo em seu escritório, no departamento de literatura da FFCL, à época situado na Avenida São Luís, FHC comenta cogitar dedicar-se à poesia, pois tivera alguma experiência literária com os jornaizinhos da escola e participara de alguns debates literários com figuras proeminentes como Mario e Oswald de Andrade. Figueiredo procura dissuadi-lo da pura dedicação à literatura e abrir seus olhos para a Faculdade de Filosofia (CARDOSO, 2006, p. 67; FOLHA, 2002; SILVA, 2013, pp. 132-133).

Cardoso confessa que "tinha em mente ir para a USP, mas não tinha definido meu campo de estudo. Poderia ter cursado direito, caminho tradicional naquele tempo para boa parte da elite brasileira. Acabei na Faculdade de Filosofia, como Fidelino Figueiredo havia sugerido, e dentro dela gravitei para a sociologia" (CARDOSO, 2012a, p. 22). Acabar na Faculdade de Filosofia não deixa de ser uma maneira de esquivar-se do inconveniente de ter que anunciar o fracasso na seleção para a Faculdade de Direito, onde não foi admitido devido ao insucesso na prova de latim (GARCIA, 2004, p. 289, LEONI, 1997 , p. 55, 58). No exame de admissão para a faculdade FHC conheceu sua futura esposa Ruth Correa Leite (1930-2008), que obteve a primeira classificação no vestibular (CARDOSO, 2006, p. 68). Ela conta que: “ele estava sozinho em São Paulo e queria cursar filosofia e direito. Sentado ao meu lado, íamos fazer exame oral. Matreiro, ele me comoveu, dizendo que não tinha tido tempo de estudar, me contou uma história dramática, de maneira que passei todas as fichas a ele. Aí começou" (Ruth Cardoso Apud BRANDÃO, 2010, pp. 42-43).

Ruth nasceu em Araraquara, filha única de uma família de proventos modestos. Seu pai era guarda-livros e a mãe era farmacêutica e fora professora de química e biologia no ginásio estadual e no Colégio São Bento, além de lecionar botânica na Faculdade de Farmácia e Odontologia e ser responsável por duas farmácias de sua cidade. Ela foi o modelo de mulher ativa e aberta à modernidade que Ruth buscaria mimetizar. Se o capital econômico não era vasto, eles tinham acumulado algum capital cultural. A reverência pelo conhecimento foi herdada do avô materno que era um educador e professor de matemática e transmitida pela mãe, Mariquinha, também lente, que teria feito questão que Ruth fosse educada na ciência e não na religião, razão pela qual haveria se recusado a 
matricular sua filha em um dos colégios confessionais da cidade (BRANDÃO, 2010, pp. 15-27).

Além da educação, a família cuidava do cultivo do capital social, vigiando os engajamentos sociais da filha para cuidar de sua reputação. Querer que a filha fosse informada pela moderna ciência não era, na visão de sua mãe, incompatível com o ensino do controle corporal, dos modos e dos cuidados com a apresentação de si requeridos à conquista do matrimônio. Mariquinha costurava as roupas para os bailes, regulava as saídas das filha e fazia questão de que as vestimentas estivessem impecavelmente passadas. Ruth estudou piano no conservatório musical, aprendeu a declamar e praticava as artes de boa moça nas reuniões familiares. Começou nesse momento também paixão pelo cinema que arrastou pela vida toda. Além disso tinha seus flertes, fortemente supervisionados pela mãe. Um dos mais constantes foi Renato Rocha, de família proeminente de Araraquara, os Moraes Rocha, donos de uma grande fazenda na região. Renato era irmão de Gilda Moraes Rocha (1919-2005), que foi para São Paulo estudar e ingressou na Faculdade de Filosofia, onde tornou-se assistente de Roger Bastide. Gilda casou-se com o professor da Faculdade de Filosofia da USP, Antônio Candido de Mello Souza. A amizade com os Mello Souza, favorecida pelos laços araraquarenses, seria importante apoio pessoal e acadêmico para Ruth Cardoso em toda sua trajetória (BRANDÃO, 2010, pp. 23-36).

A primeira influência de Gilda sobre Ruth adveio do efeito que teve sobre sua mãe o sucesso da transferência da moça do interior para estudar na capital, fazendo com que Mariquinha passasse a vislumbrar para a filha destino semelhante. Gilda havia ido morar em São Paulo na casa de uma tia-avó, Maria Luísa, mãe do escritor Mário de Andrade que teve grande ascendência sobre ela (PONTES, 2004, p. 24). A primeira vez que voltou a sua casa após ingressar na faculdade, conta Gilda, passou a ser olhada com curiosidade e cautela, inclusive por sua mãe que "observava orgulhosa e inquieta a filha sobressair e, por conseguinte, afastar-se da realização usual que era o 'bom casamento'. Seus amigos para ela cantavam uma quadrinha popular que dizia 'Menina que sabe muito é mulher atrapalhada; para ser mãe de família saiba pouco ou saiba nada'.”. Não era necessariamente verdade. Gilda e depois dela Ruth casaram-se com moços de famílias estabelecidas que tornar-se-iam professores proeminentes (Gilda de Mello Souza in: BLAY, 2004, pp. 65-66). 
Dona Mariquinha matriculou Ruth no colégio Des Oiseaux, conhecido por combinar prestígio e recato. Ao concluir os estudos, foi morar em um pensionato de freiras e começou a preparar-se para ingressar na Faculdade de Filosofia. O mesmo trajeto fez uma amiga sua de Araraquara, Maria Sylvia de Carvalho Franco (1930), de pai delegado de polícia e mãe proveniente de família de elite rural, os Pinto Ferraz. Maria Sylvia depois de passar pelo Colégio Des Oiseaux também foi admitida na FFCL em 1949, junto com Ruth e FHC. Ainda no primeiro ano de Faculdade, Ruth passou a namorar o rapaz que conhecera no exame de admissão. Juntos frequentavam a elite intelectual paulistana: faziam aulas no Museu de Arte de São Paulo (MASP) com Pietro Maria Bardi, frequentavam o clube dos artistas e amigos da arte de Flávio de Carvalho e encontravam-se com os colegas de faculdade na biblioteca Mario de Andrade, ponto de reunião dos jovens acadêmicos. Casaram-se em fevereiro de 1953, imediatamente após a conclusão do curso de Filosofia (SPIRANDELLI, 2008, p. 48, 115; BRANDÃO, 2010, pp. 41-47).

Ainda na graduação, FHC havia sido indicado por Mario Wagner Vieira da Cunha, diretor do Instituto de Administração, muito amigo de seu professor Florestan Fernandes, para prestar serviços técnicos ao curso de Administração da Faculdade de Ciências Econômicas e Administrativas da USP (FCEA-USP) (item 4.2). Na FCEA, Fernando Henrique e sua colega Maria Sylvia de Carvalho Franco tinham como chefe Maurício Segall, filho de Lasar Segall e militante do PCB, que esconderia José Serra e ajudaria Fernando Henrique a deixar do Brasil (CARDOSO, 2006b, p. 81). Segall designou-o para trabalhar com "Lucila Hermann, que era uma socióloga de campo e fazia um trabalho sobre classe trabalhadora”. Esse vínculo durou do final de 1951 à metade de 1952. Na sequência FHC passou a ocupar a posição de primeiro assistente da professora Alice Piffer Canabrava ${ }^{236}$, responsável pelas cadeiras de história econômica geral e de formação

\footnotetext{
${ }^{236}$ Alice Piffer Canabrava (1911-2003) nasceu em Araras, no interior paulista. O pai era fazendeiro em uma propriedade que o avô médico recebera como retribuição por curar um Visconde local. Sua mãe, austríaca, almejava a independência das filhas pela via profissional, permitindo que partissem para São Paulo para dar sequência aos estudos. Segundo Canabrava, ela e a irmã foram as únicas crianças da cidade a prosseguir os estudos após o nível primário. Vieram para o internato Stratfford, escola laica e de classes mistas. Após o ensino básico, Alice ingressou na Escola Normal da Praça da República. Com o grau de normalista, voltou ao interior paulista onde deu início a sua carreira de professora primária. Além de lecionar começou a estudar francês com um suíço que residia em sua cidade, idioma que seria essencial para que pudesse cursar o ensino superior na FFCL. Alice conta que "como tantas outras, fui uma das professoras do magistério primário beneficiadas pelo ato do Governo Estadual que facultou o comissionamento das interessadas junto à recém-criada Faculdade de Filosofia, Ciências e Letras da Universidade de São Paulo, desde que aprovadas em concurso de provas." (Alice Piffer Canabrava in: BLAY, 2004, p. 87). Na FFCL lecionou como professora assistente e defendeu a tese $O$ comércio português no Rio da Prata. Não conseguiu, entretanto, ser aprovada no concurso para a cátedra de
} 
econômica do Brasil, doutora pela FFCL e primeira mulher a assumir uma cátedra na USP, em 1951. Fernando Henrique conta que tornar-se o primeiro assistente ainda na graduação

era uma coisa um pouco escandalosa, porque o primeiro era o principal, não é, e eu não tinha... Tinha 20 anos; não tinha nem terminado a faculdade - o reitor teve que baixar uma portaria para me autorizar a dar aula. E a Alice, que era muito rigorosa, primeiro me fez dar um curso sobre história econômica da Europa, para a Faculdade de Economia. Bem, eu não sabia nada, eu tinha lido [somente a] História econômica geral, do Weber [...] para quem não conhecia a Faculdade de Economia, esses autores [da história econômica] não eram habituais. Então, por isso, eu dei curso lá e também assisti às aulas de economia na Faculdade de economia [com o professor Dorival Teixeira Vieira]. [...] Ela era, como o Florestan, muito rigorosa, e tal. Eu tinha que trabalhar muito, levantar dados... Mas minha vocação era muito mais teórica na altura. Eu não entendia onde é que ela queria chegar. Era dado, dado, dado. Não tinha muita hipótese e tal. Bom, então, tive um certo treinamento aí também, um pouco de história econômica e li algo de economia, nunca deixei de ler economia. Então, pouco a pouco eu fui me transformando em sociólogo. Aí, houve uma... A Alice se desentendeu comigo. Eu voltei para... Já tinha terminado o curso, aí o Florestan me levou de volta para a Faculdade de Filosofia, e eu fui ser assistente - nem assistente; fui rebaixado, era primeiro assistente, fui ser auxiliar de ensino do Roger Bastide (CARDOSO, 2012, pp. 7-8).

$\mathrm{Na}$ metade de 1953, FHC deixa a posição de assistente depois de desentender-se com Alice ${ }^{237}$. Ela, que fazia pesquisa empírica rigorosa, teria dito a ele: "Você é como o Antonio Candido, vocês nunca vão ser cientistas" (CARDOSO, 2012a, p. 24). Fernando Henrique comenta ter achado a bronca um elogio, pois Candido "fascinava pela síntese entre um sabor literário indiscutível, a finura de sua antropologia social, seu discreto socialismo e sua invulgar capacidade de transformar os ‘tijolos acadêmicos' em arabescos de sutileza e penetração intelectual" (Fernando Henrique Cardoso apud BRANDÃO, 2010, pp. 46-47; CARDOSO, 2011, p. 16). A maledicência proferida por Alice só pode ser compreendida à luz dos jogos pela acumulação do capital científico que corriam na FFCL naquele momento.

história da América. Conta que "a resistência masculina na Faculdade em aceitar as mulheres em cargos de categoria refletia arraigada consciência de superioridade, a tradição do meio quanto à predominância dos padrões masculinos" (Alice Piffer Canabrava in: in: BLAY, 2004, p. 102). Os colegas diziam estar protegendo o ensino superior do baixo nível das professoras provenientes das escolas normais e do magistério primário, em expressiva desqualificação simultânea das mulheres, dos níveis básicos de ensino e da área educacional. Canabrava relata diversas tentativas de sabotagem de sua participação no concurso onde chegara a empatar com o outro candidato. O diretor da banca examinadora justificou o desempate em favor do homem, dizendo que o outro candidato já ocupava a posição em regime temporário e portanto convinha que ali permanecesse. Nesse momento Alice, derrotada, abdicou do jogo transferindo-se para a FCEA, para assumir a cátedra de história econômica (Alice Piffer Canabrava in: in: BLAY, 2004, pp. 87-102; CANABRAVA, 1997, p. 162; SAES, 1999, p. 42).

${ }^{237}$ Fernando Henrique não fora o único a desentender-se com Alice. Fernando Novais, anos depois, teria o mesmo destino (RODRIGUES, 2011, pp. 136-137, 325). 
Em esquema simplificado, é possível dizer que havia dois polos que convergiam na defesa da atividade intelectual como atividade científica, em oposição ao diletantismo e ao amadorismo, mas que divergiam no que concerne ao modo e forma do exercício científico. De um lado predominaria uma defesa da explicação formulada a partir da coleta metódica e interpretação sistemática de dados. De outro lado estaria a defesa do caráter carismático da intepretação das observações, em que o fazer científico estaria associado à produção cultural e à arte, sendo o modo de exposição das descobertas de pesquisa predominantemente ensaístico, com feições literárias (GARCIA, 2002, pp. 99, 145-146). O primeiro grupo é correntemente associado à posição de Florestan Fernandes que se tornaria orientador de FHC e o segundo à figura de Antonio Cândido de Mello e Souza.

Nesta contraposição, como sugere o próprio FHC, Alice alia-se a Florestan, no grupo daqueles para quem a ciência era uma inexaurível tarefa de coleta e análise de dados. Para além de dizer que Cardoso não era talhado para a ciência pode haver no comentário de Alice uma marcação da posição social de Fernando Henrique. O grupo de Antonio Candido era essencialmente o daqueles que provinham de famílias tradicionais e adquiriram o traquejo com a literatura precocemente, em sua socialização familiar, escolar, e na frequência aos círculos intelectuais da alta sociedade (GARCIA, 2002, p. 87). Fernando Henrique enquadra-se perfeitamente neste perfil: frequentava a elite intelectual e cultural, manejava as insígnias artísticas e havia mesmo cogitado seguir a carreira literária. Em oposição, Alice e Florestan seriam aqueles que teriam batalhado sua ascensão na Universidade contra a naturalidade da reprodução das posições sociais. Florestan, de origem social muito modesta, lutava com incansável dedicação para alcançar o repertório intelectual e a fluência nos idiomas estrangeiros daqueles que vinham dos meios privilegiados. Alice lutava para ser aceita como intelectual, desviando do padrão feminino de classe média do interior, cujo destino social provável teria sido permanecer em sua cidade natal como professora primária.

É elucidativo também que Cardoso entenda a crítica de Alice como um elogio, dado identificar-se com os padrões culturais representados pela sociologia com atributos literários de Antonio Cândido, repleta de "arabescos de sutileza e penetração intelectual" (Fernando Henrique Cardoso apud BRANDÃO, 2010). Não obstante, Fernando Henrique volta para a Faculdade de Filosofia levando consigo o aprendizado da pesquisa 
empírica, tão cara a Florestan, de quem se tornaria primeiro assistente em 1954 (RODRIGUES, 2011, pp. 136-137; PULICI, 2008, p. 37). Ruth, por sua vez, conseguiu uma colocação na Secretaria do Trabalho onde fez pesquisas sobre emprego e desemprego na cidade de São Paulo e a condição de vida da classe trabalhadora (BRANDÃO, 2010, p. 54).

O ano de 1954 é agitado para o casal Cardoso. Além de tornar-se primeiro assistente, em abril nasce o primeiro filho deles, Paulo Henrique. Pouco antes de ir para o hospital com Ruth, Fernando Henrique conhece um colega que teria importância em sua trajetória, o filósofo José Arthur Giannotti que foi ao seu apartamento buscar um livro do Max Weber. De 1956 à metade de 1958 Giannotti viveu na França. Quando retornou ao Brasil criou o hábito de visitar o casal Cardoso todos os sábados. Os encontros puramente mundanos dos finais de semana são rapidamente substituídos por um seminário de leituras do livro O Capital de Karl Marx. Não era o primeiro contato de FHC com o pensamento da esquerda, pois ele estivera envolvido em atividades editoriais da revista comunista Problemas e integrara o conselho da revista Fundamentos, dirigida por Caio Prado Junior. O Seminário do Capital não era associado a qualquer espécie de militância, já que a familiarização com o marxismo era antes um exercício intelectual e o cultivo de um instrumento de análise social do que um horizonte para a ação política. Bento Prado sintetiza isto ao dizer que "na época todo mundo era de esquerda, mas ninguém tinha a intenção de fazer a revolução no dia seguinte, tudo era muito teórico, muito acadêmico" (CARDOSO, 2006, 75; LEONI, 1997, p. 77; Bento Prado Júnior apud LEONI, 1997, p. 87). Fernando Henrique ao falar do surgimento do grupo faz um détour no qual revela as conexões sociais em articulação naquele mundo acadêmico-social:

\begin{abstract}
isso foi na segunda metade dos anos 50. A idéia inicial foi do Giannotti. Nós estávamos na praia no Rio de Janeiro - eu ia com muita frequência ao Rio nas férias. Giannotti, Ruth, Roberto Cardoso, meu cunhado, e talvez o Darcy Ribeiro, que morava no subúrbio e vinha para a casa do meu pai no Arpoador, íamos todos juntos à praia. Darcy era mais velho do que eu, nossa amizade foi através do meu cunhado que trabalhou com ele no Museu do Índio no Rio de Janeiro. Darcy gostava muito de meus pais e nós dele e da Bertha, sua primeira mulher. Bem, retomando a história do seminário, Giannotti voltava naquele momento da França entusiasmado com a ideia da análise estrutural de texto (CARDOSO, 2006, p. 75).
\end{abstract}

Giannotti, ao contrário, diz que a ideia foi coletiva. Ele narra:

A gente costumava visitar Ruth e Fernando Henrique Cardoso aos sábados, e eu havia voltado com essa bibliografia que fazia a crítica da burocracia soviética. A minha ideia era estudar esses textos, mas o Fernando Novais contestou: "não: 
nós nunca lemos Marx direito, é melhor ir às fontes". Então resolvemos fazer a leitura sistemática do Capital, e o grupo foi ampliado de modo a incorporar economistas - como o Paul Singer, que eu não conhecia - e tantos outros. [As sessões] eram muito divertidas. Alguém comandava o seminário (ainda tenho os meus três volumes do Capital com todas as marcações de quem fez o quê), depois jantávamos bem, em seguida discutíamos aquilo que era a base do nosso programa e dava o sentido das nossas ligações, o Brasil. O problema era pensar o Brasil, o que estava acontecendo no país, como seria possível engatar o desenvolvimento (GIANNOTTI, 2009, p. 55).

O grupo do Capital começou com Fernando Henrique e Ruth Cardoso. Giannotti e Bento Prado, da Filosofia. Octávio Ianni, que também era assistente de Florestan. Fernando Novais, historiador, e por ele convidado seu aluno da FCEA Paul Singer. Depois passariam pelo seminário Juarez Brandão, Sebastião Advíncula, Francisco Weffort, Michel Löwy e Roberto Schwarz, além de outros visitantes esporádicos. Ruth, a única mulher do grupo, dividia-se entre os debates e os deveres domésticos tradicionais, correndo da mesa de estudos para a cozinha para cuidar dos lanches e quitutes com os quais se fartava o grupo, revelando uma vez mais a dualidade estrutural à qual estava submetida pela não ruptura com a condição feminina tradicional (BRANDÃO, 2010, p. 60; CARDOSO, 2006, p. 79; CARDOSO, 2006a, p. 98; GARCIA, 2004, p. 292; RODRIGUES, 2011, pp. 34-47).

FHC argumenta que o seminário teve influência sobre a sua formação e a sua tese. A incorporação de Marx funcionou como um contraponto ao funcionalismo de seu orientador que, diz ele, rejeitou a versão marxista do prefácio de sua tese. Florestan achava que o flerte dos jovens com o marxismo à la Lukács ou à la Sartre beirava o ensaísmo, contra o qual contrapunha-se incansavelmente. O marxismo funcionaria também como um trunfo em meio às esquerdas intelectuais que ganhavam espaço na política universitária (BRANDÃO, 2010, p. 60; CARDOSO, 2006, p. 79; CARDOSO, 2006a, p. 98; GARCIA, 2004, p. 292; RODRIGUES, 2011, pp. 34-47;).

O ano de 1954, além de proporcionar a chegada do primeiro filho do casal, o posto de primeiro assistente e o encontro de FHC com Giannotti, foi ainda mais marcante pois, em outubro, Leônidas Cardoso, que deixara a carreira militar, logra elegerse deputado federal pelo PTB, com apoio dos comunistas e nacionalistas. Junto a ele e ao seu tio, Felícissimo Cardoso - que ficou conhecido como o General do Petróleo por sua ávida campanha em favor da exploração nacional do petróleo e criação da Petrobrás -, FHC inicia sua vida política. Participa primeiro do movimento O Petróleo é Nosso e depois 
da campanha de candidatura de seu pai. Eleito, Leônidas retorna ao Rio de Janeiro, deixando o casal Cardoso só na cidade com os deveres acadêmicos e um recém nascido. Ruth deixa a Secretaria em 1955 e começa a dar aulas de antropologia em uma faculdade em Sorocaba. Depois passa a lecionar sociologia na Fundação Escola de Comércio Alvares Penteado (FECAP) (item 4.1), finalmente é convidada a voltar à Filosofia como auxiliar de Gioconda Mussolini (1913-1969) na cadeira de antropologia. Em 1959 torna-se mestre em sociologia com a dissertação $O$ papel das associações juvenis na aculturação dos japoneses (BRANDÃO, 2010, p. 59, 61;CARDOSO, 2012, p. 26; GARCIA, 2004, p. 291).

À estreia na vida política nacional, ao lado do pai e do tio, somou-se a estreia na política universitária. Fernando Henrique começara a participar da

articulação pelo estabelecimento da Associação dos Auxiliares de Ensino da USP (AAE-USP), composta pela "esquerda" da Faculdade de Medicina e pelo grupo da FFCL próximo à Sociologia: jovens preocupados com o plano de carreira, com a arbitrariedade de seu destino profissional sob arbítrio catedrático, e com a recuperação do regime de tempo integral. Este setor modernizante, na intenção de disputar espaço com os grupos que dominavam a política universitária, centrados na Faculdade de Direito, Politécnica e "direita" da Medicina, instam o jovem sociólogo Fernando Henrique Cardoso a se tornar representante dos exalunos da USP junto ao CO. Antonio Delfim Netto era seu suplente, em função da tentativa de atrair mais aliados, que os levou até a Economia e a Arquitetura. Esse amealhado obteve sua primeira vitória na disputa pela vaga no $\mathrm{CO}$ e Fernando Henrique Cardoso, sua primeva experiência de exercício do "capital científico temporal", pelo qual foi criando gosto ao mesmo tempo em que conquistava o círculo (RODRIGUES, 2011, p. 157).

Fernando Henrique participa do Conselho Universitário da USP, de abril de 1957 a abril de 1958, como representante dos ex-alunos e em 1961 volta ao Conselho como docente. Ele relata que os membros do CO impressionavam-se com sua polidez, com o respeito aos mais velhos, com seu tom antes conciliador do que radical, com o fato de estar sempre bem vestido e outras qualidades esperadas daqueles que foram socializados entre as elites. Assim ganhou as graças dos conservadores que dominavam a política universitária. Estes reconheciam nele um par do ponto de vista da sua constituição social, que era semelhante àquela das elites que povoavam as escolas dominantes da política universitária, as tradicionais Faculdades de Medicina, Direito e Engenharia (CARLOTTO, 2014, 468-469). Fernando Henrique passou inclusive a ser admitido nos espaços extraoficiais de congregação dessa elite acadêmica, sendo convidado para os jantares e reuniões do grupo. Conseguiu aglutinar apoio da esquerda e tolerância de parte da direita universitária, conquistando papel destaque na política uspiana (Célio Benevides de Carvalho in: LEONI, 1997, p. 54; ROMÃO, 2006, pp. 100-103) 
Em algum momento, os membros do CO vieram a saber de suas raízes. Descobriram que seu pai era deputado federal, o tio, presidente do Banco do Brasil, o Ministro da Guerra e o prefeito do Rio seus primos e decidiram acioná-lo para resolver problemas que requeriam transito político. Apesar de afirmar: "nunca usei nada disso [seus contatos privilegiados], nem tive nenhuma mordomia, mesmo quando meu pai foi deputado" (CARDOSO, 2006, p. 74), Fernando Henrique vai revelando como mobilizava seus laços para obter apoio político e recursos para seus projetos e os daqueles que integravam o seu grupo. Caso paradigmático da ativação de seu capital social é a montagem do Centro de Estudos de Sociologia Industrial e do Trabalho, ligado à cadeira de Sociologia I de Florestan Fernandes.

O modelo para a criação do CESIT foi o Laboratoire de Sociologie Industrielle, organizado por Georges Friedmann, acadêmico de destaque da área de sociologia industrial, que tinha sido convidado por Fernando de Azevedo para visitar a USP, e por seu discípulo, Alain Touraine. FHC explicita ter o capital cultural, econômico e a politesse requerida para tecer os laços com os professores franceses, que foram fundamentais para sua progressão na carreira acadêmica, quando conta que:

\begin{abstract}
quando George Friedmann, grande patron da sociologia do trabalho francesa, visitou o nosso departamento de sociologia [em 1954], como eu tinha automóvel e falava francês ciceronei-o por São Paulo e fiquei bastante próximo dele. A certa altura, ele disse: "vocês precisam de uma pessoa mais jovem aqui, vou mandar um assistente meu". Era o Alain Touraine. Touraine chegou, leu nossos trabalhos e comentou: "Vocês estão descrevendo o Brasil como se estivessem na Europa, com classes sociais bem estabelecidas. Aqui não é bem assim. O Estado tem mais força do que as classes, a ideia de nação é central". Touraine sempre teve essa preocupação com a nação e o Estado. Elogiou o que tínhamos feito, mas botou uns pontinhos de dúvida no nosso nascente marxismo com sabor de Sena. Ele me influenciou muito (CARDOSO, 2012a, p. 25).
\end{abstract}

Alain Touraine (1925) era de uma geração mais próxima à de Fernando Henrique. Ele havia estado em Santiago, em missão de cooperação científica acordada por Friedmann com a Universidade do Chile, onde fez pesquisas empíricas sobre as relações de trabalho e a formação da consciência social dos trabalhadores chilenos da mineração e da siderurgia, nas quais contou com a colaboração de um jovem assistente, Enzo Faletto (CARDOSO, 2012, p. 18; FALETTTO, 2007, p. 190).

A relação de Friedmann com o jurista Gustavo Lagos Matus e com o reitor da UC Juan Gómez Millas foi central para a constituição da FLACSO e para a aproximação do grupo francês de estudos sobre sociologia industrial com a América Latina. Gustavo 
Lagos Matus (1924-2003), criador e primeiro secretário da FLACSO, foi quem pleiteou o apoio da Organização das Nações Unidas para a Educação, a Ciência e a Cultura (UNESCO) para o novo centro de ciências sociais. Ele era filho de engenheiro civil formado na Universidade do Chile e neto, por parte de pai, de Dagoberto José Lagos Pantoja (1861-1890), advogado que foi presidente da Suprema Corte Chilena, e por parte de mãe da filha de Pedro Lagos Marchant, importante militar que foi chefe do Estado Maior Chileno ${ }^{238}$. Gustavo Lagos estudou em colégio católico de elite, o Sagrado Coração, e depois formou-se advogado pela Universidade do Chile.

\begin{abstract}
Lagos trabalhava na cátedra de Walker Linares na Faculdade de Direito e Ciências Sociais, e estava retornando de um período de estudos na França, onde ele se aproximou da sociologia industrial de Georges Friedmann, que por sua vez tinha relações com Walker Linares na UNESCO. Diante da impossibilidade de comparecer à IX Conferência [Geral da UNESCO], Walker Linares convidou para assumir seu lugar na delegação chilena. Mas foi na X Conferência Geral em 1958, em Paris, que Lagos teve um papel internacional mais significativo, sendo o relator do Grupo de Trabalho sobre Ciências Sociais. Foi lá que se autorizou o Diretor Geral a recolher contribuições dos países membros para os novos centros de ciências sociais da América Latina, distribuindo-os igualmente ao Centro (CLAPCS, Brasil) e à FLACSO (BEIGEL, 2009, p. 324).
\end{abstract}

A iniciativa de Lagos na fundação da FLACSO quase repete o que ocorrera anos antes com Hernán Santa Cruz no momento de criação da CEPAL. Gustavo Lagos também pleiteia a instalação da organização internacional no Chile sem ter autorização prévia de seu governo. Como no caso de Santa Cruz, tal ousadia só foi possível pois partira de alguém com longo e prestigioso enraizamento na sociedade chilena que lhe conferia largo capital simbólico e social (item 1.1). No caso da FLACSO, supõe-se que a intenção de atrair o organismo podia já ter até sido aventada na diplomacia nacional mas, como acreditava-se que haveria unanimidade em torno da designação do Brasil para sediar o novo órgão, os chilenos sequer discutiram formalmente a possibilidade de abrigar o novo órgão. Percebendo a cisão existente na conferência da UNESCO no Rio de Janeiro quanto ao destino geográfico da nova organização, Lagos decidiu improvisar uma candidatura para o posto e usou exatamente a mesma tática que Santa Cruz empregara ao propor a criação da CEPAL. Enviou ao seu país, no dia anterior, um telegrama dizendo: caso não se oponham, estamos propondo Santiago como sede para a FLACSO. Iniciativa que teria baixíssima chance de ser contestada em tão breve espaço de tempo. Ao fim, a conferência decidiu conciliar as demandas dos dois países, optando por criar um Centro

\footnotetext{
${ }^{238}$ Ver: http://www.genealog.cl/Chile/L/Lagos/\#LagosMarchant,Pedro. Consultado em 14/12/2105.
} 
Latino-americano de Pesquisas em Ciências Sociais no Brasil e uma Faculdade Latinoamericana de Ciências Sociais no Chile (BEIGEL, 2009, pp. 322-325; FRANCO, 2007, pp. 28-32).

A decisão tomada por Lagos não causou maiores controvérsias pois a proposta era convergente com o projeto de modernização do sistema universitário chileno e com a postura do Ministério das Relações Exteriores do Chile no que concerne à política internacional de cooperação científica. Como visto, havia sido criada uma instituição semelhante à FLACSO para o ensino de economia: Escuela Latinoamericana de Economía para Graduados da Faculdade de Economia da Universidade do Chile. Ademais, um dos líderes do processo de modernização da Universidade, o Reitor da UC Juan Gómez Millas, que fora presidente da Associação Internacional de Sociologia, também mantinha boas relações com Georges Friedmann. Fora ele a estabelecer em 1956 o acordo de cooperação científica com a École Pratique des Hautes Études en Sciences Sociales através do qual Friedmann enviara seus alunos Touraine, François Bourricaud, Daniel Reynaud, Lucien Brams e Edgar Morin para lecionar na FLACSO e estudar a mineração e a siderurgia chilenas. Foi depois de ter passado pelo Chile que Touraine colaborou com Fernando Henrique e os demais membros da Cadeira de Sociologia I de Florestan Fernandes no projeto que levaria à criação do CESIT, um Laboratoire de Sociologie Industrielle tropical (BEIGEL, 2009, pp. 322-325; 28-29; FALETTO, 2007, p. 193; FRANCO, 2007, p. 74 ROMÃO, 2006, pp. 112-114).

O contexto político no qual a proposta do CESIT transitou era bastante favorável à constituição de um espaço que fosse, ao mesmo tempo, um centro de produção acadêmica e um órgão capaz influenciar no debate sobre o desenvolvimento nacional e o planejamento, tão em voga nos anos 1950 e 1960. O CESIT foi articulado no ano de 1961 e passou a funcionar oficialmente em fevereiro de 1962. Em 1959 havia assumido o Governo do Estado de São Paulo Carlos Alberto Carvalho Pinto (1910-1987), cujo lema era: Mais administração e menos política. No projeto de racionalização da administração pública por ele conduzido, a Universidade e seus técnicos desempenhavam papel essencial, pois cabia a eles a missão de ajudar a conceber e legitimar, em nome da ciência, as diretrizes de modernização e o projeto de desenvolvimento que tinham para o Estado. Nesse cenário, o CESIT poderia dar bem vinda contribuição ao planejamento econômico e urbanístico elaborado por sua gestão, que já contava com suporte de outros grupos de 
intelectuais, como os economistas ligados a Delfim Netto e Ruy Leme (item 4.2), os arquitetos da SAGMACS e os politécnicos ligados a Paulo de Menezes Mendes da Rocha, diretor da POLI entre 1943 e 1947 - e pai do arquiteto internacionalmente consagrado Paulo Mendes da Rocha. Decidiram contar também com a expertise do BNDE, que acabara de coordenar o Plano de Metas, para elaboração da parte econômica do Plano de Ação. Primeiro convidaram Aníbal Villela, que indicou, em seu lugar, dois jovens funcionários do Banco: Sebastião Advíncula e Diogo Adolpho Nunes de Gaspar (ROMÃO, 2006, pp. 103-106; SAMPAIO, 2004, pp. 513-514).

Um dos principais assessores de Carvalho Pinto e coordenador do Plano de Ação do Governo, Plínio de Arruda Sampaio era, como o governador, advogado formado pela Faculdade de Direito do Largo São Francisco, democrata cristão e descendente de famílias paulistas tradicionais, autodenominadas quatrocentonas para diferenciar-se dos imigrantes e homens livres em ascensão social (SEVCENKO, 1992). Plínio vinha da família Arruda Sampaio, ligada por casamento aos Almeida Prado, aos Arruda Botelho e outras famílias de prestígio e posses. Seu pai, também formado pela Faculdade de Direito de São Paulo, foi figura importante do Ministério Público Paulista e era amigo de Carvalho Pinto, também proveniente de família de advogados e políticos. O avô materno de Carvalho Pinto, Virgílio Rodrigues Alves fora juiz de paz, senador e vice-presidente de São Paulo e seu tio avô Francisco Rodrigues Alves foi deputado, senador, Ministro da Fazenda, Presidente de São Paulo e finalmente Presidente da República. Ao final do governo Carvalho Pinto, Plínio de Arruda Sampaio daria início à sua própria carreira política sendo eleito, em 1962, deputado federal pelo Partido Democrata Cristão (DHBB verbetes: Plínio de Arruda Sampaio e Carlos Alberto Carvalho Pinto; SAMPAIO, 2004, pp. 511) 239 .

A aliança estratégica dos colegas do Colégio Perdizes, Plínio e Fernando, era um trunfo político para ambos, pois FHC ganhava um ponto de apoio no Estado e prestígio junto ao CO por seus laços com a política estadual e Plínio aproximava-se com mais facilidade da administração da universidade, o que era essencial na estratégia de modernização adotada por Carvalho Pinto. Com apoio de Arruda Sampaio e com participação intensa de Cardoso, os grupos progressistas da universidade - compostos por quadros das escolas à época dominadas, como a filosofia, a arquitetura e a economia,

239 Ver: http://www.apmp.com.br/index.php/noticias-01/2381-pai-de-plinio-de-arruda-sampaio-foi-um-dosfundadores-da-apmp e http://www.pucsp.br/cedic/colecoes/joao_batista.html. Consultados em 14/12/2015. 
e partes dominadas das escolas dominantes, como os comunistas da Medicina - fizeram uma aproximação com o governo de Carvalho Pinto, que resultou na queda do grupo mais conservador da reitoria, no aumento da verba da universidade e no iní́cio da construção da cidade universitária, a "Brasília de Carvalho Pinto"240 (ROMÃO, 2006, p. 108). Essa articulação viabilizou, ademais, a criação da Fundação de Amparo à Pesquisa do Estado de São Paulo (FAPESP), também fundada em 1962 (ROMÃO, 2006, pp. 107109; SAMPAIO, 2004, pp. 517-519).

$\mathrm{O}$ prestígio de Fernando Henrique junto à nova liderança do $\mathrm{CO}$ e junto ao governo do Estado foi essencial para que conseguisse aprovar o projeto do Centro de Estudos de Sociologia Industrial e do Trabalho que passaria a presidir. Os recursos iniciais do CESIT, por sua vez, vieram de outro elo pessoal de Cardoso, o engenheiro formado pelo Mackenzie e industrial do ramo têxtil Fernando Gasparian, um de seus melhores amigos. Laço reforçado pela amizade que a esposa de Gasparian, Dalva Funaro, irmã de Dílson Funaro 241 (item 5.1), mantinha com Ruth Cardoso desde os tempos de colégio. Gasparian, nacionalista e filiado ao PDC desde 1960, havia sido nomeado presidente da Confederação Nacional das Indústrias (CNI) por um dos Ministros do Trabalho de João Goulart, o democrata cristão André Franco Montoro (item 5.4). As linhas de pesquisa seguidas pelo CESIT eram particularmente apreciadas pelos industriais da CNI e pelo governo Carvalho Pinto, visto que o primeiro projeto ali desenvolvido, o Economia e Sociedade no Brasil, ocupava-se de tema precioso à São Paulo que queria correr em direção à modernidade: a indústria. Ao apresentar sua tese de livre-docência, Empresário industrial e desenvolvimento econômico no Brasil, FHC explica o enfoque do grupo:

\footnotetext{
240 “A qualificação da cidade universitária como "A Brasília de Carvalho Pinto” é bastante alusiva. As duas encarnavam projetos modernizantes realizados por grupos associados à elites intelectuais progressistas, representavam um deslocamento de uma estrutura central para uma área distante e pouco populosa - A USP ficava em uma área de várzea do Rio Pinheiros, praticamente um pântano - e representavam obras monumentais que contariam com a colaboração de importantes arquitetos modernistas para o desenho de seus prédios. Além dos prédios da Faculdade de Arquitetura e Urbanismo, de João Batista Vilanova Artigas, e da Faculdade de História e Geografia, de Eduardo Corona, que foram feitos conforme o projeto original e são ícones da arquitetura paulista, diversos outros prédios contaram com projetos feitos por outros arquitetos da faculdade que não foram construídos - como o prédio da Filosofia e Ciências Sociais, cujo projeto foi feito por Paulo Mendes da Rocha, o de Letras, de Fábio Penteado, o de Geociências, de Pedro Paulo Melo Saraiva, e o da Matemática, de Joaquim Guedes - pois o improviso acabou prevalecendo em relação ao planejamento" (ROSATTI, 2012, p. 2).

${ }^{241}$ Se Fernando Gasparian foi a fonte essencial de recursos para a montagem do primeiro Centro de Estudos dirigido por Fernando Henrique, o CESIT, Dílson Funaro, irmão da esposa de Gasparian, que era Secretário da Fazenda do governo do Estado de Abreu Sodré, foi o contato que permitiu que obtivesse os fundos para a montagem do seu segundo centro de pesquisas, o CEBRAP, em 1969 (CARDOSO, 2012b, p. 200; CARDOSO, 2012, p. 37).
} 
O presente estudo sobre os empreendedores é o primeiro destes trabalhos que chega à termo. Em breve seguir-se-ão outros onde a "sociedade industrial" que se forma no Brasil aparecerá na multiplicidade de seus aspectos: o Estado e o desenvolvimento econômico, a mobilização do operariado, as disparidades regionais do desenvolvimento, a estrutura da indústria paulista, os problemas de qualificação da mão-de-obra, são os temas a que se dedicam os companheiros de trabalho intelectual da cadeira de sociologia I e do CESIT (CARDOSO, 1964, p. $5)$.

Ao selecionar tais tópicos para suas pesquisas, os membros do CESIT inseriam-se nas discussões sobre planejamento e desenvolvimento que fervilhavam em um Brasil no qual a política econômica passara a ser dominada pelos desenvolvimentistas cosmopolitas ou nacionalistas (SOLA, 1998) - que fizeram o Plano de Metas, o Plano Trienal, que estavam na Federação das Indústrias do Estado de São Paulo (FIESP), no CNI, no BNDE, na SUDENE e em outros órgãos centrais, como visto no Primeiro Movimento (CARDOSO, 2006, p. 74; CARDOSO, 2012b, p. 200; KEINERT, 2011, pp. 64-65; ROMÃO, 2006, pp. 28, 36, 119).

Pouco depois da criação do CESIT, o vínculo com Touraine levaria Fernando Henrique para uma temporada na França. Uma parte da verba do CESIT passou a ser alocada em bolsas de estudo a serem concedidas aos membros do centro para estudos complementares no exterior. Os dois primeiros beneficiados foram Octávio Ianni, segundo assistente de Florestan Fernandes, que foi enviado para estudar desenvolvimento industrial na London School of Economics (LSE) e Fernando Henrique que foi, no inverno de 1962 para 1963, para o Laboratoire de Touraine na École Pratique des Hautes Études en Sciences Sociales em Paris. Nos quatro meses em que ali reside, Cardoso prepara a sua tese de livre-docência, que dará origem ao livro Empresário industrial e desenvolvimento econômico no Brasil (1964), que foi feito com base em entrevistas realizadas com industriais de São Paulo, Blumenau, Recife, Belo Horizonte e Salvador e com os dados coletados no survey sobre as indústrias da grande São Paulo desenhado e conduzido pelo CESIT (CARDOSO, 1964, p. 6; GARCIA, 2004, pp. 292; ROMÃO, 2006, p. 124).

$\mathrm{Na}$ França, o casal Cardoso vivia na Maison Internationale e Bento e Lúcia Prado na Maison du Brésil na Cité Universitaire. Enquanto Fernando Henrique transitava no laboratório de Touraine, proferia algumas conferências sobre a sociedade brasileira baseadas em suas pesquisas e nas de seu grupo e escrevia sua tese, Ruth frequentava os cursos de Claude Lévi-Strauss, aprofundando seu treinamento em antropologia e reforçando os laços com o estruturalismo. Nas férias partem os Prado e os Cardoso no 
carro de FHC para Florença, onde Arthur Giannotti os aguardava para ciceronear os amigos pela arte italiana, da qual julgava ser bom conhecedor (BRANDÃO, 2010, pp. 71 72; RODRIGUES, 2011, p. 160).

De volta ao Brasil, Fernando Henrique obtém a livre-docência, ocupa-se da direção do CESIT e leciona na FFCL. Alguns dias depois do golpe de 1964, Ruth Cardoso e Lourdes Sola alertam Fernando Henrique para não ir à faculdade porque estava sendo esperado por agentes da repressão. Suas ações reformistas no CO, os trabalhos no CESIT e sua ligação com empresários nacionalistas qualificavam-no como um homem à esquerda. Além disso, logo depois do golpe, esteve ao lado de Francisco Weffort, que discursara em Assembleia dos Professores da USP falando sobre a inépcia dos militares para governar o país (BRANDÃO, 2010, pp. 75; GIANNOTTI, 2009, p. 55).

Fernando Henrique comenta haver sido denunciado como subversivo pelos colegas de direita da Faculdade, que ganhariam espaço com a saída dele da docência e da política universitária. Pouco depois de tomar o poder, a ditadura instalou um Inquérito Policial Militar na USP para acabar com as atividades subversivas. Os grupos conservadores que se opunham aos modernizadores que chegaram ao poder com Carvalho Pinto teriam aproveitado para reconquistar o poder delatando seus adversários como esquerdistas. FHC escondeu-se na casa de amigos até que Maurício Segall - o mesmo que escondera Serra -, conseguiu mobilizar seus contatos na Air France para identificar em que aeroporto ele não constava na lista dos procurados. FHC embarcou para a Argentina no aeroporto de Campinas (Fernando Henrique Cardoso Apud BRANDÃO, 2010, p. 76; CARDOSO, 2006b, p. 81; ROMÃO, 2006, pp. 130-131).

Ao chegar em Buenos Aires recebeu convites dos sociólogos Gino Germani e Torquato Di Tella para lecionar no departamento de sociologia da Universidade de Buenos Aires (UBA). Lá também encontra-se com seu colega Nuno Fidelino Lobo da Costa Figueiredo (1923), economista formado na Universidade de Lisboa com doutorado em Economia Política obtido na FFCL, filho do Nuno Figueiredo que o aconselhara a entrar para a Faculdade de Filosofia. Nuno Fidelino Lobo fora colega de docência de FHC na FCEA e na FFCL e, por influência de Cardoso, tornara-se diretor da Comissão de Desenvolvimento Industrial e Planejamento (CODIPLAN), órgão ligado ao CESIT, onde trabalhava também o economista da FCEA e do seminário do Capital, Sebastião Advíncula, membro do Departamento Econômico do BNDE. Nuno era diretor da 
divisão de desenvolvimento industrial da CEPAL desde 1957 e conseguira, inclusive, um financiamento da Comissão Econômica para ministrar no CODIPLAN um curso sobre o desenvolvimento econômico da América Latina (CANABRAVA, 1984a, p. 237; CEPAL, 1960, pp. 4-5; CEPAL, 1963, p. 3; RODRIGUES, 2011, p. 162; ROMÃO, 2006, pp. 124125).

Também FHC tivera alguma cooperação com a CEPAL nos anos pré-golpe. No agradecimento de sua tese de livre-docência, FHC já menciona o apoio dado pela CEPAL à sua pesquisa (CARDOSO, 1964, p. 10). Conta, em uma de suas entrevistas, que havia feito um trabalho, via CESIT, para uma das pesquisas que José Medina Echevarría, sociólogo weberiano e principal cientista social da CEPAL, conduzira no início dos anos sessenta sobre os aspectos sociais do desenvolvimento da América Latina (CARDOSO, 2012, p. 22). Enzo Falleto esclarece:

Don José dirigia o setor de desenvolvimento social na CEPAL [...]. Antes que FHC chegasse, eu trabalhava com Don José em um informe para a Conferência de Mar del Plata, em 1962, "O desenvolvimento social na América Latina", que era a contraparte de um informe sobre o desenvolvimento econômico. Era a primeira vez que se procurava realizar um trabalho sistemático sobre o desenvolvimento social da América Latina. Don José já havia feito algumas coisas sobre os aspectos sociais do desenvolvimento, mas era uma formulação teórica, isto é, como enfocar uma sociologia do desenvolvimento na América Latina. Era algo como os trabalhos do [sociólogo argentino Gino] Germani, de Florestan, no Brasil. No trabalho para o informe havia-se pensado em alguns grupos sociais claros como importantes para o desenvolvimento. Um deles era o grupo empresarial. Em vários países, os pesquisadores se encarregaram de estudar os empresários. No Brasil, quem fez este trabalho foi FHC. Foi a primeira vez que tive conhecimento do seu trabalho (FALETTO, 1995 [online]).

FHC atua como consultor convidado pela CEPAL e envia a Medina um relatório intitulado El empresario industrial en América Latina, incluído nos documentos apresentados na décima reunião da CEPAL, realizada em Mar del Plata em 1963. Na Argentina, Nuno Fidelino Lobo transmitiu a Fernando Henrique a intenção de José Medina Echevarría de levá-lo para a organização internacional, em Santiago, convite que FHC aceitou prontamente (CARDOSO, 2006b, p. 86; CEPAL, 1963a).

Como os dois Nunos Fidelino, que deixaram Portugal, e Fernando Henrique, que agora afastava-se do Brasil, José Medina também era exilado, o que criava uma solidariedade entre esses homens afastados de suas terras por suas aspirações políticas e acadêmicas. José Medina Ramón Eschevarría (1903-1977) nasceu na Espanha, em Castellón de la Plana. Seu pai era funcionário do Ministério da Fazenda, trabalhando em 
Barcelona, e o avô paterno era tenente-coronel da Marinha. José Medina fez seus estudos em Barcelona e em Valência. Na sequência ingressou na Faculdade de Direito da Universidade de Valência, seguindo para o doutorado em filosofia na Universidade Central de Madrid. Durante o doutorado conseguiu uma bolsa de um ano para estudar na Universidade de Paris, onde tomou contato com a sociologia de Émile Durkheim e de Augusto Comte. Ao concluir a tese, Medina segue para Marburg, na Alemanha, onde teve contato com as obras de Karl Mannheim, Georg Simmel e Alfred e Max Weber, sendo o último a sua maior influência teórica. De volta à Espanha, Echevarría trabalhou como Oficial Letrado de las Cortes, na Câmara dos Deputados, e tornou-se professor assistente da cadeira de filosofia do direito na Universidade Central de Madrid. Malgrado estar alocado na Faculdade de Direito, transitou progressivamente da filosofia jurídica à sociologia. Em 1935 passa a ser professor catedrático de filosofia do direito na Universidade de Múrcia e começa a editar a Serie Sociológica da Editorial Revista de Derecho Privado. Pouco depois conquista a cátedra da Universidade Central de Madrid e prepara seu libro Panorama de la sociología contemporánea, uma das primeiras obras da área de sociologia elaboradas na Espanha, cuja publicação só ocorreria em 1940, pois foi interrompida pela Guerra Civil Espanhola.

A Guerra Civil, iniciada em 1936, pôs fim à sua trajetória acadêmica na Espanha. Em setembro de 1936 anunciaram que ele não poderia desfrutar da bolsa que solicitara para estudar na Inglaterra e nas universidades de Columbia e Chicago nos Estados Unidos. Na metade de 1937, com o progressivo controle do estado pelos franquistas, instaura-se um inquérito que acusa Echevarría de ter ideias extremistas, ser apoiador da Frente Popular, dos grupos esquerdistas e trabalhar para a imprensa vermelha. Sua licença para exercer cargos de direção e confiança em instituições culturais e de ensino foi logo suspensa e sua cátedra foi arrancada por seu maior adversário, um membro-fundador da agremiação política fascista Falange Española Tradicionalista (MARTíN, 2010, pp. 134$135)^{242}$.

No final de 1937, Medina parte para a Polônia com a família. Trabalha diretamente com o embaixador da Espanha em Varsóvia até 1939, quando inicia sua viagem ao México. Em maio de 1939 chega ao Distrito Federal mexicano, onde havia uma colônia

\footnotetext{
242 Ver:

http://portal.uc3m.es/portal/page/portal/instituto_figuerola/programas/phu/diccionariodecatedraticos/lcatedratico s/mechevarria. Consultado em 15/12/2015.
} 
de acadêmicos espanhóis exilados. Lá viveu até 1946. Ele ajudou a trazer a sociologia alemã para o México, traduzindo para o espanhol o clássico Economia e sociedade de Max Weber, obra que foi publicada pelo Fondo de Cultura Económica ${ }^{243}$, editora que mantinha uma coleção sobre sociologia da qual era editor e coordenador. Começou também a lecionar na Universidad Nacional Autónoma de México (UNAM) e no Centro de Estudos Sociales (CES) do Colegio de México. Em 1944, Raúl Prebisch estava no México para realizar uma série de conferências no Banco de México a convite de Victor Urquidi e Cossío Villegas, dois colegas do CES que trabalhavam no Banco e eram ávidos seguidores de Don Raúl. Resolveram convidá-lo para fazer a conferência inaugural de um seminário sobre América Latina que Medina estava organizando no CES e foi nessa ocasião que eles travaram contato pela primeira vez (BABB, 2003, p. 107; HODARA, 2008, p. 49).

A realização deste seminário sobre a América Latina e a publicação de Jornadas, revista do CES, serviram para Medina apresentar-se e fazer-se conhecer em uma comunidade científica maior do que a mexicana, a latino-americana. Medina teve a oportunidade de estabelecer uma relação com Raúl Prebisch, com quem se encontraria, anos depois, na CEPAL em Santiago do Chile. Se Prebisch apoiou em vários momentos a carreira de Medina Echevarría, deveu-se também a Alfonso Reyes, diretor do Colegio de México, e a Daniel Cossio Villegas, secretário da mesma instituição, que eram muito próximos dele há anos, quando Prebisch dirigia o Banco Central da Argentina. Além disso, Victor Urquidi, embora mais jovem, também tinha uma relação excelente e próxima tanto com Prebisch quanto com Medina (URQUIDI, 1986). Parece claro, portanto, que estes três mexicanos facilitaram o contato entre Medina e Prebisch (MARTÍN, 2010, p. 145).

Víctor Urquidi (item 1.2) conta que o impressionava muito que

Medina estava completamente a par do pensamento econômico neoclássico recente e havia lido e compreendido Keynes. Conversávamos muito sobre isso, já que seu conhecimento dos escritos de Keynes era maior do que o de muitos economistas locais. As discussões sobre planejamento eram frequentes, como resultado da Teoria Geral keynesiana, das obras de Schumpeter e outras (URQUIDI, 1986, p. 6).

\footnotetext{
${ }^{243}$ A editora Fondo de Cultura Económica logrou suprir uma lacuna de literatura sobre economia e ciências sociais em língua espanhola produzida na América Latina. Estavam envolvidos com a criação do Fondo de Cultura os mesmos professores que estavam engajados na formação do departamento de economia da UNAM e na organização das ciências sociais no México. O mesmo grupo criou pouco depois a primeira revista de economia mexicana, EL trimestre económico, que data de 1934, dez anos antes das primeiras revistas brasileiras de economia. O Fondo de Cultura teve influência decisiva não só no México e nos países de língua espanhola. Também os economistas brasileiros passaram a ler a maior parte das obras de economia nas traduções feitas por eles. Diversos deles relatam em entrevistas ter adquirido fluência do espanhol desta maneira, pois era a língua na qual estava disponível a bibliografia econômica (BABB, 2003, pp. 81-82).
} 
Medina e Urquidi foram nesse período professores de Juan Francisco Noyola Vázquez, que como eles iria trabalhar para a CEPAL, integrando-se à “divisão vermelha" comandada por Celso Furtado (item 1.5) (URQUIDI, 1986, p. 6).

Segundo Furtado, logo após a conclusão da conferência do México, em 1951, ele discutiu com Prebisch a possibilidade de que fossem incluídos nos quadros da CEPAL estudiosos de outras ciências sociais:

[Prebisch] reagiu favoravelmente e indagou se eu tinha alguém em mente. Disselhe que convinha que começássemos por um sociólogo de peso, e que havia pensado em Juan Medina Echevarría, de quem tracei um pequeno esboço biográfico. Aparentemente ele não o conhecia [na realidade o conhecia da conferência do CES em 1944], mas autorizou-me a procurá-lo. Havia partido da hipótese que José Medina ainda vivia no México, onde se estabelecera desde o fim da Guerra Civil Espanhola. [...] Logo fui informado pelo economista mexicano Juan Noyola Vásquez, que acabava de incorporar-se ao nosso staff, e fora aluno de José Medina na antiga Casa de España (depois transformada em Colegio de México), de que o maestro, como o qualificava, já havia alguns anos vivia em Porto Rico, a cuja universidade se ligara. Mas não desanimei, e decidime a visitá-lo em seu refúgio. Aportei a San Juan e sem aviso prévio apresenteime na universidade [...] Falou-me da pobreza da vida intelectual em San Juan, cuja universidade era um college norte-americano, com suas qualidades e seus defeitos. Mas, ainda assim, ele tinha mais tempo para estudar e escrever do que no México, onde viver como intelectual, sem ocupar um cargo público, era extremamente penoso [...]. Expus-lhe o alcance e a orientação dos nossos trabalhos, o interesse que tinha pessoalmente em aproximar a economia da história, o importante que seria a constituição na CEPAL de um núcleo de estudos sociológicos, a penetração que começavam a ter nossos trabalhos no mundo universitário latino-americano, o bom que era o clima de Santiago, essa miniatura de metrópole, o buquê dos vinhos chilenos. No elã em que me embalei, quase falo da beleza da mulher chilena. Ele me olhava com um ar meio divertido. Anos depois, diria que me olhara daquela forma, meio perplexo, porque poucas vezes teria visto alguém que irradiasse uma confiança tão grande em poder alcançar o que queria. Disse-me que ia pensar e escreveria a Santiago. José Medina, com seu ar modesto, sem jamais forçar a passagem, viria a ser o grande mestre da sociologia do desenvolvimento na América Latina. Que o diga Fernando Henrique Cardoso, e tantos outros que com ele trabalharam em Santiago (FURTADO, 2014, pp. 110-111).

Em 1952 começou a funcionar o núcleo de estudos sociológicos na CEPAL sob sua direção (MARTÍN, 2010, pp. 146-147; FALETTO, 2007, p. 194). Em 1957, Medina é indicado pelo diretor do Departamento de Sociologia da UC, Eduardo Hamuy Berr ${ }^{244}$ (1916-1989), casado com Tereza Santa Cruz, irmã de Aníbal Pinto (item 1.5), e próximo de

\footnotetext{
${ }^{244}$ Eduardo Hamuy Berr (1916-1989) havia estudado leis e filosofia na UC e iniciado a pós-graduação em sociologia - sobretudo nas áreas de métodos e técnicas de pesquisa - em Columbia. Mesmo tendo regressado ao Chile sem concluir o doutorado, tornou-se diretor do departamento de sociologia de 1952 a 1961. Nos anos seguintes fundou um instituto de pesquisas de opinião e tornou-se diretor do CESO da Faculdade de Economia da UC (1965-1967) (BLANCO, 2007, p. 99), https://fr.scribd.com/user/251311058/Archivo-Eduardo-HamuyBerr-1916-1989\# e http://www.genealogiachilenaenred.cl/gcr/IndividualPage.aspx?Id=I91619. Consultados em 29/01/2016.
} 
Juan Gómez Millas, para ocupar o cargo de primeiro diretor da FLACSO, afastando-se temporariamente da CEPAL. Mas a estadia na FLACSO foi breve graças às divergências com Gustavo Lagos e Peter Heintz, acerca da orientação da escola. Peter Heintz, que assumiu a direção no lugar de Medina, era suíço, formado em economia política na Universidade de Zurique e em sociologia na Universidade de Colônia, além de fortemente influenciado pela sociologia quantitativa norte-americana. Fazia dupla na FLACSO com Johan Galtung, norueguês matemático e sociólogo que havia sido discípulo de Paul Lazarsfeld ${ }^{245}$ em Columbia. Heintz, Galtung e Lagos acabaram afastando Medina e, na sequência, Hamuy, considerados por eles ultrapassados para uma escola que pretendia oferecer uma formação com marcante "caráter científico" - não puramente humanista -, na qual modernos métodos de pesquisa deveriam estar colados à formulação teórica (BLANCO, 2007, pp. 95, 98, 100, 107-108; FRANCO, 2007, pp. 60, 65).

Schwartzman, um dos três colegas de Vilmar e Regina Faria de Minas Gerais que foram para a FLACSO antes deles, explicita essa orientação ao relatar que Octávio Cintra, Fábio Reis e ele foram entrevistados e recrutados pelo sociólogo francês e professor de metodologia Lucien Brams para ir para o Chile com bolsas da Organização dos Estados Americanos (OEA). Segundo ele Brams explicou que na FLACSO:

\begin{abstract}
faziam uma coisa que era juntar a tradição francesa (que eu conhecia - a gente lia os franceses) com uma coisa que a gente não conhecia - que era a tradição da sociologia empírica americana - e que a gente ia aprender isso. Que era uma coisa que a gente não conhecia [...]. O Lucien Brahms, que foi esse professor que nos convidou, ele, rapidamente, foi embora; no ano seguinte, ele tinha ido embora já. E depois veio o Johan Galton [sic] [Johan Galtung], que era o norueguês [formado nos EUA] que dava aula de metodologia [...]. Aí que eu comecei a ler inglês, por exemplo. Eu não tinha lido. Mal sabia ler inglês quando fui para lá. Comecei a ler os autores americanos, conhecer a tradição... O Galton [sic] tinha uma formação muito na linha da tradição de Columbia, então a tradição de Lazarsfeld. Lazarsfeld é um alemão, mas ele é que introduz e desenvolve a sociologia quantitativa nos Estados Unidos, na verdade. E o Robert Merton, que é o sociólogo da teoria de alcance médio. Então eu comecei a ver essa literatura, que era basicamente da Escola de Columbia que o Galton [sic] tinha trazido (SCHWARTZMAN, 2010, pp. 6-7).
\end{abstract}

Essa inflexão na FLACSO tem grande efeito sobre a formação desse grupo de brasileiros. Octávio Cintra, Fábio Reis e Simon Schwartzman retornaram ao Brasil em

\footnotetext{
${ }^{245}$ Austríaco com doutorado em matemática pela Universidade de Viena que foi estudar nos EUA com uma bolsa da Rockefeller Foundation e tornou-se especialista em metodologias quantitativas voltadas às áreas de psicologia e ciências sociais. Ver: http://www.asanet.org/about/presidents/Paul_Lazarsfeld.cfm. Consultado em $25 / 01 / 2015$.
} 
1964 e passaram a lecionar na UFMG ${ }^{246}$, trazendo com eles para Minas os conhecimentos de teoria social e dos métodos quantitativos dominantes nos EUA, impulsionando os alunos a ler teoria contemporânea em inglês. Foi para alguns dos estudantes um passo penoso, mas acelerava a possibilidade de inserção internacional das novas gerações (KEINERT, 2011, pp 124-125; REIS, 1998, p. 6). José Murilo de Carvalho, outro aluno do grupo dos bolsistas, conta que:

Eu, por exemplo, com uma diferença de dois, três anos para os colegas, cheguei a ser aluno do Fábio, do Antônio Otávio e do Simon, que tinham ido à FLACSO e voltado. E aí sim, entrou um outro estilo de pensamento, uma outra orientação: entrou a ciência política americana, via FLACSO. Não foi realmente minha ida para os Estados Unidos que me introduziu a esse campo; comecei a ler os autores na bibliografia do Antônio Otávio, do Simon Schwartzman, do Fábio Wanderley (CARVALHO, 1998, p. 362).

Carvalho chegou a ser entrevistado para ir para a FLACSO, mas como não soube resolver algumas equações não conseguiu a bolsa ${ }^{247}$. Ele comenta: “isso já mostra o estilo de orientação deles, particularmente do Galtung: uma orientação muito matemática, muito quantitativa, que tinha muito a ver com a ciência social norte-americana" (CARVALHO, 1998, p. 362).

A revolução quantitativa e a entrada das teorias norte-americanas nas ciências sociais latino-americanas são conduzidas por matemáticos e economistas que, em paralelo ao que estava ocorrendo na ciência econômica, aderiam-se à matematização, que revestia de cientificidade as ciências sociais. Pouco antes da FLACSO ser fundada, chegava ao Chile a missão dos economistas da Universidade de Chicago que aportavam a ciência econômica de matriz neoliberal, sustentada sobre elegantes modelos matemáticos, para a América Latina, tema que será discutido adiante (item 4.4).

Afastado da FLACSO, Medina regressou à CEPAL em 1959 e, no final de 1963, passou a ser o diretor da divisão de desenvolvimento do ILPES. Foi lá que Fernando Henrique encontrou com ele em 1964. Como Echevarría mantinha ainda laços com a

\footnotetext{
${ }^{246}$ Pouco depois de começar a lecionar em Belo Horizonte, Simon Schwatzman foi preso, pois sabiam de seu envolvimento prévio com a esquerda estudantil. Ficou um mês na cadeia. Depois conseguiu, com ajuda de seu professor da FLACSO Johan Galtung, bolsa para estudar em Oslo, partindo em dezembro de 1964. Na volta trabalhou por algum tempo em Buenos Aires, no Instituto Di Tella, e então conseguiu bolsa de doutorado da Fundação Ford para estudar na UC Berkeley. Voltou para o Brasil em 1968 e logo teve sua vida buleversada pelo AI-5. Acabou indo trabalhar no Rio de Janeiro, ao invés de voltar para Belo Horizonte como previsto no acordo com a Ford, pois sentia que não havia abertura política para lecionar na UFMG. Aceitou convite para integrar-se à equipe do Instituto Universitário de Pesquisa do Rio de Janeiro (IUPERJ), onde atuaram vários de seus colegas de Minas Gerais (SCHWARTZMAN, 2010, pp. 8-12).

${ }^{247}$ José Murilo acabou indo para Stanford, onde foi contemporâneo do cientista Wanderley Guilherme dos Santos (CARVALHO, 1998, p. 367).
} 
FLACSO, rapidamente abriram-se portas para que FHC também lá lecionasse. O convite é estendido a Ruth Cardoso que passou a lecionar ciências sociais na UCC e na FLACSO e organizou seminários sobre o livro $O$ pensamento selvagem, sendo uma das responsáveis pela difusão, no Chile, da obra de Lévi-Strauss, que fora seu professor na França (FALETTO, 2007, p. 203).

Enquanto Ruth e os filhos do casal não haviam se transladado para o Chile, Fernando Henrique Cardoso morou em uma espécie de república de adultos com Celso Furtado, com seu aluno Francisco Weffort, que também foi incorporado ao ILPES e com o colega também docente da área de sociologia Wilson Cantoni (1926-1977), socialista que até o golpe lecionava na Faculdade de Faculdade de Filosofia, Ciências e Letras de São José do Rio Preto, onde tinha como assistente Michel Löwy, recrutado através da Liga Socialista Independente. Eles recebiam em casa outros exilados como Paulo Freire, Thiago de Mello, Jader de Andrade, Francisco de Oliveira e Estevam Strauss para discutir o que ocorria no Brasil (Fernando Henrique Cardoso Apud BRANDÃO, 2010, p. 79; CARDOSO, 2006b, p. 86; LÖWY, 1996).

Furtado conta que nessas conversas:

Concordávamos todos em que o Brasil não fugiria ao quadro geral da América Latina, mas não nos escapava que a explicação do que ocorrera entre nós tinha de ser buscada na realidade particular de nosso país. Que estaria acontecendo no Brasil. Esta questão a ser respondida antes de tudo o mais. Estávamos convencidos de que não se tratava de um simples assalto ao poder, no estilo de um Pérez Jiménez, na Venezuela, ou de um Fulgencio Batista, em Cuba. Era fácil carregar as tintas a propósito da irresponsabilidade e imaturidade das esquerdas. Chegavam-me muitas cartas de amigos que me interpelavam sobre os fatos. Do professor Maurice Byé, de Paris, de Dudley Seers, que andava então pela África, de Werner Baer, que estava em Yale, de Albert Hirschman, de Princeton (FURTADO, 2014, p. 424).

Ao mesmo tempo que ocorriam esses debates informais os exilados começaram a elaborar hipóteses teóricas acerca dos eventos que desembocaram no golpe. Um dos espaços nos quais corriam as tentativas de análise acerca das raízes sociais e econômicas do fenômeno era o próprio ILPES que, sob a direção de Furtado, estava conduzindo uma releitura dos clássicos da CEPAL “à luz da experiência recente da perda de dinamismo das principais economias latino-americanas" (FURTADO, 2014, p. 423), tendo como questão de fundo a instauração do regime ditatorial no Brasil.

As questões debatidas naquele seminário não eram totalmente novas para Furtado. Seu livro de 1961, Desenvolvimento e subdesenvolvimento, apresentava na seção "Problemas e 
tendências atuais" o seguinte questionamento: face a um cenário de ascensão da industrialização em diversos países latino-americanos, que chegou em casos como o do Brasil próxima ao ponto em que havia diferenciação suficiente para dar impulso a um processo de produção de dentro para dentro, o que ocorreria quando se esgotassem os impulsos oferecidos pela substituição de importações e houvesse uma queda no ritmo de crescimento? Apresenta ele uma hipótese segundo a qual:

Se assim ocorrer, caminhará o Brasil para uma etapa de agudas tensões sociais, em contraste com o clima de relativa harmonia que caracterizou os últimos decênios. As pequenas fricções da fase das grandes ondas inflacionárias nada serão comparadas com as tensões que advirão de uma redução no ritmo de crescimento. É, portanto, perfeitamente possível que estejamos entrando numa daquelas fases decisivas em que os problemas tipicamente políticos adquirem forte ascendente sobre os demais, inclusive os econômicos (FURTADO, 1961, p. 266).

Ele argumenta que esse cenário só poderia ser evitado se o país caminhasse em direção à combinação de aumento de produtividade nas indústrias, com uma maior transferência dos frutos dessa produtividade para os assalariados, e de uma transformação na estrutura agrária que permitisse racionalizar o uso dos fatores terra e mão-de-obra, ou seja, caminhar em direção a uma sociedade mais produtiva e menos desigual no campo e na cidade (FURTADO, 1961, pp. 267-268).

Furtado não parece confiante quanto às chances de que semelhante movimento de aprofundamento da igualdade ocorra, posto que ele encontraria forte obstáculo político naqueles que temem perder os privilégios enraizados na ordem social até então vigente. Receava que a permanência no poder de grupos ligados aos interesses agrárioexportadores - as oligarquias regionais que tanto combatera enquanto atuava na SUDENE - e outras forças conservadoras levassem a políticas falhas e incoerentes e não ao avanço social (FURTADO, 1961, pp. 254, 268). A explicação que ele oferece para os entraves ao desenvolvimento econômico e social não residia, pois, na economia em si, mas na estrutura de classes e nos embates por elas travados. Nessa leitura a teoria cepalina começa a ganhar um enfoque sociológico, para além do economicismo, que era precisamente o que se intencionava ao trazer Echevarría e outros sociólogos para a instituição.

O livro de Furtado Dialética do Desenvolvimento (1964), escrito pouco antes do golpe, apresenta uma interpretação ainda mais explícita da situação: “o impasse em que se encontra a economia do país, submetida a uma série de estrangulamentos estruturais, é 
por sua natureza uma situação instável”. A instabilidade criada pela não realização do desenvolvimento adquiriria "a energia potencial das águas de um rio barrado" que poderia levar a uma "ruptura do equilíbrio de forças existente e à superação dos métodos políticos convencionais" em duas direções possíveis: seja levando a uma transformação social, via tomada de consciência que indicaria que a solução dos problemas básicos e um novo projeto nacional não seriam equacionados dentro do quadro institucional comandado pelos antigos grupos dirigentes; seja à arraigada defesa dos interesses e privilégios dos grupos dirigentes que prevaleceriam "sobre os fatores dinâmicos causando a estagnação" (FURTADO, 1964, pp. 134-136).

Diante da "atuação mais agressiva das massas trabalhadoras e a extensão dos conflitos sociais aos campos" as frações da elite agrária e industrial, que viviam em constante luta, tenderiam a esquecer suas contradições internas e unir-se em oposição às forças insurgentes (FURTADO, 1964, pp. 81, 123). O pacto das frações de elite notadamente latifundiários e exportadores, de um lado, e capitalistas industriais, em aliança com o Estado, de outro - contra aqueles que buscavam amplas transformações sociais revelaria o quanto a estagnação do desenvolvimento, resultante das concessões às frações da classe dirigente que se beneficiam do atraso, teria raízes antes na estrutura social do que na economia nacional. O que teria se evidenciado, por exemplo, nas tensões provocadas pelos programas de reforma propostos por órgãos como a SUDENE ou mesmo a Aliança para o Progresso. Não era a falta de recursos econômicos ou de projetos o principal impecílio à melhoria das condições de vida, e sim a pressão política para a conservação da estrutura social desigual.

Uma vez postulada a centralidade do estudo das estruturas sociais e de poder, Furtado critica a abordagem que se restringe ao econômico e propõe novo programa de investigações no qual:

O subdesenvolvimento deve ser entendido, em primeiro lugar, como um problema que se coloca em termos de estrutura social. O fato de que sejam os seus aspectos econômicos os mais estudados e conhecidos é simples confirmação da tese geral de que, no processo de desenvolvimento social, aos fatores econômicos cabe, quase sempre, papel predominante. Desta forma a caracterização do subdesenvolvimento em termos estritamente econômicos, sendo tarefa mais simples, constitui método perfeitamente legítimo com vistas a uma primeira formulação do problema. Seria, entretanto, equívoco total esperar que os economistas, usando os instrumentos de análise que lhe são próprios, viessem a esgotar essa matéria, que possui importantes aspectos a serem abordados do ângulo da sociologia e da ciência política. Pensar em subdesenvolvimento em termos de renda per capita constitui, entretanto, uma das obsessões de nossa época com sérios reflexos negativos para uma 
compreensão global do problema no plano histórico. Aos economistas coube extraordinária tarefa no desbravamento deste campo de pesquisa social, mas já não é possível continuar a apoiar-se apenas neles para orientar-se com segurança nesta complexa matéria. Assim, continuamos a falar de planejamento econômico como se se tratasse de um problema de opção entre técnicas elaboradas por hábeis economistas, quando o planejamento pressupõe a formulação de políticas e uma atitude com respeito ao grau de racionalidade que se deseja alcançar em política econômica. Ora, não cabe pensar em política senão em termos de fatores que condicionam o exercício do poder, o que exige superar os "modelos analíticos" e abordar a atividade humana concreta dentro de uma realidade histórica (FURTADO, 1964, pp. 77-78).

É essa perspectiva que baliza as discussões do grupo que se reunia no ILPES com a participação de economistas e sociólogos. Transcender a fronteira da economia e conceber a barreira ao desenvolvimento como um problema da estrutura social de classes e de suas relações de poder foi o caminho por eles trilhado para a explicação da crise econômica na América Latina e da acentuação das contradições sociais que teriam levado ao golpe no Brasil - e levariam a outros tantos na sequência.

Fernando Henrique Cardoso reporta que o seminário de Furtado "foi muito importante para mim, [...] foi uma reavaliação do trabalho da CEPAL feita pelo Prebisch, pelo Celso Furtado, pelo Aníbal Pinto, pelo Osvaldo Sunkel, aí estávamos eu, o Weffort, o Faletto" (CARDOSO, 2012, p. 22). Faletto, por sua vez, afirma que foi então que começou a ser gestado o Dependência e desenvolvimento na América Latina (1969), que escreveu com Cardoso, certamente enquadrado no programa de pesquisa delineado por Furtado (FALETTO, 2007, p. 203).

Enzo Faletto (1935-2003) nasceu em Santiago, filho de um comerciante italiano que chegara ao Chile em 1924 com “uma mala e um salame na mão" e tornara-se dono de um armazém de bens alimentícios em Santiago (FALETTO, 2007, pp. 212-213). A mãe passou parte da juventude na Itália e acabou regressando ao Chile, onde nascera. Faletto relata ter sido um aluno problema, que não frequentava a escola com regularidade, foi expulso do colégio naval, trabalhava enquanto estudava, de modo que, diz ele, se tornou em alguma medida autodidata. Apesar da educação básica falha, logrou ingressar, em 1955, na licenciatura em geografia e história da UC. A aproximação com a sociologia ocorreu por intermédio de um colega de militância do grupo anarquista Juventude Libertária que estava trabalhando no Instituto de Sociologia. Ele comunicou a Enzo que o Instituto estava buscando alunos para trabalharem na pesquisa da área de sociologia do trabalho, que a missão francesa de Friedmann e seus discípulos estava conduzindo no 
Chile. Ele conta que: "como bom anarquista, odiava qualquer assunto relacionado com o mundo da indústria. Mas meu amigo me disse que provavelmente a participação no grupo seria remunerada, ou seja, um espírito mercenário foi decisivo para a minha inclinação pela sociologia". Foi assim que, em 1957, ingressou no grupo liderado por Alain Touraine (FALETTO, 2007, p. 191).

Em meados de 1958, recusa o convite de Touraine para ir estudar na França, ingressando na primeira turma de pós-graduação da recém-criada FLACSO, onde tornase aluno e discípulo de Medina Echevarría. Ao concluir o curso, leciona por um ano e meio na Faculdade de Economia da UC, onde havia um centro de estudos interdisciplinar sobre planejamento, e, no início de 1962, é convocado por Medina para ajudar a preparar o informe social que a CEPAL deveria enviar para a conferência de Mar del Plata, intitulado Desenvolvimento social na América Latina no pós-guerra. A entrada da CEPAL no tema social, argumenta Faletto, foi impulsionada pelo lançamento da Aliança para o Progresso. A Comissão desejava apresentar uma voz latino-americana sobre os programas que seriam financiados, discutindo as reformas propostas, suas condições de implementação e seus efeitos, em cada uma das sociedades nacionais nas quais a Aliança pretendia aplicá-las (FALETTTO, 2007, pp. 195-197).

A partir da incorporação de Fernando Henrique e Francisco Weffort à equipe de Medina no ILPES e dos seminários de Furtado, tem início a colaboração entre Cardoso e Faletto que resulta no livro de 1969. Enzo conta que a ideia surgiu em uma viagem à Argentina, em 1965, na qual Fernando, que pesquisava os empresários, Francisco, que analisava o populismo, e ele, que estudava os movimentos operários, começaram a comparar as histórias do Brasil, da Argentina e do Chile, observando os efeitos políticos, econômicos e sociais internos das relações entre os países latino-americanos e as potências centrais (FALETTO, 2007, pp. 202-203). Dalí em diante, encontravam-se quase todas as noites na casa de Cardoso para escrever o livro. Faletto resume a experiência dizendo: "davam-me duas garrafas de vinho para que eu falasse, ou seja, como brincava Ruth, 'Faletto fala e Fernando pensa' [risos]... e isso até tarde”. Trabalharam juntos até Fernando Henrique deixar o Chile no final de 1967, com o livro praticamente pronto. José Medina ajudou na correção de cada versão e, ainda que seus autores estivessem ligados à CEPAL, o livro não saiu foi publicado pela organização que, enquanto burocracia internacional, não quis comprometer-se com uma obra controversa - 
reatualizando o caso do Manifesto de Prebisch, ocorrido em 1949 (item 1.2) (CARDOSO, 1995, p. 83; CARDOSO, 2012, p. 24).

Dependência e desenvolvimento na América Latina, explicam, "visava estabelecer um diálogo com os economistas sobre desenvolvimento na América Latina, para salientar a natureza social e política daquele processo" mostrando "como se dá esta relação e que implicações derivam da forma de combinação que se estabelece entre economia, sociedade e política em momentos históricos e situações estruturais distintos" (CARDOSO e FALETTO, 1970, p. 7). Neste ponto a leitura ecoa explicitamente o desenho de pesquisa dos participantes do seminário do ILPES, sintetizado por Furtado quando afirma que se trata de entender as condições históricas particulares, as estruturas sociais e os modos de exercício do poder em cada sociedade para compreender as raízes do subdesenvolvimento e pensar acerca das condições de transformação social.

A capacidade para combinar economia, sociologia, história e política, através de uma análise da interação das classes sociais em diferentes contextos está de alguma maneira contida nas trajetórias complementares dos dois autores. Fernando Henrique um sociólogo brasileiro com especialização em sociologia do trabalho que havia lecionado história econômica e economia e estudado elites empresariais e questões raciais. Falleto um historiador e sociólogo com experiência nos estudos de trabalho e classes sociais, enfocando a condição operária. As origens sociais díspares, os países diferentes - Faletto descendente de imigrantes italianos que ingressavam na classe média chilena; FHC de família de elite econômica, política e cultural brasileira -, os objetos de estudo complementares e as vivências políticas em grupos com afiliações diversas ajudavam a ampliar a visão que tinham do processo social latino-americano. A fluência dos dois em Marx e Weber ajudava na adoção de uma perspectiva comparada para a análise de classe empregada para explicar as polarizações ideológicas internas ao países do continente e permitia que se transbordasse a leitura das estruturas econômicas para os arranjos sociais e políticos.

Logo no início do livro os autores explicitam a confrontação que pretendem estabelecer com as teses de Walt Rostow, americano que fazia parte da equipe do governo Kennedy encarregada da política para a América Latina, cuja teoria da modernização inspirou a Aliança para o Progresso (item 2.4). Em The stages of economic growth: a noncommunist manifesto (1960), Rostow sustenta que é possível decompor a história do 
desenvolvimento econômico em 5 etapas: 1) a sociedade tradicional, 2) as pré-condições para o take-off, 3) o take-off, 4) a marcha para a maturidade e 5) a era do consumo em massa. A passagem da primeira etapa para a segunda supõe a incorporação de tecnologia e elevação da produtividade. Na segunda etapa podem coexistir atividades modernas geridas por potências econômicas externas com resíduos tradicionais e observa-se a criação de um Estado forte e de um nacionalismo que se colocam em oposição aos interesses agrários e regionais, o que é pré-condições para o take-off. Ao chegar à terceira etapa, a forma moderna de produção passa a dominar a sociedade enraizando-se em seus hábitos e estruturas institucionais. Neste momento a agricultura experimenta uma racionalização semelhante à experimentada pela indústria, elevando sua produtividade, alterando o status e o modo de vida dos antigos proprietários de terras. A quarta etapa ocorre algo como 60 anos após o take-off e resulta em uma generalização da tecnologia moderna por toda atividade econômica. Finalmente, há a etapa do consumo de massa em que os bens duráveis e serviços prevalecem enquanto atividades econômicas centrais (ROSTOW, 1978, pp. 12-24).

Cardoso e Falleto argumentam que Rostow, ao conceber uma sequência natural e necessária transformações econômicas e sociais que constituiriam etapas a serem atravessadas em direção ao desenvolvimento, não considerara a existência de variações nas trajetórias históricas de cada país e nas estruturas sociais que são constitutivas de cada situação de subdesenvolvimento. Não precisam distanciar-se para buscar exemplos que contradissessem as predições de Rostow, visto que na América Latina já encontravam grande número de casos em que a progressão por ele prevista estava longe de ser aplicável. É o que explicitam ao descrever as estruturas particulares de diversos países da região com o intuito de mostrar que a estrutura social e econômica interna e o tipo de relação que o país manteve com o exterior moldaram os trajetos percorridos em direção ao desenvolvimento (CARDOSO e FALETTO, 1970, p. 19).

O ataque a Rostow traz implícita, em alguma medida, uma tentativa de responder à falência do programa da Aliança, tema que tanto frustrava Prebisch e os outros cepalinos que por algum tempo acreditaram que a proposta da gestão Kennedy poderia ser finalmente um reconhecimento de suas ideias e uma oportunidade única para a implementação de um programa sistemático de apoio ao desenvolvimento latinoamericano. Seguindo o raciocínio de Furtado e Falleto, é possível argumentar que porque 
concebida a partir do programa de modernização de tipo rostowiano, a Aliança não era capaz de entender que deveria olhar para as condições sociais específicas e estruturas de classe particulares em cada uma das sociedades latino-americanas. Havia, pois, um problema primordial nos fundamentos da Aliança que transbordava os constrangimentos ao programa impostos pelas lutas internas entre as frações dominantes e dominadas do governo norte-americano pela alocação do orçamento. Era esta cegueira face à especificidade histórica e à estrutura social que faria com que, mesmo que houvesse um grande volume de recursos disponíveis e projetos coerentes elaborados por técnicos qualificados, estes não pudessem ser aplicados de maneira efetiva ${ }^{248}$.

A crítica não deixa de aplicar-se à produção da primeira fase da CEPAL, que julga ter feito uma leitura contundente sobre a posição da América Latina no cenário internacional, mas não atentado para os conflitos internos aos países latino-americanos. Neste sentido o livro de Cardoso e Falleto e os livros e o programa de Furtado propunham um novo nível de análise na produção de uma teoria autóctone e crítica do desenvolvimento periférico, devedores ambos da supervisão de Medina Echevarría.

Como alternativa à generalização e ao economicismo adotam em seu estudo uma perspectiva histórico-comparativa que busca compreender as diferenças nas estruturas de classe e de poder internas aos países da América Latina e correlacionar estas com as relações que estabeleceram com os países ao seu redor, neste sentido dando continuidade às análises da CEPAL que destacavam os efeitos do imbricamento entre o centro e a periferia. A hipótese central do estudo é que o desenvolvimento econômico e social, que parecia estar ao alcance da América Latina nos anos 1950, não estancou devido ao erro que seria o planejamento centralizado com intervenção governamental como afirmavam os neoliberais; nem por falta de instituições capazes de fomentar a economia e modernizar o Estado. Essencialmente fracassara-se em atingir as condições políticas e sociais necessárias para que se pudesse aprofundar o desenvolvimento como já postulava Furtado. Era preciso, pois, observar as diferenças nas estruturas de dominação, nas formas de estratificação social e nas disputas entre as classes pelo exercício do poder e controle dos mecanismos de decisão. Além de analisar as formas de inter-relação

\footnotetext{
${ }^{248} \mathrm{Na}$ leitura de Raúl Prebisch e muitos de seus colegas da CEPAL e do ILPES, ao optar por um conselho meramente consultivo que aconselhava quanto à seleção dos projetos, ao invés de estabelecer um órgão executivo com expertise de planejamento e conhecimento das especificidades de cada país da região para implementar a ajuda externa, a Aliança condenou-se ao fracasso.
} 
mantidas por cada segmento social das nações dependentes com segmentos dos países do centro (CARDOSO e FALETTO, 1970, pp. 23-31).

Quando Dependência e desenvolvimento na América Latina foi publicado, em 1969, Fernando Henrique já não estava no Chile. Em 1967, ano em que concluíram o livro, ele recebeu convite de Alain Touraine, Michel Crozier, Henri Lefebvre e Lucien Goldman para lecionar na recém criada Université de Nanterre na França. Mudou-se para Paris pouco antes da completa tomada da instituição pelo maio de 1968 francês e voltou a conviver com Celso Furtado que também já estava por lá. Mantinham um encontro às quartas-feiras, do qual participava também o sociólogo Luciano Martins e Waldir Pires, que havia sido deputado pelo PSD e ajudara Darcy Ribeiro na implementação da Universidade de Brasília, tornando-se professor de Direito Constitucional (CARDOSO, 2012, p. 31; DHBB, verbete Waldir Pires). Pouco antes de deixar o Chile, Cardoso havia nomeado Vilmar Faria seu assistente no ILPES. Fernando Henrique conversava com Vilmar e Carlos Martins inclusive sobre a possibilidade de nomeá-los seus assistentes na USP quando voltasse a instalar-se em São Paulo. Eles haviam se aproximado enormemente, mantinham um seminário de leitura na casa de Fernando Henrique e começaram a trabalhar em parceria, tendo Vilmar ajudado FHC a fazer as análises quantitativas da tese de titularidade com a qual conquistaria a cátedra de ciência política da USP.

Foi ele quem, a custo, me ensinou o bê-a-bá das técnicas de pesquisas quantitativas que aprendeu com Gláucio ${ }^{249}$ e Galtung. Ensinava-me pacientemente a construir uma escala de atitudes, a usar melhor o $\chi$ quadrado, a avaliar o nível de significância, a perfurar cartões para submetê-los à máquina separadora (estávamos a léguas da computação) ou, na falta dela, a técnicas ainda mais rudimentares, como a McBee. Foi com as ferramentas aprendidas com Vilmar quando meu assistente no Instituto Latino-Americano e Caribenho de Planejamento Econômico e Social (ILPES/CEPAL) que desenvolvi, em Paris, parte da pesquisa sobre empresários brasileiros, chilenos, argentinos e mexicanos que serviu de pretexto para minha tese de cátedra, de 1968 (CARDOSO, 2002, p. 5).

A ideia de fazer deles seus assistentes não pode ser implementada como planejara. Cardoso retornou da França em julho de 1968. Pouco depois foi aprovado no concurso

\footnotetext{
${ }^{249}$ Glaucio Ary Dillon Soares (1934), formado em direito na Universidade Cândido Mendes e em sociologia na PUC-RJ, fez mestrado em direito na University of Tulane em Nova Orleans e doutorado em sociologia na Washington University em Saint-Louis. Esteve na Universidade de Brasília a convite de Darcy Ribeiro, deixando-a depois da instauração do governo militar. Foi nomeado diretor da ELAS-FLACSO em 1965, substituindo o suíço Peter Heintz, e ficou em Santiago até 1968 (BRIGNOLI, 2008, p. 37; FRANCO, 2007, p. 94).
} 
para a cátedra da ciência política mas permaneceu poucos meses como docente. Os conflitos sociais tomaram as universidades brasileiras em meados de 1968, ecoando os movimentos de 1968 que se espalhavam pelo mundo. Os estudantes renovaram sua luta política. Organizaram a passeata dos Cem Mil, em protesto ao assassinato de um estudante no restaurante universitário o Calabouço. Articularam um encontro das militâncias de esquerda em um sítio em Ibiúna, que se encerrou com numerosas prisões. Na rua Maria Antônia voava fogo entre os prédios da FFCL e do Mackenzie. No início de setembro, o deputado Márcio Moreira Alves faz um discurso incitando as pessoas deixar de prestigiar os desfiles militares no dia da independência do Brasil. Em 13 de dezembro de 1968 decreta-se o Ato Institucional número 5 que dava poderes excepcionais aos militares e suspendia elementares direitos civis.

Em abril de 1969, Fernando Henrique Cardoso e diversos de seus colegas na USP, dentre os quais seus companheiros do seminário do Capital Arthur Giannotti e Bento Prado, seu colega Octavio Ianni, seu professor Florestan Fernandes e outras pessoas próximas foram removidos de suas posições na universidade de um dia para outro (CARDOSO, 2006b, p. 108). Razão pela qual não houve sequer tempo hábil para conseguisse atrair seus diletos alunos Vilmar Faria e Carlos Martins para a FFCL.

Martins deixou o Chile pouco depois de Cardoso. Foi fazer o doutorado na universidade de North Caroline nos EUA, mas não se adaptou. Mudou para Essex, na Inglaterra, onde lecionava Francisco Weffort, que deixou o Chile quase ao mesmo tempo, passando a viver na mesma casa. Vilmar ficara ainda algum tempo no Chile antes de partir para o doutorado em Harvard com bolsa da Fundação Ford. Faria havia sido admitido em Cornell e Harvard. O então diretor da ELAS, Gláucio Soares, diz: "tive milhares de alunos em minha vida, muitos verdadeiramente excepcionais. Vilmar foi o melhor". Teria Gláucio determinante influência na trajetória de Vilmar, fazendo com que fosse para o doutorado em Harvard (SOARES, 2002, p. 5). Ele explica que Vilmar preferia Cornell, mas conta ter o convencido a deixar sua desconfiança de militante e ir para a segunda (CARDOSO, 2002, p. 6; MARTINS, 2012, pp. 168, 173; SERRA, 2014, pp. 192-193; SOARES, 2002, p. 5).

Antes de partir para os Estados Unidos Vilmar havia intercedido junto a Gláucio Soares para conseguir um emprego na FLACSO para seu amigo Serra, que passou, em janeiro de 1969, a lecionar introdução à economia e ao desenvolvimento para os 
sociólogos e cientistas políticos. Serra e Vilmar já não moravam na mesma casa nessa época. Serra fora viver com sua esposa Monica Allende, bailarina chilena que conheceu no final de 1966, com quem casou-se um ano depois, sendo os Faria os padrinhos do casal. Em meados de 1969, José e Monica tiveram uma filha, Verônica, que nasceu com icterícia e teve que receber doações de sangue. Um dos doadores compatíveis foi o professor Edmar Bacha (item 4.5), também do grupo dos bolsistas mineiros, que passou um ano no Chile trabalhando em um projeto de cooperação internacional do MIT com a Oficina de Planificación Nacional (ODEPLAN) (SERRA, 2001; SERRA, 2014, pp. 184185).

Bacha não cursara o doutorado no MIT e sim em Yale. Ele comenta ter pensado em fazer a pós-graduação em Cambridge ou Harvard, mas foi encorajado pelo brasilianista Werner Baer (item 4.4), que lecionava no Centro de Aperfeiçoamento de Economistas da Fundação Getúlio Vargas (CAE-FGV), a cursar o mestrado de Yale, especialmente voltado a estrangeiros, "que era por onde você entrava. Tinha um mecanismo de acomodação, de aculturação. Era mais tranquilo fazer esse curso de mestrado do que de entrar direto no doutorado"250 (Entrevista de Edmar Bacha à autora, 2012).

Em Yale, passou a integrar um grupo de latino-americanos do qual faziam parte o argentino Guilhermo Calvo e o professor cubano Carlos Federico Diaz Alejandro, que recém-adquirira o título de doutor pelo MIT. Foi Diaz Alejandro que convidou Bacha para participar de um projeto de cooperação científica que os Estados Unidos mantinham com o Chile. Tratava-se de um convênio do Center for International Affairs do MIT - "que era um nome infeliz, porque era o CIA, né [risos]. O dinheiro nominalmente vinha da Fundação Ford [risos]." -, dirigido por Rosenstein-Rodan, com a ODEPLAN em

\footnotetext{
${ }^{250}$ Ao final do primeiro ano em Yale, Bacha fez um estágio de dois meses como assistente de pesquisa na Organização Internacional do Café, em Londres. De volta a Yale escreveu uma tese combinando o tema do café com a econometria da agricultura de seu orientador, Marc Nerlove, para fazer um "modelo econométrico para a política brasileira do café e o mercado internacional do produto". Além de Nerlove, Bacha comenta terem sido influentes professores seus: Bela Balassa, especialista em comércio internacional e desenvolvimento que fora durante muitos anos ligado ao Banco Mundial, Lloyd Reynolds, especialista em economia do desenvolvimento e criador do Yale Economic Growth Center, Tjalling C. Koopmans da área de econometria e estatística, o economista keynesiano James Tobin, Edmund Phelps, especialista em crescimento econômico, os três últimos ligados à Cowles Comission e ganhadores de prêmios Nobel em economia nos anos de 1975, 1981 e 2006 respectivamente. Além deles Celso Furtado, "um mito em carne e osso", passou um ano inteiro lá (BACHA, 1996, p. 233; Entrevista de Edmar Bacha à autora, 2012).
} 
Santiago do Chile251. "A equipe trabalhava no Ministério do Planejamento. A ideia era contribuir para o planejamento do governo do primeiro Frei. Do Eduardo Frei Montalva. A lógica toda era... a proposta era a terceira via dos governos democratas cristãos ali, naquela franja toda: Chile, Venezuela, Colômbia, Peru, Costa Rica”. Ademais era final de 1968 e Bacha diz que não se sentia encorajado a voltar para o Brasil em pleno AI-5. O ambiente de Santiago era atraente, a cidade enchia-se de exiliados brasileiros que se integravam à efervescente vida intelectual do período Montalva-Allende (Entrevista de Edmar Bacha à autora, 2012).

Bacha estava em família no Chile, pois sua irmã Clélia, que havia estudado no Colégio Sion e tornara-se funcionária pública no Instituto de Previdência dos Servidores do estado de Minas Gerais, havia deixado seu emprego em 1966 e partido para o Chile junto com o marido, o jornalista mineiro Guy de Almeida ${ }^{252}$ que, por ter sido ligado ao PCB e trabalhar no jornal crítico O Binômio, foi preso ao mesmo tempo que outros tantos militantes do Partido ${ }^{253}$. Permaneceu na cadeia três a quatro meses em 1964 e continuava em julgamento pela justiça militar, razão pela qual pediu asilo à embaixada chilena. Mais ou menos na mesma época que Edmar volta ao Brasil, no final de 1969, Guy e Clélia deixam o Chile, indo morar no Peru pois Almeida fora convidado para coordenar a área andina da agência internacional de notícias Inter Press Service (Entrevista de Edmar Bacha à autora, 2012; 191; QUEIROZ, 2007a, p. 67).

\subsection{As heterodoxias na ESCOLATINA: Ana Célia Castro, Frederico Mazzucchelli e Paulo Renato Costa Souza}

Na época do nascimento de Verônica, Mônica e José estavam instalados em uma casa no bairro da Providência e eram vizinhos do professor porto alegrense Ernani Maria Fiori (1914-1985) e de sua família. Ainda que fosse filho de imigrantes italianos e que seu pai fosse alfaiate, Maria Fiori conseguiu estudar em um tradicional colégio inaciano que preparava a elite gaúcha para exercer as posições dominantes: o Anchieta. Nas palavras de

\footnotetext{
${ }^{251}$ Participaram deste convênio os economistas Rosenstein-Rodan, Hollis Chenery, Richard Eckaus, Díaz Alejandro, Jere Behrman, Peter Clark, Lance Taylor e Edmar Bacha pelo MIT e os economistas ligados à ODEPLAN, Eduardo Garcia, Cristian Ossa, Alejandro Foxley e Ana Maria Jul (BACHA, 1998, p. 200).

${ }^{252}$ Guy de Almeida era filho de funcionário público que trabalhava na Imprensa Oficial. Sua mãe era normalista e dona de casa (JORNALISMO: GUY DE ALMEIDA, 2002).

${ }^{253}$ Entre os quais Sinval Bambirra, deputado pelo PTB que era primo de Vânia Bambirra.
} 
um dos filhos de Ernani, José Luís Fiori, que estudou na mesma instituição, o colégio Anchieta:

\begin{abstract}
Era uma escola de formação extremamente sólida e hierárquica, mas com um forte viés e admiração pela ciência e pelo espírito, pela física e matemática e pelos clássicos da filosofia e da literatura. Mas guardei também para sempre uma conversa com o diretor do colégio, no fim do meu curso secundário. Eu deveria ter uns 16 anos e já estava militando na política secundarista e por isto perdia muitas aulas e fiquei sem frequência em algumas disciplinas. Foi quando o diretor me chamou "às falas" e me disse: "José Luís, pode ser o que quiser. Não é do nosso gosto, mas se quiser pode ser até comunista, mas mesmo neste caso seja quem manda. Esta é uma escola que forma a elite para mandar, portanto, se você for comunista, esteja entre os que mandam no partido (FIORI, 2015, p. 24).
\end{abstract}

Ernani Fiori concluiu a Faculdade de Ciências Jurídicas e Sociais em 1935 e começou a lecionar filosofia na Faculdade de Filosofia, Ciências e Letras da Pontifícia Universidade Católica do Rio Grande do Sul (PUC-RS) e na UFRGS. Ele e seus colegas de Anchieta mantiveram-se fortemente engajados nos movimentos católicos depois de deixar o Colégio, tornando-se membro do Centro de Católicos Acadêmicos e participante da Ação Católica. Depois migrou para os setores mais progressistas da igreja, aproximando-se da teologia do Padre Henrique Vaz. Fiori participou da fundação de um Instituto de Cultura Popular no Rio Grande do Sul e, ainda nos anos 1950, teve contato com o educador pernambucano Paulo Freire (1921-1997), com quem estabeleceu relações não só por conta do Instituto, mas por grande afinidade pessoal, política e filosófica que seria raiz de uma grande amizade (FREIRE, 1986, pp. 11-12; SOUZA, 1985, p. 28;).

Após o golpe, Ernani foi demitido da UFRGS e Paulo Freire chegou a ficar preso dois meses em Recife. Freire deixou o Brasil no final de 1964. Transferiu-se com sua família para o Chile e começou a atuar como assessor do Ministério da Educação e consultor da UNESCO, trabalhando na formulação do Plano de Educação em Massa do governo Frei e no programa de alfabetização de adultos conduzido pelo Instituto de Reforma Agrária. A partir de 1965, passou a trabalhar com ele seu amigo Álvaro Vieira Pinto, também católico, que também estivera envolvido com o movimento de conscientização popular no Brasil. Após o golpe, Vieira Pinto viu-se forçado a deixar o país. Viveu um ano em Belgrado, na então Iugoslávia, e depois aceitou o convite de Paulo Freire para cooperar com ele no programa de educação popular do governo Frei, vinculando-se formalmente ao Centro Latino-Americano de Demografia. Vieira voltou para o Brasil pouco antes do AI-5 e recolheu-se em sua casa em autoexílio por anos (CORTEZ, 2003, pp. 272-273; FREITAS, 1998, pp. 175, 195; MARTINS, 2012, p. 160). 
Ernani ainda permaneceu no Brasil algum tempo depois do golpe pois, mesmo tendo sido cassado, foi convidado pelo novo reitor da UNB, Zeferino $\mathrm{Vaz}^{254}$, para lecionar no Departamento de Filosofia. A experiência durou pouco pois a repressão logo exigiu seu afastamento. Ao mesmo tempo, a ditadura ameaçava um de seus filhos, José Luís Fiori (1945), que desde o Colégio Anchieta integrava a juventude católica secundarista. Ao ingressar na Faculdade de Filosofia da UFRGS passou a ser membro da AP e acabou preso com menos de vinte anos. Tão logo liberto, providenciou-se que deixasse o país. Chegou ao Chile no final de 1965 e abrigou-se inicialmente na casa dos amigos de seu pai, Paulo e Elza Freire. Como era um apartamento muito pequeno, acabou migrando para a residência de outro católico próximo deles, Plínio de Arruda Sampaio, onde viveu até que seus pais se reunissem a ele em Santiago em 1966 (FIORI, 2015, p. 23; FREIRE, 1986, p. 15; SOUZA, 1985, p. 32).

Ernani Fiori foi convidado para trabalhar no Instituto de Educación Rural, organização católica baseada em Santiago a partir da qual colaborou intensamente com os projetos de reforma agrária dos governos Frei e Allende. Em 1967, começou também a lecionar no Departamento de Filosofia da UCC e pouco depois passou a ocupar a posição de vice-reitor acadêmico da instituição, encarregado especialmente de conduzir o processo de reforma universitária que havia sido deflagrado por uma crise estudantil, no bojo dos movimentos universitários de 1968. Após a reforma incorporou-se ao Departamento de Ciência Política da universidade, onde "ensinava uma filosofia críticaradical, na qual convergiam noções de cultura popular, libertação com base no pensamento marxista e católico, ênfase na autoconsciência revolucionária dos povos e processos de aprendizagem e educação emancipatórios, na linha em que também trabalhava Paulo Freire" (BECA et al., 2013, p. 1026). A vivência de exílio e os debates sobre modelos de educação aproximam-no ainda mais de Freire. As famílias visitam-se todos os finais de semana e a parceria intelectual dos dois cresce, sendo Fiori convidado a fazer a introdução à Pedagogia do oprimido (1968), uma das obras mais conhecidas de Paulo Freire (BECA et al., 2013, p. 1024; SOUZA, 1985, pp. 32-33).

\footnotetext{
${ }^{254}$ Depois do golpe, a UNB foi tirada do controle de Anísio Teixeira e do Frei Mateus Rocha. Darcy Ribeiro, o primeiro reitor da universidade foi convidado por Jango para ser Ministro da Educação e depois chefe da Casa Civil. Tanto Anísio quanto Darcy acabaram exilando-se pouco depois da instauração do governo militar. Em 1964 convidaram para dirigir a UNB "Zeferino Vaz, que havia criado uma importante escola de medicina em São Paulo. Ele horrorizou-se tanto com a odiosidade da ditadura que abandonou o cargo. Foi para São Paulo, onde conseguiu, de Adhemar de Barros, recursos para criar uma UNB paulista: a UNICAMP" (RIBEIRO, 1997, p. 246), assunto que será discutido no quinto capítulo.
} 
Frequentavam a casa dos Fiori boa parte dos exilados ligados às organizações católicas e às correntes nacionalistas desenvolvimentistas. Além de Elza e Paulo Freire, de sua filha Madalena e o marido dela Francisco Weffort, eles recebiam com regularidade Paulo de Tarso Santos, Plínio de Arruda Sampaio, Almino Afonso, Marcio Moreira Alves, Jesus Soares Pereira, Francisco Whitaker e Álvaro Vieira Pinto. Ao redor do filho José Luís reuniam-se Paulo Renato Costa Souza, Raul Carrion e Luiz Alberto Gomes de Souza, todos colegas de militância católica do Rio Grande do Sul. Além deles apareciam por lá outros jovens como Paulo Baltar, filho de Antônio Bezerra Baltar, Rui Fausto e Lourdes Sola Fausto, dois professores de São Paulo que chegaram ao Chile em 1969. Logo Maria da Conceição Tavares, que se instalara definitivamente naquele país, passou a integrar o grupo (BECA et al., 2013, p. 1024).

José Serra, era conhecido dos Freire, também passou a frequentar a casa dos Fiori. Foi lá que conheceu, em 1969, o colega de José Luís dos tempos de Colégio Anchieta e de militância na AP, o porto-alegrense Paulo Renato Costa Souza (1945-2011), que se tornaria seu aluno e depois assistente na ESCOLATINA. Renato Souza, o pai de Paulo, era de Guaíba, no Rio Grande do Sul. Depois de graduar-se em direito na UFRGS, foi aprovado em concurso para a Polícia Civil, ajudando a fundar a Academia de Polícia da região. Anos depois foi eleito vereador pelo PTB. Em 1966, Renato Souza logrou elegerse deputado estadual pelo MDB, função que desempenhou de 1967 a 1969, quando teve seu mandato cassado ${ }^{255}$. Paulo Renato fez a graduação em economia na UFRGS de 1964 a 1967. Em 1966 havia começado a trabalhar na assessoria de planejamento do governador Ildo Meneghetti do PSD, tornando-se, em 1967, secretário da bancada do PSD na Assembleia Legislativa do Rio Grande do Sul e, na sequência, técnico da Assembleia. Em 1968, Paulo Renato fez o Curso de Treinamento em Problemas do Desenvolvimento do Centro CEPAL-BNDE e, dado o acirramento das tensões políticas, ele, que já era fichado, acabou transferindo-se para o Chile. Além de tornar-se assistente de Serra, ao concluir o mestrado na ESCOLATINA, Paulo Renato começou a dar aulas na FLACSO e no curso de planejamento urbano da UCC. Por dois anos foi economista da Divisão de Desenvolvimento Econômico da CEPAL e, de 1971 a 1977, trabalhou no 
Programa Regional de Emprego para a Brasil e o Caribe da OIT (DHBB, verbete Paulo Renato Costa Souza; Roda Viva Paulo Renato; FIORI, 2015, p. 26; PRATA et al, 1999, p. 44).

José Luís Fiori apresentou Serra a Paulo Renato. Serra, por sua vez, apresentou-lhe seu professor e amigo Carlos Lessa, que tornar-se-ia influência decisiva em sua carreira, ainda que tenha rejeitado sua primeira recomendação. Lessa aconselhou José Luís a seguir o curso de economia de Concepción, que considerava o melhor, mas José Luís não queria deixar Santiago "pois era onde as coisas aconteciam, onde estava a CEPAL, a UNESCO, a OIT, a FLACSO, onde estava todo mundo, onde rolava a vida política do país". "Para mim era impensável ir para o mato para virar um 'grande economista' Eu tinha outros interesses que não seriam atendidos no mato, eu gostava também de história e filosofia e, fora da universidade, de cinema, música, literatura, conversa fiada e, por que não, gastronomia...". Não sendo admitido na FLACSO ele acaba cursando graduação em sociologia na Universidade do Chile, de 1966 a 1970, e na sequência ingressa no mestrado da ESCOLATINA256 (FIORI, 2015, pp. 26-27). Em meados de 1968, Carlos Lessa deixa o Chile enquanto chega ao país Maria da Conceição Tavares, com quem, anos à frente, Fiori colaboraria, nos anos 2000, na criação do grupo de economia política do Instituto de Economia da Universidade Federal do Rio de Janeiro (IE-UFRJ) e escreveria e organizaria publicações ${ }^{257}$, principalmente na área de economia política internacional. Fiori resume sua relação com os dois:

Com o Lessa eu aprendi tudo o que sei até hoje de política econômica. O Lessa,
de fato, me ensinou a usar a política econômica como um instrumento de análise
ou, digamos, de reconstrução anatômica de uma conjuntura política. Isso para
mim foi o grande salto do gato, mesmo porque foi quando comecei a estudar e
conhecer de fato a história do Brasil que eu não havia estudado na universidade
[...]. Com o Lessa e a Conceição, eu aprendi muito, pra mim foi
fundamentalíssimo porque eu aprendi economia de fato. Até aí o que eu sabia é o
que eu tinha estudado no meu curso de mestrado na ESCOLATINA lá no Chile:
muito modelo, teoria. Foi só aí que eu aprendi como que é que se juntava a
economia com a análise política sem cair no economicismo (FIORI, 2015, p. 34).

Ao voltar para o Chile, Conceição Tavares começou a escrever com José Serra o ensaio Além da estagnação: uma discussão sobre o estilo de desenvolvimento recente do Brasil (1970), cujo propósito era contrapor-se à tese que Celso Furtado apresentara em Subdesenvolvimento

\footnotetext{
${ }^{256}$ Ver: http://lattes.cnpq.br/0152127758679455. Consultado em 03/02/2016.

${ }^{257}$ O grupo de economia política da UFRJ publicará suas obras na coleção "Zero à Esquerda", da Editora Vozes, e na coleção "Estado de Sítio", da editora Boitempo, ambas organizada por Paulo Arantes, cunhado de José Luís Fiori (FIORI, 2015, p. 39).
} 
e estagnação (1966). De acordo com Furtado, a industrialização da América Latina, que se generalizara em diversos países da região nos anos 1950, encontrava-se à beira de uma estagnação que decorreria do agravamento do dualismo estrutural, resultado da persistência em meio à economia capitalista de um setor tradicional representado pelas oligarquias regionais agrícolas. Furtado acreditava que sem implementar reformas estruturais que permitissem uma maior integração da força de trabalho no campo e na cidade; que impedissem a concentração de renda; que permitissem a ampliação dos mercados; e que empregassem o progresso tecnológico para modernização das economias regionais e das estruturas sociais não seria possível transpor a fase inicial da industrialização por substituição de importações e dar prosseguimento ao desenvolvimento econômico (FURTADO, 1968, pp. 39-40, 84-87).

O ensaio de Tavares e Serra parte da seguinte questão: “Como falar em estagnação no final dos anos sessenta, se a economia estava crescendo, desde 1968, gerando um gigantesco ciclo de capitalismo selvagem?” (TAVARES, 1997a, p. 9). A tese que sustentavam em Além da estagnação contrapunha-se à ideia de que a perda de dinamismo do desenvolvimento industrial calcado na substituição de importações levaria necessariamente a uma estagnação econômica. Segundo os autores poderia ser este um estágio de transição em direção a um modelo ao mesmo tempo dinâmico e socialmente perverso de capitalismo, no qual a aceleração econômica seria promovida com ainda maior concentração de renda, exclusão social, privação material, concentração espacial e subemprego ${ }^{258}$. Modelo este que preservaria as oligarquias regionais e serviria aos interesses dominantes brasileiros em associação com o capitalismo internacional e não à nação e sua população como um todo (SERRA, 1998, p. 6; TAVARES e SERRA, 1976, pp. 211-212, 224-227, 238).

Para explicar o rápido crescimento que o Brasil começara a experimentar a partir de 1967, conhecido como milagre econômico, os autores principiam por avaliar como o Estado e o capital internacional passam a colaborar para atrair tecnologia e incrementar a produtividade em áreas de ponta como a petroquímica, mineração, siderurgia, energia elétrica etc. De acordo com eles, o investimento nesses setores, somado à modernização da produção, à compressão dos salários e à aniquilação do poder de reivindicação das classes trabalhadoras pelo regime ditatorial, fez com que o custo da produção fosse

\footnotetext{
${ }^{258}$ Como será discutido no próximo capítulo, Além da estagnação faria parte de um conjunto de denúncias do modelo de capitalismo com concentração de renda adotado pelo governo militar (itens 4.3 e 4.4 ).
} 
reduzido, tornando as exportações competitivas e elevando os lucros, que sendo em parte repatriados satisfaziam os investidores estrangeiros (SERRA, 1998, p. 6; TAVARES e SERRA, 1976, pp. 211-212, 224-227, 238). Nesse modelo, o Estado atua:

a) na orientação dos investimentos públicos destinados a proporcionar diversas modalidades de economias externas às atividades do setor moderno ou beneficiar diretamente o consumo de grupos incorporados a este setor; b) na política econômica propriamente dita. Seria o caso da política salarial ou cambiária e mesmo de financiamento, tendente a beneficiar direta ou indiretamente as atividades e o consumo moderno. Esta concentração de investimentos privados e públicos e do consumo, bem como as facilidades institucionais criadas, tendem a permitir que a acumulação do excedente gerado no polo moderno se mantenha em condições de certa rentabilidade (TAVARES e SERRA, 1976, pp. 232).

Seguindo esta fórmula,

a política do novo governo militar criou condições para uma reorganização do esquema distributivo "conveniente" ao sistema, começando por redistribuir a renda em favor dos setores das classes médias "altas" e contra as classes populares assalariadas. Esta redistribuição teve início primeiramente ao nível do gasto, mediante novos esquemas ampliados de financiamento de bens duráveis e, posteriormente, pelo lado da renda, mantendo-se a queda dos salários mínimos reais mas permanecendo mais ou menos constantes os médios, permitindo-se, então, uma abertura do leque e da escala de remuneração em favor dos novos grupos emergentes. Tudo leva a pensar que a concentração na cúpula continuou, e ainda com mais vigor, desde o significativo crescimento do excedente a partir de 1967, possibilitado por um nível de salários reais rebaixado em quase $30 \%$, no caso do salário mínimo (em relação a 1961), em condições de recuperação e expansão acelerada do nível de atividade econômica urbana [...]. o esquema de distribuição de renda em 1970 mostraria, em relação a 1960, uma maior taxa global de desigualdade e uma maior concentração na cúpula [...] [eles estimam que] do aumento de US\$ 15 bilhões na renda nacional no período, US\$ 12 bilhões foram distribuídos entre $20 \%$ da população, contribuindo para alimentar a expansão do mercado dinâmico; apenas US $\$ 3$ bilhões foram distribuídos entre os $80 \%$ restantes da população e teriam contribuído para aumentar o mercado tradicional (TAVARES e SERRA, 1976, pp. 244-246).

Os resultados da economia brasileira no período contradiziam a tese estagnacionista mostrando que poderia haver crescimento econômico com concentração da renda e da produção nos setores modernos, caso o capital nacional estivesse associado ao capital estrangeiro com o patrocínio do Estado. Nessa configuração, a expansão produtiva não dependeria de um aumento do poder aquisitivo da população que funcionasse como fator propulsor da ampliação do mercado interno, requerida para dar vasão à ampliação da produção, pois esta poderia escoar para outros países. Ao contrário, a baixa remuneração da classe trabalhadora funcionaria como fator de atração do capital internacional que se beneficia da baixa parcela dos lucros a ser partilhada com a força de 
trabalho quando comparada com o nível de remuneração da classe trabalhadora vigente em seus próprios países, conquistado nas lutas sindicais pela ampliação dos direitos trabalhistas. Em uma situação de total ausência de liberdades, não se abria aos trabalhadores brasileiros espaço para lutar por direitos e ganhos salariais, o que só agravava a concentração de renda.

Cláudio Salm comenta o efeito que a tese de Serra e Tavares teve sobre o universo dos exilados:

\begin{abstract}
dominava [entre os exilados no Chile] um clima de 'ano que vem no Brasil' Havia a convicção de que as crises econômicas seriam determinantes para a criação de condições pré-revolucionárias. Ou seja, havia muito de wishful thinking quanto à aposta na continuidade do relativo marasmo econômico (1962-1967), percepção cada vez mais difícil de sustentar diante da retomada da economia e das altas taxas de crescimento do 'milagre'. O artigo de Tavares e Serra deu uma sacudida na ideia de que os militares iriam se dar mal por conta da economia e de que, portanto, a ditadura chegaria ao fim em breve, como de fato viria a acontecer, mas só dez anos depois. No final dos 1960, ocorre justamente o contrário (SALM, 2011, pp. 169-170).
\end{abstract}

Ao invés de declinar econômica e politicamente, a ditatura se fortalecia e endurecia. Ana Célia Castro, que terminou a graduação no Chile e ingressou na ESCOLATINA, conta que a promulgação do decreto-lei 477, de fevereiro de 1969 - que oficializava as medidas repressivas na universidade e previa sansões e expulsões de professores e alunos que fossem considerados subversivos - foi decisiva para que seu marido Antonio Barros de Castro, à época professor da UFRJ, embarcasse para Santiago em 1969, em busca de "um ambiente mais respirável", passando a lecionar no ILPES e na ESCOLATINA, tal como haviam feito seus diletos colegas Lessa e Conceição anos antes (Entrevista de Ana Célia Castro à autora, 2014).

Ana Célia Castro (1950) é carioca de pai romeno e mãe ucraniana que chegaram ao Brasil pouco antes da Segunda Guerra Mundial, fugindo da perseguição aos judeus. Não fizeram estudos formais. O pai trabalhou como operário, mascate, operador de bonde até que, junto com o cunhado, abriu um armarinho em uma loja alugada no Jardim Botânico. A loja foi crescendo e eles conseguiram comprar a propriedade, ingressando aos poucos na classe média. O pai conseguiu garantir que os filhos estudassem, o que era sua grande prioridade. Ana frequentou o Colégio de Aplicação da UFRJ, escola com enorme presença de organizações de esquerda da qual saíram numerosos quadros para a militância e para a política nacional. Ana Célia conta ter começado sua militância junto ao PCB na escola. Diz ter sido comunista dos 15 aos 18 anos, mas acabou afastando-se da política 
estudantil por não ter vocação para a luta armada ou para a clandestinidade. Na Faculdade de Economia da UFRJ conheceu o professor Castro, com quem veio a casar. Ela foi para o Chile não por ser alvo de perseguição, já que havia deixado a militância formal, mas para acompanhar o marido em sua busca por uma vida intelectual em liberdade, completando a graduação em Santiago e cursando o mestrado na ESCOLATINA (Entrevista de Ana Célia Castro à autora, 2014).

$\mathrm{Na}$ ESCOLATINA, o casal Castro reúne-se a um grande número de exilados da segunda geração, quase todos jovens que foram forçados a deixar o país após o AI-5. Alguns dos que ali estavam haviam chegado na primeira leva e fizeram inclusive a graduação no Chile. Era o caso de José Luís Fiori e de Paulo Baltar que estavam em Santiago com suas famílias e de Liana Aureliano que retornava ao Chile depois de alguns anos no Brasil. Além deles havia uma grupo de recém chegados que se enquadravam, quase todos, no perfil médio da segunda geração de brasileiros exilados.

A leva daqueles que deixaram o Brasil após 1969 era composta majoritariamente por jovens de 20 a 30 anos, nascidos em meados dos anos 1940 (média 1941, moda 1945), e não ao redor dos anos 1930 como os exilados da primeira geração (média 1932, moda 1937). Seus antecessores eram, em sua maioria, profissionais qualificados: políticos, altos quadros de órgãos públicos, professores e artistas. Pessoas que, durante os anos 1960, assumiram publicamente posições progressistas, razão pela qual foram perseguidas pelos militares. Os exilados do AI-5 não eram figuras públicas. A maioria deles estava na universidade quando eclodiu a ditadura, tendo sua formação superior interrompida ou prejudicada (Tabela III) (ROLLEMBERG, 1999, pp. 50-51).

Socialmente também eram diferentes da primeira geração, na qual muitos dos intelectuais eram membros das classes médias e altas, alguns provendo de famílias bastante enraizadas na sociedade e na política brasileira. A segunda leva tem menor número de pessoas de origem privilegiada e uma maior parcela de filhos de imigrantes em trajetórias de ascensão social pela via escolar. Lourdes Sola, Ruy Fausto, Ana Célia Castro, Adhemar Kyotoshi Sato, Eduardo Kugelmas, Frederico Mazzucchelli, Emir e Eder Sader, por exemplo, enquadram-se neste perfil, tendo pais imigrantes que aos poucos foram transacionando para a classe média, em geral por meio de atividades ligadas ao comércio, o que permitiu que investissem na educação escolar dos filhos. 
Quanto à forma de ação política, a primeira geração era composta por figuras cuja luta pela transformação era institucional e, portanto, visível; o pleito da segunda geração pela transformação social foi feito de forma anônima e subterrânea, conduzido na clandestinidade por uma grande variedade de organizações de esquerda, em geral críticas à política do PCB, estando parte delas dispostas a lutar com armas pelo advento da revolução no Brasil. Com o acirramento da repressão, as condições de exercício da militância foram reduzidas, tendo sido as novas esquerdas fortemente perseguidas pelos órgãos da repressão. As prisões, inquéritos e torturas a que foram submetidos os seus militantes fizeram com que muitos ativistas deixassem o país, sendo Santiago um dos destinos mais prováveis.

A UC, UCC, a ESCOLATINA e a FLACSO e centros de pesquisa ligados às universidades conseguiram absorver parte dos jovens brasileiros que se avolumavam em Santiago e arredores. Tanto aqueles que chegaram ao Chile sem ter ao menos completado a graduação quanto recém-formados que foram dirigidos à pós-graduação e começavam a lecionar. A presença de professores brasileiros da primeira leva de exilados no corpo docente dessas universidades facilitava o ingresso da nova coorte na academia. Raul Carrion conta que obteve seu ingresso na Faculdade de Química da Católica com a ajuda de Ernani Fiori, pai de seu colega de militância José Luís (CARRION, 2013, pp. 2, 9). Foi ele também que conseguiu que Ruy Fausto ${ }^{259}$, colega na Filosofia da USP de sua filha Otília Arantes, se tornasse professor no departamento de Filosofia na UCC (FAUSTO, 2000, p. 152). César Maia, que viria a ser prefeito do Rio, foi estudar na UC por recomendação de José Serra (SERRA, 2002, p. 105; César Maia apud ALVES, 1996). Emir Sader foi trabalhar com Ruy Mauro Marini, que foi quem o recebeu no Chile. Frederico Mazzucchelli chegou ao Chile com uma recomendação de FHC para estudar na ESCOLATINA (Entrevista de Frederico Mazzucchelli à autora, 2014).

A FLACSO, que recebera Simon Schwartzman, Antônio Octavio Cintra e Fábio Wanderley Reis antes do golpe e Vilmar e Regina Faria e Ayrton Fausto, da AP, na primeira geração de exilados, recebia agora outra leva de estudantes empurrados para o

\footnotetext{
${ }^{259}$ Ruy Fausto era de uma família de judeus do Império Austro-Húngaro por parte de pai e da Turquia por parte de mãe. $\mathrm{O}$ avô paterno era comerciante e seu pai seguiu o mesmo caminho ao chegar no Brasil, tornando-se pequeno comerciante de café. A mãe faleceu em 1938, quando ele tinha 3 anos de idade. Ruy Fausto graduou-se em direito e filosofia na USP e passou a dar aulas na universidade em Rio Claro. Foi para a França em 1960 fazer o doutorado. Regressou ao Brasil e à Faculdade de Filosofia da USP, permanecendo até o decreto do AI-5. Partiu com sua esposa Lourdes Sola para o exílio no Chile. Depois de ali viver e lecionar por dois anos e meio foi para a França terminar o doutorado e o golpe no Chile acabou determinando que ali ficasse, tornando-se professor em Paris (FAUSTO, 2000, pp. 145-149; FAUSTO, 2008, pp. 7, 18-19).
} 
exterior no pós-AI-5. Fizeram parte da turma ELAS de 1970-1971 José Guilherme Cantor Magnani (1944) ${ }^{260}$, aluno da Faculdade de Filosofia, Ciências e Letras da Universidade Federal do Paraná (UFPR), que foi presidente do diretório dos estudantes e depois de condenado à prisão por promover passeatas e subversão em Curitiba; Maria Hermínia Tavares de Almeida (1942) 261 , nascida em São José do Rio Preto, aluna da FFCL da USP e militante do Partido Operário Revolucionário Trotskista; e Theodoro Buarque de Holanda (1946) ${ }^{262}$, carioca que estudava engenharia civil na PUC do Rio de Janeiro, preso por ter participado de assalto a um banco. Na turma seguinte, de 19721973, estava ainda Sônia Miriam Draibe (1943), graduada na Faculdade de Educação da USP, que já lecionava na PUC-SP quando foi presa em 1971 por sua atuação na POLOP. Como a FLACSO, a escola de pós-graduação para latino-americanos do Departamento de Economia da UC havia sido estruturada com apoio internacional. Criada em 1957, a ESCOLATINA recebeu financiamento das Fundações Ford e Rockefeller e foi inicialmente dirigida pelo professor austríaco Joseph Grunwald (1920$1997)^{263}$. A proposta de criar uma pós-graduação em economia para latino-americanos era advogada pela CEPAL desde 1953, ano em que a Comissão começou a sistematizar os cursos de especialização que passariam a ser oferecidos pelo ILPES (item 1.5). A ESCOLATINA e a CEPAL/ILPES passariam a partilhar vários professores que lecionavam simultaneamente nos dois lugares. O programa oferecido pela pós-graduação nos anos iniciais era bastante eclético. Como a FLACSO, a ESCOLATINA passou a incluir em seus quadros, além dos latino-americanos que já eram vinculados à UC e à CEPAL, diversos professores estrangeiros, provenientes de universidades como Stanford, Harvard, Yale, MIT e LSE, procurando oferecer aos alunos formação em metodologias

\footnotetext{
$260 \quad$ Ver: $\quad$ http://fflch.usp.br/sites/fflch.usp.br/files/Joe_Guilherme Magnani.pdf $\quad$ e http://www.arquivoestado.sp.gov.br/memoriapolitica/prontuario.php?prontuario=BR_SP_APESP_DEOPS_SAN P003428_01. Consultados em 05/02/2016. Ver: http://www.usp.br/imprensa/?p=40644 e http://www.arquivoestado.sp.gov.br/memoriapolitica/documento.php?ficha=DOPSSANTOSA00799. Consultados em 05/02/2016.

http://www.arquivoestado.sp.gov.br/memoriapolitica/documento.php?ficha=BR_SPAPESP_DEOPSSPOSFICO NST000107. Consultado em 05/02/2016 e HOLANDA, 2007, pp. 220-221.

${ }^{263}$ Nascido em Viena em 1920, Joseph Grunwald, fugitivo do nazismo, mudou-se para os EUA em 1938. Radicou-se em Baltimore onde trabalhou como faxineiro em uma fábrica ascendendo até ser promovido a gerente. Cursou economia na Johns Hopkins à noite, a mesma escola que havia sido frequentada por Arnold Harberger (item 4.4). Obteve seu diploma em 1943 e logo foi convocado, como Harberger, para lutar na II Guerra Mundial. De volta aos EUA defendeu tese de doutorado na University of Columbia sobre as finanças públicas na Noruega e pouco depois aceitou a missão de ajudar a UC a fundar sua pós-graduação em economia, transferindo-se para Santiago em 1954 (CILAS, 1997, p. 2).
} 
quantitativas de pesquisa. Com apoio da USAID e das Fundações, a ESCOLATINA estabeleceu acordos de cooperação com algumas escolas norte-americanas, em geral as mais abertas ao diálogo com a heterodoxia, como a University of California e o centro de estudos latino-americanos de Yale 264 (MONTECINOS, 2009, pp. 167-168; PARMAR, 2012, pp. 199-203; VALDÉS, 1995, pp. 114-116).

O representante da Fundação Ford para o Chile naquele período, John Strasma, doutor em economia pela Universidade de Harvard que lecionava na UC desde 1960, argumenta que:

\begin{abstract}
Instituto de Economia da UC era "claramente o mais pluralista" grupo de economistas em Santiago, uma mistura de socialistas, liberais e conservadores, bem como vários "técnicos apolíticos". Claro, havia economistas da CEPAL como Osvaldo Sunkel e Pedro Vuskovic que lecionavam na UC, mas sua economia não era necessariamente exclusivamente "marxista". Grunwald ajudou a criar na UC uma rede estreita de economistas posicionados para "absorver" novas doações da Ford em 1962, quando o Instituto de Pesquisa Econômica e a Escola de Pós-Graduação em Economia foram fundidos. Isso foi feito "para desenvolver um programa de ensino cientificamente orientado em economia, para evoluir, refinar e promover análises sólidas e objetivas, e soluções técnicas para os problemas de desenvolvimento econômico" [...]. A missão de Strasma, plenamente partilhada pela Ford, incluía planos de trazer para o Chile economistas de "países avançados" para trabalhar junto com os emergentes quadros de graduados da UC para "fornecer um retrato científico e autêntico dos problemas reais do continente e, com esse núcleo [...] criar uma atmosfera científica adequada para analisar as realidades latino-americanas" (PARMAR, 2012, p. 201; John Strasma apud PARMAR, 2012, p. 201).
\end{abstract}

Assim era a ESCOLATINA na qual Serra e Claudio Salm ingressaram na metade dos anos sessenta. Tinham aula com professores cepalinos como Sunkel, Aníbal Pinto e Pedro Vuskovic, estudavam as teorias clássicas e contemporâneas de diversas vertentes e tinham ao mesmo tempo uma formação quantitativa sólida, semelhante àquela que se generalizava pelas universidades norte-americanas, matematização que, conforme visto, ecoava também na FLACSO.

Entre 1967 e 1968, quando Edgardo Boeninger (1929-2009), engenheiro civil pela UCC e engenheiro comercial com menção em economia pela UC, assumiu a direção da Faculdade de Ciências Econômicas da UC, a ESCOLATINA experimentou uma primeira inflexão. Começou-se a desenhar uma reforma curricular que tornava a escola mais atraente para aqueles que se opunham à ciência econômica de matriz norte-americana que adentrava o Chile com força através do convênio da UCC com a University of

\footnotetext{
${ }^{264}$ Depois de regressar do Chile, Grunwald passou a fazer parte do Centro de estudos latino-americanos de Yale reunindo-se aos latino-americanistas Werner Baer e Carlos Dias-Alejandro que lá estavam.
} 
Chicago (item 4.4). Boeninger era um democrata cristão muito ligado ao Presidente Frei, de quem fora diretor de orçamento, e trabalhava no ILPES. Tinha amplo contato, pois, com o pensamento econômico formulado na CEPAL e grande afinidade transformações sociais que o Chile ensaiava. A reforma levou a ESCOLATINA, cada vez mais, à leitura e produção de um pensamento latino-americano e à elaboração de estudos, diagnósticos e recomendações para o governo. Em questionário de opinião respondido pelos alunos à época da reforma é visível que os discentes, ainda mais do que os docentes, pleiteavam a abertura à heterodoxia. Eles argumentam que o programa do curso era demasiado teórico, falhando na análise da realidade que os envolvia. Ademais, acusavam o programa de ser ideologicamente adepto ao capitalismo e ao neoliberalismo e reivindicavam que ele se voltasse à preparação dos alunos para engajarem-se na transformação social, devendo o currículo enfocar antes conhecimentos sobre América Latina do que uma formação convencional para tornarem-se técnicos eficientes (FRANCO, 2013, p. 183; MONTECINOS, 2009, p. 167-168; PARMAR, 2012, pp. 201-205).

Foi nesse período que Maria da Conceição Tavares, Antonio Barros de Castro e José Serra passaram a lecionar na Escuela e também que um grupo de brasileiros que chegou ao Chile no pós-1968 incorporou-se à pós-graduação. Além dos já mencionados Paulo Renato, José Luís Fiori, Paulo Baltar, Ana Célia Castro e Liana Aureliano, lá estudaram: Sulamis Dain ${ }^{265}$, formada pela UFRJ que trabalhava no Escritório de Pesquisa Econômica Aplicada (EPEA); José Carlos Souza Braga 266 também graduado em economia pela UFRJ; Jorge Mattoso (1949) 267 , estudante de economia na UFRGS que militava no Partido Operário Comunista (POC), preso em 1971; e Lauro Pacheco Ferraz (1942) 268 que fora presidente do diretório dos estudantes de direito do Mackenzie foi preso duas vezes, uma distribuindo material subversivo e outra no congresso de Ibiúna.

Outros vieram da FFCL da USP. Lourdes Sola ${ }^{269}$ (1942), à época esposa de Ruy Fausto (1935), havia feito a graduação e o mestrado em ciências sociais na USP, sendo

\footnotetext{
${ }^{265}$ Ver: http://lattes.cnpq.br/5347631502837998. Consultado em 05/02/2015.

${ }^{266}$ Ver: http://lattes.cnpq.br/4847808748249580. Consultado em 05/02/2015.

267 Ver: http://www.ihu.unisinos.br/noticias/noticias-anteriores/5041-mattoso-o-ex-militante-que-virouprofessor. Consultado em 05/02/2015.

http://www.arquivoestado.sp.gov.br/memoriapolitica/documento.php?ficha=BR_SPAPESP_DEOPSSPOSFICO NSL000118. Consultado em 05/02/2016.

${ }^{269}$ Lourdes Sola (1942) nasceu em São Paulo. Seu pai era um imigrante espanhol de origem proletária que se tornou próspero comerciante, dono da Leiteira Campo Belo, e proprietário de imóveis. A mãe era descendente de italianos, Lourdes tendo sido matriculada no colégio particular dos descendentes de italianos de classes médias e altas, o Dante Alighieri. Ingressou na FFCL em 1958 e logo após a conclusão da graduação começou a escrever
} 
orientada em sua dissertação por Florestan Fernandes, de quem tornou-se assistente na cadeira de sociologia I e no CESIT. Eduardo Kugelmasº ${ }^{270}$ (1946-2006), por sua vez, era graduado em direito pela São Francisco e em ciências sociais pela FFCL. Na época em que foi decretado o AI-5, ele pesquisava no departamento de ciência política da FFCL. Segundo ele, embora não atuasse na luta armada, participava das movimentações ajudando a esconder pessoas, de modo que teve que deixar o Brasil. Em 1966, Kugelmas havia feito, com dois colegas da Faculdade de Direito e das Ciências Sociais, Luiz Gonzaga Belluzzo e João Manuel Cardoso de Melo (item 5.2), o curso que o Centro CEPAL-BNDE oferecera na cidade de São Paulo, via pela qual conhecera alguns dos professores da CEPAL que reencontraria no Chile. Sola chegou a Santiago em 1969, Kugelmas em 1970. Ambos inscreveram-se no mestrado da ESCOLATINA e lá viveram até o golpe de 1973 (SPIRANDELLI, 2008, p. 118; PULICI, 2008, p. 135; KUGELMAS, 2012, pp. 250-251).

Ingressaram na ESCOLATINA também uma série de alunos e egressos da Faculdade de Contabilidade, Economia e Administração da USP: Adhemar Kyotoshi Sato (1942), que já era professor assistente da Faculdade, havia sido recrutado por Walter Barelli para militar na JUC e ajudara a esconder diversos clandestinos durante a ditadura, razão pela qual optou por deixar o Brasil em 1970271. Carlos Alberto Woldemar Kurkineva (1945) 272, estudante de economia, foi preso em 1966 ao distribuir panfletos subversivos e partiu para o Chile após concluir a graduação em 1969. Carlos Alonso

\footnotetext{
o mestrado sob supervisão de Florestan Fernandes e a trabalhar no CESIT. Viveu no Chile de 1969 a 1973, onde cursou o mestrado na ESCOLATINA e lecionou na FLACSO. Partiu para a Inglaterra em 1974, realizando seus estudos doutorais em Cambridge e Oxford (SPIRANDELLI, 2008, p. 118; PULICI, 2008, p. 135; http://lattes.cnpq.br/3990218273581743 e http://www.abc.org.br/ lsola. Consultados em 03/02/2015.

${ }^{270}$ Eduardo Kugelmas (1946-2006) nasceu em São Paulo. Seus pais eram imigrantes judeus do Império AustroHúngaro. O pai havia estudado economia e contabilidade em Viena e no Brasil tornou-se administrador de empresas. Eduardo cursou concomitantemente a graduação em direito e ciência sociais, de 1960 a 1964. Trabalhava na FFCL ao lado da professora Maria do Carmo Campello de Souza, que também foi presa por suas ligações com as organizações de esquerda. Após o golpe no Chile foi para a França. Anistiado, pode regressar à USP e defendeu o doutorado em 1986, tornando-se professor da FFCL (KUGELMAS, 2012).

${ }^{271}$ Descendente de japoneses que eram agricultores no interior paulista por parte de pai e mãe japonesa de família tradicional decadente, Kyotoshi nasceu em São Paulo (1942) e cursou as graduações de economia e de direito na USP. Foi da primeira turma que fez mestrado na própria FCEA, onde trabalhava como professor assistente, ao mesmo tempo que estudava ciências sociais. A militância na AP obrigou-o a deixar tudo e partir. Ver:

http://sites.correioweb.com.br/app/noticia/encontro/revista/2014/10/24/interna_revista, 1687/algo-no-poder-naocheirava-bem.shtml e

http://www.portaldoenvelhecimento.com/revista-nova/index.php/revistaportal/article/viewFile/295/295.

Consultados em 06/02/2016.

${ }^{272}$ Ver:

http://www.arquivoestado.sp.gov.br/memoriapolitica/documento.php?ficha=BR_SPAPESP_DEOPSSPOSFTEX SNK000421. Consultado em 05/02/2016.
} 
Barbosa de Oliveira, casado com a aluna da FLACSO Sônia Draibe, chegou a Santiago no início dos anos 1970. Reinaldo Carcanholo e Silvério Soares Ferreira deixaram o Brasil sem sequer concluir a graduação. Frederico Mazzucchelli ${ }^{273}$ (1947), que já trabalhava no CEBRAP, obteve, com a ajuda de Fernando Henrique Cardoso, uma bolsa da Fundação Ford para estudar no Chile (Entrevista de Frederico Mazzucchelli à autora, 2014).

Silvério Soares Ferreira e Frederico Mazzucchelli haviam sido presos ${ }^{274}$ em junho de 1968, junto com outro colega de FCEA, Luciano Galvão Coutinho (item 5.2), que fez breve passagem pelo Chile em 1971. Coutinho, que cursava o doutorado na University of Cornell, conseguiu uma bolsa de estudos latino-americana para seguir alguns cursos da CEPAL e da ESCOLATINA durante as férias de verão. Andrea Calabi, que fazia o doutorado em Berkeley, teve experiência semelhante à de Luciano, dois anos depois, quando recebeu bolsa da Fundação Ford para fazer um curso de verão organizado em conjunto pela FLACSO e pelo MIT, sobre modelos matemáticos de análise política. Chegou lá com Gilda Portugal Gouvêa, esposa do colega deles de FCEA, Roberto Perosa (item 5.1). Eles combinaram um encontro com Frederico Mazzucchelli e outros amigos de USP que lá estavam e Serra apareceu. Foi quando Calabi conheceu José, dali em diante trabalhariam próximos em muitas oportunidades ${ }^{275}$ (Entrevista de Luciano Coutinho à autora, 2013; Entrevista de Andrea Sandro Calabi à autora, 2012).

Coutinho conta que no Chile:

assisti algumas aulas de alguns professores entre os quais a professora Maria da Conceição, o professor Aníbal Pinto, Osvaldo Sunkel. Então isso me trouxe um pouco de volta para o Celso Furtado e para a previsão latino-americana. Voltei dessa viagem com uma outra bagagem tanto de macro, que incorporou [Michal] Kalecki, quanto de organização industrial, porque a Conceição me introduziu ao

\footnotetext{
${ }^{273}$ Frederico Mazzucchelli (1947), nasceu em São Paulo. Seus avós maternos eram libaneses. O Avô era comerciante e vendia café. Os avós paternos e o pai eram italianos. O Avô era advogado e o pai tornou-se industrial, criando no Brasil um laboratório farmacêutico. A irmã de seu pai vivia na Itália e era casada com o crítico de arte Giulio Carlo Argan. Frederico fez sua graduação na FEA e teve ativa vida no movimento estudantil mesmo sem estar formalmente vinculado a nenhuma dos grupos da esquerda organizada. Ainda na graduação começou a trabalhar no CEBRAP como assistentes de Paul Singer e Francisco de Oliveira. O agravamento da situação política fez com que fosse estudar na ESCOLATINA. Depois do golpe regressou ao CEBRAP e tornou-se aluno de pós-graduação e depois professor da UNICAMP (Entrevista de Frederico Mazzucchelli à autora, 2014).

${ }^{274}$ Ver:

http://www.arquivoestado.sp.gov.br/memoriapolitica/documento.php?ficha=BR_SPAPESP_DEOPSSPOSFTEX SNC005334. Consultado em 05/03/2016; O Estado de São Paulo, 3 de julho de 1968, p. 11.

${ }^{275}$ Calabi relata que ele Gilda e outros colegas chegaram em Santiago em pleno 1973, encontrando os trancaços, greves e passeatas de um país em ponto de ebulição. "Nós fomos pra rua. A Fundação Ford ficou muito agitada, porque como estudantes estrangeiros nós tínhamos um visto especial, etc. O consulado acompanhava e eles diziam que ir para a rua era uma atitude política que não podia ter por causa da uma neutralidade... mas a situação política era tão dividida, que nós argumentamos que não ir também era a tomada de uma posição política" (Entrevista de Andrea Sandro Calabi à autora, 2012).
} 
Sylos [Paolo] Labini, o famoso Oligopólio e progresso técnico, e outros autores, talvez Karl Polanyi (Entrevista de Luciano Coutinho à autora, 2013).

Ana Célia Castro conta que liam correntemente Sylos Labini e Joe Bain, na área de organização industrial, Michal Kaleki, Piero Sraffa e Joan Robinson. “Todas essas visões heterodoxas que são relevantes no período passam a ser ensinadas junto com a economia política, junto com o pensamento marxista que vai ser estudado em profundidade”. Além disso Otávio Rodriguez, que estava fazendo uma história do pensamento cepalino, que resultaria em seus livros Teoria do subdesenvolvimento da CEPAL (1980) e O estruturalismo Latino-Americano (2006), exercitava com os alunos uma releitura da produção da CEPAL. À essa combinação teórica somar-se-iam os estudos de Marx que os brasileiros faziam em encontros semanais nos quais discutiam "O Capital. Capítulo a capítulo. Volume a volume. Os três volumes. Nós lemos os três volumes. Digamos que a gente não tenha terminado o terceiro volume porque não deu tempo" (Entrevista de Ana Célia Castro à autora, 2014).

Fernando Henrique conta que o seminário que realizamos no Chile, era similar ao antigo Seminário Marx de São Paulo. Este
grupo era menos famoso, talvez, mas igualmente notável. Um membro era um
cineasta, Leon Hirszman, enquanto outro mais tarde tornou-se líder de meu
governo no Senado, Paulo Alberto Monteiro de Barros. Almino Afonso, que foi
ministro do Trabalho de Goulart, e meu velho amigo de infância Plinio de
Arruda Sampaio também participaram. Esse "Seminário de Santiago" foi muito
mais abertamente político que os encontros Marx - tornou-se um think thank de
diversos exilados (CARDOSO, 2006b, p. 92).

Pouco depois, "Serra estabeleceu amizade comigo e logo se juntou ao seminário" (CARDOSO, 2006b, p. 92). Ana Célia Castro relata que na época em que o frequentou, o seminário era composto por cerca de quinze pessoas, dentre as quais Castro, Conceição, Serra, Jader de Andrade e Gerson Gomes, da CEPAL, e um conjunto de alunos de mestrado da ESCOLATINA, entre os quais Zé Carlos Braga, Paulo Baltar, Eduardo Kugelmas e José Luís Fiori (Entrevista de Ana Célia Castro à autora, 2014).

Com a ascensão de Salvador Allende e a radicalização dos conflitos sociais, políticos e teóricos no início anos 1970, o corpo docente da Faculdade de Ciências Econômicas da UC começa a fragmentar-se. Parte significativa dos simpatizantes do governo Allende, muitos dos quais ligados à CEPAL, vão trabalhar no governo. Pedro Vuskovic, que era funcionário da CEPAL e professor da UC, da FLACSO e do ILPES, talvez seja o caso mais emblemático dessa migração já que se tornou ministro da 
economia do governo Allende e organizador do plano econômico que defendia a radicalização da reforma agrária, a nacionalização da indústria do cobre e o controle direto do Estado sobre diversas áreas da economia. Outros professores da ESCOLATINA, inclusive brasileiros como Maria da Conceição Tavares e José Serra, passariam a colaborar com o governo, convertendo-se em assessores do Ministério da Fazenda (FRANCO, 2013, p. 237; FURTADO, 2014, p. 526; TAVARES, 2010). Conceição conta que

no último período do governo Allende, antes do golpe militar, a situação econômica e política tinha se complicado muito. A maioria dos diretores da CEPAL tinha postos importantes no governo. Assim, a partir de março de 1972 até março de 1973, pedi licença na CEPAL e fui colaborar, assim como outros economistas estrangeiros (TAVARES, 2010, [online]).

Quando os professores que acreditavam na via democrática para o socialismo passaram a trabalhar para Allende dedicando cada vez menor tempo à Escuela, sobraram, de um lado, os docentes mais conservadores e, de outro, a esquerda revolucionária. A polarização era tamanha que a Faculdade acabou por dividir-se em duas unidades com dois currículos diferentes. A primeira era a Sede Occidente, dominada por economistas predominantemente ligados à democracia cristã que mantinham a estrutura do ensino de economia que se generalizava a partir dos Estados Unidos, dita neoclássica. A segunda unidade era a Sede Norte formada essencialmente por economistas críticos propagadores de uma economia política de viés marxista (BARRALES, 2015, pp. 35-36; MONTECINOS, 2009, p. 168). A maior parte dos asilados brasileiros acabou engajandose no projeto da Sede Norte, passando muitos deles inclusive a dar aula na nova escola.

Reinaldo Carcanholo, um dos exilados brasileiros que esteve envolvido com a formulação do currículo ${ }^{276}$ da Sede Norte, relata:

Durante meses no ano de 1972 e durante parte do primeiro semestre de 1973, no Chile socialista de Salvador Allende, um grupo de professores e estudantes de economia, chilenos e de outros países latino-americanos, lançaram-se a elaborar uma proposta de reforma curricular no ensino dessa matéria, que nunca chegou a ser implementada, pelo menos por período significativo. Tratava-se, em concreto, de uma nova grade curricular, com suas respectivas ementas e

\footnotetext{
${ }^{276}$ No currículo da Sede Norte as disciplinas de Introdução à economia política e Economia Política I, II e III eram essencialmente baseadas no ensino de $O$ Capital. A elas seguiam-se: um curso de desenvolvimento econômico geral baseado nos textos da CEPAL de Aníbal Pinto, Osvaldo Sunkel e Maria da Conceição Tavares, apresentando a contribuição da teoria da dependência na versão elaborada no CESO sob a direção de Theotônio dos Santos e André Gunder Frank; um curso de desenvolvimento e economia chilena também baseado essencialmente em textos de autores da CEPAL; um curso de história econômica; um de história do pensamento econômico; um curso optativo de economia política do socialismo; e, então, cursos de análise econômica, política econômica, diversos cursos de planejamento e planificação, cadeiras sobre cooperativismo, sendo residual a parte do programa dedicada à contabilidade, comercialização e outras matérias mais técnicas (CARCANHOLO, 2012).
} 
bibliografia básica para cada disciplina. $\mathrm{Na}$ verdade, era muito mais do que isso, consistia em uma proposta que buscava concretizar uma nova concepção do ensino de economia, crítica e pluralista. $\mathrm{Na}$ verdade, o ensino crítico já encontrava muito espaço na Escola de Economia da Universidade do Chile, desde antes. Algumas disciplinas, na prática, tinham conteúdo alternativo e outras tantas foram sendo introduzidas para a discussão séria, em particular, da problemática latino-americana e, em geral, do Terceiro Mundo. Estudava-se também, com seriedade, economia clássica e marxista. No entanto, ao que parece, não existia uma articulação global, dentro de um projeto didático coerente e totalmente articulado. Os professores que participaram, em 1972, dos debates e da organização do novo currículo exerciam sua docência na Escuela de Economia (especialmente no Departamento de Economía y Planificación e no Centro de Estúdios Sócio-Económicos - CESO) e, principalmente, no programa de pós-graduação, muito famoso na época na América Latina, denominado ESCOLATINA (Programa de Estudos Latinoamericanos para Graduados). [...] Essas duas instituições agrupavam um número expressivo de professores de primeira grandeza, destacando-se, entre eles, os brasileiros, além de chilenos, argentinos e de outras nacionalidades. Nomes como o do brasileiro, falecido há pouco tempo, Ruy Mauro Marini, além de Theotônio dos Santos, Pedro Paz, Conceição Tavares e Antonio Barros de Castro, estavam entre eles [...] Talvez em razão da divisão na Universidade e, em conseqüência da redução do número de docentes para essa escola, para o semestre agosto-dezembro de 1973, foram designados como professores ad honorem (isto é, sem remuneração), vários dos então estudantes da ESCOLATINA, bolsistas muitos deles ou quase todos. Tivemos a oportunidade [ele e diversos outros brasileiros] de estar entre eles (CARCANHOLO, 2012, [online]).

A referência aos professores Theotônio dos Santos e Ruy Mauro Marini, que faziam parte do Centro de Estudios Sociales ligado à Faculdade de Economia da UC, e a inclusão dos textos deles e de André Gunder Frank na bibliografia da Sede Norte - e a não inclusão do livro de Cardoso e Falleto - são indicações das afinidades do grupo que ali se instalava com a versão marxista da teoria da dependência. Enquanto Cardoso e Faletto cerziam a sua a teoria da dependência vinculados à CEPAL e ao ILPES, esse segundo grupo - composto por Theotônio dos Santos e sua esposa, Vânia Bambirra, bolsistas da FACE, por seu colega de militância na POLOP, Ruy Mauro Marini, e por Andre Gunder Frank, vindo dos EUA e que com eles havia lecionado na UNB, - tecia, paralelamente, considerações de temática análoga no CESO.

\subsection{Vânia Bambirra, Theotônio dos Santos e Ruy Mauro Marini: teoria e práxis}

Theotônio (1937) nasceu em Carangola, no interior de Minas Gerais, mas residiu durante quase toda a infância em Muriaé. Lá estudou no colégio Edmundo Germano, do qual foi expulso por participar do jornalzinho $A$ Voz Juvenil, formado por jovens que já 
tinham algum contato com o marxismo. Seu pai o transfere então para o Colégio Granbery, instituição metodista em Juiz de Fora, fundada por missionários estadunidenses, onde passou a ter contato direto com jovens comunistas e com a literatura de esquerda. Aos 16 anos mudou-se para Belo Horizonte e ingressou no Colégio Estadual Marconi onde foi contemporâneo de Simon Schwartzman, que seria seu colega na UFMG e na POLOP. Theotônio conta que decidiu ingressar no curso de sociologia da FACE por influência de um colega de militância, José Nilo Tavares (1935-1997), que acabara de ingressar na FACE e contou-lhe acerca da experiência das bolsas de estudo. Ele comenta: "em decorrência da bolsa, nós tínhamos, talvez, um dos melhores locais de trabalho que eu já tive na minha vida [...], impressionante, eu nunca mais vi algo parecido. Depois eu ganhei uma sala sozinho, com banheiro, todos os livros, máquina de escrever". Em 1961, Theotônio concluiu a graduação e foi cursar o mestrado na UNB. O mesmo fez pouco tempo depois Vânia Bambirra, sua colega e namorada (SANTOS, 2009).

Vânia Gelape Bambirra (1940) nasceu em Belo Horizonte. Segundo seu depoimento:

os chefes da minha família provinham de extremos opostos: minha mãe, de origem italiana, havia sido muito rica; meu pai, brasileiro miscigenado, muito pobre. Ela, burguesa, com atitudes herdadas ou adquiridas, quem sabe, de nobreza; ele artesão interiorano, alfaiate, com uma profunda raiz popular; ela, com curso secundário e com uma inteligência média; ele com curso primário dado pela sua mãe que era professora, com uma inteligência viva, mas sobretudo com um sentido de justiça exacerbado que, muitas vezes, eclipsava sua razão e o tornava um visionário. Foi assim natural a sua entrada no Partido Comunista do Brasil e a entrega paulatina a este dos bens adquiridos com a herança da esposa [...]. Eu fui a única "ovelha negra", por encantar-me, desde pequena, com os ideais pregados pelo meu pai (BAMBIRRA, 1991, pp. 2-3).

Por influência do polo materno, burguês, no qual a liberdade feminina não podia transpor o exercício da profissão de professora primária, Vânia estudou para ser normalista. Chegou a cogitar a carreira de pianista, arte das moças refinadas. Argumenta, no entanto, que não tinha vocação para ser professora de crianças e acabou desistindo também do piano. Optou por seguir para a sociologia pois lia muita literatura e romances históricos e pensava que poderia tornar-se romancista social. Vânia também destaca a experiência da bolsa que recebeu na FACE como "uma oportunidade que mudou minha vida". Foi o que permitiu que afastasse "a perspectiva de um emprego necessário em um jardim de infância" e conseguisse se dedicar intensamente aos estudos. Ao lado da atividade discente, Vânia deu início à militância política. Engajou-se, ao lado de seu primo 
Sinval de Oliveira Bambirra (1933-2003) - vinculado inicialmente ao PCB, Sinval seria eleito deputado estadual pelo PTB em 1963 e cassado logo em seguida -, em atividades políticas e educacionais nas favelas da região de Belo Horizonte. Depois atuou nas ligas camponesas inspiradas pelo líder nordestino Francisco Julião. Era também amiga de jovens das vanguardas literárias de sua geração, comentando: “o nosso Estado é assim: gera, ao mesmo tempo, os elementos mais conservadores e os mais subversivos, o mais radical em todos os parâmetros. A combustão entre eles provoca o catapultamento dos melhores, dos de vanguarda"; a contradição existindo dentro de sua própria família faz com que ela própria possa se considerar efeito de tal catapultamento provocado pela combustão (BAMBIRRA, 1991, pp. 3-18; DUARTE, 2004, pp. 600-601).

Muito influenciados pelo exemplo que oferecia a revolução cubana, Vânia e Theotônio desviam da militância no PCB e envolvem-se com a criação da POLOP, ocasião em que conhecem Ruy Mauro Marini, um dos principais articuladores do movimento no Rio de Janeiro. Vânia conta que não foi amor à primeira vista. Fazia frio e o moço vestia-se como se estivesse em Paris, de onde acabara de voltar. Ela achava que tal extravagância não era digna de um revolucionário. Mas a antipatia logo se desfez, ela acabou sendo conquistada por seu "raciocínio brilhante e dialético" e ele se tornou o seu “mais querido amigo" (BAMBIRRA, 2011, p. 271).

Também Ruy Mauro Marini (1932-1997) era mineiro, de Barbacena. Seu avô paterno havia sido costureiro em Gênova e a avó camponesa da região da Calábria. De parte de mãe descendia de uma família de latifundiários de Minas Gerais que decaiu com a abolição da escravidão pois, malgrado a perda das fontes de rendimentos, mantinha o padrão de dispêndios ao qual estava acostumada. O pai de Marini, que começou a vida adulta lecionando matemática na escola agrícola local, conseguiu ascender socialmente através da Faculdade de Direito e do concurso público para inspetor de impostos. Vinculou-se aos círculos do Estado Novo e do PSD, transitando bem no universo das elites mineiras. Ruy parte para o Rio de Janeiro depois de concluir sua educação secundária no Colégio Estadual de Barbacena, onde conta ter aprendido latim, inglês, francês e espanhol. Estabelece-se na capital em 1950 com a intenção de tornar-se médico. Desiste. Ao invés de dar continuidade aos estudos acaba optando pelo concurso público pois, diz ele, desejava ter alguma independência financeira para aproveitar "o cinema, o teatro, as praias e a bohemia", que eram as grandes atrações do Rio de Janeiro. Logra 
ingressar no Instituto de Aposentadorias e Pensões dos Industriários (IAPI) e faz algumas traduções e trabalhos jornalísticos para complementar a renda (MARINI, 2011, pp. 5556).

Em 1953, Marini decidiu dar continuidade aos estudos, ingressando na Faculdade Nacional de Direito, onde teve contato com um movimento estudantil nacionalista e desenvolvimentista que procurava esboçar projetos para o país. Insatisfeito com o curso, matricula-se na Escola Brasileira de Administração Pública da Fundação Getúlio Vargas (EBAP-FGV-RJ), criada entre 1950 e 1951 com apoio das Nações Unidas. O IAPI concedeu uma licença remunerada para que Ruy pudesse estudar na EBAP, já que consideravam que essa formação poderia ser benéfica ao próprio Instituto. Lá teve contato com uma intelectualidade crítica, notavelmente com o professor Alberto Guerreiro Ramos, que até então era membro do IBESP e que teve grande influência sobre ele e também sobre o casal Bambirra e Santos, tornando-se inclusive padrinho de casamento dos dois. Marini converte-se em assistente de Guerreiro Ramos nos cursos que ele ministrava no Departamento Administrativo do Serviço Público (DASP) e, com incentivo dele e por intermédio de um professor francês que lecionava no EBAP, François Gazier - cientista político vinculado ao Institut d'Études Politiques de Paris (Science Po) que se tornaria depois coordenador do Institut d'Étude du Développement Économique et Social da Université de Paris -, Marini obtém bolsa para dar continuidade a seus estudos na Science Po. Parte para a França em 1958 e lá permanece dois anos. Em Paris, além de cultivar seu cosmopolitismo por meio de viagens pela Europa e de imergir nas tendências culturais da época, passou a estudar sistematicamente Hegel, Marx e Lenin (D’ARAÚJO, 1999, p. 112; MARINI, 2011, pp. 57-60).

Conforme seu relato:

O período que ali passei coincidiu com o auge da teoria desenvolvimentista na América Latina e no Brasil - com a qual eu me familiarizara na EBAP, pela mão de [Alberto] Guerreiro Ramos, havendo inclusive assistido de perto o processo de formação do ISEB (e, antes dele, do IBESP) - e com sua difusão na academia francesa, tendo [Georges] Balandier como pontífice [...]. As teorias do desenvolvimento, em voga nos Estados Unidos e nos centros europeus, se me revelaram, então, como o que realmente eram: instrumento de mistificação e domesticação dos povos oprimidos do Terceiro Mundo e arma com a qual o imperialismo buscava fazer frente aos problemas criados no após-guerra pela descolonização. Começa, então, o meu afastamento em relação à CEPAL, fortemente influenciado, ademais, pela minha crescente adscrição ao marxismo. Isso me levaria, ainda na França, a tomar contato com o grupo que editava, no Brasil, a revista Movimento Socialista, órgão da juventude do Partido Socialista 
(que publicou um artigo meu, onde ajustava contas com o nacionaldesenvolvimentismo), em particular Eric Sachs, com o qual eu viria a estabelecer, a meu regresso, uma grande amizade e cuja experiência e cultura política me influenciaram fortemente. Esse grupo, com suas principais vertentes no Rio, São Paulo e Belo Horizonte, constituirá, mais adiante, a Organização Revolucionária Marxista - Política Operária (MARINI, 2011, pp. 60-61).

Ao regressar, em meados dos anos 1960, Ruy voltou ao IAPI e começou a escrever para veículos de comunicação de esquerda, colaborando inclusive com Carlos Estevam Martins no jornal crítico O Metropolitano. Quando, em 1962, a UNB foi criada por Anísio Teixeira, Darcy Ribeiro, Frei Mateus e outros, Marini integrou-se ao corpo docente como auxiliar de pesquisa da área de ciência política e como estudante de doutorado. Lá reuniu-se aos dois jovens professores auxiliares que cursavam seus mestrados em Brasília, Vânia Bambirra e Theotônio dos Santos, com os quais havia estabelecido amizade desde o congresso da fundação da POLOP, realizado em Jundiaí em 1961 (MARINI, 2011, pp. 61-63; SADER, 2013, pp. 8-9).

Pouco depois, o grupo de professores por eles formado passou a ser integrado também por Andre Gunder Frank (1929-2005). Nascido em Berlim, Frank foi enviado ainda pequeno para colégios internos na Suíça onde permaneceu até 1941, ano em que sua família foi para os Estados Unidos para escapar do nazismo ${ }^{277}$. Seu pai, Leonhard Frank, nascido em uma família pobre de Würzburg, no interior da Alemanha, tornou-se escritor expressionista e crítico social, integrando o círculo de amizades de Bertolt Brecht. Ao final da vida escreveu a autobiografia was Links, wo das Herz ist [coração na esquerda]. Seu filho seguiria os mesmos passos. Nos EUA, Gunder Frank estudou economia no Swarthmore College, tornando-se na época keynesiano. Diz ele que, sem saber onde estava se metendo, inscreveu-se em 1950 no doutorado da Universidade de Chicago, que "desde então se tornou o oráculo da direita (que não é direita!) e a bíblia da economia praticada pelo governo de Ronald Reagan" sob a liderança do maior expoente do neoliberalismo, Milton Friedman (item 4.4) (FRANK, 1998; HOFE, 1947, p. 122).

Segundo relata, mesmo tendo sido aprovado em todos os exames do doutorado, recebeu uma carta do departamento aconselhando-o a deixar o curso por sua incompatibilidade teórica com a escola, reforçada por sua militância estudantil, em pleno macartismo. Depois de sucessivas experiências de desencontro com Chicago, começou a trabalhar em um projeto sobre o mundo eslavo que o levou a escrever uma tese sobre a

\footnotetext{
${ }^{277}$ Ver: http://rrojasdatabank.info/agfrank/personal.html. Consultado em 21/12/2015.
} 
organização da atividade econômica na União Soviética e na Ucrânia, razão pela qual foi enviado para fazer pesquisas na União Soviética, onde teve contato com outros modelos de pensamento econômico (FRANK, 1998).

Em 1957, Frank conseguiu um posto de professor assistente em economia na Michigan State University. Lá diversificou ainda mais suas referências, fazendo leituras nas áreas de antropologia e com teorias relativas ao desenvolvimento no terceiro mundo. Seu conhecimento acerca das teorias do desenvolvimento e da modernização foi ampliado na estadia, em 1958, no Center for International Studies do MIT, ao qual estavam ligados Walt Rostow e Max Millikan, que acabavam de publicar $A$ proposal: key to an effective foreign policy (1957). Rostow estava trabalhando à época naquele que seria seu livro mais conhecido: Stages of Growth: A Non-Communist Manifesto, publicado em 1960. Gunder Frank e sua escola dependentista tornar-se-iam, alguns anos depois, particularmente críticos dos teóricos da modernização norte-americanos, que consideravam, apesar de sua filiação ao keynesianismo, perseguir os objetivos neoclássicos, antirrevolucionários e mesmo contrarreformistas da guerra fria tão explicitamente quanto possível. Frank diz que sua crítica em relação à política da Guerra Fria e à teoria do desenvolvimento produzida à sua sombra fez com que deixasse Michigan e fosse estudar fora dos Estados Unidos, que julgava ser "parte do problema, e não da solução" (FRANK, 1998, [online]).

Frank chegou ao Brasil em 1963, a convite de Darcy Ribeiro que muito apreciara um artigo em que comparava as remessas de lucros com a entrada de capitais do exterior. Frank transmitiu para seus colegas brasileiros a grande influência que recebera dos neomarxistas ligados à revista Monthly Review278, Paul Baran e Paul Sweezy, professores de Stanford e Harvard respectivamente. A leitura que faziam do capitalismo em chave internacional - que falava sobre o efeito deletério das estruturas de monopólio e do imperialismo e considerava que problemas como "a irracionalidade e a injustiça social não podem ser resolvidos por meio de melhores soluções políticas, desenhadas dentro do enquadramento do Estado e das relações de propriedade capitalistas" - teria grande influência nesta versão da teoria da dependência (MARINI, 2011, p. 63; PHELP, 1999).

A aterrisagem na Brasília de 1963 é, neste ponto, bastante frutífera, pois Gunder Frank ingressa em um ambiente no qual sua crítica teórica encontrava-se com uma vida política efervescente. Lá, o marxismo com o qual começara a tomar contato nos EUA

\footnotetext{
${ }^{278}$ Revista de inspiração marxista que começou a ser publicada em 1949 por Paul Sweezy e Leo Huberman, e segue operando até o presente (PHELP, 1999).
} 
encontrou-se com as leituras que Theotônio, Vânia e Ruy faziam do Capital, segundo modelo que lhes foi transmitido pelo colega de POLOP, Paul Israel Singer, que participara do Seminário do Capital da Faculdade de Filosofia da USP. Vânia e Theotônio haviam tido também contato com membros da FFCL, como Fernando Henrique Cardoso, Octavio Ianni e Francisco Weffort, no congresso da Sociedade Brasileira de Sociologia de 1959, realizado em Minas Gerais quando ainda lá estudavam. Outra influência que alcançou os jovens professores foi o escritório CEPAL-BNDE que ofereceu em Brasília um de seus cursos intensivos de Treinamento em Problemas do Desenvolvimento, no segundo semestre de 1962 (SANTOS, 2009). A relação que já tinham com o ISEB, via Guerreiro Ramos, o contato com a CEPAL, com as ciências sociais da USP e sua leitura do Capital, somados à militância revolucionária de inspiração cubana e o marxismo estadunidense trazido por Gunder Frank, eram os ingredientes principais da versão da teoria da dependência que iriam redigir no Chile.

Gunder Frank reconhece que reconhece que sua crítica só deixou de ser fundamentalmente liberal depois que sua experiência na América Latina fez com que entendesse que era preciso abandonar a premissa segundo a qual só se pode fazer ciência objetiva com neutralidade política (FRANK, 1967, p. xiv). Na efervescente Brasília, ele passou a conduzir um seminário no qual apresentou aos jovens professores o moderno marxismo estadunidense de Baran e Sweezy. Foi nesse espaço que começaram a formular

uma crítica ao estrutural-funcionalismo, que era o pensamento básico da teoria do desenvolvimentismo. A CEPAL não era suficientemente crítica nisso. Ela tinha uma postura do tipo keynesiana, ela tava muito mais próxima das ambições e da programática da nossa burguesia nacional, não propriamente do movimento operário, dos trabalhadores, isso não fazia parte do universo deles. Toda a questão do sujeito do processo estava no plano burguês. Tinha uma linha nacional-democrática. Ao trazermos essa crítica e entrarmos nessa discussão política, ao mesmo tempo fazíamos a leitura de O Capital, pensando no marxismo. Nós entramos num ponto crítico muito avançado (SANTOS, 2009, [online]).

Ruy Marini concorda, argumentando que a teoria da dependência marxista nasceu justamente na confluência ocorrida nesse seminário da UNB. Para ele o contexto político ali vivenciado foi fundamental para a sua elaboração:

$\mathrm{Na}$ realidade, e contrariando interpretações correntes, que a vêem como subproduto e alternativa acadêmica à teoria desenvolvimentista da CEPAL, a teoria da dependência tem suas raízes nas concepções que a "nova esquerda" [da qual a POLOP é exemplo] - particularmente no Brasil, embora seu desenvolvimento político fosse maior em Cuba, na Venezuela e no Peru elaborou, para fazer frente à ideologia dos partidos comunistas. A CEPAL só se 
converteu também em alvo na medida em que os comunistas, que se haviam dedicado mais à história que à economia e à sociologia, se apoiaram nas teses cepalinas da deterioração das relações de troca, do dualismo estrutural e da viabilidade do desenvolvimento capitalista autônomo, para sustentar o princípio da revolução democrático-burguesa, anti-imperialista e antifeudal, que eles haviam herdado da Terceira Internacional. Contrapondo-se a isso, a "nova esquerda" caracterizava a revolução como, simultaneamente, anti-imperialista e socialista, rechaçando a ideia do predomínio de relações feudais no campo e negando à burguesia latino-americana capacidade para dirigir a luta antiimperialista. Foi no Brasil da primeira metade dos anos de 60 que essa confrontação ideológica assumiu perfil mais definido e que surgiram proposições suficientemente significativas para abrir caminho a uma elaboração teórica, capaz de enfrentar e, a seu tempo, derrotar a ideologia cepalina - não podendo ser, pois, motivo de surpresa o papel destacado que nesse processo desempenharam intelectuais brasileiros ou ligados, de alguma forma, ao Brasil (MARINI, 2011, pp. 63-64).

De todo modo há grande afinidade entre as premissas e as conclusões sustentadas pela vertente marxista da dependência e aquelas de grupos marxistas, como a POLOP, que consideravam que melhorias efetivas das condições sociais só poderiam ser aportadas por uma transformação de tipo revolucionária. A obra inaugural da teoria marxista da dependência, Capitalism and underdevelopment in Latin America (1967), dedicada a Paul Baran e Paul Sweezy, evidencia a coincidência entre a política e a ciência da política. Ela reúne um conjunto de ensaios de Andre Gunder Frank alinhados pela visão segundo a qual:

A estrutura contemporânea do capitalismo também não provê o desenvolvimento autônomo de uma burguesia nacional independente o suficiente para conduzir (ou muitas vezes até mesmo tomar parte ativa em) um verdadeiro movimento de libertação nacional ou progressivo o suficiente para destruir o subdesenvolvimento capitalista, então não pode mais ser a burguesia, em qualquer de suas formas, aquela que é fazer essa revolução. A missão histórica e o papel da burguesia na América Latina - que era acompanhar e promover o subdesenvolvimento da sua sociedade e de si mesma - está concluída. $\mathrm{Na}$ América Latina, como alhures, o papel de promover o progresso histórico recai agora nas massas do povo, e aqueles que honesta e realmente servem ao progresso do povo devem apoiá-lo na obtenção de progressos por e para eles mesmos (FRANK, 1967, pp. xii-xiii).

As duas vertentes convergiam, assim, na crítica à mudança social por etapas e à tese do PCB segundo a qual o desenvolvimento de uma burguesia nacional e de um operariado moderno no país levaria, no longo prazo, à criação das condições para a instalação do comunismo. Contra isso e inspirados na revolução cubana, pleiteavam uma tomada do poder imediata pelas classes subjugadas do mundo subdesenvolvido.

O golpe de 1964 afastou da UNB os quatro professores e interrompeu temporariamente esse ensaio de conjugação de teoria e militância. Theotônio passou alguns meses na clandestinidade em São Paulo. Vânia teve seus livros, papéis e escritos 
revirados. Processada, afastou-se da UNB e foi trabalhar como pesquisadora em uma agência de publicidade, na qual aprendeu a fazer pesquisa de opinião, tabular respostas de entrevistas e até fazer observação participante. Gunder Frank partiu para o México em meados de 1964, tornando-se professor da UNAM. Marini foi preso, depois passou 3 meses na clandestinidade. Acabou por asilar-se na embaixada do México e partir, pois sua família estava ameaçada. Quando chegou à Cidade do México, Frank ajudou-o a integrarse à vida intelectual e política apresentando-o a simpatizantes da esquerda que se solidarizavam com os brasileiros. Marini conseguiu posições de professor no Centro de Estudios Latinoamericanos da Facultad de Filosofía da UNAM e no Centro de Estudios Internacionales do Colegio de México, onde lecionou ao mesmo tempo que Victor Urquidi, descrito por ele como "desenvolvimentista ilustre, mas capaz de respeitar o direito de opinião". Além do mais, coordenava um seminário do Capital com seus alunos e alguns professores, que acontecia em sua própria casa, nas manhãs de sábado. Em 1968, com a repressão violenta ao movimento estudantil no México, Marini, professor de Marx, considerado incitador de estudantes, vê-se constrangido a deixar o país (BAMBIRRA, 1991, pp. 21-22; MARINI, 2011, pp. 65; SANTOS, 2009).

Marini aventou ir para a França ou para a Argélia sem sucesso. Acabou mudando o Chile no final de 1969 e por quase um ano, deu aulas no Instituto Central de Sociologia em Concepción, onde participou entusiasticamente das movimentações do MIR. Depois agregou-se formalmente ao CESO, reencontrando companheiros dos tempos de Brasília (MARINI, 2011). O casal Bambirra-Santos havia chegado a Santiago em 1966. Ao preparar sua partida para o exílio, Theotônio entrou em contato com Fernando Henrique Cardoso para solicitar ajuda para inserir-se profissionalmente. Escreve:

Caro Fernando Henrique você já deve ter tido notícia de minha condenação e de meu asilo. Encontro-me atualmente na embaixada à espera do salvo-conduto, que deve demorar ainda um mês e meio. Mas como Vânia (você a conheceu em Minas, era bolsista na FCE [FACE]), minha esposa, está para ser julgada a qualquer momento, pois o inquérito sôbre ela em Brasília foi para Juiz de Fora, estou apressadíssimo em encaminhar minha situação para que ela possa ir o mais rapidamente possível. O principal motivo pelo qual escolhi a asilo no Chile foi a possibilidade de trabalhar com você e Weffort. Gostaria de saber se de fato será possível, se você poderia encaminhar as coisas nêste sentido. Minha situação curricular é a seguinte: fui monitor, depois bolsista, depois auxiliar de pesquisa, enquanto aluno na FCE; depois, fui instrutor durante dois anos em Brasília, onde completei o curso de mestrado e apresentei uma tese sôbre estrutura da classe dominante no Brasil. Apesar de ter apresentado a tese algumas semanas antes do golpe de abril de 64, até hoje a UNB não a julgou, e creio que nunca a julgará. Depois de março, levei uma vida clandestina, sem possibilidades profissionais [...]. Vânia também foi instrutora em Brasília e trabalha atualmente numa 
companhia de publicidade como assistente de pesquisa onde adquire uma boa experiência. Gostaria de saber se existe alguma possibilidade para ela também, mesmo que não seja tão urgente como para mim, já que, garantida a situação de um dos dois, o problema imediato seria sanado. Ruy Mauro Marini escreveu para um amigo fazendo referência à sua ida ao México, espero que tenha gostado dêle, pois era um dos melhores da UNB e é um grande amigo nosso. Soube também que Oswaldo Gusmão foi para aí e deve trabalhar na CEPAL, mas não sei se já resolveu a situação dêle. Enfim, são muitos os amigos que estão por essas bandas, mas espero estar aí para poder revê-los pessoalmente (Carta de Theotônio dos Santos a Fernando Henrique 20.03.1966 279).

\section{Theotônio não foi o único membro da POLOP a solicitar ajuda de Fernando}

Henrique para buscar trabalho no Chile. Paul Singer, face à incerteza que se seguiu ao golpe escreveu a FHC para perguntar se haveria alguma possibilidade de inserção na CEPAL ${ }^{280}$ :

Meu caro Fernando Henrique. Penso que os jornais e a correspondência já devem ter dado uma ideia bastante clara - na medida em que é possível tê-la - da situação no Brasil. Por enquanto duas tendências parecem chocar-se no seio dos partidários da "revolução": os que acham que ela está ainda longe de ter alcançado seus objetivos: eliminação do comunismo, da corrupção, e os que propugnam o seu encerramento no menor prazo possível para que o país possa voltar à normalidade legal. A primeira tendência, cujo porta-voz mais explícito é o "Estado", pretende que a repressão se estenda ainda muito mais; a segunda, chefiada no plano civil pelos candidatos à presidência em 1965: JK, Magalhães Pinto e inclusive Adhemar, luta para que a fase repressiva seja liquidada no menor prazo possível. [...] Confesso que eu estou muito cético a respeito das possibilidades desta resistência. Aqui em S. Paulo, o expurgo ainda não foi feito, nem na Assembléia Legislativa, nem na Câmara Municipal, nem no Funcionalismo Estadual, nem na USP. Talvez demore ainda alguns dias ou semanas, mas virá e parece não haver motivos para otimismo. O Mário Wagner pediu aposentadoria o que me força a sair da Faculdade de Ciências Econômicas. Para não prolongar uma situação chata resolvi pedir dispensa de uma vez e creio que ela me será concedida até o fim do mês. Tenho que reelaborar minhas perspectivas para o futuro. Uma das minhas chances é continuar em duas Faculdades do interior, o que me permite sobreviver, embora algo precariamente, e continuar me dedicando ao ensino. Outra possibilidade (se a primeira não der certo) é trabalhar como economista em alguma empresa, talvez ganhando mais, mas tendo que pendurar no prego minha carreira e trabalho intelectual. $\mathrm{O}$

\footnotetext{
${ }^{279}$ Disponível em arquivo IFHC: http://acervo.ifhc.org.br/. Documento número 01/0008041-002; 01/0008041009. Consultado em 20/12/2015.

${ }^{280}$ Partir para o Chile representaria para Paul Israel Singer (1932) deixar tudo e mudar-se novamente. Isto porque chegara ao Brasil em 1940, com oito anos de idade, deixando a Áustria por conta das perseguições aos judeus. Lá seus pais eram donos de uma mercearia em uma comunidade operária na periferia de Viena. Radicaram-se em São Paulo e ele passou a dividir o tempo entre o trabalho como auxiliar de escritório e a escola técnica de eletrotécnica. Trabalhou por 4 anos na indústria de elevadores Atlas, foi quando começou suas lutas ao lado do operariado. Na época filiou-se ao Partido Socialista Brasileiro e participava da juventude sionista socialista. A atuação política levou-o a interessar-se pelos problemas econômicos, que considerava porta para conhecer a sociedade e o mundo. Começou os estudos de economia de maneira autodidata, ingressou na FCEA em 1956 e em 1959 tornou-se professor assistente ligado à Mario Wagner e começou, no início dos anos 1960, a estudar temas ligados ao desenvolvimento econômico. Após o golpe a perspectiva de herdar a cadeira de Wagner desapareceu. Paul sequer havia completado o doutorado quando foi aconselhado a deixar a faculdade, o que fez ao mesmo tempo que a outra assistente do professor, Lenina Pomeranz, também ligada à esquerda (SINGER, 2009, pp. 75-80; SINGER, 1999, pp. 55-56).
} 
Giannotti me contou que você lhe escreveu (não li a carta) dizendo que havia possibilidades de emprego para nós em universidades argentinas e chilenas e na CEPAL. Acredito que trabalhar na CEPAL seria para mim o mais interessante. Gostaria que você me escrevesse de que lugares se trata, que tipo de trabalho envolveria, remuneração, qual é o prazo em que tenho que me decidir (minha situação aqui deverá se esclarecer nas próximas 3 ou 4 semanas) e sobretudo qual a sua opinião pessoal a respeito do que devo fazer. Escreva-me ainda como você vai indo, que atividades você está tendo e o que vai acontecendo pelo Chile. Agradeço-te de antemão por tudo o que você puder fazer a respeito do que te peço e estou a tua disposição aqui se você precisar de algo que eu possa fazer ou te mandar. Transmita ao Weffort minhas lembranças e aceite um abraço. Do Paul. (São Paulo, 20 de maio de 1964).

Afinal, Singer acabou ficando em São Paulo onde trabalhou para uma empresa de consultoria em engenharia de projetos, a Hidroservice, e em um projeto de demografia na saúde pública (item 5.3). Vânia e Theotônio partiram efetivamente para Santiago. Ela trabalhou inicialmente em um centro de pesquisa de opinião pública, empregando as técnicas que havia aprendido na publicidade. O centro pertencia a Eduardo Hamuy Berr, democrata cristão e sociólogo chileno, amigo de Florestan Fernandes que - por intermédio de FHC - escreveu pedindo que recebesse os dois. Além de dedicar-se ao centro de pesquisas de opinião, Hamuy havia se tornado diretor do CESO, da Faculdade de Economia da UC, que ajudara a fundar em 1965 com o objetivo de promover o entendimento dos aspectos econômicos, sociológicos e psicossociais do experimento de transformação social que estava em curso no Chile. Theotônio foi trabalhar no CESO logo que chegou e em pouco tempo Vânia acabou transferindo-se para lá pois Fernando Henrique cedeu para ela uma de suas cadeiras (SINGER, 2009, p. 80; BAMBIRRA, 1991, pp. 24-26; CASTRO, 2015, pp. 124-126; SANTOS, 2009).

No CESO, Vânia e Theothônio, e depois também Marini e Gunder Frank, dão continuidade à tentativa de sistematizar uma leitura marxista do problema da dependência das nações subdesenvolvidas. Em linhas muito gerais, em comum com a análise de Cardoso e Falleto, há uma percepção de que a industrialização das periferias não trouxe a elas autonomia que lhes permitisse engrenar uma trajetória de desenvolvimento com elevação geral do nível de vida. Os dois grupos atribuem esse entrave a um novo tipo de dependência, em que o capital internacional monopolista passa a ocupar posição privilegiada no desenvolvimento industrial periférico, financiando e controlando a oferta de tecnologia da produção e mesmo conduzindo atividades econômicas diretamente, o que lhe permite obter parte substantiva do lucro ali produzido e adquirir poder sobre a tomada de decisão no espaço interno da periferia, empurrando as burguesias nacionais 
para a condição de sócios menores dos desígnios do capital internacional (CARDOSO e FALETTO, 1970, pp. 125-126; SANTOS, 1970, pp. 231-232).

Em ambas as vertentes é possível enxergar que, tendo como pano de fundo o caso brasileiro, imputam o estabelecimento do novo modelo de dependência à ruptura de um pacto de classes que se estabeleceu a partir dos anos 1930, viabilizado principalmente pelo recuo das forças externas durante o período de crises e guerras (itens 2.1 e 2.2). No caso brasileiro, o pacto que os grupos desenvolvimentistas mantinham até então com as elites oligárquicas impedia avanços na inclusão social dos camponeses, visto que essa exigiria reformas na estrutura agrária e extensão para o campo dos direitos conquistados pelo operariado urbano, que havia sido contemplado no pacto populista. As progressivas reivindicações sociais combinadas com a deterioração da condição econômica externa favorável no início dos anos 1960 e com o peso do endividamento externo, teria dado fim ao modelo de desenvolvimento voltado para dentro que vigorara por quase trinta anos. Acirradas as tensões sociais instaurou-se um governo autoritário que favorecia a associação das burguesias com o capital internacional ao suprimir a crítica popular e garantir o alto patamar de reprodução dos lucros protegidos do avanço dos direitos sociais. Como Tavares e Serra, os dois grupos de dependentistas não viam neste arranjo qualquer tendência à estagnação, ao contrário, apostavam que a industrialização e a expansão econômica teriam continuidade no novo arranjo, promovendo crescimento sem que houvesse necessariamente distribuição de renda e inclusão social.

Do ponto de vista de Cardoso e Faletto, ainda que a instalação de uma ditadura que reprimisse os conflitos distributivos fosse considerado um desdobramento possível, dado o arranjo de classes que se estabelecera, não era este o único a que se poderia ter chegado. Eles argumentam que é preciso escapar tanto da ideia de que a história far-se-ia sem constrangimentos estruturais, como aqueles dados pela ordem econômica internacional vigente; quanto da ideia segundo a qual haveria uma determinação mecânica do interno pelo externo. Nesse sentido, procuraram mostrar como diferentes arranjos de classe e pactos políticos permitiram às nações percorrer trajetórias econômicas e políticas distintas. Não haveria, pois, um imperativo dado externamente que fosse um condicionante absoluto e sim uma interação das lutas internas - entre classes, grupos, organizações e movimentos sociais com ideários diferentes - com as estruturas externas. Os autores concluem, depois de analisar diversos casos, que talvez fosse preciso pensar 
em termos de interdependência, já que as lutas entre as frações de classe dominantes internas teriam impacto sobre os arranjos estabelecidos com os atores externos, podendo eventualmente, inclusive, promover algumas modalidades de modernização e desenvolvimento dependente, com reinvestimento dos lucros na periferia, diversificação da produção e ampliação do mercado interno para consumo dos bens localmente produzidos. Nesta chave analítica, superexploração sob o autoritarismo ou socialismo deixariam de ser as duas únicas possibilidades no horizonte da América Latina, tendo a análise dos trajetos concretos levado-os a postular que rearranjos sociais e políticos poderiam gerar novas modalidades de pacto entre as classes (CARDOSO e FALETTO, 1970, pp. 127, 139-143).

Do ponto de vista da teoria que usa as categorias marxistas para analisar a condição de dependência, o arranjo ditatorial concentrador de renda que se estabelecera no Brasil resultava essencialmente do tipo de função desempenhada pela periferia no sistema de acumulação capitalista visto em escala internacional. Sendo o subdesenvolvimento um reflexo necessário dos movimentos econômicos das nações dominantes, não haveria margem alguma para a estruturação interna de pactos de classe em prol do desenvolvimento, a não ser em situações de supressão do poder externo, como a observada no interlúdio configurado pelos anos de crises e guerras. A ideia de um controle internacional de tipo monopolista da economia periférica, em que grande parte da mais valia é transferida para os centros, condicionaria as sociedades subdesenvolvidas a permanecerem subordinadas aos ímpetos do capital. Não apenas a exportação de bens primários seria regida pelo princípio de máxima exploração de uma força de trabalho abundante e subjugada, mas a própria evolução industrial não traria uma melhoria para essa população, na medida em que ela não produziria bens a serem consumidos no mercado interno pela classe trabalhadora e não representariam empregabilidade, porquanto feitas com alta tecnologia e capital importado. Ademais, a industrialização era conduzida de modo a atender os desejos supérfluos das elites e classes médias urbanas, ao invés de incrementar a produção de bens que fizessem parte da cesta essencial à reprodução da força-de-trabalho, não tendo, pois, efeito sobre as condições de vida e consumo dos trabalhadores (MARINI, 2011a, pp. 138, 155, 159-162).

Dois fatores permitiam a instauração de tal modelo de industrialização: a existência de uma larga mão-de-obra de reserva que podia ser explorada à exaustão porque era 
facilmente substituível e a possibilidade de expandir a economia voltando a circulação das mercadorias e do capital excedente para o exterior, o que dispensava-os de ter que ampliar o poder de consumo das camadas populares, já que o mercado interno não seria necessário para dar vasão à produção capitalista nacional. Finalmente, conclui-se que a superexploração na periferia permitiria, ao transferir para fora o excedente, avançar na inclusão social dos trabalhadores no centro reduzindo as tensões políticas naquelas áreas às expensas do agravamento da subjugação das classes exploradas das periferias. De acordo com a vertente marxista a condição de dependência e a subordinação por ela imposta não gerava desenvolvimento nacional algum e só poderia ser rompida através da supressão das relações de produção nela implicadas (MARINI, 2011a, pp. 134-135). Nos anos 1960, a luta de classes teria desembocado em um arranjo no qual conflitos políticos e militares nas nações periféricas poderiam ter dois desdobramentos: seja o uso da força para a criação de regimes de tipo fascista, como aquele que já se instaurara no Brasil, que ajudavam a preservar o status quo dos interesses do capital; seja uma revolução popular que se movesse em direção ao socialismo (SANTOS, 1970, p. 236).

Vânia Bambirra, em seu livro El capitalismo dependiente latino-americano, em sintonia com Santos e Marini, argumentava que a integração monopólica mundial desnacionalizara a propriedade dos instrumentos de produção nos seis países que teriam constituído burguesias industriais nacionais nos anos 1940 e 1950: México, Brasil, Chile, Argentina, Colômbia e Uruguai. Consequentemente, tornavam-se as burguesias desses países sócias menores das multinacionais, classes dominantes dominadas, desprovidas das bandeiras nacionalistas e anti-imperialistas, em processo que haveria culminado nos golpes de Estado da América Latina e no acirramento das tensões sociais. Concluía igualmente que as contradições do capitalismo dependente não poderiam ser resolvidas com reformas burguesas, só podendo, em tal configuração, chegar-se ao fascismo ou ao socialismo (BAMBIRRA, 1991, pp. 32-34) 281.

Vânia Bambirra menciona a grande repercussão de seu livro entre os militantes socialistas e comunistas da América Latina, que nele encontravam embasamento para suas lutas. As obras da vertente marxista da teoria da dependência encorajavam a luta revolucionária, apresentada como a única alternativa que o subcontinente teria para

\footnotetext{
${ }^{281}$ Não se pretende aqui fazer uma análise extensa do debate entre as vertentes da teoria da dependência, com suas réplicas e tréplicas. São esboçados, apenas em linhas gerais, alguns dos principais contrapontos entre as orientações com o objetivo de situar cada um dos grupos envolvidos na crítica às teorias clássicas e cepalinas do desenvolvimento, relacionando suas perspectivas às trajetórias de seus membros.
} 
escapar da condição de dependência que resultaria necessariamente em um arranjo social que classifica como fascista. Os próprios brasileiros do CESO estavam diretamente engajados na luta pela revolução. Vânia declara que Theotônio, Marini e ela estavam prontos para, a qualquer momento, regressar ao país e engajar-se em ações revolucionárias. Ainda que planejassem logo voltar ao Brasil, não deixaram de agir politicamente no próprio Chile. Em sintonia com suas teses, consideravam que o imperialismo monopolista era um problema que atingia a América Latina como um todo. Seria coerente, nesse sentido, lutar pela emancipação onde estivessem. Theotônio relata que:

nós aprofundamos a crítica ao desenvolvimentismo, a ideia de que as transformações nacional-democráticas estavam esgotadas, não que elas estivessem totalmente esgotadas, pois havia ainda uma realidade nacional democrata, mas que, para poder resolver esses problemas, nós tínhamos que avançar para o socialismo. Isso foi o fundamento do programa da Unidade Popular. Nós tínhamos, dentro do Partido Socialista, o MIR [Movimiento de Izquierda Revolucionaria], diretamente sob a influência do Ruy [Mauro Marini], totalmente dentro da nossa linha de concepção. Na esquerda do Partido Socialista também tinha uma grande frente que contava comigo e dava muitos cursos para a militância do partido [...]. Então, aí se formou uma concepção crítica muito importante dos limites de uma transformação nacional democrática para resolver os problemas da própria revolução nacional democrática, de reforma agrária, do controle estatal dos processos das riquezas naturais fundamentais, controle nacional das riquezas fundamentais, tudo isso nós fomos mostrando. A revolução cubana era também uma referência prática disto tudo, mostrava que a solução desses problemas não era possível dentro do quadro, de um projeto nacional democrático limitado, mas já de um projeto socialista (SANTOS, 2009, [online]).

Theotônio tinha simpatia pelo Partido Socialista Chileno. Vânia passou a dedicarse ao estudo dos casos em que o socialismo fora implementado para entender que lições deveria tirar para organizar o processo chileno, tendo alguma proximidade com o MIR (BAMBIRRA, 1991, p. 39; SANTOS, 2009). Marini engajou-se firmemente na luta à esquerda do governo Allende, tornando-se referência para militantes do MIR ${ }^{282}$. Relata

\footnotetext{
282 "Desde o inicio, muitos viam com ceticismo a chamada via chilena ao socialismo. Influenciados pela Revolução Cubana e capitaneados pelo Movimiento de Izquierda Revolucionário (MIR), parcelas do MAPU e pelo Partido Socialista - o partido de Allende -, estes setores entendiam que esquerda e governo deveriam seguir a estratégia de "pólo revolucionário", contestando de maneira antagônica o "poder burguês", agindo no sentido de aprofundar as contradições e conflitos até se produzir uma situação pré-revolucionária. Para isso, era preciso "avanzar sin transar", ou seja, aprofundar as transformações sociais e econômicas sem negociação alguma com outros segmentos do espectro político chileno. O MIR não apoiara a eleição de Allende e, durante todo o período, permaneceu como a força oposicionista mais ativa no campo da esquerda. Seu líder mais expressivo, Miguel Enriquez (que anos mais tarde seria brutalmente assassinado pela ditadura) qualificava de "mentirosa" a formulação da via chilena como um segundo caminho para se chegar ao socialismo. De uma forma geral, todos esses setores de esquerda eram contundentes críticos do projeto da via chilena ao socialismo - e a maior
} 
seu período de chegada no Chile como um momento em que era "difícil de distinguir o que foi atividade acadêmica e o que foi atividade política. Minha vida pessoal foi, de certo modo, anulada, em benefício de uma prática pedagógica incessante, nas salas de aula, nas reuniões com militantes, durante as refeições, nas tertúlias em minha casa, nas visitas a dirigentes e bases operárias" (MARINI, 2011, p. 82). Acompanharam Marini na luta do MIR Emir Sader (1943) e Marco Aurélio Garcia (1941), dois brasileiros da segunda leva de exilados com posições políticas bastante afinadas às dos marxistas dependentistas, que Theotônio trouxe para pesquisar no CESO com eles na época em que se tornou coordenador do Centro de Estudos.

Emir Sader é paulistano, filho do libanês Nahul Sader, proveniente de uma pequena aldeia ao norte de Beirute, que chegou ao Brasil em 1930, sem estudo, e trabalhou como mascate na região de Sorocaba. Depois de casar com a professora de piano Ercilia Simão, montaram uma loja de roupas infantis em São Paulo. Ercilia era descendente de libaneses também radicados no interior de São Paulo, que se ocupavam do comércio e do beneficiamento de café, dividindo-se entre o campo e a cidade. Um dos irmãos de Ercilia era o sociólogo Azis Simão (1912-1990), que teve grande influência sobre os destinos dos sobrinhos Eder (1941-1988) e Emir Simão Sader283 (GARCIA, 1988; SIMÃO, 1989).

Azis havia perdido a vista de um olho na juventude e por isso não ingressara diretamente no ensino superior. Sem poder estudar, foi vender café com o pai, trabalhou como comerciante ambulante em São Paulo e acabou aproximando-se do sindicato dos gráficos, transitando aos poucos para o ofício de jornalista. No jornal, vinculou-se a membros da Federação Operária de São Paulo e da União dos Trabalhadores Gráficos, ao lado dos quais iniciou sua vida política. Em 1931, Azis iniciou estudos de farmácia, à revelia do pai que queria evitar que lesse demasiado, e logo ingressou no centro acadêmico da Faculdade de Farmácia e Odontologia. Filiou-se ao Partido Socialista Brasileiro (PSB) e passou a trabalhar em prol da Aliança Nacional Libertadora que tentara reunir as esquerdas na década de trinta. Em 1935, quando da Intentona Comunista e posterior repressão sistemática das esquerdas, Azis estava hospitalizado pois a outra retina se havia descolado. Deixou a farmácia e ingressou, em 1938, na Faculdade de Filosofia, 
onde os amigos ajudavam-no com os estudos e a sociabilidade política era intensa. Azis contava, ademais, com a ajuda de suas irmãs e dos sobrinhos Eder e Emir para fazer as tarefas requeridas pelos professores (SIMÃO, 1989).

Foi lendo para Azis que os irmãos Sader tiveram seu primeiro contato com a sociologia e ouviam-no falar da militância política. Rumaram os dois para a Faculdade de Filosofia. Eder, o irmão mais velho em 1960, e Emir em 1962. Nesse momento o tio já havia conquistado a posição de professor assistente e conduzia pesquisas nas áreas de sociologia do trabalho e do operariado. O tio ajudou os sobrinhos, que já militavam no movimento secundarista, a entrar no universo da sociologia e da esquerda universitária. Os dois aproximaram-se da Liga Socialista Independente, pequeno grupo influenciado pelas ideias de Rosa Luxemburgo (CARVALHO, 2006; GARCIA, 1988; PULICI, 2008, pp. 242-243). Michel Löwy, que havia sido assistente do professor Wilson Cantoni na Faculdade de Filosofia, Ciências e Letras de São José do Rio Preto, relembra a:

\begin{abstract}
famosa Liga Socialista Independente. Era um grupo muito pequeno - minúsculo, microscópico -, inspirado em Rosa Luxemburgo, do qual faziam parte, no começo, Paul Singer, Rocha Barros, Sachetta, Sader. Na realidade, eu me considerava um discípulo de Paul Singer. Foi ele quem me iniciou na obra de Rosa Luxemburgo. Lembro que por volta de 1953-54 ele estava no Partido Socialista e distribuiu um panfleto protestando contra a invasão da Guatemala. Mas depois de um ano ele se decepcionou com o partido, e aí começaram as discussões para se criar um novo grupo, a Liga Socialista Independente [...]. Em 1960 uma parte do pessoal que estava na Liga Socialista Independente se juntou com outros grupinhos e criou uma organização chamada Política Operária, POLOP - esta já é mais conhecida. Acho que a Liga Socialista Independente, só os nossos amigos é que conheciam... Participei da fundação da POLOP junto com Paul Singer, os irmãos Sader, Juarez Brito, Teotônio dos Santos e Ruy Mauro Marini (LÖWY, 1996).
\end{abstract}

Os irmãos Sader transitaram, assim, para a POLOP, movimento, por sua vez, fortemente influenciado por Eric Sachs (1922), judeu austríaco que se refugiara na Rússia para fugir do antissemitismo. Em Moscou, Sachs conflitou com a política stalinista, sendo expulso do país em 1937. Passou pela oposição comunista alemã, influenciada por Rosa Luxemburgo, e conheceu membros de diversos partidos operários europeus. Quando chegou ao Brasil, em 1939, trouxe essas referências e a crítica ao stalinismo para a militância política brasileira, encontrando eco em grupos de jovens propensos à ruptura com o PCB, cujo modelo julgavam hierárquico e pouco dinâmico. Em 1966, com boa parte das lideranças da POLOP no exílio, alguns dos militantes restantes juntaram-se a um grupo dissidente do PCB do Sul dando origem ao POC, que apesar do termo 
operário, era, bem como a POLOP, essencialmente, uma tendência estudantil de classe média intelectualizada que estava à esquerda do PCB e que teve pouco sucesso em aproximar-se efetivamente do mundo operário (GARCIA, 1988; MEYER, 1988; REIS, 2007, p. 301).

Emir e Eder Sader engajaram-se nesse movimento, reunindo-se ao grupo do qual também faziam parte Jorge Mattoso e Marco Aurélio Garcia (1941). Natural de Porto Alegre, filho de advogado e de funcionária pública, Garcia estudou no colégio público Júlio de Castilhos, onde descobriu a militância política e vinculou-se ao PCB. Ao ingressar na Faculdade de Direito e Filosofia da UFGRS, converteu-se em uma das principais lideranças estudantis. Eleito para a diretoria da UNE, frequentou o grupo do CPC, ajudando nas montagens teatrais. Pouco tempo depois de participar da criação do POC, Marco Aurélio partiu com a esposa, Elizabeth de Souza Lobo Garcia - porto alegrense formada em letras e também militante, para a França, onde ingressou na École des Hautes Études en Sciences Sociales (EHESS). O casal volta brevemente para o Brasil, em 1969, com a intenção de alavancar a POC, mas a intensificação da repressão faz com que fujam para o Chile, onde Aurélio passaria a trabalhar no CESO e lecionar na FLACSO (DIEGUEZ, 2009; REIS, 2007, pp. 328-329).

Por esses tempos Eder Sader tornava-se instrutor na cadeira de Sociologia II da USP e Emir estava escrevendo seu mestrado Estado e Política em Marx, que foi arguido pelos membros do seminário do Capital, Bento Prado, Arthur Giannotti e Ruy Fausto, seu orientador. Ruy e Emir integravam, o que pode ser chamado de a segunda geração do seminário do Capital, da qual teriam participado também Roberto Schwarz, Lourdes Sola, Emília Viotti, Marilena Chauí, Sérgio Ferro, João Quartim, Francisco Weffort, Cláudio Volga Albertina Costa, Paulo Sandroni e Beth Milan (SADER, 2005). Sandroni 284 ,

\footnotetext{
${ }^{284}$ Sandroni é descendente, por parte de mãe, de uma família brasileira de Guaxupé-MG e, por parte de pai, de imigrantes italianos da Toscana. Seu pai era contador de formação e tornou-se empresário, transferindo-se com a família para o Rio de Janeiro, onde nasceu. Estudou nos colégios Brasil-América e Colégio Rio de Janeiro. Ingressou na FNCE em 1960, mas se transferiria concluindo a graduação na USP em 1964. Foi presidente do CAVC em 1962 e desde 1961 era auxiliar de pesquisa na FCEA, posição que ocupou até 1965 quando tornou-se professor da Faculdade de Filosofia de Rio Claro. Simultaneamente cursava a pós-graduação em Ciências Sociais na USP, lecionava economia na PUC-SP e trabalhava como colunista de economia na Folha da Tarde, por indicação de Jorge da Cunha Lima. Além de participar da segunda geração do seminário d'O Capital, Sandroni mantinha com seus alunos da PUC um grupo d'O Capital que se reunia clandestinamente aos sábados na Livraria Sal. Um infiltrado delatou as reuniões como atividades subversivas e Sandroni foi demitido em dezembro de 1968. Ao mesmo tempo, sua namorada, Vera Marão, que era estudante de graduação da USP fora presa no congresso de Ibiúna em outubro de 1968. Os dois decidiram deixar o país no início de 1970 em direção ao Chile. Sandroni tornou-se professor da UC e viveram em Santiago até o golpe de 1973 que fez com que se deslocassem para a Colômbia, onde ele lecionou na Universitad de Bogotá e na Universitad de Los Andes, retornando ao Brasil após a anistia (MARCOVICH, 1984, p. 346; CANABRAVA, 1984a, p. 300; KUSHNIR,
} 
economista formado na FEA com pós-graduação nas ciências sociais encontrava-se também no Chile, lecionando na UC, onde estudava Maria Moraes, irmã de Quartim, também cientista social da FFCL que viveu o exílio na França e no Chile (item 5.3).

Defendido o mestrado Emir partiu para a França, no segundo semestre de 1968, onde começou a escrever sua tese de doutorado, em estreito diálogo com o marxista grego Nicos Poulantzas, de quem tornou-se assistente, transferindo depois a posição a Michel Löwy. Passado um ano na França, voltou para a USP e para a militância, mas o AI-5 já atingia duramente a universidade e a POC. Acreditando que poderia ser preso a qualquer momento, Emir entra na clandestinidade e deixa o país em direção ao Chile. Lá foi recebido por Paulo Renato de Souza, hospedado por Ruy Mauro Marini e logo ingressou no CESO e na Faculdade de Economia da UC. Seu irmão Eder chegou a Santiago quase ao mesmo tempo e foi professor na UCC, onde lecionava Ruy Fausto, e em Concepción, dedicando-se ao estudo dos movimentos sociais (GARCIA, 1988).

De um lado, os Sader, Marco Aurélio Garcia e Ruy Mauro Marini engajaram-se fortemente no MIR, alinhado à percepção de que só a via revolucionária socialista poderia levar a América Latina ao desenvolvimento. De outro lado, muitos daqueles que eram membros da AP, da democracia cristã, cepalinos e nacionalistas acreditavam que cooperar com Allende para a instalação do socialismo por via democrática era uma grande oportunidade que se abria para a esquerda. Alguns brasileiros chegaram mesmo a ocupar importantes posições ao lado do presidente chileno (AGGIO, 2007, pp. 155-119), caso de Betinho que havia chegado ao Chile no final de 1971, após dez anos como militante e clandestino. A convite de Serra, Herbert vai trabalhar na FLACSO, onde organiza debates e cursos para os exilados. Tavares relata que reencontrou seu colega de Centro CEPALBNDE, em 1972, na casa de Luiz Alberto Gomes de Souza, “um cientista social, também fundador da AP, que abandonara a militância e fora contratado para a Divisão de Desenvolvimento Social da CEPAL". Betinho passou a trabalhar, como Conceição e Serra, na ODEPLAN com Juan Garcés (AFONSO, 2001, p. 105; GONTIJO, 1988, p. 111; SOUZA, 1976, p. 97; SOUZA, 2001, p. 52; SERRA, 2002, p. 104; SERRA, 2014, p. 176; TAVARES, 2001, pp. 57-61).

2004, pp. 235, 240, 264 e http:/www.ccmj.org.br/sites/default/files/pdf/5/cicero.pdf e http://www.arquivoestado.sp.gov.br/memoriapolitica/documento.php?ficha=BR_SPAPESP_DEOPSSPOSFICO NSV000253. Consultados em 18/03/2016). 
Thiago Mello ocupou a diretoria de comunicação do Instituto de Reforma Agrária, Adhemar Kyotoshi Sato foi trabalhar para a Corporación de Fomento de la Producción, Darcy Ribeiro, que havia conhecido Allende anos antes, em visita que Salvador fizera a Jango e aos exilados brasileiros em Montevideo, tornou-se um de seus mais próximos conselheiros de Allende. Como Juan Garcés, tinha acesso às reuniões ministeriais e ajudava o presidente a redigir documentos e discursos. Darcy aconselhara o presidente a adequar as leis à transição democrática para o socialismo, a trabalhar o estatuto da propriedade e avançar passo a passo. Não contava, entretanto, com a simpatia das frações internas do governo que pressionavam por uma aceleração revolucionária. Deixou o Chile em junho de 1973 quando aceitou missão para colaborar com o governo peruano, indicando Betinho para ocupar sua posição de assessor pessoal e redator dos discursos de Allende (RIBEIRO, 1997, pp. 413-416; SOUZA, 1976, pp. 98-99285).

A colaboração dos brasileiros com o governo de Allende não durou muito. Em 1973 as tensões políticas exacerbavam-se, razão pela qual Conceição deixou o Chile, em março de 1973, para reassumir suas funções docentes no Rio de Janeiro, voltando a trabalhar para a CEPAL brasileira, mesmo sem plena liberdade. Em 1975, quando ia embarcar para uma de suas atividades na sede da organização, Conceição foi presa e transportada para o DOPS e de lá para a Polícia do Exército. Os contatos que a professora tinha no universo político foram fundamentais para que fosse rapidamente liberada.

Em Brasília, o então ministro de Indústria e Comércio, Severo Gomes, ligou para o DOPS, para o I Exército, e lhe responderam que não havia ninguém preso ou detido com o nome da economista. Severo Gomes ligou, então, para Simonsen. Conceição conta como foi o diálogo: "Severo Gomes: 'Prenderam sua colega, a Maria'. Simonsen: 'Ela é maluca. Não pode ser'. Severo Gomes: 'Prenderam, sim, e ninguém sabe para onde a levaram. Fale com o presidente". Simonsen estava em Brasília e foi ao Geisel. O general deu um murro na mesa: "Não é contra ela, é contra mim", segundo relato, mais tarde, do próprio ministro. Sem saber, a professora se vira envolvida nas disputas entre Geisel e os porões. Ordens foram dadas e, em horas, Conceição estava livre. Daí foi a vez de Bulhões, já não mais ministro, interferir. Ligou para Simonsen e explicou que Conceição poderia ser presa novamente se tentasse viajar. E Simonsen mandou que, em carro oficial e com escolta, Conceição fosse deixada na escada do avião - em outro voo, porque o primeiro fora perdido (DURÃO e TOTI, 2012; Maria da Conceição Tavares apud DURÃO e TOTI, 2012).

285 Ver: http://sites.correioweb.com.br/app/noticia/encontro/revista/2014/10/24/interna revista, 1687/algo-nopoder-nao-cheirava-bem.shtml e http://www.portaldoenvelhecimento.com/revistanova/index.php/revistaportal/article/viewFile/295/295. Consultados em 06/02/2016. 
Antonio Barros de Castro e Ana Célia partiram para a Inglaterra também em meados de 1973, aceitando convite da Universidade de Cambridge. Serra, Betinho, Theotônio, Vânia e tantos outros exilados estavam ainda no Chile quando ocorreu o golpe de 11 de setembro de 1973 que destruiu o Palacio de la Moneda, matou o presidente e instaurou a ferrenha ditadura de Pinochet. Como brasileiros já foragidos, foram obrigados a exilar-se do exílio. Começaram então a articular modos de deixar o país. Aqueles que eram funcionários internacionais ajudavam com as credenciais e os veículos diplomáticos a levar as pessoas para as representações diplomáticas. Muitos brasileiros asilaram-se na embaixada do Panamá, que tão cheia estava que teve que ser transferida para um local maior. Theotônio dos Santos ofereceu sua casa e para lá mudaram-se a bandeira do Panamá e todos os refugiados. Serra foi para a embaixada da Itália e quando tentou deixar o país foi detido no aeroporto e transladado para o estádio nacional e conta que o major que o liberou do estádio foi assassinado poucos dias depois. José voltou à Embaixada da Itália onde permaneceu até maio de 1974 sem conseguir salvo conduto. Nesse período Paulo Renato, já era funcionário da OIT, era sua visita mais constante e sua ponte com o mundo externo (RETRATOS DO SERRA, 2010; GONTIJO, 1988, p. 125; SERRA, 2014, pp. 214-221).

A colônia brasileira findou por dispersar-se entre Estados Unidos, França, México, Colômbia, Costa Rica, Peru e outros países que receberam grandes contingentes de exilados latino-americanos. Parte dos integrantes do grupo do CESO foi para o México, outros tornaram-se dirigentes internacionais do MIR na Europa. A Itália recebeu alguns funcionários internacionais. Outros militantes foram para a Argentina e os que podiam regressaram ao Brasil.

\begin{tabular}{|c|c|c|c|c|}
\hline Alice Piffer Canabrava & $1911-2003$ & Araras - SP & $\begin{array}{l}\text { Graduação em geografia } \\
\text { e história (FFCL-USP). } \\
\text { Doutorado em história } \\
\text { (FFCL-USP) }\end{array}$ & $\begin{array}{l}\text { Pai fazendeiro em Araras. } \\
\text { Mãe austríaca. }\end{array}$ \\
\hline Maurício Klabin Segall & 1926 & Berlim - Alemanha & $\begin{array}{l}\text { Graduação em } \text { ciências } \\
\text { políticas e } \\
\text { (ELSP). Museólogo e e } \\
\text { teatrólogo }\end{array}$ & $\begin{array}{l}\text { Pai pintor Lasar Segall. Mãe } \\
\text { escritora e tradutora Jenny } \\
\text { Klabin Segall, filha de } \\
\text { Mauricio Klabin, grande } \\
\text { industrial da área de papel e } \\
\text { celulose. }\end{array}$ \\
\hline Paul Israel Singer & 1932 & Viena - Áustria & 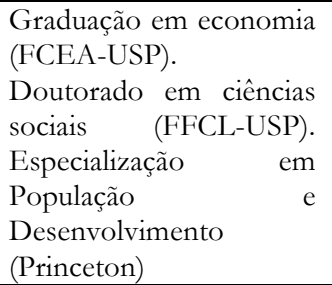 & $\begin{array}{l}\text { Pais eram comerciantes, } \\
\text { donos de uma mercearia em } \\
\text { uma comunidade operária na } \\
\text { periferia da cidade de Viena. }\end{array}$ \\
\hline
\end{tabular}




\begin{tabular}{|c|c|c|c|c|}
\hline Enzo Faletto & $1935-2003$ & Santiago - Chile & $\begin{array}{l}\text { Graduação em geografia } \\
\text { e história } \quad \text { (UC). } \\
\text { Mestrado em } \\
\text { (FLACSO) }\end{array}$ & $\begin{array}{l}\text { Pai comerciante italiano. No } \\
\text { Chile tornou-se dono de um } \\
\text { armazém de bens } \\
\text { alimentícios. Mãe chilena } \\
\text { passou juventude na Itália e } \\
\text { regressou ao Chile. }\end{array}$ \\
\hline $\begin{array}{l}\text { Wanderley Guilherme } \\
\text { dos Santos }\end{array}$ & 1935 & Rio de Janeiro - RJ & 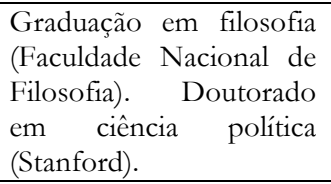 & $\begin{array}{l}\text { Pai faleceu precocemente. } \\
\text { Criado por tios-avôs. Mãe } \\
\text { trabalhava para sustentar a } \\
\text { família. }\end{array}$ \\
\hline $\begin{array}{l}\text { Clóvis de } \\
\text { Carvalho }\end{array}$ & 1938 & Franca - SP & $\begin{array}{l}\text { Aluno de filosofia e } \\
\text { teologia no seminário } \\
\text { Anchieta em Nova } \\
\text { Friburgo. Graduação } \\
\text { engenharia (POLI-USP) }\end{array}$ & Pai promotor público. \\
\hline Cláudio Moura Castro & 1938 & Rio de Janeiro - RJ & $\begin{array}{l}\text { Graduação em (FACE). } \\
\text { Pós-graduação rem } \\
\text { economia (CAE-FGV). } \\
\text { Mestrado em economia } \\
\text { (Yale). Doutorado em } \\
\text { economia } \\
\text { (Berkeley/Vanderbilt). }\end{array}$ & s.d. \\
\hline Walter Barelli & 1938 & São Paulo - SP & $\begin{array}{l}\text { Graduação em economia } \\
\text { (FEA-USP). Pós- } \\
\text { graduação em sociologia } \\
\text { Desenvolvimento } \\
\text { (FFCL-USP). }\end{array}$ & $\begin{array}{l}\text { Pai mecânico de manutenção } \\
\text { na Nitroquímica e na fábrica } \\
\text { de papel e papelão do } \\
\text { Matarazzo, morreu } \\
\text { precocemente. Mãe tecelã e } \\
\text { passadeira. }\end{array}$ \\
\hline Paulo Roberto Haddad & 1939 & Oliveiras - MG & $\begin{array}{l}\text { Graduação em economia } \\
\text { (FACE-UFMG). Pós- } \\
\text { graduação em economia } \\
\text { (Haia). }\end{array}$ & $\begin{array}{l}\text { Pai era vereador. Irmãos } \\
\text { vereadores, prefeitos e } \\
\text { deputados. }\end{array}$ \\
\hline $\begin{array}{l}\text { José Murilo de } \\
\text { Carvalho }\end{array}$ & 1939 & Andrealândia - MG & $\begin{array}{l}\text { Graduação sociologia e } \\
\text { política (FACE-UFMG). } \\
\text { Mestrado e doutorado } \\
\text { em ciência política } \\
\text { (Stanford) }\end{array}$ & $\begin{array}{l}\text { Pai dentista e pequeno } \\
\text { proprietário de terras. }\end{array}$ \\
\hline Sérgio Motta & $1940-1998$ & São Paulo - SP & $\begin{array}{l}\text { Graduação engenharia } \\
\text { (FEI). Sócio proprietário } \\
\text { da livraria cultura e arte } \\
\text { popular. } \quad \text { Sócio } \\
\text { proprietário da empresa } \\
\text { de produção cultural } \\
\text { difusão. Proprietário da } \\
\text { Hidrobrasileira }\end{array}$ & $\begin{array}{l}\text { Pai funcionário público } \\
\text { técnico de raio-x. }\end{array}$ \\
\hline $\begin{array}{l}\text { Vinícius Caldeira } \\
\text { Brandt }\end{array}$ & 1941-1999 & Belo Horizonte - MG & $\begin{array}{l}\text { Graduação sociologia e } \\
\text { política (FACE) }\end{array}$ & $\begin{array}{l}\text { dois tios-avôs deputados, um } \\
\text { dos quais foi também } \\
\text { secretário de finanças de } \\
\text { Minas e diretor do BB. }\end{array}$ \\
\hline $\begin{array}{l}\text { Luiz Carlos Mendonça } \\
\text { de Barros }\end{array}$ & 1942 & São Paulo - SP & $\begin{array}{l}\text { Graduação engenharia } \\
\text { (POLI-USP). }\end{array}$ & $\begin{array}{l}\text { Pai médico cardiologista } \\
\text { formado na Faculdade } \\
\text { Nacional de Medicina. Avô } \\
\text { paterno industrial do setor } \\
\text { farmacêutico. Avô materno } \\
\text { funcionário da estrada de } \\
\text { ferro Moginana e Mãe } \\
\text { normalista. }\end{array}$ \\
\hline Amaury de Souza & $1942-2012$ & Uberlândia - MG & s.d. & s.d. \\
\hline Bolívar Lamounier & 1943 & Dores do Indaiá - MG & $\begin{array}{l}\text { Graduação em sociologia } \\
\text { e política (FACE). } \\
\text { Doutorado em Ciência } \\
\text { Política (UCLA). }\end{array}$ & $\begin{array}{l}\text { Pai pequeno fazendeiro da } \\
\text { região de Dores do Indaiá. } \\
\text { Mãe professora primária em } \\
\text { área rural. }\end{array}$ \\
\hline Gilberto Dupas & 1943-2009 & Campinas - SP & $\begin{array}{lrr}\text { Graduação } & \text { engenharia } \\
\text { (POLI-USP). } & \text { Curso } & \text { de } \\
\text { Treinamento } & & \text { em } \\
\text { Problemas } & & \text { do } \\
\text { Desenvolvimento } & \\
\end{array}$ & $\begin{array}{l}\text { Pai fiscal de rendas do } \\
\text { estado. Avô paterno dono de } \\
\text { serraria em Araras e avô } \\
\text { materno dono de uma venda } \\
\text { em uma fazenda no interior }\end{array}$ \\
\hline
\end{tabular}




\begin{tabular}{|c|c|c|c|c|}
\hline & & & $\begin{array}{lr}\text { (Centro } & \text { CEPAL- } \\
\text { BNDE). } & \text { Pós-graduação } \\
\text { (Delft). } & \\
\end{array}$ & de São Paulo. \\
\hline $\begin{array}{ll}\text { Paulo } & \text { Gustavo } \\
\text { Carvalho } & \end{array}$ & 1943 & $\begin{array}{l}\text { São José do Rio Preto } \\
\text { - SP }\end{array}$ & $\begin{array}{l}\text { Graduação em medicina } \\
\text { (UFPR) }\end{array}$ & Pai promotor público. \\
\hline
\end{tabular}

Tabela IV - Trajetórias das principais personagens do Intermezzo que não circularam pelo Chile

\subsection{Rede do Intermezzo}

O Intermezzo, que transcorre entre 1964 e 1973, retoma personagens que foram apresentados na Abertura ao narrar seus deslocamentos para o Chile, em razão das perseguições perpetradas pelo governo militar. Esses deslocamentos foram consubstanciados através das redes de vínculos que os ligavam originalmente à sede da organização internacional para a qual trabalhavam no Brasil. Ao longo do capítulo foram apresentadas as vias pelas quais os intelectuais brasileiros exilados no Chile inseriram-se nas escolas de pós-graduação e organizações internacionais existentes em Santiago, com destaque para a CEPAL/ILPES, a ESCOLATINA/UC e a FLACSO, os principais centros de agregação apresentados no capítulo, tendo, pois, grande grau de conexão na rede.

Ao longo do capítulo discutiu-se a existência de duas ondas de deslocamento de brasileiros para Santiago: uma logo após o golpe em 1964 e outra após o AI-5 decretado no final de 1968. Na rede, os exilados do primeiro grupo aparecem, via de regra, na região delimitada pela guia oval posicionada ao centro. A primeira leva abriga pessoas geralmente nascidas entre 1925 e 1940 que, em sua maioria, eram profissionais com visível inserção na intelectualidade e na política. Na primeira geração há, também, maior incidência de famílias bem estabelecidas na sociedade brasileira, com laços com a política e segurança financeira. A segunda leva, representada fora do perímetro central e acima da linha guia que divide o plano em dois, foi integrada majoritariamente por estudantes de graduação ou recém formados, engajados nas tendências da nova esquerda que se mantiveram ativas durante o regime militar. A segunda geração corresponde em média aos nascidos entre 1940 e 1950, figurando no grupo descendentes de imigrantes que começavam a ingressar na classe média pelo comércio, permitindo que os filhos estudassem e tivessem acesso à universidade (Tabela III). 
Há perfis específicos que não se enquadram nessa classificação temporal. É o caso de José Serra, membro da geração de exilados, entretanto, nascido em 1942, descendente de imigrantes e estudante de graduação. Antonio Barros de Castro é um exemplo do caso contrário, visto ser uma pessoa que chegou no Chile na segunda geração, mas tem o perfil da primeira, nascido em 1938, descendente de famílias tradicionais brasileiras, bem inserido profissionalmente e com vínculos com a CEPAL. Há ocorrências também de pessoas que chegaram após 1969, mas pertencem à primeira onda de exilados, tendo vivido em outros países antes de chegar ao Chile, casos, por exemplo, de Darcy Ribeiro, Francisco Whitaker e Ruy Mauro Marini. Se considerado o momento em que a pessoa deixou o Brasil como o parâmetro principal, os perfis de cada onda de migração tornamse ainda mais coerentes.

$\mathrm{Na}$ parte superior da guia oval, encontram-se membros da primeira onda de exílio, majoritariamente economistas e cientistas sociais situados entre o PCB e o desenvolvimentismo nacionalista, tendências que têm intersecções. Há uma concentração de nordestinos nesse ponto do espaço, que agrega também indivíduos como Celso Furtado, apresentados anteriormente em suas conexões com a CEPAL, a SUDENE, o BNDE e o Clube dos Economistas.

$\mathrm{Na}$ parte de baixo encontra-se o grupo da primeira geração do exílio cujos principais vínculos eram com as tendências próximas ao universo cristão, seja a democracia cristã, seja o humanismo socialista da JUC e da AP, que compartilhavam referências filosóficas. Há uma concentração de gaúchos nessa parte da rede que giravam ao redor da família Fiori. Paulo Renato Costa Souza situa-se mais ao centro, por acumular laços tanto com instituições acadêmicas e organizações internacionais quanto com militantes da JUC/AP de sua geração. Ao centro estão também Vilmar Faria e Carlos Estevam Martins, o primeiro conectando a nova esquerda da AP às novas instituições de pesquisa em ciências sociais e o segundo conectando-as à velha esquerda do ISEB e do PCB.

São intermediários entre o universo da democracia cristã da primeira geração de exilados e os socialistas humanistas da JUC/AP que não se exilaram, Herbert de Souza, que fazia a interface com os mineiros da FACE, muitos dos quais deixaram o país para fazer pós-graduação no exterior, e José Serra, que se conecta com os politécnicos da USP que permaneceram no Brasil exercendo atividades privadas, muitos deles em bancos de 
investimentos. Betinho chegou tardiamente ao exílio e logo engajou-se em atividades políticas junto ao governo de Salvador Allende. Serra, que tem grande destaque na rede, chegou ao Chile logo no início do período e ficou até o golpe militar que instaurou Pinochet no governo. Ele funcionou como ponto de agregação pois às conexões que tinha com os militantes da AP e com os quadros da UNE agregou elos com instituições chilenas voltadas ao ensino e à pesquisa econômica, por intermédio dos membros do Centro CEPAL-BNDE, ao lado dos quais aparece na rede. Nas instituições criadas para agregar e amparar a colônia de exilados e nas casas que viveu e frequentou Serra ampliou seu espectro de relações na colônia brasileira, passando ele mesmo a atuar como intermediário na inserção de recém-chegados.

Fernando Henrique Cardoso aparece como o principal intermediário entre a velha e a nova geração, no ponto em que o desenvolvimentismo nacionalista da parte superior do plano conecta-se às ciências sociais da USP e da UFMG e às novas esquerdas, que conquistaram espaço na FACE e na FFCL. Cardoso tinha idade intermediária. Transitava entre a sociologia e a economia, entre o Brasil, a Europa e a América Latina, entre os grupos de empresários nacionalistas, os professores comunistas e desenvolvimentistas e os estudantes de filosofia esquerdistas, entre as elites nacionais às quais pertencia e o universo dos imigrantes paulistas de sua faculdade, disposições e pertencimentos que favoreciam a multiplicação das conexões que lhe permitiram congregar ao seu redor diversos segmentos de exilados.

Na parte de cima da área que congrega os exilados da segunda geração há um trecho ocupado pelos mineiros ligados à POLOP, à POC e ao CESO, em conexão com os paulistas da POLOP. Abaixo, outro trecho concentra os cariocas ligados ao Centro CEPAL-BNDE e ao IPEA, que tem vínculos com a CEPAL/ILPES e com a ESCOLATINA. O resto da área é majoritariamente recoberta por paulistas, sociólogos da FFCL e economistas ligados à FEA e à ESCOLATINA, os primeiros mais próximos das novas esquerdas representadas pela POLOP e pela POC; os segundos do desenvolvimentismo nacionalista e do estruturalismo de matriz cepalina.

Um dado morfológico a ressaltar é o aumento do número de mulheres entre aqueles que tiveram suas trajetórias analisadas. Ainda que muitas delas sejam casadas com outros militantes, não é possível dizer que partiram para o Chile apenas na condição de esposas, já que muitas delas enfrentavam situações frente à justiça militar piores ou tão 
ruins quanto as dos maridos. São os casos, por exemplo, de Lourdes Sola, Miriam Draibe, Liana Aureliano e Elizabeth Souza Lobo.

O cruzamento das trajetórias permite pensar os efeitos da concentração em Santiago de grupos de militantes e intelectuais que estavam dispersos pelo Brasil. Os vínculos estabelecidos no exterior foram estruturais na organização da redemocratização e na formação dos primeiros governos de oposição à ditadura. Talvez os dois casos mais aparentes da rearticulação dos laços cerzidos no Chile sejam o Instituto de Economia da UNICAMP e o CEBRAP, instituições que passarão a reunir em seus quadros paulistas, cariocas, pernambucanos, mineiros e gaúchos que se conheceram no exterior. Será justamente pela apresentação destes dois órgãos que principiará o quinto capítulo da tese, fazendo com que várias personagens aqui apresentadas retornem à cena junto aos candidatos de oposição nas lutas pela redemocratização.

No Intermezzo foram também apresentadas militâncias e escolas de produção de pensamento econômico latino-americanas situadas à esquerda, que estavam debatendo temas como planejamento econômico, classes sociais, reforma agrária, redistribuição de renda e economia cooperativa. Em seguida, no Segundo Movimento, aparecerá a gestão econômica da ditadura militar brasileira, em paralelo às perspectivas econômicas em vigência no Chile dos Chicago Boys. 


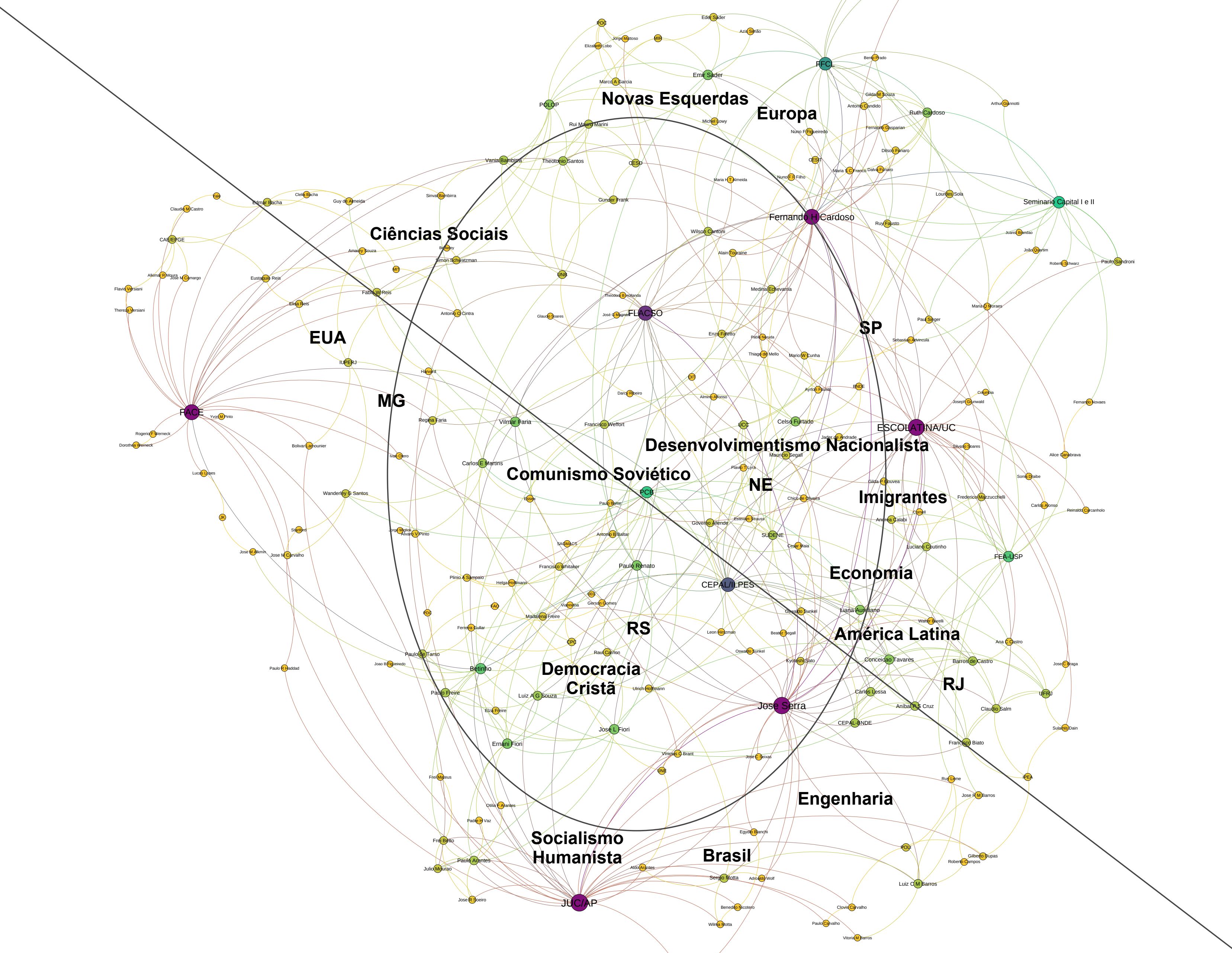




\section{SEGUNDO MOVIMENTO: Visões matematizadas ciência econômica (1967-} 1979)

O Primeiro Movimento apresentava quatro histórias de maneira integrada: 1) a da diplomacia econômica Brasil-Estados Unidos; 2) a da institucionalização do ensino e da pesquisa em economia e da multiplicação dos órgãos de Estado encarregados de políticas econômicas; 3) a da criação e estruturação inicial do Banco Nacional de Desenvolvimento Econômico (BNDE) e 4) a das transformações do perfil social e das trajetórias educacionais dos especialistas em economia.

1) O crescimento das trocas científicas Brasil-Estados Unidos, financiadas pela Agência Norte-Americana para o Desenvolvimento Internacional (USAID) e pelas Fundações Ford e Rockefeller, observado nos anos 1950 e 1960, terá, no Segundo Movimento, impacto decisivo pois o regresso dos jovens economistas formados no exterior provocará reestruturações nas escolas de economia e no tipo de pesquisa econômica desenvolvido no país. Muitos dos novos professores voltam ao país embuídos da missão de modernizar a estrutura do ensino e da pesquisa em economia e, para tanto, empenham-se em transformar as escolas existentes ou criar novas instituições conforme os modelos com os quais tiveram contato em suas circulações internacionais.

A política externa econômica dos Estados Unidos da América (EUA) para a América Latina, tão presente no Primeiro Movimento, sairá agora do foco, ainda que desdobramentos de acordos pregressos sigam sendo alvo de considerações. Essa temática estará em evidência sobretudo quando for abordado o projeto de cooperação que o Instituto de Pesquisa Econômica Aplicada (IPEA) manteve com a University of California - Berkeley (item 4.3) e a influência exercida pela University of Chicago (item 4.4) em diversos países da região, através dos convênios que estabeleceu com as universidades e das bolsas de estudo que concedeu a estudantes latino-americanos. No caso brasileiro, não foi firmado um convênio direto entre Chicago e alguma universidade nacional, mas foram ofertadas bolsas de doutorado, sendo esta a principal porta de entrada no país do pensamento econômico de Chicago (itens 3.3 e 3.4 ). 
As trajetórias que conduzirão o leitor por essas vertentes serão, respectivamente, as dos brasileiros Pedro Malan, Régis Bonnelli (item 4.3) e Geraldo Langoni (item 4.4), em conexão com as de alguns professores norte-americanos que tiveram influência nos acordos de cooperação internacional que serão analisados: Werner Baer, no caso do estabelecimento dos programas de pós-graduação em economia na Universidade de São Paulo (USP) e na Fundação Getúlio Vargas (FGV-RJ), e Alfred Fishlow, no caso do acordo IPEA-Califórnia. Arnold Harberger, finalmente, será alvo de considerações mais longas, visto o efeito que teve sua circulação pela América Latina sobre as diretrizes que guiaram as políticas econômicas de diversos países da região nos anos 1970 e 1980, sendo discutida a relação entre Chicago e as ditaduras latino-americanas, principalmente no caso chileno, em que seus alunos, que ficaram conhecidos como Chicago Boys, obtiveram larga influência sobre o governo militar

O contraste entre as universidades de Chicago e da Califórnia ecoa no Brasil, por exemplo, na controvérsia sobre a distribuição de renda, que opõe Pedro Malan aliado a Albert Fishlow a Geraldo Langoni, calcado nas ideias de Arnold Harberger, Milton Friedman, Gary Becker e Theodore Schultz, seus mestres em Chicago, e apoiado nacionalmente pelo Ministro da Fazenda Delfim Netto. A controvérsia da distribuição de renda permite sintetizar polarizações. Em primeiro lugar, entre aqueles que ocupavam posições políticas opostas em relação ao regime militar e sua política econômica. Em segundo lugar, entre os adeptos e os críticos das teorias econômicas gestadas em Chicago. Finalmente, havia discussão acerca das fronteiras que separam o fazer científico do fazer político em economia. Tendo recém-consolidado suas instituições e adquirido configurações mais ou menos nítidas, os economistas brasileiros começam a definir posições acerca das condições da produção de conhecimento em uma área disciplinar que reivindica autonomia científica mas detém profundo enraizamento no campo do poder.

2) No que concerne ao surgimento de instituições responsáveis pela administração econômica governamental, é possível dizer que neste momento a maioria burocracias econômicas centrais já existia. Poucas alterações no organograma governamental serão observadas no período tratado neste capítulo. $O$ único caso brevemente mencionado é a transformação do Fundo de Financiamento de Estudos de 
Projetos e Programas do BNDE na Financiadora de Estudos e Projetos (FINEP), empresa pública vinculada ao Ministério do Planejamento (item 4.5).

A criação de novas escolas de Economia, por sua vez, tem lugar de destaque no período. O Segundo Movimento começa com a apresentação de duas instituições que surgiram em paralelo à criação das primeiras faculdades de economia no Rio de Janeiro analisadas no Primeiro Movimento: A Faculdade de Ciências Econômicas de São Paulo, ligada à Escola de Comércio Álvares Penteado, começa a funcionar em 1932 (item 4.1) antecedendo inclusive a criação da Faculdade de Ciências Econômicas e Administrativas do Rio de Janeiro (FCEARJ) (item 2.1) - e a Faculdade de Ciências Econômicas e Administrativas da Universidade de São Paulo (FCEA-USP), que surgiu concomitantemente à Faculdade Nacional de Ciências Econômicas (FNCE) da Universidade do Brasil (UB, futura UFRJ) e ao Núcleo de Economia da Fundação Getúlio Vargas (FGV-RJ) (item 2.1) e, logo após, a criação da Faculdade de Ciências Econômicas e Administrativas de Minas Gerais (FACE) da Universidade de Minas Gerais (UMG, futura UFMG) (item 3.1).

A introdução das duas escolas paulistas será mediada pela trajetória de figuras que foram influentes não apenas na estruturação de suas escolas, mas também na organização, em escala nacional, das polarizações do espaço dos economistas. Ao falar sobre a Escola de Comércio Álvares Penteado será apresentada a trajetória de Roberto Cochrane Simonsen, professor de história econômica e grande representante dos industriais paulistas. O debate que Roberto Simonsen travou com Eugênio Gudin (item 2.1) acerca da industrialização, do protecionismo e da intervenção do Estado na economia, que ficou conhecido como a controvérsia do planejamento de 1945, será analisado em detalhes já que funciona como guia para enxergar as linhas de força que tensionam o espaço dos economistas.

No caso da FCEA, a narrativa será conduzida pela trajetória de Antônio Delfim Netto, o primeiro ex-aluno da escola a obter uma cátedra na faculdade. Acompanhar-se-á o caminho de Delfim da USP até o ministério, tentando avaliar quais conexões e ideias foram fundamentais para sua ascensão, e de que modo ele logrou tornar-se, com o apoio de seus Delfim Boys, o "Czar" da área econômica nos governos Artur da Costa e Silva e Emílio Garrastazu Médici. O perfil de Delfim será comparado com o de Mario Henrique Simonsen, seu sucessor no Ministério da Fazenda. Mario e Delfim têm idades próximas, 
papéis centrais na modernização e matematização do ensino de economia em suas faculdades e atuam no governo militar em momentos próximos. No entanto, no que concerne à origem social, estilo de exercício do poder e prioridades na administração do Estado diferiram substantivamente, o que teve efeitos sobre suas escolas e sobre a forma de exercício do poder que serão discutidos ao longo do capítulo.

$\mathrm{Na}$ sequência serão tematizadas as transformações atravessadas pelos departamentos de economia da Universidade de Brasília (UNB) e da Pontifícia Universidade Católica do Rio de Janeiro (PUC-RJ) (item 4.6). Nos dois casos já existiam cursos de graduação em economia, mas a entrada de professores formados no exterior irá modificar as feições e diretrizes das escolas, especialmente a partir da criação dos cursos de pós-graduação. Nos dois casos, aqueles que capitanearam os projetos eram dissidentes da Fundação Getúlio Vargas: Edmar Bacha, Francisco Lopes e Dionísio Dias Carneiro (item 4.6), insatisfeitos com os rumos da Escola de Pós-Graduação em Economia (EPGE), e com a forma como Mario Henrique Simonsen gerira a sucessão afastou-se para atuar no governo. A eles reuniram-se economistas egressos da FNCE e outros jovens que regressavam da pós-graduação no exterior, como André Lara Resende e Persio Arida (item 4.0).

A cooperação entre os especialistas em economia que, a despeito das tensões entre nacionalistas e cosmopolitas, marcara o Primeiro Movimento, dá lugar, nos anos 1960 e 1970, ao conflito explícito. As oposições entre frações dominantes e frações dominadas e entre estabelecidos e aspirantes tornam-se visíveis em um espaço em pleno movimento de diferenciação interna. Nesse cenário, a criação de novas escolas amplia a superfície ao alcance dos jovens doutores em economia, oferecendo àqueles que ocupavam posições dominadas nas antigas escolas a chance de conquistar territórios que pudessem reger de acordo com suas regras e princípios. Em uma situação de intensa contradição política entre os apoiadores da ditadura e seus opositores, as posições políticas são uma das molas propulsoras dos conflitos que levam ao estabelecimento de novas escolas, visto haver demanda por ambientes nos quais pudessem ser feitas livres críticas ao governo que, na área econômica, tinha como representantes máximos justamente os membros mais poderosos dos departamentos de economia da USP e da FGV.

Em 1966 dois eventos são importantes sinalizadores do processo de consolidação do espaço dos economistas no Brasil, em curso no período. O primeiro deles é o 
encontro de Itaipava, no qual especialistas de diversas universidades e órgãos econômicos do governo reúnem-se para discutir os rumos do ensino e da pesquisa em economia. O segundo é a criação dos dois primeiros mestrados brasileiros na área, que representam a internalização de um grau formação que antes só podia ser adquirido no exterior, solidificando as escolas e multiplicando, com maior velocidade e menor custo, os quadros necessários para a academia e para a administração econômica. Passa-se, assim, da fase dos especialistas em economia ou economistas práticos para a dos economistas profissionais.

3) Quanto à história do BNDE, no Primeiro Movimento narrou-se o processo de sua criação e ascensão com o Plano de Metas em meados dos anos 1950 e a queda sofrida a partir dos anos 1960, quando perde centralidade nas reflexões acerca das rotas e prioridades do desenvolvimento econômico (itens 2.3 e 2.5). Com a instauração da ditadura, o BNDE teve sua estrutura alterada sendo multiplicado o número de fundos associados ao Banco, com o objetivo de, aos poucos, dissociar o orçamento da instituição das reservas do Estado e promover uma abertura em direção à captação privada e internacional. Nesse período o BNDE foi distanciado ainda mais do centro das decisões econômicas, já que a função de planejamento de longo prazo foi transferida para o Escritório de Pesquisa Econômica Aplicada (EPEA, depois convertido em IPEA).

No Segundo Movimento, que corresponde aos governos de Arthur da Costa e Silva, Emílio Garrastazu Médici e Ernesto Geisel, o Banco começa sendo dirigido por Jayme Magrassi de Sá, contador de carreira do Banco e figura com pouco prestígio nacional e pouca receptividade por parte do poderoso ministro Delfim. Durante esse período, o BNDE permanece afastado do núcleo da decisão econômica, sem ter tido atuação pulsante, mesmo em momento de retomada do crescimento econômico. Em 1970, Magrassi de Sá é demitido da presindência do Banco depois de assinar sucessivos artigos criticando a política econômica de Delfim Netto, acusando-o de praticar fórmulas injustas de correção monetária e de correção salarial, promovendo concentração da renda (item 4.2).

O substituto escolhido foi Marcos Pereira Vianna, que era o secretário do Ministério do Planejamento de João Paulo dos Reis Velloso desde 1969 e exercia concomitantemente a presidência do IPEA. Durante o governo Médici, Vianna contratou 
uma consultoria para propor mudanças no organograma e nos procedimentos administrativos da instituição e alterou o estatuto jurídico do Banco de autarquia para empresa pública, o que permitiu a criação de uma série de subsidiárias, dando maior flexibilidade às operações e contratações. Concluídas as reformas, organizou uma série de concursos públicos para renovar o quadro do BNDE, que havia ficado estagnado por muitos anos. Tais alterações preparam o Banco para um nível mais intenso de atividade que não ocorreu de imediato visto haver um constrangimento material, dado pela limitação do nível de recursos. Ainda que Marcos Vianna não conflitasse diretamente com Delfim, como seu antecessor, o Banco continuava não sendo peça fundamental na administração econômica do governo Médici. Essa situação se reverterá alterada com a indicação de Ernesto Geisel para a presidência, já que, em seu governo, Reis Velloso e seu Ministério do Planejamento adquirem proeminência e conferem ao BNDE papel essencial na consecução do Segundo Plano Nacional de Desenvolvimento (II PND) (item 4.5).

4) Finalmente, no que concerne à transformação no perfil social e nas trajetórias educacionais dos especialistas em economia, algumas transformações poderão ser observadas. No capítulo dois, as trajetórias mais recorrentes eram ora provenientes de meios sociais privilegiados, ora migrantes de famílias empobrecidas ou descendentes de famílias decadentes do Nordeste que ascenderam socialmente por meio da educação e do concurso público. Neste capítulo seguem sendo preponderantes os membros de elite, mas há alterações no que concerne à procedência das famílias de origens modestas.

Se havia até agora algum imigrante ou descendente de imigrante eram pessoas como Isaac Kerestenetzky e Alexandre Kafka, cujas famílias deslocaram-se para os trópicos com o intuito de escapar das perseguições antissemitas e da mazelas da II Guerra Mundial; ou imigrantes abastados como os antepassados de Eugênio Gudin e Roberto Simonsen que vieram ao Brasil sem ter sido constrangidas, para ocupar funções de alto prestígio. Neste movimento, os imigrantes multiplicam-se, sobretudo porque o Estado de São Paulo, que recebeu aproximadamente $57 \%$ dos imigrantes do país ${ }^{286}$, passa a ocupar

\footnotetext{
${ }^{286}$ Ver: Dicionário da Elite Política Republicana 1889-1930 do Centro de Pesquisa e Documentação de História Contemporânea do Brasil, disponível em https://cpdoc.fgv.br/dicionario-primeira-republica/4, consultado em $17 / 09 / 2015$.
} 
maior espaço na narrativa. Como no Intermezzo, que ocorreu também entre os anos 1960 e 1970, há maior incidência de paulistas e correlatamente de casos de imigração na narrativa.

Não apenas a recorrência das histórias de imigração torna-se maior como também elas são qualitativamente distintas. Além de casos semelhantes aos de Kerestenetzky e Kafka, aparecerão famílias de imigrantes pobres, em geral italianos, japoneses e libaneses, que chegaram ao Brasil em busca de alternativas à miséria e aos conflitos sociais que enfrentavam em seus países de origem. Para eles, a São Paulo do café, da indústria e do crescimento figurava como uma promessa de reinserção social. As histórias de alguns dos especialistas em economia que serão analisadas a seguir representam casos de sucesso dos investimentos familiares na reconversão social que, em geral, trazem associados dois elementos: a remediação da condição financeira familiar por meio de atividades ligadas ao comércio e/ou aos serviços públicos exercidas pelos pais e o investimento na educação escolar dos filhos, de modo similar também aos casos dos descendentes de imigrantes analisados no Intermezzo.

A origem regional dos especialistas experimenta também uma transição já que os nordestinos estão praticamente ausentes da narrativa e os paulistas ganham cada vez mais espaço. O resto da população estudada segue sendo constituída essencialmente por cariocas e mineiros. Quanto ao corte geracional, passou-se de um período em que a maior parte dos estudados nascera entre 1910 e 1930, para um momento no qual a geração alvo de considerações nasceu entre 1930 e 1950. A presença de mulheres na narrativa segue sendo rara, eventualmente serão mencionadas professoras, mas figuras femininas na administração econômica do Estado seguem inexistentes.

\subsection{Roberto Cochrane Simonsen: a economia política dos industriais}

Como no Rio de Janeiro, surgiram em São Paulo, no início do século vinte, escolas técnicas de comércio privadas. A primeira delas foi a Escola Prática de Comércio de São Paulo, fundada em 1902287, com recursos privados, por iniciativa de Horácio Berlinck, o titular da cadeira de escrituração mercantil da Escola Politécnica de São Paulo e contador

\footnotetext{
${ }^{287}$ Em 1905, a Escola Prática de Comércio de São Paulo aderiria ao currículo da Academia de Ciências Comerciais do Rio de Janeiro, até então adotado como padrão para que se pudesse outorgar diplomas da área (CANABRAVA, 1984, p. 28).
} 
pessoal do empresário Conde Antônio Álvares Penteado, desde a juventude. Em 1907, ao receber do Conde a doação do terreno no Largo São Francisco no qual foi construído o Palácio do Comércio, a escola, para lá transferida, passou a chamar Escola de Comércio Álvares Penteado. Em conformidade com a legislação de 1931, que havia criado o bacharelado em economia, foi instalada, em 1932, na Escola Álvares Penteado, a Faculdade de Ciências Econômicas de São Paulo. Em janeiro de 1935, os primeiros formandos da Faculdade criaram a Ordem dos Economistas de São Paulo, com o objetivo de regulamentar o exercício da nova profissão 288 (MARTINS et al., 2006, pp. 120-121).

De 1933 a 1947, funcionou também no Palácio do Comércio a Escola Livre de Sociologia e Política (ELSP), criada com o intuito de formar quadros técnicos especializados em ciências sociais que fossem capazes de utilizar os métodos científicos e os conhecimentos desenvolvidos no que consideravam ser o mundo civilizado, ou seja, a Europa e a América do Norte, para compreender e intervir conscientemente sobre a vida social. A ELSP oferecia cursos de economia política, história econômica e introdução à economia como parte da formação geral dos alunos do curso de ciências políticas e sociais. O primeiro professor ${ }^{289}$ de história econômica da escola foi o engenheiro, industrial, historiador, político e um dos fundadores da ELSP, Roberto Crochane Simonsen (1889-1948). Notório defensor da industrialização, do planejamento da economia e da racionalização do aparato econômico nacional, Simonsen presidiu a Federação das Indústrias do Estado de São Paulo (FIESP), de 1937 a 1946, e via na criação da ELSP um instrumento para formar uma elite administrativa moderna que fosse composta por um conjunto de técnicos capazes de amparar sua ação na ciência. Não foi essa sua única iniciativa nessa direção. Em 1931 havia participado da fundação do Instituto de Organização Racional do Trabalho (IDORT), órgão destinado a transferir para o Brasil os conhecimentos sobre management e organização científica e racional do trabalho e da produção que estavam sendo formulados nos países do centro,

\footnotetext{
${ }^{288}$ Ver: http://www.fecap.br/novoportal/institucional.php\#.VfdN9p1Viko. Consultado em 14/09/2015. Criada em 11 de janeiro de 1935, por 34 jovens economistas formados na Faculdade de Ciências Econômicas da FECAP, a Ordem dos Economistas de São Paulo - que deu origem em 1947, à Ordem dos Economistas do Brasil (OEB) nasceu da tentativa de estabelecer uma entidade representativa dos interesses dos economistas, independente da tutela governamental. Atualmente a Ordem publica livros e revistas, organiza eventos e palestras e encarrega-se do prêmio O Economista do Ano (SZMRECSÁNYI e COELHO, 2007, p. IX; site Ordem dos Economistas do Brasil: http://www.oeb.org.br/Conteudo/Conteudo.asp?idConteudo=1 consultado em 20/08/2015).

${ }^{289}$ Simonsen logo convidou Alexandre Kafka (item 2.1) para lecionar introdução à economia na ELSP e para juntar-se ao departamento econômico da FIESP (KAFKA, 1998, p. 40).
} 
essencialmente nos EUA (MICELI, 2001, p. 102; MAZA, 2004, p. 62; KAFKA, 1998; FERREIRA, 2008, pp. 151, 162).

Existem diversas similaridades nas trajetórias dos pioneiros no estudo dos problemas econômicos no Brasil e fundadores dos primeiros cursos de economia no Rio de Janeiro e em São Paulo: Eugênio Gudin e Roberto C. Simonsen. Como Gudin, Simonsen era descendente de imigrantes europeus extremamente bem inseridos na sociedade brasileira. Seu pai, Sidney Martin Simonsen, nascera em Londres e transferira-se para o Brasil com 25 anos, para ser gerente do Banco Inglês, envolvendo-se posteriormente com atividades de importação e exportação de café. No Brasil, casou-se com Robertina da Gama Cochrane, filha de Inácio Wallace da Gama Cochrane290, descendente de escoceses e de famílias tradicionais de Minas Gerais e São Paulo. Inácio era engenheiro formado na Faculdade Nacional Engenharia, no Rio de Janeiro, foi deputado da Assembleia Legislativa Provincial, grande exportador de café enraizado na cidade de Santos, diretor da Companhia Paulista de Estradas de Ferro e fundador da City Santos Improvements, empresa que, associada a capital inglês, se ocupava dos serviços de transporte, água e luz na cidade de Santos (TEIXEIRA et al., 2010, p. 37; MARCOVITCH, 2007, p. 184; CEPÊDA, 2003, pp. 61-62).

Roberto C. Simonsen, tal qual Eugênio Gudin, teve uma educação cosmopolita. Nasceu no Rio de Janeiro e passou parte da infância em Santos. Transferiu-se para São Paulo para estudar no Colégio Anglo-Brasileiro, internato situado na Avenida Paulista que fora fundado pela colônia inglesa para educar seus rebentos à moda de seu país. Como Gudin, Simonsen bacharelou-se precocemente em engenharia. Ingressou aos 15 anos na Escola Politécnica de São Paulo, obtendo seu diploma em 1910. Também como Gudin começou sua carreira trabalhando em uma companhia estrangeira da área serviços públicos: a Southern Brazil Railway. Deixou a ferroviária para trabalhar na prefeitura de Santos, onde permaneceu pouco tempo pois logo começou a fundar suas próprias companhias. Neste ponto as duas trajetórias começam a divergir, já que Eugênio Gudin permaneceu ligado às companhias estrangeiras e à agricultura enquanto Simonsen não se limitou a conduzir o empreendimento de exportação de café familiar, enveredando para a

\footnotetext{
${ }^{290}$ O pai adotivo e responsável pela criação de Inácio Wallace da Gama Cochrane era também escocês: Thomas Cochrane, bacharel em letras pela Universidade de Paris e formado em medicina e cirurgia pela Universidade de Londres, atuou incansavelmente na organização das estradas de ferro brasileiras. Era, ademais, primo de Lord Thomas Alexander Cochrane, mercenário que lutara a serviço do Império para reprimir a Confederação do Equador, obtendo de D. Pedro I o título de Marquês do Maranhão (AZEVEDO, 1965).
} 
gestão de negócios próprios, tal qual fizera seu avô Inácio, e tornando-se grande industrial (TEIXEIRA et al., 2010, p. 37; MARCOVITCH, 2007, p. 184; CARONE, 1971, pp. 2324; CEPEिDA, 2003, p. 62).

Simonsen começou sua vida de empreendedor na área de construção civil e de planejamento urbano, com as suas Companhia Construtora de Santos e Companhia Santista de Habitações Econômicas. À elas seguiram-se a Companhia Frigorífica de Santos e a Companhia Frigorífica e Pastoril de Barretos, além de atividades junto à Companhia Nacional de Artefatos de Cobre, à Companhia Nacional de Borracha, à Cerâmica São Caetano e à Fábrica de Tecidos Santa Helena. O reconhecimento profissional, somado aos capitais sociais e políticos herdados e adquiridos, fez com que fosse escolhido para representar os industriais em diversas comissões, conselhos e órgãos de classe. Participou, por exemplo, da fundação do Centro das Indústrias do Estado de São Paulo (CIESP) e da FIESP, onde foi colega de Horácio Lafer, Ministro da Fazenda sob a égide do qual nasceram o BNDE e o Fundo de Reaparelhamento Econômico (FRE) (item 2.2) (TEIXEIRA et al., 2010, pp. 37-47; CARONE, 1971, pp. 23-24).

Simonsen foi ainda deputado constituinte por São Paulo e participou do Conselho Nacional de Política Industrial e Comercial (CNPIC) de Getúlio Vargas. Foi um documento apresentado por ele ao CNPIC, intitulado A planificação da economia brasileira, que deu origem à paradigmática Controvérsia do Planejamento, travada entre ele e Eugênio Gudin, no ano de 1945. Ela pode ser considerada um marco inicial da polarização entre os especialistas em economia, separando os partidários da intervenção econômica e do planejamento dos defensores da supremacia do mercado. Gudin responde ao texto de Simonsen com a réplica Rumos da política econômica. Simonsen formula a tréplica $O$ planejamento da economia brasileira, respondida, por fim, em carta de Gudin à Comissão de Planejamento Econômico (CARONE, 1971, p. 24; TEIXEIRA et al., 2010, pp. 20-21).

A controvérsia foi despertada pela defesa feita por Simonsen da planificação racional e científica das indústrias-chave, da infraestrutura e da moderna agricultura voltada à alimentação. Ele ressalta o papel do planejamento em países como a Rússia e a Turquia, e até mesmo nos Estados Unidos e na Inglaterra, para aprimorar o desenvolvimento material e social, ao elevar a renda nacional de modo a satisfazer as necessidades essenciais da população. Ainda que desse destaque ao planejamento da 
industrialização, Simonsen afirma que esta não deveria dissociar-se do incremento da produtividade na agricultura, que também deveria ser racionalizada visto ser essencial por prover qualquer atividade econômica dos subsídios indispensáveis. Argumenta que agricultura, industrialização e comércio seriam igualmente beneficiados pelas melhorias na infraestrutura e nos serviços de utilidade pública, pela concessão de crédito e pela regulação do trabalho e dos conflitos sociais. O Estado teria função essencial nesse processo, estimulando e amparando a iniciativa privada e produzindo ele mesmo em setores nos quais as empresas não tivessem recursos ou condições apropriadas para fazêlo (SIMONSEN, 2010, pp. 44-45; MAZA, 2004, pp. 155-156, 178).

Simonsen defendia também a implementação de um protecionismo racional, que visasse não o aumento da arrecadação tributária mas a criação de um mercado interno para impulsionar o desenvolvimento da indústria nacional, de modo a permitir que o Brasil deixasse sua posição subordinada entre as nações, alcançando independência econômica relativa. Neste ponto inspirava-se nas teses do ex-ministro do comércio e da indústria da Romênia, Mihail Manoïlesco, que fez com que fosse traduzido ao português. Manoilesco contrapunha-se ao livre-cambismo e à teoria das vantagens comparativas de David Ricardo argumentando que uma análise histórica demonstraria que o protecionismo é um fenômeno social de caráter geral, presente em todas as sociedades a despeito do grau de sua evolução industrial e que era praticado sempre e por toda parte, malgrado sua condenação pela ciência econômica liberal. A generalização do protecionismo decorreria do desejo de promover a produção industrial, que seria necessariamente a melhor forma de aumentar a produtividade e consequentemente o lucro líquido e a remuneração da força de trabalho. Tratava-se de proteger os países das trocas desiguais entre bens primários e manufaturados, a única maneira de caminhar em direção à riqueza e ao desenvolvimento (MANOÏLESCO, 2011; MAZA, 2004, pp. 204205, 209-228; MANESCHI, 2008, pp. 130-131).

Gudin ridiculariza Simonsen pela menção à Manoïlesco, que considera ter sido ultrapassado por Jacob Viner e Gotffried Haberler - suas maiores referências -, ambos publicados na sua Revista Brasileira de Economia (RBE) e por ele convidados para palestrar em sua FGV. Reatualiza-se o debate da década de 1930 quando Viner e Haberler desqualificam a argumentação do ministro romeno por falta de sustentáculo teórico, rejeitando sumariamente a defesa do protecionismo como uma solução racional. Neste 
sentido há uma continuidade nas polarizações: Viner versus Manoïlesco (1932), Gudin versus Simonsen (1945), Viner versus Prebisch (início dos anos 1950), Gudin versus Prebisch (1953) e Octavio Bulhões versus Celso Furtado (1953) (item 2.2). Em todos estes casos há uma crítica à formulação de teorias baseadas em empiria para dar conta de casos que não se enquadram nas previsões feitas pela análise econômica standard (FURTADO, 2014, p. 130; MANESCHI, 2008, p. 131).

Para Gudin, a planificação econômica é incompatível com a democracia liberal, que deve funcionar necessariamente sob o livre mercado. Argumenta que o planejamento seria próprio dos sistemas coletivistas totalitários que utilizam o Estado para administrar produção e consumo. O projeto de Simonsen, afirma, colocaria o Brasil, "não intencionalmente decerto", no rumo do totalitarismo, pois ampliaria ainda mais o campo de ação do Estado em detrimento da economia privada (GUDIN, 2010 pp. 70, 80, 100). Ele conclui que "a mística da planificação é, portanto, uma derivada genética da experiência fracassada e abandonada do New Deal americano, das ditaduras italiana e alemã que levaram o mundo à catástrofe, e dos planos quinquenais da Rússia, que nenhuma aplicação podem ter a outros países" (GUDIN, 2010, p. 74).

Para Gudin, a defesa do planejamento atendia a interesses de segmentos sociais que estariam agindo em benefício próprio sem pensar na maximização bem estar geral:

Há vários grupos sociais e econômicos para os quais a mística do plano pode constituir precioso instrumento para a vitória de suas doutrinas políticas ou de seus interesses econômicos. São primeiro os socialistas-comunistas, partidários da supressão da propriedade privada dos meios de produção, que veem no "plano", formulado e dirigido pelo Estado, um excelente instrumento, que de fato é, para a invasão pelo Estado no campo da economia e da iniciativa privadas e, portanto, para o caminho da socialização. Segundo, a burocracia, que no regime do plano passa a enfeixar nas mãos uma soma considerável de poderes (e talvez de proventos) na direção da economia. Terceiro, last but not least, os chamados "interesses reacionários" (vested interests), que veem, e com razão, no plano um excelente instrumento de eliminação da liberdade de concorrência e de consolidação, sob a égide governamental, das situações adquiridas, de que são a expressão estereotipada, com o sacrifício do consumidor à tirania dos produtores. "O plano", escreve Von Mises, "daria aos atuais proprietários e dirigentes das indústrias uma posição privilegiada, protegendo-os contra possíveis novos e eficientes concorrentes. Seria uma abdicação parcial do Estado em benefício de pequenos grupos de homens ricos" (GUDIN, 2010, pp. 77-78).

Sem rejeitar diretamente a indústria, Gudin se contrapõe frontalmente à visão segundo a qual os países industrializados seriam mais ricos, argumentando que condições técnicas e naturais adequadas dariam à agricultura uma vantagem capaz de promover um alto padrão de vida, como revelaria o caso argentino (GUDIN, 2010, pp. 105-6). Ele 
reconhece que o Brasil não desfruta das mesmas benesses naturais que a Argentina, e diz que por isso a manufatura não seria em si um mal, mas esta só não seria nociva ao equilíbrio econômico se conquistada sem os artifícios totalitários defendidos por Simonsen. A prioridade absoluta, argumenta, deve ser a estabilização monetária, que depende, dentre outras coisas, da redução das obras e dos investimentos conduzidos pelo Estado e da redução do fornecimento de crédito. Ressalta, ademais, a importância da atração de capital estrangeiro para o que o país deveria garantir: estabilidade cambial, livre entrada e saída de capital, igualdade de tratamento ao capital nacional e estrangeiro e baixo imposto de renda para atrair o investimento externo; o que dependeria da completa rejeição de qualquer sorte de protecionismo e bloqueio nacionalista (GUDIN, 2010, p. 114-116).

Cabe destacar a proximidade entre alguns argumentos sustentados por Simonsen e pela Comissão Econômica para a América Latina (CEPAL). Estes, ainda que formulados em termos distintos e com graus de familiaridade com a ciência econômica dissimilares, propunham caminhos semelhantes para o desenvolvimento latino-americano. Partilhavam, por exemplo, a convicção de que seria um equivoco aderir à teoria das vantagens comparativas, seja por avaliar que a inelasticidade da demanda e a deterioração dos termos de troca estariam na raiz de uma desigualdade sistêmica, como afirma Prebisch; seja por considerar que haveria uma menor produtividade da agricultura e da extração mineral que retardaria o desenvolvimento daqueles que permanecessem dependentes desse setor, como sustenta Manoilesco. Por raciocínios distintos os dois seriam levados a propor a industrialização como política estratégica para as nações que buscavam desenvolver-se e proclamam que ela deveria poder contar com auxílio do planejamento centralizado, da intervenção estatal e do protecionismo. Gudin, por sua vez, posiciona-se repetidamente ao lado de Viner, também opositor da CEPAL, na luta pela abertura ao comércio mundial, na rejeição da ação econômica do Estado e na ojeriza dos desequilíbrios orçamentários. Neste cenário, a industrialização só nasceria se a iniciativa privada estivesse pronta para sustentá-la sem mecanismos de apoio que implicassem em déficit público ou protecionismo.

Gudin opunha sua ciência econômica ao que considerava ser um proselitismo interessado dos grupos industriais, dos socialistas e da burocracia de Estado contemplados pelo discurso de Simonsen. A neutralidade "científica" desinteressada de 
sua posição é contradita quando se situa socialmente o próprio crítico mostrando que também ele era um interessado que seria beneficiado diretamente pela política que defendia. A raiz de seu argumento estaria situada em outra fração das elites brasileiras, aquela ligada à agricultura de exportação, ao capital internacional e às empresas estrangeiras enraizadas no Brasil (MAZA, 2004, p. 179), atividades econômicas que ele próprio desempenhava como visto anteriormente (item 2.1). A exposição das posições representadas por estes dois especialistas em economia permite arrazoar como diferiam o conhecimento econômico e a política econômica gestados sob os auspícios dessas duas frações das elites.

\subsection{Antonio Delfim Netto: a FCEA-USP e o exercício do poder}

Ainda que Roberto Simonsen tenha tido importante atuação na promoção do ensino da economia política e da história econômica e na formação de quadros no âmbito da ELSP e do IDORT, não foi sob sua tutela que se criou, em São Paulo, a principal faculdade de ciências econômicas - no que diferia de Gudin, que fora o criador das duas mais importantes escolas de economia no Rio. Esta surgiu não na ELSP, mas na USP, instituição criada pela oligarquia paulistana com o intuito de armar com a ciência seus rebentos para reconquistar o domínio da vida política, perdido para as oligarquias de outros estados da federação, apoiadas na figura de Getúlio Vargas (MICELI, 2001, pp. 101-102; CARLOTTO, 2014, pp. 113-114).

Quando foi criada a Universidade de São Paulo, em 1934, previa-se um Instituto de Ciências Econômicas e Comerciais, que não chegou a ser implementado. O Direito, a Engenharia e a Faculdade de Filosofia, Ciências e Letras (FFCL) incluíam em seus cursos cadeiras dedicadas ao ensino da economia política, mas não havia uma unidade específica até 1946, ano de criação da Faculdade de Ciências Econômicas e Administrativas (FCEA $)^{291}$, instalada na rua Doutor Vila Nova ${ }^{292}$ e conectada, por um pátio interno, ao edifício da FFCL da rua Maria Antônia. O corpo docente da Faculdade de Economia

\footnotetext{
${ }^{291}$ A Faculdade de Ciências Econômicas e Administrativas (FCEA) teve seu nome alterado para Faculdade de Economia e Administração (FEA) em 1969. Em 1990 passou a chamar-se Faculdade de Economia Administração e Contabilidade, mantendo, não obstante, a sigla FEA (GAROFÁLO e RIZZIERI, 2007, pp. 179$180)$.

${ }^{292}$ Edifício no qual a Faculdade permaneceu até 1971, quando foi transferida para a Cidade Universitária Armando de Salles Oliveira. Em 1992, a FEA instalou uma segunda unidade no campus de Ribeirão Preto.
} 
recrutou parte de seu quadro inicial em outras escolas da USP, sendo 13 dos seus primeiros professores provenientes de sua vizinha FFCL, 19 da Faculdade de Direito, 2 da Engenharia e 1 contador (CANABRAVA, 1984, pp. 30-33; PINHO, 1984, p. 39).

Bem como os demais cursos de ciências humanas da Universidade de São Paulo, a economia teve forte influência francesa ${ }^{293} \mathrm{em}$ sua constituição inicial. Predominava uma orientação humanista, associada ao estudo de teoria e às investigações de caráter histórico, que representava antes uma tendência à produção desinteressada de conhecimento do que uma proposta de especialização técnica - como aquela que circulava, por exemplo, no IDORT e na Escola de Comércio. Antes da criação da FCEA, a Faculdade de Filosofia, Ciências e Letras já havia recebido alguns jovens economistas políticos franceses, com afiliações teóricas bastante discrepantes, financiados pela Fundação Rockefeller para atualizar a bibliografia utilizada nos cursos e disseminar novos métodos de investigação. Em 1936, a FFCL recebeu François Perroux (1903-1987), economista crítico ao qual Aníbal Pinto Santa Cruz refere-se como o pai de uma escola partidária da análise estrutural com afinidades com a economia praticada na CEPAL. No ano seguinte Perroux foi substituído por René Courtin (1900-1964), economista liberal, crítico de Keynes, que viria a ser um dos fundadores do jornal Le Monde e secretário de Charles de Gaulle. Um ano depois, Courtin foi sucedido por Pierre Fromont (1894-1959), especialista em economia rural. O último economista político da Missão Francesa foi Paul Hugon (19021973) que, diferentemente de seus colegas, teve longa permanência no Brasil. Viveu em São Paulo de 1939 a 1970 e participou ativamente da criação da FCEA, tornando-se o responsável pelas áreas de economia política e história das doutrinas econômicas (CRUZ, 1977, p. 11; LEFEBVRE, 1990; PINHO, 1984, pp. 42-45; VIEIRA, 1981, p. 362; DENORD, 2007, p. 195; BERNIS, 2000, pp. 494-501; JUILLARD, 1959).

A primeira década de funcionamento da FCEA foi marcada por baixa frequência dos alunos aos cursos e baixo número de diplomados. Em 1956, houve uma greve para exigir melhora da qualidade das aulas. Um das soluções concebidas pela comissão de sindicância da Universidade instaurada para avaliar o caso foi a adequação do ensino às exigências do mercado de trabalho, tornando o currículo menos generalista, com ênfase na teoria econômica e no cultivo do ferramental matemático e estatístico,

\footnotetext{
${ }^{293}$ Sobre a influência francesa na constituição da Universidade de São Paulo ver Um Departamento Francês de Ultramar (ARANTES, 1994) e "Les professeurs français des missions universitaires au Brésil 1934-1944" (LEFEBVRE, 1990).
} 
progressivamente requerido no exercício da profissão. Tal proposta não foi consensual, já que a orientação aplicada da economia era vista por alguns como mera qualificação técnica tida como inferior à perspectiva humanista que combinava economia, direito, história e filosofia. Para implementar o programa de modernização, o Conselho Universitário (CO) nomeou para a direção da Faculdade em 1957 um professor externo, o engenheiro Ruy Aguiar da Silva Leme, que lecionava economia política, estatística aplicada e organização administrativa na Escola Politécnica (item 3.2). A crise levou também à separação da economia dos cursos de contabilidade, administração e ciências atuariais, nisso acompanhando a Universidade do Brasil que já oferecia uma formação exclusivamente dedicada ao ensino de economia (PINHO, 1984, pp. 45-48; COSTA e NOZOE, 1984, pp. 125-126; BUENO, 1997, p. 334).

Faziam parte do grupo inicial de docententes da FCEA pessoas que tiveram influência na moldagem do espaço dos economistas em São Paulo: o engenheiro formado pelo Mackenzie e especialista em Estatística Econômica pela ELSP, Luiz de Freitas Bueno ${ }^{294}$, contratado para ocupar a cadeira de "estatística metodológica e estatística econômica". A geógrafa e historiadora Alice Piffer Canabrava 295 da cadeira de "história econômica geral e formação econômica do Brasil”, doutora pela Faculdade de Filosofia com a tese $O$ comércio português no Rio da Prata, primeira professora da FCEA a tornar-se catedrática por concurso e, em 1951, a primeira mulher a assumir uma cátedra na USP (item 3.3). Por fim o professor André Franco Montoro, catedrático de "instituições de direito privado", formado pela Faculdade de Direito do Largo São Francisco e procurador do Estado, que viria a ocupar os cargos de vereador, deputado, senador, governador de São Paulo e ministro do trabalho (item 5.4).

O professor Luiz Freitas Bueno difundiu na FCEA a combinação de métodos quantitativos e teoria econômica. Em texto sobre suas experiências acadêmicas para a revista Economia Aplicada, intitulado "Métodos quantitativos na FEA-USP, minha realização profissional", conta que tornou-se professor, ainda no ginásio em Ribeirão Preto (CANABRAVA, 1984a, p. 209), por questão de sobrevivência. Na época em que foi convidado para lecionar na escola técnica que pertencia à Universidade Mackenzie, aproveitou a oferta que lhe foi feita para ali estudar engenharia. Ao concluir a graduação,

\footnotetext{
${ }^{294}$ Eram discípulos de Luiz Freitas Bueno: Antonio Delfim Netto, Affonso Celso Pastore, Akihiro Ikeda e Guilherme Leite Dias.

${ }^{295}$ Foram discípulos de Alice Canabrava: Francisco Vidal Luna, Antônio Muniz Barreto (item 5.4) e Zélia Cardoso de Mello (item 6.2).
} 
conseguiu ser aprovado em um exame para assumir a cadeira de estatística da recémcriada Faculdade de Economia da USP, onde pode dedicar-se a sua grande paixão, que era a matemática aplicada. Conta que ao se instalar na FCEA requereu “à reitoria um laboratório de cálculo. Tínhamos máquinas Facit manuais e elétricas, havia duas máquinas de somar Vitor e inúmeras réguas de cálculo” (BUENO, 1997, pp. 335-336). Seu aluno e assistente Antonio Delfim Netto declara que a maior contribuição de Bueno "foi, certamente, a formação de um grupo de estudantes interessados no desenvolvimento da economia quantitativa insistindo sempre na modelagem de séries de tempo. Ele foi o primeiro professor da FEA a escolher como assistentes seus ex-alunos e a estimulá-los a avançar para além dos seus mestres” (DELFIM NET'TO, 2006, [online]).

No Rio de Janeiro Mario Henrique Simonsen promoveu a revolução matemática da economia. Em São Paulo, seus homólogos foram Bueno e seus discípulos, notavelmente Antônio Delfim Netto, que ingressou na FCEA em 1948. Assim que concluiu o bacharelado, em 1951 Delfim tornou-se assistente de Freitas Bueno e, dez anos depois, já experiente professor, defendeu sua tese de doutorado intitulada $O$ problema do café no Brasil, redigida

no melhor e mais moderno "economês" da época. Se sua tese tivesse sido apresentada, por exemplo, em Cambridge-USA ou Cambridge-Inglaterra, creio, teria sido aprovada com menção honrosa. A tese seguia o padrão que, após os anos 50, nos Estados Unidos, passou a ser o sine qua non da boa tese: formulação de hipóteses, preferencialmente em termos matemáticos, e teste delas, pelo uso de técnicas econométricas (EKERMAN, 1989, pp. 123-124).

Em 1963, Delfim Netto foi o primeiro ex-aluno da faculdade a assumir uma cátedra na instituição. Apresentou para o concurso o livro Alguns problemas do planejamento para o desenvolvimento econômico e passou a ser responsável pela cadeira de "economia brasileira, planejamento governamental e desenvolvimento econômico". Se havia na carreira de Delfim uma adesão à matematização, ela não era descolada de uma pretensão política de intervenção na economia, bem expressa no nome de sua cadeira. Escreveu sobre os problemas econômicos de seu tempo, começando pela análise da agricultura e do café e avançando para os domínios da política econômica e financeira do governo e da relação entre inflação, planejamento e desenvolvimento (CANABRAVA, 1984a, pp. 9394).

Nos anos 1960, Delfim Netto dividiu com Mario Henrique Simonsen a mais decisiva influência sobre a conformação do ensino de economia no Brasil e a 
responsabilidade pela introdução na academia brasileira do tratamento matemático da economia que se tornara hegemônico no pós-guerra. Há semelhanças no papel desempenhado pelos dois na academia e na política. Mario Henrique e Delfim fizeram toda a sua carreira no espaço nacional e, assim mesmo, foram os precursores da instalação no Brasil das visões matematizadas da economia que ecoava no cenário internacional. Os dois foram ministros do planejamento e da fazenda no governo militar, tendo a chance de reger a economia de acordo com convicções cultivadas na academia. Diferiam, entretanto, radicalmente no que concerne à trajetória social anterior à chegada ao poder e ao estilo por cada um adotado na condução das escolas e dos cargos.

Ao contrário de Simonsen, Delfim Netto (1928) provinha de uma família de imigrantes recentes e foi criado em meio social modesto, sendo o arquétipo do descendente de imigrante que se reinventou pela escola e que por ela foi inventado. De office boy, neto de imigrante que aplicava blocos de pedra nas calçadas, a ministro plenipotenciário da fazenda, ele representa um daqueles casos de quebra da tendência à reprodução das posições de classes que oferecia aos Giuseppes e Macabéas que chegavam em São Paulo a promessa de ascensão pelo mérito. Os milagrosos "Delfims" são apresentados como prova de que o sucesso estaria ao alcance de todos, crença fundadora da illusio ${ }^{296}$ que mantem os sujeitos engajados no jogo escolar, independente de uma racionalização acerca das possibilidades objetivas de sucesso (BOURDIEU, 2005, p. 312; CARIELLO, 2014; SAFATLE, 2012).

Os quatro avós de Delfim eram imigrantes italianos. O avô paterno deixou a Calábria no final do século XIX, com menos de vinte anos. Ao contrário de muitos dos italianos que chegaram a São Paulo nesse período, ele não foi trabalhar na lavoura. Permaneceu na capital do estado onde começou trabalhando como calceteiro de vias públicas a serviço da prefeitura e terminou como dono de uma das minas de pedras que forneciam os paralelepípedos com os quais a prefeitura fazia o calçamento. Seu pai fora escriturário na Companhia Municipal de Transportes Coletivos e a mãe costurava para fora. Quando se casaram, os pais de Delfim decidiram permanecer no casarão do avô, que

\footnotetext{
296 “A illusio é o fato de estar engajado no jogo, de ser tomado pelo jogo, de levar o jogo a sério, de crer que o jogo vale a pena, ou, para dizer simplesmente, que vale a pena jogar" (BOURDIEU, 1994, p. 151). "A illusio não é da ordem dos princípios explícitos, das teses que colocamos e defendemos, mas da ação, da rotina, das coisas sempre fizemos, e que fazemos porque elas se fazem e porque sempre fizemos assim [...]. Às questões sobre as razões do pertencimento, do engajamento visceral no jogo, os participantes não tem nada a dizer, em definitivo, e os princípios que podem ser invocados em tais casos não são mais do que racionalizações a posteriori, destinadas a justificar, para si mesmo e para os outros, um investimento injustificável" (BOURDIEU, 1997, p. 147).
} 
abrigava o clã familiar e ficava localizado em um dos bairros operários de São Paulo, o Cambuci. A situação familiar foi melhorando aos poucos. Deixaram a casa dos avós, depois o pai conseguiu comprar um sítio na Vila Carrão onde criava alguns animais e acabou, por fim, sentindo-se integrado a ponto de começar a militar no Partido Republicano Paulista (CARIELLO, 2014; SAFATLE, 2012; YOKOTA, 2009, pp. 2-4).

Delfim começou sua vida de trabalhador entregando os vestidos que a mãe costurava para ganhar uns trocados. Acostumado às entregas foi trabalhar como officeboy na companhia de produtos de higiene pessoal Gessy. "Levava papéis de uma mesa para outra. Depois aprendi datilografia, sozinho, e respondia a cartas de clientes" (Delfim Netto apud CARIELLO, 2014, [online]). Durante a adolescência estudou no Instituto Liceu Siqueira Campos, no Cambuci, e depois frequentou a Escola Técnica de Contabilidade Carlos de Carvalho. Sonhava com a sólida e estabelecida engenharia mas não tinha "as condições econômicas para cursar a faculdade de engenharia: um claro problema de escolha com escassez", diz usando o jargão de economista, e continua... "na ocasião fiz um concurso para o DER [Departamento de Estradas de Rodagem]. Simultaneamente saiu a lei que permitia que o contador prestasse vestibular para a universidade. Então eu fui para a Faculdade de Ciências Econômicas e fui muito feliz" (DELFIM NETTTO, 1997, p. 736).

A FCEA oferecia cursos noturnos, sendo, pois, conciliável com o trabalho durante o dia. Delfim fez parte da segunda turma da faculdade e engajou-se na política universitária, tendo sido presidente da agremiação dos estudantes da FCEA, o Centro Acadêmico Visconde de Cairu (CAVC) ${ }^{297}$. Como tantos economistas de seu tempo, Delfim ressalta o caráter autodidata de seus estudos, dizendo ter estudado muito por conta própria e garimpando obras em sebos e livrarias (COELHO, 2007, p. 425; CARIELLO, 2014; SAFATLE, 2012; CANABRAVA, 1984a, pp. 93-94).

Foi com os livros escolhidos a dedo ao longo da vida, com os quais enchia carrinhos de supermercado nas livrarias que frequentava assiduamente, mundo afora, que Delfim presenteou a universidade à qual deve a sua ascensão. Além disso, adquiria, por vezes, bibliotecas inteiras, em geral pertencentes a economistas. Deste modo reuniu os livros em português, inglês, francês, italiano e espanhol - lê com facilidade nos quatro idiomas, mas afirma que até hoje seu tardio inglês oral não é fluente - que formam uma

\footnotetext{
${ }^{297}$ Outros Delfim Boys que ocuparam a posição foram: Affonso Celso Pastore, em 1959, Miguel Colasuonno, em 1960, e Eduardo Pereira de Carvalho, em 1961 (MARCOVITCH, 1984, p. 346).
} 
das maiores e mais relevantes bibliotecas especializadas em economia do país, tendo investido largos recursos pessoais na montagem da coleção. A FEA, por sua vez, fez dobrar as dependências da biblioteca para receber o tesouro de seu professor emérito (CONTI, 2011; YOKOTA, 2009, p. 9).

Neste ponto, há um nítido contraste com a trajetória de Mario Henrique Simonsen (item 2.4). Delfim é visto e vê-se como alguém que muito deve à Faculdade de Economia. Ao falar de Mario Henrique Simonsen, costumeiramente diz-se que a EPGE era a sua escola, na qual ele decidia o que iria lecionar e terminava por lecionar quase tudo. Simbolicamente a escola pertencia a ele, devia à sua figura e não o contrário. Não se atribui o seu triunfo acadêmico e profissional a nenhuma das instituições pelas quais passou: nem à Faculdade de Engenharia, nem à FGV, nem à CONSULTEC. Aqueles que conviveram com ele sempre ressaltam a precoce genialidade do moço, que tivera berço de ouro, fora educado em colégio de elite, dava aula no lugar dos professores que faltavam, jogava xadrez, cantava ópera e vivia de excessos de bebida, cigarro, jogo e comida.

Apenas neste último ponto eram próximos, já que o amor infatigável à boa e excessiva mesa era praticado também por Delfim Netto, adepto inconteste das cozinhas francesa e italiana (YOKOTA, 2009, p. 9). Era ao redor das távolas das pizzarias e restaurantes que Delfim reunia seus aprendizes e colaboradores. O grupo começou a formar-se ainda na universidade quando, além das disciplinas regulares, organizava junto com o professor Freitas Bueno seminários complementares de teoria econômica.

\footnotetext{
Nós estávamos desenvolvendo um núcleo de estudos, que começou com um seminário que acontecia todas as sextas-feiras. Aquilo foi se acomodando, crescendo, ampliando-se. Os horários eram os mais extravagantes do mundo, um dos seminários era das sete da manhã às nove, o seminário de matemática, e depois tinha o seminário da sexta-feira, em que se tentava estudar os artigos mais recentes, que estavam na fronteira ou no que supúnhamos ser a fronteira do conhecimento (DELFIM NETTO, 1996, p. 95).
}

Affonso Pastore, um de seus colaboradores mais próximos, afirma que havia um dia de seminário de teoria neoclássica e um de teoria marxista e conta que Delfim foi importante em sua formação não por conta do curso de graduação e sim pelo seminário complementar (PASTORE, 1996, p. 216). Eckerman, em depoimento, detalha a rotina do grupo:

No ano de 1964, em que participei do grupo de estudos, o programa era intenso: diariamente das $7 \mathrm{~h} 30 \mathrm{~min}$ às $8 \mathrm{~h} 30 \mathrm{~min}$ se estudava o texto de Allen, Mathematical analysis for economists; das $14 \mathrm{~h}$ às $15 \mathrm{~h}$, alternadamente, os textos que na época eram denier-cri: Anderson e Quandt, Microeconomic theory e Ackley, Macroeconomic theory; 
das $18 \mathrm{~h}$ às $19 \mathrm{~h}$, textos de periódicos internacionais, também os últimos lançamentos da estação. Ao fim da tarde de sexta-feira, o grupo de estudos fazia "vaquinha" para comprar uísque Drurys ao sabor do qual se discutia o livro de Paul Sweezy, Teoria do desenvolvimento capitalista, texto famoso de economia marxista. A impressão que fiquei era de que os textos de teoria econômica eram para ser levados a sério, o texto de Sweezy para ser levado a uísque (ECKERMAN, 1989, pp. 123-124).

O fechamento da semana de Delfim e daqueles que orbitavam ao seu redor era marcado pelo whisky ou pelas "noitadas de pizza num restaurante chamado Camelo, na rua Pamplona, que de tanto servir a esse grupo acabou por incluir no seu cardápio uma pizza chamada "Lufrebu" em homenagem ao professor Luiz de Freitas Bueno" (MACEDO, 1984, p. 326). Participavam do seminário, dentre outros, seus assistentes Affonso Celso Pastore, Eduardo Pereira de Carvalho, Carlos Antonio Rocca, Gianpaolo Marcelo Falco, Carlos Viacava, Paulo Yokota, Pedro Cipollari, Miguel Colassuono, Heraldo Barbuy, José Kirsten, Akihiro Ikeda, Betty Mindlin, Raul Ekerman e José Roberto Mendonça de Barros - irmão de Luiz Carlos Mendonça de Barros (item 3.2) (ECKERMAN, 1989, pp. 123-124; PINHO, 1984, p. 83). Foi no âmbito desses encontros que se articulou o grupo de economistas que ficou conhecido como os Delfim Boys, que acompanharia o mestre em sua trajetória acadêmica e governamental.

Delfim notabilizou-se inicialmente em nível estadual, tendo transcendido as fronteiras da USP para oferecer consultoria a empresários e prestar serviços ao Governo do Estado de São Paulo. No começo dos anos 1960, participou da comissão interestadual voltada ao planejamento regional da Bacia Paraná-Uruguai, transitou pela Associação Comercial e pela Bolsa de Mercadorias de São Paulo, foi vice de Fernando Henrique Cardoso (item 3.3) na representação dos ex-alunos da USP no CO, vice-presidente da Ordem dos Economistas de São Paulo nas gestões 1959-1960 e 1965-1966 e trabalhou com Ruy Leme, da FCEA, e Sebastião Advíncula da Cunha e Diogo Adolfo Nunes Gaspar, ambos do BNDE, na formulação da estratégia econômica do Plano de Ação do governador Carlos Alberto Carvalho Pinto (item 3.3).

Pastore relata que a ideia de criar um Instituto de Pesquisas Econômicas na FCEA (IPE-USP) teria decorrido da atividade de consultoria que os professores da USP prestavam ao governo do estado. Ele explica que quando foram escrever o Plano de Ação viram a necessidade de calcular coisas como a relação custo/benefício dos investimentos e perguntavam-se, por exemplo: “como é que nós vamos decidir quanto gastar em 
educação, quanto gastar em estradas?”. Consideraram necessário levantar dados sobre a economia de maneira sistemática para ter elementos para tomar esse tipo de decisão e pensaram: "nós precisamos ter aqui um instituto de pesquisa que faça isso", e decidiram que iriam “criar isso na universidade, que é o lugar ideal” (PASTORE, 1996, p. 214).

No final de 1959, a FCEA enviou ao CO pedido de autorização para a criação do IPE298 e o professor Zeferino Vaz (item 5.2), da Faculdade de Medicina de Ribeirão Preto, relator técnico encarregado da análise do pedido, emitiu parecer favorável. A administração central da USP indagava apenas de onde viriam os recursos para a manutenção do novo Instituto. O diretor da Faculdade de Economia solicitou, então, ao Governo do Estado de São Paulo a verba necessária para que o IPE pudesse dar início às suas atividades. O prestígio de Delfim e seu grupo junto ao governador Carvalho Pinto foi essencial para que a FCEA fosse agraciada com uma verba inclusive superior àquela que fora solicitada. Ao iniciar suas atividades em 1964, o Instituto começou a planejar a criação de um curso de pós-graduação em economia. Em 1966, no mesmo ano em que foi instalada a Escola de Pós-Graduação em Economia (EPGE) na Fundação Getúlio Vargas, começou a funcionar curso homólogo na Universidade de São Paulo (CANABRAVA, 1984, p. 378; ROCCA et al., 1984, pp. 228-229).

Naquele mesmo ano, reuniram-se, entre os dias 4 a 6 de março, na cidade de Itaipava, especialistas em economia de diversas regiões país e os representantes da Fundação Ford que estavam ajudando a estruturar os primeiros cursos de pós-graduação em economia no Brasil 299 , com o objetivo de avaliar o estado do ensino e da pesquisa em escala nacional.

\footnotetext{
${ }^{298}$ Em 1974 a FEA cria a Fundação Instituto de Pesquisas Econômicas (FIPE), um instituição de direito privado, que tem por objetivo dotar a faculdade de uma instituição com personalidade jurídica capaz de estabelecer, com entidades privadas e públicas, contratos e convênios remunerados de prestação de serviços. Diferentemente do Instituto Brasileiro de Economia (IBRE) da FGV-RJ que prestava serviços desde sua fundação, a FEA, por ser uma faculdade pública, não poderia estabelecer esse tipo de relação comercial, razão pela qual cria uma fundação associada, decisão essa que permanece sendo alvo de controvérsias movidas pelo debate acerca da função social da universidade pública.

${ }^{299}$ A criação da pós-graduação em economia é parte de um movimento mais amplo de instalação de cursos de pós-graduação no Brasil, que ocorreu de maneira mais sistemática a partir de meados de 1960 com a instalação primeiro no BNDE do Fundo de Desenvolvimento Técnico-Científico (FUNTEC), em 1964, seguido pela criação, em 1969, do Fundo Nacional de Desenvolvimento Científico e Tecnológico (FNDCT), que passou a ser administrado, em 1971, pela Financiadora de Estudos e Projetos (FINEP) (item 4.4); e com a reorganização do sistema de apoio à pós-graduação formado pelo Conselho Nacional de Pesquisas (CNPq) e pela Coordenadoria de Aperfeiçoamento do Pessoal de Nível Superior (CAPES), ambos criados em 1951. "Paralelamente, a reforma universitária foi complementada pela construção de um sistema nacional de pós-graduação, praticamente inexistente até então, o que possibilitou uma considerável ampliação e uma relativa democratização da carreira de pesquisador no país. Essas mudanças, ocorridas a partir de 1968, acabaram por aumentar radicalmente o número de profissionais dedicados à ciência, sobretudo no setor público, fruto da aceleração do processo de
} 
O encontro foi patrocinado pela Fundação Ford e contou com a presença dos seguintes especialistas em economia: Antonio Delfim Netto do IPE-USP; Mario Henrique Simonsen da EPGE-FGV; Ari Sá Cavalcante do Centro de Aperfeiçoamento de Economistas do Nordeste da Universidade Federal do Ceará; Ary Burger do Centro de Estudos e Pesquisas Econômicas da Universidade Federal do Rio Grande do Sul; David Carneiro Jr da Universidade de Maringá; João Paulo Almeida Magalhães da Universidade do Estado da Guanabara (UEG atual UERJ); João Paulo dos Reis Velloso e Og Francisco Leme do EPEA; Julian Chacel do IBRE-FGV 300 ; Manoel Orlando Ferreira do Conselho Nacional de Economia (CNE) e da UEG; e Maria da Conceição Tavares da CEPAL. Além dos americanos Werner Baer, enviado pela Ford para lecionar no Brasil, e Reynold Carlson e Stacey Widdicombe, diretores da Fundação Ford no Brasil de 1961 a 1965 e de 1965 a 1967 respectivamente (RBE, 1996) ${ }^{301}$.

A preocupação dos especialistas em economia desta primeira geração com a transformação da ciência econômica em uma disciplina acadêmica com um ferramental próprio e uma teoria específica resultou nas seguintes diretrizes para o encontro: 1) fazer um balanço dos avanços na institucionalização da área 2) discutir o problema do ensino e da pesquisa em economia no Brasil e 3) levantar possíveis soluções para os problemas por eles detectados como: a falta de organicidade das formações oferecidas, a proliferação de centros de ensino de economia que não contavam com profissionais preparados, os muitos interessados em Administração que ingressavam em Economia pelo maior valor social do diploma, a baixa disponibilidade de material de estudo traduzido para o português, a necessidade de oferecer bolsas e remuneração adequada para que a dedicação dos alunos e professores pudesse ser integral, dentre outros.

Uma proposta que resultou do Encontro foi a organização de uma associação de economistas que promovesse encontros anuais, nos quais fossem oferecidas palestras de atualização e se pudesse intercambiar com regularidade os avanços de pesquisa de cada

\footnotetext{
formação de novos pesquisadores e da consolidação da carreira nas instituições públicas de pesquisa tais como as universidades e institutos de pesquisa ligados ao Estado" (CARLOTTO, 2008, pp. 136, 144-145).

${ }^{300}$ Isaac Kerstentzky enviou um texto escrito com Julian Chacel para fomentar a discussão no encontro, mas não consta que tenha estado presente.

${ }^{301}$ O texto de Ramón García Fernández e Carlos Eduardo Suprinyak (2015, p. 10), ao buscar a lista dos participantes do Encontro no livro de Maria Rita Loureiro (1997), que menciona apenas os mais conhecidos dentre eles, concluí que só havia economistas do eixo Rio-São Paulo no encontro, o que é negado pela lista que consta no prefácio do número da RBE de 1966 dedicado a relatar a experiência e apresentar os textos produzidos para o encontro de Itaipava. Só ali são mencionados os economistas do Sul e do Nordeste que estavam também presentes no encontro.
} 
um dos centros participantes. Outra foi a realização de exames unificados de seleção de estudantes para os cursos de pós-graduação. Essas propostas se materializaram a partir da criação da Associação Nacional de Centros de Pós-Graduação em Economia (ANPEC), em 1971302, que passou a organizar encontros anuais e instituiu um exame integrado para ingresso nos mestrados em economia. Tais medidas são, ao mesmo tempo, reflexo e marcos da consolidação da economia como um espaço integrado em luta por autonomia para definir suas fronteiras e estabelecer uma linguagem comum, procedimentos e métodos, princípios de consagração, aproximando-se, neste ponto, da forma de um campo científico (DELFIM NETTO, 1966, p. 13; KERESTENETZKY e CHACEL, 1966, p. 56, SIMONSEN, 1996, p. 29; LOUREIRO, 1997; BOURDIEU, 1983, p. 127; LEBARON, 2000, pp. 42-45).

Quanto à organização dos cursos de pós-graduação, a ideia que prevalecia nos debates era que estes deveriam, inicialmente, ser voltados à formação de mestres e que os alunos que desejassem cursar o doutorado deveriam dirigir-se ao exterior. Só alguns anos depois, quando houvesse maior contingente de professores brasileiros com sólida e atualizada formação, é que o curso de doutorado poderia ser oferecido no país (SIMONSEN, 1966, p. 22). Argumentava-se, também, que os atuais professores de graduação das escolas de economia deveriam complementar e renovar sua formação frequentando os cursos de pós-graduação, e que poderiam fazê-lo como assistentes dos professores estrangeiros que os programas de cooperação científica internacional enviariam para ajudar na montagem dos mestrados. Ao qualificar os professores das escolas já existentes, haveria um efeito de multiplicação e dispersão acelerada da moderna formação em economia (DELFIM NETTO, 1966, pp. 11-12). Essa filosofia era coerente com a estratégia inicial adotada pela ajuda externa norte-americana, que optou por financiar os dois primeiros cursos de pós-graduação criados em 1966, o da FGV-RJ e o da USP, centrados no eixo Rio-São Paulo, julgando que a partir deles a moderna economia poderia espalhar-se por todo país (FERNÁNDEZ e SUPRINYAK, 2015, pp. $13-15)^{303}$.

\footnotetext{
${ }^{302}$ A data oficial da instituição da ANPEC é 1973, momento em que foi registrada em cartório, mas as atividades já aconteciam desde 1971 (VERSIANI, 2007, p. 241).

${ }^{303}$ O IPE-USP, por exemplo, além de desenvolver sua própria pós-graduação, passou a agir também no sentido de disseminar o treinamento em economia, tarefa para a qual criou um programa de extensão que oferecia cursos intensivos, promovia o intercâmbio de pessoal e providenciava assistência técnica aos centros de ensino e pesquisa de outras universidades e regiões, em certo sentido mimetizando internamente a fórmula de assistência que os EUA ofereciam ao Brasil. Pouco tempo depois, a assistência norte-americana passou a ocupar-se
} 
Como assinalado, o encontro de Itaipava ocorreu exatamente no ano em que o embrionário Centro de Aperfeiçoamento de Economistas (CAE-FGV) de Mario Henrique Simonsen, que tinha por objetivo oferecer um reforço na formação teórica em economia e reading knowledge para que os alunos pudessem pleitear bolsas de estudo nos Estados Unidos (item 2.5), foi transformado em Escola de Pós-Graduação em Economia (EPGE). Pouco depois, o cursinho do Mario Henrique deixaria a precária garagem que ocupava no antigo Colégio Aldridge e mudar-se-ia para o edifício Luiz Simões Lopes, projetado por Oscar Niemeyer ${ }^{304}$ e financiado pela USAID. O acordo da FGV com a USAID previa que a ajuda externa cobriria no primeiro ano 100\% das despesas da escola. "No segundo, 80\%. Depois 60\%, 40\%, 20\%. Ao cabo de cinco anos, a EPGE tem que voar com suas próprias asas" (Julian Chacel in: ALBERTI et al., 2002, pp. 84-85).

Ao mudar do CAE para a EPGE, o curso de pós-graduação passou de um para dois anos de duração e os candidatos que desejassem ingressar na Escola começaram a ser selecionados por meio de exames de matemática, estatística e teoria econômica (SIMONSEN, 1966, p. 26). O conteúdo do curso da EPGE, em seu ano inicial, era dividido da seguinte maneira:

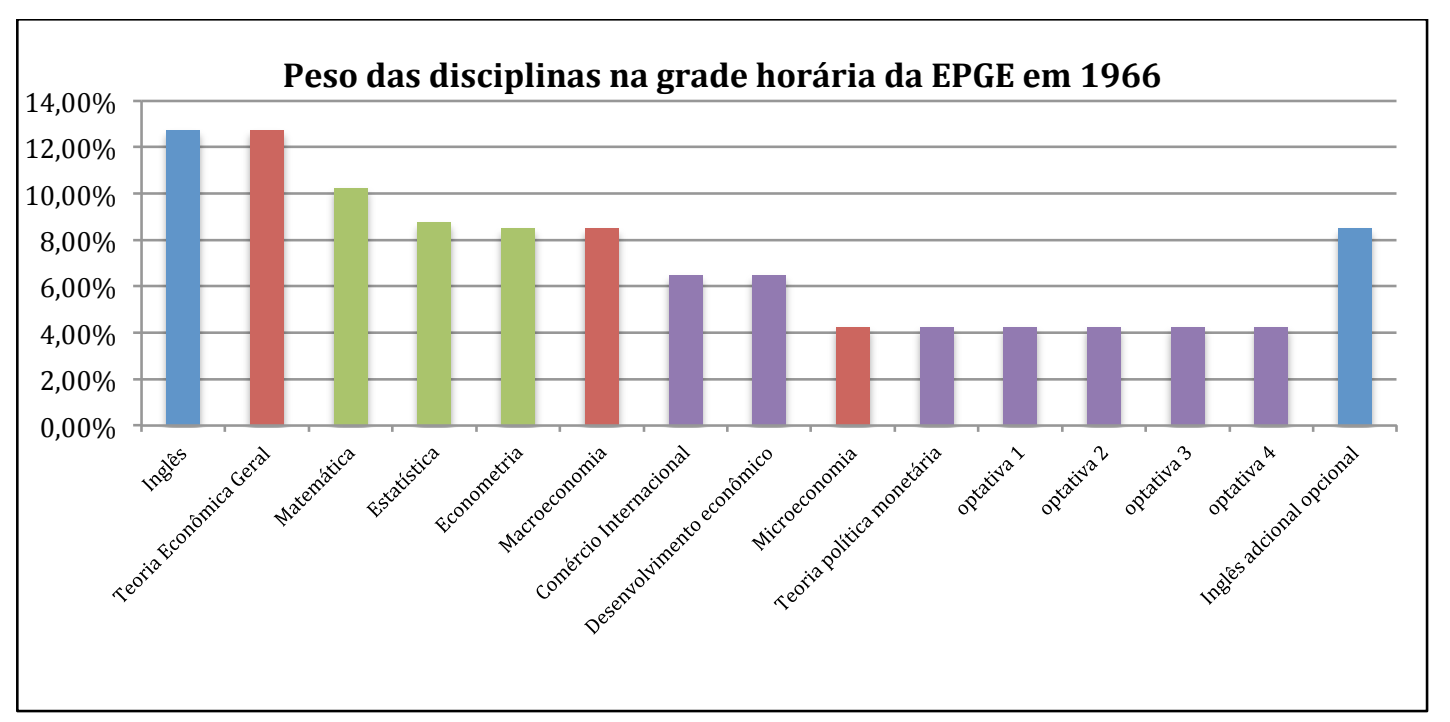

diretamente dos centros de economia que emergiam fora do eixo Rio-São Paulo, financiando, por exemplo, o Centro de Aperfeiçoamento de Economistas do Nordeste, da Universidade Federal do Ceará, o Centro de Desenvolvimento e Planejamento Regional, da Universidade Federal de Minas Gerais, o curso da Universidade de Brasília e o programa de pós-graduação em Economia da Universidade de Pernambuco (FERNÁNDEZ e SUPRINYAK, 2015, pp. 8-11).

${ }^{304}$ Em dezembro de 2013 foram integrados ao edifício Simões Lopes - cujos pilotis em V deram origem ao símbolo da Fundação - uma segunda torre, já prevista no projeto original, e um centro cultural, também projetado por Oscar Niemeyer. Retoma-se aqui a consideração feita no capítulo anterior sobre a convergência da arquitetura modernista com as instituições voltadas à gestão econômica do Estado, que era o objetivo inicial da FGV (item 2.3). 
Gráfico III: Peso das disciplinas na grade horária da EPGE em 1966. Fonte dos dados: SIMONSEN, 1966, p. 28. Elaboraşão própria. Legenda: Inglês: azul. Métodos e técnicas quantitativos: verde. Teoria econômica pura: vermelho. Áreas especializadas do conhecimento econômico: roxo. * Disciplinas optativas: Política Fiscal, História Econômica, História das doutrinas econômicas, Planejamento econômico, Problemas econômicos brasileiros, Economia agrícola, Economia industrial. * $\mathrm{O}$ cálculo foi feito sem o inglês adicional, ele está representado apenas para que se possa ver que peso ele teria caso comparado com os outros itens da grade regular.

Algumas observações podem ser feitas a partir do exame da estrutura do curso de pós-graduação da FGV. Primeiramente, é possível destacar o peso do inglês no programa. As aulas do idioma partilham com a teoria econômica a primeira posição em número de horas na grade. Se for contabilizado também o inglês adicional, oferecido aos alunos ainda não proficientes, ele passa à primeira posição. Isso indica que o mestrado da EPGE, como o CAE antes dele, partia da premissa que a sua função primordial era preparar os alunos para completar a formação nos Estados Unidos. Em segundo lugar, é notável o espaço ocupado na grade pelo ensino do instrumental quantitativo. Juntas, a matemática, a econometria e a estatística ocupavam quase um terço do programa, a exata parcela representada pela soma das disciplinas voltadas propriamente ao ensino da economia: microeconomia, macroeconomia e teoria econômica geral.

O curso funcionava das "oito horas da manhã às cinco da tarde, com uma hora e meia de intervalo para o almoço. Normalmente as aulas eram de manhã, e o resto do dia era para estudar - a não ser pelas aulas extras que o Mario dava, que não tinham horário" (José Luiz Carvalho in: D’ARAÚJO, 1999, p. 195). Além dos professores do CAE, a EPGE passou a contar com um grupo de professores visitantes estrangeiros, trazidos através de um acordo estabelecido com a Universidade de Vanderbilt nos Estados Unidos. Mario Henrique continuava a ministrar as aulas de teoria econômica e de matemática. Ocupava-se, além disso, de tudo mais que fosse necessário e ainda ensinava o que mais quisesse, a ponto de ter chegado a lecionar teoria da relatividade e física quântica para alunos interessados (Entrevista de André Lara Resende à autora em 2012). O curso de estatística cabia a Jessé Montello. O coordenador administrativo do curso, Ney Coe de Oliveira, oferecia um curso de lógica. Isaac Kerestenetzky ministrava a optativa de planejamento econômico. Julian Chacel ensinava economia agrícola e Reis Velloso macroeconomia e economia brasileira. Um professor norte-americanos, Werner Baer, ensinava comércio internacional e desenvolvimento econômico (José Luiz Carvalho in: 
D’ARAÚJO, 1999, pp. 194-195; João Paulo dos Reis Velloso in: ALBERTI et al., 2002, p. $88)$.

Werner Baer (1931-2016) nasceu em Berlim e mudou-se com a família para os Estados Unidos, com a intenção de escapar do nazismo. Conta que interessou-se - talvez por impacto da experiência familiar ${ }^{305}$-, desde a juventude,

pelas causas das revoluções políticas e sociais [...]. Sempre fui um ávido leitor de
periódicos e revistas que tratavam de temas mundiais e de lutas econômicas e
políticas em países menos desenvolvidos. Como cresci falando três idiomas, e
dado meu interesse por questões mundiais, decidi tentar uma carreira no serviço
diplomático. Assim quando entrei na universidade (Queens College), parecia lógico
especializar-me em ciência política, com ênfase em questões internacionais [...]
Como especialista em ciência política, era necessário fazer o curso de Princípios
de Economia. Impressionou-me o maior rigor desta disciplina em tratar temas
contemporâneos e, assim, mudei minha especialização (BAER, 1998, p. 767).

Baer ingressou em Harvard na época em que florescia o debate sobre desenvolvimento e modernização entre os membros da Charles River School, que se tornariam, pouco depois, os assessores de Kennedy. Dois professores dos círculos centrais dos democratas, que circulavam nesse meio, Alexander Gerschenkron e John K. Galbraith, foram suas maiores influências intelectuais enquanto esteve em Harvard. Sua tese de doutorado versou sobre a recuperação do comércio internacional da Alemanha no pós-guerra, mas não era esse o tema que mais lhe interessava. Conta que "Gottfried Haberler, que ministrava o curso de Economia Internacional, frequentemente atacava as teorias do Prebisch/CEPAL tão veementemente que decidi ler acerca das controvérsias que as rodeavam. Quanto mais o Haberler atacava, mais eu lia e simpatizava com Prebisch” (BAER, 1998, p. 768; Respostas de Werner Baer por e-mail a questões enviadas pela autora, 2015).

Galbraith indicou seu nome para uma equipe que estava desenvolvendo um estudo sobre a industrialização de Porto Rico. Naquela ocasião aprendeu espanhol e definiu que iria especializar-se na temática do desenvolvimento econômico da América Latina. Aceitou prontamente a oferta para ligar-se ao recém criado Economic Growth Center de Yale e conduzir, em qualquer outro país da região, uma pesquisa sobre o processo de industrialização. Baer conta ter olhado no mapa, pensado e optado por estudar o Brasil que apresentava, diz ele, problemas fascinantes: industrialização, inflação,

\footnotetext{
${ }^{305}$ Cabe ressaltar o grande peso dos judeus europeus deslocados pelo nazismo e pela Segunda Guerra Mundial entre aqueles que desenvolveram as teorias que associavam desenvolvimento econômico e liberdade. O impacto social desastroso que a falência econômica teve sobre as sociedades das quais provieram talvez tenha sido o grande propulsor para que passassem a pensar estabilidade econômica e política de maneira associada.
} 
problemas de distribuição de renda etc. O Economic Growth Center contatou Alexandre Kafka, com a intenção de vinculá-lo à Fundação Getúlio Vargas, que o acolheu pela primeira vez em julho de 1962 (BAER, 1998, p. 768; Respostas de Werner Baer por email a questões enviadas pela autora, 2015). Ao falar de seu crescente interesse pelo Brasil, Baer explica que:

além de ser atraído pela sociedade brasileira por causa da cordialidade, da energia e do prazer de viver de seu povo, fascinou-me o vasto panorama que ela oferecia de uma sociedade e uma economia em transição. Os desafios da extraordinária migração rural-urbana, o impacto (positivo e negativo) da industrialização pelo processo de substituição de importações, as desigualdades que acompanharam os períodos de crescimento acelerado, os argumentos a favor e contra investimentos estrangeiros, o papel do Estado, os debates sobre as causas e impactos da inflação etc. fizeram do estudo da economia brasileira uma aventura e um desafio intelectuais excitantes (BAER, 1998, p. 768).

As primeiras pessoas com as quais Baer teve contato no Brasil foram os professores Isaac Kerstenetzky, Mario Henrique Simonsen e Aníbal Villela. Ele começou trabalhando com Kerstenetzky, com quem diz ter se entendido muito bem, partilhando as mesmas visões acerca da economia. Depois de seguidas visitas ao país, em 1965 aceitou o convite da Fundação Ford para passar uma temporada mais longa no Rio de Janeiro, como professor visitante na FGV. Em 1966, Baer passou a colaborar também com a Universidade de São Paulo, tendo tido, pois, ativa participação no processo de montagem dos dois primeiros cursos de pós-graduação. Atuou, ademais, como advisor da Fundação Ford para concessão de bolsas e intermediário para o envio de uma geração de economistas para as faculdades de Yale e Vanderbilt, nas quais lecionou no período. Depois de retornar aos EUA em 1968, continuou atuando como intermediário da circulação internacional dos brasileiros e tornou-se consagrado brasilianista (Respostas de Werner Baer por e-mail a questões enviadas pela autora, 2015).

Tal como a da FGV, a pós-graduação da USP foi viabilizada com auxílio da Fundação Ford e da USAID. O acordo estabelecido com a USAID instituía a seguinte divisão de tarefas: o IPE encarregar-se-ia da montagem das instalações nas quais funcionaria o curso e da administração e manutenção dos salários dos bolsistas e a USAID ocupar-se-ia do envio de professores estadunidenses para o Instituto. Estes, além de lecionar, ajudariam os brasileiros a desenhar os currículos, planejar as pesquisas e avaliar os alunos. Para tanto, foi estabelecido, em 1965, um convênio com o Graduate 
Program in Economic Development da Universidade de Vanderbilt ${ }^{306}$. Em paralelo, a Fundação Ford assinou um convênio com o IPE através do qual concedeu "uma doação de US $\$ 433,000$ para cobertura de parte dos gastos com o programa de aperfeiçoamento em teoria econômica, quais sejam: financiamento de pesquisadores nacionais e estrangeiros em regime de tempo integral; recursos para a compra de equipamentos e complementação da biblioteca; pagamento de bolsas de estudos locais e no exterior". Verba essa que foi suplementada, em 1969, por uma doação adicional no valor de US\$ 285,000 (ROCCA et al., 1984, pp. 229-230).

$\mathrm{Na}$ divisão de trabalho instituída, os estrangeiros encarregavam-se das disciplinas principais e os docentes locais atuavam como seus colaboradores. Conforme discutido em Itaipava, a exposição dos brasileiros aos cursos oferecidos pelos norte-americanos visava qualificar o professorado local e divulgar as mais recentes tendências da pesquisa econômica. Assim, ao fim da cooperação, os professores da FCEA e das outras universidades brasileiras que frequentassem o mestrado estariam prontos para lecionar uma ciência econômica que estivesse em sintonia com a produção internacional. Esse ciclo de investimentos na modernização do ensino seria concluído quando a faculdade incorporasse em seu corpo docente os alunos que enviara ao exterior para que completassem sua formação.

No primeiro ano do mestrado, o professor Werner Baer encarregou-se da disciplina de Desenvolvimento Econômico, a mesma que oferecia na FGV. William Oliver Thweatt ofereceu os cursos de microeconomia I e II e macroeconomia I e II, tendo como colaborador local o professor Luiz Carlos Pereira de Carvalho. Gian Singh Sahota ensinou econometria, acompanhado por Affonso Pastore e Carlos Rocca, e os professores brasileiros sênior Ruy Leme e Delfim Netto assumiram, respectivamente, as cadeiras de economia das empresas e economia brasileira, sendo Delfim auxiliado por Eduardo Pereira de Carvalho e José Roberto Mendonça de Barros. No ano seguinte Andrea Maneschi passou a lecionar finanças públicas. Thweatt assumiu uma cadeira adicional, a de história do pensamento econômico. Delfim deixou o curso e Dorival

\footnotetext{
306 "Em 1965, a Faculdade de Ciências Econômicas e Administrativas da USP entrou em entendimentos com a Universidade de Vanderbilt, tendo sido formada uma Comissão Mista, da qual participaram do lado americano os professores N. Georgescu-Roegen, W. Carlson e. W, Nicholls e, do lado brasileiro, os professores Ruy Aguiar da Silva Leme, José de Freitas Bueno e Dorival Teixeira Vieira. Dos estudos realizados por esta Comissão, com o apoio da Fundação Ford e da Universidade de Vanderbilt, surgiu o Instituto de Pesquisas Econômicas da Universidade de São Paulo, com duas finalidades: realização de cursos de mestrado e doutorado para o aperfeiçoamento de pesquisadores e professores na área de Ciências Econômicas" (VIEIRA, 1981, p. 368).
} 
Teixeira Vieira ${ }^{307}$ assumiu uma cadeira de política monetária e fiscal. Em 1968, Werner Baer passou a oferecer também um curso de comércio internacional e Pastore tornou-se o titular da cadeira de econometria II, além de colaborador de Sahota na econometria I. Em 1969 surgiram as cadeiras de matemática e estatística e de história econômica, já dirigidas por professores da própria FEA (ROCCA et al., 1984, pp. 242-243).

Ano a ano aumentava o número de professores da casa encarregados dos cursos, até que, em $1970^{308}$, todas as aulas passaram a ser oferecidas por brasileiros. Nesse mesmo ano a pós-graduação é credenciada junto ao Ministério da Educação e Cultura. Inicialmente composta por um mestrado em teoria econômica, a pós-graduação foi acrescida, em 1974, de doutorado em economia (ROCCA et al., 1984, p. 236) - no mesmo ano a FGV, já sob o controle de Carlos Geraldo Langoni, dá início ao processo de montagem de seu doutorado (item 4.6). Mesmo que os titulares dos cursos da FEA fossem agora membros da Faculdade, o sistema de colaboração dos professores mais novos com os professores titulares das disciplinas manteve-se, dando continuidade à tradição de formação interna de quadros e promovendo a integração dos novos entrantes no corpo docente da faculdade.

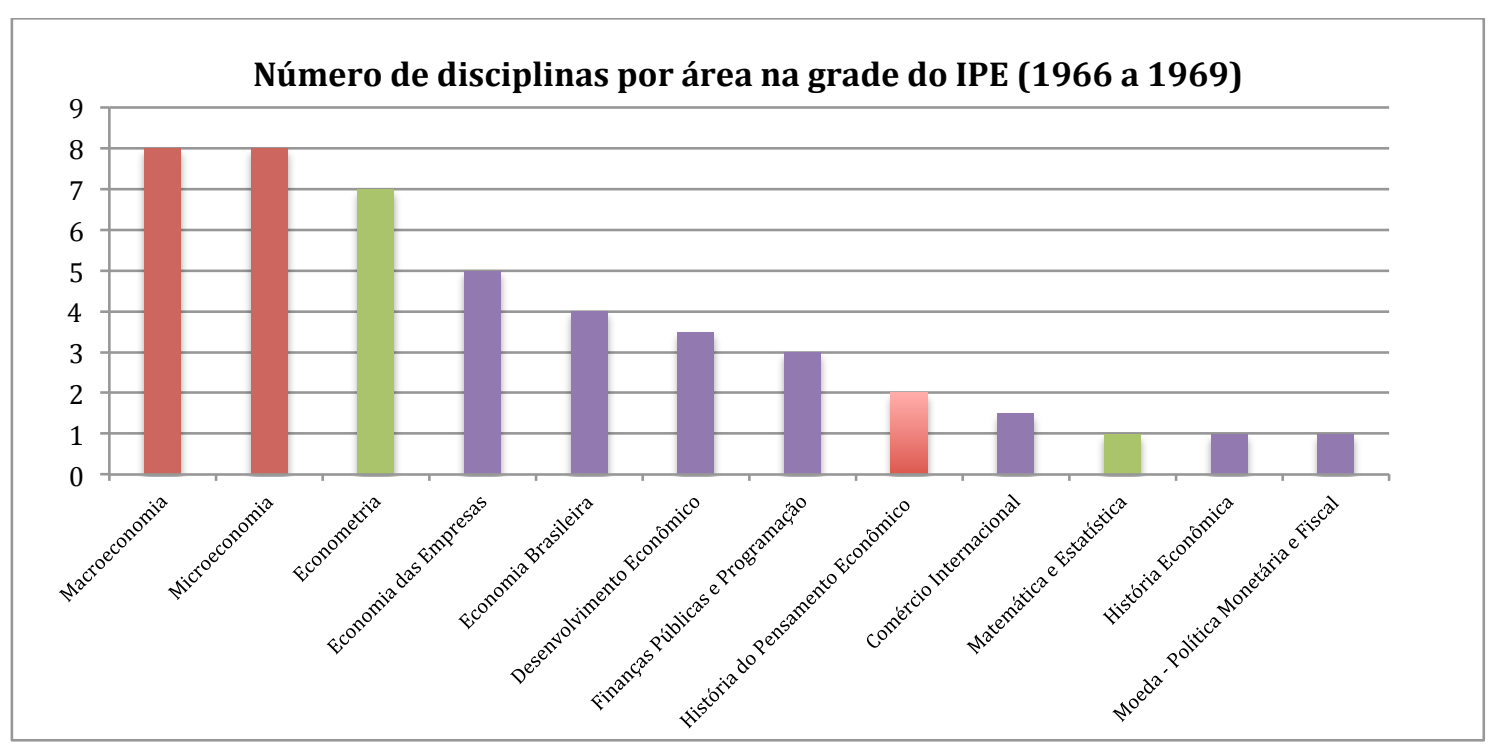

Gráfico IV: Número de disciplinas por área na grade do IPE (1966 a 1969). Fonte dos dados: ROCCA et al., 1984, pp. 242-243. Elaboração: própria. Legenda: Inglês: azul. Métodos e técnicas

\footnotetext{
${ }^{307}$ Dorival Teixeira Vieira (1915-2012) fora também dos primeiros professores da FCEA. Filho de um pugilista e controlador de linha de trem, Teixeira Vieira estudou na escola Caetano de Campos e graduou-se e doutorou-se em Ciências Sociais. Ver: http://www1.folha.uol.com.br/cotidiano/1044460-dorival-teixeira-vieira-1915-2012--estudante-e-professor-catedratico-da-usp.shtml, consultado em 22/05/2016.

308 No mesmo ano de aprovação do mestrado o IPE-USP começa a publicar a Revista Teoria e Pesquisa Econômica que, em 1971, converter-se-ia na revista Estudos Econômicos, um dos periódicos brasileiros de ciência econômica de maior alcance (ROCCA et al., 1984, p. 236).
} 
quantitativos: verde. Teoria econômica pura: vermelho. Áreas especializadas do conhecimento econômico: roxo.

Ainda que tivessem sido criadas ao mesmo tempo e por vias semelhantes, há diferenças substantivas entre as grades da pós-graduação da USP e da FGV. Primeiro, os cursos de estatística e matemática, que tinham grande peso na formação oferecida pela EPGE, só foram integrados à grade da USP no quarto ano de funcionamento do mestrado. Somadas, a estatística, a matemática e a econometria ocuparam, nesses anos iniciais de funcionamento da pós-graduação, em média 17,5\% da grade do IPE-USP, em contraste com o quase um terço do curso do Rio de Janeiro. Outra diferença, ainda mais contrastante, é a ausência na grade do IPE do inglês, que ocupa outro um terço do curso da FGV. Além disso, os cursos de história econômica, história do pensamento econômico, economia brasileira, desenvolvimento econômico e finanças e programação, que eram optativos na FGV, faziam parte da grade regular da USP. A diferença de enfoque mostra que a formação da EPGE continuava sendo majoritariamente voltada para o ensino das ferramentas quantitativas e do inglês que eram qualificações mínimas para que seus estudantes pudessem ir para o exterior. Já a USP adotava uma estratégia mista, encaminhava estudantes para outros países, mas procurava promover, simultaneamente, um processo de substituição de importação de saberes e especialistas, através da preparação de professores de todo o país para a docência.

Em segundo lugar, a USP dispunha de um corpo docente maior e que trabalhava diretamente em cooperação com os estrangeiros. Mesmo que Delfim Netto tivesse adquirido um certo destaque entre os membros da escola, o ensino não se concentrava em suas mãos. Havia na FCEA um maior grau de institucionalização, uma preocupação com a formação local das novas gerações e com a montagem de uma faculdade integrada, na qual o poder era rotativo e as decisões tomadas em colegiados, conforme vigente na universidade. Trata-se de notável contraste com a EPGE que, ao enviar para o exterior todos os candidatos promissores, não fez um processo de transição interna da responsabilidade pelos cursos. A baixa institucionalização, a grande centralização do poder e a falta de integração do corpo docente da Fundação resultariam em problemas sucessórios e conflitos quando Mario Henrique Simonsen começasse a se ausentar como será discutido adiante (item 4.0). 
Delfim ensinava o que havia de mais atual em seminários paralelos, mas nunca se propôs, como Simonsen, a dar aula de tudo o que precisasse, até porque já não estava tão presente no momento em que a pós-graduação foi criada. Se ele ainda lecionava no ano de 1966, quando foi nomeado secretário da fazenda do Estado de São Paulo, ao assumir o Ministério da Fazenda, em 1967, sua presença na USP rarefaz-se. Ele ainda assume o curso de Economia Brasileira ainda em 1967 e 1969 e depois desaparece da grade (ROCCA et al., 1984, pp. 242-243).

A passagem de Delfim do governo estadual para o governo federal foi um desdobramento do prestígio que conquistara na universidade, somado aos laços que costurara com as elites econômicas paulistas e com os governos locais. Um evento pontual importante para que seu nome deixasse de ser local e passasse a circular nacionalmente foi o convite que recebeu, em 1964, para ocupar a posição de secretário geral da Associação Nacional de Programação Econômica e Social (ANPES), entidade patrocinada por banqueiros paulistas e pelo Instituto de Pesquisas Econômicas e Sociais (IPÊS) que reunia muitos empresários paulistas com os quais havia estabelecido boas relações (ECKERMAN, 1989, pp. 123-124; MACEDO, 1984, pp. 325-326). Roberto Campos oferece a seguinte versão sobre a criação da ANPES:

Como desejava conciliar as atividades empresariais com tarefas acadêmicas e de planejamento, eu sugerira a empresários paulistas a criação de uma associação de pesquisas que pudesse fazer uma avaliação permanente das políticas econômicas do governo Goulart, então instáveis e caóticas, mas sobretudo formular cenários alternativos e análises de perspectivas. Criou-se então em São Paulo a ANPES Associação Nacional de Planejamento Econômico e Social, presidida pelo empresário Teodoro Quartim Barbosa. Fui seu primeiro secretário geral e convidei para diretor técnico Mario Henrique Simonsen. Mal havíamos começado os trabalhos e chegou-me o convite de Castello Branco para o ministério do Planejamento. Simonsen e eu embarcamos então de corpo e alma na preparação do PAEG [Plano de Ação Econômica do Governo], com secundária atenção à ANPES. Preocupados, muito justamente, com o nosso absenteísmo, os patrocinadores, entre os quais se destacavam Gastão Vidigal, do Banco Mercantil, e Sérgio Mellão, do Brasul, pediam-nos que visitássemos São Paulo para dar conta de nossas atividades. Apresentei-lhes as ideias fundamentais do PAEG, que obviamente eram consoantes com a ideologia da livre empresa (apesar dos receios empresariais de excessivo rigor na concessão de crédito) e ao mesmo tempo apresentei minha renúncia, pela impossibilidade de conciliação das tarefas. Simonsen continuou na ANPES pouco tempo mais, porém, carioca irredutível, detestava os deslocamentos para São Paulo (CAMPOS, 1994, p. 607).

Lucas Lopes, por sua vez, relata que:

um belo dia fui chamado a São Paulo para participar da criação de um instituto de pesquisa econômica pura, que deveria ser totalmente independente e reuniria gente com experiência de planejamento. Fui até lá, tivemos uma reunião provisória no banco do Sérgio Mellão, decidimos criar a entidade, e fui designado 
presidente provisório. Eu deveria participar da cerimonia de fundação, e escrevi um discurso radicalmente liberal. Mas na véspera da criação da ANPES, Juscelino foi cassado [8 de junho de 1964], e eu, como seu amigo, fiquei muito chocado. Achei que não deveria aparecer em nenhuma cerimônia e não fui. Quem leu o discurso que eu escrevi foi Luiz Simões Lopes, presidente da Fundação Getúlio Vargas. A ANPES foi mantida e teve uma evolução importante, mas perdi o contato (LOPES, 1991, pp. 281-282).

Com a ANPES, o grupo ligado a Roberto Campos passaria a operar também em São Paulo, onde tinham pouco enraizamento. A organização aproximava os desenvolvimentistas não nacionalistas, dentre os quais Campos, Mario Henrique, Lucas Lopes, Luiz Simões Lopes, Ary Torres e Vitor da Silva, do empresariado paulista, de cujo apoio precisariam para governar. Após a saída de Campos e Simonsen, a ANPES passou a ser presidida por Gastão de Bueno Vidigal, tendo na vice-presidência Sérgio Mellão, Ary Torres, Edmundo de Macedo Soares e Silva, João Ademar de Almeida Prado, Lélio Toledo Pisa e Almeida Filho, Lucas Lopes, Luiz Simões Lopes e Paulo de Almeida Barbosa (DELFIM NETTO et al., 1965, p. VII). Na apresentação do primeiro volume dos Estudos ANPES, o editor resume a missão da Associação:

A falta de uma visão em perspectiva das tendências da economia nacional, a descontinuidade dos programas dos Governos e a crescente intoxicação da opinião pública, mal informada sobre assuntos econômicos, vem tornando extremamente difícil a ação empresarial no Brasil. Com o intuito de eliminar pelo menos parte das dificuldades que a empresa privada tem que enfrentar para se desenvolver, foi constituída, nos moldes de associações congêneres existentes em vários países do mundo, a Associação Nacional de Programação Econômica e Social - ANPES. Destacam-se entre os objetivos da ANPES a realização e publicação de levantamentos, estudos e recomendações relacionados à formulação de medidas de política econômica e social tendo em vista acelerar o desenvolvimento do Brasil [...]. Como o próprio nome designa, a ANPES é uma associação privada de programação. A palavra "programação", ao invés de planejamento, indica que a contribuição da iniciativa privada não pode realisticamente ir além de formular uma visão de perspectiva da economia brasileira, dentro de diferentes hipóteses, sem procurar nenhuma forma de planejamento global que não é compatível com a organização política, social e econômica do país (DELFIM NETTO et al., 1965, p. ix).

É possível dizer que a ANPES foi um antecedente do EPEA, tendo ensaiado construir estudos que subsidiassem uma programação econômica para o desenvolvimento. Ela começou a ser desenhada antes da queda do governo de João Goulart e, como o EPEA, era uma iniciativa de Campos coordenada pelo secretário administrativo da CONSULTEC, Vitor Silva (item 2.5) (BARBOSA, 2012, p. 136) 309 .

\footnotetext{
${ }^{309}$ Neste sentido há uma semelhança com o caso da elaboração do programa Ladrillo pelos chilenos do grupo dos Chicago Boys, no qual os especialistas em economia que trabalhariam para o Regime Militar reunia-se aos empresários para traçar planos econômicos antes mesmo da queda do governo (item 4.4).
} 
Alguns aspectos da inflação brasileira (1965), o primeiro texto publicado pela ANPES, foi escrito por Delfim Netto em colaboração com três de seus Delfim Boys: Affonso Pastore, Eduardo Pereira de Carvalho e Pedro Cippolari. A receptividade do estudo foi grande entre os membros da nova equipe econômica do Governo Federal, que era chefiada por Octavio Gouvêa de Bulhões, autocaracterizado como incansável inimigo da inflação (item 2.1), e por Roberto Campos, que desde o final do governo JK estava engajado em fazer com que vingasse um plano de estabilização. Não apenas o tema era convergente com as preocupações do governo central, mas a explicação que ofereciam para o fenômeno inflacionário era vista com bons olhos por Bulhões e Campos. Affonso Pastore ${ }^{310}$ explica que a ideia do artigo era testar as hipóteses do estruturalismo cepalino e dos monetaristas sobre as origens da inflação, levando-os a concluir que:

\begin{abstract}
a ligação contemporânea entre as taxas de inflação e de expansão monetária, de um lado, e as evidências empíricas de que a taxa de expansão monetária era provocada fundamentalmente pelo déficit público, reduziam, ou eliminavam, as dúvidas sobre a direção de causalidade, e permitiam atribuir a inflação ao déficit público. Nesse sentido a magnitude da taxa de inflação não podia ser explicada pela tese da CEPAL de que a inflação era produzida pelos gargalos estruturais como a inelasticidade de oferta de alimentos e os efeitos da deterioração dos termos de intercâmbio (PASTORE, 1996 apud COELHO, 2007, p. 439).
\end{abstract}

A interpretação por eles apresentada contradizia as premissas cepalinas, sancionando a visão de política econômica de Campos e Bulhões. Eles argumentavam que o déficit público era a mais grave dentre as quatro fontes de inflação detectadas, a saber: 1) os déficits do setor público e a forma de seu financiamento, 2) as pressões de custo derivadas dos reajustes salariais, 3) as pressões de custo derivadas das desvalorizações cambiais e 4) as pressões provenientes do setor privado (DELFIM NETTO et al., 1965, p. 147). Estavam em harmonia com as medidas econômicas prioritárias do Plano de Ação Econômica do Governo Castello Branco (PAEG) não apenas ao dizer que o deficit público era a maior fonte de inflação, mas também no que concerne à política salarial, já

\footnotetext{
${ }^{310}$ Roberto Macedo, que trabalhou como assistente de Affonso Pastore, afirma que a tese de doutorado de Pastore, A resposta da produção agrícola aos preços no Brasil, foi um marco no processo de solidificação do novo modelo de conjunção da teoria com o aparato de teste matemático e que a rusga com a CEPAL era muito mais evidente nos escritos e posicionamentos de Pastore do que do próprio Delfim. Pastore - que em 1976 viria a ser professor convidado na Universidade de Chicago - apresentava as teses de Theodore Schultz, da Universidade de Chicago, como uma alternativa ao estruturalismo, dizendo que os agricultores eram agentes racionais e que a agricultura não se modernizava por falta de estímulos econômicos e recursos tecnológicos e humanos adequados ao crescimento da produção, não sendo, pois, o setor inerte aos incentivos do sistema de preços. Consequentemente, o atraso econômico não teria raízes estruturais ligadas ao sistema internacional de comércio, devendo-se essencialmente à prevalência de um sistema de latifúndios que deveria ser dissolvido (MACEDO, 2001, p. 381).
} 
que afirmam que não seria possível reajustar os salários elevando o salário médio real, pois o conflito distributivo subsequente criaria pressão inflacionária. A política salarial draconiana do PAEG, com a qual estavam de acordo, evitava tanto aumentos decorrentes do conflito distributivo quanto crescimento da demanda que também criaria pressões sobre os preços (DELFIM NETTO et al., 1965, pp. 148-149). Os autores preocupavamse, entretanto, com as consequências recessivas do reequilíbrio das contas públicas e apresentam uma solução alternativa:

\begin{abstract}
suponhamos que o Govêrno decida restringir tal déficit cortando substancialmente a despesa de investimentos. Ora, se do combate à inflação resultar uma queda na taxa de expansão dos investimentos (já que as decisões de investir poderão estar ligadas ao grau de liquidez das empresas), determinando, portanto, uma redução da demanda efetiva, a diminuição do investimento governamental debilitará ainda mais a demanda global, podendo inclusive fazer com que o sistema se defronte com uma crise. Dada a possibilidade de ocorrer tais consequências, o Govêrno poderá ser levado a tentar manter seu nível de dispêndio. Tal fato, não implica, necessariamente, em um abandono da política de combate à inflação, uma vez que resta a alternativa de se financiar tais dispêndios, pelo menos em parte, via ajuda externa, substitutiva parcial das emissões tradicionais (DELFIM NETTO et al., 1965, p. 150).
\end{abstract}

Essa solução, que não prevê simples corte dos dispêndios públicos e investimentos, não é a mais ortodoxa e monetarista, já que propõe uma tentativa de conciliar crescimento e combate da inflação financiando o déficit público e o investimento com endividamento externo. A gestão Bulhões-Campos conseguiu reduzir a inflação de 91,8\%, em 1964, para 65,7\% em 1965 e para 41,3\% em 1966. Já a média de crescimento do Produto Interno Bruto (PIB) ficou em 4,2\% a.a. contra 8,1\% a.a. no governo JK, sendo inclusive inferior aos 5,3\% a.a. dos governos de Jânio e Jango, que transcorreram em plena crise institucional e política (ABREU, 1990, pp. 403, 406).

Quando Delfim foi nomeado Ministro da Fazenda ele alterou de fato a estratégia econômica, para evitar o custo recessivo do combate à inflação que, mesmo com todos os cortes e a desaceleração, havia estagnado ${ }^{311}$ ao redor de 22\%. Adota, para tanto, a proposta alternativa que esboçara já em 1965, na qual o endividamento externo aparecia

${ }^{311} \mathrm{O}$ fato de que a inflação tivesse estagnado na casa dos $22 \%$ faz também com que haja uma releitura do tipo de inflação com o qual estavam lidando. Consideravam que o corte salarial e o controle monetário rígido haviam promovido parte da queda da inflação, mas julgavam que o que restara não poderia mais ser tido como decorrente da alta demanda e sim da alta de custos. Assim, "o cenário seria propício para se relaxar a política monetária sem gerar pressões de demanda e, ao mesmo tempo, reduzir os custos financeiros. Para compensar o afrouxamento da política monetária sobre a inflação, foram instituídos controles de preços, por meio de um órgão criado para este fim, a Comissão Nacional de Estabilização de Preços (CONEP), mais tarde denominada Comissão Interministerial de Preços (CIP). Logo o Ministério da Fazenda, por intermédio deste órgão, passou a controlar os preços públicos, tais como tarifas, câmbio e juros do crédito público, mas também outros preços privados, sobretudo insumos industriais que influenciavam os custos" (TAVARES, 2010a, p. 135). 
como alternativa para financiar o déficit, permitir o investimento e, desse modo, promover incrementos na produção que pudessem gerar superávit externo em volume suficiente para cobrir os gastos internos. Tal reversão deveras ocorreu, já que o saldo do balanço de pagamentos que fora derrubado de 331 milhões de dólares para 153 e depois para -245 pela gestão anterior, passou a crescer para 32, depois para 549, até atingir 2.178,6 milhões de dólares no final do delfinato, em 1973, sendo que o saldo da balança comercial média nos 10 anos anteriores tinha sido negativa no valor de -104,9. Em paralelo, a dívida externa subiu neste período de 3281 milhões de dólares até 9521, sendo que a média de endividamento nos 10 anos anteriores tinha sido 3049,2 (ABREU, 1990, pp. 404, 406, 409).

O retorno do investimento e do gasto público foi acompanhado de medidas de incentivo ao desenvolvimento do setor privado. O governo

\begin{abstract}
alongou provisoriamente o prazo de recolhimento do IPI, aportando maior capital de giro às empresas. Também no campo monetário e creditício, a política foi muito mais frouxa, com expansão do crédito do Banco do Brasil ao setor agrícola, cuja safra aumentou consideravelmente. Também houve aumento do crédito concedido ao setor privado, tanto para giro quanto para financiamento, e cresceu o crédito direto ao consumidor, vinculado às financeiras - instrumento criado no contexto das reformas da gestão anterior e que alavancou o setor de bens duráveis (TAVARES, 2010a, p. 136).
\end{abstract}

A contraposição sustentada por Delfim e seus alunos à tese da inflação estrutural não veio, portanto, acompanhada de uma rejeição de outras premissas defendidas pela CEPAL, tais como a intervenção do Estado na economia e a elaboração de uma política econômica que incentivasse a industrialização como estratégia para, no médio prazo, reduzir a dependência nacional. Nesse sentido a perspectiva de Delfim era consideravelmente próxima da posição do jovem Campos: melhorar o sistema de preços e os incentivos de mercado, associando-os a intervenções para a superação dos estrangulamentos econômicos. Ainda que Campos tenha radicalizado a crítica ao intervencionismo no fim de sua vida, não é possível dizer que, em meados dos anos 1960, quando estava empenhado em criar escritórios de programação, políticas setoriais, planos decenais e as associações de pesquisa voltadas para o planejamento, ele tivesse uma postura antiestatista radical como aquela de Gudin. 
A simpatia de Campos pelas posições que Delfim exibia nos idos de 1965 fez com que o designasse como substituto na secretaria geral da ANPES 312 . Conta ele que:

\begin{abstract}
os empresários patrocinadores insistiram em que indicássemos substitutos. Ambos propusemos que o novo secretário geral da ANPES fosse o jovem economista Antônio Delfim Netto. Este depois recrutou Affonso Celso Pastore para o Departamento Técnico. Delfim se tornou, anos mais tarde, ministro da Fazenda e Pastore foi para o Banco Central, no governo Figueiredo. Assim, em curto espaço de tempo, a ANPES se tornou uma plataforma de decolagem para a vida pública de três ministros - Campos, Delfim e Simonsen. A piada corrente entre os economistas nos anos 70 era: 'Pesquisar na ANPES é o caminho mais curto para mandar em Brasília' (CAMPOS, 1994, p. 607).
\end{abstract}

Campos assume também a responsabilidade pela indicação, em 1966, de Delfim para a posição de Secretário da Fazenda de Laudo Natel, que substituiu o governador cassado Adhemar de Barros. Paulo Egydio Martins, que era Ministro da Indústria e do Comércio desde o início de 1966, afirma que teria sido ele a sugerir o nome de Delfim, que ele conhecia da Associação Comercial. Declara que, depois de ter tido problemas com os secretários da fazenda do período de Adhemar de Barros, a equipe econômica federal decidiu fazer ela mesma a indicação de um nome. Egydio entrou em contato com outros colegas da Associação Comercial e o nome unânime foi o de Delfim, que "pela sua habilidade logo encantou Bulhões e Campos, que o conheciam apenas através de publicações” (MARTINS, 2007, pp. 214-217). O próprio Delfim tende a atribuir sua nomeação às relações tecidas na Associação Comercial, ainda que reconheça a influência de Campos para confirmar a escolha dos paulistas (Delfim Netto apud CARIELLO, 2014).

Seja qual for a versão mais próxima do ocorrido, há alguns elementos invariáveis nos relatos: o primeiro deles é o apoio que Delfim recebera do empresariado paulista, com o qual manterá relações próximas durante todo o seu reinado. O segundo é que, tenha sido Campos a indicá-lo ou não, suas ideias e escritos tinham afinidade e contavam com a simpatia do Ministro do Planejamento, partilhada, segundo ele, por Costa e Silva:

quando Costa e Silva, presidente eleito, indicou a Castello que desejava ter um "seminariozinho" de informações, por técnicos do governo, sobre a política econômica, Castello me encarregou da tarefa. Destaquei João Paulo dos Reis Velloso, então diretor do EPEA, para cuidar do assunto, recomendando-lhe que entre os expositores figurassem Mario Henrique Simonsen e Delfim Netto. Costa e Silva achou Simonsen competente mas abstrato, e simpatizou mais com a

\footnotetext{
${ }^{312}$ Se seguirmos o depoimento de Simonsen no livro Conversas com economistas brasileiros, haveria uma etapa intermediária, na qual o empresário Sérgio Mellão teria ocupado a secretaria geral e Delfim a diretoria técnica (SIMONSEN, 1996, p. 192). Neste caso, só depois Delfim teria passado à secretaria geral e Pastore à diretoria técnica, contradizendo a narrativa de Campos.
} 
exposição do "gordinho concreto" de São Paulo. Convidaria depois Delfim para ser ministro da Fazenda. Mas o curioso é que todos os instrutores do "seminariozinho" se tornaram ministeriáveis. Reis Velloso foi ministro do Planejamento nos governos Médici e Geisel. Delfim Netto foi ministro da Fazenda de Costa e Silva e Médici, e, anos depois, ministro do Planejamento do governo Figueiredo. Simonsen foi ministro da Fazenda de Geisel, e, por alguns meses, ministro do Planejamento de Figueiredo (CAMPOS, 1994, p. 730).

Em 1967, Delfim, o imigrante de origem social modesta, aos 39 anos, confronta-se com a tarefa de operar o Ministério da Fazenda, no qual permanece até 1974. Diz ele que a elite carioca pensava: "chegou esse gordo, italiano e vesgo. Nós vamos matá-lo em seis meses, tá certo? E além de tudo tem uns animais estranhos com ele, uns japoneses”, e acreditava que "aquele paulista caipira não aguentaria até o fim do ano" (Delfim Netto apud SAFATLE, 2012). A referência aos japoneses explica-se pelo fato de que alguns membros de seu grupo eram descendentes de imigrantes japoneses recentes, com trajetórias similares à sua. Entre eles estava Akihiro Ikeda e Paulo Yokota, que até hoje trabalham com ele em sua consultoria Idéias, ambos provenientes de famílias de imigrantes e que, como Delfim, haviam passado por escolas técnicas de contabilidade antes de ingressar na FCEA. Yokota, por exemplo, provinha de meio modesto, era filho de alfaiate e também tinha trabalhado como office-boy na juventude (SAFATLE, 2012; CARIELLO, 2014).

Os Delfim Boys, em sua maioria, fizeram a trajetória acadêmica completa na USP e mantinham com seu mestre uma relação de mutualismo. Ajudavam a sustentá-lo no poder e partilhavam do prestígio que dele emanava ao serem indicados para ocupar cobiçados cargos de confiança no topo do Estado e das estatais. A lista é longa e nela não estão incluídos todos os colaboradores de Delfim, só alguns dos mais conhecidos:

- Affonso Celso Pastore ${ }^{313}$ foi assessor de Delfim na Secretaria da Fazenda do Estado de São Paulo e participou da assessoria conjunta dos ministérios da Fazenda e do Planejamento com sede no IPEA. Depois de alguns anos envolvido principalmente com a organização da pós-graduação da FEA, tornou-se superintendente da Carteira de Comércio Exterior do Banco do Brasil (CACEX), depois Secretário da Fazenda do Estado de São Paulo e, por fim, Presidente do Banco Central.

- Akihiro Ikeda 314 foi assessor de Delfim na Fazenda, Consultor da Sabesp, DiretorSuperintendente da Valenorte, Diretor da Alumina Norte, Coordenador de Assuntos

\footnotetext{
${ }^{313}$ Pastore (1939), nasceu em São Paulo e estudou no Colégio Dante Alighieri. Fez a graduação e o doutorado na FCEA, além de uma pós-graduação em estatística matemática na Escola Politécnica (CANABRAVA, 1984a, p. 75; DHBB, verbete Affonso Pastore)

${ }^{314}$ Ikeda, descendente de japoneses, fez o secundário e a escola técnica em Presidente Prudente e tornou-se funcionário do Banco América do Sul antes de ingressar na FEA, onde cursou a graduação em economia. Em 1962, três anos depois de formado, fez um mestrado em economia na Universidade de Michigan (CANABRAVA, 1984a, p. 78; http://www.naguisa.com.br/noticias/especial0809.html. Consultado em 22/05/2016).
} 
Econômicos do Ministério da Agricultura e secretário de assuntos econômicos da Secretaria de Planejamento da Presidência da República (SEPLAN).

- Carlos Antonio Rocca foi assessor de Delfim na Fazenda, Secretário-Executivo do Conselho de Política Aduaneira e titular da Secretária de Estado dos Negócios da Fazenda do Estado de São Paulo

- Carlos Viacava foi coordenador da assessoria do Ministério da Fazenda, diretor do Instituto Brasileiro do Café, diretor da companhia Cacique Café Solúvel, Secretário de Abastecimento da SEPLAN e Secretário Geral do Ministério da Fazenda.

- Eduardo Pereira de Carvalho foi assessor na Secretária de Estado dos Negócios da Fazenda do Estado de São Paulo, coordenador da Assessoria Econômica do Ministério da Fazenda, diretor da Docegeo, da Vale do Rio Doce, da Albrás, da Safron-Teijin, da Valenorte alumínio, presidente do Banco do Estado de São Paulo (BANESPA), Secretário da Secretaria do Planejamento do Estado de São Paulo e Secretário Geral do Ministério da Fazenda.

- José Tiacci Kirsten foi presidente do Conselho Regional de Estatística e Diretor Geral da Fundação IBGE.

- Miguel Colasuonno 315 foi Secretário da Secretário da Secretaria do Planejamento do Estado de São Paulo, prefeito de São Paulo, presidente da Embratur e Coordenador de Projetos da SEPLAN.

- Paulo Yokota 316 foi da Assessoria Técnica Conjunta do Ministério da Fazenda-Banco CentralBanco do Brasil, diretor do Banco Central e presidente do Instituto Nacional de Colonização e Reforma Agrária (INCRA).

- Pedro Cipollari foi assessor do Ministério da Fazenda, da Companhia Energética de São Paulo e da Caixa Econômica Federal, Diretor da Companhia de Promoção de Exportações de Manufaturados e Secretário das Finanças da Prefeitura do Município de São Paulo.

Além deles o professor Ruy Aguiar da Silva Leme, com quem trabalhara no Plano de Ação do governo Carvalho Pinto, torna-se presidente do Banco Central em 1967 e Luiz de Freitas Bueno é feito diretor do Conselho Federal de Educação, presidente da Companhia de Processamento de Dados do Estado de São Paulo e, entre 1970 e 1971, diretor da EPGE - assunto que será discutido adiante (item 4.6) (CANABRAVA, 1984a, pp. 75-76, 78, 109, 111, 127-128, 193-194, 209, 227, 248, 246, 263-264).

\footnotetext{
${ }^{315}$ Colasuonno (1939-2013) era filho de imigrantes italianos. Seu pai, José Colasuonno, era guarda de fronteira na Itália, a mãe professora primária. $\mathrm{O}$ irmão do pai já vivia no Brasil e trabalhava como pintor, o pai assumiu a função quando o irmão voltou para a Itália e começou a retratar a elite paulistana. Passou também a importar material de pintura e abriu o empório artístico Michelangelo, até hoje existente, via pela qual acumulou capital econômico. Miguel estudou no Dante Alighieri e cursou graduação e pós-graduação em economia na FEA. Ver: http://turismoemnumeros.com.br/edicao/edic18/files/assets/basic-html/page37.html; DHBB, verbete Miguel Colasuonno).

${ }^{316}$ Paulo Yokota (1939) é paulistano, descendente de japoneses e criado no bairro da Liberdade. Seu pai era alfaiate e ele, "ainda garoto, trabalhou como office-boy. Fez curso técnico de contador e foi estudar economia na Universidade de São Paulo", onde fez graduação e pós-graduação (CARIELLO, 2014, [online]; CANABRAVA, 1984a, p. 247). http://www.asiacomentada.com.br/2015/01/uma-famlia-paulistana/. Consultado em 22/05/2016.
} 
O vasto controle de Delfim sobre a economia é atribuído à sua capacidade de manejar um grupo de fiéis seguidores, já que ao espalhar - como a lista acima mostra por todo governo aqueles que a ele eram leais, ele conseguia manter, por extensão, o controle das filigranas do Estado (SCHNEIDER, 1991, p. 91). Diz o próprio Delfim que “é uma questão de lealdade [...]. Você tem que ter gente que soma com você, com o projeto, e que é leal”. Um dos Delfim Boys, Luís Paulo Rosenberg ${ }^{317}$, comenta a agregação dos pares à mesa ao contar que eram obrigados a almoçar com o chefe todos os dias, sendo esta a estratégia que Delfim utilizava para conseguir reunir as informações que vinham de todos os lados, o que era central para o controle sobre a máquina de Estado (Luís Paulo Rosenberg apud CARIELLO, 2014). Outro de seus colaboradores, Eduardo Pereira de Carvalho, declara que "o poder de fazer as coisas acontecerem era multiplicado pelas centenas de pessoas que o Delfim tinha em tudo quanto é lugar. O poder de ação que a gente tinha, o poder de informação, era infernal”. Os dois ressaltam que ser membro da turma e ter uma lealdade cega para com o chefe eram os requisitos para ocupar aquelas posições (Eduardo Pereira de Carvalho apud CARIELLO, 2014).

Uma questão a ser colocada é: se Delfim conseguiu criar uma extensa rede de colaboradores e espalhá-los pela administração econômica de amplas porções do Estado, tendo logrado instalar aliados no Banco Central, na CACEX, nas estatais e por pouco tempo até no IPEA, por que nenhum de seus colaboradores mais próximos foi instalado no BNDE?

\subsection{Pedro Malan, Regis Bonelli e a Missão Califórnia}

No período em que Delfim Netto esteve à frente do Ministério da Fazenda de Arthur da Costa e Silva, o presidente do BNDE foi o contador e economista portoalegrense Jayme Magrassi de Sá (1921-s.d.), filho de um comerciante e industrial. Nos anos 1950, Magrassi havia sido técnico do CNE, professor da Universidade do Brasil e do Instituto Rio Branco e membro do Clube dos Economistas. Foi responsável pela seção de economia e finanças do jornal Correio da Manhã e funcionário do departamento

\footnotetext{
${ }^{317}$ Há de se dizer que Luís Paulo Rosenberg era no mínimo um Delfim Boy suis generis já que sua trajetória não é análoga à da maior parte dos discípulos de Delfim. Ele não permaneceu na FEA após a graduação, foi fazer o doutorado em Vanderbilt e, ao retornar, lecionou primeiro na Universidade de Brasília (UNB), a convite de Edmar Bacha (item 4.6). Só passou a integrar a equipe quando Delfim Netto foi nomeado Ministro do Planejamento no governo de João Figueiredo.
} 
econômico e consular do Itamaraty, razão pela qual participou de diversas conferências internacionais da área econômica. Como funcionário do Itamaraty, chegou, inclusive, a prestar alguma assistência à Comissão Mista Brasil-Estados Unidos (CMBEU), que deu origem ao BNDE (item 2.2).

Em 1955, Magrassi fez o curso de formação na Escola Superior de Guerra (ESG), aproximando-se dos militares. Em 1960 foi admitido no BNDES por meio de um concurso para a posição de contador e por ter sido aluno da ESG, seguiu sendo próximo do "grupo da Sorbonne", segmento dos militares ligados à ESG que tinha maiores conexões com o exterior, em especial com os EUA e que esteve à frente do governo durante o período Castello Branco ${ }^{318}$ (STEPAN, 1974, pp. 240-241; DHBB, verbete Jayme Magrassi de Sá). Destarte, Magrassi tornou-se diretor do departamento econômico do BNDE durante o primeiro governo militar e, em 1967, o primeiro funcionário de carreira a assumir a posição de presidente do Banco. Jayme não tinha nenhum elo de ligação com Delfim e não havia sido indicado para o posto por ele. Talvez tenha sido convidado diretamente pelos militares, talvez por Hélio Beltrão, do Ministério do Planejamento e Coordenação Geral, ao qual o BNDE passou a estar subordinado em fevereiro de 1967 e ao qual estava também vinculado o IPEA.

Beltrão (1916-1997) tinha uma trajetória bastante diferente daquela do Ministro da Fazenda, sendo filho de família brasileira bem inserida na política nacional. Seu avô Antônio de Arruda Beltrão era um engenheiro que fora dirigente da Companhia Açucareira Pernambucana e transferiu-se com a família para o Rio de Janeiro em 1891. Era uma figura pública de tal notoriedade em sua cidade que suas idas e vindas do Rio para Recife eram noticiadas no Diário Pernambucano. O pai de Hélio, Heitor da Nóbrega Beltrão, recebeu o diploma de advogado junto com uma medalha por seu exímio desempenho na graduação. Tornou-se jornalista da Gaz̧eta de Notícias, Secretário-Geral da Associação Comercial do Rio de Janeiro, fundador e presidente do Tijuca Tennis Club, vice-presidente da Associação Brasileira de Imprensa e membro da Academia Carioca de Letras. Foi um dos fundadores da União Democrática Nacional (UDN), partido pelo qual elegeu-se vereador e deputado. No fim da vida exerceu ainda a função de conselheiro das Caixas Econômicas Federais, na época em que Gudin foi Ministro da Fazenda. Em suma,

\footnotetext{
${ }^{318}$ Sobre a oposição entre a "Sorbonne" de Castello Branco e a "linha dura" de Costa e Silva vide: STEPAN, 1974, pp. 229-236.
} 
era um homem muito bem posicionado no circuito político, social e econômico carioca ${ }^{319}$ e pernambucano.

A trajetória do filho não foi muito diferente. Hélio Beltrão estudou no Colégio Pedro II, à época bastante consagrado, e formou-se advogado pela Faculdade Nacional de Direito em 1937. Tornou-se funcionário do Instituto de Pensões e Aposentadorias dos Industriários (IAPI) por concurso e, já em 1938, foi designado chefe de gabinete da presidência. Em 1941 foi nomeado diretor do Instituto de Previdência e Assistência dos Servidores do Estado e, ao retornar ao IAPI em 1945, foi procurador-geral e presidente. Deixou a posição em 1947 para cursar a pós-graduação em direito comparado na New York University (NYU) e, ao regressar, ingressou no Conselho Nacional do Petróleo e depois na Petrobrás. Como o pai era parte dos círculos internos da UDN, tendo sido secretário do Interior e do Planejamento de Carlos Lacerda no Estado da Guanabara. Chegou a concorrer a suplente de Senador pelo partido e foi cogitado para ser o candidato da UDN a governador da Guanabara em 1965. No momento em que foi fundada a Aliança Renovadora Nacional (ARENA), foi um dos primeiros a filiar-se, mas acabou ocupando somente cargos de confiança, ao invés de concorrer em eleições. Foi encarregado, na administração Castello Branco, de desenhar um plano de reforma e desburocratização do Estado e, tão logo Costa e Silva tornou-se presidente, assumiu o Ministério do Planejamento (DHBB, verbete Hélio Beltrão; LEMOS, 2000, pp. 13-15).

Beltrão manteve João Paulo dos Reis Velloso (item 2.5), que também fora funcionário do IAPI, na direção do EPEA, que foi transformado em fundação e passou a chamar-se Instituto de Pesquisa Econômica Aplicada (IPEA), permanecendo ligado ao Ministério do Planejamento. O IPEA foi por ele encarregado da organização do Programa Estratégico de Desenvolvimento (PED), que deveria guiar a ação econômica do governo Costa e Silva. Velloso argumenta que havia uma diferença de ênfase entre o PED e o PAEG. "Enquanto o PAEG falava em conciliar crescimento com inflação, o objetivo básico do PED era obter uma alta taxa de crescimento com a condição de a inflação continuar sendo reduzida progressivamente. A ênfase passou a ser o crescimento" (João Paulo dos Reis Velloso in: D’ARAÚJO e CASTRO, 2004, p. 100). Participaram também da elaboração do PED os membros da "Missão Califórnia" e três dos Delfim Boys: Affonso Pastore, Eduado Pereira de Carvalho e Carlos Antonio Rocca,

319 Ver: http://memoria.bn.br/DocReader/DocReader.aspx?bib=089842_06\&PagFis=48835. Consultado em $09 / 02 / 2016$. 
assessores do Ministério da Fazenda que ficaram alocados no IPEA por alguns meses. Velloso conquistou a confiança de Beltrão e acabou sendo nomeado por ele para ocupar a secretaria geral do Ministério do Planejamento em 1968. Pouco tempo depois Velloso passou a assessorar diretamente o General Emílio Garrastazu Médici, que se tornaria o próximo Presidente da República (João Paulo dos Reis Velloso in: D’ARAÚJO et al., 2005, pp. 31, 33; Pedro Malan in: D’ARAÚJO et al., 2005, p. 61).

O documento do PED sustentava a intepretação segundo a qual a estagnação da inflação na casa dos $22 \%$ indicava que não se estava mais lidando com uma inflação derivada do excesso de dispêndios e de demanda, visto ter havido drástico estancamento dos gastos públicos e salários e controle monetário rígido. Julgavam que a inflação restante não poderia mais ser tida como decorrente da alta demanda, e sim da alta de custos. Consequentemente, advogavam que se afrouxasse a política monetária e que, simultaneamente, fosse estabelecido um controle sobre os preços, tarifas, câmbio e juros do crédito público, estabilizando os custos e preços, além de apoiar o setor privado que estava fragilizado (TAVARES, 2010a, p. 135; MINISTÉRIO DO PLANEJAMENTO, 1967).

A vertente econômica dominante no segundo governo militar, julgava, pois, que a manutenção da estabilidade era necessária, mas advogava, sobretudo, em favor do investimento e do crescimento. Para tanto, considerava ser necessário voltar a investir em infraestrutura, de modo melhorar a utilização da capacidade de produção. Sustentava, ademais, uma reversão progressiva da estatização, fortalecendo a empresa privada e o mercado de capitais nacional, sem discriminar o capital externo, que seria importante para complementar a poupança interna e contribuir para o desenvolvimento tecnológico (MINISTÉRIO DO PLANEJAMENTO, 1967). “Em termos de política industrial, as diretrizes gerais do PED apontavam para a expansão de setores considerados dinâmicos, como o de bens de capital - com ênfase nas indústrias mecânica e elétrica -, de bens intermediários - principalmente siderurgia e metalurgia do alumínio - e para a modernização das indústrias tradicionais" (TAVARES, 2010a, p. 138).

Durante o governo do General Costa e Silva, procurou-se, de modo geral, dar incentivos aos empreendimentos privados, adotando medidas como o aumento do prazo para recolhimento dos impostos, de modo a ampliar o capital de giro e a capacidade de investir das empresas e reduzir progressiva das taxas de juros e a ampliação da oferta de 
crédito ao setor privado, especialmente via Banco do Brasil. A atuação do BNDE nesse período é coerente com o desenho do PED. 1968 é o primeiro ano em que o Banco direciona mais recursos para o setor privado (54,2\%) do que para o setor público $(45,8 \%)$, sendo que a parcela destinada ao setor privado atingiu 65,4\% dos financiamentos em 1970, último ano da gestão de Magrassi de Sá320. Também em 1968 criou-se o Fundo Especial para o Financiamento do Capital de Giro (FUNGIRO) que, como a delonga na cobrança dos impostos, operava no sentido de fortalecer a capacidade de investimento do setor industrial (NAJBERG, 2002, p. 353; CENTRO CELSO FURTADO DE POLÍTICAS PARA O DESENVOLVIMENTO, 2009, p. 343; MACARINI, 2000, pp. 7 9).

Nos anos em que o BNDE foi dirigido por Jayme Magrassi de Sá os recursos do Banco continuaram sua trajetória de ascensão mas mantiveram o ritmo de crescimento experimentado nos anos anteriores. Se de 1964 para 1965 os recursos mobilizados pelo banco variaram $227 \%$, ou seja, mais do que dobraram, nos anos seguintes eles variaram $123 \%, 121 \%, 111 \%$ e $111 \%$, ou seja, cresceram continuamente, mas sem sobressaltos (Gráfico II). O aumento dos recursos do BNDE no segundo governo militar não reflete, entretanto, de modo algum, o crescimento do Produto Interno Bruto (PIB) que o país experimentou no período, que foi de 8,5\% (PROCHNIK, 1995, p. 162; ABREU, 1990, pp. 403, 408), cabendo indagar: com o país crescendo em tal ritmo, porque a evolução dos recursos do BNDE pouco variou em relação ao período anterior?

Para responder a essa questão é preciso recuperar a trajetória do BNDE nos anos anteriores e analisar a dinâmica interna da gestão de Magrassi de Sá e a face externa representada por sua relação com o poderoso Ministério da Fazenda. No capítulo anterior, discutiu-se a queda de prestígio e centralidade que o BNDE experimentara após o governo JK. Durante os governos Jânio e Jango, além de experimentar uma queda no

\footnotetext{
${ }^{320}$ A reativação do gasto público permitiu que o governo voltasse a fazer investimentos em infraestrutura, e com isso há uma volta dos gastos do BNDE em serviços de utilidade pública como energia e transportes que sobem do patamar de 11,2\% das operações em moeda nacional aprovadas pelo Banco entre 1964 e 1966 para 35,2\% de 1967 a 1969 - lembrando que até o governo militar os serviços de utilidade pública haviam representado em média $60 \%$ das operações. Além dos repasses do próprio Banco, o Fundo de Financiamento para a Aquisição de Máquinas e Equipamentos Industriais (FINAME) operava em favor dos investimentos no setor industrial, que são também diversificados. Se no período 1964-1966 a siderurgia abarcou 71,5\% das operações para o setor industrial, no triênio seguinte ela ficou com apenas 30,6\% dos financiamentos. Em parte, Magrassi tentava livrar-se do estigma de Banco do Aço que o BNDE ganhara nos anos anteriores; em parte cresciam outras áreas como papel e celulose, química e petroquímica, cimento, alumínio e zinco, fiação e tecidos, borracha e refrigeração, que passam a ter papel de destaque no rol dos financiamentos do Banco (TAVARES, 2010a, pp. 127-128 153; SOARES, 2009, pp. 216-219).
} 
volume de recursos, o Banco foi dirigido por figuras que não eram especialistas em economia de renome e chegou mesmo a ficar um ano sem um presidente oficial. No primeiro governo militar o BNDE foi dirigido por um monetarista do grupo de Bulhões, sendo a função de formulador e centralizador da implementação dos planos de desenvolvimento para o país transferida para o EPEA. Ainda que haja um crescimento dos recursos, eles estavam vinculados a fundos especiais que, imaginava-se, com o tempo, serem retirados do orçamento da União (item 2.5).

Não há no governo Costa e Silva uma alteração no status e nas funções do BNDE. Magrassi de Sá, o primeiro funcionário de carreira a ocupar a posição de presidente da instituição, tampouco era uma figura de projeção nacional. Pior do que isso, não era um Delfim Boy e não tinha os ouvidos do Ministro da Fazenda. A avaliação interna de sua gestão tampouco é favorável. Nos depoimentos de funcionários e dirigentes do BNDE concedidos em 1982 ao Projeto Memória comemorativo dos 30 anos de Banco, Magrassi é mencionado poucas vezes, em geral de maneira bastante negativa. O único comentário favorável ${ }^{321}$ é de Marcos Vianna, que diz não ter alterado a equipe de Magrassi que, segundo ele, era boa - o que no fundo é um elogio apenas indireto a ele (VIANNA, 2009, p. 76). Negativamente indica-se que foi ele responsável pela desestruturação do apoio do BNDE ao setor siderúrgico e comenta-se que era uma pessoa pouco acessível (SOARES, 2009, p. 219, 223).

Mais grave, atribui-se a ele o envelhecimento e redução do quadro do Banco, que teria sido consequência da quase ausência de concursos para profissionais com educação superior no período em que foi presidente 322 (Gráfico I). A não reposição de pessoal em um período no qual nem a economia nacional nem as finanças do BNDE estavam estagnadas não deve ser lida apenas como uma idiossincrasia do presidente do Banco, descrito por seu sucessor, Marcos Vianna, como um "unha de fome" (Marcos Vianna,

\footnotetext{
${ }^{321} \mathrm{Na}$ literatura produzida sobre o BNDE o único outro comentário sobre a gestão Magrassi encontrado é positivo e refere-se à importância que teve para evitar que fosse instalada, no BNDE, uma Assessoria de Segurança de Informações, como aquelas que o SNI começava a espalhar pelo aparelho de Estado para controlar a subversão interna. Ligado à ESG e desfrutando da confiança dos militares Magrassi logrou convence-los a não transferir um representante da segurança nacional para dentro do Banco. $\mathrm{O}$ acordo a que chegaram foi que o seu chefe de gabinete colaboraria com um representante indicado do SNI quando solicitado. Era ele Alberto Abade, funcionário do BNDE admitido em 1955 para a posição de assistente administrativo da área de Cálculo e Estatística. Abade também era próximo dos militares. Ele lecionara estatística no curso de Técnica de Ensino do Estado Maior do Exército e fora aluno da Escola Superior de Guerra, em 1962, tendo sido convidado a tornar-se membro do corpo permanente da ESG. Abade teria empenhando-se em encontrar um funcionário do Banco que havia desaparecido nas mãos do regime militar e rejeitado pedido do SNI de embargo da nomeação de uma exlíder estudantil (LIMA, 2006, pp. 73-75; BNDES, 2012, p. 58).

${ }^{322}$ Magrassi concursou apenas 27 profissionais com ensino superior em sua gestão, todos contadores como ele.
} 
presidente do BNDE, in: TAVARES, 2010a, p. 294). Mais do que decorrência de algum traço da personalidade de seu dirigente, a ausência de concursos é uma evidência de que o Banco não recuperara seu prestígio, já que, caso estivesse operando como instrumento central do planejamento e fosse considerado importante pelo superministro Delfim, não se deixaria que fosse esvaziado, não importando quão sovina fosse o seu presidente.

Finalmente coube a Magrassi encerrar o convênio CEPAL-BNDE, razão pela qual é também criticado. Em 1967 rompeu-se o acordo que permitia que o Centro CEPALBNDE funcionasse nas instalações do Banco e que atribuía ao BNDE a responsabilidade pela remuneração dos jovens economistas brasileiros que colaboravam com os funcionários internacionais enviados pela CEPAL (item 1.6). O relatório administrativo daquele ano inclui uma singela nota:

O Centro CEPAL/BNDE encerra suas atividades, após haver prestado serviços relevantes no exame crítico e sugestões de programação do desenvolvimento econômico nacional, bem assim cooperando intensamente na formação especializada de técnicos para as agências de fomento. A CEPAL prosseguirá suas atividades no Brasil com a instalação de um escritório e o BNDE reorientará os recursos liberados do acôrdo para um programa específico de capacitação do seu quadro técnico e de qualificação de analistas e operadores dos agentes financeiros (BNDE, 1967, p. 45).

No trecho, a reorientação dos recursos que estariam alocados no acordo seria a justificativa apresentada para o término do convênio. Novamente é possível formular a pergunta: idiossincrasia de um presidente "unha de fome" ou deslocamento do BNDE do centro das decisões sobre o desenvolvimento econômico nacional?

Maria da Conceição Tavares, que era funcionária do Centro CEPAL-BNDE, conta que recorreu ao

Hélio Beltrão, que tinha ido para o Planejamento, e ao Velloso, que era diretor do IPEA. Foram eles que socorreram o acordo do governo brasileiro com a CEPAL, transformando o acordo CEPAL-BNDE no acordo CEPAL-IPEA. Parte dos jovens economistas do Centro foi trabalhar na equipe que o Velloso montou no IPEA. Na verdade, essa foi a equipe que, de 1967 a 1973, foi o correspondente ideológico e "pensante" do Departamento Econômico daqui do BNDE, porque o Departamento Econômico daqui começou a se esvaziar, a despeito da luta pungente do Pelúcio Ferreira (TAVARES, 2009, p. 179).

Ao desvincular-se da CEPAL, o Banco desligava-se ainda mais das dimensões relativas à formação de pessoal para pensar e planejar o Brasil, à reflexão sobre o desenvolvimento, à realização de diagnósticos de longo prazo e ao desenho de planos 
para transformação econômica e social. Essas funções estavam, desde 1964, deslocandose para o EPEA/IPEA para onde iria também o convênio com a CEPAL ${ }^{323}$.

Se a razão da entrada de Magrassi no Banco não pode ser atribuída a Delfim Netto, sua saída, ao contrário, deve-se a ele, resultando da querela pública entre os dois que se estabeleceu em 1970. Em 5 de setembro Magrassi concedeu entrevista ao Correio da Manhã, um dos jornais de maior destaque no Brasil, na qual criticava abertamente os critérios de correção monetária adotados pelo governo. Na matéria intitulada "Magrassi de Sá justifica a correção da correção" ele sustenta que:

A correção monetária tal como vem sendo aplicada é um mal que gera diversos males. Não é assunto para teses ou doutrinas, a não ser como defesa natural de interesses mercenários. É uma questão de números e de raciocínio. Não pode ser industriosamente dissimulada com argumentações tão floridas quanto sibilinas, lançadas como suposta defesa da formação de poupança, da expansão do mercado de capitais, e quejandas. Não. Trata-se apenas de um problema de transferência indevida de renda, generosa para uns quantos e atroz para o grande número; de um pecado - que se diria capital - em matéria de combate à inflação, pois neutraliza parcela enorme dos resultados perseguidos pelo próprio combate que é intenso. Remunerar o capital-dinheiro na economia capitalista é função dos juros e não de mecanismos que, à guisa de preservar o real valor do principal, acrescem impropriamente a remuneração por este obtida. Combater a inflação é um esforço de contenção de custos e preços de um modo geral, não concebendo a sobre-remuneração e tratamento favorecido em matéria de benefícios. Para "corrigir" a correção, pois, só estamos necessitando da decisão, que há de chegar, pois é bem menos árdua do que a que foi necessária quando da aplicação da medida. Naquela ocasião, contundiu-se o grande número, a bem da justiça. Agora, trata-se tão só de retirar privilégio a uns tantos, para sanar as injustiças ("Magrassi de Sá justifica a correção da correção". Correio da Manbã. Ano I, número 24, Rio de Janeiro, 5 de setembro de 1970324).

Ainda que os critérios da correção monetária não tenham sido desenhados na gestão Delfim e sim no PAEG, ela foi generalizada por ser uma forma não inflacionária de financiamento do déficit público e um estímulo à poupança que poderia ser revertida em produção, beneficiando aqueles que pudessem adquirir tais títulos e dispor da valorização por eles proporcionada (CAMPOS, 1994, p. 642; MACARINI, 2005, p. 69). Magrassi indica o benefício diferenciado oferecido aos que pudessem adquirir as Obrigações Reajustáveis do Tesouro Nacional (ORTN), visto serem corrigidos sempre acima da inflação, enquanto os salários eram constantemente reajustados abaixo da

\footnotetext{
${ }^{323}$ Em 1968, o Centro CEPAL-BNDE converteu-se no Escritório CEPAL-Instituto Latino-Americano de Planificação Econômica (ILPES) para o Brasil e, em 1971, foi incorporado ao IPEA porque a CEPAL declarava não ter mais recursos para manter a sede brasileira, passando a chamar-se CEPAL-IPEA. Ele funcionou na sede do IPEA do Rio de Janeiro até junho de 1978, data em que transferiu-se para a sede de Brasília (IPEA/CEPAL, 2004, p. 3; João Paulo dos Reis Velloso in: D'ARAÚJO et al., 2005, p. 27). 324 Ver:

http://memoria.bn.br/DocReader/Hotpage/HotpageBN.aspx?bib=089842_08\&pagfis=11104\&pesq=\&url=http:// memoria.bn.br/docreader\#. Consultado em 16/10/2015.
} 
inflação, provocando perda de renda daqueles cuja renumeração adviesse do trabalho e não do capital.

Em 23 de outubro de 1970, Magrassi demite-se da presidência do BNDE invocando "razões de ordem pessoal". O Ministério do Planejamento, agora nas mãos de Reis Velloso, tenta caracterizar como "rumores" a associação entre a demissão e as divergências em relação à política econômica do governo. Só o fato de que o Ministro do Planejamento estivesse diretamente empenhado na tarefa de desfazer o suposto boato mostra a força da perturbação gerada ${ }^{325}$, evidenciando o caráter político da demissão.

A existência de um padrão diferencial de tratamento dos rentistas e dos assalariados que geraria desigualdade em nome da poupança, da produtividade, do fortalecimento do mercado de capitais e do crescimento, ou seja, a "transferência indevida de renda, generosa para uns quantos e atroz para o grande número", passou a ser um dos principais alvos da crítica à política econômica do governo militar, originando, no início dos anos 1970, à controvérsia sobre a distribuição de renda no Brasil. Como visto no capítulo anterior - em que foram apresentadas as reflexões das teorias da dependência e o ensaio Além da estagnação, que, por diferentes caminhos, buscavam deslindar os rumos que a economia brasileira assumiu após a repactuação das disputas de classes e reestruturação da relação do Brasil com as potências externas (itens 3.3, 3.4 e 3.5) - a crítica ao modelo de crescimento com desigualdade instaurado no regime militar já ecoava entre os opositores da ditadura. Agora ela adentrava também os círculos oficiais.

A manifestação de Magrassi, ainda que fosse circunscrita ao tema correção monetária, que era apenas um ingrediente do crescimento torto do bolo, e sequer tocasse em temas delicados como a relação do Brasil com o exterior ou o arranjo de classes, era um ataque vindo de dentro do grupo de colaboradores do regime que foi imediatamente ceifado. Não seria o único. A crítica à concentração de renda que mais ecoou também foi feita por alguém que se envolvera com a administração econômica no governo militar. Ela foi elaborada por Albert Fishlow a partir da comparação sistemática dos censos de 1960 e 1970 e publicada, em 1972, no texto Brazilian size distribution of income.

Fishlow é um economista norte-americano que foi o segundo dirigente da missão de cooperação internacional acordada entre a University of California - Berkeley e o 
EPEA/IPEA. A “Missão Califórnia” colaborou com a equipe do IPEA de 1965 a 1968 e participou da elaboração do PED e do Plano Decenal. Além de formular o PAEG, que era um plano limitado a um governo, a gestão de Campos no Ministério do Planejamento buscara elaborar em conjunto com o EPEA um Plano Decenal ${ }^{326}$ para o período 1967 1976, que nunca chegou a ser implementado. Para ajudar desenhar o Plano, o EPEA acolheu em 1965 uma missão de cooperação técnica financiada pela USAID que ficou conhecida como "Missão Califórnia" ou "grupo de Berkeley”, requisitado para "ajudar a fazer o diagnóstico das áreas de educação, de comércio exterior e o plano macroeconômico - que teve pela primeira vez uma função de produção estimada, coisa que era absolutamente inovadora para a época" (Entrevista de Régis Bonelli à autora, 2012).

A Missão foi dirigida inicialmente por Howard Sylvester Ellis, professor de Berkeley que fora presidente da Associação dos Economistas dos Estados Unidos, onde conheceu Roberto Campos ${ }^{327}$ (Albert Fishlow in: D’ARAÚJO et al., 2005, p. 50). Nascido em Denver-Colorado, Howard Ellis ${ }^{328}$ (1898-1992), era professor da área de economia monetária com ampla experiência internacional. Adquirira seu PhD em Harvard, depois de passar um ano em Heidelberg, e fizera dois anos de estudos pós-doutorais em Viena. Antes de vir ao Brasil, ele já havia sido professor visitante em Tokyo, Atenas e Bombaim. Ellis estava aposentando-se de seu posto em Berkeley quando assumiu a coordenação dessa Missão que era integrada essencialmente por doutorandos e recém-doutores em

\footnotetext{
326 "Um dia, o Campos, que naquele tempo acreditava em planejamento global mais do que eu, e que acreditava até em planejamento quantificado, de longo prazo, me chamou: 'Olha, Velloso, está na hora de fazermos uma espécie de plano estratégico para o governo'. Eu disse: 'Mas isso não é coisa que lembra a Rússia?' E ele: 'Não, não. Vamos fazer um plano decenal, a Rússia fez um plano de 25 anos'. Discutimos, discutimos, ele insistiu, começamos a fazer um plano decenal [...]. A verdade é que o plano decenal só foi decenal no modelo econométrico, que ficou como documento mimeografado. Quando o Ministério do Planejamento fez a publicação impressa, em 1968, com o Programa Estratégico de Desenvolvimento, já tinha um modelo completamente diferente. Feito pelo Fishlow, revisto pelo Simonsen, era então um modelo macroeconômico para três anos, 1968 a 1970. Nessa ocasião, os diagnósticos do IPEA tiveram grande sucesso" (João Paulo dos Reis Velloso in: D’ARAÚJO e COSTA, 2004, pp. 88-90).

327 Velloso conta que Campos convidou dois outros consultores externos para o EPEA: Paul Rosenstein-Rodan, economista judeu nascido na Cracóvia que obteve o $\mathrm{PhD}$ em Viena e que à época estava no MIT e atuava como um dos consultores de Kennedy na Aliança para o Progresso, e Benjamin Higgins, economista canadense que lecionou no MIT, foi aluno de Rodan em Londres e com ele estabeleceu forte amizade (João Paulo dos Reis Velloso in: D'ARAÚJO et al., 2005, p. 24). Conforme relatado no capítulo anterior, Rosenstein Rodan dirigiu a missão do MIT com a Oficina de Planificación Nacional (ODEPLAN) do Chile, na qual Edmar Bacha trabalhou entre 1968 e 1969.

${ }^{328}$ Sobre Howard Ellis: http://www.nytimes.com/1992/04/22/us/no-headline-459792.html. E para Fishlow sobre Gerschenkron: https://eh.net/book_reviews/economic-backwardness-in-historical-perspective-a-book-of-essays/. Consultados em 02/09/2015.
} 
economia $^{329}$ (ELLIS, 1969, pp. xv-xxi).

Em 1967, a coordenação da missão foi transmitida a Albert Fishlow (1935), igualmente professor de economia em Berkeley. Nascido na Filadélfia-Pensilvânia, Filshlow também havia obtido o PhD em Harvard, onde foi orientado por Alexander Gerschenkron - o mesmo professor que influenciara decisivamente Werner Baer - que havia sido assistente em Berkeley do professor Howard Ellis. Gerschenkron, formado em economia na Áustria, fazia parte de um grupo de europeus deslocados pela guerra que, no início dos anos 1940, auxiliavam os professores em Berkeley no desenvolvimento de suas pesquisas. Integrava também esse grupo Albert Hirschman, berlinense e também judeu, que lutara na resistência francesa antes de partir para a América. Os dois desenvolveram estudos na fronteira da história econômica e da teoria do desenvolvimento. Ellis convidou seus assistentes Gerschenkron e Hirschman para juntar-se a sua equipe no Federal Reserve Board, no período em que colaboravam com os esforços do New Deal do governo democrata de Franklin Delano Roosevelt (ADELMAN, 2013, pp. 258, 282; ALMEIDA, 2008, p. 171; DAWIDOFF, 2003, pp 121-122). Fishlow menciona a influência dos dois em sua formação e carreira:

Acredito também que a educação que eu tive em Harvard, concentrando-me primeiro na área de história econômica para depois passar para a discussão sobre desenvolvimento, me deu uma grande vantagem. Muitos economistas hoje começam a estudar os problemas relativos ao desenvolvimento sem entenderem nada do passado, sem saberem quais foram os elementos positivos e negativos dos processos anteriores, quais as diferenças existentes entre hoje e o que aconteceu no passado etc. Ter, pois, começado com a história econômica foi fundamental na minha formação. Por isso creio que a primeira grande influência intelectual que devo registrar é a do Gerschenkron e das coisas que ele escreveu [...]. As contribuições do Hirschman também foram, evidentemente, muito importantes na minha formação. Quando ele explica o processo de substituição das importações e a importância do governo, quando ele inclui esse elemento político, além do elemento econômico, e em vários livros seus isso está presente, isso me influenciou muito e tem reflexos em muitas das coisas que eu escrevi (FISHLOW, 2003, p. 668).

Albert Fishlow e Werner Baer - que, dos muitos consultores e professores que circularam no Brasil por meio dos acordos de cooperação do período da Aliança para o Progresso, foram certamente dos que mais perene influência exerceram sobre o espaço dos economistas no Brasil - tiveram, pois, trajetórias bastante similares. Os dois fizeram o

\footnotetext{
${ }^{329}$ Apesar de identificado como grupo de Berkeley ou da Califórnia, além de Allan Abouchar e Samuel A. Morley $^{329}$, que eram alunos de PhD em Berkeley, de Donald W. Baerresen, da UCLA, e de Joel Bergsman, ligado a Stanford, o grupo incluía alguns estudantes de fora do Estado da Califórnia, caso de Gordon W. Smith, que fazia o PhD em Harvard, e Willy van Rijckeghem, que concluíra pouco tempo antes o doutorado na universidade de Gent na Bélgica (ELLIS, 1969, pp. xv-xxi).
} 
doutorado em Harvard e começaram suas carreiras na área de história econômica, tendo grande proximidade com Gerschenkron e com os setores mais progressistas dos estudos do desenvolvimento, provenientes dos círculos democratas e fortemente influenciados por ideias keynesianas.

Os dois foram quase contemporâneos em suas estadias no Brasil. Nenhum dos deles era especialista em Brasil antes de se deslocar para o país e ambos falavam espanhol e não português. Baer mencionou ter precisado olhar no mapa onde ficava o Brasil; Fishlow conta que, na primeira visita ao Brasil, em 1965, ao ouvir português acreditou estar escutando alemão, tal era sua familiaridade com o idioma e com o país. Fishlow fez outra visita em junho de 1966 e trabalhou por alguns meses com a equipe de Ellis na elaboração do Plano Decenal. Transferiu-se definitivamente para os trópicos em agosto de 1967, já com uma nova tarefa, elaborar o PED do governo Costa e Silva (Albert Fishlow in: D’ARAÚJO et al., 2005, p. 50). Ele relata que:

\begin{abstract}
Em vez de trabalhar com os analistas principais, fiz questão de trabalhar com os jovens: Pedro Malan, Regis Bonelli, Marcelo de Paiva Abreu e outros, porque havia falta de pessoas bem treinadas e experientes na construção da política macroeconômica. Entre os mais experientes estavam Arthur Candal, Conceição Tavares, que trabalhava na CEPAL mas mantinha contatos freqüentes, e Antonio Barros de Castro; tentei aproveitar todo esse grupo. Minha idéia era que nosso grupo, embora estrangeiro, tinha a necessidade de trabalhar junto com a comunidade brasileira, dentro e fora do IPEA. Por isso, dei ao mesmo tempo um curso sobre desenvolvimento econômico na Escola de Pós-Graduação em Economia da Fundação Getúlio Vargas, tratando de dar alguma noção ao grupo que estava sendo treinado sobre as coisas discutidas no exterior (Albert Fishlow in: D'ARAÚJO et al., 2005, p. 52).
\end{abstract}

A missão de Berkeley encerrou-se após a promulgação do AI-5, em dezembro de 1968. Fishlow afirma que recomendou que o convênio não fosse renovado, mesmo que a USAID continuasse apoiando atividades no Brasil nesse período. A razão alegada por ele é que a Universidade de Berkeley, uma das mais progressistas dos Estados Unidos, que ocupava uma posição crítica em relação às violações praticadas pelo próprio país, não poderia compactuar com a suspensão dos direitos humanos pelo governo ditatorial brasileiro $^{330}$. A influência de Berkeley sobre o Brasil não deixou de existir por conta do encerramento do convênio, já que Fishlow recebeu levas sucessivas de estudantes brasileiros, a começar por seus assistentes no EPEA, Pedro Malan e Regis Bonelli, aos

http://www.ipea.gov.br/desafios/index.php?option=com_content\&view=article\&id=3018:catid=28\&Itemid=23, consultado em 04/09/2015 e João Paulo dos Reis Velloso in: D’ARAÚJO et al., 2005, p. 25. 
quais se seguiram Andrea Calabi, Paolo Zhagen e tantos outros (Edson de Oliveira Nunes in: D’ARAÚJO et al., 2005, p. 264).

Régis Bonelli (1942) nasceu no Rio de Janeiro e viveu até os 5 ou 6 anos no afastado bairro do Rio Comprido, de onde a família transferiu-se para Ipanema. Os avós paternos de Bonelli eram italianos da região da Calábria que imigraram para o Brasil no início do século XX para fugir da miséria. O avô chegou ao Brasil com um irmão mais velho e os dois foram trabalhar na construção civil, alcançando, no final da vida, a posição de mestre de obras. Os avós maternos eram de uma família de brasileiros descendentes de portugueses e índios. O avô era carioca e havia sido industrial do ramo de calçados, mas faliu. A mãe de Régis nasceu no Rio de Janeiro e estudou até o ginásio, deixando os estudos para trabalhar, o que fez até casar, quando se tornou, como as duas avós de Régis, “do lar". Ao concluir o secundário o pai de Régis frequentou uma escola técnica de contabilidade, obtendo posto de funcionário público no Instituto de Aposentadoria e Pensões dos Empregados em Transportes e Cargas (Entrevista de Régis Bonelli à autora, 2012).

Bonelli cursou o primário na Escola Municipal Henrique Dodsworth, em Ipanema, e o ginásio e o científico no tradicional Colégio Pedro II, em Botafogo. Na escola chegou a iniciar o aprendizado de inglês e de francês. O inglês aprimorou na pós-graduação no exterior e o espanhol adquiriu ao frequentar cursos de extensão universitária proferidos naquela língua. Posteriormente frequentaria o Instituto Italiano de Cultura e estudaria italiano com professores particulares. Ao completar o científico, Régis fez vestibular para engenharia e foi aprovado na Pontifícia Universidade Católica (PUC-RJ) e na Nacional de Engenharia. Ao ser indagado acerca das motivações que o levaram à engenharia responde: "para ser absolutamente honesto, foi porque, aspas, todo mundo estava fazendo, fecha aspas” (Entrevista de Régis Bonelli à autora, 2012).

Entre as duas universidades nas quais foi aprovado, optou pela PUC. Diz que "era perto de casa e tinha esse fascínio, essa aura do pilotis ${ }^{331}$. Essa possibilidade, mais fictícia que real, de você congregar com o sexo oposto. $\mathrm{Na}$ verdade não era bem assim... mas homem é muito tolo, achava que funcionava”. A PUC-RJ era uma universidade mista, já a Nacional de Engenharia, “embora o vestibular não fosse segregado por gênero, de fato

\footnotetext{
${ }^{331}$ Ao elevar o primeiro piso do prédio, os pilotis criam áreas livres de circulação no térreo, que, no caso do prédio da PUC do Rio de Janeiro, formam a principal área de convívio estudantil.
} 
eram só homens" que ficavam em um prédio exclusivamente dedicado ao curso no Largo São Francisco e não em um espaço frequentado por graduandos e graduandas de todas as outras especialidades, como a PUC-RJ. Bonelli relata que frequentou a universidade com uma bolsa social, razão pela qual a ponderação entre o gratuito e o pago, que poderia ter sido decisiva em favor da Nacional de Engenharia, não se colocou. Depois de dois anos de cursos básicos, optou pela especialização em metalurgia, por influência de dois amigos que seguiram esse caminho (Entrevista de Régis Bonelli à autora, 2012).

Régis diz ter perdido o interesse na engenharia muito cedo. Gostava das matérias mais abstratas, como mecânica racional e cálculo, e tinha "péssima afinidade" com áreas puramente empíricas, como resistência dos materiais. Chegou a fazer um estágio no meio do quarto ano em uma empresa metalúrgica em Barra Mansa que foi, segundo ele, o mês mais chato de sua vida, levando-o a concluir que aquilo era "exatamente o que eu não quero para o resto da minha vida” (Entrevista de Régis Bonelli à autora, 2012). No quinto ano inscreveu-se no curso noturno de economia da UEG, que "ficava num prédio velho na avenida Mem de Sá, perto da praça da Cruz Vermelha, no Centro" (Pedro Malan in: D’ARAÚJO et al., 2005, p. 58). Dois colegas da PUC ingressaram na Economia da UEG ao mesmo tempo: Pedro Malan, da engenharia elétrica, e Marcelo de Paiva Abreu, um ano mais novo, que cursava engenharia mecânica. Os três estudavam engenharia na PUC-RJ no período da manhã, trabalhavam na companhia estatal Aços Especiais Itabira privatizada em 1992 - no período da tarde e iam para a UEG à noite. Não tinham folga nem aos sábados que era o dia das aulas de laboratório da engenharia.

Pedro Sampaio Malan (1943), nascido em Petrópolis, era poucos meses mais novo que Régis. Ainda que seu avô, Alfredo Malan d'Angrogne, fosse também italiano, sua família chegou ao Brasil em condições econômicas e sociais bastante distintas das da família de Bonelli. Não eram imigrantes pobres dispostos a ser mão-de-obra braçal no novo mundo para recomeçar a vida. Ao contrário, eram genoveses que foram convidados a vir para o Brasil e desfrutaram de fácil e altiva inserção social - nesse sentido assemelhando-se ao tipo de imigração das famílias de Roberto Simonsen e Eugênio Gudin (DHBB, verbetes Alfredo Malan d'Angrogne, Alfredo Souto Malan e Pedro Malan).

D’Angrogne chegou no Brasil no final do século XIX, com doze anos de idade. Transferiu-se para o Rio de Janeiro com a família porque seu pai havia sido convidado a 
exercer atividades consulares junto à corte de Dom Pedro II. Em 1890, ingressou na Escola Militar da Praia Vermelha, recebendo os diplomas de bacharel em matemática e ciências físicas. Depois de ter sido promovido a major, foi designado para ocupar a posição de Adido Militar na França e, ao regressar, em 1920, tornou-se chefe de gabinete do ministro da guerra, Pandiá Calógeras. Diz-se que ele teria sido convidado por Washington Luís para o Ministério da Guerra, mas conjectura-se que teria recusado devido a discordâncias políticas com o Presidente. D’Angrogne apoiou a revolução de 1930 e, depois da vitória dos getulistas, foi nomeado chefe do Estado-Maior do Exército (EME), posição que ocupou até morrer em janeiro de $1932^{332}$ (DHBB, verbetes Alfredo Malan d'Angrogne, Alfredo Souto Malan e Pedro Malan).

Um dos tios de Pedro, Alfredo Souto Malan, seguiu os passos do pai. Ingressou na Escola Militar do Realengo e foi nomeado adido militar nos Estados Unidos, tendo participado da delegação brasileira que esteve presente na fundação da ONU. Estudou na Escola Superior de Guerra francesa e, ao regressar, fez parte do grupo que organizou a ESG brasileira. Como seus colegas da ESG, apoiou o movimento de 1964, sendo promovido a comandante da Academia Militar das Agulhas Negras e, como D’Angrogne, chegou ao final de sua carreira à chefia do EME. O pai de Pedro Malan, Elysio Souto Malan, não seguiu a trajetória militar predominante em sua família. Assegurou a renda familiar trabalhando como funcionário público: agente fiscal do imposto de consumo. A família de Malan desfrutava de estabilidade e prestígio, dispondo de capital político e econômico, além de largos trunfos dentro do universo militar. Diferentemente de Régis, Malan pôde estudar em colégios privados destinados aos membros da elite. Fez o primário no Instituto Carlos Alberto Werneck, em Petrópolis, transferindo-se, no ginásio, para o tradicional Colégio Santo Inácio, em Botafogo.

Para explicar sua opção pela engenharia, Pedro diz que as carreiras universitárias consolidadas à época eram medicina, engenharia e direito e ponto e declara:

Cursei engenharia na Escola Politécnica da Universidade Católica do Rio de Janeiro de 1961 até 1965. É preciso levar em conta que o início dos anos 60 foi de grande interesse politico para aqueles que se envolveram, como eu, a partir de 1961, no movimento estudantil 333 [do Diretório Acadêmico da Engenharia e da

\footnotetext{
${ }^{332}$ Ver: http://memoria.bn.br/DocReader/Hotpage/HotpageBN.aspx?bib=175102\&pagfis=4548\&pesq=\&url=http://mem oria.bn.br/docreader\#. Consultado em 11/02/2016.

${ }^{333}$ Régis também teve algum envolvimento com o movimento estudantil. Segundo ele, era "obviamente de esquerda, mas não tinha nenhum partido, nenhuma sigla por trás. Fui diretor do centro acadêmico de engenharia no segundo ano... um dos diretores [...]. Na verdade eu era um ingênuo. Eu era o tesoureiro. Então eu queria
} 
campanha para o Diretório Central dos Estudantes da PUC ${ }^{334}$, em conseqüência da renúncia de Jânio Quadros, da posse de Jango, do parlamentarismo. Sempre tive interesse em história, na interação entre as questões políticas, sociais, econômicas e diplomáticas, entre as questões internacionais e a questão doméstica e, em função disso, durante o próprio curso de engenharia, comecei a mudar para a economia. Tanto que fiz vestibular para economia no que naquela época chamava-se Universidade do Estado da Guanabara, um curso que não cheguei a concluir. Mas meu interesse em economia foi-se consolidando (Pedro Malan in: ALBERTI et al., 2002, p. 97).

Segundo Bonelli, nenhum dos três achava o curso de economia da UEG satisfatório. Para remediar a situação eles tentaram estabelecer um regime autônomo de estudos que resultou ser muito desorganizado. Trocavam textos, tentavam avançar nas leituras. Tampouco foi satisfatório. Marcelo Abreu abandonou o curso da UEG primeiro, Régis no fim ano e Malan ficou lá até o início de 1966. Quando concluiu a engenharia, Bonelli chegou a "fazer um trabalho para um empresa de consultoria no começo do ano seguinte. Foi quando apareceu a possibilidade de fazer esse curso da CEPAL em Vitória” e formalizar, um pouco, o estudo da economia.

Não tinha a menor ideia do que fosse a CEPAL, mas o curso se chamava Curso Intensivo do Problema de Desenvolvimento Econômico e [o folheto de divulgação] tinha uma descrição, digamos assim, muito atraente. Como de fato foi o curso, muito atraente. Para mim foi uma descoberta. Parecia que me dava a chave do mundo. Sabe? Dava a impressão de conhecer os movimentos sociais, econômicos... É isso! Finalmente! É o que nós estamos fazendo nesse mundo! Então eu fiz [o curso] com muito interesse, estudando tudo. Mesmo as matérias mais chatas tinham interesse. Era um curso de 18 semanas, em tempo integral, e muito bem ministrado. Os professores eram de qualidade. Vinha muita gente da CEPAL de Santiago, além do pessoal do Centro CEPAL-BNDE aqui do Rio, que era um grupo muito bom também (Entrevista de Régis Bonelli à autora, 2012).

Para Régis o professor mais marcante do curso foi Antonio Barros de Castro que, "além de ser bom professor e conhecer a economia, era um grande contador de histórias". Ele usava em suas aulas o "Castro-Lessa", manual de Introdução à economia: uma abordagem estruturalista (1967), escrito com Carlos Lessa, que, segundo Régis, também é "fascinante e fala muito bem" - embora Lessa não tenha sido professor dele nessa ocasião pois, como visto no capítulo anterior, estava entre os brasileiros exilados em Santiago desde 1964. O apelido "Castro-Lessa", fazia, como relatam Bonelli e outros, que fosse corrente a impressão de que Castro e Lessa eram uma só pessoa. De fato, eram à

botar ordem nas finanças. Eu não queria deixar que todo mundo chegasse lá e botasse a mão na caixinha e fosse fazer estandarte. Então eu não tinha muita discussão política, mas a discussão política estava por todo lado. Isso era 1962" (Entrevista de Régis Bonelli à autora, 2012).

${ }^{334}$ Pedro Malan in: D'ARAÚJO et al., 2005, p. 57. 
época muito próximos pessoal e intelectualmente (item 1.5) (Entrevista de Régis Bonelli à autora, 2012).

Diversamente de Régis, que diz que não tinha "a menor ideia do que fosse a CEPAL", Malan alega que já tinha familiaridade com os escritos da escola. Argumenta:

todos nós líamos Celso Furtado - Formação Econômica do Brasil, Desenvolvimento e subdesenvolvimento. Eu lia também os livros da Fondo de Cultura Económica, do México; por exemplo, o livro do Prebisch sobre Keynes, o do Alvin Hansen, Sunkel, Norberto Gonzales... Eu tinha interesse nesses textos da CEPAL. Um livro muito importante, que me marcou muito na época e até hoje, passado quase meio século, vale a pena ler, é o do Albert Hirschman sobre estratégia de desenvolvimento econômico [...]. Depois que concluí engenharia, fiz o curso da CEPAL, nos primeiros meses de 1966. Naquela época a CEPAL estava ministrando esses cursos, cada ano numa capital diferente de um estado brasileiro. Em 1966 foi em Vitória, Espírito Santo, e morei uns quatro meses lá. Foi um curso interessante. Os professores, que eu me lembre, eram Liechenstein, uruguaio, Antonio Barros de Castro, Guilherme Vassalo, Ferdinando Figueiredo. Norberto Gonzalez deu uma palestra. A maioria dos alunos era de Vitória. Do Rio de Janeiro fomos, que eu me lembre, Régis Bonelli e eu (Pedro Malan in: ALBERTI et al., 2002, p. 98).

Dois meses depois de concluído o curso da CEPAL, Régis Bonelli e Pedro Malan foram admitidos no EPEA. Uma vez que o Escritório funcionava como uma empresa, não dependendo de concurso público, os dois puderam ser contratados com base apenas em seus currículos e em uma entrevista: "o que equivale a dizer, no bom desempenho que tínhamos tido [no curso da CEPAL] e um pouco de sorte”, segundo Bonelli. A vantagem do EPEA, para ele, era que "você era contratado em uma carreira chamada técnico de planejamento e pesquisa, para a qual você podia ter qualquer diploma superior. Não tinha que ter uma carreira superior específica". Não precisavam, pois, de habilitação ou diploma em economia, como seria necessário, por exemplo, para concorrer a uma vaga de economista do BNDE. Na ocasião, os dois foram entrevistados por Helder Mota, coordenador do setor de indústria do Escritório, e logo designados para trabalhar com Arthur Pinto Ribeiro Candal, que acabara de substituir Mota na direção da área. Além deles, passaram a integrar a equipe Francisco de Almeida Biato, formado em economia na Universidade Federal do Rio de Janeiro (UFRJ), que havia sido funcionário do Centro CEPAL-BNDE e acabava de voltar da especialização no ILPES, em Santiago e Cláudio Salm, que também integrou-se ao IPEA depois de retornar do Chile em 1967 (item 3.2) (Entrevista de Régis Bonelli à autora, 2012; Francisco Biatto in: D’ARAÚJO et al., 2005, p. 83). 
Arthur Pinto Ribeiro Candal (1935-2011), nascido em Porto Alegre, era filho de um desembargador que chegou a ser presidente do Tribunal de Justiça do Rio Grande do Sul. Como o pai, estudou direito, bacharelando-se na Universidade Federal do Rio Grande do Sul (UFRGS). Diz que depois de advogar por dois anos decidiu estudar economia. Fez o curso do ILPES em Santiago em julho de 1962, aprofundando-se em programação industrial. Ao retornar trabalhou por dois anos no governo do Rio Grande do Sul e partiu para Varsóvia, onde ficou 8 meses cursando especialização que a Escola Superior de Estatística e Planejamento estava oferecendo para economistas do Terceiro Mundo, da qual participaram também Lenina Pomeranz e Jorge Miglioli. Um dos organizadores do curso, o professor Ignacy Sachs, conta que se apoiavam bastante nos escritos de Michal Kaleki e Oskar Lange, dois economistas poloneses conhecidos por seus escritos sobre planejamento econômico, lidos com afinco nas escolas críticas de economia $^{335}$ (SACHS, 2004, pp. 370-371). Depois da Polônia, embarcou em uma missão coordenada pela CEPAL na Bolívia, da qual foi expulso por ter deixado vazar um documento confidencial, o que o impediu de seguir seu plano de juntar-se a Aníbal Pinto no escritório CEPAL-BNDE336 (Arthur Candal in: D’ARAÚJO et al., 2005, pp. 41-45). Candal assim explica como ingressou no EPEA:

\begin{abstract}
Lembro que em Porto Alegre recebi um telefonema do Helder Mota, que coordenava o setor de indústria geral do IPEA [sic EPEA], convidando-me para uma conversa no Rio de Janeiro, para discutir uma proposta de emprego no IPEA [sic EPEA]. Por alguma razão, ele sabia que eu tinha experiência prévia em análise industrial; talvez Maria da Conceição Tavares, que era sua amiga e estava no escritório CEPAL-BNDES, no Rio de Janeiro, tenha comentado algo com ele. De qualquer maneira, Helder mandou-me uma passagem e eu vim ao Rio, onde tivemos um longo almoço e ele me convidou para trabalhar no IPEA [sic EPEA]. Ele sabia que eu tinha curso na Polônia, que tinha sido expulso da Bolívia - achei tudo muito estranho, muito liberal, mas ele estava autorizado pelo Velloso. E a razão pela qual eles me convidavam era que o IPEA [sic EPEA] estava elaborando o Plano Decenal - aliás, o último levantamento exaustivo da economia brasileira; de lá para cá não se fez mais nada de forma sistemática. Como já comentei, Helder Mota coordenava o setor de indústria geral, que vim a assumir quando ele foi embora trabalhar na ALALC [Associação Latino Americana de Livre Comércio]. Esse setor englobava os vários segmentos industriais: química, alimentos, têxtil, metalurgia, mecânica etc. Os pesquisadores tinham terminado seus diagnósticos setoriais, mas faltava o diagnóstico central. Assim, voltei para Porto Alegre, peguei a minha malinha, um pequeno pacote de livros e desembarquei aqui no Rio em setembro de 66 (Arthur Candal in: D’ARAÚJO et al., 2005, p. 43).
\end{abstract}

\footnotetext{
${ }^{335}$ Como visto no caso da Escuela Latinoamericana de Economía de la Universidad de Chile, abordada no capítulo anterior, e da Universidade Estadual de Campinas (UNICAMP) (item 5.1).

336 Ver: http://memoria.dieese.org.br/museu/nossas_historias_menu/lenina-pomeranz. Consultado em 04/09/2015.
} 
Malan e Bonelli começaram sua carreira no EPEA como assistentes na equipe dirigida por Arthur Candal e Joel Bergsman, encarregada da elaboração dos diagnósticos sobre o setor industrial. Estes resultaram no texto Industrialização brasileira: diagnóstico e perspectivas, publicado em 1966. Malan, que tinha especial interesse na área de história econômica do Brasil, escreveu um capítulo fazendo uma análise retrospectiva do tema (Arthur Candal in: D'ARAÚJO et al., 2005, p. 44). Depois de contratado pelo EPEA, Bonelli participou de um segundo curso organizado pelo centro CEPAL-BNDE, desta vez oferecido no Rio de Janeiro e voltado especificamente à programação industrial. Dele participou também Marcelo de Paiva Abreu, logo foi admitido para trabalhar com seus dois colegas da engenharia no agora chamado IPEA. Desta vez tiveram aulas com Maria da Conceição Tavares, caracterizadas por Régis como muito interessantes. "Concorde-se com ela ou não, é muito culta e expressiva" (Entrevista de Régis Bonelli à autora, 2012).

No momento em que Régis e Pedro ingressaram no EPEA, o Escritório estava transferindo-se do andar que ocupava no Ministério da Fazenda para o edifício do Banco do Estado do Rio de Janeiro (BANERJ), então chamado Banco do Estado da Guanabara. A nova sede ficava na esquina da Rua da Ajuda com Nilo Peçanha naquele que talvez fosse o mais moderno edifício do Rio naquele momento ${ }^{337}$. O EPEA ocupava uma parte desse edifício, a representação no Brasil do Banco Interamericano de Desenvolvimento (BID) tomava outro andar e todos os outros eram utilizados pelo departamento de estado americano e pela agência do desenvolvimento internacional USAID. Como atestado pela presença das missões de Berkeley e dos consultores externos, as relações do EPEA com a ajuda externa americana iam bem além da contiguidade espacial.

Foi através do contato com Fishlow e com auxílio econômico da USAID e da Fundação Ford que Malan e Bonelli puderam fazer seus doutorados em Berkeley. Régis Bonelli relata que Pedro Malan, Marcelo Abreu e Sulamis Dain eram quase assistentes diretos de Fishlow no EPEA. Albert "viu que tinha um grupo de jovens que a ele lhe parecia promissor, entre os quais eu me incluía. Ele perguntou se a gente não queria completar a formação fazendo doutorado na Universidade da Califórnia. Obviamente se a gente passasse nos exames, no GRE, Graduate Record Examination, que é um exame muito duro" (Entrevista de Régis Bonelli à autora, 2012). Régis e Pedro foram para

\footnotetext{
${ }^{337}$ O prédio do Banco do Estado da Guanabara, ou edifício BANERJ, foi projetado em 1963 e construído em 1965 pelo escritório de arquitetura de Henrique Ephim Mindlin, professor da Faculdade de Arquitetura da UFRJ, autor do livro Modern Architecture in Brazil, e irmão do bibliófilo José Mindlin - o pai de Betty Mindlin, aluna e assistente de Delfim Netto.
} 
Berkeley em setembro de 1969. Marcelo Abreu fez um mestrado sem tese na University of London, entre 1970 e 1971, e obteve bolsa do Ministry of Overseas Development da Grã-Bretanha para fazer o doutorado na University of Cambridge, de 1974 a 1977338 . Sulamis Dain viveu de 1969 a 1974 no Chile, onde cursou o mestrado da Escuela Latinoamericana de Economía de la Universidad de Chile (ESCOLATINA) com financiamento da Organização dos Estados Americanos (OEA) e orientação da professora Maria da Conceição Tavares (item 3.4). Na sequência, doutorou-se na UNICAMP, sob a orientação de Luciano Coutinho. No meio do doutorado Sulamis teve a oportunidade de passar um ano na University of London com financiamento da FINEP ${ }^{339}$. Formou-se assim um grupo altamente internacionalizado, que voltou para o IPEA com conhecimentos adquiridos nos diversos países e universidades pelos quais passaram.

A tese de Pedro Malan, orientada Fishlow e defendida em 1977, recebeu o título de Foreign exchange constrained growth in a semi-industrialized economy: aspects of the Brazilian experience 1946-1976. Nela, Malan dava continuidade à tentativa de fazer uma história econômica do Brasil, passando a tematizar a intersecção entre a história interna e a política externa. Dessa combinação resultaram também os seus textos publicados no início dos anos 1980 sobre a política econômica externa do Brasil, Relações econômicas internacionais do Brasil (1945-1964) e Política econômica externa e industrialização no Brasil (19391952), escrito com Régis Bonelli, Marcelo Abreu e José Eduardo de Carvalho Pereira. Bonelli seguiu na área de política industrial na qual trabalhava no IPEA, defendendo, em 1975, a tese intitulada Growth and technological change in Brazilian manufacturing industries during the sixties.

Régis declara que viveu de 1969 a 1972 em Berkeley. No ano de 1963 voltou ao Brasil para retomar o trabalho no IPEA e coletar dados e só retornou a Berkeley em 1975, por mais alguns meses, para terminar e defender a tese. Nesse intervalo chega a Berkeley novo grupo de brasileiros para estudar com Fishlow. Entre eles Andrea Calabi, que conta ter ajudado a calcular algumas regressões e a fazer a revisão dos trechos empíricos das teses de Malan e Bonelli (Andrea Calabi in: D’ARAÚJO et al., 2005, pp. 223-224). Ficaram amigos. Bonelli conta que ele e Calabi tinham "muita afinidade, de área de trabalho inclusive" (Entrevista de Régis Bonelli à autora, 2012). Seus caminhos cruzar-se-

\footnotetext{
${ }^{338}$ Informações disponíveis em: http://lattes.cnpq.br/9502772132500692. Consultado em 03/11/15.

${ }^{339}$ Informações disponíveis em: http://lattes.cnpq.br/5347631502837998. Consultado em 03/11/15.
} 
iam novamente alguns anos depois, já que Calabi ocuparia a presidência do IPEA em 1985 e os três integrariam as equipes econômicas dos mesmos governos (item 5.4).

Se, de um lado, Albert Fishlow levava seus estagiários do EPEA para Berkeley, com apoio das verbas da Fundação Ford e da USAID, de outro, um dos primeiros funcionários do EPEA, o economista Og Francisco Leme, encaminhou diversos jovens para a Universidade de Chicago ${ }^{340}$. Velloso aponta a presença de Og Leme na instituição como símbolo da pluralidade de opiniões ${ }^{341}$ que reinava no EPEA, argumentando que a Universidade de Chicago, onde Og Leme estudara, era antípoda ${ }^{342}$ de Yale, onde ele havia feito mestrado. Segundo ele conviviam no IPEA de Arthur Candal, que cursara especialização na União Soviética e era visto como um comunista, até Og Leme, que se tornaria o fundador do Instituto Liberal (João Paulo dos Reis Velloso in: D’ARAÚJO et al., 2005, p. 22).

Og Francisco Leme (1922-2004) concluiu o curso de Ciências Sociais e Políticas pela Escola Livre de Sociologia e Política (ELSP) de São Paulo em 1945. Em 1946-47, frequentou uma especialização em sociologia e antropologia social na mesma faculdade e, em 1952, concluiu o bacharelado na Faculdade de Direito da Universidade de São Paulo. Foi na sequência estudar na University of Chicago, obtendo título de mestre em 1956.

\footnotetext{
${ }^{340}$ Rubem de Freitas Novaes, economista com doutorado na University of Chicago e professor da EPGE que foi diretor do BNDES, escreve texto resumindo o pensamento dos principais expoentes de Chicago no qual afirma: "Registro minha homenagem póstuma ao mestre liberal e amigo Og Francisco Leme, que me iluminou os caminhos para Hyde Park, Chicago". Ver: http://ordemlivre.org/posts/a-escola-de-chicago-atraves-de-seusexpoentes. Consultado em 11/09/2015.

${ }^{341}$ Essa ideia da pluralidade interna do EPEA/IPEA e da possibilidade que ali reinava de fazer a crítica ao governo militar para o qual trabalhavam é considerada por Marcia Cunha um mito de origem do EPEA, que aparece sucessivamente nas narrativas sobre a constituição da instituição (CUNHA, 2012, pp. 30-31). Tal discurso ecoa em numerosos depoimentos de pessoas que lá trabalharam no período. Por exemplo: "Diante de um governo militar de comportamento meio errático em relação à vida intelectual, o Velloso protegeu brilhantemente o IPEA, que sempre foi uma ilha de liberdade total de pensamento, filtradas as pessoas antecipadamente por sua competência técnica e por um certo comportamento intelectual civilizado" (Claudio de Moura Castro in: ALBERTI et al., 2002, pp. 91-92). Permitia-se ali até que Fishlow tivesse uma foto enorme do Che Guevara em sua sala (SALM, 2011, p. 169). Além disso o IPEA abrigava sabidos críticos do regime e forneceu os dados de muitos escritos que atacaram a economia dos militares, como será discutido adiante.

${ }^{342}$ No caso dos Estados Unidos, é mais difícil fazer uma contraposição de escolas de pensamento associando-as às universidades, já que os professores têm maior grau de circulação entre diferentes instituições durante suas carreiras e que os departamentos de economia são grandes e comportam uma maior diversidade de tendências. Nesse sentido, ao falar de economistas estadunidenses procurar-se-á fazer antes uma genealogia intelectual, usando os relatos sobre influências que tiveram em sua formação, do que um mapeamento das tendências de pensamento de cada universidade. Não obstante, uma possível sugestão da contraposição entre o perfil do alunato de Yale e de Chicago, que Velloso afirma serem antípodas, está presente no survey que Colander e Klamer conduziram no início dos anos 1980, no qual entrevistaram alunos da pós-graduação em economia das universidades de Chicago, Columbia, Harvard, MIT, Princeton, Stanford e Yale. Ele indica a existência de grandes disparidades no perfil e nas orientações dos alunos de Chicago e dos alunos de Yale (COLANDER e KLAMER, 1987, p. 104).
} 
Chegou a completar os créditos requeridos o doutorado, mas não escreveu uma tese ${ }^{343}$. De volta ao Brasil passou a lecionar na FGV em tempo parcial e começou a trabalhar como economista na FIESP, representando-a no comitê de comércio latino-americano da CEPAL, órgão ao qual esteve vinculado por seis anos. Em 1964, Og foi convidado por Roberto Campos para juntar-se à sua assessoria no Ministério do Planejamento e à equipe do recém-criado EPEA. Leme passou a ocupar-se dos convênios do Escritório com a Fundação Ford e com a USAID, através dos quais enviava para os Estados Unidos os melhores alunos do curso de programação econômica oferecido pelo Centro de Treinamento para o Desenvolvimento Econômico e Social (CENDEC) do EPEA, que fora criado em 1967 e era por ele dirigido.

Clóvis de Faro, que fora aluno do CENDEC, relata que, ao fim do curso ministrado pelos professores da FGV, Jessé Montello e Isaac Kerstenezky, os melhores alunos eram "entrevistados pelo professor Arnold Harberger, da Universidade de Chicago, que estava ali na qualidade de observador da Fundação Ford, a agência que havia financiado o curso [...]. Naquela ocasião, em função da sua entrevista, [Carlos Geraldo] Langoni foi para Chicago com a única bolsa disponível, patrocinada pela Fundação Ford” (Clóvis de Faro in: ALBERTI et al., 2002, p. 100). Além de Langoni, outros alunos do CENDEC obtiveram bolsas para estudar nos Estados Unidos: Claudio Luiz da Silva Haddad também foi para Chicago, José Julio Senna fez seu doutorado na John Hopkins University e Ricardo Varsano e Clóvis de Faro foram para Stanford (CAMPOS, 1994, p. 807; Ricardo Varsano in: D’ARAÚJO et al., 2005, pp. 195-196). Arnold Harberger, o observador da Fundação Ford, ficou conhecido como o pai ${ }^{344}$ dos Chicago Boys, a coorte de economistas latino-americanos que estudou em Chicago e colaborou para implementar, em seus países, um conjunto de reformas econômicas de cunho neoliberal.

\footnotetext{
${ }^{343}$ Ver: http://livros01.livrosgratis.com.br/cd004820.pdf visitado em 11/09/2015.

${ }^{344}$ A alcunha "pai dos Chicago Boys" pode ser lida de duas maneiras. O primeiro sentido da paternidade decorria do profundo envolvimento de Harberger com a criação do projeto de cooperação científica entre Chicago e as universidades latino-americanas $\mathrm{O}$ segundo estaria associado ao modo como Harberger tratava seus estudantes, já que os auxiliava na resolução dos mais prosaicos problemas da vida no exterior, recebia-os em sua casa e procurava fazer com se integrassem no universo social e acadêmico de Chicago. A transmissão do espírito de Chicago, iniciada nas aulas, completava-se assim na intensa convivência extrauniversitária que tinham com os professores. Harberger referia-se aos seus alunos como my children e frequentemente, em suas entrevistas, fala de quantos latino-americanos teriam sido alunos seus e quantos notáveis teria entre seus protegidos (VALDÉS, 1995, p. 155; HARBERGER, 2000).
} 


\subsection{Arnold Harberger e Carlos Geraldo Langoni: Chicago no Brasil}

A vida de Harberger foi fortemente moldada por uma decisão fortuita de sua adolescência: a de estudar espanhol no colegial e na universidade. Foi o espanhol fluente que permitiu que Arnold se transformasse em Alito, como o chamavam carinhosamente seus alunos latino-americanos. Harberger (1924), nascido em Newark-New Jersey, começou seus estudos universitários de economia na John Hopkins University, sendo forçado a interromper a graduação quando convocado para servir ao exército durante a Segunda Guerra Mundial. Ao regressar, sem haver concluído a graduação, ingressou no curso de pós-graduação de Relações Internacionais da Universidade de Chicago que tampouco concluiu. Transferiu-se em 1947 para o Departamento de Economia de Chicago, obtendo seu $\mathrm{PhD}$ em 1950. Segundo ele, as três maiores influências que teve no doutorado foram Theodore W. Schultz, professor da área de economia agrária, Milton Friedman, que ensinava teoria dos preços e da moeda, e Jacob Marschak, professor de macroeconomia de matriz neokeynesiana (HARBERGER, 1999; HARBERGER 2003).

Marschak presidiu, de 1943 a 1948, a Cowles Commission for Economic Research que reunia economistas com forte afinidade com a matemática, responsáveis também pela criação da Sociedade de Econometria e do jornal Econometrica ${ }^{345}$. A sede da Comissão mudou, em 1939, de Colorado Springs para a Universidade de Chicago, deslocando para lá o centro dinâmico de investigações econômicas e passando a receber fundos, em 1942, da Rockefeller Foundation e do National Bureau of Economic Research.

Sob a liderança de Jacob Marschak, o programa de pesquisa da Comissão começou passou focar na modelagem da economia como um sistema de equações econômicas simultâneas com variáveis aleatórias. No processo os scholars da Cowles também desenvolveram métodos estatísticos para estimar parâmetros dos modelos econômicos a partir de dados de observação. Se a Comissão Cowles não inventou a linguagem da economia moderna, ela certamente desempenhou um papel fundamental em tornar a "construção de modelos estatísticos baseados em estimativas" parte da vulgata disciplinar (FOURCADE, 2009, p. 87).

A Cowles Comission acolheu europeus exilados, com maior familiaridade com a matemática, que foram essenciais para a transformação lógica e metodológica da produção acadêmica em economia. Parte deles era francamente simpática ao

\footnotetext{
${ }^{345} \mathrm{O}$ dado segundo o qual um terço dos ganhadores do prêmio Nobel de economia entre 1969 e 1990 esteve formalmente ligado à essa Comissão explicita o prestígio e as vantagens colhidos pelas universidades que a acolhiam (FOURCADE, 2009 , p. 87).
} 
planejamento e à intervenção econômica, tendo contribuído para a elaboração das ferramentas que o governo dos EUA utilizou para fazer a programação econômica New Deal de Franklin Roosevelt - como as matrizes de input-output, a contabilidade nacional, a programação linear etc., que estavam também entre as técnicas transportadas pela CMBEU para o Brasil. Ainda que houvesse setores que pendessem para o polo intervencionista, a versão matematizada da economia que predominou em Chicago e que passou a caracterizar a Escola foi a de Milton Friedman, que havia sido aluno do monetarista neoliberal Jacob Viner e que desconfiava profundamente de qualquer um que pregasse a importância do planejamento e da ação do Estado, lutando para incutir em seus alunos profundo respeito pelo mercado (FOURCADE, 2009, p. 88; FOURCADE, 2009a, p. 257; HARBERGER, 2003, p. 347).

Harberger define sua Escola como um espaço no qual: 1) valorizava-se a teoria como recurso para lidar com problemas complexos de modo organizado; 2) consideravase que a teoria só é importante quando capaz de fazer compreender como o mundo funciona; e 3) respeitava-se os mercados com firme e inabalável convicção, não acreditando que sejam perfeitos, mas considerando-os como uma força genuína, que deixará em apuros aqueles que tentarem combatê-los (HARBERGER, 2003, pp. 338339). Ele relata que:

profundo respeito pelos mercados você adquiria através de Milton, tanto no que diz respeito à moeda quanto ao preço. Você adquiria de T. W. Schultz, você adquiria de D. Gale Johnson, Deus sabe, você adquiria de Gregg Lewis, você adquiria de Gary Becker, Harry Johnson... Você vê o que eu quero dizer? Não importa onde fosse, não importa como esses caras votam. Não há ninguém que eu conheça que seja um competidor sério em Chicago que não exale, em um sentido ou outro, este profundo respeito pelas operações de mercado. De modo que eu acho que esse é o verdadeiro elemento que caracteriza a verdadeira "Escola de Chicago"(HARBERGER, 2003, p. 347).

Milton Friedman, além de monetarista e advogado incansável dos livres mercados, viria a ser assessor próximo de Ronald Reagan, presidente republicano que liderou a guinada neoliberal dos EUA nos anos 1980. Em um de seus livros mais conhecidos, Capitalismo e liberdade (1962), ele explicita os pressupostos subjacentes à sua convicta defesa do mercado. No primeiro ensaio argumenta que economia e política não são fenômenos distintos, postulando que a liberdade econômica não é um fim em si, mas parte de uma liberdade mais ampla. Ele sustenta que "o tipo de organização econômica que promove diretamente a liberdade econômica, isto é, o capitalismo competitivo, 
também promove a liberdade política porque separa o poder econômico do poder político” (FRIEDMAN, 1985, pp. 17-18). Há algumas convicções políticas subjacentes à doutrina de Friedman. A primeira delas é que "o comunismo destruirá todas as nossas liberdades", sendo uma rota para a servidão (FRIEDMAN, 1985, p. 27) e a segunda é que a intervenção do Estado na economia seria também necessariamente uma ameaça, já que tolhe a liberdade de condução da economia pelos indivíduos, caminhando, assim, em direção contrária à democracia.

Em mais de uma ocasião, Harberger declara que não era essa a economia que Friedman ensinava em sala de aula. Sustenta que ele não usava o ideológico Free to choose livro no qual desenvolve as ideias apresentadas nas palestras reunidas em Capitalismo e liberdade - em sala de aula, e sim seu A monetary history of the United States, que era uma teoria dos preços e suas aplicações (HARBERGER, 1999; HARBERGER, 2000), e completa: "nas nossas aulas, não estavam ensinando ideologia, ou o que eu chamo de o lado austríaco da economia, economia como religião, mas sim economia como ciência" (HARBERGER, 2000 [online]). Uma ciência que acredita que

\begin{abstract}
As forças do mercado são apenas isso: elas são forças; elas são como o vento e as marés; são coisas que, se você quiser tentar ignorar, você ignora correndo seu próprio risco; e se você entender que estão lá, agindo a sua maneira, se você encontrar uma maneira de ordenar sua vida que seja compatível com essas forças, que aproveite essas forças em benefício de sua sociedade, este é o caminho a se seguir (HARBERGER, 2000 [online]).
\end{abstract}

Mas como separar as duas coisas, se o próprio Harberger afirma que a ideia de Friedman de que não se deveria intervir na moeda derivava de sua profunda desconfiança em relação aos burocratas e ao Estado, de suas premissas político-filosóficas ou, como diz Harberger acima, de seu lado "economia como religião"? Não haveria uma convicção, derivada do profundo respeito aos mercados como a forma mais adequada à liberdade humana, subjacente à ideia que as forças de mercado são elementos da natureza que não devem ser abalados? Cabendo indagar se seria possível dissociar as teorias e as técnicas apresentadas como científicas das lógicas políticas e do conjunto de valores à elas subjacentes? (MARCUSE, 1998, pp. 116-117).

É possível sustentar, pois, que havia fronteiras pouco nítidas entre a forma dogmática da economia neoclássica - calcada no ideal estadunidense de livre mercado e no seu entendimento da democracia - e a justificação altamente matematizada de tais convicções, apresentada como ciência (FOURCADE, 2009, p. 95). Por que seria tão 
urgente negar a existência de crenças e pressupostos? Ao recobrir de matemática e cientificismo a via tecnocrática, apresentando-a como uma intervenção qualificada e apolítica, um instrumento que conduziria a sociedade necessariamente ao ponto ótimo, justifica-se a atuação dos economistas treinados nestes marcos.

A generalização da crença no caráter racional, neutro e universal das decisões tomadas com base na razão formal, abstrata, metódica e sistemática, que se estabelece progressivamente como a forma predominante de racionalidade na ciência e na burocracia científico-especializada, faz estar ao alcance dos economistas o poder de fazer recomendações cientificamente legitimadas e assim performar a vida e a estrutura econômica. Isso pois as escolhas feitas por eles passam a ser tomadas como simples aplicação da ciência para a melhora do bem estar geral sem qualquer forma de discussão pública acerca das finalidades e prioridades da otimização (MARCUSE, 1998, pp. 116117; CALLON, 1998; LEBARON, 2000, p. 99).

A difusão das vertentes matematizadas da ciência econômica promove uma transição de um estágio no qual havia um conflito entre os "técnicos", com orientações assumidamente políticas que poderiam e deveriam ser debatidas - entre os pares -, e os "políticos", que eram rejeitados pelos intelectuais por serem desprovidos das ferramentas que julgavam ser necessárias para atuar sobre a economia - como no conflito entre os desenvolvimentistas não nacionalistas e os homens de Getúlio Vargas, que tomou o BNDE em meados dos anos 1950 (item 2.3) - para um estágio no qual a discussão sobre os fundamentos políticos das discórdias entre os técnicos e os intelectuais são obnubiladas por debates acerca das ferramentas, medidas, cálculos, construção e uso de indicadores e coleta de dados, sem consideração pelas finalidades últimas da condução econômica praticada com base nas - e legitimadas pelas - análises e instrumentais mobilizados pelos economistas (PÉCAUT, 1989, pp. v-vii; KLÜGER, 2015b).

Ao reunir ambição de cientificidade e precisão técnica, advinda da econometria, da matematização e da estatística, provenientes da pesquisa à la Cowles com a crença no livre mercado personificada por Friedman, Chicago conferia estatuto universal à economia neoliberal e sua crítica ao keynesianismo intervencionista e às heresias latino-americanistas da CEPAL. O primeiro grande experimento de exportação do monetarismo/neoliberalismo de Chicago para a América Latina foi feito, no Chile, justamente onde as ideias cepalinas, combatidas com vigor por Viner, Friedman e seus 
seguidores foram gestadas e proliferavam de maneira mais vigorosa. A teoria econômica de Friedman e da Escola de Chicago era a mais convenientemente exportável para a América Latina naqueles anos republicanos de Eisenhower, quando a política externa estadunidense evitava conceder qualquer espécie de apoio financeiro à região, alegando que a fórmula para a recuperação econômica estaria na abertura dos mercados ao investimento internacional e na redução da intervenção econômica por parte do Estado (item 2.3).

Em 1953, Theodore Schultz propôs que Arnold Harberger fosse contratado como professor de finanças públicas em Chicago. Dois anos depois, sabendo que ele dominava o espanhol, levou-o em viagem exploratória a Santiago do Chile, com o intuito de estabelecer convênio de cooperação científica entre Chicago e alguma universidade chilena, a ser financiado com as verbas do Ponto IV (HARBERGER, 2003, p. 343). O diretor da cooperação Estados Unidos-Chile à época, Albion Patterson, era um especialista em mercados agrícolas, que havia trabalhado em uma missão do Institute of Inter-American Affairs de ajuda externa ao governo do Paraguai, especificamente direcionada à melhoria da produção de alimentos. Na condição de expert do setor agrícola, Patterson conheceu Theodore Schultz, então diretor do Departamento de Economia de Chicago, que tinha seus principais trabalhos na área de economia agrícola. Patterson inspirou-se em Schultz para desenvolver seu principal projeto enquanto representante do Ponto IV, o Chile Project ou Plan Chillán, que começou como um programa de cooperação para o desenvolvimento agrícola, passou a incluir iniciativas nas áreas de saúde, educação, saneamento e transporte e por fim englobou iniciativas nas áreas de educação e ciência econômica (VALDÉS, 1995, pp. 109-112).

Theodore Schultz estava encarregado de um projeto da National Planning Association, financiado pela Fundação Ford, que consistia em recomendar políticas e métodos de ação para agências públicas, grupos privados e governos na América Latina. Como representante desse projeto, encontrou-se com Patterson, que até então não conhecia pessoalmente. Mantiveram conversas por duas semanas sobre as possibilidades de desenvolvimento agrícola e educacional no Chile, nas quais Schultz expôs as teorias do capital humano que se estavam fabricando em Chicago. Dessas conversas decorreu a extensão dos projetos de cooperação apoiados por Patterson para a área da educação superior. Passaram então a engajar-se na tarefa de estabelecer convênios de Chicago com 
universidades chilenas a serem financiado pelo governo dos EUA com o objetivo de, nos termos de Chicago, modernizar o ensino da economia (VALDÉS, 1995, pp. 113-114).

Patterson relata que apresentou o projeto ao reitor da Universidad de Chile (UC) e investigou se haveria receptividade à iniciativa. Diz que teria sido veementemente rejeitada pelos esquerdistas que controlavam o departamento de economia, aos quais Chicago muito desagradava. Já os professores da UC que participaram das negociações argumentam que a querela deveu-se à decisão do corpo docente da UC de não restringir o convênio a um intercâmbio com Chicago, sustentando que era preciso deixar aberta aos alunos a escolha da escola para a qual se dirigiriam (VALDÉS, 1995, pp. 114-116; MONTECINOS, 2009, p. 167; PARMAR, 2012, pp. 199-203).

Enquanto a UC argumentava prezar por sua liberdade para flertar com universidades norte-americanas que fossem compatíveis com a heterodoxia, o estruturalismo, o keynesianismo etc., o reitor da Universidade Católica do Chile (UCC) procurou Patterson para manifestar seu interesse em abrigar o convênio, propondo que o departamento de agricultura fosse o beneficiário. Patterson insistiu que a economia fosse o foco. Albion logo relatou a Schultz a vitória obtida, que, segundo ele, permitiria equilibrar o pensamento econômico no Chile, promovendo a modernização da economia e difundindo o respeito pelo mercado, explicitando a razão de sua insistência em um convênio exclusivo com a universidade de Friedman e discípulos. A área de economia da UCC, que até então só abrigava os desvalorizados cursos de comércio, não tendo professores permanentes ou mesmo uma boa biblioteca, seria enormemente beneficiada material e simbolicamente pelos recursos de proveniência estrangeira. E também Chicago, que não era da Ivy League 346 e acabara de perder a Cowles Comission e suas verbas para a concorrente Yale, beneficiar-se-ia da criação de um convênio que lhe aportaria dinheiro, alunos e visibilidade (VALDÉS, 1995, pp. 116-118 ; MONTECINOS, 2009, pp. 167168).

Schultz e Harberger chegam ao Chile para negociar o acordo pela primeira vez em 1955. Harberger registra que foi quando conheceu Ernesto Fontaine e Sergio de Castro, dois estudantes do quinto ano da U. Católica que foram os intérpretes chilenos do grupo de Chicago. "Eles nos acompanharam durante toda a nossa semana no Chile, como

\footnotetext{
${ }^{346}$ Ivy League é o conjunto de universidades formado por Harvard, Yale, Columbia, Pennsylvania, Cornell, Brown, Dartmouth e Princeton, consideradas como as escolas de maior prestígio acadêmico e de recrutamento mais seletivo nos EUA.
} 
nossos intérpretes, porque eles eram Grange School "old boys" e sabiam inglês perfeitamente. Nos demos muito bem, e eles nos acompanharam com todas as pessoas com que entramos em contato. Então, quando Ernesto [Fontaine] e Tejo [Sergio de Castro] vieram para Chicago, eles compartilharam um apartamento com outros chilenos. Foi quando eu conheci Anita" (HARBERGER, 2003, p. 343), chilena com quem se casou, o que alimenta sua convicção de que estudar espanhol foi decisivo em sua vida.

Haberger, na sequência, explicita a relação que havia entre as escolas privadas anglofonas e anglófilas como a Grange School e a criação do grupo conhecido como Chicago Boys:

Há um par de importantes escolas privadas para meninos no Chile - eu não sei se elas são mistas hoje em dia ou não - mas em todo caso, a Grange School era uma e St. George era a outra. Ao menos a Grange School foi construída firmemente sobre o modelo inglês de Eton e Harrow. Eles chamavam todos os seus exalunos de "the old boys." Então, é daí que o ditado Inglês "old boy network" vem. Ex-alunos de Eton e Harrow, esses são os "old boys". Eles todos se conhecem, eles fazem favores uns aos outros por toda a vida, e assim por diante. Muitos dos nossos primeiros meninos de Chicago e até mesmo alguns que vieram depois foram da Grange School. De modo que eram "old boys". E quando eles começaram a atuar como uma unidade coesa era muito natural que algum jornalista desconhecido os rotulasse como "Chicago boys" (HARBERGER, 2003, p. 348).

Não bastaria trazer a Escola de Chicago para Santiago, era preciso que, no Chile, ela encontrasse um universo preparado para recebê-la, quer dizer, um espaço no qual as pessoas fossem cosmopolitas e partilhassem dos valores aportados pelos novos missionários. O lema da Grange School Nunquan non paratus, nunca despreparado, e o regulamento interno ajudam a vislumbrar que tipo de disposições eram ali cultivadas:

A filosofia educacional da Grande Escola é inspirada no conceito de "AllRounder". É um ideal que tem suas raízes no humanismo cristão renascentista e destaca o desenvolvimento completo e harmonioso de cada pessoa em sua totalidade, ou seja, tanto espiritual quanto o intelectual, moral, artístico, esportivo e social. O Colégio realça também a importância do "Fair Play", conceito que se conecta, à primeira vista, com a ética esportiva. No entanto, é na verdade uma metáfora cuja aplicação pode se estender muito além das quadras, por um lado, "Fair Play" é um ideal que convida à superação pessoal, à criação de hábitos e a lutar com espírito de equipe. Por outro lado, exige competir e participar respeitando as regras do jogo, ou seja, com a ética e consciência clara de que todos os participantes são pessoas cuja dignidade jamais pode ser ameaçada (The Grande School: reglamento interno y normas de convivencia escolar, 2015, p. $\left.5^{347}\right)$.

347 Disponível em https://drive.google.com/file/d/0B1uyqE3OwCakeVd2Z1QycklaLWM/view, visitado em 12/09/2015. Ainda que o regulamento seja atual, a descrição nele contida é compatível com aquela feita pelos envolvidos com a escola na época no que concerne à formação do indivíduo para a competição. 
É possível notar grande similaridade em relação aos valores cultivados nas escolas de elite brasileiras, que se ocupam da formação de jovens cosmopolitas nas línguas e nos hábitos, preparados para o jogo do poder através do incentivo à contínua superação pessoal e à competição (itens 1.5 e 2.4). A visão de mundo cultivada nesses espaços converge com o individualismo metodológico subjacente à teoria econômica neoliberal propagada por Chicago, com sua ênfase no indivíduo imerso em uma competição regrada na qual a vitória seria dada ao meritório e sua ideia de que a maximização do bem estar geral deriva do respeito individual às regras. Aqui se tratando das regras da ética, no caso de Chicago das regras de mercado.

Ainda que tenham sido também educados em instituições escolares de alto nível, aqueles que dominariam o processo de modernização neoliberal do Chile diferem das elites tradicionais - sólidas ou decadentes - e do grupo dos que ascenderam pela via eclesiástica já que provém, em sua maioria, de famílias de imigração recente que tiveram sua ascensão promovida pela acumulação de capital econômico no comércio e/ou pela formação cultural e pela frequência ao ensino superior em instituições de prestígio (VALDÉS, 1995, pp. 152-153). Nesse sentido, diferiam radicalmente dos quadros da primeira geração da CEPAL que, como visto anteriormente (itens 1.1, 1.2, 1.3 e 1.5) eram compostos, essencialmente, por membros das mais sólidas e tradicionais elites chilenas e latino-americanas que se profissionalizaram em economia e se internacionalizaram antes da era das abundantes bolsas da Aliança para o Progresso.

Para os imigrantes recentes, a profissionalização e a via tecnocrática representavam um atalho para o universo dos dominantes

mas igualmente a possibilidade de transformar a classe, de modificar radicalmente
sua ideologia e até sua composição, algo para que foram psicológica e
intelectualmente preparados, pois - em geral - eles não tinham nenhum
parentesco ou relações de propriedade a defender e preservar, e sua prática
científica imporia suficiente respeito e influência para erodir a resistência que
encontrariam entre esses grupos de interesses tradicionais (VALDÉS, 1995, pp.
154).

A trajetória de ascensão social de imigrantes pela via aberta pela tecnocratização da gestão econômica observada no caso dos Chicago Boys espelha tendência que ocorre no Brasil no mesmo período, onde à elite tradicional agrega-se nova fração de classe, proveniente de um universo de imigrantes que ascenderam socialmente por via 
profissional e que, aos poucos, vão corroendo as possibilidades das antigas elites de alcançar os postos de direção especializados sem o atestado de competência auferido pelos diplomas.

O convênio firmado, em março de 1956, permitia que alunos de destaque da Universidade Católica cursassem a pós-graduação em Chicago com bolsas oferecidas pela USAID, pela Fundação Ford, pela Fundação Rockefeller e pela Organização dos Estados Americanos. Os relatórios indicam que os principais critérios para seleção dos estudantes eram o domínio do inglês e do raciocínio lógico e o treinamento em economia. Entre os anos de 1956 e 1964348 , foram enviados para cursar o PhD em Chicago trinta estudantes que, ao retornar ao Chile, assumiram postos de professor, transmitindo às gerações seguintes teorias, métodos e visões de mundo incorporadas em sua circulação internacional. No exterior tornaram-se amigos, viviam juntos, festejavam, criaram uma comunidade e uma equipe que se transladaria a Santiago pronta para ensinar e governar. O fato de que os alunos que retornavam e assumiam cátedras no Chile passassem também a ter voz na seleção de novos candidatos para o programa de intercâmbio ajudou a criar um grupo extremamente coeso e social e ideologicamente afinado (VALDÉS, 1995, pp. 136-138).

Por iniciativa de Harberger e seus colegas, convênios semelhantes ao estabelecido com o Chile espalharam-se para outros países da América Latina. Patterson, que passou a chefiar a USAID na Argentina, participou com Harberger das negociações para a criação de um convênio de Chicago com a Universidade de Cuyo, localizada em Mendoza. Prevendo tanto o envio de estudantes para Chicago quanto a circulação de professores da Universidade Católica do Chile e da Universidade de Chicago pela Argentina, o programa teve início em 1962 e durou até 1967. Foram enviados dois professores de Chicago e dois chilenos da Universidade Católica para Cuyo, onde remodelaram inteiramente o currículo da Faculdade de Economia. A Universidade de Tucumán agregou-se à iniciativa pouco

\footnotetext{
348 “Ainda que financiamento para o Projeto Chile tenha secado em 1964, a Universidade de Chicago aproveitou outros recursos para sustentar o recrutamento de estudantes chilenos e para construir o currículo latinoamericano de Universidade de Chicago. Verbas da Fundação Ford, da OEA, do Ministério do Planejamento (ODEPLAN) e do Banco Central do Chile ajudaram a financiar os estudantes chilenos. Adicionalmente, a Fundação Ford doou US\$ 750.000 ao longo de um período de 10 anos para o Center for Latin American Economic Research da University of Chicago [...]. Mais de 150 estudantes chilenos receberam treinamento em Chicago, uns 30-50 deles como parte do programa de intercâmbio ao longo do início dos anos 1970. A relação com Chicago continuou por mais de 3 décadas, com o patrocínio vindo de USAID, das Fundações Ford e Rockefeller, e da OEA. Em essência, uma vez iniciado o programa, o fluxo de estudantes jamais cessou" (BIGLAISER, 2002, pp. 275-276).
} 
depois, experimentando o mesmo tipo de reforma, adicionalmente 24 alunos argentinos foram contemplados com bolsas estadunidenses. A Fundação Rockefeller, que financiava a Universidade Valle del Cali, na Colômbia, requisitou que Harberger e seus Chicago Boys também ali trabalhassem na reformulação curricular. Em 1974, o Uruguai passou a enviar estudantes de economia para a Universidade de Chicago e Harberger e seus discípulos atuaram, de 1974 a 1976, como consultores do governo militar que ali se instalou em 1973, sendo encarregados de algumas reformas feitas no sistema de tarifas e política comercial (VALDÉS, 1995, pp. 180-185; BIGLAISER, 2002, pp. 277-280).

Muitos dos Chicago Boys transbordaram do espaço acadêmico para a o serviço público, tendo ativo papel na construção de programas de governo e na gestão do Estado em diversos países da América Latina, sobretudo no Chile. Em introdução a "El Ladrillo": bases de la política económica del gobierno militar chileno, Sergio de Castro relata que, quando ele e os outros chilenos retornaram do exterior, não assumiram apenas os cursos regulares de economia da Universidade Católica mas passaram, em 1967-1968, a oferecer também cursos para um grupo de empresários na Sociedad de Fomento Fabril. Foi quando acadêmicos e empresários passaram a cooperar na produção de um programa econômico alternativo para Jorge Alessandri, o principal candidato da direita no pleito que elegeu o socialista Salvador Allende (CASTRO, 1992, p. 7). Nesse sentido, há paralelismos entre a associação dos Chicago Boys chilenos com os empresários, políticos conservadores e militares e, no caso brasileiro, a reunião na CONSULTEC e na ANPES dos economistas que constituiriam a tecnocracia da ditadura militar com empresários, políticos e militares que se chocarão com a tendência à esquerda do governo de João Goulart, apoiando a instauração de um regime de exceção. Castro declara que

\footnotetext{
as diretrizes fundamentais do programa alternativo, apresentado a Don Jorge Alessandri, eram a abertura da nossa economia, a eliminação de práticas monopolistas, a liberação do sistema de preços, a modificação do sistema tributário para um mais neutro, eficiente e equitativo, a criação e formação de um mercado de capitais, a geração de um novo sistema previdenciário, a normalização da atividade agrícola nacional, destruída pela reforma agrária, e a proteção dos direitos de propriedade [...]. Todos nós, estando convencidos dos benefícios da liberdade econômica, tínhamos sido bombardeado por anos de estatismo e havíamos experimentado, em maior ou menor medida, dependendo do grau de entendimento e convicção pessoal, alguma erosão intelectual e política (CASTRO, 1992, pp. 8-11).
}

As propostas de liberalização dos mercados, adesão aos fluxos de comércio internacional, estímulo à iniciativa privada, redução do poder de intervenção do Estado 
via cortes na extensão da burocracia e privatização de empresas públicas (SILVA, 2012, p. 79) converter-se-iam no receituário neoliberal que iria conquistar corações e mentes de latino-americanos a partir da década de 1970. O programa dos Chicago Boys era similar mas, ao mesmo tempo, mais radical do que as medidas adotadas no PAEG que, não obstante privilegiasse a iniciativa privada e a abertura do mercado, falava largamente em planejamento e não concebia privatizar as estatais.

Como no caso das reformas promovidas pelo PAEG no início do governo militar brasileiro, o programa dos Chicago Boys, conhecido como Ladrillo, já vinha sendo formulado há alguns anos, mas só conseguiria ser executado no governo ditatorial, visto conter uma série de medidas econômicas altamente impopulares, como cortes salariais, constrição monetária recessiva, dentre outros. Mesmo Jorge Alessandri havia apresentado resistências às propostas dos Chicago Boys, que achava que deveriam ser implementadas de maneira lenta e gradual e não por meio de um choque radical. A tomada do governo por um golpe militar, em 11 de setembro de 1973, que silenciou as vozes da oposição, permitiu que tais medidas fossem aprovadas a galope e sem resistência popular, tal qual desejavam seus ideólogos. Sergio de Castro descreve a entrada de seu grupo no governo dizendo que:

\footnotetext{
Um dos membros do grupo acadêmico, sem que o resto de nós soubesse ou sequer suspeitasse, teve contato com oficiais superiores da Armada Nacional. Grande foi, portanto, a nossa surpresa quando descobrimos que a Junta Militar tinha o nosso documento e que a aplicação era contemplada como possível. O primeiro efeito do Programa de Desenvolvimento Econômico foi a migração de quase todos seus autores dos claustros da universidade para o árido e difícil, mas espiritualmente gratificante, campo do serviço público (CASTRO, 1992, p. 11).
}

No princípio da ditadura de Augusto Pinochet, os Chicago Boys ocupavam posições secundárias nos ministérios e agências de Estado, que foram inicialmente controlados pelos próprios militares. Em algum tempo conquistaram a Oficina de Planificación Nacional (ODEPLAN) e a partir desse posto espalharam-se por todas as instâncias encarregadas da gestão econômica do Estado, tornando-se a intelligentsia do novo regime.

Incansáveis defensores do mercado e da estabilidade monetária, que julgavam ser a solução econômica mais adequada independentemente de contexto histórico ou posição geográfica, passaram a ocupar, na administração Pinochet, cargos que em governos anteriores haviam sido exercidos por membros da CEPAL e pessoas por ela 
influenciadas. Elas sustentavam o exato oposto da verdade única de Chicago, já que consideravam haver uma especificidade na condição periférica que fazia com que as soluções econômicas para o continente diferissem daquelas adequadas ao centro e não ecoassem da livre iniciativa. Ademais, as propostas intervencionistas calcadas em planejamento econômico pela CEPAL apregoadas eram absolutamente incompatíveis com o livre mercado e com controle estrito, se necessário recessivo, da moeda advogado por Chicago.

A chegada dos Chicago Boys ao poder no governo Pinochet levou ao ocaso a vitalidade da CEPAL - a Comissão passou a ter que se ocupar correntemente da defesa de seus funcionários contra as arbitrariedades do regime e passou a operar de modo mais cuidadoso para conseguir defender seus princípios em um contexto que lhe era hostil (ROSENTHAL, 2004, p. 392; MONTECINOS, 2009, p. 152). Se nos anos 1950 e 1960 era a CEPAL que oferecia cursos por toda parte, treinando técnicos de governos da América Latina, agora eram os egressos de Chicago que instalavam filiais em diversos países e corriam o continente em cursos, consultorias e palestras.

Um exemplo icônico dessa circulação de Chicago e de seu vínculo com o governo Pinochet, episódio que teve prolongados efeitos sobre a carreira de Milton Friedman, foi a viagem que ele, Harberger e o brasileiro Carlos Geraldo Langoni fizeram ao Chile, em março de 1975, para participar de seminário organizado pela Fundación de Estudios Económicos, ligada ao Banco Hipotecario de Chile. Na principal conferência que ofereceu no Chile, em 26 de março, Friedman argumentou que havia dois objetivos econômicos básicos no Chile naquele momento: combater a inflação e estabelecer uma economia de mercado vigorosa que pudesse gerar crescimento econômico.

Para que a inflação fosse reduzida, afirma, "há um só caminho, somente um! Apenas um! Consiste em reduzir dos gastos do governo. Uma redução de 20 a $25 \%$ nos gastos do governo é uma condição absoluta encerrar satisfatoriamente a inflação" (FRIEDMAN, 2012, [kindle 289]). Seria possível reduzir a inflação com endividamento externo e aumento das taxas de juros, mas essas medidas não podem ser mais do que transitórias, porque "é preciso recordar que o verdadeiro custo do governo é o que ele gasta” (FRIEDMAN, 2012, [kindle 296]). Na sequência, argumenta que o combate à inflação deve ser feito através de um tratamento de choque e não por meio de medidas graduais: 
Eu não acho que para o Chile uma política gradualista faça sentido. Temo que o "paciente" pode morrer antes que o "tratamento" faça efeito. Acho que o Chile possa ganhar muito se examinar os exemplos relacionados com o tratamento de "choque" para o problema da inflação e da desorganização. A experiência brasileira, explicada neste seminário, é sem dúvida um bom exemplo (FRIEDMAN, 2012, [kindle 312]).

Carlos Geraldo Langoni havia exposto, dois dias antes, a política econômica da ditadura brasileira: o programa de combate à inflação do PAEG e o "milagre" do crescimento nos anos seguintes, caminho que era visto com bons olhos pelo grupo de Chicago $^{349}$, recomendando que se implementasse abertura ao mercado externo, criação de mercados de capitais e reformas tributárias (MONTES, 2015, pp. 10-12).

Friedman admite que a transição para o novo modelo de abertura ao mercado privado, fim das barreiras ao mercado externo e corte de gastos públicos poderia ter, inicialmente, efeitos negativos, podendo acarretar falências, desemprego e recessão temporários, para só depois criar um mercado competitivo, sem barreiras ou subsídios. Rejeita, não obstante, o controle de preços para contornar as dificuldades econômicas da transição, dizendo que só faria prejudicar ainda mais o país enfermo. Finalmente Friedman afirma que o governo estaria adotando muitas "medidas que estão de acordo com a orientação que sustento e defendo" e concluí: "Confio que o Chile terá a coragem, a força e a sabedoria para acelerar esse processo e superar este período inicial difícil, de forma que possam iniciar a decolagem para uma grande melhoria dos padrões de vida. É viável e possível” (FRIEDMAN, 2012, [kindle 512]).

Além apresentar suas ideias em conferências ao público, Friedman, Harberger e Langoni fizeram uma visita ao general Pinochet e encontraram-se com agentes centrais dos setores público e privado do país. Friedman enviou a Pinochet, em 21 de abril, uma carta com uma síntese do conjunto de suas recomendações para a política econômica chilena (FRIEDMAN, 2012a; MONTES, 2015, pp. 9-10). No mês seguinte, o governo chileno anunciou uma política de choque para combater a inflação e pouco depois Sergio de Castro, o principal líder dos Chicago Boys e chefe de departamento da economia da Universidade Católica desde 1965, tornou-se Ministro da Economia, Fomento e Reconstrução e, em seguida, Ministro da Fazenda. Castro esteve à frente da área econômica do governo de 1975 a 1982 e conduziu o Chile ao primeiro experimento de

\footnotetext{
${ }^{349}$ Ainda que houvesse uma afinidade claramente maior com o PAEG do que com os gastos financiados por endividamento externo praticados por Delfim. Como deixa bem claro Friedman ao falar que o problema central era o deficit público e dizer que o endividamento externo não resolveria o problema.
} 
equiparação da cidadania à liberdade de escolha do consumidor (MONTECINOS, 2009, pp. 151-152; SILVA, 2012, p. 80).

As críticas à Escola de Chicago decorrentes de sua associação com o governo militar chileno, só aumentaram após a viagem de Friedman ao Chile (HARBERGER, 2000). Andre Gunder Frank (item 3.5), marxista que fora estudante de PhD em Chicago, casado com uma chilena e exilado depois do golpe de 1973, criticava veementemente sua antiga escola e mobilizava seus alunos a participarem de boicotes a Chicago. Ele escreve para seus professores a carta intitulada Economic genocide in Chile:

Milton Friedman e Arnold Harberger: vocês devem lembrar que, após a primeira visita pública de Harberger ao Chile depois do golpe militar, escrevi-lhe uma carta aberta, em 6 de agosto de 1974. Após a segunda visita de Haberger e do anúncio público da intenção de Friedman de ir para o Chile também, escrevi um pós-escrito em 24 de fevereiro de 1975. Vocês devem se lembrar que, nesta carta aberta e pós-escrito, comecei rememorando os anos 1950, quando eu era estudante de graduação do "programa do Chile" no Departamento de Economia da Universidade de Chicago, no qual vocês treinaram os ditos "Chicago boys", que agora inspiram e executam a política econômica da Junta militar no Chile. Eu, então, passei a resumir [sic] a "lógica" da política de vocês e da Junta citando declarações públicas de Harberger no Chile e dos porta-vozes e imprensa oficial da Junta. Finalmente, examinei com você as consequências, especialmente para o povo do Chile, da aplicação pela força militar desta política de Chicago/Junta: repressão política e tortura, monopolização e venda ao capital estrangeiro, desemprego e fome, declínio da saúde e aumento da criminalidade, todos promovidos por uma política calculada de genocídio político e econômico. [...] Vós mesmos, Milton Friedman e Arnold Harberger, tornaram-se o objeto de severas críticas por seu apoio teórico, político e pessoal ativo da Junta militar chilena. Primeiro houveram cartas ao editor e editoriais no jornal estudantil da Universidade de Chicago, o Maroon, chamando-o à tarefa. Em seguida, um "Comitê Contra a colaboração de Friedman e Harberger com a Junta chilena" recebeu apoio cada vez mais generalizado de muitos em seu próprio campus, que sentiram corretamente que você está prejudicando a reputação da sua Universidade. Em seguida, uma Comissão oficial de Inquérito da Universidade foi criada para examinar a sua colaboração com a Junta militar no Chile e suas implicações (FRANK, 1976, pp. 880-881).

Os protestos contra Chicago ganharam vulto em 1976, quando Orlando Letelier, que havia sido o embaixador de Allende nos EUA, foi assassinado em Washington, após escrever uma carta como a de Frank, apresentando severas críticas ao envolvimento de Friedman com o governo ditatorial chileno. Pouco tempo depois, Friedman ganha o "Nobel" 350 de economia, sendo obrigado a viajar acompanhado de segurança para receber

\footnotetext{
${ }^{350}$ Cabe ressaltar que o Prêmio Nobel de Economia difere dos outros pois não foi ideia de Alfred Nobel, nem foi proposto pela Fundação Nobel, mas sim pelo Banco Central Sueco, mais uma expressão da justaposição entre a ciência econômica e o campo do poder. A ideia foi posteriormente apresentada à Academia Sueca de Ciências e à Fundação Nobel, que ofereceram incluso certa resistência antes de aprovar o prêmio em 1968. Só então ele
} 
o prêmio pois era por toda parte seguido e vaiado por multidões (MONTES, 2015, p. 19). O que se indagava era: como o autor de Capitalismo e liberdade (1962) oferecera apoio e recomendações a um ditador, compactuando com a instauração de um capitalismo sem liberdade? Em sua obra, entretanto, ele sustenta explicitamente que o comunismo seria a aniquilação completa da liberdade econômica e humana; em comparação, uma ditadura com liberdade econômica poderia oferecer a esperança de um dia levar à liberdade política, já que a causalidade ocorria nessa direção.

O experimento neoliberal chileno, marcado pela abertura total aos mercados, desregulação, privatização e combate à inflação foi replicado em diversas áreas do globo nos anos seguintes, atingindo países centrais e periféricos. No caso brasileiro, a inflexão neoliberal não foi conduzida de modo centralizado por economistas organicamente ligados a Chicago. Ocorreu predominantemente como expressão da tendência neoliberal que ganhava o mundo após a conversão dos EUA de Ronald Reagan e da Inglaterra de Margareth Thatcher à nova doutrina. Tampouco houve no Brasil a colonização de um centro universitário pela Escola de Chicago, como nos casos do Chile, da Argentina e da Colômbia, e não consta no currículo de Harberger que tenha oferecido consultoria direta ao governo brasileiro, como no caso do Uruguai ${ }^{351}$. A cooperação entre Chicago e o Brasil não parece, pois, ter ultrapassado o nível da recepção, no programa de pósgraduação de Chicago, de brasileiros bolsistas da USAID e da Fundação Ford, instituições das quais Harberger tornou-se consultor, respectivamente, em 1963 e 1965. Lograram, não obstante, exercer influência.

Os primeiros brasileiros egressos dos doutorados de Chicago, alguns dos quais enviados ao exterior por intermédio do CENDEC, dirigido por Og Leme, só aos poucos foram apoderando-se do espaço no governo e na academia. Nos anos 1970, começaram por conquistar postos de direção na Escola de Pós-Graduação em Economia da Fundação Getúlio Vargas do Rio de Janeiro, mas apenas no início dos anos 1980 passarão a ocupar cargos públicos de destaque, levando a liberalização e o monetarismo à la Chicago para a administração do Estado e radicalizando as reformas pró-mercado que

passou a ser chamado de prêmio Nobel de economia e incorporou as regras aplicadas aos outros prêmios apoiados pela Fundação (LEBARON, 2006a, p. 89).

${ }^{351}$ Harberger menciona ter dado consultorias a Índia, Panamá, Chile, Colômbia, Uruguai, El Salvador, Indonésia, Canadá, Bolívia, México, Paraguai, China, México, Malawi, República Dominicana, Venezuela, Nicarágua, Equador e Rússia. Ver o currículo em http://www.econ.ucla.edu/harberger/AH-longcv.pdf, consultado em 13/09/2015. 
teriam sido ensaiadas em versão moderada no PAEG. No Brasil, o economista mais diretamente associado a Chicago é Carlos Geraldo Langoni, que esteve ao lado de Friedman e Harberger na visita ao Chile de Pinochet em 1975.

Langoni (1944) nasceu em Nova Friburgo, no Rio de Janeiro, neto de Pedro Curió, jornalista e autor de obra acerca da fundação e história de sua cidade. Langoni frequentou o Colégio Nova Friburgo com bolsa de estudos oferecida pela Fundação Getúlio $\operatorname{Vargas}^{352}$ e ingressou na Faculdade de Economia da UFRJ. Lá chegou a participar de atividades estudantis da frente que organizava a oposição ao regime militar, decretado quando cursava o segundo ano da faculdade (CARNEIRO, 2003, p. 8). Em 1967, um ano depois de graduado, Geraldo frequentou o curso do CENDEC e foi selecionado por Harberger para tornar-se bolsista da Fundação Ford na University of Chicago, onde defendeu, em dezembro de 1970, o doutorado A study in economic growth: the Brazilian case, no qual consta o seguinte agradecimento:

Sou profundamente grato ao meu presidente do meu comitê [de tese], o professor Arnold C. Harberger, por seu apoio contínuo e orientação basal nas linhas principais desta tese. Sem a sua vontade de compartilhar comigo seu vasto conhecimento da economia e da metodologia de pesquisa, este trabalho nunca poderia ter sido feito. Eu gostaria também de agradecer aos outros membros do meu comitê, os professores Mary Jane Bowman e Larry Sjaastad por suas numerosas e valiosas sugestões. Uma nota de agradecimento também vai para o professor T. W. Schultzcom de quem aprendi a estrutura teórica geral na qual este estudo é desenvolvido. Uma palavra especial de agradecimento ao Dr. Og Leme, que, como diretor da unidade de treinamento do Ministério do Planejamento do Brasil (CENDEC), me ofereceu - através da bolsa Fundação Ford - os fundos necessários para todo meu trabalho acadêmico na Universidade de Chicago. Mas, ainda mais importante, quero agradecer-lhe por seu entusiasmo, estímulo e amizade (LANGONI, 1970, p. ii).

Ao regressar ao Brasil, no início dos anos 1970, Langoni trabalhou na reestruturação do mestrado do IPE-USP que, nesse ano, vivia a transição da titularidade dos cursos entre os membros da missão de Vanderbilt e os professores da casa, que até então eram apenas assistentes. Langoni declara que buscou:

Reestruturar o programa de mestrado em economia em moldes modernos, semelhantes aos das universidades americanas, evidentemente com muita influência de Chicago. Introduzi, por exemplo, a idéia de trimestre e um esquema em que havia cadeiras obrigatórias, um exame no meio do curso e depois cadeiras opcionais. Esse exame das cadeiras obrigatórias era chamado de core examination e, além da tese, dava acesso ao título de mestre (Carlos Geraldo Langoni in: D'ARAÚJO, 1999, p. 181).

352 Ver: http://gvces.com.br/fgv-faz-60-anos-e-aposta-alto-na-educacao?locale=pt-br. $\quad$ Consultado em $14 / 02 / 2016$. 
Sua ligação com o IPE resultou também no engajamento em um estudo contratado por Delfim Netto, então Ministro da Fazenda, para avaliar as mudanças no padrão de distribuição de renda nos censos de 1960 e 1970, com o intuito de responder aos estudos de Albert Fishlow, que indicavam que a política econômica dos militares teria provocado enorme concentração de renda.

Albert Fishlow, enquanto dirigira a Missão Califórnia, havia trabalhado com uma amostra do censo demográfico de 1960 para fazer um estudo sobre a distribuição de renda no Brasil. Conta ele que:

Foi possível selecionar uma amostra segundo os elementos das rendas
diferenciadas e, se não me engano, conseguimos cerca de 6 mil observações, o
que constituiu a base do estudo em que me concentrei em 69 , depois que saí do
Brasil [...]. Foi considerado uma coisa notável o fato de eu estar aproveitando os
dados disponíveis no IBGE, e havia grande interesse no assunto. Surgiu um
problema mais tarde, quando voltei ao Brasil como professor independente, se
não me engano, em 71. Acabavam de ser divulgados os resultados preliminares
do Censo Demográfico de 1970 . Tive a idéia de fazer uma comparação entre a
distribuição de renda em 60 e em 70 e consegui acesso a essas informações com a
ajuda do ministro Velloso, que ainda estava no IPEA [353]. Foi aí que constatei,
em primeira mão, como tinha piorado a distribuição de renda entre 1960 e 70 .
Com esses dados, escrevi um artigo que apresentei na convenção da Associação
Americana de Economia. Hollis Chenery, que agora estava trabalhando no Banco
Mundial, presidia a sessão, e logo depois da reunião fui chamado ao Banco
Mundial, que estava interessado no problema de distribuição de renda e fazia
estudos em outros países. Falei também com Robert McNamara, presidente do
banco, que estava igualmente interessado no problema (Albert Fishlow in:
D’ARAÚJO et al., 2005, pp. 53-54).

Ainda que os pesquisadores da Escola Superior de Agricultura Luiz de Queiroz (ESALQ) Rodolfo Hoffmann e João Carlos Duarte e a CEPAL estivessem trabalhando simultaneamente dados sobre a distribuição de renda no Brasil, pode-se dizer que foi o artigo Brazilian size distribution of income, apresentadopor Fishlow na reunião da American Economic Association em dezembro de 1971, que fez circular publicamente a controvérsia do desenvolvimento. Ao ecoar nas mãos do presidente do Banco Mundial, o artigo de Fishlow incitou reações por parte dos representantes do governo, que se tornou alvo de críticas em escala internacional. A réplica oficial foi elaborada por Geraldo Langoni, em 1972, e contava com o patrocínio do Ministério da Fazenda de Delfim Netto e com exclusivo acesso aos dados completos do censo e do imposto de renda. Ainda que a controvérsia seja larga e tenha repercutido em diversos setores da intelectualidade, ater-

\footnotetext{
${ }^{353}$ Velloso não estava mais no IPEA neste momento, já era o Ministro do Planejamento, mas o IPEA ficava sob o controle de seu ministério.
} 
se-á aqui à exposição dos posicionamentos de quatro personagens apresentadas neste capítulo: Fishlow, Delfim Netto, Langoni e Malan.

Em Brazilian size distribution of income Fishlow sustenta que o crescimento da renda das nações em desenvolvimento é uma medida de performance econômica inadequada, já que ela negligencia um importante aspecto do desenvolvimento que é a distribuição de renda, que pretende analisar no artigo. Para tanto, estimou a variação da distribuição ao longo da década de 1960 e avaliou a conexão entre a crescente assimetria econômica e as políticas implementadas pelo governo ao longo do período analisado (FISHLOW, 1972, pp. 391). Fishlow argumenta que antes de entusiasmar-se com o "milagre" econômico brasileiro cabe ver que o censo de 1970 traz resultados pouco promissores, ao mostrar que houve grande concentração de renda no topo da sociedade brasileira, de modo que a faixa dos 3.2\% da população economicamente ativa de maior renda, que concentravam 27\% da renda do país em 1960, passam a controlar 33.1\% da renda brasileira ${ }^{354}$ em 1970 (FISHLOW, 1972, p. 399).

Fishlow contesta a explicação segundo a qual a concentração de renda observada nos anos 1970 seria mero reflexo do crescimento econômico do final da década, dizendo que apenas o período final daqueles anos foi marcado por crescimento acelerado, sendo que a piora dos indicadores de equidade começara muito antes disso. Indica, portanto, que a degradação da igualdade seria resultado, essencialmente, da política de estabilização adotada pelo PAEG, que provocou declínio de 20\% no valor real do salário mínimo. Mantidas as diretrizes políticas, não haveria espaço para otimismo quanto a efeitos distributivos da taxa de crescimento, visto que os setores com principal expansão não eram os que atendiam ao mercado interno de baixa renda, como alimentos e têxteis, e sim bens de consumo duráveis e automóveis (FISHLOW, 1972, p. 400).

A análise de Fishlow converge com aquelas tecidas no Chile no mesmo período, analisadas no capítulo anterior, que criticam o modelo de crescimento calcado na concentração da renda, via compressão dos salários e aniquilação do poder de reivindicação popular, e no deslocamento das atividades produtivas para setores voltados

\footnotetext{
${ }^{354}$ Comparando os dados de Fishlow e Hoffman e Duarte, José Serra mostra que chegam a conclusões bastante próximas: o primeiro aponta para um declínio de $10,49 \%$ para $7,14 \%$ na renda dos $40 \%$ mais pobres e os segundos de $11,20 \%$ para $9,05 \%$ e mostram que a concentração no topo ( $5 \%$ mais ricos) teria variado por volta de $10 \%$, tendo, no primeiro estudo, o valor variado de $28,55 \%$ em 1960 para $38,22 \%$ em 1970 e, no segundo estudo, de $27,35 \%$ para $36,25 \%$ (SERRA, 1975, p. 280). Langoni fala de um aumento de 39,66\% para 47,79\% da renda concentrada nos $10 \%$ mais ricos (LANGONI, 1973, p. 206).
} 
à população de alta renda, o que acentuava o dualismo da estrutura econômica brasileira. Isto com patrocínio do Estado que, ao mesmo tempo que comprimia as classes populares, oferecia subsídios ao investimento em setores intensivos em capital, inclusive conferindo vantagens para que o capital externo adentrasse o país (TAVARES e SERRA, 1976, pp. 211-212, 224-227, 238). Esse último ponto, o pacto da elite dirigente interna com o capital monopolista externo, destacado tanto no texto de Tavares e Serra de 1970 quanto nas teorias da dependência, não figurava na explicação de Fishlow, que atribuía inteiramente às políticas internas a crescente desigualdade detectada. É possível indagar se, ao não adentrar tal tópico, seu texto não se tornou mais palatável a órgãos como o Banco Mundial.

A defesa da disseminação das técnicas modernas na agricultura, cuja ausência era vista por ele como um entrave ao crescimento acelerado e à modernização no campo que resultaria em pobreza em termos absolutos de grandes parcelas da população (FISHLOW, 1972, p. 394) era em alguma medida compatível com a posição de Furtado por reformas estruturais que permitissem maior integração da força de trabalho no campo e na cidade; que impedissem a concentração de renda; que permitissem a ampliação dos mercados; e que empregassem o progresso tecnológico para modernização das economias regionais e das estruturas sociais, sem as quais não seria possível transpor a fase inicial da industrialização por substituição de importações e dar prosseguimento ao desenvolvimento econômico (FURTADO, 1968, pp. 39-40, 84-87).

Furtado, Tavares, Serra e os dependentistas cepalinos e marxistas consideravam ser a estrutura de classes existente no Brasil o entrave principal à instauração de um modelo econômico igualitário. A observação sociológica, colada à análise econômica, leva-os a argumentar que há entraves de natureza política e social subjacentes à adoção de um modelo econômico calcado na exploração e concentração de renda. Fishlow indica a natureza política das escolhas que teriam levado ao efeito econômico observado e vincula estas à decisão do regime militar de constranger econômica e politicamente as classes populares, vistas por eles como uma ameaça à ordem social. Para sustentar semelhante argumento, confronta-se com a necessidade de descartar explicações alternativas, como um inoportuno efeito concentrador decorrente da desorganização da remuneração do trabalho provocada pelo rápido crescimento ou um efeito direto da variação na escolaridade que aumenta desproporcionalmente os rendimentos daqueles expostos a um 
mais largo período de escolarização, criando uma disparidade transitória decorrente da mudança no perfil educacional em uma economia que experimentava um acelerado crescimento (FISHLOW, 1972 pp. 398-402).

Ao avaliar a hipótese concernente aos efeitos da educação sobre a concentração de renda, Fishlow dirige-se diretamente à Escola de Chicago, dizendo que a importância das variáveis educação e idade na composição da desigualdade poderia favorecer a interpretação proposta pela Teoria do Capital Humano de Theodore Schultz e Gary Becker, se não houvesse evidências em contrário, a saber:

1) há um suposto causal na teoria segundo o qual o investimento educacional leva necessariamente ao acréscimo de renda. No caso observado essa relação é inversa, uma vez que o acréscimo de renda das famílias é um importante determinante do grau de investimento educacional, sendo a educação de nível superior, essencialmente monopolizada por aqueles já abastados economicamente e filhos de pais altamente escolarizados; 2) mesmo a ampliação da escolarização não garantiria uma transformação da estrutura social, já que outros mecanismos institucionais poderiam surgir para favorecer a persistência de diferenças de renda; 3) finalmente ressalta o pouco da desigualdade observada que pode ser atribuída à educação, visto que, juntamente com a idade, a variação atribuída às duas variáveis não passa o um terço da desigualdade observada - isso caso sejam considerados os indicadores como independentes de outras propriedades sociais. Mais do que isso, não são os anos de escolaridade tomados em si, e sim a distância entre o aumento da escolaridade em diferentes grupos o mais importante determinante da parte da desigualdade associada à educação. Conclui, portanto, que a "suposição de que a desigualdade é afetada diretamente somente pela taxa de retorno e número de anos de escolarização é uma grande profissão de fé” (FISHLOW, 1972, pp. 398-399, 401-402).

O fato de passar duas das doze páginas do texto confrontando a Escola de Chicago e de usar o mesmo tipo de demonstração econométrica por eles empregado para comprovar sua tese mostra a que ponto o debate era pautado pelas teses formuladas em Illinois e o quanto a validade científica era medida pela capacidade de formular uma explicação com o mesmo tipo de demonstração estatística e matemática por eles empregada. A crítica de Fishlow adequa-se, pois, aos parâmetros de cientificidade dominantes entre os economistas de seu tempo, não deixando de "ter, ser e fazer aquilo 
que eles têm, são e fazem” (BOURDIEU, 1994a, p. 128). Neste sentido, sua produção não é herética, visto que não contesta as regras instituídas, ao contrário, busca competir com a interpretação dominante em seu próprio jogo, no caso tentando usar a econometria, a principal arma de Chicago, contra Chicago (BOURDIEU, 1994a, pp. 139140). O eco internacional do artigo e o convite para falar e ser ouvido no Banco Mundial derivam dessa capacidade de confrontar o modelo explicativo dominante em seus próprios termos, o que a explicação de matriz sociológica já existente sobre o tema não era capaz de fazer (LOPES, 1973, pp. 47-48, 54).

Em 1973, ao comentar a controvérsia, o economista e antropólogo que trabalhava na FINEP, José Sérgio Leite Lopes, familiarizado com Bourdieu, faz notar o caráter fetichista do debate acerca da distribuição de renda, feito com base em um tratamento estatístico que mistifica e abstrai o caráter humano e ativo da criação da desigualdade. As contribuições dos economistas, tecidas na linguagem completamente exotérica do tratamento de variáveis econométricas e estatísticas, são amplamente comunicadas a um público leigo como uma discussão sobre números com consequências políticas previstas pelos especialistas, e não apresentadas como um debate acerca dos fundamentos políticos, centrado nas reivindicações econômicas de diferentes grupos sociais e aberto à participação de toda a população e todos os tipos de especialistas (LOPES, 1973, pp. 4748).

Se Fishlow contrapunha-se claramente às teses da Escola de Chicago, Carlos Geraldo Langoni, em sua contribuição ao debate da distribuição de renda, exposta de maneira mais sistemática no livro Distribuição da renda e desenvolvimento econômico do brasil (1973), contrapõe-se frontalmente a Fishlow fundamentando sua análise na teoria do capital humano. Affonso Pastore diz, de maneira anedótica, que o debate sobre a distribuição da renda foi travado por "Langoni, que defendia a mesma posição do Delfim, e o [Pedro] Malan, que defendia a posição do Fishlow. Quando Delfim não queria brigar direto com Fishlow, mandava Langoni, quando Fishlow não queria brigar, mandava Malan (risos). Era Chicago contra Berkeley" (PASTORE, 1996, p. 225). O livro de Langoni é prefaciado por Delfim Netto, que oferece uma síntese da interpretação ali contida, desqualificando as teses adversárias:

No momento em que o sucesso do modelo de desenvolvimento posto em prática, a partir de 1964, tornou ridícula a discussão em torno da viabilidade econômica do país ou da fatalidade inflacionária das economias em crescimento, 
o problema da distribuição de renda se transformou em um dos mais controversos temas da atualidade brasileira. A publicação dos resultados do Censo Demográfico permitiu constatar o aumento da desigualdade de distribuição da renda entre 1960 e 1970. Alguns com pouca imaginação, com mais ideologia do que teoria, tentaram atribuir à política econômica da segunda metade da década a responsabilidade maior pelo que tinha acontecido. Outros mais afoitos e menos equipados chegaram a sugerir a troca de alguns pontos de percentagem na taxa de crescimento por reduções proporcionais nos índices de concentração, um verdadeiro conto do vigário que terminaria por deixar o País dividindo a miséria de maneira mais equitativa. Langoni prova que o aumento observado de desigualdade é consequência direta dos desequilíbrios de mercado característicos do processo de desenvolvimento. Deste modo, o comportamento das rendas relativas reflete, primordialmente, o processo intenso de diferenciação da força de trabalho causada pela rápida expansão dos setores modernos. Nestes setores, entretanto, a mão-de-obra é altamente produtiva recebendo, por isso mesmo, níveis de maior remuneração relativamente elevados, ainda que a sua dispersão seja maior. Dentro deste contexto não há sentido em tomar o aumento da desigualdade como indicador de piora de bem-estar. Pelo contrário, como enfatiza Langoni, o crescimento acelerado é o instrumento mais poderoso para redistribuir oportunidades (DELFIM NETTO, 1973, pp. 13-14).

Langoni argumentava ser "falaciosa a tentativa de atribuir a este aumento de concentração qualquer conotação de piora ou redução de bem-estar", já que a desigualdade estaria associada, essencialmente, a mudanças qualitativas que acompanham o processo de desenvolvimento econômico, por exemplo, o aumento do nível educacional, a entrada de jovens e mulheres no mercado de trabalho e a transferência de mão-de-obra do setor primário para o secundário e terciário (LANGONI, 1973, p. 15). Contra as teses da CEPAL, de Hoffmann e Duarte e de Fishlow, sustenta que a deterioração da equidade de renda faz parte da transição em direção a um arranjo econômico e social mais estável e moderno que tenderá, naturalmente, a reduzir-se. Mais pessoas serão empregadas e, uma vez que a educação tenha alcançado maiores parcelas da população ${ }^{355}$, os salários elevados daqueles poucos que até então tinham qualificação de nível superior serão corrigidos pelas forças poderosas que atuam do lado da oferta e da demanda, nivelando a remuneração da força de trabalho no ponto ótimo (LANGONI, 1973, pp. 97, 190, 214).

A correlação entre a remuneração do trabalho e o nível de educação, prevista pela

\footnotetext{
${ }^{355}$ No capítulo 10, sobre implicações políticas, Langoni sugere uma série de medidas para a aceleração da formação do capital humano: 1) defende a expansão prioritária da educação básica, que tem um custo menor do que a educação superior. O setor público deveria, pois, reduzir sua participação nas universidades, concentrandose no nível primário; 2) sugere que se cobre dos estudantes ricos os custos diretos da educação superior subsidiando os mais pobres ou que se cobre de todos e se instale um sistema de empréstimos estudantis a serem saldados após a entrada no mercado de trabalho - como nos EUA; e 3) recomenda oferecer no ensino superior formações menos especializadas, deixando ao mercado a tarefa de complementar o treinamento dos recrutados na direção que lhe aprouver (LANGONI, 1973, pp. 218, 221).
} 
teoria do capital humano e objetada por Fishlow, é um a priori no trabalho de Langoni, que parte do pressuposto que "os investimentos em educação [medidos em anos de estudo] resultam em acréscimos de produtividade, cuja contrapartida no mercado são ganhos de salário real e que se constituem justamente nos benefícios (privados) destes investimentos" (LANGONI, 1973, p. 103). De acordo com o autor:

na medida em que os indivíduos respondem à sinalização fornecida pelo mercado, haverá estímulo para investimentos adicionais em capital humano em geral e, particularmente, no treinamento específico para ocupações e qualificações em que maior é a expectativa de aumentos de demanda. Em nível de educação formal, esta pretensão pode evidentemente esbarrar na rigidez da oferta pelo setor público: de qualquer maneira, é razoável esperar-se que, sendo suficientemente forte a pressão da demanda, até mesmo as instituições (ainda que com certo atraso) respondam às necessidades da economia. Por outro lado, a limitação da oferta de certos tipos de mão-de-obra significa aumento de custos para a firma individual, criando consequentemente incentivos para que também o setor privado invista relativamente mais no treinamento específico e até mesmo no aumento de suas transferências para o sistema de educação formal (LANGONI, 1973, p. 190).

Em dezembro de 1973, Pedro Malan e John Wells ${ }^{356}$, que eram alunos de Fishlow em Berkeley, publicam uma resenha do livro Distribuição de renda e desenvolvimento econômico do Brasil, na qual contestam, antes de tudo, a aceitação mecânica do postulado do comportamento racional, apresentando as seguintes objeções à teoria do capital humano: 1) o modelo supõe que a renda equivaleria à produtividade de cada indivíduo, mas é impossível medir a produtividade marginal de cada trabalhador; 2) não é possível vincular a renda diretamente aos atributos sociais ignorando o processo social de produção de bens e serviços, a distribuição prévia de ativos reais e financeiros e a estrutura de poder da sociedade; e 3) a direção da causalidade (investimento em educação - produtividade renda) pode estar completamente viciada ignorando, por exemplo, o efeito que a renda e o background familiar teriam sobre a educação dos filhos e sua renda subsequente 357 como postulado por Fishlow (MALAN e WELLS, 1975, pp. 241-243, 258-259, 354).

Finalmente Malan e Wells argumentam que "Langoni simplesmente ignora, de

\footnotetext{
${ }^{356}$ Ver: http://www.independent.co.uk/arts-entertainment/obituary-john-wells-1126818.html. Consultado em $17 / 02 / 2016$.

${ }^{357}$ Ao que Langoni responderá: "a correlação entre status social e nível de educação é bem menor do que possa parecer à primeira vista, reiterando, desta maneira, a influência independente desta variável. Este último resultado é consistente com o bom senso. Em uma economia como a brasileira, em que o estoque de capital humano sob a forma de anos de escolaridade da força de trabalho é pequeno, mas onde o fluxo em termos de entrada de novos indivíduos mais qualificados (ou seja, acréscimos de anos de escolaridade) é extremamente elevado, existem todas as condições para que seja quebrada a relação entre background familiar e nível de educação dos filhos e seja, portanto, maximizada a influência independente da educação" (LANGONI, 1974, p. 173).
} 
forma deliberada, a existência de interpretações alternativas à sua para as causas desse aumento de desigualdade, em particular aquelas enfatizando a condução da política econômica durante a década" e reportam que não há indicações de que haja tendências intrínsecas que levem à distribuição automática de renda ou riqueza após o crescimento. Quando isso ocorreu, dizem, resultou de "atividades organizadas politicamente por parte dos grupos e classes interessadas no controle ou na influência sobre a estrutura de poder da sociedade, consubstanciada no aparato institucional do Estado", o que o autor, crente nas forças impessoais do mercado, ignora (MALAN e WELLS, 1975, pp. 246, 256-257).

Em sua resposta, Distribuição de renda: uma versão para a minoria (1974), Langoni acusa os adversários de terem rompido com a teoria econômica.

O verdadeiro conteúdo das críticas de Mallan [sic] e Wells é revelado na última parte do trabalho. Eles simplesmente afastam a possibilidade de aceitar uma análise com base na teoria econômica, já que consideram ser impossível submeter a qualquer teste empírico a teoria da produtividade e, consequentemente, a teoria do capital humano, sua extensão mais recente. Esta afirmativa surpreendente é contrariada por uma respeitável herança cultural, que afinal de contas levou a Economia ao status de ciência [...]. É agora fácil entender o empenho de Mallan [sic] e Wells em negar a validade a qualquer interpretação que se baseie na teoria econômica. É porque neste caso as forcas impessoais de oferta e demanda substituem, segundo suas próprias palavras “... atividades organizadas politicamente por parte dos grupos e classes interessados no controle ou na influência sobre a estrutura da sociedade consubstanciada no aparato institucional do Estado" (LANGONI, 1974, p. 179).

Completa dizendo: "nós só não sabemos o que desagrada mais a Malan e Wells; a demonstração, uma vez mais, da relevância do instrumental neoclássico de oferta e demanda, ou a previsão implícita no modelo de redução no grau de desigualdade" (LANGONI, 1974, p. 175), que arrefece o poder da crítica que apresentam ao governo militar.

Ao que Malan responde, também em 1974, em Ainda sobre a distribuição de renda, afirmando que o debate apresenta

uma importante peculiaridade: peca por não distinguir claramente entre o debate teórico em economia, o debate sobre os procedimentos estatísticos utilizados na manipulação dos dados empíricos, e o caráter especificamente político da questão. Em uma clara manifestação deste último aspecto, a controvérsia tem sido apresentada em termos de um discutível maniqueísmo, que contrapõe uma posição científica a uma posição política sobre o tema. Assim, de um lado, estariam aqueles que enfatizam um genérico processo de diferenciação da força de trabalho, que se acentuaria nas fases de aceleração do crescimento econômico, gerando um desequilíbrio de curto prazo no mercado de trabalho, que beneficiaria - temporariamente - aqueles mais qualificados (educados) dada sua escassez relativa (e inelasticidade da oferta a curto prazo). De outro lado, estariam 
E retruca:

aqueles que não reduzem o fenômeno à operação deste impessoal jogo de forças de mercado competitivo de trabalho, chamando a atenção não só para a distribuição de ativos reais e financeiros, como também para a importância da política econômica passada, presente e futura do Governo, para a questão da distribuição pessoal e funcional (entre salários e lucro) da renda [...]. Infelizmente, Langoni parece ter optado definitivamente pela miopia maniqueísta. O propósito de sua recente nota é o de desqualificar os comentários apresentados em uma resenha bibliográfica de nossa autoria sobre sua obra tachando-os ora de “ingênuos" ora de "radicais" (MALAN, 1974, pp. 116-117).

não rompemos com a teoria econômica. Pelo contrário, sentimo-nos em excelente companhia ao lado daqueles que têm sérias divergências com as teorias de capital humano, com simplistas associações de salários às produtividades marginais e com a metodologia as if da economia positiva. Citar nomes de autores, departamentos de economia e escolas de pensamento econômico seria demasiado longo. Afinal, Chicago não é o centro do mundo acadêmico, nem a teoria econômica um monolítico bloco de dogmas para aplicação imediata [...] Em resumo, não tentamos "invalidar" a evidência "empírica" apresentada por Langoni, nem tampouco "romper" com a teoria econômica. Apenas sugerimos várias qualificações à forma de utilização de certa evidência empírica, com fins de corroborar determinada interpretação baseada em hipóteses a priori escolhidas (e acriticamente aceitas pelo autor) que nós - juntamente com outros economistas que não romperam com a ciência - consideramos legitimamente discutíveis, tanto ao nível teórico quanto ao nível das interpretações resultantes (MALAN, 1974, p. 118).

O debate acerca da distribuição de renda converte-se, pois, em uma discussão sobre o que é fazer ciência econômica e quais as fronteiras da disciplina. A conjugação de considerações provenientes das ciências sociais, na interpretação de Langoni seria uma rejeição da ciência econômica, pois desviaria de buscar na própria economia um modelo de análise. A visão de Chicago, vocalizada por ele, que ganhava cada vez mais espaço internacional, concebe a economia como uma ciência a parte, na qual as variáveis relevantes para a análise devem estar integradas no modelo econométrico e somente a elas o resultado poderia dizer respeito. Langoni afirma que,

do ponto de vista de teste do modelo, o que é efetivamente relevante é a significância estatística das variáveis consideradas no modelo e não necessariamente o seu poder de explicação. No nosso trabalho, entretanto, ambos os resultados foram inteiramente satisfatórios [...]. Não faz o menor sentido julgar a relevância de nosso modelo pela sua capacidade de reproduzir a distribuição observada. Ele simplesmente não foi construído para este objetivo. $\mathrm{O}$ interesse nos perfis estimados a partir das regressões é unicamente o de simular qual seria o grau de desigualdade na distribuição de renda, caso as diferenças individuais fossem somente as representadas pelas variáveis do modelo (LANGONI, 1974, p. 168).

Nesse sentido, a presente controvérsia pode ser remetida à contraposição, feita no Primeiro Movimento, entre Prebisch, patrono de uma teoria econômica voltada à 
explicação de casos concretos e particulares, e Viner, professor dos professores de Chicago, que concebia a teoria econômica como um sistema lógico integrado e universal, no qual não faria sentido, por exemplo, pensar em uma teoria voltada à análise do caso latino-americano, visto como uma exceção à teoria do comércio internacional, que deveria ser total. Novamente há, de um lado, um pleito político associado a uma intepretação sobre a economia e, de outro lado, uma defesa da universalidade da ciência econômica que deveria poder abstrair as dimensões sociais e políticas, supondo, como Friedman, que a democracia advirá naturalmente da estabilidade econômica ou, como Langoni, que há uma tendência natural de correção, pelo mercado, da desigualdade gerada na transição.

O debate sobre a distribuição de renda é fulcral na demarcação da posição daqueles que criticavam o governo militar. Seminários sobre o tema floresceram em redutos críticos como o Centro Brasileiro de Análise e Planejamento (CEBRAP) e a Universidade Estadual de Campinas (UNICAMP). Pouco depois alguns especialistas em economia que ficaram mais conhecidos por sua oposição à política econômica do regime militar: Luiz Gonzaga Belluzzo, Maria da Conceição Tavares, Paul Singer, Rodolfo Hoffmann, Edmar Lisboa Bacha, Albert Fishlow, John Wells, Pedro Malan, José Serra e José Leite Lopes publicam suas contribuições sobre o tema no livro $A$ controvérsia sobre distribuição de renda e desenvolvimento (1975), prefaciado por Fernando Henrique Cardoso (item 3.3). Nele atacam seus oponentes justamente por justificar a política econômica dos militares através do linguajar esotérico da economia calcada em técnicas matemáticas e premissas dogmáticas (CARDOSO, 1975, p. 9). A tendência à matematização representada por Chicago se arraigaria com os anos, detendo cada vez maior controle sobre o espaço dos economistas, de modo que mesmo os insurgentes viram-se obrigados a lutar com as mesmas armas e termos para conquistar espaço para suas teses contestatórias.

\subsection{Marcos Vianna: Brasil Potência-BNDE Potência}

Além de trabalhar no IPE-USP, Carlos Geraldo Langoni passou a fazer parte do quadro docente da EPGE, tendo sido seu nome levado a Mario Henrique Simonsen por Edmar Bacha. Langoni conta ter conhecido Bacha nos Estados Unidos e explica que "Bacha já estava se destacando na área acadêmica e ficamos logo amigos. Em diversas 
ocasiões participamos de discussões e debates. Era um bom relacionamento acadêmico". Além de Edmar, Langoni só conhecia na FGV Issac Kerstenetzky e Jessé Montello, dos quais foi aluno no curso do CENDEC. Bulhões fora seu professor na FNCE, mas, segundo Langoni, era uma figura inacessível. Bacha, por sua vez, explica que o determinante para que indicasse Langoni a Mario Henrique foi a recomendação que recebeu do professor Arnold Harberger, que conhecera no período em que esteve no Chile como consultor do projeto MIT-ODEPLAN. Carlos Geraldo consegue um contrato temporário com o IBRE para o primeiro semestre de 1971 e torna-se professor da casa a partir de 1972, quando Bacha já não fazia parte da Escola, da qual se dissociou no começo de 1971 (item 4.6) (Entrevista de Edmar Bacha à autora, 2012; Carlos Geraldo Langoni in: D’ARAÚJO, 1999, pp. 182-183).

Em 1969, ao retornar de seu ano no Chile, Edmar Bacha foi incorporado ao quadro da FGV, trabalhando com Simonsen e Kerstenetzky, e ao Instituto de Pesquisa do IPEA (INPES), a convite de João Paulo dos Reis Velloso. Bacha foi, depois de Velloso, dos primeiros alunos do Centro de Aperfeiçoamento de Economistas (CAE) a ser incorporado ao corpo docente da EPGE e argumenta que sua posição ali representava uma certa novidade para Mario Henrique Simonsen: "professor de tempo integral dando matérias substantivas era uma coisa que até então não existia”. À exceção de Simonsen, todos os professores exerciam a pesquisa e a docência na FGV em tempo parcial e mantinham outras atividades não acadêmicas em paralelo. Pouco depois de Bacha, Claudio de Moura Castro e Hamilton Tolosa, que retornavam de Vanderbilt e Pennsylvania, respectivamente, também tornaram-se professores da casa, dedicando-se às aulas na EPGE e às pesquisas coordenadas por Aníbal Villela no INPES (BACHA, 1998, p. 201; Edmar Bacha in ALBERTI et al., 2002, p. 96; Entrevista de Edmar Bacha à autora, 2012).

A incorporação dos ex-alunos do CAE ajudou a suprir a lacuna de professores que resultara do profundo entrelaçamento do corpo docente original da escola com a administração econômica do governo militar. $\mathrm{Na}$ época em que os jovens $\mathrm{PhDs}$ começaram a trabalhar na Fundação, Isaac Kerstenetzky afastou-se pois assumiu a presidência do IBGE de 1970 a 1979. Jessé Montello foi presidente do IBGE na sequência, de 1979 a 1985. Não tardaria a chegar a vez de Mario Henrique Simonsen que, em 1970, deixou de ser um colaborador apenas informal do regime e foi convidado pelo 
Ministro da Educação do governo Médici, o militar Jarbas Passarinho, a dirigir e captar recursos para o Movimento Brasileiro de Alfabetização (MOBRAL) ${ }^{358}$, um programa de caráter emergencial, que procurava reduzir o analfabetismo que assolava $30 \%$ da população brasileira. Por fim, João Paulo dos Reis Velloso, que já dividia suas atividades entre a Escola e o IPEA, afastou-se ainda mais quando assumiu a Secretaria Geral do Ministério do Planejamento, em 1968, e na sequência o Ministério do Planejamento, em outubro de 1969. Ele havia sido convidado pelo próprio presidente para passar do cargo de secretário do Ministério do Planejamento à posição de Ministro. Hélio Beltrão não quis permanecer no cargo e ele, além de ser o segundo homem do Planejamento, já dispunha de quatro anos de experiência à frente do EPEA/IPEA que ajudavam a qualificá-lo para o posto. Uma vez empossado, Velloso começou a trabalhar na elaboração do primeiro Plano Nacional de Desenvolvimento (I PND), que deveria orientar a política econômica e de desenvolvimento do período 1972-1974.

Mais do que o PED, o I PND enfatizava aspectos ligados à modernização da empresa nacional e da administração governamental e à implementação de uma política tecnológica nacional, para que o Brasil pudesse desenvolver tecnologia própria e favorecer a transferência de tecnologia para o país. Falava-se mais em educação e formação de recursos humanos, neste ponto enquadram-se o MOBRAL e as políticas de fomento à ciência e tecnologia, com o fortalecimento da FINEP, que passaria a gerenciar o Fundo Nacional de Desenvolvimento Científico e Tecnológico. O BNDE, de um lado, garantindo o financiamento à grande empresa nacional e aos grandes empreendimentos nacionais, especialmente nas áreas de infraestrutura e industrias básicas, e investindo em setores como siderurgia, petroquímica, energia nuclear, transportes e construção naval; e a FINEP, de outro lado, cuidando da atualização tecnológica, deveria ser órgãos chaves para a implementação do I PND (BRASIL, 1971, pp 7-9; João Paulo dos Reis Velloso in: D’ARAÚJO e CASTRO, 2004, pp. 114-117). Velloso conseguira garantir a influência sobre estes órgãos nomeando José Pelúcio Ferreira para a presidência da FINEP, em 1971, e Marcos Pereira Vianna para a presidência do BNDE, no final de 1970. Além disso

\footnotetext{
${ }^{358}$ O MOBRAL apropriou-se do adiantamento de $1 \%$ do imposto de renda das pessoas jurídicas e dos recursos da loteria esportiva para implantar um programa de alfabetização padronizada em massa. O governo enviava o material didático e recursos para pagar o professor, proporcionalmente ao número de alunos matriculados, e a gestão era feita comunitariamente em nível municipal. Para a secretaria executiva do MOBRAL, Simonsen recrutou Arlindo Corrêa, um amigo íntimo, que trabalhara com ele na CONSULTEC e era funcionário do Centro Nacional de Recursos Humanos do IPEA (Claudio de Moura Castro in: ALBERTI et al., 2002, pp. 133, 137; Arlindo Lopes Correa in: ALBERTI et al., 2002, pp. 136, 138-139).
} 
convidou Isaac Kerstenetzky, seu colega na FGV, para assumir o IBGE em 1970, o que aumentava o número de seus aliados estratégicos.

José Pelúcio Ferreira (1928-2002) era mineiro de Lambari, nascido em uma família sem posses. Sua mãe faleceu quando ele tinha um ano e meio e o pai partiu para o Rio de Janeiro em busca de melhores oportunidades de trabalho, deixando os filhos com os sogros em Baependi. Quando estava para ingressar no ginasial, a família transferiu-se para o Rio e Pelúcio foi estudar na escola que o Colégio São Bento mantinha para crianças pobres, dirigindo-se, no científico, para um colégio público. Por indicação do marido de uma tia de segundo grau, que era advogado e trabalhava no IBGE, Pelúcio conseguiu, aos 17 anos, um trabalho de mensageiro daquele órgão. Pouco depois foi aprovado em concurso interno para a função de auxiliar, indo trabalhar na área de Inquéritos Econômicos e depois na seção de Documentação Municipal. Em 1948, ingressou no curso noturno de graduação em ciências econômicas da UEG. No ano em que se formou, 1952, Pelúcio foi aprovado no concurso para Oficial Administrativo do IBGE, passando a fazer parte do quadro permanente da instituição (FERRARI, 2001, pp. 21-24.)

Ao ser montada a primeira equipe econômica para o BNDE, Roberto Campos convidou o tio de segundo grau de Pelúcio para ir para o Banco e ele levou junto o sobrinho, que foi nomeado interinamente para a função de assistente técnico e logo foi indicado para trabalhar com Celso Furtado no Grupo Misto CEPAL-BNDE. De agosto de 1954 a setembro de 1955, Pelúcio, que se tornou funcionário concursado do CNE, pode disfrutar de uma bolsa do Ponto IV, para estudar na Faculdade de Ciências Sociais da Universidade de Porto Rico. Gostaria de ter ido para uma universidade anglo-saxã, como fez seu colega Juvenal Osório que foi para a London School of Economics (LSE), mas seu nível de inglês não era suficientemente bom. Ao regressar, Pelúcio foi aprovado no primeiro concurso público realizado pelo BNDE, no qual foram admitidos também Juvenal Osório e Ignácio Rangel. A proximidade que estabeleceu com Celso Furtado na época do Grupo Misto fez com que ele fosse um dos convocados para trabalhar com Furtado no Plano Trienal do governo João Goulart, ficando encarregado do grupo responsável pelo setor agrícola, enquanto Juvenal Osório coordenava o setor industrial (FERRARI, 2001, pp. 25-30).

De volta ao BNDE, Pelúcio passou a ocupar-se cada vez mais dos temas ligados à tecnologia e formação de pesquisadores e profissionais qualificados, pontos que julgava 
serem grandes entrave ao desenvolvimento nacional, já que o país precisava adquirir parte substantiva da tecnologia e do know-how no exterior. A primeira iniciativa do BNDE voltada para o problema tecnológico foram as Cotas de Educação e Treinamento Técnico, criadas em 1958. A resolução que as criou definia que as empresas tomadoras de empréstimos do BNDE poderiam contar com um volume extra de recursos para investir na qualificação de seu corpo funcional. Quase nenhuma empresa solicitou essa verba, o que fez com que estudassem outras maneiras de enfrentar o problema. Pelúcio consultou nomes de destaque de universidades, centros de pesquisa, institutos tecnológicos e institutos militares para desenvolver uma nova proposta. Esta deu origem, em 1964, ao Fundo de Desenvolvimento Técnico-Científico do BNDE (FUNTEC) que passou a direcionar apoio para a formação de cursos de pós-graduação ${ }^{359}$ e para o desenvolvimento de pesquisas técnico-científicas, projetos piloto e experimentações no campo das indústrias básicas (FERRARI, 2001, pp. 33-42).

A prioridade atribuída ao desenvolvimento de ciência e tecnologia nacional, que contava com entusiasmado apoio dos nacionalistas da esquerda e da direita, só crescera nos anos seguintes, como é visível nos textos do Primeiro e do Segundo Plano Nacional de Desenvolvimento, dos governos Médici e Geisel. Para operacionalizar as políticas para o setor foi criado, em 1969, o Fundo Nacional de Desenvolvimento Científico e Tecnológico (FNDCT), do qual Pelúcio foi logo encarregado por ordem de Reis Velloso. Em 1971, o FNDCT e Pelúcio foram transferidos para a FINEP, órgão que havia sido criado no BNDE, como um Fundo de Financiamento de Estudos de Projetos e Programas que concedia empréstimos em áreas de pesquisa e desenvolvimento, e que, em 1967, fora convertido em uma empresa pública separada do Banco, a Financiadora de Estudos e Projetos (FINEP). Pelúcio, que trabalhara por quase um ano como secretárioajunto do Ministério do Planejamento, foi deslocado para a presidência da FINEP, na qual permaneceu até o fim da gestão de Velloso no Planejamento, em 1979 (FERRARI, 2001, pp. 69-73; SCHWARTZMAN, 2010, p. 14; João Paulo dos Reis Velloso in: D’ARAÚJO e CASTRO, 2004, pp. 117-118).

\footnotetext{
359 “É certamente notável o fato de que, tudo indica, a primeira regulamentação de cursos de mestrado e doutorado tenha sido adotada no país, ainda que para seu uso próprio, por uma instituição federal dedicada ao desenvolvimento econômico e que tenha sido responsável por sua formulação detalhada um economista de 36 anos de idade, que nunca tenha tido o magistério por profissão" (FERRARI, 2001, p. 43). Durante algum tempo houve rivalidade entre o CNPq e a FUNTEC, já que em teoria o CNPq deveria gerir a instalação do sistema de pós-graduação, mas na prática o FUNTEC tinha um orçamento muito maior e mais impacto, pois concentrava grandes montantes em um pequeno número de projetos (FERRARI, 2001, p. 49).
} 
O secretário-geral do Ministério do Planejamento, o outro homem de confiança de Velloso, era Marcos Pereira Vianna (1934-2012). Descendente distante de portugueses por parte de pai e mãe e membro de família católica pouco praticante, Vianna nasceu em Vitória, filho de Ary de Siqueira Vianna. Seu pai começou a vida adulta trabalhando como caixeiro viajante e depois tornou-se contador e funcionário público. Foi trabalhar na Secretaria da Fazenda, seguindo o rumo do avô, o coronel Alziro Vianna ${ }^{360}$, que havia sido primeiro diretor de contabilidade e depois secretário principal da Secretaria das Finanças de Vitória, tornando-se figura proeminente da política do Espírito Santo. Ary de Siqueira foi feito inspetor geral da Fazenda, depois diretor da Receita Pública e diretorgeral dos departamentos das Municipalidades e do Serviço Público do Espírito Santo. Em 1944, foi nomeado por Getúlio Vargas prefeito de Cachoeiro do Itapemirim, a segunda maior cidade do Espírito Santo. Na sequência foi eleito deputado federal e depois senador pelo PSD. Marcos Vianna cresceu nessa família nacionalista, getulista e imersa na política local. Ele diz ter sido um leitor ávido e que em sua casa eram todos "sôfregos devoradores de livros". Conta que passou a infância lendo o nacionalista Monteiro Lobato, mais tarde foi descobrindo Machado de Assis, Eça de Queiroz e outros (Marcos Vianna in: BETTENCOURT et al, 2010, pp. 21-22; DHBB, verbete Ary de Siqueira Vianna; Entrevista de Sérgio Besserman Vianna à autora, 2012; VIANNA, 2002, [DVD]).

Em 1945, a mãe de Vianna organizou a campanha da candidatura do marido a deputado federal, coordenando o envio de cartas escritas à mão para os eleitores. Ficavam mãe, filhos, tias e quem mais se dispusesse a colaborar redigindo as notas personalizadas que distribuíam pela região. Eleito, Ary Vianna transfere-se com a família para o Rio de Janeiro em 1946. Luiz Guilherme Vianna, o filho mais velho, é matriculado no Colégio Andrews, prestigiosa instituição de ensino carioca localizada em Botafogo. Marcos era mais novo, a mãe queria que estudasse perto, razão pela qual é matriculado no Colégio Hebreu-Brasileiro, que ficava na rua em que moravam na Tijuca. Ao entrar no científico, ele será transferido para o Andrews. Seu bom desempenho em matemática fez com que fosse contratado, assim que deixou a escola, aos 19 anos, para lecionar a disciplina no próprio Andrews enquanto cursava engenharia na Escola Nacional (VIANNA, 2002, [DVD]).

\footnotetext{
${ }^{360}$ Ver:
}

http://memoria.bn.br/DocReader/DocReader.aspx?bib=313394\&PagFis=78550 e

http://memoria.bn.br/DocReader/Hotpage/HotpageBN.aspx?bib=313394\&pagfis=78550\&pesq=\&url=http://me moria.bn.br/docreader\#. Consultados em 17/02/2016. 
Da graduação ele destaca a influência do Professor Antônio Dias Leite (item 2.4), catedrático responsável pela cadeira de economia, que foi o primeiro elo de ligação que teve com a área. Na faculdade era colega de Mario Henrique Simonsen, também fortemente influenciado por Dias Leite, que mais cedo do que Marcos enveredaria para a economia. Juntos Marcos e Mario serviram à Marinha em 1955. Marcos comenta: “durante este período compartilhamos experiências que guardarei para sempre na memória como as garrafas de cachaça consumidas às escondidas em nossos plantões noturnos ou as peripécias amorosas vividas em nossas viagens". Vinte anos depois seriam novamente colegas, um como presidente do BNDE, o outro como Ministro da Fazenda (Marcos Vianna in: BET'TENCOURT et al., 2010, pp. 24-32).

Enquanto cursava engenharia, Marcos concorreu à presidência do diretório estudantil por uma coligação dos nacionalistas com a esquerda comunista, mas perdeu a eleição. Seu irmão mais velho, Luiz Guilherme Vianna, aluno da Faculdade de Medicina, também era parte dessa fração de esquerda de inspiração varguista, que tinha algo de positivista e muito de nacionalista. Diferentemente do irmão, que foi trabalhar para os militares, Luiz Guilherme ingressou na militância comunista seguindo sua esposa Helena Besserman, judia de família polonesa, que ele conheceu na Medicina e que era irmã de um colega de Marcos do Colégio Hebreu (Marcos Vianna in: BETTENCOURT et al, 2010, pp. 30-31; Entrevista de Sérgio Besserman Vianna à autora, 2012). Sérgio Besserman Vianna, filho de Luiz Guilherme e Helena, que se tornaria diretor do BNDES e presidente do IBGE nos anos 1990, conta, em tom anedótico, que não teria nascido se Vargas não houvesse se suicidado:

O Partido Comunista era profundamente anti-Vargas, quase tanto quando o [Carlos] Lacerda, ou tanto quanto, pelo outro lado. O meu pai [que vinha de família getulista] começou a achar aquilo uma besteira e aí rompem o namoro. Só que no meio do caminho o Vargas se mata. No que ele se mata, o Partido Comunista, isso é história, muda de posição em 24 horas [...] e aí a minha mãe chega na Faculdade de Medicina ainda contra Vargas, [e lhe dizem] mudou, mudou, mudou... literalmente dão a ela uma ordem, pega um lençol branco, joga sangue de galinha e vamos para a passeata. Mataram Vargas! Mataram Vargas! E ela era a principal líder, cumpre a ordem mas antes passa na casa do meu pai... reatam o namoro [risos]. Se o Vargas não se mata, pronto, eu não estava aqui (Entrevista de Sérgio Besserman Vianna à autora, 2012).

O suicídio de Vargas também teve impacto na vida de Marcos Vianna que quase perdeu seu emprego na firma de Engenharia Civil e Portuária depois de dar um soco em seu supervisor, um udenista que debochou da morte do presidente. Ganhou a fama de 
esquentado, mas foi perdoado pelo alto escalão da empresa. Pouco depois foi alocado para trabalhar na construção da primeira estação portuária da Companhia Vale do Rio Doce, que se dedicava à exploração, comercialização, transporte e exportação mineral. Ao final da obra, foi convidado por Eliezer Batista, diretor da Vale, para integrar-se à empresa. Começou em 1956 como subchefe da Divisão Portuária e terminou como Superintendente Geral de Desenvolvimento. Em 1964, deixou a Vale, por discordar da abertura da exploração mineral à companhia estadunidense Hanna Mining, o que considerou um atentado ao interesse nacional (Marcos Vianna in: BETTENCOURT et al., 2010, pp. 38-42, 46, 55, 63, 72, 75-78; João Paulo dos Reis Velloso in: BET'TENCOURT et al., 2010, p. 231).

Foi então trabalhar na indústria Aços Anhanguera, em Mogi das Cruzes, e lá estava quando o recém empossado Ministro do Planejamento, João Paulo dos Reis Velloso, telefonou convidando-o para jantar. Reis Velloso não o conhecia pessoalmente, só de nome, tendo sido informado que havia sido um gestor eficiente e estratégico na Vale. Velloso convida-o para a Secretaria Geral do Ministério do Planejamento e para a presidência do IPEA. Foi então que Marcos começou a dedicar-se mais ao estudo de economia, já que tinha que enfrentar os densos relatórios, repletos de teoria econômica e econometria fabricados pelos $\mathrm{PhDs}$ que povoavam o IPEA (Marcos Vianna in: BETTENCOURT et al., 2010, pp. 38-42, 46, 55, 63, 72, 75-78; João Paulo dos Reis Velloso in: BETTENCOURT et al., 2010, p. 231).

Em setembro de 1970, Reis Velloso tem a oportunidade de participar da nomeação de um novo presidente para o BNDE. As críticas públicas de Jayme Magrassi de Sá a Delfim Netto resultaram rapidamente em sua demissão e era preciso encontrar um novo candidato ao posto. Propôs ao Presidente Médici que Marcos Vianna, seu braço direito no Ministério, assumisse a presidência do BNDE. A parceria Velloso-Vianna durou 10 anos e à ela atribui-se, frequentemente, o fim do isolamento do Banco e a restauração de seu prestígio - ainda que haja outros elementos que condicionaram o novo ciclo de ascensão do BNDE, que serão discutidos adiante. Logo que assumiu o Banco, Vianna fez uma reforma administrativa e, na sequência, renovou os quadros do Banco. Mas havia uma dificuldade adicional: o Fundo de Reaparelhamento Econômico, repasse do Imposto de Renda que alimentava o BNDE desde 1952, fora dissolvido em 1969. Consequentemente, qualquer verba de que o Banco pretendesse dispor deveria ser 
disputada no Conselho Monetário Nacional, presidido pelo Ministro da Fazenda. As negociações não eram fáceis e não havia previsibilidade da dotação de recursos para os anos seguintes, o que limitava o poder de ação de longo prazo do BNDE (PROCHNIK, 1995, p. 162; VIANNA, 2002, [DVD]).

Com o intuito de modernizar a instituição, Marcos Vianna começou por contratar uma consultoria externa estadunidense, a Booz-Allen Hamilton, para fazer uma reforma na estrutura operacional da instituição. Na metade dos anos 1960, o BNDE, em parceria com o BID, havia contratado essa mesma consultoria para fazer um um estudo sobre o setor siderúrgico (BNDE, 1966, p. 94). Comentava-se o sucesso que a Booz-Allen tivera na reestruturação administrativa e na expansão da siderúrgica estatal Usiminas, razão pela qual Vianna - com apoio de Ignácio Rangel, Saturnino Braga e Juvenal Osório que estavam entre os mais antigos e respeitados funcionários da casa e eram seus principais aliados - segue a fórmula e encomenda estudo de gestão e um plano de reforma administrativa para modernizar o Banco. Ele explica que a ideia era envolver na reforma o corpo funcional do BNDE, que julgava estar visivelmente desmotivado após uma década de solavancos. Ao tornar o processo participativo e perguntar que funções o BNDE deveria desempenhar, fazia-se com que todos se sentissem contemplados e representados (Marcos Vianna in: BETTENCOURT et al., 2010, pp. 85-87; VIANNA, 2010, p. 295; VIANNA, 2009, pp. 76-77; SOARES, 2009, p. 221; BRAGA, 2010, pp. 260-261).

O relatório administrativo do BNDE de 1972 expõe os objetivos do projeto:

A Administração busca elevar os índices de eficácia, através de sistemáticas e
procedimentos que a conduzam à melhor aplicação de seu contingente funcional,
razão pela qual foi preparado, como empreendimento conjunto do BNDE e de
conceituada empresa de consultoria, um projeto de melhoria organizacional e
administrativa. Entre os pontos mais relevantes, incluídos no trabalho, estão os
seguintes: reformulação do processo de decisão; - nova sistemática de
planejamento; - utilização de novas forças motivacionais; - ênfase especial à
melhoria de comunicações; - novas práticas de seleção e aperfeiçoamento da
equipe profissional (BNDE, 1972, p. 45).

Uma das modificações centrais introduzidas pela reforma foi a separação do setor de planejamento e prioridades da área de orçamento e concessão de crédito. O BNDE passou a ter uma veia operacional, que analisava a viabilidade e bancabilidade dos projetos, e uma divisão dedicada à reflexão sobre o desenvolvimento e à definição de prioridades de longo prazo. Entendia-se que "o planejamento é vital para um órgão como o Banco, cuja própria razão de existir é procurar identificar, com antecipação, sejam os 
gargalos do processo de desenvolvimento, sejam os fatores motrizes que, uma vez ativados, vão excitar focos de crescimento, focos de desenvolvimento" (VIANNA, 2009, pp. 77). Ao separar a função intelectual da agência de desenvolvimento, responsável por examinar criticamente o cenário econômico e elaborar planejamentos de longo prazo, da análise imediata de projetos, que é a função bancária, procurava-se restaurar o papel estratégico do BNDE e estabelecer um horizonte de planejamento econômico que atravessasse gestões governamentais (VIANNA, 2009, pp. 77-78).

Outra transformação foi a conversão do Banco de autarquia governamental em empresa pública, o que dava à instituição maior flexibilidade para estabelecer contratos, usar seus recursos e recrutar pessoal, além de permitir ligações com empresas subsidiárias. Isto permitiu que, em 1971, o Fundo de Financiamento para Aquisição de Máquinas e Equipamentos (FINAME) fosse convertido na primeira empresa subsidiária do BNDE, à qual se somariam, em 1974, três outras: a Mecânica Brasileira S.A. (EMBRAMEC), a Insumos Básicos S.A. (FIBASE) e a Investimentos Brasileiros S.A. (IBRASA), reunidas em 1982 para formar a BNDES Participações (BNDESPAR). Finalmente, a reforma criou o sistema, vigente até hoje, no qual cada diretor do Banco fica responsável por uma das áreas de atuação da instituição ${ }^{361}$ (CABRIA, 2012, p. 192; VIANNA, 2002, [DVD]).

Depois de refazer o arranjo organizacional, o Banco instaurou processos seletivos para cobrir as lacunas de pessoal deixadas pelos 5 anos quase sem renovação. Foram realizados concursos nos anos de 1972, 1973, 1975, 1976 e 1979, nos quais admitiu-se 100 contadores, 106 engenheiros, 110 advogados e 146 economistas, totalizando 462 profissionais de nível superior nessas 4 carreiras em 10 anos. Nas duas décadas anteriores, o Banco havia contratado 183 profissionais nessas áreas, o que não corresponde sequer à metade das vagas abertas nos anos 1970 (Gráfico I). A demanda por funcionários era tamanha que o BNDE contratou, no início da década de 1970, vários estagiários para

\footnotetext{
${ }^{361}$ Nesse período surgiram também dois novos fundos. O Fundo de Modernização e Reorganização Industrial (FMRI), criado em 1970 para financiar projetos de fusões e de reorganização técnica e administrativa de indústrias brasileiras, dentro da política de modernização da empresa privada nacional a que se refere o I Plano Nacional de Desenvolvimento, notadamente quanto a estrutura financeira, atualização tecnológica e desenvolvimento da capacidade gerencial. Visava primordialmente a redução de custo e o avanço qualitativo do produto final, de modo a elevar o poder de competição da indústria nacional. O FMRI absorveu, parcialmente, os programas relativos aos Fundos de Desenvolvimento da Produtividade (FUNDEPRO) e de Financiamento de Estudos e Pesquisas Técnicas (FUNESPE) (BNDE, 1971, p. 7). Velloso ressalta a importância da pesquisa do centro CEPAL-IPEA, feita por Fernando Fajnzylber, que indicava ser preciso apoiar a reestruturação do setor industrial privado do ponto de vista do financiamento e capitalização (João Paulo dos Reis Velloso in: D'ARAÚJO e CASTRO, 2004, p. 116), o que os levou a criar tanto o FMRI quanto o Fundo de Desenvolvimento de Mercado de Capitais (FUMCAP), em 1971, cujo objetivo era "dinamizar o mercado de títulos e valores mobiliários e facilitar a reestruturação financeira de empresas nacionais" (BNDE, 1971, p. 32).
} 
estancar o déficit de pessoal. Para manter os jovens profissionais treinados internamente, conhecedores da máquina e dos procedimentos operacionais, criou-se a categoria de adestrando, que era o estagiário que, depois de formado, permanecia na instituição até que houvesse concurso, sendo muitos deles admitidos no quadro regular da instituição nos anos seguintes (KLÜGER, 2015c, pp. 94-95).

Durante o governo Médici, Marcos Vianna investiu na reorganização interna do Banco. Faltavam-lhe, entretanto, a abundância de recursos e as atribuições prioritárias. Mesmo que ele não se chocasse diretamente com Delfim Netto, como fizera seu antecessor, ele ainda era um outsider. Vianna não integrava a rede dos Delfim Boys e o BNDE ficava fora da esfera de alcance do "Czar". Isto tinha implicações para a dotação de recursos do Banco, cujo orçamento, que agora dependia das decisões do Conselho Monetário Nacional, foi reduzido progressivamente. Os recursos em 1971 corresponderam a 84,29\% do orçamento de 1970 , e os de 1972 a 81,36\% dos de 1971362 em um cenário de crescimento médio do PIB de 12,5\% (ABREU, 1990, p. 408). Tendo em vista essa informação é possível compreender porque Marcos Vianna refere-se repetidamente à dificuldade de obter recursos nos seus primeiros anos como presidente do BNDE:

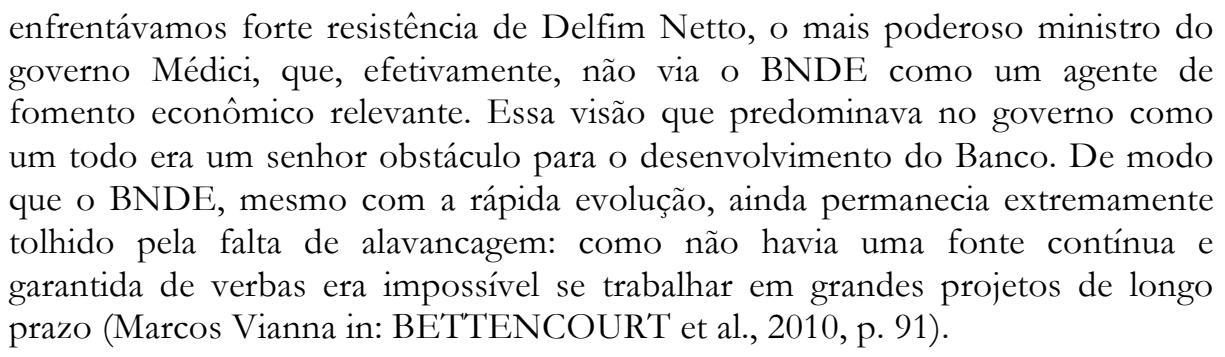

Entre os estratagemas utilizados para driblar a situação estavam desde coordenar um teatro conjunto com o presidente do Banco do Brasil nas reuniões do CMN, em que um atacava o outro para levar Delfim a tentar pacificar a situação, concedendo aos dois o que queriam, até adotar estratégias de "blefe", usando de uma "certa dose de audácia irresponsável - ou quase irresponsável”, ao comprometer-se com projetos antes de receber o aval do governo para usar os recursos, de modo a pressionar pela liberação da verba (VIANNA, 2009, p. 72; VIANNA, 2002, [DVD]).

\footnotetext{
${ }^{362}$ Há de se mencionar que em 1972 o FINAME transformou-se em empresa subsidiária deixando de figurar seus recursos no orçamento do Banco. Se tivesse mantido essa verba os recursos equivaleriam aos de 1971, sendo, pois, $80 \%$ dos de 1970 .
} 
Os problemas orçamentários e a necessidade de barganhar recursos ano a ano encerraram-se com a ascensão de Ernesto Geisel à presidência da república. Geisel mantém Reis Velloso no Planejamento, Marcos Vianna permanece no BNDE e para o Ministério da Fazenda foi convidado Mario Henrique Simonsen, amigo de juventude de Vianna. Já Velloso relata: "Eu tinha muito mais afinidade com o Simonsen, que tinha sido meu professor e amigo desde o início dos anos 1960" (João Paulo dos Reis Velloso in: D’ARAÚJO e CASTRO, 2004, p. 126). Fossem os debates econômicos entre Velloso e Simonsen mais ou menos acalorados, esses ocorriam no espaço restrito do relacionamento dos dois, sendo as diferentes propostas arbitradas diretamente pelo presidente que, de acordo com diversos depoimentos, era bem mais assertivo e centralizador do que Médici. Marcos Vianna conhecia Geisel do tempo em que apresentara aos militares suas queixas quanto à entrada da Hanna Mining no Brasil. Nos anos 1970 passaram a conviver mais constantemente, já que Vianna estava à frente do BNDE e Geisel da Petrobrás, agências que tinham amplo relacionamento e que, conjuntamente, empenharam-se no desenvolvimento dos polos petroquímicos nacionais ${ }^{363}$, sendo bom relacionamento dos dois favorável ao BNDE (Marcos Vianna in: BETTENCOURT et al., 2010, p. 93).

Ocorreram logo no início do governo Geisel algumas mudanças estruturais que beneficiaram o Banco. A primeira delas foi a conversão do Ministério do Planejamento em uma Secretaria de Planejamento (SEPLAN), ligada diretamente à Presidência da República, que passou a ocupar um espaço contíguo ao da presidência. A segunda foi a criação do Conselho de Desenvolvimento Econômico, que remetia ao conselho existente no período do Plano de Metas de JK e permitia que se discutisse com frequência regular e de forma centralizada as estratégias de desenvolvimento, tornando a ação de longo prazo do governo mais clara e integrada. A terceira mudança, que para o Banco era a mais essencial, foi a transferência para o BNDE da gestão dos fundos do Programa de Integração Social (PIS) e do Programa de Formação do Patrimônio do Servidor Público (PASEP), criados em 1964 e até então alocados na Caixa Econômica Federal e no Banco

\footnotetext{
${ }^{363}$ Data deste período o início do desenvolvimento do Polo Petroquímico de Camaçari, na Bahia, que era financiado em modelo tripartite, com capital privado, capital público nacional e capital externo, tendo o BNDE ampla participação na estruturação do projeto (BNDES, 2002, p. 90).
} 
do Brasil ${ }^{364}$. Vianna narra ter sido chamado para conversar com o presidente antes da posse e ter sinalizado a ele que era necessário que o Banco passasse a ter uma fonte fixa de recursos para poder operar no longo prazo (Marcos Vianna in: BETTENCOURT et al., 2010, pp. 100-103). Velloso, por sua vez, relata que Geisel convocou-o pois "queria saber se os recursos alocados no BNDE eram suficientes" e que ele respondeu sugerindo a transferência do PIS e do PASEP para o Banco, com o objetivo de "fazer um grande programa de desenvolvimento, tendo o BNDE como o principal financiador no longo prazo” (João Paulo dos Reis Velloso in: D’ARAÚJO e CASTRO, 2004, p. 156).

A centralidade que o BNDE alcançou nesse período - o que não ocorria desde o governo JK - não decorreu apenas do rearranjo institucional e do crescimento e estabilidade no fluxo de recursos, que passou de 753.181.000 dólares, em 1973, para 1.609.720.000 dólares, em 1974, e chegou no final da gestão Vianna a 4.998.145 mil dólares (Gráfico II) (PROCHNIK, 1995, pp. 163-164). A alteração geral na estratégia econômica do país é igualmente determinante para a reconquista da centralidade na concepção e implementação do desenvolvimento econômico. O governo Geisel teve início logo após a eclosão do primeiro choque do petróleo, que teve impacto decisivo sobre a estratégia econômica adotada em sua gestão.

O governo anterior experimentou uma conjuntura econômica internacional favorável à expansão das exportações e adotou uma estratégia de desenvolvimento expansionista que conjugava abertura externa e fortes incentivos à agricultura e à exportação com subsídios à atividade industrial privada, que se expandiu especialmente em direção ao setor de bens duráveis 365 . Buscava-se promover uma "revolução na agricultura e no abastecimento, a partir da ideia básica dos insumos modernos [...]. Nossa ideia era criar uma agricultura moderna, que experimentasse grandes aumentos de produtividade a partir do uso de insumos modernos, tais como fertilizantes e mecanização" (João Paulo dos Reis Velloso in: D’ARAÚJO e CASTRO, 2004, p. 114). No modelo adotado, a agricultura altamente subsidiada operava de um lado para melhorar a balança de pagamentos do país, evitando o estrangulamento externo e viabilizando - em

http://www.bndes.gov.br/SiteBNDES/export/sites/default/bndes_pt/Galerias/Arquivos/empresa/fundos/PIS_Res 298.pdf. Consultado em 21/02/2016.

${ }^{365}$ Velloso ressalta que a abertura externa era "assimétrica: proteção muito grande aos bens de consumo convivendo com regimes especiais que isentavam de impostos as importações de produtos intermediários, quer dizer, matérias-primas para a indústria e os equipamentos para diversos setores" que eram necessários para impulsionar o crescimento econômico interno (João Paulo dos Reis Velloso in: D'ARAÚJO e CASTRO, 2004, pp. 138-139). 
conjunto com as emissões de títulos e endividamento externo - o déficit provocado pelos incentivos oferecidos ao setor privado e pelos gastos em infraestrutura; e, de outro lado, agia no sentido de reduzir o custo dos insumos, colaborando para a própria expansão industrial e encorajando o investimento privado, que conseguiu apropriar-se da larga estrutura de produção e estoque de capital que estavam até então ociosos (MACARINI, 2005, pp. 60-65, 77-78; LAGO, 1990, p. 237, 241). No governo Geisel essa estratégia, bem vista pelos governantes ou não, seria forçosamente alterada pela mudança na conjuntura.

O choque do petróleo de 1973 acertou um Brasil que estava experimentando um superaquecimento do crescimento econômico que esbarrava na escassez de matérias primas e bens de capital e na grande necessidade de importação de insumos e de capital, concorrendo para aumentar o endividamento externo e impactando negativamente a balança comercial. A dependência externa que o Brasil tinha em relação a bens como combustíveis, fertilizantes, celulose, equipamentos e tecnologia colaborava para deteriorar ainda mais a balança externa (MACARINI, 2008, pp. 6-7). Além disso, a inflação não deixara de rondar o país, visto haver artifícios como o controle de preços e a correção monetária. Nesse cenário, argumenta Vianna, tornou-se necessário optar entre dois caminhos: ou o da covardia, que estabeleceria um freio de arrumação e levaria a uma recessão, ou buscar-se-ia compensar o déficit com outras estratégias que mantivessem o país em atividade (VIANNA, 2002).

Em um primeiro momento flertou-se com uma política de ajustamento dos preços e controle da inflação. Parecia prevalecer a voz de Mario Henrique Simonsen, umbilicalmente ligado ao grupo de Roberto Campos e Bulhões que havia feito o ajuste recessivo em 1964. Tentou-se liberar os preços que estavam reprimidos, revisar a lei de salários, mudar as regras da correção monetária, com o objetivo de ter uma real percepção do grau de inflação e alguma capacidade de prever as oscilações. Ainda que os ministros sustentassem ser necessário desaquecer a economia, o PIB do país cresceu 9,4\% nesse ano, continuando a incorrer nos problemas gerados pela conjugação de superaquecimento e dependência externa (ABREU, 1990, p. 408; CARNEIRO, 1990, pp. 299-302).

Concorrendo com a proposta de contenção de Simonsen, figurava o programa desenvolvimentista de João Paulo dos Reis Velloso que, em vez de promover um ajuste recessivo, propunha que se lutasse para manter o crescimento por meio da elevação do 
grau de investimento, do financiamento industrial e da realização de obras de infraestrutura. A estratégia centrava-se na propulsão uma nova onda de substituição de importações, com o objetivo de reduzir o déficit na balança comercial brasileira e, consequentemente, o grau de dependência externa do país. Sua proposta foi formalizada no Segundo Plano Nacional de Desenvolvimento (II PND), elaborado pela SEPLAN e lançado em dezembro de 1974, que começava da seguinte maneira:

O Brasil se empenhará, até o fim da década, em manter o impulso que a Revolução vem procurando gerar, para cobrir a área de fronteira entre o subdesenvolvimento e o desenvolvimento. Essa próxima etapa será, necessariamente, marcada pela influência de fatores relacionados com a situação internacional, principalmente quanto à crise de energia. O País está cônscio das dificuldades para manter o crescimento acelerado dos últimos anos, mas reafirma a sua determinação de superá-las, na expectativa de que se realize esforço no sentido de caminhar, progressivamente, para razoável normalidade no cenário mundial. Será preciso acostumarmo-nos à idéia de que o mundo enfrentará graves problemas, provavelmente crises. O Brasil deverá conviver com eles, procurando preservar a sua capacidade de desenvolvimento e explorando novos caminhos e alternativas. A Nação será mobilizada para, crescendo rapidamente, mas sem superaquecimento, controlar a inflação e manter em razoável equilíbrio o balanço de pagamentos, com alto nível de reservas (BRASIL, 1974, p. 15).

Em termos de suas propostas efetivas o II PND não diferia estruturalmente do I PND, exceto no que concerne à ênfase que adquire a área energética e a necessidade de ajustamento à escassez de petróleo, decorrências diretas da conjuntura internacional. A variação não estava, pois, no tipo de plano que cada um dos PNDs apresentava e sim na exequibilidade resultante da transformação do cenário internacional, do contexto político interno e do equilíbrio entre os economistas no poder. Os dois planos enfatizam, por exemplo, a necessidade de trabalhar em prol da integração nacional, a importância da política científica e tecnológica e a necessidade de modernização e atualização do sistema produtivo. O I PND não funcionou como guia para a ação econômica no início da década, pois não foi capaz de prevalecer em relação ao projeto econômico agrárioexportador sustentado pelo Ministério da Fazenda que estava nas mãos de Delfim (MACARINI, 2005, pp. 60-65, 77-78). O II PND, ao contrário de seu antecessor, tornarse-ia a guia mestra da política econômica de Geisel, retomando o planejamento estratégico da indústria e a substituição de importações, atividades nas quais o BNDE passou a ter importante papel.

O Banco passou a atuar intensivamente no financiamento de áreas definidas como prioritárias no II PND: siderurgia, petroquímica, papel e celulose, soda cáustica, cloro, estanho, zinco, alumínio, cimento e fertilizantes, além de promover a indústria de bens de 
capital em geral. O Banco buscava empresários aptos a entrar nesses ramos e oferecia-lhes financiamento a juros subsidiados, de modo a incentivar a ocupação ou a modernização e ampliação da produção nos setores considerados estratégicos para equilibrar a balança comercial. Os recursos que, em 1968, favoreceram pela primeira vez mais o setor privado do que o setor público, chegaram, no II PND, a ser dirigidos, em média, 78,24\% à iniciativa privada. As subsidiárias FIBASE, EMBRAMEC e IBRASA foram criadas justamente para insuflar capital nas empresas privadas e operavam da seguinte maneira: repassava-se dinheiro do BNDE aos grupos privados em troca de "ações preferenciais [das empresas], sem direito de voto, para não distorcer o caráter privatista da coisa" e o proprietário poderia recomprá-las caso se mostrasse apto a financiar e administrar sozinho seu negócio (João Paulo dos Reis Velloso in: BNDES, 2002, p. 90; BNDES, 2002, p. 98; NAJBERG, 2002, p. 353; VIANNA, 2002).

A razão pela qual prevaleceu o projeto de Velloso em detrimento do ajuste de Simonsen pode ser discutida. Uma hipótese aponta para a prioridade que Geisel atribuía à conquista de apoio político para sua proposta de transição lenta, gradual e segura para a democracia. Um fracasso econômico e a reversão da rota do Brasil à condição de potência econômica poderiam favorecer a "linha dura" dos militares que não eram tão entusiastas da abertura. Além disso, a ARENA havia sofrido derrotas importantes para o Movimento Democrático Brasileiro (MDB) nas eleições de 1974, o que fortalecia os segmentos mais conservadores dos militares, pouco dispostos a passar o poder para os civis que, quando tinham chance de manifestar-se, elegiam a oposição. Tanto Velloso quanto colaboradores próximos de Simonsen, como Dionísio Dias Carneiro e Augusto Jefferson Lemos, ressaltam o caráter centralista de Ernesto Geisel que procurava dar a palavra final sobre tudo, arbitrando diretamente entre as soluções propostas por Simonsen e por Velloso. Ademais relatam que Mario Henrique enxergava em Geisel uma figura paternal. Tinha amplo respeito por ele, evitava embates diretos e não o abandonaria mesmo que discordasse dele - o mesmo não ocorreu na gestão Figueiredo, tendo Simonsen abandonado o governo ao ser contrariado (CARNEIRO, 1990, pp. 297-298).

Não se pode dizer se Simonsen subestimava o poder e a influência de Velloso, como argumenta Chacel, ou se ele simplesmente aceitava a opção do presidente de seguir o plano apresentado por Velloso. Augusto Jefferson, o número dois da Fazenda, teve uma briga com Velloso e deixou o governo em 1976; Mario Henrique, por mais que 
fizesse objeções, nunca deixou Geisel. O estilo de exercício do poder de Simonsen tampouco favorecia a centralização dos poderes ao redor de seu ministério. Ele era completamente diferente de Delfim Netto também no que concerne ao modo de gestão de pessoas, seja no Estado seja na academia, o que tinha impacto sobre o alcance de sua influência (Augusto Jefferson Lemos in: ALBERTI et al., 2002, pp. 152-154, 157, 171; Dionísio Dias Carneiro in: ALBERTI et al., 2002, p. 150; CARNEIRO, 2003, pp. 21-22).

Quando Mario Henrique deixou a FGV para ir para o governo, ele convidou para serem seus colaboradores na Fazenda seus estagiários na CONSULTEC, Augusto Jefferson de Oliveira Lemos e Arlindo Lopes Correa, e alguns alunos da Fundação, como Alfredo Luís Baumgarten, Chico Lopes e Dionísio Dias Carneiro. Diferentemente de Delfim, Simonsen não foi capaz de criar ao seu redor um grupo com forte amálgama, engajado em um projeto comum. Dionísio deixa claro o quanto Simonsen não era adepto do trabalho coletivo, quando afirma que Mario "virou o seu próprio assessor. Aliás era o seu melhor assessor, o seu melhor datilógrafo, provavelmente o seu melhor engraxate, o seu melhor tudo...” (Dionísio Dias Carneiro in: ALBERTI et al., 2002, p. 150). Mario interessava-se tão pouco pela composição da equipe que entregou a Jefferson a escolha dos assessores. Além disso, aceitaram indicações, mantiveram pessoas da gestão anterior e em alguns casos deixaram até que quadros burocráticos ocupassem as posições de confiança (Jefferson Lemos in ALBERTI et al., 2002, p. 152). Não havia, como no caso do Delfim, um grupo grande e coeso de colaboradores próximos, filialmente devotados a Mario, que pudesse ser facilmente espalhado pela administração e ajudasse a manter o controle sobre os recônditos do Estado.

Como ressaltam alguns depoimentos de professores que com ele conviveram na FGV, Simonsen era um formador de escola no sentido intelectual, mas, ao contrário de Delfim, não tinha habilidades de gestão institucional e de pessoas. Nas palavras de Claudio de Moura Castro:

o Mario não tinha respeito pela lógica interna de funcionamento de nenhuma organização, qualquer que fosse ela. Sempre foi um displicente total no que se refere à maneira pela qual as pessoas se relacionavam umas com as outras. 'Olha, fulano não se dá com fulano' - ele ouvia isso como se alguém estivesse lhe falando em sânscrito. Era ruído analítico, ele passava por cima. Como consequência, sempre fez muita barbeiragem na alocação de pessoas para os lugares [...]. Como o Mario não sabia construir time, de uma forma ou de outra, ele lhe dava a impressão de que você estava ali como podia não estar, não fazia falta [...]. Se você tomar uma pessoa como o Delfim, vai descobrir que ele tinha os "amarra-cachorro" que carregavam a mala dele, mas tinha também os "sócios honorários", pessoas do mesmo naipe intelectual, que ele respeitava, com quem 
convivia num plano intelectualmente muito elevado, e que compunham um exército absolutamente leal e confiável. Todos os que trabalhavam com o Delfim trabalhavam confiantes, uns carregando mala, mas outros numa posição de igualdade, que o Delfim sabia valorizar. Em outras palavras, sempre teve time (Claudio de Moura Castro in: ALBERTI et al., 2002, pp. 91-93).

A esse traço de personalidade e ao caráter centralizador de Simonsen na EPGE é correntemente atribuída a crise sucessória que se instaurou na Escola quando ele deixou o curso para ir para o governo. A saída de Delfim Netto da USP para o Ministério da Fazenda não provocou crise sucessória na FEA, já que o grupo organicamente vinculado a ele era grande e circulava entre as salas de aula, as posições administrativas da Faculdade e os diversos órgãos econômicos do Estado, não tendo jamais abandonado a faculdade por completo. Mario Henrique, ao se afastar da FGV, não tinha fieis colaboradores com os quais pudesse deixar a escola. A própria estrutura da EPGE havia sido montada em torno da sua pessoa. Os professores antigos eram colaboradores que lecionavam um curso ou outro, mas que, via de regra, não tomavam parte essencial nas decisões administrativas, na definição de currículo, nas regras para seleção de alunos etc., tudo isso cabia quase exclusivamente ao Mario. O que fazer então em sua ausência? Para quem transferir a Escola?

\subsection{Edmar Bacha, Chico Lopes, Dionísio Dias Carneiro, Persio Arida e André Lara Resende: disputas na FGV e origens da PUC-RJ}

No início dos anos 1970, a EPGE havia começado a incorporar alguns estudantes do CAE que Mario havia enviado para estudar no exterior. Edmar Bacha, que retornara de Yale, Claudio de Moura Castro, que voltara de Vanderbilt, e Hamilton Tolosa, que regressava da Pensilvanya, foram dos primeiros professores da casa a lecionar disciplinas centrais da pós-graduação, antes reservadas a Simonsen. Eles chegaram na EPGE exatamente na época em que Mario Henrique fora convidado para dirigir o MOBRAL, razão pela qual começou a ausentar-se mais e mais de sua escola. Nessas ocasiões, reclama Bacha, deixava "a administração do curso a cargo de burocratas", entenda-se, do diretor administrativo da EPGE, Ney Coe de Oliveira, que ele chega a chamar em uma entrevista de o "bedel" da escola do Mario Henrique (Edmar Bacha in: ALBERTI et al., 2002, pp. 95). 
Ao invés de passar as funções de direção aos jovens professores, Simonsen convidou para a posição de diretor de ensino o professor sênior da cadeira de Estatística Metodológica e Estatística Econômica da Universidade de São Paulo, Luiz de Freitas Bueno, de quem Delfim fora assistente. Tal escolha deixou indignados os discípulos que aspiravam maior controle sobre a Escola. Bacha diz nunca ter entendido a "lógica da vinda do Bueno para a EPGE, se foi uma tentativa de aproximação com a USP. Mais ou menos na mesma época o Pastore veio para o IPEA, trazido pelo Velloso" - junto com José Roberto Mendonça de Barros e João Sayad - o que poderia ser uma evidência de uma suposta aliança das duas escolas (Edmar Bacha in: ALBERTI et al., 2002, p. 96; Entrevista de João Sayad à autora, 2014).

Dionísio Carneiro, por sua vez, argumenta que o conflito que opôs Simonsen a Bacha era mais profundo que a simples rejeição do exercício da coordenação por Luiz Bueno ou Ney Coe. Girava também em torno do modelo de pós-graduação que os jovens doutores desejavam implantar na escola. De acordo com ele, Bacha queria que a EPGE seguisse o modelo de um departamento americano, sem uma liderança unitária e voltado fundamentalmente para a pesquisa. Ou seja, não poderia mais ser "a escola do Simonsen”, na qual se ensinava tudo com as apostilas feitas pelo próprio professor. Mario Henrique, por sua vez, argumentava que o modelo norte-americano não dava atenção ao ensino, só à pesquisa, divergindo da divisão de trabalho estabelecida na Fundação, na qual as aulas cabiam à EPGE e as pesquisas ao IBRE (Dionísio Dias Carneiro in: CUNHA et al., 2014, pp. 64-65).

Um a um os jovens professores afastam-se da EPGE. Tolosa deixou a fundação em 1971 e foi lecionar no Instituto Alberto Luiz Coimbra de Pós-Graduação e Pesquisa de Engenharia da UFRJ (COPPE-UFRJ). Moura Castro passou os anos de 1973 e 1974 como professor visitante no Comparative Education Center na Universidade de Chicago. Ele indica que sua saída deveu-se à falta de sensibilidade para alocação de pessoas de Mario Henrique, que começou a "botar gente lá que não se dava com os que já estavam, como o Langoni. Eu estava lá e, como mencionei, tinha péssimas relações com o Langoni. Claramente, juntar os dois era uma receita explosiva ${ }^{366 " ~(C l a u d i o ~ d e ~ M o u r a ~}$

\footnotetext{
${ }^{366}$ Antes mesmo de Langoni tornar-se professor da EPGE havia troca de farpas com Claudio de Moura Castro, como fica visível em uma série de artigos publicados na revista Pesquisa e Planejamento no ano de 1971, que começa com o texto de Moura Castro Investimento em Educação no Brasil: comparação de três estudos (CASTRO, 1971), passa pela resposta de Langoni Investimento em Educação no Brasil: um comentário (LANGONI, 1971), que, segundo ele, o IPEA ameaçou não publicar por achar ofensiva (Carlos Geraldo Langoni
} 
Castro in: ALBERTI et al., 2002, pp. 91-92). Bacha, por fim, aceita convite de Isaac Kerstenetzky para criar um programa de pós-graduação em economia na Universidade de Brasília (UNB) (BACHA, 1998, p. 202; Clóvis de Faro in: ALBERTI et al., 2002, p. 122) 367 .

O vice-reitor da UNB, José Carlos Azevedo - oficial da marinha, engenheiro naval e PhD em física pelo MIT -, tinha convidado Issac para organizar a pós-graduação em economia. Ele queria "colocar Brasília no mapa" e prometia liberdade de iniciativa e de recursos ao novo curso. Bacha relata: "fomos a Brasília eu, o Isaac e a Conceição [Tavares], à qual o comandante sempre se referia como Aparecida. Ele não lembrava que santa que era [risos]. Começamos os três. O Isaac não queria sair do Rio. Tinha uma posição muito proeminente aqui [na presidência do IBGE]. A Conceição estava muito associada à CEPAL, ou estava pensando já em Campinas ${ }^{368}$ e eu estava mais ou menos disponível" (Entrevista de Edmar Bacha à autora, 2012). Bacha conta ter conseguido uma lista de todos os PhDs que estavam retornando ao Brasil e que passou 1971 indo à Brasília uma vez por mês e enviando cartas para todos os jovens doutores apresentandolhes o projeto da "Cambridge do Planalto ${ }^{369 "}$ (Edmar Bacha in: CUNHA et al., 2014, pp. $8,74)$, que pretendia ser:

um mestrado "alternativo" aos dois então existentes: o da FGV, de Simonsen, e o da USP, de Delfim Netto. Um mestrado que usasse a técnica da academia americana para a análise dos temas relevantes da economia brasileira e latinoamericana, conforme descortinados pela CEPAL. Em 1972 mudei-me para Brasília e em 1973 abri meu mestrado, tendo Lance Taylor como professor visitante, Pedro Malan como professor itinerante, e um bando de jovens professores no quadro permanente, entre os quais se destacavam Dionísio Carneiro, Francisco Lopes, Charles Mueller, Luís Paulo e Elca Rosenberg (esses chegaram em 1974), Flavio e Tereza Versiani, além de um boliviano e outro americano, ambos recém-graduados de Vanderbilt. A prata da casa incluía Lauro

in: D’ARAÚJO, 1999, p. 189), e acaba na réplica de Castro, Investimento em Educação no Brasil: uma réplica (CASTRO, 1971a). Os autores, de parte a parte, buscam desqualificar o trabalho do outro, cada qual reivindicando ter um melhor enquadramento para os estudos que conjugam as áreas de economia e educação, área da qual eram pioneiros no Brasil. Relembrando a asserção de Velloso sobre Yale, onde Castro estudou, ser o antípoda de Chicago, de onde vinha Langoni, é possível supor que haja um efeito do conflito de suas escolas de origem nas disputas que travam uma vez situados no Brasil. Além de Yale, Moura Castro passou por Berkeley e Vanderbilt. Foi em Berkeley que teve contato com a área de economia da educação em uma palestra com Amartya Sen. Langoni, por sua vez, tem contato com a área através da teoria do capital humano na linha de Theodore Schultz e Gary Becker.

${ }^{367}$ Ver currículos Claudio de Moura Castro e Hamilton Tolosa em: http://claudiomouracastro.com.br/wpcontent/uploads/2015/02/CMC_CV_2007_12112007.pdf e http://www.tolosa.ecn.br/CV_Tolosa_en.html. Consultados em 22/02/2016.

${ }^{368}$ Nessa época, na realidade, Maria da Conceição Tavares estava vivendo no Chile, onde permaneceu de 1968 a 1973, como exposto no capítulo anterior. É possível que tivesse feito viagens ao Brasil nas quais esteve em Brasília, mas certamente não estava disponível.

${ }^{369}$ Referência à cidade de Cambridge, Massachusetts, onde estão localizadas a Universidade de Harvard e o MIT. É o mesmo local ao qual se refere o nome Charles River, do grupo de assessores de Kennedy (item 2.4). 
Campos, Helga Hoffmann e Décio Munhoz, entre outros (BACHA, 1998, p. 202).

O mestrado deveria ser alternativo no que diz respeito à organização departamental, não separando ensino e pesquisa nem graduação e pós, devendo todas as atividades ser exercidas pelos mesmos professores; e alternativo no sentido político, já que seria uma escola não alinhada com o governo militar (Edmar Bacha in: CUNHA et al., 2014, p. 77). A graduação em economia da UNB contava com alguns docentes que foram incorporados ao time do mestrado: Lauro Campos, keynesiano-marxista que havia sido professor da FACE e integrava o departamento de economia da UNB desde 1966; Décio Munhoz, funcionário do Banco do Brasil e professor de comércio internacional desde 1968; e Helga Hoffmann (1938), irmã de Ulrich Hoffmann (item 3.2), graduada em filosofia na Universidade do Brasil que fez o curso do Centro CEPAL-BNDE em 1962. Helga fez parte da equipe de alunos da Filosofia que trabalhou com Álvaro Vieira Pinto no Instituto Superior de Estudos Brasileiros (ISEB) e lecionou na Escola de Administração da FGV entre 1967 e 1968. Em 1969 começou a dar aulas em Brasília e, em 1972, completou o doutorado em Ciências Sociais na USP370 (LOVATTO, 2009, pp. 189-190).

Lance Taylor, que lecionava em Harvard e tinha trabalhado com Edmar no projeto MIT-ODEPLAN no Chile, foi convidado diretamente por Bacha. Dos muitos brasileiros que foram aos EUA por meio dos convênios estabelecidos pela USP e pela FGV com a Universidade de Vanderbilt ${ }^{371}$, Bacha conseguiu recrutar Charles Curt Mueller, Luís Paulo Rosenberg e Elca Rubinstein Rosenberg, todos graduados pela USP, e Flavio Ribeiro Versiani e Maria Teresa Andrade Ribeiro de Oliveira Versiani, ex-alunos da UFMG que haviam passado pelo CAE. Para ajudar o amigo Edmar, Pedro Malan passou curto período ministrando aulas na segunda-feira, dormindo na casa de Bacha e voltando para o Rio na terça. Bacha também convidou dois ex-alunos da EPGE que acabavam de

\footnotetext{
${ }^{370}$ Ver currículo Helga Hoffmann: http://www.usp.br/iri/documentos/bcfd1896a07d19678e792719e6d3c6ab.pdf. Consultado em 22/02/2016.

${ }^{371}$ Maria Rita Loureiro calcula que $60 \%$ dos professores que, em 1991, lecionavam em cursos de pós-graduação em economia estudaram no exterior. "Destes, destacam-se os que cursaram universidades norte-americanas: 46\%, ou seja, 158 professores. Na França, estudaram 7,5\% e na Inglaterra, 5,5\% deles. Entre as universidades norte-americanas que mais formaram brasileiros sobressaem-se as seguintes: Vanderbilt, onde 18 professores brasileiros se diplomaram graças aos acordos já mencionados; a Universidade de Chicago, onde 16 economistas obtiveram seu doutoramento, sendo 13 da EPGE e três da USP; Berkeley, que formou 12 professores, e Harvard, com 11. A Universidade de Yale formou oito e as de Michigan e Illinois diplomaram, cada uma, sete brasileiros em economia" (LOUREIRO, 1997a, p. 67).
} 
regressar dos EUA, Francisco Lopes e Dionísio Dias Carneiro, amigos próximos desde a graduação na UFRJ.

Dionísio Dias Carneiro (1945-2010) provinha de família maranhense e paraibana. A mãe, que foi colega de Celso Furtado (item 1.3) e de Cleantho de Paiva Leite (item 1.4) no Liceu Paraibano, era pianista e foi secretária no Ministério de Viação e Obras Públicas no Rio de Janeiro. Casou-se com Godofredo Carneiro, que cursara direito em São Luís e trabalhava na área jurídica do mesmo ministério. Dionísio nasceu no Rio de Janeiro e viveu, do meio da infância até a ida para o doutorado, com os padrinhos João e Lourdes Broxado, no Flamengo. João Broxado era funcionário do governo federal e trabalhava com comércio exterior. Viviam em ambiente sofisticado, repleto de obras de arte e com uma ampla biblioteca e possuíam uma casa de veraneio em Petrópolis. Ao ser criado por essa família adotiva, Dionísio teve a chance de crescer em um ambiente intelectualmente estimulante, no qual pode adquirir amplo capital cultural e frequentar meios de elite do Rio de Janeiro (CUNHA et al., 2014, pp. 23-30).

Dionísio foi aluno dos colégios militares de Belo Horizonte e do Rio de Janeiro, nos quais teve boa formação em matemática e estudou francês, italiano e alemão. O inglês começou a aprender na adolescência, na Cultura Inglesa. Ao contrário da maior parte de seus colegas de escola militar, não quis estudar engenharia. Sonhava ser diplomata possivelmente inspirado pelas andanças do padrinho pelo mundo - mas era novo demais para ingressar na carreira (CUNHA et al., 2014, pp. 33-35). Nesse meio tempo, decidiu cursar economia, por influência do pai e do padrinho que "eram funcionários públicos e como tal, haviam se envolvido com questões econômicas, especialmente quando colaboraram junto ao Departamento Administrativo do Serviço Público, mais conhecido como DASP, no plano Salte, durante o governo Dutra" (CUNHA et al., 2014, p. 42). Dionísio menciona também a importância do contato com Ignácio Rangel, presença corrente na casa de seus pais. Ele fora colega de seu pai na Faculdade de Direito do Maranhão, mas antes mesmo já tinham vínculos, porque o pai de Rangel era juiz federal junto com o irmão de seu avô. Dionísio relata:

Quando foi feito o Plano Trienal do Celso Furtado, em 1962, ele [Rangel] estava na comissão do plano; estava doente nessa época, hospedava-se na casa dos meus pais em Brasília, e à mesa a conversa era sobre o Plano Trienal. Eu, passando férias em casa, menino de 16 anos, muito metido, participava das discussões, até que um dia o Ignácio se queimou com a minha intromissão constante e indevida. Quando veio ao Rio, ou foi a Belo Horizonte, comprou para mim uma introdução à economia do Guitton, que tenho até hoje, e pôs uma dedicatória: "Para o Dionísio iniciar seus estudos de economia." Esse é o outro lado de como 
me interessei pelo assunto. Juntaram-se as duas influências e terminei fazendo vestibular para economia, enquanto todos os meus colegas foram para a engenharia. $\mathrm{Na}$ verdade, eu não tinha a menor noção do que ia fazer quando me formasse, era um cara muito pouco prático. A economia me fisgou independentemente de finalidades (Dionísio Dias Carneiro in: ALBERTI et al., 2002, p. 108).

A influência destes três funcionários públicos foi, pois, decisiva para que Dionísio Dias Carneiro optasse pela economia. A gestão da economia pelo Estado também é mais do que central na história familiar de Francisco Lafayette Lopes (1947), filho de Lucas Lopes (item 2.3), nascido em Belo Horizonte. Seu pai teve atuação decisiva no Plano de Metas de JK, afinal foi presidente do BNDE e Ministro da Fazenda. Chico Lopes declara ter se interessado por economia por influência de seu pai e por meio da convivência precoce com os vários economistas que frequentavam sua casa, como Roberto Campos e Mario Henrique Simonsen. Ele conta que o pai e Roberto Campos tentaram demovê-lo da intenção de cursar economia, argumentando que os cursos existentes eram muito ruins. Diziam que ele deveria estudar engenharia primeiro e depois especializar-se em economia. Chico prestou o vestibular para economia assim mesmo (LOPES, 1999, pp. 333-334).

Dionísio e Francisco entraram na FNCE em 1964. Com a instauração do regime ditatorial, muitos professores daquela escola acabaram envolvendo-se com a gestão econômica do governo Castello Branco ${ }^{372}$, afinal, o mais conhecido professor da Faculdade, Octavio Gouvêa de Bulhões, tornou-se Ministro da Fazenda. Dionísio comenta a insatisfação dos estudantes com a escola. Na interpretação dele, a indignação decorria do trauma do golpe militar e do fechamento do diretório dos estudantes. Eles passaram "a achar que [os professores] estavam nos escondendo coisas e que tínhamos que estudar por nós mesmos” (Dionísio Dias Carneiro in: ALBERTI et al., 2002, p. 108), razão pela qual os alunos da economia formavam grupos paralelos para ler Celso Furtado, Karl Marx e outros textos que não eram oferecidos no programa regular da Faculdade. Francisco Lopes conta ter organizado "uma sociedade secreta, um pouco inspirada nas minhas leituras sobre a biografia de Keynes, que tinha a história dos apóstolos. Então,

\footnotetext{
${ }^{372}$ Por exemplo: "Hélio Schlittler dava aula de moeda e tinha sido encarregado das projeções de balanço de pagamentos do PAEG; Antônio de Abreu Coutinho era professor de economia internacional e foi o primeiro diretor de câmbio do Banco Central... [...]. O secretário-geral, na época diretor-geral, do Ministério da Fazenda, em suma, o vice-ministro, que era o Eduardo Lopes Rodrigues, era professor de finanças públicas" (Dionísio Dias Carneiro in: ALBERTI et al., 2002, p. 109).
} 
pensei, vamos imitar os apóstolos aqui” (LOPES, 1999, p. 336). A sociedade secreta tratava-se de:

um clube de amigos, formado, inicialmente, por Francisco Lopes, Dionísio Dias Carneiro e Aloísio Barbosa de Araújo, nos moldes do clube que Keynes havia constituído em Cambridge. A Carta de Princípios da sociedade, onde estavam presentes, norteando as discussões, os "quatro princípios do Método" de Descartes, também é assinada por José Tavares de Araújo, Celso Alves da Cruz, Eduardo Petersen e José Eduardo de Carvalho Pereira [...]. Em tal grupo, cada um apresentava um texto, uma espécie de monografia sobre temas escolhidos. Uma sociedade de apresentação de ensaios. Tudo revestido de uma certa ambição e de uma formalidade atípica em jovens de 19 anos (Francisco Lopes in: CUNHA et al., 2014, pp. 51-52).

Cada reunião era na casa de um. Uma vez na minha casa, outra na casa dos Broxado. Nós tínhamos uma seriedade intelectual, não política. Não éramos politizados. No momento havia muito engajamento político. Nós [já] éramos o que tentamos ser na vida, que é esse meio termo, uma posição keynesiana, mas tínhamos uma ambição. Ali havia muito idealismo, a ideia de aprender, de crescer como economista, com viés muito científico, muito acadêmico (Francisco Lopes in: CUNHA et al., 2014, p. 54).

Sempre tínhamos tema para discutir. Estávamos preocupados com o que sustentava o crescimento, como se distribuía mais rápido o crescimento. A visão que tínhamos era a seguinte: o trem está correndo, a locomotiva e os vagões. A questão era sair do subdesenvolvimento e entrar nas nações desenvolvidas. De alguma forma, você tem de correr lá dos últimos vagões para o vagão da frente, com o trem correndo. Como é que se faz isso em economia? (José Eduardo de Carvalho Pereira in: CUNHA et al., 2014, p. 52).

Simbolicamente esses jovens economistas procuravam alinhar-se à Britishness da heterodoxia de Cambridge; na prática não diferiam dos brasileiros críticos de seu tempo, ou seja, reuniam-se para discutir os caminhos do desenvolvimento da periferia. Eles faziam-se cosmopolitas evocando a imagem do Keynes's Club: um seminário de economia política que John Maynard Keynes mantinha, nas noites de segunda-feira, em seus aposentos no King's College. Dele participavam essencialmente alunos de graduação, convidados diretamente por ele, que liam e debatiam trabalhos de seus colegas. A referência aos apóstolos poderia ser dirigida também ao Keynes's Circus, um grupo de jovens professores ligados a Keynes que incluía Richard Kahn, Piero Sraffa, Austin e Joan Robinson e James Meade e se reunia semanalmente, eventualmente na presença do mestre, para discutir os escritos de Keynes (CATE, 2013, pp. 87-89). Mas nem só de economia, matemática e filosofia viviam. Saiam para tomar cerveja, falar das amigas, iam a shows na praia e havia dias em que o Chico tocava saxofone. Havia um lado festivo nada similar à formalidade dos seminários de Cambridge (José Eduardo de Carvalho Pereira in: CUNHA et al., 2014, p. 54). 
Durante a graduação Chico Lopes estagiou na CONSULTEC, empresa de seu pai e de Mario Henrique Simonsen. Dionísio e Aloísio Barboza de Araújo, por sua vez, estagiaram no Instituto Nacional do Óleo. Na sequência, Dionísio e José Eduardo de Carvalho vão para a Comissão de Estímulo à Estabilização de Preços (CONEP). No último ano da graduação Dionísio e Chico fizeram o curso do CENDEC e frequentaram algumas aulas de Mario Henrique no CNE. As rusgas com a ditadura e o interesse por Marx, Furtado e Keynes não os impediu de optar pelo mestrado na EPGE, fortemente associada ao regime militar (CUNHA et al., 2014, pp. 54-55). Os amigos do clube da UFRJ, Chico Lopes, Dionísio Dias Carneiro e Aloísio Barbosa de Araújo, ingressam no mestrado da FGV em 1968, segundo Chico Lopes, "em busca de um ideal científico" (Francisco Lopes in: CUNHA et al., 2014, p. 55), reiterando a formulação empregada para falar de seu clube, segundo a qual não havia politização em suas orientações, só uma busca idealista pelo conhecimento.

Dionísio Dias Carneiro retrata Francisco Lopes de maneira um pouco menos neutra. Segundo ele, Chico insistia na ideia de que os professores estavam "querendo enfiar as coisas deles na cabeça da gente" e teria solicitado ao Mario Henrique que convidasse a Conceição Tavares, que tinha sido professora deles na UFRJ, para dar aulas ali também. Para surpresa deles, Mario Henrique teria aceitado dividir a aula de macroeconomia com ela em sua própria Escola. Ele dava aulas no período da manhã, com a presença inquieta e ruidosa dela na sala de aula, e ela no período da tarde (Dionísio Dias Carneiro in: ALBERTI et al., 2002, pp. 113-114; Lucas Lopes in: CUNHA et al., 2014, p. 57). Já Francisco Lopes relata que Conceição decidiu ela mesma ir para lá dar aulas lá e conseguiu isso através do Bulhões (LOPES, 1999, p. 338). Conceição podia estar distante politicamente, mas não era um corpo estranho à casa já que fora assistente do Bulhões por anos e havia sido professora do CAE. O experimento não durou muito pois Conceição logo transferiu-se para o exílio, indo trabalhar na sede CEPAL (item 3.4).

Depois do mestrado, os membros do clube separam-se, Lopes vai para Harvard fazer o PhD, Dionísio para Vanderbilt e Aloísio Barbosa de Araújo para Paris I. Na tese que desenvolveu em Harvard, sob a supervisão do professor Lance Taylor, amigo de Edmar Bacha que iria trabalhar com eles em Brasília, Chico Lopes busca aplicar o

modelo insumo-produto para simular o que acontece com a economia quando você muda a distribuição de renda. Meu argumento era que você tem dois efeitos quando muda a distribuição de renda: por um lado, há uma redução da taxa de poupança, mas por outro você também muda a composição setorial da produção 
e com isso a relação capital-produto cai. Então você pode ter uma redistribuição que aumenta o crescimento ao invés de diminuí-lo [...] [o que] contraria a ideia de que a desigualdade de renda pode ser justificada pela necessidade de estimular a poupança (LOPES, 1999, p. 340).

Ele declara que o interesse pelo tema da desigualdade decorria de suas leituras de Celso Furtado que tratavam da relação entre desigualdade de renda e subconsumo. Por essa via, acabou desenvolvendo uma visão crítica de uma das justificativas apresentadas pelos defensores do governo militar para o aumento da desigualdade, segundo a qual a concentração da renda, em uma fase de transição, era funcional ao crescimento por permitir o aumento da taxa de poupança. Ao abordar o tema em sua tese, Chico entrava no debate mais pulsante à época em que estava terminando o doutorado, ou seja, a controvérsia da distribuição de renda, utilizando dados do IPEA, que José Eduardo de Carvalho Pereira, seu amigo dos tempos de UFRJ que agora trabalhava sob a supervisão de Fishlow, cedeu-lhe para que pudesse fazer a pesquisa (LOPES, 1999, p. 340; José Eduardo de Carvalho Pereira in: CUNHA et al., 2014, p. 52).

Dionísio Dias Carneiro e a esposa, por sua vez, vão para Vanderbilt junto com os Rosenberg e os Versiani. Em Vanderbilt, a maior influência de Carneiro foi Nicholas Georgescu-Roegen, romeno que havia estudado matemática e estatística e que, ao transferir-se para os EUA, tornou-se colaborador de Schumpeter. O orientador de Dionísio não foi, entretanto, Georgescu, e sim Fred Westfield, que estava desenvolvendo estudos sobre regulação de preços de serviços públicos, em especial, energia ${ }^{373}$. Foi nessa área que se enquadrou a tese de Carneiro sobre regulação de preços em empresas de utilidade pública. O tema era convergente com a experiência que havia tido no CONEP e que embasaria a assistência que posteriormente daria a Simonsen no Conselho Interministerial de Preços. Bacha relata que, quando resolveu montar Brasília, já sabia quem eram Dionísio e Chico Lopes. Diz que provavelmente havia passado por Harvard em algum momento enquanto Chico estava lá e por Vanderbilt enquanto Dionísio ali estava. Convidou-os então para juntarem-se à "Cambridge do Planalto", para onde transferiram-se em 1972 (LOPES, 1999, pp. 338, 341; Dionísio Dias Carneiro in: CUNHA et al., 2014, pp. 54-55).

\footnotetext{
${ }^{373}$ Currículo de Fred Westfield: http://www.vanderbilt.edu/econ/faculty/cv/WestfieldCV.pdf. Consultado em $22 / 02 / 16$
} 
Ainda que o reitor da UNB, Azevedo fosse um homem da confiança da "linha dura" dos militares e tivesse prometido liberdade para os novos professores organizarem o departamento, a independência esteve longe de ser plena (Edmar Bacha in: ALBERTI et al., 2002, p. 119). Bacha tentou montar um seminário inaugural sobre o modelo brasileiro, para o qual "foram chamados os principais economistas e cientistas sociais do país. Estavam lá na lista Ignácio Rangel, Maria da Conceição Tavares, Albert Fishlow, Reis Velloso, Mario Henrique Simonsen, Delfim Netto, Pastore, entre outros" (Edmar Bacha in: CUNHA et al., 2014, p. 77). Acontece que "o programa caiu na mão do Serviço Nacional de Informações (SNI), que comunicou ao Azevedo que estava vetado e os que estavam do lado da ditadura não foram, porque foram advertidos pelo SNI que essa era uma atividade subversiva" (Entrevista de Edmar Bacha à autora, 2012). Fishlow conta que, quando chegou ao Brasil para dar sua palestra no seminário, seu aluno Malan recebeu-o no aeroporto e "disse que seria melhor que eu não fosse para Brasília. Fiquei então no Rio e não falei a ninguém sobre o assunto. Eu sabia muito bem que, agindo diferente, havia a possibilidade de eu me tornar um herói. Mas para mim era muito fácil. Eu poderia ir embora, voltar à Califórnia, enquanto o Edmar e os outros tinham de continuar aqui e enfrentar suas responsabilidades" (FISHLOW, 2003, p. 660).

O SNI não parou por aí. Eles começaram a investigar os professores do departamento e acusaram a professora Helga Hoffmann de ter sido demitida do ISEB. Ela havia sido presidente da União dos Estudantes Secundaristas e liderança da união da juventude comunista, tendo chegado a passar nove meses na União Soviética em 1961 (LOVAT'TO, 2009, pp. 189-190). Ao saber que ela havia sido contratada pela UNB sem que a ficha tivesse sido mandada para o SNI, os militares responsáveis pelo combate à subversão

ligaram para o Azevedo [dizendo] que ela tinha que ser demitida. O Azevedo me falou isso: a Helga Hoffman é AI-5, foi demitida, você tem que demiti-la. Eu falei assim: Azeredo, se você demitir a Helga Hoffmann eu fecho o departamento no dia seguinte. Ele falou: você não pode fazer isso. Eu fecho. Fecho e vou embora. Então vamos conversar com o [Jarbas] Passarinho... Passarinho é Ministro da Educação. Aí lá fomos eu e o Azevedo conversar com o Passarinho. O Passarinho falou assim: "Bacha, mas é AI-5, cara". "Passarinho, foda-se o AI-5! Entendeu?" Se vocês demitirem ela eu fecho o departamento. Aí vai, conversa lá, conversa cá... então deixa eu falar uma coisa para vocês. Eu tenho uma bolsa aqui. Eu tenho dinheiro da Fundação Ford, eu vou mandar a Helga para Cambridge com a bolsa, para o tempo que ela quiser, ganhando o salário que ela ganharia aqui. Aí a resposta dos dois foi: Bacha, faz o que você quiser, mas não 
diz pra gente [risos]. Foi aí que a Helga começou a sua carreira profissional internacional ${ }^{374}$ (entrevista de Edmar Bacha à autora, 2012).

Dali em diante Bacha relata ter mudado de tática e passado a manter dois conjuntos separados de seminários: um "aos sábados de manhã com pessoas que podiam falar publicamente. Lembro que participaram, por exemplo, Carlos Castelo Branco, Severo Gomes, Paulo Lira [...]; e um sexta à noite, lá em casa, com pessoas proibidas: Fernando Henrique Cardoso, Maria da Conceição Tavares, Paul Singer, Francisco de Oliveira, gente que eu não podia levar à universidade" (Edmar Bacha in: ALBERTI et al., 2002, p. 120).

O departamento era, assim, de um lado, afetado pela repressão advinda dos órgãos de segurança nacional. Quando o regime encaminhou-se para a abertura política, o reitor "resolveu ficar do lado da fechadura e começou a reprimir, porque, obviamente, com a abertura começou a ter greve" (Entrevista de Edmar Bacha à autora, 2012). Os estudantes, por outro lado, passaram a engajar-se fortemente na política universitária, faziam greves e a polícia invadia reprimindo severamente (Edmar Bacha in: CUNHA et al., 2014, p. 75). A radicalidade de parte a parte tornava o ambiente acadêmico profundamente instável. Dionísio relata que não aguentava mais esse "negócio de students power" e resolveu voltar para o Rio, aceitando convite de Mario Henrique para lecionar na FGV e escrever um livro em parceria com ele. Chico recebeu do pai Lucas o "seguinte recado: Simonsen disse que é para você ir para a Fundação" (Edmar Bacha in: CUNHA et al., 2014, p. 81). Transferiram-se, Dionísio e Chico, para o Rio em outubro de 1973. Dias Carneiro conta que, na ocasião, teria perguntado a Mario Henrique se ele não iria para o governo, tendo recebido como resposta: "não, de jeito nenhum”. Pouquíssimo tempo depois Simonsen aceita o convite de Geisel para ser ministro da fazenda (CARNEIRO, 2003, p. 25).

Eis o epitáfio da experiência de Brasília redigido por Bacha:

\footnotetext{
${ }^{374}$ Com ajuda de Bacha e Werner Baer, Helga Hoffmann partiu pela primeira vez para o exterior. Lá ocupou posições de: Visiting Fellow no Instituto de Relações Europeo-Latinoamericanas em Madri, diretora da Divisão de Meio Ambiente e Desenvolvimento da CEPAL, chefe da Seção para as Economias em Desenvolvimento do Departamento Econômico da ONU. Foi pesquisadora na Copenhagen School of Economics and Business Administration, no Instituto de Estudos Ibero-americanos em Hamburgo, Alemanha, e Visiting Fellow na Universidade de Cambridge, Inglaterra.

Ver: http://www.usp.br/iri/documentos/bcfd1896a07d19678e792719e6d3c6ab.pdf. Consultado em 04/10/2015; Helga Hofmann in: CUNHA et al., 2014, pp. 78-79.
} 
Entre a hostilidade dos alunos e a do planalto central, e os atrativos do Rio e da FGV, Dionísio e Chico só aguentaram um ano e vieram de volta para o Rio. Pedro Malan se cansou da ponte aérea e Lance Taylor voltou para Cambridge. Helga Hoffmann teve que se afastar do País. O charme do programa "alternativo" também não conseguiu resistir à abertura do mestrado em Campinas, para onde os melhores alunos do País passaram a se dirigir. A graça do Planalto acabou. Em meados de 1975, com alguma culpa, despedi-me dos colegas e fui fazer um segundo doutorado, aproveitando-me de um convite do Harvard Institute for International Development para uma Visiting Scholarship. Entre agosto de 1975 e dezembro de 1977 permaneci em Harvard, como Visiting Scholar [...]. De volta dos EUA, passei uma ano (1978) em Brasília, mas foi só por "old times' sake" (BACHA, 1998, pp. 202-204).

Bacha deixou a Cambridge do Planalto em 1975 e voou para a Cambridge americana. Estava casado com Eliana Cardoso que, como ele, provinha de família de comerciantes mineira e católica. Ela tinha sido a primeira aluna do mestrado de Brasília a defender sua dissertação e fora aprovada para o doutorado no MIT (Entrevista de Edmar Bacha à autora realizada em 2012). Na graduação, Eliana tinha sido aluna da PUC-RJ. A melhor aluna da classe, diz André Lara Resende, seu colega de turma. Como Eliana, André também estava decidido a ir para Brasília cursar o mestrado. Havia estado em um seminário proferido por Bacha e adorara. Chegou a conversar por telefone com Edmar sobre a possibilidade de ir para lá, mas ficou sabendo que o curso estava passando por dificuldades. Ademais, mudar para o planalto não lhe parecia algo atraente, de modo que ficou no Rio e foi fazer o mestrado na EPGE. Os dois colegas, Eliana e André, reencontraram-se em Cambridge. André comenta que, ao fazer seu application para o MIT, “estava convencido que eu não ia ser aceito porque a Eliana ia ser aceita. Ela estava um ano na minha frente e tinha feito um trabalho com o Lance Taylor, que era professor do MIT. Eu falei: eles não vão aceitar dois brasileiros no mesmo ano [...]. [Ao final] foi uma enorme alegria. Fomos aceitos juntos" (Entrevista de André Lara Resende à autora, 2012).

André Pinheiro de Lara Resende (1951) é carioca mas provém de tradicional família mineira, extremamente católica e bem inserida social e politicamente. Dispôs de largos capitais políticos, econômicos, culturais e foi iniciado muito precocemente no cosmopolitismo, visto ter mudado com os pais para o exterior duas vezes na juventude e ter frequentado diversos colégios internacionais.

André é bisneto de João Pinheiro da Silva (1860), formado na Faculdade de Direito de São Paulo, membro-fundador do Partido Republicano Mineiro e diretor do jornal republicano O Movimento. Em 1889, João Pinheiro candidatou-se à deputado 
provincial pelo Partido Republicano Mineiro e, em janeiro de 1890, foi nomeado vicegovernador de Minas. Um mês depois, o titular foi convidado para a pasta do Ministério do Interior e ele assumiu o governo do Estado. Ao final do mandato transferiu-se da vida pública para a indústria, montando uma fábrica de cerâmica em Caeté, mas não ficou afastado da política por muito tempo. Em 1906 foi eleito governador de Minas Gerais, tendo vindo a morrer no exercício do cargo em outubro de 1908 (BARBOSA, 1966, pp. 25-50).

Israel Pinheiro da Silva (1896), filho de João Pinheiro e avô materno de André, seguiu os passos do pai. Tornou-se empresário e envolveu-se com a política mineira desde muito jovem. Estudou engenharia na Escola de Minas de Ouro Preto ${ }^{375}$, recebendo como prêmio oficial por seu desempenho na faculdade, uma viagem para dar continuidade a seus estudos na Europa, onde especializou-se no setor siderúrgico. Em seu retorno ao Brasil, Israel aderiu ao Partido Republicano, pelo qual foi eleito prefeito e vereador de Caeté. Ocupava-se, então, simultaneamente, da fábrica de cerâmica do pai e da política. Participou do movimento revolucionário de 1930 e foi nomeado secretário da Agricultura, Viação e Obras Públicas pelo interventor de Vargas em Minas Gerais, Benedito Valadares. Pouco depois, participou da criação e tornou-se o primeiro presidente da Companhia Vale do Rio Doce. Na sequência, foi eleito Deputado Federal pelo PSD e participou do planejamento da transferência da capital para Brasília, deixando o cargo de deputado ao ser convidado por JK para presidir a Novacap, companhia responsável pela urbanização da nova capital do país. Em abril de 1960, Israel Pinheiro entregou simbolicamente as chaves da nova capital a JK e foi nomeado o primeiro prefeito da cidade ${ }^{376}$. Em 1966, voltou para Belo Horizonte, eleito governador de Minas pelo PSD ${ }^{377}$.

A mãe de André Pinheiro de Lara Resende era Helena Uchôa Pinheiro, filha de Israel e Coracy Uchoa Pinheiro. Ela fez estudos superiores em serviço social em Minas Gerais e chegou a trabalhar como assistente no Serviço Social da Indústria (SESI) antes

\footnotetext{
${ }^{375}$ Como comentado em capítulo anterior, Israel Pinheiro estudara com o pai de Lucas Lopes na Escola de Minas de Ouro Preto e fora ele que indicara Lucas Lopes para o posto de secretário de Viação e Obras Públicas (item 2.3).

376 Ver: $\quad$ http://www1.folha.uol.com.br/cotidiano/2013/09/1345757-coracy-uchoa-pinheiro-1906-2013---aprimeira-moradora-de-brasilia.shtml http://memoria.bn.br/DocReader/Hotpage/HotpageBN.aspx?bib=089842_07\&pagfis=4203\&pesq=\&url=http://m emoria.bn.br/docreader\#. Consultados em 05/10/2015.

${ }^{377}$ Ver http://israelpinheiro.org.br/conheca-a-fundacao/historia-da-familia/ consultado em 05/10/2015; DHBB eletrônico, verbete Israel Pinheiro.
} 
de ter filhos. Helena casou-se com Otto de Oliveira Lara Resende (1922), escritor mineiro de São João Del Rei, que ele descreve como "uma comunidade de alta Idade Média. O peso daquele décor barroco, agravado pela massa física das igrejas que aprisiona a cidade numa proteção apavorante, imprime na alma da gente uma marca indelével" (Otto Lara Resende, apud MEDEIROS, 1998, p. 19). A avó paterna de André, Maria Julieta de Oliveira, não estudou, dedicando-se à criação dos 14 filhos que cresceram dos 20 que teve com Antônio de Lara Resende. Órfão e em difícil situação familiar, Antônio havia sido entregue aos 9 anos ao Colégio Caraça, instituição educacional das tradicionais famílias mineiras, dirigida por padres lazaristas, à qual atribui toda a sua formação. Tornou-se educador e católico militante, fundando e dirigindo um grande colégio católico em Minas Gerais, o Instituto Padre Machado, que funcionou inicialmente em São João Del-Rei e depois foi transferido para Belo Horizonte. Ali teve como aluno João Guimarães Rosa, que ficaria amigo de seu filho Otto. A educação católica rigorosa conduziria e assombraria a vida e os escritos de Otto por toda a vida. Lia a bíblia e ia à missa mas não se esquivava à crítica do universo católico, tema recorrente em seus escritos e cartas (Entrevista de André Lara Resende à autora realizada em 2012; RESENDE, 2011).

Ainda adolescente Otto lecionara português, francês e história no instituto dirigido pelo pai. Na sequência bacharelou-se em Direito na Universidade de Minas Gerais, mas nunca advogou pois, ao término da faculdade, já estava plenamente absorvido pelo jornalismo, trabalhando para O Diário, jornal do qual seu pai era diretor-gerente, e atuando como escritor, atividade que exercia junto com seus amigos Fernando Sabino ${ }^{378}$, Hélio Pellegrino e Paulo Mendes Campos. Em 1939, Otto obteve um emprego público no Serviço do Imposto Territorial da Secretaria de Finanças de Minas. Mas ao final de seus estudos universitários, em 1945, largou o Serviço e mudou-se para o Rio, onde chegou empregado no Diário de Notícias, conseguindo logo transferir seu emprego público para a capital. De jornal em jornal e secretaria em secretaria chegou, em 1960, à Procurador do Estado da Guanabara. Foi também, por breve período, diretor do Banco da Produção Mineira, a convite do governador do estado Magalhães Pinto, de quem era amigo (MEDEIROS, 1998). Sobre o círculo de amizade de seu pai, André comenta que frequentavam a casa, além dos "clássicos" Fernando Sabino, Hélio Pellegrino e Paulo Mendes Campos, personalidades intelectuais e artísticas consagradas como Nelson

\footnotetext{
${ }^{378}$ A primeira esposa de Fernando Sabino, Helena, era filha do governador Benedito Valadares.
} 
Rodrigues, Dalton Trevisan, Vinicius de Moraes, Armando Nogueira, Carlos Castello Branco, Lúcio Cardoso, Baden Powell, Glauber Rocha e Luís Carlos Barreto (Entrevista de André Lara Resende à autora, 2012).

Otto casou-se com Helena Pinheiro em 1948. André, nascido em abril de 1951, é o mais velho dos quatro filhos do casal. Durante o governo JK, Otto transferiu-se para Bruxelas onde foi adido cultural na embaixada do Brasil na Bélgica. Desde o período de alfabetização, portanto, André estudou francês, tendo sido aluno do Liceu Francês Charles Lepierre, no período em que a família viveu em Lisboa, de 1967 a 1969, quando Otto foi, uma vez mais, trabalhar como adido cultural brasileiro. André Lara Resende conta que começou a estudar inglês no Rio de Janeiro, entre as duas estadias da família no exterior. No Rio frequentou o Instituto Souza Leão e o britânico Colégio Andrews, onde teve contato inicial com a língua inglesa, dando sequência aos estudos na Cultura Inglesa. Também aprendeu um pouco de espanhol e consegue ler em italiano. Sobre a escolha profissional declara:

Eu sempre quis fazer engenharia, especialmente engenharia aeronáutica, mas por razões circunstanciais [não fiz]. Eu voltei de Portugal, do Liceu Francês para o Colégio Andrews no meio do ano [de 1969]. Uma professora de química orgânica, que talvez seja a única matéria que eu tenha horror na minha vida, resolveu me deixar de segunda época [...] Se fosse para engenharia no último ano teria que fazer a segunda época, se escolhesse economia não precisava. Tinha uma certa diferença nos requisitos [...], resolvi não fazer a segunda época e estudei economia... também porque li um livro do Leo Huberman, História da riqueza dos bomens. Achei muito interessante e falei: vou prestar economia (Entrevista de André Lara Resende à autora, 2012).

Também o desencontro com o vestibular da UFRJ fez parte de seu caminho acidentado para a economia. Lara Resende diz que assinalou na linha errada todas as respostas das questões de múltipla escolha da prova de matemática do vestibular para a UFRJ, ficando com zero. Segundo ele, como era muito bom aluno, saiu da prova em 40 minutos achando que tinha tirado dez. E na verdade tinha tirado zero. Mas afirma que, de fato, já tinha preferência pela economia da PUC-RJ. Indagado sobre a razão de tal preferência, diz “o campus era agradável e o curso não era considerado nada pior do que a UFRJ". Como outros entrevistados, refere-se antes aos atributos físicos da PUC-RJ do que a qualidades educacionais da instituição (Entrevista de André Lara Resende à autora, 2012).

Sobre seu curso de graduação declara que foi "muito bom porque tinha muitos professores que trabalhavam no IPEA e davam aula lá". Seu professor mais influente no 
período foi Aloísio Barbosa de Araújo, o amigo de Chico e de Dionísio dos tempos do clube da UFRJ, que fez com eles mestrado na EPGE e o doutorado em Paris, e que organizava um seminário com os alunos que funcionava uma vez por mês à noite. Além dele menciona Alfredo Luiz Baumgarten Júnior, que fez graduação em economia na UFRJ algumas turmas antes de Aloísio, Chico e Dionísio. Havia estagiado no gabinete do ministro Roberto Campos e feito pós-graduação na FGV, tornando-se, pouco tempo depois, assessor de Simonsen e presidente da FINEP. Havia também Jorge Viana Monteiro, contemporâneo de Baumgarten na UFRJ, que fez CAE e partiu para um doutorado na Iowa State University, que não chegou a concluir (RESENDE, 1996, p. 286; Entrevista de André Lara Resende à autora, 2012).

Depois de desistir da ideia de fazer o mestrado em Brasília, André ingressou na pós-graduação da FGV. Chegou quando Simonsen já havia saído para ser ministro. Ele conta que seus professores mais influentes na EPGE foram Chico Lopes e Dionísio Dias Carneiro, que haviam retornado de Brasília e agora integravam o quadro de professores da Fundação. O primeiro usando o Tratado sobre a moeda de Keynes para ensinar macroeconomia e o segundo oferecendo curso sobre equilíbrio geral extremamente matematizado na microeconomia (RESENDE, 1996, p. 286). Menciona também o curso de economia internacional de Cláudio Haddad, que o convidaria para trabalhar no Banco Garantia. Com o Simonsen só teve aulas anos depois de deixar a EPGE, aquelas de física quântica e teoria da relatividade, oferecidas para alguns poucos, obviamente fora da grade escolar (Entrevista de André Lara Resende à autora, 2012).

Indagado acerca de sua decisão de ir para o MIT, André explica que o diretor da EPGE, à época Carlos Geraldo Langoni, insistiu para que fosse para Chicago, dizendo que a aceitação ali era certa. Mas a escola não o atraía: “[eu] achava a escola... tem que ter um certo cuidado para não parecer assim o estereótipo... Como eu digo? Eu achava a Universidade de Chicago mais simplória e eu sempre tive interesse multidisciplinar". Questionado sobre divergências ideológicas com a escola, ele contesta: "eu nunca fui uma pessoa muito ideológica. Não achava uma universidade tão interessante. Ao contrário, Chicago era muito ideológico. Eu tinha interesse em uma coisa menos ideológica”. Ele conta que "muito pretensiosamente, eu fiz [applications] para Harvard, Princeton, MIT e Yale. Fui aceito em todos, menos em Harvard. Por que eu escolhi ir para o MIT? Era minha primeira escolha". "O MIT era disparado o melhor departamento de economia na 
época". "Eu sabia quem eram os professores do MIT. Na época tinha Paul Samuelson, Robert Solow, Charles Kindleberger [...]. O Dornbusch chegou em seguida. Ficou muito meu amigo e foi meu orientador. Depois tinha Peter Diamond, Martin Weitzman. Era um dream team de economia” (Entrevista de André Lara Resende à autora, 2012).

Ele comenta que o seminário mais marcante que frequentou no período:

\begin{abstract}
Macroworkshop, que era dirigido por Franco Modigliani, Stanley Fischer, e Rudi Dornbusch. Para você ver o que é um dream team [risos]. E esse macroworkshop era maravilhoso. Frequentava quem tinha feito ou estava fazendo tese em macro. Participava desse seminário toda semana. Só pra você ter uma ideia dos alunos e alunas dessa época que eram meus colegas, entraram junto comigo: Ben Bernanke, mas nunca foi meu amigo. Até vi ele pouco, mas muito bom aluno. Kenneth Rogoff, esse era muito meu amigo. Jogávamos muito tênis, era grande mestre de xadrez. Paul Krugman, um ano na nossa frente. Maurice Obstfelt, professor de Princeton. Depois assim de estrangeiros teve o Mario Draghi, três anos antes, esse eu não conheci na época. O Pedro Aspe, muito meu amigo. Rene Cortázar, que foi ministro do Chile, muito meu amigo, grande figura. Depois teve Persio Arida, que chegou no ano seguinte. Miguel Belezas, que foi ministro de Portugal. A lista do MIT dessa época é uma coisa extraordinária. Depois participavam ainda [do Macroworkshop], porque estudavam em Harvard, o Domingo Cavallo, a tese dele usei muito na minha tese. O Jeffrey Sachs. Então era um ambiente extraordinário[ $\left.{ }^{379}\right]$ (Entrevista de André Lara Resende à autora, 2012).
\end{abstract}

Sob a orientação de Rudi Dornbusch, Lara Resende defendeu doutorado na área de macroeconomia, intitulado Inflation, growth and oligopolistic pricing in a semi-industrialized economy: the case of Braz̧il (1979), tema no qual se especializaria (item 5.6). Resende começou tentando desenvolver um trabalho sobre arbitragem de juros e câmbio, usando o caso do mercado paralelo brasileiro, que abandonou porque achou que a econometria mostrava que os resultados que tinha eram pouco robustos. Passou a desenvolver então um primeiro trabalho "sobre inflação com inércia inflacionária, que Rudi detestava porque era uma coisa assim não mainstream". Acabou recebendo ajuda dos professores Lance Taylor e de Michael Priore, que ele descreve como um professor bem alternativo da área de labor economics, e seguiu com o projeto. Ele declara não gostar do seu doutorado porque a tese ainda estava em estágio preparatório: “ajudou a entender coisas, mas não é um trabalho pronto" (Entrevista de André Lara Resende à autora, 2012).

Além dos seminários da faculdade, André frequentava o grupo que Edmar Bacha reunia, de 15 em 15 dias, em sua casa com Eliana em Cambridge (André Lara Resende in:

\footnotetext{
${ }^{379}$ Peter Diamond, Robert Solow, Franco Modigliani, Paul Samuelson e Paul Krugman receberam prêmios Nobel de economia. Ver: http://www.nobelprize.org/nobel_prizes/economic-sciences/laureates/. Consultado em 29/02/16.
} 
CUNHA et al., 2014, p. 95). Segundo ele, o seminário "não era de economia, era sobre tudo. Só de amigos. Era assim uma espécie de grupo de discussão de texto”, do qual participavam Roberto Mangabeira Unger, professor de Harvard, e Luís Aranha Corrêa do Lago, que estava fazendo o doutorado em Harvard, além dos doutorandos do MIT Eustáquio Reis, José Marcio Camargo, Eduardo Modiano, Eliana Cardoso, André Lara Resende e Persio Arida. Eustáquio Reis e Zé Marcio Camargo eram da segunda geração de alunos da FACE que tinham passado pela EPGE e ido para o exterior. Eliana e André conheciam Eduardo Modiano, que fizera engenharia na PUC-RJ, porque haviam feito juntos o curso de econometria. Persio Arida, que havia sido aluno da FEA-USP, eles conheceram somente no MIT (Entrevista de André Lara Resende à autora, 2012).

André e Persio tornaram-se muito amigos. No período do MIT eles e as esposas, Cláudia Jaguaribe, que estava estudando história da arte em Wellesley, e Suzi Sólon, socióloga, mantinham um grupo de estudos, que era mais de filosofia do que de economia. André e Persio eram também companheiros de escrita. Persio afirma que “várias ideias são conjuntas, enfim, já não sei mais o que é dele, o que é meu [risos], mas, ao mesmo tempo, há coisas muito distintas do André em muitas dimensões" (Entrevista de Persio Arida à autora, 2012). Inicialmente destaca as diferenças teóricas no que concerne às soluções para a estabilização monetária, “o André sempre gostou de Currency Boards e eu sempre gostei de câmbio flutuante". Ao ser indagado acerca da existência de diferenças sociais, responde:

O André, primeiro, é família brasileira. Família brasileira do establishment, você entende? Filho do Otto, que frequentava toda a elite carioca. Então é o mais oposto de uma família de imigrantes que você pode imaginar. Depois eu tenho essa dimensão, assim, muito intelectual: da filosofia, da música, da literatura. O André adorava esportes. Corria de carro, bicicleta, pular cavalo, pilota avião [risos]. Com muito talento. Sempre fez tudo muito talentosamente (Entrevista de Persio Arida à autora, 2012).

Persio (1952) não era, como André, membro de tradicional família brasileira. Nasceu na cidade de São Paulo e seus avós eram todos estrangeiros, três nascidos no Líbano e uma no Vêneto italiano, aportados no Brasil à época da Primeira Guerra Mundial. O avô paterno teria participado de uma revolta contra os turcos, em 1915, que resultara da possibilidade de desagregação do Império Turco-Otomano. Diz que o avô teria fugido apavorado, tomado um navio, circulado um pouco e chegado ao Rio de Janeiro em 1918. Ao aportar, "casou com uma italiana que conheceu na Rua da Alfândega - com quem por muito tempo não conseguiu trocar nenhuma palavra" (ARIDA, 2011, 
[online]). Do lado materno a migração fora provocada por uma radicalização religiosa durante a guerra do Líbano. Persio conta: "meu avô materno e minha avó materna eram de religiões distintas. Ela era católica romana, ele era muçulmano. Então a maneira pela qual você lidava com problema, quando o conflito religioso era intenso, era um rapto consentido. Os dois saíam de casa e fugiam". Depois de passar pela Austrália os avôs maternos instalaram-se no Brasil. A mãe de Persio seguiu o catolicismo ortodoxo da avó; o pai era agnóstico; Persio declara-se ateu (Entrevista de Persio Arida à autora, 2012; ARIDA, 2011, [online]).

Ao narrar a história da família Persio explica que o deslocamento dos avós resultou de um "fenômeno de aglomeração de escala, típico de imigração. Se vem um, a probabilidade de ter um é pequena. A de ter dois é um pouco maior. Se tem uma certa escala, aí todo mundo vem" (Entrevista de Persio Arida à autora, 2012). A inserção econômica dos avôs de Persio fez-se através do comércio, "comprando barato e vendendo caro, tão simples quanto isso". O avô materno tinha um entreposto comercial em Jacutinga, a partir de onde escoava tecidos fabricados em São Paulo para o interior de Minas. A mãe de Persio, Alice Farah Arida, nasceu em Minas, mas a família voltou para o Líbano enquanto ela era ainda pequena. Cresceu lá e depois voltou para São Paulo. Ela estudou latim e letras neoclássicas na USP e tornou-se professora. O pai de Persio, Riad Arida, nasceu no Paraná, onde o avô exportava madeira. Riad chegou a estudar veterinária, mas não terminou o curso. A escolha pela veterinária teria sido motivada pelo desejo de escapar da infantaria caso fosse convocado para a guerra. Tinha asma e não era capaz de marchar. Fazendo veterinária iria para a cavalaria, onde quem faz força é o cavalo (ARIDA, 2011). Deixou o exército, a veterinária e, como seu pai, tornou-se comerciante. Ele começou como caixeiro-viajante no interior de São Paulo. "Pegava a Mogiana e ia embora". Teve uma tinturaria com um sócio judeu, a Arida \& Korn Ltda. Finalmente montou no centro de São Paulo, em sociedade com um irmão e o cunhado, uma série de armarinhos que vendiam material escolar, discos, conveniências, enfeites etc. Tornaram-se donos de cinco lojas que administravam a partir de escritório na Ladeira General Carneiro (Entrevista de Persio Arida à autora, 2012). Além disso o pai se envolvia em

atividades como negociante independente, preparado para aproveitar toda e qualquer oportunidade que se lhe atravessasse o caminho. Comprava e vendia firmas falidas, se metia em sociedades com escrituras em nome de terceiros, intermediava operações sem capital algum, numa sucessão vertiginosa de altos e 
baixos que narrava em detalhes em todas as refeições [...]. Quando ganhava dinheiro, trocava de carro, viajava e deixava minha mãe comprar quadros e objetos de arte; quando as coisas iam mal, reclamava do custo da assinatura do Estadão, evitava pisar em restaurantes, ficava deprimido e diminuído perante si mesmo (ARIDA, 2011, [online]).

Quando Persio nasceu a família já tinha uma situação econômica privilegiada. Morava em uma casa na Rua Veneza, no elegante bairro dos Jardins, que sua mãe construiu quando casou. Registra, em escrito autobiográfico, ter sido "estudante abonado, que morava com os pais numa casa chique nos Jardins", que tinha "tapetes persas, Gallés e óleos". Deixa entender, também, que a família tinha empregados, no plural. A disponibilidade de capital econômico favorecia o acúmulo de capital cultural, permitindo que Persio estudasse inglês e francês com professores particulares, a partir dos 6 anos de idade, e violoncelo no Conservatório Pró-Arte, com Hans-Joachim Koellheutter, importante "compositor, professor e esteta" (TOURINHO, 1999) - mesmo que não tivesse um violoncelo próprio porque o pai achava caro. Além do inglês e do francês que estudou na infância, diz ele, "arranho e falo mal" alemão, italiano e espanhol. A reconversão do capital predominantemente econômico paterno em capital cultural manifesta-se no distanciamento dos negócios familiares (Entrevista de Persio Arida à autora, 2012). Ele diz: "no fundo [meu pai] gostaria que eu o sucedesse nos negócios, que o acompanhasse na vida de comerciante, mas respeitava meu pendor acadêmico" (ARIDA, 2011, [online]).

Ainda que a família dispusesse de capital, Persio foi matriculado apenas em colégios públicos, o Caetano de Campos na Praça da República, durante o primário, e depois a Escola de Aplicação da Universidade de São Paulo que teve, segundo ele, enorme influência em sua vida. "Era uma escola politizada. Os professores eram da USP, né?” (Entrevista de Persio Arida à autora, 2012). Eram da Escola de Aplicação os colegas junto aos quais engajou-se na vida política participando das atividades do movimento secundarista e entrando para a Vanguarda Armada Revolucionária-Palmares (VARPalmares), organização da esquerda revolucionária armada. A adesão à VAR fez-se “em parte por opção - o Partidão era lugar de gente velha, frouxa, e portanto desqualificado in limine - e em parte por conveniência - a VAR fora a única organização de luta armada que se aproximara de nós" (ARIDA, 2011).

Matriculou-se no curso de história da Universidade de São Paulo em 1970, sendo preso no mesmo ano por seu envolvimento com a militância revolucionária. Ao saber da 
prisão de um colega, acreditou que poderia ser identificado e preso, razão pela qual confessou aos pais o envolvimento com a VAR. Com a ajuda deles entrou na clandestinidade. Ia ao encontro de uma militante quando foi preso por militares à paisana e levado para a Operação Bandeirante (OBAN), na Rua Tutóia. Ali ficou algum tempo até ser transferido para o quartel da Polícia do Exército, na Rua Barão de Mesquita, no Rio de Janeiro, passando do encarceramento ao "sadismo, desgovernado e bestial" da tortura. Os pais conseguiram mobilizar uma rede de contatos para trazê-lo de volta do Rio para a OBAN e de lá foi entregue ao Departamento de Ordem Política e Social (DOPS), diz ele, “sinal auspicioso de desinteresse dos torturadores pela minha pessoa”. E acrescenta:

Lá reencontrei todos os meus companheiros [...]. Cada um contava sua história, a besteira que fez com que fosse preso. Uns tinham sido torturados, outros não, alguns resistido, outros não, o que importava é que estávamos novamente todos no mesmo barco. O périplo que começara na amizade do banco escolar e passara pela clandestinidade continuava agora em um novo capítulo, nas celas do DOPS. Contei em detalhes minhas peripécias. Tinha sido o único brindado com um passeio pelo Rio de Janeiro. Foi no DOPS que assinei meu depoimento formal. Ninguém me perguntou nada e eu tampouco li o que assinava. Minha confissão já estava pronta e datilografada - era só assinar. O descaso com o ritual jurídico era tal que a cerimônia foi coletiva - éramos todos réus no mesmo processo e, para ganhar tempo, assinávamos por atacado, juntos e na mesma sala. Foi-nos dito que a libertação ocorreria em breve. A alegria foi tanta que no meio daquela farta e irresponsável distribuição de rubricas e assinaturas, originais e cópias feitas com papel carbono, um de meus companheiros atendeu um telefone que tocava insistentemente na mesa ao lado. - VAR-Palmares, às suas ordens. Ao que outro emendou: - Você se esqueceu de dizer que é da seção juvenil da VAR, seu burro! (ARIDA, 2011, [online]).

Assim terminou o envolvimento de Persio com a militância. Chegou a ser ameaçado ainda uma vez de prisão preventiva e, como parte da defesa armada por seu tio advogado, cabia buscar um emprego que atestasse a reabilitação social do jovem revolucionário. Conseguiram para ele uma posição na DPZ, agência de publicidade de Roberto Duailibi, Francesc Petit e José Zaragoza, o primeiro de origem libanesa, os outros dois espanhóis. Ali corrigia a redação das peças da agência antes da publicação. Absolvidos, ele e os colegas, decidiu retomar os estudos. Havia perdido o primeiro ano da faculdade e acabou deixando a história, a música e o emprego. Começou a fazer "vestibular todo ano. Eu fazia uma vez numa escola noturna, uma vez em uma escola diurna". Ele passou pela matemática, pela filosofia e chegou por fim à economia em 1972, onde decidiu permanecer. Conta que que seu "pai ficou satisfeito - era uma profissão sem o prestígio da medicina, advocacia ou engenharia, mas que me prepararia para ganhar 
dinheiro e sustentar uma família" (ARIDA, 2011, [online]; Entrevista de Persio Arida à autora, 2012).

Arida conta ter optado pela economia "porque era marxista. Naquela época, o entendimento da infraestrutura era considerado a chave mestra do conhecimento. Parece algo ridículo hoje, mas refletia o sentimento vigente. Logo no primeiro ano, no entanto, percebi que o Departamento de Economia da USP não oferecia praticamente nada de marxismo, que o interesse estava todo voltado para construção e teste de modelos”. Não era o que sonhara inicialmente, mas acabou bastante afeito aos modelos. Ao ser indagado sobre o que o teria fascinado no estudo da economia responde: "o jogo conceitual, voltado à construção de modelos. Eu tinha algum talento para matemática e uma base razoável de filosofia da ciência. [...]. Era como se eu conseguisse juntar a matemática e a filosofia naquele mundo de modelos" (ARIDA, 1996, p. 320).

$\mathrm{Na}$ graduação diz ter sido influenciado, sobretudo, por "Ruben Almonacid, com sua reflexão sobre fundamentos e dinâmica. Raul Ekerman, por sua curiosidade intelectual e gosto pela história do pensamento. E Ibrahim Eris que trazia o apreço pelos modelos formais e o pensamento dedutivo". Ainda antes de terminar a graduação, Persio prestou o doutorado em Chicago e foi aceito. Mas, como André, relata ter tido certa desconfiança da escola "porque Chicago estava associado com o governo Pinochet", ou, como também disse André, era uma escola demasiado ideológica. Segundo ele ficou dividido entre o MIT na Cambridge americana ou a Cambridge inglesa. Celso Furtado tentou convencê-lo a ir para a segunda, dizendo que o MIT era uma escola muito conservadora e o levou para falar com Fernando Henrique Cardoso no CEBRAP, com a intenção de conseguir para ele uma carta de recomendação para ir para a Inglaterra. Não resultou em nada, pois Persio acabou optando pelos Estados Unidos (Entrevista de Persio Arida à autora, 2012). Arida conta que seu pai entendeu e apoiou sua decisão e relata que, depois de apresentar um documento mostrando que tinha sido absolvido pela justiça militar, conseguiu o visto para partir para os EUA (ARIDA, 2011).

Ao ser indagado sobre sua experiência no MIT, Arida responde mencionando quase as pessoas citadas por Resende:

O MIT foi para mim uma experiência extraordinária. Apresentava um elenco de professores de primeiríssima linha. Tive aulas com [Paul] Samuelson, [Robert] Solow, [Franco] Modigliani, Stanley Fischer e [Rudiger] Dornbusch. Era um momento intelectualmente muito fértil de Cambridge. [Paul] Krugman, Larry Summers e [Olivier] Blanchard haviam acabado de se formar. Datam daquela ocasião minhas primeiras conversas com Michael Bruno. Foi lá também que 
conheci André [Lara Resende] e Eliana [Cardoso], que estavam um ano na minha frente, Edmar [Bacha] que tinha um escritório em Harvard e tantos outros amigos. Lembro-me que [Domingo] Cavallo e Pedro Aspe estavam terminando a tese quando cheguei. A lista é longa (ARIDA, 1996, p. 321).

Entre todos, Persio imputa a maior influência sobre ele a Robert Solow,

porque era um cara bom de modelo. É a fascinação que eu tinha desde a faculdade, olhar uma economia que é um fenômeno extraordinariamente complexo, pinçar algumas relações que têm que ser relevantes, tratá-las analiticamente. É um jeito de pensar muito fascinante e muito difícil de fazer bem, você entende? Tem gente que faz modelos complicadíssimos e perde a ciência das coisas. Mas como é que você faz um modelo simples, captando a essência e tal? O Solow era the very best (Entrevista de Persio Arida à autora, 2012).

A redação da tese de Persio foi marcada por alguns percalços. Ele conta que depois de fazer o exame de qualificação foi convidado pelo latino-americanista Albert Hirschman para ser seu assistente em Princeton. Lá "tinha um escritório só para mim, tinha secretária e aí eu voei longe. Longe da economia e saiu uma tese muito interdisciplinar. Hoje seria uma tese quase mainstream, porque a economia foi nessa direção da interdisciplinaridade, mas é uma tese que tinha racionalidade limitada, caminhos heurísticos de reflexão. Era muito nova" (Entrevista de Persio Arida à autora, 2012).

Ao regressar para o MIT teve a tese rejeitada. Seu orientador, que não havia participado do processo, sentia-se desconfortável e os outros membros da banca vetaram o trabalho antes mesmo de apreciá-lo porque, argumentavam, "não é uma tese de economia" e "sendo uma tese interdisciplinar, não era aquele o departamento para o qual deveria ser apresentada". Ele diz ter ficado "em estado de choque, discordei deles, achei que tinham uma visão muito estreita de economia". Anos mais tarde reconheceria que “não é uma tese de economia. É uma tese intelectual pura, com aspectos econômicos, sem dúvida, mas o departamento não poderia aprová-la nunca”. Acabou voltando ao MIT quase uma década depois, para escrever uma segunda tese e receber oficialmente o título. Dessa vez ateve-se a um tema convencional de sua preferência, que resultou nos seus Essays on Brazilian stabilization programs (1992). O que ocorreu já depois de ele mesmo ter tomado parte no Plano Cruzado. Arida acrescenta que a reflexão feita na tese seria útil na elaboração do Plano Real, que teria início um ano depois (ARIDA, 1996, pp. 322-323).

As trajetórias familiares de André e Persio são e não são distintas. André parte de uma situação eximiamente privilegiada, com uma inserção mais antiga e prestigiosa na 
sociedade brasileira; Persio é descendente de imigrantes, mas nasce em uma casa já enriquecida e tem a oportunidade de multiplicar enormemente seu capital cultural. Persio havia sido politicamente ativo e ingressado na economia devido ao flerte com o marxismo; André não tinha atividades políticas e queria ter sido engenheiro. Adquiriram, com o tempo, posições bastante próximas em economia. Os dois manejavam com facilidade e desenvolveram interesse pela abstração, o que foi essencial para que aderissem a uma ciência econômica repleta de modelos e para que reivindicassem o predomínio na economia da lógica e não da ideológica, razão pela qual ambos rejeitam Chicago. Ainda que haja um caráter mais propriamente político na resposta de Persio, que menciona a conexão dos Chicago Boys com a ditadura chilena como aquilo que o desencorajava, não se pode dizer que sua escolha pelo MIT tenha sido motivada por seu passado politizado, já que, como visto, ele não segue o conselho de Celso Furtado, que dizia que devia ir para a Inglaterra, argumentando que o MIT era uma escola conservadora. Os dois reportam ter sido influenciados praticamente pelos mesmos professores nos EUA, mas acabaram desenvolvendo estudos bastante dissimilares no doutorado. André fez uma tese convencional, que não o satisfez; Persio fez uma tese nada convencional que o reprovou, evento que, como a prisão, funciona na formação de Persio, como um ponto de inflexão que pressiona-o a conformar-se aos ditames.

A proximidade que se criou entre André e Persio fez com que mantivessem intensa colaboração intelectual e política (item 5.6) não obstante terem seguido, inicialmente, para universidades diferentes. Ao regressar dos EUA, Persio Arida volta para a USP, onde passa a lecionar, a partir de 1980, metodologia do pensamento econômico, história do pensamento econômico, micro e macroeconomia. Persio diz que estava insatisfeito primeiro porque "a USP tinha tido uma reforma universitária pouco antes, e todas as vagas de livre-docente já haviam sido tomadas por gente jovem”, ou seja, acreditava que não teria chance de "virar livre docente nos próximos dez anos". A segunda questão era que a USP tinha um departamento muito grande e "uma natural dispersão de escala. Gente que discute economia regional, economia de transportes, economia agrícola, [...], desenvolvimento econômico. É quase como se acontecesse de tudo ali, menos estabilização, sabe?” (Entrevista de Persio Arida à autora, 2012).

Comparada com a USP, diz Arida, a PUC-RJ "era uma casquinha de ovo. O departamento tinha doze professores. Devia ter cem na USP [...]. A vantagem específica é 
que o departamento era focado nas áreas que me interessavam mais, que eram macroeconomia e estabilização", motivando-o a aceitar o convite feito por Edmar Bacha para lecionar na PUC-RJ, para onde fora também André Lara Resende. Ao regressar dos EUA, André foi convidado para reunir-se a um "grupo que eu gostava muito", formado por Edmar Bacha, Dionísio Dias Carneiro, Francisco Lopes e Rogerio Werneck, que queriam "fazer um departamento de gente nova, com ênfase em pesquisa e uma pósgraduação". Passou a lecionar macroeconomia e finanças e, concomitantemente, a trabalhar em um banco de investimentos, o Garantia, a convite de Cláudio Haddad, que havia sido seu professor na EPGE (Entrevista de Persio Arida à autora, 2012; Entrevista de André Lara Resende à autora, 2012).

A construção do departamento de economia da PUC-RJ começou com Dionísio Dias Carneiro e Francisco Lopes que, depois de deixar Brasília, haviam sido convidados por Mario Henrique Simonsen para integrar-se à EPGE. O conflito que levou Edmar Bacha, Hamilton Tolosa e Claudio de Moura Castro a deixaram a FGV, no início dos anos 1970, quando Simonsen começou a colaborar oficialmente com o governo e não confiou a administração à eles, repetir-se-ia na geração seguinte. Ao tornar-se Ministro da Fazenda, em 1974, Simonsen deixou a administração nas mãos de Carlos Geraldo Langoni, que já estava na escola há dois anos. Entregou a diretoria de ensino ao recém chegado Chico Lopes e a diretoria de pesquisa a José Luiz Carvalho (1943), amigo de Langoni dos tempos de Colégio Nova Friburgo e colega de doutorado em Chicago, que havia sido, como Chico, aluno de Simonsen na primeira turma da EPGE (José Luiz Carvalho in: D’ARAÚJO, 1999, p. 197).

A FGV incorporara cada vez mais doutores em seus quadros, alterando o padrão reinante nos tempos de Simonsen. Agora havia diversas estrelas, cada uma tentando brilhar mais forte e ofuscar as outras. A divisão de poderes que Mario Henrique instituiu, posicionando na direção geral e na diretoria de ensino pessoas de grupos diferentes, resultou em uma tensão tal que a Escola rompeu. Vencedor, Langoni trouxe para a escola Cláudio Luiz da Silva Haddad e Edy Luiz Kogut, dois engenheiros de formação que foram colegas e contemporâneos de Langoni e José Luiz em Illinois. Vários trabalhos desenvolvidos na EPGE na época trazem agradecimentos a Arnold Harberger e outros professores de Chicago. Assim, se não houve acordo formal de Chicago com uma 
universidade brasileira, como no Chile, na Argentina e na Colômbia, a EPGE tornou-se o ponto principal de congregação de seus ex-alunos.

Aos egressos de Chicago, somaram-se os diplomados em escolas próximas, como "José Júlio Senna [que] era da Johns Hopkins, que sofre grande influência de Chicago, e Fredricka Pickford Santos [que] era da Colúmbia, prima irmã de Chicago" (José Luiz Carvalho in: D’ARAÚJO, 1999, pp. 197-198). Além de Clóvis de Faro, que fora colega de Langoni no CENDEC e estudara em Stanford, e Antônio Carlos Lemgruber, economista pela UFRJ, com doutorado em Virgínia, pesquisador do IBRE por indicação de Alexandre Kafka e redator-chefe da Conjuntura Econômica de 1974 a 1979 (DHBB, verbete Antônio Carlos Lemgruber; Carlos Geraldo Langoni in: D’ARAÚJO, 1999, p. 186; Fernando Soares de Sá in: D’ARAÚJO, 1999, p. 77).

Em oposição a eles, estavam os professores que Simonsen havia trazido de Brasília, Francisco Lopes e Dionísio Dias Carneiro. Os dois convidaram Rogério Ladeira Furquim Werneck, que não conheciam mas com quem tinham afinidades. Rogério era um pouco mais novo do que eles, foi bolsista da FACE, mestrando da EPGE e, como Chico, fez doutorado em Harvard sob a supervisão de Lance Taylor, analisando a interação entre crescimento e equidade (Rogério Werneck in: CUNHA et al., 2014, p. 83) ${ }^{380}$.

De 1974 a 1977 os atritos entre os dois grupos foram crescendo até tornarem-se insustentáveis. Diversas justificativas para a crise são apresentadas pelos envolvidos no conflito ou próximos dos participantes:

1) Os dois grupos eram formados por pessoas com influências teóricas diferentes. As escolas nas quais fizeram seus doutorados nos EUA configuravam tradições distintas e havia desconfianças teóricas recíprocas (Francisco Lopes in: CUNHA et al., 2014, p. 84; Edmar Bacha in: CUNHA et al., 2014, p. 84).

2) Os grupos tinham projetos distintos para a pós-graduação. O grupo de Langoni queria abrir um doutorado. Os outros achavam que era preciso solidificar o mestrado e seguir enviando os melhores alunos para o exterior (Rogério Werneck in: CUNHA et al., 2014, p. 85; CARNEIRO, 2003, pp. 75-77). Há de se destacar que a USP inaugurara seu doutorado em 1974.

3) Havia um conflito interno relativo ao estilo de governo acadêmico. Uma coisa era Simonsen, "o gênio", exercer controle total sobre "a sua escola". Outra coisa era

\footnotetext{
${ }^{380}$ Lattes Rogério Werneck: http://lattes.cnpq.br/0818273339577951. Consultado em 25/02/2016.
} 
Langoni, o Chicago Boy convertido em diretor aos 29 anos, querer fazer o mesmo, em uma nova conjuntura e com um corpo docente com qualificação equivalente a sua. Houve, pois, resistência e pressões para que as decisões se tornassem colegiadas (Clóvis de Faro in: ALBERTI et al., 2002, p. 123; Dionísio Dias Carneiro in: ALBERTI et al., 2002, p. 126; Rogério Werneck in: CUNHA et al., 2014, p. 86).

4) A Fundação funcionava como uma chocadeira de projetos políticos a serem implementados na sociedade e de quadros para a administração pública. Ter o domínio sobre aquele aparato contribuía para a elevar a projeção pessoal e ajudava a munir de colaboradores aqueles que eram indicados para o governo, sendo, portanto, também uma disputa por influência política (José Luiz Carvalho in: D’ARAÚJO, 1999, pp. 199-200).

Langoni relata o desfecho da crise:

a certa altura fui conversar com o Simonsen e disse: "Há uma rivalidade interna muito complicada, estou sentindo que a escola está sendo conduzida por dois grupos que não se comunicam. Considero isso prejudicial à qualidade do programa que queremos desenvolver e acho que a solução é, de fato, termos uma uniformidade de comando. Para isso, vou ter que substituir o diretor de ensino". Disse o Simonsen: "Você tem toda a autonomia, faça o que for melhor para a escola". Foi muito sofrido para mim. Conversei com o Chico, expliquei a minha posição, e ele admitiu que, de fato, o ambiente estava inadministrável e era necessário promover alguma mudança. Mas evidentemente ficou decepcionado com a decisão (Carlos Geraldo Langoni in: D’ARAÚJO, 1999, pp. 190-191).

O grupo de Chico Lopes, Dionísio Dias Carneiro e Rogério Werneck desliga-se da EPGE e empreende busca de novas terras para colonizar. A PUC-RJ, que já tinha uma pós-graduação em administração, planejava criar um mestrado em economia, mas não tinha nem contingente de professores com doutorado nem recursos (ABREU, 1993, p. 139; Dionísio Dias Carneiro in: ALBERTI et al., 2002, pp. 126-7). Ao incorporarem-se ao departamento, os dissidentes da FGV-RJ mobilizam suas redes para buscar fontes de financiamento. Hamilton Tolosa, dissidente da EPGE da geração anterior, na época superintendente do Instituto de Pesquisa (INPES), divisão do IPEA responsável pela área de pesquisa, relata seu encontro com Chico, Dionísio e Rogério:

Nesse almoço, do qual pouca gente tem conhecimento, a PUC recebeu praticamente um cheque em branco do [Programa Nacional de Pesquisa Econômica] PNPE[381] para dar suporte ao grupo. Lembro que disse a eles: "Podem ir em frente, que o IPEA banca". A partir daí, a PUC tornou-se uma espécie de colchão amortecedor para pesquisadores do IPEA; Marcelo de Paiva

\footnotetext{
${ }^{381}$ PNPE, "fundo instituído pela SEPLAN em 1977 e constituído com recursos do IPEA, IBGE, BNDES, CNPQ e FINEP, destinava-se a financiar e divulgar pesquisas na área de economia. O INPES desempenhava a função de Secretaria Executiva do Programa, determinando, em parceria com a ANPEC, a distribuição das verbas entre os centros de pós-graduação" (D’ARAÚJO et al., 2005, p. 448).
} 
Abreu, o próprio Bacha e Regis Bonelli também estiveram por lá. Sempre assim, em idas e vindas. O pessoal que criou o mestrado da PUC era muito ligado ao INPES; o próprio Chico Lopes foi superintendente, mas por pouquíssimo tempo. Não sei bem por quê, pois estava fora na época. Sem o IPEA não teriam conseguido sobreviver no início. Depois passaram a contar com recursos da FINEP, até porque entre 79 e 80 o presidente da FINEP foi Alfredo Baumgarten, meu colega de turma na EPGE. Era um mundo pequeno, todo mundo era muito ligado (Hamilton Tolosa in: D’ARAÚJO et al., 2005, pp. 161162).

A receptividade da proposta por parte de Tolosa que, poucos anos antes, tinha tido problemas semelhantes na FGV e que dirigia um departamento do IPEA que questionava fortemente as posições de Langoni foi fundamental para que obtivessem recursos. Além disso, encontraram um aliado na figura de Luís Paulo Rosenberg, que era o diretor da ANPEC naquela época, e havia sido professor com eles em Brasília. Com o apoio destes órgãos, o mestrado da PUC começou a ser erguido. A partir de 1979, a economia da PUC-RJ passou a contar também com verbas da Fundação Ford, que se tornaram essenciais, correspondendo, no início dos anos 1990, a quase 15\% do orçamento da faculdade, além de ser fonte de bolsas para numerosos alunos da casa (ABREU, 1993, p. 142).

Edmar Bacha, que havia deixado Brasília, reuniu-se a Dionísio, Chico e Rogério no final de 1978, primeiro ano de funcionamento do mestrado. Pedro Malan e Régis Bonelli, que trabalhavam no INPES, passaram a transitar entre a PUC-RJ e o IPEA. Na sequência José Márcio Camargo, Lara Resende e Eduardo Modiano concluíram os doutorados no MIT e, ao regressar ao Brasil, uniram-se ao grupo. Persio Arida veio da USP 382 reunir-se a colegas e amigos do período da Cambridge estadunidense.

Em 1981 o departamento de economia da PUC recebeu Marcelo de Paiva Abreu, também pesquisador do INPES e amigo, desde a graduação, de Bonelli e Malan, e Winston Fritsch, graduado e mestre em engenharia de produção na UFRJ, que havia sido colega de Abreu no doutorado na Universidade de Cambridge. Os dois eram professores da área de história econômica do recém-criado Instituto de Economia Industrial (IEI) da UFRJ (item 5.5) e, após severos desentendimentos com a professora Maria da Conceição Tavares e seus seguidores na Federal, transferiram-se para a PUC-RJ. Lá foram parar a convite de Dionísio, que fora nomeado vice-presidente da FINEP, quando Baumgarten, seu amigo e vizinho, assumiu a presidência em 1979. Na época, Marcelo Abreu estava

\footnotetext{
${ }^{382}$ Consta no livro sobre Dionísio Dias Carneiro que Arida tenha ingressado na PUC em 1980 e no livro sobre a FEA-USP, que ele estava ligado à FEA até 1982 (CUNHA et al, 2014, p. 103; CANABRAVA, 1984a, p. 248).
} 
cedido pelo IPEA para a FINEP, razão pela qual passaram a ter intensa convivência (RESENDE, 1996, p. 313; FRANCO, 2007a, p. 234; BACHA, 2014, p. 8; DHBB, verbete Eduardo Modiano; André Lara Resende in: CUNHA et al., 2014, p. 95; Marcelo de Paiva Abreu in: CUNHA et al., 2014, p. 96; Luiz Roberto Cunha in: CUNHA et al, 2014, p. 160).

O núcleo inicial da PUC-RJ acabou, pois, sendo composto pelo grupo que se reunia na casa de Edmar Bacha em Cambridge (Arida, Resende, Modiano, José Marcio Camargo e Eustáquio Reis ${ }^{383}$ ), os amigos engenheiros que resolveram ser economistas e fizeram os cursos do Centro CEPAL-BNDE (Abreu, Malan e Bonelli), os amigos do Keynes Club brasileiro (Chico, Dionísio e Aloísio que lá já lecionava) e seu colega de EPGE (Rogério Werneck, que como Edmar Bacha, José Marcio Camargo e Eustáquio Reis fora bolsista na FACE).

O novo departamento funcionava de modo colegiado (Dionísio Dias Carneiro in: ALBERTI et al., 2002, pp. 126-127), com um currículo que priorizava temas de macroeconomia como "dívida externa, inflação, déficit de conta corrente, problemas de balanço de pagamentos, relações com o Fundo Monetário Internacional" etc. (André Lara Resende in: CUNHA et al., 2014, p. 95). A abertura política em curso estimulava trabalhos voltados à intervenção na política econômica pública (ABREU, 1993, p. 140), havendo também ligações com os grupos políticos de oposição. Pedro Malan e Edmar Bacha eram figuras públicas do movimento dos economistas que fazia frente ao governo militar e numerosos quadros da PUC-RJ envolver-se-iam com a administração econômica dos primeiros governos de oposição (itens 5.6, 6.2 e 6.3).

\begin{tabular}{|c|c|c|c|c|}
\hline Personagem & Cronologia & Local de nascimento & Formação & Filiação \\
\hline Roberto Simonsen & $1889-1948$ & Rio de Janeiro - RJ & $\begin{array}{l}\text { Graduação em engenharia } \\
\text { (POLI-USP). }\end{array}$ & $\begin{array}{l}\text { Pai, Sidney Martin } \\
\text { Simonsen, nascera em } \\
\text { Londres e transferira-se } \\
\text { para o Brasil com 25 } \\
\text { anos, para ser gerente do } \\
\text { Banco Inglês, } \\
\text { envolvendo-se depois } \\
\text { com a importação e } \\
\text { exportação de café. } \\
\text { Casou-se com Robertina } \\
\text { da Gama Cochrane, filha } \\
\text { de Inácio Wallace da }\end{array}$ \\
\hline
\end{tabular}

\footnotetext{
${ }^{383}$ Reis já lecionava economia internacional na PUC-RJ antes da criação da pós-graduação e lá permaneceu após a reforma do departamento. Ver: http://www.ipea.gov.br/portal/index.php?option=com_content\&view=article\&id=25548..$\quad$ Consultado em 26/02/2016.
} 


\begin{tabular}{|c|c|c|c|c|}
\hline & & & & $\begin{array}{l}\text { Gama Cochrane, } \\
\text { descendente de escoceses } \\
\text { e de famílias tradicionais } \\
\text { de Minas Gerais e São } \\
\text { Paulo, era engenheiro } \\
\text { formado na Nacional } \\
\text { Engenharia do Rio de } \\
\text { Janeiro, e foi: deputado } \\
\text { da Assembleia Legislativa } \\
\text { Provincial, grande } \\
\text { exportador de café } \\
\text { enraizado na cidade de } \\
\text { Santos e diretor da } \\
\text { Companhia Paulista de } \\
\text { Estradas de Ferro e } \\
\text { fundador da City Santos } \\
\text { Improvements, empresa que } \\
\text { se ocupava dos serviços } \\
\text { de transporte, água e luz } \\
\text { na cidade de Santos. }\end{array}$ \\
\hline Howard Ellis & 1898-1992 & Denver - USA & $\begin{array}{l}\text { Doutorado em economia } \\
\text { (Harvard). }\end{array}$ & s.d. \\
\hline Dorival Teixeira Vieira & $1915-2012$ & s.d. - SP & $\begin{array}{lll}\text { Graduação em } & \text { ciências } \\
\text { sociais e políticas } & \text { (FFCL). } \\
\text { Doutorado em } & \text { ciências } \\
\text { (FFCL). } & & \\
\end{array}$ & $\begin{array}{l}\text { Pai pugilista } \\
\text { controlador de trem. }\end{array}$ \\
\hline Hélio Pena Beltrão & 1916-1997 & Rio de Janeiro - RJ & $\begin{array}{l}\text { Graduação em direito } \\
\text { (Faculdade Nacional de } \\
\text { Direito). Pós-graduação em } \\
\text { direito comparado (NYU). }\end{array}$ & $\begin{array}{l}\text { Avô paterno Antônio de } \\
\text { Arruda Beltrão era um } \\
\text { engenheiro } \\
\text { pernambucano que fora } \\
\text { dirigente da Companhia } \\
\text { Açucareira } \\
\text { Pernambucana } \\
\text { transferiu-se com a } \\
\text { família para o Rio de } \\
\text { Janeiro em 1891. O pai } \\
\text { Heitor da Nóbrega } \\
\text { Beltrão era advogado, } \\
\text { jornalista da Gazeta de } \\
\text { Notícias, Secretário-Geral } \\
\text { da Associação Comercial } \\
\text { do Rio de Janeiro, } \\
\text { fundador e presidente do } \\
\text { Tijuca Tennis Club, vice- } \\
\text { presidente da Associação } \\
\text { Brasileira de Imprensa, } \\
\text { membro da Academia } \\
\text { Carioca de Letras. Foi um } \\
\text { dos fundadores da UDN, } \\
\text { partido pelo qual elegeu- } \\
\text { se vereador e deputado e } \\
\text { quando faleceu exercia a } \\
\text { função de conselheiro } \\
\text { das Caixas Econômicas } \\
\text { Federais, quando Gudin } \\
\text { era ministro da Fazenda. }\end{array}$ \\
\hline Luiz Freitas Bueno & 1919-2006 & Cravinhos - SP & $\begin{array}{l}\text { Graduação em engenharia } \\
\text { elétrica (Mackenzie). Pós- } \\
\text { graduação (ELSP). }\end{array}$ & s.d. \\
\hline Joseph Grunwald & 1920-1997 & Viena - Áustria & $\begin{array}{lll}\begin{array}{l}\text { Graduação } \\
\text { Johns }\end{array} & \text { economia } & \text { Hopkins). } \\
\begin{array}{l}\text { Doutorado } \\
\text { (Columbia). }\end{array} & \text { em } & \text { economia } \\
\text { (Couto } & \\
\end{array}$ & $\begin{array}{l}\text { Família judia austríaca } \\
\text { que se mudou para } \\
\text { Baltimore em } 1938\end{array}$ \\
\hline Jayme Magrassi de Sá & 1921 & Porto Alegre - RS & $\begin{array}{l}\text { Graduação em contabilidade } \\
\text { e economia (Rio Grande do } \\
\text { Sul). }\end{array}$ & $\begin{array}{l}\text { Pai comerciante e } \\
\text { industrial }\end{array}$ \\
\hline Og Francisco Leme & $1922-2004$ & s.d. & $\begin{array}{lr}\text { Graduação em } & \text { ciências } \\
\text { sociais e políticas } & \text { (ELSP). } \\
\text { Especialização em } & \text { sociologia } \\
\text { e antropologia } & \text { social }\end{array}$ & s.d. \\
\hline
\end{tabular}




\begin{tabular}{|c|c|c|c|c|}
\hline & & & $\begin{array}{l}\text { (ELSP). Graduação em } \\
\text { direito (FD-USP). Mestrado } \\
\text { economia (Chicago). }\end{array}$ & \\
\hline Arnold Harberger & 1924 & Newark - USA & $\begin{array}{l}\text { Graduação em } \\
\text { incompleta } \\
\text { Dohn Hopkins). } \\
\begin{array}{l}\text { Doutorado em } \\
\text { (Chicago). }\end{array}\end{array}$ & s.d. \\
\hline $\begin{array}{l}\text { Ruy Aguiar da Silva } \\
\text { Leme }\end{array}$ & 1925-1997 & São Paulo - SP & $\begin{array}{l}\text { Graduação em engenharia } \\
\text { (POLI-USP). Pós-graduação } \\
\text { em estatística (POLI-USP). }\end{array}$ & $\begin{array}{l}\text { Seu avô paterno, Luiz } \\
\text { Gonzaga da Silva Leme } \\
\text { era advogado formado na } \\
\text { Faculdade de Direito do } \\
\text { Largo São Francisco e } \\
\text { engenheiro formado no } \\
\text { Instituto Politécnico de } \\
\text { Rensselaer, em Troy em } \\
\text { Nova York. No Brasil } \\
\text { ajudou a projetar as } \\
\text { estradas de ferro do } \\
\text { estado de São Paulo. Seu } \\
\text { pai, Hildebrando da Silva } \\
\text { Leme era advogado pela } \\
\text { Faculdade de Direito do } \\
\text { Largo de São Francisco. }\end{array}$ \\
\hline Antonio Delfim Netto & 1928 & São Paulo - SP & $\begin{array}{l}\text { Graduação em economia } \\
\text { (FCEA-USP). Doutorado } \\
\text { em economia (FCEA-USP). }\end{array}$ & $\begin{array}{l}\text { Seu avô paterno deixou a } \\
\text { Calábria no final do } \\
\text { século XIX, com menos } \\
\text { de vinte anos. Em São } \\
\text { Paulo começou } \\
\text { trabalhandor como } \\
\text { calceteiro de vias públicas } \\
\text { a serviço da prefeitura e } \\
\text { terminou como dono de } \\
\text { uma das minas de pedras } \\
\text { que forneciam os } \\
\text { paralelepípedos com os } \\
\text { quais a prefeitura fazia o } \\
\text { calçamento. Seu pai era } \\
\text { escriturário na } \\
\text { Companhia Municipal de } \\
\text { Transportes Coletivos e a } \\
\text { mãe costurava para fora. }\end{array}$ \\
\hline Pelúcio Ferreira & $1928-2002$ & Lambari - MG & $\begin{array}{l}\text { Graduação em economia } \\
\text { (UEG). Especialização em } \\
\text { economia (Universidade de } \\
\text { Porto Rico). }\end{array}$ & $\begin{array}{l}\text { Família de origem } \mathrm{e} \\
\text { proventos modestos. }\end{array}$ \\
\hline Werner Baer & $1931-2016$ & Berlim - Alemanha & $\begin{array}{llr}\begin{array}{l}\text { Graduação } \\
\text { (Queens }\end{array} & \text { em } & \text { economia } \\
\text { Doutorado } & \text { em } & \text { Ecollege) } \\
\text { Economia } \\
\text { (Harvard). }\end{array}$ & $\begin{array}{l}\text { Família de judeus que } \\
\text { mudou para os EUA para } \\
\text { fugir do nazismo. }\end{array}$ \\
\hline Marcos Vianna & $1934-2012$ & Vitória - ES & $\begin{array}{l}\text { Graduação em engenharia } \\
\text { (Nacional de Engenharia). }\end{array}$ & 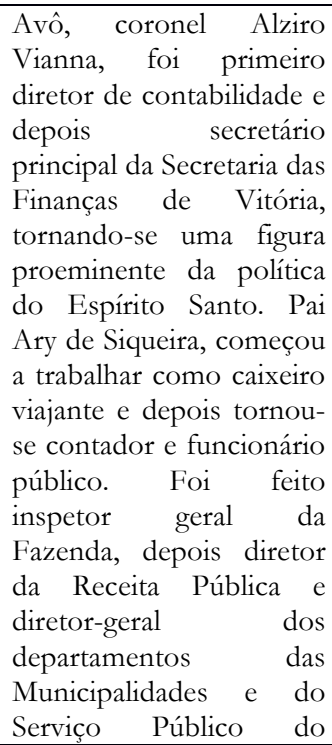 \\
\hline
\end{tabular}




\begin{tabular}{|c|c|c|c|c|}
\hline & & & & $\begin{array}{l}\text { Espírito Santo. Em 1944, } \\
\text { foi nomeado por Getúlio } \\
\text { Vargas prefeito de } \\
\text { Cachoeiro do Itapemirim, } \\
\text { a segunda maior cidade } \\
\text { do Espírito Santo, e na } \\
\text { sequência foi eleito } \\
\text { Deputado Federal e } \\
\text { depois Senador pelo } \\
\text { PSD. }\end{array}$ \\
\hline Albert Fishlow & 1935 & Filadélfia - USA & $\begin{array}{l}\text { Graduação em economia } \\
\text { (Pennsylvania) Doutorado } \\
\text { em Economia (Harvard) }\end{array}$ & s.d. \\
\hline $\begin{array}{l}\text { Arthur Ribeiro Pinto } \\
\text { Candal }\end{array}$ & 1935-2011 & Porto Alegre - RS & $\begin{array}{l}\text { Graduação em direito } \\
\text { (UFRGS). Pós-graduação } \\
\text { em economia (ILPES). Pós- } \\
\text { graduação em economia } \\
\text { (Escola Superior de } \\
\text { Estatística e Planejamento - } \\
\text { Varsóvia). }\end{array}$ & $\begin{array}{l}\text { Pai Desembargador } \\
\text { Hugo Candal, foi } \\
\text { presidente do Tribunal de } \\
\text { Justiça do Rio Grande do } \\
\text { Sul. }\end{array}$ \\
\hline Akihiro Ikeda & s.d. & s.d. & $\begin{array}{l}\text { Graduação em economia } \\
\text { (FEA-USP). Mestrado em } \\
\text { economia (Michigan). }\end{array}$ & s.d. \\
\hline Affonso Celso Pastore & 1939 & São Paulo - SP & $\begin{array}{l}\text { Graduação em economia } \\
\text { (FEA-USP). Pós-graduação } \\
\text { em economia (FEA-USP). }\end{array}$ & s.d. \\
\hline Miguel Colasuonno & $1939-2013$ & São Paulo - SP & $\begin{array}{l}\text { Graduação em economia } \\
\text { (FEA-USP). Pós-graduação } \\
\text { em economia (FEA-USP). }\end{array}$ & $\begin{array}{l}\text { Pais imigrantes italianos. } \\
\text { O pai era guarda de } \\
\text { fronteira na Itália, a mãe } \\
\text { professora primária. O } \\
\text { irmão do pai já vivia no } \\
\text { Brasil e trabalhava como } \\
\text { pintor, o pai, José } \\
\text { Colasuonno, assumiu a } \\
\text { função quando o irmão } \\
\text { voltou para a Itália e } \\
\text { começou a retratar a elite } \\
\text { paulistana. Passou } \\
\text { também a importar } \\
\text { material de pintura e } \\
\text { abriu o empório artístico } \\
\text { Michelangelo }\end{array}$ \\
\hline Paulo Yokota & 1939 & São Paulo - SP & $\begin{array}{l}\text { Graduação em economia } \\
\text { (FEA-USP). Pós-graduação } \\
\text { em economia (FEA-USP). }\end{array}$ & 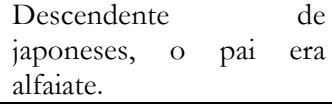 \\
\hline Edmar Bacha & 1942 & Lambari - MG & $\begin{array}{l}\text { Graduação em } \\
\text { (FACE-UFMG). } \\
\text { graduação em economia } \\
\text { (CAE-FGV). Mestrado em } \\
\text { economia (Yale) Doutorado } \\
\text { em economia (Yale). }\end{array}$ & $\begin{array}{l}\text { Família de comerciantes } \\
\text { libaneses do lado } \\
\text { paterno. Pai comerciante, } \\
\text { trabalhou como } \\
\text { secretário da prefeitura } \\
\text { de Lambari. Um dos seus } \\
\text { tios foi prefeito de } \\
\text { Cambuquira. Do lado } \\
\text { materno era descendente } \\
\text { da elite política local. A } \\
\text { mãe era normalista. O } \\
\text { avô materno, João de } \\
\text { Almeida Lisboa era } \\
\text { farmacêutico de } \\
\text { formação e foi eleito } \\
\text { prefeito de Lambari e } \\
\text { deputado federal. Duas } \\
\text { das irmãs de sua mãe } \\
\text { foram eleitas para a } \\
\text { Academia Mineira de } \\
\text { Letras. }\end{array}$ \\
\hline Regis Bonelli & 1942 & Rio de Janeiro - RJ & $\begin{array}{lr}\text { Graduação em } & \text { engenharia } \\
\text { metalúrgica } & \text { (PUC-RJ). } \\
\text { Especialização } & \text { em } \\
\text { problemas } & \text { do } \\
\end{array}$ & $\begin{array}{l}\text { Um avô imigrante } \\
\text { italiano trabalhava na } \\
\text { construção civil o outro } \\
\text { era um industrial falido. }\end{array}$ \\
\hline
\end{tabular}




\begin{tabular}{|c|c|c|c|c|}
\hline & & & $\begin{array}{l}\text { desenvolvimento (CEPAL- } \\
\text { BNDE). Doutorado em } \\
\text { economia (Berkeley). }\end{array}$ & $\begin{array}{l}\text { O pai era contador e } \\
\text { funcionário público do } \\
\text { Instituto } \\
\text { Aposentadoria e Pensões } \\
\text { dos Empregados em } \\
\text { Transportes e Cargas. }\end{array}$ \\
\hline Pedro Malan & 1943 & Petrópolis - RJ & $\begin{array}{lr}\begin{array}{l}\text { Graduação em } \\
\text { mecânica }\end{array} & \text { (PUC-RJ). } \\
\text { Especialização } & \text { em } \\
\text { problemas } & \text { do } \\
\text { desenvolvimento (CEPAL- } \\
\text { BNDE). Doutorado em } \\
\text { economia (Berkeley). }\end{array}$ & $\begin{array}{l}\text { Avô Chefe do Estado } \\
\text { Maior do Exército e pai } \\
\text { funcionário público, } \\
\text { agente fiscal do consumo. }\end{array}$ \\
\hline $\begin{array}{ll}\text { Carlos } & \text { Geraldo } \\
\text { Langoni } & \end{array}$ & 1944 & Nova Friburgo - RJ & $\begin{array}{l}\text { Graduação em economia } \\
\text { (IEI-UFRJ). Especialização } \\
\text { em economia (CENDEC). } \\
\begin{array}{l}\text { Doutorado em economia } \\
\text { (Chicago). }\end{array}\end{array}$ & 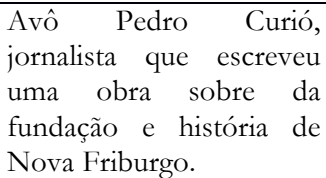 \\
\hline $\begin{array}{ll}\text { Dionísio } & \text { Dias } \\
\text { Carneiro } & \end{array}$ & $1945-2010$ & Rio de Janeiro - RJ & $\begin{array}{lrr}\text { Graduação } & \text { em } & \text { economia } \\
\text { (IEI-UFRJ). } & \text { Mestrado em } \\
\text { economia } & & \text { (EPGE). } \\
\text { Doutorado } & \text { em } & \text { economia } \\
\text { (Vanderbilt). } & & \end{array}$ & $\begin{array}{l}\text { A mãe paraibana era } \\
\text { pianista e foi secretária } \\
\text { no Ministério de Viação e } \\
\text { Obras Públicas. Pai } \\
\text { maranhense advogado } \\
\text { formado em São Luís e } \\
\text { trabalhava na área jurídica } \\
\text { do mesmo ministério. Foi } \\
\text { criado por um padrinho } \\
\text { abastado, João Broxado, } \\
\text { que era um funcionário } \\
\text { do Governo Federal que } \\
\text { trabalhava com comércio } \\
\text { exterior. }\end{array}$ \\
\hline Francisco Lopes & 1947 & Belo Horizonte - MG & $\begin{array}{lrr}\text { Graduação } & \text { em } & \text { economia } \\
\text { (IEI-UFRJ). } & \text { Mestrado em } \\
\text { economia } & & \text { (EPGE). } \\
\text { Doutorado } & \text { em } & \text { economia } \\
\text { (Harvard). } & & \end{array}$ & $\begin{array}{l}\text { Bisavô vereador } \\
\text { coronel no Rio Grande } \\
\text { do Sul, agraciado com } \\
\text { um título de Barão. Avô } \\
\text { engenheiro, diretor de } \\
\text { obras da prefeitura de } \\
\text { Belo Horizonte, } \\
\text { historiador e colaborador } \\
\text { do SPHAN. Pai } \\
\text { engenheiro pela } \\
\text { Faculdade de Minas e } \\
\text { Ouro Preto Ministro da } \\
\text { Fazenda, Presidente do } \\
\text { BNDE e membro da } \\
\text { CONSULTEC. }\end{array}$ \\
\hline André Lara Resende & 1951 & Rio de Janeiro - RJ & $\begin{array}{lrr}\text { Graduação } & \text { em } & \text { economia } \\
\text { (PUC-RJ). } & \text { Mestrado em } \\
\text { economia } & & \text { (EPGE). } \\
\text { Doutorado } & \text { em } & \text { economia } \\
\text { (MIT). } & & \end{array}$ & 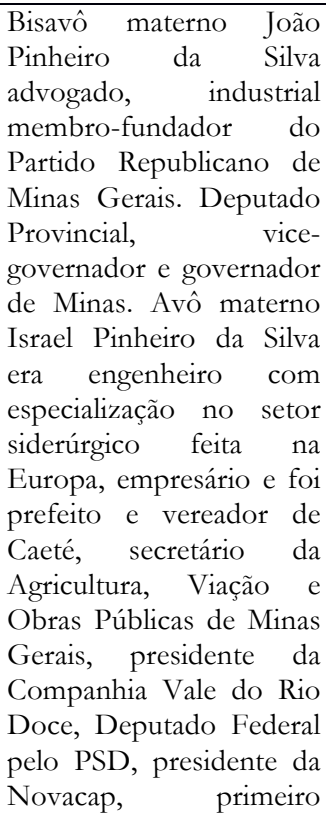 \\
\hline
\end{tabular}




\begin{tabular}{|c|c|c|c|c|}
\hline & & & & $\begin{array}{l}\text { prefeito da de } \text { Brasília e } \\
\text { governador de Minas. } \\
\text { Mãe, Helena Uchôa } \\
\text { Pinheiro fez estudos } \\
\text { superiores em serviço } \\
\text { social e chegou a } \\
\text { trabalhar como assistente } \\
\text { no SESI antes de ter } \\
\text { filhos. Avô paterno era } \\
\text { educador, fundou e } \\
\text { dirigindo um grande } \\
\text { colégio católico em } \\
\text { Minas Gerais. Pai Otto } \\
\text { Lara Resende formou-se } \\
\text { advogado, foi funcionário } \\
\text { público, jornalista, } \\
\text { escritor e adido cultural } \\
\text { na Bélgica e em Portugal. }\end{array}$ \\
\hline Pérsio Arida & 1952 & São Paulo - SP & $\begin{array}{l}\text { Graduação em economia } \\
\text { (FEA-USP). Doutorado em } \\
\text { economia (MIT). }\end{array}$ & $\begin{array}{l}\text { Três avós nascidos no } \\
\text { Líbano e uma na Itália. } \\
\text { Chegaram ao Brasil na } \\
\text { época da primeira guerra. } \\
\text { O avô materno revendia } \\
\text { em Minas Gerais tecidos } \\
\text { comprados em São } \\
\text { Paulo. O avô paterno } \\
\text { vivia no Paraná e vendia } \\
\text { madeira. O pai não } \\
\text { completou a faculdade de } \\
\text { veterinária e verteu } \\
\text { também para o comércio, } \\
\text { chegando a administrar } 5 \\
\text { lojas na região da } 25 \text { de } \\
\text { março. A mãe estudou } \\
\text { Latim e e Letras } \\
\text { neoclássicas na FFCL- } \\
\text { UsP e foi professora }\end{array}$ \\
\hline
\end{tabular}

Tabela V: Trajetórias das principais personagens do Segundo Movimento. Elaboração: própria.

\subsection{Rede do Segundo Movimento}

No Primeiro Movimento, que se ocupou do período que vai dos anos 1940 ao primeiro governo militar, acompanhou-se um processo de crescimento e diferenciação interna do espaço dos economistas. Se, no princípio predominara a cooperação para solidificar as escolas e instituições governamentais voltadas à administração econômica, ao final observa-se um recrudescimento das divisões teóricas e políticas no interior do espaço. A rede do Primeiro Movimento, que busca representar o arranjo alcançado ao final do período, expressa a polarização a que se chegou depois de um conjunto de eventos disruptivos que levaram à clivagem que deu origem aos polos desenvolvimentista nacionalista, desenvolvimentista não nacionalista e monetarista. 
$\mathrm{Na}$ rede referente ao Segundo Movimento - centrado no período que vai do surgimento dos cursos de mestrado e doutorado nos anos seguintes a 1966 aos anos 1980 - as clivagens são acentuadas e multiplicam-se. Aproximam-se no espaço os monetaristas e desenvolvimentistas não nacionalistas, agregando a maior parte daqueles que apoiavam o regime militar e estavam dispostos a colaborar com ele, assumindo postos de destaque na administração econômica. O polo formado por esses dois grupos e por um novo conjunto de agentes, vindos de São Paulo, que também atuaram em prol da ditadura, é designado pelo marcador governo militar e encontra-se na parte inferior do plano, abaixo da linha guia. Apenas um grupo de jovens doutores é visto nessa área, aqueles titulados pela escola de Chicago, que se integrarão ao governo militar, ocupando postos de direção nos últimos anos da ditatura.

No plano superior concentra-se a oposição ao governo militar, que inclui os desenvolvimentistas nacionalistas e seus laços com a CEPAL, a Superintendência do Desenvolvimento do Nordeste (SUDENE) e o Clube dos Economistas, agora afastados do poder e, em diversos casos, afastados do país. Além deles há um grande segmento de oposição que não tinha laços com essas instituições. Eram jovens que retornavam das pós-graduações no exterior - resultantes dos convênios estabelecidos com as escolas brasileiras ao longo dos anos 1960 -, a maior parte dos quais sustentará críticas ao governo militar.

A economia, que antes dividia espaço com a advocacia e a engenharia, encontra-se agora no centro do plano, visto que, ao longo do governo militar, os economistas conquistam prestígio, legitimidade e poder, passando, por um lado, a monopolizar os postos de direção da área econômica e, por outro, a ter importante voz na crítica ao governo militar. O único resquício de engenheiros está na borda ocupada pelos desenvolvimentistas cosmopolitas do período anterior, coincidindo com a geração mais velha retratada no espaço (1915-1930). O número de advogados remanescente é negligenciável já que os poucos que restam, em geral, possuíam especializações ou pósgraduação em economia.

Quanto ao gênero dos representados, no primeiro movimento havia somente duas mulheres na narrativa, Margareth Hansen e Maria da Conceição Tavares. Nos anos 1960 e 1970 o número de mulheres aumenta. Além de Alice Canabrava e Maria da Conceição Tavares, representantes da primeira geração de economistas, aparecem Eliana Cardoso, 
Elca Rosenberg, Helga Hoffmann, Tereza Versiani, Sulamis Dain, Dorothea Werneck, Zélia Cardoso de Mello e Betty Mindlin. As mulheres concentram-se na parte superior do plano, tanto por serem parte da geração mais jovem quanto por estarem longe do poder político. Além disso concentram-se na região do plano que abriga a heterodoxia.

Em termos regionais, há também grande alteração. Ainda que haja gaúchos e nordestinos, são poucos e relativamente dispersos, razão pela qual as regiões sequer estão assinaladas na rede. Os mineiros e cariocas do período anterior seguem em destaque, ocupando o Rio de Janeiro posição bastante central. A novidade em termos regionais é a massiva entrada de paulistas no governo. Se, no período anterior, havia algum ministro ou empresário paulista representado na rede, São Paulo ainda não representava força central. Sua principal escola de economia foi criada no mesmo ano que a FNCE e o Núcleo de Economia da FGV no Rio de Janeiro e sua primeira pós-graduação data do mesmo período que a da FGV, mas até o governo militar tinha pouca projeção nacional.

No início, São Paulo aparece como uma meritocracia sem laços quando comparada ao cenário da capital. Seus primeiros professores eram também advogados, engenheiros e cientistas sociais que se especializaram no estudo dos problemas econômicos. Seus cursos também nasceram de contatos com o exterior; primeiro, com as missões francesas na Faculdade de Filosofia da USP, depois, com os convênios com a Fundação Ford, a USAID e universidades dos EUA, a partir dos quais se originaram as pós-graduações. Entretanto, no que concerne ao recrutamento social de seus professores e alunos, São Paulo difere do Rio. Em lugar de Gudin e Bulhões, largamente dotados de capitais econômicos, culturais e vínculos com a elite da capital, os primeiros professores de destaque da Faculdade de Economia da Universidade São Paulo são originários de camadas médias e baixas, muitos filhos de imigrantes, sem proximidade com os grupos dirigentes da sociedade nacional.

$\mathrm{Na}$ primeira geração encontravam-se, por exemplo, Dorival Teixeira Vieira, filho de pugilista e controlador de trem formado em ciências sociais; Alice Canabrava, filha de fazendeiro do interior e de imigrante austríaca, professora primária que estudou história na Faculdade de Filosofia e, depois perder um concurso de cátedra na FFCL, deslocou-se para a FEA; Luiz Freitas Bueno, que teve que lecionar desde a idade ginasial em Ribeirão Preto e bacharelou-se em engenharia no Mackenzie com bolsa integral; André Franco Montoro, advogado de pai imigrante italiano que trabalhava como gráfico e mãe imigrante 
da região basca. Ruy Leme, o único de origem social privilegiada, era catedrático da Escola Politécnica e passou a figurar entre os professores da casa apenas ao final dos anos 1950.

Na geração seguinte, ao invés de Mario Henrique Simonsen, de família de elite, formado nos melhores colégios privados, jogador de xadrez e cantor de ópera, a figura proeminente era Delfim Netto que, em suas palavras, julgava ser visto pelos cariocas como um "paulista caipira, [...] gordo, italiano e vesgo. [...]. E além de tudo tem uns animais estranhos com ele, uns japoneses" (Delfim Netto apud SAFATLE, 2012, [online]). Delfim e diversos dos seus Delfim Boys eram descendentes de imigrantes, sobretudo japoneses e italianos como Paulo Yokota, Akihiro Ikeda e Miguel Colasuonno, muitos deles originários de camadas médias e baixas, formados em escolas públicas, com passagem pelo ensino técnico antes de ingressar na Faculdade de Economia. Não tinham, pois, um recurso essencial para chegar a postos de indicação, os laços com as elites políticas e econômicas nacionais. Tampouco eram conectados a membros da elite como Gudin e Bulhões, que haviam levado alunos seus para cargos de poder.

A chegada de São Paulo aos postos de comando percorre um caminho "técnico" no sentido em que é uma gradual ascensão que começa com a prestação de serviços aos governos locais, passa pela entrada em comissões econômicas paulistas, espaço de aproximação com empresários e políticos do Estado, que os levam a participar de órgãos de agregação de classe, ocupando-se das análises de conjuntura e debates econômicos. A presença dos professores da FCEA na ANPES, localizada entre os monetaristas e os desenvolvimentistas não nacionalistas, congregando muitos ministros da área econômica do governo militar, foi momento importante para sua ascensão para a esfera de poder nacional. Trata-se, portanto, de trajeto bastante dissimilar da via de Gudin, Bulhões ou Lucas Lopes, que, mais do que especialistas em economia, eram profunda e diretamente conectados às elites políticas e econômicas.

Por meio da ANPES, Delfim projetou-se nacionalmente. Foi apresentado aos presidentes militares, que fizeram dele ministro da fazenda durante dois governos, depois ministro da agricultura e ministro do planejamento. Por seu intermédio, muitos de seus discípulos foram alçados ao governo, formando a rede de leais associados que lhe dava suporte. A vastidão da teia de laços construída por Delfim explica ser um dos pontos de 
maior destaque na rede, posição que lhe confere capital social e prestígio suficiente para conquistar poder de mando na área econômica.

Em termos de posicionamento econômico, Delfim aparece a meio caminho entre os desenvolvimentistas nacionalistas e os desenvolvimentistas não nacionalistas, não porque mantivesse relações com os nacionalistas - à exceção dos quadros do BNDE ligados ao Clube dos Economistas que com ele trabalharam no governo Carvalho Pinto -, mas porque sua escola dividiu-se entre o governo militar e a oposição. Ainda assim, há um sentido em tal posição, visto que a configuração plural de sua escola convergia com sua própria atuação na condução do Estado. Como visto ao longo do capítulo, os escritos teóricos e a política econômica de Delfim eram bastante plurais em suas referências, distanciando-se sobretudo do modelo ortodoxo clássico. Mantinha o Estado bastante presente na economia, operando sem contenção de gastos e contando com o endividamento para impulsionar o crescimento, o que desagradava os monetaristas e era bem visto por setores nacionalistas; fomentava a agricultura de exportação como via para equilibrar a balança, aproximando-se àqueles para quem o país tinha vantagens comparativas na agricultura; mantinha considerável protecionismo, o que agradava os nacionalistas e era profundamente rejeitado pelos monetaristas; mas conservava a política de arrocho salarial instaurada pelos desenvolvimentistas não nacionalistas, o que desagradava toda oposição. Como será abordado no próximo capítulo, ao final do governo militar, Delfim ensaiou uma guinada ortodoxa para reduzir a inflação (item 5.5); em suma, empregava visões de economia de procedência eclética.

Além do grupo de Delfim e dos desenvolvimentistas cosmopolitas da geração de 1910-1930, encarnados nesta rede, sobretudo, por Roberto Campos, Lucas Lopes e João Paulo Reis Velloso, e do velho monetarismo à la Gudin, do qual Mario Henrique Simonsen estava próximo, há, no plano inferior, que concentra os colaboradores do governo militar, um novo monetarismo, aqui caracterizado como ortodoxia matematizada, visando indicar, simultaneamente, o respeito pelos mercados e pela moeda e a adesão às visões matematizadas. Princípios que emanavam da Escola de Chicago, instituição na qual estudaram a maior parte dos jovens economistas brasileiros que aparecem nessa região do plano, financiados por programas de cooperação científica, notavelmente alunos do curso do CENDEC, dirigido pelo egresso de Chicago, Og Leme. 
Arnold Harberger é a figura de maior destaque na área do espaço em que o Brasil se conecta a Chicago. Foi intermediário das relações de Chicago com a América Latina em diversos casos, com destaque para o Chile, onde seus Chicago boys são agentes centrais da implementação de políticas neoliberais - abertura externa, desregulação financeira, descentralização da economia e privatização (MONTECINOS, 2009, p. 149), receituário que conquistará o Brasil uma década e meia depois (item 6.2). No Brasil, o Chicago boy de maior destaque foi Carlos Geraldo Langoni, que sobressai nesse ponto do plano, sendo responsável por atrair diversos professores e pesquisadores com visões de economia análogas a sua para a FGV. Seria também ele, que mantinha laços tanto com os economistas cariocas ligados aos militares quanto com Delfim Netto, o canal de acesso ao governo de seus colegas de Fundação.

Como visto no capítulo anterior, houve ataques à política econômica do governo militar advindos do núcleo de economistas e cientistas sociais exilados (itens 3.3 e 3.5), que tinha maior identificação com a economia política clássica e com teorias do desenvolvimento de inspiração keynesiana e cepalina, que até os anos 1960 haviam tido grande difusão no espaço acadêmico brasileiro. Esse ataques foram deferidos por membros da vertente não matematizada da heterodoxia, setor do espaço no qual se encontram os desenvolvimentistas nacionalistas e ponto do plano no qual há mais conexões com a América Latina e com a Europa, nele estando posicionadas pessoas que estudaram em Varsóvia e na Inglaterra e os que tiveram vínculos com a CEPAL e com as universidades chilenas.

Neste Movimento foi apresentado o debate no qual o governo e seus apoiadores, com destaque para Delfim e Langoni, engajaram-se com determinação: a Controvérsia da distribuição de renda, do início dos anos 1970, iniciada quando da apresentação de artigos que acusavam o governo militar de ter aumentado a desigualdade econômica e social no país. Aqueles que atacavam partilhavam com os Chicago boys o treinamento recebido nos EUA e a capacidade de empregar a matemática e a estatística como ferramentas de legitimação da argumentação, procedimento em ascensão no centro do espaço dos economistas. Para a oposição, a matemática era aliada à crítica política e à contestação dos pressupostos fundamentais da teoria neoclássica; para a situação, era uma ferramenta utilizada para justificar, com números, os pressupostos neoliberais e a política dos militares. Nos dois casos, entretanto, é possível observar que a prova e a refutação passam 
a dever-se essencialmente à capacidade de demonstrar e justificar estatística e econometricamente as análises, fazendo uso de linguagem altamente esotérica, que excluía aqueles que não tinham formação especializada, encerrando os debates econômicos em um universo de iniciados e distanciando a economia das ciências humanas.

A difusão das vertentes matematizadas da ciência econômica promove a transição de um estágio no qual havia um conflito entre os "técnicos", com orientações assumidamente políticas que poderiam e deveriam ser debatidas entre os pares, e os "políticos", rejeitados pelos primeiros, por serem desprovidos das ferramentas que os "técnicos" julgavam necessárias para atuar na economia - por exemplo, o conflito entre os desenvolvimentistas não nacionalistas e os homens de Getúlio Vargas que tomou o BNDE em meados dos anos 1950 (item 2.3) -, para um estágio no qual a discussão sobre os fundamentos políticos das discórdias entre os "técnicos" e os "políticos" são obnubiladas por debates acerca das ferramentas, medidas, cálculos, construção e uso de indicadores e coleta de dados, sem consideração pelas finalidades últimas da condução econômica praticada com base nas - e legitimadas pelas - análises e instrumentais mobilizados pelos economistas (PÉCAUT, 1989, pp. v-vii; KLÜGER, 2015b).

$\mathrm{Na}$ rede as duas vertentes matematizadas (ortodoxa e heterodoxa) aparecem lado a lado. Seus membros figuram entre os mais jovens representados no espaço (1945-1955), tendo feito a pós-graduação nos Estados Unidos quase todos ao mesmo tempo. Frequentaram, entretanto, instituições nas quais prevaleciam crenças econômicas distintas, localizadas em pontos distantes do espaço dos economistas estadunidense. Cabe aqui um breve esclarecimento sobre isso. O survey de Colander e Klamer, aplicado com alunos de pós-graduação da maior parte das escolas norte-americanas aqui contempladas, pouco depois do período em que a maior parte dos economistas representados no plano passou pelos Estados Unidos, revela significativas diferenças entre as escolas pelas quais passaram os economistas de cada vertente.

As opiniões dos alunos do MIT e de Harvard aparecem, quase sempre, em estreita oposição àquelas dos alunos de Chicago. Yale estando, via de regra, próxima a Harvard e ao MIT. Por exemplo, Chicago tem o maior número de respondentes a concordar fortemente com a afirmação "a economia é a mais científica das ciências sociais", enquanto Harvard e Yale têm os maiores números de pessoas que discordavam da afirmação. Quase todos os entrevistados de Chicago consideravam que o Banco Central 
deve manter crescentes reservas monetárias. A maioria dos respondentes de Harvard, do MIT e de Yale discordava. 70\% dos respondentes de Chicago achava que a existência do salário mínimo aumenta o desemprego de jovens e trabalhadores desqualificados. O MIT e Harvard são as escolas nas quais o menor número de respondentes concordava com essa afirmativa, $24 \%$ e $15 \%$, respectivamente. Nenhum respondente de Chicago discordava da frase: a inflação é um fenômeno puramente monetário, sendo que 84\% concordavam fortemente com ela. Ao passo que só 7\% e 15\% dos alunos do MIT e de Harvard, respectivamente, concordavam com a afirmação. Como último exemplo, apenas 6\% dos alunos de Chicago concordavam inteiramente com a afirmativa "a distribuição de renda nas nações desenvolvidas deve ser mais igualitária" contra mais de 50\% dos alunos do MIT, de Harvard e de Yale (COLANDER e KLAMER, 1987, pp. 103-104).

No caso de Vanderbilt, universidade que aparece ao centro do polo heterodoxo justamente por ter tecido convênios diretos tanto com o Rio de Janeiro quanto com São Paulo, a relação do Brasil era especificamente com membros do programa de pósgraduação em desenvolvimento econômico, estando os professores que acolhiam os brasileiros longe do coração da economia monetarista. Quanto à Berkeley, que aparece na fronteira entre a heterodoxia matematizada e o desenvolvimentismo nacionalista, Marion Fourcade explica que o departamento de economia situava-se, nos anos 1960, no mesmo prédio que as outras ciências sociais. Ao longo dos anos 1970 parte do departamento começou a migrar para o prédio da matemática e da estatística, notavelmente aqueles que tinham maior inclinação para a econometria, entre os quais Gerard Debreu, membro da sociedade de econometria e fundador do Journal of Mathematical Economics (item 1.5). Restaram no prédio das ciências sociais economistas como Albert Fishlow, da história econômica, Lloyd Ulman, que estudava finanças públicas e trabalho, e Joe Bain, da área de organização industrial. "Fishlow, Bain e Ulman certamente não eram anti-técnicos, mas o uso que faziam da estatística era majoritariamente descritivo, evitando modelagens formais mais complexas. Eles também estavam fortemente envolvidos com trabalhos práticos, com governos, fundações, agencias regulatórias e sindicatos" (FOURCADE, 2009, pp. xi-xiii). A maior parte dos brasileiros representados na rede estudaram em Berkeley enquanto o departamento ainda ficava junto às ciências sociais. Alguns chegaram a viver o período de transição, mas o vínculo mais forte que mantinham era com Albert 
Fishlow, que era da área de história e permanecia não profundamente imerso na matemática.

Ao retornar da pós-graduação nos EUA, os egressos de diferentes escolas tenderam a ocupar postos em instituições diferentes. Os doutores por Vanderbilt espalharam-se pelo país, coincidindo, alguns deles coincidindo com egressos do MIT, de Harvard e de Yale em Brasília. Em um segundo momento, houve uma agregação de Harvard, Yale, MIT e Berkeley na PUC-RJ, que incorporou os professores que deixaram a FGV ao perder a disputa pelo controle da EPGE para Chicago. A participação dos professores mais antigos no governo abrira espaço para os novos doutores nas escolas já existentes. Além disso, há movimentos de colonização de espaços pouco institucionalizados, como a UNB e a PUC-RJ, nos quais os PhDs mimetizaram os modelos de ensino, pesquisa e a administração colegiada das universidades nas quais estudaram no exterior. $O$ indivíduo de maior destaque na vertente heterodoxa matematizada é Edmar Bacha que, além de ter sido figura importante na criação da UNB e professor ativo na PUC-RJ, costumava reunir, em sua casa em Cambridge, alunos seus e colegas de sua esposa Eliana Cardoso, que estavam em Harvard e no MIT, estreitando os laços entre aqueles que com ele seguiriam para a PUC-RJ.

No que concerne à posição do BNDE no espaço nesse período, nota-se que ele permaneceu entre os dois desenvolvimentismos, sendo seus funcionários de carreira predominantemente nacionalistas e seus presidentes, um pouco mais próximos dos cosmopolitas. É possível pensar o grau de centralidade da instituição a partir da comparação dos dois dirigentes que o Banco teve no período e do tipo de laços que cultivavam. Magrassi de Sá era um burocrata de carreira, com vínculos com diversas instituições da área econômica e com militares ligados à ESG, mas sem laços com personalidades importantes do governo, desfalque agravado pela relação de animosidade com Delfim, o ministro mais poderoso do governo. Marcos Vianna, ao contrário, tinha elos com o presidente Geisel, com Mario Henrique Simonsen, que conhecia desde a universidade, e com Reis Velloso. É em sua gestão, em meio ao projeto econômico capitaneado por Reis Velloso, que voltava a apostar em um desenvolvimento com impulso do planejamento e do Estado, que o Banco volta a crescer em termos de pessoal, orçamento e destaque político. 
O Terceiro Movimento, que se ocupa da década de oitenta, dá sequência ao Intermezzo, acompanhando o retorno do grupo deslocado do espaço nacional pela ditadura em meio à abertura, mostrando como eles e aqueles que figuram no Segundo Movimento como oposição assumem postos de direção na economia e na política na Nova República. 


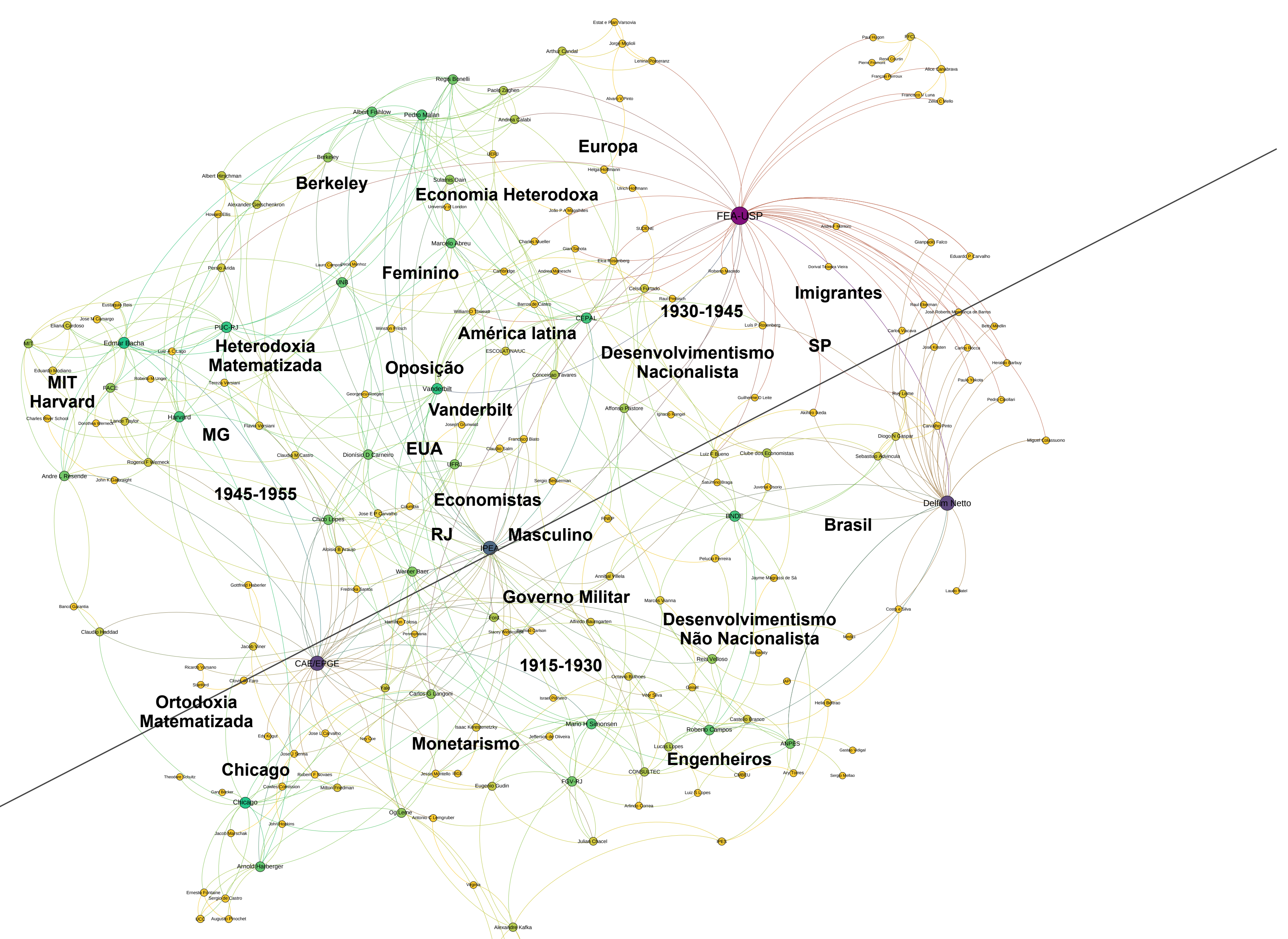




\section{TERCEIRO MOVIMENTO: A frente de oposição no governo (1979-1990)}

O Intermezzo encerra-se após a tomada do Estado chileno pelos militares, evento que dispersou a colônia brasileira que ali vivia. Muitos não tinham a opção de voltar ao Brasil. Obrigados a exilar-se novamente, transferiram-se para o Canadá, a Suécia, a França, o México e onde mais conseguissem asilo. Parte dos que puderam retornar ao país radicou-se em estruturas institucionais nas quais houvesse espaço para o exercício da crítica política. O Terceiro Movimento principia pela apresentação do processo de construção das ilhas de liberdade intelectual nas quais abrigaram-se muitos daqueles que retornavam ao país e às quais aderiram também diversos professores e pesquisadores ligados às esquerdas que haviam permanecido no país. Eram pessoas que perderam sua posição na universidade e na política por conta das perseguições promovidas pelos militares ou que sequer puderam ingressar na carreira docente, por suas vinculações e por não encontrar nas escolas existentes a possibilidade de expressar suas ideias.

Com o objetivo de delinear dois dos territórios criados pela oposição, o Departamento de Planejamento Econômico (DEPE) da Universidade Estadual de Campinas (UNICAMP) e o Centro Brasileiro de Análise e Planejamento (CEBRAP) em São Paulo, acompanhar-se-á o trajeto de regresso de alguns exilados e os movimentos internos de pressão pela abertura de novos centros de produção intelectual. A narrativa do Terceiro Movimento inicia-se (item 5.1) precisamente onde o Intermezzo interrompese, recuperando o trajeto que José Serra faz após deixar o Chile. Depois de passar alguns meses na Europa, ele foi aceito no doutorado na University of Cornell nos EUA, onde foi contemporâneo de alguns brasileiros que estavam fazendo pesquisa ou concluindo a pósgraduação naquela universidade. Eram em sua maioria pessoas ligadas à Escola de Administração de Empresas de São Paulo da Fundação Getúlio Vargas (EAESP-FGV), como Yoshiaki Nakano e Manoel Berlinck, e doutorandos advindos da Universidade de São Paulo (USP), como Renata Rosenthal, Luciano Coutinho, Gilda Portugal Gouvêa e Roberto Perosa.

A apresentação da área de economia da EAESP-FGV principia pela análise das trajetórias de Yoshiaki Nakano e Luiz Carlos Bresser Pereira, dando ênfase aos atritos entre a Fundação do Rio de Janeiro e de São Paulo, decorrentes do pleito para que se 
instalasse em São Paulo um departamento de economia. A direção da FGV do Rio manifestou-se contrária à iniciativa paulista argumentando que o novo departamento teria em seus quadros pessoas que "flertavam com a subversão", como Luiz Carlos Bresser Pereira, Eduardo Suplicy, Luiz Antônio de Oliveira Lima e Yoshiaki Nakano.

Ao tematizar as trajetórias de Luiz Carlos Bresser Pereira e de seu grande amigo Fernão Bracher serão tecidas considerações acerca da geração da Juventude Universitária Católica (JUC) que antecedeu a conquista da União Nacional dos Estudantes (UNE) e a origem da Ação Popular (AP), processos narrados no Intermezzo. A JUC de Bresser e Bracher provinha dos colégios católicos de elite, concentrava-se na Faculdade de Direito do Largo São Francisco e espelhava-se nos jovens políticos da Democracia Cristã, como André Franco Montoro e Plínio de Arruda Sampaio. Ao falar sobre Eduardo Suplicy, outro dos professores de economia da EAESP, os laços entre famílias das elites industriais paulistas e as relações destas com a Federação das Indústrias do Estado de São Paulo (FIESP), o meio acadêmico e o poder político começam a ser delineados. Alguns destes industriais paulistas associar-se-ão ao Movimento Democrático Brasileiro (MDB) e ao Partido do Movimento Democrático Brasileiro (PMDB). O engajamento na luta pela redemocratização seria um trunfo para a nomeação para altas posições na Nova República (item 5.1). Exemplo notável desta comunhão é a nomeação, no governo de José Sarney, de Dílson Funaro para o Banco Nacional de Desenvolvimento Econômico e Social (BNDES) e depois para o Ministério da Fazenda (item 5.5).

As trajetórias dos descendentes de elites econômicas, culturais e políticas serão contrastadas com o percurso de Yoshiaki Nakano até Cornell. A narrativa verte então em direção ao outro grupo que cursou o doutorado nessa universidade, os casais Perosa e Coutinho, provenientes do Instituto de Pesquisas Econômicas da USP (IPE-USP). A trajetória de Coutinho é o elo que conduz a narrativa de Cornell à Universidade Estadual de Campinas (UNICAMP), na qual se constituirá um departamento de economia crítico sob os auspícios dos brasileiros que estiveram vinculados à Comissão Econômica para a América Latina (CEPAL) (item 5.2).

Houve, na montagem da UNICAMP, uma convergência entre pessoas que permaneceram no Brasil e foram alunos de cursos do Centro CEPAL-BNDE, notavelmente Luiz Gonzaga Belluzzo, João Manuel Cardoso de Mello e Wilson Cano que atraíram para a nova escola os principais quadros do Centro CEPAL-BNDE, Maria da 
Conceição Tavares, Carlos Lessa e Antonio Barros de Castro, e um grande grupo de alunos e professores da Escuela Latinoamericana de Economía de la Universidad de Chile (ESCOLATINA), entre os quais Adhemar Kyotoshi Sato, Ana Célia Castro, Carlos Alonso Barbosa de Oliveira, Cláudio Salm, Frederico Mazzucchelli, Jorge Mattoso, José Carlos Braga, José Serra, Liana Aureliano, Paulo Baltar, Paulo Renato Souza e Sulamis Dain (item 5.2).

Uma vez construída e caracterizada a nova escola, passam ao centro da narrativa os vínculos entre a UNICAMP, o Centro Brasileiro de Análise e Planejamento (CEBRAP) e os intelectuais de oposição agregados nessas duas instituições com o Movimento Democrático Brasileiro (MDB). A construção do CEBRAP começa com o retorno de Fernando Henrique Cardoso da França para o Brasil, seguida da conquista da cátedra da ciência política. O retorno de FHC à USP foi breve pois, meses depois, ele e diversos colegas foram cassados em consonância com as medidas de segurança nacional decretadas pelo Ato Institucional No. 5. (AI-5). Eles e outros pesquisadores que haviam perdido o espaço nas universidades mas não tinham a intenção de deixar o país agregaram-se em centros de pesquisa privados fomentados com recursos de fundações internacionais, conquistados com auxilio de seus trunfos cosmopolitas e o apoio de setores nacionalistas das elites políticas e econômicas com as quais possuíam laços (item 5.3).

Conforme o regime começa a abrir-se politicamente, os quadros do CEBRAP deixam de restringir-se a pesquisas voltadas para o meio acadêmico e à prestação de serviços de planejamento e passam a expressar publicamente suas críticas à política e à economia conduzidas pelos militares. A criação de um conjunto de veículos de comunicação dirigidos e sustentados pela oposição propiciou a entrada dos intelectuais no debate público. Começaram divulgando suas ideias no jornal Opinião, de propriedade de Fernando Gasparian, amigo próximo de FHC. Três anos depois, um grupo dissidente do Opinião, liderado pelos setores da AP que adotaram uma perspectiva maoísta aderindo ao Partido Comunista do Brasil (PC do B), funda o jornal Movimento. Ainda que os dois jornais fossem nacionalistas e apoiassem a ideia de criação de uma frente ampla contra a ditadura liderada pelo MDB, eles apoiavam setores diferentes dentro do partido (item 5.3).

À essa divisão seguiu-se a cisão interna ao Movimento que deu origem ao jornal Em Tempo, que incorporou militantes do Partido Operário Comunista (POC), alguns dos 
quais constavam entre os exilados chilenos, e frações ligadas ao grupo DEBATE, que reunia jovens brasileiros exilados na França e remanescentes no país que ajudavam a circular no Brasil os escritos e ideias por eles produzidos. A transição para o Em Tempo é conduzida pela trajetória de Guido Mantega, ligado ao mesmo tempo ao jornal e ao CEBRAP, que fez parte do primeiro grupo de intelectuais que se associou ao Partido dos Trabalhadores (PT), em formação no final dos anos 1970. A posição favorável à organização autônoma dos trabalhadores que predominava no Em Tempo era igualmente sustentada pelos principais pesquisadores do Centro de Estudos de Cultura Contemporânea (CEDEC), dissidência do CEBRAP, cujas pesquisas concentravam-se nas áreas de movimentos sociais, trabalho e dinâmicas sociais urbanas, e por uma parte do Departamento de Economia da Pontifícia Universidade Católica de São Paulo (PUC-SP), que teve seu curso reformado por Paul Singer e passou a incluir em seus quadros economistas que se ligaram ao PT, como Paulo Sandroni, Guido Mantega, Walter Barelli e Plínio de Arruda Sampaio (item 5.3).

Até a formação do novo partido houve uma convergência eleitoral da intelectualidade que se associaria ao PT e daqueles que se vinculavam ao $\mathrm{MDB}$. $\mathrm{Na}$ metade dos anos 1970, parte do CEBRAP e diversos economistas da UNICAMP trabalharam na produção dos programas do MDB para as eleições. Em 1974, a anticandidatura de Ulysses Guimarães conquistou simpatia da oposição por ter usado o espaço de uma disputa eleitoral perdida para fazer campanha contra a ditadura, ecoando as críticas produzidas pelas esquerdas ao longo da década (item 5.3). Em 1978, Fernando Henrique Cardoso aceitou ser candidato ao Senado pelo MDB, contando com o apoio dos trabalhadores organizados sob a liderança de Luiz Inácio Lula da Silva, líder sindical que se destacou nas greves do final da década e se converteria no principal nome do PT desde a fundação do partido. Como previsto, FHC não foi eleito pois o candidato mais forte do MDB ao Senado por São Paulo era André Franco Montoro, mas conquistou a suplência. Em 1982, quando Montoro foi eleito governador do Estado de São Paulo, Cardoso assumiu seu posto como senador (item 5.4).

Montoro reuniu assessores e secretários de quatro procedências em seu governo: 1) políticos do MDB; 2) católicos ligados ao Partido Democrata Cristão (PDC), à Juventude Estudantil Católica (JEC) e à Juventude Universitária Católica (JUC); 3) antigos militantes da Ação Popular (AP) e colegas deles dos tempos de exílio; e 4), na Secretaria 
da Fazenda e órgãos a ela subordinados um grupo de colegas de André Franco Montoro Filho, que era professor da Faculdade de Economia e Administração da Universidade de São Paulo (FEA-USP) e havia sido contemporâneo de João Sayad e de Marcos Giannetti da Fonseca no doutorado em Yale, sendo incluídos também na equipe Andrea Calabi, Francisco Vidal Luna e Philippe Reichstul. As trajetórias da equipe da Fazenda conduzirão a narrativa até a ida de João Sayad para o Ministério do Planejamento, sendo tecidas considerações acerca da forma de composição dos ministérios na retomada da democracia, momento em que considerações de natureza política e arranjos partidários voltam a ter explícito peso no processo de nomeação (item 5.4), como ficará evidente ao observar a composição da primeira diretoria do Banco Nacional de Desenvolvimento Econômico e Social (BNDES) do período democrático (item 5.5).

A apresentação da primeira gestão do BNDES da Nova República é precedida por uma discussão sobre o período que vai da saída de Marcos Vianna da Presidência em 1979 à nomeação de Dílson Funaro em 1985. As diretorias neste interlúdio foram compostas e desfeitas em resposta a disputas pela sucessão presidencial que opõem Antônio Carlos Magalhães (ACM) a Paulo Maluf. Magalhães indicou dois presidentes para o Banco, um foi derrubado por ele mesmo por aliar-se a Maluf, o outro foi derrubado pelos apoiadores de Maluf por permanecer fiel a ACM. Do ponto de vista interno, a política do Banco acaba colando-se aos esforços de ajuste econômico promovidos por Delfim Netto que retornara ao poder, agora como Ministro do Planejamento. A mudança de vulto no período é a criação de uma área social no Banco, decorrente da alocação dos recursos do Fundo de Investimento Social (FINSOCIAL). Essa expansão do agora Banco Nacional de Desenvolvimento Econômico e Social é correntemente interpretada como uma manobra política de teor populista, especialmente porque pretendia-se que os recursos do Fundo fossem investidos sem passar pelo departamento de prioridades e pela avaliação técnica, aos quais todos os outros projetos deveriam ser submetidos (item 5.5).

O modo de gestão dos recursos do FINSOCIAL é alterado com a nomeação de Carlos Lessa para a diretoria da área. Lessa estava enraizado há alguns anos no Rio de Janeiro. Depois de ter ajudado a montar a pós-graduação da UNICAMP, reuniu-se ao grupo de pesquisadores do Fundo de Financiamento de Estudos de Projetos e Programas (FINEP) e de professores do Instituto Alberto Luiz Coimbra de Pós-Graduação e Pesquisa de Engenharia (COPPE-UFRJ) que montou o Instituto de Economia Industrial 
da UFRJ (IEI-UFRJ), que agregaria boa parte dos economistas cariocas ligados ao Partido do Movimento Democrático Brasileiro (PMDB), atuantes também no Instituto de Economistas do Rio de Janeiro (IERJ). Nas mãos de Lessa a área social passaria a fomentar projetos de pretensão universalista que pudessem ser reproduzidos com sucesso em escala nacional pelos órgãos federais, estaduais ou municipais competentes. Neste ponto discutir-se-á brevemente o conflito entre esferas vivenciado pelo BNDES na tentativa de entrar na área social, na qual já atuavam tantas instâncias governamentais (item 5.5).

Além de uma série de políticos de diferentes regiões do país, de Carlos Lessa indicado pelo PMDB do Rio e de Dílson Funaro e André Franco Montoro Filho, presidente e vice, ambos indicados pelo PMDB de São Paulo, integrava a diretoria Francisco André Roberto Gros, escolhido por Funaro para dirigir a área de capitais e para a BNDES Participações S.A. (BNDESPAR). Gros era um pioneiro do mercado financeiro no Brasil, tendo trabalhado em instituições nacionais e internacionais da área e sendo um dos fundadores da Comissão de Valores Mobiliários (CVM). Sua primeira passagem pelo BNDES durou dois anos, de 1985 até ele ser convocado para a presidência do Banco Central do Brasil (BCB) no início de 1987. Em fevereiro de 2000, Gros retornaria ao Banco, na função de presidente, que desempenharia até o início de 2002 (itens 5.5 e 6.5 ).

Francisco Gros foi transferido para o BCB, no momento em que chegara ao fim a experiência do Plano Cruzado, o primeiro de uma série de experimentos heterodoxos de controle da inflação, momento de grande projeção dos economistas na vida nacional. Especial ênfase é dada a ele no capítulo, pois encerra um período no qual prevalece a cooperação dos economistas de oposição em torno do projeto democrático, estando imbuídos da tarefa de acabar com a crise atravessada pelo Brasil sem deteriorar ainda mais as condições econômicas dos trabalhadores, especialmente porque seus artífices eram parte da oposição que passara os últimos 15 anos criticando o modelo de crescimento com desigualdade adotado pela ditadura (item 5.6).

Desde 1984, circulavam publicamente propostas heterodoxas de estabilização, baseadas na ideia de inflação inercial, que propunham derrubar a inflação sem recessão, arrocho e concentração de renda. Depois de um período de fracasso da intensa ortodoxia, liderada pelo ministro da Fazenda, Francisco Dornelles, sobrinho de Tancredo e 
professor da Escola de Pós-Graduação em Economia da Fundação Getúlio Vargas do Rio de Janeiro (EPGE-FGV), José Sarney decide fazer uma substituição na equipe econômica, convocando Funaro e Bracher para a Fazenda e o Banco Central respectivamente. Com Dílson vieram os professores da UNICAMP Luiz Gonzaga Belluzzo e João Manuel Cardoso de Mello para a Fazenda. Fernão Bracher montou uma equipe centrada na Pontifícia Universidade Católica do Rio de Janeiro (PUC-RJ). André Lara Resende e Persio Arida eram os dois autores de uma das principais propostas de estabilização baseada no diagnóstico que a inflação brasileira tinha uma grande componente inercial. Francisco Lopes, autor de outra das mais conhecidas propostas heterodoxas para eliminação da inflação, e Eduardo Modiano, que colaborou com cálculos e cenários subsidiários para implantação de um plano heterodoxo, eram colegas de PUC-RJ e aceitaram oferecer consultoria à nova equipe econômica. Edmar Bacha, que lecionava na mesma escola, foi convidado a presidir o Instituto Brasileiro de Geografia e Estatística (IBGE) (item 5.6).

Com essa composição a equipe econômica do governo assumiu uma configuração heterodoxa e dispôs-se a tentar uma saída não convencional para a crise. Quando Sarney aceitou trilhar o caminho por eles indicado, Argentina e Israel atravessavam percursos semelhantes, fazendo com que não parecesse mais apenas uma ousadia de um grupo de jovens intelectuais. A implementação apressada do Plano e o pioneirismo foram certamente elementos de seu fracasso, mas parte do caminho trilhado até a implementação de uma solução adequada para o problema, calcada nos mesmos princípios e nos aprendizados acumulados em 7 anos de experimentações antiinflacionárias não ortodoxas. A travessia fez com que o equilíbrio frágil entre economistas com diferentes orientações teóricas e filiações políticas ruísse, impulsionando o processo de reconfiguração do espaço dos economistas no Brasil que afastou e salientou as diversas frações no interior do agora antigo polo de oposição. A apresentação dos conflitos existentes no período mostrará, não obstante, que as tensões decorrentes das afiliações distintas era apenas uma parcela do confronto existente, visto haver embates funcionais entre o Ministério do Planejamento, a Fazenda e o Banco Central do Brasil (BCB). Além disso, havia impactos das disputas políticas nacionais no processo decisório que colocavam os economistas uns contra os outros e muitos contra os governantes. As colisões resultantes da tarefa de implementar um projeto antiinflacionário experimental 
em uma situação de alta tensão política e em meio a uma crise econômica aguda, em conjugação com a multiplicação partidária, foi criando subgrupos que orbitavam diferentes partidos (item 5.6) ou formavam núcleos diferentes entre os apoiadores de um mesmo partido, configuração que prevalecerá no Quarto Movimento.

\subsection{Luiz Carlos Bresser Pereira e Yoshiaki Nakano: a EAESP-FGV}

Em maio de 1974, quando finalmente obteve liberação para deixar o Chile, José Serra partiu para a Itália, país em cuja embaixada esteve asilado por mais de meio ano. Ao chegar a Roma, hospedou-se na casa da única pessoa que conhecia na cidade, Ivan de Otero Ribeiro, economista da Faculdade de Ciências Econômicas e Administrativas da Universidade Federal de Minas Gerais (FACE-UFMG) e militante do Partido Comunista Brasileiro (PCB) que, depois de ter vivido no Chile e na Polônia, conseguiu um emprego na Organização das Nações Unidas para a Alimentação e a Agricultura (FAO) em Roma. Fazendo planos para o doutorado, Serra visitou os brasileiros Marcelo de Paiva Abreu e Winston Fritsch que estudavam em Cambridge e teve conversas com Celso Furtado, que ocupava a cátedra Simon Bolívar ${ }^{384}$ naquela universidade. Acabou, entretanto, indo para o programa de doutorado da University of Cornell, mudando-se para Ithaca em julho de 1974 (SERRA, 2014, pp. 225-228).

Nos EUA, foi recebido novamente pelos Arruda Sampaio. Plínio lá estava desde 1970, trabalhando no programa da FAO com o Banco Interamericano de Desenvolvimento (BID) e residindo em Washington. No Programa de Estudos LatinoAmericanos da Universidade de Cornell, Serra passou a ser orientado por Tom E. Davis, responsável pela maior parte dos brasileiros que estudaram economia em Cornell naqueles anos, que era um economista com antiga ligação com a América Latina, tendo vivido e lecionado no Chile no programa de cooperação científica de Chicago com a Universidad Católica de Chile (VALDÉS, 1995, p. 134).

Ao instalar-se em Ithaca, Serra comprou a mobília de dois estudantes que estavam voltando para o Brasil: Yoshiaki Nakano e Sergio Mindlin. Sergio, como ele, era politécnico e havia participado de experimentos teatrais universitários críticos, atuando, por exemplo, na montagem que Flávio Império fez, em 1968, da peça Os Fuð̨is de Senhora

\footnotetext{
${ }^{384}$ Ver: http://www.centrocelsofurtado.org.br/geral.php?ID_M=483. Consultado em 01/03/2016.
} 
Carrar de Bertold Brecht ${ }^{385}$. Além disso, era irmão de Betty Mindlin, então casada com Celso Lafer ${ }^{386}$ (1941). Betty e Celso, provenientes de famílias industriais paulistanas, educados em colégios privados de elite e egressos da USP, haviam feito o mestrado em Cornell, entre 1965 e 1967. Ela, que estudara no Colégio Bandeirantes e que fora assistente de Delfim Netto na FEA, matriculou-se no mestrado em economia sob a direção de Tom E. Davis; ele, que estudara nos colégios American Graded School e Dante Alighieri e havia feito o bacharelado na Faculdade de Direito do Largo São Francisco, seguiu o mestrado em ciência política. Lá foi aluno de Hannah Arendt e Octávio Paz, que afirma terem tido decisiva influência em sua formação 387 (CANABRAVA, 1984a, pp. 106; DHBB, verbete Celso Lafer).

Betty Mindlin foi para Cornell quase ao mesmo tempo que Raúl José Ekerman (1941), seu colega da Faculdade de Economia e Administração e Contabilidade da Universidade de São Paulo (FEA) ${ }^{388}$. Ekerman era filho do representante e distribuidor no Brasil dos filmes da Columbia Pictures e estudou no Colégio Rio Branco, outra das escolas paulistanas de elite, ingressando na FEA um ano depois de Betty. Tornaram-se frequentadores dos seminários do Delfim e, pouco depois, alunos da pós-graduação em Cornell. De volta ao Brasil, passaram alguns semestres como assistentes dos professores da missão de Vanderbilt. Betty e Ekerman colaboravam com os professores da cadeira de macroeconomia e ele trabalhava também com Werner Baer, na área de desenvolvimento econômico. Betty esteve ligada à USP até 1970. Em 1975, passou a lecionar na EAESPFGV e depois infletiu sua carreira em direção à antropologia ${ }^{389}$. Raúl lecionou na USP até 1979, juntando-se à sua colega na Fundação Getúlio Vargas de São Paulo (FGV-SP)

\footnotetext{
${ }^{385}$ Ver: http://www.flavioimperio.com.br/galeria/507949/507951. Consultado em 6/12/2015 e MACHADO, 2014.

${ }^{386}$ Lafer e Mindlin eram duas famílias de judeus europeus enraizados na cidade São Paulo que enriqueceram por meio de empreendimentos no setor industrial. Celso Lafer é filho Abraão Jacob Lafer, dirigente da empresa Klabin Papel e Celulose e fundador fábrica de autopeças Metal Leve. Abraão era, ademais, irmão de Horácio Lafer, que fora Ministro da Fazenda de Getúlio Vargas. Betty e Sergio eram filhos José Mindlin, advogado formado na Faculdade de Direito do Largo São Francisco, bibliófilo e sócio de Lafer na Metal Leve (DHBB, verbete Celso Lafer). A razão pela qual Sergio, Betty e Celso optaram por ir para Cornell, ou os contatos que mobilizaram para chegar lá não aparecem no material consultado. É possível aventar, contudo, que teriam contado com apoio familiar para deixar o país pois eram provenientes de famílias abastadas, ambas marcadas pela perseguição judaica experimentada na Europa, razão pela qual os patriarcas tenderiam a ajudar seus filhos a deixar o país no momento de instauração de um estado de exceção.

387 Ver: http://www.academia.org.br/academicos/celso-lafer/discurso-de-posse, consultado em 6/12/2015 e LAFER, 2007-2008; Além de ter sido sua professora, Hannah Arendt passou a ser um dos grandes temas de suas reflexões acadêmicas. Ver, por exemplo, LAFER, 2007.

${ }^{388}$ Ver:

http://memoria.bn.br/DocReader/Hotpage/HotpageBN.aspx?bib=090972_09\&pagfis=5124\&pesq=\&url=http://m emoria.bn.br/docreader\#. Consultado em 01/03/2016.

${ }^{389}$ Ver: http://lattes.cnpq.br/6111905016266365. Consultado em 08/03/16.
} 
pouco depois (CANABRAVA, 1984a, pp. 106, 250). Betty e Ekerman inspiraram e mediaram a ida de alguns alunos da FEA para Cornell; entre eles, Yoshiaki Nakano, que afirma ter sido influenciado por eles ao definir onde cursaria a pós-graduação.

Nascido na cidade paranaense de Cafelândia e criado em Maringá, Nakano (1944) é filho de imigrantes japoneses que, segundo ele, o criaram conforme os preceitos do código de conduta dos samurais ${ }^{390}$. Explica que a militância política e o socialismo marcaram seu caminho até a economia, com a consciência da injustiça levando-o "a querer mudar radicalmente a realidade em que vivíamos e a sonhar com grandes utopias. A escolha da economia me permitiu compreender essas questões e trilhar o caminho da utopia para a política, só que aí equipado com um instrumental poderosíssimo" (NAKANO, 1999, p. 247). Ele argumenta que, por viver no interior e estudar em um lugar que tinha acabado de implementar o curso secundário, não tinha informações sobre a então não convencional carreira de economista. Ingressou no curso de administração de empresas da FGV pois este reunia disciplinas de várias áreas que lhe atraíam: as ciências sociais, a economia, o direito e a psicologia (NAKANO, 1999, p. 248).

O despertar para a economia, ainda na graduação, foi influenciado pelo professor Luiz Carlos Bresser Pereira, que no seminário de desenvolvimento econômico sustentava que "a Ciência Econômica fornecia os instrumentos para compreender e mudar a realidade deste país". Segundo Bresser, Nakano foi "o meu mais próximo colaborador, sempre”. Quando seu professor na graduação, Bresser não era formalmente um economista, e sim um advogado e administrador em processo de migração para a fronteira entre a economia, a sociologia e a administração. Em suas aulas discutia os escritos de Max Weber e John Galbraith, empregava a literatura sobre sociologia da burocracia e abordava tópicos ligados à problemática do subdesenvolvimento (NAKANO, 1999, p. 248; Entrevista de Bresser Pereira à autora, 2012).

A formação superior inicial de Luiz Carlos Bresser Pereira (1934) fora adquirida na Faculdade de Direito da USP. Seguira os passos de seu pai, Sylvio de Lima Gonçalves Pereira, e do avô paterno, Horácio Gonçalves Pereira, indo estudar no Largo São Francisco ${ }^{391}$. O avô, paulistano descendente de portugueses, era advogado, dono de um cartório de registro de imóveis e ligado ao Partido Republicano Paulista (PRP). Uma de

\footnotetext{
${ }^{390}$ Ver: http://www.fundacaomariocovas.org.br/mariocovas/pronunciamentos/secretario-da-fazenda/. Consultado em 03/03/206.

${ }^{391}$ Ver: http://memoria.bn.br/DocReader/DocReader.aspx?bib=090972_08\&PagFis=3326 e http://memoria.bn.br/DocReader/DocReader.aspx?bib=090972_08\&PagFis=15764. Consultados em 08/03/16.
} 
suas filhas casou-se com Alexandre José Barbosa Lima Sobrinho, pertencente a tradicionais famílias nordestinas com amplos laços com a política. Bacharel em direito, Lima Sobrinho foi redator-chefe do Jornal do Brasil e eleito duas vezes presidente da Academia Brasileira de Imprensa. Na sequência, ingressou na vida política, sendo deputado federal por Pernambuco, depois presidente do Instituto do Açúcar e do Álcool e, finalmente, governador de Pernambuco (DHBB, verbete Lima Sobrinho).

O pai de Bresser não seguiu caminhos tão distintos daqueles de seu cunhado. Também era membro da Associação Brasileira de Imprensa, mas não teve tanto sucesso na política, na qual estreou em 1946, ao ser eleito para a Assembleia Legislativa pelo Partido Trabalhista Brasileiro (PTB). Luiz Carlos conta que seu pai tinha grande admiração por Getúlio Vargas, de quem Lima Sobrinho se aproximara, e dizia aos seus filhos que "a política era a arte do compromisso, no sentido de compromise $\left.{ }^{392}\right]$. Quando dizia isso ele estava se referindo ao Getúlio Vargas que é, até hoje, para mim, o grande estadista do século XX brasileiro" (Entrevista de Luiz Carlos Bresser Pereira à autora, 2012).

Como não logrou reeleger-se, Sylvio Pereira adquiriu o jornal $O$ Tempo, ao qual vinculou-se como associado, contratando, para ser editor, o trotskista Hermínio Sacchetta, diretor da Liga Socialista Independente, pequena agregação política que reunia um grupo de intelectuais ligados às ciências sociais, entre os quais Antônio Candido, Paul Singer, Wilson Cantoni, Michel Löwy, Eder e Emir Sader (SADER, 2013, p. 8; LÖWY, 1996, pp. 3-4). A experiência de Sylvio Pereira com o jornal resultou em sua falência, provocando endividamento e levando à dilapidação da propriedade familiar. Fez também com que abandonasse a vida política e a imprensa e voltasse à advocacia e ao funcionalismo público para poder saldar as dívidas e refazer o status familiar (Entrevista de Luiz Carlos Bresser Pereira à autora, 2012).

Diferentemente do pai, Luiz Carlos nunca advogou. Conta que pouco interesse tinha no direito. Gostava mesmo de cinema, que estudou por um ano em curso do Museu de Arte de São Paulo (MASP), e tinha interesse nas ciências sociais. Acabou combinando o jornalismo e a política paternos com a atividade educacional que predominava na família de sua mãe. Seu avô materno, Alfredo Bresser da Silveira, nascido em São Paulo, era descendente, do lado paterno, de portugueses e, por parte de mãe, de Karl Bresser,

\footnotetext{
${ }^{392}$ No sentido de costurar os acordos e resolver as disputas fazendo concessões.
} 
geômetra proveniente de Krefeld, na Alemanha, que emigrara para São Paulo para orientar a construção de estradas e pontes (UNZELTE, 2003). Alfredo tornou-se educador e dirigiu a Segunda Escola Modelo e o Grupo Escolar do Carmo ${ }^{393}$. A avó materna e a mãe de Luiz Carlos também foram educadoras. Mas a mãe, que frequentou a Escola Normal Caetano de Campos, lecionou regularmente por pouco tempo pois, ao casar-se, passou a oferecer apenas algumas poucas aulas particulares (Entrevista de Luiz Carlos Bresser Pereira à autora, 2012).

Segundo Bresser, a valorização da educação, mais do que o envolvimento com o catolicismo, foi o fator determinante para que, depois de ter passado pelos grupos escolares públicos Princesa Isabel e Marechal Deodoro, seus pais decidissem matricular os filhos Luiz Carlos e Sylvio Luiz no Colégio São Luís. De acordo com ele, “o São Luís era o melhor colégio que havia em São Paulo. Acho que foi uma questão de prestígio, uma estratégia de ascensão social”. Lá estudou francês a partir do primeiro ano do ginásio e inglês a partir do segundo ${ }^{394}$, o que foi decisivo para que anos depois conseguisse interagir com os professores estrangeiros na EAESP-FGV e cursar a pós-graduação no exterior (Entrevista de Luiz Carlos Bresser Pereira à autora, 2012). Embora a religiosidade não tenha sido, a seu ver, a razão da escolha dos pais, uma vez no colégio:

virei, é claro, praticante. Quando cheguei aos 16 anos, eu descobri a Ação Católica fora do Colégio São Luís, através do Jorge da Cunha Lima[395], que era filho de uma grande amiga da minha mãe e eu conhecia, portanto, há muito anos. Era um pouquinho mais velho que eu, dois ou três anos. Aí eu descobri a Juventude Estudantil Católica (JEC) e a Juventude Universitária Católica (JUC) (Entrevista de Luiz Carlos Bresser Pereira à autora, 2012).

$\mathrm{Na}$ Juventude Católica ele e seu irmão fizeram seus “amigos mais antigos e fiéis, como Fernão Bracher, no meu caso, e Luiz Berlinck, no caso de Sylvio Luiz" (PEREIRA, 2012, p. 1, [online]), muitos dos quais reúne até hoje em sua residência. Luiz Tosta Berlinck, que era o grande amigo de seu irmão é filho de Cyro Berlinck, amigo e secretário particular de Roberto Simonsen, por ele designado Secretário-Geral da FIESP. Parte do grupo de fundadores e diretor por 33 anos da Escola Livre de Sociologia e

\footnotetext{
${ }^{393} \mathrm{http}: / /$ www2.camara.sp.gov.br/projetos/1952/00/00/0A/5W/00000A5W0.PDF. Consultado em 02/03/2016.

${ }^{394}$ Além desses dois idiomas diz falar "mais ou menos" espanhol e italiano. Explica que o "espanhol eu nunca estudei seriamente e o italiano foi a partir de 1988, depois do Ministério da Fazenda", com um professor particular (Entrevista de Luiz Carlos Bresser Pereira à autora, 2012).

${ }^{395}$ Jorge da Cunha Lima (1931) também estudava na Faculdade de Direito da USP, atuou no jornalismo e tornou-se escritor. No governo de André Franco Montoro foi Secretário da Cultura e depois diretor nas redes televisivas Gazeta e Cultura. Explica que foi bom cursar direito e não letras, ainda que quisesse ser escritor, pois "todos os meus amigos, a maioria, tava todo mundo indo pra Direito, o Bresser [Pereira], Fernão [Bracher], todo mundo, então, eu fui pra Direito também" (LIMA, 2011, [online]).
} 
Política (ELSP), Cyro era filho de outro pioneiro do ensino universitário em São Paulo, Horácio Berlinck, o contador que lecionara na Escola Politécnica, fora secretário do Conde Alvares Penteado e fundador da Escola de Comércio Álvaro Penteado (item 4.1). O irmão mais velho de Luiz, Manoel Tosta Berlinck (1936-2016), foi aluno da ELSP na graduação e no mestrado, de 1958 a 1964, ano em que foi fazer doutorado em sociologia urbana na University of Cornell. Ao regressar em 1969, foi convidado por Fernando Henrique Cardoso para participar da montagem do CEBRAP e por Bresser Pereira para trabalhar na EAESP, onde lecionou até 1972, ano em que foi feito diretor do Instituto de Filosofia e Ciências Humanas (IFCH) da UNICAMP (item 5.2) (HILTON, 1948, p. 36; BERLINCK, 2001, pp. 46-51).

Foi igualmente na JEC/JUC que Luiz Carlos conheceu seu "grande amigo, que vem desta época, até antes da Faculdade de Direito, que é o Fernão Bracher” (Entrevista de Luiz Carlos Bresser Pereira à autora, 2012). Bracher, por sua vez, diz: "O Luiz Carlos e eu somos muito amigos até hoje. Somos compadres, reciprocamente. Ele é padrinho de meu filho e eu sou padrinho da filha dele" (BRACHER, 2004, p. 499). Fernão também estudou em colégio confessional, o São Bento, depois fez alguns anos de Bandeirantes. Tal como Bresser descendia, por um lado, de imigrantes europeus e, por outro, de brasileiros de famílias antigas e tradicionais (Entrevista de Fernão Bracher à autora, 2013).

Seu bisavô paterno deixou a Suíça pelo Brasil no final do século XIX. Ele trabalhou inicialmente como jardineiro e depois associou-se à Dierberger Plantas, comércio até hoje existente de frutas, sementes e plantas selecionadas. O avô, Godofredo, nasceu em Curitiba e cedo trabalhou na área de seguros de uma importadora controlada por estrangeiros. Quando os donos da companhia foram forçados a deixar o país por não serem brasileiros, ele passou a administrar diretamente os seguros das firmas brasileiras. A avó paterna de Bracher era alsaciana da cidade de Mulhouse e deixou seu país após a anexação da região ao Império Alemão. O pai Eduardo, já nascido em São Paulo, estudou contabilidade no Mackenzie e, como o avô, iniciou a carreira em uma grande importadora e em seguida abriu comércio próprio. "O pé de meia foi feito mesmo pelo avô Godofredo e pelo meu pai Eduardo", declara Fernão. "O meu pai tinha uma situação de classe média e pode se casar com uma moça da antiga aristocracia cafeeira" (Entrevista de Fernão Bracher à autora, 2013). 
A família de sua mãe era de "fazendeiros, filhos de fazendeiros, netos de fazendeiros". Seu bisavô materno era Antonio Carlos de Arruda Botelho, o Conde do Pinhal, que herdara largas sesmarias na região de Araraquara, nas quais cultivou-se cana associada à pecuária e, a partir de 1840, café. Em suas terras delimitou-se o povoamento de Campos de Araraquara, inicialmente formado por algumas ruas e uma capela. Antonio Carlos ocupou diversos postos públicos e recebeu sucessivos títulos nobiliárquicos até tornar-se Conde. O avô materno de Fernão, Carlos Amadeu, era o mais novo dos filhos homens do Conde e ajudou a administrar, além da sua parte da propriedade, a de vários dos irmãos. Ele "foi para a Inglaterra estudar quando moço, mas não quer dizer que tenha estudado". Títulos universitários efetivamente não tinha, vivia da terra. Carlos Amadeu casou-se com Brazilia de Oliveira Franco Lacerda, que também descendia de grandes famílias de fazendeiros da região, os Franco Lacerda e os Whitaker (Entrevista de Fernão Bracher à autora, 2013; FURLAS, 2016).

A mãe de Fernão estudou no colégio francês para moças Des Oiseaux, mas não se casou no universo de seus pares, e sim com moço de procedência social menos privilegiada, de família de imigração recente e ligado ao comércio. A diferença de "estamentos sociais", segundo ele, teria sido importante fator na separação dos pais. A mãe deixou a cidade e foi ser funcionária pública no Rio de Janeiro, ao passo que ele foi criado com o pai e os avós Bracher. Em casa dos avós teve contato com o idioma alemão, que seria extremamente útil em sua vida futura, já que permitiu que pudesse, ao concluir a faculdade, viver quase três anos na Alemanha, inicialmente com a ideia de fazer um doutorado em direito em Freiburg, posteriormente trabalhando como tradutor em Heidelberg e, finalmente, em escritórios de advocacia em Munique. Além disso, o domínio do alemão será elemento fundamental de sua transferência da advocacia para o mundo das finanças, como exposto adiante (item 5.0). Eduardo Bracher casou-se em segundas núpcias com uma moça francesa e assim Fernão incorporou também esse idioma em prática cotidiana, reforçando os conhecimentos advindos das aulas de francês do Colégio São Bento. O inglês aprendeu posteriormente, na União Cultural BrasilEstados Unidos e no trabalho, tendo que ouvir correspondentes estrangeiros, falar com banqueiros estrangeiros e ler em inglês (Entrevista de Fernão Bracher à autora, 2013).

Tal qual seu amigo Bresser Pereira, Bracher entrou na Ação Católica ainda no colégio e diz ter levado aquilo "muito a sério. Fiz a peregrinação de Chartres quando fui 
para França. Estava inteiramente engajado no movimento religioso". Foi na Ação Católica que conheceu sua esposa, Sônia Bracher, aluna do Des Oiseaux que estudou História e Geografia na Faculdade de Filosofia Ciências e Letras (FFCL) enquanto ele cursava a Faculdade de Direito (Entrevista de Fernão Bracher à autora, 2013).

Sobre a experiência na Ação Católica, Bresser relata que:

\begin{abstract}
Nós éramos jovens e a grande figura de política brasileira era o André Franco Montoro. Nós éramos um grupo de jovens intelectuais alienados, porque a nossa referência era a França, nós não sabíamos nada do Brasil. Nossa paixão eram as catedrais góticas francesas, o canto gregoriano, Bach, bom, o cinema de Ingmar Bergman e o cinema italiano, o neorrealismo italiano, que dizer, de Brasil sabíamos muito pouco. Mas estávamos associados a um partido, o Partido Democrata Cristão [PDC], que era o partido do Montoro e de um político um pouco mais velho que o Montoro que chamava-se [Antônio de] Queirós Filho, que era um bom partido nessa mesma linha, assim, idealista-alienado (Entrevista de Luiz Carlos Bresser Pereira à autora, 2012).
\end{abstract}

É possível notar que há uma semelhança nas trajetórias escolares destes adeptos da Ação Católica e do PDC. Eles estudaram nos mais importantes colégios cristãos de São Paulo daquele tempo e seguiram para a Faculdade de Direito. Queirós Filho havia sido aluno do Colégio São Luís e ingressara na Faculdade de Direito. Franco Montoro estudara no São Bento e também diplomara-se no direito da USP. Fernão Bracher e Jorge Cunha Lima estudaram no São Bento e Bresser no São Luís. Plínio de Arruda Sampaio, que se tornaria presidente da JUC, não frequentou colégios católicos mas cursou, como os outros, Direito na USP.

Bresser conta que foi em uma colônia de férias da Ação Católica, em Itanhaém, em 1955, que esbarrou com o número quatro do Cadernos de Nosso Tempo do Instituto Superior de Estudos Brasileiros (ISEB). Segundo ele, a leitura provocou grande inflexão em sua vida, levando-o a romper com a Ação Católica e aproximar-se dos desenvolvimentistas nacionalistas. Fascinou-se com a leitura de Helio Jaguaribe, Guerreiro Ramos e Ignácio Rangel, e pouco depois teve contato com os escritos Celso Furtado e da CEPAL. Afirma que foi então que "eu entendi o que era o Brasil", as classes sociais, o desenvolvimentismo, o nacionalismo. Apoiado nas novas referências, passou a discordar da JUC por apoiar Juarez Távora para o pleito presidencial e não Juscelino Kubitscheck, que era o candidato do desenvolvimentismo. À época, a JEC e a JUC ainda não viviam a politização plena, o que "só aconteceu depois que eu me formei”, lá nos anos 1960 (Entrevista de Luiz Carlos Bresser Pereira à autora, 2012), razão pela qual passou a discutir política em outros espaços, como no grupo que batizaram de 
"O Porão", que era liderado por Sylvio Luiz Bresser Pereira, por Luiz Carlos Bresser Pereira e por Jorge da Cunha Lima, entre outros, que se reunia num porão da casa do pai do atual desembargador José Ozório de Azevedo Jr., em Higienópolis. Ali [diz Manoel Berlinck] tivemos aulas sobre o Brasil com membros do Instituto Superior de Estudos Brasileiros - ISEB como Alberto Guerreiro Ramos, Cândido Mendes de Almeida e Hélio Jaguaribe. Estávamos intensamente interessados no teatro, no cinema, na música, enfim, em tudo aquilo que nos falasse do Brasil, que era visto como um grande enigma a ser decifrado (BERLINCK, 2001, p. 47).

Já decidido a não ser advogado, Bresser começa a explorar possibilidades. Pensa fazer um curso na ELSP, o que não se concretiza. Envia currículos para a CEPAL, mas não é convocado. Engaja-se então no jornalismo e trabalha por algum tempo em empresas de publicidade (PEREIRA, 2002, p. 548). Em 1959, seu irmão Sylvio Luiz, que havia desistido do direito e estudado na EAESP-FGV, alerta Luiz Carlos para o concurso para professor aberto em sua escola (PEREIRA, 2012, p. 2). Para ingressar na Fundação, naquela época, não era necessário ser administrador ou economista. Bastava ser capaz de oferecer uma boa aula de administração e ser aprovado no concurso. Uma vez admitido, Bresser conta que era preciso

\begin{abstract}
ficar um ano estudando um pouco de inglês, frequentando algumas aulas, porque tinha uma missão americana na FGV, da Michigan State [University], apoiada pela USAID [Agência Norte-Americana para o Desenvolvimento Internacional] e tinham 4 professores permanentemente lá, em rodízio. Você dava assistência a eles, assistia algumas aulas que eles davam e fazia um paper [...]. Eu fiz um paper, eu fiz um bruta paper, é o meu primeiro paper de verdade de sociologia, assim, que chama The rise of middle class and middle management in Brazil, que é pura sociologia. E tinha que fazer em inglês o paper, eu fiz no meu inglês muito macarrônico (Entrevista de Luiz Carlos Bresser Pereira à autora, 2012).
\end{abstract}

O convênio previa que os professores, depois de período inicial de treinamento na FGV, fossem enviados para a Michigan State University (MSU), onde permaneceriam 18 meses em contato com o estilo estadunidense de fazer business administration, management, marketing, finanças, organização de pessoal. A própria EAESP-FGV havia sido criada com o suporte desse convênio, financiado por meio da assistência do Ponto IV de Harry Truman. O acordo com Michigan foi inaugurado no mesmo ano que a Escola, em 1953, e duraria até 1965. Incialmente, a EAESP só oferecia cursos de curta duração para empresários. Alguns anos depois instituíram um curso de graduação que seria reconhecido pelo Conselho Federal de Educação em 1962 (Geraldo Lins in: D’ARAÚJO, 1999, pp. 138-141; Antônio Angarita in: D’ARAÚJO, 1999, p. 143).

A circulação de pessoas e ideias está na gênese da EAESP-FGV, começando com Geraldo Lins, oficial da Marinha que fizera mestrado em engenharia naval e iniciara 
doutorado em administração industrial no Massachusetts Institute of Technology (MIT). Ele conhecia a versão norte-americana da administração e assumiu a responsabilidade pela montagem do currículo da nova escola, que foi agraciada com alguma verba do Governo Federal oferecida como contrapartida aos norte-americanos que, além de viabilizar materialmente a nova instituição, forneceram pessoal e, através deles, transmitiram uma determinada concepção de administração de empresas (Geraldo Lins in: D'ARAÚJO, 1999, pp. 138-141).

Em 1966, o mesmo ano que a FGV do Rio de Janeiro recebeu apoio financeiro para concluir sua sede projetada por Oscar Niemeyer, a EAESP recebeu verba da Aliança para o Progresso para concluir seu edifício, batizado de John F. Kennedy e ornamentado com um busto do ex-presidente dos EUA na entrada, fazendo visível a gratidão que a Escola tem “a este grande homem”, declara Luiz Simões Lopes, o fundador da FGV (LOPES, 2003, pp. 23, 55). A política externa norte-americana para a América Latina surtia, assim, o efeito desejado de aproximação com os grupos dirigentes das sociedades aliadas que visava manter como e participação na formação da visão de mundo de suas futuras elites.

Bresser foi enviado para a pós-graduação na MSU em 1960 e decidiu “assistir o maior número possível de cursos de sociologia e de economia e o mínimo de administração de empresas". Foi neste momento que teve contato com os escritos de Schumpeter, uma das principais referências que passou a empregar em suas aulas para conectar temas da administração, como firmas e empresários, a tópicos de economia e desenvolvimento. Permaneceu um ano em Michigan e alguns meses em Harvard, regressando à FGV em setembro de 1961 (Entrevista de Luiz Carlos Bresser Pereira à autora, 2012).

Em janeiro 1962, na Faculdade de Ciências Econômicas e Administrativas da USP (FCEA-USP), “o Ruy Leme e o Delfim Netto, nesta ordem, eram, digamos, os hosts de uma conferência organizada pela Organização das Nações Unidas para a Educação, a Ciência e a Cultura (UNESCO) de economistas do desenvolvimento. Estavam lá Michal Kalecki, [Nicholas] Kaldor, Jan] Tinbergen e [Maurice] Allais, grandes economistas. Eu fui lá e participei, dei palpites, fiz perguntas, muito interessado em tudo aquilo [...]. Quando chegou o final da conferência eu falei com o Delfim para ver se ele podia ser meu orientador de doutorado e ele topou" (Entrevista de Luiz Carlos Bresser Pereira à 
autora, 2012). Bresser começa então a frequentar o seminário das sextas, aquele em que liam marxismo regado a whisky Dreyer (item 4.2). Segundo ele, Delfim

era desenvolvimentista claramente, admirava Celso Furtado. Discutíamos o Ignácio Rangel, a Inflação Brasileira, no seminário dele. Ele não era do grupo, então ele fazia algumas críticas... mas ele era um desenvolvimentista, como é até hoje. Eu acho que ele é o melhor economista que o Brasil tem. Agora, quando vem a revolução, aí ele mudou. Aí é que ele realmente passou para o lado... ele continuou desenvolvimentista, mas ele é um desenvolvimentista conservador e não de esquerda [...]. E aí então ele resolveu dar paulada, especialmente na CEPAL. Eu nunca vi ele falar mal do Celso Furtado, mas da CEPAL, dos cepalinos tal, ele mandava brasa, porque aí era um político. Ele é um intelectual mas é um político também (Entrevista de Luiz Carlos Bresser Pereira à autora, 2012).

Em 1963, por intermédio também de seu irmão Sylvio Luiz, que havia estudado com Abílio Diniz na FGV, Bresser vai trabalhar na empresa Pão de Açúcar. Primeiro como publicitário, depois como administrador. O trabalho com Diniz e as aulas na FGV vão delongando seu doutorado. Nesse meio tempo Delfim deixa a FEA para ser ministro e ele muda de orientador para concluir a tese Mobilidade e carreira dos dirigentes das empresas paulistas (1972), que passa a ser supervisionada pela professora Diva Benevides Pinho. Os dados usados no doutorado provinham de pesquisa que fez com outros professores da FGV, razão pela qual nela agradecia, dentre outros, a seu aluno Nakano e a Manoel Tosta Berlinck, ${ }^{396}$ que lecionava na FGV desde 1969 (PEREIRA, 2012, p. 2; Entrevista de Luiz Carlos Bresser Pereira à autora, 2012; PEREIRA, 1972).

Os estudos na fronteira da economia com a sociologia levaram Bresser para o Departamento de Fundamentos Sociais e Jurídicos da Administração da FGV-SP, que passou a reunir os economistas e cientistas sociais que não se contentavam com a administração. Algum tempo depois, conseguiram criar um Departamento de Planejamento e Análise Econômica Aplicados à Administração, que era na prática um departamento de economia (PEREIRA, 1996, p. 156). Ao tentar criar um programa de pós-graduação em economia, encontraram oposições do Rio de Janeiro, "nunca muito claras, mas houve". Para eles "nós éramos da área de administração de empresas e eles de economia, e [...] a deles era uma teoria econômica neoclássica e a minha não era”.

Eu montei uma base que eu chamaria de compromise. Porque havia três cursos básicos, além de economia brasileira. Quatro cursos básicos portanto. Micro, que eu queria que um neoclássico desse. Macro, que um keynesiano desse. Desenvolvimento econômico, que um estruturalista desse e economia brasileira, também que um estruturalista desse [...]. Evidentemente isso não era uma escola

\footnotetext{
${ }^{396}$ Ver: http://lattes.cnpq.br/0233197996647701. Consultado em 02/03/2016.
} 
ortodoxa [...], nada a ver com o Rio de Janeiro. O Rio de Janeiro era pura ortodoxia, neoclássica (Entrevista de Luiz Carlos Bresser Pereira à autora, 2012).

Não era a primeira vez que as duas escolas tiveram desavenças. Rio e São Paulo passaram por disputas financeiras, tendo o grupo do Rio ameaçado fechar a graduação em administração, argumentando não ser economicamente sustentável. Além da dimensão orçamentária havia conflitos de poder, conectados a divergências de ordem política. Os paulistas queixam-se das tentativas de ingerência da parte de Simões Lopes nas escolhas das diretorias da EAESP-FGV. Os cariocas tentavam evitar que nomes à esquerda chegassem aos postos de direção e, para tanto, chegaram a alterar regras de eleição, mudar a constituição da Escola, escolher os menos votados na lista tríplice etc. Os diretores da sede carioca acreditavam que os comunistas tinham maior trânsito em São Paulo e falavam em intervir na edição da Revista de Administração de Empresas, que não publicava só administração, mas também sociologia e política, áreas consideradas menos técnicas e mais permeáveis à subversão. Reclamavam ainda que São Paulo era tolerante com os militantes da UNE cuja sede teria chegado a funcionar informalmente na Escola (Gustavo Silva Sá in: D’ARAÚJO, 1999, pp. 148-149; Ary Oswaldo in: D’ARAÚJO, 1999, pp. 150151; Fernando Carmona in: D’ARAÚJO, 1999, pp. 154, 157-158).

Sobre a querela por ocasião da criação do Departamento de Economia em São Paulo, Carlos Bertero relata que os diretores do Rio:

resistiam muito à idéia de ter um programa de pós-graduação em economia em São Paulo, certamente para não fazer concorrência à EPGE [Escola de PósGraduação em Economia da FGV-RJ], e também por razões de economia política. Aliás, o dr. Simões dizia sempre: "Sobre economia, como não entendo nada, o senhor pode falar o que quiser, o Mario pode falar o que quiser, mas eu vou me entender com o dr. Gudin". Aqui em São Paulo, Luís Carlos e Eduardo Suplicy eram identificados na época com uma posição de esquerda. O dr. Simões não gostava disso, mas aos poucos foi-se ajustando. Mas é preciso que se faça justiça: quem deu o aval final, quem assegurou que não haveria problema, foi Mario Henrique. Esse foi um período de crescimento do Luís Carlos no cenário nacional. $\mathrm{Na}$ época em que ocorreram esses entendimentos, ele era professor da escola, presidente do BANESPA [Banco do Estado de São Paulo] e depois foi secretário de Governo do Franco Montoro. Depois foi ministro da Fazenda. E dentro da mentalidade governista da Fundação, ministro é sempre objeto de algum respeito (Carlos Bertero in: D’ARAÚJO, 1999, p. 160).

Ary Oswaldo também menciona que em São Paulo havia economistas que

estavam bem mais à esquerda que os do Rio: Luís Carlos Bresser Pereira, Yoshiaki Nakano, Oliveira Lima, Eduardo Suplicy. Isso causava mal-estar aos economistas da EPGE e a alguns poucos economistas da USP, principalmente Delfim Netto, que estava saindo do Ministério da Fazenda. Acabar com o nosso Departamento de Economia era uma questão de decisão política, e não de 
racionalidade acadêmica ou econômica (Ary Oswaldo in: D’ARAÚJO, 1999, p. 153).

Eduardo Suplicy (1941), paulistano que havia sido aluno de graduação da EAESP e presidente do Centro Acadêmico da Escola em 1964, ingressou no corpo docente da FGV em 1966, partindo em 1968 para o mestrado nos EUA. Mesmo que o convênio formal entre a MSU e a FGV estivesse encerrado, os jovens professores da Escola continuavam viajando para aquela universidade para dar continuidade à formação. Ao mesmo tempo que Suplicy, fora estudar em Michigan, Luiz Antônio de Oliveira Lima que era, como Bresser, advogado formado na USP e, como Eduardo, tornara-se professor da FGV no concurso de 1966. Suplicy ficou pouco tempo lecionando na FGV depois do mestrado. Voltou aos EUA em 1970 para cursar o doutorado em economia na própria MSU. Na sequência fez pós-graduação em Advanced Management of Education em Stanford, na Califórnia. Voltou ao Brasil em 1973 e passou a exercer, ao mesmo tempo, a docência, o jornalismo e a militância, associando-se ao MDB em 1977 e sendo eleito deputado estadual um ano depois ${ }^{397}$.

Luiz Antônio de Oliveira Lima cursou o doutorado na UNICAMP, defendendo a tese Teoria de uma Economia Monetária: a Análise de Keynes (1986) sob a orientação de Luiz Gonzaga Belluzzo, seu colega e amigo dos tempos de Largo São Francisco. Fora Oliveira Lima, anos antes, que indicara a Belluzzo e João Manuel Cardoso de Mello que fossem cursar ciências sociais na FFCL. Os três trabalharam juntos na Secretaria do Planejamento e na Secretaria das Finanças do governo Abreu Sodré nos final dos anos 1960, sob a direção do industrial Dílson Funaro. Descendente de calabreses e filho de comerciante italiano, Funaro (1933-1989) nasceu em São Paulo, cursou engenharia no Mackenzie, casou-se com uma irmã de Eduardo Suplicy e fundou a Trol S. A., indústria e comércio de plásticos e brinquedos. Seu contato com a política começou na nas associações industriais, tendo ocupado posições de destaque na FIESP398. A família reforçou seus vínculos com a elite industrial paulistana por meio dos casamentos de Dílson com Ana Maria Matarazzo Suplicy e de sua irmã, Dalva, com Fernando Gasparian. Dílson ocuparia

\footnotetext{
${ }^{397}$ Ver: http://lattes.cnpq.br/5514251151465023 e http://eduardosuplicy.com.br/biografia/trajetoria/. Consultado em 03/03/2016.

${ }^{398}$ Ver: https://familysearch.org/ark:/61903/3:1:3QS7- 996D-1ZDS?mode=g\&i=592\&wc=Q4T9$\mathrm{J} 49 \% 3 \mathrm{~A} 1056964801 \% 2 \mathrm{C} 1057068101 \% 3 \mathrm{Fcc} \% 3 \mathrm{D} 2140223 \& \mathrm{cc}=2140223 \mathrm{e}$ http://docvirt.com/docreader.net/DocReader.aspx?bib=cd_1_d_sert\&pagfis $=11624 \& p e s q=$. Consultados em $05 / 03 / 2015$.
} 
posição central no grupo dos empresários desenvolvimentistas que se aliam ao MDB. O cunhado, Eduardo Suplicy, era, do lado materno, bisneto do italiano Francisco Matarazzo, grande industrial paulista agraciado com o título de conde. Seu pai, por sua vez, era primo de Roberto Cochrane Simonsen, pertencente a outra grande família industrial, desta vez de raízes escocesas e inglesas. Estava situado, pois, no coração de elite econômica paulista com intrincados laços na política (TOTTI, 2013; MELLO, 1999, p. 184; DHBB, verbete Dílson Funaro).

Nakano era realmente o caso dissonante entre os "esquerdistas" da economia da FGV-SP. Diferentemente dos Simonsen, dos Matarazzo e dos Bresser, a imigração de sua família era bastante recente e a única não europeia. Ao contrário dos outros que nasceram na cidade de São Paulo e eram membros de famílias que há algumas gerações já acumulavam capital cultural, político e simbólico, Nakano cresceu no interior do Paraná e sequer foi possível coletar informações sobre a ocupação de seus pais. A possibilidade que teve de transferir-se para a cidade grande para cursar o ensino superior indica, entretanto, não ser sua família comprimida por urgências materiais tais que o retirassem precocemente do sistema de ensino. Nakano concluiu a graduação em 1968 e tornou-se professor da FGV em 1969. Na sequência, diferentemente dos professores da primeira geração, não foi para Michigan. Bresser esclarece que na época em que Yoshiaki foi para a pós-graduação "não se era [mais] obrigado a fazer o mestrado em administração. Podia-se fazer inclusive o doutorado em economia. Foi o que ele fez" (Entrevista de Luiz Carlos Bresser Pereira à autora, 2012).

Nakano começou, em 1968, a frequentar, na condição de ouvinte, o curso de pósgraduação do IPE-USP. Lá teve contato com professores norte-americanos, dentre os quais menciona especialmente Werner Baer, responsável pelas disciplinas de comércio internacional e desenvolvimento econômico. O curso ocupava-se sobretudo do ensino da matemática e da estatística, fortemente requeridas para ingressar no doutorado no exterior. Yoshiaki explica que a maior parte dos alunos do IPE seguia para Vanderbilt, o principal convênio que mantinham. Como era apenas ouvinte na USP, Nakano recorreu à FGV para conseguir a bolsa para cursar a pós-graduação no exterior, assim pode ir para outra escola (NAKANO, 1999, pp. 248-251). Tom Harblin, doutorando em sociologia da University of Cornell que estava fazendo pesquisa na FGV, e Betty Mindlin e Raul 
Ekerman, ambos assistentes da cadeira de macroeconomia da pós da USP, foram determinantes para que ele soubesse que

Cornell era uma universidade extremamente flexível, cujo lema era que cada um
tivesse a liberdade de estudar o que quisesse [...]. Cornell é uma universidade que
estimula fortemente os alunos a fazerem cursos em outras áreas, para você ter
contato com outras partes do conhecimento humano que não o da sua
especialização. Esse estímulo e a liberdade de montar um programa de estudos
de acordo com meus interesses foram os grandes atrativos para ir para Cornell.
Foi muito importante para a minha formação, pois, ao mesmo tempo que podia
estudar e conviver com a heterodoxia e o ecletismo, podia ter um conhecimento
mais aprofundado da teoria econômica convencional e sanar minhas deficiências
em Matemática e Econometria (NAKANO, 1999, p. 251).

Na Cidade de Ithaca, Nakano conviveu com Manoel Tosta Berlinck, também professor da FGV, que havia sido aluno de doutorado em Cornell de 1964 a 1969 e que, nos anos de 1972 e 1974, estivera em Cornell por alguns meses para a realização da pesquisa que daria origem ao livro Marginalidade social e relações de classes em São Paulo (1973) e à sua tese de livre docência $A$ vida como ela é: marginalidade social ou desenvolvimento capitalista periférico na cidade de São Paulo (1974) ${ }^{399}$. Berlinck, no prefácio ao livro, diz que sua "estadia em Ithaca foi especialmente agradável e proveitosa graças ao carinho e à inteligência de Gilda e Roberto Perosa, Renata e Luciano Coutinho e Anna e Yoshiaki Nakano. Algumas das mais importantes dicas teóricas deste trabalho me foram generosamente dadas por Yoshiaki, de quem tenho a honra de ser amigo" (BERLINCK, 1975, p. 2). Os outros dois casais mencionados eram formados pelos ex-alunos da USP, Roberto Mário Perosa Júnior e Gilda Portugal Gouvêa Perosa e Luciano Galvão Coutinho e Renata Rosenthal Coutinho.

Roberto Mário Perosa Júnior, filho de político que foi prefeito da cidade de Urupês ${ }^{400}$, no interior de São Paulo, graduou-se na FEA em 1968. O irmão de Roberto, Antônio de Pádua Perosa, agrônomo formado na Escola Luiz de Queiroz, fora liderança da AP e mais tarde aderiu à Vanguarda Armada Popular Revolucionária Palmares (VARPalmares), sendo preso em 1970, na mesma ocasião em que a polícia capturou Dilma Rousseff401, mineira que havia sido militante da Organização Revolucionária Marxista Política Operária (ORM-POLOP) e depois da VAR. Em 1986, Antônio de Pádua foi

\footnotetext{
${ }^{399}$ Ver: CV: http://lattes.cnpq.br/0233197996647701. Consultado em 03/03/2016.

400 Ver: http://www.memorialdosmunicipios.com.br/listaprod/memorial/historico-categoria, 173,H.html. Consultado em 03/03/2016.

${ }^{401}$ Ver:

http://www.arquivoestado.sp.gov.br/uploads/acervo/textual/deops/dossies_ordem_social/BR_SPAPESP_DEOPS

OS000239.pdf. Consultado em 03/03/2016/
} 
eleito deputado federal pelo PMDB, na sequência faria parte do grupo de fundadores do Partido da Social Democracia Brasileira (PSDB). Foi na militância junto ao irmão na AP que Roberto conheceu sua primeira esposa ${ }^{402}$, Gilda Portugal Gouvêa (1944), filha de Américo Portugal Gouvêa, advogado formado na USP que foi Chefe da Casa Civil do governo Carvalho Pinto e Ministro do Tribunal de Contas de São Paulo. Gilda era irmã de Sylvia Portugal Gouvêa, a esposa de Sylvio Luiz Bresser Pereira (DHBB, verbete Antônio Perosa; TCE-SP, 2009, p. 37; GOUVÊA, 2014).

No Colégio Sacre Coeur de Marie, Gilda dera início à sua militância católica, começando como presidente do grêmio estudantil e depois participando da União Paulista dos Estudantes Secundaristas e da JEC. Ao ingressar na graduação em ciências sociais na PUC de São Paulo, Gilda transitou para a AP e se aproximou da direção nacional, da qual faziam parte os irmãos Perosa. Marta Teresa Vasconcelos Suplicy (1945), descendente de industriais e famílias com títulos nobiliárquicos, que se casou com Eduardo, fez caminho semelhante a partir do Des Oiseaux, sendo aconselhada por Madre Cristina, uma das principais inspiradoras da AP em São Paulo, a cursar psicologia na PUC. As duas eram moças de elite, educadas nos mais tradicionais colégios femininos, que entraram na militância por influência das freiras progressistas e casaram-se com moços também provenientes de setores progressistas da elite católica (GOUVÊA, 2014; DHBB, verbete Marta Suplicy; SUPLICY, 1998).

Após concluir a graduação na PUC-SP, Marta seguiu com Eduardo para Michigan, onde fez o mestrado enquanto ele cursava o doutorado. Gilda foi orientanda de mestrado de Affonso Celso Pastore, redigindo dissertação sobre O Comportamento do Estudante: um estudo do radicalismo e do conformismo (1971). Logo que concluiu o mestrado, partiu para Cornell com seu marido. Explica: “O clima estava insuportável. Roberto era economista e ganhou duas bolsas de estudo simultaneamente para estudar nos Estados Unidos. Fomos morar no 'país inimigo'. Estávamos em 1971 e depois fomos para o Chile"403 (GOUVEA, 2014).

Ao regressar de Michigan, Marta começou a lecionar e atuar como psicóloga no Sedes Sapientiae, centro criado por Madre Cristina, e ingressou no Partido do Trabalhadores

\footnotetext{
${ }^{402}$ Anos mais tarde Roberto contrairia segundas núpcias com Beatriz Bracher, filha de Fernão Bracher, o grande amigo de Bresser Pereira (MUNIZ, 2013). O primeiro casamento de Beatriz havia sido com Pedro Henrique Mariani, filho do advogado, político e banqueiro Clemente Mariani e grande amigo de André Lara Resende (Entrevista de André Lara Resende à autora, 2012).

${ }^{403}$ Ver: http://lattes.cnpq.br/9520179377249618. Consultado em 04/03/2016.
} 
em 1981, sendo eleita pela primeira vez em 1994, para o posto de deputada federal e pela segunda vez, em 2000, para a prefeitura de São Paulo. Gilda passou a lecionar na UNICAMP e entrou no MDB, passando para o PSDB no momento da fundação do partido. Tornou-se assessora de alguns dos homens de maior projeção do PSDB, como Fernando Henrique Cardoso e José Serra, foi chefe de gabinete do Secretário da Educação, Paulo Renato Souza, e depois chefe de gabinete da Casa Civil durante o governo estadual de Franco Montoro. Foi também assessora especial de Paulo Renato no Ministério da Educação durante todo o governo de FHC e colaborou diversas vezes com Bresser Pereira. Ele declara: "minha assessora política, minha representante em São Paulo e grande amiga foi a Gilda Portugal Gouvêa. Sem entender de economia, mas tendo bom senso e conhecendo muito bem a política, ela teve sempre um papel decisivo no meu ministério” (PEREIRA, 1988, p. 4; GOUVEA, 2014; DHBB, verbete Marta Suplicy).

\subsection{Luciano Galvão Coutinho, Luiz Gonzaga Belluzzo e João Manuel Cardoso de Mello: a construção da pós-graduação em economia na UNICAMP}

Luciano Galvão Coutinho e Renata Rosenthal Coutinho formavam o outro casal com o qual Manoel Berlinck, os Nakano e os Perosa conviveram em Cornell. Os dois eram graduados em economia na FEA-USP e foram para Cornell cursar o doutorado, ele em economia sob a direção de Tom E. Davis, ela em história econômica orientada por David M. Davidson, historiador da América Latina com PhD em Yale. Renata provém de família judia, do lado da mãe proveniente de judeus da Bessarábia, por parte de pai de judeus alemães que passaram pela Inglaterra antes de chegar ao Brasil. Os pais dela nasceram já em São Paulo. Ele deu continuidade aos negócios iniciados pelo avô e passou a atuar como corretor financeiro e colecionador de arte. A mãe deixou os estudos ao casar-se. Ainda que fosse uma família predominantemente assentada em capital econômico advindo do comércio, integravam um círculo altamente intelectualizado, ligado ao Partido Comunista ${ }^{404}$. Após a conclusão da pós-graduação Renata tornou-se professora de história econômica na UNICAMP e foi, na sequência, trabalhar nas áreas de cultura e planejamento no setor público, atuando como

\footnotetext{
${ }^{404}$ No PCB entraram em contato com um dos principais nomes da moderna arquitetura paulista, João Batista Vilanova Artigas, também parte dos círculos intelectuais do Partido e professor cassado da USP, que construiu para a família uma residência no Pacaembu (ROSATTI, 2014, p. 15).
} 
coordenadora de estudos de planejamento da Secretaria de Planejamento da Secretaria Geral do Ministério da Cultura na época em que este foi dirigido por Celso Furtado 405 (ROSATTI, 2014, p. 15; Entrevista de Luciano Coutinho à autora, 2013).

Luciano Galvão Coutinho (1946) tinha origens sociais bastante diferentes das de sua esposa. Nasceu em Recife, em família católica e brasileira há muitas gerações, pertencendo ao ramo familiar formado por profissionais liberais, fortemente ligados ao mundo universitário. Relata sua gênese social da seguinte maneira:

\begin{abstract}
Os avós paternos eram de família pernambucana tradicional. De duas famílias tradicionais pernambucanas, a família Domingues e a família Coutinho. Principalmente a família Domingues, que era a mãe do meu pai, era uma família um pouco aristocrática, dona de engenho de açúcar [descendentes do Barão de Amaraji]. Um dos tios do meu pai havia sido governador de Pernambuco, o Dr. José Domingues [outro tio, Mario Domingues, também foi governador]. A família Coutinho também era uma família tradicional e houve alguns casamentos entre as duas famílias [...]. A minha avó era Dona Ester Domingues e o meu avô Sinfrônio Coutinho. Ele era advogado e promotor público [formado na Faculdade de Direito de Recife]. Faleceu muito cedo com gripe espanhola. A minha avó teve uma educação aristocrática, falava línguas e tal mas, como à época, não era profissional. Depois, com a impossibilidade de dividir as terras originais, as duas famílias têm uma geração de profissionais liberais e de professores. Médicos, advogados e engenheiros, principalmente do lado Coutinho. Houve um momento em que na Faculdade de Medicina existiam quatro professores catedráticos da família Coutinho. Há até a brincadeira na medicina da Federal de Pernambuco: "na Medicina, quem não é Coutinho é coitado, quem não é Marques é marcado e quem não é Cavalcanti é cavalgado". Então eu venho desse lado da família que era de profissionais liberais e tinha um lado da família que manteve terras, usina de açúcar e engenhos de cana de açúcar (Entrevista de Luciano Coutinho à autora, 2013).
\end{abstract}

Amaury Domingues Coutinho ${ }^{406}$, seu pai, era um dos tantos profissionais liberais da família. O avô paterno, Sifrônio, morreu antes dos 30 anos. Viúva, a avó Esther Domingues contou com a ajuda dos irmãos e cunhados para criar os 5 filhos. Amaury foi criado pelos tios e muito influenciado por Oscar Coutinho, irmão de seu pai, casado com uma irmã de sua mãe, um dos fundadores da Faculdade de Medicina do Recife. Seguiu os passos do tio e ingressou aos 16 anos na Faculdade de Medicina de Recife. Na sequência, fez residência em centros médicos avançados no exterior, essencialmente nos EUA. Especializou-se no estudo de doenças tropicais e venceu, em dezembro de 1960, concurso para a Cátedra de Clínica Médica da Universidade Federal de Pernambuco

\footnotetext{
${ }^{405}$ Ver: http://www.jusbrasil.com.br/diarios/3569600/pg-21-secao-2-diario-oficial-da-uniao-dou-de-21-081986/pdfView. Consultado em 04/03/2016.

${ }^{406}$ Ver: http://www.dichistoriasaude.coc.fiocruz.br/iah/pt/pdf/facmedrec.pdf, http://www.genealogiasobralense.com.br/arquivos_gen/7896c7bfe61e0544f930b98ca5a5ecbd.pdf e http://memoria.bn.br/DocReader/DocReader.aspx?bib=029033_14\&PagFis=6932. Consultados em 31/01/2016.
} 
(UFPE) (PRATA, 1995, p. 433; COUTINHO, 1995, pp. 187-188; Entrevista de Luciano Coutinho à autora, 2013; DHBB, verbete José Domingues da Silva).

Seus avós maternos eram da Paraíba. O avô de sobrenome Galvão era filho de portugueses e comerciante de secos e molhados em Olinda. A avó teve 14 filhos e cuidava da casa. A mãe de Luciano, Anna Galvão, fez faculdade de Belas Artes e chegou a praticar pintura e escultura, mas acabou dedicando-se mais à família do que à carreira de artista. Ela ocupava-se do preparo cultural dos filhos, tendo papel essencial nas escolhas educacionais e na transmissão da religião. Luciano conta que foi ela quem o levou a um concerto pela primeira vez, no Teatro Municipal do Recife. Relata que que os pais escutavam música em casa com frequência. Tinham uma coleção de discos que escutavam em um aparelho de som de alta qualidade que seu pai trouxera dos Estados Unidos. Luciano chegou a estudar piano, mas diz que não tinha nenhum pendor para a música.

Quanto à educação formal, Anna matriculou-o incialmente no Instituto Recife, escola dirigida pela educadora Eulália Fonseca que, além de larga experiência, possuía formação no Teatcher College de Columbia e subscrevia linhas pedagógicas à época inovadoras ${ }^{407}$. Na sequência foi estudar no Colégio São Luís. Luciano foi criado no catolicismo professado por sua mãe, já que seu pai, ainda que tivesse raízes católicas, tinha forte desconfiança em relação à religião, suscitada por alguns tios-avôs que estavam entre os fundadores do PCB. Durante a juventude, chegou a ter uma vida religiosa ativa e fez primeira comunhão, mas relata que, desde que foi para a faculdade, a vida intelectual se superpôs, deixando pouco espaço para a religião. No colégio marista Coutinho começou a aprender francês e depois inglês, que aprimorou no período em que viveu nos EUA. Nunca fez curso de espanhol mas entre as leituras, as viagens, a temporada no Chile, os amigos latino-americanos e as aulas e os eventos acadêmicos acabou aprendendo.

Como todos os irmãos, Luciano seguiu a tradição familiar optando por uma carreira liberal. Dos seis filhos de Amaury e Anna, cinco são acadêmicos, nas áreas de economia, comunicação e design, física, artes plásticas e medicina. A única filha que não possui doutorado é arquiteta e urbanista com pós-graduação e trabalha no setor público. Indagado sobre as origens de seu interesse pela economia, Coutinho relata ter assistido palestra de Celso Furtado no auditório da Superintendência do desenvolvimento do Nordeste (SUDENE) quando ficou muito impressionado com sua visão e estratégia de

407 Ver: http://memoria.bn.br/DocReader/DocReader.aspx?bib=029033_15\&PagFis=64257. Consultado em $31 / 01 / 2016$. 
desenvolvimento para o Nordeste. Diz que já tinha motivação política e social e que a palestra alertou-o para o "sentido da economia". Além disso, explica, "alguns dos amigos do meu pai tinham uma experiência política, especialmente um dos amigos do meu pai, que era engenheiro mas com incursão em economia, Dr. Antônio [Bezerra] Baltar, que tinha uma relação com a CEPAL. Eu então conversei muito com esse senhor a respeito de economia e me entusiasmei e essa foi minha motivação para estudar economia" (Entrevista de Luciano Coutinho à autora, 2013).

Se as origens sociais e as fontes de rendimentos materiais das famílias de Renata e Luciano eram bastante distintas, havia uma semelhança no que concerne às raízes políticas progressistas das duas famílias. O pai fazia parte dos mesmos círculos políticos à esquerda frequentados por Antônio Bezerra Baltar (item 3.2). O irmão dele, Maurício Coutinho, havia estudado engenharia com Pelópidas da Silveira que se tornou prefeito de Recife pela primeira vez por indicação do tio deles, José Domingues. Pouco depois, Pelópidas elegeu-se apoiado pelos partidos socialista e comunista que se contrapunham às forças açucareiras que há tanto dominavam a política local. Tanto Maurício quanto Pelópidas eram engenheiros da UFPE ligados aos grupos que buscavam a modernização tecnológica. Tinham laços com o Instituto de Pesquisas Tecnológicas de São Paulo e participaram da fundação do Instituto Tecnológico do Estado do Pernambuco. Fazia parte também desse grupo Miguel Arraes, que seria prefeito de Recife após Pelópidas e governador do Estado às véspera do golpe. Amaury construiu sua casa em frente a de Miguel Arraes, ficando as duas famílias amigas. Coutinho diz ter crescido nesse "ambiente de crítica social à forte desigualdade do país [...], uma esfera de relações sociais indutora de uma reflexão sobre as condições de vida da sociedade, a desigualdade" e a necessidade e os rumos do desenvolvimento (Entrevista de Luciano Coutinho à autora, 2013, SILVEIRA, 2005, pp. 5-10; COUTINHO, 1995, pp. 195).

Quando Luciano declarou a intenção de estudar economia, o pai pesquisou a qualidade das faculdades existentes no Brasil e recomendou ao filho a Universidade de São Paulo. Amaury viajava frequentemente para congressos médicos e em uma passagem por São Paulo "visitou o cursinho Visconde de Cairu [da FCEA] e comprou todas as apostilas", que Luciano usou por seis meses para preparar-se para o vestibular. Na graduação conta ter sido

aluno do Delfim muito pouco, porque logo naquele período ele foi chamado para ser Secretário da Fazenda de São Paulo no Governo do Laudo Natel e 
depois Ministro. Então eu tive poucas aulas com ele, infelizmente. Ele foi substituído por um da sua gangue, como eles mesmos se chamavam [...]. Fui aluno do Pastore. Fui aluno do Ikeda, fui aluno do Eduardo Ferreira Carvalho. Fui aluno da Betty Mindlin, que era assistente na época. Fui aluno de quase todos os expoentes da turma do Delfim. Eu fui aluno deles e fui um excelente aluno de econometria. Gostava muito de métodos quantitativos [...], mas era, digamos assim, um economista de formação política, economia política. Eu devo dizer que a USP me deu uma formação em métodos quantitativos, em matemática e em modelística formal etc. muito importante para o meu exercício profissional posterior. Por outro lado era relativamente pobre em macro e mesmo em microeconomia, porque ela se baseava muito em livros texto convencionais. Eu fiz uma reflexão muito mais profunda, e em grande medida autodidata, no meu doutorado nos Estados Unidos (Entrevista de Luciano Coutinho à autora, 2013).

Ao concluir a graduação na turma de 1968, Coutinho começou um mestrado na própria USP, tendo aula com os professores da Missão de Vanderbilt que ali ainda estavam. Diz terem sido seus professores mais importantes, naquela época, o italiano Andrea Maneschi e o indiano Gian Singh Sahota, que lecionavam finanças públicas e econometria, respectivamente. Luciano começou a escrever uma dissertação sobre o desenvolvimento do Nordeste e o antigo sistema de incentivos fiscais. Indagado acerca da ausência de sua dissertação de mestrado na biblioteca da Faculdade, explica: "você há de lembrar que o ano de 1968-69 foi um ano muito quente [...] Então nesse período tumultuado, eu concluí, apresentei, mas não tive a oportunidade de fazer formalmente a defesa" (Entrevista de Luciano Coutinho à autora, 2013).

Coutinho conta ter participado intensamente da política estudantil. Foi diretor cultural do centro acadêmico, representante na congregação e participou de várias eleições e chapas: "eu era um estudante de esquerda contra o regime ditatorial independente. Não tinha vinculação com as organizações partidárias". De qualquer modo, "estava numa situação difícil por causa das questões políticas, [uma situação] de risco" (Entrevista de Luciano Coutinho à autora, 2013). João Sayad (item 5.4), que se formou na FEA uma turma antes, conta que "o Luciano teve que se esconder um pouco e eu escondi ele na minha casa. Era uma situação de muito medo" (Entrevista de João Sayad à autora, 2013). Em 28 junho de 1968, Coutinho foi preso com seus colegas de faculdade Silvério Soares Ferreira e Frederico Mazzucchelli ${ }^{408}$. Nesse contexto, partir diretamente para o doutorado em Cornell, sem defender o mestrado no Brasil, era uma questão de segurança pessoal (Entrevista de Luciano Coutinho à autora, 2013).

\footnotetext{
${ }^{408}$ Ver:

http://www.arquivoestado.sp.gov.br/memoriapolitica/documento.php?ficha=BR_SPAPESP_DEOPSSPOSFTEX SNC005334. Consultado em 05/03/2016; O Estado de São Paulo, 3 de julho de 1968, p. 11.
} 
Conseguiu, através de Andrea Maneschi, uma bolsa de estudos da Fundação Ford:

era que meio pegar ou largar, quer dizer, ou eu ficava aqui com a vida meio clandestina, sem poder trabalhar, enfim... Mas a primeira oferta foi para ir para um posto muito enlatado e eu não quis. Falei: olha, eu prefiro não ir. Aí eu tomei conhecimento, através da Betty Mindlin e do Celso Lafer, que era na época casado [com ela], a respeito da Universidade de Cornell que era uma universidade tradicional, da chamada Ivy League, mas com uma orientação muito liberal, no sentido americano: livre. O Departamento de Economia era um departamento curioso, ele tinha professores extremamente mainstream, de economia matemática [...]. Eu fiz todos esses cursos com o conforto de quem tinha tido uma boa formação de modelística matemática e de econometria aqui. Ao mesmo tempo, uma vez que você cumpria os requisitos básicos e passava nesses cursos com nota, o cara dizia assim: esse cara sabe o mainstream direitinho. Aí você tem liberdade para fazer o que quiser. Eu tive um orientador que era uma pessoa maravilhosa, um professor de economia latino-americana que chamava Tom Davis. Era um economista de formação institucionalista e de história, uma pessoa muito instigante, aberta, que estimulava e gostava de discutir com alunos que queriam pensar diferente. Então nesse período ele me deu toda liberdade para estudar (Entrevista de Luciano Coutinho à autora, 2013).

Luciano entra então em contato com as teorias de organização industrial e oligopólio, à época emergentes. Fez um curso com um institucionalista sobre o Business Cycles de Schumpeter e estudou Keynes com Robert Wylie Kilpatrick, que exigia leitura das principais obras do autor, sem o uso de intermediários e comentadores, na tentativa de pensar fora do sistema que os intérpretes criaram, ou seja, "para além do modelo do Hicks e a curvinha de ISLM. Ele dizia: 'não é isso que o Keynes queria dizer. Isso aqui é uma construção formal que engessa a percepção das fortes oscilações da preferência por liquidez, que é uma coisa mutilada por expectativas'.” (Entrevista de Luciano Coutinho à autora, 2013).

Conforme relatado no capítulo anterior, nas férias do verão de 1971, Luciano passou alguns meses no Chile, quando teve contato mais direto com as ideias da CEPAL, frequentando aulas de Conceição Tavares, Aníbal Pinto Santa Cruz e Osvaldo Sunkel no Instituto Latino-Americano de Planificação Econômica (ILPES) e na ESCOLATINA. Ali conheceu outras vertentes da macroeconomia, como o planejamento de Michal Kaleki, a organização industrial de Sylos Paolo Labini e algo de Karl Polanyi. Foi nesse período que conheceu José Serra, com quem teria muito breve overlap em Cornell, quando Serra passou a ser mais um exilado a figurar na lista de orientandos de Tom Davis. A solicitude do professor Davis para com os brasileiros foi essencial ainda para que Plínio de Arruda Sampaio, em casa de quem Serra fora inicialmente abrigado nos EUA, fosse admitido no 
curso de mestrado de economia rural de Cornell (Entrevista de Luciano Coutinho à autora, 2013; SERRA, 2014, p. 223).

Serra fez um doutorado expresso em Cornell, os créditos em um ano e a tese no ano seguinte. Em 1975, transferiu-se para o Institute for Advanced Studies de Princeton, a convite de Albert Hirschman, que ele havia conhecido brevemente no Chile. Por aqueles tempos, Fernando Henrique foi professor visitante no mesmo instituto. Até então, ele e Serra mantinham um relacionamento bem cordial mas não muito intenso (SERRA, 2002, p. 125). Foi em Princeton que se tornaram amigos e colaboradores intelectuais. Juntos escreveram o ensaio As desventuras da dialética da dependência (1978), uma resposta às críticas que Ruy Mauro Marini apresentara à teoria da dependência de Cardoso e Falleto (SERRA, 2014, pp. 123, 233-234; SERRA, 2002, p. 123). De acordo com Serra, “a amizade, que se desdobraria por décadas, consolidou-se ali, quando discutíamos de tudo. O ensaio em parceria refletiu a afinidade teórica e identidade quanto ao que fazer na política nos anos seguintes. Foi Fernando Henrique quem me explicou como funcionava o MDB, que ele assessorava de perto" (SERRA, 2014, p. 240).

José regressou ao Brasil em 1977, sendo recebido por seu colega de militância e amigo de muitos anos, Sérgio Motta (item 3.2). Em 1978, quando se instalou definitivamente no Brasil, João Manuel Cardoso de Mello, por sugestão de suas grandes amigas do período chileno, Conceição Tavares e Liana Aureliano, convidou-o para lecionar na UNICAMP, onde assumiu cursos nas áreas de economia brasileira, política econômica, história do pensamento econômico e macroeconomia. $\mathrm{Na}$ mesma época, passou a fazer parte do corpo do CEBRAP, dirigido por Fernando Henrique Cardoso (SERRA, 2014, p. 252; SERRA, 2002, pp. 153-154).

Diversos pós-graduandos brasileiros que estudaram em Cornell estiveram em algum momento vinculados à UNICAMP: Gilda Portugal deu aulas na ciências sociais em 1975. Nakano assumiu o curso de clássicos da economia por algum tempo, antes de ser professor exclusivamente da EAESP (NAKANO, 1999, p. 251). Um dos filhos de Plínio, seu homônimo Plínio de Arruda Sampaio Júnior, fez o mestrado sob supervisão de Serra, o doutorado com João Manuel Cardoso de Mello e tornou-se professor do Instituto de Economia (IE), além de pesquisador no grupo de estudos sobre conjuntura econômica que Serra passou a dirigir no CEBRAP no final da década de 1970. Manoel Tosta Berlinck, que estava ligado ao CEBRAP desde a sua fundação em 1969 e que trabalhava 
na EAESP, foi convidado em 1972 para assumir a direção do Instituto de Filosofia e Ciências Humanas da UNICAMP.

Foi Manoel Berlinck que convidou Coutinho para lecionar na UNICAMP. Ao regressar, no segundo semestre de 1974, Luciano voltou à FEA como previa sua bolsa de estudos, mas explica que sua incorporação na USP não era simples. Passava o tempo, ia lecionando sem receber salário e a contratação continuava sem ser aprovada. Na FEA, de 1975 a 1978 lecionou cursos de organização industrial, mas não de macroeconomia pois, relata, havia barreira ao ensino de determinadas vertentes da economia: "eu poderia ter voltado para a FEA e dado cursos de macroeconomia ou de organização industrial ou de economia internacional mas, obviamente, querer instituir uma visão de macroeconomia diferente da visão que... à época o diretor era o Pastore, imagina! Não ia ser possível, tá?’. Nessa situação, o convite de Berlinck para conhecer a UNICAMP parecia extremamente atraente. Ele relata que foi para Campinas, visitaram a universidade rapidamente e foram à reitoria.

\begin{abstract}
Chegou lá na reitoria e pediu para conversar com o reitor professor Zeferino Vaz. A gente esperou uns dez, quinze minutos, e ele me recebeu. Aí ele [Manoel] me apresentou: "Ah olha professor, aqui está um jovem doutor, veio dos EUA, é professor, tal". E o professor Zeferino disse assim: "Meu jovem você não quer trabalhar aqui na UNICAMP? Eu lhe ofereço uma posição imediatamente de professor assistente doutor" [...]. Eu disse assim: "Olha professor, na minha situação eu não tenho como dizer não, porque eu estou numa situação meio...". Aí ele apertou um botão assim Pléeeee, e apareceu uma secretária, ele disse: "prepare um contrato". Ele perguntou, "o senhor, meu jovem, você trouxe os seus documentos? Eu falei: "não, eu não.... eu não...". Aí ele disse: "bom, como você não trouxe..? "Eu falei: "eu não, eu não sabia que ia receber nenhum convite". "Então você volta aqui amanhã, traz os documentos, e aí ele disse assim, eu já vou deixar tudo assinado para ir para o Diário Oficial". E realmente em 48 horas o Zeferino Vaz me contratou como professor. Eu trouxe os documentos e ele me contratou. Ora, isso causou na USP uma irritação enorme. Aí o reitor da USP reclamou que a UNICAMP tinha me roubado... e terminou sendo muito bom, porque a USP tomou as dores e me contratou. Foi feito um entendimento entre as duas universidades, pelo qual eu era tempo parcial na USP e tempo completo na UNICAMP. Existia esse negócio. Então me dividia entre três dias inteiros da semana na UNICAMP e duas tardes, ou uma tarde, um dia e meio na USP. Sei lá, não me lembro como é que eu fazia. Mas eu dava cursos na UNICAMP e na USP [...] e na UNICAMP os cursos estavam sendo montados e a pós-graduação estava sendo montada, então eu tive a oportunidade de influir (Entrevista de Luciano Coutinho à autora, 2013).
\end{abstract}

A pós-graduação da UNICAMP de fato era muito nova na época. O mestrado havia sido implementado em 1974 e em 1978 inaugurou-se o doutorado em economia. A própria UNICAMP era novíssima. Ela começou a ser planejada em 1961, em um grupo de trabalho coordenado pelo reitor da USP que era integrado pelos homens do grupo 
modernizante da Universidade, aliados ao governador Carvalho Pinto (item 3.3). Os estudos para a criação de um núcleo universitário em Campinas foram instaurados devido à pressão existente para a criação de uma faculdade de medicina em Campinas. A classe médica, que detinha poder e prestígio em uma cidade ainda dominada pelas elites tradicionais, sentia-se desprestigiada face às escolhas de cidades como Ribeirão Preto e Botucatu para sediar as escolas de medicina do interior. Carvalho Pinto autorizou, então, a criação de uma universidade que começou, evidentemente, pela Escola de Medicina, inaugurada em $1963^{409}$ (GOMES, 2007, pp. 35-36).

Até 1965 a Universidade de Campinas era constituída de uma única faculdade, a Medicina. Criou-se então uma equipe para coordenar a implantação da universidade, dirigida por Zeferino Vaz (1908-1981), médico paulistano, filho de abastados espanhóis da Galícia, que se tornou catedrático aos 27 anos. Vaz fora diretor da Faculdade de Medicina de Ribeirão Preto, reitor-interventor da Universidade de Brasília de abril de 1964 a agosto de 1965 e foi quem deu o parecer favorável à criação do Instituto de Pesquisas Econômicas da USP em 1959. Ao regressar de Brasília, Zeferino perdeu a eleição para o Conselho Estadual de Educação. Seus adversários no Conselho, querendo ver-se livres de suas sistemáticas oposições, designam-no para dirigir a equipe de implementação da Universidade de Campinas. Em outubro de 1966, lançou a pedra fundamental da UNICAMP no canavial de um banqueiro e fazendeiro de uma das famílias ditas quatrocentonas da região, os Almeida Prado, no distrito de Barão Geraldo. Em dezembro, Zeferino foi nomeado por Laudo Natel o primeiro reitor da nova universidade. Dois anos depois foi criado o Departamento de Planejamento Econômico e Social (DEPES) que daria origem ao Instituto de Filosofia e Ciências Humanas (IFCH), no interior do qual funcionava o Departamento de Planejamento Econômico (DEPE), que depois se separaria formando o Instituto de Economia (IE-UNICAMP) 410 (GOMES, 2007 , pp. 17, 41-47).

A área de economia do Departamento de Planejamento Econômico e Social começou a ser organizada em 1967, sob a liderança de Fausto Castilho (1929-2015)411,

\footnotetext{
${ }^{409}$ Ver: http://www.unicamp.br/unicamp/a-unicamp/história. Consultado em 05/03/16.

${ }^{410}$ Ver: http://www.unicamp.br/unicamp/a-unicamp/história. Consultado em 05/03/16.

${ }^{411}$ Nascido em Cambará no Paraná, Castilho descendia de um grande proprietário de terras que mantinha uma residência em São Paulo. Ele foi enviado para estudar no Liceu Pasteur em São Paulo, cultivando pois um exímio francês. Foi o trunfo que permitiu que, depois de desistir do destino programado, que era a Faculdade de Direito, ele conseguisse ingressar na filosofia da Sorbonne. Partiu do Brasil com uma carta de Antônio Cândido dirigida a Paulo Emílio Salles Gomes - o mesmo que ajudou Celso Furtado a tomar conhecimento da Biblioteca
} 
que Zeferino conheceu através do prefeito Vicente Faria Lima, amigo de ambos. Formado em filosofia na Sorbonne, Castilho lecionava em Araraquara antes de ser cassado pelo regime. Em 1965 aceitou o convite do prefeito Vicente Faria Lima para ser assistente técnico do gabinete para a área da educação e da cultura. Castilho relata que Faria Lima era um militar diferente, educado na Escola Politécnica francesa e interessado por coisas que em geral os militares não apreciam, conquistando assim o apoio de setores progressistas e tornando-se o candidato da oposição, ainda que fosse militar. Castilho e Faria Lima, que havia sido presidente do BNDE durante o rápido governo de Jânio Quadros, conseguiram atrair para a cidade de São Paulo uma edição do Curso de Treinamento em Problemas do Desenvolvimento Econômico do Centro CEPALBNDE. Naquela época, Aníbal Pinto, Conceição Tavares e Antonio Barros de Castro ainda estavam à frente do Centro; Lessa já vivia asilado no Chile.

Participaram também pesquisadores recém-integrados ao escritório brasileiro, como Wilson Cano. Filho de imigrantes espanhóis, criado no bairro paulistano do Tucuruvi, Cano viveu uma infância modesta e chegou a trabalhar como office boy, trajetória semelhante à de alguns filhos de imigrantes estudados no capítulo anterior. Influenciado pela efervescência do Plano de Metas, decidiu estudar economia e ingressou na graduação da PUC de São Paulo, concluindo o curso em 1962. Logo matriculou-se em um dos cursos de Treinamento em Problemas do Desenvolvimento oferecidos pela CEPAL no Rio de Janeiro e depois em um curso de Treinamento em Programação Industrial oferecido pela Comissão em Belo Horizonte. “Aquilo abriu minha cabeça e me fez enxergar a precariedade do que se ensinava nas universidades. Conheci um Brasil e uma América Latina que ainda não conhecia porque as escolas brasileiras se limitavam a transplantar o que vinha de fora, sem fazer um diagnóstico de nosso subdesenvolvimento" (Wilson Cano in: LEVY, 2008). Ao concluir o curso, foi convidado a ligar-se ao Centro CEPAL-BNDE. Dois outros economistas foram incorporados ao

Brasiliana de Paris. Paulo Emílio ajuda-o na busca por um apartamento e lhe ensina o essencial para viver na cidade. Depois de concluir os estudos Fausto vive algum tempo na Alemanha antes de regressar. No Brasil lecionou por algum tempo no Paraná, posto que obteve por influência de um amigo que se tornara governador. Insatisfeito, conseguiu ter seu nome indicado por Antônio Cândido, que ele define como seu mentor e protetor, para tornar-se professor na faculdade que se abria em Araraquara. Foi Castilho que promoveu a visita de Jean Paul Sartre àquela faculdade, mencionada no capítulo 3, quando descrita a interação dos Cardoso com os Sartre (CASTILHO, 2013, pp. 21-39). 
Centro naqueles anos, Ferdinando Figueiredo, formado na UFRJ em 19631, e Roberto Manoel Ruiz de Gamboa ${ }^{413}$ (CANO, 2013).

Foram alunos no curso da CEPAL de São Paulo, além do próprio Fausto Castilho, os colegas de Largo São Francisco e de ciências sociais da USP, Eduardo Kugelmas, João Manuel Cardoso de Mello e Luiz Gonzaga Belluzzo ${ }^{414}$. Ao concluir o curso, os três foram convidados por Castilho para participar da constituição da área de economia da ainda sequer construída Universidade Estadual de Campinas (MELLO, 1999, pp. 194-195; CASTILHO, 2013, pp. 21-44). Kugelmas acabou não indo, pois conseguiu uma posição como historiador na USP e logo exilou-se no Chile, onde fez a pós-graduação da ESCOLATINA (KUGELMAS, 2012, p. 251).

João Manuel largou a posição que tinha no Banco Mercantil Finasa, de Gastão Bueno Vidigal, e foi para Campinas, onde recebia significativamente menos. O pai considerou uma loucura. A posição no Finasa era segura e promissora, pois o Banco havia sido fundado pelo pai de Vidigal em associação com o primo do pai de João Manuel, José Joaquim Cardoso de Mello Neto, advogado e político paulista. José Joaquim Neto foi diretor da Faculdade de Direito de São Paulo e, na política, ocupou os cargos de deputado, prefeito, governador do Estado de São Paulo e Superintendente da Moeda e do Crédito. Era, ademais, casado com uma filha do presidente Rodrigues Alves (DHBB, verbete José Joaquim Mello Neto) ${ }^{415}$.

João Manuel (1942) vinha, portanto, de família tradicional de São Paulo e José Joaquim não era o único elo dos Cardoso de Mello com o direito e com a política. Seu bisavô, José Joaquim Filho, já havia cursado a Faculdade de Direito e, além de advogar, vivenciara a política. Alguns de seus tios avôs foram também políticos e lecionaram no Largo São Francisco. Seu avô, depois de bacharelar-se em direito, advogou em Jaboticabal e São Paulo e foi Pretor e Juiz de Órfãos no Distrito Federal. Também reforçou os laços da família com a elite jurídica ao casar-se com Maria Suzana Machado, irmã de José

\footnotetext{
${ }^{412}$ Ver: http://www.unicamp.br/unicamp/noticias/2014/12/15/unicamp-perde-ferdinando-figueiredo. Consultado em 06/03/2016.

413 http://memoria.bn.br/DocReader/DocReader.aspx?bib=089842_07\&PagFis=86602. Consultado em 06/03/2016. Não consta se Roberto Gamboa era brasileiro ou chileno. Ele lecionou na UNICAMP, depois na UFRJ e faleceu precocemente em 1981. Aparece muitas vezes também como Lucas Gamboa, nome pelo qual era conhecido.

${ }^{414}$ Consta que tenham participado do curso também Amélia e Gabriel Cohn e Luiz Pereira, das Ciências Sociais da USP, além do economista Carlos Eduardo do Nascimento Gonçalves, que se tornaria professor da UNICAMP.

415 Ver: http://www2.camara.sp.gov.br/projetos/1953/00/00/0A/AK/00000AAKW.PDF. Consultado em 07/03/2016.
} 
Alcântara Machado, escritor e jurista, e filha de Brasílio Augusto Machado de Oliveira, advogado, professor de direito e político que ocupou a presidência da província do Paraná. O pai de João Manuel, João de Deus Cardoso de Mello, fora delegado de policia, promotor público, subprocurador, procurador geral, secretário da justiça, da educação e, finalmente, Ministro do Tribunal de Contas. Casou-se com a filha de um juiz ${ }^{416}$.

João Manuel explica sua opção pelo direito:

Eu sou filho de uma família que tradicionalmente teve advogados, professores de direito e burocratas do Estado. No meu tempo, quando fui escolher uma profissão, havia três profissões valorizadas. Nem sabia o que era economia. Havia direito, medicina e engenharia. Quem não gostava de latim não podia fazer direito. Quem não gostava de ver sangue não podia ser médico. Quem não gostava de matemática não podia ser engenheiro. Era o espectro das profissões, vamos dizer, valorizadas socialmente. Eram esses os critérios de escolha. Naturalmente eu fui para o direito ... nem podia deixar de ser (MELLO, 1998, p. 222).

João Manuel Cardoso de Mello relata sua decepção com a Faculdade de Direito. Com o colega Luiz Antônio de Oliveira Lima, professor da FGV que havia feito o mestrado em Michigan e que, na época, cursava direito e estudava na FFCL, desabafou um dia: "Lima, eu não aguento mais essa porcaria dessa faculdade. Quero fazer outra coisa. Aí, ele me disse: 'Mas, por que você não vai fazer ciências sociais?’ Nem sabia da existência desse curso. 'Me explica esse negócio de ciências sociais.' E fomos conversando... então eu e o Belluzzo resolvemos prestar o vestibular para ciências sociais. Esse sim era um curso estupendo, onde eu aprendi a raciocinar. Um curso notável. Grandes professores” (MELLO, 1998, p. 223). Começaram também a frequentar diversas aulas na Faculdade de Economia, que ficava em um prédio na rua Doutor Vilanova que se conectava ao da FFCL por um pátio interno.

João Manuel e Luiz Gonzaga Belluzzo tinham forte amizade que precedia os tempos de faculdade. Belluzzo declara, inclusive, que João Manuel é o seu mais antigo e melhor amigo (BELLUZZO, 1996, p. 258). Os dois foram colegas no ginasial do Colégio São Luiz e desde então muito próximos. Belluzzo (1942) também era paulistano e filho de um advogado formado na São Francisco, mas suas origens eram um tanto distintas. Seu pai também principiou a carreira de advogado na polícia, tendo depois feito concurso para a magistratura. Foi juiz em várias cidades do interior, carregando a família um pouco

\footnotetext{
${ }^{416}$ Ver: http://www.arquivopublico.pr.gov.br/arquivos/File/pdf/texto_brasilio_oliveira.pdf e http://www2.camara.sp.gov.br/projetos/1953/00/00/0A/AK/00000AAKW.PDF. Consultados em 07/03/16.
} 
por todo lado. Luiz Gonzaga comenta que, em 1947, quando seu pai fez o exame para a magistratura, "havia uma certo preconceito contra os 'italianinhos', ele era uma pessoa muito talentosa, meu pai escrevia muito bem, estudioso, estudiosíssimo, mas ele sofreu discriminação na magistratura" (Entrevista de Luiz Gonzaga Belluzzo à autora, 2014). Além do mais, era getulista, ao contrário da maior parte dos professores e colegas da Faculdade de Direito que encarnavam o espírito da Revolução de 1932 e seu pai achava que 1932 era "um retrocesso, uma tentativa da oligarquia paulista cafeeira de voltar para trás". Belluzzo relata ter sido “criado com essa visão. Não se podia em São Paulo falar desse assunto, se falasse era mal considerado [...]. Isso era uma coisa bem paulista" (BELLUZZO, 2011, p. 428).

Seu pai era descendente de italianos do Vêneto e da Calábria que se casaram no Brasil. O bisavô foi empregado como administrador da fazenda de um Almeida Prado, em Jaú. O avô paterno nasceu em Analândia, um ano depois dos bisavós instalarem-se na nova terra. Ele foi coletor de impostos e casou-se com uma imigrante italiana. O pai de Luiz Gonzaga nasceu em Bariri, cidade que concentrava grande colônia de italianos. Na juventude foi enviado para São Paulo para estudar no Colégio Rio Branco e depois na Faculdade de Direito. Foi então viver em uma pensão para estudantes que pertencia a uma senhora de Orlândia, de família "quatrocentona", cujo marido fora fazendeiro de café que, pouco antes da crise de 1929, vendeu a fazenda e comprou uma importadora na cidade de Batatais. Ele vendia bens importados para os fazendeiros que, beneficiados pela moratória do Getúlio, não pagaram, de modo que sua empresa quebrou. O pai de Luiz Gonzaga casou-se, em 1942, com uma das filhas da dona da pensão, normalista que chegou a lecionar em algumas das cidades nas quais viveu com o marido (Entrevista de Luiz Gonzaga Belluzzo à autora, 2014).

A família de Belluzzo era bastante católica e ele, além do Colégio São Luís, chegou a frequentar o seminário do Colégio Santo Inácio no Rio de Janeiro. Ao fazer o vestibular para direito teve a vantagem da formação em português e latim no seminário. No final do bacharelado, o pai insistiu que fizesse o exame para o Ministério Público. Ainda que a ideia não o atraísse, começou a estudar para o concurso, mas então surgiu a oportunidade de fazer o curso da CEPAL, que ele abraçou "para decepção do meu pai, que ficou desesperado" (BELLUZZO, 2011, p. 422). Não teve volta. Belluzzo começou a lecionar economia na PUC-SP e João Manuel e ele foram trabalhar com Fausto Castilho, primeiro 
na chefia de gabinete da Secretaria de Educação, depois na montagem da área de economia da UNICAMP (GOMES, 2007, pp. 61-62). Segundo ele: "Zeferino convidou o Fausto para fundar o Departamento de Planejamento Econômico e não queria uma réplica da FEA-USP, então quem convidou? Convidou os cepalinos, que era o máximo de heterodoxia que se permitia aqui” (Entrevista de Luiz Gonzaga Belluzzo à autora, 2014).

Esses convites aos cepalinos coincidiram com a desmontagem do Centro CEPALBNDE, assinada por Jayme Magrassi de Sá, em 1967. Entre a quebra do vínculo com o BNDE em 1967 e a incorporação ao Instituto de Pesquisa Econômica Aplicada (IPEA) em 1971, o Centro funcionou autonomamente sob o nome de CEPAL-ILPES, mas quase não tinha recursos (item 4.3). Face à crise instaurada, a oportunidade de enraizar-se em uma nova estrutura institucional fazia-se atraente para os membros do Centro que, ademais, estava desfalcado pela fuga de seus principais membros para o Chile (itens 3.2 e 3.4). A proteção institucional que a UNICAMP oferecia aos dissidentes era um elemento adicional de atração. O reitor garantia que lá pudessem ser simpatizantes do Partido Comunista, lecionar Marx e animar debates sobre política com seus alunos (Entrevista de Luiz Gonzaga Belluzzo à autora, 2014; Entrevista de Carlos Lessa à autora, 2012; MELLO, 1999, pp. 196-197).

Zeferino era respeitado pelos militares e usava seu prestígio e autoridade para garantir o controle total sobre a universidade que considerava ser sua. Assim, se quisesse convocar cepalinos ou comunistas para ali lecionar seriam "os seus comunistas". Nesse sentido assemelha-se aos casos, descritos em capítulos anteriores, de Getúlio Vargas, Roberto Campos, João Paulo Reis Velloso e Marcos Vianna. Líderes e colaboradores de ditaduras dotados de larga autoridade, que permitia que tivessem seus comunistas protegidos. Getúlio mantinha pessoas sabidamente comunistas em sua Assessoria; Campos não aceitou que os homens de esquerda aprovados no concurso para o BNDE fossem desclassificados por critérios ideológicos; Velloso mantinha críticos do regime no IPEA, dando-lhes liberdade para escrever; Vianna chegou a tirar alguns de seus funcionários da cadeia e rejeitava as exigências de atestados ideológicos do Serviço Nacional de Informações (SNI). Com Zeferino não foi diferente (GOMES, 2007, p. 61, $74,93)$.

Ainda que tenha ignorado a prisão de alguns alunos - especialmente em casos nos quais, em sua opinião, o comportamento deles conturbava o funcionamento da 
universidade - em geral Zeferino intercedia pessoalmente para assegurar a liberdade dos seus, principalmente quando se tratava do corpo docente que havia escolhido a dedo. Também os laços de João Manuel com a elite política eram úteis para a proteção dos quadros da universidade. Zeferino chegou a ser informado por João de Deus, o pai de João Manuel, da existência de uma trama no Conselho de Educação contra a renovação de sua posição como reitor. Igualmente era de serventia o contato com Emiliano Cardoso de Mello, irmão de João de Deus e pai de Zélia Cardoso de Mello (item 6.2), que era delegado do Departamento de Ordem Política e Social (DOPS) e alertava quando algo perigoso estava para acontecer. Foi ele que, em 1975, quando a repressão vivia uma fase aguda, aconselhou a Belluzzo que deixasse o país e só voltasse quando as coisas acalmassem. A consequência foram três meses na Europa esperando poder voltar e pensando o que deveria fazer se fosse forçado a permanecer (GOMES, 2007, p. 165; Entrevista de Luiz Gonzaga Belluzzo à autora, 2014).

Belluzzo e João Manuel atuaram ainda na obtenção de verbas para a implementação da cidade universitária. No final dos anos 1960, tornaram-se assessores diretos de Dílson Funaro, que foi nomeado Secretário do Planejamento e da Fazenda do governo Abreu Sodré. Seus pupilos permitiram que o reitor estabelecesse um canal de diálogo permanente com o homem que cuidava das finanças do Estado, o que foi essencial para irrigar a universidade com recursos para fazer avançar a construção do campus e a implementação de novos cursos (GOMES, 2007, pp. 64, 99, 103; MELLO, 1998, p. 238; Entrevista de Luiz Gonzaga Belluzzo à autora, 2014).

Belluzzo e João Manuel tinham um regime de trabalho quase especial dentro do corpo docente. Lecionavam na UNICAMP, trabalhavam no governo do Estado com Funaro e viajavam constantemente, o que muito incomodava Fausto Castilho. As viagens deles e dos outros membros da economia eram devidas à preservação da tradição do Centro CEPAL-BNDE de espalhar pelo país o debate sobre o desenvolvimento e as técnicas de programação. Em 1968, foi aprovado convênio com o Centro CEPAL/ILPES, que previa que cinco cursos de pós-graduação fossem oferecidos pela nova universidade 417 . Em 1973, foi criado no IFCH o Centro Técnico de Assessoria Empresarial (CTAE), que passou a ser responsável por cursos de extensão e de pósgraduação diretamente voltados a empresários, sobre modernização organizacional,

$417 \quad$ Ver: $\quad$ http://www.siarq.unicamp.br/siarq/images/siarq/pesquisa/levantamentos_documentais/ifch.pdf. Consultado em 07/03/2016. 
tecnológica e de gestão, visando fazer progredir a pequena e média empresa nacional ${ }^{418}$ (BACIC e SOUZA, 2006; PAGNANI, 2006). Tanto o CTAE quanto os cursos ligados à CEPAL/ILPES eram prioritários no projeto de Zeferino Vaz para a UNICAMP, que buscava aproximar a universidade das empresas, da sociedade e da administração pública.

Os programas dos cursos-livres exigiam deslocamentos constantes do grupo de economistas, com ausências prolongadas e viagens de centenas e até milhares de quilômetros, tal a demanda que chegava dos empresários e das administrações públicas. [...] Nas asas de um generoso financiamento do BNDE, hoje BNDES, os economistas perdiam-se por meses nas estradas esburacadas do interior do país, praticando, afinal, o que pregava o Partido Comunista e o que a ala nacionalista do regime (Zeferino inclusive) estava longe de desprezar: "promover o desenvolvimento" da pequena e média indústria, ou seja, do capital nacional (GOMES, 2007, p. 104).

As exceções que se abriam aos economistas, incluindo as ausências decorrentes das constantes viagens, foram um dos motivos da discórdia entre Castilho, de um lado, e Zeferino Vaz e os cepalinos, de outro. O desfecho da crise foi a substituição, na direção do IFCH, de Castilho por Manoel Berlinck, ocorrida em 1972 (GOMES, 2007, pp. 104106, 127, 159). Sob a direção de Berlinck o IFCH e o ensino de economia expandiram-se. O mestrado em economia foi criado em 1974 e precisava de professores credenciados para orientar, ou seja, detentores do título de doutor, que até então nenhum professor da UNICAMP possuía. Para tanto, contataram João Paulo de Almeida Magalhães, que havia feito o doutorado na Sorbonne sob a supervisão de Maurice Byé, o mesmo professor que orientara Celso Furtado (item 1.3). Almeida Magalhães era um desenvolvimentista próximo de Furtado, colaborador do Instituto Superior de Estudos Brasileiros (ISEB) e membro do Clube dos Economistas. Ele tinha relações com a indústria, tendo chefiado o departamento econômico da Confederação Nacional das Indústrias (CNI) e trabalhado na área de planejamento governamental (FELDHUES, 2014, pp. 81-82). Foi Almeida Magalhães quem dirigiu as teses de Wilson Cano, Luiz Gonzaga Belluzzo, Osmar Marchese e Ferdinando Figueiredo, que datam de 1975-1976. Já a tese de João Manuel consta ter sido orientada pelo próprio Belluzzo.

Os recém-doutores passaram a orientar as teses de mestrado e, aos poucos, somaram-se à equipe alguns professores que regressavam do exílio, inicialmente, antigos

${ }^{418}$ O CTAE era dirigido por Osmar de Oliveira Marchese e Éolo Marques Pagnani, dois especialistas formados por meio de convênio entre a Fundação Instituto de Administração da FCEA-USP e o Research Institute for Management Science da Universidade Tecnológica de Delft, financiado pelo FUNTEC do BNDE e parte de Programa de Cooperação Internacional da ONU para o Desenvolvimento Industrial. O convênio funcionou entre 1966 e 1967 e objetivava formar "um corpo de especialistas brasileiros em políticas e assistência técnicoorganizacional para empreendimentos industriais de pequeno e médio porte" (PAGNANI, 2006, [online]). 
membros do Centro CEPAL-BNDE. Carlos Lessa estava no Brasil desde 1968, dando aulas na Administração Pública da FGV do Rio de Janeiro e começou a fazer o que ele chama de "esforço romântico" para a criação de uma escola crítica de economia. Tratavase de "pegar uma Faculdade Federal bem fraca e investir em massa para fazer concursos nela. Fizemos isso na Federal Fluminense” (UFF) (Entrevista de Carlos Lessa à autora, 2012). Alguns professores que tiveram contato com Lessa no Chile, como Liana Aureliano e Claudio Salm, lecionaram na UFF por algum tempo, mas a experiência fracassou pois não havia a proteção e a liberdade necessárias para que se criasse um espaço aberto à crítica (Entrevista de Marcio Henrique Monteiro de Castro à autora, 2012; Entrevista de Carlos Lessa à autora, 2012).

Lessa havia sido advertido pelo reitor da UFF que "a escola tinha virado uma referência para a esquerda e que os órgãos de informação estavam cada vez mais querendo saber dele sobre a escola". Ele relata que viajava frequentemente para dar cursos

\begin{abstract}
no México, na Venezuela, na Espanha, na Argentina, no Chile... Esses cursos são bem pagos, então, fazendo dois ou três cursos desses por ano eu conseguia me sustentar bem. Só que os órgãos de informação passaram a achar que eu era o porta-voz para os exilados no exterior das coisas que aconteciam aqui dentro. Sabe porque achavam? É evidente. Eu ia para o exterior e quem se reunia comigo? A esquerda latino-americana e a brasileira exilada, [...] então havia um dossiê contra mim e o reitor me falou: "olha, professor, não viaje mais para o exterior". Eu disse: "o senhor me desculpe, eu vou pedir demissão" (Entrevista de Carlos Lessa à autora, 2012).
\end{abstract}

Ao desligar-se da UFF, Lessa passou alguns anos trabalhando com Rômulo de Almeida (item 1.4) em sua empresa de consultoria. Lá teve a oportunidade de ajudar "a definir o polo da Aracruz, fiz o estudo de viabilidade econômica do polo petrolífero de Camaçari. Fiz um monte de estudos e projetos Brasil afora", chegando a ser presidente de uma das firmas do polo petrolífero, a Detergentes do Nordeste S.A. No final dos anos 1970 foi contatado por João Manuel, Luiz Gonzaga, Ferdinando Figueiredo e Wilson Cano e convidado para integrar a pós-graduação da UNICAMP (Entrevista de Carlos Lessa à autora, 2012). Conceição Tavares, que estava no Brasil desde o final de 1973, também aderiu ao projeto. Antônio Barros de Castro chegou um pouco depois. Ele havia partido com sua esposa Ana Célia para a Inglaterra em 1973, onde ocupou um posto de Visiting Scholar em Cambridge até 1974. Na volta tornou-se professor da UNICAMP e Ana Célia fez mestrado sob a supervisão de Wilson Cano. 
Em 1976, Carlos Lessa e Tamás József Márton Károly Szmrecsányi - formado em filosofia na FFCL, professor da Faculdade de Rio Claro que deixou o país em 1965, indo cursar o mestrado na New School for Social Research (BAIARDI 2009, p. 205) defenderam seus doutorados, ambos orientados por Jorge Miglioli, o assistente de Álvaro Vieira Pinto que voltava do doutorado na Polônia, onde havia tomado contato com o planejamento soviético e sido aluno de Michal Kalecki, autor que teria grande influência na UNICAMP (item 3.3) (MIGLIOLI, 2005, pp. 71-76; SACHS, 2004). Com a incorporação de Luciano Coutinho na metade dos anos 1970, houve um fortalecimento do ensino de Schumpeter e da área de organização industrial. As ideias da CEPAL tinham grande força naquele ambiente, dada a presença de Cano, Figueiredo, Belluzzo, João Manuel, Lessa, Castro, Tavares e, posteriormente, José Serra e Paulo Renato que tinham tido contato próximo com as teorias cepalinas e da dependência no Chile. João Paulo de Almeida Magalhães e Jorge Miglioli traziam para Campinas a vertente do desenvolvimentismo nacionalista do ISEB, da CNI, do Clube dos Economistas e o enfoque no planejamento econômico soviético.

A combinação dessas vertentes, a influência transversal de Marx e Keynes e a prioridade dada às áreas de História e Teorias do Capitalismo, Interpretação Histórica e Socioeconômica do Brasil e Economia Política levaram à constituição de uma escola bastante distinta daquelas nas quais a economia é construída sobre os alicerces da teoria da ação racional, modelada com largo uso da econometria e concebida como ferramenta neutra, universal e apartada da política. As divergências entre essas distintas concepções de economia manifestam-se na crise ocorrida quando a UNICAMP tentou ingressar no Associação Nacional de Centros de Pós-Graduação em Economia (ANPEC).

Flávio Rabelo Versiani, em texto sobre A ANPEC 25 anos: passado e futuro (1997), conta que Paulo Roberto Haddad, o primeiro Secretário-Geral da ANPEC, demonstrava, já em 1972, preocupação com a preservação da pluralidade de orientações metodológicas e ideológicas na Associação (VERSIANI, 1997, p. 237). Em sua palestra no primeiro encontro nacional da ANPEC, em 1973, Haddad ilustrou seu argumento através da exposição de casos em que as divergências entre diferentes concepções de ciência econômica e política econômica levaram a conflitos no interior do espaço dos economistas. Ele conta que a American Economic Association quase foi desmembrada no fim do século XIX, início do XX, devido a uma luta entre a orientação liberal e a 
vertente que prezava a intervenção do Estado, da igreja e da ciência na solução dos problemas sociais. Haddad explora também os atritos criados pela definição de ciência econômica postulada por Lionel Robbins, que separava a economia "como ciência, que estuda o comportamento humano enquanto relação entre fins e meios escassos que têm usos alternativos", da história econômica, à qual só caberia estudar os diversos arranjos desses elementos observados no tempo. A definição era rejeitada por muitos economistas políticos e historiadores econômicos que a consideravam limitada, incapaz de lidar com as instituições e com a evolução das estrutura e fechada ao diálogo com as outras ciências sociais, sendo, no limite, um instrumento de racionalização em favor do status quo (HADDAD, 1998, pp. 185-190).

Ao fim de tal preleção, Haddad apela à tolerância e aceitação da pluralidade na Associação. Não demorou um ano para que o conflito ocorresse. Haddad relata que:

\begin{abstract}
houve, na época uma contestação da EPGE à entrada da UNICAMP e essa contestação foi de natureza eminentemente doutrinária. Não foi teórica, foi explicitamente ideológica. A expressão usada foi de que a orientação da UNICAMP, naquela época, não era de "natureza científica". No fundo, o que aconteceu é que se estava tentando organizar, através da UNICAMP, um grupo de pensadores e de economistas de orientação neomarxista. Então aquilo criou um constrangimento [...]. Nós tentamos, por convencimento, dialogar com a direção do EPGE, mas nada conseguimos. Então fizemos uma comissão que foi constituída por mim e pelo Prof. Pastore. Visitamos Campinas e elaboramos um relatório favorável à entrada do DEPE no programa da ANPEC. No dia da votação houve um voto contrário, o da EPGE. Ela acabou se desligando da ANPEC (HADDAD, 1997, pp. 235-236).
\end{abstract}

O contexto da ditadura e as controvérsias entre o diretor da EPGE, Carlos Geraldo Langoni (item 4.4), defensor e aliado do governo, e os economistas do polo crítico acentuavam as rivalidades propriamente metodológicas, propiciando o surgimento desse tipo de cisão. Em 1974 o mestrado de Campinas foi oficializado e passou a fazer parte da ANPEC, a despeito dos protestos do grupo de Chicago da EPGE. Contrariada, a FGV-RJ deixa a Associação, permanecendo desfiliada até o final de 1979, quando Mario Henrique Simonsen retomou o controle sobre a sua escola e reestabeleceu o diálogo com a Associação.

A UNICAMP não era apenas uma escola à esquerda no que concerne ao tipo de teoria econômica ali praticada, mas um espaço habitado por vários economistas que haviam sido perseguidos por suas posições contrárias ao governo. Uma parte significativa dos primeiros alunos que defenderam dissertações e teses na UNICAMP integravam o “Grupo Pinochet” (MELLO, 1999, p. 198), ou seja, estiveram exilados no Chile e foram 
forçados a deixar o país no momento da tomada de poder pela junta militar. Muitos deles haviam sido alunos do ILPES e do programa de pós-graduação em economia da ESCOLATINA, onde cultivaram repertório bastante semelhante ao da UNICAMP, uma combinação de pensamento cepalino, marxismo, keynesianismo e autores críticos como Sylos Labini, Joe Bain, Michal Kaleki, Piero Sraffa e Joan Robinson.

Integraram o "Grupo Pinochet”, dentre outros, Ana Célia Castro, Liana Aureliano, José Carlos Braga, Sulamis Dain e Paulo Renato Costa Souza, Frederico Mazzucchelli, Carlos Alonso Barbosa de Oliveira, Paulo Baltar, Cláudio Salm, Jorge Mattoso e Adhemar Kyotoshi Sato ${ }^{419}$. Também os departamentos de ciências sociais e história do IFCH abrigaram diversos professores que regressavam do exílio, como Vilmar Faria, Carlos Estevam Martins, Maria Hermínia Tavares de Almeida, Elizabeth Souza Lobo, Marco Aurélio Garcia, Sônia Draibe, Lourdes Sola e José Guilherme Cantor Magnani. Alguns desses economistas e cientistas sociais, além de lecionar na UNICAMP, ligaram-se ao CEBRAP.

Havia entre a UNICAMP e o CEBRAP intensa troca acadêmica. Professores de Campinas como Luciano Coutinho, Claudio Salm, Antonio Barros de Castro, Maria da Conceição Tavares e Luiz Gonzaga Belluzzo publicaram artigos nos primeiros números dos Cadernos CEBRAP e membros do CEBRAP circularam nas palestras e outras atividades acadêmicas realizadas em Campinas. Ademais, conforme avançava o processo de redemocratização, os dois núcleos começaram a aproximar-se do MDB, passando a elaborar os programas dos candidatos, oferecer assessoria econômica, participar das comissões econômicas em formação e até mesmo ingressar efetivamente na política partidária. Muitas reuniões daqueles que se alinhavam ao MDB ocorreram no CEBRAP. Belluzzo comenta que, naquela época,

o Luciano Coutinho era o coordenador da pós-graduação e nós tínhamos reuniões regulares no CEBRAP. Lá, quem participava das discussões eram a Conceição, o Pedro Malan, o Chico de Oliveira, o Paul Singer, o João Manuel, eu, o Wilson Cano e o Celso Furtado, que ia muito lá quando vinha ao Brasil, participava das discussões, mas o Celso era assim muito caladão... O Edmar Bacha ia também. Hoje em dia as pessoas ficam pasmas de ver como é que se reunia tanta gente, mas era um momento de frente única contra a ditadura. Depois houve divergências, o que é muito natural; terminada aquela pressão sobre a ditadura, cada um tomou o caminho que lhe parecia mais compatível com a sua formação (BELLUZZO, 2011, p. 423).

\footnotetext{
${ }^{419}$ Ver: http://www.bibliotecadigital.unicamp.br/indicadores/acessodownload.php? unidade=31\&link=1\&sort=i. Consultado em 04/02/2016.
} 
Outros economistas e também um grande grupo de sociólogos participam das atividades no CEBRAP que resultariam na elaboração dos programas do MDB para as área social e econômica e na assessoria a alguns de seus principais candidatos, como Ulysses Guimarães e André Franco Montoro. Dessa articulação resultou, em 1978, a primeira candidatura de Fernando Henrique Cardoso, que o levou ao Senado em 1982, depois que Montoro foi eleito governador.

\title{
5.3 Guido Mantega: a PUC-SP e as raízes da intelectualidade petista
}

Em 1967, após concluir o livro Dependência e desenvolvimento, escrito em parceria com Enzo Falleto (item 3.3), Fernando Henrique Cardoso deixou o Chile para lecionar, a convite de Alain Touraine, no recém criado campus da Université de Nanterre, onde foi professor de Daniel Cohn-Bendit, uma das lideranças do Maio de 1968 francês. Fernando Henrique ainda viu alguns dos efeitos das greves e barricadas que tomaram Paris naquele mês. Foi afetado pelo fechamento da universidade mas, como confessa,

\begin{abstract}
minha cabeça nunca esteve realmente na França - estava focada em como voltar para o Brasil. Eu aproveitei o tumulto e praticamente me tranquei na minha casa, escrevendo minha tese e falando com amigos no Brasil, tentando aferir o estado dos ânimos de onde venho. Falava-se sobre um amolecimento, relaxamento da ditadura. Ruth e eu estávamos ansiosos para voltar, depois de quase cinco anos no exterior; as nossas crianças quase não falavam português mais (CARDOSO, 2006b, p. 101).
\end{abstract}

Ruth Cardoso regressou primeiro para organizar a reinstalação da família em São Paulo. A ordem para prisão de Fernando Henrique havia sido cancelada por um parecer de Peri Constant Bevilacqua, militar e político ligado ao avô de FHC. Simultaneamente, o falecimento do professor Lourival Gomes Machado tornara disponível uma cátedra de ciência política à qual Fernando Henrique pretendia concorrer. Ruth cuidou da inscrição do marido no concurso e da correção e montagem dos escritos da tese que ele enviava ao Brasil. FHC foi aprovado exame para a cátedra ocorreu em outubro de 1968, regressando à FFCL (BRANDÃO, 2010, pp. 84-85; CARDOSO, 2014, [online]).

Se FHC pode esconder-se do Maio de 1968 francês, não foi tão simples escapar dos eventos que tomaram o Brasil poucos meses depois. Os estudantes, constrangidos pelos anos de ditadura e incitados pelas lutas estudantis que levantaram o mundo naquele ano, renovaram sua luta política. Organizaram a passeata dos Cem Mil em protesto ao 
assassinato de um estudante no restaurante universitário o Calabouço e articularam um encontro das militâncias de esquerda em um sítio em Ibiúna. A Faculdade de Filosofia viveu uma luta de rua contra o Mackenzie, escola que abrigava grupos conservadores, parte dos quais pessoalmente engajados na tarefa de extinguir à força as ameaças subversivas que emanavam da USP. Fernando Henrique relata ter tido suas coisas reviradas e ter ouvido de um delegado do Departamento de Segurança Pública que ele "deveria se preocupar mais consigo mesmo" do que com o caos instaurado na universidade (CARDOSO, 2006b, p. 104). Com o AI-5 ocorre nova onda de cassações na universidade. Fernando Henrique, seu professor Florestan Fernandes e seus colegas José Arthur Ginanotti, Octavio Ianni, Bento Prado e outros tiveram seu afastamento da USP selado em abril de 1969 (CARDOSO, 2006b, p. 108).

As cassações foram o motor da criação de um centro de pesquisa independente para abrigar intelectuais tolhidos do acesso à universidade que não desejavam partir para o exterior ou que estavam retornando de seus périplos no exílio (GIANNOTTI, 2009, p. 57; BERQUÓ, 2009, p. 99). Juarez Brandão Lopes, cientista social formado na ELSP, vinculado à Faculdade de Arquitetura e Urbanismo, que lecionava a convite na FFCL, participante do grupo d'O Capital e um dos fundadores do CEBRAP, explica:

as relaçães entre os seus fundadores eram antigas. Tinham sido cimentadas em
ocasiões anteriores, tais com no movimento de reforma da universidade, ou na
participação do grupo de discussão d'O Capital, ou na luta pela criação da
FAPESP. Vários de nós estavam há tempos discutindo a viabilidade da criação
de um centro de pesquisas externo à USP. Sentia-se que dentro da universidade,
sobretudo como a carreira estava estruturada, havia empecilhos à pesquisa
coletiva e multidisciplinar. As aposentadorias de abril apressaram a fundação do
CEBRAP. Reuniam-se assim pessoas de formação diversa, com larga experiência,
que há muito interagiam à vontade. Outros, mais no início de suas carreiras
científicas, foram incorporados, trazidos pelos membros do grupo central.
Tornou-se logo um centro de atração. Especialistas de outras cidades - Rio de
Janeiro e Campinas, por exemplo - juntaram-se na discussão de temas os mais
variados, independentemente das suas disciplinas de formação (LOPES, 2006a,
pp. 105-106).

Fernando Henrique já havia experimentado formar um centro de pesquisa anteriormente, o Centro de Estudos de Sociologia Industrial e do Trabalho (CESIT). Na ocasião, era representante no Conselho Universitário (CO), tinha livre trânsito no governo e apoio de empresários, especialmente de seu grande amigo Fernando Gasparian. Os laços com o empresariado foi o único dos trunfos essenciais mobilizados para criar o CESIT que não desapareceu com a ditadura. Desta vez o empresariado desempenhou o essencial papel de atestar a idoneidade do novo centro de pesquisas, respaldando-o face 
aos potenciais investidores externos e protegendo-o, na medida do possível, da arbitrariedade dos militares.

Paul Singer, economista, Elza Berquó, estatística, e Cândido Procópio Ferreira de Camargo, sociólogo ligado à ELSP com formação em direito pela USP e filosofia pela PUC, participavam, logo antes do AI-5, de uma pesquisa na Faculdade de Saúde Pública na área de demografia e reprodução humana no Brasil que "era uma pesquisa de campo muito grande, financiada pela Fundação Ford. Então surgiu a ideia de obter recursos da Fundação para criar um centro de pesquisa, que acabou sendo o CEBRAP” (SINGER, 2009, p. 81; BERQUÓ, 2009, pp. 99-100), para onde transferiram inclusive a pesquisa em desenvolvimento na Saúde Pública. Eram, afinal, professores cassados, muito deles com conhecidos vínculos com a esquerda. FHC explica que foi preciso, então, dar um “jeitinho”, o que qualifica como a solução brasileira de ir aos poucos burlando as regras do sistema, para conseguir fundos, apoio e proteção para o centro (CARDOSO, 2006b, p. 112).

FHC autocaracteriza-se como alguém que se tornou "cosmopolita à força" devido à experiência nas Nações Unidas. "Prebisch me nomeou para representá-lo num centro que as Nações Unidas criaram em Genebra. Era eu quem ia para Genebra representar o Prebisch. Eu todo ano tinha que ir a Nova York". Ele afirma que o mundo "passou a ser uma coisa mais familiar para mim, já não tinha medo das fundações, nem de coisa nenhuma". Ele contatou dois representantes da Ford, William Carmichael e Peter Bell, para convencê-los de que aquele seria um bom investimento (CARDOSO, 2012, pp. 3536). Bolívar Lamounier - que trabalhava no Instituto Universitário de Pesquisas do Rio de Janeiro (IUPERJ) e que se agregaria ao CEBRAP em 1970 trazido por Carlos Estevam Martins - relata que fez parte da intermediação entre o Centro e a Fundação Ford pois conhecia Peter Bell do tempo em que a Ford financiara as ciências sociais em Minas Gerais. Tornaram-se amigos, de modo que o acompanhou em várias viagens feitas a São Paulo, ocasiões em que encorajou a Ford a firmar um acordo com aqueles professores. "Eu não sei se eu devia dizer isso tão taxativamente, mas eu olho para trás... Eu tinha a seguinte ideia na minha cabeça: 'Eu sei que, se eu bater à porta do CEBRAP, eles vão me acolher de braços abertos'." (LAMOUNIER, 2013, pp. 21, 24).

Financiar um grupo de pessoas associadas com a esquerda não era tão fácil, tendo a proposta encontrado resistências na unidade central da Fundação. Havia um certo 
temor por parte da Fundação Ford de que se estivesse financiando atividades de cunho subversivo. No caso da USAID, agência diretamente subordinada ao governo dos EUA, seria praticamente impossível oferecer apoio e proteção a um grupo que se opunha ao regime que, aos olhos da linha dura da política estadunidense, fora implantado para garantir a proteção do Brasil e do subcontinente contra o comunismo. A Ford tinha maior liberdade de atuação e, ainda que fosse movida por um ideário anticomunista, seus emissários, em geral, estavam mais próximos das doutrinas da Charles River School e dos princípios que orientaram a política externa do governo de John Kennedy do que dos falcões que apostaram nos golpes latino-americanos como a solução contra a ameaça comunista (item 2.4) (MICELI, 1993, pp. 37-45, 55; CARDOSO, 2006b, p. 113).

O CEBRAP podia ser associado à esquerda - era gerido por professores cassados, era a transposição para um órgão de pesquisa de um grupo que estudava $O$ Capital e abrigava pessoas que foram presas ou exiladas - mas a produção de seus membros não desviava das diretrizes da Ford ${ }^{420}$. Escreviam sobre democratização, concentração de renda, rejeição da tortura, demografia, mudanças no campo e na cidade, operariado, quando muito redigiam ensaios críticos na linha da teoria da dependência e flertavam com as teorias do imperialismo, mas estavam muito longe de ser um bastião do pensamento revolucionário. As ideias debatidas no CEBRAP, mesmo quando escritas por pessoas declaradamente à esquerda, não eram tão desviantes dos temas pelos quais a Charles River School e o governo Kennedy interessaram-se, incluindo a reforma agrária como parte da pauta de modernização da política externa norte-americana do início dos anos 1960 (item 2.4).

Especialmente engajada na modernização institucional dos países nos quais se alojava, investindo largos recursos no treinamento científico e na formação de quadros para a administração pública, seria um desperdício para a Ford que os cérebros por ela financiados em seus estudos no exterior e cultivados para melhorar o Brasil acabassem dispersos pelo mundo por não encontrar espaço para enraizar-se, uma vez deslocados das universidade pelos militares (GIANNOTTI, 2009, p. 57). A criação de uma instituição privada de pesquisa parecia uma solução adequada para lidar com o problema e a Ford estava disposta a dialogar com os proponentes.

\footnotetext{
${ }^{420} \mathrm{O}$ apoio ao CEBRAP não foi o primeiro nem o único caso em que grupos com conhecidas afinidades com o marxismo foram financiados pela agência. O apoio ao programa de pós-graduação em economia da Universitad de Chile, mesmo depois de adquirir fortes tonalidades vermelhas, incluindo em seus quadros diversos partidários comunistas e socialistas, é um caso análogo (PARMAR, 2012, p. 201).
} 
Para encorajá-la a conceder o empréstimo, recorreram, sobretudo, aos laços do grupo com o empresariado, com a igreja e com homens considerados insuspeitos por terem ocupado altos cargos nos governos militares. A escolha de Procópio Ferreira de Camargo para a Presidência do CEBRAP foi, portanto, estratégica. Ele não era um homem diretamente vinculado à esquerda, não estava cassado, portanto oferecia credibilidade à empreitada. Além disso, ajudou os pesquisadores a conquistarem o respaldo de seus amigos Paulo Egydio Martins, empresário que fora ministro da Indústria e do Comércio de Humberto Castello Branco e que se tornaria o governador do Estado de São Paulo em 1975, e Severo Gomes, formado na Escola Superior de Guerra, que foi Ministro da Agricultura de Humberto Castello Branco e se tornaria Ministro da Indústria e do Comércio de Ernesto Geisel em 1974. Havia, pois, uma negociação com setores menos endurecidos da elite militar para criação do Centro, que seria tolerado desde que se ativesse a atividades de pesquisa. Como os dois eram pessoas com inegável trânsito no governo, o apoio por eles concedido foi essencial para encorajar a Ford a conceder os primeiros empréstimos ao centro, que resultou ser o $22^{\circ}$ maior receptor de doações feitas pela Fundação no Brasil no período 1962-2001 (CARDOSO, 2009, p. 32; GIANNOT'TI, 2009, p. 60; CARDOSO, 1987, pp. 26-27; BROOKE e WITOSHYNSKY, 2002, p. 50).

No meio industrial contavam com o apoio dos Mindlin e dos Lafer, ligados à Klabin e à Metal Leve. Além dos laços próximos, revela Cardoso, "tem um lado judaico, que são solidários às perseguições, foram muito solidários também, ficaram no Conselho" avalizando com seus nomes a organização (CARDOSO, 2012, p. 36). Além deles, tinham suporte de seu grande amigo Gasparian e do cunhado dele, Dílson Funaro. Dílson e seus assessores Luiz Gonzaga Belluzzo e João Manuel Cardoso de Mello foram essenciais à obtenção de recursos, para além do respaldo político, já que, posicionados nas secretarias da área econômica do governo do Estado de São Paulo de Abreu Sodré, conseguiram para o CEBRAP numerosos contratos de prestação de serviços técnicos na área de planejamento (CARDOSO, 2009, pp. 32, 37; SINGER, 2009, pp. 81-83).

O nome de Centro Brasileiro de Análise e Planejamento, além de soar técnico e neutro, favorecendo as simpatias dos financiadores e tentando reduzir as suspeitas de subversão do regime, sinalizava que estavam dispostos a entrar no mercado de serviços de planejamento. A Hidrobrasileira, empresa dirigida por Sérgio Motta, antigo militante da AP e grande companheiro de Luiz Carlos Mendonça de Barros e José Serra, que 
abrigava diversos perseguidos pelo regime, foi uma das maiores clientes do CEBRAP. Sérgio Motta, que fora apresentado a FHC por Paul Singer, ajudava aquele grupo de intelectuais com os quais tinha afinidade política por meio de contratos de prestação de serviços. Nesse momento começou o relacionamento que levaria Motta a ser um dos maiores articuladores das campanhas políticas de Fernando Henrique e, posteriormente, seu Ministro das Comunicações (CARDOSO, 2009, pp. 32, 37; SINGER, 2009, pp. 8183; PRATA et al., 1999, pp. 62-63).

Viabilizado do ponto de vista financeiro, o CEBRAP expande-se. O grupo inicial fora formado por Procópio (1922-1987), que tinha livre trânsito na academia e na política; Fernando Henrique, Arthur Giannotti (1930) e Octávio Ianni (1926-2004) que haviam sido cassados da Faculdade de Filosofia; Juarez Brandão (1925-2011) que seguiu lecionando na FAU ainda que frequentasse os mesmo círculos que seus colegas cassados; e Singer (1932) e Berquó (1931) que trabalhavam juntos no projeto da Saúde Pública e eram ligados aos círculos em torno dos socialistas e do PCB ${ }^{421}$. Mantiveram também, na época da fundação do Centro, relações com a FGV-SP, que abrigou algumas das reuniões iniciais. Antônio Angarita, da EAESP, ajudou na montagem do centro e indicou Luiz Carlos Bresser Pereira para o Conselho do CEBRAP. Manoel Tosta Berlinck (1936-2016) logo passou a integrar a equipe de pesquisadores (SINGER, 2009, p. 81; CARDOSO, 1987, p. 27; BERLINCK, 2001, p. 51; Entrevista de Luiz Carlos Bresser Pereira à autora, $2012)^{422}$.

A segunda geração de pesquisadores incorporada ao CEBRAP era em média uma década mais nova que os fundadores, sendo composta essencialmente por pessoas com as quais Fernando Henrique havia interagido no exílio, a começar por seus diletos alunos do período chileno, Vilmar Faria (1941-2001), regressando de Harvard, e Carlos Estevam Martins (1934-2009), voltando do doutorado em Essex. Da Inglaterra também retornava

\footnotetext{
${ }^{421}$ Ainda que Singer fizesse parte da Liga Socialista Independente, o professor catedrático da FEA com o qual trabalhava, Wagner Vieira da Cunha, era próximo a círculos intelectuais do PCB. Havia inclusive feito um projeto para o concurso de Brasília com Vilanova Artigas, arquiteto comunista que construíra a casa de Elza Berquó - bem como a anteriormente mencionada casa dos Rosenthal - na qual ela escondeu diversos perseguidos pelo regime (BERQUÓ, 2009, p. 108; ROSATTI, 2012, p. 24; DEDECCA, 2012, p. 122). Na ocasião em que Singer viu-se constrangido a deixar a FEA sem concluir o doutorado, Wagner abandonou a cátedra que pretendia passar ao seu discípulo. Singer trabalhou por algum tempo na consultoria Hidroservice, até ser indicado por Florestan Fernandes, que também circulava no meio dos intelectuais do PCB, e por seus colegas do grupo D'O Capital à Elza Berquó para trabalhar no projeto que ela coordenava na Saúde Pública. Foi no bojo desse trabalho que conseguiu ir para Princeton fazer especialização em dinâmica populacional (SINGER, 2009, p. 80).

${ }^{422}$ Ver: http://cebrap.org.br/v3/index.php?r=noticias/exibir\&id=343. Consultado em 13/03/2016.
} 
Francisco Weffort (1937), que fora professor ao lado de FHC na USP e no Chile. Além deles, da França vieram Lúcio Kowarick e Vinicius Caldeira Brant (1941-1999) que eram originários da JEC/JUC/AP tal qual Bolívar, os Faria, José Serra, Sergio Motta, Bresser Pereira, Berlinck, Walter Barelli e tantos outros colaboradores do CEBRAP423. Francisco de Oliveira (1933), que passou pelo Chile e trabalhou para a CEPAL no México e na Guatemala, foi levado ao CEBRAP por Octavio Ianni, com quem teve contato em cursos que ofereceu na SUDENE (OLIVEIRA, 2009, p. 164). Na segunda geração entrou também para o CEBRAP Bolívar Lamounier (1943), que havia feito o doutorado na University of California - Los Angeles (UCLA) e estudado em Yale, vindo do IUPERJ.

Compõe a terceira geração um conjunto de jovens que, via de regra, tiveram problemas com o governo militar em 1968, alguns dos quais regressavam do Chile após o golpe de 1973, como Frederico Mazzucchelli (1947), Maria Hermínia Tavares de Almeida (1942), Adhemar Kiotoshi Sato (1942), Jorge Mattoso (1949) e Eduardo Kugelmas (19462006), mencionados no capítulo anterior. Antes de partir para o Chile, Mazzucchelli já havia trabalhado no CEBRAP. Começou a fazer pesquisas com Paul Singer e Chico de Oliveira no Centro quando ainda cursava a graduação da FEA. Ameaçado, Fernando Henrique oferece ajuda para que fosse para Oxford ou para a ESCOLATINA. Ele chega ao Chile em 1972, onde conheceria vários dos futuros colegas de UNICAMP e de CEBRAP. Na mesma época Cardoso também ajudou Henri Philippe Reichstul (1949), aluno da FEA que chegou ao CEBRAP por indicação de Mazzucchelli e pesquisava com Chico de Oliveira, a deixar o país em direção a Oxford (Entrevista de Philippe Reichstul à autora, 2014).

Nascido em Paris, Reichstul é descendente de família de sobreviventes do holocausto. Seu avô materno era comerciante atacadista de frutas em Lwów, na Polônia,

\footnotetext{
${ }^{423}$ Lúcio Kowarick foi membro da AP e seu coordenador em São Paulo, sem nunca ter sido da JUC ou da JEC pois não era católico. Formado nas ciências sociais da ELSP, trabalhou na Sociedade de Análise Gráfica e Mecanográfica Aplicada aos Complexos Sociais (SAGMACS) fundada pelo Padre Lebret e integrada por Antônio Bezerra Baltar (item 3.2). Através da SAGMACS participou da elaboração do Plano de Ação do Governo Carvalho Pinto. Preso logo após o golpe, Kowarick deixou o país e passou quatro anos na França. Foi indicado por Octávio Ianni para Florestan e por Florestan para Alain Touraine que o aceitou na pós-graduação. Kowarick passou oito meses em Louvain e 3 anos em Paris. Voltou para o Brasil logo antes do AI-5. Foi dar aulas na FGV e entrou na USP e no CEBRAP em 1970. Esteve ligado ao CEBRAP até 1976 quando conseguiu uma bolsa para pesquisar na Inglaterra e depois um posto de professor integral na USP (KOWARICK, 2009, pp. 128-134). Vinícius Caldeira Brant, que havia regressado ao Rio de Janeiro em 1967 e engajara-se na fundação do Partido Revolucionário dos Trabalhadores, foi preso em setembro de 1970 e, ao deixar a prisão em 1973, convidado a integrar o grupo de pesquisadores do CEBRAP. Ver: http://www.arquivoestado.sp.gov.br/memoriapolitica/prontuario.php?prontuario=BR_SP_APESP_DEOPS_SAN _P000408_01. Consultado em 11/03/2016; DHBB, Verbete Vinícius Caldeira Brant.
} 
hoje Lviv, na Ucrânia. Do lado paterno, o avô trabalhava com madeira na cidade de Kowel, que na época também ficava na Polônia. Para fugir das perseguições aos judeus, a avó materna e a mãe passaram-se por católicas e foram acolhidas em Varsóvia pela família de uma amiga que se arriscou para salvá-las. O pai abrigou-se na Sibéria depois de perder a família em um massacre que ocorreu em sua cidade enquanto ele buscava possível rota de fuga. Os dois conheceram-se em um campo de reencontros, casaram-se e foram para Praga, onde nasceu sua irmã Pauline. Dezoito meses depois, mudaram para Paris onde o pai trabalhou com exportação de máquinas. Viajou pela primeira vez ao Brasil por conta de uma venda presa na alfândega, gostou do país e decidiu transladar-se com a família. Foram viver em São Paulo onde ele montou uma fábrica de autopeças. Os filhos estudaram no Liceu Pasteur onde, além do francês, estudava-se inglês. Depois disso, Philippe aprendeu espanhol, com os muitos latino-americanos que viviam em Oxford e teve contato também com o italiano e com o polonês (Entrevista de Philippe Reichstul à autora, 2014).

Ao concluir a escola, Pauline foi estudar psicologia em Genebra e Philippe ingressou na FEA. Ele explica a opção profissional dizendo que: "não foi muito consciente. Eu me lembro que eu fiz o vestibular de economia, de engenharia, de física, eu acho... mas também, eu tinha dezessete anos... e depois fiz estudos orientais [russo]". Na graduação tinha maior afinidade com as áreas de história econômica, história, cálculo e macroeconomia, e menciona Alice Canabrava e Affonso Pastore como dois professores influentes, "eu gostava do jeitão dele [Pastore], apesar de não ser da mesma linha ideológica". Philippe cursou a graduação na época em que explodiram os conflitos entre a USP e o Mackenzie e converteu-se em militante de apoio da Vanguarda Popular Revolucionária (VPR) - um dos grupos que daria origem à VAR-Palmares - ao lado de seu cunhado, Ladislau Dowbor, preso trocado por um embaixador e enviado à Argélia, e de sua irmã Pauline, assassinada pela repressão em 1973424. Philippe ficou 9 meses preso em 1970. Ao ser solto concluiu a graduação em economia e foi acolhido pelo CEBRAP, onde trabalhou até ser aceito em Oxford e receber permissão da auditoria militar para partir (Entrevista de Philippe Reichstul à autora, 2014).

Ainda que o CEBRAP funcionasse como abrigo para muitas pessoas ameaçadas pelo governo militar, o próprio Centro e seus membros não estavam completamente

${ }^{424}$ Ver: http://cemdp.sdh.gov.br/modules/desaparecidos/acervo/ficha/cid/351. Consultado em 13/03/2016. 
imunes a perseguições. Para proteger os colegas, aqueles que eram mais bem inseridos apelavam para seus vínculos com o mundo dos oficiais. Cardoso recorreu a velhos amigos militares de seu pai, Berquó pediu proteção a um tio do exército. Severo Gomes desempenhava papel parecido ao que Zeferino Vaz tinha na UNICAMP, usando seu prestígio para credenciar e proteger aqueles que apresentavam posições críticas à ditadura, tendo sido convocado com frequência para tirar pessoas da prisão - como no caso mencionado de Conceição Tavares, presa em uma de suas viagens ao Chile e liberada com a ajuda de telefonemas de Simonsen e Severo Gomes ao alto escalão militar (CARDOSO, 2009, pp. 32-34; BERQUÓ, 2009, p. 108; CARDOSO, 2006b, p. 116).

Em 1974, diversos pesquisadores do CEBRAP foram presos. Permaneceram detidos por quase um mês Francisco de Oliveira, que havia sido preso em 1964, Frederico Mazzucchelli, que havia sido preso em 1968, e Carlos Eduardo Fernandes da Silveira que em 1969 havia sido preso dentro do Cursinho do Centro Acadêmico Visconde de Cairu da Faculdade de Economia da USP. Paul Singer ficou preso por uma semana. Também foi preso novamente Regis Stephan de Castro Andrade (1938-2002), advogado formado pela São Francisco, que trabalhava com Francisco Weffort em pesquisas sobre o operariado e era ligado ao Partido Operário Comunista (POC), tendo sido preso pela primeira vez em 1970. Outros foram interrogados e ameaçados ${ }^{425}$. Não pode haver sinal mais claro de que o Centro não estava totalmente seguro do que o detonar, em 1976, de uma bomba na frente da sede CEBRAP na Rua Bahia.

O aumento da repressão coincidiu com um deslocamento progressivo das atividades do CEBRAP para a sociedade civil e com a crescente exteriorização das desavenças políticas em relação às diretrizes do governo. Os primeiros tempos, voltados exclusivamente à atividade de pesquisa e à prestação de serviços, começavam a dar lugar à exposição pública das ideias ali produzidas em seminários e nos Cadernos CEBRAP, editados de 1971 a 1978. Em 1975, o CEBRAP publicou o livro São Paulo 1975: crescimento e pobreza (1975), estudo coordenado por Lúcio Kowarick e Procópio Ferreira que denunciava a degradação das condições econômicas e de vida durante o regime militar e

\footnotetext{
${ }^{425}$ Ver: http://bnmdigital.mpf.mp.br/DocReader/docreader.aspx?bib=BIB 06\&PagFis=68040, http://www.arquivoestado.sp.gov.br/memoriapolitica/prontuario.php?prontuario=BR_SP_APESP_DEOPS_SAN P000726_01,

http://www.arquivoestado.sp.gov.br/memoriapolitica/documento.php?ficha=BR_SPAPESP_DEOPSSPOSFTEX $\underline{\text { SNS006713 e }}$

http://www.arquivoestado.sp.gov.br/memoriapolitica/documento.php?ficha=BR_SPAPESP_DEOPSSPOSFTEX SNM002607, Janice Theodoro da Silva in: BIAZO, 2014, pp. 272, 281. Consultados em 12/03/2016.
} 
era prefaciado pelo Cardeal Dom Evaristo Arns, que contestava abertamente o regime e encomendara o livro em nome dos setores eclesiásticos progressistas.

Havia também recorrente participação dos membros do CEBRAP nos veículos de comunicação da oposição. Em 1972, Fernando Gasparian lançara o Opinião, jornal voltado ao grande público e disposto a fazer análises críticas da política, da economia e da sociedade brasileira mesmo sob censura. Nele tinham voz intelectuais de diversas correntes da oposição, já que a ideia era organizar uma frente unificada contra o governo. Muitos intelectuais do CEBRAP usavam esse jornal para fazer circular suas ideias, o que era favorecido pelas excelentes relações de FHC com Gasparian. No Opinião manifestavam-se também autores como Celso Furtado, Luciano Martins, Antonio Candido, os economistas da UNICAMP e outros nomes com bom trânsito e aceitação na esquerda nacionalista. Finalmente, o jornal fazia circular diversas matérias de autores estrangeiros, buscando ao mesmo tempo a valorização social decorrente do cosmopolitismo e respaldo internacional que o ajudasse a proteger-se das interferências da ditadura (SINGER, 2009, p. 83; KUCINSKI, 2003, pp. 299, 315).

O Opinião existiu até 1977, mas, em 1975, grande parte de seus membros, inclusive Raimundo Pereira, o editor geral - que havia sido indicado a Gasparian por Bernardo Kucinski enquanto estavam exilados na Inglaterra -, desgarra-se e forma o jornal Movimento, que funcionou até 1981 sob a supervisão financeira do militante da AP e empresário Sérgio Motta, que forneceu o capital inicial para a criação do jornal (AZEVEDO, 2011, p. 30). De acordo com FHC, "o Movimento era mais influência do PC do B e o Opinião mais influência, enfim, burguesa-comunista, não sei como é que eu vou chamar aquilo..." (CARDOSO, 2012, p. 30). Inicialmente o Movimento pretendeu ser, como seu antecessor, um jornal de frente política que pretendia incluir os diversos grupos engajados na luta pela redemocratização. Havia, até então, uma pluralidade de tendências que conviviam dentro dele, militantes remanescentes de quase todos os grupos políticos que atuaram clandestinamente durante a ditadura. Com o tempo, prevaleceu o maoísmo das parcelas da Ação Popular que aderiram ao PC do B conforme viram sua estrutura política democrática ser desarticulada pela repressão. Ademais, o Movimento diferia do Opinião ao buscar um público mais popular, para o que assumia um viés mais abertamente nacionalista e simplificava a linguagem (KUCINSKI, 2003, pp. 346-347). 
A cisão do jornal que deu origem ao Movimento ocorreu no contexto das eleições de 1974. Até o início dos anos 1970, o Movimento Democrático Brasileiro (MDB), partido oficial de oposição ao regime, era amplamente rejeitado pela esquerda por ser percebido como um títere do governo. A situação começou a alterar-se quando, de um lado, os grupos da esquerda que optaram pela luta armada foram dilacerados, notavelmente depois da queda da guerrilha do Araguaia, e, de outro lado, os militares do grupo de Ernesto Geisel começaram a falar em distensão. Ao ver a redemocratização como um horizonte próximo, a sociedade civil passou a engajar-se em debates sobre as vias e os termos da instalação de um novo regime político.

Neste contexto, o MDB assumiu papel de articulador da redemocratização, buscando aproximar-se dos segmentos intelectuais que se expressavam nos jornais de oposição, que voltavam a ocupar espaço nas universidades que estavam produzindo estudos sobre os problemas sociais e econômicos brasileiros. O CEBRAP funcionava como um ponto de confluência desses intelectuais na cidade de São Paulo, reunindo personalidades em ascensão cujas pesquisas eram apoiadas por norte-americanos e toleradas, ainda que a contragosto, pelos militares. Coligar-se com o CEBRAP foi um movimento estratégico do MDB para angariar apoio de jovens e intelectuais. O deputado Pedro Simon, presidente do MDB gaúcho, fez um primeiro movimento na direção do CEBRAP, convidando Arthur Giannotti, Fernando Henrique e Chico de Oliveira para ministrar conferências na Assembleia do Rio Grande do Sul. Paul Singer conta que

\footnotetext{
a aproximação concreta com o MDB se deu na minha casa, através de uma sobrinha do deputado do MDB, João Pacheco Chaves, muito próximo a Ulysses Guimarães. Era um fazendeiro do interior de São Paulo. A sobrinha deles, Ana, da Faculdade de Filosofia, me perguntou se eu receberia o João [Pacheco Chaves] e o Ulysses na minha casa para conversar. Eu concordei. Então eles vieram na minha casa e conversamos os três. Eles nem sabiam direito o que era o CEBRAP. Eles queriam conversar comigo, com meus amigos, porque eles achavam que precisavam criar um programa, uma visão político-ideológica para o MDB. Eu imediatamente sugeri o CEBRAP (SINGER, 1999, p. 72).
}

Assim aproximou-se do CEBRAP o deputado Ulysses Guimarães, presidente nacional do $\mathrm{MDB}$, que estava articulando uma anti-candidatura para as eleições presidenciais de 1974, tendo o tio de Bresser Pereira, Barbosa Lima Sobrinho, como candidato a vice. Ainda que todos soubessem que conquistar a presidência era impossível, a campanha foi um sucesso porquanto serviu para denunciar a farsa que era a eleição e para levar aos palanques a insatisfação com o autoritarismo, a tortura, a censura e outras arbitrariedades promovidas pelos militares. A anti-campanha somada à eleição de 
candidatos do MDB para 16 das 22 cadeiras disponíveis no Senado revelaram a intensidade do descontentamento da população com o governo, para desespero dos militares que acreditavam que poderiam controlar calmamente o processo de transição para a democracia. A derrota experimentada pela Aliança Renovadora Nacional (ARENA) sinalizou haver espaço para que o MDB crescesse pela via eleitoral, o que atraiu tanto políticos que até então achavam que não seria possível eleger-se pelo MDB quanto segmentos de intelectuais à esquerda interessados em promover uma democracia aberta à participação popular (KINZO, 1988, pp. 46-47, 145-146, 151; CORRÊEA, 2011, pp. 34-50).

A Fernando Henrique e Paul Singer, Ulysses Guimarães encomendou um programa eleitoral. Outros membros do CEBRAP, como Maria Hermínia, Weffort, Bolívar Lamounier, Chico de Oliveira e Estevam Martins, aceitaram participar da elaboração do programa que resultou em um livrinho vermelho que deveria orientar o posicionamento dos membros do partido sobre temas sociais e econômicos. Constavam no livreto considerações acerca do arrocho salarial, da concentração de renda, da dívida externa, dos direitos das mulheres e dos trabalhadores, da miséria urbana e outros dos temas dos estudos realizados no Centro (GIANNOTTI, 2009, p. 59; CARDOSO, 2009, pp. 35-36; DHBB, verbete Ulysses Guimarães; KINZO, 1988, pp. 154-155; Francisco de Oliveira in: BIAZO, 2014a, p. 118; CARDOSO, 2006, p. 82).

Além dos membros do próprio CEBRAP, colaborou com o desenho dos programas do MDB um conjunto de economistas que circulavam pelo Centro, participando dos debates ali promovidos e colaborando com os Cadernos CEBRAP. Esse grupo daria origem ao que se convencionou chamar de os “economistas do MDB”. Luiz Gonzaga Belluzzo conta que:

De 1973 para frente, o Fernando Henrique fez aquelas reuniões com os economistas, lá no CEBRAP na Rua Bahia, e participaram Celso Furtado, Pedro Malan, [...] Edmar Bacha, Maria da Conceição, eu [Luiz Gonzaga Belluzzo], Luciano Coutinho, João Manuel, Chico de Oliveira. Daí saíram os economistas do MDB. Na verdade, os que eram assessores diretos do Ulysses mesmo eram o João Manuel, eu e o Luciano. Os outros participavam, a Conceição, Lessa... o Serra chegou depois (Entrevista de Luiz Gonzaga Belluzzo à autora, 2014).

Cabe lembrar que houve, neste momento, uma aproximação entre os vários núcleos de economistas que criticavam as políticas econômicas dos militares, sendo exemplo da cooperação entre eles o livro $A$ controvérsia sobre distribuição de renda $e$ 
desenvolvimento (1975), prefaciado por FHC, com artigos de Luiz Gonzaga Belluzzo, Maria da Conceição Tavares, Paul Singer, Rodolfo Hoffmann, Edmar Bacha, Albert Fishlow, John Wells, Pedro Malan, José Serra e José Leite Lopes, todos atacando o governo militar e indicando as consequências pérfidas da concentração de renda observada entre os anos 1960 e 1970.

Por meio do CEBRAP, Ulysses Guimarães estabeleceu vínculos com diversos professores de economia. Dentre eles tinha maior afinidade com aqueles vinculados ao DEPE da UNICAMP, que se tornaram seus assessores diretos para assuntos econômicos. Eles passaram a frequentar a casa de Ulysses e a responsabilizarem-se pela elaboração dos trechos que versassem sobre economia nos discursos e nos textos programáticos lançados pelo MDB nos anos seguintes, Constituinte com Anistia (1978) e Esperança e Mudança (1982). Relata Luciano Coutinho:

praticamente todos os domingos ele [Ulysses] reunia na casa dele na Rua Campo Verde um conjunto restrito de assessores, e dele participavam alguns economistas, à época todos do MDB. Estavam o Belluzzo, o João Manuel Cardoso de Mello, o Paulo Renato de Souza, o Serra e eu. Eu era, digamos assim, muito próximo, e muitas vezes o deputado me pedia para escrever uma nota técnica, elucidar uma coisa, ou tinha um projeto qualquer, precisava orientar a bancada, e ele pedia opinião técnica (Entrevista de Luciano Coutinho à autora, 2013).

Dos principais economistas do MDB, Serra foi o único que integrou oficialmente o corpo do CEBRAP. Ele havia conhecido FHC no Chile e estreitado laços com ele em Princeton, tendo sido atraído por Cardoso para a equipe. No Centro, Serra passou a dirigir um grupo para estudar a conjuntura econômica, integrado por alunos da pósgraduação da UNICAMP como Antônio Kandir, Monica Baer, Lídia Goldenstein e Plínio de Arruda Sampaio Jr., costurando mais um laço entre as duas instituições (GIANNOTTT, 2009, p. 61).

A cisão no Opinião que deu origem ao Movimento ocorreu precisamente nesse contexto de grande aproximação dos intelectuais do CEBRAP, da UNICAMP e de outros centros críticos com o partido de oposição. No Opinião também prevalecia a ideia de uma aproximação entre a esquerda e a frente democrática que se formava ao redor do MDB, vista como um passo inicial para qualquer rota progressista de transformação social. Havia divergências, entretanto, quanto aos setores do MDB que deveriam ser apoiados. A AP-PC do B, que tinha crescente poder dentro do Opinião através da influência que exercia sobre o diretor Raimundo Pereira, achava que o segmento do MDB liderado por 
Ulysses Guimarães, do qual Gasparian e o grupo dos intelectuais do CEBRAP e da UNICAMP aproximaram-se, não era aquele que deveria ser prioritariamente apoiado. Esse grupo tinha maior afinidade com o grupo do MDB que ficou conhecido como "autêntico", formado por políticos mais jovens, dispostos a atacar a ditadura de maneira frontal. Aos autênticos é atribuída a ideia de uma candidatura de confronto de Ulysses em 1974, mas eles pretendiam retirar a candidatura ao final e anular os votos, mostrando discordar do sistema eleitoral. Não foi o que fizeram Ulysses e os "moderados", candidatos mais velhos, acostumados a negociar termos com a ditadura. Eles optaram por levar a candidatura até o Colégio Eleitoral, tornando Ulysses, na prática, um candidato efetivo, ainda que sem chance de ganhar (AZEVEDO, 2011, p. 29; KUCINSKI, 2003, pp. 304, 331; CORRÊEA, 2011, pp. 25, 34, 48).

A disputa política e atritos de ordem salarial, somados a embates na definição dos princípios editoriais e outros enfrentamentos na gestão diária da redação, levaram parte dos jornalistas profissionais do Opinião e muitos quadros da AP-PC do B a afastarem-se para criar seu próprio jornal, identificado com o segmento "autêntico" do MDB a ponto de contar com artigos dos políticos dessa linha e com a presença de um deles, Chico Pinto, no conselho editorial. Entre o Opinião e o Movimento procurou-se fazer uma transição pacífica que foi negociada por intelectuais que eram próximos dos dois grupos, entre os quais Cardoso e Chico de Oliveira. "Foram acertados os seguintes pontos: a equipe de redação não atacaria Fernando Gasparian e nem iria à Justiça do Trabalho; Fernando Gasparian daria à equipe acesso aos arquivos d'Opinião e compraria duas cotas do novo jornal, como demonstração de apoio ao projeto" (KUCINSKI, 2003, p. 333). FHC passou a fazer parte do conselho do Opinião e do Movimento e escrevia para os dois jornais. Francisco de Oliveira, por sua vez, diz ter colaborado com ambos intensamente e afirma que "outra pequena dissidência da qual fiz parte tentou formar o jornal Em Tempo, mas não cheguei a me integrar a esse veículo de comunicação. Aí encerrei minha participação na imprensa” (Francisco de Oliveira in: BIAZO, 2014, p. 36).

Em 1977, o Movimento, hegemonizado pelo grupo da AP-PC do B, viveu também uma cisão interna que deu origem ao jornal Em Tempo que passou a abrigar setores da nova esquerda. O jornal era formado essencialmente por gaúchos, paulistas e mineiros, alguns independentes, outros mais próximos do POC ou advindos do grupo Centelha de Minas Gerais. Os membros do novo jornal embasavam suas análises primordialmente nos 
escritos de Leon Trotsky, Antonio Gramsci, Ernest Mandel, Louis Pierre Althusser, Rosa Luxemburgo e Nico Poulantzas (LOPES, 2013, p. 125), grandes influências da nova esquerda, e não aceitavam associar-se nem aos "autênticos" nem aos "moderados" do MDB, pleiteando a formação imediata de um partido socialista. Este deveria ser construído em meio à classe trabalhadora, posto acreditarem que o caminho para o socialismo não passaria pela aliança com as camadas burguesas, aceita pelos nacionalistas e comunistas que abraçaram a Frente Democrática (AZEVEDO, 2011, pp. 140, 154, 274; KUCINSKI, 2003, pp. 424-425).

Chegou-se a cogitar a formação de um partido popular ou socialista que reunisse os setores à esquerda do MDB, como FHC e Almino Affonso, e parte do grupo do Em Tempo. A criação do Partido dos Trabalhadores (PT), articulado a partir das greves de 1978 e fundado oficialmente em fevereiro de 1980, dividiu-os. A esquerda do MDB optou por seguir no agora PMDB enquanto parte significativa dos ativistas do Em Tempo aproximou-se do PT, alguns integrando simplesmente o grupo de intelectuais do partido, outros dando origem à Democracia Socialista (DS), fração trotskista ligada à corrente de Ernest Mandel, que concebia o PT como o início de um partido revolucionário e a democracia socialista como uma transição para o socialismo. Nas palavras de Raul Pont, um dos líderes do grupo do Em Tempo que deu origem à DS, o PT era visto por eles como "a grande oportunidade de a gente ter um partido de massas, um partido de base sindical. Do nosso ponto de vista, pela primeira vez estava se concretizando o sonho da velha POLOP, o sonho do POC, o sonho dos anos 1960" (PONT, 2008, p. 224). O grupo do PC do B e o antigo PCB, por sua vez, rejeitaram a criação do PT, que consideravam uma dissidência que dispersava a fragmentava a luta que vinham conduzindo (AZEVEDO, 2011, pp. 140, 154, 274; KUCINSKI, 2003, pp. 424-425; ANGELO, 2007, pp. 11-12).

Ain da que Chico de Oliveira tenha apenas ensaiado migrar para o Em Tempo, mas seus escritos foram fundamentais para o grupo que articulou o jornal, já que deles extraíam a ideia que a saída não elitista para a crise deveria calcar-se primordialmente na livre organização dos trabalhadores (KUCINSKI, 2003, p. 404). Outros membros do CEBRAP, como Guido Mantega (1949), acabaram efetivamente tornando-se quadros do novo jornal. Mantega explica que "não podia pôr o meu nome, porque eu tinha tido problemas com o SNI. Então eu não assinava, mas era editor de economia". Os problemas com o SNI decorreram de um artigo que foi publicado enquanto participava 
de um seminário em Caracas. Explica: "falei mal da ditadura e saiu no jornal local. Aí eu descobri que você não pode fazer isso. Você pode falar mal dentro [do país]. Não pode falar mal fora" (Entrevista de Guido Mantega à autora, 2015). Ao regressar da Venezuela,

um coronel do SNI me telefonou. A sede era onde hoje é o Ministério da Fazenda. Quem diria que um dia eu comandaria isso aí? [...]. Aí liguei para o Giannotti e para o Fernando Henrique, que estavam no CEBRAP. "O SNI está atrás de mim. O que é que eu faço?". "Em vez de você ir lá, chama na sua casa. Seu pai é empresário, chama na sua casa". Era um belo apartamento na Alameda Itu, nos Jardins, área nobre da capital paulista. Dois coronéis foram lá, em trajes civis. Giuseppe estava presente. Eles levaram cópias de vários artigos que eu tinha escrito e me intimidaram, dizendo que eu era estrangeiro. Eu ainda não tinha me naturalizado, porque achava que, se a coisa apertasse, eu, como cidadão italiano, poderia recorrer à embaixada. A última frase dos arapongas foi [...] "O $\mathrm{O}$ senhor está sob alça de mira, estamos de olho" (Guido Mantega apud CARVALHO, 2012, [online])

Ao dizer “meu pai empresário, né? Então não pegaram pesado" (Entrevista de Guido Mantega à autora, 2015), Mantega revela o que transparece em tantos depoimentos, a redução da pressão experimentada por aqueles que tinham meios e laços. Os militares precisavam do apoio do empresariado e das elites em geral para governar e respeitavam aqueles que tinham parentes no meio militar, aos quais as famílias recorriam para buscar proteção para seus filhos e para os amigos rebeldes de seus filhos ${ }^{426}$. Giuseppe Mantega, seu pai, e o avô paterno eram, diz Guido, “da Sardenha, da terra do Gramsci”. Por parte de mãe, Guido descendia de genoveses, cidade onde também ele nasceu. As duas famílias eram católicas e os avôs materno e paterno eram funcionários públicos. Ele explica que o pai chegou a fazer um curso preparatório para ser professor do secundário, mas quando pensava iniciar a faculdade foi convocado para o serviço militar

porque a Itália começou a sua expansão africana. Aí ele ficou, acho, 11 anos no exército e passou pela Segunda Guerra [...]. Durante a Guerra esteve na Espanha, então aprendeu a falar espanhol. Ele tinha um espírito aventureiro... enfim, queria fazer fortuna, então veio para o Brasil, mas não como imigrante. Ele pagou a passagem. Tinha algum dinheiro, era gerente lá na Itália. Veio para o Brasil e montou uma fábrica de móveis. Então, em dois anos, ele já tinha uma fábrica e foi bem sucedido. A minha mãe, antes de casar, tinha um ateliê de alta costura. Quando casou, evidentemente tornou-se dona de casa, como era costume naquela época (Entrevista de Guido Mantega à autora, 2015).

Guido declara que o pai "estava do lado errado", pois lutou com Mussolini na Itália e com Francisco Franco na Espanha e completa: "Naquela época, quase toda a Itália

\footnotetext{
${ }^{426}$ Enquadram-se neste perfil os casos relatados da proteção oferecida pelo tio de João Manuel Cardoso de Mello e pai de Zélia Cardoso de Mello ao amigos militantes de seus familiares, pelo tio médico-chefe da guarda civil metropolitana e pelo tio advogado criminalista a Persio Arida, o telefonema de Mario Henrique Simonsen que liberou Maria Conceição Tavares etc.
} 
estava com Mussolini. No início, ele era muito popular. Sob certos aspectos, lembra o Getúlio Vargas aqui. Fez reformas sociais na Itália. O povo gostava do Mussolini. O Mussolini veio da esquerda..." (Guido Mantega in: CARVALHO, 2012). Afirma que o pai estava do lado errado também quando quis que ele desse continuidade à fábrica ao invés de trabalhar "com esses sociólogos. 'Esse Fernando Henrique Cardoso, esses caras não têm futuro! Você não tem futuro nenhum! Você não vai ganhar nada.' E de fato não se ganhava quase nada, né?” Mantega havia ingressado no CEBRAP, em 1973, por intermédio de Maria do Carmo Campello de Souza ${ }^{427}$ que foi sua professora no curso de ciências sociais. Ao entrar na pós-graduação, Guido passou a trabalhar em pesquisa do CEBRAP sobre Estado e Nação conduzida por Carlos Estevam Martins e Fernando Henrique (Entrevista de Guido Mantega à autora, 2015).

Além de almejar que o filho trabalhasse na fábrica, Guiuseppe queria que ele tivesse sido engenheiro, mas Guido achava que "não ia me dar muito bem na engenharia, porque era muito árido, muito chato. Química, física, matemática”; “e também só tinha homem de engenharia, uma coisa muito chata". Optou, com outros colegas, pela economia, que julgavam ser uma "profissão que nos dê um salário, um sustento e, ao mesmo tempo, horas livres para fazer o que gostamos, que é alguma coisa em ciências humanas", pois não era um curso em período integral. Mantega ingressou na economia da USP em 1968 e nas ciências sociais em 1969. Da economia diz que "tinha muita matemática, e eu gostava de história econômica, macroeconomia, mas estudava mais as matérias das ciências sociais. Na verdade eu gostava de política, de sociologia...”. Gostava das aulas do Weffort e do Gabriel Cohn, que se tornou seu orientador do seu mestrado que virou doutorado. Ainda que o tema de sua tese fosse a economia política brasileira, o enquadramento era sociológico. Explica que "na FEA não tinha muita condição de fazer o doutorado, que era muito conservadora naquela época, né? Tinha lá os Delfim Boys, muita econometria. Aí eu preferi a área de humanas”, mesmo que a tese fosse de temática econômica (Entrevista de Guido Mantega à autora, 2015).

\footnotetext{
${ }^{427}$ Maria do Carmo Campello de Souza, conhecida como Carmute, era parte dos círculos mais à esquerda das ciências sociais e foi presa de maio a novembro de 1970, sob a alegação de ter fornecido apoio à VPR. Foi orientanda de doutorado de Francisco Weffort e era grande amiga de Eduardo Kugelmas, ambos exilados no Chile. Carmute foi companheira de Bolívar Lamounier, participando com ele da criação do Instituto de Estudos Econômicos, Sociais e Políticos de São Paulo (IDESP) e com seu orientador Weffort da montagem do Centro de Estudos de Cultura Contemporânea (CEDEC).

Ver:

http://www.arquivoestado.sp.gov.br/memoriapolitica/documento.php?ficha=BR_SPAPESP_DEOPSSPOSFICO NSM000932. Consultado em 14/03/2016.
} 
Já a opção pelas ciências sociais decorreu de seu viés militante. Segundo ele:

\begin{abstract}
apesar do meu colégio não ser grande coisa [estudou no Liceu Eduardo Prado e no Colégio Brasil-Europa], ele tinha professores muito bons. Por exemplo, o Carlos Vogt foi meu professor de português. Foi reitor da UNICAMP até recentemente. O João Quartim era professor de filosofia. A gente lia textos de filosofia, de marxismo, já com 15, 16 anos, líamos Huxley, Orwell. Irmãos mais velhos de meus amigos estavam entrando na militância naquela época e nos puxavam. Então era a época do Colégio Objetivo, do Aplicação, eram centros da esquerda. Os professores todos eram militantes. Então, quando eu entrei na faculdade, eu já estava engajado (Entrevista de Guido Mantega à autora, 2015).
\end{abstract}

João Quartim, seu professor de filosofia, fazia parte do que pode ser considerada uma segunda geração do seminário d'O Capital que, segundo um dos membros, Emir Sader, incluía também Weffort, Roberto Schwartz, Ruy Fausto, Paulo Sandroni e Lourdes Sola, que se asilaram no Chile, Marilena Chauí, que foi fazer mestrado na França ao mesmo tempo que Quartim, além de Emília Viotti, Sérgio Ferro, Cláudio Volga, Albertina Costa e Beth Milan (SADER, 2005, p. 172). Na época em que Guido entrou na USP, João Kfouri Quartim Moraes, regressava da pós-graduação na França. Ele era irmão de Maria Lygia Kfouri Quartim Moraes, grande amiga e parceira de escrita e de política de Guido. Os dois eram primos do cientista social e jornalista Juca Kfouri, que também foi um dos mais próximos amigos de Mantega na graduação (CARVALHO, 2012).

No final de 1969, João Quartim deixou a VPR e voltou para a França. Passou a lecionar em 1971 na Université de Vincennes e organizou a revista DEBATE que reuniu, no início dos anos 1970, um grupo de jovens intelectuais exilados para discutir os rumos da revolução brasileira ${ }^{428}$. Maria Lygia Quartim foi para a França mais ou menos na mesma época e fez especialização em sociologia do desenvolvimento no Institut d'Etudes du Développement Économique et Social (IEDES), até 1971. Na sequência foi para o Chile onde fez dois anos de ESCOLATINA e voltou para França para fazer doutorado em Nanterre (CRUZ, 2010, p. 45; PEZZONIA, 2011; ROLLEMBERG, 1999, p. 196)

Nesse período, Mantega declara ter ido "várias vezes para a França. Cheguei a fazer uns cursos em Vincennes, na época em que os estudantes eram mais rebeldes lá [do que] em Paris. E tinha muitos exilados brasileiros lá, amigos, porque eu sou da geração de 68. Nós pegamos o início da ditadura e muitos colegas se envolveram com organizações, então tinha muitos asilados em Paris", entre os quais o círculo militante que girava ao

\footnotetext{
${ }^{428}$ Ver: CV: http://lattes.cnpq.br/4958262500691607. Consultado em 16/03/16.

${ }^{429}$ Ver: http://lattes.cnpq.br/6832023291977489. Consultado em 16/03/16.
} 
redor dos Quartim ${ }^{430}$. Na França, Guido gravitou no circuito do DEBATE e assistiu aulas de Nico Poulantzas. Explica que em seu tempo as ciências sociais eram muito influenciadas pelos autores do estruturalismo francês, "tinha que ler Poulantzas, Althusser, Balibar...” (Entrevista de Guido Mantega à autora, 2015).

Os Kfouri-Quartim haviam sido ativos na VPR por algum tempo. Mantega fora ligado ao Universidade Crítica, braço estudantil que a POC mantinha nas ciências sociais. Como discutido no capítulo anterior, os irmãos Sader, Elisabeth Souza Lobo, Marco Aurélio Garcia e Jorge Mattoso também faziam parte da POC, grupo que se engajou fortemente na redação do Em Tempo. Ao grupo da POC, que se concentrava no Rio Grande do Sul, agregaram-se militantes de Minas Gerais que antes pertenciam ao Movimento. Entre eles estava Maurício Borges Lemos, diretor do BNDES durante todo o período em que o PT esteve no Governo Federal, que nos dois jornais interagira com Mantega e Maria Quartim (Entrevista de Maurício Borges Lemos à autora, 2012). Além de Quartim, Mantega e Sader, faziam parte do segmento paulista do Em Tempo, dentre outros, o jornalista Bernardo Kucinski, em casa de quem se articulou a cisão do Movimento e a criação do novo jornal, e a psicóloga Maria Rita Khel, coautora do livro Sexo e Poder com Guido Mantega e Maria Quartim Moraes. Chico de Oliveira, relata Kuckinski, cujos escritos eram uma das principais fontes de inspiração do grupo, afastou-se assim que constituído o jornal pois acreditava que, assim como o Movimento acabara se tornando um jornal hegemonizado pela facção maoísta ligada à parte da AP que transitou para o PC do B, o Em Tempo tenderia a tornar-se uma agregação trotskista sectária (ANGELO, 2007, pp. 40-41; REIS, 2007, p. 206; KUCINSKI, 2003, pp. 404-406).

Aos poucos, a previsão concretizou-se. O grupo que daria origem, em 1979, à DS acabou controlando o jornal que se tornou expressão dessa tendência. Não havia grande discordância interna quanto ao apoio ao surgimento do Partido dos Trabalhadores. Os

\footnotetext{
${ }^{430}$ Como Mantega, Maria Lygia Quartim Moraes faz notar a importância dos irmãos mais velhos como porta de entrada da militância e explica como se formou a teia de seu núcleo de militância por meio dos laços familiares: "Eduardo é irmão da Miriam Abramovay, que é casada com Samuel Iavelberg que era irmão da Iara Iavelberg. A Iara Iavelberg foi namorada do meu irmão João, militava no mesmo grupo, eu conheci Iara Iavalberg, nós éramos muito amigas... Entende? Então você tem de pensar muito nas relações pessoais. Então tinha a família Abramovay, a família Quartim de Moraes, quer dizer são grupos familiares, não é? Tinha o Luis e tinha a mulher dele, quer dizer tem, é uma "figuraça", a Vera Tude. (...) Pessoal da USP basicamente, das ciências sociais (...), esse pessoal mais jovem, que tinha tido militância estudantil ou intelectual, isso... todo mundo se conhecia. Isso tanto vale pra São Paulo como vale para os cariocas, eram grupos de afinidades. E se não havia afinidade, não se conheciam antes, acabaram se conhecendo depois. Eu conheci muita gente lá por intermédio dos Abramovay, eles conheceram por nosso intermédio, e assim circulava" (Maria Lygia Quartim Moraes apud PEZZONIA, 2011, p. 41).
} 
jornais antecessores, Movimento e Opinião, tendiam a dar suporte ao MDB que julgavam ser a frente legítima de oposição e privilegiavam a construção institucional do país, como etapa na luta revolucionária. O Em Tempo, apesar de algumas divergências internas, tendia fundamentalmente a enfatizar a visão da classe trabalhadora como agente privilegiado da concretização dos ideais socialistas. Não haveria uma etapa de desenvolvimento burguesa conforme previsto no comunismo do antigo PCB, devendo o socialismo ser construído ativa e diretamente, de forma não elitista, no cotidiano de luta dos trabalhadores (KUCINSKI, 2003, p. 350; ANGELO, 2007, pp. 9, 39-40).

A eclosão das greves do setor metalúrgico na região de Santo André, São Bernardo e São Caetano (ABC paulista), que começou com a paralisação da fábrica da Scania em maio de 1978 e desdobrou-se em sucessivas greves e na perseguição e prisão de lideranças sindicais, inflamava a cisão das duas perspectivas. De um lado a luta junto ao MDB, ressaltando as instituições políticas oficiais e os sindicatos clássicos; do outro a promessa de um socialismo construído por movimentos espontâneos de trabalhadores, vistos como força revolucionária autêntica que deveria permanecer autônoma à tutela tradicionalmente praticada pela esquerda comunista. O crescimento das lutas dos trabalhadores no ABC era objeto de grande interesse de segmentos das novas esquerdas que procuraram estudar e aproximar-se desses movimentos (PERRUSO, 2008, p. 110).

A cisão dos jornais tinha expressões homólogas em outras áreas do espaço dos intelectuais. A divisão do CEBRAP, da qual resultou o CEDEC, um novo núcleo de pesquisa apartado da universidade, expressa um alinhamento de forças bastante semelhante. Como no caso da transição do Opinião para o Movimento, houve um apoio formal do CEBRAP ao CEDEC, que passou a contar em seu conselho consultivo com diversos nomes advindos do CEBRAP, como Candido Procópio Ferreira de Camargo, Fernando Henrique Cardoso e Juarez Brandão Lopes. Além deles, integravam o conselho os professores Antônio Candido de Mello e Souza, Azis Simão, Florestan Fernandes e Ruy Galvão de Andrada Coelho da FFCL, Faculdade da qual provinham quase todos os membros do novo Centro, e Paulo Freire, figura de destaque da intelectualidade crítica e sogro de Francisco Weffort (ARAÚJO, 2012, p. 86). Ademais, o CEDEC recebeu, como 
o CEBRAP, apoio da Fundação Ford, o que permitiu que se estruturasse com rapidez ${ }^{431}$ (BROOKE e WITOSHYNSKY, 2002, p. 50).

O CEDEC foi liderado, inicialmente, por Weffort, que coordenava no CEBRAP muitos dos estudos sobre movimentos sociais e era conhecido por seus trabalhos críticos às estruturas do populismo político. Weffort atraiu para o novo centro diversos orientandos, entre os quais Maria Victoria Benevides, José Álvaro Moisés e Regis Stephan de Castro Andrade. Francisco de Oliveira era um inspirador e colaborador do CEDEC. Marilena Chauí, da filosofia, Walter Barelli, Adhemar Kyotoshi Sato e Paulo Sandroni, da economia, Fábio Konder Comparato, do direito, e Vinicius Caldeira Brant, da sociologia, atuaram como consultores em projetos e escreveram relatórios e artigos com os coordenadores das pesquisas. Para os estudos sobre o mundo sindical, José Álvaro Moisés associou-se com Roque Aparecido da Silva, sociólogo formado no exílio na Suécia e na França, que fora na juventude operário e líder sindical ${ }^{432}$. Também atuaram no CEDEC Marco Aurélio Garcia, antiga liderança do POC, exilado no Chile, pesquisador do Centro de Estudios Sociales (CESO) da UC, professor da UNICAMP e membro do Em Tempo, e Jorge Mattoso, militante do POC, aluno da ESCOLATINA, próximo ao CESO e pós-graduando da UNICAMP, além do próprio Theotônio dos Santos, um dos nomes de maior projeção do CESO.

Em 1981, Lúcio Kowarick, que havia tido experiência na SAGMACS, trabalhado no plano urbano do governo Carvalho Pinto e sido aluno de Henri Lefebvre na França, passou a liderar no CEDEC muitos estudos na área temática Movimentos Sociais Urbanos e Movimentos Sindicais e Trabalho Urbano, incorporando a literatura marxista da sociologia urbana. Das pesquisas por ele coordenadas participaram o sociólogo Eder Sader, o economista Paulo Sandroni e um grupo de jovens arquitetos e urbanistas, dentre os quais Nabil Bonduki, Raquel Rolnik e Clara Levin Ant. Francisco de Oliveira, que havia sido levado por Juarez Lopes Brandão para lecionar alguns cursos na Faculdade de Arquitetura e Urbanismo (FAU) da USP, estabeleceu pontes com as urbanistas Ermínia Maricato e Clara Ant e os arquitetos Sérgio Ferro e Rodrigo Lefebvre, com quem teceu vínculo por meio de Gabriel Bolaffi, que conheceu no exílio no México, que havia sido

\footnotetext{
${ }^{431}$ Além do CEDEC, o CEBRAP daria origem, em 1981, a um terceiro centro de pesquisa, liderado por Bolívar Lamounier, o Instituto de Estudos Econômicos, Sociais e Políticos de São Paulo (IDESP), também financiado pela Fundação Ford, que tinha o objetivo de fazer pesquisas na área de instituições políticas e do Judiciário, que Bolívar considerava não serem suficientemente prioritárias dentro do CEBRAP (LAMOUNIER, 2013, p. 29).

${ }^{432}$ Ver: http://www.webdiario.com.br/?din=view_noticias\&id=23534\&search=. Consultado em 16/03/16.
} 
assistente de Florestan Fernandes, feito parte do seminário d'O Capital e era professor da FAU e amigo próximo de Michel Löwy e Roberto Schwarz (LÖWY, 1996, p. 2; OLIVEIRA, 2009, pp. 168, 174; KOWARICK, 2009, p. 130).

Os projetos de pesquisa conduzidos pelo CEDEC de 1977 a 1985 tematizam sobretudo movimentos sindicais e condições do operariado, movimentos sociais no campo; e cidadania e violência em contextos de transformação urbana.

Argumenta-se que o CEDEC procurava um enfoque menos economicista do que o do CEBRAP, que estaria muito ocupado com temas como dependência, concentração de renda, planejamento e demografia. Ali não se trataria apenas de estudar o trabalhador, sua relação com a cidade, o movimento social e o sindicalismo, mas também de interagir com os sujeitos dos processos estudados, para conhecê-los e com eles construir a política. Os intelectuais do CEDEC pretendiam fazer dos grupos que estudavam seus interlocutores, organizando seminários com os militantes, levando os debates às periferias, sindicatos, fábricas e outros pontos de agregação trabalhadora e popular (SORJ, 2001, p. 46; LAHUERTA, 2001, p. 84; PERRUSO, 2008, pp. 48, 88, 105, 118).

Os temas privilegiados pelo CEDEC guardam afinidade com o enfoque prevalecente na revista Em Tempo. Os dois procuravam distanciar-se tanto do MDB quanto do PCB e PC do B, tidos por eles como núcleos da antiga política, envolta em populismo nacionalista e coorporativista que tutelava e coagia os trabalhadores, tomados como massas a serem conduzidas pelas elites dirigentes. Do ponto de vista do socialismo que inspirava grande parte dos membros do CEDEC e do Em Tempo, a velha política populista, mesmo quando à esquerda, era incapaz de incorporar a perspectiva de autonomia do novo sindicalismo e dos novos movimentos sociais por estar presa à perspectiva que subordinava a representação popular a parcelas esclarecidas das classes dominantes (PERRUSO, 2008, pp. 59, 110).

O contexto político no qual se insere a aproximação do CEDEC e do Em Tempo com o universo dos trabalhadores é o da eclosão das lutas sindicais no $\mathrm{ABC}$ que resultaria na consagração de Luiz Inácio Lula da Silva como liderança política e na formação do PT. Do CEDEC e do Em Tempo veio a maior parte dos reconhecidos intelectuais que se engajaram na criação do partido ${ }^{433}$. Dos 16 intelectuais elencados ${ }^{434}$ como os de maior

\footnotetext{
${ }^{433} \mathrm{O}$ Em Tempo acabou sendo monopolizado pela DS que acreditava que o "PT deveria ser um partido político estratégico, dirigente das lutas dos trabalhadores, revolucionário e socialista - e não uma frente popular aberta à
} 
influência na criação do PT, quase todos tinham participação em uma ou nas duas instituições mencionadas, todos eram professores da área de ciências humanas e quase todos eram vinculados à USP. São eles: Marilena Chauí, Dalmo Dallari, José Álvaro Moisés, Paul Singer, Francisco Corrêa Weffort, Marco Aurélio Garcia, Florestan Fernandes, Fábio Konder Comparato, Eduardo Suplicy, Francisco de Oliveira, Antônio Cândido, Maria Victória Benevides, Paulo Sandroni, Ermínia Maricato, Guido Mantega e Eder Sader (ALMEIDA, 1992, p. 40).

Entre os intelectuais ligados ao CEDEC e ao Em Tempo, Weffort tornou-se secretário-geral nacional do PT. Marco Aurélio Garcia chegou a ser assessor internacional da presidência e vice-presidente do partido. José Álvaro Moisés foi secretário de formação política e parte da direção paulista do PT. Jorge Mattoso participou da coordenação econômica dos programas eleitorais de Lula e foi nomeado presidente da Caixa Econômica Federal. Maurício Borges Lemos foi secretário de planejamento de Belo Horizonte por dez anos e diretor do BNDES de 2003 a 2016. Clara Ant foi deputada e depois assessora especial da Presidência da República de 2003 a 2010. Raul Pont foi deputado federal e prefeito de Porto Alegre. Marilena Chauí foi secretária de cultura da Prefeitura de São Paulo de Luiza Erundina, entre 1989 a 1992. O grupo de arquitetos que circulava ao redor de Kowarick e de Chico de Oliveira daria origem ao urbanismo petista: Ermínina Maricato foi secretária de habitação de Erundina e Nabil Bonduki e Raquel Rolnik trabalharam em sua equipe.

Dos economistas, Paulo Sandroni tornou-se chefe de gabinete de Erundina e depois presidente da Companhia Metropolitana de Transportes Coletivos. Guido Mantega, que chegaria a ser Ministro do Planejamento, depois presidente do BNDES e, por fim, Ministro da Fazenda durante as presidências do PT, começou sua vida de economista do partido quando foi convidado por Paul Singer, que ele conhecia do CEBRAP, para ser diretor de orçamento da Secretaria de Planejamento da gestão Erundina. Ao fim da gestão, Lula convidou-o "para ser assessor econômico no que hoje é o Instituto de Cidadania, que era o Shadow Cabinet. Quando ele perdeu a eleição para o Collor, ele montou um governo paralelo. Montou lá os ministérios, o que cada um tinha que acompanhar" (Entrevista de Guido Mantega à autora, 2015). A área econômica do integrando-se quase todos ao PT (ANGELO, 2007, p. 9).

${ }^{434}$ A lista foi feita por Maria Hermínia Tavares de Almeida (1992) e submetida ao crivo de militantes do PT que definiram a relação final dos intelectuais mais influentes. 
Shadow Cabinet do PT era coordenada por Walter Barelli. Adhemar Kiotoshi Sato ficou encarregado da Reforma Administrativa e Francisco de Oliveira do grupo de Desenvolvimento Regional. Estes primeiros economistas do PT eram todos professores da PUC-SP no início dos anos 1980.

O Departamento de Economia da PUC-SP descende da Faculdade de Estudos Econômicos, fundada em 1948 no Liceu Coração de Jesus dos padres salesianos. Ela oferecia cursos noturnos voltados à capacitação de profissionais para o setor privado e ministrados por professores que mantinham diversas atividades paralelas às acadêmicas. Em 1964, a Faculdade foi incorporada pela PUC-SP, assumindo, em 1968, o nome de Faculdade de Economia e Administração (FEA-PUC). Nos anos 1960, a única diferença substantiva na grade curricular da FEA-PUC, quando comparada com a FEA-USP, era a presença dos cursos de filosofia moral, lecionados a todos os alunos da Universidade Católica (GAROFÁLO e RIZZIERI, 2007, p. 179).

Paulo Henrique Ribeiro Sandroni começou a lecionar logo após a incorporação da Faculdade de Estudos Econômicos à PUC-SP, ingressando no corpo docente em 1966 e permanecendo até o final de 1968. Na época em que ali lecionou, além de participar da segunda geração do seminário d'O Capital, mantinha com seus alunos grupo análogo que se reunia clandestinamente aos sábados na Livraria Sal (Sociedade Amigos do Livro), frequentada pela jovem intelectualidade católica paulistana, que havia sido comprada por Jorge da Cunha Lima e Sonia Bracher ${ }^{435}$. Um infiltrado delatou as reuniões como atividades subversivas e Sandroni foi demitido em dezembro de 1968. Ficou na clandestinidade algum tempo e depois partiu para o exílio no Chile e na Colômbia. Ao regressar, voltou a lecionar na PUC e passou a fazer parte do corpo docente da EAESP. Sandroni foi diretor do Departamento de Economia da PUC de 1983 a 1985, logo após o período em que Singer dirigiu a escola (LIMA, 2011; KUSHNIR, 2004, p. 248; BORGES

\footnotetext{
${ }^{435}$ A livraria já era uma espaço de reunião de militantes católicos antes de ser comprada por Cunha Lima e Bracher. Lima relata que "éramos jovens e frequentávamos a Livraria Sal, no fim da tarde. Vendia livros franceses e ficava num andar do Edifício Esther, na Praça da República. Dr. Hugo Ribeiro de Almeida, o dono, era um médico famoso, católico e gostava de literatura. A livraria era frequentada por intelectuais, Carlos Pinto Alves, às vêzes Dr. Alceu de Amoroso Lima, Murillo Mendes, quando vinha a São Paulo, Candido Mendes de Almeida, Franco Montoro, Paulo Cotrim, o dono do João Sebastião Bar, Clovis Garcia, e um grupo de estudantes da JEC e da JUC. Lembro-me de Fernão Bracher, Luiz Carlos Bresser Pereira, Plinio de Arruda Sampaio, Roberto Sampaio, José Ozorio Azevedo, Soninha Sawaya, Luiz D Eça, Joaquim Guedes e Zeca Ribeiro de Almeida".

Ver: http://jorgedacunhalima.ig.com.br/index.php/2009/12/21/hotel-cadoro/. Consultado em 18/03/2016.
} 
et al., 1998, pp. 52-53; MARCOVICH, 1984, p. 346; CANABRAVA, 1984a, p. 300; KUSHNIR, 2004, pp. 235, 240, 264).

Na gestão de Paul, a escola passou por uma reforma que ficou conhecida como "Reforma Singer". O currículo passou a priorizar fortemente a área de humanidades e foram incluídos Marx e outros autores que haviam sido proibidos durante os períodos de intensa repressão militar. Singer organizou as primeiras seleções de professores para o departamento e relata que "no primeiro concurso, lá por 1979 ou 80, entraram o Chico de Oliveira, o Barelli e o Plínio de Arruda Sampaio. [...]. Nos anos seguintes, entraram por concurso o Paulo Sandroni, o Ladislau Doborow, o Ricardo Abramovay, Guido Mantega, Álvaro Zini, a Lídia Goldenstein, o Antônio Kandir, o José Marcio Rego” (SINGER, 1999, p. 66), Adhemar Sato, Aloísio Mercadante, Jorge Mattoso, muitos dos quais fundadores do PT, além de um grupo de professores mais jovens, entre os quais Antônio Kandir, José Francisco de Lima Gonçalves e Luís Eduardo Alves de Assis, formados pela USP e pela UNICAMP, que participariam da equipe econômica da ministra Zélia Cardoso de Mello no início dos anos 1990 (BORGES et al., 1998, pp. 53, 66, 69, 83-84).

Ainda que tenha havido, entre 1974 e 1978, um conjunto de cisões no espectro da oposição, com a criação de diversos jornais, a divisão dos centros de pesquisa e a dispersão dos economistas de oposição em diversas escolas - que já refletem uma disputa acerca das estratégias a adotar uma vez que o poder político voltasse a estar ao alcance dos civis -, até 1978 as diversas correntes da esquerda tinham um objetivo comum e prioritário, a redemocratização. As sucessivas vitórias do MDB, de 1974 em diante, mostravam a força do pleito pela democracia e o grau de desgaste do regime. Em 1978, começou a ser planejada uma reforma eleitoral que restaurasse o sistema pluripartidário. Em agosto de 1979, foi aprovada a lei da anistia que permitiu o retorno dos exilados. A reforma partidária foi sancionada em novembro, dissolvendo os antigos partidos e obrigando os novos a incluir a palavra "partido" em seus nomes (KINZO, 1988, pp. 206207).

Embora legalmente dissolvidos, nem a ARENA nem o MDB desapareceram de fato após a reforma partidária. Ansiosa por se ver livre de sua sigla impopular, a ARENA mudou seu nome para Partido Democrático Social - PDS. Inversamente, a imagem popular de MDB, a "sigla mágica", determinava o simples acréscimo da palavra partido ao nome original, como exigia a nova lei. Surgiu, assim, o Partido do Movimento Democrático Brasileiro - PMDB. O leque partidário rapidamente se ampliou com a criação de quatro outros partidos políticos em 1980: o Partido Popular (PP), fundado por dissidentes da ARENA e moderados do MDB, sob a liderança de Magalhães Pinto e Tancredo Neves, para 
representar as forças liberal-conservadoras; o Partido dos Trabalhadores (PT), criado por sindicalistas sob a liderança de Luiz Inácio da Silva (Lula) que, juntamente com alguns setores da esquerda, pretendia organizar um autêntico partido de classe trabalhadora. A tentativa de seguidores do antigo PTB de ressuscitar seu partido resultou em um racha dos trabalhistas e na criação do Partido Democrático Trabalhista (PDT), liderado por Leonel Brizola, e do Partido Trabalhista Brasileiro (PTB), montado por Ivete Vargas, que conseguiu herdar a velha sigla do PTB após longa disputa com o grupo de Brizola (KINZO, 1988, p. 209).

Do ponto de vista da oposição, a abertura partidária criava uma contradição pois o pluripartidarismo, ao mesmo tempo que atendia um pleito de longa data dos que desejavam maior representatividade, poderia provocar cisões e enfraquecer a articulação contrária a ditadura. A fragmentação concretizou-se em parte. De fato já havia articulações para a criação de novos partidos e, desde o momento em que se começou a vislumbrar a possibilidade de abertura, eclodiram conflitos entre aqueles que achavam que era preciso formar uma frente e aqueles que queriam seguir com suas próprias lideranças e pautas. Não obstante, houve um período no qual os vários grupos em gênese colaboravam em prol da redemocratização, como visível na campanha pelas eleições diretas de 1983-1984, conhecida como "Diretas Já”. Algumas candidaturas também teriam um efeito de agregação de variados grupos insatisfeitos com o regime militar. No Estado de São Paulo, a intelectualidade crítica agregou-se majoritariamente ao redor dos candidatos do MDB, André Franco Montoro e Fernando Henrique Cardoso, este último conseguindo apoio inclusive do novo sindicalismo e dos pensadores do futuro PT (KINZO, 1988, p. 207).

\subsection{O MDB no governo do Estado de São Paulo: André Franco Montoro Filho,} Andrea Calabi e João Sayad

A relação do CEBRAP e dos economistas da oposição com a política partidária, que começou em 1973/1974 como uma ajuda para a elaboração dos programas do MDB, rapidamente transfigurou-se na candidatura de Fernando Henrique ao Senado, lançada em 1978. A despeito dos protestos de amigos que diziam estar subscrevendo um sistema corrompido, para FHC, “a ideia era mobilizar um grupo de pessoas que não estavam vinculadas à vida partidária para ajudar na luta contra o regime pela via democrática e aumentar a votação do MDB”. Ele declara que inclusive achava que sua candidatura seria 
impugnada por ter sido cassado pelo AI-5 e que estava certo que Montoro venceria a eleição, razões pelas quais não se considerava um verdadeiro candidato (CARDOSO, 2009, pp. 41-42).

André Franco Montoro (1916-1999) nasceu na cidade de São Paulo, filho de André de Blois Montoro, italiano de Cosenza, na Calábria, e de Tomásia Alijostes Montoro, nascida em San Sebastian, em terras bascas. Os dois chegaram ao Brasil no início da infância, carregados pelos pais que para cá mudaram em busca de melhores condições econômicas. André de Blois tornou-se gráfico e participou intensamente das atividades sindicais de sua categoria. André Franco, por sua vez, estudou na escola pública Caetano de Campos, depois transferiu-se para o Colégio São Bento, como já se viu, instituição escolar cristã de grande prestígio e núcleo de concentração dos jovens que se integrariam à Ação Católica e dariam origem à JEC e à JUC. Em 1934, Montoro ingressou na Faculdade de Direito da USP, onde foi colega de Ulysses Guimaraes, Jânio Quadros e Roberto Abreu Sodré. Ao mesmo tempo, estudou filosofia e pedagogia na Faculdade São Bento, na qual estudou também sua esposa Lucy. Nascida em Jundiaí e filha de advogado e dono de cartório, Lucy ingressou nos cursos de filosofia e serviço social após concluir os estudos no Caetano de Campos. Casaram-se pouco depois de formados (Entrevista de André Franco Montoro Filho à autora, 2014; Eduardo Mullayert in: ALBUQUERQUE, 2008, pp. 38-40; DHBB, verbete André Franco Montoro; LIMA, 2009).

Ainda na graduação, Montoro ensinou lógica, psicologia, filosofia e história da filosofia no Colégio São Bento. Após graduar-se lecionou na Faculdade São Bento-PUC e, depois de lá obter o doutorado, tornou-se catedrático da Faculdade de Economia da USP na área de Instituições do Direito Privado, de 1947 até 1970, quando transferiu-se para a Faculdade de Direito. Entre 1968 e 1970 lecionou direito também na UNB (CANABRAVA, 1984a, p. 89; Eduardo Mullayert in: ALBUQUERQUE, 2008; DHBB, verbete André Franco Montoro). Tão logo formado, Montoro tornou-se secretário-geral do Departamento de Serviço Social da Secretaria da Justiça de Adhemar de Barros e ingressou na carreira de procurador do Estado. Exerceu atividades políticas junto aos católicos desde o colégio, sendo muito influenciado pelo Padre Lebret, por Jacques Maritain e pelos humanistas cristãos franceses em geral, a mesma corrente teológica que 
influenciaria a JEC e a JUC (item 3.1). Plínio de Arruda Sampaio, que foi uma das lideranças da JUC paulista, conta que teve

contato com ele [André Franco Montoro] ainda muito jovem. Ele era uma espécie de figura referencial da nossa geração no plano político. E ele agregava. As reuniões eram na casa dele, ele tinha uma disponibilidade enorme, e com muitos filhos, a casa vivia cheia de jovens, para discutir questões teóricas. Qualquer coisa que acontecia, a referência era na casa do Montoro. E as pessoas de minha geração que criticavam o Montoro, [...] que o achavam muito conservador. Essas pessoas foram trabalhar com ele no governo (Plínio de Arruda Sampaio in: ALBUQUERQUE, 2008, p. 188).

Jorge Cunha Lima dá depoimento semelhante quando diz que seu

grupo se aproximou de Montoro quando fundamos a JEC (Juventude Estudantil
Católica) no Colégio São Bento, onde, aliás, Montoro havia estudado. Amigo e
colega de filosofia do reitor do São Bento, que era D. Cândido Padin, Montoro
foi logo trazido a nos falar sobre a Ação Católica, que ele havia fundado no
Brasil, e sobre a Democracia Cristã, movimento político já bastante implantado
na Europa do pós-guerra, sobretudo na Itália, França e Alemanha, onde
Schumann, De Gasperi e Adenauer lideravam a reconstrução da Europa, com
um projeto social democrático de inspiração cristã. Na América do Sul, o
movimento se consolidou numa famosa reunião no Uruguai, à qual compareceu
Montoro, convidado por Tristão de Ataíde, que logo lhe passou o cetro do
Partido Democrata Cristão, pois dizia não ter pendores para a militância política
profissional. Nos primeiros contatos conosco, Montoro falava mais da Ação
Católica, pois era presidente da LUC (Liga Universitária Católica), que reunia
profissionais liberais, depois de ter sido fundador da JUC (Juventude
Universitária Católica), que cuidava do setor universitário. Ele sempre convidava
os grupos para irem a sua casa, mais usada do que a Igreja para suas pregações.
Gostava de confundir o espaço da família com o espaço da sociedade. E fez isso
a vida inteira. Sua casa foi durante sessenta anos um comitê político (LIMA,
2009, pp. 9-10).

No final dos anos 1940, o grupo de jovens militantes católicos do qual Montoro, Queiroz Filho, Plínio de Arruda Sampaio e outros faziam parte decidiu integrar-se ao Partido Democrata Cristão (PDC), criado em 1945. Buscavam uma terceira via entre o comunismo e o capitalismo, adotando um linha política muito próxima à dos democratas cristãos chilenos do Presidente Eduardo Frei Montalva. Em 1950, Montoro exerceu seu primeiro cargo, vereador da cidade de São Paulo. Na sequência foi eleito deputado estadual e deputado federal. De 1961 a 1962 foi Ministro do Trabalho do governo de João Goulart, época na qual seu partido começou a fragmentar-se. Paulo de Tarso e Plínio de Arruda Sampaio posicionam-se favoravelmente às reformas propostas pelo Presidente Goulart e aproximam-se da esquerda estudantil e do próprio Jango; Montoro não. Aqueles que se posicionaram à esquerda tiveram que deixar o país, Montoro aderiu ao MDB e de deputado federal passou a senador em 1970 (Darcy Passos in: 
ALBUQUERQUE, 2008, pp. 217-218; LIMA, 2009; Roberto Saturnino Braga in: ALBUQUERQUE, 2008, pp. 218).

Em 1978, candidata-se à reeleição ao lado de FHC que disputava também o Senado pelo MDB a convite de Ulysses Guimarães. Conforme comentado, FHC não seria o eleito, mas contava-se com ele para angariar votos das classes médias urbanas, atraindo jovens intelectuais e artistas para a campanha (CARDOSO, 2006b, pp. 128-129; CARDOSO, 2006c, p. 83; MELHEM, 1998, p. 203). Surpresa foi a adesão do novo sindicalismo a sua candidatura. Francisco de Oliveira transmitiu a FHC mensagem indicando o apoio dos sindicatos do ABC. Fernando Henrique havia conhecido o principal líder do novo sindicalismo, Luiz Inácio Lula da Silva, em 1973, no CEBRAP, através de Francisco Weffort e Regis de Castro Andrade.

Lula (1945) é nordestino de Garanhuns, em Pernambuco. Descendente de lavradores pobres, de família numerosa, deslocou-se para São Paulo em busca de melhores condições de vida. Estudou formalmente até a quinta série, trabalhou como ambulante e engraxate enquanto cursava o primário e depois especializou-se torneiro mecânico no Serviço Nacional de Aprendizagem Industrial (SENAI). Trabalhando na Metalúrgica Villares aproximou-se do sindicato de São Bernardo do Campo e Diadema por influência de seu irmão José Ferreira Mello, o "Frei Chico", ligado ao PCB e ao Sindicato de São Caetano. Diferentemente do irmão, Lula nunca se aliou aos comunistas, sendo mais próximo dos segmentos da igreja católica que rodeavam o proletariado. Frei Chico, impedido de disputar a direção do sindicato em 1969, indicou o irmão para a posição de suplente. Na eleição seguinte, em 1972, Lula conquistou o secretariado do sindicato e assumiu o departamento jurídico e o setor de previdência. Nas eleições de 1975 conquistou a presidência do sindicato, sendo reeleito em $1978^{436}$ (DHBB, verbete Luiz Inácio Lula da Silva; PINTO, 2011, pp. 52, 88-91).

Em 1975, quando o irmão Frei Chico foi preso e torturado, a ditadura tornou-se alvo da política de Lula, que até então ocupava-se exclusivamente do universo dos trabalhadores. Segundo ele: "eu não era um cara altamente politizado, eu era um sindicalista, a única coisa que eu queria era melhoria das condições de vida dos trabalhadores". "A gente fazia greve para melhorar a qualidade de vida da gente. Depois, quando as pessoas vão ficando sofisticadas, as pessoas podem dizer que fazia greve por

\footnotetext{
${ }^{436}$ Ver: http://www.institutolula.org/lula. Consultado em 22/03/2016.
} 
outra coisa. Mas o dado concreto é que a única coisa que motivava a gente a fazer greve é que a gente queria melhorar de vida. A gente queria aumento de salário, a gente queria constituir comissão de fábrica nas empresas”. Em 1978, 1979 e 1980 houve grandes greves no ABC, sendo Lula preso em abril de 1980, o que, argumenta, foi uma burrice dos militares, pois só aumentou a efervescência do movimento que atraía cada vez mais atenção dos grupos de oposição. Políticos, intelectuais e estudantes passam a circular no universo sindical, ampliando a convergência da luta pela democracia437 (SILVA, 2014, [online]).

Fernando Henrique narra o encontro com Lula em 1978, dizendo que ele ofereceu-lhe o apoio do sindicato pois agradava-lhe que FHC não se apresentasse como um candidato dos trabalhadores e não pretendesse falar por eles, como Montoro fazia. Era uma recusa à tutela e, ao mesmo tempo, uma busca pelo próprio espaço na política em uma época na qual já cogitavam articular um partido próprio. Em 1978, Lula e Cardoso fizeram campanha lado a lado, discursaram, entregaram panfletos nas periferias, e beberam uns tantos cafés e cachaças juntos. Como esperado, Cardoso não foi eleito. Sua campanha foi, não obstante, suficientemente vitoriosa para fazer dele o suplente de Franco Montoro no Senado (CARDOSO, 2006b, pp. 136-137; MELHEM, 1998, pp. 203205). Em 1982, as eleições para governador que haviam sido suspensas em 1965 pelo Ato Institucional No 2 voltaram a ser realizadas. Desta vez, Lula era o próprio candidato, concorrendo pelo PT, e o grupo que orbitava ao redor de Fernando Henrique passou a apoiar a candidatura de Franco Montoro para o governo do Estado.

Eleito Montoro, Fernando Henrique assumiu o Senado e muitos de seus apoiadores conquistaram postos de destaque na administração estadual. Havia quatro grupos dominantes no secretariado de Montoro ${ }^{438}$.

1) os políticos filiados ao MDB, dentre os quais Almir Pazzianotto Pinto, nomeado secretário de relações do trabalho que se tornaria Ministro do Trabalho em 1985. João Pacheco e Chaves, muito próximo de Ulysses Guimarães, que foi o primeiro secretário de cultura. Mario Covas, apontado para a Secretaria de Transportes, que na sequência seria prefeito, senador e governador por São Paulo. E Almino Affonso, o exMinistro do Trabalho de João Goulart que regressara do exílio.

\footnotetext{
${ }^{437}$ Ver: http://www.institutolula.org/lula. Consultado em 22/03/2016.

${ }^{438}$ Ver: http://www.al.sp.gov.br/repositorio/legislacao/decreto/1983/decreto-20884-29.03.1983.html. Consultado em 23/03/2016 e ALBUQUERQUE, 2008.
} 
2) os católicos ligados ao PDC, à JEC e à JUC, de onde vieram Paulo de Tarso Santos que foi o primeiro secretário da educação. O secretário da informação e comunicações e depois secretário da cultura, Jorge Cunha Lima. Chopin Tavares de Lima que era secretário do interior. Gilda Portugal Gouvêa que trabalhou na Secretaria de Educação e depois foi chefe de gabinete da Casa Civil, além de cuidar das contas residenciais da família Montoro. Luiz Carlos Bresser Pereira foi nomeado presidente do BANESPA, secundado por Fernando Milliet, e depois chefe de governo.

3) um pouco mais jovens eram os militantes do grupo da AP que girava ao redor de José Serra e os militantes com os quais ele teve contato no exílio. O próprio Serra foi nomeado secretário de planejamento. Gilberto Dupas foi diretor do BANESPA, secretário de agricultura e abastecimento e presidente da Caixa Econômica. José Carlos Seixas foi secretário da habitação. Ulrich Hoffmann trabalhou na direção da Companhia de Entrepostos e Armazéns Gerais de São Paulo (CEAGESP), da Companhia de Saneamento Básico do Estado de São Paulo (SABESP) e da Coque e álcool da madeira S/A (COALBRA). Paulo Renato Costa Souza assumiu a secretaria de educação em abril de 1984, quando Paulo de Tarso deixou o posto para trabalhar no Tribunal de Contas do Estado. Sérgio Motta, que se tornara coordenador das campanhas políticas de FHC, foi apontado para a vice-presidência da Eletropaulo. Carlos Estevam Martins foi assessor especial de Montoro. Clóvis Carvalho foi primeiro diretor da SABESP, depois secretárioadjunto de Serra e finalmente tornou-se o secretário de planejamento quando Serra deixou o governo para concorrer ao posto de Deputado Constituinte.

4) a Secretaria da Fazenda de Montoro foi ocupada por João Sayad e sua equipe formada por Marcos Giannetti da Fonseca, Andrea Sandro Calabi, Philippe Reichstul e Francisco Vidal Luna, todos colegas de André Franco Montoro Filho na Faculdade de Economia Administração e Contabilidade da USP. Montoro Filho explica que o Sayad fora uma indicação direta sua: "eu que levei”. Ele conta também que, junto com seu colega Marcos Giannetti da Fonseca, elaborou o programa Montoro e organizou "uma série de grupos de estudo, a respeito de diversos problemas. Como eu era professor universitário e tinha muito contato eu trouxe muita gente, os grupos foram se firmando e grande parte do secretariado saiu daí" (Entrevista de André Franco Montoro Filho à autora 2014). 
André Franco Montoro Filho (1944) nasceu em São Paulo e foi criado em meio ao catolicismo e à política da residência dos Montoro na rua Conselheiro Zacarias, nos Jardins. Estudou nos colégios católicos Nossa Senhora das Graças e Santa Cruz. Escolas que aos poucos estavam substituindo os tradicionais São Luís e São Bento como destinos educacionais preferenciais da elite católica - e com o passar do tempo, também de elites não católicas ${ }^{439}$. A família Montoro guarda estreitas relações com o Colégio Santa Cruz ${ }^{440}$. Fundado por padres canadenses, o Santa Cruz oferecia em sua grade francês e inglês, além de latim. Complementarmente, André Franco Montoro Filho tinha aulas de francês em casa e chegou a frequentar escolas particulares de inglês, mas diz ter apreendido realmente o idioma ao morar nos EUA durante o doutorado. O espanhol explica ter aprendido na vida (Entrevista de André Franco Montoro Filho à autora 2014).

Ao terminar o colégio escolheu cursar economia porque "gostava de português, história e gostava de matemática [...]. Achei então que economia era uma ciência social com matemática". Diz ter vislumbrado isso ao conversar com o pai de um amigo de Clube Paulistano que era professor de contabilidade da Faculdade de Economia. Relata ter se interessado, na graduação, pela combinação de métodos quantitativos, matemática e estatística e macroeconomia, destacando as áreas de finanças públicas e moeda e diz que os professores que mais influência tiveram sobre ele foram Delfim Netto e Affonso Pastore, "porque eram bons professores, brilhantes". Ainda que tivesse sido influenciado por eles não chegou a integrar o grupo de Delfim e, ao contrário da maioria dos Delfim Boys, não fez a sua formação completa na USP (Entrevista de André Franco Montoro Filho à autora 2014).

Ao concluir a graduação partiu para o Rio de Janeiro para fazer mestrado na Escola de Pós-Graduação em Economia (EPGE) da FGV-RJ. Explica, “achei que o que eu aprendi na escola [USP] era pouco. Eu recebi boas informações do mestrado, do curso

\footnotetext{
${ }^{439}$ Fundado em 1952, o Colégio Santa Cruz funcionou em uma casa emprestada em Higienópolis até 1957, quando transferiu-se para a sede construída no, então distante, Alto de Pinheiros, em terreno doado aos padres canadenses pela também canadense Light and Power. Situado na margem oposta da Universidade de São Paulo, quase na mesma altura, passou-se a dizer que ao terminar a escola os alunos atravessavam a ponte, em expressão do caminho natural de seus alunos à instituição de ensino superior prestígio.

${ }^{440}$ Ver: http://www.exsanta.com.br/site/?p=386. Consultado em 23/03/2016. "Há dez anos falecia Franco Montoro, ilustre ex-aluno e membro de uma família profundamente ligada ao colégio. Curiosamente, a única Montoro não ex-aluna é a conhecida Malu, que trabalha no colégio há muito tempo. A família convida a comunidade de ex-alunos para participar de uma homenagem ao ex-governador, que será realizada em 16 de julho no Mosteiro de São Bento, incluindo missa, exibição de documentário e lançamento de livro". O texto do site erroneamente diz que o próprio Franco Montoro teria sido aluno do Colégio, o que não é possível, já que o governador entrou na faculdade em 1934 e o Santa Cruz só foi fundado em 1952.
} 
lá [EPGE]. Prestei o concurso, entrei e resolvi ir”. Passou, então, a viver na ponte-aérea e dividir o tempo entre o mestrado no Rio e a docência na USP e o trabalho na consultoria na Hidroservice, em São Paulo. Na EPGE seu professor mais influente foi Mário Henrique Simonsen que, comenta ele como tantos outros, "dava aula de quase tudo". Além dele, menciona João Paulo Velloso e Jessé Montello, da área de estatística, como professores interessantes. André concluiu o mestrado com a dissertação $A$ Aviação no Brasil (1969), tema escolhido por influência de trabalho encomendado pela Hidroservice sobre a construção de aeroportos no Brasil (Entrevista de André Franco Montoro Filho à autora 2014).

O bom desempenho no mestrado fez com Montoro Filho fosse recomendado por Werner Baer para o doutorado em Yale, onde estiveram antes dele seus professores João Paulo dos Reis Velloso e Edmar Bacha, que também apoiaram sua ida para lá. André relata que "não queria ir para Chicago por causa da linha muito conservadora e não queria ir para a Califórnia... então eu queria alguma coisa ali pela Nova Inglaterra". Diz ter sido um pouco pretensioso e feito applications também para Harvard e Princeton. Foi aceito em Yale e Princeton e optou pela primeira. Em Yale, comenta ter sido influenciado pelos professores James Tobin, William Brainard, Hugh Patrick e também por Carlos Dias Alejandro, orientador de sua tese The recent development of the Brazilian financial system and the application of a general equilibrium (1976), na qual tentava aplicar o modelo de Tobin e Brainard ao caso brasileiro (TOBIN e BRAINARD, 1963). André explica que Dias Alejandro era "o orientador dos brasileiros. Porque ele era cubano, muito amigo, se dava bem com a gente e era muito amigo do Edmar Bacha", além de estudar temas de América Latina e desenvolvimento (Entrevista de André Franco Montoro Filho à autora 2014).

Além de Franco Montoro Filho (PhD 1976), Dias Alejandro orientara, naqueles anos, os professores João Sayad (PhD 1975), Marcos Giannetti da Fonseca (PhD 1978) e Simão Davi Silber (Master 1976, PhD 1983), além de estar na banca de tese de Denisard Alves (PHD 1972), todos colegas de FCEA. Além deles, esteve em Yale naquele período José Roberto Mendonça de Barros, irmão de Luiz Carlos Mendonça de Barros, que havia concluído o doutorado na FCEA em 1973, e ficou entre 1973 a 1974 como pesquisador associado ao Economic Growth Center de Yale. André Franco Montoro e José Roberto foram colegas de Colégio Santa Cruz e graduaram-se na FCEA em 1965. Davi Simão Silber era da turma de 1966, João Sayad e Denisard Alves, de 1967 e Marcos Giannetti, 
também ex-aluno do Santa Cruz, é algumas turmas mais jovem, tendo obtido o bacharelado em 1970. Nesses anos, Albert Fishlow também lecionou em Yale, integrando a banca de Simão Silber e orientando a tese de Raúl Wagner dos Reis Velloso (Master 1977, PhD 1981), irmão mais novo do ministro João Paulo dos Reis Velloso, que seguira os passos dele até Yale, cursando a graduação em economia na UERJ e o mestrado da EPGE. Ao regressar, Raul logo tornou-se assessor do irmão no Ministério do Planejamento e depois passou a integrar o IPEA ${ }^{441}$. Todos os outros foram incorporados ao corpo docente da FEA.

Quando essa geração concluiu o doutorado e foi reincorporada à FEA, houve atritos com membros do grupo de Delfim Netto, até então dominante na Faculdade. Há menções, nas entrevistas feitas com professores da FEA, a aspectos políticos dos conflitos, já que os Delfim Boys eram colaboradores do governo militar e a maioria dos professores que regressava, aliados da oposição. Uma segunda dimensão das disputas internas decorria dos alinhamentos no universo da teoria econômica. Era "Chicago, que é o [Affonso] Pastore e o [Rubens] Almonacid, contra todo o resto" (SAYAD, 1998, p. 184), formado predominantemente por pessoas egressas das universidades de Vanderlbilt, Berkeley e Yale, onde foram alunos de professores como Albert Fishlow, Werner Baer e Dias Alejandro, que regularmente contrapunham-se à visão de Chicago sobre a América Latina (itens 4.2 e 4.4). Finalmente havia uma faceta das tensões que decorria da contraposição entre uma geração que acumulara títulos acadêmicos e que tinha o credenciamento da formação no exterior contra uma geração que se formara no Brasil, ainda em momento no qual os doutorados não eram muito estruturados, e que combinara investimentos acadêmicos com trabalhos no governo e nas consultorias. Quando deixaram o Estado e tentaram retornar à carreira acadêmica, parte dos Delfim Boys encontrou dificuldades para concorrer com os professores que retornavam com insígnias acadêmicas que eles não puderam acumular ao transferirem-se precocemente para a vida pública. Foram, assim, perdendo espaço e os postos de direção da Faculdade para os PhDs recém-chegados (Entrevistas à autora, 2012-2015).

Ainda que houvesse desavenças ligadas ao percursso de formação, às perspectivas políticas e às linhas econômicas, elas não incorreram, como no caso da EPGE, em cisão e

441 Ver:
$\%$ http://repositorio.enap.gov.br/bitstream/handle/1/1035/D $\% 202.3 \% 20-$ Consultado em 24/03/2016. 
criação de uma nova escola (item 4.0). A amplitude do corpo docente tornava viável a existência de diversas correntes no interior da faculdade. O maior grau de institucionalização, por sua vez, permitia que elas coexistissem, já que tornava possível disputar os cargos com base em regras instituídas, em conselhos, em eleições e não por indicação dos sêniores, como no caso da FGV-RJ. A USP não ficou, pois, nem no extremo quantitativo à la Chicago que prevalecia na FGV, nem alinhou-se ao polo cepalino-keynesiano representado pela UNICAMP. Havia na FEA tanto uma ênfase no treinamento em métodos quantitativos quanto uma área reconhecida de história econômica e economia brasileira, além de inúmeras áreas especializadas como economia regional, agrícola, industrial, urbana, de transportes, de energia, o que favorecia a atividade de consultoria especializada na qual se engajava grande parte do corpo docente (ROCCA et al., 1984, pp. 243-267).

Ao retornar dos EUA, André Franco Montoro Filho liga-se a uma dessas consultorias, um projeto conjunto da Fundação Instituto de Pesquisas Econômicas (FIPE) com a FGV-RJ e o Banco Central do Brasil (BCB) para a construção de uma matriz de fluxo de fundos no Brasil e pesquisa sobre o sistema financeiro, os fundos de pensão e a aposentadoria complementar (Entrevista de André Franco Montoro Filho à autora, 2014). João Sayad, colega de Montoro no doutorado, indica como a atividade de pesquisa feita na faculdade era influenciada pelos convênios ao esclarecer que a razão da escolha do tema Inflação e agricultura: um enfoque microeconômico (1978) para sua tese de livre docência resultava do financiamento "pelo Ministério da Agricultura, então eu tinha que procurar um tema que ligasse o financiador com o meu interesse, que era inflação”. Nos anos seguintes ele participa de pesquisas da FIPE na área de energia quando passa a combinar sua predileção, a inflação, com o setor energético, de onde vinha o financiamento (Entrevista de João Sayad à autora, 2014).

Em 1979, a FEA estabeleceu convênio com a Companhia Energética de São Paulo, do qual Sayad ficou encarregado. O objetivo era compreender porque a Companhia encontrava barreiras em todas as suas tentativas de diversificação energética (Entrevista de Andrea Calabi à autora, 2012). Para compor a equipe, Sayad recrutou seu colega de faculdade e amigo de muitos anos, Andrea Calabi. Sayad e Calabi foram vizinhos e amigos desde a infância. Andrea conta que:

Sayad era vizinho de Pacaembu. Ele morava na rua Itabacoara, eu morava na rua de cima que então chamava rua Itaguaçu, hoje chama Manoel Maria Tourinho. 
Então nós éramos amigos de Pacaembu, de bicicleta, desde crianças. Depois na adolescência a gente ia zoar em algum cantinho ali da vizinhança [...]. A mãe do João fazia um quibe excepcional, esfihas... a gente vivia indo lá. O Sayad depois fez clássico. Eu fiz científico. Uma diferença importante. Ele estava em dúvida se fazia letras, depois foi fazer economia. Eu fui fazer um ano depois e decidi fazer economia. Depois o Sayad fez mestrado, aí eu entrei no mestrado, depois ele começou a dar aula, depois eu comecei a dar aula, depois ele foi para Yale, depois eu fui para Berkeley no ano seguinte. Tínhamos sempre um ano de defasagem (Entrevista de Andrea Calabi à autora, 2012).

Os dois amigos eram nascidos em São Paulo, em 1945, e provenientes de famílias de imigrantes. Sayad de libaneses católicos, Calabi de judeus italianos, parte dos quais convertidos ao catolicismo. João começou os estudos em uma escola pública municipal, depois foi transferido para o Colégio Rio Branco, escola particular de prestígio. Andrea estudou no Dante Alighieri, colégio da elite italiana, e depois no Colégio Bandeirantes, instituição educacional que também gozava de alto reconhecimento. Os dois falam inglês, francês e espanhol. Ambos estudaram inglês extra-curricularmente, mas dizem ter aprendido efetivamente ao cursar o doutorado nos EUA. Além desses idiomas, Calabi aprendeu o italiano, que era falado em sua casa e ensinado no Dante.

A família de Calabi era toda italiana e originalmente judia. Seu pai nasceu em Verona e a mãe em Modena. Seus avô paterno era engenheiro e trabalhava na rede ferroviária federal da Itália e o avô materno era diretor da Banca Commerciale Italiana, e veio para o Brasil justamente como diretor de uma agência no Brasil. O contexto da transferência de sua família para o Brasil era o das crescentes perseguições aos judeus na Europa. Inclusive parte de sua família materna converteu-se ao catolicismo preventivamente, o que teve efeitos que alcançaram sua geração, já que foram criados como católicos e iam, inclusive, à missa. Seu pai havia estudado na escola de comércio Bocconi, em Milão. A mãe havia começado a faculdade de letras em Roma, mas não concluiu porque mudou-se para o Brasil, onde casaram-se. Depois de instalar-se em São Paulo, seu pai foi contador e depois diretor administrativo da Gessy. Quando a Lever comprou a Gessy, ele abriu um "escritório de consultoria em economia, basicamente de investimentos estrangeiros e análise fiscal de holdings de empresas e foi muito bem. Sempre quis evidentemente que eu assumisse o escritório" (Entrevista de Andrea Calabi à autora, 2012).

O pai teve influência decisiva em sua opção profissional. Andrea pensava cursar administração na EAESP-FGV e chegou a fazer cursinho dirigido para a FGV, mas o pai 
achava que "a FGV é muito método do caso, é uma coisa muito de business administration. Ele disse: 'Estuda economia, lê os clássicos, depois você especializa em administração' [...]. Assim fui para a economia, que era o passo inicial, mas lá continuei. Depois fiz mestrado, depois entrei na faculdade, depois fui para Berkeley, fiz doutorado, comecei a dar aula”. Nunca migrou para a administração, embora declare ter carregado essa dubiedade ao longo da vida, mantendo sempre um enfoque na área de empresas em seus estudos de economia. Gostava de microeconomia e deu aulas de organização industrial, que define como "uma microeconomia de mercados mais concentrados ou globalizados". Cultivava, desse modo, a possibilidade de um dia "ir para o escritório e começar a ganhar dinheiro" (Entrevista de Andrea Calabi à autora, 2012).

João Sayad, ainda que almejasse estudar direito, optou pela economia porque naquele momento lhe "parecia algo que era uma profissão, como dentista. [...]. Eu imaginava que economista podia trabalhar no BNDES, e portanto dedicar o resto do meu tempo para escrever [literatura], que era o meu sonho na época". Mesmo que o pai e o avô materno exercessem atividades comerciais, ele julga não ter havido influência familiar na escolha pela economia: "o meu pai nem sabia o que era economia. Nem eu... [risos]". Seus quatro avós eram libaneses católicos que chegaram ao Brasil, acredita ele, no final do século XIX, para "fazer a América”. O avô materno instalou-se no Rio de Janeiro e abriu uma loja de tecidos no centro da cidade. A mãe foi matriculada em um colégio de freiras, deixando o Rio de Janeiro para casar-se com um primo de São Paulo. O avô paterno também era libanês; Sayad não soube dizer o que ele fazia, mas devia ter alguns proventos visto ter matriculado o filho no Colégio São Luís. Ao concluir o colégio, o pai de João tornou-se comerciante. Ele começou arrematando produtos de leilão e acabou tendo um armarinho no Largo D. Pedro II, chamado Sayad e Cia. (Entrevista de João Sayad à autora, 2014).

Quando indagados acerca de suas influências predominantes na faculdade os dois mencionam a catedrática da área de história, Alice Canabrava (item 3.3) e alguns professores do grupo de Delfim, como Affonso Pastore, Carlos Antonio Rocca, Carlos Viacca, Akihiro Ikeda e José Eduardo Pereira de Carvalho (item 4.2). Consideram que eles, ainda que fossem, em geral, "reacionários e governistas", formavam um "bom conjunto de professores do ponto de vista de qualidade das aulas" e eram "importantes porque eram os professores que falavam de economia" em um contexto no qual a maioria dos 
professores não eram economistas (Entrevista de João Sayad à autora, 2014; Entrevista de Andrea Calabi à autora, 2012)

Ao concluir a graduação, tanto Calabi quanto Sayad fizeram mestrados no IPE com Pastore, que era especialista em moeda. Calabi redigiu a dissertação Alguns aspectos recentes da oferta de moeda no Brasil. Sayad foi estudar a estrutura tributária empregando técnicas de programação linear, tema que adotou depois de ter gostado do curso de finanças públicas de um dos professores norte-americanos que lecionava no IPE. Foi orientado por Pastore porque, no início dos anos 1970, havia ido trabalhar com ele e com o José Roberto Mendonça de Barros no IPEA, no período em que a USP fez uma expansão em direção ao Rio de Janeiro, espalhando professores seus pela EPGE e pelo IPEA (item 4.6) (Entrevista de João Sayad à autora, 2014; Entrevista de Andrea Calabi à autora, 2012; Edmar Bacha in: ALBERTI et al., 2002, p. 96; Pedro Malan in: D’ARAÚJO et al., 2005, p. 61).

A escolha do local para fazer o doutorado, no caso de João, decorreu da percepção de que "em todas as universidades americanas havia um excesso de competitividade e Yale se apresentava como uma escola de um ambiente menos competitivo, o que não é verdade, mas é bem melhor que Chicago... e tinha algum relacionamento do Brasil, da USP, com Yale". Chegou também a tentar o ingresso em Princeton, mas quando foi aceito em Yale optou imediatamente por New Haven. Lá diz ter sido bastante influenciado pelo schumpeteriano Richard Nelson e por Carlos Dias Alejandro que dirigiu sua tese Regulation of Brazilian commercial banks (1975), tema que escolheu "pragmaticamente. Eu tinha dados e gostava de organização industrial. Então eu fiz regulamentação do sistema bancário brasileiro” (Entrevista de João Sayad à autora, 2014)

Desta vez, Calabi não seguiu Sayad. Ele conta feito applications para Cornell, John Hopkins e Berkeley e optado pela última, para onde mudou em 1972442. Explica: "eu gostei de Berkeley e tinha ligações com o Fishlow. Tinha tido uma conversa com ele quando ele esteve aqui”. Indagado sobre a aura de escola crítica, Calabi responde que "tinha, mas pouco. Era um pouco ilusório, porque o pessoal de economia de Berkeley é heavy em matemática. Então estava longe de ser uma coisa mais desenvolvimentista. $\mathrm{O}$

\footnotetext{
${ }^{442}$ Como mencionado no capítulo 3, de julho a agosto de 1973 Andrea Calabi e Gilda Portugal Gouvêa disfrutam de bolsas "da National Science Foundation para um seminário na FLACSO em Santiago, na Faculdade Latino-Americana de Ciências Sociais. Era um seminário conjunto FLACSO-MIT, de modelos matemáticos de análise política" que ocorreu no período de altíssima agitação política que antecedeu o golpe militar. Lá encontram-se com seu colega de FEA, Frederico Mazzucchelli, e conhecem José Serra (Entrevista de Andrea Calabi à autora, 2012).
} 
Fishlow dava com o Bent Hensen, que era um professor sueco, um field de desenvolvimento econômico que nós fizemos, mas era pesado em matemática”. Em Berkeley, Calabi estabeleceu amizade com Pedro Malan e Regis Bonelli, os orientandos brasileiros de Fishlow da primeira leva, chegando a ajudá-los com cálculos para suas teses. Ali Calabi defendeu o trabalho Price formation in Brazilian industry (1982), que "tratava da expectativa de preços. No caso dos preços industriais, quanto era atribuível a uma expectativa de inflação, e quanto era atribuível a variações na estrutura de preços relativos" (Andrea Calabi in: D’ARAÚJO et al., 2005, p. 224). Ele comenta que foi este mais um dos momentos nos quais manteve um pé na economia e outro no mundo das empresas (Entrevista de Andrea Calabi à autora, 2012).

Ao regressar, Andrea tornou-se assistente de Sayad na cadeira de Organização Industrial dos cursos de pós-graduação da FEA de 1977 a 1980, passando a trabalhar com ele nas pesquisas financiadas pela CEST. Além de Sayad e Calabi, trabalhavam nos estudos sobre o setor elétrico Henri Philippe Reichstul, que regressara da Inglaterra e estava tentando concluir o doutorado na UNICAMP, Francisco Vidal Luna e os irmãos Marcos e Eduardo Giannetti da Fonseca (ROCCA et al., 1984, pp. 249-251; Entrevista de Francisco Vidal Luna à autora, 2014).

Luna (1946) nascera em Barcelona e viera para o Brasil ainda criança, com os pais que romperam com o universo da pequena agricultura no qual foram criados e transferiram-se, no pós-guerra, para a América em busca de melhor inserção social. No Brasil, seu pai trabalhou como motorista de caminhão e depois em uma empresa de autopeças e a mãe trabalhou na companhia Singer e fez serviços domésticos. Francisco foi matriculado em colégios públicos que diz terem sido muito bons. Neles começou a aprender francês e inglês, idiomas que continuou estudando em escolas particulares depois. O espanhol dominava de berço e o italiano compreendia pois havia trabalhado por dez anos em uma firma pertencente a italianos. Luna explica que teria condições para ser aprovado no exame para a engenharia, seu desejo à época, mas como trabalhava para ajudar a sustentar a família, só poderia fazer um curso noturno e optou pela economia, uma das poucas escolas que oferecia os dois períodos, mesmo "sem conhecer muito o que era". Observa que muitos colegas tinham condições similares a sua, só estando no ensino superior graças ao curso noturno em universidade pública e gratuita (Entrevista de Francisco Vidal Luna à autora, 2014). 
As dessemelhanças entre o noturno e o diurno não se resumiam às diferentes origens sociais daqueles que frequentavam a faculdade. Em primeiro lugar o próprio curso era diferente pois nem todos os professores lecionavam no noturno. Sua futura orientadora, Alice Canabrava, por exemplo, só dava aulas durante o dia, de sorte que só travariam conhecimento anos mais tarde. Em segundo lugar, "o usual na faculdade de economia era quem estuda de manhã terminar a faculdade e fazer o mestrado, que é em período integral, com bolsa. Eu nem pensei em fazer isso, eu trabalhava”. Luna levou dois anos para voltar à faculdade, como aluno de pós-graduação e professor, a convite de seus professores da área de história, Antônio Emílio Muniz Barreto e Ibrahim Eris, que já o haviam incluído no grupo de estudos avançados que mantinham. Em setembro de 1980, Luna defendeu seu doutorado Minas Gerais: Escravos e Senhores - análise da estrutura populacional e econômica de alguns centros mineratórios (1718/1804). Na sequência deixou o trabalho de assessor econômico da Bolsa de Valores para dedicar-se exclusivamente à vida acadêmica (Entrevista de Francisco Vidal Luna à autora, 2014). Nesse momento,

o Sayad virou diretor de cursos da FIPE. Ele tinha voltado do exterior e virou
diretor de cursos da FIPE e me convidou para ser coordenador [...]. Nós
montamos um grupo de pesquisas que era sobre energia. Tinha explodido o
preço de petróleo em 1979, então a ideia toda era quanto custaria a energia em
geral e principalmente no setor elétrico. Um grupo de pesquisa de que fazia parte
o Sayad, eu, o Marcos Giannetti, o Calabi e o Philippe Reichstul. Então nós
ficamos juntos á́ uns dois ou três anos fazendo essas pesquisas. Quando o Sayad
foi indicado para ser secretário da fazenda esse grupo todo foi com ele. O Sayad
Secretário. O Calabi para tocar a DIVESP [Distribuidora de Valores e Títulos
Mobiliários do Estado de São Paulo], eu cuidava da assessoria econômica. O
Philippe cuidava das estatais e o Marcos foi como presidente da Caixa. Nós
fomos todos com ele. Então esse grupo ficou um grupo muito próximo
(Entrevista de Francisco Vidal Luna à autora, 2014).

A família dos irmãos Giannetti da Fonseca - Marcos, Roberto e Eduardo, os três economistas formados pela FEA em 1970, 1976 e 1978 respectivamente -, ainda que parcialmente de ascendência italiana, já era bem estabelecida no país. Nascidos em Minas Gerais, eles eram bisnetos, por parte de pai, de João Pinheiro (item 4.0), tal qual dois outros economistas de destaque da mesma geração, André Lara Resende e Paulo Nogueira Batista Júnior. O avô paterno era juiz de direito e diplomata. Segundo seu filho, Justo Pinheiro da Fonseca, "para sentar na mesa grande [da casa de seu pai] tinha que ser doutor e casado [...] os dois valores fundamentais eram a família e a cultura" (FONSECA, 1990, p. 6). 
Por parte de mãe descendiam de Américo René Giannetti que, como João Pinheiro, era um misto de empreendedor e político. Foi pioneiro do setor de siderurgia criando, a pedido de seu conterrâneo e amigo Getúlio Vargas, parte das primeiras indústrias de alumínio no Brasil. No âmbito político foi presidente da Federação das Indústrias de Minas Gerais (FEMIG), secretário de agricultura de Minas e por fim prefeito de Belo Horizonte (FONSECA, 1990). A mãe deles escrevia poesia e nos anos 1970 estudou psicologia e trabalhou como psicanalista, para desgosto do pai, que "achava um absurdo você revelar os sentimentos mais íntimos" e que protestava se "ao chegar do trabalho, minha mãe não estivesse na sala, arrumada, esperando por ele" (Roberto Giannetti e Eduardo Giannetti apud CARIELLO, 2015).

Justo Pinheiro da Fonseca era formado na Escola de Minas de Ouro Preto, como seu tio Israel Pinheiro e Lucas Lopes, tendo feito um ano de estudos e treinamento nos EUA. Quando o tio Israel inaugurou e presidiu a Vale do Rio Doce, Justo tornou-se um dos primeiros engenheiros da companhia, participando das atividades de planejamento da cidade industrial de Minas. Na sequência foi trabalhar na indústria do sogro e passou a integrar os grupos que debatiam, em Minas, a racionalização da organização industrial coordenados, muitos deles, por Lucas Lopes. Justo Pinheiro declara que seu sogro Américo, seu tio Israel, Lucas Lopes, Magalhães Pinto e ele partilhavam a mesma visão de desenvolvimento segundo a qual Minas havia de aprender a pensar em termos econômicos. Eram, segundo ele, os pioneiros da Minas Gerais industrial e moderna que Juscelino Kubitschek ajudou a erguer quando governou o Estado com seu programa voltado ao binômio energia e transporte (FONSECA, 1990, pp. 1-9).

Como Lucas Lopes, Justo engajou-se na criação da Faculdade de Ciências Econômicas de Minas Gerais, onde lecionou economia geral por dois anos. Participou também da criação do Centro de Estudos Econômicos de Minas Gerais, cujo objetivo era dar "suporte doutrinário e racional" e "respaldo à atividade econômica das entidades de classe". "Nós tínhamos influência na Associação Comercial, na Federação das Indústrias" (FONSECA, 1990, p. 13; FONSECA, 1990a, p. 2). Igualmente fez parte da criação de um departamento de produtividade e organização racional do trabalho na FEMIG. Quando foi diretor de Crédito Agrícola e Industrial do Banco do Brasil, no governo de Jânio Quadros, criou a "Unidade Móvel de crédito Rural. [...] Em vez de esperar que o sujeito viesse pedir no banco, ia oferecer para o pequeno produtor agrícola" (FONSECA, 1990a, 
p. 3), ideia saída dos debates do Centro de Estudos Econômicos. Ao ser preterido para a presidência da FEMIG ${ }^{443}$, posto que já julgava ser seu, decide mudar com os filhos pequenos para São Paulo, sendo convidado a dirigir as empresas de Francisco Matarazzo Pignatari, neto do Conde Matarazzo, e depois a ocupar a presidência da Federação Brasileira de Bancos. Instalaram-se inicialmente em um apartamento no bairro de Higienópolis e depois construíram uma grande casa no Jardim Europa, na qual recebiam personalidades da época, como o Ministro Delfim Netto, amigo da família (FONSECA, 1990, p. 10; CARIELLO, 2015).

Os irmãos Giannetti estudaram no Santa Cruz e depois ingressaram, um a um, na FEA. Eduardo (1957), que estudou ciências sociais concomitantemente, fez doutorado em Cambridge e tornou-se professor universitário, transitando entre as áreas de filosofia, história das ideias e história do pensamento econômico. Roberto tornou-se executivo de grandes empresas, entre as quais a Cotia Trading, foi diretor da FIESP e representante em outros órgãos de classe e, no governo FHC, secretário da Câmara de Comércio Exterior $^{444}$. Marcos fez o mestrado na FEA e o doutorado em Yale. Em 1985, deixou a Caixa Econômica Estadual para substituir João Sayad na Secretaria da Fazenda do Estado de São Paulo. Na sequência, assumiu a Secretaria de Planejamento do Ministério da Economia, Fazenda e Planejamento (que substituiu, no governo de Fernando Collor de Mello, o Ministério do Planejamento).

A nomeação de João Sayad para o Ministério do Planejamento, em 1985, não é inteiramente clara para ele. Indagado, responde em tom de brincadeira que seria preciso perguntar para o Tancredo Neves por que escolheu ele e não o Serra, que parecia a todos ser o nome que ocuparia aquela posição (Entrevista de João Sayad à autora, 2014). O PMDB de São Paulo, de Ulysses e Montoro, teria tido algum peso na composição do Ministério de Tancredo Neves, cuja candidatura apoiaram. Uma vez eleito, Tancredo tinha dívidas políticas a saldar com o PMDB de São Paulo que exigia posições no Ministério, em especial na área econômica.

Havia uma percepção geral de que o nome paulista para a área econômica seria José Serra. Antes mesmo da posse de Tancredo, Serra tomava parte nos círculos oficiais.

\footnotetext{
${ }^{443}$ Justo confessa que gostaria de ter sido mais do que presidente da FEMIG, seguindo os passos de seu tio e avô: "Eu tinha muita ambição. Hoje eu já posso falar. Eu queria ser Secretário de Agricultura, governador de Minas, qualquer coisa assim. Só isso que me interessava. Riqueza, não havia, só o poder político que interessava. [...] Para minha mãe, era muito mais importante eu ser Prefeito de Caeté do que eu ter uma fábrica em São Paulo (FONSECA, 1990a, p. 5).

${ }^{444}$ Ver: http://www.oas.org/en/sedi/desd/PSF/bios/Roberto_Fonseca_e.pdf. Consultado em 26/03/2016.
} 
Ele ocupou a posição de coordenador ${ }^{445}$ da Comissão do Plano de Ação do Governo (COPAG) que reuniu acadêmicos, políticos e empresários com posições políticas e orientações econômicas divergentes para discutir a situação da economia e produzir diagnósticos e documentos que ajudassem na orientação do novo governo. Serra, juntamente com Celso Furtado e Luciano Coutinho, indicados por Ulysses, formava o polo dos economistas de oposição; do outro lado estavam posicionados Sebastião Marcos Vital, pós-graduado na EPGE, que havia sido redator chefe da Conjuntura Econômica da FGV, professor da EPGE e assessor de Mario Henrique Simonsen (Fernando Soares de Sá in: D’ARAÚJO, 1999, p. 77; Carlos Langoni in: D’ARAÚJO, 1999, p. 190); os engenheiros-empresários Sergio Franklin Quintella ${ }^{446}$, presidente da construtora Internacional de Engenharia, Sérgio Silva Freitas ${ }^{447}$, diretor do Itaú indicado por Olavo Setúbal; e o político e jurista Hélio Beltrão (item 4.3), indicado pelo Partido da Frente Liberal (PFL) (Entrevista de Luciano Coutinho à autora, 2013; SERRA, 1998a, pp. 339340).

Vários outros cooperaram com os trabalhos da Comissão. Guilherme Dias Leite e José Roberto Mendonça de Barros escreveram documento sobre agricultura (SERRA, 1998, p. 340). Calabi colaborou com a parte sobre finanças, moedas e títulos, justamente porque na época estava alocado na DIVESP. Ele menciona também a participação de Lídia Goldenstein e Mônica Baer, duas pesquisadoras que faziam parte do grupo de Serra no CEBRAP 448 (Entrevista de Andrea Calabi à autora, 2012). A COPAG elaborou também estudos relativos às finanças públicas ${ }^{449}$ e posicionou-se em favor da busca de

\footnotetext{
${ }^{445}$ A indicação de Serra para a coordenação não foi pacífica. Houve contestação interna desde o princípio, revelando dificuldades primárias na construção de consensos para a gestão econômica do futuro governo. http://memoria.bn.br/DocReader/docreader.aspx?bib=030015 10\&PagFis=90054. Consultado em 28/03/16.

${ }^{446}$ Ver: http://www.anebrasil.org.br/ane2014/images/pdf/cv/cv-sergio-quintella.pdf. Consultado em 27/03/2016.

${ }^{447}$ Ver: http://www.bloomberg.com/research/stocks/people/person.asp?personId=2907802\& privcapId=364040. Consultado em 27/03/2016. Em 2010 foi tesoureiro da campanha de Serra à Presidência da República.

${ }^{448}$ Ver: http://www.saopaulo.sp.gov.br/spnoticias/lenoticia.php?id=206505. Consultado em 27/03/16.

${ }^{449}$ Desde o início dos anos 1980, discutia-se intensamente o reordenamento das finanças públicas, unificação de orçamentos, das fontes de recursos, divisão mais acurada das funções da Fazenda, do Planejamento, do Banco Central e do Banco do Brasil, dentre outros aspectos que passaram a ser analisados por uma Comissão para o Reordenamento das Finanças Públicas, coordenada pelo Secretário Geral do Ministério da Fazenda, Maílson da Nóbrega, e integrada por 106 funcionários dos órgãos de governo que seriam afetados pelas reformas. Uma das principais mudanças decorrentes desses estudos e das empreitadas do grupo de economistas do PMDB que atuou no governo Sarney foi o encerramento da conta-movimento que ligava o Banco Central ao Banco do Brasil, criada em 1965 como um mecanismo "através do qual o Banco Central supria recursos para o Banco do Brasil, que apresentaria a conta de seus gastos", que com o tempo se tornou "fonte de recursos para suprir a maioria dos empréstimos e financiamentos definidos pelo Governo e que estivessem fora do orçamento fiscal durante todo o regime militar, mas principalmente depois de 1974. Ela transformou-se em um poderoso instrumento para injetar ou contrair a liquidez de moeda no sistema financeiro nacional, através do controle das operações ativas do Banco do Brasil" e portanto um instrumento que dava ao poder executivo "grande flexibilidade de ação em
} 
termos mais vantajosos para a reestruturação da dívida externa, sujeita a altos juros que elevavam o déficit público incorrendo em efeitos inflacionários ${ }^{450}$ (Entrevista de Luciano Coutinho à autora, 2013).

Um relatório sobre a área industrial foi apresentado por Antônio Kandir, engenheiro com mestrado na UNICAMP e doutorado em curso, que também era integrante do grupo de Serra no CEBRAP, ex-funcionário do IPEA e professor da PUCSP, e por Wilson Suzigan, historiador econômico com mestrado na EPGE e doutorado na University of London, que acabara de deixar o IPEA para lecionar na UNICAMP451. Segundo Kandir o documento “afirma: 'Acabou a fase de substituição de importações. A estrutura industrial já está cristalizada, e agora é questão de aumentar a qualidade dessa estrutura'. Sem falsa modéstia, posso afirmar que o começo da nova política de abertura do comércio exterior partiu deste documento pioneiro" (Antônio Kandir in: D'ARAÚJO, 2005, p. 314). Ficará visível no próximo capítulo que também o BNDES já caminhava no mesmo sentido (item 6.1). Serra empenha argumentação semelhante a de seu aluno ao dizer que aquele programa:

pela primeira vez propunha uma abertura, fundamentalmente no sentido de você aumentar a exposição da indústria doméstica à concorrência, porque, realmente, com o governo Geisel, nós chegamos ao limite da autarquia em matéria de desenvolvimento industrial [...]. Diga-se de passagem, sempre se falou muito isso no Brasil, mas não se levou a cabo. Nem durante o regime autoritário, nem na fase Campos/Bulhões, nem na fase Delfim, nem na fase Simonsen, do ponto de vista substancial, nem na fase do PMDB já no governo Sarney. Ironicamente isso coube ao governo Collor, que fez a abertura no estilo da cavalaria antiga: uma carga rápida e mal feita (SERRA, 1998a, p. 340).

Kandir e Serra, em momentos diferentes, trabalhariam para implementar a abertura econômica externa, privatização e políticas para o aumento da competividade. Kandir teve chance de agir primeiro, nomeado Secretário de Política Econômica do Ministério da Economia, Fazenda e Planejamento do governo Collor. Serra e, na sequência, novamente Kandir deram continuidade a essas iniciativas ao ocupar, um após

\footnotetext{
termos orçamentários. E para o Banco do Brasil e sua burocracia significava a perda de poder, pois na prática a Conta Movimento garantia a esta instituição seu papel de autoridade monetária" (GOUVÊA, 1994, pp. 105-116). Extinta a Conta Movimento, criou-se a Secretaria do Tesouro, na qual unificaram-se o "orçamento fiscal, monetário, previdência e estatais", o que ajudava a visualizar e controlar o gasto e o déficit público, tornando viável o exercício da "programação financeira, do gasto, emissão de papeis, controle de dívidas, avais, participações acionárias, contabilidade, controle interno". Andrea Calabi, que foi com Sayad para o Governo Federal, foi o primeiro Secretário do Tesouro (Entrevista de Andrea Calabi à autora, 2012).

450 Ver: http://memoria.bn.br/DocReader/docreader.aspx?bib=030015_10\&PagFis=91177. Consultado em $28 / 03 / 16$.

${ }^{451}$ Ver: http://lattes.cnpq.br/6094323148067379. Consultado em 27/03/16.
} 
o outro, o cargo de Ministro do Planejamento na primeira presidência de Fernando Henrique Cardoso (Antônio Kandir in: D’ARAÚJO, 2005, pp. 315-316).

Tancredo, de um lado, mantinha a COPAG como representação oficial que lutava por conciliar as posições dos economistas do PMDB com a dos representantes da Frente Liberal, sob a liderança de Serra, que tinha até uma sala nos escritórios da FGV de Brasília, e consultava Décio Munhoz, economista da $\mathrm{UNB}^{452}$, que tinha a simpatia do PMDB. De outro lado, reinava um grupo de conselheiros leais ao seu sobrinho, Francisco Oswaldo Neves Dornelles, homem de inteira confiança do Presidente que era o candidato favorito ao Ministério da Fazenda. Sebastião Marcos Vidal, braço direito de Dornelles e membro da COPAG, jogava o jogo duplo, mas concentrava-se na equipe de assessoria de Dornelles, na qual circulavam as ideias econômicas monetaristas que prevaleciam na EPGE. Se eram as reflexões da COPAG a vir a público; era Dornelles quem controlava a transição, viajando ao lado de seu tio para o exterior, dialogando com Delfim Netto para inteirar-se da situação econômica e fazendo os convites para a equipe econômica 453 (SARDENBERG, 1987, pp. 74-79; Plínio Sampaio Júnior e Rui Affonso, 1986, p. 12 apud GOUVEA, 1994, p. 192).

Francisco Neves Dornelles (1935) carregava consigo dois sobrenomes dos mais conhecidos na política nacional. Seu pai, Mozart Dornelles, nascido em São Borja, era primo de Getúlio. Ele fez sua carreira militar em São João Del Rei, onde conheceu Mariana Neves, irmã de Tancredo, com a qual viria a casar-se. Francisco nasceu em Belo Horizonte mas cedo transferiu-se com a família para o Rio de Janeiro. Foi matriculado no Colégio Militar, mas não seguiu a carreira. Fez curso técnico de contabilidade e depois iniciou a Faculdade de Direito da Universidade do Brasil, em 1954, que só concluiu em 1960 pois trabalhou algum tempo no consulado de Los Angeles. Bacharel, Dornelles foi logo nomeado por Tancredo secretário de finanças de Minas Gerais e também secretário particular do tio quando Primeiro-Ministro do governo de João Goulart. A experiência na administração econômica levou-o a buscar treinamento na área. Frequentou curso de finanças públicas na Université de Nancy, fez especialização em tributação internacional em Harvard, tendo lecionado tributação na FGV e em outras escolas. Em 1969, tornou-se professor de direito financeiro na UFRJ, onde obteve os títulos de mestre e doutor em

\footnotetext{
452 Ver: http://memoria.bn.br/DocReader/docreader.aspx?bib=030015 10\&PagFis=86997. Consultado em 28/03/16

453 Ver: http://memoria.bn.br/DocReader/docreader.aspx?bib=030015 10\&PagFis=93692. Consultado em 28/03/16.
} 
direito público. Simultaneamente, integrou comissões econômicas nacionais e internacionais, negociando diversos acordos no exterior. Em 1979, foi convidado para assumir a Secretaria da Receita Federal do Ministério da Fazenda no governo de João Baptista de Oliveira Figueiredo (DHBB, verbete Francisco Neves Dornelles).

Seu vínculo com o último governo militar que era razão de descrédito junto ao PMDB, fazia dele um nome capaz de captar a confiança da Frente Liberal. Como advogado com especializações na área econômica, ficava a meio caminho entre a cepa antiga, tipicamente um advogado com bom trânsito nas elites políticas e alguma experiência prática de gestão, e o moderno doutor em economia, no perfil padrão da direção econômica na Nova República. Sentindo-se preterido por Dornelles, Décio Munhoz deixou a posição de assessor econômico de Tancredo. Serra não resistiu muito mais (SARDENBERG, 1987, p. 75). Ele argumenta ter se posicionado contra a própria nomeação para o Ministério do Planejamento, porque "pretendia ser candidato a deputado em 1986. Então, não ia ao Ministério por 1 ano, para largar em fevereiro de 86”, mas acrescenta, que "estava claro que ele [Tancredo] pretendia entregar a coordenação da política econômica ao Ministério da Fazenda e queria que o Ministério do Planejamento na época se chamava Secretaria do Planejamento - fosse mais um órgão de assessoria, de elaboração de planos de longo prazo. O que não me tentava muito. Mas, realmente, a questão fundamental foi que eu pretendia ser candidato" (SERRA, 1998, pp. 339-340).

A versão que diz que queria ser deputado não é a mais correntemente mencionada e sim o atrito com Dornelles. Durante o período da montagem do ministério já observava-se grandes discrepâncias nas orientações econômicas dos dois. Serra teria apoio popular, fora um exilado, um líder estudantil e representava o discurso de um PMDB que falava para a população. O crédito simbólico e o apelo popular de Dornelles eram bem menores. Seus grandes trunfos eram os sobrenomes e o trânsito que tinha nas oligarquias regionais e quadros do antigo governo. Conjectura-se que os dois tenham brigado, que Tancredo visse em Serra uma ameaça futura - não quer ser ministro, quer ser presidente ou que Serra teria sido delatado como subversivo e vetado pelos conservadores que integravam a aliança democrática (Entrevistas à autora, 2012-2015; SARDENBERG, 1987, pp. 90-93). Por alguns destes, todos esses ou ainda outros motivos, Serra acabou 
fora da articulação. Chegou-se a aventar a convocação de Fernando Henrique para o posto, mas esse acabou ganhando a liderança do Senado ${ }^{454}$.

O PMDB paulista continuava, entretanto, exigindo participação na área econômica. Tancredo acatou a recomendação feita por Montoro de João Sayad, bem avaliado no comando da Secretaria da Fazenda paulista. Um técnico com credenciais acadêmicas, fama de bom gestor, que agradava o PMDB paulista e não tinha ambições políticas explícitas. Sayad explica: “o Tancredo me colocou lá para fazer estudos sobre propostas de longo prazo, então eu era encarregado da reforma administrativa, da reforma tributária" (Entrevista de João Sayad à autora, 2014). A política econômica caberia a Dornelles. Tudo havia sido feito para que Francisco conduzisse a economia em condições mais do que favoráveis. Seu Ministério da Fazenda havia sido enriquecido com diversos órgãos que antes pertenciam ao Planejamento, como o Conselho de Preços e a Superintendência do Abastecimento e Preços, além disso o Banco Central do Brasil (BCB) fora entregue a aliados seus ${ }^{455}$.

No BCB chegou-se mesmo a cogitar a indicação de Carlos Antonio Rocca, um Delfim Boy, ${ }^{456}$ mas a rejeição apresentada pela oposição seria enorme. Optou-se então por Antônio Carlos Lemgruber, colega de Marcos Vital que fora, como ele, editor da Conjuntura Econômica e tornou-se professor da EPGE a convite de Carlos Geraldo Langoni (item 4.4). Lemgruber trouxe com ele outros professores e alunos da EPGE, como seus colegas José Julio Senna e Roberto Castello Branco, que fora orientado em seu doutorado por Carlos Langoni e Arnold Harberger. Alberto Furuguem, também pós-graduado na EPGE que havia sido assessor de Simonsen no Ministério da Fazenda, foi igualmente convocado e ainda Sergio Silva Freitas, o indicado do Itaú na COPAG.

A composição do ministério de Dornelles e aquela do Banco Central, que substituíra Langoni e Pastore por diversos discípulos de Langoni, fazia com que a Nova República parecesse velho governo. Eram pessoas da mesma cepa e a política por eles preconizada não muito era diferente. Apostavam que a credibilidade de Tancredo era o ingrediente que faltava para uma sólida política de austeridade fiscal, com cortes no gasto público, restrição monetária, juros altos e crédito enxuto; aliada a uma política econômica

454 Ver: http://memoria.bn.br/DocReader/docreader.aspx?bib=030015_10\&PagFis=93732. Consultado em 28/03/2016.

455 Ver: http://memoria.bn.br/DocReader/docreader.aspx?bib=030015 10\&PagFis=92824. Consultado em 28/03/2016.

456 Ver: http://memoria.bn.br/DocReader/docreader.aspx?bib=030015 10\&PagFis=92824. Consultado em 28/03/2016. 
externa que não se esquivasse do pagamento dos juros da dívida e não fizesse recurso a novos empréstimos, seria capaz de reduzir a inflação e realinhar a economia. Finalmente, para assegurar condições para agir, submeteram-se aos termos e recomendações do Fundo Monetário Internacional (FMI), do qual dependiam para rolar os prazos do pagamento das dívidas externas (MACARINI, 2009, pp. 11-12; Plínio Sampaio Júnior e Rui Affonso, 1986, p. 12 apud GOUVEA, 1994, p. 192).

O grupo que acompanhava Sayad acreditava que as políticas ortodoxas adotadas para dizimar a inflação não seriam capazes de solucionar o problema, já que não atacavam uma das maiores responsáveis pela renitência da inflação que era, no diagnóstico daqueles de quem se cercara, a inércia inflacionária. Consideravam que era preciso desmontar a componente inercial da inflação, a expectativa que levava ao reajustamento automático dos preços, não importando se havia real razão ou não para o reajuste. $\mathrm{Na}$ imagem tecida pelo, à época, presidente do IBGE, Edmar Bacha, em $A$ "inflaflução": os preços em alta no pais do futebol (1985), combater a inércia era fazer com que todos os torcedores em um estádio sentassem ao mesmo tempo, parando de atrapalhar-se mutuamente para tentar ver o jogo melhor, o que fazia com que passassem a partida toda em posições desconfortáveis. Um juiz preparado, que comunicasse ao público que todos deveriam sentar ao mesmo tempo, poderia acabar com o incômodo coletivo e permitir que todos vissem o jogo com maior nitidez (BACHA, 2012).

A abertura para essas novas ideias só apareceu quando Dornelles deixou o governo, meio ano depois de assumir, momento no qual José Sarney, vice-presidente empossado na presidência devido à morte de Tancredo, aproximou-se do grupo do Planejamento que, retomando os estudos dos economistas do PMDB consolidados nos escritos da COPAG, formulou o Primeiro Plano Nacional de Desenvolvimento da Nova República, sintetizado nos seguintes termos:

O governo recusa a recessão como alternativa de política econômica. Mas este plano também parte da tese de que nenhum modelo de crescimento é capaz, por si só, de erradicar a pobreza que atinge, em níveis intoleráveis, grande parcela da população brasileira. Não se trata somente de evitar novos sacrifícios aos trabalhadores e às camadas mais pobres. A retomada do crescimento, conforme os propósitos deste plano, supõe a gradual recuperação do salário real. Nas opções deste plano, o governo considerou também, como ponto essencial, que a erradicação da pobreza exige investimentos com esse fim específico. Assim, a meta de combate à pobreza passa, de um lado, pela melhoria na distribuição de renda, através da recuperação dos salário. $\mathrm{E}$, de outro, pela concentração de 
esforços e recursos em programas sociais para reduzir os problemas de saúde, alimentação e habitação dos brasileiros mais pobres (BRASIL, 1986457).

Ao invés dos juros e da recessão do Ministério da Fazenda, os heterodoxos falavam em crescimento, distribuição, recuperação salarial e estancamento do vazamento de divisas para o exterior (SARDENBERG, 1987, pp. 107-108). Dornelles, Lemgruber e suas equipes deixam o governo em agosto de 1985, depois da demissão de Sebastião Vital, que acusara publicamente o governo de não conter gastos e dificultar as negociações com o FMI ${ }^{458}$. A equipe de Dornelles considerava que o crescimento, a estabilidade dos salários, a paz social e o investimento só poderiam ocorrer depois que fossem feitos todos os sacrifícios necessários para conter a inflação, o pior dos males, à la Milton Friedman no Chile (item 4.4). Havia acordo no diagnóstico segundo o qual a inflação era um grande vilão a ser urgentemente combatido, mas divergência quanto às políticas. Para a equipe de Sayad a recessão não poderia acabar com uma inflação com forte componente inercial e restringir os gastos com o saneamento da dívida externa era mais eficaz do que demolir o serviço público. A possibilidade de testar o receituário heterodoxo para cura da inflação que circulava no planejamento surgiu quando o Presidente do BNDES, Dílson Funaro, foi transferido para o Ministério da Fazenda.

\subsection{Francisco Gros: do mercado financeiro ao BNDES}

$\mathrm{Na}$ divisão do reinado da economia feita por Tancredo, o BNDES havia sido oferecido como uma espécie de contrapartida ao PMDB paulista pela entrega do Banco Central ao grupo de Dornelles (SARDENBERG, 1987, p. 120). Dílson Funaro fora secretário da fazenda e do planejamento do Estado de São Paulo durante a ditadura, tendo algum trânsito no meio militar. Ao mesmo tempo circulava nos circuitos do PMDB, apoiou o CEBRAP, participou na campanha das Diretas e seus assessores eram os economistas da UNICAMP, João Manuel Cardoso de Mello e Luiz Gonzaga Belluzzo. Finalmente, contava com a simpatia da FIESP, órgão do qual foi vice-presidente, e com o apoio de Matias Machline, empresário que era um dos melhores amigos de Sarney. Sua

\footnotetext{
${ }^{457}$ Ver: http://www.planalto.gov.br/ccivil_03/leis/1980-1988/L7486.htm. Consultado em 28/05/2016.

$458 \quad$ Ver: $\quad$ http://memoria.bn.br/DocReader/docreader.aspx?bib=030015 10\&PagFis=102259, http://memoria.bn.br/DocReader/docreader.aspx?bib=030015 10\&PagFis $=102053$, http://memoria.bn.br/DocReader/docreader.aspx?bib=030015_10\&PagFis $=101884 \mathrm{e}$ http://memoria.bn.br/DocReader/docreader.aspx?bib=030015_10\&PagFis=101851 Consultados em 28/03/2016.
} 
trajetória e o trânsito entre diferentes setores da elite dirigente faziam dele um forte candidato para dirigir um Banco que estava na fronteira entre o Estado e as empresas. Seu vice portava titulação acadêmica que dava suporte e legitimidade à gestão do empresário e um sobrenome mais que conveniente, era o $\mathrm{PhD}$ em economia André Franco Montoro Filho ${ }^{459}$.

O BNDES que Dílson Funaro e André Franco Montoro Filho encontraram atravessava um segundo período de decadência, resultado da combinação 1) de uma desarticulação de sua função no cenário nacional, em um contexto de profunda crise econômica, quando o crescimento do PIB caiu de uma média de 6,8\% no governo de Ernesto Geisel, para 2\% no governo de João Figueiredo (ABREU, 1990, p. 408); 2) do afastamento do Banco do centro do poder; e 3) da entrega da direção da instituição a personalidades com capital político junto às oligarquias regionais, sendo as indicações frutos de acordos políticos entre a presidência e as lideranças estaduais. Todos esses elementos que haviam caracterizado a crise na qual o Banco mergulhara ao final do ciclo de crescimento do Plano de Metas de JK (item 2.5), repetiram-se ao término do período em que o Banco esteve tomado pelos investimentos requeridos pelo II Plano Nacional de Desenvolvimento (II PND) de Geisel.

Durante o governo Figueiredo, o Banco experimentou nova estagnação no afluxo de pessoal, sendo contratados apenas 27 advogados, 24 engenheiros e 16 economistas (KLÜGER, 2015c). Os recursos só não apresentaram semelhante declínio pois foi atribuída ao Banco a gestão de uma nova fonte de capital, o FINSOCIAL, criado em 25 de maio de 1982 e constituído a partir da "contribuição de 0,5\% da renda bruta das empresas públicas e privadas, incluindo instituições financeiras e seguradoras" (TAVARES, 2010a, p. 183) ${ }^{460}$. As verbas deste fundo deveriam ser investidas pelo Banco exclusivamente nas áreas de educação, saúde, habitação, alimentação e amparo ao pequeno produtor rural (BNDES, 1983, p. 18).

No início do governo Figueiredo, Marcos Vianna deixa a presidência do BNDE depois de quase nove anos à frente da instituição. Seu substituto, o baiano da cidade de Nazaré, Luiz Sande de Oliveira (1933-1995), era advogado formado na Universidade

\footnotetext{
${ }^{459}$ Ver: http://memoria.bn.br/DocReader/docreader.aspx?bib=030015_10\&PagFis=94752 e http://www2.senado.leg.br/bdsf/bitstream/handle/id/441936/PS\%20jan_mar1986\%20$\% 200097$.pdf? sequence $=1$. Consultados em 28/03/2016 e 10/04/2016

${ }_{460}$ Ver: http://memoria.bn.br/DocReader/DocReader.aspx?bib=030015_10\&PagFis $=43404$. Consultado em $10 / 04 / 2016$.
} 
Católica de Salvador com especialização profissionalizante em administração na Michigan State University, a mesma que mantinha convênios com a EAESP-FGV. Sande chegou a lecionar na Escola de Administração da Universidade Federal da Bahia e na Universidade Católica de Salvador, atuando paralelamente como diretor do departamento industrial da Federação das Indústrias da Bahia ${ }^{461}$. Sua carreira no Estado foi feita ao lado de Antônio Carlos Magalhães (ACM), de quem foi secretário da fazenda da Prefeitura de Salvador. Quando ACM deixou a Prefeitura, Sande tornou-se diretor-superintendente do Banco do Estado da Bahia e logo que AMC conquistou o governo, Sande foi feito secretário da fazenda do Estado da Bahia. Quando Antônio Carlos encerrou seu mandato no Estado, Sande constava na lista-tríplice de candidatos para substituí-lo. Não sendo escolhido, foi feito membro da direção do Banco Nacional da Habitação (BNH) e presidente do Banco do Estado da Bahia. Em 1979, ACM indicou-o para a Presidência do BNDE, como um dos elementos de contraparte pelo apoio regional ao General Figueiredo (DHBB, verbete Luiz Sande de Oliveira; VIANNA, 2010, p. 306; LIMA, 2006, p. 109).

A gestão de Sande no BNDE foi condicionada pelas estratégias de saneamento financeiras desenhadas no nível ministerial. Ao primeiro choque do petróleo o Brasil respondera com uma intensificação do endividamento externo para sustentar os investimentos do II PND em infraestrutura, especialmente no setor energético, e no desenvolvimento das indústrias de ponta. No final dos anos 1970, a estratégia de crescimento com endividamento externo gerou, concomitantemente, uma capacidade produtiva ociosa que estava à disposição do país e poderia ser ativada sob incentivos adequados e uma desordem financeira, caracterizada pela alta da inflação, da dívida externa e do déficit fiscal, amplificados pela dificuldade de gerar superávits em um contexto de encarecimento das importações. Quando Figueiredo assumiu a presidência, em 1979,

os preços do petróleo passam de 12 dólares o barril para 36 dólares. E aquelas taxas de juros que tinham regulado os nossos empréstimos - já estávamos com cinqüenta e tantos bilhões de dólares de empréstimos, depois passou para 80 -, de $6 \%$, a política americana de controle da inflação, o senhor Paul Volcker [do Federal Reserve System], jogou a taxa americana a $20 \%$, a taxa prime rate nos Estados Unidos, a taxa básica [...] à taxa de juros a $20 \%$, não há taxa de retorno de investimento que pague. Nós entramos num processo de realmente não podermos pagar os juros. Começamos a acumular juros em cima da dívida a partir de 1979. E aí que começam os piores problemas. De 79 a 83 ocorrem três coisas terríveis, três agressões externas, em repetição daquilo que tinha ocorrido

\footnotetext{
${ }^{461}$ Ver: http://memoria.bn.br/DocReader/docreader.aspx?bib=030015_09\&PagFis=192577 http://memoria.bn.br/DocReader/docreader.aspx?bib=030015_09\&PagFis=192841. Consultados em 30/03/2016.
} 
em 74: o petróleo, que triplica; os juros, que multiplicam por três ou por quatro, e os bancos, num determinado momento de crise - vêm a crise da Polônia, a crise da Argentina, depois a crise do México em 82 -, os bancos fecham as portas aos países do Terceiro Mundo. Então, bruscamente, o Brasil, que recebia um bilhão de dólares por mês de financiamentos do sistema bancário internacional, de repente, parou tudo. Era pagar aquelas dívidas e pagar os juros e não havia entrada líquida de recursos. Então, começa, realmente, uma crise do petróleo, dos juros, do sistema bancário... (GALVÊAS, 1990, p. 53).

O Brasil e os vários dirigentes da área econômica do período tentam estratégias bastante dissimilares para enfrentar os efeitos adversos do choque do petróleo, da elevação da taxa de juros pelo Federal Reserve System (FED) e da constrição das fontes de financiamento externo. Nenhuma das tentativas feitas durante o período, entretanto, foi capaz de reverter ou minorar a crise em curso.

O governo Figueiredo havia começado com a transferência de Mario Henrique Simonsen do Ministério da Fazenda, posto que ele ocupara no governo Geisel, para o Planejamento. Simonsen atraiu para o Planejamento a administração da relação com as finanças internacionais e enriqueceu-o com o controle sobre "O órgão mais importante, de maior agilidade, de maior poder de decisão no esquema administrativo brasileiro", o Conselho Monetário Nacional, passando a supervisionar também as atividades da Secretaria da Receita Federal e do Conselho Interministerial de Preços (GALVÊAS, 1990, p. 50; CARNEIRO, 1990, p. 309). Seu interesse era obter o maior domínio possível sobre a área orçamentária para conseguir reorganizar, equilibrar as contas públicas e sanar a inflação. Não tinha ganas de cuidar das funções executivas que cabiam ao Planejamento, tanto que pouco interessou-se pelo Conselho de Desenvolvimento e que desfez-se do BNDE, passando-o para o Ministério da Indústria e do Comércio, em 1979. Ao que Velloso comenta:

coisa com que eu nunca concordaria, pois achava que o BNDE era o instrumento mais importante de que dispúnhamos para a execução dos projetos prioritários do II PND. Por isso mesmo, em hipótese alguma eu iria abrir mão do BNDE. Mas o Simonsen estava muito empenhado em resolver certos problemas, e até concordo com ele, por exemplo, de querer eliminar os subsídios que havia no orçamento monetário. Havia subsídios à agricultura, e ele fez um plano para eliminar totalmente esses ou quaisquer outros, porque lugar de subsídio não é dentro do orçamento monetário, e sim dentro do orçamento normal do governo, para ser pago com dinheiro do Tesouro, e não com recursos do Banco Central. Ele procurou fazer isso, começou, mas só foi até certo ponto. Aconteceu que a situação externa se agravou, ele insistiu na ideia de que era preciso desacelerar o crescimento para qualquer coisa da ordem de $3 \%$, mas havia outra ala dentro do governo que queria acelerar. O presidente Figueiredo ficou com a outra ala, e o Simonsen foi para casa (João Paulo dos Reis Velloso in: ALBERTI et al., 2002, p. 195). 
O programa de estabilização de Simonsen previa cortes em áreas não prioritárias, redução dos subsídios, limitação do acesso das estatais ao crédito com o objetivo de melhorar o balanço de pagamentos e reduzir o ritmo de endividamento externo. $\mathrm{O}$ ataque ao Planejamento não veio nem do Ministério da Fazenda, que ficou nas mãos de Karlos Heinz Rischbieter, que era um indicado de Simonsen que fora presidente do Banco do Brasil (BB) quando Simonsen estava na Fazenda, nem do Banco Central que estava nas mãos de Carlos Brandão, que Rischbieter conhecia do Banco do Brasil. Veio do Ministério da Agricultura, ocupado por Delfim Netto, e dos próprios militares. Eles acreditavam que as medidas propostas pelo Ministro seriam extremamente impopulares, já que provavelmente gerariam recessão e concentração de renda, semelhante ao que ocorrera nos anos do Plano de Ação Econômica do Governo (PAEG) do governo de Humberto Castello Branco, do qual Simonsen foi um dos principais redatores. Em um cenário no qual a ditadura já vinha sofrendo revezes eleitorais e no qual começava a haver abertura - a censura chegava ao fim, os anistiados retornavam e as greves eclodiam -, embarcar em um programa que soasse a arrocho poderia incitar uma deposição revanchista no lugar da lenta, gradual, discreta e pacífica transição do poder para os civis (MACARINI, 2008, pp. 8-11; CARNEIRO, 1990, p. 308; GALVÊAS, 1990).

Sem conseguir fechar o orçamento de 1979 e sem ter suficiente apoio para seu programa de estabilização, Simonsen deixou o governo em agosto de 1979. Seu ajuste econômico foi substituído por uma política prioritariamente voltada ao crescimento que prometia estabilizar sem desaquecimento. A equipe econômica era agora liderada por Delfim Netto a partir do Ministério do Planejamento. Ernane Galvêas, que fora presidente do Banco Central durante quase todo o delfinato, volta ao posto por 5 meses, transferindo-se em janeiro de 1980 para o Ministério da Fazenda, onde ficou até a redemocratização ${ }^{462}$. Galvêas conta ter ido

para o Banco Central e para o Ministério da Fazenda pela mão do Delfim Netto. Não importa que o Figueiredo tenha me chamado, tenha me dito que a escolha foi pessoal dele [...]. eu voltei para o governo pela mão do Delfim de quem eu era amigo incondicional [...] eu trabalhava com o Delfim a quatro mãos, como o Roberto Campos e o dr. Bulhões. Como eu trabalhei com ele, antes, quando ele era ministro da Fazenda e eu era presidente do Banco Central. Nós já tínhamos essa experiência de nos reunirmos toda manhã, às sete horas da manhã, e de noite e... Ainda mais em Brasília, em que nós praticamente saíamos do ministério

462 Ver: http://memoria.bn.br/DocReader/docreader.aspx?bib=030015_10\&PagFis=1. Consultado em $30 / 03 / 2016$. 
às nove horas da noite, jantávamos juntos; de manhã estávamos juntos, de tarde estávamos juntos, as reuniões todas juntas (GALVÊAS, 1990, pp. 50-51).

Galvêas argumenta que era essencial haver afinidade entre os dois ministérios, que tendem a brigar a não ser que os ministros estejam plenamente dispostos a trabalhar a 4 mãos. Ele sabia que Delfim seria o primeiro-ministro da área econômica e estava a disposto a colaborar com ele, não pretendendo ser uma superestrela. O lugar de Galvêas no Banco Central foi ocupado por Geraldo Langoni, que atuava já como diretor da Área Bancária do BCB.

No princípio da gestão de Delfim no Planejamento, a estratégia para sobreviver à crise situava-se no espectro da heterodoxia, já que buscava propulsionar crescimento sem ajuste prévio. Se o governo Geisel e o II PND apostaram na industrialização e na tecnologia, Delfim retornava à agricultura, área de sua predileção desde os tempos de FEA. Em seu discurso de posse, ele conclama: "Senhores, preparem seus arados e suas máquinas: nós vamos crescer" (Delfim Netto apud MACARINI, 2008, p. 13). Quanto mais a agricultura e as exportações crescessem melhor seria o balanço de pagamentos e maior a deflação. Ao mesmo tempo em que incentivava a agricultura, Delfim tentava reduzir o déficit do governo, que desde a década de 1960 julgava ser a principal fonte inflacionária, promovendo cortes em áreas que ele não considerava prioritárias, notavelmente nos segmentos industriais de ponta que haviam sido priorizados pelo II PND dos seus antecessores (MACARINI, 2008).

As ousadias de feições heterodoxas não duraram muito. Ao final de 1980, em meio à aguda crise internacional que se instaurara e à redução do comércio internacional, com o qual Delfim contava para sanear a balança, sua política tornou-se insustentável, sendo substituída por um conjunto clássico de medidas ortodoxas: elevação dos juros, contenção de gastos, arrocho salarial, restrição do crédito e limitação do crescimento das estatais. Tais medidas visavam não apenas a correção da situação das finanças, mas também a emissão de sinais aos credores internacionais de que o país estava disposto a adequar-se às regras da "boa conduta econômica" (MODIANO e CARNEIRO, 1990; MACARINI, 2008).

Ainda que estivesse atravessando um momento de profunda adversidade, agravado pela suspenção geral do crédito após a crise polonesa e a moratória mexicana, o governo aguardou até o fim das eleições de 1982 para recorrer ao FMI. Novamente a política econômica respondia ao desejo de não ser impopular e incorrera no maior déficit do 
balanço de pagamentos já registrado, mais de duas vezes maior do que o de 1980 que já havia sido considerado crítico. A partir de janeiro de 1983, o Brasil começou a trocar cartas de intenções com o FMI, aceitando submeter-se ao controle do Fundo em troca da possibilidade de repactuar os termos de pagamento da dívida e reabrir as negociações com os credores. Os termos das negociações com o FMI eram tão rígidos que levaram Geraldo Langoni, o Chicago Boy brasileiro, a deixar o Banco Central por considerar as metas por eles definidas não factíveis. Langoni chegou ao ponto de declarar que o Brasil deveria batalhar por termos mais favoráveis pois os acordos tal qual estabelecidos em 1983 não trariam benefícios, ao contrário, levariam o país à miséria generalizada já no ano seguinte. Langoni foi substituído por Affonso Pastore no BCB e nunca retornou ao setor público $^{463}$ (MODIANO e CARNEIRO, 1990; MACARINI, 2008).

A ação do BNDE respondeu, durante o governo Figueiredo, às duas estratégias adotadas por Delfim - no início do mandato incentivos estatais ao crescimento e subsídios exportações agrícolas, seguido da política de cortes e desaquecimento de matriz ortodoxa. No relatório de atividades de 1979, o Banco anuncia ter feito "alguns deslocamentos em sua estratégia de atuação, em benefício dos setores de energia, agricultura e infra-estrutura" e explica que a medida faz parte da "intensificação das ações que visam atenuar as pressões do desequilíbrio do balanço de pagamentos e do recrudescimento da inflação" (BNDE, 1979). O apoio à agroindústria, à produção de alimentos, à armazenagem, à exportação de bens primários e à produção de bens de consumo populares são novidades, já que essas áreas nunca foram prioritárias. O investimento em energia, ao contrário, era uma área antiga de atuação do Banco e dava continuidade às políticas do governo anterior para o setor. A ideia de buscar grupos particulares nacionais dispostos a iniciar um processo de privatizações, é anunciada pela primeira vez como uma possibilidade. Em suma, o BNDE de 1979 adota uma rota contrária àquela do II PND, que estivera concentrado no crescimento industrial voltado à produção de bens de capital com fomento ao desenvolvimento tecnológico e intensa participação estatal ${ }^{464}$.

\footnotetext{
${ }^{463}$ Ver: http://memoria.bn.br/DocReader/docreader.aspx?bib=030015 10\&PagFis $=68774$ e http://memoria.bn.br/DocReader/docreader.aspx?bib=030015_10\&PagFis=68786 Consultado em 30/03/16.

${ }^{464}$ Ver: http://memoria.bn.br/DocReader/DocReader.aspx?bib=030015_09\&PagFis=194199 http://memoria.bn.br/DocReader/DocReader.aspx?bib=030015_09\&PagFis=194415. Consultados $30 / 03 / 2016$.
} 
Em 1980, o Banco passa a atuar no saneamento financeiro de empresas nacionais em situação de fragilidade decorrente da crise econômica. O BNDESPAR, que passou a reunir as subsidiárias Investimentos Brasileiros S.A. (IBRASA), Mecânica Brasileira S.A. (EMBRAMEC) e Insumos Básicos S.A. (FIBASE), foi o principal responsável pela capitalização das empresas em dificuldade, adquirindo seus ativos. Algumas vezes o Banco passava a controlar diretamente a companhia, outras vezes atuava em conjunto com os proprietários originais. Tal política onerou os quadros do Banco com atividades de administração de empresas e chegou a comprometer mais de 50\% do capital do BNDESPAR, passando o BNDE a ser correntemente chamado de "hospital de empresas”465 (VELASCO JR, 2010, pp. 316-318; MOURÃO, 1994, pp. 4-6).

A orientação do Banco para os setores de infraestrutura, agricultura e, a partir de 1982, social - ou seja, projetos nas áreas de saúde, educação, habitação popular e pequena agricultura - não deixava de ser uma conformação a um modelo liberal, no qual o país voltava a buscar vantagens comparativas agrícolas e o Estado fornecia algum apoio periférico, realizando as obras faraônicas que o setor privado não seria capaz de suportar e administrando políticas sociais alimentadas com contribuições privadas compulsórias. Convergentemente, para administrar os projetos do Banco na área social, Delfim Netto aponta um homem de sua confiança, um liberal convicto, discípulo de Og Leme, PhD pela universidade de Chicago e professor da EPGE, Rubem de Freitas Novaes ${ }^{466}$.

Funcionários do BNDES alegam que a criação da área social não foi fruto de projeto que emanasse da instituição, que sequer foi consultada. Além disso, a atribuição do social ao Banco foi severamente contestada por ser interpretada como uma manobra fiscal e uma medida populista do governo (Entrevistas à autora, 2012-2015). Houvesse ou não intenção de promover melhoria social, a transferência do FINSOCIAL para o BNDES fora conveniente ao grupo dominante da área econômica pois, em primeiro lugar, foi acompanhada da volta do BNDES para o Ministério do Planejamento, sob alegação que com funções sociais o órgão não teria porque estar vinculado ao Ministério

\footnotetext{
${ }^{465}$ Eram pacientes do hospital de empresas companhias como a Caraíba Metais, a CEPLAG papel e celulose a Companhia de Celulose da Bahia, a Companhia Brasileira do Cobre, A Companhia Nacional de Tecidos Nova América, a COSINOR Siderurgia do Nordeste, a Máquinas Piratininga, a SIBRA eletrossiderurgia e a Mafersa. Outras empresas, como a Aracruz, a Siderúrgica Nossa Senhora Aparecida, a CIMETAL, a COBRA computadores e Nitrogenados Riograndenses não passaram a ser controladas pelo BNDE mas contavam com grande participação do Banco (VELASCO JR, 2010, pp. 317-318).

${ }^{466}$ Ver: http://memoria.bn.br/DocReader/docreader.aspx?bib=030015 10\&PagFis $=87069 \mathrm{e}$

http://ordemlivre.org/posts/a-escola-de-chicago-atraves-de-seus-expoentes. Consultados em 30/03/16.
} 
da Indústria e Comércio 467 e, em segundo lugar, o orçamento da área social foi prioritariamente direcionado para as áreas de alimentação e pequena produção rural, coadunando com a total prioridade que o Planejamento dava à agricultura, além de não onerar o orçamento do Banco ou do governo, visto ser baseado em contribuições privadas (BNDES, 1983, p. 18). Cabe citar ainda que o modo de aplicação das verbas do FINSOCIAL gerou controvérsia no princípio.

Ao Banco tinha sido dada a atribuição, na prática, de executar apenas, portanto contratar decisões do Governo Federal expressas em instruções de motivos assinadas pelo Presidente da República, na época o Figueiredo: [...] temos que fazer estradas nas áreas, projetos de assentamentos na Amazônia, não sei o que... então eu destino 50 milhões para isso. $\mathrm{E}$ ao banco era dada a incumbência de executar. Aí [houve] o primeiro grande conflito, porque a gente estava acostumado a analisar projeto, a avaliar as coisas. De jeito nenhum [aceitariam esse procedimento]. Aí começamos a discutir e acabou que houve uma repartição. Quando o [Carlos] Lessa entrou para o Banco, conseguimos finalmente chegar em um entendimento e dividiu-se o FINSOCIAL. Uma parte ficou diretamente em Brasília, não sei que fim levou, e a outra parte vinha para o BNDES, que [...] podia utilizá-lo conforme bem entendesse (Entrevista à autora, 2012-2015).

Em setembro de 1983, um ano e pouco depois da criação da BNDESPAR, da instalação da área social e alteração do nome do Banco, Luiz Sande foi obrigado a deixar a presidência pois ACM, que fora quem o designara para o posto, estava insatisfeito com as pretensões políticas de seu apadrinhado e com as alianças por ele travadas, principalmente porque Sande vinha cortejando uma aproximação com Paulo Maluf, adversário de ACM na briga pela posição de candidato do Partido Democrático Social (PDS) - sucessor da ARENA - à eleição indireta para a Presidência da República.

Os problemas de Sande não eram apenas externos ao Banco, ele era acusado publicamente de usar as obras do BNDES para divulgação pessoal, por exemplo batizando com seu nome uma rodovia e um complexo metalúrgico feitos com apoio do Banco 468 e membros da burocracia do Banco até hoje expressam repúdio quando referem-se a sua gestão. Marco Antônio Lima, ex-funcionário do Banco, que escreveu um mestrado sobre a instituição, afirma que "as subsidiárias haviam passado por uma dura experiência no início da década de 80, durante a gestão de Luís Sande, quando os parâmetros de recrutamento das subsidiárias foram substituídos por práticas patrimonialistas, o que gerou, inclusive, um fortalecimento do movimento sindical dentro

\footnotetext{
${ }^{467}$ Ver: http://memoria.bn.br/DocReader/DocReader.aspx?bib=030015 10\&PagFis=43404 http://memoria.bn.br/DocReader/DocReader.aspx?bib=030015_10\&PagFis=43448. Consultados em 30/03/16. 468 Ver: http://memoria.bn.br/DocReader/DocReader.aspx?bib=030015_10\&PagFis=69024. Consultado em $30 / 03 / 2016$.
} 
do Banco" (LIMA, 2006, p. 88). Alguns entrevistados chegaram a utilizar as seguintes expressões para caracterizar sua gestão: "um presidente que trouxe uns assessores esquisitos, chamado Luiz Sande", "foi o pior presidente da história do BNDES". "Tentou efetivamente transformar o Banco em uma instituição que seguisse os seus interesses políticos", chegou-se mesmo a dizer que ele consagrou-se à "busca mesquinha de interesses particulares", foi o único caso de uma gestão sobre a qual todas as opiniões encontradas na literatura e registradas nas entrevistas eram negativas (Entrevistas à autora, 2012-2015).

Assim que despossou um de seus apadrinhados, ACM prontificou-se a nomear outro baiano de sua confiança para a Presidência do Banco, Jorge Lins Freire (1942). Nascido em Salvador e filho de um telegrafista e escriturário do ministério de Viação e Obras, Freire cursou Química Industrial na Escola Técnica Federal e depois formou-se administrador na Universidade Federal da Bahia (UFBA). As condições familiares desprivilegiadas levaram-no, ainda adolescente, a trabalhar na Secretaria da Fazenda do Estado, onde ascendeu de office boy a secretário da fazenda, substituindo Sande, de quem fora assessor chefe. Antes de ir para o BNDES, ele havia sido ainda presidente do Banco de Desenvolvimento da Bahia ${ }^{469}$ (DHBB, verbete Jorge Lins Freire). Freire é descrito como um "técnico", ainda que fosse um apadrinhado, por ter feito trajeto ascendente no serviço público antes de ser adotado por ACM Em outubro de 1984, um ano depois de assumir o Banco, foi a vez de Freire ser derrubado pela disputa sucessória entre ACM e Paulo Maluf. Freire ficou do lado de ACM, entregando sua carta de demissão depois de ter se sentido intimado a deixar o BNDES pelo presidente nacional do PDS que disse que deveriam ser afastados do governo todos aqueles que se recusassem a apoiar a candidatura de Maluf. Jorge Lins Freire não foi o único exonerado na ocasião, acompanhou-o, por exemplo, Jorge Murad, diretor da Caixa Econômica que depois se tornaria o assessor mais próximo de José Sarney ${ }^{470}$.

Faltando poucos meses para o novo governo, Delfim optou por não nomear alguém próximo a Maluf, como requisitavam as forças ligadas ao PSD. Passou à presidência o diretor da área internacional e financeira do Banco, José Carlos Perdigão Medeiros da Fonseca (1925-2012), uma pessoa sem vínculos partidários e com uma longa

\footnotetext{
${ }^{469}$ Ver: http://www.alba.ba.gov.br/noticias/Noticia.php?id=3007. Consultado em 30/03/16.

${ }^{470}$ Ver: http://memoria.bn.br/DocReader/docreader.aspx?bib=030015 10\&PagFis $=87012$ http://memoria.bn.br/DocReader/docreader.aspx?bib=030015_10\&PagFis $=87233$ http://memoria.bn.br/DocReader/docreader.aspx?bib=030015_10\&PagFis=87052. Consultados em 30/03/16. 
carreira na burocracia de Estado e experiências internacionais na área econômica. José Carlos Fonseca era carioca e filho de Arnoldo Medeiros da Fonseca, um advogado que fora professor da Faculdade Nacional de Direito da Universidade do Brasil e que chegou a ser presidente do Instituto dos Advogados do Brasil. Seguiu o caminho familiar, estudando direito na faculdade onde o pai lecionava e trabalhando no escritório dele antes de ingressar no departamento jurídico da Superintendência da Moeda e do Crédito (SUMOC), onde trabalhou de 1953 até 1965, com uma pequena interrupção de 1958 a 1961, quando foi assessor do Gabinete Civil de JK. Quando a SUMOC foi convertida em BCB, Medeiros da Fonseca foi transferido para o novo órgão. Nos anos seguintes dividiuse entre cargos no BCB e no Banco Interamericano de Desenvolvimento (BID). De volta ao Brasil em 1982, foi nomeado para a área financeira do BNDES, posição que ocupou até ser nomeado presidente do Banco dois anos depois (DHBB, verbete José Carlos Perdigão Medeiros da Fonseca).

Foi das mãos de Perdigão da Fonseca que Dílson Funaro e André Franco Montoro Filho receberam o BNDES. A diretoria do Banco do primeiro governo da Nova República resultara quase inteiramente de uma composição político-partidária. Cláudio de Araújo Peçanha antes de ser engenheiro civil formado na UFRJ com mestrado em economia na FEA, era filho de Celso Peçanha, líder do PTB na Câmara Federal que tinha longa carreira política no PTB e depois no MDB, além de ser da família do Presidente Nilo Peçanha. Ivandro Cunha Lima da Paraíba era advogado de formação e trabalhara como tabelião e agropecuarista antes de entrar na vida política e ser eleito senador pelo MDB. José Augusto Amaral de Souza era político originalmente do PSD, depois deputado e governador pela ARENA e na reforma partidária migrou para o PDS mas não apoiou a candidatura de Maluf para a presidência. Ronaldo Tostes Mascarenhas, advogado formado pela PUC-RJ e procurador de Justiça do Estado do Rio de Janeiro era uma indicação do PFL, legenda pela qual era governador do Piauí Hugo Napoleão, cunhado de Mascarenhas ${ }^{471}$. Rômulo de Almeida, ainda que fosse economista e respeitado por sua longa carreira na administração econômica, a começar pela Confederação Nacional das Indústrias e pela Assessoria Vargas, tinha também seu lado político. Havia sido deputado federal pela Bahia nos anos 1950 e era, na ocasião em que foi nomeado

\footnotetext{
${ }^{471}$ Ver: http://memoria.bn.br/DocReader/DocReader.aspx?bib=386030\&PagFis=123903 e http://memoria.bn.br/DocReader/DocReader.aspx?bib=170054_02\&PagFis=12875. Consultados em 01/04/2016.
} 
para o BNDES, presidente de honra do PMDB baiano (DHBB, verbetes Celso Peçanha, Ivandro Cunha Lima, Amaral de Souza, Rômulo de Almeida, Hugo Napoleão).

A gestão de 1985 contou, além disso, com 3 pessoas que em algum momento ocupariam a presidência do BNDES. André Franco Montoro Filho, que sucederia Funaro em agosto de 1985, e Francisco Gros (item 6.5) e Carlos Lessa que seriam presidentes nos anos 2000 (item 1.5). Na época em que Lessa assumiu a diretora social do BNDES ele ainda colaborava com a UNICAMP, mas já havia obtido posição de professor titular no Instituto de Economia Industrial da UFRJ (IEI-UFRJ) e voltado ao Rio de Janeiro.

O IEI é decorrência e continuidade do Grupo de Pesquisa da Financiadora de Estudos e Projetos (FINEP), criado por Pelúcio Ferreira, funcionário do BNDE que presidiu a Financiadora de 1971 a 1979. O grupo começou enquanto Pelúcio ainda estava no Ministério do Planejamento de Reis Velloso e transferiu-se com ele para a FINEP, sendo a direção de pesquisa entregue inicialmente a Fábio Erber, economista formado na FNCE em 1965, que fora aprovado em concurso para o BNDE em 1966. Além de trabalhar no BNDE, Erber fora professor assistente de economia na PUC-RJ, na Universidade do Estado da Guanabara (UEG) e na Cândido Mendes, entre 1967 e 1969, partindo para a Inglaterra em 1970 com bolsa do British Council para fazer mestrado em desenvolvimento econômico na University of East Anglia. De volta ao Brasil em 1971, Erber foi levado por Pelúcio para a FINEP.

O grupo de pesquisa dedicava-se a produzir conhecimento que orientasse a aplicação dos recursos da FINEP nas áreas de ciência e tecnologia de modo a alavancar o desenvolvimento econômico. Segundo Eber a ideia provavelmente decorria da longa experiência de Pelúcio no Departamento Econômico do BNDE, que fez com que concebesse que os órgãos de Estado precisavam ter condições de internamente "elaborar, monitorar e modificar as políticas públicas de que estavam encarregados" (Fábio Erber apud FERRARI, 2002, p. 167). No período em que foi dirigido por Erber, de 1971 a 1974, o grupo desenvolveu a pesquisa Criação e absorção de tecnologia na indústria de bens de capital, tema privilegiado pelo Ministério do Planejamento durante toda a gestão de Reis Velloso entre 1969 e 1979 (item 4.5).

Quando Erber partiu novamente para Inglaterra, agora para fazer o doutorado Technological development and State intervention: a study of the Brazilian capital goods industry (1978) na University of Sussex, o grupo foi assumido por outro economista formado na FNCE, 
José Tavares de Araujo Júnior, que concluíra a graduação em 1968 e fizera parte da sociedade secreta à la Keynes Club de Francisco Lopes e Dionísio Dias Carneiro. Como seus colegas, José Araujo havia feito o mestrado na EPGE e, logo na sequência, passou a integrar o grupo de pesquisa da FINEP. Em suas mãos, de 1974 a 1977472, o grupo ampliou seu escopo de atuação, passando a incorporar pesquisadores de diversas áreas. Criou-se um grupo coordenado por Simon Schwartzman que conduzia um projeto sobre A Formação da Comunidade Científica no Brasil, outro atribuído a Luciano Martins que reuniu equipe para dar continuidade às pesquisas sobre as elites de Estado que havia começado a desenvolver nos anos sessenta na UFRJ, antes de exilar-se na França e havia uma pesquisa sobre Emprego e mudança socioeconômica no Nordeste, da qual participaram os economistas formados na PUC-RJ Anfrânio Garcia e José Sergio Leite Lopes, desenvolvendo pesquisas etnográficas que seriam influentes na formação da pós-graduação em antropologia social do Museu Nacional da UFRJ. Finalmente, a FINEP reuniu um grande grupo economistas que atuavam como pesquisadores ou consultores nas pesquisas sobre o complexo industrial brasileiro, entre os quais Antonio Barros de Castro, Eduardo Augusto Guimarães, Jacob Frenkel, Leane Naidin, Maria da Conceição Tavares, Maria Fernanda Gadelha, Marcelo de Paiva Abreu, Mario Possas, Luís Otávio Façanha, Ricardo Bielschowsky, Ricardo Tolipan, Sulamis Dain e Vera Pereira. Todos eles acabariam, mais cedo ou mais tarde, ligados ao IEI-UFRJ ou ao seu substituto, o Instituto de Economia (IE-UFRJ) 473 (FERRARI, 2002).

Até o final dos anos 1970, a pós-graduação da Fundação Getúlio Vargas imperara livremente no Rio de Janeiro. Em São Paulo, além da USP com sua diversidade ideológica interna, havia duas escolas de feições críticas, a UNICAMP e a PUC-SP. Em contexto de intensificação da luta contra a ditadura, os economistas cariocas de oposição agregam-se ao redor do Instituto dos Economistas do Rio de Janeiro (IERJ) - sendo seus primeiros presidentes conhecidos nomes da oposição, Pedro Malan, Maria da Conceição Tavares, Antônio Barros de Castro, Carlos Lessa, Fábio Sá Earp, Ricardo Bielschowsky e Sulamis Dain, quase todos ligados às pesquisas da FINEP e todos, com exceção de Malan, ${ }^{474}$

\footnotetext{
${ }^{472}$ Em 1977, José Araujo deixou a FINEP e foi fazer seu doutorado na University of London, onde escreve a tese Technical progress and forms of competition, a case study of the glass industry (1982).

${ }^{473}$ O IE-UFRJ nasceu em 1996 da fusão da pós-graduação em economia oferecida pelo IEI com a graduação em economia da Faculdade de Economia e Administração (FEA-UFRJ).

${ }^{474}$ Pedro Malan tentou ingressar no quadro docente da UFRJ mas perdeu o concurso contra Antonio Barros de Castro em 1982, partindo para os Estados Unidos onde tornou-se diretor da divisão de análise de políticas e depois diretor de economia internacional da ONU. Na sequência foi indicado para o posto de diretor executivo
} 
futuros professores da UFRJ. Alguns dos pesquisadores da FINEP e membros do IERJ lecionavam na época no Instituto Alberto Luiz Coimbra de Pós-Graduação e Pesquisa de Engenharia (COPPE-UFRJ), começando a partir de lá a organizar a pós-graduação em economia da UFRJ. Quase ao mesmo tempo surgiu a pós-graduação em economia da PUC-RJ, que data de 1978.

Em consonância com o vínculo que os professores que dariam origem ao curso da UFRJ mantinham com a FINEP, a nova escola passou a enfocar as áreas de tecnologia e indústria, sendo, pois, batizada de Instituto de Economia Industrial, inaugurado em 1979. Como o COPPE tinha grupos de pesquisadores ligados à área industrial e à economia da tecnologia e havia aberto, em 1976, um programa de mestrado na área, foi feito um convênio para levar os professores que conduziram a pós-graduação em economia na engenharia para o IEI. Migraram do COPPE para o novo instituto, professores como João Saboia, José Antonio Ortega, José Ricardo Tauile e Winston Fritsch, que tinha graduação e mestrado em engenharia pela UFRJ, e havia sido colega de Marcelo Abreu na pós-graduação em economia de Cambridge. De Campinas, a UFRJ absorveu Maria da Conceição Tavares, Carlos Lessa e Antonio Barros de Castro que voltavam à universidade que foram forçados a deixar 15 anos antes, quando se instaurou a ditadura. Da FINEP vieram outros tantos economistas, como Fábio Erber, José Tavares de Araújo, Sulamis Dain, Jacob Frenkel e Eduardo Augusto Guimarães. Finalmente convidou-se Américo Cury, Antonio Dias Leite e Pelúcio Ferreira que eram nomes da primeira geração de economistas brasileiros. Pelúcio fora quem concedera, via FINEP, a verba solicitada por Cury e Conceição Tavares, seus colegas dos tempos de BNDE, para que o instituto pudesse ser criado. Logo os primeiros pós-graduandos da escola começaram a lecionar no IEI, casos, por exemplo, de Edward Amadeo, Luiz Orenstein, Beatriz Azeredo e seu marido Aloísio Teixeira (FRENKEL, 2013, p. 7; MEDEIROS, 2005).

Pouco depois da Fundação Getúlio Vargas passar pelo processo de cisão interna que levou à migração do núcleo formado por Francisco Lopes, Dionísio Dias Carneiro e Rogério Werneck para a PUC-RJ, a UFRJ viveu experiência semelhante. Depoimentos conjecturam motivos diversos para a ruptura no recém criado IEI. Fala-se de disputa pelo controle das posições de direção, de disputa de vaidades e personalidades, de conflitos

do Brasil no Banco Mundial e em seguida no BID. De 1991 a 1993 foi negociador da dívida externa Brasileira, permanecendo ao todo dez anos nos EUA (DHBB, verbete Pedro Malan). 
entre os professores que voltavam com formação anglo-saxã que tendia a ortodoxia e adeptos do desenvolvimentismo, de divergência quanto à orientação que a escola deveria adotar: se deveria privilegiar a formação de quadros para o setor público ou se deveria concentrar-se em pesquisa acadêmica alinhada aos parâmetros internacionais. Provavelmente vários destes pontos de atrito operaram simultaneamente ${ }^{475}$. Após a separação, Américo Cury aposentou-se, Pelúcio foi ocupar-se da Fundação Padre Leonel França da PUC-RJ, Jacob Frenkel voltou a dar aulas apenas na graduação e Marcelo Abreu e Winston Fritsch migraram para a PUC-RJ, ficando o IEI nas mãos do grupo de Campinas aliado a uma grande parte dos engenheiros da COPPE e dos pesquisadores oriundos da FINEP (FRENKEL, 2013; MEDEIROS, 2005, pp. 73-74; Entrevistas à autora 2012-2015).

Diversos professores do IEI-UFRJ ocupariam cargos de direção no BNDES. Fábio Erber foi diretor do Banco em duas ocasiões, Beatriz Azeredo, Luiz Orenstein e João Carlos Ferraz foram diretores e Barros de Castro e Lessa foram diretores e ocuparam a presidência da instituição. Lessa, quando foi indicado para a diretoria em 1985, além de professor da UFRJ era parte do grupo dos economistas do PMDB, muito ligado a Ulysses Guimarães, sendo por ele indicado a Tancredo Neves para a diretoria da área social. Tỉnha também boas relações com o novo presidente do Banco, Dílson Funaro, que caracteriza como um "militante progressista" e diz ser "amicíssimo meu. Eu tinha ajudado a ele, quando ele foi secretário em São Paulo”. Lessa conseguiu, assim, espaço para implementar seu projeto para a área social (Entrevista de Carlos Lessa à autora, 2012).

Até o exercício de Carlos Lessa e sua equipe - que incluía os futuros diretores Aluysio Asti, Luiz Orenstein e Marcio Henrique Monteiro de Castro -, a área social dedicava-se a repassar capital para programas de cunho assistencial já existentes. Além de oferecer apoio material o Banco dava suporte técnico para a programação dos investimentos e os trâmites burocráticos relacionados aos projetos (BNDES, 1984). A partir de 1985, o conceito de aplicação das verbas destinadas ao social é alterado, visto que além de apoiar iniciativas apresentadas por órgãos implementadores, o Banco passou

\footnotetext{
${ }^{475}$ Não apenas Fritsch e Abreu estudaram na Inglaterra, mas sim um grande grupo que incluía Sulamis Dain, José Araujo Tavares e Eduardo Augusto Guimarães na University of London, Barros de Castro, em Cambridge, Fábio Erber em East Anglia e Sussex, Ricardo Bielschowsky em Leicester, professores das gerações seguintes como José Cassiolato, Helena Lastres e João Carlos Ferraz em Sussex e tantos outros. A afinidade com a Inglaterra dá-se pela concentração do IEI nos temas ligados à indústria e tecnologia e à história econômica, áreas de pesquisa nas quais a Inglaterra tem destaque.
} 
a operar diretamente na pesquisa e formulação de programas para a área social. No relatório de 1985, é anunciado que

a atuação do Banco, no que concerne à gestão do FINSOCIAL, evoluiu no sentido de operar com maior autonomia na definição das ações a serem apoiadas. Concentrou-se esforços na identificação de oportunidades localizadas de investimentos que pudessem ser exitosas na promoção da qualidade de vida de um grupo específico da população e, também, permitissem ao BNDES realizar um papel de agente modernizador (BNDE, 1985, p. 18).

A ideia central era "fomentar, estruturar e bancar os chamados projetos exemplares", ou seja, "projetos que você não faz para o país inteiro mas faz um, dois, para demonstrar que desta forma é melhor, mais prático, mais eficiente e mais efetivo”, induzindo os órgãos competentes a implementar os novos métodos sistematicamente. Dentre as iniciativas pioneiras havia, por exemplo, projetos de saneamento urbano, com o incentivo à construção de sistemas de esgoto simplificados para locais de aglomeração de populações de baixa renda, associada à criação de fábricas de baixo custo para produzir insumo para as obras e projetos de construção de usinas de beneficiamento de lixo que empregariam os catadores formalizando seus empregos (BNDES, 1985, 1986, 1987, 1988). A ideia adotar "temas que nós percebemos que eram enormemente importantes e sobre os quais se fazia pouca experiência ou não havia um debate ou não havia iniciativas que servissem para avaliar as coisas" (Entrevista de Carlos Lessa à autora, 2012). (Entrevista de Aluysio Asti à autora, 2012).

As dificuldades enfrentadas pela área social eram, não obstante, múltiplas. Em primeiro lugar havia um enorme conflito de competências entre os numerosos órgãos encarregados das política sociais em nível federal e também entre os níveis federal, estadual e municipal e as diversas secretarias, ministérios e autarquias. O departamento teve conflitos com Brasília e com os órgãos que denunciaram por não estarem implementando as ações para as quais recebiam verbas. Ex-diretores explicam que atuar na área social era uma grande mudança:

Eu estava costumado a visitar empresas e bancos, então de repente você vai visitar comunidades no interior do Brasil, coisas horrorosas. Quando você estava ali nos anos setenta [cuidando da industrialização], a impressão que você tinha é que o país estava crescendo no ritmo das coisas que o Banco fazia. Mas só uma parte de fato acompanhou. Tinha uma parte que ficou meio esquecida e atrasada. $\mathrm{Na}$ área social a gente teve muito contato com isso. [O que mais chocava era] o atraso, a pobreza, a miséria [...], isso por um lado. Por outro lado, a idiotice governamental que provocava uma disputa entre governos, agências, todo mundo querendo fazer alguma coisa, uma descoordenação absoluta. O contraste da política pública para a área social e a política pública para a área industrial era tanto. $\mathrm{O}$ pessoal que trabalhava com empresa era tão mais bem preparado, tão 
mais coordenado. A confusão na área social era muito impressionante, acho que foi um contraste muito grande (Entrevista à autora, 2012-2015).

Tal contraste entre a expertise e a autonomia que o Banco tinha para atuar na área industrial, já que desde o início do período de acelerado desenvolvimento nacional o BNDE consagrara-se como o principal agente do setor, e a enorme dificuldade de entrar na área social, que já tinha uma miríade de iniciativas em curso muitas das quais em conflito entre si, fazia com que parte dos quadros e dirigentes da instituição não visse sentido na atuação do Banco neste segmento, até porque a área era vista por muitos como uma simples travessura orçamentária de Delfim Netto. Em um dos depoimentos argumenta-se que

fora o pessoal que estava no Social, o resto do Banco desconhecia, nem queria saber disso. Tanto é que jamais aqueles projetos que fizéssemos transitaram pela porta de entrada tradicional do BNDES, que é o departamento de prioridades que orienta as decisões do comitê de prioridades do Banco para dizer se o projeto vai ser realizado ou não. Nem isso a gente conseguiu. Então era natural que dois ou três anos... especialmente na transição para o Collor isso fosse terminado na prática (Entrevista à autora, 2012-2015).

De fato, com os cortes ordenados por Collor, a área acabou extinta e só seria remontada em meados dos anos noventa. Ainda que a segunda experiência com o social não tenha resultado de uma estratégia para obter mais recursos, ela continuava não tendo grande enraizamento interno, sendo vista por parte do Banco com reticência. Sobre a segunda experiência com a área social, no final dos anos 1990, revela-se que no princípio "não se criou um diretor social, se criou uma área, em nível de superintendência. Ninguém sabia o que é que ia ser essa área, porque ninguém acreditava muito que o Banco pudesse ter uma área de fato operacional. Meio que foi quase que uma atitude política, do tipo, bota uma área social no BNDES” (Entrevista à autora 2012-2015).

Ao contrário da área social de Lessa, que teve uma vida intermitente e desfrutava de pouco prestígio interno, a área de mercado de capitais entregue a Francisco Gros, o outro diretor de 1985 que se tornou presidente nos anos 2000, teve uma ascensão meteórica. Francisco Roberto André Gros (1942-2010) foi o único diretor escolhido diretamente por Funaro. Contava a seu favor uma trajetória bastante reconhecida no mercado de capitais, para a qual foi designado. Nascido no Rio de Janeiro, Gros era filho de um advogado francês que chegou a ser jurisconsulto do Ministério das Relações Exteriores da França e juiz na Corte Internacional de Haia. Ele veio para o Brasil no final 
da década de 1930, em uma das missões francesas, tornando-se professor de ciência política na Faculdade Nacional de Direito da Universidade do Brasil. No Rio de Janeiro casou-se com Dulce Simões Correa Gros, filha de família brasileira com longínqua ascendência portuguesa, bisneta de Francisco Simões Correa, médico especializado em febre amarela, professor da Faculdade de Medicina do Rio de Janeiro e fundador da Casa de Saúde São Sebastião, em Botafogo, na qual trabalhou também o avô, Álvaro Simões Correa (SANGLARD e FERREIRA, 2010; GROS, 2002).

Francisco cresceu em Botafogo, sempre próximo à Casa de Saúde, que era, diz ele, "um pouco extensão da casa da minha família" (GROS, 2002, [DVD]), e estudou até o final do ginásio no Colégio Santo Inácio, localizado no mesmo bairro. Quando completou 16 anos, mudou-se para os EUA com a mãe que havia casado em segundas núpcias com um norte-americano. Lá terminou os estudos em um colégio que estava

cerca de dez kilômetros da Universidade de Princeton. Eu achava aquela universidade, aquele lugar, realmente lindo, uma beleza. Eu era um bom estudante, tinha boas notas no colégio e fiz uma aplicação [para a universidade] antes do fim do meu penúltimo ano no colégio. Fui aceito cedo, um ano antes, na Universidade de Princeton e nunca fiz aplicação para nenhuma outra, quer dizer, foi aquele caso de amor à primeira vista [...]. Eu iniciei lá os meus estudos em setembro de 1960 e terminei em junho de 1964 [...] Eu estudei essencialmente dentro de um programa especializado que tinha na universidade que é a escola Woodrow Wilson de Assuntos Internacionais e Públicos, que é um centro de estudos avançados bastante conhecido e que me permitia ter uma especialização mais ampla, ter cursos não só de economia, como de história e política para obter o meu diploma (GROS, 2002, [DVD]).

Como tantos dos brasileiros que estudaram no exterior, Gros revela ter sido um brasilianista seu professor mais influente. No caso era Stanley Julien Stein, que viveu um tempo no Brasil na década de 1940 e fez uma pesquisa documental sobre fazendas de café da região de Vassouras no período de 1850-1900. Stein orientou-o na redação de um trabalho sobre "o processo de expropriação mexicana da indústria do petróleo em 1938”. Formado, Francisco viveu 9 meses na África do Sul, trabalhando para um grande conglomerado de mineração e voltou para os Estados Unidos onde cursou mestrado em economia na University of Columbia (GROS, 2002).

Dez anos depois de deixar o país, Gros retornou e empregou-se na Companhia Metropolitana de crédito, financiamento e investimento, no Rio de Janeiro, onde permaneceu cinco anos. Foi a primeira de muitas experiências no mundo das finanças. No início da década de 1970, trabalhou no banco de investimentos Kidder, Peabody \& Co, localizado a alguns minutos de Wall Street. Diz que a experiência enterrou "de vez 
qualquer pretensão de trabalhar fora do Brasil. Eu cheguei à conclusão que as oportunidades eram por aqui, que nós tínhamos todo um país por construir e que eu certamente seria mais feliz trabalhando no Brasil". Ao regressar conseguiu emprego em outra financeira, a corretora Multiplic. No final de 1976, reuniu-se aos especialistas em mercado de capitais que estavam organizando a Comissão de Valores Mobiliários (CVM), que passou a funcionar em 1977 e assumiu funções de regulação do mercado financeiro antes pertencentes ao BCB (GROS, 2002, [DVD]). Gros narra sua experiência do período:

Juntou-se em torno da CVM um grupo de pessoas extremamente capacitadas, extremamente ativas. Com grande espirito público. A maioria dos quais são meus amigos até hoje. O primeiro presidente da CVM foi o Roberto Teixeira da Costa, que foi sucedido pelo Jorge Hilário Gouvêa Vieira, liderando um grupo grande de profissionais de mercado de primeiríssima qualidade. Eu me juntei a eles e fui o funcionário número 7 da CVM. Construímos aquela organização que foi, eu diria, um dos grandes momentos da construção do mercado de capitais brasileiro. Trabalhei na CVM mais de quatro anos, até 1981, e essa foi minha primeira experiência de governo. Foi uma experiência muito rica. Foi uma experiência muito interessante. Num primeiro momento sendo Mario Henrique Simonsen ministro da fazenda, que foi o responsável pela criação, pelo patrocínio da montagem da CVM (GROS, 2002, [DVD]).

Ao deixar a CVM, Gros voltou para o setor financeiro, ocupando posição de diretor da área de mercado de capitais do UNIBANCO. Para tanto, passou quatro anos na ponte aérea Rio-São Paulo. Foi seu colega de CVM, Roberto Teixeira da Costa, que, sabendo de seu interesse em voltar para o Rio, recomendou seu nome a Dílson Funaro, que buscava alguém para a gestão das participações do Banco e do BNDESPAR no mercado de capitais. Gros explica:

profissionalmente eu continuei fazendo o mesmo tipo de coisa que eu fazia no UNIBANCO [...], a única diferença é que o BNDES era muito maior do que o UNIBANCO, então eu continuei a fazer as mesmas coisas com uma equipe muito maior, com uma carteira de investimentos muito maior, com uma escala muito maior [...]. O que eu sempre digo é que havia uma diferença básica: o BNDES era um ponto de observação extraordinário do Brasil, da economia e da realidade brasileira. Eu digo sempre que isso aqui é um curso de pós-graduação em Brasil. Você começa a entender o que é que faz esse país funcionar, quais são os desafios, quais são os pontos importantes [...]. Viajei esse Brasil todo pelo BNDES e mesmo aqui na sede você tinha acesso a problemas, a questões que tinham a ver com as grandes questões do desenvolvimento nacional que você só tem, primeiro, dentro do governo, segundo, dentro do governo em nenhum lugar é melhor do que no BNDES (GROS, 2002, [DVD]).

A primeira passagem de Gros pelo BNDES foi interrompida por outro chamado de Dílson Funaro, agora para assumir a presidência do Banco Central. Em fevereiro de 
1987 tornou-se o terceiro presidente do BCB em um período de dois anos. O governo Sarney teria mais 3 presidentes e um interino. O BCB foi, pois, dirigido por sete pessoas em cinco anos. Gros havia sido nomeado para substituir Fernão Bracher, presidente do Banco Central de agosto de 1985 a fevereiro de 1987. Foi no intervalo em que Bracher esteve à frente do BCB que o governo Sarney implementou o Plano Cruzado, marcando o início de um ciclo de ensaios de políticas de combate à inflação não assentadas em ajuste fiscal, arrocho salarial, desaquecimento econômico e limitação do crédito.

O Plano Cruzado é um evento central no processo de reconfiguração do espaço dos economistas no Brasil da Nova República. A partir desse momento, as propostas e prioridades defendidas por cada um dos grupos de economistas que estavam envolvidos com o governo Sarney passaram a espelhar diferenças entre eles, resultantes de posições políticas e visões econômicas que, ainda que pró-democráticas, eram em muitos aspectos distintas. O Plano Cruzado foi o último momento no qual a maior parte das tendências da oposição colaboram com um mesmo governo, unindo forças para preparar a economia para a democracia. As batalhas travadas nos anos que transcorreram do lançamento à derrocada do Cruzado aprofundaram as clivagens existentes na oposição, redefinido as linhas de tensão do espaço dos economistas e criando novas polarizações.

Dois livros de relato das histórias e conflitos do Cruzado, escritos logo após os eventos, Os pais do Cruzado contam por que não deu certo (1987) e Aventura e agonia nos bastidores do Cruzado (1987), respectivamente por Alex Solnik e Carlos Alberto Sardenberg, expõem as feridas abertas na época e o imbróglio de conflitos institucionais, pessoais, políticos e teóricos que caracterizaram o período. As entrevistas com 11 pessoas que trabalharam diretamente no Plano Cruzado ou no governo Sarney muito próximas ao núcleo de elaboração do Cruzado - André Lara Resende, Andrea Calabi, Edmar Bacha, Fernão Bracher, Francisco Vidal Luna, João Sayad, Luiz Carlos Mendonça de Barros, Luiz Gonzaga Belluzzo, Persio Arida, Philippe Reichstul e Regis Bonelli -, feitas quase 30 anos depois dos eventos e de inúmeras outras tentativas de estabilização, permitem ver a persistência das linhas de oposição criadas naquele momento, mas indicam um maior número de fatores percebidos como responsáveis pelo fracasso do experimento, que ultrapassavam em muito os conflitos de personalidades tão vivazes nos livros produzidos à época. Ainda que certos relatos contenham resquícios de amarguras do período, há um acordo quanto à importância do episódio como ensaio e aprendizado que foi criando a 
expertise e o acúmulo de conhecimentos necessário para que, uma década depois, tivessem sucesso em estabilizar.

\subsection{O Plano Cruzado e a reconfiguração do espaço dos economistas na Nova República}

Nos anos quarenta e cinquenta, o foco do debate econômico brasileiro era o desenvolvimento econômico e sua relação com o comércio internacional, tema discutido nos capítulos 1 e 2. Nos anos 1960 há, no polo ortodoxo, um debate sobre a inflação, sobre os ajustes e sobre a entrada de capital externo, discussões retratadas nos capítulos 2 e 4. No polo heterodoxo, a aproximação com o marxismo traz para o sistema de análise o argumento segundo o qual há uma desigualdade estrutural entre as nações, inaugurado nos anos 1950. À ele adiciona-se o enfoque sociológico que permite observar o efeito que as estruturas sociais particulares de cada nação e os conflitos entre classes nelas existentes produzem na conformação dos sistemas econômicos, das culturas e da política de cada país e na moldagem das relações de cada um deles com o sistema internacional, tema discutido no capítulo 3. Nos anos 1970, há um grande ataque da oposição ao caráter concentrador de renda das políticas econômicas adotadas pela ditadura militar brasileira. Simultaneamente, o governo encarregava-se de equacionar um cenário de constrição externa decorrente da crise do petróleo que levou ao desenho de uma política de substituição de importações de setores intensivos em tecnologia e das áreas energéticas, temas analisados no capítulo 4. Nos anos 1980, as pautas principais são a inflação, que passa a ser alvo de considerações de todos os envolvidos no espaço dos economistas, e a dívida externa, ambos profundamente ampliados nos últimos anos do governo militar.

Em respostas aos fracassos dos programas ortodoxos de controle da inflação testados na primeira metade dos anos 1980, uma série de economistas, em geral de oposição, a maioria dez a quinze anos mais novos do que os principais dirigentes da área econômica da ditadura e quase todos beneficiários dos acordos de cooperação internacional que concederam bolsas de estudo no exterior (NEIBURG, 2004, p. 178) começaram a argumentar que a inflação não era derrubada pois as medidas adotadas não podiam vencer a componente inercial da inflação decorrente da generalização da correção monetária. Em um contexto de redemocratização, mais do que achar uma solução para a 
crise econômica e para a aceleração inflacionária, era preciso que as medidas selecionadas para remodelar a economia não levassem a uma deterioração da situação financeira das classes trabalhadoras, afinal, agora a os responsáveis pela economia eram os críticos do modelo de crescimento e estabilização econômica adotado na ditadura às expensas dos grupos dominados.

As teorias da inflação inercial sustentavam que parte importante do aumento inflacionário poderia ser suprimido pela simples anulação do reajuste preventivo dos preços decorrente seja dos constantes reajustes pelos picos que decorrem da constante tentativa de preservar a renda real média, seja da prática de reajustar preventivamente com a intenção de garantir a renda real contra a inflação que sabidamente ocorrerá (PAULANI, 1987, p. 26). Fosse a inflação inercial, não seria preciso promover uma recessão, mas somente anular a expectativa que levava os agentes a reajustarem constantemente e ciclicamente os preços, salários, tarifas e contratos em geral. Assim, os autores envolvidos no debate acreditavam poder encontrar uma fórmula neutra do ponto de vista distributivo para a estabilização. Uma vez controlada a inflação, tornar-se-iam visíveis os problemas estruturais da economia e seria possível pensar a redistribuição de renda em um cenário controlado. Diversos projetos heterodoxos que propunham conter da inflação sem concentrar vieram à público logo antes da redemocratização, sendo o ano de 1984 um marco da publicação e disseminação das principais ideias que sustentaram o Plano Cruzado.

A velocidade de difusão das novas promessas era altíssima. Os economistas da oposição usavam todos os veículos à disposição: falavam nos espaços especializados como seminários das universidades onde apresentavam seus textos para discussão e encontros mais amplos, como os da ANPEC, que reuniam economistas de todo o país para debater. Manifestavam-se também em veículos especializados como publicações acadêmicas e revistas voltadas aos profissionais da área, como o boletim de conjuntura Economia em Perspectiva, veículo de comunicação do Conselho Regional de Economia de São Paulo (CORECON) - órgão que de 1984 a 1985 foi dirigido por Luciano Coutinho, economista do PMDB e participante da COPAG, o que tornava aquele espaço convidativo às manifestações da oposição ${ }^{476}$. Os debates não se restringiram, entretanto,

\footnotetext{
476 Até a instauração da Nova República, os textos publicados na Economia em Perspectiva são fundamentalmente de autores da oposição, dentre os quais, Luciano Coutinho, Luiz Gonzaga Belluzzo, Antônio Kandir, Celso Furtado, Monica Baer, Francisco Lopes, Décio Munhoz, Persio Arida, Paulo Nogueira Batista,
} 
aos meios especializados. Os jovens economistas começaram a publicar suas exotéricas ideias nos jornais, tentando simplificar e desmatematizar a linguagem para tornar o tema acessível ao leitor não familiarizado com a teoria econômica. Dois anos depois, estariam na televisão anunciando para todo o país os novos tempos que decorreriam da implementação de suas ideias.

Não bastara detectar que a ortodoxia não seria capaz de resolver o problema com seus métodos usuais, era preciso propor um novo caminho, dizer como afinal deveria ser desmontada a inércia inflacionária. As respostas variavam. Francisco Lopes (item 4.6), professor da PUC-RJ, em seu texto "Só um choque heterodoxo pode derrubar a inflação" publicado em Economia em Perspectiva em agosto de 1984, afirma que as políticas ortodoxas praticadas pelo governo desde o início dos anos 1980 lograram reduzir o déficit fiscal e contiveram o crescimento dos meios de pagamento sem, entretanto, ter efeitos redutores sobre a inflação, dado seu caráter inercial. $O$ choque heterodoxo consistiria no “congelamento ríspido e total dos preços acompanhado por uma liberalização das políticas monetárias e fiscais", o que "acaba com a inflação quase por definição". As medidas previstas para a implementação do choque heterodoxo seriam 1) o congelamento dos preços administrado pelo governo; 2) o acordo salarial que interromperia a correção dos salários, sendo concedidos previamente abonos para evitar a corrosão do poder de compra dos trabalhadores; 3) o câmbio deveria ser administrado para estabilizar os preços; 4) seria retomada a atividade de investimento com vistas ao crescimento, para tanto a taxa de juros deveria ser reduzida, a liquidez da economia ampliada e o governo deveria voltar a investir. "A reativação econômica permitiria às empresas suportar mais facilmente o congelamento inicial e o controle posterior dos preços” (LOPES, 1986, pp. 118-120).

Em setembro, Persio Arida e André Lara Resende apresentaram sua contribuição ao debate. Colegas desde o doutorado no MIT, eram, como visto (item 4.6) próximos pessoalmente e habituados a debater e escrever conjuntamente. Em 1984, Arida e Lara Resende eram professores na PUC-RJ. Arida estava quase partindo para uma temporada como professor visitante no Smithsonian Institution de Washington. Lara Resende trabalhava simultaneamente no Banco Garantia. Em 1980, Claudio Haddad, PhD por Chicago, havia sido convidado por seu colega de EPGE Carlos Geraldo Langoni para a

José Roberto Mendonça de Barros, José Carlos Braga, Sulamis Dain, Régis Bonelli e Carlos Lessa; e não há nenhum texto de qualquer um dos atores identificados com o regime militar. 
diretoria do Banco Central. Telefonou na ocasião a André Lara Resende, que havia sido seu aluno na EPGE, para convidá-lo a ocupar seu lugar no Banco Garantia. Jorge Paulo Lemann, economista formado em Harvard, e alguns sócios haviam comprado em 1971 uma corretora de nome Garantia que transformam em um banco de investimentos em 1976. Na época em que Lara Resende entrou no Garantia, o banco ainda era pequeno, mas já tinha traços distintivos em relação às diversas instituições do mercado financeiro nascente. Resende explica que havia

uma percepção de meritocracia e remuneração variável, que é uma coisa complicada, inclusive de administrar. Assim, você esse ano, esse semestre, pode ganhar muito, pode ganhar nada. Era difícil de entender e era um pouco... para me contratar diziam assim: Quanto é que você ganha? Aí tinha que reduzir quanto você ganhava. O Garantia na época era um banco que tinha uma cultura de todo mundo tem que vir ser liquidante, então o fato de eu ter PHD pelo MIT, era completamente... eu falava: parece que o fato de você ter PHD desvaloriza aqui [risos]. Conta contra mim porque eu não fui liquidante. Todo mundo tem que começar gastando sola de sapato, por baixo, e eu cheguei lá e assumi a área de análise de bolsa e de mercado e o departamento econômico (Entrevista de André Lara Resende à autora, 2012).

Pelo Garantia passaram muitas pessoas que acabaram trabalhando no governo. Cláudio Haddad convidou André Lara Resende. André levou para o Garantia Armínio Fraga, que fora seu aluno do mestrado na PUC-RJ e acabava de retornar do $\mathrm{PhD}$ em Princeton. Armínio, que ocuparia a presidência do Banco Central de 1999 a 2003, era amigo de Golfe Clube e depois cunhado de José Luiz Osório de Almeida (1951), engenheiro civil com especialização em transportes pela PUC-RJ, mestrado no departamento de Civil Engineering Planning and Management de Stanford e experiência no Bank of Boston. Sobre sua entrada no Garantia, Osório conta:

eu quase fui para lá quando voltei dos Estados Unidos, mas não conhecia o
Garantia. Não conhecia ninguém do Banco. Depois, quando o Armínio estava lá,
ele falou com o pessoal e eu fui conversar com eles. Naquela época você tinha
que entrevistar com dez pessoas [...]. Era uma forma interessante de contratação.
E assim cria um, uma coobrigação. Não é: "esse é seu... esse é dele...". Fui
entrevistado com muita gente. O Jorge Paulo [Lemann], o Marcel [Telles], são
figuras certamente fora do... ali você via que [era] oitenta, noventa por cento
transpiração e dez por cento inspiração. Muito focado. Muito voltado para a
meritocracia [...]. Então acho que atraía muita gente boa também (Entrevista de
José Luiz Osório à autora, 2012).

José Luiz Osório, por sua vez, era o responsável pela conta da Alcoa Alumínio e convidou para trabalhar no Garantia o diretor-tesoureiro da Alcoa, Eleazar de Carvalho Filho (1957). Graduado em Economia na NYU, com mestrado em Relações Internacionais na Johns Hopkins e experiência no Banco Mundial e no Citybank, Eleazar 
foi conversar com Jorge Paulo Lemann e com Cláudio Haddad, que lhe propuseram juntar-se ao Garantia. Ele conta que saiu "da Alcoa, fui para o Garantia no lugar do Osório que foi abrir a corretora [do Garantia] em Nova York. Quando ele foi para o BNDES, eu fui depois" (Entrevista de Eleazar de Carvalho Filho à autora, 2012). Eleazar de Carvalho Filho, que foi diretor e depois presidente do BNDES no início dos anos 2000, explica que o Garantia

fez a ponte entre o que era o mercado nos anos 1970, [...] um mercado muito mais de intuição, vamos dizer assim... talvez seja um pouco forte mas... para um mercado altamente profissional, técnico. O Garantia sempre teve, por um lado, aquela coisa de dizer: você cresce no mérito, o que é verdade, você começa de baixo. Vários sócios começaram entregando lanche para o Jorge Paulo, então aquela coisa de fato de todo mundo começar como liquidante, então valores assim muito fortes de trabalho... e, ao mesmo tempo, fez uma transição para exigir cada vez mais um nível técnico, acadêmico muito forte (Entrevista de Eleazar de Carvalho Filho à autora, 2012).

Normalmente as pessoas começam muito cedo, saiam da escola e já iam para lá, viravam liquidantes. Durante uma certa época era você levar um cheque e pegar um contrato, [...] mas a ideia é que isso ia viabilizar um processo muito rápido de treinamento onde você ia ver exatamente como as coisas funcionam. Todas as fases do processo e era assim que funcionava. A cultura muito aberta, numa época que não era aberta. Uma plataforma distribuída em micros quando você usava mainframe, ou seja, tudo diferente do que eram os concorrentes (Entrevista de Eleazar de Carvalho Filho à autora, 2012).

Além de Armínio, Lara Resende havia levado para o Garantia outro aluno seu da PUC-RJ, Bruno Lima Rocha. André explica que "a discussão sobre a moeda indexada, eu sempre conto isso, foi com ele. A ideia da moeda indexada, saiu numa conversa com o Bruno. 'Então quer dizer que se você indexasse tudo tinha solução?’ Eu conversando com ele sobre inflação, solução... Eu falei: 'exatamente'. Aí eu falei: 'pô, se tivesse uma moeda indexada...’ Aí eu pude escrever o artigo" (Entrevista de André Lara Resende à autora, 2012). A solução proposta por eles figurou inicialmente nos artigos "A moeda indexada: uma proposta para eliminar a inflação inercial" e "A moeda indexada: nem mágica nem panaceia", publicados por André Lara Resende, em setembro e dezembro de 1984, respectivamente na Gazeta Mercantil e na série texto para discussão do departamento de economia da PUC-RJ, e nos textos de Persio Arida "Neutralizar a inflação: uma ideia promissora" e "Economic stabilization in Brazil", publicados em setembro e novembro de 1984, o primeiro como artigo no boletim Economia em Perspectiva e o segundo como Working Paper do Woodrow Wilson International Center For Scholars. Estes foram sintetizados em uma proposta conjunta, apresentada em dezembro de 1984 em uma conferência em Washington, sob o nome de "Inflação inercial e reforma monetária", 
conhecida também como proposta "Larida", apelido que ganhou do orientador de doutorado de André, Rudi Dornbush que foi o comentador do trabalho na conferência.

Os dois autores também aceitavam o diagnóstico segundo o qual havia grande componente inercial na inflação brasileira, mas discordam do choque heterodoxo de Chico Lopes, contrapondo-se, sobretudo, ao congelamento. Arida explica em seu primeiro texto:

Quanto ao congelamento de preços e salários, note-se que, por mais sofisticado que seja, sempre envolve uma dificuldade crucial. A essência da inércia inflacionária está em que os conflitos distributivos geram tensões de preços relativos que só se resolvem com o tempo. O congelamento bem-sucedido equivale a um pacto social onde os vários grupos e setores concordam em abrir mão da possibilidade diacrônica de melhorar sua posição relativa no interior da sociedade. A urdidura de tal pacto não é tarefa simples, mesmo para um governo idealmente dotado de credibilidade (ARIDA, 1986, p. 160).

Além disso, Lara Resende pergunta-se, no texto da Gazeta Mercantil, como seria possível "congelar preços numa economia onde a cada momento alguns preços estão à véspera de ser reajustados, portanto, muito baixos, e outros acabaram de ser reajustados, portanto, muito altos? A cada ponto no tempo a estrutura de preços está distorcida pela assíncrona dos reajustes. A sua cristalização provocará ganhos e perdas de renda real insustentáveis". Alternativamente, os dois começam a tecer uma proposta de estabilização que partia da percepção que a alternativa ao congelamento com pacto social estaria na generalização da indexação que simularia uma hiperinflação sem suscitar consequências econômicas trágicas de uma experiência longa de escalada inflacionária. As hiperinflações, explicam, "carregam em si mesmas as sementes de sua autodestruição na medida em que obrigam os agentes a reduzir o período do contrato”. Em uma situação como essa os agentes deixam inteiramente de confiar na moeda existente, já que ela não é mais capaz de cumprir "as funções de reserva de valor e unidade de conta até mesmo por períodos de horas", passando a buscar outras moedas para usar como referência (RESENDE, 1986, pp. 155-156).

No caso brasileiro, sequer seria preciso usar uma moeda estrangeira como parâmetro, já que a população havia adotado uma referência interna para a realização de cálculos, previsões e contratos, as Obrigações Reajustáveis do Tesouro Nacional (ORTN). Arida explica que:

A observação de intermediários financeiros que captam e emprestam em ORTN, ou de firmas que contraem dívidas com fornecedores e remarcam seus preços em ORTN, sugere que os efeitos reais da inflação podem ser em boa medida neutralizados utilizando o indexador em todas as transações. A neutralização da 
inflação, aliás, é uma tendência espontânea em curso no sistema econômico (ARIDA, 1986, pp. 160-161).

Isto posto, os autores acreditam que se poderia acelerar o processo de eliminação da inércia inflacionária impulsionando todos os agentes a transitar para a nova referência que não estava contaminada com a corrida descoordenada dos atores para garantir a renda real. A partir desta constatação, a solução por eles proposta seria transformar a ORTN, que já funcionava como unidade de conta, em unidade de troca e reserva de valor, ou seja, criar uma moeda paralela que variasse com a ORTN, os agentes tenderiam a adotar a nova moeda por não se deteriorar como a anterior, estimulando inclusive a poupança e a redução da velocidade de circulação, o que antes seria irracional pois dinheiro que não estivesse em movimento acabaria por desvalorizar (RESENDE, 1986, pp. 152-154).

Em novembro de 1984, Francisco Lopes apresenta no encontro da ANPEC o texto "Inflação inercial, hiperinflação e desinflação: notas e conjecturas" no qual, depois de debater o conceito de inflação inercial e discutir os processos de hiperinflação, apresenta uma proposta combinada de reforma monetária com introdução de nova moeda, que "parece ter grande força psicológica além do atrativo de minimizar os problemas de readaptação do sistema financeiro a um ambiente de preços estáveis", com controle de preços e proibição de indexação. A justificativa aponta para a proteção dos assalariados, que teriam seus rendimentos imediatamente convertidos pela média evitando a deterioração face ao preço de outros produtos que, ao não serem alvo de regulamentação contratual, poderiam ser reajustados pelo pico. Eduardo Modiano e Dionísio Dias Carneiro, em "A mágica do novo cruzeiro e a geração da inflação", também insistem na conjugação de medidas que protegeriam a nova moeda das contaminações decorrentes de variações no grau de inflação do cruzeiro 477 (LOPES,

\footnotetext{
${ }^{477}$ A necessidade do controle governamental e da transição compulsória decorre de não haver garantia que a compatibilidade distributiva do sistema pudesse ser mantida com a simples pressão para a conversão dos preços pela média, já que haveria uma discriminação entre salários, alugueis, tarifas públicas e outros bens que se poderia forçar a converter pela média e os preços dos bens no mercado, que não são reajustados por contrato, podendo ser convertidos pelo pico, o que cria vantagens em relação aos que foram forçados a seguir a média (LOPES, 1986, pp. 139, 145). Eduardo Modiano e Dionísio Dias Carneiro subscrevem a crítica de Chico Lopes e a proposta de combinar a transição monetária com controle de preços. Eles argumentam que seria preciso ter controle pleno da inflação em cruzeiros para não haver contaminação da nova moeda pois, sendo esta atrelada à ORTN, e a ORTN variável em função da inflação em cruzeiro, se a inflação no cruzeiro não fosse estável a nova moeda sofreria variações e começaria a inflacionar mecanicamente. Assim sendo, seria preciso ter controle de preços para assegurar a estabilidade do cruzeiro e, assim, a credibilidade e funcionalidade da nova moeda e a conversão de todos para o novo sistema seria obrigatória e simultânea sem desvantagens para aqueles que são obrigados a reajustar pela média, como explicitou Lopes (MODIANO e CARNEIRO, 1988, pp. 181-187).
} 
1986, pp. 139, 145; MODIANO e CARNEIRO, 1988, pp. 181-187), ademais, ao longo de 1985, Eduardo Modiano e Francisco Lopes ocupam-se do estudo aprofundado de um dos temas mais controversos das propostas de ajuste heterodoxo, as formas de conversão e reajuste de salários, fazendo cálculos para avaliação das vantagens e desvantagens da adoção de cada uma das fórmulas em pauta: trimestralidade dos reajustes, aumentos prévios, correção dos salários pela média ou pelo pico e introdução de uma escala móvel (conhecida como gatilho) de reajuste automático cada vez que a inflação atingisse um determinado patamar (MODIANO e LOPES, 1988).

As propostas para estabilização inercial circulavam com desenvoltura entre os economistas de oposição, fazendo fervilhar as discussões sobre os princípios e detalhes de cada fórmula heterodoxa de estabilização, mas os políticos, incluindo aqueles ligados ao PMDB, ofereciam certa resistência. Tancredo Neves até ouviu o filho do Lucas Lopes, uma vez, lhe oferecendo um cargo na Comissão de Valores Mobiliários, posto onde não teria grande espaço para implementar suas novas ideias. Chico recusou (SARDENBERG, 1987, pp. 79-80) e, com Eduardo Modiano criou a consultoria Macrométrica. Mario Henrique Simonsen, que se entusiasmara com as ideias de seu aluno André Lara Resende, recomendou-o para o Banco Central. Tancredo não aceitou. Foi-lhe oferecida também a CVM. Segundo Lara Resende, Simonsen "queria que eu fosse para a CVM, como uma espécie assim de Shadow [Cabinet] do Central Bank", mas ele não aceitou, permanecendo na PUC-RJ e no Garantia (Entrevista de André Lara Resende à autora, 2012).

Persio Arida foi o único deles a entrar no governo logo nos primeiros momentos, no Ministério do Planejamento, com João Sayad e sua equipe, que ele conhecia dos tempos de FEA. Enquanto esteve na Secretaria da Fazenda de São Paulo, Sayad mantinha almoços de quinze em quinze dias com Persio Arida e Lara Resende para discutir a conjuntura. Quando foram lançados os artigos referentes ao combate da inflação inercial, mostrou franco interesse nas propostas por eles formuladas (André Lara Resende in: SOLNIK, 1987, pp. 17-18). Sayad explica:

eu já cheguei pensando que o problema mais grave era a inflação e me articulando com o Persio Arida para fazer o plano de combate à inflação. $\mathrm{O}$ Tancredo, quando eu falei vamos trazer o Persio e o André para o Banco Central... você está maluco! Vem a ideia de desindexação, indexação total acaba com o país! Me proibiu. Aí eu trouxe o Persio para trabalhar como assessor meu, já com essa incumbência de pensar [em um plano] (Entrevista de João Sayad à autora, 2013). 
No Ministério de Sayad, o amigo Andrea Calabi começou como Secretário Geral, o que lhe atribuía concomitantemente a presidência do IPEA, e depois passou a ser o primeiro encarregado da Secretaria do Tesouro, criada após a unificação orçamentária e o encerramento da conta movimento do BB. Philippe Reichstul começou na Secretaria de Controle de Empresas Estatais (SEST), depois ocupou o lugar de secretário que era de Calabi. Francisco Luna começou na chefia da Seplanzinha, secretaria de planejamento do Ministério à qual estava ligada o Instituto de Planejamento (IPLAN), o braço do IPEA voltado ao planejamento, e depois ocupou a assessoria especial de assuntos econômicos que fora de Persio Arida. A função desempenhada pela assessoria de Arida era essencialmente pensar um plano heterodoxo de estabilização, mesmo sem receptividade política. Despois de um ano de acentuado descontrole econômico e da adoção de medidas contra a inflação inercial na Argentina e em Israel, o presidente Sarney dispõe-se a conversar com os economistas que propunham tais heterodoxias (Entrevistas à autora de Andrea Calabi, 2012, Philippe Reichstul, 2014 e Francisco Vidal Luna, 2014).

A substituição de Dornelles por economistas do espectro heterodoxo permitiu que Fazenda e Planejamento caminhassem juntos em direção ao Cruzado. Dílson Funaro havia sido indicado por Abreu Sodré, amigo de Sarney e governador de São Paulo do qual Funaro fora secretário da Fazenda e do Planejamento ${ }^{478}$. Sua equipe no Ministério da Fazenda era presidida por seus assessores dos tempos de Secretaria, João Manuel Cardoso de Mello e Luiz Gonzaga Belluzzo, muito próximos de Ulysses Guimarães. Ainda que as teorias que circulassem em Campinas não fossem as mesmas que prevaleciam na USP ou na PUC-RJ, havia um consenso na rejeição de medidas ortodoxas de combate à inflação e de qualquer política de caráter concentrador de renda.

Belluzzo explica que seu grupo tinha

uma visão mais relacionada com crise da dívida, ou seja, efeitos [externos] na economia. E eles tinham uma visão muito mais interna. No sentido que bastava você construir uma âncora nominal para a economia crível, ou seja, havia pouca percepção de quais eram as relações entre uma crise monetária daquelas proporções e a derrocada do financiamento externo [...]. Isso tinha a ver exatamente com o momento que você estava empreendendo um movimento de globalização, que não era chamada assim... internacionalização, você recua com uma visão doméstica das questões (Entrevista de Luiz Gonzaga Belluzzo à autora, 2014).

\footnotetext{
${ }^{478}$ Ver: http://www2.senado.leg.br/bdsf/bitstream/handle/id/441936/PS\%20jan_mar1986\%20\%200097.pdf? sequence $=1$. Consultado em 11/03/2016.
} 
Embora convictos de que "seria mais proveitoso que se prosseguisse o debate sobre a reforma financeira, a renegociação da dívida externa e a verdadeira natureza das restrições ao crescimento sustentado e ao combate à inflação" (TAVARES e BELLUZZO, 1986, pp. 52, 70-71), os assessores de Funaro dispunham-se a dialogar com o grupo da inflação inercial e buscar conjuntamente soluções para a crise (SARDENBERG, 1987, p. 134).

O Banco Central foi atribuído a Fernão Bracher, advogado de formação, que fizera a maior parte de sua carreira no mercado financeiro. Pouco depois de retornar da pósgraduação na Alemanha, Bracher foi convidado por um colega dos tempos de Ação Católica, genro de Clemente Mariani - advogado e político que foi presidente do Banco do Brasil, Ministro da Educação e da Saúde, Ministro da Fazenda e ligado ao Banco da Bahia desde de 1942 -, para trabalhar no departamento de câmbio do Banco da Bahia. Segundo ele, a razão da escolha liga-se à sua familiaridade com a língua alemã, idioma quase oficial do departamento que agrupava antigos funcionários dos bancos alemães que haviam sido fechados durante a guerra. Bracher ficou ligado ao Banco da Bahia de 1961 até 1973, quando o Bahia foi comprado pelo Bradesco e relata que o esprit de corps dos funcionários da casa fez com que se sentisse um corpo estranho. Foi então que Paulo Lira, presidente do Banco Central indicado por Mario Henrique Simonsen, que ele não conhecia pessoalmente, convidou-o a assumir a diretoria de câmbio do BCB, entre 1974 a 1979. Ao final do governo Geisel, Bracher retornou à iniciativa privada, trabalhando na companhia de seguros Atlântica Boa Vista e depois sendo encarregado da criação de uma agência do Bradesco em Nova York (Entrevista de Fernão Bracher à autora, 2013).

A segunda experiência de Bracher no governo começou em 1985, a convite de Funaro, que o conhecia dos circuitos financeiro-empresariais. Como banqueiro que atendia a Trol S.A., "eu emprestava dinheiro, não emprestava, brigava com ele”. Além disso, "éramos da mesma geração, mais ou menos do mesmo meio". Anos depois, ele veio a saber que Olavo Setúbal, dono do Itaú e, à época, Ministro das Relações Exteriores, havia recomendado seu nome a Sarney. "Eu estava com o Sarney, disse o Olavo, e o Sarney me diz, 'olha, eu convidei o Dílson Funaro para ser ministro da Fazenda', eu disse, 'ah, então você precisa ter no mínimo o Fernão Bracher'.”. Era um convite ao banqueiro para contrabalancear o empresário (Entrevista de Fernão Bracher à autora, 2013). 
Nomeado para o BCB, Bracher conseguiu convencer André Lara Resende a deixar o Banco Garantia para assumir a diretoria da dívida pública e mercado aberto. Conhecia-o há muito tempo pois sua filha Beatriz Bracher fora casada com Pedro Henrique Mariani, "que é meu amigo desde criança, adolescência", diz Lara Resende. Além disso, André era próximo de outro filho de Fernão, Cândido Bracher, que também trabalhava com os Mariani no Banco da Bahia. Lara Resende explica que os ajudava em muitas coisas e chegara mesmo a montar uma corretora com pessoas do Banco da Bahia (Entrevista de André Lara Resende à autora, 2012).

Bracher conseguiu também que Persio deixasse o Ministério do Planejamento e passasse para o Banco Central em abril de 1986. Ele também conhecia Persio do universo social, já que um dos melhores amigos de Arida, Roberto Bielawski, é casado com Liane Ralston, irmã de Teresa Cristina Ralston, esposa de Cândido Bracher (Entrevista de Persio Arida à autora, 2012; Entrevista de Fernão Bracher à autora, 2013). Eduardo Ralston, irmão de Liane e Teresa, e Roberto e seu primo Ricardo Abramovay eram companheiros de Persio dos tempos de USP e de militância na VAR-Palmares. Eduardo Ralston era amigo próximo também de Guido Mantega. Faziam parte daquele grupo centrado no Colégio de Aplicação e na FFCL e liderado pelos Kfouri-Quartim que daria origem à revista DEBATE (CARVALHO, 2012; PEZZONIA, 2011, pp. 56-59).

Bracher conta que montar a diretoria do BCB não foi tão simples. Um dia depois ter assumido seu posto anunciam

um deputado para falar comigo. Não tinha hora marcada, não tinha nada. Muito bem. "Boa tarde". "Boa tarde". [O deputado fala] "dentro da nossa chave de distribuição de poder, de cargos no governo, coube ao nosso partido, agora nem sei que partido era... Coube ao nosso partido o Banco Central, de modo que nós queríamos acertar com o senhor as diretorias de tal e tal Estado". Eu disse: "mas senhores, eu estou um pouco confuso porque o Banco Central não é uma coisa.... não entra nessa... é um órgão técnico. Nunca teve isso e eu não estou preparado para isso. Vocês me desculpem mas eu acho que vocês têm que ver como é que é. Não sei com quem é que vocês falaram isso, se é com o presidente, não sei. Mas de fato não há essa possibilidade". Eles saíram muito descontentes. Pensei, agora não sei o que vai acontecer. Depois falaram que iam pôr um outro diretor lá em um lugar que eu não gostava. Aí eu disse: “o que é que eu vou fazer?” [...]. Liguei para o Sayad: "Senhor Sayad, eu estou aqui nessa situação, me dizem que tem que aceitar fulano como diretor. Eu não vou fazer isso. É um troço muito chato, é besta esse negócio". "Bom. Eu vou te ajudar aî". "Está bom, muito obrigada então". E ajudou de fato. Então eu passei por essas escaramuças, que eram constantes porque você não tinha um poder forte lá, a coisa era complicada (Entrevista de Fernão Bracher à autora, 2013). 
Bracher aceitou recomendações vindas da própria direção do governo, como Luiz Carlos Mendonça de Barros (item 3.2), indicado da seguinte maneira: um dos melhores amigos do presidente era Matias Machline, empresário do Grupo Sharp. Luis Paulo Rosenberg - que havia estudado em Vanderbilt e lecionado em Brasília - havia sido indicado por Machline para a assessoria econômica da presidência. Matias era grande cliente da Consultora MBE, de José Roberto Mendonça de Barros e de Ibrahim Eris, à qual Rosenberg, colega de José Roberto dos tempos de FEA e de Ibrahim do doutorado em Vanderbilt, era associado ${ }^{479}$. Machline queria que Ibrahim fosse nomeado para o Banco Central, mas Dílson, também seu amigo, insistiu que fosse Bracher. A Ibrahim foi oferecida uma das diretorias do Banco Central. Luiz Carlos Mendonça de Barros, irmão de José Roberto, conta que "o Ibrahim não quis ser diretor e perguntou, você quer ser? Eu falei que estava querendo ter uma experiência de governo, aí então quem me indicou para o Sarney foi o Mathias Machline" (Entrevista de Luiz Carlos Mendonça de Barros à autora, 2012). A essa altura, Luiz Carlos já se convertera da engenharia para a economia e tinha acumulado experiência na longa trajetória no mercado financeiro, tendo trabalhado no Investbanco, na Corretora Patente e no Planibanc. Segundo a versão anedótica, expressiva da consciência irônica que estes agentes têm das dinâmicas sociais envolvendo os laços sociais, Sarney teria dito: “está decidido, vai ser o amigo do Machline, o filho do Otto e o índio do Saulo480", Lara Resende diz que Luiz Carlos adora contar essa história e completa: "se não é vero, é muito verossímil” (Entrevista de Luiz Carlos Mendonça de Barros à autora, 2012; Entrevista de André Lara Resende à autora 2012).

Edmar Bacha completava a equipe na presidência do IBGE, órgão que pertencia aos domínios do Ministério do Planejamento. Calabi conta ter indicado Bacha "ao Sayad e nós levamos [ele] para o IBGE, por sugestão do Régis Bonelli (item 4.3), que foi diretor geral do Bacha no IBGE, que vinha das questões de Berkeley. Por isso veio o Bacha” (Entrevista de Andrea Calabi à autora, 2012). Régis Bonelli, o número dois do IBGE na gestão de Bacha, conta que havia ficado amigo de Andrea, que era da geração seguinte à sua no doutorado em Berkeley, e diz que Calabi

$$
\begin{aligned}
& \text { sugeriu que eu trabalhasse com ele. Só que eu não queria ir para Brasília. Então o } \\
& \text { que eu fizz? Eu apontei um nome bom para ele levar para Brasília e disse que } \\
& \text { trabalharia no Rio para ele, quer dizer, para o Ministério do Planejamento [...]. Eu }
\end{aligned}
$$

\footnotetext{
${ }^{479}$ Nos anos 1990, José Roberto ficaria com a MB enquanto Eris e Luís Paulo Rosenberg fundariam a financeira Linear Investimentos.

${ }^{480}$ Diretor de carreira do Banco Central de nome Tupy Caldas que Saulo Ramos, advogado e consultor geral da república e amigo de Sarney desde os anos 1960, teria indicado.
} 
não tinha status para ser presidente do IBGE, tá? O presidente do IBGE naquela época, ao contrário de hoje em dia, era um cargo muito alto na hierarquia, era uma pessoa muito poderosa, muito próxima do ministro e muito importante (Entrevista de Régis Bonelli à autora, 2012).

Bacha, por sua vez, relata que na época da montagem do governo estava em Columbia lecionando um curso conjunto com Carlos Díaz Alejandro sobre América Latina. Decidiu voltar pois

\begin{abstract}
estava a fim de participar do governo, desde que não fosse em Brasília, né [...]. A alternativa aqui, o BNDES, era demais para o meu bico na época. O IBGE era uma coisa que parecia bem legal [...] e o IBGE estava embaixo do Sayad, que era uma pessoa que eu já conhecia [...]. Quando ele ainda estava se preparando para ir para o exterior, ele trabalhou uma certa temporada no IPEA, junto com o Pastore. Foi nessa época que eu conheci ele (Entrevista de Edmar Bacha à autora, 2012).
\end{abstract}

A nomeação para o Instituto Brasileiro de Geografia e Estatística (IBGE) não foi imediata pois havia um político e economista baiano no páreo. Além disso ele estava longe de ser o nome preferido da equipe econômica de Dornelles, formada pelos mais conservadores quadros da FGV. Resultou disso que sua nomeação demorou para ser aceita. Bonelli relata que, como no caso do BCB, houve uma disputa para ter "liberdade de fazer a diretoria. Os políticos queriam que o diretor de informática fosse beltrano. Que o diretor de economia fosse cicrano. A gente conseguiu isolar tudo isso. Em boa medida ajudado também pelo Ministro e pelo secretário executivo, o Sayad e o Calabi" (Entrevista de Régis Bonelli à autora, 2012). Além de Bonelli, integraram a equipe do IBGE Eduardo Augusto de Almeida Guimarães, que havia trabalhado na FINEP e era da equipe de fundadores do IEI-UFRJ e Charles Curt Mueller, graduado na USP, pósgraduado em Vanderbilt, que havia sido professor com Bacha em Brasília. Serra indicou seu amigo do período do Chile, Cláudio Salm (Entrevista de Edmar Bacha à autora, 2012).

Bacha relata ter nomeado os delegados regionais rapidamente, para tentar fugir às interferências dos políticos. No dia seguinte teve que ouvir "toda a Nova República falando que eu estava rompendo com o acordo, com a aliança, que a base de sustentação do governo estava tremendo porque eu não tinha respeitado o acordo que havia, que os delegados do IBGE não pertenciam a mim, pertenciam a cada político local. Eu falei: eu não vou desnomear ninguém. Esses são os delegados”. Para sustentar a situação Bacha 
pediu aos delegados que escolheu que buscassem padrinhos políticos, obtendo sucesso em 25 do total de 27 casos (BACHA, 2006, [online]).

Os heterodoxos, que agora ocupavam quase todo o topo da área econômica do governo, começaram a reunir-se para discutir procedimentos para atacar a inflação de modo semelhante ao que ocorrera na Argentina e em Israel meses antes. Persio que estava há algum tempo encarregado do assunto, tendo sido inclusive enviado a Israel para mapear o que estava ocorrendo ali, era acompanhado nas reuniões que deram origem ao Plano pelo coautor do Larida, André Lara Resende, e por Luiz Carlos, ambos diretores do BCB. Belluzzo e João Manuel representavam a Fazenda. Andrea Calabi aparecia algumas vezes. Contavam ainda com participações dos professores da PUC-RJ, Chico Lopes e Eduardo Modiano que, mesmo não estando no governo, eram reconhecidos por suas posições nos debates sobre a inflação. Os ministros e o presidente do Banco Central ainda não participavam regularmente dos encontros. Não estava claro, até o final de 1986, se o governo aceitaria ou não implementar as ideias que eles mirabolavam e como não havia certeza, não havia pressa. Até o dia que houve. Lara Resende comenta que Luiz Carlos sempre alertava "vamos preparar o plano. O pessoal diz que não vai sair, mas na hora que decidirem que vai sair, eles vão querer para amanhã. Vamos ficar com tudo pronto" (André Lara Resende in: SOLNIK, 1987, pp. 20-21).

No final de 1985 o governo parecia convencido de que algo precisava ser feito. Os ministros começaram a aparecer com regularidade nas reuniões e Chico Lopes e Eduardo Modiano não puderam mais participar, visto ser preciso manter sigilo. Decidiu-se, por fim, implementar o Cruzado depois da crise dos índices inflacionários, ocorrida em janeiro de 1986. A FGV, que há décadas elaborava o Índice Geral de Preços (IGP), sinalizou que a inflação de janeiro seria superior a todas observadas no ano anterior. $\mathrm{O}$ IGP de janeiro, segundo a FGV, fora 17,79\% 481 . O Índice Nacional de Preços ao Consumidor Amplo (IPCA) do IBGE indicava 14,37\% ${ }^{482}$. Houve forte reação da população tanto alto grau de inflação constatado quanto à transformação do IPCA do IBGE em indicador oficial, decisão vista como uma manobra pouco sutil para apresentar resultados menos desfavoráveis (André Lara Resende in: SOLNIK, 1987, pp. 21-22).

Nesse momento, o secretário principal de Sarney, Jorge Murad, passou a participar das reuniões que se arrastam até o final de fevereiro (André Lara Resende in: SOLNIK,

\footnotetext{
${ }^{481}$ Ver: http://www.debit.com.br/consulta30.php?indice=igp. Consultado em 11/04/ 2016.

${ }^{482}$ Ver: http://www.portalbrasil.net/ipca.htm. Consultado em 11/04/ 2016.
} 
1987, pp. 21-22). Sabiam que fariam um plano, mas não havia consenso quanto ao conjunto de medidas que deveriam adotar. Congelar ou não congelar os preços? Como deveriam ser convertidos os salários? Pela média? Deveria haver um gatilho que reajustasse os vencimentos automaticamente conforme subisse a inflação? Que reajuste deveria ser dado aos trabalhadores para evitar arrocho? Como evitar desabastecimento se houvesse aumento do poder de compra? O que fazer com as tarifas dos serviços públicos? O que fazer com o câmbio e com os juros? Simplesmente introduzir a nova moeda ou usar a ORTN como parâmetro? Era preciso fazer uma reforma fiscal e administrativa? Quando? Todas essas decisões foram tomadas muito rapidamente e, ainda que os estudos já circulassem há algum tempo e que os exemplos argentino e israelense ajudassem moldar o Plano, havia muita incerteza quanto ao padrão de reação da economia brasileira a cada uma dessas decisões.

Em 28 de fevereiro de 1986, José Sarney anunciou em rede nacional o Plano Cruzado, implantado por decreto-lei, estando o Congresso em recesso. Tratava-se da ideia de Chico Lopes que combinava congelamento de preços com a mudança de moeda do Larida. O cruzeiro seria substituído pelo cruzado na proporção 1000 para 1 e a correção monetária eliminada. Preços, tarifas e serviços, congelados. Salários convertidos pela média, reajuste salarial e gatilho indicavam a combinação do foco na inflação e na distribuição de renda. A taxa de câmbio não foi alterada. Finalmente, o presidente convocava os brasileiros a evolverem-se no programa atuando como fiscais dos preços (MACARINI, 2009, pp. 23-27). O anúncio gerou apreensão e comoção ao mesmo tempo. As pessoas dispuseram-se realmente a colaborar com a fiscalização os preços. Havia telefones do governo disponíveis para tirar dúvidas que a população tivesse e os economistas não paravam de aparecer na televisão. Em março de 1986, Maria da Conceição Tavares chorou em rede nacional, falando emocionada que neste momento finalmente teve orgulho de sua profissão e argumentando que aquela equipe econômica redimia politicamente o país, dando direito ao PMDB de retomar sua bandeira de 1982: Esperança e Mudança ${ }^{483}$. Os índices de inflação foram derrubados em dois meses para menos de um 1\% ao mês. O Plano Cruzado, explica um entrevistado:

é meia dúzia de páginas, é uma coisa muito simples, muito singela, algumas ideias. Ninguém tinha a menor ideia do que ia acontecer depois. As consequências no setor habitacional, mensalidade escolar, a relação entre fornecedores e supermercado, as consequências da tablita, era tudo muito novo. Ele foi feito

${ }^{483}$ Ver: https://www.youtube.com/watch?v=7p9Xt9z5PSs. Consultado em 27/05/2016. 
correndo [...]. Na semana não houve disputa [...]. O problema todo foi o trabalho depois. Aí teve que administrar, teve coisa muito complexa depois para ser feita, regulamentar todo esse trabalho. Foram consequências que ninguém podia imaginar. Depois você tinha que fazer reunião com o pessoal do supermercado porque a margem que ele trabalhava, se você colocasse a tablita, dava prejuízo. Mensalidade escolar, apreciação do $\mathrm{BNH},[. .$.$] quebrou o sistema financeiro da$ habitação inteiro. Então depois disso foi muito trabalho. Eu te diria que também não teve, em um primeiro momento, um grande conflito. Começou a haver conflito em meados do ano, quando era a questão de descongelar ou não descongelar (Entrevista à autora, 2012-2015).

Em meados de 1986, a boa convivência dá espaço às tensões. Via de regra, nas narrativas, os entrevistados comentam que, mesmo face à divergências teóricas, estilos diferentes de viver, pensar e agir na economia, predominava a intenção de cooperar face à necessidade de encerrar a crise e legitimar a democracia. Conforme o plano ruía as querelas apareciam. O aumento salarial e a estabilização dos preços inflaram o consumo com velocidade. Nem o Estado nem a fiscalização popular foram capazes de conter o desabastecimento que resultava da expectativa de que o congelamento chegaria ao fim, fazendo com que pudessem vender os produtos a preços mais elevados. Havia uma corrida dos consumidores pela fruição imediata simultaneamente à retirada dos produtos do mercado. O principal desafio seria encontrar uma via para descongelar sem gerar nova inflação e sem derrubar o apelo popular ao Plano. O sucesso do plano foi mortal porque, como a inflação era um incomodo muito
grande na vida das famílias, você tinha que antecipar compras. Recebia o salário,
ia no supermercado e antecipava compras. Outros não conseguiam chegar até o
fim do mês para o salário. Era uma situação muito, muito desagradável para
quem tinha que administrar sua renda. Quando a inflação caiu, logo no primeiro
mês teve deflação. Quando caiu dessa maneira, foi um alívio porque as pessoas,
geralmente aquelas que não tinham proteção da indexação, se sentiram aliviadas.
Há vários casos, várias histórias de gente que vinha me dizer, olha, eu devo a
minha casa a você. Eu passei a consumir. Um que disse que passou a consumir
azeitona, que era um chofer de taxi que nunca tinha comprado porque era muito
caro. Essas coisas. Então isso reforçou na população a adesão ao plano e a
adesão ao plano deu muita confiança. As pessoas começaram a gastar, a se
endividar. Nas condições brasileiras... e o câmbio congelado evidentemente
desatou uma onda de importações que gerou um déficit importante na balança
comercial e o Brasil não tinha reservas e tinha uma situação externa deplorável.
Do ponto de vista distributivo ele teve efeitos positivos (Entrevista à autora,
2012-2015).

No mesmo período, o processo de reorganização das finanças do Estado, com a unificação dos orçamentos e a criação da Secretaria do Tesouro, fez com que constatassem a amplitude do desequilíbrio fiscal, com uma alta folha de salários do governo, subsídios e isenções, que era um grande fator de pressão inflacionária 
(MODIANO, 1990, p. 362). A partir do momento em que concluíram que o Cruzado não se sustentaria facilmente, cada equipe correu para definir quais métodos deveriam ser utilizados para solucionar a crise. Virou um "cada um por si e deus por todos" que criou animosidades que aparecem muito explicitamente no livros de Sardenberg e Solink de 1987, que contam a história do Plano, e ainda ecoam em algumas das entrevistas feitas quase 30 anos depois dos eventos. Não era a primeira e não seria a última vez que Fazenda, Planejamento e Banco Central teriam conflitos, havia entre os órgãos tensões funcionais e disputas por poder dentro da estrutura do Estado.

Quanto às tensões funcionais, um entrevistado explica que "Fazenda e Planejamento sempre se bicam. Porque o Planejamento [...] faz todo um trabalho de alocação de recursos, discute com a Educação, Saúde, tenta fazer o melhor possível. Aí o caixa está na Fazenda então libera para um, não libera para outro, faz uma alocação... então tem essa tensão, e ela é funcional, portanto permanente, mas ela pode se agudizar ou não dependendo dos momentos” (Entrevistas à autora, 2012-2015). Galvêas comenta que no conflito entre os dois órgãos, "de um modo geral, a pessoa que tem a maior ligação com o presidente é aquela que vai comandar" (GALVÊAS, 1990, p. 50). Sendo um momento de aguda tensão, no qual as competências chocavam-se e as soluções propostas por cada parte divergiam, todos passam a disputar o apoio do presidente às suas ideias.

Além de grupos com referências teóricas distintas e experiências profissionais diferentes e das tensões usuais entre Fazenda e Planejamento, uma vez que o Plano foi implementado, passou a haver embates entre as prioridades políticas do Presidente e do PMDB e as considerações “técnicas”. Até então haviam sido adotadas medidas populares preventivas para conquistar apoio político para o Plano, como a introdução do gatilho, sem que houvesse debate político aberto. Uma vez implementado o Cruzado, a reação extremamente favorável da população passou a influenciar diretamente as tomada de decisão. Não se tratava mais de um Plano que só precisava sair de uma desesperadora crise econômica, mas de um forte instrumento político. Acabar com o congelamento seria impopular, criar um fundo de desenvolvimento era popular, cortar o déficit público era impopular e assim por diante. Sarney percebia o poder dos instrumentos econômicos e assumiu papel de árbitro que até então não tivera (SOLA, 1989, pp. 17-18, 21-22). 
Sarney defendia com afinco a criação de um Fundo Nacional de Desenvolvimento que permitisse retomar o investimento público. O Fundo foi financiado com a criação de impostos sobre o consumo de gasolina, automóveis, passagens aéreas e compra de moeda estrangeira, para desaquecer o consumo. A medida, denominada Cruzadinho, criou novo conflito de ordem técnico-política. Deveriam ser os impostos adicionados aos índices de preços que passariam a acusar inflação? Bacha criou dois indicadores, um que aumentava com os novos impostos e outro que mostrava a variação inflacionária provocada pela medida. Isso apareceu para o governo como extremamente impopular. Bacha perde o poder de que desfrutava e deixa o IBGE em novembro, momento em que o governo montou o Cruzado II (MODIANO, 1990, pp. 362-363; BACHA, 2006, [online]).

O Cruzadinho não tinha conseguido reduzir o consumo e o déficit público seguia alto. Novas medidas de ajuste deveriam ser tomadas. Por consideração política, estas medidas impopulares foram implantadas depois da eleição de novembro de 1986 e receberam o nome de Cruzado II. Persio descreve a luta interna à administração econômica que antecedeu o Cruzado II da seguinte maneira:

Qual era a posição da Fazenda? A Fazenda queria aumentar muito os impostos indiretos, como IPI [imposto sobre produtos industrializados], fazer um corte profundo de gastos e não aumentar as taxas de juros. Qual era a posição do Planejamento? O Planejamento queria aumentar os impostos diretos, não os indiretos; não estava sensibilizado para fazer os cortes de gastos, mas concordava em aumentar a taxa de juros. Então a Fazenda e o Planejamento não batiam em nada. Qual era a posição do Banco Central? Era aumentar a taxa de juros (e nesse sentido fechava com o Planejamento), mas cortar gastos (e nesse sentido fechava com a Fazenda), e não aumentar nenhum tipo de imposto (onde discordava dos dois). Por quê? Qual era a visão da Fazenda? A visão da Fazenda era a seguinte: não se pode aumentar a taxa de juros, porque ela é fator de custo para as empresas; não se pode aumentar os impostos diretos porque imposto direto quem paga é o trabalhador; quando se aumenta impostos indiretos - como gasolina - todo mundo paga. É melhor do que aumentar Imposto de Renda. Ao mesmo tempo, a posição da Fazenda estava ancorada no fato de que era importante cortar gastos, para evitar pressão de demanda, etc. Não parece razoável? Parece. Agora, uma boa defesa para o lado do Planejamento. O Planejamento poderia dizer o seguinte: que aumentar impostos indiretos é uma loucura porque sinalizaria aumento de preços e explodiria o congelamento (o que aconteceu); que aumentar a taxa de juros seria necessário para evitar acumulação de estoques; que cortar gastos é ruim porque os gastos são de investimento, cortar gastos de custeio ninguém corta, o país precisa investir, etc. Também parece razoável. Ponha-se na posição do Banco Central. Não quer aumentar nenhum tipo de impostos, porque acha que o Estado já tem uma carga tributária muito grande e quer cortar gastos. E gastos de custeio. Parece razoável. Para que aumentar impostos? Para financiar a máquina do governo, muito onerosa? É melhor cortar a máquina do governo! O Banco Central queria aumentar a taxa de juros, para evitar formação especulativa de estoques. Claro que a minha posição é essa do Banco Central. Mas nenhuma das três era tola. Na prática, o que saiu (no Cruzado II)? Um forte aumento de impostos indiretos - proposição da Fazenda. Não se cortou gastos públicos - e nesse aspecto vigorou a tese do Planejamento. 
Aumentou-se fortemente a taxa de juros - aí vigorou o Banco Central (Persio Arida in: SOLNIK, 1987, pp. 74-75).

O aumento dos impostos e dos preços reativou o processo inflacionário, a indexação começou a reaparecer e logo foi disparado o primeiro gatilho de reajuste salarial, resultando ser, entre março e abril, a inflação registrada maior do que aquela que motivou a instauração do Plano no início de 1986 (MODIANO, 1990, p. 364). Concomitantemente houve perda de reservas e uma grande deterioração da balança de pagamentos, ou seja, o país passou a enfrentar simultaneamente crises internas e externas (MACARINI, 2009, p. 37). Em 10 de janeiro, Bracher e sua equipe, que discordavam da moratória que Sarney pretendia pedir, acabaram desligados do governo. Em março foi a vez da equipe do Ministério do Planejamento, que sentia ser preterida nos confrontos com a Fazenda. Sayad foi substituído por Aníbal Teixeira, político mineiro com formação em direito e administração que era bastante próximo à Tancredo Neves. Francisco Gros foi trazido do BNDES para o Banco Central por Dílson Funaro, no dia 20 de fevereiro. Uma semana depois de assumir o BCB, o Brasil decretou a moratória. Gros conta que dos 79 dias em que esteve no governo, "passei 45 dias viajando, fora do país, tentando contar para os nossos principais interlocutores o que estava acontecendo no Brasil. Foi uma época extremamente conturbada da vida do país" (GROS, 2002, [DVD]). O período de Francisco à frente do BCB tão foi curto porque ele deixou o governo junto com Funaro e sua equipe, no final de abril. Havia um desgaste político da sua gestão na Fazenda, provocado pela derrocada do Cruzado. Ao mesmo tempo, sentiram-se afastados por Sarney que começou a fazer a negociação da dívida externa com outra equipe em paralelo à que eles estavam conduzindo.

Quando Funaro deixou a Fazenda, foi substituído por Bresser Pereira que conta que seu nome tinha sido apresentado por Ulysses Guimarães em uma lista na qual constavam também as indicações de Celso Furtado, José Serra e Raphael de Almeida Magalhães. O PMDB de São Paulo requisitava um ministro paulista. No Planejamento já havia sido posicionado um mineiro. Bresser contava com o apoio de Montoro, cujo governo havia servido. Orestes Quércia, eleito governador do Estado de São Paulo, rejeitava José Serra, razão pela qual apoiou Bresser. Sarney fazia objeções aos outros dois candidatos. Além disso, Fernão Bracher, antes de deixar o governo, já tinha levantado o nome de Bresser para o ministério caso Sarney quisesse fazer mudanças. A convergência 
desses fatores fez com que Luiz Carlos fosse escolhido para o Ministério (Entrevista de Fernão Bracher à autora, 2013; Entrevista de Luiz Carlos Bresser Pereira à autora, 2012; PEREIRA, 1988, pp. 1-2).

O Ministério da Fazenda vai ser uma grande aventura para mim. Foi interessante porque quando eu assumi o Ministério da Fazenda... duas coisas curiosas, uma é que eu vou para o Rio de Janeiro e lá encontro o Celso Furtado, que era Ministro da Cultura. Aí o Celso chega para mim e diz assim: "Bresser! Bresser, você é louco! Você está assumindo o Ministério da Fazenda na pior crise desde 1930". Era uma crise aguda total. Era o colapso do Plano Cruzado. Isso é abril de 1987. É o colapso do Plano Cruzado. Há uma decepção profunda do povo brasileiro. A inflação tinha ficado zerada, agora volta a $14 \%$ ao mês. Os salários que tinham subido $30 \%$ em termos reais, caem $30 \%$ em termos reais nos primeiros meses do ano. O Brasil entra em moratória, as empresas estão quebrando, os Estados estão quebrando, é uma situação absolutamente caótica. Nessa situação caótica eu assumo o Ministério. Aí eu vou para São Paulo. Lá, em uma reunião de empresários, eu encontro um empresário que tinha a mesma idade do Celso Furtado, também foi um grande amigo meu. Era banqueiro e tinha posições políticas opostas ao Celso Furtado e diz para mim: "Bresser você é louco! Você está assumindo o Ministério da Fazenda na pior crise desde 1930". Frase por frase. Palavra por palavra ele repetiu. A outra coisa foi quando um jornalista me pergunta porque é que eu estava assumindo aquele ministério naquela coisa. Eu disse: porque eu me preparei a vida inteira para isso. Era a obrigação que eu tinha com o país. Acabou. Não tinha isso de saber se aceitava ou não aceitava (Entrevista de Luiz Carlos Bresser Pereira à autora, 2012).

Para sua assessoria econômica escolheu seu mais próximo colaborador, Nakano, e para a assessoria política Gilda Portugal Gouvêa, irmã da esposa de seu irmão. Nakano contou com a colaboração de Chico Lopes para a elaboração do Plano Bresser. Calabi foi mantido na Secretaria do Tesouro. Bresser tentou negociar a volta do amigo Fernão Bracher para o Banco Central. "O Sarney diz: 'Olha, eu gosto muito do Fernão, mas não dá'. Entrar e sair assim... Então o Luiz Carlos diz: 'ao menos eu quero que ele fique tomando conta da dívida externa'. O Sarney diz: 'está muito bem’ [...], e convidou, para presidente do Banco Central, o Fernando Milliet, que era, à essa altura do campeonato ainda eu acho, casado com uma prima minha, Maria Alice Milliet" (Entrevista de Fernão Bracher à autora). Fernando, que também estudara em Michigan e era professor da FGVSP, já havia sido vice de Bresser quando ele esteve no BANESPA e depois seu substituto quando tornou-se secretário no governo Montoro (DHBB, Verbete Fernando Milliet). Pereira explica que Sarney havia imposto uma única condição ao convidá-lo:

O secretário geral deveria ser nordestino. A condição era ao mesmo tempo curiosa e razoável. O Nordeste, compreensivelmente, está entranhado em Sarney. E me entregou uma lista com 14 nomes, datilografada, como uma colaboração sua. Não conhecia praticamente ninguém da lista. O Maílson da Nóbrega, então diretor de um banco em Londres, fora esquecido por Sarney. Voltei para o Ministério e comecei minhas consultas. Cheguei a fazer duas entrevistas. Até que o Yoshiaki lembrou-me do nome do Maílson. Conhecia-o da época em que eu 
fora presidente do Banespa e ele secretário geral do ministro Ernani Galveas [sic], que ocupara o Ministério da Fazenda enquanto Delfim era Ministro do Planejamento. Embora conservador, sabia-o um excelente administrador público. Minhas conversas com ele haviam me deixado uma excelente impressão. Telefonei imediatamente para Londres, ao mesmo tempo que consultava o Sarney. Em uma semana Maílson estava no Brasil. Foi um excelente auxiliar. E, quando decidi me demitir, transformou-se em meu sucessor (PEREIRA, 1988, p. 3).

Os planos econômicos praticados por Bresser e seu sucessor Maílson partiram da experiência acumulada durante o Cruzado. Bresser desfez o gatilho. Decretou vários aumentos preventivos para desaquecer a demanda antes de decretar novo congelamento. Os aumentos foram computados na taxa de inflação, não gerando conflitos na montagem dos índices. O Cruzado foi desvalorizado e a taxa de câmbio mantida livre. Bresser e Maílson procuraram atacar o déficit público e começaram a tentar retomar as negociações externas. O plano Verão de Maílson combina a ortodoxia de taxa de juros elevada, corte de gastos, reforma administrativa com a heterodoxia da desindexação total e introdução de outra moeda, o cruzado novo, que foi desvalorizado até a paridade de 1 para $1 \mathrm{com}$ o dólar, com o objetivo de lastrear as unidades em uma medida externa objetiva e forçar o governo a manter o controle do valor (MODIANO, 1990). O período foi marcado por sucessivos decretos com medidas para conter a inflação que chegou, em março de 1990, mês da transição de governo, a 80\%.

\begin{tabular}{|c|c|c|c|c|}
\hline Personagem & Cronologia & Local de nascimento & Formação & Filiação \\
\hline Zeferino Vaz & $1908-1981$ & São Paulo - SP & $\begin{array}{l}\text { Graduação em Medicina } \\
\text { (USP). }\end{array}$ & $\begin{array}{l}\text { Descendente de abastados } \\
\text { espanhóis da Galícia }\end{array}$ \\
\hline Franco & 1916-1999 & São Paulo - SP & $\begin{array}{l}\text { Graduação em direito } \\
\text { (FD-USP). Filosofia e } \\
\text { Pedagogia (Faculdade São } \\
\text { Bento). Doutorado em } \\
\text { Filosofia }\end{array}$ & $\begin{array}{l}\text { Pai imigrante italiano e mãe } \\
\text { imigrante da basca da } \\
\text { Espanha. No Brasil o pai } \\
\text { tornou-se gráfico ativo na } \\
\text { representação sindical de } \\
\text { sua categoria. }\end{array}$ \\
\hline $\begin{array}{l}\text { José Carlos Perdigão } \\
\text { Medeiros da Fonseca }\end{array}$ & $1925-2012$ & Rio de Janeiro - RJ & $\begin{array}{l}\text { Graduação em direito } \\
\text { (UB). }\end{array}$ & $\begin{array}{l}\text { Pai Arnoldo Medeiros da } \\
\text { Fonseca, advogado que fora } \\
\text { professor da Faculdade } \\
\text { Nacional de Direito da } \\
\text { Universidade do Brasil e } \\
\text { chegou a ser presidente do } \\
\text { Instituto dos Advogados do } \\
\text { Brasil. }\end{array}$ \\
\hline Fausto Castilho & $1929-2015$ & Cambará - PR & $\begin{array}{l}\text { Graduação em Filosofia } \\
\text { (Sorbonne). }\end{array}$ & $\begin{array}{l}\text { Descendente de grandes } \\
\text { proprietário de terras. }\end{array}$ \\
\hline $\begin{array}{l}\text { Dílson } \quad \text { Domingos } \\
\text { Funaro }\end{array}$ & 1933-1989 & São Paulo - SP & $\begin{array}{l}\text { Graduação } \\
\text { engenharia (Mackenzie). }\end{array}$ & $\begin{array}{l}\text { Avô paterno Domingos } \\
\text { Funaro (Calábria). Pai } \\
\text { Pascoal Funaro nascera na } \\
\text { Itália e tornara-se } \\
\text { comerciante no Brasil. }\end{array}$ \\
\hline Luiz Sande de Oliveira & $1933-1995$ & Nazaré - BA & $\begin{array}{lrr}\text { Graduação } & \text { em } & \text { direito } \\
\text { (UC } & \text { Salvador). } \\
\text { Especialização } & \text { em }\end{array}$ & s.d. \\
\hline
\end{tabular}




\begin{tabular}{|c|c|c|c|c|}
\hline & & & Administração (MSU). & \\
\hline $\begin{array}{ll}\text { Luiz Carlos } & \text { Bresser } \\
\text { Pereira } & \end{array}$ & 1934 & São Paulo - SP & 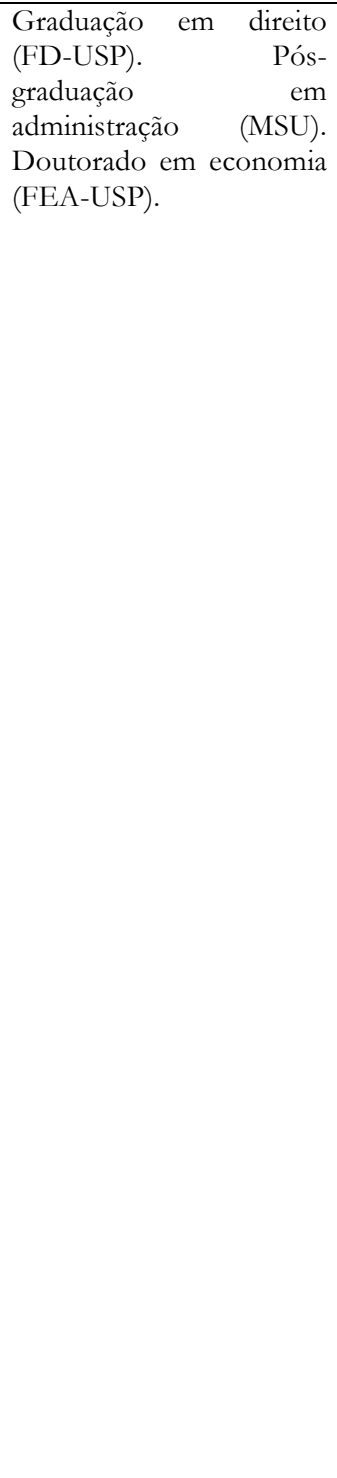 & $\begin{array}{l}\text { Avô paterno Horácio } \\
\text { Gonçalves Pereira, formado } \\
\text { na Faculdade de Direito do } \\
\text { Largo São Francisco. } \\
\text { Descendente distante de } \\
\text { portugueses, já nascido em } \\
\text { São Paulo Horácio foi } \\
\text { advogado, dono de um } \\
\text { cartório de registro de } \\
\text { imóveis e era ligado ao } \\
\text { PRP. Uma das filhas de } \\
\text { Horácio casou-se com } \\
\text { Alexandre José Barbosa } \\
\text { Lima Sobrinho, bacharel em } \\
\text { Direito que foi Deputado } \\
\text { Federal de Pernambuco, } \\
\text { depois foi presidente do } \\
\text { Instituto do Açúcar e do } \\
\text { Álcool e finalmente } \\
\text { Governador der de } \\
\text { Pernambuco. O pai, Sylvio } \\
\text { de Lima Gonçalves Pereira, } \\
\text { era advogado formado na } \\
\text { Faculdade de Direito do } \\
\text { Largo São Francisco. } \\
\text { Entrou na política em 1946, } \\
\text { sendo eleito para a } \\
\text { Assembleia Legislativa pelo } \\
\text { PTB. Foi proprietário do } \\
\text { jornal O Tempo, advogou e } \\
\text { teve um emprego público. } \\
\text { O avô materno, Alfredo } \\
\text { Bresser da Silveira, nascido } \\
\text { em São Paulo, era } \\
\text { descendente, do lado } \\
\text { paterno, de portugueses e, } \\
\text { por parte de mãe, de Karl } \\
\text { Bresser, um geômetra de } \\
\text { Krefeld na Alemanha. } \\
\text { Alfredo tornou-se } \\
\text { educador, como também } \\
\text { sua avó materna e a mãe. }\end{array}$ \\
\hline Fernão Bracher & 1935 & São Paulo - SP & $\begin{array}{l}\text { Graduação em direito } \\
\text { (FD-USP). } \\
\text { graduação incompleta em } \\
\text { direito (Freiburg). }\end{array}$ & $\begin{array}{l}\text { Bisavô paterno suíço que } \\
\text { trabalhou jardineiro e } \\
\text { associou-se à Dierberger } \\
\text { Plantas. O avô paterno } \\
\text { Godofredo nasceu em } \\
\text { Curitiba e trabalhou na área } \\
\text { de seguros; primeiro, em } \\
\text { uma importadora } \\
\text { controlada por estrangeiros, } \\
\text { depois, autonomamente. A } \\
\text { avó paterna era alsaciana da } \\
\text { cidade de Mulhouse e } \\
\text { deixou seu país após a } \\
\text { anexação de sua região ao } \\
\text { Império Alemão. O pai } \\
\text { Eduardo, nascido em São } \\
\text { Paulo, no no } \\
\text { contabilidade nadou } \\
\text { Mackenzie, trabalhou no } \\
\text { início da carreira em uma } \\
\text { grande importadora e abriu } \\
\text { um comércio próprio. Sua } \\
\text { mãe era descendente do } \\
\text { fazendeiro e político Conde } \\
\text { do Pinhal. O avô de } \\
\text { materno de Fernão, Carlos }\end{array}$ \\
\hline
\end{tabular}




\begin{tabular}{|c|c|c|c|c|}
\hline & & & & $\begin{array}{l}\text { Amadeu, era o mais novo } \\
\text { dos filhos homens do } \\
\text { Conde e administrou várias } \\
\text { das terras da família. Casou- } \\
\text { se com Brazilia de Oliveira } \\
\text { Franco Lacerda, que } \\
\text { também descendia de } \\
\text { grandes famílias de } \\
\text { fazendeiros da região, os } \\
\text { Franco Lacerda e os } \\
\text { Whitaker. A mãe de Fernão } \\
\text { estudou no colégio francês } \\
\text { para moças Des Oiseaux e } \\
\text { chegou a trabalhar como } \\
\text { funcionária pública. }\end{array}$ \\
\hline $\begin{array}{ll}\text { Francisco } & \text { Neves } \\
\text { Dornelles } & \end{array}$ & 1935 & Belo Horizonte - MG & $\begin{array}{l}\text { Graduação em direito } \\
\text { (UB). Especialização em } \\
\text { finanças públicas e } \\
\text { tributação Internacional } \\
\text { (Université de Nancy, } \\
\text { Harvard). Mestrado em } \\
\text { direito público (UB). } \\
\text { Doutorado em direito } \\
\text { público (UB). }\end{array}$ & $\begin{array}{l}\text { Seu pai, Mozart Dornelles } \\
\text { nascido em São Borja, era } \\
\text { primo de Getúlio. Fez sua } \\
\text { carreira militar em São João } \\
\text { Del Rei, onde conheceu } \\
\text { Mariana Neves, irmã de } \\
\text { Tancredo com a qual viria a } \\
\text { casar-se. }\end{array}$ \\
\hline Manoel Tosta Berlinck & 1936 & São Paulo - SP & $\begin{array}{lr}\text { Graduação em } & \text { ciências } \\
\text { sociais (ELSP). } & \text { Mestrado } \\
\text { em ciências } & \text { Ssciais } \\
\text { (ELSP) Doutorado em } \\
\text { sociologia } & \text { urbana } \\
\text { (Cornell). } & \end{array}$ & $\begin{array}{l}\text { Pai Cyro Berlinck era amigo } \\
\text { e secretário particular de } \\
\text { Roberto Simonsen. Foi por } \\
\text { ele designado Secretário- } \\
\text { Geral da FIESP, fez parte } \\
\text { do grupo de fundadores e } \\
\text { foi diretor da ELSP por } 33 \\
\text { anos. O avô Horácio } \\
\text { Berlinck, era contador, } \\
\text { lecionara na POLI-USP, } \\
\text { fora secretário do Conde } \\
\text { Alvares Penteado e o } \\
\text { fundador da Escola de } \\
\text { Comércio Álvaro Penteado. }\end{array}$ \\
\hline $\begin{array}{l}\text { Tamás József Márton } \\
\text { Károly Szzmrecsányi }\end{array}$ & $1936-2009$ & Budapeste - Hungria & $\begin{array}{l}\text { Graduação em filosofia } \\
\text { (FFCL). Mestrado em } \\
\text { economia (New School). } \\
\text { Doutorado em economia } \\
\text { (IE-UNICAMP) }\end{array}$ & $\begin{array}{l}\text { Pais imigrantes húngaros } \\
\text { chegaram ao Brasil após a } \\
\text { Segunda Guerra Mundial. } \\
\text { Pai advogado. }\end{array}$ \\
\hline Betty Mindlin & s.d. & São Paulo - SP & $\begin{array}{lr}\text { Graduação em } & \text { economia } \\
\text { (FEA-USP). } & \text { Mestrado } \\
\text { em economia } & \text { (Cornell). } \\
\text { Doutorado } & \text { em } \\
\text { antropologia (PUC-SP). }\end{array}$ & $\begin{array}{l}\text { Filha José } \\
\text { advogado formado na } \\
\text { Faculdade de Direito do } \\
\text { Largo São Francisco, } \\
\text { bibliófilo e sócio de Abraão } \\
\text { Lafer na companhia de } \\
\text { autopeças Metal Leve. }\end{array}$ \\
\hline Celso Lafer & 1941 & São Paulo - SP & $\begin{array}{l}\text { Graduação em Direito } \\
\text { (USP). Mestrado em } \\
\text { Ciência Política (Cornell). } \\
\text { Doutorado em Ciência } \\
\text { Política (Cornell). }\end{array}$ & $\begin{array}{l}\text { Filho Abraão Jacob Lafer, } \\
\text { advogado formado na } \\
\text { Faculdade de Direito do } \\
\text { Largo São Francisco, } \\
\text { dirigente da empresa Klabin } \\
\text { Papel e Celulose e fundador } \\
\text { fábrica de autopeças Metal } \\
\text { Leve. Abraão era, ademais, } \\
\text { irmão de Horácio Lafer, } \\
\text { Ministro da Fazenda de } \\
\text { Vargas. }\end{array}$ \\
\hline Eduardo Suplicy & 1941 & São Paulo - SP & $\begin{array}{lr}\text { Graduação } & \text { em } \\
\text { administração } & \text { (EAESP- } \\
\text { FGV). Pós-graduação em } \\
\text { administração } & \text { (MSU). } \\
\text { Mestrado } & \text { em } \\
\text { administração } & \text { (Stanford). } \\
\text { Doutorado em } & \text { economia } \\
\text { (MSU). } & \end{array}$ & $\begin{array}{l}\text { Do lado materno é bisneto } \\
\text { do italiano Francisco } \\
\text { Matarazzo, industrial, } \\
\text { fundador da FIESP, } \\
\text { nomeado primeiro Conde } \\
\text { Matarazzo. Seu pai, Paulo } \\
\text { Cochrane Suplicy, foi para a } \\
\text { área de exportação de café } \\
\text { na qual havia trabalhara seu }\end{array}$ \\
\hline
\end{tabular}




\begin{tabular}{|c|c|c|c|c|}
\hline & & & & 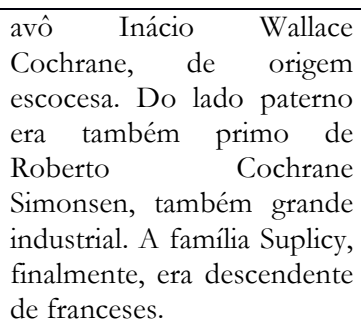 \\
\hline Raul Ekerman & 1941 & São Paulo - SP & $\begin{array}{l}\text { Graduação em economia } \\
\text { (FEA-USP). Doutorado } \\
\text { em economia (Cornell) }\end{array}$ & $\begin{array}{l}\text { Filho do representante e } \\
\text { distribuidor no Brasil dos } \\
\text { filmes da } \\
\text { Pictures. }\end{array}$ \\
\hline Fabio Stefano Erber & -2011 & s.d. & $\begin{array}{l}\text { Graduação em economia } \\
\text { (FNCE). Mestrado em } \\
\text { economia (East Anglia). } \\
\text { Doutorado em economia } \\
\text { (Sussex). }\end{array}$ & s.d. \\
\hline $\begin{array}{ll}\text { Francisco } & \text { Roberto } \\
\text { André Gros } & \end{array}$ & $1942-2010$ & Rio de Janeiro - RJ & $\begin{array}{l}\text { Graduação em economia } \\
\text { e relações internacionais } \\
\text { (Princeton). Mestrado em } \\
\text { economia (Columbia). }\end{array}$ & $\begin{array}{l}\text { Pai advogado francês que } \\
\text { chegou a ser Jurisconsulto } \\
\text { do Ministério das Relações } \\
\text { Exteriores da França e Juiz } \\
\text { na Corte Internacional de } \\
\text { Haia. No início da carreira } \\
\text { veio ao Brasil em uma das } \\
\text { missões francesas, } \\
\text { tornando-se professor de } \\
\text { Ciência Política na } \\
\text { Faculdade Nacional de } \\
\text { Direito da Universidade do } \\
\text { Brasil. Do lado materno } \\
\text { provinha de uma família } \\
\text { brasileira com longínqua } \\
\text { ascendência portuguesa. } \\
\text { Bisavô, Francisco Simões } \\
\text { Correa era um médico } \\
\text { especializado em febre } \\
\text { amarela, professor da } \\
\text { Faculdade de Medicina do } \\
\text { Rio de Janeiro e fundador } \\
\text { da Casa de Saúde São } \\
\text { Sebastião em Botafogo, na } \\
\text { qual trabalhou também o } \\
\text { avô, o médico Álvaro } \\
\text { Simões Correa. }\end{array}$ \\
\hline $\begin{array}{l}\text { João Manuel Cardoso } \\
\text { de Mello }\end{array}$ & 1942 & São Paulo - SP & $\begin{array}{l}\text { Graduação em direito } \\
\text { (FD-USP). Especialização } \\
\text { em problemas do } \\
\text { desenvolvimento } \\
\text { (CEPAL-BNDE). } \\
\text { Doutorado em economia } \\
\text { (IE-UNICAMP). }\end{array}$ & $\begin{array}{l}\text { A família de João Manuel } \\
\text { faz parte da elite jurídica e } \\
\text { política paulista. Avô } \\
\text { paterno, depois de } \\
\text { bacharelar-se em Direito, } \\
\text { advogou em Jaboticabal e } \\
\text { São Paulo e foi Pretor e Juiz } \\
\text { de Órfãos no Distrito } \\
\text { Federal. Casou-se com } \\
\text { Maria Suzana Machado, } \\
\text { irmã de José Alcântara } \\
\text { Machado, escritor e jurista e } \\
\text { filha de Brasílio Augusto } \\
\text { Machado de Oliveira, } \\
\text { também advogado, } \\
\text { professor de direito e } \\
\text { político que ocupou a } \\
\text { presidência da província do } \\
\text { Paraná. O pai de João } \\
\text { Manuel, João de Deus } \\
\text { Cardoso de Mello, fora } \\
\text { delegado de Policia, } \\
\text { Promotor durborico, } \\
\text { Subprocurador, Procurador } \\
\text { Geral, Secretário da Justiça, }\end{array}$ \\
\hline
\end{tabular}




\begin{tabular}{|c|c|c|c|c|}
\hline & & & & $\begin{array}{l}\text { da Educação e finalmente } \\
\text { Ministro do Tribunal de } \\
\text { Contas. Casou-se com a } \\
\text { filha de um juiz. José } \\
\text { Joaquim Cardoso de Mello } \\
\text { Neto, primo de seu pai, foi } \\
\text { diretor da Faculdade de } \\
\text { Direito do Largo São } \\
\text { Francisco e ocupou os } \\
\text { cargos de Deputado, } \\
\text { Prefeito, Governador do } \\
\text { Estado de São Paulo e } \\
\text { Superintendente da Moeda } \\
\text { e do Crédito, além de ser } \\
\text { casado com uma filha do } \\
\text { presidente Rodrigues Alves. }\end{array}$ \\
\hline Jorge Lins Freire & 1942 & Salvador - BA & $\begin{array}{l}\text { Graduação } \\
\text { administração (UFBA) }\end{array}$ & $\begin{array}{l}\text { Pai telegrafista e escriturário } \\
\text { do ministério de Viação e } \\
\text { Obras. }\end{array}$ \\
\hline $\begin{array}{ll}\text { Luiz } & \text { Gonzaga } \\
\text { Belluzzo } & \end{array}$ & 1942 & São Paulo - SP & $\begin{array}{l}\text { Graduação em Direito } \\
\text { (FD-USP). Especialização } \\
\text { em problemas do } \\
\text { desenvolvimento } \\
\text { (CEPAL-BNDE). } \\
\text { Doutorado em economia } \\
\text { (IE-UNICAMP). }\end{array}$ & $\begin{array}{l}\text { Descendente de italianos do } \\
\text { Vêneto e da Calábria. O } \\
\text { bisavô foi administrador da } \\
\text { fazenda de um Almeida } \\
\text { Prado, em Jaú. O avô } \\
\text { paterno foi coletor de } \\
\text { impostos e casou-se com } \\
\text { uma imigrante italiana. O } \\
\text { pai de Luiz Gonzaga nasceu } \\
\text { em Bariri, estudou no } \\
\text { Colégio Rio Branco e } \\
\text { depois Direito (FD-USP). } \\
\text { Principiou a carreira de } \\
\text { advogado na polícia, depois } \\
\text { fez concurso para a } \\
\text { magistratura e foi juiz em } \\
\text { várias cidades do interior. A } \\
\text { família materna era } \\
\text { paulistana tradicional em } \\
\text { decadência. O avô havia } \\
\text { sido fazendeiro de café e } \\
\text { dono de uma importadora } \\
\text { que quebrou após a } \\
\text { moratória que Getúlio } \\
\text { Vargas concedeu aos } \\
\text { fazendeiros afetados pela } \\
\text { crise de 1929. A avó } \\
\text { materna era dona de uma } \\
\text { pensão e a mãe normalista e } \\
\text { professora primária. }\end{array}$ \\
\hline Wilson Cano & s.d. & São Paulo - SP & $\begin{array}{l}\text { Graduação em economia } \\
\text { (PUC-SP). Especialização } \\
\text { em problemas do } \\
\text { desenvolvimento } \\
\text { (CEPAL-BNDE). } \\
\text { Doutorado em economia } \\
\text { (IE-UNICAMP). }\end{array}$ & $\begin{array}{l}\text { Filho de } \\
\text { espanhóis radicados } \\
\text { bairro Tucuruvi em } \\
\text { Paulo. }\end{array}$ \\
\hline Roberto Perosa & s.d. & Urupês - SP & $\begin{array}{l}\text { Graduação em economia } \\
\text { (FEA-USP). Mestrado } \\
\text { em economia (FEA- } \\
\text { USP). Doutorado em } \\
\text { economia (Cornell). }\end{array}$ & $\begin{array}{l}\text { Pai político que foi prefeito } \\
\text { da cidade de Urupês. }\end{array}$ \\
\hline $\begin{array}{l}\text { André } \\
\text { Montoro Filho }\end{array}$ & 1944 & São Paulo - SP & $\begin{array}{ll}\text { Graduação em } & \text { economia } \\
\text { (FEA-USP). } & \text { Mestrado } \\
\text { em economia } & \text { (EPGE). } \\
\text { Doutorado em economia } \\
\text { (Yale). }\end{array}$ & $\begin{array}{l}\text { Avô paterno imigrante } \\
\text { italiano e avó paterna } \\
\text { imigrante da basca da } \\
\text { Espanha. No Brasil o avô } \\
\text { tornou-se gráfico ativo na } \\
\text { representação sindical de } \\
\text { sua categoria. O pai André } \\
\text { Franco Montoro era } \\
\text { advogado formado na FD- }\end{array}$ \\
\hline
\end{tabular}




\begin{tabular}{|c|c|c|c|c|}
\hline & & & & $\begin{array}{l}\text { USP, com graduação e } \\
\text { doutorado em filosofia pela } \\
\text { Faculdade São Bento. O } \\
\text { avô materno era advogado e } \\
\text { dono de cartório. Sua mãe } \\
\text { Lucy nasceu em Jundiaí e } \\
\text { cursou Filosofia e Serviço } \\
\text { Social na Faculdade São } \\
\text { Bento. }\end{array}$ \\
\hline Gilda Portugal Gouvêa & 1944 & São Paulo - SP & $\begin{array}{l}\text { Graduação em ciências } \\
\text { sociais (FFLCH-USP). } \\
\text { Mestrado em economia } \\
\text { (USP). Doutorado em } \\
\text { economia (Cornell). }\end{array}$ & $\begin{array}{l}\text { Pai Américo } \text { Portugal } \\
\text { Gouvêa, advogado formado } \\
\text { na USP que foi Chefe da } \\
\text { Casa Civil do governo } \\
\text { Carvalho Pinto e Ministro } \\
\text { do Tribunal de Contas de } \\
\text { São Paulo. }\end{array}$ \\
\hline Yoshiaki Nakano & 1944 & Cafelândia - PR & 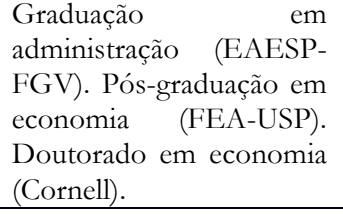 & s.d. \\
\hline Andrea Calabi & 1945 & São Paulo - SP & $\begin{array}{l}\text { Graduação em economia } \\
\text { (FEA-USP). Mestrado } \\
\text { em economia (USP- } \\
\text { Berkeley). Doutorado em } \\
\text { economia (Berkeley). }\end{array}$ & $\begin{array}{l}\text { Família italiana, o pai } \\
\text { nasceu em Verona, a mãe } \\
\text { em Modena. Avô paterno } \\
\text { era engenheiro e trabalhava } \\
\text { na rede ferroviária federal } \\
\text { da Itália. O avô materno era } \\
\text { diretor da Banca Commerciale } \\
\text { Italiana, e veio para o Brasil } \\
\text { justamente como diretor de } \\
\text { uma agência no Brasil. O } \\
\text { pai fez administração na } \\
\text { escola de comércio } \\
\text { Bocconi, em Milão, A } \\
\text { começou a faculdade de } \\
\text { letras em Roma, mas não } \\
\text { concluiu pois mudou-se } \\
\text { para o Brasil. No Brasil o } \\
\text { pai foi contador, diretor } \\
\text { administrativo da Gessy e } \\
\text { proprietário de um } \\
\text { escritório de consultoria } \\
\text { econômica. Mãe aos } \\
\text { quarenta anos torna-se } \\
\text { professora de yoga. }\end{array}$ \\
\hline João Sayad & 1945 & São Paulo - SP & $\begin{array}{l}\text { Graduação em economia } \\
\text { (FEA-USP). Mestrado } \\
\text { em economia (FEA- } \\
\text { USP). Doutorado em } \\
\text { economia (Yale). }\end{array}$ & $\begin{array}{l}\text { Os quatro avós eram } \\
\text { imigrantes libaneses. O avô } \\
\text { materno abriu uma loja de } \\
\text { tecidos no Rio de Janeiro. } \\
\text { O pai tornou-se } \\
\text { comerciante, proprietário de } \\
\text { um armarinho no centro de } \\
\text { São Paulo. }\end{array}$ \\
\hline $\begin{array}{l}\text { Luiz Inácio Lula da } \\
\text { Silva }\end{array}$ & 1945 & Garanhuns - PE & Sem ensino superior. & $\begin{array}{l}\text { Descendente de lavradores } \\
\text { pobres que migraram para } \\
\text { São Paulo em busca de } \\
\text { melhores oportunidades de } \\
\text { trabalho. }\end{array}$ \\
\hline $\begin{array}{l}\text { Marta } \quad \text { Teresa } \\
\text { Vasconcelos Suplicy }\end{array}$ & 1945 & São Paulo - SP & $\begin{array}{l}\text { Graduação em Psicologia } \\
\text { (PUC-SP). Mestrado em } \\
\text { Psicologia (Michigan). }\end{array}$ & $\begin{array}{l}\text { Filha de Luís Afonso Smith } \\
\text { de Vasconcelos, } \\
\text { descendente de industriais, } \\
\text { de família com títulos } \\
\text { nobiliárquicos. }\end{array}$ \\
\hline Francisco Vidal Luna & 1946 & Barcelona - Espanha & $\begin{array}{l}\text { Graduação em economia } \\
\text { (FEA-USP). Doutorado } \\
\text { em economia (FEA- } \\
\text { USP). }\end{array}$ & $\begin{array}{l}\text { Avós eram pequenos } \\
\text { agricultores na Espanha. Os } \\
\text { pais transferiram-se para o } \\
\text { Brasil no pós-guerra, o pai } \\
\text { foi como motorista de } \\
\text { caminhão e depois }\end{array}$ \\
\hline
\end{tabular}




\begin{tabular}{|c|c|c|c|c|}
\hline & & & & $\begin{array}{l}\text { trabalhou uma empresa de } \\
\text { autopeças. A mãe trabalhou } \\
\text { na companhia Singer e fez } \\
\text { serviços domésticos. }\end{array}$ \\
\hline Luciano Coutinho & 1946 & Recife - PE & $\begin{array}{l}\text { Graduação em economia } \\
\text { (FEA-USP). Mestrado } \\
\text { em economia (USP- } \\
\text { Cornell). Doutorado em } \\
\text { economia (Cornell). }\end{array}$ & $\begin{array}{l}\text { Descendente de famílias } \\
\text { tradicionais de Pernambuco, } \\
\text { a família Domingues e a } \\
\text { família Coutinho, donas de } \\
\text { engenho de açúcar. Da } \\
\text { parte de pai eram descentes } \\
\text { do Barão Barão de Amaraji. } \\
\text { Dois de seus tios foram } \\
\text { governadores } \\
\text { Pernambuco. O de } \\
\text { Sinfrônio Coutinho era } \\
\text { advogado e promotor } \\
\text { público. Seu pai era médico } \\
\text { e professor catedrático da } \\
\text { UPFE e a mãe formada em } \\
\text { Belas Artes. }\end{array}$ \\
\hline $\begin{array}{l}\text { Marcos Giannnetti da } \\
\text { Fonseca }\end{array}$ & s.d. & Belo Horizonte - MG & $\begin{array}{l}\text { Graduação em economia } \\
\text { (FEA-USP). Doutorado } \\
\text { em economia (Yale). }\end{array}$ & $\begin{array}{l}\text { Bisavô paterno era João } \\
\text { Pinheiro industrial e político } \\
\text { que alcançou governo do } \\
\text { estado. O avô paterno era } \\
\text { juiz de direito e diplomata. } \\
\text { Por parte de mãe } \\
\text { descendiam de Américo } \\
\text { René Giannetti que, como } \\
\text { João Pinheiro, era um misto } \\
\text { de empreendedor e político. } \\
\text { Foi pioneiro do setor de } \\
\text { siderurgia, presidente da } \\
\text { Federação das Indústrias de } \\
\text { Minas Gerais, secretário de } \\
\text { Agricultura de Minas e por } \\
\text { fim prefeito de Belo } \\
\text { Horizonte. A mãe escrevia } \\
\text { poesia e nos anos 1970 } \\
\text { resolveu estudar psicologia } \\
\text { e trabalhar como } \\
\text { psicanalista. O pai, Justo } \\
\text { Pinheiro da Fonseca, era } \\
\text { formado na Escola de } \\
\text { Minas e Ouro Preto e havia } \\
\text { feito um ano de estudos e } \\
\text { treinamento nos EUA. Foi } \\
\text { engenheiros da Vale. } \\
\text { Trabalhou na indústria do } \\
\text { sogro. Engajou-se na na de } \\
\text { criação da Faculdade de } \\
\text { Ciências Econômicas de } \\
\text { Minas Gerais, onde } \\
\text { lecionou economia geral e } \\
\text { organizou um departamento } \\
\text { de produtividade e e } \\
\text { organização racional do } \\
\text { trabalho na FEMIG. Foi } \\
\text { diretor do crédito Agrícola } \\
\text { Industrial do Banco do } \\
\text { Brasil, no governo de Jânio } \\
\text { Quadros. Ao ser preterido } \\
\text { para a presidência da } \\
\text { FEMIG muda-se, onde } \\
\text { tornou-se diretor das } \\
\text { empresas de Francisco } \\
\text { Matarazzo Pignatari, neto } \\
\text { do Conde Matarazzo e } \\
\text { depois presidente da } \\
\text { Federação Brasileira de } \\
\text { Bancos. }\end{array}$ \\
\hline
\end{tabular}




\begin{tabular}{|c|c|c|c|c|}
\hline Renata Rosenthal & s.d. & São Paulo - SP & $\begin{array}{l}\text { Graduação em economia } \\
\text { (FEA-USP). Mestrado } \\
\text { em economia (FEA- } \\
\text { USP). Doutorado em } \\
\text { história econômica } \\
\text { (Cornell). }\end{array}$ & $\begin{array}{l}\text { Por parte de mãe família de } \\
\text { judeus da Bessarábia. Por } \\
\text { parte de pai eram judeus } \\
\text { alemães que tiveram uma } \\
\text { passagem pela Inglaterra } \\
\text { antes de chegar ao Brasil. } \\
\text { Os pais nasceram em São } \\
\text { Paulo. Ele deu continuidade } \\
\text { aos negócios iniciados pelo } \\
\text { avô e passou a atuar como } \\
\text { corretor financeiro e } \\
\text { colecionador de arte. } \\
\text { Frequentavam o círculo da } \\
\text { intelectualidade paulistana } \\
\text { de esquerda. }\end{array}$ \\
\hline Guido Mantega & 1949 & Gênova - Itália & $\begin{array}{l}\text { Graduação em } \\
\text { e conomia } \\
\text { (FFLCH-USP). } \\
\text { Doutorado em ciências } \\
\text { sociais (FFLCH-USP). }\end{array}$ & $\begin{array}{l}\text { Família da Sardenha por } \\
\text { parte de pai e de Gênova } \\
\text { por parte de mãe. Os avôs } \\
\text { materno e paterno eram } \\
\text { funcionários públicos. O } \\
\text { pai, serviu o exército por } \\
\text { uma década. Regressou à } \\
\text { Itália ao final da Segunda } \\
\text { Guerra Mundial. Poucos } \\
\text { anos depois emigrou para o } \\
\text { Brasil onde montou uma } \\
\text { fábrica de móveis. A mãe } \\
\text { teve um atelier de alta } \\
\text { costura antes de casar. }\end{array}$ \\
\hline $\begin{array}{ll}\text { Henri } & \text { Philippe } \\
\text { Reichstul } & \end{array}$ & 1949 & Paris - França & $\begin{array}{l}\text { Graduação em economia } \\
\text { (FEA-USP). Doutorado } \\
\text { incompleto em economia } \\
\text { (Oxford). Doutorado } \\
\text { incompleto em economia } \\
\text { (IE-UNICAMP). }\end{array}$ & $\begin{array}{l}\text { Avô materno era } \\
\text { comerciante atacadista de } \\
\text { frutas em Lwów na Polônia, } \\
\text { hoje Lviv, na Ucrânia. Do } \\
\text { lado paterno, o avô } \\
\text { trabalhava com madeira na } \\
\text { cidade de Kowel, que na } \\
\text { época também ficava na } \\
\text { Polônia. Para da } \\
\text { perseguição aos judeus, a } \\
\text { avó materna e a mãe } \\
\text { passaram-se por católicas e } \\
\text { foram acolhidas em } \\
\text { Varsóvia pela família de } \\
\text { uma amiga que se arriscou } \\
\text { para salvá-las. O pai, } \\
\text { também judeu, abrigou-se } \\
\text { na Sibéria depois de perder } \\
\text { a família em um massacre. } \\
\text { Em Paris o pai começou a } \\
\text { trabalhar com exportação } \\
\text { de máquinas no Brasil } \\
\text { montou uma fábrica de } \\
\text { autopeças. }\end{array}$ \\
\hline $\begin{array}{l}\text { Eduardo Giannetti da } \\
\text { Fonseca }\end{array}$ & 1957 & Belo Horizonte - MG & $\begin{array}{l}\text { Graduação em economia } \\
\text { (FEA-USP) e ciências } \\
\text { sociais (FFLCH-USP). } \\
\text { Doutorado em economia } \\
\text { (Cambridge). }\end{array}$ & $\begin{array}{l}\text { Bisavô paterno era João } \\
\text { Pinheiro industrial e político } \\
\text { que alcançou governo do } \\
\text { estado. O avô paterno era } \\
\text { juiz de direito e diplomata. } \\
\text { Por parte de mãe } \\
\text { descendiam de Américo } \\
\text { René Giannetti que, como } \\
\text { João Pinheiro, era um misto } \\
\text { de empreendedor e político. } \\
\text { Foi pioneiro do setor de } \\
\text { siderurgia, presidente da } \\
\text { Federação das Indústrias de } \\
\text { Minas Gerais, secretário de } \\
\text { Agricultura de Minas e por } \\
\text { fim prefeito de Belo } \\
\text { Horizonte. A mãe escrevia }\end{array}$ \\
\hline
\end{tabular}




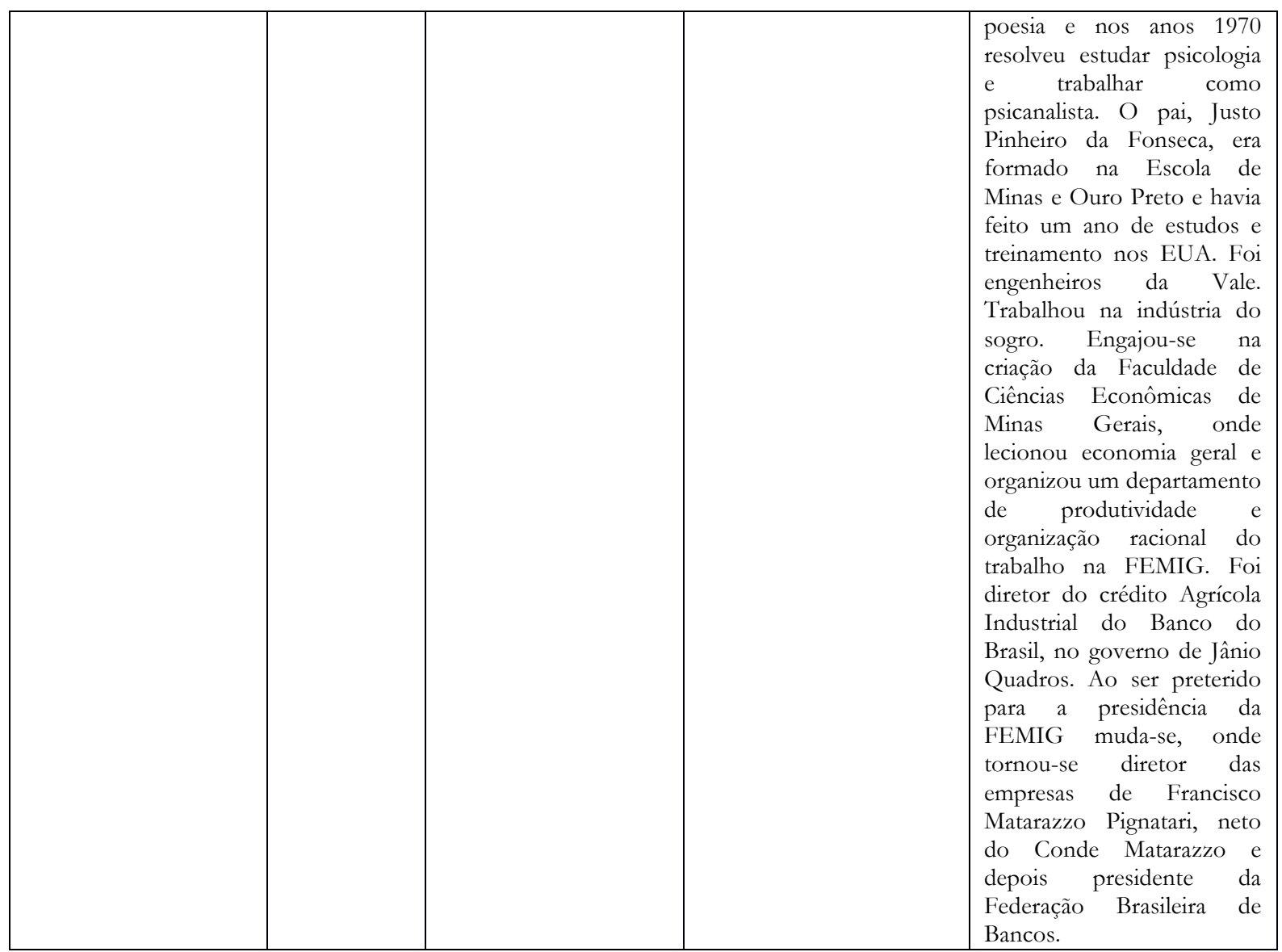

Tabela VI: Trajetórias das principais personagens do Terceiro Movimento. Elaboração: própria.

\subsection{Rede do Terceiro Movimento}

$\mathrm{Na}$ rede referente ao Segundo Movimento, que abarcava os governos militares até os anos 1980, foi observada uma clivagem central entre, de um lado, os monetaristas, a ortodoxia matematizada e o desenvolvimentismo não nacionalista, que colaboraram com a gestão econômica do governo, e, de outro, o desenvolvimentismo nacionalista, a economia heterodoxa e a heterodoxia matematizada, situados na oposição. O Terceiro Movimento, que vai do início do governo de João Figueiredo ao final do mandato de José Sarney, é marcado pela chegada dos críticos do regime militar aos postos de comando da economia. Ao longo dos anos 1980, a dispersão da frente de oposição no plano político, com o surgimento dos novos partidos, corresponde, no espaço dos economistas, movimento análogo de diferenciação e reconfiguração interna, no caso vinculado ao aumento do número de cursos de pós-graduação em economia, que encerra um ciclo de cooperação das oposições e origina novas polaridades. 
Ao invés de uma linha guia que divide o plano, optou-se, nesta rede, pelo uso de uma escala que vai da tendência econômica mais matematizada e monetarista para a mais desenvolvimentista e próxima das ciências humanas. Na escala, o governo Figueiredo aparece em ponto médio entre a área paulista e a área carioca e bastante próximo à ortodoxia matematizada, tendo recrutado quadros na Fundação Getúlio Vargas e nos segmentos da FEA que serviam ao regime militar desde o final dos anos 1960. Delfim Netto e seus discípulos, principais elos da USP com a última administração militar, foram posicionados, no movimento anterior, entre o desenvolvimentismo nacionalista e o desenvolvimentismo não nacionalista; na nova configuração, aparecem próximos à ortodoxia matematizada de Carlos Geraldo Langoni, presidente do BCB no período.

O governo Sarney também aparece na fronteira entre São Paulo e o Rio de Janeiro. À exceção das equipes de Francisco Neves Dornelles e Antônio Carlos Lemgruber, que permaneceram apenas seis meses em suas pastas, os economistas associados ao primeiro governo da Nova República pertencem majoritariamente ao espectro da heterodoxia. Percorrendo a escala de cima para baixo, participaram da gestão economistas da UNICAMP, posicionada entre o desenvolvimentismo nacionalista de inspiração cepalina e as novas heterodoxias, como João Manuel e Belluzzo, da Fazenda, e Luciano Coutinho, da Ciência e Tecnologia; docentes da UFRJ, como Carlos Lessa no BNDES e Eduardo Augusto Guimarães no IBGE; quadros da EAESP-FGV, situada entre a economia heterodoxa e a heterodoxia matematizada, como Luiz Carlos Bresser Pereira e Yoshiaki Nakano na Fazenda; professores dos segmentos de oposição da FEA-USP, posicionada entre as heterodoxias, como João Sayad no Planejamento, Andrea Calabi no Tesouro e Montoro Filho no BNDES; e pessoas afiliadas à PUC-RJ, alinhada à heterodoxia matematizada, como Edmar Bacha no IBGE e Persio Arida e André Lara Resende no Banco Central.

Das escolas de oposição, a mais distante do governo federal é a PUC-SP, abrigando grande grupo de economistas ligados ao recém criado Partido dos Trabalhadores e à prefeitura de Luiza Erundina em São Paulo. Os cursos de economia da PUC-SP e da UNICAMP, com diversos vínculos entre si, são os mais próximos das ciências sociais, partilhando pesquisadores com o CEDEC e o CEBRAP. Como visto, a "Reforma Singer" visava exatamente aproximar a PUC-SP das humanidades, traço característico das heterodoxias em geral, notavelmente do desenvolvimentismo 
nacionalista. O quadro permite observar, dentro do espectro das ciências sociais, uma transição entre as elites paulistanas ligadas ao capitalismo industrial, como Celso Lafer, ou à terra, como Plínio de Arruda Sampaio, que aparecem próximas à Faculdade de Direito, e os grupos ligados ao comércio, parte dos quais imigrantes, da Faculdade de Filosofia da USP que congrega, ademais, o maior número de mulheres, exemplos dos quais seriam os irmãos Emir e Eder Sader e Lourdes Sola.

O governo Montoro, finalmente, fica próximo ao epicentro da heterodoxia. Sua gestão, que antecedeu a redemocratização, foi outro momento de convergência das oposições, havendo, não obstante, forte tendência de seleção de quadros entre os políticos e militantes católicos, estando sua gestão próxima à JUC/AP e ao PDC. O catolicismo aparece entre a EAESP e a PUC-SP, sendo professores como Luiz Carlos Bresser Pereira e Plínio de Arruda Sampaio representantes das conjunções entre a academia e a militância católica.

Um dado a ressaltar é a proximidade das militâncias na JUC/AP, VAR/VPR e POLOP/POC com as ciências sociais de São Paulo, embora ocorram, especialmente ao redor dos grupos que deram origem ao PT, conexões com o Rio Grande do Sul. O PCB é o único dos vínculos militantes a aparecer entre São Paulo e Rio de Janeiro, situado em posição próxima à ocupada por Pernambuco, onde encontram-se aqueles que tiveram vínculos com a SUDENE, com a CEPAL e com as esquerdas dos anos de Miguel Arraes. O MDB aparece no centro da rede, expressão da característica política central do período, a ampla adesão das oposições à frente democrática.

Como nos movimentos anteriores, as relações com a América Latina e a Europa aparecem mais próximas ao polo heterodoxo. As ciências sociais apresentam maior proximidade com a França, país de onde advieram missões estrangeiras para a FFCL, criando laços que facilitaram o acesso dos cientistas sociais, inclusive exilados, às universidades francesas. A FLACSO, no Chile, acolheu diversos cientistas sociais exilados, figurando também em destaque na área do espaço recoberta pelas ciências sociais. No caso dos economistas posicionados entre o desenvolvimentismo e a heterodoxia, o principal laço é com a América Latina, concretizado pelos vínculos com a ESCOLATINA e com a CEPAL. As duas instituições aparecem muito próximas no plano à UNICAMP, que acolheu grande grupo de economistas que deixou o Chile ao ser instaurada a ditadura militar em 1973. Próximas à UFRJ encontram-se as universidades 
inglesas pelas quais circularam seus professores e os pesquisadores da FINEP, especialmente aqueles que estudavam temas ligados à tecnologia e organização industrial.

No que concerne às circulações nos EUA, Chicago conserva posição no extremo da ortodoxia matematizada, sendo seus vínculos majoritariamente com professores da FGV. Yale, Harvard e MIT aparecem próximas e situadas entre a heterodoxia matematizada e a ortodoxia matematizada. Yale posiciona-se entre a FEA e a FGV e Harvard e o MIT entre a FGV e a PUC-RJ e próximas a Minas e Rio de Janeiro. Berkeley e Vanderbilt posicionam-se ao meio, Vanderbit mais próxima à USP e Berkeley a meio caminho entre a USP e a PUC-RJ. O padrão de distribuição dessas escolas mantém-se quando comparado com o movimento anterior. Nesse capítulo aparecem duas outras universidades que tiveram destaque na formação dos economistas estudados, Cornell e MSU. Nos dois casos prevaleceram fluxos de alunos da USP e da EAESP, aparecendo os convênios no polo correspondente a São Paulo. Tal qual Berkeley e Vanderbilt, Cornell e Michigan aparecem situadas entre as duas heterodoxias, visto serem escolas que abriam, ao lado do ensino da economia mainstream, espaço para a veiculação de outras correntes de pensamento econômico.

As duas figuras de maior destaque no plano, no período, são Fernando Henrique Cardoso e José Serra, expressão da intensa circulação dos dois entre os militantes e os acadêmicos. Em suas experiências na França e no Chile, eles criaram e aprofundaram laços com amplo grupo de exilados e diversas instituições. FHC aparece na parte de cima da rede, entre a FFCL, os centros de pesquisa brasileiros e a FLACSO e a CEPAL. José Serra situa-se no centro, mais próximo dos economistas da UNICAMP e da PUC-SP. Está posicionado, ademais, entre o centro de agregação daqueles que se exilaram no Chile e o núcleo católico da JUC/AP, ao qual pertenceu na juventude. A trajetória de FHC, em especial, revela a força da socialização internacional para o cultivo de disposições essenciais ao exercício do poder, como a coragem, a autoconfiança e a segurança de si. Embora dotado de grande volume de recursos de variado tipo desde o nascimento, é na rememoração da experiência internacional que fornece passagem reveladora ao olhar sociológico. Abordando a experiência do exílio, descrita como "cosmopolitismo à força", ele escreve: o mundo "passou a ser uma coisa mais familiar para mim, já não tinha medo [...] de coisa nenhuma" (CARDOSO, 2012, pp. 35-36). Finalmente, outro traço comum nos dois casos é a imbricação entre a "política" e a "técnica", quando passam a atuar na 
política partidária nacional, FHC como senador e Serra como deputado federal e constituinte. Eles corporificam o surgimento do híbrido que reconfigura e complexifica a polaridade anterior entre técnicos e políticos. Constituindo-se como políticos com autoridade técnica, embaçando as linhas de força e alimentando a justificação de opções políticas por razões de tipo técnico-científico, fornecidas pelo desenvolvimento do pensamento econômico especializado.

O BNDES, que apareceu nos Movimentos anteriores entre os dois desenvolvimentismos, posiciona-se agora entre uma heterodoxia que incluí o desenvolvimentismo nacionalista e uma corrente heterodoxa matematizada, mais próxima do monetarismo, e não necessariamente desenvolvimentista. O Banco passou por dois momentos bastante distintos no período. Durante o governo Figueiredo foi comandado pelos presidentes baianos de ACM, contando com diretores apontados por Delfim Netto, como Rubens Freitas, que era ligado a Chicago. No governo Sarney, além de Montoro, do banqueiro Gros e do empresário Dílson Funaro, situado do centro para baixo, o Banco contou com Rômulo de Almeida e Carlos Lessa na diretoria, os dois associados ao desenvolvimentismo nacionalista, localizado na parte de cima do plano. A posição centralizada do Banco resulta dessa multiplicidade de orientações. Geograficamente o BNDES situa-se próximo ao Rio de Janeiro, cidade onde está localizado e de onde provém a maioria de seus funcionários neste período.

O Terceiro Movimento, que se encerra ao final do governo Sarney, foi caracterizado pela cooperação das oposições em busca da solidificação da economia do regime democrático. Às diferenças entre as escolas existentes no início do período, inicialmente abafadas em nome da missão comum, agregaram-se cisões partidárias e divergências decorrentes das disputas que os grupos tiveram ao tentar governar juntos. $\mathrm{O}$ Quarto Movimento caracteriza-se por uma nova estrutura de polarização em que aparecem apartadas as frações da antiga oposição ao governo militar, tema que será explorado tendo como linha condutora as gestões do BNDES dos anos 1990 e início dos $\operatorname{anos} 2000$. 







\section{QUARTO MOVIMENTO: O BNDES dos governos Collor, Itamar e FHC (1990-2003)}

O sexto capítulo promove uma inversão da perspectiva até este ponto adotada na narrativa. Nos movimentos anteriores partia-se da constituição do espaço dos economistas, das escolas e dos governos e inseria-se na narrativa as transformações experimentadas pelo Banco Nacional de Desenvolvimento Econômico e Social (BNDES). No quarto e último movimento, as personagens apresentadas, instituições construídas e escolas delineadas convergem na análise das inflexões e continuidades na gestão e nas ações do BNDES. Parte-se da narrativa sobre as experiências do Banco no final do século XX e início do XXI, mantendo o diálogo com as alterações no balanço de poder externo, visto que a ascensão e queda dos dirigentes do Banco e a transformação em seus rumos insere-se em um universo ampliado de lutas nas quais estão envolvidos atores, grupos e instituições. A interface com o ambiente externo, obviamente, não desaparece, dado que muitos dos eventos como políticos, alterações no grupo dirigente, mudanças nas condições econômicas, injeção de verba etc. são elementos cruciais para compreender a operação do Banco.

No capítulo anterior, a narrativa sobre o BNDES interrompeu-se após a montagem da diretoria do primeiro governo da Nova República e da apresentação das políticas da área social durante o governo Sarney. O quarto movimento principia pela apresentação da dinâmica interna do Banco no início dos anos oitenta, enfocando as tensões entre os técnicos e os diretores indicados que levaram à instauração de um novo processo de planejamento estratégico. Seguindo as trajetórias de Julio Olímpio Fusaro Mourão e de Luiz Paulo Vellozo Lucas analisa-se o período em que o Banco desenhou cenários para a economia nacional com o objetivo de entender de que modo deveria reposicionar-se para promover melhoria das condições econômicas. Um dos cenários criados, o da Integração Competitiva, teve grande impacto externo e interno. Propunha-se uma abertura das fronteiras para aumentar a intensidade das trocas internacionais e levar as empresas brasileiras a atuar no exterior. Para tanto, uma face da abertura voltaria-se ao incremento das condições de competitividade, seja melhorando a infraestrutura interna 
para reduzir custos, seja modernizando e dinamizando com alta tecnologia os grupos existentes (item 6.1).

As ideias que emanavam da integração competitiva eram de tal modo influentes que alguns participantes do planejamento foram alçados ao Governo Federal quando Fernando Collor de Mello conquistou a presidência. Ainda que contasse com pessoas do BNDES, como Vellozo Lucas, e da Financiadora de Estudos de Projetos e Programas (FINEP) em sua equipe econômica, o novo governo acabou conduzindo uma abertura violenta, não acompanhada das medidas voltadas à competitividade que acompanhariam a integração. Feita em ritmo acelerado, sem que houvesse um tempo para que as empresas se adaptassem às novas condições e investissem o suficiente para competir - para o que precisariam do crédito que o governo restringiu - o resultado seria uma simples desindustrialização que arrastaria tanto os improdutivos, quanto grupos produtivos que precisavam de algum tempo e ajuda para ampliar seus horizontes de atuação (item 6.1).

O grupo da Integração Competitiva nem conseguiu estender suas recomendações com efetividade para o Governo Federal nem conseguiu que o BNDES seguisse o plano que conceberam para balizar as ações da instituição. No início do governo Collor, assumiu a presidência do BNDES o professor da Pontifícia Universidade Católica do Rio de Janeiro (PUC-RJ) Eduardo Modiano, que convergia com o departamento de planejamento do BNDES no que concernia à necessidade de abrir a economia e privatizar parcelas do Estado. Não obstante, ao invés de negociar os pontos em que tinha divergências com os altos quadros do Banco, optou por, para implementar seu projeto, deslocar aqueles que ocupavam os postos de maior prestígio e poder na casa, alçando pessoas que tinham maior sintonia com seus desígnios. Modiano transformou o BNDES no principal instrumento do processo de desestatização acelerada preconizado pelo novo governo. As privatizações por ele conduzidas divergiam daquelas anteriormente perpetradas pela instituição pois não pretendiam apenas devolver empresas que o BNDES abrigara e ajudara a reestabelecer em um momento de crise, mas avançar para toda a atividade industrial conduzida pelo Estado, fossem as empresas sãs e produtivas, ou débeis e endividadas, o que foi visto com ressalvas mesmo por grupos do Banco que defendiam a privatização, quando feita em outros moldes (item 6.2).

As trajetórias da Ministra da Fazenda Zélia Cardoso de Mello, do presidente do BNDES Eduardo Modiano e do vice-presidente do Banco, José Pio Borges, que se 
converteria em Presidente anos depois, conduzem o leitor pelas disputas que marcam a política econômica e industrial do governo Collor, com o objetivo de situar as inflexões experimentadas pelo BNDES no contexto mais amplo das mudanças econômicas que o governo pretendeu empreender. Em linhas gerais detecta-se a presença no governo de um núcleo de pessoas ligadas à Universidade de São Paulo (USP), à Estadual de Campinas (UNICAMP) e à Pontifícia Universidade Católica de São Paulo (PUC-SP), formado, essencialmente, por amigos de Zélia, alguns dos quais eram próximos de José Serra e trabalhariam com ele nos governos Partido da Social Democracia Brasileira (PSDB). Um segundo grupo era formado por pessoas ligadas ao Instituto de Economia Industrial da Universidade Federal do Rio de Janeiro (IEI-UFRJ) com vínculos com o BNDES e a Petrobrás, que era o grupo da Integração Competitiva, ao qual pertencia Luiz Paulo Vellozo Lucas, que estabeleceram contato com Zélia quando ela participou da gestão de Dílson Funaro na Fazenda. O terceiro polo era formado por especialistas em economia ligados à área de comércio exterior, a maior parte dos quais proveniente da maior empresa de importação e exportação privada da época, a Cotia Trading. Zélia havia sido sócia, em sua consultoria, de um membro da Cotia e o grupo ganhou espaço em sua administração. Finalmente, durante algum tempo contaram com consultorias e colaboração de professores da PUC-RJ, dentre os quais Marcelo Abreu, Winston Fritsch e Gustavo Franco, que rapidamente viram-se excluídos do núcleo do poder, abandonando a equipe e esperando três anos para voltar ao centro com Fernando Henrique Cardoso (item 6.2).

O impeachment de Fernando Collor de Mello e a ascensão de Itamar Franco dão origem a uma ciranda de titulares nas pastas econômicas. O BNDES tem três presidentes em dois anos, cada um com uma visão de economia e política bastante distinta, e não é diferente a situação nos outros órgãos do topo do Estado, evidenciando a falta de coesão política e coerência de projeto para a economia nestes anos. O período começa com Antonio Barros de Castro (item 1.5) na presidência do Banco, um acadêmico reconhecido, que havia circulado internacionalmente, sido vinculado à Comissão Econômica para a América Latina (CEPAL), lecionado na UNICAMP e na Universidade Federal do Rio de Janeiro (UFRJ) e sido consultor da FINEP e do próprio BNDES nos anos 1980. Castro fora trazido para o Banco por Paulo Haddad, Ministro do Planejamento e depois da Ministro da Fazenda, também acadêmico. Ambos reivindicavam a recuperação da ideia de planejamento e o investimento na competitividade das empresas, concebida como 
atualização tecnológica e modernização, mas o cenário era de constrição de verbas e dificuldades para estabilizar a economia (item 6.3).

Castro e Haddad perderam seus postos rapidamente, devido a conflitos com o Presidente e com o núcleo de assessores e ministros mais próximos de Itamar, conhecidos como a "República do Pão de Queijo". No caso de Castro, houve uma disputa com um dos membros do círculo próximo de Itamar, protagonizada por decisões quanto aos destinos e modo de operar o processo de privatização. O sucessor de Castro, o empresário paulista Luís Carlos Delben Leite, indicado pelo Partido do Movimento Democrático (PMDB) de São Paulo, teve o mesmo destino, sendo destituído por atritar com um membro do núcleo central do governo e tendo pouca chance de implementar um projeto próprio no Banco. A intensa circulação na área econômica só arrefece quando Fernando Henrique Cardoso (FHC) aceita o posto de Ministro da Fazenda e consegue de Itamar liberdade para definir sua equipe e para conduzir as políticas que considerasse necessárias para estabilizar a economia, que continuava debatendo-se com uma crescente inflação (item 6.3).

FHC logo atrai uma grande equipe de colaboradores ligados à PUC-RJ, dentre os quais Pedro Malan, Winston Fritsch, Edmar Bacha, Persio Arida e André Lara Resende, os três últimos economistas que já haviam lutado contra a inflação no Plano Cruzado, no início do governo Sarney, e que há anos se dedicavam ao tema da estabilização (item 5.0). Além deles, entra em cena uma nova geração, formada por economistas que foram alunos seus na graduação e no mestrado na PUC-RJ, entre os quais Gustavo Franco, Armínio Fraga e Elena Landau. Lado a lado à equipe da PUC-RJ, atuou um núcleo paulista com o qual FHC tinha contato desde os tempos de resistência à ditadura, centrado nas figuras de José Serra, Clóvis Carvalho, Sérgio Motta e dos irmãos Luiz Carlos e José Roberto Mendonça de Barros (item 3.2). Enquanto foi Ministro da Fazenda no governo Itamar, FHC operou com algumas equipes em paralelo: Edmar Bacha, Clóvis Carvalho Winston Fritsch, Gustavo Franco e José Roberto Mendonça de Barros trabalhavam na definição das políticas de ajuste fiscal do Estado e reestruturação orçamentaria, com apoio de Serra e da assessoria que ele mantinha como deputado. Pedro Malan dialogava com eles, encarregava-se da negociação da dívida externa e ajudava André Lara Resende, incumbido da concepção da política de estabilização, em constante parceria com Persio Arida, indicado por FHC para substituir Delben Leite no BNDES (item 6.3). 
Procura-se mostrar como como as políticas do BNDES, no período em que o Banco foi conduzido por Persio Arida e por seu sucessor Edmar Bacha, alinharam-se ao projeto de estabilização da esfera federal. Deram continuidade ao processo de privatização, previsto nas políticas de reordenação do Estado e ajuste e, simultaneamente, buscaram reestruturar o modelo de empréstimo e a definição das prioridades de alocação dos recursos do Banco, argumentando que o BNDES deveria concentrar-se nas falhas de mercado e em investimentos que gerassem externalidades produtivas. O lema seria, "se o mercado privado pode financiar, o Banco não deve participar" pois, de um lado, há de concentrar-se em áreas nas quais o setor privado ainda não consegue agir sozinho, como investimentos de longo prazo em infraestrutura e, de outro lado, a participação do BNDES - que emprestava a taxas de juros reduzidas - em empreendimentos que poderiam ser financiados privadamente, inibiria o avanço do mercado de capitais brasileiro (item 6.3).

Conforme a economia estabiliza-se, o BNDES torna a crescer por duas razões, a primeira é a maior demanda por financiamento de agentes econômicos que voltam a ter perspectiva de longo prazo para investir. A segunda é a política de compensação que o Banco adotou para contrabalancear os efeitos recessivos provocados pelo arranjo macroeconômico desenhado para estabilizar a economia, notavelmente a combinação de câmbio apreciado e juros elevados. No final de 1995, o BNDES passa a ser dirigido por Luiz Carlos Mendonça de Barros, que participava da linha do governo que era favorável à redução dos juros e desvalorização do câmbio por julgar que estes tinham efeitos deletérios sobre a produção, a balança comercial e o crescimento. O primeiro mandato de Fernando Henrique Cardoso na Presidência da República é marcado pelo conflito entre um grupo "liberal-desenvolvimentista", do qual faziam parte José Serra, Clóvis Carvalho, Andrea Calabi Sérgio Motta e os irmãos Luiz Carlos e José Roberto Mendonça de Barros, e um grupo "neoliberal", posicionado no Ministério da Fazenda e no Banco Central, encarnado, essencialmente, por Pedro Malan e Gustavo Franco. Em posições intermediárias encontravam-se economistas como Edmar Bacha, Persio Arida e André Lara Resende, que circulavam entre os dois grupos e tinham críticas aos dois extremos (item 6.4).

Fernando Henrique buscava equilibrar-se entre os dois polos de sua equipe econômica, fazendo concessões de parte a parte. Não tendo modificado a política 
econômica restritiva, passou a permitir que outros instrumentos do governo atuassem para preservar o sistema produtivo. O BNDES, nesse arranjo, realizou crescentes desembolsos, promoveu um retorno do investimento industrial e ampliou o financiamento às exportações, com a intenção de melhorar a balança comercial externa. $\mathrm{O}$ Banco passou também a atuar mais fortemente nas políticas sociais e para micro, pequenas e médias empresas, tentando compensar o desemprego e a redução dos programas sociais do Estado decorrentes dos cortes promovidos pelo ajuste das contas públicas que antecedeu a implementação do Plano Real. Qualitativamente, o Banco também alterou sua diretriz, ao tentar impulsionar grandes empresas com alto nível tecnológico, que passaram a ser apoiadas na tentativa de formar fortes competidores internacionais (item 6.4).

A privatização no período mudou de alvo, passando do setor produtivo aos serviços públicos, além do apoio à privatização nos estados e municípios da federação, o que implicava conceber modelos de concessão e partilha de funções entre Estado e iniciativa privada para garantir o acesso a serviços básicos como energia, comunicações e transportes. Foi justamente na ocasião de uma das privatizações da telefonia que parte do grupo liberal-desenvolvimentista foi afastado do governo, por conta do vazamento do registro de grampos telefônicos que poderiam sugerir que a equipe haveria tendido a privilegiar um dos grupos concorrentes no leilão de privatização. A saída de Luiz Carlos e José Roberto Mendonça de Barros e de André Lara Resende decorrente deste episódio enfraqueceu aqueles que pregavam a ampliação das políticas voltadas ao crescimento e uma mais robusta atuação social do Estado (item 6.4).

O Presidente Fernando Henrique chegara a planejar uma alteração para o segundo mandato que colocaria esses economistas em postos chave, visando justamente uma ampliação do lado desenvolvimentista de seu liberalismo. O episódio dos grampos afetou sua ideia de criar um ministério voltado à produção e entregá-lo a algum representante desse grupo, tendo até tentado, em 1999, fazer algumas alterações nesse sentido, fortalecendo o Ministério do Desenvolvimento, Indústria e Comércio (MDIC), inclusive com a transferência do BNDES para a pasta. Simultaneamente, substituiu Gustavo Franco, grande defensor da política de austeridade, por Armínio Fraga e foi forçado a desvalorizar o câmbio. Tais medidas não lograram, todavia, reverter o equilíbrio das forças na equipe econômica já que, Clóvis Carvalho, um dos poucos remanescentes do 
grupo liberal-desenvolvimentista, foi retirado do MDIC depois de fazer críticas públicas a Malan, dizendo, em linhas gerais, que a política do governo era conservadora e pouco ousada, tendo efeitos negativos sobre o crescimento e o nível de emprego. Foi substituído por Alcides Tápias, que tinha longa carreira no mercado financeiro. Ele logo removeu da presidência do BNDES Andrea Calabi, também associado ao polo liberaldesenvolvimentista, que manteve as políticas voltadas à propulsão do crescimento e preservação do parque produtivo (item 6.4).

No lugar de Calabi, Tápias colocou um colega de longa data do mercado financeiro, Francisco Gros, que havia sido diretor do BNDES no governo Sarney e presidente do Banco Central em duas ocasiões, o que reforçava os representantes da orientação neoliberal e experiência de mercado de capitais no governo. Ao entrar no Banco, Gros buscou conduzir um processo de planejamento interno do qual emanaram sete diretrizes prioritárias para a atuação do BNDES, nenhuma das quais nova em relação aos discursos que já circulavam no Banco desde o primeiro mandato. A grande inflexão estava em diagnosticar que o BNDES precisava atuar em parceria com o mercado de capitais visando, não apenas ampliar a área de abrangência da atuação do Banco, mas fomentar o próprio mercado financeiro, visto como instrumento crucial para a implementação de um moderno capitalismo no Brasil. A pulverização da carteira de ações do BNDES Participações (BNDESPAR), com grandes vendas de ativos de antigas companhias públicas que haviam permanecido nas mãos do Estado, são um exemplo do tipo de iniciativa adotada para que o Banco caminhasse nesta direção (item 6.5).

Não apenas as ações do Banco foram modificadas pela adoção da ótica do mercado de capitais, mas o próprio BNDES teve sua maneira de operar alterada, a começar pela própria estrutura física da instituição que foi reformatada para ecoar o modelo de um banco de investimentos privados, em que toda a direção partilha uma única sala de modo a dinamizar as interações entre a cúpula. As áreas passaram a ser divididas entre um segmento voltado à interação com clientes e outro segmento dirigido a produtos do próprio Banco. A mudança da orientação teve impacto nos concursos, cuja bibliografia recomendada passou a incluir uma proporção maior de títulos relativos a conhecimentos de finanças. Finalmente, os diretores que ingressaram na diretoria enquanto Gros, e seu sucessor, o também financista Eleazar de Carvalho Filho, estiveram à frente do Banco eram pessoas provenientes do mercado de capitais e mesmo os 
diretores da casa que foram alçados à diretoria eram quase todos da área financeira (item $6.5)$.

A transição para o governo Lula será rapidamente mencionada à guisa de conclusão. As gestões do Banco nos governos do Partido dos Trabalhadores (PT) não serão analisadas nesta tese. Não obstante, procura-se mostrar que, logo de início, há uma tentativa de rejeitar a perspectiva neoliberal que dominou o governo anterior, sobretudo a partir do segundo mandato. A nova gestão, presidida por Carlos Lessa, procura desmontar as reformas feitas por seus antecessores com a intenção de aproximar o BNDES da operação de um banco privado de investimentos. Há uma contraposição do que seria uma instituição voltada à propulsão do capital e aquela que estaria, como argumentam que o Banco esteve historicamente, voltada ao desenvolvimento econômico e social nacional. A reestruturação interna passou por uma grande alteração dos titulares dos altos postos do Banco e incluiu o oferecimento de cursos de formação voltados à transmissão das teorias do desenvolvimento, perspectiva que alega ter sido perdida na casa. O capítulo encerra-se com a sugestão que o tom combativo e a rejeição do governo anterior foram sendo amenizados com o passar das gestões do PT, surgindo um modelo de síntese entre a perspectiva do desenvolvimento que o novo governo buscava resgatar e os modos de operação de mercado voltadas à promoção da competitividade em um cenário de abertura internacional (item 6.0).

\subsection{O BNDES da Integração Competitiva}

No início da Nova República, Dílson Funaro e André Franco Montoro Filho foram designados presidente e vice-presidente do BNDES. Ao ingressar na instituição, depararam-se com um processo de planejamento interno autonomamente conduzido pelo corpo técnico, que estava em curso desde 1983, e era liderado pelo Departamento de Planejamento (DEPLAN). A ideia decorrera, de um lado, do colapso da capacidade Banco de exercer sua função de financiador do desenvolvimento em uma economia que, na primeira metade dos anos 1980, atravessava período de crise e desaquecimento, havendo feito acordos com o Fundo Monetário Internacional (FMI) que impunham condições ainda mais restritivas para o gasto público. Nesse cenário, o planejamento de 
longo prazo perdera espaço na instituição e havia pouca clareza acerca das prioridades que deveriam ser adotadas pelo Banco (MOURÃO, 1994, pp. 4-6).

No período em que Delfim Netto fora Ministro do Planejamento o Governo Federal determinou que o BNDES atuasse nas áreas social e de agricultura, que nunca lhe couberam e para as quais não tinha, até então, expertise. Em contrapartida, o setor industrial, que fora incumbência do Banco desde o início, com destaque para os anos 1970, vivia grandes dificuldades. Muitas empresas longamente apoiadas pelo Banco não possuíam meios para honrar as dívidas contraídas, razão pela qual o Banco acabou intervindo, em diversas ocasiões, visando preservar o parque produtivo nacional que ajudara a criar. Em alguns casos, chegou mesmo a ser um "hospital de empresas", assumindo a gestão das companhias resgatadas, o que era percebido como um desvio da finalidade da instituição e como um ônus para o orçamento do Banco e para os técnicos chamados a desempenhar atividades gestão empresarial.

De outro lado, o Banco atravessara uma crise política interna, decorrente da rejeição de dirigentes indicados pelo governo no início dos anos 1980 (item 5.5). Um exdiretor relata que:

No governo Figueiredo foi nomeado um presidente que, para mim, foi o pior presidente da história do BNDES. Um cara chamado Luiz Sande de Oliveira. E esse cara tentou, efetivamente, tomar, digamos assim, o BNDES e transformar o Banco numa instituição que seguisse os seus interesses políticos. Mas ele não foi bem sucedido não. A casa o rejeitou. Em algum momento foi criado esse chamado comitê de enquadramento e prioridades que existe até hoje, que é um Comitê de Superintendentes. Os superintendentes são os deputy directors do Banco. São sempre funcionários de carreira, obrigatoriamente. E esse comitê é, para mim, o instrumento de governança mais importante do Banco e que mais garante que o Banco seja um órgão de Estado e não de governo, porque todos os assuntos passam por esse comitê antes de irem à diretoria. E não tem influência política. Quer dizer, existe... pode existir uma sensibilidade política. Mas ingerência política não há (Entrevista à autora 2012-2015).

O comitê de superintendentes e os procedimentos para análise de projetos são destacados, em mais de uma entrevista, como uma barreira a empreitadas políticas que considerem ameaçar a instituição. Outro ex-diretor explica que a solução foi

montar um sistema que era assim: o projeto tem que ser analisado e lido por um monte de gente. Aí vai para o comitê de prioridades. Aí ele é visto por um monte de gente que analisa. Aí é encaminhado para não sei onde, até chegar no comitê de crédito. Aí passa pelos assessores de cada diretoria e os jurídicos de cada diretoria e aí chega na diretoria. Tenta-se fazer isso do jeito mais rápido que se pode. É claro que isso atrasa um pouquinho, mas qualquer coisa vira um segredo de polichinelo porque tem sempre umas 300 pessoas capazes de entender o que está acontecendo [...], sabendo do mais mínimo detalhe de qualquer... então isso foi criado para blindar corrupção (Entrevista à autora, 2012-2015). 
Um terceiro ex-diretor diz que ao levar os projetos já com apoio dos superintendentes e dos chefes de departamento para as reuniões de diretoria, o resultado era que

inibia o político, porque você tratava a questão tão tecnicamente que o cara até ficava com vergonha de perguntar ou de contestar ou de sugerir alguma coisa. Isso criou, de certa maneira, anulou, ou anulava naquela época, eventuais ingerências mais políticas nas decisões e dava ao corpo técnico uma valorização, que ele antes tinha e que tinha deixado de ter. O que começou a criar um certo... "O que é que a gente está fazendo aqui?" (Entrevista à autora, 2012-2015).

Finalmente, um entrevistado mostra que os procedimentos instituídos começaram a favorecer os próprios diretores que, se eram pressionados por políticos com pedidos inconvenientes, respondiam simplesmente que não eram eles que decidiam, pois o projeto tinha que passar no comitê de prioridades, de crédito, pelos gerentes e superintendentes e só então, já com os pareceres técnicos, é que a diretoria olharia para o pedido que, caso fosse ruim, já viria de baixo com uma negativa. Outro entrevistado compara esse arranjo com a estrutura de uma empresa congênere do setor privado, dizendo que:

No BNDES tudo é de baixo para cima; no setor privado de cima para baixo. No BNDES as decisões são tomadas de baixo para cima, através de pareceres técnicos, de reuniões de colegiado, até que o assunto já chegue bastante discutido e bastante consensual na diretoria. [...] Tanto que quando algum empresário, qualquer pessoa, vier fazer algum lobby junto a mim, eu falava: bom, você tem que falar com o gerente. Ele é que decide. Ele é que vai dar o parecer. Eu apenas vou receber o parecer dele aqui e vou encaminhar para a decisão de diretoria. Então o BNDES tinha muito essa questão interessante. Quer dizer, é lógico que os diretores tinham um papel importante, assim, de traçar estratégias, de dar orientações, mas as decisões que eles tomavam eram sempre respaldadas com base em pareceres técnicos e decisões colegiadas. Nós tínhamos no BNDES um comitê de prioridades que definia se aquele projeto que estava entrando no Banco era prioritário de acordo com as diretrizes operacionais do BNDES. Nós tínhamos um comitê de crédito que avaliava se aquela empresa tinha uma capacidade financeira adequada a receber aquele empréstimo, que a gente chamava de rating. Depois nós tínhamos um grupo de análise que analisava o projeto em todos os seus aspectos mercadológicos, jurídicos, de engenharia, de economia. Um grupo que era formado por um economista, um advogado, um engenheiro, um contador, que então elaboravam um relatório e que era submetido então a um gerente, depois a um chefe de departamento, depois ao superintendente, depois a um diretor que submetia à diretoria. Era um processo mais longo do que o convencional, obviamente, até porque se estava tratando de dinheiro público, então tinha que ser muito mais cuidadoso (Entrevista à autora, 2012-2015).

Um presidente do Banco explica que o comitê de superintendentes era uma força tal que era preciso descer ao comitê e negociar, caso desejasse promover inflexões nos 
rumos da instituição. Não era possível agir sem eles. O acúmulo de poder no topo do corpo técnico do BNDES fez com que, doravante, uma das estratégias adotadas por novos presidentes que pretendessem mudar radicalmente os rumos da instituição, fosse uma quebra no nível dos superintendentes, desfazendo a coesão e o poder da equipe. Via de regra, os superintendentes são substituídos aos poucos. Mantém-se a maior parte dos nomes mesmo quando há transição de presidência. Em três momentos houve alterações nas quais quase todos os superintendentes foram substituídos ao mesmo tempo: com a entrada de Luiz Sande de Oliveira, em 1979, com Eduardo Marco Modiano, em 1990, e com Carlos Lessa, em 2003. A partir dos anos 1990, a diretoria do Banco volta a contar regularmente com funcionários de carreira, o que cria uma camada de amortecimento, reduzindo potenciais animosidades e facilitando a integração entre os dois níveis.

Bem como o comitê de superintendentes, o planejamento estratégico aparece como um dispositivo de proteção da instituição ativado pelo "espírito de corpo" de sua burocracia. A ciranda de diretores que julgavam não ter largo comprometimento com a instituição, que assolou o Banco nos anos 1980, revelara para aquela geração de funcionários - que saía de um período de 8,5 anos da forte, estável e quase sempre admirada liderança de Marcos Pereira Vianna - que nem sempre poderiam confiar nos dirigentes indicados para dar rumos à instituição, razão pela qual tomam a iniciativa de conduzir autonomamente o planejamento. O DEPLAN tentou fazer com que a alta administração do Banco estivesse ao menos a par das discussões. Não foram inteiramente bem sucedidos na tentativa de incluir a cúpula, dada a grande circulação de diretorias. A vertiginosa reposição de presidentes, que em média não permaneciam nem um ano no Banco, era, em si, uma das razões para que os funcionários da casa decidissem tomar as rédeas e criar linhas de continuidade em meio a tal instabilidade (CASTRO et al., 2002, p. 249).

A ideia de planejar o Banco e dar novo rumo à instituição depois de um momento de avaria não era original. Marcos Vianna havia começado sua gestão, em 1970, trazendo uma consultoria para pensar as funções do BNDES em novo cenário. O contexto nacional e o próprio Banco mudaram, impulsionando a retomada da questão que a Booz Allen fizera a eles uma década e meia antes. Os quadros do Banco haviam aprendido, naquela ocasião, que, quanto mais inclusivo fosse o processo de planejamento, maior legitimidade as propostas dele emanadas adquiririam, razão pela qual buscaram coletar 
opiniões de mais de 800 técnicos e executivos. O DEPLAN propunha que os funcionários ajudassem a responder as seguintes indagações: $O$ que sou? Onde estou? Para onde estou sendo levado? Para onde desejo ir? E identificar os pontos fortes e fracos do Banco, com o objetivo de saber o que seria preciso alterar (CASTRO et al., 2002, p. 247). Os lemas da época eram "nada de planejar o Brasil, e sim o Banco" e “planeja quem executa”, explica o superintendente do DEPLAN daquele período, Julio Olímpio Fusaro Mourão (MOURÃO, 1994, p. 7).

O comitê de planejamento era formado pelos chefes de departamento e superintendentes do Banco e ficaria responsável pela aprovação final dos documentos, que sequer tiveram chance de passar pelo crivo da diretoria que foi alterada duas vezes, em curto espaço de tempo, no final do governo Figueiredo. Julio Mourão (1944), superintendente do DEPLAN, e Luiz Paulo Vellozo Lucas (1956), chefe do Departamento de Planejamento, dois dos principais nomes do grupo que conduziu o planejamento estratégico, eram filhos de profissionais liberais e haviam sido militantes do Partido Comunista Brasileiro (PCB).

Vellozo Lucas nasceu em Vitória, filho do dentista Laércio de Almeida Lucas, formado em ortodontia e direito na Federal do Espírito Santo ${ }^{484}$, que foi professor universitário e atuou no hospital dos funcionários públicos. A mãe, administradora de empresas, foi funcionária do Instituto de Aposentadorias e Pensões dos Industriários (IAPI) e do Instituto Nacional de Seguro Social (INSS). Anos depois, Maria José Vellozo Lucas ingressou na vida política. Chefiou a Casa Civil e a Secretaria de Educação e Cultura do governo do Espírito Santo nos anos 1970 e, em 1979, ingressou no Tribunal de Contas do Espírito Santo, onde trabalhou até os anos 2000. Seguindo o filho, filiou-se ao Partido da Social Democracia Brasileira (PSDB) e foi eleita deputada federal em 2003.

Luiz Paulo Velloso Lucas graduou-se em engenharia e é mestre em engenharia industrial pela Universidade Federal do Rio de Janeiro (UFRJ). Durante a faculdade, foi diretor do centro acadêmico, funcionando como elo dos setores jovens do Partido Comunista Brasileiro (PCB) carioca e as agremiações estudantis comunistas do Espírito Santo. Vellozo Lucas começou a trabalhar no BNDES como estagiário na Investimentos Brasileiros S.A. (IBRASA), atual BNDESPAR, sendo contratado como engenheiro em

\footnotetext{
484 Ver: http://www.al.es.gov.br/appdata/anexos_sptl/ata_sessao_plenaria/Solene_38_27.10.2015.pdf e http://www.sefaz.es.gov.br/painel/vultos24.htm. Consultados em 31/03/16.
} 
1980. Quatro anos depois foi aprovado no concurso do Banco e logo convidado por Mourão para participar do processo de planejamento que estava principiando. Vellozo Lucas conta que, no final de 1986, Júlio Mourão foi promovido a Superintendente e ele foi convidado por Nildemar Seches para chefiar o DEPLAN e dar continuidade ao planejamento, contando, em sua equipe, com Sérgio Besserman Vianna e Guilherme Gomes Dias (HARTUNG, 2008, p. 171; Luiz Paulo Vellozo Lucas in: BNDES, 2002, p. 127).

Mourão nasceu em Belo Horizonte, filho de engenheiro que foi secretário do departamento de viação aérea da Secretaria de Viação e Obras Públicas. Iniciou sua vida política na JUC, sendo mencionado por Frei Betto dentre os membros da república de estudantes cristãos militantes que, no início dos anos 1960, dividiam apartamento na esquina da rua Laranjeiras com a rua Pereira da Silva (item 3.1). Lá viveram, além deles dois, o filósofo Paulo Arantes e Roberto Soeiro, que também se tornaria funcionário do BNDES (BETTTO, 1997). Mourão começou a graduação em economia na Faculdade de Ciências Econômicas e Administrativas da Universidade Federal de Minas Gerais (FACEUFMG), mas transferiu-se para o Rio de Janeiro, concluindo o curso na Universidade Federal do Rio de Janeiro (UFRJ). Fez mestrado no Instituto Alberto Luiz Coimbra de Pós-Graduação e Pesquisa de Engenharia (COPPE-UFRJ) e cursou o doutorado na Universidade Estadual de Campinas (UNICAMP), mas não defendeu a tese. Ainda na UFRJ, Mourão migrou da JUC para o PCB, integrando-se ao grupo de estudos d'O Capital que era comandado pelo estudante de engenharia da UFRJ, Aloísio Teixeira ${ }^{485}$, sendo convidados a participar de um curso de formação em Moscou, em 1968. Os vínculos de Mourão com o PCB fizeram com que fosse preso mais de uma vez pela ditadura. Sendo funcionário do BNDE desde 1966, foi libertado com ajuda dos altos quadros do Banco que possuíam bons relacionamentos com os militares. Comunista ou não, argumentavam, era um bom funcionário e não deveria ser preso (MALTA, 2012, p. 386; LIMA, 2006, pp. 74-75; PAULO NETTO, 2012, p. 61).

Em 1988, agrega-se ao DEPLAN outro militante do PCB que havia sido colega de Vellozo Lucas na engenharia e no movimento estudantil, o carioca Sergio Besserman

\footnotetext{
${ }^{485}$ Depois de um período na clandestinidade, Aloísio Teixeira retorna à universidade, migrando para o curso de economia. Na sequência obteve o mestrado na UFRJ e o doutorado na UNICAMP, ambos sob a direção de Maria da Conceição Tavares. Tornou-se professor da economia da UFRJ de onde foi reitor de 2003 a 2011. Era casado com Beatriz Azeredo (item 6.4) Ver: http://lattes.cnpq.br/8008057988826694. Consultado em $15 / 04 / 2016$.
} 
Vianna (1957), filho do irmão mais velho, médico e comunista, do ex-presidente do Banco Marcos Vianna (item 4.5) . Besserman é graduado e mestre em economia pela Pontifícia Universidade Católica do Rio de Janeiro (PUC-RJ) e ingressou no BNDES por ter sido o primeiro colocado no Prêmio BNDES de Economia do ano de 1987, com a dissertação A política econômica no segundo governo Vargas (1986). O trabalho foi orientado por Winston Fritsch, com grande participação de Marcelo Abreu, ambos professores da área de história econômica, departamento no qual Sergio passará a lecionar. Ao ingressar no BNDES, foi trabalhar em uma gerência de análise econômica, criada quando a vivência da hiperinflação levou o Banco a fazer análise de conjuntura. Simultaneamente, participou do grupo de Vellozo Lucas que conduziu as etapas finais do planejamento estratégico (Entrevista de Sérgio Besserman à autora, 2012; MOURÃO, 1994, p. 14).

O método de elaboração de cenários adotado pelo DEPLAN tinha por referência o trabalho de Michel Godet, do Conservatoire National des Arts et Métiers da França. Eduardo Marques, engenheiro especializado em planejamento e acompanhamento de projetos, conheceu Godet e seu trabalho na época de seu doutorado em economia industrial e da tecnologia na Université de Paris-Dauphine. Marques era funcionário da Comissão Nacional de Energia Nuclear e foi cedido ao BNDES, entre 1984 e 1987, justamente para orientar o planejamento estratégico ${ }^{486}$. Contavam também com frequentes consultorias de Antonio Barros de Castro (item 1.5), sobre os caminhos da economia brasileira no curto prazo e as interações possíveis com atores do sistema internacional (MARQUES, 2002; MOURÃO, 1994, pp. 5-11).

A partir de estudos sobre as possíveis estratégias dos atores engajados na economia e avaliações das potenciais mudanças no ambiente político e econômico, buscaram imaginar cenários que poderiam caracterizar a economia brasileira no período 1983-1986. A partir deles, os técnicos puseram-se a pensar que táticas o Banco poderia adotar para ajudar a refazer a economia no pós-crise. O primeiro cenário, nomeado "Retomada", previa que a economia voltaria a crescer, não por ter adotado as políticas preconizadas pelo Fundo Monetário Internacional (FMI), mas sim como consequência da maturação dos investimentos que haviam sido feitos durante o Segundo Plano Nacional de Desenvolvimento (II PND), nos anos 1970. Em razão das dificuldades atravessadas pelas empresas estatais, acreditavam que a força motriz do crescimento, nesta nova etapa,

\footnotetext{
${ }^{486}$ Ver: http://lattes.cnpq.br/3004439066645820. Consultado em 31/03/2016.
} 
seria o setor privado, razão pela qual deveria ele ser o alvo prioritário das ações do Banco. Estas deveriam visar, sobretudo, a modernização das companhias para aumentar o nível de tecnologia incorporada e a competitividade. Isso incluía promover melhorias na infraestrutura e expandir a fronteira agrícola para reduzir os custos de produção. Nesse cenário, continuava-se ambicionando substituir importações, agora em setores de ponta. O capital estrangeiro era visto com reservas e o grau de protecionismo adotado pelo Estado era tido como adequado (MOURÃO, 1994, pp. 9-12).

O cenário de 1985, denominado "Integração Competitiva", comportava alterações ideológicas substantivas, sustentando que: 1) o modelo de desenvolvimento baseado em substituição de importações estava esgotado; 2) o país estava sendo prejudicado pelo grau de fechamento externo e pela barreira ao capital internacional. Tal grau de enclausuramento dificultava a absorção de novos paradigmas tecnológicos e modos de gestão da produção, além de isolar o país da competição e do alcance de novos mercados; e 3) o Estado estava em crise e não conseguiria mais alavancar o investimento produtivo, devendo, pois, ser enxugado; e 4) o maior constrangimento ao desenvolvimento advinha da defasagem da infraestrutura, em especial aquela do setor elétrico, razão pela qual parte do planejamento foi feita em conjunto com a Petrobrás e com a Eletrobrás. O cenário projetado assumia que o setor público não tinha mais condições de eliminar os gargalos da falta de infraestrutura, com o orçamento público comprometido em atividades não prioritárias - como a produção siderúrgica ou de fertilizantes - e as empresas estatais sujeitas a limitações e desvios de função que as tornavam, muitas vezes, ineficientes e incapazes de competir internacionalmente. A privatização era, portanto, vista como uma necessidade (MOURÃO, 1994, pp. 13-19).

A defesa da privatização no Banco não era nova, mas até os anos 1980 não passava de uma voz dissonante. Ignácio Rangel (item 1.4), um dos primeiros funcionários do BNDE, em seu livro Introdução ao Desenvolvimento Econômico Brasileiro (1955), já argumentava que a ação direta do Estado na economia deveria restringir-se aos setores e projetos que não pudessem ser assumidos imediatamente pela iniciativa privada e, tão logo o capital privado tivesse interesse e capital para assumir o empreendimento, este deveria ser privatizado, liberando os recursos do Estado para serem investidos em outros setores. Essa defesa, que poderia ser entendida como compatível com a orientação liberal/neoliberal, intencionava, em realidade, fazer com que o Estado recuperasse verbas 
para aprimorar outros setores da economia. Não era, portanto, uma teoria fundada no tipo de liberalismo que argumenta que a ação do Estado na economia é ineficiente e distorce a alocação de recursos (RANGEL, 1990, pp. 121-122).

Conforme exposto na Abertura, Ignácio Rangel (item 1.4) foi militante do PCB na juventude, tendo rompido com o partido cujas teses considerou pouco atentas à realidade econômica nacional. Rangel parecia estar sempre em descompasso, podendo ter sido caracterizado por Maria da Conceição Tavares como "o mais ilustre marginal que o Banco já teve" (TAVARES, 2009, p. 173). Brigou com o PCB por não considerar a reforma agrária etapa necessária para o socialismo. Foi afastado do centro das decisões do BNDE no governo militar, por ser vinculado aos comunistas. Defendeu a transferência para a iniciativa privada dos investimentos estatais já maturados, sendo condenado pela esquerda por defender o capital contra o Estado.

$\mathrm{Na}$ época em que a desestatização passa a ser alvo de grandes controvérsias nacionais, Rangel engajou-se fortemente no debate público. Argumentava: "talvez como eu venho prevendo insistentemente, a privatização dos ditos serviços seria posta na ordem do dia com força invencível: a força que os gregos chamavam Moira, isto é, o Destino. Usei todos os meios ao meu alcance para preparar o país para a emergência junto aos jovens quadros que me honraram com sua amizade, alguns dos quais foram meus estagiários ou estagiários dos meus estagiários" (RANGEL, 1988). Ainda que não ocupasse nenhuma posição proeminente no Banco, Rangel era respeitado como pensador da casa e atuava como conselheiro de jovens que ingressavam no Banco. Aluysio Asti, que se tornou diretor do Banco no início dos anos 2000, explica que "ninguém esperava que [Rangel] fosse analisar projeto, não. Ele ficava pensando o tempo todo e a gente tinha que procurá-lo, esgotar o gás do Rangel” (Entrevista de Aluísio Asti à autora, 2012). Julio Mourão, outro que se aconselhava com ele, em seus depoimentos relata que quando entrou no Banco, em 1966,

[tive a] sorte de ficar lotado no Departamento Econômico e fui trabalhar na sala do professor Ignácio de Mourão Rangel. Embora tenha Mourão, não é meu parente. Ele era um professor renomado de economia, com vários livros publicados, um pensador nato e que gostava muito de conversar. Ali eu fiz uma espécie de segundo curso em economia. Aprendi muito com ele. Estávamos na Divisão dos Estudos Regionais. O professor Rangel estava um pouco encostado, porque ele tinha sido considerado de esquerda. Com o golpe de 1964, ele perdeu o poder dentro e fora do Banco. Ele participava de conselhos em instituições de planejamento e de estudos econômicos. Eu acho que, nesse período, ele tinha tido um enfarte. Ficou afastado durante muito tempo, mas depois o médico o autorizou a trabalhar no período da tarde. Então, ele ia pro BNDES à tarde e 
ficava nesse departamento de estudos regionais, dedicado ao desenvolvimento regional (Júlio Olimpio Fusaro Mourão in: BNDES, 2012, p. 54).

Sobre sua mesa, uma pilha a perder de vista de relatórios, dados econômicos, gráficos, tabelas imensas. O dia a dia dele era cavar informações, mais do que ler livros teóricos. Ficava efetuando pesquisas de seu interesse individual - boletins do Fundo Monetário Internacional (FMI), Banco Mundial, estatísticas globais, particularmente da União Soviética -, não estudos para o órgão propriamente dito. Esta prerrogativa era concedida em respeito a ele - um pensador, com todo um histórico de atuação política. Não obstante o clima marcado por um debate econômico complexo, em razão da conjuntura do país, deixavam-no livre para fazer o que bem pretendesse, sem, necessariamente, participar das discussões eventuais em pauta. Neste ângulo, meu relacionamento com Rangel - que, afável, adorava receber e influenciar pessoas, de estagiários a jornalistas, manifestando-se acerca do resultado de suas observações e análises -, era mais de amizade. Aprendi muito nesse convívio, fui uma espécie de seguidor dele, que me tratava quase como a um filho. Frequentava sua casa, tornei-me amigo da família (Júlio Mourão in: FARO e SINELLI, 2014, pp. 148-149).

Outro seguidor de Rangel, também militante do Partido Comunista, era Marcio Henrique Monteiro de Castro (1951), que se tornaria diretor do Banco em 2003. Marcio Henrique explica que escolheu estudar economia porque queria ter um instrumental para melhor entender os textos que lia na militância e optou pela Universidade Federal Fluminense (UFF), pois era onde, na época, lecionavam os professores que retornavam do Chile e haviam tido contato com CEPAL, como Carlos Lessa, Liana Aureliano e Claudio Salm, que estavam fazendo o que Lessa chamou de o "esforço romântico" de criação de uma escola de economia crítica (item 5.2). Já como funcionário do Banco, Monteiro de Castro cursou o doutorado na UNICAMP. Inicialmente foi orientando de Belluzzo, depois de Carlos Lessa, com quem passou a trabalhar na área social do BNDES (Entrevista de Marcio Henrique Monteiro de Castro à autora, 2012). Sua tese de doutorado, Reforma agrária e pequena produção (1992), é dedicada a Rangel e foi ele a prefaciar o livro que reúne a obra de seu mestre. Marcio Henrique conta:

Eu me lembro que ele deu um curso em 1971 na Fluminense. Foi a primeira vez que eu vi o Ignácio Rangel. Ele deu um curso de economia brasileira para a turma que estava se formando. Eu estava fazendo introdução à economia II, com o [professor] Marcello Averbug[487] que chegou um dia e falou: "olha, tem um cara que vai dar um curso aqui de economia brasileira que eu considero o maior economista brasileiro. Ele vai dar um curso aqui para a turma que está se

\footnotetext{
487 "Marcello Averburg é economista e por três décadas lecionou economia na Universidade Federal Fluminense (UFF). Trabalhou para o Banco Nacional de Desenvolvimento Econômico e Social (BNDES) durante cerca de vinte anos, onde foi chefe dos departamentos de Planejamento, Avaliação de Programas e de Indústria Naval, além de assessorar a presidência. É ex-assessor do Banco Interamericano de Desenvolvimento (BID) em Washington, onde exerceu a função de "Country Economist" para a Argentina e o Paraguai, e foi secretário de planejamento do Estado do Rio de Janeiro. Averburg é formado pela Universidade Federal do Rio de Janeiro (UFRJ) e pós-graduado pelo Instituto Latinoamericano y del Caribe de Planificación Económica y Social (ILPES/CEPAL - Chile)" e pelo Institut des Hautes Etudes de l'Amérique Latine - Université de Paris. Ver: http://www.institutomillenium.org.br/author/marcello-averbug/. Consultado em 15/04/2016.
} 
formando, coisa e tal, à noite". Aí eu cheguei para ele e falei: "quer saber de uma coisa, eu vou assistir como ouvinte esse negócio" [...]. Eu já tinha lido alguma coisa dele e nunca tinha entendido muito (Entrevista de Marcio Henrique Monteiro de Castro à autora, 2012).

Fiquei fascinado, pois o professor vinha de uma matriz própria, com uma visão completamente diferente do que se debatia à época - o racha entre a burguesia nacional e a guerrilha: a tese da dualidade básica. A turma de esquerda brigava muito com Rangel, que ganhava as discussões de lavada, deixando as pessoas sem argumento. A partir daí, me dediquei a estudar suas obras. Eu sabia que ele era funcionário do BNDE. Em 1973, fui aprovado num processo de seleção no Banco, e começamos uma convivência de perto, juntamente com um grupo que, alçando funções de chefia de departamento, passou a trabalhar ideias tipicamente rangelianas. A principal se referia à privatização, por um enfoque que não tinha nada a ver com o que os tucanos fizeram. Era todo um changer de place da economia - privatizar os serviços de utilidade pública e estatizar as finanças e o comércio exterior. Atuamos muito nisso ao longo dos anos 80. O então presidente da instituição, Márcio Fortes, gostava do assunto e permitia que a superintendente de Infraestrutura, Maria do Rosário Pizzo, tocasse a ideia do Rangel. No início do governo Collor, houve uma reforma arrasa-quarteirão, nossa equipe foi toda trocada (Marcio Henrique Monteiro de Castro in: FARO e SINELLI, 2014, pp. 169-170).

Por intermédio do grupo que circulava ao redor de Rangel, a privatização, tal qual preconizada por ele, começou lentamente a ecoar dentro do Banco. Algumas de suas ideias orientaram os escritos do DEPLAN, que foram bem recebidos por André Franco Montoro e pelo presidente seguinte, Marcio Fortes. Em janeiro de 1987, André Franco Montoro Filho foi substituído por Fortes na presidência do Banco, posto que ocupava desde agosto de 1985, data em que Dílson Funaro tornou-se Ministro da Fazenda. Montoro Filho conta que nunca foi efetivamente "nomeado presidente. Eu fiquei presidente de exercício” (Entrevista de André Franco Montoro à autora, 2014). Só foi substituído quando Wellington Franco Moreira, que acabara de ser eleito governador do Rio de Janeiro pelo Partido do Movimento Democrático Brasileiro (PMDB), pediu ao Presidente Sarney que nomeasse para o posto Marcio Fortes, provável candidato a sua sucessão no Rio.

Marcio João de Andrade Fortes (1944) nasceu em Belo Horizonte em família de militares. Seu avô paterno, o tenente-coronel Enéas de Carvalho Fortes, era engenheiro militar e pertencia ao Estado Maior do Exército Brasileiro. Faleceu em meio à revolução de 1932, deixando a esposa, a professora Didia Machado Fortes, com os filhos. João Machado Fortes, que tinha 14 anos à época, foi matriculado pela mãe no Colégio Militar do Rio de Janeiro e de lá seguiu para a Escola Militar do Realengo, onde foi colega de João Batista de Oliveira Figueiredo. João Fortes pretendia seguir, como seus 
antepassados, a carreira militar, mas foi atingido, em um treinamento, por um tiro que perfurou-lhe o pulmão e inviabilizou sua permanência no exército. Cursou então a Faculdade Nacional de Engenharia e pouco depois fundou a João Fortes Engenharia, uma das maiores construtoras do país ${ }^{488}$.

Marcio Fortes é o filho mais velho de João com a professora Maria Augusta de Andrade Fortes. Cursou engenharia civil na PUC-RJ, fez especializações em engenharia econômica na UFRJ e em elaboração e análise de projetos habitacionais na Fundação Getúlio Vargas do Rio de Janeiro (FGV-RJ) e trabalhou na construtora do pai. Começou sua vida política no centro acadêmico da faculdade e foi indicado por João Figueiredo, amigo de seu pai, para a secretaria-geral do Ministério da Fazenda de Karlos Rischbieter, posto que ocupou até o início de 1980, quando Delfim Netto trouxe Ernane Galvêas para o cargo e trocaram toda equipe. Marcio Fortes retornou à empresa do pai e aproximou-se do Movimento Democrático Brasileiro (MDB), partido ao qual se filia em 1983. Em troca do apoio nas eleições estaduais de 1986, Moreira Franco indica seu nome para a presidência do BNDES ${ }^{489}$ (DHBB, verbete Marcio Fortes).

André Franco Montoro Filho explica que, ao deixar a presidência, "Marcio pediu para eu ficar um pouco, eu fiquei alguns meses e depois sai”. Deixou o Banco em meados de 1988, na época em que "houve o rompimento [PMDB/PSDB] aqui em São Paulo. Eu estava um pouco como representante de São Paulo e o [Orestes] Quércia pôs o [Bruno] Nardini, que foi para o meu lugar. Mas já era esperado, tá certo, porque eu era a representação de São Paulo no Banco, enquanto o nosso relacionamento com o Quércia foi aceitável, e depois..." (Entrevista de André Franco Montoro Filho à autora, 2014). A substituição, no BNDES, do filho de Montoro pelo industrial paulista Bruno Nardini Feola, que tinha o apoio da Federação das Indústrias de São Paulo (FIESP) e do grupo de Quércia ${ }^{490}$, ocorreu em período de crescentes altercações entre, de um lado, José Sarney e

\footnotetext{
${ }^{488}$ Ver:

http://www.camara.gov.br/proposicoesWeb/prop_mostrarintegra;jsessionid=A3BAA19936B1D009E416CE0049 35D08F.proposicoesWeb1? codteor=19855\& filename=Tramitacao-DIS+574/2002; http://memoria.bn.br/DocReader/DocReader.aspx?bib=089842_04\&PagFis=13597; http://memoria.bn.br/DocReader/DocReader.aspx?bib=089842_04\&PagFis=13528; http://memoria.bn.br/DocReader/DocReader.aspx?bib=089842_04\&PagFis=13540; http://memoria.bn.br/DocReader/DocReader.aspx?bib=089842_04\&PagFis=49890; http://memoria.bn.br/DocReader/DocReader.aspx?bib=093718_01\&PagFis=11047. Consultado em 15/04/2016. ${ }^{489}$ Ver: http://memoria.bn.br/DocReader/DocReader.aspx?bib=030015_10\&PagFis=199344; http://memoria.bn.br/DocReader/DocReader.aspx?bib=030015_10\&PagFis=200531; Consultados em 15/04/2016.

${ }^{490}$ Ver:
} 
Orestes Quércia e, de outro, os segmentos do PMDB paulista liderados por André Franco Montoro, Mário Covas e Fernando Henrique Cardoso.

Apesar de suas diferenças, os círculos que giravam ao redor do senador Fernando Henrique Cardoso, de André Franco Montoro, que governou o Estado de São Paulo de março de 1983 a março de 1987, e de Mário Covas, prefeito de São Paulo de maio de 1983 a janeiro de 1986, uniram-se contra o grupo liderado por Orestes Quércia, governador desde o início de 1987. Em junho de 1988, eles saem do PMDB e fundam o Partido da Social Democracia Brasileira (PSDB), abrindo caminho para que Mario Covas disputasse a presidência em 1989 e o Governo do Estado em 1990 (CARDOSO, 2009a, pp. 44-45; MELHEM, 1998, pp. 197-198; ROMA, 2002, pp. 73-74).

Além do sucessor de Franco Montoro Filho, Bruno Nardini, e de Marcio Fortes, foi incluído na diretoria um terceiro empresário com vínculos políticos, o baiano Ney Fontes de Mello Távora (1947), contemporâneo de Fortes na engenharia civil da PUC-RJ, com mestrado em transportes na Northwestern University em Chicago. Seu pai, Edison José de Melo Távora, também engenheiro, fora secretário de Viação e Obras no Ceará, elegendo-se deputado federal sucessivas vezes. No início do governo Sarney, Edison José de Melo Távora foi feito diretor da Petrobrás. Em agosto de 1988, seu filho Ney, que trabalhava em empresas privadas de engenharia desde os anos 1970, ingressou no BNDES e um ano depois substituiu Fortes na presidência do Banco ${ }^{491}$ (DHBB, verbetes Ney Fontes de Mello Távora e Edison José de Melo Távora).

Os presidentes do BNDES André Franco Montoro Filho, Marcio Fortes e Ney Fontes Távora abraçam o processo de planejamento interno e as diretrizes dele derivadas ${ }^{492}$. Seus relatórios administrativos expressam a adesão aos resultados do planejamento estratégico, visto que incorporam expressões provenientes dos cenários traçados pelo DEPLAN. Em 1985 e 1986, consta nos relatórios que BNDES seguiu as linhas definidas pelo planejamento para priorizar: 1) a implantação e desenvolvimento dos setores tecnológicos de ponta; 2) a modernização e expansão da capacidade produtiva; 3) o aproveitamento das oportunidades agrícolas e 4) a ampliação e modernização dos

\footnotetext{
http://memoria.bn.br/DocReader/DocReader.aspx?bib=030015 10\&PagFis=49568

http://memoria.bn.br/DocReader/DocReader.aspx?bib=030015_10\&PagFis=172835. Consultados em $15 / 04 / 2016$.

491 Ver: http://memoria.bn.br/DocReader/DocReader.aspx?bib=100439_12\&PagFis=82683. Consultado em $15 / 04 / 2016$.

492 No relatório de 1984 há apenas uma breve menção ao Banco estar fazendo um planejamento (BNDES, 1984).
} 
serviços sociais - que constituíam as estratégias preconizadas para a "Retomada", corroboradas pelos sinais de recuperação econômica e pelo aumento nos desembolsos do BNDES. Em 1988 e 1989, os relatórios apresentam o cenário da "Integração Competitiva", argumentando que o Brasil precisava adequar-se aos padrões internacionais de competitividade para inserir-se na economia mundial e, nacionalmente, deveriam ampliar e integrar os mercados, com vistas à redução das desigualdades regionais e sociais. No ano de 1987, em meio à transição do cenário da "Retomada" para o da "Integração Competitiva", o relatório apresenta a meta de "ampliação e compatibilização da base de recursos próprios do Banco com o novo ciclo de expansão da economia brasileira", justificando o processo de privatização das empresas que estavam sob seu controle, que tivera início naquele ano (BNDES, 1987).

Marcio Fortes explica que:

O BNDES estava envolvido financeiramente com o setor estatal da economia. O Banco possuía 23 empresas. Ele era dono de 35\% da Eletrobrás, da Rede Ferroviária Federal, da Nuclebrás, da Chesf e de Furnas. Tinha emprestado dinheiro sob a forma de empréstimo a essas empresas. As empresas estatais não pagavam ao Banco, porque tudo é do mesmo patrão. Em 1987, o Banco não tinha dinheiro para pagar a própria folha de pagamento. Foi salvo pela privatização da Fábrica de Tecidos Nova América. A equipe de planejamento do Banco elaborou o cenário da economia brasileira, onde ficou clara uma série de coisas. Em 1987, o Planejamento Estratégico do Banco, resultado do cenário montado, mudou a postura do Banco, tornando-o operacional para a nova fase de desenvolvimento brasileiro. O Brasil precisava de uma inserção na economia internacional. Naquela época, chamamos de Integração Competitiva, na linguagem de hoje é a tal da globalização (Marcio Fortes in: BNDES, 2012, p. 95).

De 1987 até o início do governo Collor, a privatização era um política do próprio BNDES, conduzida pela BNDESPAR, que não respondia aos planos do Conselho de Desestatização do governo Sarney, posto ser, sobretudo, uma devolução das empresas das quais o Banco havia se encarregado durante a crise. Ao desfazer-se destas companhias, o Banco agia com vista à restauração do patrimônio, arrecadando e transferindo dívidas para o setor privado, e à recuperação do pessoal que estava imobilizado na gestão dessas empresas. Até então, prevalecia a lógica rangeliana: devolver ao setor privado aquilo que já existe e está saneado financeiramente e adequado tecnicamente, para conseguir investir em segmentos que necessitem crescer com apoio do Estado. Nesse sentido, "tratava-se de uma orientação pragmática do Banco, que entendia a privatização como um meio de fortalecer uma intervenção desenvolvimentista em setores outros situados na ponta do desenvolvimento tecnológico. Em outras palavras, o BNDES estaria buscando uma 
reciclagem alocativa dos seus recursos” (Ben Ross Schneider, 1991 apud, VELASCO JR, 2010, pp. 214-315.).

Para implementar as políticas previstas na "Integração Competitiva" e a privatização, Marcio Fortes recrutou Sérgio Zendron e Licínio Velasco Júnior, da BNDESPAR, e nomeou para a diretoria um funcionário de carreira do Banco, Nildemar Secches (1948), engenheiro mecânico pela Universidade de São Paulo (USP), com especialização em finanças na PUC-RJ, que era funcionário do banco desde 1972 e ocupava naquele momento a superintendência de planejamento (Licínio Velasco Júnior in: BNDES, 2012, p. 90). Como um dos principais responsáveis pela privatização no BNDES, Nildemar passou a ser consultado por Fernando Collor de Mello, eleito para a Presidência da República, que intencionava conduzir privatizações em grande escala, razão pela qual acreditava-se que Nildemar Secches assumiria a presidência do BNDES em 1990, tornando-se o segundo funcionário de carreira a presidir a casa, vinte anos depois de Jayme Magrassi de Sá (Marco Antonio Lima in: NOGUEIRA, 2010, p. 79; NASSIF, 2007, p. 155).

\subsection{O BNDES e a Privatização}

Ao invés de Secches, Zélia Cardoso de Mello, a responsável pela montagem da equipe econômica e titular do novo Ministério da Economia - que congregava a Fazenda e o Planejamento com o objetivo de suprimir o conflito burocrático entre os dois que vigorou nas décadas anteriores - indicou para o BNDES o professor Eduardo Marco Modiano. Zélia Maria Cardoso de Mello (1953) foi a primeira protagonista feminina da administração econômica do Estado brasileiro. Era paulistana e prima de João Manuel Cardoso de Mello (item 5.2). Descendente, portanto, de família tradicional de São Paulo, com fortes elos com o direito e com a política. Do lado materno, eram descendentes da família de latifundiários, advogados e políticos de Brasílio Augusto Machado de Oliveira. Como o pai de João Manuel, João de Deus Cardoso de Mello, o pai de Zélia, Emiliano Cardoso de Mello, era advogado de formação e começou sua carreira profissional pelo concurso para delegado de polícia. Ao contrário de João de Deus, que deixou a polícia e tornou-se promotor público, subprocurador, procurador geral, secretário da justiça, da educação e finalmente ministro do Tribunal de Contas, Emiliano continuou na polícia, 
tornando-se delegado do Departamento de Ordem Política e Social (DOPS). Ainda que tal vínculo criasse animosidade entre os amigos de Zélia, ele foi estratégico para prevenir e resgatar diversos colegas da filha e dos sobrinhos. Conforme comentado no capítulo anterior, fora Emiliano quem evitara a prisão de Luiz Gonzaga Belluzzo na metade dos anos 1970.

Emiliano casou-se com Auzélia Castiglioni Martoni, filha de imigrantes italianos, razão pela qual a filha tinha familiaridade com o italiano, além de falar inglês e francês. Zélia foi criada no Jardim Paulistano e passava férias nas fazendas da família. Chegou a frequentar o curso de Madame Poças Leitão, que iniciava as jovens das famílias abastadas nas boas maneiras e no bailado. Teve rigorosa formação católica e com os pais ia à missa na igreja Nossa Senhora do Brasil, localizada nos Jardins e frequentada pela alta elite paulistana. As principais inflexões na trajetória de Zélia foram promovidas por alguns primos que atuavam na política e na economia. A primeira mudança de vulto foi a transferência para o Colégio de Aplicação da USP. Seus primos conseguiram convencer Emiliano e Auzélia da superioridade intelectual da escola, na qual lecionavam professores ligados à USP. Lá, Zelia aproximou-se de grupos de esquerda e durante a faculdade chegou a atuar algum tempo no PCB (SABINO, 1991, pp. 11-31).

João Manuel e outros primos mais velhos foram também influência fundamental para que estudasse economia. Ingressou na Faculdade de Economia, Administração e Contabilidade da Universidade de São Paulo (FEA-USP) e, ainda que a graduação tenha sido um misto de artes, boêmia e política que tornaram secundário o estudo da economia, ao concluir a graduação em 1975, ingressou diretamente na pós-graduação. Logo tornouse professora assistente na cadeira de Formação Econômica e Social do Brasil, domínio no qual redigira sua tese Metamorfoses da riqueza - contribuição ao estudo da passagem da economia mercantil escravista à economia exportadora capitalista (1981), dirigida por Alice Canabrava, de quem fora estagiária durante a graduação, experiência que caracteriza, nos agradecimentos da tese, como "determinante em sua formação intelectual e acadêmica". A segunda pessoa a que agradece, logo após a orientadora, é João Manuel Cardoso de Mello, "primo e amigo [... cuja] capacidade analítica e profundo conhecimento do tema evitaram que eu percorresse caminhos estéreis. Seu carinho e cuidado constantes me ajudaram a manter a serenidade em momentos difíceis no período de elaboração da tese". Ao concluir o doutorado Zélia foi convidada por um amigo diplomata de João Manuel para reorganizar 
o departamento econômico da embaixada brasileira em Londres. Roberto Campos era o embaixador naquele período, mas quase não tiveram contato. De volta ao Brasil retomou as aulas na USP e passou a oferecer consultorias (MELLO, 1981, pp. 1-2; SABINO, 1991, pp. 40-61).

$\mathrm{Na} F E A$, Zélia aproximou-se de boa parte daqueles que comporiam sua equipe de governo: José Francisco de Lima Gonçalves formou-se duas turmas depois dela, em 1977, Luís Eduardo Alves de Assis e Venilton Tadini, em 1978. Zélia e Tadini fizeram a pósgraduação na FEA ao mesmo tempo e eram da turma de Martus Tavares, economista cearense que também juntou-se ao grupo. José Francisco de Lima Gonçalves e Luís Eduardo Alves de Assis cursaram o mestrado na UNICAMP. Lá conheceram Antônio Kandir, engenheiro formado na Escola Politécnica que trabalhou no Instituto de Pesquisa Econômica Aplicada (IPEA), fez mestrado e doutorado na UNICAMP, participava do grupo de pesquisadores liderado por Serra no Centro Brasileiro de Análise e Planejamento (CEBRAP) e, juntamente com Assis e Gonçalves tornou-se professor na PUC-SP na época em que Paul Singer assumiu a liderança da escola (item 5.3) (Antônio Kandir, in: D’ARAÚJO et al., 2005, p. 313; BORGES et al., 1998) ${ }^{493}$.

Foi na FEA também que Zélia teve contato com Ibrahim Eris (1945), turco de Bafra, que havia sido militante de esquerda em seu país natal e era formado em economia na Middle East Technical University, em Ancara. Ibrahim concluiu em 1975 o doutorado em Vanderbilt sob a supervisão de Nicholas Georgescu-Roegen. Na sequência transferiuse São Paulo, acompanhando sua esposa brasileira Cláudia Cunha Campos Eris que era graduada pela FEA, mestre por Vanderbilt e fez o doutorado em Rice, Texas, onde Ibrahim lecionou por algum tempo (Antônio Kandir, in: D’ARAÚJO et al., 2005, p. 313; CANABRAVA, 1984a, pp. 115, 158) ${ }^{494}$.

Quando André Franco Montoro foi eleito para o governo do Estado de São Paulo, um primo de Zélia por parte de mãe, o também economista formado na FEA, Pedro Paulo Martoni Branco, foi convidado a presidir a Companhia de Desenvolvimento da Habitação. Zélia Maria assumiu a diretoria administrativa e financeira da Companhia. Em 1985, foi João Manuel que carregou a prima para o governo. Ele e Luiz Gonzaga Belluzzo seguiram com Dílson Funaro, de quem eram assessores desde o final dos anos 1960, para

\footnotetext{
${ }^{493}$ Ver: http://exame.abril.com.br/revista-exame/edicoes/642/noticias/os-jogadores-m0050400. Consultado em 24/04/2016.

${ }^{494}$ Ver: http://exame.abril.com.br/revista-exame/edicoes/642/noticias/os-jogadores-m0050400. Consultado em $24 / 04 / 2016$.
} 
o Ministério da Fazenda em Brasília. Por intermédio de João Manuel, Zélia foi convidada para a assessoria do Secretário do Tesouro, Andrea Calabi, com o qual ela também tivera contato na FEA. Em sua equipe da assessoria trabalhavam os amigos José Francisco Gonçalves, Martus Tavares e Venilton Tadini. No final de 1986, conheceu Fernando Collor de Mello. Eleito governador do Alagoas, ele havia ido ao Tesouro tratar das finanças de seu Estado. Aproximaram-se. Zélia demitiu-se do ministério junto com Dílson Funaro e sua equipe em abril de 1987. De volta a São Paulo, montou a ZLC consultores associados - com Carlos Henrique Moraes, ligado à Cotia Trading, e Lélio Ravagnani Filho, proprietário da Corema Trading - e foi até Maceió oferecer seus serviços de assessoria econômica a Collor (SABINO, 1991, pp. 68-79).

Zélia e Collor mantiveram contato permanente nos anos de 1987 e 1988, razão pela qual, quando ele decidiu concorrer à Presidência da República, ela resolveu que o apoiaria. Os círculos intelectuais à esquerda que ela frequentava em São Paulo abominaram a decisão. Zélia não ouviu seus colegas e conseguiu inclusive convencer alguns deles a participarem da assessoria ao candidato. No princípio, trabalhavam com ela Luís Eduardo Alves de Assis, que foi nomeado diretor do Banco Central do Brasil (BCB), José Francisco Gonçalves, seu assessor direto, e Venilton Tardini, que seria diretor do BNDES. Logo reuniram-se a eles Antônio Kandir, que ficou com a Secretaria de Política Econômica e com a Presidência do IPEA, e Martus Tavares que foi secretário adjunto de política econômica, trabalhando diretamente com Kandir. O Banco Central foi entregue a Ibrahim Eris (SABINO, 1991, pp. 76-112).

Ao grupo inicial, agregou-se o carioca Eduardo de Freitas Teixeira, que havia sido secretário adjunto de assuntos econômicos do Ministério da Fazenda de Funaro e acabara de concluir o mestrado na UFRJ. Teixeira ingressou no governo como secretário executivo do ministério e depois foi nomeado presidente da Petrobrás e Ministro de Infraestrutura. Também aceitou fazer parte da equipe Luís Octávio Motta da Veiga, advogado carioca ligado ao Banco da Bahia, que presidira a Comissão de Valores Mobiliários (CVM) de setembro de 1986, com Fernão Bracher no BCB, até o início de 1988. Veiga antecedeu Teixeira na presidência da Petrobrás e trouxe com ele para o governo Eduardo Marco Modiano, que assumiu a presidência do BNDES.

Eduardo Marco Modiano (1952) é carioca. Seu pai, Umberto Modiano, nasceu em Marselha, na França, mas passou a maior parte da juventude em Tanger, no Marrocos 
com seus pais. Umberto chegou ao Brasil em 1947. Falante de francês, inglês, alemão, espanhol e um pouco de italiano, conseguiu trabalho em uma agência que vendia gêneros alimentícios para a Europa. Passou a fazer transações de café e abriu a própria empresa de exportação e importação, que entrou em concordata em 1957. Nos anos 1960, foi dono da companhia Ouro Fino que se tornou a maior exportadora de café do país. Os negócios de café estavam em baixa quando Modiano passou a acionar na Justiça o Instituto Brasileiro do Café, alegando ter sido prejudicado por ele em suas transações. Dos anos 1970 aos 1990, instaurou 22 processos contra o governo, tendo, no maior deles, recebido 50 milhões de dólares de uma só vez. Umberto explica que sua esposa, a médica e diretora da indústria farmacêutica Labonobel, Liliane Esther Modiano495, e os filhos "não sabiam se eu era um gênio ou um louco" (Umberto Modiano apud AULER, 1990). Na metade dos anos 1970, começou a investir em terras, montando a empresa Rural e Colonização que fez grandes investimentos na região de Búzios. Ele adquiriu largas porções de terra na região, montou uma fazenda na qual criava gado, comprou uma pedreira da qual extraía material para suas obras. Construiu um aeroporto, um campo de golfe em hotel cinco estrelas e loteou vastas áreas, valorizando os terrenos com a abertura de canais para dar acesso individual ao mar (AULER, 1990) ${ }^{496}$.

Depois de passar pelos colégios Mello de Souza e Brasil-América, Eduardo Modiano iniciou, em 1970, a graduação em engenharia de sistemas na PUC-RJ. Ele conta que:

desde o início do curso de engenharia eu senti que eu não estava plenamente satisfeito com o que eu estava fazendo. Na verdade eu sempre tive um pouco de dúvida de qual a carreira que eu deveria seguir. Como eu tinha uma boa aptidão para a matemática, para as áreas quantitativas eu acabei sendo empurrado de fato para fazer engenharia. Depois, passado o vestibular, iniciado o curso de engenharia, no ano seguinte eu fiz um vestibular para administração pública na Fundação Getúlio Vargas. Cursei lá dois anos. Acabei me transferindo para a Cândido Mendes, onde passei para o curso de economia e paralelamente concluí a engenharia de sistemas em 1973. Depois de concluído o curso de engenharia eu trabalhei durante algum tempo como analista de sistemas, até na própria Petrobrás... mas logo quis seguir adiante fazendo mestrado e doutorado. Então eu consegui uma bolsa para os Estados Unidos e fui, em 1974, fazer um mestrado, na época em pesquisa operacional. Ao chegar no Massachusetts Institute [of Technology], eu fiz os cursos do mestrado em pesquisa operacional muito rapidamente, praticamente um ano [...]. No final daquele primeiro ano resolvi ficar para um doutorado interdepartamental, que envolvia pesquisa

495 Ver: http://memoria.bn.br/DocReader/DocReader.aspx?bib=089842_08\&PagFis=17355. Consultado em $18 / 04 / 2016$.

496 Ver: http://memoria.bn.br/DocReader/DocReader.aspx?bib=030015 11\&PagFis=3743. Consultado em $18 / 04 / 2016$. 
operacional e economia. Ao mesmo tempo comecei a fazer cursos também na área de administração [...]. No final de 1978, eu acabei concluindo um doutorado interdepartamental em pesquisa operacional e economia e também o meu mestrado, um MBA em administração. Em 1978, ainda na metade do ano, eu fui convidado pelo próprio MIT para ficar lecionando lá durante um ano como professor visitante na escola de administração. Então eu fiquei de 1978 até meados de 1979 como professor visitante na Alfred P. [Sloan] School of Management (MODIANO, 2002, [DVD]).

\section{Enquanto esteve no Massachusetts Institute of Technology (MIT), Modiano} conviveu com os doutorandos do curso de economia, André Lara Resende, que já conhecia da PUC, e Persio Arida e frequentou o grupo de professores e pós-graduandos que se reunia na casa de Edmar Bacha (item 4.0). Ele explica que sua "convivência com esse grupo de economistas fez com que eu fosse convidado, em 1979, a me juntar ao departamento de economia da PUC do Rio de Janeiro que estava se formando". Na PUC, relata:

Me dedicava a fazer modelos de planejamento, um pouco por causa da minha formação básica de engenharia. Essa tentativa que eu sempre fiz de mesclar, de certa maneira, a minha formação de engenharia com os meus interesses na área de economia. Então durante esses anos eu trabalhava muito com modelos macroeconômicos que permitiam fazer avaliações de impacto de diferentes políticas econômicas, em termos das principais variáveis da economia brasileira. Em meados dos anos 1980, nós já tínhamos desenvolvido na PUC um ferramental de modelagem macroeconômica bastante interessante que permitia, inclusive, fazer projeções da economia e avaliar o impacto dos diferentes programas de estabilização que vinha se tentando implementar no país. Eu comecei também a fazer muitos trabalhos, paralelamente, de consultoria[497] para várias grandes empresas. Comecei a estar ao mesmo tempo na vida acadêmica e, digamos, na vida política e na vida empresarial do país. Curiosamente, eu acho que, no fim dos anos 1980, alguns dos meus trabalhos acadêmicos foram utilizados, em parte, na estruturação tanto do Plano Cruzado quanto do plano Bresser. Foram duas tentativas que não vingaram mas que tinham elementos na tentativa de estabilizar, ou pelo menos eliminar um foco do problema inflacionário, que era a própria inércia da inflação que se auto-alimentava [...]. No fim dos anos 1980, acho que 1988, 1989, eu vinha trabalhando muito com a questão da importância do ajuste fiscal na economia brasileira e seu impacto em termos de balanço de pagamentos, em termos de retomada do crescimento econômico, paralelamente à ideia da ruptura com a inflação. Então, eu estava muito ativo e muito presente nas discussões de política econômica naquele momento (MODIANO, 2002, [DVD]).

Modiano narra sua aproximação com o governo Collor da seguinte maneira:

Exatamente em 1989, eu percebi que havia uma oportunidade, no sentido de que o candidato Fernando Collor não tinha ainda um programa econômico muito bem definido e tinha chances de vir a ser eleito. Havia uma grande resistência da comunidade acadêmica em relação a seu nome e ao grupo que o rodeava, mas eu

\footnotetext{
${ }^{497}$ Modiano havia tido experiência na consultoria Macrométrica de Chico Lopes e fundado a consultoria Econotech em 1986.
} 
acabei sendo procurado pelo... na verdade o meu contato foi pelo Luiz Otávio da Motta Veiga, que na época veio a presidir a Petrobrás, ao mesmo tempo que eu vim a presidir o BNDES. [Foi ele a] me colocar em contato com a equipe econômica do governo Collor que estava se formando, para que eu e mais alguns outros professores do departamento de economia que depois não se juntaram no governo pudéssemos dar algum embasamento para as políticas que estavam sendo discutidas naquele grupo. Algum embasamento com ferramental melhor metodológico e também para discutir os problemas. Eu senti logo nas primeiras conversas uma razoável afinidade entre o que eu achava que precisava ser feito para mudar a economia brasileira daquela década perdida [...]. Eu senti uma grande identificação com as principais linhas de ação que o novo governo pretendia dar e comecei então a me envolver, a ajudar. Uma ajuda totalmente desinteressada no sentido de que a minha ideia era ficar na PUC-RJ e continuar a minha vida acadêmica. Aos poucos a minha participação na elaboração do programa, nas discussões, acabou me envolvendo de uma certa maneira que, depois, quando eu quis sair, não me deixaram. Neste momento, o presidente já estava praticamente eleito e não tinha mais volta. Eu já estava, de certa maneira, envolvido e também comprometido com as políticas de liberalização, de desestatização, de privatização que o novo governo tinha prometido implantar. Então eu fui convocado a continuar dentro do governo, a trabalhar pelas ideias que eu vinha, durante o ano de 1989, publicamente defendendo, também em nome desse grupo que havia chegado ao poder. Minha posição naquele momento foi que eu só queria ir para o governo se eu pudesse ficar como presidente do BNDES, comandar o programa de privatização e escolher todos os meus diretores. E essas condições foram aceitas (MODIANO, 2002, [DVD]).

A liberalização, a abertura externa e a desestatização eram alguns itens da pauta de modernização advogada pelo governo Collor, muito semelhante ao programa El Ladrillo dos Chicago Boys chilenos (item 4.4). Roberto Campos (item 2.2), à essa altura um convicto liberal, conta que o "Collor candidato, esse provocou meu destramelado entusiasmo. Era uma mensagem [...] super moderna, o Brasil do futuro. Ele pregava o evangelho que eu sempre defendia: combate à inflação, desregulamentação, privatização, liberalização comercial, reinserção do Brasil na comunidade financeira internacional, retorno do Brasil ao mundo e à história" (CAMPOS, 1991, [online]).

Para conduzir seu projeto modernizador, entretanto, Collor não convidou nenhuma réplica de Roberto Campos. Sua equipe principal - Zélia de Mello, Luís Eduardo Assis, José Francisco de Lima Gonçalves, Venilton Tadini, Antônio Kandir, Martus Tavares, Ibrahim Eris, Eduardo de Freitas Teixeira, Luís Octávio Motta da Veiga e Eduardo Modiano - era formada essencialmente por jovens que fizeram a sua trajetória acadêmica no Brasil, a maioria deles ligados às instituições de ensino vistas como espaços da oposição, a UNICAMP, a PUC-SP, a PUC-RJ e alguns setores da USP não ligados ao grupo de Delfim. Parte deles, ademais, tinha tido militância comunista na juventude. Afora Ibrahim, que pertencia à outra geração, os dois únicos com experiências 
internacionais longas eram Eduardo Modiano e Otávio Motta. Dentre eles, Modiano declarava afinidade com a abertura, tinha longa produção na área de estabilização e defendia a instalação de um programa privatização. Vellozo Lucas e João Maia transitavam no grupo da "Integração Competitiva", que preconizava a abertura, desde que houvesse política industrial. Fossem mais ou um menos afeitos a ideias neoliberais, não eram Chicago Boys (SCHNEIDER, 1991, p. 9).

Se havia um lado claramente neoliberal na política de Collor, que anunciava cortes, privatizações, interrupção dos gastos públicos e todo tipo de abertura, não se pode dizer que a política de estabilização por ele adotada fosse ortodoxa ou não-intervencionista. Roberto Campos diz nunca ter imaginado "que ele começasse com essas medidas brutalmente heterodoxas, o que eu chamo o 'con-con': congelamento e confisco. E na primeira oportunidade que eu tive de falar com ele, expressei-lhe o meu desapontamento, e ele me disse: 'Nossos objetivos são comuns, apenas os meus caminhos são diferentes e lhe parecerão um pouco esquisitos'. Eu disse: 'Põe esquisito nisso' [risos]” (CAMPOS, 1991, [online]). O bloqueio das contas e poupanças ${ }^{498}$, a medida mais emblemática adotada pelo novo governo, não era uma proposta nova. A Argentina, também fortemente afetada pela crise da dívida e pelo insucesso de programas de estabilização anteriores, adotou programa calcado no bloqueio em dezembro de 1989, imediatamente antes do novo governo brasileiro adotar a mesma linha.

As discussões dessas políticas também não eram novas no país e antecediam inclusive o lançamento do bloqueio argentino. Carlos Eduardo Carvalho, coordenador do programa de governo do PT para 1989, afirma que uma síntese de proposta de reforma monetária associada à redução de liquidez via confisco foi apresentada no texto Crise $e$ reforma monetária no Brasil, escrito entre 1988 e 1989 por Luiz Gonzaga Belluzzo e Julio

\footnotetext{
498 "A proposta de bloqueio da liquidez dos haveres financeiros no Brasil procurava responder a três grandes problemas que desafiavam o debate econômico dos anos 1980 a respeito das dificuldades para conter a inflação elevada, quais sejam: a tendência de monetização acelerada e de explosão da demanda agregada em momentos de desinflação abrupta; a elevada liquidez dos haveres financeiros, a chamada 'moeda indexada'; e a tendência de rápido crescimento da dívida mobiliária interna e a fragilidade do esquema de refinanciamento diário no mercado monetário. Os três problemas eram agravados pela forte e persistente restrição externa, com o corte dos fluxos voluntários de capitais desde a crise da dívida externa, em 1981-1982, e pelos seus danosos efeitos físcais e financeiros sobre o setor público. A proposta de bloqueio da liquidez queria enfrentar as três questões em conjunto, na ausência de apoio financeiro externo. O objetivo maior era impedir que os detentores de haveres financeiros pudessem deles dispor livremente, para controlar a monetização e impedir movimentos especulativos depois da pretendida desinflação abrupta. Outro objetivo era viabilizar o ajuste fiscal, tido como impossível sem a drástica redução do custo que os juros reais elevados acarretavam. Como se entendia, porém, que os juros não podiam ser reduzidos sem provocar a 'fuga' em massa dos aplicadores, a meta fiscal dependia do bloqueio da liquidez" (CARVALHO, 2006, pp. 108-109).
} 
Sergio Gomes de Almeida ${ }^{499}$, economistas bem distantes do polo neoliberal. Os dois elaboraram a proposta para a assessoria de Ulysses Guimarães, candidato que apoiavam. Desarticulada a candidatura deste, a proposta foi levada por seus alunos da UNICAMP, Antônio Kandir e Aloizio Mercadante, para a assessoria econômica do PT, figurando provável alternativa a ser adotada pelo partido para combater a inflação ${ }^{500}$. Guilherme Fiuza, em seu livro 3000 Dias no Bunker, baseado em entrevistas com economistas que trabalharam para os governos FHC, conta que a proposta teria sido discutida na casa de José Marcio Camargo, economista formado no MIT, à época ligado ao PT, razão pela qual alguns economistas da PUC-RJ conheciam o plano (CARVALHO, 2006; FIUZA, 2008, pp. 59-60).

Quando Lula foi derrotado, Kandir, que havia feito parte de sua assessoria, foi convidado por seus colegas de UNICAMP e PUC-SP a integrar a equipe econômica do governo Collor, levando com ele a proposta que já era conhecida também por alguns professores da PUC-RJ e provavelmente por Zélia, via João Manuel. Esta passou a ser discutida com afinco pelo grupo e, ao final do mês dezembro, ficou definido que o confisco seria usado pelo novo governo como solução de emergência para derrubar a inflação. "Collor aprovou integralmente a ideia. Vetou apenas a possível criação de grupos com políticos e representantes de setores da sociedade para negociação de acordos. Collor insistia que a luta contra a inflação fosse apresentada como um embate dramático e decisivo" (CARVALHO, 2006, p. 123).

Anunciado em 16 de março de 1990, um dia depois da posse de Fernando Collor de Mello, o programa econômico impunha: 1) um pacote de "saneamento moral" que manteria o congelamento e puniria aqueles que escondessem mercadorias, exagerassem nos preços, iludissem o consumidor, os sonegadores; 2) o fechamento de ministérios, autarquias e empresas públicas e afastamento de maus de funcionários; 3) o reajuste de

\footnotetext{
${ }^{499}$ Julio Sergio Gomes de Almeida tinha graduação na UFRJ, mestrado e doutorado em economia na UNICAMP, lecionou na UNICAMP, fez parte da equipe da Fazenda de Funaro e voltaria à Fazenda em 2006, como Secretário de Política Econômica de Guido Mantega. Ver: http://lattes.cnpq.br/3084033217210040. Consultado em 19/04/2016.

${ }^{500} \mathrm{Em} 19$ de março de 1990, o PT se posiciona face ao Plano congratulando Zélia, explicando que teria adotado medidas semelhantes, mas dizendo que era preciso atacar prioritariamente a especulação financeira, aumentando a flexibilidade em relação àqueles que poupavam para adquirir uma casa ou para poder planejar seus gastos cotidianos. Propõem a criação de um imposto territorial rural que punisse os latifundiários improdutivos que ficaram fora do alcance das medidas propostas. Eles solicitam um aumento da proteção ao trabalhador que poderia ser penalizado e uma maior rigidez nas negociações externas. Finalmente solicitam esclarecimentos sobre a política industrial, detalhando o modo pelo qual incentivariam o investimento público e privado (Jornal do Brasil, 19 de março de 1990). http://memoria.bn.br/DocReader/docreader.aspx?bib=030015_11\&PagFis=4895. Consultado em 19/04/2016.
} 
preços públicos; 4) o controle da flutuação cambial; 5) a suspensão de todos os subsídios, inclusive às exportações e à informática; 6) a tributação dos ganhos na bolsa de valores; 7) a tributação sobre lucros da agricultura; 8) a abertura da economia com redução das barreiras à importação e estímulo à participação de capital estrangeiro no desenvolvimento nacional; 9) a instauração de um grande programa de desestatização; 10) o controle dos salários que passam a ser prefixados; 11) a substituição do Cruzado Novo pelo Cruzeiro e; 12) a limitação do acesso a contas bancárias e poupanças, passando a haver um limite ao saque ${ }^{501}$.

Ao lado do grupo centrado em Zélia que debatia a política econômica e a reforma monetária, foram encomendados estudos para a elaboração da política industrial e de comércio externo do novo governo. Zélia entrou em contato com o economista da PUCRJ, Marcelo de Paiva Abreu, e pediu que detalhasse uma proposta de liberalização comercial. Ao mesmo tempo, Modiano fez pedido semelhante amigos que elaboraram programa para o candidato Mario Covas, liderado por Eduardo Augusto Guimarães e Winston Fritsch. Como Abreu, Eduardo e Winston eram economistas do grupo que se desligara do IEI-UFRJ, na cisão de 1981, e passara a trabalhar na PUC-RJ. Eles contavam com o suporte, dentre outros, de Gustavo Franco, também professor da PUC-RJ, e de Maria de Fátima Serro Pombal Dib, funcionária do DEPLAN, admitida no BNDES através do Prêmio BNDES recebido pela dissertação Importações brasileiras: políticas de controle e determinantes da demanda (1984), orientada por Dionísio Dias Carneiro e examinada por Modiano e Marcelo Abreu. Além deles, tomava parte nos debates Wilson Suzigan, professor da UNICAMP, que havia redigido com Antônio Kandir relatório de política industrial para a Comissão do Plano de Ação do Governo (COPAG) de Tancredo Neves, no qual pregavam a abertura ao comércio internacional, associada ao aumento de qualidade da estrutura produtiva (Antônio Kandir in: D’ARAÚJO, 2005, p. 314; COSTA, 2011, p. 51; PIO, 2001a, p. 225; FIUZA, 2008, pp. 61-62) ${ }^{502}$.

Foi este grupo o responsável pela elaboração da Medida Provisória que organizou a abertura comercial e a extinção do sistema de subsídios fiscais, da lista de importações proibidas e do "emaranhado de incentivos à produção, ao investimento e às exportações

\footnotetext{
${ }^{501}$ Ver o lançamento do Plano Collor em: https://www.youtube.com/watch?v=uIgLowlY8Io. Consultado em 06/05/2016.

502 Ver: http://memoria.bn.br/DocReader/docreader.aspx?bib=030015_11\&PagFis=2958. Consultado em 20/04/2016.
} 
industriais". De acordo com seus estudos, a liberalização comercial - que deveria expor as empresas brasileiras à competição internacional com o objetivo de acabar com as práticas de concorrência desleais e pressionar em direção à eficiência e modernização -, deveria ser acompanhada de incentivos destinados a favorecer a adequação técnica, o aumento da competitividade das empresas e promover o desenvolvimento de indústrias nascentes em áreas tecnologicamente avançadas (FRITSCH, 1991, p. 345). Suzigan, um dos elaboradores da proposta, explica que:

\begin{abstract}
a abertura ou liberalização indiscriminada, sem a âncora de uma política industrial e tecnológica que dê condições efetivas para a capacitação tecnológica da empresa nacional e proteção/promoção para o desenvolvimento das indústrias de tecnologia avançada, pode colocar o País ainda mais distante da fronteira tecnológica e à margem do processo de transformação da base produtiva capitalista que está elevando extraordinariamente a produtividade e a competitividade internacional dos países desenvolvidos e de alguns NICs (Newly Industrializing Countries) (SUZIGAN, 1991, p. 342).
\end{abstract}

Convém lembrar que Marcelo Abreu, que ficou com a Secretaria Nacional de Economia, e Eduardo Augusto Guimarães, que assumiu a presidência do Instituto Brasileiro de Geografia e Estatística (IBGE), tiveram participação nas pesquisas da FINEP que buscavam, justamente, formas de promover criação e absorção de tecnologia na indústria brasileira. Maria de Fátima Serro do Pombal Dib participara do planejamento no BNDES que levou à elaboração do programa de Integração Competitiva, que também enfatizava a necessidade de conciliar a liberalização com um foco na formação de indústrias com capacidade de competir internacionalmente, o que decorreria de redução gradual das barreiras tarifárias associada a melhorias na infraestrutura para promover modernização do parque produtivo, capacitação tecnológica e automação industrial (MOURÃO, 1994, pp. 18-19). Neste ponto, havia mais identidade do que diferenças entre a orientação da política industrial desenvolvida pelo grupo ligado à PUC-RJ e as propostas que emanaram do segundo grupo envolvido com a formulação da política industrial e comercial do governo Collor, integrado por economistas ligados à UFRJ, muitos dos quais ex-militantes do PCB, que tinham afinidade com o projeto da Integração Competitiva do BNDES.

Uma das principais figuras dessa vertente era João da Silva Maia que, depois de ter sido obrigado a deixar a Faculdade de Engenharia da Universidade de Brasília (UNB) por causa de seus vínculos com o movimento estudantil, transferiu-se para o Rio onde cursou economia e mestrado em economia industrial e da tecnologia na UFRJ. João Maia 
manteve contato com Zélia durante o governo Sarney através da equipe de Funaro na Fazenda. Na sequência, foi secretário de planejamento da prefeitura do Rio na gestão de Saturnino Braga ${ }^{503}$, período no qual manteve algum diálogo com a consultoria de Zélia. Maia convidou para sua equipe seu colega de PCB, Luiz Paulo Velloso Lucas, do BNDES, e Edgard Antonio Pereira, graduado na UNICAMP e mestre pela UFRJ504. Maia, que lecionava economia na Universidade Federal Fluminense (UFF), participara das reuniões dos técnicos do BNDES, da Petrobrás e da Eletrobrás que deram origem ao cenário da "Integração Competitiva". Chegou-se a esboçar convites para que Nildemar Secches ou Julio Mourão, nomes centrais da "Integração Competitiva", assumissem a Secretaria de Planejamento do Ministério da Economia, mas esta acabou nas mãos de Marcos Giannetti da Fonseca (SABINO, 1991, pp. 133-134; NASSIF, 2007, pp. 154-157; PIO, 2001a, p. 242).

\section{Gustavo Franco afirma que:}

eles [Maia e Lucas] queriam porque queriam criar uma estrutura de câmaras setoriais, Grupos Executivos de Política Setorial, um troço assim mobilizador... e a gente achava aquilo uma m... Justamente porque toda a concepção de uma nova política passava pelo fato de rever por inteiro as relações entre o público e o privado, neste domínio. Então era, talvez, criar o que você chamou de insulamento: o isolamento do burocrata que toma decisões separado das pessoas atingidas pela decisão. Poderia haver consultas como qualquer democracia, mas jamais envolver a pessoa sujeita à regulamentação, à concepção e à execução da regulamentação, que era a ideia que os caras tinham e eram os liberais e nós os socialdemocratas... então a briga começou aí. Eles diziam "vocês são uns liberais, selvagens e tal, não pode fazer assim, porque tem que ouvir a cadeia produtiva..." Cadeia produtiva um c...! Cadeia produtiva é coisa do governo Geisel, CDI... precisa acabar com essa porcaria. Isso não existe em economia de mercado nenhuma (Gustavo Franco apud PIO, 2002, p. 274).

Ainda que pudessem haver fortes atritos entre o grupo da UFRJ e os professores da PUC-RJ que se afastaram da UFRJ pouco tempo antes, não era entre eles que ocorria a batalha central 505 . Havia um terceiro grupo envolvido na definição da política comercial do governo, formado por um conjunto de traders provenientes da maior companhia privada de comércio exterior do país. Carlos Henrique Moraes, egresso da Cotia Trading e ex-sócio de Zélia, tornou-se seu assessor e teve grande influência na montagem da equipe

\footnotetext{
${ }^{503}$ Ver: http://www.nominuto.com/noticias/politica/conheca-a-trajetoria-de-joao-maia/40302/. Consultado em $18 / 04 / 2016$.

504 Ver: http://memoria.bn.br/DocReader/DocReader.aspx?bib=030015_11\&PagFis=5438. Consultado em 20/04/2016.

${ }^{505}$ Winston Fritsch, indagado se haveria cabeças velhas na equipe do governo Collor, responde dizendo que há exceções, "tem algumas pessoas como o Luiz Paulo Vellozo Lucas, entusiasmadas em reformar a política industrial. Mas não é um sentimento generalizado e fazer um julgamento sobre isso é difícil" (FRITSCH, 1990, p. 7).
} 
econômica. Com ele vieram, além do secretário de planejamento Marcos Giannetti, que havia sido professor de Zélia, o chefe de gabinete, Sérgio Nascimento, o consultor da área de infraestrutura, Antonio José Louça Pargana, o diretor da Companhia Nacional de Abastecimento, João Mauro Boschero e o subsecretário de economia e presidente da Embraer, José Rodrigues Cunha (FONSECA, 2002, p. 278). O grupo oriundo da Cotia Trading entrou em conflito com o Secretário Nacional de Economia desde o princípio, o que fez com que Abreu deixasse o governo, que começara dia 16 de março, no dia 29 do mesmo mês, sendo a ele atribuído o desabafo: "engulo sapo, paca e tatu; cotia não" 506 .

Envolvidos há muitos anos com comércio exterior, os Cotia apoiavam rápida abertura externa, com extinção da burocracia de importação e exportação, da listagem de produtos de importação proibida ou controlada, da dissolução da Petrobrás Comércio Internacional S.A. (INTERBRÁS) e da Companhia Brasileira de Entrepostos e Comércio (COBEC), empresas públicas de trading que eram as principais concorrentes da Cotia Trading. A incompletude da nova política de comércio exterior, na opinião de Roberto Giannetti da Fonseca, sócio da Cotia, devia-se à extinção muito rápida dos mecanismos que a $\mathrm{CACEX}^{507}$ tinha para dar apoio ao comércio exterior, que haviam sido abolidos sem que nada novo fossem implementado para auxiliar os traders (FONSECA, 2002, p. 279).

Os grupos ligados à Integração Competitiva e à abertura com fomento à tecnologia, por sua vez, consideravam a política industrial adotada pelo governo Collor ineficaz e inconclusa por outra razão. Argumentavam que foi aplicada "a toque de caixa", de maneira desregrada, "à reboque da estabilização", afetando negativamente todas as empresas, sem distinguir produtivas e improdutivas, com base em mecanismos de competitividade (SUZIGAN, 1991, p. 340). Fritsch fala em "aparente despreocupação das autoridades em acelerar o preenchimento do vácuo deixado pelo enterro quase total dos instrumentos de política industrial anteriormente existentes" (FRITSCH, 1991, p. 346), referindo-se às medidas voltadas à modernização e capacitação tecnológica de empresas nacionais.

\footnotetext{
${ }^{506}$ Ver: http://memoria.bn.br/DocReader/DocReader.aspx?bib=100439_13\&PagFis=1803, http://interbras.blogspot.com.br/, http://memoria.bn.br/DocReader/DocReader.aspx?bib=030015_11\&PagFis=5403. Consultados em 20/04/2016.

${ }^{507}$ De modo geral, o grupo mais próximo PUC-RJ fazia fortes críticas à CACEX. Nas palavras de Eduardo Augusto Guimarães, por exemplo, "havia - não digo corrupção - confusão de interesses público/privado, pois eles estavam tão acostumados a interagir com o setor privado [...]. Então era uma confusão de identidade grande. Além disso, a CACEX era uma instituição que tinha muito poder e este poder todo era construído em torno da arbitrariedade da política de comércio exterior da época: gaveta, negar licença... então era uma burocracia" (Eduardo Augusto Guimarães Apud PIO, 2001a, pp. 275-276).
} 
No BNDES também ecoavam críticas à desnacionalização resultante de uma política de abertura sem um programa voltado à competitividade. Marco Antônio Lima, funcionário do Banco, argumenta que:

na Integração Competitiva, gestada por nós, teria que haver uma preparação das empresas nacionais para que concorressem com as que viriam para o país. Porque na Integração Competitiva é obvio que as empresas estrangeiras viriam entrar no nosso mercado, mas as brasileiras teriam que estar preparadas. Não houve programa algum para preparar as empresas brasileiras. A Metaleve e a Cofap foram vendidas. Houve um processo de desnacionalização muito grande nesse período. Foi uma falha de política. Em um programa de Integração Competitiva, as empresas brasileiras deveriam ter sido preparadas para competir com essas empresas que viriam disputar o mercado interno mais aberto. Porque para que o país se integrasse no exterior, era necessário abrir o mercado interno, mas dentro de uma estratégia bem definida (Marco Antônio Lima Apud NOGUEIRA, 2010, p. 87).

Ainda que João Maia tenha mantido a Secretaria Nacional de Economia e tenha conseguido nomear Vellozo Lucas, que era um homem de sua confiança para o Departamento de Indústria, a política industrial baseada nos preceitos da "Integração Competitiva" não foi implementada. No âmbito federal, Vellozo Lucas e seus aliados foram derrotados pelos Cotias; no BNDES, a equipe da Integração Competitiva foi afastada por Eduardo Modiano. Segundo Mourão, no BNDES, “assim como em outras áreas do governo, a visão neoliberal foi imposta. A equipe do Planejamento foi dispersada, tendo sido descontinuados o Planejamento Estratégico e o trabalho de cenários. O BNDES tornou-se naquele momento o Banco da Privatização" (MOURÃO, 1994, pp. 21-22; NASSIF, 2007, p. 155).

Do grupo de funcionários do BNDES que havia acumulado poder e prestígio durante os anos do planejamento estratégico, os únicos a permanecer em evidência foram Sérgio Zendron e Licínio Velasco, os principais responsáveis pela privatização dentro da BNDESPAR. Zendron foi nomeado para a diretoria do Banco e ocupou a posição de diretor-superintendente da BNDESPAR. Licínio ficou na diretoria da BNDESPAR. A mudança não se restringiu a evitar a permanência na diretoria de Nildemar Secches, que estava em evidência e chegou a ser informalmente candidato à presidência do Banco, atingindo vários superintendentes e chefes de departamento ${ }^{508}$, entre os quais Paulo Roberto Vales de Souza, Aluysio Asti, Adílson Drubscky, Maria do Rosário Pizzo, Márcio Henrique Monteiro de Castro, José Roberto Soeiro, Darc Luz da Costa, Roberto Timóteo

\footnotetext{
${ }^{508}$ Processos semelhantes ocorreram ao mesmo tempo em outras grandes burocracias do Estado, como o IPEA e a Petrobrás (D’ARAÚJO et al., 2005, p. 301; SILVEIRA, 2009a).
} 
da Costa, Marco Antônio Lima de Araújo e Júlio Mourão. Via de regra eram nacionalistas e/ou ex-comunistas, e/ou pessoas envolvidas com o Planejamento Estratégico e/ou com a área social do Banco, que a gestão de Modiano suprimiu. Diversos dentre eles deixaram o Banco para trabalhar em outros órgãos de governo, ou estudar, ou lecionar. Alguns voltaram, outros aposentaram-se logo (NOGUEIRA, 2010, pp. 79-82; Entrevistas à autora, 2012-2015).

Eduardo Modiano justifica a mudança dizendo que:

Grande parte das políticas que o governo Collor queria implementar já vinham sendo discutidas, geradas, trabalhadas dentro da área de planejamento do próprio banco. O que se queria era dar uma guinada, uma acelerada nesse processo de modernização. Mesmo a privatização, que assumiu a forma de Programa Nacional de Desestatização, com uma estrutura e uma legislação próprias, já tinha sido iniciada e vinha sendo gerida, ainda que timidamente dentro do banco, pela BNDESPAR. [...]. A abertura da economia, que causaria grande mudança na atuação do banco e na economia brasileira, já que configurava um afastamento das políticas setoriais e do intervencionismo, também já vinha sendo discutida dentro da área de planejamento do banco. Mas vinha sendo discutida e implementada numa velocidade mais lenta e de uma forma gradual. A idéia era aproveitar esse processo de mudanças e dar-lhe um forte impulso nessa direção. Por isso foi necessário mudar alguns superintendentes e as diretorias do Banco (Eduardo Modiano apud NOGUEIRA, 2010, p. 81).

Sobre a composição da diretoria Eduardo Modiano relata:

Quando fui convidado para ser presidente do BNDES, eu disse que só aceitaria se eu tivesse condições de nomear a diretoria. Eu não queria uma diretoria imposta politicamente que limitasse a minha capacidade de agir. Eu queria pelo menos fazer nomear três diretores, o que me daria maioria na diretoria. Ficou combinado então que eu indicaria três diretores, a Ministra Zélia indicaria o quarto e o presidente Collor indicaria o quinto e último diretor. Foi aí que eu trouxe para a diretoria o José Pio Borges, Octávio Tourinho e o Sérgio Zendron [509], todos amigos e já ligados ao BNDES. A Ministra Zélia indicou o Venilton Tadini, que é um profissional excepcional e foi um grande amigo e colaborador [...]. Em determinado momento o presidente Collor me ligou e disse para eu escolher quem eu quisesse que ele não tinha ninguém para indicar para a diretoria do BNDES. Foi então que consegui a nomeação do Pedro Bodin de Moraes, meu ex-aluno e companheiro no Departamento de Economia da PUC/RJ. Acabei, então, com uma diretoria que tinha grande afinidade (Eduardo Modiano apud NOGUEIRA, 2010, p. 83).

Pedro Bodin cursou na PUC-RJ a graduação em economia e redigiu o mestrado Proteção tarifária e a industrialização antes da Ia. Grande Guerra: uma revisão da literatura recente (1982). Na sequência, fez doutorado no MIT, tal qual Modiano, e ao regressar também passou a lecionar na PUC-RJ. Octávio Tourinho fora contemporâneo de Eduardo Modiano tanto na Engenharia da PUC-RJ quanto na graduação em economia da Cândido

\footnotetext{
${ }^{509}$ Não foi possível encontrar informações relativa à origem dos laços entre Eduardo Modiano e Sérgio Zendron.
} 
Mendes. Quando Modiano foi para o MIT, Tourinho foi para a University of California Berkeley, onde fez o mestrado em economia e o doutorado em administração de empresas. Tourinho era funcionário concursado do BNDES desde 1974, mas estava cedido há alguns anos para o IPEA. Modiano o trouxe de volta para o Banco ${ }^{510}$.

O vice-presidente, o carioca José Pio Borges de Castro Filho (1948), também era funcionário do BNDES, mas na época estava licenciado e trabalhava no Banco da Bahia e na Petroquímica Pronorte. Pio Borges é engenheiro mecânico graduado na PUC-RJ, carreira que escolheu porque "eu não me via como advogado. Naquela época havia três profissões, advocacia, medicina e engenharia. Economia não era uma faculdade respeitada. Aí não dá. Nem administração. Administração era uma coisa, assim, para contador. Então era bom aluno, fiz engenharia e escolhi mecânica porque eu gostava de carro e tal” (Entrevista de José Pio Borges à autora, 2012). A opção pela PUC-RJ, por sua vez, é explicada nos seguintes termos:

\begin{abstract}
o Colégio Militar é na Tijuca e era muito, muito rígido em termos de disciplina. Eu terminei o colégio militar, em 1965, quer dizer, era o começo dos anos sessenta. Já na times are changing, né. Eu terminei já com aquela disciplina me massacrando. [...] E eu era bom aluno, então o pessoal queria que eu fizesse concurso para o ITA [Instituto Tecnológico de Aeronáutica] e para o IME [Instituto Militar de Engenharia] [...], mas eu não queria nem ouvir falar de qualquer coisa que tivesse rigidez militar, então a PUC-RJ era uma faculdade na Zona Sul do Rio, com um campus bonito, naquela época tinha muito menos alunos, então foi uma opção, assim mesmo, de respirar um pouco (Entrevista de José Pio Borges à autora, 2012).
\end{abstract}

Pio Borges havia sido matriculado no Colégio Militar pois era filho de general e engenheiro militar que lecionava geometria e cálculo na escola militar. Originário de família de prosperos comerciantes do Ceará, seu pai transferiu-se para o Rio de Janeiro, onde fez carreira no exército e casou-se com moça de família carioca, filha de funcionário público, que "fez normal, depois fez curso de extensão e mestrado, todos em educação" (Entrevista de José Pio Borges à autora, 2012).

$\mathrm{Na}$ engenharia, explica, "o que me interessou mais foram os cursos que bandearam para o lado das finanças". "Já na engenharia eu comecei a fazer, no Instituto de Administração e Gerência, cursos de finanças, análise de balanços, etc. Aí comecei a gostar um pouco mais”, razão pela qual acabou fazendo, na sequência, especialização em engenharia industrial, na própria PUC-RJ. Logo que concluiu o mestrado, em 1971, fez concurso para estágio no BNDES, do qual soube por anúncio em jornal. O estágio

\footnotetext{
${ }^{510}$ Ver: http://lattes.cnpq.br/2176409229651097. Consultado em 20/04/2016.
} 
terminou em 1973 e, após dois anos trabalhando na área financeira da IBM, Pio Borges fez novo concurso, agora para funcionário do Banco. Ingressou no departamento de indústrias químicas, depois foi superintendente da Insumos Básicos S.A. (FIBASE) (Entrevista de José Pio Borges à autora, 2012).

De 1979 a 1982 esteve licenciado do BNDE para fazer o mestrado em história do pensamento econômico e economia política na New School for Social Research, nos Estados Unidos. Explica que optou por uma pós-graduação mais teórica porque "eu tinha tido uma formação matemática boa. Eu conhecia finanças bem, tinha feito o mestrado na PUC e tinha uma experiência concreta de finanças muito boa no BNDE, então eu achava que você ir para Stanford, ou para um fazer um MBA, para repassar o que eu já tinha estudado... evidente que eu ia aprofundar um pouco mais... mas, por outro lado, eu sentia uma certa lacuna de leitura. Marx, por exemplo, economia, eu tinha muita curiosidade de ler os clássicos". Além de fazer o mestrado, chegou a terminar os créditos para o doutorado e fazer as provas escrita e oral, "só não fiz a tese. Porque o meu tempo, que o BNDE tinha cedido, estava se esgotando. Podia ter pedido mais, mas não pedi naquela ocasião" (Entrevista de José Pio Borges à autora, 2012).

Ao voltar para o BNDES, passou 3 anos como chefe de departamento na área de indústrias químicas, ao final dos quais trabalhou no Banco da Bahia e, depois, nas petroquímica do grupo Mariani. Lá estava quando Modiano convidou-o para a vicepresidência do Banco. Conheciam-se, pois Modiano também "estudava engenharia, depois ele foi para Boston e ficou amigo de amigos meus: o André Lara, o Persio e uma série de outros. O Dudu [Modiano] morou lá em Cambridge e era mais ou menos contemporâneo deles, então quando eu fui lá visitá-los, eu estive com ele de novo lá. E a primeira mulher dele era uma grande amiga minha, Isabel Modiano, que eu conheci antes de conhecer ele" (Entrevista de José Pio Borges à autora, 2012).

O diretor da Financiamento para a Aquisição de Máquinas e Equipamentos Industriais (FINAME), que em 1991 passou a fazer parte também da diretoria do Banco, era o carioca José Mauro Mettrau Carneiro da Cunha (1949), engenheiro formado na Universidade Católica de Petrópolis com especialização na área de Projetos Industriais e de Transportes na COPPE e funcionário do BNDES desde 1974. José Mauro relata: quando Eduardo "entrou no Banco, eu já tinha tido algum contato com ele anterior, por pessoas que a gente conhece em comum, que frequentavam Teresópolis. Então tem uma 
coisa muito superficial de Teresópolis. Mas principalmente eu tive contatos antes de ele ir para o BNDES, eu já como superintendente" (Entrevista de José Mauro Mettrau Carneiro da Cunha à autora, 2012).

Finalmente, o chefe de gabinete de Modiano, Sergio Besserman Vianna, declara:

o Eduardo tinha algumas pessoas que ele conhecia do Banco, entre elas eu, que tinha trabalhado com ele, tinha sido estagiário dele na FINEP. Foi o meu primeiro trabalho profissional como economista. Eu fiz um modelo de uso de carvão mineral no Brasil, coordenado pelo Eduardo. Depois, ele me chamou para ser coordenador adjunto de graduação na PUC-RJ. Porque ele era o coordenador de graduação e eu fiz tese em história econômica com o Marcelo Abreu e o Winston Fritsch. [...] Ele vira presidente do BNDES e eu era funcionário do BNDES, aí ele me chama para chefe de gabinete da presidência (Entrevista de Sergio Besserman Vianna à autora, 2012).

Conforme relatado, à exceção de Venilton Tadini, a equipe dirigente de Modiano era inteiramente composta por pessoas de círculos próximos, quase todos ligados à PUCRJ, alguns deles funcionários da casa, de competência técnica internamente reconhecida. Um presidente entrevistado explica o caráter estratégico da indicação de quadros da casa para a direção do Banco dizendo que: "se você nomeia a diretoria toda nova e tem uma agenda de transformação do Banco, a chance de rejeição era enorme. Para transformar o Banco é preciso ter uma diretoria de gente predominantemente do Banco que entenda a mensagem, entende? E faça sua a minha mensagem" (Entrevista à autora, 2012-2015).

A gestão de Modiano no BNDES pretendia contribuir, de um lado, para a nova política industrial que pretendia estimular a competitividade e o desenvolvimento tecnológico em um cenário de abertura e, de outro, para o processo de ajuste econômico e estabilização. A nova política industrial é mencionada algumas vezes nos relatórios de 1990 e 1991, mas não há menção de ações específicas nesta direção. Falam em estudos em curso, exortam a necessidade de fazer algo neste sentido, sem grande consequência prática (BNDES, 1990; BNDES, 1991). A análise dos dispêndios do Banco no período (Gráfico V) corrobora a percepção de que o apoio à tecnologia, em especial, funcionava mormente como artifício retórico, já que "os setores industriais com alto potencial tecnológico não fizeram parte das aprovações e dos desembolsos do Banco, de modo que os recursos permaneceram concentrados na indústria de transformação. Isto é, embora o [...] BNDES tenha realizado estudos que sugeriam incentivos nesses setores, não se avançou nesse sentido" (COSTA, 2011, p. 85). O incentivo à competitividade passou pela adoção de critérios de avaliação de projetos que estimulassem a modernização dos princípios de gestão e dos métodos de produção, o que era complementado por uma 
política, muito discreta, de apoio à exportação operada pelo recém-criado Programa de Financiamento à Exportação de Máquinas e Equipamentos (FINAMEX) ${ }^{511}$. Tais iniciativas ainda estavam bastante aquém do preconizado pelos economistas que elaboraram o plano do governo para a área industrial, já que o apoio à exportação não foi complementado pela capacitação tecnológica das empresas e incentivo à entrada em setores nascentes.

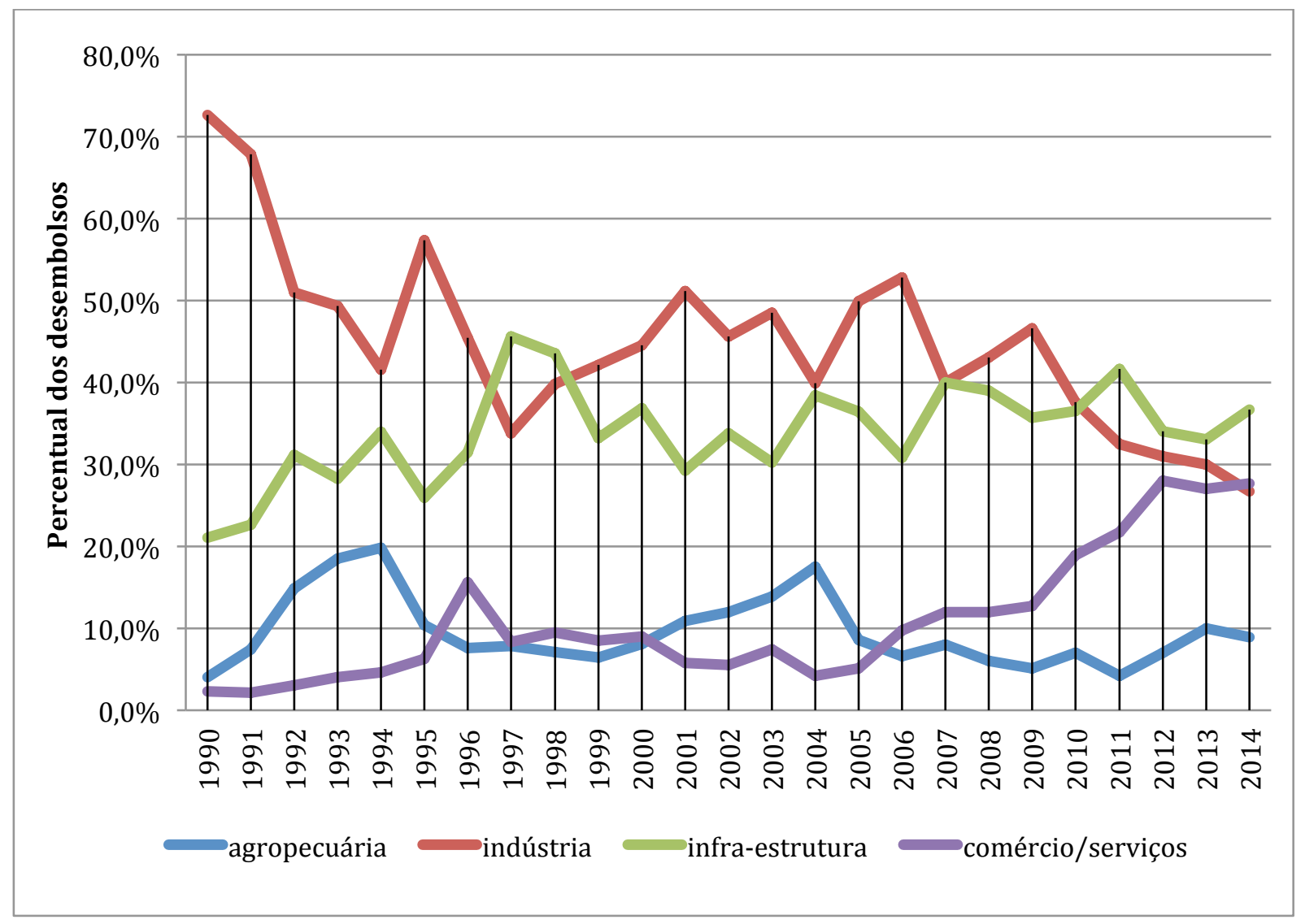

Gráfico V: Desembolsos do BNDES por setor entre 1990 e 2014. Fontes: COSTA, 2011, pp. 94-95, 234, 235; BNDES, 2003; BNDES, 2004; BNDES, 2005; BNDES, 2006; BNDES, 2007; BNDES, 2008; BNDES, 2009; BNDES, 2010; BNDES, 2011; BNDES, 2012a; BNDES, 2013; BNDES, 2014 e http://memoria.bn.br/DocReader/DocReader.aspx?bib=030015_11\&PagFis=202167, consultado em 20/12/2016. Elaboração: própria.

No que concerne à política de estabilização, o Banco contribuiu, primeiramente, conduzindo um reforma administrativa interna. Foram enxugados os quadros através de demissões, terceirização dos serviços e redução dos cargos de confiança, conforme exigido pelo Governo Federal. Em segundo lugar, o BNDES tornou-se o responsável pelo Programa Nacional de Desestatização. Meses antes do início de seu governo, Collor

\footnotetext{
${ }^{511}$ Ainda que tenha sido criado em 1990, o financiamento do BNDES às exportações só ganhará destaque em 1997, quando o Banco passa a ter uma forte política para a área (CATERMOL, 2005, p. 16).
} 
havia pedido expressamente a sua equipe econômica que estudasse os processo de privatização da Inglaterra, da Espanha e de Portugal, pois pretendia fazer algo semelhante $^{512}$. O BNDES, por ter adquirido experiência com o tema no final dos anos 1980, ao privatizar as empresas que estavam sob seu controle, foi designado gestor geral da desestatização, cabendo-lhe "dar suporte administrativo, financeiro e técnico" a um programa de privatização que pretendia ser bem mais amplo e ambicioso ${ }^{513}$ (COSTA, 2011, p. 88; BNDES, 1990; BNDES, 1991; MODIANO, 2002, [DVD]).

A política de desestatização foi a grande marca da gestão Modiano, como ele ressalta em seu discurso de despedida do Banco: "O BNDES, que foi o Banco do planejamento econômico quando isso era o futuro; que foi o Banco da siderurgia quando isso representava a nossa independência; que foi o Banco da substituição de importações quando isso representava a nossa sobrevivência; é o Banco da privatização quando isso representa a nossa esperança” (MODIANO, 1992, [DVD]). A desestatização monopoliza tanto seu discurso de despedida quanto a entrevista que concede ao Projeto Memória do BNDES, dez anos depois de deixar o Banco. Nas duas ocasiões, Modiano empenhava uma gravata de elefantinhos brancos, a mesma que usava nos leilões de privatização. Ele explica a razão de ser da iconografia dos elefantes dizendo que:

Grande parte do desafio do processo de privatização era exatamente defendê-lo e explicar as vantagens que isso iria trazer a longo prazo para a economia brasileira e para a população. As resistências foram muito grandes, de fato. Eu acho que uma das explicações claras para isso é que o Brasil nunca teve, ao contrário de outros países da América Latina, uma tradição liberal, e acho que não teve nem períodos na história econômica de liberalismo [...]. Então houve essa grande dificuldade de transmitir isso [...]. Todos os processos de privatização tinham uma campanha própria. Foram contratadas empresas para fazer constantemente pesquisas de opinião pública e, ao mesmo tempo, fazer programas que passavam na televisão e no rádio, em cada privatização, mostrando as vantagens e o que se esperaria da privatização dessa ou daquela empresa [...]. Então havia momentos em que, paralelamente ao processo de discussão e restruturação das empresas, você estava discutindo com as agências de publicidade um novo filme, um novo programa para a televisão que ajudasse a mudar a cabeça do povo brasileiro no sentido de que o setor público brasileiro podia ser simpático mas ele estava superdimensionado [...]. A gente foi direcionando a nossa propaganda, as nossas aparições, o nosso posicionamento em função dos resultados dessas pesquisas e da reação da população a essa publicidade, que tinha a marca do elefante [...], embora simpático, mastodôntico e precisava realmente ser passado para o setor privado [...]. A gravata [com figuras de elefantes, usada à época por Modiano] é um dos talismãs que era levado para as principais reuniões e para os principais

\footnotetext{
512 Ver: http://memoria.bn.br/DocReader/DocReader.aspx?bib=030015_11\&PagFis=3237 . Consultado em 20/04/2016.

${ }^{513}$ Para as diferenças procedimentais entre os programas de privatização do governo Sarney e do governo Collor ver VELASCO JÚNIOR, 2010.
} 
leiloes de privatização para enfrentar as situações e defender o programa de uma forma emblemática (MODIANO, 2002, [DVD]).

As campanhas publicitárias contrastavam a imagem de um elefante moderno e fitness, que havia perdido o peso desnecessário, com um elefante grande, lento e desajeitado que derrubava paredes e atrapalhava as empregadas domésticas que tentavam servir o jantar da família brasileira ${ }^{514}$.

A estratégia adotada pelo governo Collor almejava tornar a política de desestatização irreversível, implementando-a de modo veloz e obrigatório. Em primeiro lugar, as decisões foram instituídas por medida provisória, evitando o poder legislativo. A emenda elaborada por deputados, que previa o controle do Congresso sobre a escolha das empresas a serem privatizadas, foi vetada pelo presidente. Em segundo lugar, as instituições financeiras, seguradoras e previdências privadas foram obrigadas a adquirir certificados de privatização que eram moedas que poderiam ser trocadas por ações das companhias públicas vendidas nos leilões de privatização ${ }^{515}$. Como os certificados desvalorizavam rapidamente, as companhias que os adquiriam passavam a pressionar por rápidas privatizações. Em terceiro lugar, o governo começou a trabalhar com a ideia de privatizações paradigmáticas. $\mathrm{Na}$ primeira semana de sua presidência, Collor sumariamente decretou a extinção de onze estatais, fazendo ver que o processo seria irreversível (SCHNEIDER, 1992). A escolha da Usiminas para o primeiro grande leilão do Programa de Desestatização, que ocorreu em 24 de outubro de 1991516, tinha forte caráter simbólico,

porque era considerada a melhor indústria do setor siderúrgico e todo mundo se questionava por que começar pelo setor siderúrgico e por que começar pela melhor empresa do setor. A ideia, de fato, era mostrar que o governo brasileiro pretendia se desfazer de todas as suas participações no setor siderúrgico, no setor

\footnotetext{
${ }^{514}$ Ver as propagandas em: https://www.youtube.com/watch?v=ljQjA21I d8, https://www.youtube.com/watch?v=2WfChfvOO4I, https://www.youtube.com/watch?v=1T50XJOlZm0, https://www.youtube.com/watch?v=E951YJ1DtD8. Consultados em 06/05/2016.

${ }^{515}$ Ver: http://www.planalto.gov.br/ccivil 03/Leis/1989 1994/L8018.htm e http://www.bcb.gov.br/pre/normativos/res/1990/pdf/res_1721_v3_P.pdf. Consultados em 21/04/2016.

${ }^{516}$ Modiano explica que: "esperava-se que naquele momento a economia brasileira já estivesse estabilizada, que houvesse uma inflação baixa, que pudesse se usar, na época, os cruzados que estavam bloqueados para aquisição dessas empresas, que houvesse um grande fluxo de capitais estrangeiros, de investimentos estrangeiros para o país, que o país já tivesse resolvido seu problema da dívida externa, esperava-se tudo e nada disso aconteceu [...], portanto os investidores estrangeiros continuavam receosos em relação ao investimento no Brasil. Os setores produtivos não eram aqueles que estavam comandando os grandes investimentos no mundo porque, já naquele momento, outros países estavam privatizando seus setores de telecomunicação, sua infraestrutura, energia elétrica e era para isso que os grandes capitais estavam se movendo, e não para comprar siderúrgicas ou então empresas de processamento de produtos petroquímicos. [...]. Então o processo de privatização foi deslanchado em um momento de muito poucos investidores e pouca capacidade de investimento" (MODIANO, 2002, $[\mathrm{DVD}])$.
} 
produtivo e não apenas vender as empresas que não estavam dando lucro ou que eram grandes empresas que davam grandes prejuízos, ou empresas que ninguém queria. Então, a ideia era interessante porque você tornava quase que o processo irreversível. Porque no momento em que você começa a vender as melhores empresas do setor então não há como parar depois (MODIANO, 2002, [DVD]).

Ao final do governo Collor, "16 processos de desestatização haviam sido concluídos, a um valor total aproximado de US\$ 3,9 bilhões. Esses números, quando comparados com os do período anterior - 17 processos e arrecadação de US\$ 549 milhões -, permitem uma ideia da mudança de patamar que significou o PND [Plano Nacional de Desestatização]" (VELASCO JÚNIOR, 2010, pp. 342-343). Modiano argumenta que, mais do que arrecadar e ajudar a sanear a dívida pública, havia um caráter didático na privatização, que pretendia "nortear o futuro do país", mostrando para a população que “o papel do Estado era zelar pelo cidadão e pelos serviços básicos, atividades típicas de governo como a saúde, educação, segurança, e não produzir aço, produzir produtos petroquímicos, fertilizantes... e mesmo, como nós vimos depois, alguns serviços públicos podiam, bem regulados, passar para a iniciativa privada” (MODIANO, 2002, [DVD]).

Modiano argumenta, igualmente, que a privatização deveria funcionar como uma lição para o próprio BNDES, que passaria a balizar sua atuação "não mais pela ideia de que é preciso instalar pelo menos uma indústria [por setor] ou apoiar a ampliação de capacidade produtiva local; e muito mais dentro da ideia de que um projeto tinha que ser financiado pelo Banco de alguma forma se ele, na verdade, tornasse, de alguma maneira, a economia mais competitiva [...], num mundo globalizado". Era isto que "deveria nortear se apoia um ou outro projeto e não se ele está inserido naquele setor preferido ou não" (MODIANO, 2002, [DVD]). As reformas no organograma do Banco, promovidas logo no início de sua gestão, iam nessa direção, tendo suprimido toda a estrutura de departamentos que se encarregava de setores particulares ${ }^{517}$.

\footnotetext{
517 “Antes da reforma, eram cinco Áreas de Projeto com doze Departamentos. Restaram duas (Área de Projetos Empresariais e Área de Infra-Estrutura) com seis Departamentos (três em cada uma). A estrutura anterior contemplava departamentos como Indústrias Químicas, Indústrias Metalúrgicas e Mineração, Indústrias Tradicionais e de Bens de Capital, Ação Regional com Agentes I e II, Desenvolvimento Regional e Agrícola, Operações Sociais I e II e Mercado de Capitais. A Área de Projetos II incluía departamentos de energia, infraestrutura e construção naval. É importante perceber que essa estrutura reflete a lógica setorial com a qual o Banco ainda operava, mas que passou a ser criticada internamente e contrariava os preceitos da proposta de política industrial do governo. Com efeito, a reforma administrativa implicou o estabelecimento de uma Área de Projetos com três departamentos não específicos (Análise I, II e III) e a Área de Infra-Estrutura com os departamentos de Energia e Comunicações, Infra-Estrutura e Transportes e Serviços Urbanos. Estes setores preocupavam a instituição pelos gargalos estruturais a que estavam submetidos, o que a levou a defender a
} 
Tanto a privatização quanto o fim do programa de substituição de importações e da esturutra setorial faziam parte dos planos originais do grupo que projetou a "Integração Competitiva", mas com diferença de enfoque. $\mathrm{Na}$ opinião de parte dos envolvidos com a "Integração Competitiva", houve um desequilíbrio entre a integração e o incentivo à competitividade. $O$ avanço descompassado das faces do programa desestruturava a ordem produtiva, pois as empresas não foram preparadas para a abertura e não tinham apoio para modernizar seus empreendimentos, assim, quebravam ou especializavam-se em produtos de baixo valor agregado que não exigiam investimentos intensivos (NOGUEIRA, 2010). Havia, em alguns casos, também divergências quanto ao destino dos recursos, que estavam sendo utilizados apenas para quitar as dívidas do Estado e não reinvestidos para alargamento da infraestrutura e da estrutura produtiva nacional, como preveria uma privatização de inspiração rangeliana. Na lógica de Ignácio Rangel, diferentemente do professado por Modiano, a ação do Estado na economia não era em si o problema. Não era preciso abraçar uma tradição liberal, ao contrário, deveriam privatizar justamente para que se pudesse garantir a ampliação contínua das estruturas e levar o investimento para áreas de fronteira.

No início da década de 1990, o Banco experimentou substantivo declínio em seu orçamento. Da estabilidade na faixa dos 7.000.000.000 dólares ao ano, com a qual operava desde a redemocratização, o orçamento caiu para uma média de 5.000.000.000 dólares ao ano (Gráfico II) (PROCHNIK, 1995, p. 165). Nos últimos meses da gestão Modiano, em 1992, o Banco abriu edital para a realização de um concurso para contratação de profissionais com ensino superior, o primeiro desde 1984, que contratou 62 pessoas, 24 das quais advogados (Gráfico I). Nos anos 1980 e 1990 houve um "crescimento da proporção de advogados entre os profissionais liberais contratados pelo Banco, que ultrapassou pela primeira vez o volume de admissões para as carreiras de economista e engenheiro. Tal mudança pode ser relacionada à instauração do Programa Nacional de Privatização, que contava com um comitê jurídico para operar leilões, fazer auditorias, licitar, desenhar contratos etc. A prevalência dos advogados foi preservada nos 20 anos seguintes” (KLÜGER, 2015c, p. 99; COSTA, 2011, pp. 44-45).

aplicação de investimentos privados e a tentar viabilizá-los. As alterações empreendidas na estrutura organizacional do BNDES mostram a adequação aos novos princípios e as mudanças na estratégia de desenvolvimento por ele capitaneada. No entanto, essas mudanças implicaram mais a atenuação do enfoque setorial do que a sua extinção" (COSTA, 2011, pp. 88-89). 


\subsection{O BNDES em meio à estabilização econômica}

Quando Fernando Collor de Mello foi afastado do poder, em outubro de 1992, Eduardo Modiano, um dos poucos a permanecer na equipe econômica depois que Zélia saiu do Ministério da Economia, deixa o BNDES. Modiano explica que:

O presidente Itamar Franco queria o meu lugar, queria o lugar da presidência do
banco. A minha relação com o então vice-presidente nunca foi muito boa. Ele
não estava afinado com a política de privatizações do próprio governo. Era
muito difícil você ter um presidente apoiando e um vice presidente dificultando.
Quando o presidente Collor viajava e o vice presidente Itamar Franco assumia a
presidência a condução da privatização ficava muito difícil. Várias das vozes
contra a privatização, como a do governador Leonel Brizola, se aglomeravam em
torno do vice presidente e isso era um problema complicado dentro do próprio
governo. Eu tive vários embates com o vice presidente e era óbvio que a partir
do momento que ele assumisse a presidência eu não iria ficar nem 24 horas à
frente do BNDES (Eduardo Modiano apud NOGUEIRA, 2010, p. 97).

Logo que Itamar Franco assume a presidência, o Ministério da Economia é desfeito e volta-se ao modelo de dois ministérios, Fazenda e Planejamento, retornando o BNDES para a estrutura do Ministério do Planejamento, órgão para o qual foi convidado o economista Paulo Roberto Haddad. Mineiro como o novo presidente, Haddad foi mencionado em alguns pontos da narrativa. Provinha de família com fortes laços com a política de Minas e fez parte do grupo dos bolsistas da FACE-UFMG (item 3.1). Depois de fazer pós-graduação em planejamento econômico no Institute of Social Studies em Haia, regressou a Belo Horizonte e ajudou a fundar o Centro de Desenvolvimento e Planejamento Regional (CEDEPLAR), que oferecia os cursos de pós-graduação em economia na UFMG. Haddad foi o primeiro secretário-geral da Associação Nacional de Centros de Pós-Graduação em Economia (ANPEC) (item 4.2) e tinha experiência na gestão pública, pois havia sido Secretário do Planejamento e Coordenação Geral de Minas Gerais e depois o Secretário de Estado da Fazenda no governo de Francelino Pereira. Havia atuado, também, nas campanha de Itamar Franco para governador de Minas, em 1986 e, na sequência, na elaboração dos programas econômicos dos candidatos do PSDB, partido ao qual filou-se (DHBB, verbete Paulo Haddad) ${ }^{518}$.

Haddad, em discurso na cerimônia de posse de Antônio Barros de Castro, sucessor de Modiano no BNDES, afirma que o Presidente Itamar:

518 Ver: http://www.rodaviva.fapesp.br/materia/235/entrevistados/paulo_haddad_1992.htm. Consultado em $23 / 04 / 2016$. 
tem a preocupação, ao resgatar o planejamento, que as instituições que se responsabilizam pelo financiamento do desenvolvimento, particularmente uma instituição como o BNDES, não se insira apenas nos programas de estabilização, não se insira apenas na questão de reordenamento das finanças públicas, mas que estas instituições possam se articular com outros órgãos da administração para formular a política industrial, para formular a política científica e tecnológica, para formular a modernização do sistema agrícola do país [...]. Objetivo, como ministro do Planejamento, dar ao BNDES, essa instituição que nos é tão cara, as melhores condições para que a atual diretoria, formada por pessoas competentes, eticamente comprometidas com o interesse público, possa essa diretoria possa realmente resgatar as tradições mais nobres desta instituição (HADDAD, 1992, [DVD]).

Haddad faz claro contraponto à gestão anterior, sustentando que o Banco não deveria restringir-se à política de estabilização, ou seja, atuar como agente da privatização, mas deveria resgatar a perdida tradição do interesse público ao planejar a indústria, a política científica, a modernização. Para reorientar o Banco, Haddad convidara Antônio Barros de Castro (item 1.5), originalmente associado às ideias cepalinas, com formação nas áreas de planejamento e desenvolvimento e longa experiência no exterior. A relação de Castro com o BNDES não era nova, ele havia sido consultor do Banco durante o processo de elaboração de cenários do planejamento feito nos anos 1980 e foi também consultor da FINEP na época em que ela desenvolvia as pesquisas que conectavam indústria e avanço tecnológico (MOURÃO, 1994, p. 9). Como parte do grupo que pensara a competitividade em um cenário de abertura e sendo um estudioso que adotava a perspectiva internacional para pensar a economia nacional, Castro era um nome para redirecionar os investimentos para uma inserção internacional competitiva.

O discurso de posse de Castro situa sua perspectiva na síntese histórica entre o total e arbitrário planejamento da demanda, do pós-guerra, e a total recusa à intervenção econômica, que se alastrou nos anos 1980. Ele cita o exemplo do desenvolvimento japonês para sustentar “a ousada hipótese dos homens dos anos 1950 e 1960, de que é possível ir além do mercado, de que é possível promover o desenvolvimento a partir de uma aliança participativa entre governo e empresa privada e com resultados formidáveis”. Ainda que Castro também enfatize a necessidade de reestruturação da atuação do governo na área econômica, incluindo a privatização, ao invés de caracterizar o Estado como um elefante branco, Castro faz um longo elogio ao setor público brasileiro:

a grande marca da empresa pública foi exatamente o sentido de missão, a mobilização para grandes fins, o devotamento quase cívico, o sentido de participação dos que nela trabalharam. Estas características que diversas empresas públicas tiveram durante décadas no Brasil e que, a despeito de tudo, algumas 
não perderam até hoje, eram extemporâneas em um mundo dominado por empresas tayloristas e não participativas. Que empresa pelo mundo afora, nos anos 1950, contava com a dedicação e o entusiasmo dos que trabalhavam numa Petrobrás, num BNDE, numa CEMIG [Companhia Elétrica de Minas Gerais]? Que empresas tinham, àquela época, a preocupação central de estruturar setores? Pois essa característica tão pioneiramente nossa, é exatamente uma das mais características marcas das empresas japonesas. É a característica também que no ocidente, na Alemanha e na Itália, cada uma a seu modo, vem se desenvolvendo. Um dos traços mais peculiares da atualidade é a migração de qualidades originariamente tidas como públicas para a empresa privada [...]. O universo empresarial brasileiro emergiu do processo de substituição de importações num mundo imprevisto, caracterizado pela dupla revolução, tecnológica e organizacional, e pela longa estagnação dos anos 1980. Apesar de todas as desvantagens do meio ambiente interno, numerosas empresas do meio empresarial privado, e mesmo algumas do setor público, vêm fazendo grandes esforços para reestruturar-se. Aqui está a nova chance histórica do BNDES. A orientação geral da instituição deverá ser a de grande aliado, e na medida de suas forças, promotor da reestruturação. Refiro-me aqui tanto ao processo de reestruturação do setor público, em pleno curso, quanto ao programa de desestatização. A privatização deve ser entendida como um instrumento do processo de reestruturação e deve ser também um mecanismo capaz de promover o reingresso de capitais privados nos serviços de utilidade pública, através de empresas com características peculiares, inspiradas na experiência internacional e qualificadas à luz do contexto brasileiro. Evidentemente, ao definir o BNDES como banco da reestruturação pretendemos retomar a perspectiva do longo prazo (CASTRO, 1992a, [DVD]).

Castro usa as palavras desestatização e privatização 2 vezes em um discurso de 1430 palavras. Modiano usa-as 17 vezes em fala de 1622 palavras, o que evidencia a diferença de ênfase da privatização em uma e outra gestão. Nos relatórios administrativos de Modiano, a desestatização está por toda parte. Castro só falará no tema em uma seção exclusivamente dedicada a ele. $\mathrm{Na}$ sua mensagem presidencial, os temas de destaque são o investimento, o desenvolvimento, a capacitação tecnológica, a qualidade, o treinamento, a renovação da base produtiva, a eficiência e a modernização para adaptar-se a um ambiente de maior competição com padrões internacionais.

Fabio Eber, antigo funcionário do Banco, que havia sido pesquisador da FINEP e era especialista na conjugação de economia industrial e tecnologia, relata que Castro entendia

que era hora de voltar a fazer política industrial. Ninguém sabia o que seria o governo Itamar. Era um período de grande incerteza. Havia um problema de instabilidade muito grave na economia, que precisava ser atacado. Mesmo assim, tínhamos a ideia de fazer algo de política industrial a partir do Banco, um dos poucos aparatos burocráticos que tinham sobrevivido ao desmonte do Estado feito durante o governo Collor. Preparamos um projeto de reforma das áreas que eu dirigia: Crédito para Indústria, Comércio e Serviços, com exceção de Infraestrutura. Junto às áreas operacionais do Banco foram estabelecidas "gerências setoriais" que teriam por objetivo inicial dar apoio às operações, estudando os setores em que essas operações estivessem concentradas (como 
papel e celulose). Esse tipo de organização é corriqueiro em grandes bancos de investimento internacionais. Posteriormente, foi estendido às outras áreas operacionais do BNDES (Fábio Stefano Erber in: BNDES, 2002).

Não só a ideia de política industrial retornava ao palco. Os setores, que se tentou abolir nas reformas da estrutura interna, também voltavam a fazer parte do discurso. Erber foi escolhido pela grande afinidade teórica e por ser, "por definição, o cara que entende de política industrial e política tecnológica. Então ele [Castro] precisa desse sujeito porque é essa direção que ele quer imprimir no Banco" (Entrevista de Ana Célia Castro à autora, 2014). Além dele, a diretoria de Castro congregava uma pluralidade de orientações, decorrente do caráter diversificado do projeto que trazia para a instituição.

Do período anterior, foram mantidos os funcionários do Banco José Mauro Carneiro da Cunha e Sérgio Zendron, responsáveis também pela FINAME e pela BNDESPAR, respectivamente. Zendron era o principal funcionário envolvido com a privatização e mantê-lo na diretoria era indício de que o programa não seria abandonado. Da FEA-USP, Castro trouxe Guilherme Leite Dias, especialista em economia agrícola, que havia feito carreira próxima ao grupo de Delfim Netto e chegara a fazer uma parte de sua pós-graduação em Chicago. Ele seria a pessoa a atuar na modernização e competitividade do agrobusiness (BNDES, 1992, p. 5; CANABRAVA, 1984a, p. 149).

Finalmente, Barros de Castro convidou Marcos Vianna, o presidente do Banco dos anos 1970, para a vice-presidência, o que simbolizaria um resgate do BNDES do II Plano Nacional de Desenvolvimento, de um BNDES que acreditava no Estado, que pensava em termos de setores, opondo-se início da década de 1990. Mas Vianna permaneceu poucos meses no Banco, sendo substituído por um indicado de Itamar Franco, Alexis Stepanenko ${ }^{519}$ (1938), paulistano que iniciou a graduação em ciências sociais na Escola Livre de Sociologia e Política (ELSP) e concluiu na PUC-RJ. Stepanenko havia atuado no mercado editorial e lecionado ciências sociais na Universidade Federal de Juiz de Fora (UFJF) e marketing na FGV antes de tornar-se assessor de Itamar, de quem se

\footnotetext{
${ }^{519}$ Alexis era filho do russo Dimitri Stepanenko, “engenheiro químico, republicano e proprietário de minas de carvão que participou da política ao lado do imperador e chegou ao posto de major. Após passar pela Tchecoslováquia, o pai de Stepanenko desembarcou no Brasil. Na década de 1950, a Segunda Guerra Mundial trouxe muitos cientistas políticos que eram amigos da família. A discussão política era muito frequente dentro de casa e muitas ideologias eram debatidas". Alexis diz que foi o contato com a política em casa que o levou a filiar-se à juventude comunista e decidir estudar ciências sociais (RAFAEL, 2014, p. 5).

Ver: http://memoria.bn.br/DocReader/DocReader.aspx?bib=089842_06\&PagFis=749

https://issuu.com/fabriciocasella/docs/jornal_raizes_diario_97532509440477. Consultados em 07/05/2016.
} 
aproximara nos anos sessenta quando viveu em Minas Gerais (DHBB, verbete Alexis Stepanenko).

Ao contrário de Modiano, Castro fez poucas alterações nas superintendências e manteve Besserman como seu chefe de gabinete. Permaneceu, entretanto, poucos meses no Banco, em gestão marcada por sucessivos atritos com o Governo Federal, mormente com José de Castro Ferreira, o Advogado Geral da União, político mineiro e tesoureiro das campanhas de Itamar. Apesar de desconfianças em relação às politicas da gestão anterior, o governo Itamar optou por manter a desestatização, mas defendendo revisão das regras envolvendo o tipo de pagamento, o modelo do leilão, a participação do capital estrangeiro, a divulgação de fatos relativos ao processo de privatização, a integração com a política industrial, dentre outras questões. Ao final, outros 17 processos de desestatização foram concluídos, totalizando US\$ 4,7 bilhões arrecadados (BNDES, 1992, p. 46; VELASCO JUNIOR, 2010, pp. 358-359).

Do ponto de vista de José de Castro, alterar a privatização passava por acabar com o protagonismo do BNDES no programa, já que a instituição tinha forte controle sobre a preparação e os leilões ficavam, pois, fora da esfera de influência federal. A primeira providência, nesse sentido, foi interromper temporariamente o programa e, na sequência, afastar Antonio Barros de Castro da Comissão Nacional de Desestatização. O indicado para a presidência da Comissão, André Franco Montoro Filho, havia passado pelo BNDES e diz ter sido indicado por Castro e por seu colega de FEA, Guilherme Dias Leite, para o posto. Ele tinha a vantagem de contar com a confiança de Barros de Castro e ao mesmo tempo ser conhecido e aceito dentro do Banco (Entrevista de André Franco Montoro Filho à autora, 2014) ${ }^{520}$.

As desavenças com José de Castro e a constante interferência no trabalho conduzido pelo Banco levaram à demissão de Antônio Barros de Castro, em março de 1993521. Ainda que as batalhas com o círculo mineiro de Itamar tenham representado a

\footnotetext{
${ }^{520}$ Ver: http://memoria.bn.br/DocReader/DocReader.aspx?bib=030015 11\&PagFis=70106, http://memoria.bn.br/DocReader/DocReader.aspx?bib=030015 11\&PagFis=84012, http://memoria.bn.br/DocReader/DocReader.aspx?bib=030015_11\&PagFis $=82563$, http://memoria.bn.br/DocReader/DocReader.aspx?bib=030015_11\&PagFis $=87069$, http://memoria.bn.br/DocReader/DocReader.aspx?bib=030015_11\&PagFis=80305, http://memoria.bn.br/DocReader/DocReader.aspx?bib=030015_11\&PagFis=78318, Consultados em 24/04/2016. ${ }^{521}$ Ver: http://memoria.bn.br/DocReader/DocReader.aspx?bib=030015 11\&PagFis $=78318$, http://memoria.bn.br/DocReader/DocReader.aspx?bib=030015_11\&PagFis=79360, http://memoria.bn.br/DocReader/DocReader.aspx?bib=030015 11\&PagFis=79970, http://memoria.bn.br/DocReader/DocReader.aspx?bib=154083_05\&PagFis=17897, Consultados em 23/04/2016.
} 
parte mais amarga de sua gestão, os problemas do período não se restringiam à disputa no âmbito da privatização. As finanças do Banco permaneciam estagnadas. Era igualmente frágil a tentativa de conduzir uma política de incentivo ao crescimento sem que houvesse clareza programática por parte de um governo emergencial e de coalizão que não tinha diretrizes para assuntos referentes ao longo prazo (Entrevista de Ana Célia Castro à autora, 2014).

Anunciada a saída de Castro, o governador de São Paulo, Luís Antônio Fleury, prontifica-se a indicar um substituto, seu secretário de Ciência e Tecnologia, Luís Carlos Delben Leite (1945). Nascido na cidade de Araras e filho de casal de empresários do setor gráfico, Delben Leite diplomou-se em ciências econômicas pela PUC-SP e foi trabalhar na indústria que seu pai presidia. Liderança estudantil durante a graduação, Luís Carlos logo engajou-se na representação patronal de seu setor, tendo fundado e presidido a Associação Brasileira da Indústria de Máquinas e Equipamentos Gráficos ${ }^{522}$, antes de ser convidado por Fleury para trabalhar no governo do Estado (DHBB, verbete Luís Carlos Delben Leite).

No período em que Delben Leite esteve à frente do Banco, as privatizações foram retomadas. Ocorreram 5 leilões, sendo o da Companhia Siderúrgica Nacional o maior deles (DINIZ, 2004, p. 117). Não obstante, os conflitos entre o BNDES e a "República do Pão de Queijo", alcunha dada ao enorme grupo de mineiros levados por Itamar para o governo, não cessaram. No caso de Delben Leite, a briga foi com Alexis Stepanenko que, em maio de 1993, havia deixado a diretoria do BNDES para ocupar o Ministério do Planejamento. Embora paulista de nascimento, era listado entre os homens das Gerais, já que conheceu e aproximou-se do presidente quando lecionou na UFJF, cidade de onde provinha Itamar.

Com a chegada de Delben Leite, os diretores do BNDES, Erber, Zendron e José Mauro Carneiro, foram mantidos e para substituir Guilherme Dias, que retornou à São Paulo, foi nomeado outro funcionário do Banco, Luiz Orenstein (1954), mencionado no capítulo anterior como um dos alunos da UFRJ que passou a lecionar no IEI-UFRJ. Orenstein acabava de concluir doutorado em ciência política, feito parte no Instituto Universitário de Pesquisas do Rio de Janeiro (IUPERJ), parte na University of California,

\footnotetext{
${ }^{522}$ Ver: http://memoria.bn.br/DocReader/DocReader.aspx?bib=030015 11\&PagFis=84426, http://memoria.bn.br/DocReader/DocReader.aspx?bib=093718 05\&PagFis $=44333$ http://memoria.bn.br/DocReader/DocReader.aspx?bib=093718_05\&PagFis $=38568$ http://memoria.bn.br/DocReader/DocReader.aspx?bib=093718_05\&PagFis=38568. Consultados em 23/04/2016.
} 
em San Diego. Ao retornar dos Estados Unidos da América, trabalhou como superintendente no departamento de crédito, área sob a diretoria de Guilherme Dias, sendo chamado para substituí-lo em agosto de 1993 (Entrevista de Luiz Orenstein à autora, 2012).

Os problemas de Delben Leite começaram com as tentativas de Stepanenko de interferir na diretoria do Banco. Ele decidiu demitir o diretor de privatização Sergio Zendron e determinou que Delben Leite dividisse o poder com um vice-presidente que escolheria. Tais ingerências levaram à renúncia de Delben no dia seguinte, seguida de denúncias de irregularidade da atuação de Stepanenko no período em que ele esteve na vice-presidência do Banco. O episódio foi estopim de grandes atritos entre o PMDB paulista e o governo Itamar que fizeram Fleury recusar-se a indicar novo substituto. Afinal não se tinha garantia da permanência de ninguém que não fosse um aliado da "República do Pão de Queijo"523.

O presidente seguinte do BNDES, Persio Arida, foi escolhido pelo novo Ministro da Fazenda do governo Itamar Franco, Fernando Henrique Cardoso. FHC, que havia entrado no governo em outubro de 1992, na pasta das Relações Exteriores, foi convocado emergencialmente, em maio de 1993, para substituir o Ministro da Fazenda, Eliseu Resende, engenheiro e político que havia ocupado o Ministério dos Transportes e sido candidato ao governo de Minas. Rezende caiu depois de apenas dois meses no Ministério por ter sido acusado de aceitar suborno e favorecer a empresa Odebrecht ${ }^{524}$, da qual havia sido diretor. Fernando Henrique e Itamar conheciam-se desde 1983, quando passaram a conviver no Senado. Respeitavam-se, embora Cardoso tenha feito menções à sua teimosia. Na época do impeachment de Collor, aproximaram-se e, dali em diante, tornaram-se amigos. Depois da queda de Rezende, Itamar ligou para Cardoso, que estava no Japão, convidando-o para o Ministério e sequer esperou a resposta dele para fazer a nomeação. A condição exigida por FHC era liberdade para compor sua equipe. Itamar consentiu (CARDOSO, 2006c, pp. 36-43).

\footnotetext{
${ }^{523}$ Ver: http://memoria.bn.br/DocReader/DocReader.aspx?bib=030015 11\&PagFis=96835, http://memoria.bn.br/DocReader/DocReader.aspx?bib=030015 11\&PagFis=96912, http://memoria.bn.br/DocReader/DocReader.aspx?bib=030015_11\&PagFis=96915, http://memoria.bn.br/DocReader/DocReader.aspx?bib=030015_11\&PagFis=96917, Consultados em 24/04/2016. ${ }^{524}$ Ver: http://memoria.bn.br/DocReader/DocReader.aspx?bib=154083 05\&PagFis $=17826$ http://memoria.bn.br/DocReader/DocReader.aspx?bib=154083_05\&PagFis=27272 Consultados em 24/04/2016.
} 
FHC relata que, em passagem por Nova York no caminho de volta para o Brasil, pediu que:

os economistas Pedro Malan e Armínio Fraga fossem ver-me no gabinete do embaixador Ronaldo Sardenberg [...]. Malan eu conhecia desde o final da década de 1960. Na época ele estava casado com uma sobrinha do sociólogo da USP Juarez Brandão Lopes, um dos fundadores do CEBRAP, meu amigo e vizinho em Ibiúna, e veio com a mulher visitá-lo. Em 1971, sendo eu professor-visitante na Universidade de Stanford, na Califórnia, e ele aluno do economista Albert Fishlow no doutoramento em Berkeley, estivemos, de novo, juntos em diferentes ocasiões. Posteriormente, em São Paulo, ele se sentaria à mesa em alguns seminários no CEBRAP. O próprio Malan me apresentaria Armínio, com quem tive alguns contatos quando de sua passagem por uma das diretorias do BC, durante o governo Sarney [...]. Convidei Malan para trabalhar comigo no Brasil. Malan tão surpreso quanto eu ficara com o convite do Presidente Itamar, talvez perplexo porque, como negociador da dívida externa, sabia até mais do que eu o tamanho do problema que a nova equipe econômica deveria enfrentar - acedeu em me ajudar esporadicamente: 'vou trabalhar em Brasília com vocês uma semana por mês'. Num primeiro momento manteria sua posição como negociador da dívida externa e representante do Brasil no Banco Mundial. Armínio, entretanto, desculpou-se e declinou qualquer função, pois recémingressara no mercado financeiro em Nova York (CARDOSO, 2006c, pp. 137138).

Além deles, recrutou Clóvis Carvalho (item 3.2), que deixou a vice-presidência da empresa Villares para assumir a Secretaria Executiva do Ministério da Fazenda e

três economistas que participaram dos debates para a formação do PSDB e integrantes do partido, Edmar Bacha - de há muito meu conhecido, desde que lecionei nos anos 1970 nos EUA, onde ele aperfeiçoava seus estudos -, Winston Fritsch e, logo após, Gustavo Franco, igualmente vieram colaborar, mais por dever político do que por crença na possibilidade que teríamos de fazer o necessário, tal a desconfiança que tinham do governo e dos políticos. Bacha incorporou-se à equipe como consultor especial, ocupando-se, de início, da tarefa de arquitetar os passos indispensáveis à recomposição das finanças públicas. Fritsch assumiu como secretário de Política Econômica e Gustavo Franco, inicialmente, seria seu adjunto para logo depois se encarregar da área externa do BC[B] (CARDOSO, 2006c, pp. 140-141).

Dos economistas contatados por Cardoso, dois ainda não foram alvo de contextualização social: Gustavo Franco (1956) e Armínio Fraga (1957), que seriam os principais presidentes do Banco Central nos mandatos de FHC na Presidência da República. Fraga e Franco nasceram e foram criados no Rio de Janeiro, Armínio morando no Jardim Botânico; Gustavo na Urca. Estudaram em colégios católicos tradicionais, Armínio no Santo Inácio, Gustavo no São Vicente de Paulo e no Sion. Cursaram a graduação e o mestrado em economia na PUC-RJ. O doutorado fizeram ambos nos EUA, Armínio em Princeton; Gustavo em Harvard. 
Quanto à origem social, Franco é filho de Guilherme Arinos Lima Verde de Barroso Franco. Nascido em Itacoatiara, no interior do Amazonas, Arinos perdeu o pai precocemente. Sua mãe era professora primária em Itacoatiara, cidade onde fez os estudos até o ginásio. No início dos anos 1930, Guilherme contou com a ajuda da família estendida para ir a Belém do Pará prestar concurso para o Banco do Brasil (BB). Aprovado, foi trabalhar na área de câmbio em Belém e acabou estudando contabilidade. No início da II Guerra Mundial, foi um dos escolhidos para participar dos debates da mobilização econômica, encarregado de pensar como defender as reservas cambiais brasileiras. $\mathrm{Na}$ sequência, foi convidado para ser chefe-de-gabinete do Ministro da Fazenda do General Dutra, Gastão Vidigal, e permaneceria no posto com a ascensão de Horácio Lafer ao Ministério, no II Governo Vargas (FRANCO, 1999, p. 383; NASSIF, 2005; LEO, 2012; FIUZA, 2008, p. 63).

Além de trabalhar no Ministério da Fazenda, Guilherme Arinos tornou-se assessor direto do Presidente Vargas, sendo por ele indicado também para o primeiro Conselho de Administração do BNDES ${ }^{525}$. Sergio Besserman declara-se fruto do suicídio de Vargas, que reconciliou os pais, de frações diferentes da esquerda (Entrevista de Sergio Besserman à autora, 2012). Gustavo Franco é outro fruto do suicídio, que acabou com os motivos para o adiamento, que já durava dez anos, do casamento de seu pai com Maria Isabel Ottoni Guedes Barbosa, descendente de prestigiosas famílias mineiras. Gustavo descreve a devoção do pai a Getúlio: até o fim da vida, "todo dia 24 de agosto ele manda rezar uma missa em homenagem ao 'Velho Getúlio', na qual se reúnem vários senhores de cabelos brancos, que trocam sorrisos mansos e compartilham a paz interior que lhes confere a paixão pelo amigo que saiu da vida para entrar na história” (FRANCO, 2011, p. 114).

Depois da morte de Vargas, Guilherme Barroso Franco foi diretor do grupo industrial Monteiro Aranha e sócio de Jorge Paulo Lemann na compra da corretora Garantia, que deu origem, em 1976, ao Banco Garantia. Deste modo acumulou considerável patrimônio financeiro ao longo de sua vida. Gustavo Franco escolheu estudar economia por influência paterna: seu pai "foi deixando o filho ver que estaria tudo bem entre eles dois, qualquer que fosse o caminho escolhido [por Gustavo], desde

\footnotetext{
${ }^{525}$ Ver: http://memoria.bn.br/DocReader/DocReader.aspx?bib=093718_03\&PagFis=17940 http://memoria.bn.br/DocReader/DocReader.aspx?bib=093718_02\&PagFis=48964. Consultados em 25/04/2016.
} 
que esse caminho levasse a uma faculdade de economia" (FIUZA, 2008, p. 65). Segundo ele:

\begin{abstract}
[ao] escolher uma profissão, fiquei entre Arquitetura e uma carreira na área financeira. Acabei fazendo vestibular para Administração e Economia. Cursei Administração Pública na EBAP [Escola Brasileira de Administração Pública]/FGV, aqui do Rio, e Economia na PUC-RJ, ao mesmo tempo, até o terceiro ano. Desisti da EBAP no momento em que me vi diante de um curso de 'Administração de Material'. Foi demais. Tive vontade de começar a Arquitetura, ou mesmo Letras, enquanto continuava com a Economia. Mas deu preguiça. Continuei a Economia até o fim. Depois, segui o mestrado em Economia na PUC mesmo (FRANCO, 1999, pp. 383-384).
\end{abstract}

Durante a faculdade, chegou a estagiar no Garantia, mas não verteu para o mercado, ingressando diretamente na pós-graduação. Seu mestrado, Reforma monetária e instabilidade durante a transição republicana (1982), foi orientado por Winston Fritsch, ao lado de quem trabalharia na elaboração do Plano Industrial do governo Collor e no Plano Real. A dissertação recebeu o primeiro lugar no prêmio BNDES de 1983, e foi publicada pelo Banco. No ano anterior, havia ganho o prêmio Edward Amadeo (1956), carioca filho de uma belga e de um americano, nascido em Guantánamo. O pai, Joaquin Jacinto Amadeo, era guarda-livros na época em que chegou ao Brasil. Anos depois, fundou a primeira fábrica de bebidas, Bacardi do Brasil, em Recife, onde Edward viveu parte da infância ${ }^{526}$. De volta ao Rio, Amadeo foi estudar no Colégio São Vicente, onde tornou-se amigo e parceiro de banda de rock de Gustavo. Juntos cursaram a graduação em economia na PUC e em administração na EBAP-FGV. Ao contrário de Franco, Amadeo concluiu o curso de administração e, invés de permanecer na PUC-RJ, fez o mestrado no IEI-UFRJ, onde defendeu a tese Desemprego, salários e preços: um estudo comparativo de Keynes e do pensamento macroeconômico da década de 70 (1981), sob orientação de Maria da Conceição Tavares (DHBB, verbete Edward Amadeo).

Tanto Gustavo Franco quanto Edward Amadeo cursaram o doutorado em Harvard no início dos anos 1980. Gustavo, cujo mestrado havia sido em história econômica e política e tematizava a história monetária no período do encilhamento, seguiu na mesma linha e dedicou-se às hiperinflações europeias. Conta que, quando começou a escrever a tese Aspects of the economics of hyperinflations: theoretical issues and historical studies of four European byperinflations of the 1920s (1986), seu interesse pela hiperinflação era

\footnotetext{
${ }^{526}$ Ver: https:/familysearch.org/ark:/61903/3:1:33SQ-G5B3-9TKD?mode=g\&i=105\&wc=QS6BPTP\%3A1019548401\%2C1021199601\%3Fcc\%3D1932363\&cc $=1932363 \mathrm{e}$ http://www2.uol.com.br/JC/_1998/3105/rjc3105.htm. Consultados em 25/04/2016.
} 
histórico e motivado pela "oportunidade única na vida de estudar países europeus a partir das bibliotecas e arquivos de Harvard”. Naquele momento não achava que o Brasil tomaria a rota de uma hiperinflação na metade dos anos 1980 e não imaginava que a solução que seus professores da PUC-RJ proporiam para a inflação adviria da análise das formas de encerramento das hiperinflações. Gustavo explica que "no final de 1985, a Bolívia já estava em hiperinflação. Era perfeito para mim. Era como estudar paleontologia e descobrir que alguém achou um dinossauro vivo num lugar remoto. Você fica doido para ir lá ver, e testar suas conjecturas". Franco teve três orientadores; Jeffrey Sachs, que estava justamente trabalhando como consultor para a Bolívia, Barry Eichengreen, historiador econômico que escreveu sobre as mudanças nos padrões monetários internacionais, e Lance Taylor, amigo de Edmar Bacha, que havia lecionado na UNB e era o orientador dos brasileiros, que Gustavo Franco classifica de "o heterodoxo de plantão no MIT" (FRANCO, 1999, pp. 389-390, 392).

Amadeo seguiu estudando Keynes e redigiu a tese Keynes's principle of effective demand and Its relationship to alternative theories of distribution and accumulation (1986), dirigida por Lance Taylor e Murray Milgate, mais fortemente dedicado à economia política e à obra de Keynes. De volta ao Brasil, tanto Franco quanto Amadeo passaram a lecionar na PUC-RJ. Indicado por Pedro Malan, que havia sido professor deles, para Fernando Henrique, Franco passaria logo a trabalhar para o PSDB; Amadeo chegaria a prestar assessoria ao PT, junto com o José Marcio Camargo, e criticar o processo de abertura econômica de FHC antes de aceitar o posto de Ministro do Trabalho, que ocupou de abril de 1998 ao final do primeiro mandato (DHBB, verbete Edward Amadeo; FRANCO, 1999, pp. 389390, 392).

Armínio Fraga Neto (1957) era um misto de Franco e Amadeo. Por parte de pai tinha longa linhagem brasileira. A mãe era estadunidense, sendo ele cidadão dos dois países. Os avós paternos eram nordestinos. Seu avô, Armínio Fraga, era um médico baiano que recebeu bolsa da Fundação Rockefeller para fazer especialização nos Estados Unidos e tornou-se conhecido dermatologista e professor da Faculdade de Medicina da Universidade do Brasil (UB). Casou-se com Leopoldina de Souza Leão Fraga, neta de Antônio de Souza Leão, o Barão de Morenos, de família proprietária de engenhos em 
Pernambuco ${ }^{527}$. Sylvio Fraga, filho do casal, seguiu os passos do pai. Formou-se em medicina na UB. Fez a residência na Filadélfia, onde especializou-se em dermatologia e tornou-se livre-docente da UFRJ e depois da PUC-RJ. Nos Estados Unidos, conheceu e casou-se com Margareth Ann Breslin, enfermeira e professora de enfermagem, descendente de irlandeses. Os laços de Armínio Fraga Neto com o universo médico eram ainda mais vastos incluindo o diretor da Faculdade de Medicina Clementino Fraga Filho, que dá nome ao hospital universitário da UFRJ (NOBRE, 2003; DHBB, verbete Armínio Fraga; Entrevista de José Luís Osório à autora, 2012; RIBEIRO, 2013).

Armínio declara ter sido criado com os costumes dos dois países, mas alfabetizado primeiro em português, considerando-se "mais brasileiro, melhor dizendo, carioca, da Zona Sul", onde cresceu entre a casa no Jardim Botânico, o Santo Inácio em Botafogo e o Golfe Clube e a PUC na Gávea (RIBEIRO, 2013). Adolescente, seguiu a classe preparatória para medicina no Colégio Santo Inácio "pelo exemplo da família. Aquilo era uma espécie de default, mas um belo dia senti que não era a minha vocação. Vendo a paixão que a medicina representava para meu pai, meu avô, meus tios, senti que não era para mim. Eu gostava muito de matemática e pensava que poderia desenvolver alguma atividade no mundo dos negócios” (Armínio Fraga in: ALBERTI et al., 2002, p. 244). A família recebeu mal a escolha. No preparatório para medicina do Santo Inácio tinha dois colegas cariocas que fizeram desvio semelhante para a economia. Ambos tornar-se-iam diretores do BNDES no governo Fernando Henrique. Wallim Vasconcellos (1958), que ingressou na engenharia da PUC-RJ e depois transferiu-se para a economia e Elena Landau (1958), então namorada de Armínio, que afirma ser economista por causa dele. Ela conta:

\begin{abstract}
eu ia fazer medicina, por isso que somos da turma de medicina. O Armínio vem de uma família de médicos. Na hora de me inscrever no vestibular, eu desisti e fui fazer matemática. Sempre gostei de matemática. Fiquei seis meses na PUC fazendo matemática. Achei muito abstrato. Eu queria fazer história. Aí o Armínio que fazia economia diz: "Se matemática é abstrato, história você também não vai ter aplicabilidade. Faz economia, que eu estou adorando". Aí fiz as duas faculdades até um ponto. Fiz dois anos de matemática, depois abandonei e fiquei só na economia (Entrevista de Elena Landau à autora, 2012).
\end{abstract}

A opção pela matemática, em lugar da medicina, não foi chocante para a família de Elena. A mãe, antes de tornar-se estilista, havia ingressado faculdade de matemática. A ela

\footnotetext{
${ }^{527}$ Ver: http://memoria.bn.br/DocReader/DocReader.aspx?bib=110523_04\&PagFis=5117 e http://memoria.bn.br/DocReader/DocReader.aspx?bib=110523_02\&PagFis=24721,
} 
Landau atribui o legado do talento. "Todos lá em casa tínhamos facilidade com matemática. Porque ela tratava matemática como uma coisa bonita”. O lado paterno não destoava, sendo o pai engenheiro.

Ao final da graduação, Wallim fez especialização em finanças coorporativas na PUC-RJ e ingressou na BNDESPAR no final de 1982, através de processo seletivo que analisava currículo e entrevista. Elena e Armínio seguiram para o mestrado em economia na própria PUC-RJ. A dissertação dela, A aceleração inflacionária de 1979 (1982), foi inicialmente orientada por André Lara Resende e depois por José Marcio Camargo, conquistando a segunda posição do prêmio BNDES de 1983. A dissertação de Armínio, Expectativas racionais e modelos macroeconômicos: uma sistematização da discussão recente ${ }^{528}$ (1981), foi orientada por Chico Lopes. Como Gustavo Franco e Pedro Bodin, Armínio e Elena faziam parte do primeiro grupo de alunos de mestrado da PUC-RJ aprovados para cursar o doutorado no exterior. Armínio optou por Princeton, onde escreveu a tese Essays in international lending and adjustment (1985). Ele diz ter sido

o primeiro brasileiro a fazer doutorado lá e um dos primeiros latino-americanos. Princeton não tinha uma tradição, como tinham Chicago ou o MIT, de atrair alunos daqui. Resolvi ir pelo corpo docente. Eu também me candidatara a Harvard, MIT, Stanford, entrei em todas, mas como queria estudar economia internacional, macroeconomia, finanças, e existia muita gente boa nessas áreas em Princeton, optei por lá. Carlos Ivan [Simonsen] e Sérgio [Ribeiro da Costa] Werlang também foram, um ano depois de mim. Eles tinham uma trajetória diferente da minha, embora Carlos Ivan e eu tivéssemos sido colegas no Santo Inácio - somos amigos há não sei quantos mil anos. Em Princeton, nos aproximamos ainda mais, e o Sérgio, que eu não conhecia, hoje também é um grande amigo e colega (Armínio Fraga in: ALBERTI et al., 2002, p. 244).

Carlos Ivan Simonsen Leal (1957), presidente da FGV desde 2000, é carioca, filho de advogado e sobrinho de Mario Henrique Simonsen, que teve vasta influência sobre sua vida. Como o tio, Carlos Ivan estudou no Colégio Santo Inácio, graduou-se em engenharia na UFRJ, fez cursos de matemática no Instituto Nacional de Matemática Pura e Aplicada (IMPA) e verteu para a economia, mantendo-se na interface desta com a matemática. Sergio Werlang (1956), que faria parte da diretoria de Armínio Fraga no BCB, também nascido no Rio, estudou no São Bento e era amigo de Carlos Ivan desde a graduação (DHBB, verbete Carlos Simonsen Leal). Werlang conta que na engenharia da UFRJ

logo comecei a fazer cadeiras extras de matemática e física no IMPA e no CBPF [Centro Brasileiro de Pesquisas Físicas]. Faltando pouco mais de um ano para

\footnotetext{
${ }^{528}$ Ver: http://www.race.nuca.ie.ufrj.br/teses/pucrj/pucrj-me.htm. Consultado em 25/04/2016.
} 
terminar a engenharia, Carlos Ivan Simonsen Leal, que era meu colega, insistiu que eu ia gostar de economia. Eu achava aquilo muito estranho - economia? mas ele me deu para ler um texto do Mario Henrique Simonsen, que na época tinha acabado de sair do governo. Li e achei fascinante: era uma coisa lógica, que eu consegui entender, não tinha nada a ver com o que eu lia nos jornais e não entendia. Ele usava a matemática até para mostrar que havia um raciocínio formal por trás do que dizia, não era uma questão de "achismo". Eu estava fazendo várias cadeiras de mestrado e doutorado no IMPA e comecei então, em 1980, a fazer cadeiras de economia matemática com o Aloisio Araújo. A turma éramos eu, Carlos Ivan e Ricardo Paes de Barros [...]. Afinal em 1981 fiz o exame da ANPEC para a EPGE e entrei. Aí me tornei aluno do Simonsen e foi fantástico (Sérgio Werlang in: ALBERTI et al., 2002, p. 240).

Carlos Ivan relata que, quando ele e Werlang foram para a Escola de PósGraduação em Economia da FGV-RJ (EPGE), “fomos dispensados de várias cadeiras, o que nos permitiu fazer todos os créditos de mestrado e doutorado em um ano e três meses. O IMPA tinha um professor, Aloísio Pessoa de Araújo, também nosso professor na EPGE, que foi o grande impulsionador para que eu e Sérgio Werlang fôssemos fazer o doutorado fora, embora com mais seis meses ou um ano pudéssemos obter o título de doutor aqui na Fundação" (Carlos Ivan Simonsen Leal in: D’ARAÚJO, 1999, p. 202). Ele conta ainda que o

Sérgio Werlang e eu fomos aceitos em várias boas universidades americanas, mas optamos por Princeton, que tinha na época o melhor departamento de teoria dos jogos e de economia matemática. Na parte de microeconomia os professores eram considerados os melhores do mundo, e essas eram áreas pelas quais eu me interessava. Recebi da Fundação uma bolsa de uns 100 ou 150 dólares por mês. Em troca disso, todas as férias de verão lá, eu vinha para cá e passava três meses ensinando no mestrado. Também tinha oportunidade de conversar e ouvir meu tio. Terminei o doutorado e me tornei professor em 1986 (Carlos Ivan Simonsen Leal in: D’ARAÚJO, 1999, p. 206).

Os dois voltaram para a EPGE com teses na área de teoria dos jogos, que era, naquele momento, a fronteira mais avançada da economia com a matemática. Werlang escreveu Common knowledge and game theory (1986) e Carlos Ivan Topics in non-cooperative game theory : byperstability of Nash equilibria, Brown-Von Newmann fictitious play and principal's problem (1986). Quando regressaram, os dois passaram logo a lecionar na FGV, que havia perdido vários professores nos períodos em que os professores da casa, Langoni e Lemgruber, (itens 4.4 e 4.0) presidiram o Banco Central. Armínio foi convidado por eles para lecionar também na FGV. Passou a dividir seu tempo entre as aulas na PUC-RJ, na EPGE e o trabalho no Banco Garantia (item 5.6). Esse arranjo durou menos de três anos pois, em 1988, foi convidado para ser professor visitante no Departamento de Finanças da Wharton School, da University of Pennsylvania, e acabou tornando-se, em junho de 1989, 
vice-presidente do banco de investimentos Salomon Brothers (DHBB, verbete Armínio Fraga).

Depois da queda de Zélia, Marcílio Marques Moreira, no Ministério da Fazenda de Collor, convidou o banqueiro Francisco Gros (item 5.5), que conhecia dos tempos em que trabalharam no UNIBANCO, para retornar à presidência do Banco Central (MOREIRA, 2001, p. 272). Armínio foi por eles convidado para integrar a diretoria de assuntos internacionais do BCB, por recomendação de seus professores Lara Resende e Persio Arida (OLIVIERI, 2001, p. 53). Lá permaneceu até outubro de 1992, quando voltou para os EUA para trabalhar nos empreendimentos financeiros do magnata George Soros e lecionar na área de relações internacionais da Universidade de Columbia.

Integrava também a equipe do BCB de Francisco Gros, Gustavo Jorge Laboissière Loyola (1952), goianiense, filho do advogado Cleomar de Barros Loyola, que foi Procurador-geral do Estado e presidiu a Ordem dos Advogados do Brasil goiana, e sobrinho do desembargador Clenon de Barros Loyola, ex-presidente do Tribunal de Justiça de Goiânia ${ }^{529}$. Gustavo Loyola era formado em economia pela UNB e havia feito parte da turma de Werlang e Carlos Ivan na pós-graduação da FGV. Funcionário de carreira do BCB, Loyola permaneceu no Brasil e completou o doutorado, Preços relativos em um processo inflacionário (1988), na própria EPGE. No início do governo Itamar, substituiu Francisco Gros na presidência do Banco Central, mas permaneceu à frente da instituição apenas de novembro de 1992 à março de 1993, pois, como quase todos os membros da equipe econômica, teve atritos com o grupo de Itamar Franco e acabou caindo (DHBB, verbetes Gustavo Loyola e Armínio Fraga).

Pedro Bodin foi igualmente convidado a juntar-se à equipe de Gros, razão pela qual deixou seu posto na diretoria do BNDES. Para substituí-lo, Eduardo Modiano designou outra ex-aluna da EPGE, colega de Loyola e Carlos Ivan e então esposa de Werlang, Maria Silvia Bastos Marques (1956). Nascida em Bom Jesus de Itabapoana, no interior do Rio de Janeiro. Era a única mulher e a mais velha dentre os filhos do mais antigo médico da cidade, casado com uma pianista. Maria Silvia cursou o ensino básico em colégios públicos de Bom Jesus de Itabapoana e enfrentou o pai mudando-se para a casa de uma tia, na capital, para cursar o ensino superior. Ingressou na faculdade de administração da Universidade Estadual do Rio de Janeiro (UERJ). Pouco depois,

\footnotetext{
${ }^{529}$ Ver: http://www.sgc.goias.gov.br/upload/links/arq_164_BoletimAInformativoAnAA14.pdf. Consultado em 26/04/2016.
} 
transferiu-se para a EBAP-FGV, onde foi aluna de diversos alunos e professores da EPGE. Por influência deles, deu sequência aos estudos de economia naquela escola. Relata que, tendo feito administração, e não economia ou engenharia, e estudado no interior, e não nos grandes colégios cariocas, como seus colegas, tinha grandes dificuldades, especialmente com a matemática, que procurou superar com muito estudo e aulas complementares no IMPA. Em 1982, Maria Silvia defendeu na EPGE o mestrado Moeda e inflação: a questão da causalidade e, em 1987, o doutorado Inflação e Política Macroeconômica pós $1^{\circ}$ Choque do Petróleo (MARQUES, 2008, pp. 27-28 43; Maria Silvia Bastos Marques in: ALBERTI et al., 2002, pp. 249-250; MAGALHÃES, 2015).

Ao final do doutorado, Maria Silvia passou a trabalhar na própria FGV, no Centro de Estudos Monetários e de Economia Internacional que havia sido criado por Lemgruber em 1979. O Centro era dirigido, desde 1982, por Luiz Aranha Corrêa do Lago (1950), filho do diplomata Antônio Correa do Lago e neto, por parte de mãe, do Ministro da Fazenda e diplomata Osvaldo Aranha e, por parte de pai, do major e adido militar do Brasil na Bélgica Manoel Corrêa do Lago (DHBB, verbete Antônio Correa do Lago). Professor com graduação na UFRJ, mestrado em Duke, na Inglaterra, e o doutorado The transition from slave to free labor in agriculture in the Southern and coffee regions of Brazil : a global and theoretical approach and regional case studies (1978) em Harvard, Aranha foi diretor do Banco Central entre 1987 e 1988 e lecionou na PUC-RJ e na FGV-RJ530, conseguindo atrair para o centro pesquisadores de ambas. Maria Silvia atuou no Centro de 1982 a 1989 e conta que:

foi uma coisa muito importante para a minha formação, era um centro pequeno, de excelentes profissionais, eu entrei substituindo Roberto Rezende Rocha que foi para o FMI nessa época, o Gustavo Franco estava lá, o Paulo Nogueira Batista, o próprio Luís [Corrêa do Lago], pessoas realmente excelentes e a gente trabalhava em política econômica aplicada, então trabalhava muito com questão de inflação, déficit fiscal, acordos com o FMI, e eu fiz muitos papers nessa ocasião com o Luís, com o Paulo. Aí travei conhecimento, através principalmente do Paulo e do Luís, com a PUC (MARQUES, 2008, p. 44).

Ela explica que:

O Paulo Nogueira Batista era da Fundação, do Centro de Estudos Monetários, e tinha uma ligação com a PUC, com o Bacha e as pessoas de lá. Então, através do Paulo eu conheci o Bacha. Depois, veio trabalhar com a gente, no Centro de Estudos Monetários, a Isabel Modiano, na época era casada com o Modiano, hoje não é mais. Mas através dela eu conheci o Modiano e fiquei muito amiga dele. Fiz esse livro com o Bacha e fiquei muito amiga dele, conheci o Dionísio.

\footnotetext{
${ }^{530}$ Ver: http://lattes.cnpq.br/9371330484171711. Consultado em 26/04/2016.
} 
Aí, fui conhecendo as pessoas e a minha cabeça era muito parecida com a deles. Então, eu sempre fui muito dividida [risos] (MARQUES, 2008, p. 44, pp. 28-29).

Foi Modiano quem apresentou Maria Silvia e Werlang a Antônio Kandir, que assumiu a Secretaria de Política Econômica do Ministério da Economia e o IPEA no governo Collor. Ela conta que "Kandir convidou o Sergio para ser coordenador de política monetária e eu, coordenadora de política externa. Eu não queria ir, queria a vida acadêmica. Sergio quis. Estávamos casados fazia pouco mais de um ano e fomos os dois. Ele ficou três meses e eu só saí quando Collor deixou o governo" (Maria Silvia Bastos Marques apud MAGALHÃES, 2015). Com Kandir, Maria Silvia trabalhou "um ano e dois meses na negociação da dívida externa e nos acordos com o FMI. Em abril de 1991, transferiu-se do Ministério para o BNDES para trabalhar, primeiramente como assessora do Modiano, depois como diretora, tendo coordenado o grupo que regulamentou as moedas que poderiam ser utilizadas nos leilões de privatização e participado das equipes responsáveis por algumas das privatizações que estavam sendo preparadas (MARQUES, 2008, p. 44, pp. 6-7).

Quando Persio Arida assumiu a direção do BNDES, pela segunda vez, a casa teve uma mulher na diretoria, a colega de Armínio de Santo Inácio e PUC-RJ, Elena Landau. Após concluir o mestrado, Elena foi para o MIT, onde estudaram seus dois orientadores, José Marcio Camargo e André Lara Resende. Lá foi contemporânea de Pedro Luiz Bodin Moraes que, como ela, estudou no Santo Inácio e fez graduação e mestrado na economia da PUC-RJ. Landau era amiga dos tempos de faculdade de matemática da esposa dele, Suzana, e conviveram bastante no exterior. Elena explica porque não se adaptou ao MIT da seguinte maneira:

A gente estudava no mestrado como combater a inflação, como isso, como aquilo... Não tinha administração, eu nunca tive matemática financeira, era opcional, então eu não sabia nem calcular juro composto. Não me interessava isso. Então era o negócio do policy making mesmo. Public policy. Eu acho que foi o meu erro no doutorado é que eu deveria ter ido fazer a John Kennedy, por exemplo, e fui fazer MIT. Odiei com todas as forças [risos]. Era muito mais puro. Eu peguei o início da econometria. Esse time series. Eu achava aquilo um negócio pavoroso de chato, sem sentido [...]. O que é que eu estou fazendo aqui? Eu quero mudar o Brasil. Com time series eu não vou fazer nada [...]. Eu devia ter feito uma coisa, uma coisa mais de policy, de accountability, transparência, de organização e não ficar em time series, mas era um movimento da PUC natural. As pessoas que chegavam mandavam outras... era uma coisa, assim, de ciclo. Todo mundo adorava, tanto que, quando eu voltei, foi um choque. Ninguém me arranjou emprego no Rio [...], porque eles queriam que eu passasse fome aqui para voltar para o MIT [risos]. Foi declarada essa... Você vai voltar. A gente não 
vai te ajudar a ficar. Até que ficou claro que eu não ia voltar. Aí eu fui para o IPEA (Entrevista de Elena Landau à autora, 2012).

Depois de dois anos no IPEA, Elena trabalhou com Eduardo Modiano e Chico Lopes na consultoria Macrométrica e atuou no departamento de economia da Confederação Nacional de Indústrias. Em 1992, Edmar Bacha, que havia sido seu professor na PUC e tornara-se amigo, ligou para Elena: o presidente do PSDB, Tasso Jereissati, buscava um assessor econômico, porque a maior parte da assessoria econômica do partido ficava com o Serra, e ele precisava de alguém diretamente ligado a ele. Elena explica que, na assessoria, vivenciou

\begin{abstract}
todo o processo de impeachment do Collor, toda a negociação para entrar no governo, aí que eu vi como eu gostava de política. Eu adorava política. Aquilo para mim era uma cachaça. E o Tasso tinha uma coisa muito especial, ele me levava junto. Tinha reunião da executiva, eu ia junto. Tỉnha uma reunião na casa do senador, eu ia junto. Tinha uma reunião para decidir se a gente ia participar do governo, das questões econômicas com o Edmar [...]. Até que o Fernando Henrique acorda em Nova York ministro da Fazenda. [...]. Aí o Tasso pega o telefone e fala assim para mim: Elena, eu não sei se você já leu - naquela época não tinha internet - mas o Fernando Henrique é o novo Ministro da Fazenda. Sendo o Fernando Henrique o novo Ministro da Fazenda, todo o projeto do governo agora é fazer o Fernando Henrique dar certo. A gente não tem mais nenhum outro projeto. Eu não sou candidato, não tenho programa de governo... desmonta o escritório, pega a mala, vai para Brasília e faça o que o Fernando Henrique quiser que você faça (Entrevista de Elena Landau à autora, 2012).
\end{abstract}

Elena passou, então, a trabalhar com Edmar Bacha na assessoria de FHC. Ela trabalhava do Rio, interagindo diretamente com Edmar, que ia e vinha de Brasília. Este arranjo durou da nomeação de Cardoso para o ministério, em meados de maio de 1993, até a queda de Delben Leite e nomeação de Arida para o BNDES em setembro. Persio já havia perguntado a Elena se, caso assumisse o BNDES, ela faria parte de sua equipe no Banco. Tal qual Maria Silvia, Elena começou como assessora do presidente e transformou-se em diretora, ocupando-se especialmente da desestatização. Persio havia decidido centralizar a privatização em uma só diretoria que reuniria todas as operações da área, antes dispersas em diversas superintendências. Durante os anos 1980 e início dos 1990, Licínio Velasco e Sergio Zendron haviam centralizado as operações de privatização na BNDESPAR. Persio havia pensado em Velasco para o posto, mas o Ministro Alexis Stepanenko, que já havia derrubado Zendron contra a vontade de Delben Leite, não queria que Licínio ficasse como responsável pela área, razão pela qual Elena acabou assumindo a desestatização, em janeiro de 1994. Além dela, a equipe de diretoria de 
Persio incluía Régis Bonelli, também professor da PUC-RJ, à época casado com Elena, que como ela, até ser nomeado para o BNDES, havia trabalhado com Edmar na assessoria de FHC (Entrevista de Elena Landau à autora, 2012; Entrevista de Regis Bonelli à autora, 2012).

Os outros três diretores eram funcionários de carreira da BNDES, dois deles mantidos da diretoria anterior. Um era José Mauro Mettrau Carneiro da Cunha. Segundo ele, quando Persio Arida entrou, "eu já estava ficando meio escolado, porque trocava presidente e eu não saía. Eu também conhecia o Persio porque eu já estava como diretor há algum tempo e o pessoal ligado ao Modiano também conhecia bastante o Persio. A origem é o negócio da PUC-RJ. Então o Persio me confirmou lá, sem problema nenhum” (Entrevista de José Mauro Carneiro da Cunha à autora, 2012). O outro era Luiz Orenstein, que havia sido designado para substituir Zendron. Orenstein explica que só conheceu Persio no BNDES, mas que tiveram imediata afinidade, que dura até hoje (Entrevista de Luiz Orenstein à autora, 2012). Além deles, integrava a diretoria José Henrique Carneiro da Cunha Couceiro, engenheiro que era até então superintendente do Banco $^{531}$.

Arida explica que sua gestão conduziu um projeto de modernização balizado pelo lema segundo o qual "um banco de desenvolvimento tinha no adjetivo sua finalidade mas no substantivo sua essência, que um banco de desenvolvimento deveria ser antes de mais nada gerido como banco, com os rigores e cuidados que toda instituição financeira deve ter" (ARIDA, 1995, [DVD]). Até então, diz ele, no banco "se o projeto é bom para o país, nós vamos financiá-lo. Eu introduzi no Banco a ótica bancária. Ok, eu vou financiar, desde que tenha garantia suficiente, que dê retorno, que quem pediu o projeto também esteja correndo risco. Então falava, 'eu não vou financiar cem por cento de um projeto'. 'Eu ponho 70\%, você põe 30\% do seu dinheiro e eu quero o seu aval'." (Entrevista de Persio Arida à autora, 2012).

Sob o princípio de que "a coisa pública deve ser gerida com os mesmos princípios de eficiência que valem para o setor privado” (BNDES, 1993; BNDES, 1994),

531 Ver: http://memoria.bn.br/DocReader/DocReader.aspx?bib=029033 16\&PagFis=40112. Consultado em 27/04/2016. José Henrique Couceiro era filho do médico e dirigente do Conselho Nacional de Pesquisas (CNPQ), Antônio Moreira Couceiro e de Maria Violeta Carneiro da Cunha, filha do industrial e ex-governador do Pernambuco José Henrique Carneiro da Cunha. Estudou no Colégio Santo Inácio, cursou engenharia no Rio de Janeiro, fez carreira no BNDES e foi companheiro de Mariza Giannini, diretora do Banco em 2002.

Ver: http://memoria.bn.br/DocReader/DocReader.aspx?bib=029033 16\&PagFis=40112,

https://www.digesto.com.br/\#acordaoExpandir/84985. Consultados em 27/04/2016 e 07/05/2016. 
críamos, logo na partida, o comité de crédito, filtro básico que precede o enquadramento e a discussão de toda e qualquer operação dentro do banco, tornando o modo de operação do BNDES similar àquele consagrado na experiência dos bancos privados. Mudamos o foco da análise do projeto para a empresa, ou grupo ao qual a empresa está subordinada. Criamos uma classificação de riscos de crédito que foi seguida rigidamente. Inovamos ao considerar o risco envolvido nas posições acionárias. Cobramos todo e qualquer crédito inadimplente, analisamos insucessos no passado, demos enfim todos os passos cruciais para a sedimentação de uma cultura de crédito532 (ARIDA, 1995, [DVD]).

Persio explica que essa agenda "gerou muito atrito, porque até as pessoas entenderem, elas achavam que eu era contra o Banco, que estava limitando o Banco, travando o Banco" (Entrevista de Persio Arida à autora, 2012). Além disso, deram sequência à reforma administrativa interna dos anos anteriores, com redução do número de cargos (Entrevista de Elena Landau à autora, 2012), o que usualmente gera conflitos. Externamente, Persio também declara ter encontrado resistências de empresários e políticos, ao "negar pedidos de financiamento vindos de setores influentes, muitas vezes cheios de mérito social, mas que se chocavam com os preceitos da boa análise de crédito" (ARIDA, 1995, [DVD]). Outra mudança associada à regulação da concessão de crédito foi a introdução da Taxa de Juros de Longo Prazo (TJLP), que seria reduzida e estável, mecanismo concebido por Arida para proteger os empréstimos do Banco das oscilações da taxa de juros observadas em um cenário de instabilidade econômica, no qual a elevação da taxa de juros seria um dos mecanismos adotados no programa de combate à inflação desenhado pela administração por ele integrada ${ }^{533}$.

A ideia de Persio, explica Orenstein, era justificar "a existência do Banco nas falhas de mercado", ou seja, "o Persio queria que o Banco saísse do mercado para onde o mercado não funciona” (Entrevista de Luiz Orenstein à autora, 2012). Dentre os projetos que geram externalidades, a infraestrutura é prioritária. Além dela, foram prioridades do período: "a reestruturação da indústria, de modo a adequá-la a um maior grau de competição doméstica e internacional”, “a modernização do setor agropecuário,

\footnotetext{
${ }^{532}$ No período "o lucro do Banco, após impostos, subiu de US\$ 70 milhões em 1993 para aproximadamente US\$ $600 \mathrm{em}$ 1994, ano que o BNDES pagará impostos equivalentes a US\$ 315 milhões. Portanto o lucro do Banco, antes dos impostos, ascende neste exercício a mais de US\$ 900 milhões, o BNDES está hoje altamente capitalizado e inteiramente provisionado". Parte desse lucro adveio da venda "de 350 milhões de reais em participações acionárias em 1994" (BNDES, 1994; ARIDA, 1995, [DVD]).

${ }_{533}$ Ver: http://www2.senado.leg.br/bdsf/bitstream/handle/id/448525/noticia.htm? sequence=1. Consultado em $10 / 05 / 2016$.
} 
privilegiando a incorporação e difusão de novos conhecimentos tecnológicos" e "a conservação do meio ambiente” (BNDES, 1994, p. 19).

De 1979 a 1985, o percentual da alocação de recursos destinado à indústria caiu de 64\% a 41\% dos desembolsos. No primeiro governo da Nova República, os investimentos em indústria voltam a crescer, recuperando o nível do final dos anos 1970. Em 1990, atinge-se o pico de 74\% dos desembolsos dirigidos à indústria. Ao final de 1990, há contínuo declínio, acentuado durante o governo Collor, quando o percentual vai, em dois anos, de $74 \%$ a 49\%. O ritmo da derrocada reduz-se durante o governo Itamar Franco, mas é contínua, chegando a 41\% no final de 1994, momento em que começa a crescer novamente ${ }^{534}$. Em contrapartida, no início dos anos 1990, cresce tanto o percentual destinado à agricultura quanto da infraestrutura (Gráfico V). Os desembolsos do Banco no período são coerentes com as diretrizes anunciadas, à exceção do aumento da competitividade que, embora repetidamente enfatizada, foi alvo de poucas políticas ${ }^{535}$ e o tema sequer é mencionado nas entrevistas dos diretores daquela gestão.

Simultaneamente, deu-se continuidade à gestão do Programa Nacional de Desestatização, tendo sido vendidas outras 11 empresas durante a gestão de Arida, atividade fortemente enfatizada nos relatórios administrativos do período, por fazer parte das medidas consideradas necessárias para transformar a estrutura das finanças públicas e tornar viável o processo de ajuste macroeconômico e estabilização monetária liderado pelo Ministério da Fazenda (DINIZ, 2004, pp. 117-118 ARIDA, 1993, [DVD]).

Como visto FHC mantinha na Fazenda duas equipes trabalhando em paralelo. No primeiro front, Edmar Bacha, secundado por Clóvis Carvalho, Winston Fritsch e Gustavo Franco, conduzia o processo de ajuste estrutural das contas do Estado, batizado de Programa de Ação Imediata (PAI). Os rascunhos preparados por essa equipe foram levados a José Serra e seu assessor Martus Tavares que detalharam as medidas de

\footnotetext{
${ }^{534}$ Cabe ressaltar que os desembolsos correspondem sempre a aprovações que foram feitas em momentos anteriores, ou seja, os efeitos das mudanças nas gestões tem um tempo de maturação até começar a aparecer nos gastos.

${ }_{535}$ Por exemplo, em novembro de 1994 criou-se um "cadastro para fabricantes de máquinas e equipamentos que tem o certificado ISO 9001/9002 e que investem em capacitação tecnológica. Os fabricantes aí cadastrados passam a dispor de melhores condições financeiras para vender seus produtos com financiamento da FINAME. E, para os compradores de seus produtos foi aumentado o nível de participação da FINAME no valor total do investimento. Uma modificação nas Políticas Operacionais do Banco permitiu que os projetos de capacitação tecnológica e de qualidade e produtividade no valor máximo de R\$ 3 milhões, possam ser analisados e aprovados por sua rede de agentes financeiros, através da linha de crédito BNDES automático, o que permite uma tramitação mais rápida e simplificada da operação. $\mathrm{E}$ as compras de equipamentos em concorrência internacional realizadas no Brasil passam também a dispor de melhores condições financeiras capazes de competir com as oferecidas internacionalmente" (BNDES, 1994, p. 22).
} 
implementação. O programa, lançado na metade de junho de 1993, reorganizava o orçamento, os tributos, os gastos, as tarifas do setor público, a relação do Governo Federal com os estados e municípios, com as estatais, a relação entre os bancos públicos, e conceber medidas para evitar sonegação, sendo que as privatizações, conduzidas pelo BNDES, também constavam entre as medidas previstas no Programa (PRADO, 2005, pp. 64-75; CASTRO, 1999b, p. 6; CARDOSO, 2006c, pp. 144-147).

Ainda que o PAI não atacasse a inflação, suas medidas eram vistas como essenciais para a estabilização pois evitariam desajustes posteriores e as tendências à retomada dos gastos e renascimento da inflação observadas no Plano Cruzado e em programas econômicos subsequentes. No Cruzado, diversas escolhas foram feitas em função da popularidade que trariam ao governo Sarney e ao PMDB. No caso do Plano Real, uma vantagem era ser conduzido diretamente por um híbrido de técnico e político que, tendo ocupado posto de destaque no legislativo, circulava nas duas casas em busca de apoio para as medidas que pretendia implementar. Nenhum dos Cruzados conseguiria ter feito o mesmo. Aprovado os cortes no orçamento de 1994 e estando as medidas do PAI em curso, a equipe de Bacha partiu para um segundo ataque, a aprovação de um Fundo "Social" de Emergência - FHC revela que o Social no nome foi só um artifício para facilitar a aprovação no congresso -, que liberava 15\% do orçamento que seria retido e manuseado diretamente por eles, reduzindo gastos que não considerassem essenciais (CARDOSO, 2006c, 152-153; CASTRO, 1999b, pp. 9-12).

Depois de conversar longamente com seu amigo Luiz Carlos Bresser Pereira, que lhe relatou os desafios e dificuldades dos tempos do plano Bresser, Fernando Henrique procurou André Lara Resende liderava a segunda equipe, responsável por conceber um plano de estabilização a ser implementado na sequência do PAI. André explica que propôs ao presidente que Pedro Malan, que continuava como negociador da dívida externa, e Armínio Fraga, que trabalhava no setor financeiro nos EUA, participassem da troca de ideias sobre o futuro plano. Fernando Henrique consentiu. Disse que poderiam falar com Bacha, se necessário, mas não deveriam interferir no trabalho conduzido pela outra equipe. Em meados de agosto, Lara Resende e Malan tinham um encontro marcado na casa de FHC para apresentar um primeiro esboço do que poderia ser o novo plano de estabilização. A reunião, previamente agendada, coincidiu com a demissão do presidente do Banco Central, Paulo César Ximenes, funcionário de carreira do BCB, que estava à 
frente da instituição desde março de 1993. Ximenes foi mais um a cair em um episódio de reação tempestuosa de Itamar, no caso, referente a uma disputa em torno da circulação de cheques pré-datados ${ }^{536}$. Não era a primeira vez que Itamar atritava com ele. Culpava-o pelos juros altos e pela lentidão das mudanças, o mesmo que ocorrera com todos os antecessores na Fazenda e no Banco Central (PRADO, 2005, pp. 82-83, 127-130; Entrevista de André Lara Resende à autora, 2012; CARDOSO, 2006c, pp. 169-173).

Resende conta que dirigiram-se à casa de Fernando Henrique, em Brasília, como combinado.

\begin{abstract}
Chegamos antes dele e o Pedro Malan, de repente, me fala: "você sabe que você vai ter que ser presidente do Banco Central". Eu falei: "vai ser você" [risos]. E aí, bom, nessa discussão que o Fernando Henrique disse: "olha, tem que ser um de vocês dois de qualquer maneira". Eu disse: "oh eu não posso ir para o governo de jeito nenhum", tinha acabado de fazer de fazer o [Banco] Matrix, ainda uma fase assim de estruturação. Então eu falei: "eu não posso". Como a dívida eram só quatro meses pra terminar, então eu fico [...] formalmente como negociador da dívida, mas na prática eu estava fazendo o plano com Pedro Malan, ajudando, indo pra lá e pra cá (Entrevista de André Lara Resende à autora, 2012).
\end{abstract}

A equipe, que agora contava oficialmente com Resende, foi reforçada pela presença de Persio Arida que, conforme discutido, substituiu, em setembro, Delben Leite na presidência do BNDES. Com os dois de volta ao governo, a implementação de plano de estabilização derivado da proposta Larida (item 5.6) voltava à pauta, obviamente amadurecido pelas experiências prévias, brasileiras e de outros países que tentaram combater a inflação naquele período, e pelos estudos feitos pelos autores nos anos que separaram o Cruzado do Real. A regra número 1 abraçada pela equipe foi: nada de choques, já que o trauma do confisco do Plano Collor ainda rondava. A nova unidade de cálculo e depois a nova moeda corrente foram introduzidas aos poucos, sendo todos os passos da transição veiculados nos meios de comunicação (PRADO, 2005, p. 73).

Adotou-se uma combinação de três índices de preços ao consumidor, cujo valor seria próximo ao da Unidade de Renda Fiscal (UFIR), medida indexada empregada em contratos e no recolhimento de impostos. Com base nestes índices de preços estabeleceuse a Unidade Real de Valor (URV), que inicialmente seria apenas uma referência para os cálculos, exibida em paralelo aos valores em Cruzeiro. Durante o período de transição, a população teria a chance de visualizar o que ocorreria quando o Real fosse introduzido, conseguia ver a desvalorização do Cruzeiro face ao Real, ajustando previamente suas

\footnotetext{
${ }^{536}$ Ver: http://memoria.bn.br/DocReader/DocReader.aspx?bib=030015 11\&PagFis=94974 http://memoria.bn.br/DocReader/DocReader.aspx?bib=030015_11\&PagFis=95680 http://memoria.bn.br/DocReader/DocReader.aspx?bib=030015_11\&PagFis=95778. Consultados em 07/05/2016.
} 
expectativas. O intervalo entre a instalação da URV e a implantação do Real dava aos agentes econômicos tempo hábil para acertar seus preços antes da mudança para o Real, o que ajudou a evitar contaminação imediata na nova moeda, que passou a circular em julho de 1994 (CARDOSO, 2006c, pp. 174-180; PRADO, 2005, pp. 132-133; CASTRO, 1999b, p. 61-62).

Estava acordado o modo pelo qual atacariam a inércia inflacionária, havia um pacote de medidas para contenção dos gastos públicos, do déficit, um fundo de emergência e as privatizações. Entre as questões mais controversas, que se arrastaram pelos dois mandatos de FHC, estavam o câmbio e os juros. A equipe econômica avaliou diversas propostas, sem consenso. Fernando Henrique relata:

Gustavo Franco entendia ser necessário estabelecer metas mais rígidas para regular as emissões monetárias. Persio Arida acreditava ser difícil calcular a demanda monetária no momento em que a inflação caísse. Sem esquecer André Lara Resende, que namorava a ideia do currency board. Essas decisões foram sendo tomadas até às vésperas do lançamento da nova moeda, naquele $1^{\circ}$ de julho de 1994, quando eu já estava afastado do Ministério para ser candidato à Presidência da República [...]. Em matéria de política monetária e cambial o Plano Real estava longe de ser uma obra acabada. As consequências iriam se perceber logo no início de 1995, quando o governo tentou corrigir a inflação (CARDOSO, 2006c, pp. 180-181).

Começaram o primeiro mandato com juros elevados, para atrair capitais externos, e o Real estável em um valor próximo a 0,8 dólar. Dali em diante as principais batalhas econômicas internas seriam referentes ao quando, quanto e como desvalorizar o câmbio ${ }^{537}$.

FHC começa a narrativa das disputas referentes ao câmbio e aos juros dizendo que:

A crise financeira do México estourou doze dias antes, a 20 de dezembro de 1994. Isso tornava impossível a sugestão que me fora trazida por José Serra e Persio Arida, de pedir ao Presidente Itamar Franco que tomasse medidas de ajuste de câmbio para facilitar a ação do BC[B], como o presidente Sarney fizera às vésperas de transmitir o cargo ao Presidente Collor. Parecia claro que a taxa de

\footnotetext{
${ }^{537} \mathrm{O}$ câmbio fixo, ou âncora cambial, torna rígida a condução da política econômica, solidificando o programa e fornecendo um referencial estável para o realinhamento dos preços. No caso da âncora cambial, a referência são moedas externas. Para manter o valor estável em relação ao parâmetro escolhido, o governo fica obrigado a conter a expansão desordenada da moeda, neste sentido é uma medida coercitiva dirigida aos próprios governantes, que são obrigados a manter rígidos controles de emissões. "As principais funções atribuídas às ancoras são: a) dar credibilidade ao novo padrão monetário que está sendo introduzido; b) promover a coordenação das expectativas; c) forçar os agentes a abandonarem as práticas inflacionárias de formação de preços e rendas em geral. Neste último caso, ressalta-se que a âncora possui, no curto prazo, um caráter coercitivo - sobretudo se considerarmos o caso da âncora cambial com abertura. Espera-se, porém que a economia, após um determinado período, consiga passar de um estado de 'estabilidade administrada' imposto pelas âncoras, para um de estabilidade 'espontânea', em que as livres forças de mercado garantam preços no nível internacional” (CASTRO, 1999, pp. 103-104).
} 
câmbio a 82 centavos de real por dólar criaria problemas futuros para as exportações, encarecendo os produtos brasileiros. Mas interferir no câmbio quando o sistema financeiro internacional dava sinais de fadiga seria insensatez. Esse permanente pesadelo acompanhou o governo até janeiro de 1999, quando os mercados nos obrigaram a pedir a flutuação do câmbio [...]. $\mathrm{Na}$ impossibilidade de ajustar o câmbio antes de minha posse, o assunto voltou à tona logo em janeiro de 1995. Realizando reuniões com os ministros Pedro Malan, José Serra e Clóvis Carvalho e o presidente do BC[B], Persio Arida. Ampliamos os encontros para incorporar também José Roberto Mendonça de Barros, Edmar Bacha e também Gustavo Franco e Francisco Lopes, diretores do $\mathrm{BC}[\mathrm{B}]$ [...]. A maioria, eu inclusive, considerava que a valorização do câmbio chegara a um ponto impossível de manter. Gustavo era o mais resistente à mudança. Havia operado a casa de máquinas do BC[B] com competência na partida do Plano Real. Não fosse a apreciação do câmbio, dificilmente a nova moeda teria atravessado o Rubicão dos primeiros meses, quando maiores eram as pressões inflacionárias e os riscos do plano de perder credibilidade. Malan apoiava Gustavo. Se houvesse alteração de rumos, que fosse implementada de maneira lenta, gradual e segura. Serra, apreensivo com as repercussões da valorização cambial sobre a balança comercial e a indústria, sugeria puxar a taxa de câmbio, de uma só vez, para um degrau consideravelmente superior, e ali estacioná-la por um tempo. Persio compartilhava a preocupação de Serra com o nível do câmbio. Defendia, no entanto, não só uma engenharia rápida, mas a adoção de uma nova arquitetura cambial: um sistema de banda - espécie de faixa dentro de cujos limites mínimo e máximo se permitia que o valor do real flutuasse - que pudesse levar, em algum momento do futuro, à flutuação livre do câmbio. O piso e o teto da banda se ampliariam progressivamente, à semelhança do que se havia implementado em Israel e do que se estava fazendo no Chile [...]. Persio junto com Serra, batia na tecla de pedir uma decisão rápida para alcançar um nível mais confortável na relação real/dólar. Inicialmente eu simpatizava com a posição de Persio. Depois fiquei mais cauteloso (CARDOSO, 2006c, pp. 339340).

No início do governo Fernando Henrique, Persio Arida havia sido designado para a Presidência do Banco Central onde permaneceria 6 meses, saindo depois uma tentativa abortada de desvalorizar o câmbio ${ }^{538}$. Ao mudar para o $\mathrm{BCB}$, Arida acrescentara à diretoria pré-existente apenas seu colega de PUC-RJ, Chico Lopes. No BNDES, foi sucedido por seu também colega de PUC-RJ, Edmar Bacha, inicialmente convidado por FHC para o Ministério da Fazenda (CARDOSO, 2006c, p. 246).

Bacha manteve parte da diretoria de Persio. Regis Bonelli, que era amigo de muitos anos e já havia sido o braço direito de Edmar no IBGE no governo Sarney, permaneceu na direção. Elena, que manteve a diretoria de privatizações, declara que, com o professor Edmar, "tinha uma relação muito boa a vida inteira. E o Edmar tinha uma confiança

\footnotetext{
${ }^{538}$ Persio, então presidente do Banco Central, insistia em uma desvalorização que foi tentada no início de 1995 e atacada pelo mercado. Naqueles meses experimentou o desgaste de ter sido acusado de passar informações para amigos do setor privado, de sustentar longas disputas com o diretor do BCB, Gustavo Franco, na questão cambial, de travar batalhas com Mario Covas concernentes à intervenção no endividado Banespa, das querelas que teve com os ruralistas que queriam renegociar suas dívidas, dentre outros atritos que convergiram para que deixasse $\quad 0$ governo ma de $1995 . \quad$ Ver: http://memoria.bn.br/DocReader/DocReader.aspx?bib=030015_11\&PagFis=143354, consultado em 08/05/2016.
} 
absoluta comigo" (Entrevista de Elena Landau à autora, 2012). Além da convivência na PUC-RJ, Bacha e Elena haviam dividido responsabilidades na assessoria à Fazenda e na coordenação regional do PSDB (BACHA, 1995, [DVD]). O vice-Presidente José Mauro, também convidado a permanecer, descreve sua posição no Banco dizendo que:

Já conhecia quase todo mundo de PUC-RJ, de UFRJ, porque eu já estava há um tempão como diretor, e o BNDES é um negócio que te dá muita visibilidade e muito relacionamento [...]. Quando o Bacha entrou, eu continuei como vicepresidente porque ele já me conhecia. Ele me convidou porque eu conhecia muitas pessoas de dentro do Banco. Eu nunca tive nenhum acordo político. Nunca fui de partido nenhum, [não] militei, nada, nada. O que eu tinha era o conhecimento das pessoas de dentro do Banco. Eu convivia com as diferentes turmas que tinham no Banco, sem ter nenhum problema em nenhuma delas (Entrevista de José Mauro Carneiro da Cunha à autora, 2012).

Circular em todos os grupos do Banco era um grande trunfo, pois ajudava a operar a interface da diretoria com o corpo técnico. Para completar a equipe, Edmar e Regis entrevistam Helio Blak (1949), que não conheciam pessoalmente, mas fora bem recomendado. Geólogo formado na UFRJ com especialização em economia dos recursos minerais pela FGV-RJ, Blak havia trabalhado no Departamento Nacional de Produção Mineral (DNPM) e na empresa Tecnometal, consultoria que atendia o Ministério da Indústria e Comércio, antes de entrar na DoceGeo, empresa de pesquisas ligada à Vale do Rio Doce. Na Tecnometal, Blak foi colega de algumas pessoas que acabaram indo para o BNDES,

o José Henrique Couceiro, que faleceu, Adílson Drubscky, Wagner Bittencourt, que hoje é o ministro da aviação, Fernando Vivacqua. Esse pessoal todo acabou fazendo concurso, de alguma maneira acabou indo para o Banco. O Adílson tinha sido meu chefe na Tecnometal e virou chefe do departamento de mineração e metalurgia do Banco e um dia ele me, me perguntou se eu toparia ir para o Banco, trabalhar lá e tal. Eu já estava há uns 4 ou 5 anos na DoceGeo. Ele precisava ter alguém com uma formação mais próxima, porque o Banco não fazia concurso para geólogo [...]. Ele pediu uma autorização especial, se ele podia me requisitar [...]. Aí eu fui trabalhar no departamento de mineração e metalurgia [...] até, acho que 1984. Depois eu fui para o departamento de planejamento, porque nós fomos trabalhar em um plano estratégico da época. Um trabalho muito legal. $\mathrm{E}$ eu fui tocar essa parte exatamente de mineração e metalurgia, porque havia toda uma preocupação com a projeção da demanda, o que é que ia acontecer, se ia ter metal, matéria prima no caso, para suportar o crescimento. Fui trabalhar com o Júlio Mourão, que chefiava esse projeto. Até que [...] teve uma mudança qualquer na gestão lá e eles resolveram devolver todo mundo que era requisitado. Eu fui para a Vale de volta. Aí, o Marcio Fortes [...] virou presidente do Banco. O Júlio virou, se eu não me engano, superintendente geral e falou para o Márcio me requisitar de novo. Pediram lá na Vale e eu voltei para o Banco e fiquei até o início do Collor. Aí eu vim para a Vale de novo, com o [Francisco] Gros, que era muito meu amigo. Tinha trabalhado junto comigo no projeto Carajás. Eu pelo Banco, ele pela Vale. Ele me chamou para ser superintendente na Vale. Aí só voltei no Banco para ser diretor com o Bacha (Entrevista de Hélio Blak à autora, 2012). 
Tal qual José Mauro, Hélio funcionava como intermediário entre a diretoria e a casa, na qual havia trabalhado quase dez anos. Finalmente, Bacha diz em seu discurso de posse que "uma vez que Luiz Orenstein preferiu temporariamente prestar seus serviços ao setor financeiro privado, estamos propondo um 'swap' de valores equivalentes com esse mercado e dele trazendo Laura Domingues para a diretoria do Banco" (BACHA, 1995, [DVD]). Laura (1959), que fora sua aluna na graduação e no mestrado de economia da PUC-RJ, e havia redigido a dissertação Política de mercado aberto no Brasil e a experiência de 1984 (1986) sob a orientação de Dionísio Dias Carneiro, aceitou o desafio de deixar Banco da Bahia para assumir a diretoria de crédito do BNDES (Entrevista de Laura Passos Domingues à autora, 2012).

A continuidade entre Arida e Bacha não se restringia à permanência da maior parte dos altos quadros. Os discursos de posse e encerramento do período de Edmar Bacha na presidência do BNDES evidenciam a manutenção da linha de trabalho de seu antecessor. Como Persio, Bacha enquadra a atuação do Banco na luta pela estabilização econômica, na reforma das estruturas administrativas do Banco e na promoção da integração competitiva do país na economia mundial, objetivando a "minimização do custo Brasil", termo que passa a figurar no vocabulário. De acordo com ele,

o conceito de custo Brasil pode servir tanto à seleção de prioridades setoriais como à análise de projetos individuais. Num caso, trata-se de privilegiar aquelas atividades - como a privatização, infraestrutura e as exportações, que sabidamente geram aumentos generalizados de produtividade na economia, os quais não são necessariamente computados na rentabilidade direta de tais atividades. No caso de projetos individuais, o conceito de custo Brasil convida a que a análise focalize não só na rentabilidade direta dos empreendimentos, mas também as economias externas que deles se derivam. Ademais, o conceito de custo Brasil permite que se orientem os procedimentos operacionais do Banco, de forma a favorecer projetos cuja rentabilidade privada esteja sendo prejudicada pela existência de entraves externos à sua competitividade. Por exemplo, projetos com alta capacidade de geração de empregos podem estar sendo indevidamente penalizados no mercado devido ao excesso de encargos sociais que recaem sobre a contratação de mão-de-obra. O Banco, nesses casos, deveria ter uma dupla atuação: primeiro como banco de desenvolvimento, privilegiando a aprovação de tais projetos, através de uma apropriada análise de custos e benefícios sociais, condicionada a que sua rentabilidade privada seja positiva. Segundo, como braço financeiro da SEPLAN [Secretaria de Planejamento], desenvolvendo estudos e pesquisas para a eliminação dos entraves que se manifestem para a redução do custo Brasil em nível legal ou administrativo (BACHA, 1995, [DVD]).

A competitividade, nesta acepção, decorreria, não de investimentos dirigidos e incentivo à criação de setores tecnologicamente avançados e estruturação de cadeias produtivas integradas, como concebido no projeto de Integração Competitiva do BNDES 
e nas pesquisas elaboradas na FINEP. Priorizava-se agora a retirada de entraves à redução dos custos de produção, seja alterando a legislação, seja criando infraestrutura e ajudando as exportações, para orientar corretamente os investimentos. Nesse ponto, as gestões de 1994 e 1995 pouco diferem da linha de política industrial do governo Collor, preferindo agir na propulsão das exportações do que oferecer incentivos setoriais dirigidos. Desde a implantação do FINAMEX, em novembro de 1990, caminhava-se nessa direção ${ }^{539}$. Ao despedir-se, Bacha afirma que "em breve, estará o Banco, atendendo a solicitação do Ministro José Serra, apresentando proposta para uma considerável ampliação do escopo do FINAMEX, de forma a que dele possam beneficiar-se outros setores exportadores além da indústria de máquinas e equipamentos" (BACHA, 1995a, [DVD]; CATERMOL, 2005, pp. 5-6; COSTA, 2011, pp. 165-166).

Por fim, anuncia estar próxima a conclusão da etapa da privatização voltada à liquidação do setor produtivo estatal, cujo ápice seria a privatização da Companhia Vale do Rio Doce, realizada em maio de 1997. A segunda etapa do programa de desestatização, que compreendia a desestatização dos serviços públicos, teve início em julho de 1995 , com a venda da Espírito Santo Centrais Elétricas. Logo no início do governo FHC, empreenderam-se reformas constitucionais que acabavam com a discriminação em relação a empresas de capital estrangeiro e quebravam a exclusividade estatal na exploração das telecomunicações, na lavra do subsolo, além de transferir o monopólio da exploração, do refino e do transporte de petróleo e gás para a União que poderia, então, acabar com a exclusividade da Petrobrás, fazendo concessões a agentes privados. Simultaneamente, o governo começou a negociar a regulamentação da concessão dos serviços públicos nas áreas de transportes e energia (SALLUM, 1999, p. 32; BNDES, 2002, p. 115).

Nesse momento, o Banco começou a preparar as privatizações dos sistemas de eletricidade, transportes e telecomunicações, que seriam alvo de numerosos leilões nos anos seguintes. O relatório de 1995 explica "essa nova fase apresenta maiores complexidades do que a anterior - de venda de empresas produtivas -, uma vez que, ao transferir para o setor privado a operação de serviços públicos, o governo deve passar a

\footnotetext{
${ }^{539}$ No início o Banco oferecia financiamento de tipo pré-embarque. Fornecia às empresas exportadoras o capital de giro para compra da matéria prima e remuneração da força de trabalho necessária à produção. No final de 1993, o Banco passou a disponibilizar, igualmente, financiamentos de tipo pós-embarque, ou seja, adiantamento de recursos para que a empresa possa importar sem comprometer o caixa operacional da companhia (CATERMOL, 2005, pp. 5-6).
} 
desempenhar suas reais funções de regular e fiscalizar essa atividade" (BNDES, 1995, p. 23). Com a chegada de Luiz Carlos Mendonça de Barros à presidência do BNDES, em novembro de 1995, o Banco assumiu ainda outra tarefa na área de desestatizações: auxiliar os Estados e municípios da Federação a preparar as privatizações de suas próprias companhias e a sanear suas finanças. Para tanto, o Banco compraria "ações de empresas estaduais que serão privatizadas, concedendo, assim, adiantamentos aos governos estaduais, referentes à venda futura destas mesmas ações. Com este apoio, o BNDES contribui para amenizar o problema das finanças dos estados e para promover a recuperação da sua capacidade de seus investimentos” (BNDES, 1995, p. 20).

\subsection{O BNDES entre neoliberais e liberais-desenvolvimentistas}

Ao transmitir o cargo de presidente do Banco para Mendonça de Barros (item 3.2), no fim de $1995^{540}$, Bacha exalta a competência técnica do sucessor: "com sua formação de engenheiro, vocação de empresário e tarimba de financista, Luiz Carlos também traz para o Banco os insumos técnicos necessários para enfrentar os desafios da nova fase da privatização e da concessão de serviços públicos, bem como os da reestruturação industrial” (BACHA, 1995a, [DVD]). Mendonça de Barros é descrito por diversos entrevistados como um "operador", uma "pessoa dinâmica”, que "sacudiu o Banco", que "inventou produto novo, inventou função nova para o Banco", que "trouxe um lado financeiro", sendo contrastado com o caráter acadêmico dos diretores que o antecederam, pois, ainda que Luiz Carlos lecionasse e tivesse contato com a universidade, não era um acadêmico profissional como seu irmão José Roberto ou como os presidentes que o antecederam no BNDES, que eram economistas com mestrado, doutorado e experiência em pesquisa.

Depois de ter atuado no Banco Central durante a elaboração e implementação do Plano Cruzado, Luiz Carlos retomou suas atividades no mercado financeiro. Antes de trabalhar na equipe de Fernão Bracher no BCB, havia passado pelo Investbanco, pela corretora Patente e pelo Planibanc. Ao deixar o governo, Mendonça retomou suas atividades no Planibanc e passou a dar aulas de economia monetária e finanças públicas

\footnotetext{
540 Ver: http://memoria.bn.br/DocReader/DocReader.aspx?bib=154083_05\&PagFis=33365. Consultado em $10 / 05 / 2016$.
} 
na UNICAMP, a convite dos professores João Manuel Cardoso de Mello e Luiz Gonzaga Belluzzo, dos quais tornara-se amigo na época em que trabalhavam todos na equipe econômica do Cruzado.

Quando deixou o Planibanc, Mendonça de Barros procurou outro amigo dos tempos de governo, André Lara Resende, que trabalhara com ele no BCB e que também havia retornado ao setor financeiro depois de deixar a equipe econômica. Inicialmente, Lara Resende voltou para o Banco Garantia. Lá permaneceu de 1987 até 1989. Na sequência trabalhou com os Moreira Salles. Seu pai havia sido amigo de Walther Moreira Salles e André e sua primeira esposa eram amigos de vários membros da família. Concomitantemente ao trabalho como vice-presidente do Unibanco, foi diretorpresidente da Companhia Siderúrgica de Tubarão. André conta que saiu "do Unibanco, porque eu queria fazer um banco próprio [...], um negócio novo, pequeno. Aí eu tentei costurar com uma série de pessoas, por coincidência, o Luiz Carlos Mendonça de Barros me procurou e disse: 'olha, eu estou saindo da Planibanc e estou numa fase da vida que tenho duas alternativas: ou eu me aposento, ou eu faço [...] uma instituição financeira, um banco'”, ao que André respondeu dizendo que pensava fazer o mesmo. Reuniram três outros sócios, Antonio Boralli, que tinha sido presidente do Citibank, Roberto Moritz, que trabalhava para Joseph Safra, e Antônio Carlos Freitas Valles, com quem André havia trabalhado no Garantia. Juntos montaram o Banco Matrix, no início de 1993, imediatamente antes de FHC ser convidado para o Ministério da Fazenda (Entrevista de André Lara Resende à autora, 2012; Entrevista de Luiz Carlos Mendonça de Barros à autora, 2012).

A ida de Fernando Henrique para a Fazenda ocorreu, assim, em momento no qual eles estavam profundamente envolvidos na construção da própria instituição financeira, que era pequena e tinha poucos associados. Como visto, quando Paulo César Ximenes deixou o Banco Central em agosto de 1993, Lara Resende foi confrontado com nova solicitação do Ministro, agora para integrar diretamente a equipe econômica. Aceitou dar continuidade à negociação da dívida externa que estava sendo feita por Pedro Malan, justamente porque esta era uma tarefa por tempo limitado que permitiria seu rápido retorno ao Matrix (PRADO, 2005, pp. 69, 83, 130) Mendonça viveu situação semelhante no início do governo de FHC:

Quando o presidente FHC montou o governo, o Sérgio Motta veio falar comigo da possibilidade de eu participar. Acontece que eu e o André (Lara Resende) 
tínhamos fundado o Matrix havia muito pouco tempo. Achamos que seria uma falta de responsabilidade com os outros sócios abandonar tudo. Por isso não participei da equipe inicial. No fim de 1995, o Edmar Bacha tinha recebido um convite para trabalhar no setor privado e queria sair. Achei que já havia condições de sair do banco. Aceitei, mas sabia que havia um certo conflito de idéias no ar. E fui para o BNDES, convidado pelo Serra e pressionado muito pelo Sérgio Motta, amigo de 30 anos (BARROS, 1999).

Sergio Motta e José Serra eram companheiros próximos de Mendonça de Barros desde os tempos de engenharia e militância estudantil na Ação Popular (item 3.2). Sergio Motta, coordenador-geral de campanhas de FHC e um dos mais fortes sustentáculos políticos do grupo, foi designado para o Ministério das Comunicações e preparava o processo de privatização das telecomunicações que seria executado pelo BNDES. Nada melhor do que ter seu antigo sócio, amigo e aliado na direção do Banco para implementar seus planos.

José Serra, por sua vez, foi designado para o Ministério do Planejamento, ao qual o BNDES estava subordinado. FHC conta que "os futuros membros do grupo econômico e, principalmente, Sergio Motta, que gozava de grande proximidade e prestigio junto a mim, considerando o peso técnico e político de Serra, pressionaram para que eu o colocasse no Planejamento. Relutei um pouco", porque Serra era "relativamente crítico de algumas das políticas que vinham sendo postas em prática". Além disso, achava que seria problemático "ter, à frente da equipe econômica, alguém que não participara do trabalho de concepção e implantação do Plano Real". Finalmente, temia "choques de pontos de vista e temperamento, dessa feita entre o time da Fazenda e a equipe do Planejamento. Preferia Paulo Renato, mas avaliei que Serra tinha como ninguém os contatos e o pulso necessário para negociar o Orçamento como Congresso, a que pertencera como deputado e para o qual fora eleito senador (CARDOSO, 2006c, pp. 246-248).

O grupo da Ação Popular (AP) ocupava alguns outros espaços no governo. Clóvis Carvalho, o chefe da casa civil, também era amigo deles desde a militância na universidade. O irmão de Luiz Carlos Mendonça de Barros, José Roberto, já estava no governo. Foi secretário de política econômica do Ministério da Fazenda e depois secretário da Câmara de Comércio Exterior. José Roberto contava, em sua equipe, com Lidia Goldenstein e Monica Baer, duas doutoras pela UNICAMP que haviam integrado o grupo de estudos econômicos de Serra no CEBRAP. Egydio Bianchi e José Carlos Seixas, dos amigos mais antigos de $\mathrm{AP}$, estavam, respectivamente, nos correios, subordinado às 
comunicações, e na secretaria executiva do Ministério da Saúde. Paulo Renato Costa Souza assumiu o Ministério da Educação. Vilmar Faria era um dos principais assessores do Presidente desde a elaboração do programa de governo, sendo, durante o mandato, especialmente encarregado das políticas sociais. Além dos quadros propriamente conectados à AP, são frequentemente listados nesse grupo o paulistano Andrea Calabi, secretário geral do Ministério do Planejamento e presidente do IPEA sob Serra, depois presidente do Banco do Brasil e finalmente do BNDES. E Luiz Carlos Bresser Pereira, paulista, ligado aos católicos da geração anterior, que foi tesoureiro das campanhas de FHC, ministro da Reforma do Estado e ministro da Ciência e Tecnologia (PRATA et al., 1999, pp. 68-69).

$\mathrm{Na}$ época em que Mendonça de Barros aceitou a presidência do BNDES, seu grupo paulista, que remontava à AP, e que pode ser caracterizado como "liberaldesenvolvimentista", já confrontava a política econômica conduzida a partir do Ministério da Fazenda de Pedro Malan e do Banco Central, ainda não presidido por Gustavo Franco, mas fortemente influenciado por ele. Esta assumia traços "neoliberais", no sentido de serem mais radicalmente favoráveis à liberdade dos mercados. Ainda que houvesse numerosos pontos de convergência entre os quadros que geriam a economia no primeiro governo FHC - a premência atribuída ao ajuste fiscal, à redução da atuação do Estado na economia e aumento de seu investimento nas políticas sociais, à privatização de companhias públicas e à abertura da economia que deveria integrar-se globalmente - os procedimentos e a velocidade das alterações preconizadas por cada um dos grupos eram distintos:

Para a corrente neoliberal dominante a prioridade era a estabilização rápida dos preços por meio das seguintes medidas complementares: a) manutenção do câmbio sobrevalorizado frente ao dólar e outras moedas, de forma a estabilizar os preços internos e pressioná-los para baixo pelo estímulo à concorrência derivada do barateamento das importações; b) preservação e, se possível, ampliação, da "abertura comercial" para reforçar o papel do câmbio apreciado na redução dos preços das importações; c) o barateamento das divisas e a abertura comercial permitiriam a renovação rápida do parque industrial instalado e maior competitividade nas exportações; d) política de juros altos, tanto para atrair capital estrangeiro - que mantivesse um bom nível de reservas cambiais e financiasse o déficit nas transações do Brasil com o exterior, como para reduzir o nível de atividade econômica interna - evitando assim que o crescimento das importações provocasse maior desequilíbrio nas contas externas; e) realização de um ajuste fiscal progressivo, de médio prazo, baseado na recuperação da carga tributária, no controle progressivo de gastos públicos e em reformas estruturais (previdência, administrativa e tributária) que equilibrassem "em definitivo" as contas públicas; f) não oferecer estímulos diretos a atividades econômicas específicas, o que significa condenar as políticas industriais setoriais e, quando 
muito, permitir estímulos horizontais à atividade econômica - exportações, pequenas empresas, etc., devendo o Estado concentrar-se na preservação da concorrência, através da regulação e fiscalização das atividades produtivas, principalmente dos serviços públicos (mas não estatais) (SALLUM, 1999, p. 33).

Quanto ao liberal-desenvolvimentismo, por sua vez,

o velho desenvolvimentismo dos anos 50 a 70 renasce sob predomínio liberal. Nessa versão de liberalismo também dá-se prioridade à estabilização monetária, mas a urgência com que ela é perseguida aparece condicionada aos efeitos potenciais destrutivos que as políticas anti-inflacionárias ocasionarão no sistema produtivo. Por isso, combate-se o radicalismo dos fundamentalistas, exigindo-se um câmbio não apreciado, para evitar déficits na balança de transações correntes (comercial e de serviços), e juros mais baixos para não desestimular a produção e o investimento. De outra forma: a combinação de câmbio menos valorizado e juros "razoáveis" não permitiria uma queda tão brusca da inflação, mas provocaria menos desequilíbrios da economia doméstica em relação ao exterior e, assim, menor dependência de aportes de capitais estrangeiros para equilibrar o balanço de pagamentos. Este desenvolvimentismo continua industrializante, mas seu foco ampliou-se para incluir as atividades produtivas em geral, desde a agricultura até os serviços. Além disso, os seus partidários não aspiram, como desejavam seus antecessores dos anos 50 , construir no país um sistema industrial integrado. Aspiram, sim, que a produção local tenha uma participação significativa no sistema econômico mundial. No entanto, esse desenvolvimentismo limitado pelo molde liberal apenas vê com bons olhos formas bem delimitadas de intervenção do Estado no sistema produtivo. Assim, dentro dessa perspectiva, são favorecidas as políticas industriais setoriais, mas desde que limitadas no tempo e parcimoniosas nos subsídios. Tais políticas terão por objetivo não a substituição de importações a qualquer preço mas o aumento da competitividade setorial e, quando muito, o "adensamento das cadeias produtivas" para desenvolver no país o máximo possível de atividades econômicas com padrão internacional de produtividade (SALLUM, 1999, pp. 3435).

O conflito entre os dois grupos de apoiadores de FHC é o pano de fundo da gestão de Mendonça de Barros no BNDES. Ainda que Fernando Henrique mantivesse as duas correntes no governo, no início de seu primeiro mandato a estabilização, com manutenção do câmbio sobreapreciado e dos juros altos, foi priorizada. O presidente havia sido eleito por conta dos efeitos positivos trazidos pela estabilização e apostava em usar todos os mecanismos à disposição para garantir que esta fosse mantida, ainda mais em um cenário de instabilidade internacional com sucessivos ataques especulativos às moedas das nações periféricas. O temor que sua recém-conquistada estabilidade pudesse declinar velozmente, como ocorrera com o Cruzado alguns anos antes, levava o Presidente a apoiar enfaticamente medidas que prometiam debelar rapidamente a inflação e manter a economia estável, malgrado as consequências destas sobre o sistema produtivo. 
Em linhas gerais, os efeitos da política econômica que privilegiou a imediata estabilização foram: 1) A inversão da balança comercial decorrente, de um lado, do aumento violento das importações de toda sorte de bens que fora facilitada pelo Real valorizado e, de outro, da redução das tarifas alfandegárias e das exportações que se tornavam menos competitivas externamente dada a alta da moeda; 2) Consequentemente, o país tornava-se dependente de capital externo para compensar o desequilíbrio da balança. Os juros altos eram elemento essencial da política de atração de capital externo e também um mecanismo de desestímulo ao consumo que buscava evitar uma explosão de demanda resultante de estabilização semelhante àquela observada no Plano Cruzado; 3) A alta dos juros tornava o investimento financeiro mais atraente do que o investimento na produção, ainda mais em um cenário de exposição à concorrência, que exigia que as empresas fizessem investimentos para modernização de suas companhias, em meio à constrição do crédito; 4) Intensificada pelo câmbio, a exposição violenta à competição levou à dissolução ou venda para controladores estrangeiros de muitas unidades produtivas. Outras tantas passaram a importar parte significativa das componentes usadas na produção, o que fazia com que empresas fabricantes dos subsídios à produção fossem fechadas; 5) A crescente desmontagem do setor manufatureiro nacional provocou desemprego e migração dos assalariados para atividades econômicas mais informais; 6) Ainda que o barateamento de máquinas e equipamentos ajudasse a reequipar e modernizar as indústrias remanescentes, a restrição do crédito e a ausência de política industrial voltada à competitividade criavam entraves à atualização das plantas; 7) A falta de apoio foi deletéria, especialmente no caso dos setores nascentes e dependentes de alta tecnologia, o fez com que a produção nacional se concentrasse, com raras exceções, em produtos de menor complexidade, preferencialmente para consumo interno e não para exportação, que eram aqueles nos quais tinham vantagem comparativa; 8) A necessidade de reequilibrar as finanças externas rapidamente e a tendência à concentração nos setores de baixa complexidade favoreceu a concentração do investimento na agricultura de exportação (SALLUM, 1999).

Segundo um entrevistado:

O atrito básico era com o povo e sem o povo, quer dizer, no sentido de que a ortodoxia da PUC do Rio não estava de acordo com o momento democrático que se estava vivendo. Que era importante você também olhar para o crescimento, para o aumento de renda, e eles eram muito radicais na questão da rigidez fiscal. Mais do que isso, tinham uma postura, por exemplo... uma das grandes brigas - o câmbio foi a mais evidente. E o câmbio tinha muito mais uma 
visão econômica -, mas teve uma briga muito grande na renegociação da dívida dos Estados. Porque o pessoal da Fazenda queria fazer uma renegociação tipo o que a [Angela] Merkel quer fazer: não tem concessão nenhuma [...]. Eles não tinham essa visão de negociar com os partidos, com as bases sindicais. [Achavam que] não tinha que acomodar alguma coisa. Outra discussão grande foi em relação a investimentos públicos, principalmente a eletricidade, porque eles não queriam autorizar gastos. A gente estava diante de um quadro absurdo, quer dizer, você tinha energia sobrando no Norte e energia escassa no Sul, e eles não autorizavam investimento para fazer a ligação, coisa deste tipo [...]. Sempre teve essa divergência, que depois virou monetarista versus desenvolvimentista. Mas não é! Porque a maioria das coisas é em comum. A questão monetária, a questão fiscal. O problema que existe é, muito mais, que em um governo democrático como a gente tem no Brasil, se você não olhar pelo lado do bem-estar da população você corre o risco de acontecer o que aconteceu... (Entrevista à autora, 2012-2015).

Antes mesmo de entrar no governo, Gustavo Franco escreveu o artigo Um teorema sobre os "pactos sociais" no Brasil (1993), no qual posiciona-se contra a influência das negociações políticas no desenho econômico no caso brasileiro. Diz ele que "a negociação política é a democracia em movimento. Não pode haver uma sem a outra. A predileção que os governos, desde a redemocratização, têm exibido pela negociação parece alinhada com esses princípios. Todavia, existem muitas situações nas quais as 'negociações' e os acordos delas resultantes podem ser perniciosas. A vida econômica está cheia delas". Na sequência explicita: "quando existem minorias militantes e maiorias dispersas, difíceis de se fazerem representar, a 'negociação' terá sempre efeitos perversos [...]. No Brasil, minorias arrogando-se uma representatividade que, de fato, não têm, exploram maiorias inertes e sub-representadas". O pacto social com os sindicatos, nesse caso, afirma, levaria ao ganho do "setor - trabalho e capital - à custa do contribuinte" (FRANCO, 1995, pp. 280-281).

Franco rejeita o "desenvolvimentismo inflacionário tipicamente juscelinista, como também uma agenda socialdemocrata um tanto afrancesada" e julga as ideias de pactos sociais inadequadas a uma economia madura:

$\mathrm{Na}$ adolescência, um país consegue ser irresponsável durante um certo tempo, mas a partir de certo momento não dá mais para continuar. O país atingiu sua maioridade econômica; tudo o que faz tem consequências, e portanto não existe mais aquele almoço grátis [there ain’t no such thing as a free luch - expressão consagrada para dizer que alguém pagará por aquilo que parece gratuito] que existiu no passado. Numa economia aberta e com a imprensa livre, a impunidade para com os erros na economia simplesmente não existe. De novo, para os dois [Cardoso e Covas], foi um choque também no plano regulatório, em que prevaleciam noções românticas de um estado weberiano, com burocratas competentes e disciplinados, capazes de desenhar os destinos do país através da prática criteriosa de planejamento. O que se encontrou, na verdade - ainda que sem prejuízo de algumas figuras com esse perfil -, foi uma sucessão de problemas como a SUDENE, SUDAM, bancos estaduais quebrados, corrupção 
e uma absoluta degeneração da estrutura regulatória do Estado (FRANCO, 2003, p. 219).

Enquanto Gustavo Franco clamava por um "upgrade de visão de mundo" (FRANCO, 2003, p. 220), seus oponentes dentro do governo, notavelmente aqueles formados no seio da Juventude Estudantil Católica (JEC), da Juventude Universitária Católica (JUC) e da AP no início dos anos 1960, viam com desconfiança 1) A rejeição a qualquer forma de acomodação política que consideravam uma postura antidemocrática e 2) A política econômica sustentada a partir da Fazenda e do BCB, que achavam que, se prolongada indefinidamente, podia levar ao desequilíbrio externo e à desindustrialização e recriar a situação de dependência de capitais externos e bens produzidos alhures combatida pela era desenvolvimentista. O grupo proveniente da militância estudantil havia sido formado para conceber o desenvolvimento econômico e social de uma perspectiva nacionalista, recebendo influência do Instituto Superior de Estudos Brasileiros e dos setores progressistas da igreja. Além disso, vários deles tinham formação cepalina, parte deles mantendo vínculos com a UNICAMP. Ao longo dos anos 1960 e 1970, engajaram-se nos debates sobre a concentração de renda e o arrocho salarial. Seria a formação teórica e ideológica a colocá-los contra uma política econômica que poderia desestruturar o sistema nacional de produção? Nesse sentido, seriam parecidos com o grupo da Integração Competitiva com origem no PCB, e vínculos com UFRJ e a UNICAMP, que clamava por um liberalismo com incentivos ao aprimoramento do sistema nacional de produção?

Winston Fritsch e Gustavo Franco não tinham trajetórias militantes, não tomaram parte na contraposição às políticas militares e tinham permeabilidade às ideias neoliberais. Pedro Malan tinha formação distinta, já que frequentara cursos da CEPAL, trabalhara com planejamento industrial no IPEA, estudou com Albert Fishlow, confrontando repetidamente as políticas recessivas e concentradoras de renda da ditadura e dirigiu o Instituto de Economistas do Rio de Janeiro (IERJ), que agregava grupos de oposição. Não obstante, esteve posicionado próximo ao núcleo neoliberal que circulava na faculdade à qual estava vinculado.

Em algumas entrevistas e artigos, a polarização entre os economistas é creditada a diferenças regionais, essencialmente à polarização Rio de Janeiro-São Paulo. Não propriamente à cisão entre as escolas UNICAMP e USP ou PUC-RJ e FGV-RJ, e sim à experiência social dos altos estratos de economistas em cada uma das cidades. Segundo 
alguns paulistas, o grupo de economistas cariocas vive de renda, razão pela qual privilegiam as políticas financeiras. Eles cresceram “jogando xadrez em Ipanema”, nunca tendo visto uma fábrica e pensando a economia de forma abstrata. Para alguns cariocas, por sua vez, os economistas paulistas queriam proteger uma burguesia fracassada, de acordo com o populismo típico de São Paulo e sua perspectiva ora qualificada de provinciana, ora de pouco nacional, direcionada ao estrangeiro, com sua vontade expressa de se separar do resto do país. São exemplos dessas opiniões, a fala de Tavares:

O esforço, a luta dos gaúchos, dos cariocas, dos pernambucanos pela nação, ao lado do povo, é muito antiga. Minas é mais ambígua, mescla o pacto do compromisso com o libertarismo. Agora, São Paulo é fogo! Os populistas de direita - de Jânio a Maluf, passando pelo Adhemar - são de São Paulo. Os senhoritos de lá governam de costas para o país, com o olho na metrópole, antes em Paris, agora em Boston, no MIT, e em Washington. A revolução de 32 não foi uma revolução libertária, mas antes uma tentativa de contra-revolução. Isso é tudo que foi possível com aquela burguesia de quinta categoria de lá, o que, aliás, já foi dito com toda razão pelo "príncipe dos sociólogos", Fernando Henrique. O governo dele cumpre o destino dessa burguesia, levando às ultimas consequências a sua análise: tornou-se o presidente de um projeto, de uma burguesia e de um país "dependentes", abdicando da soberania e da justiça social (TAVARES, 1997, p. 8).

E a declaração de um entrevistado:

\begin{abstract}
Se você assistir uma novela que tem uma classe A carioca e outra paulista, você vai ver, eles pegam isso. O paulista, por exemplo, é um industrial cujo pai era imigrante e a briga é sobre uma indústria. Na novela carioca, você não sabe, primeiro, sobre o que eles estão brigando, em termos de dinheiro. Não está claro de onde vem o dinheiro, não se faz mais no trabalho, mas na propriedade [...]. Quem briga pelo câmbio? É o Sul... ou brigava. Para cima não faz diferença. Quem é o cara dos juros altos? É o Gustavo Franco, sucedido pelo Armínio Fraga (Entrevista à autora, 2012-2015).
\end{abstract}

Outros creditam a disputa vigente no primeiro governo FHC à usual "briga de Ministério da Fazenda contra Planejamento, entendeu? É um problema de um que gasta e um que não quer que gaste [...]. Todo mundo se pudesse saia investindo como um doido, mas não tinha dinheiro. Não tinha nem um tostão. Naquele tempo não tinha dinheiro para nada" (Entrevista à autora, 2012-2015). É possível argumentar, não obstante, que os ministérios não apenas eram funcionalmente divergentes, mas povoados por economistas com diferentes visões de economia e Estado, que lutavam pelo controle da área econômica e montavam coalizões para sustentar seu poder. $\mathrm{O}$ apoio institucional do Banco Central era essencial para assegurar ao Ministério da Fazenda a posição dominante, de modo que os dois cariocas da mesma escola tenderiam a acertar suas posições para 
fortalecer-se face ao presidente. O Ministério do Planejamento procurou aliados em seus conterrâneos e correligionários, há muitos anos próximos na luta política. Desta perspectiva, a disputa seria predominantemente um conflito por poder e influência, em que cada jogador apoia-se em seus elos para fortalecer-se, tendo sido os laços cerzidos na vivência comum, nas cidades que habitavam, nas escolas pelas quais passaram e nos grupos políticos aos quais estiveram afiliados. A explicação centrada no uso do vínculos, tecidos com aqueles que são próximos no espaço, como recurso na luta política dá sentido às alianças que mesclam elementos regionais, teóricos, políticos, funcionais, dentre outros.

Fosse um conflito 1) de escolas econômicas e ideologias políticas; 2) de habitus advindo da posição na estrutura social; 3) de ordem funcional; 4) de posição na luta por poder e influência ou uma combinação desses elementos, é possível dizer que a coalizão formada pelo grupo predominantemente paulista, com origem na AP e centrado no Ministério do Planejamento, conseguiu trazer o BNDES para sua esfera de influência quando Luiz Carlos Mendonça de Barros assume o Banco.

Os presidentes anteriores, Persio Arida e Edmar Bacha, e também André Lara Resende, que sucederia Mendonça, faziam parte de uma faixa de pessoas que transitavam entre os dois universos. Pérsio era paulistano e estudou na USP. Os três trabalharam ao lado dos paulistas João Sayad e Fernão Bracher no Plano Cruzado. André era sócio de Luiz Carlos. Edmar conviveu com Serra no Chile e esteve ao lado dele diversas vezes nos movimentos de economistas que contestavam o governo militar. Ainda que as políticas de Arida e Bacha no BNDES não tenham sido expansivas ou pró-industriais, como seriam as do grupo paulista, elas situavam-se na esfera de convergência entre os dois grupos: privatizar, reduzir o déficit, investir em infraestrutura e apoiar o setor privado. Alguns economistas que transitavam entre os dois grupos apresentavam, eles mesmos, críticas à extensão do período de uso da âncora cambial e aos juros altos, colocando-se ao centro no conflito entre as duas frações da equipe econômica. A saída dos três, ainda nos primórdios do governo, desmontou um possível meio de campo entre os dois polos.

Com Mendonça de Barros na presidência, de novembro de 1995 a abril de 1998, o BNDES manteve as linhas gerais de ação das gestões anteriores. Nos discursos e relatórios de sua gestão é possível detectar as seguintes convergências: parte-se do pressuposto que é preciso consolidar a vitória sobre a inflação para poder promover um 
desenvolvimento econômico sustentável e, para tanto, o reajuste fiscal e o programa de reformas do Estado deve prosseguir. As privatizações seguem, pois, firmes e avançam para o terreno dos serviços públicos e da reorganização dos Estados e municípios. Uma vez privatizados os serviços e a infraestrutura a eles subjacente, entende-se ser preciso apoiar os agentes privados que doravante encarregar-se-ão da infraestrutura, especialmente porque não há financiamento privado de longo prazo que cubra os investimentos nessa área, considerada a maior barreira ao crescimento e desenvolvimento. Continua-se falando em melhoria da concessão de crédito e reestruturação produtiva para modernização e aumento da competitividade em um cenário de abertura externa e globalização dos fluxos de produção. Até esse ponto, estava-se no terreno liberal de comum acordo na equipe econômica.

As mais significativas diferenças situavam-se no plano da escala e da distribuição setorial das aplicações. Os grupos que achavam que deveria haver desaquecimento, controle do crédito, deslocamento do Estado da atividade econômica poderiam temer os efeitos aceleradores de um BNDES que, em 1996, aplicou três vezes o valor de 1993 e, em 1997, cinco vezes mais do que antes do governo FHC. 


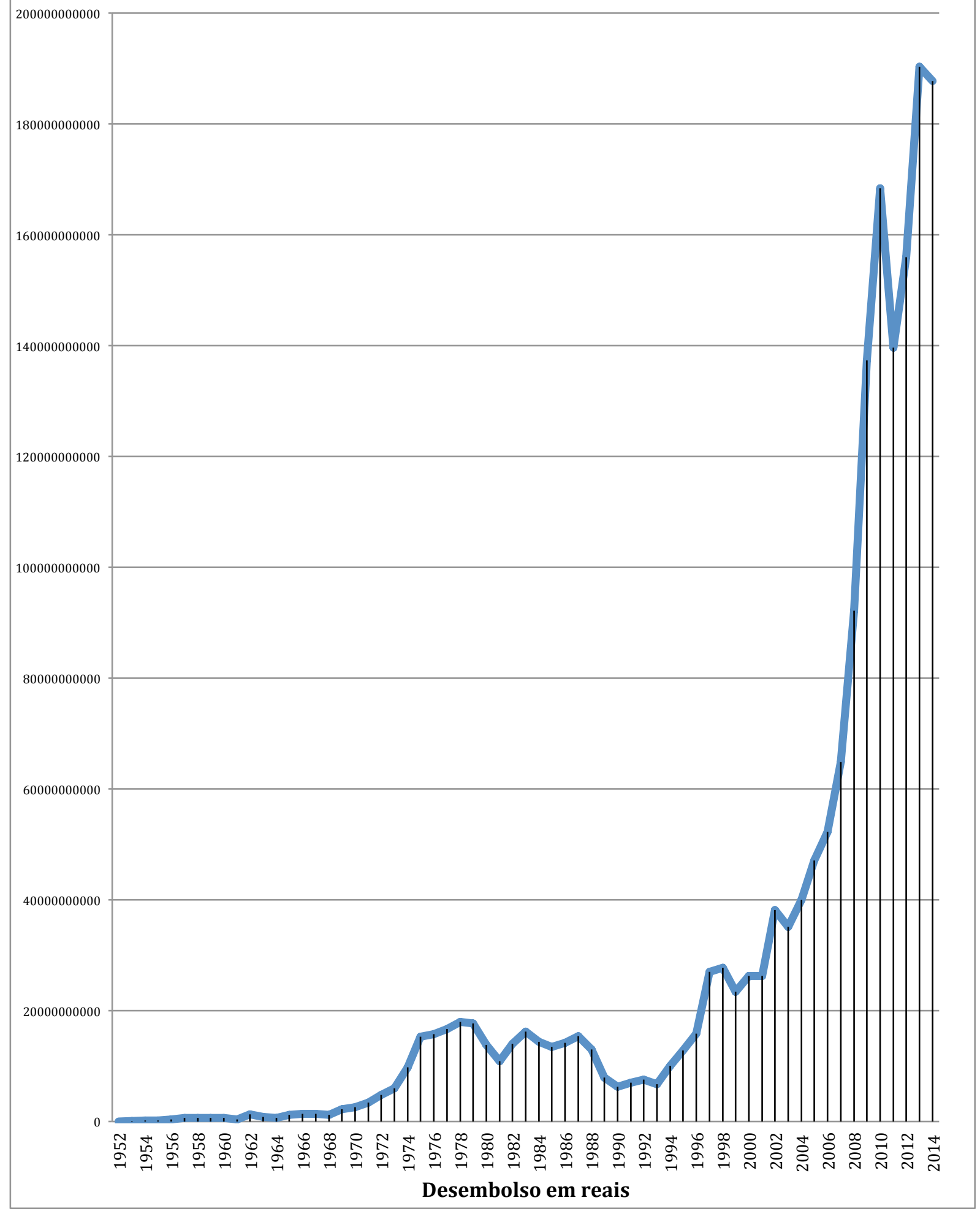

Gráfico VI: Desembolsos em reais por ano de 1952 a 2014. Fontes: BNDES 2002a, p. 182; BNDES, 2003; BNDES, 2004; BNDES, 2005; BNDES, 2006; BNDES, 2007; BNDES, 2008; BNDES, 2009; BNDES, 2010; BNDES, 2011; BNDES, 2012a; BNDES, 2013; BNDES, 2014. Elaboração: própria.

Luiz Carlos argumenta que "o BNDES estava com um nível de atividade muito baixo, porque a prioridade do governo continuava sendo o combate à inflação. Mas eu 
tinha certeza que já havia espaço para o Banco ser mais agressivo, ambicioso e ousado" (Mendonça de Barros in: BNDES, 2002, p. 151). Em sua administração, cresceram o orçamento, os desembolsos e o corpo funcional. Só no concurso de 1997 contrataram-se 386 profissionais com ensino superior nas áreas de economia, engenharia, contabilidade e direito, mais do que o dobro do total de concursados entre 1980 e 1996, que foi de 129 em 16 anos (Gráfico I) (KLÜGER, 2015c).

Ainda no plano quantitativo, há grande ampliação do apoio externo que, conforme alegam Bacha e Mendonça de Barros, era uma solicitação do Ministro do Planejamento, José Serra. A operação do FINAMEX, que começara em 30 milhões, em 1991, e atingira 380 milhões em 1995, chegaria, em 1998, ao patamar de 2 bilhões. Além disso, o apoio à exportação, antes vinculado à FINAME e restrito à área de máquinas e equipamentos, foi ampliado para outros segmentos e transformado no BNDES-Export-import (BNDESEXIM), emulando o modelo de export-import bank, adotado por vários países desenvolvidos e em desenvolvimento para operar os incentivos ao comércio internacional (CATERMOL, 2005, pp. 14-16). A adoção de uma política mais agressiva de apoio às exportações é mais do que a transposição, para o Brasil, de um modelo de política industrial que teve sucesso em outros países periféricos, notavelmente na Ásia. O apoio à exportação funciona, a princípio, como um mecanismo compensatório para um dos maiores problemas criados pela fórmula de estabilização adotada pelos setores vitoriosos da equipe do Plano Real, a saber, o câmbio fixo e sobrevalorizado que encarece as exportações brasileiras e as torna menos competitivas no mercado internacional ${ }^{541}$. Com o apoio do BNDES às exportações procurava-se abrandar um pouco os efeitos punitivos decorrentes da fórmula de estabilização adotada. Ademais, no início de 1998, José Roberto Mendonça de Barros, irmão de Luiz Carlos, que era até então o secretário de política econômica da Fazenda, depois de muito esbarrar com Malan, havia sido

\footnotetext{
${ }^{541} \mathrm{~A}$ intensificação do apoio às exportações praticada pelo BNDES é uma de uma série de medidas adotadas entre 1995 e 1998 para compensar os efeitos deletérios da política de estabilização. Outras seriam: a "criação do sistema de bandas cambiais móveis, desvalorização nominal e depois real, embora suave, do câmbio, aumento de tarifas alfandegárias para alguns produtos industriais, política industrial para o setor automotivo, ampliação extraordinária do volume de empréstimos pelo sistema do Banco Nacional de Desenvolvimento Econômico e Social com taxas especiais de juros (taxas de longo prazo), programação de investimentos em parceria com a iniciativa privada para a recuperação da infra-estrutura econômica do país (Programa Brasil em Ação), programas de estímulo à exportação, seja por isenção de impostos para produtos agrícolas, seja por financiamento a juros subsidiados, renegociação das dívidas agrícolas, programas especiais de financiamento para setores industriais selecionados, de financiamento para pequenas e médias empresas e assim por diante" (SALLUM, 1999, p. 34).
} 
transferido para a Secretaria da Câmara de Comércio Exterior, tendendo a haver uma política mais afinada com o BNDES nesse setor.

Em si, o apoio às exportações do início do governo FHC pouco diferia da política de exportações do governo Collor, exceto pelo volume que era crescente. A mudança qualitativa ocorreu quando o Banco instituiu política declarada de incentivo à exportações de produtos intensivos em tecnologia, o que era mais coerente com a política de Integração Competitiva formulada pelo BNDES no final dos anos 1980, que defendia uma política industrial que protegesse e fomentasse setores de ponta. O BNDES-EXIM apoiou, em 1997, uma grande venda de equipamentos para a construção de uma hidrelétrica na China e, entre 1997 e 1998, fez a maior operação individual de financiamento do Banco até então, a concessão de crédito para a venda de uma frota de aviões da Embraer para a American Eagle 542 (BNDES, 2002, p. 125).

Em paralelo ao crescimento do volume de crédito concedido para operações regulares e apoio à exportações, há uma modificação na distribuição setorial das aplicações. Crescem os desembolsos para a área de infraestrutura, conforme previsto para acomodar a transferência para o setor privado destas atividades. Além disso, a partir de 1997, o declínio nos desembolsos industriais encerra-se. As aplicações no setor crescem continuamente até 2001. Lembrando do efeito delay entre as aprovações e os desembolsos, é cabível concluir que, desde o início a gestão, em 1996, o apoio à indústria havia voltado a ser prioritário na pauta do Banco, depois de ter declinado de 74\% a 33,8\% em $6 \operatorname{anos}^{543}$ (Gráfico V). Finalmente, Luiz Carlos definiu que o Banco enfatizaria duas

\footnotetext{
542 “A Embraer disputou a primeira grande concorrência internacional para o fornecimento de 150 aeronaves para as empresas americanas de aviação regional ASA e Comer. A Embraer possuía melhores condições técnicas e preço, mas perdeu a concorrência por causa das condições de financiamento, melhores na concorrente que contava com apoio da agência de financiamento à exportação de seu país. As condições de financiamento à comercialização se mostraram tão importantes quanto o preço e a tecnologia do produto. Até então, as linhas de financiamento no Brasil, incluindo as disponibilizadas pelo BNDES, limitavam-se ao desenvolvimento tecnológico e investimentos fixos, pouco ajudando na parte de comercialização. As concorrentes internacionais já contavam com apoio governamental para a comercialização. O desenvolvimento do apoio do BNDES à comercialização das aeronaves foi fundamental para a reversão dessa situação. A Linha Pós-Embarque, na modalidade buyer credit, financiou o importador cobrindo até $100 \%$ do valor da operação a taxas de juros e prazos compatíveis com os internacionais. Nas concorrências seguintes, a Embraer obteve melhores resultados. Na Feira de Farnborough, na Inglaterra, ainda em 1996, foram vendidos 25 aviões para a norte-americana Continental Express e opções de mais 175 aeronaves. Em 1997, no Salão de Le Bourget, na França, foi conquistado o maior contrato de fornecimento de toda a história da empresa, com a encomenda no valor de US\$ 1,1 bilhão para a American Eagle, subsidiária de transporte aéreo regional da American Airlines" (CATERMOL, 2005, pp. 13-15). O BNDES e a Embraer concorreram, nessa operação, contra a canadense Bombardier e baixaram significativamente os juros para vencer a disputa, o que levou a Bombardier à Organização Mundial do Comércio, acusando o Brasil de concorrência desleal.

${ }^{543}$ Logicamente, nem todo o efeito da volta à industrialização pode ser creditado à gestão, visto que, para haver desembolsos, é preciso que haja demanda e a estabilidade econômica contribui substantivamente para o
} 
áreas até então não destacadas. A primeira delas era o Social, que voltava a ter alguma ênfase, depois de ter sido desmontado em 1990. A segunda era "a ampliação da disponibilidade de crédito para pequenas e médias empresas, a oferta de capital de risco para firmas dinâmicas e intensivas em tecnologia e o fomento à formação de redes verticais e horizontais de empresas” (BNDES, 1995, p. 4).

Segundo Mendonça de Barros, sua gestão adotava, em realidade, uma agenda de continuidade, visto que "o BNDES, através seus técnicos e da atual diretoria comandada pelo prof. Edmar Bacha, já vem realizando internamente há algum tempo uma profunda reflexão sobre estas questões. Como resultado existe uma agenda estratégica já estabelecida para os anos 1996/1999 e que define uma série de programas de atuação do banco. Faço deles, neste momento, o meu plano de voo" (BARROS, 1995, [DVD]). A novas diretrizes emanariam, pois, do próprio Banco e não do grupo com o qual Luiz Carlos alinhava-se no governo. Ele declara que, ao chegar no BNDES:

conhecia mais ou menos o Banco. Historicamente, sempre acompanhei aquele negócio todo, mas eu não tinha muita ideia do que é que eu ia fazer. Cheguei lá e fui desenhando. Tinha o problema da privatização, que era uma função específica do BNDES. O Serra tinha me pedido que ele gostaria de aumentar, como foi feito, a parte de comércio exterior. O que eu introduzi... o que eu resgatei mesmo foi o $\mathrm{S}$ do Social do BNDES. Eu criei várias linhas e, inclusive, consegui fazer com que um pedaço do lucro do banco pudesse ser [usado] a fundo perdido para uma série de atividades sociais. A grande experiência que eu tive lá foi a Embraer. Era o momento crucial dela se afirmar e o Banco deu um apoio decisivo [à exportação dos aviões]. Eu tinha uma visão geral, de que áreas que o Banco devia atuar, mas, essas coisas, é no dia a dia que você vai... o que eu consegui lá foi uma autonomia muito grande e uma parceria muito grande com a burocracia do Banco. Eu não levei ninguém. Eu trabalhei só com pessoas do próprio Banco. O próprio [José] Pio, que veio de fora, mas ele era funcionário de carreira do Banco. Então eu consegui uma liderança, vamos dizer assim, estratégica, deixando o dia a dia mesmo com os funcionários do Banco, que tem um quadro excepcional, o pessoal é muito sério, correto (Entrevista de Luiz Carlos Mendonça de Barros à autora, 2012).

À exceção de Elena Landau, que permaneceu à frente das privatizações até junho de 1996, a diretoria inicial de Luiz Carlos foi composta por funcionários do BNDES e apenas com eles permaneceria até a inauguração da diretoria social, na metade de 1997. Para a vice-presidência, Mendonça optou por José Pio Borges, que já havia ocupado o

crescimento dos pedidos de financiamento em setores de maior complexidade. Via de regra, a retomada do crescimento principia pelo comércio básico e serviços, que são imediatamente alavancados quando há um aumento de poder de compra da população. Em um segundo momento, o impulso se propaga pela cadeia, aumentando o peso dos setores capital-intensivos na economia. Em meados dos anos 2000, o banco experimentará uma forte onda de aumento em comércios e serviços que pode ser associada, essencialmente, a dois elementos: a inclusão de grupos sociais no universo do consumo de massa resultante do declínio das desigualdades e das políticas de crédito a micro, pequenos e médios agentes econômicos. 
cargo na gestão de Eduardo Modiano. Lara Resende conta que "quando o Luiz Carlos Mendonça de Barros foi ser presidente do BNDES eu indiquei que ele deveria levar o José Pio Borges, que é meu amigo, meu colega desde a PUC-RJ, que era funcionário de carreira do BNDES e que, quando o Eduardo Modiano foi ser presidente do BNDES, o José Pio Borges foi ser vice-presidente. Então eu disse: 'olha, Luiz Carlos, leva o José Pio Borges, que é uma pessoa que conhece o BNDES" (Entrevista de André Lara Resende à autora, 2012). Pio explica que conhecia o Luiz Carlos das visitas que fazia a André no Matrix. Quando recebeu o convite, prontamente deixou o Banco da Bahia, para onde havia retornado ao final da gestão de Modiano (Entrevista de José Pio Borges à autora, 2012).

Além de Elena e Pio Borges, a equipe de Luiz Carlos contava com José Mauro Mettrau, também funcionário de carreira do Banco, onde era diretor desde 1991 e ocupava a vice-presidência desde 1993. Para a área de infraestrutura o escolhido foi o economista Reginaldo Treiger, que entrou no Banco como estagiário, em 1972, e foi aprovado em concurso em 1974. Além de trabalhar por longos anos na área de infraestrutura, Treiger havia atuado nas desestatizações da cidade do Rio de Janeiro e sido assessor na Secretaria de Política Econômica do Ministério da Fazenda de FHC, na época em que este era coordenado por Winston Fritsch. Pouco depois, foi indicado pelo governador do Rio para dirigir a Companhia do Polo Petroquímico do Rio de Janeiro, posto no qual se encontrava quando recebeu o convite de Mendonça de Barros para assumir uma diretoria do Banco, possivelmente por indicação do governador do Rio. Nomeado no final de novembro de 1995, Treiger ficou pouquíssimo tempo no cargo pois faleceu em acidente de carro em janeiro de 1996544. Luiz Carlos convoca então um grande amigo de Treiger, Sérgio Besserman Vianna, que era o superintendente da área de planejamento. Besserman explica que:

O Banco ficou sem concurso muito tempo por causa de ajuste fiscal e os prêmios BNDES eram muito poucos e poucos optaram por entrar no Banco, dois da PUC-RJ: a Maria de Fátima Serro Pombal [...] e eu, o resto foi ganhar dinheiro no mercado financeiro[545]. O Mendonção foi uma junção disso de querer usar os

\footnotetext{
${ }^{544}$ Ver: http://memoria.bn.br/DocReader/DocReader.aspx?bib=030015 11\&PagFis=153561 http://memoria.bn.br/DocReader/DocReader.aspx?bib=030015 11\&PagFis=156094 http://memoria.bn.br/DocReader/DocReader.aspx?bib=030015 11\&PagFis=159709 http://memoria.bn.br/DocReader/DocReader.aspx?bib=030015 11\&PagFis $=159745$ http://memoria.bn.br/DocReader/DocReader.aspx?bib=154083 05\&PagFis=34920. Consultados em 1/05/2016.

545“'A nova geração era eu e mais meia dúzia de... Zé Roberto Áfonso [assessor do José Serra], Fábio Giambiagi, Guilherme [Gomes] Dias [o último ministro do planejamento do governo FHC], Sergio Besserman, Paulo Sérgio Ferracioli [...]. Luiz Paulo Vellozo Lucas, mas ele vai para a política foi deputado, depois prefeito, etc. e tal"
} 
quadros da casa, de querer usar os quadros jovens, e me conhecia da academia como justamente um cara que era da PUC-RJ, mas que discutia teoria do valor com o Belluzzo em mesa redonda. [Diz ser...] esse meio de campo entre a PUC que já estava se consagrando como um pensamento mais alinhado com a academia norte-americana e a visão de mercado e tinha a UNICAMP, a UFRJ. Eu sempre fui, embora eu fosse da PUC, meus amigos eram o Aloísio Teixeira, a Conceição me adorava, e o Mendonção tinha ouvido falar disso. O André Lara Resende, sócio do banco [Matrix], tinha sido meu professor... (Entrevista de Sérgio Besserman Vianna à autora, 2012).

Ao mesmo tempo que nomeou Besserman, Luiz Carlos optou por Fernando Perrone para substituir Helio Blak. Perrone ocupava, até então, a superintendência de privatização e, por conta disto, tinha visibilidade no Banco e tivera contato com o ministro José Serra, que supervisionava de perto as operações do Banco na área de desestatização. Advogado formado na UFF, Perrone havia ingressado no BNDES em 1970, como estagiário. De 1972 a 1974, trabalhou no Banco Denasa, que financiou sua pós-graduação em economia com foco em mercado de capitais na FGV-RJ. Na sequência, foi contratado para ser chefe do departamento financeiro da FINAME. Perrone ficou quatro anos na FINAME, três anos na direção do escritório do BNDES para o Nordeste, localizado em Recife, dois anos na presidência do Banco do Estado da Paraíba, dois anos como diretor do Banco de Desenvolvimento do Rio de Janeiro e seis anos na diretoria da Associação Brasileira de Bancos de Desenvolvimento. Em 1990, foi convidado por Pio Borges para ser seu assessor na vice-presidência e para trabalhar na área de privatizações, da qual tornou-se superintendente em seguida (Entrevista de Fernando Perrone à autora, 2012).

A primeira alteração na equipe é feita quando Elena Landau deixa o governo na metade de 1996, momento em que o programa de privatização entrava mais fortemente na área de serviços ${ }^{546}$. O vice-presidente Pio Borges assume as tarefas mais ligadas à privatização, em parceira com Perrone, que cuidava da área de infraestrutura, justamente o segmento que estavam leiloando naquele momento. Para substituir Elena na diretoria, foi convocado Eduardo Rath Fingerl (1953), engenheiro de produção formado na UFRJ com pós-graduação em planejamento industrial feita na COPPE-UFRJ no final dos anos

(Entrevista de Sérgio Besserman à autora, 2012). A razão de ser sua geração uma meia dúzia de gatos pingados foi a já mencionada baixa incidência de concursos de seleção para o BNDES nos anos 1980 e primeira metade dos 1990.

${ }^{546}$ Ver: Saída de Elena: http://memoria.bn.br/DocReader/DocReader.aspx?bib=030015 11\&PagFis=171911, http://memoria.bn.br/DocReader/DocReader.aspx?bib=030015_11\&PagFis=171788, http://memoria.bn.br/DocReader/DocReader.aspx?bib=030015_11\&PagFis=171623, Consultados em 09/05/2016. 
1970, ingressou no Banco em 1976, sendo alocado no departamento de indústrias químicas cujo gerente era José Pio Borges. Lá permaneceu até 1988, ano em que foi, como Pio, trabalhar na Petroquímica da Bahia, do grupo de Clemente Mariani. Na sequência, ficou um ano na Fundação Brasileira de Desenvolvimento Sustentável e voltou para o BNDES, em 1993, para chefiar o departamento de indústrias químicas. Eduardo era superintendente da área industrial quando foi convidado por Luiz Carlos para ser diretor da área industrial e de renda fixa e credita sua escolha a ascensão meritocrática na carreira interna (Entrevista de Eduardo Rath Fingerl à autora, 2012).

Desde o discurso de posse, Luiz Carlos Mendonça de Barros anunciou a reestruturação da área social, “com a finalidade de executar programas, projetos e estudos relacionados [...] no âmbito das questões sociais, em especial aquelas ligadas ao trabalho, ao meio ambiente e à promoção do desenvolvimento regional" (BNDES, 1996; BARROS, 1995, [DVD]). O relatório de 1997 informa que as iniciativas da área social concentram-se em educação, sistema penitenciário, desenvolvimento regional, trabalho e renda, transporte coletivo de massa, saneamento ambiental e agricultura familiar (BNDES, 1997).

Como nos anos 1980, a existência da área social seguiu sendo alvo de questionamentos, como explica um entrevistado: "não se criou um diretor social, se criou uma área, em nível de superintendência. Ninguém sabia o que é que ia ser essa área, porque ninguém acreditava muito que o Banco pudesse ter uma área de fato operacional. Meio que foi quase que uma atitude política, do tipo, bota uma área social no BNDES" (Entrevista à autora 2012-2015). Coerentemente com tal asserção, aparecem em numerosas entrevistas questionamentos à razão de ser de uma área social no Banco. As contestações vão desde o simples "Eu acho que não deveria fazer. Acho que isso não é a atuação do BNDES, isso está errado" ou “a área social ninguém queria muito meter a mão até porque a gente não conhecia. A gente entendia de indústria, de infraestrutura, mexer com energia, mexer com siderurgia, isso a gente sabia" (Entrevistas à autora, 20122015), passando por uma série de respostas que dizem que as ações do Banco na área econômica já são sociais, não devendo, pois, haver um social dissociado:

O governo tem o Ministério da Saúde. O Banco não tem que se meter em saúde. Assim como educação. O Banco tem que se meter na educação empresarial. Mas na educação pública, o Banco não tem como se meter. A mesma coisa o social. Eu não acho que o Banco tem que se meter muito no social. Eu acho que talvez o aspecto mais vulnerável do BNDES [seja] essa atuação social. É onde o Banco fica mais vulnerável às questões políticas. Porque, infraestrutura é social? Claro 
que é: saneamento, abastecimento de água, energia elétrica. Mas não tem que ser visto como social pelo BNDES. No BNDES tem que ser tratado como infraestrutura. Então, eu não gosto (Entrevista à autora, 2012-2015).

O S não está dissociado do $\mathrm{E}$. $\mathrm{Na}$ minha visão, quando você investe em infraestrutura, você investe nas empresas, você gera empregos, é social. Porque o econômico e o social estão ligados [...]. O banco resolve muito mais as questões sociais pelo lado econômico. Então eu leio esse econômico-social como uma coisa indissociável. Só que você não pode olhar o econômico sem observar os impactos sociais [...]. Como você otimiza pra gerar mais renda naquele entorno, [...] como você trata as questões sociais e ambientais relacionadas àquilo [...]. Então o social tem essa conotação, que no caso do BNDES, para mim, é muito mais relevante do que projetos micros de social (Entrevista à autora, 2012-2015).

No polo oposto há visões de que o BNDES não deveria fazer isso em teoria, mas já que o Estado brasileiro não é capaz de fazer uma política social eficiente, o BNDES poderia ajudar, pontualmente, pois tem um método adequado de avaliação de projetos que pode ser aplicado a outras áreas, mas não tem a capilaridade e a capacidade para dirigir e controlar grandes iniciativas no setor social. Outros, por fim, entendem que o BNDES deveria ter uma política clara de desenvolvimento social, com linhas sólidas de financiamento nas principais áreas sociais, o que nunca teve: "eu acho que o Banco repete, vamos dizer, a cultura do país de achar que o importante é infraestrutura, indústria e que o resto vem a reboque. Eu fico achando que se o Banco considerasse para valer, por exemplo, trabalhar em educação, em saúde, isso faria uma enorme diferença nesses setores, assim como o Banco fez enorme diferença nos setores produtivos”. Alguns entrevistados relatam ter tido grande dificuldade para fazer aprovações nas áreas sociais, já que as exigências para as áreas industriais que conheciam bem eram diferentes daquelas que deveriam operar nas áreas sociais, mas não havia clareza disso. Assim, algumas vezes simplesmente não empregavam a verba ou não estavam acostumados com o tipo de operação feita pelo social e implicavam com toda sorte de detalhes. Reclamavam que as pessoas da área social viajavam muito, que a área era de assistência social, não de economista e engenheiro (Entrevistas à autora, 2012-2015).

Em junho de 1997, a área social passou a ter um diretor próprio. O escolhido para ocupar a cadeira, que foi acrescentada ao organograma, foi o ex-prefeito de Vitória, Paulo Hartung (1957), economista formado pela Universidade Federal do Espírito Santo 
(UFES) ${ }^{547}$. Foi através de Luiz Paulo Vellozo Lucas (item 6.1), também capixaba, que Hartung ingressou no Partido Comunista Brasileiro. Os dois seguiriam trajetórias bem próximas: clandestinamente foram membros do $\mathrm{PCB}$, às claras participavam do MDB/PMDB. Hartung foi eleito deputado estadual pelo PMDB, mas transitou para o PSDB na ocasião da fundação do partido, sendo logo eleito deputado federal pela nova legenda. Vellozo Lucas passou do PMDB para o PSDB pouco tempo depois. Hartung foi prefeito de Vitória de 1993 a 1997. Vellozo, que trabalhou de 1995 a 1996 como Secretário Nacional de Acompanhamento Econômico do Ministério da Fazenda, substituiu-o na prefeitura, onde permaneceu até 2004. Enquanto isso, Hartung trabalhou meio ano no BNDES, órgão do qual Vellozo Lucas era funcionário de carreira desde 1984548. Em seguida, Paulo elegeu-se senador e, de 2003 a 2011, governou o Espírito Santo, sendo eleito novamente em 2015. Vellozo Lucas foi deputado federal de 20072011 e candidatou-se, em 2012, outra vez à prefeitura de Vitória, mas foi derrotado (HARTUNG, 2008, p. 171; Entrevista de Paulo Hartung à autora, 2012).

Luiz Carlos relata a escolha:

Eu não conhecia o Paulo Hartung. Aí tem uma jornalista de política, Cristiana Lobo, ela um dia me falou: "olha, o Delfim está dizendo que os tucanos não sabem trabalhar direito, que um dos melhores quadros jovens que eles tem, que é o Paulo Hartung, está saindo da prefeitura e não tem para onde ir". Eu escutei aquilo, fui no Sérgio [Motta] e falei: "Sérgio, conhece um tal de Paulo Hartung?" O Sérgio falou: "conheço, por que?" "Não, porque diz que ele é muito bom". "Ele é ótimo". "E eu estou precisando de um diretor da área social e eu queria pegar um político". Aí ele foi. Foi assim, e realmente foi ótimo, e foi ótimo para ele também porque ele ficou dois anos até ser candidato a governador, senador (Entrevista de Luiz Carlos Mendonça de Barros à autora, 2012).

Segundo a versão de Hartung, "o Sérgio Motta queria que eu fosse Ministro. Ele me chamou para ser Ministro da Reforma Agrária, assunto que eu não dominava. Eu disse a ele que não fazia sentido e que eu tinha vontade de ir para uma área como o BNDES” (Entrevista de Paulo Hartung à autora, 2012). Hartung ficou no Banco até março de 1998, quando afastou-se para disputar a convenção partidária que definiria os

\footnotetext{
${ }^{547}$ Ver: http://memoria.bn.br/DocReader/DocReader.aspx?bib=030015 11\&PagFis=202548, http://memoria.bn.br/DocReader/DocReader.aspx?bib=030015_11\&PagFis=213279, Consultados em $02 / 05 / 2016$.

${ }^{548} \mathrm{O}$ secretário de finanças de Paulo Hartung na prefeitura e de gestão e desenvolvimento no governo do Estado, Guilherme Gomes Dias, além de ter sido colega de Hartung na UFES, havia feito o mestrado no IEI-UFRJ e era da mesma turma de Vellozo Lucas no BNDES. Seria ele o último ministro do Planejamento do segundo governo de FHC (DHBB, verbete Guilherme Gomes Dias).
} 
candidatos ao governo do Espírito Santo e ao Senado ${ }^{549}$. Foi substituído na diretoria da área social por Beatriz Azeredo, que era a superintendente da área de desenvolvimento regional e social do Banco desde que ela foi recriada, em fevereiro de 1996.

Graduada em economia pela Cândido Mendes, com o mestrado Um estudo sobre as contribuições sociais (1987) e o doutorado Políticas públicas de emprego no Brasil: a experiência recente (1997) defendidos na economia da UFRJ, além créditos feitos na UNICAMP, Beatriz Azeredo (1956), ao contrário de Hartung, é uma especialista na área social. Começou a trabalhar com o tema das políticas sociais quando foi cedida pela Eletrobrás, empresa da qual era funcionária, para auxiliar sua orientadora Sulamis Dain, especialista em finanças públicas, na comissão de reforma tributária do Ministério do Planejamento que estava preparando estudos para a constituinte. José Serra, relator da comissão, conhecia Sulamis há anos, da Escuela Latinoamericana de Economía de la Universidad de Chile (ESCOLATINA) e da UNICAMP. Serra e o grupo dirigido por Sulamis estiveram fortemente envolvidos com a regulamentação do Fundo de Amparo ao Trabalhador (FAT), que se tornou a principal dotação orçamentária do BNDES, substituindo os repasses do Programa de Integração Social (PIS) e do Programa de Formação do Patrimônio do Servidor Público (PASEP) ${ }^{550}$, com que o Banco contava desde 1974. Sendo o FAT derivado do patrimônio dos trabalhadores, esperava-se que o Banco aplicasse, em contrapartida, recursos em áreas que melhorassem as condições de vida de seus contribuintes, razão pela qual houve uma pressão para que o BNDES voltasse à área de política social (Entrevista de Beatriz Azeredo à autora, 2012).

Ao final da constituinte, Serra convidou Beatriz Azeredo e José Roberto Afonso também orientando de Sulamis Dain na UFRJ e funcionário de carreira do BNDES do

\footnotetext{
${ }^{549}$ Ver: http://memoria.bn.br/DocReader/DocReader.aspx?bib=030015_11\&PagFis=229683, Consultado em 02/05/2016.

550 "No início da década de 1990, foi instituído o Fundo de Amparo ao Trabalhador (FAT), um fundo especial de natureza contábil-financeira, vinculado ao Ministério do Trabalho e Emprego (MTE), constituído pelo produto das arrecadações para o PIS e o Pasep, destinado a custear os programas de seguro-desemprego e abono salarial, bem como os já referidos programas de desenvolvimento econômico. De acordo com o preceito constitucional, o FAT continuou repassando $40 \%$ da arrecadação do PIS-Pasep para o BNDES. Nessa mesma época, mais precisamente em 1991, foram criados os Depósitos Especiais do FAT com base na aplicação das disponibilidades financeiras do Fundo, a serem operados pelas instituições financeiras oficiais federais e não apenas pelo BNDES. O FAT é gerido pelo Conselho Deliberativo do Fundo de Amparo ao Trabalhador (Codefat), órgão colegiado, de caráter tripartite e paritário, composto por representantes dos trabalhadores (quatro centrais sindicais), dos empregadores (quatro centrais patronais) e do governo, no qual têm assento representantes do Ministério do Trabalho, do Ministério da Previdência Social, do BNDES e do Ministério da Agricultura, Pecuária e Abastecimento. Entre outras funções importantes, cumpre ao órgão elaborar diretrizes para programas e para alocação de recursos, acompanhar e avaliar seu impacto social e propor o aperfeiçoamento da legislação referente às políticas públicas de emprego e renda, bem como de físcalização da administração do FAT” (SANTOS, 2006, pp. 4-5).
} 
concurso de 1984 - para integrar sua assessoria econômica na Câmara dos Deputados. Nos anos seguintes, além de trabalhar como assessora de Serra, Beatriz lecionou economia e trabalhou no Centro de Estudos de Políticas Públicas que fundou com José Roberto Afonso e Teresa Lobo, do Instituto Brasileiro de Administração Municipal, que também integrara a comissão de reforma tributária. Em 1995, Azeredo foi alocada no IPEA, em Brasília, subordinado ao Ministério de Serra. Beatriz já estava decidida a deixar o IPEA e voltar para o Rio de Janeiro quando Serra a indicou para Luiz Carlos, que ela não conhecia, para coordenar a área social que estava sendo refundada (Entrevista de Beatriz Azeredo à autora, 2012).

No final de abril de 1998, logo depois que Beatriz assumiu a diretoria social, Luiz Carlos foi obrigado, de maneira inesperada, a deixar o Banco para assumir o Ministério das Comunicações. Sergio Motta, o titular da pasta - companheiro de Luiz Carlos e José Serra desde os tempos de movimento estudantil, financiador do CEBRAP e de $O$ Movimento, coordenador das campanhas de FHC e figura central na articulação política do governo - faleceu em 19 de abril de 1998, deixando inconcluso o processo de privatização do sistema Telebrás, sua principal missão no governo ${ }^{551}$. Mendonça explica que assumiu o Ministério "porque precisava de alguém para terminar aquilo. Eu não queria mudar para Brasília. Eu fui em respeito ao Sérgio. Era a grande obra dele e realmente quem tinha condições de terminar aquilo, por conhecer as coisas, era eu. Eu tentei no começo fazer no BNDES, mas não dava. O centro de poder estava no Ministério das Comunicações” (Entrevista de Luiz Carlos Mendonça de Barros à autora, 2012).

Para substituí-lo no BNDES, Luiz Carlos convocou seu ex-sócio André Lara Resende. Desde o final de 1997, início de 1998, André voltara a colaborar mais intensamente com o presidente e com o ministro da Fazenda, sendo um assessor especialmente encarregado da preparação das reformas estruturais, principalmente das reforma da previdência e tributária, que o governo pretendia empreender. O falecimento de Sergio Motta, de quem ficara amigo, acabou empurrando-o de volta ao governo:

O Fernando Henrique e o Luiz Carlos Mendonça de Barros dizem: "olha, o Luiz Carlos tem que ir para o Ministério, senão isso não sai. É o único, porque ele tem

\footnotetext{
${ }^{551}$ Ver: http://memoria.bn.br/DocReader/DocReader.aspx?bib=030015 11\&PagFis=231660, http://memoria.bn.br/DocReader/DocReader.aspx?bib=030015 11\&PagFis=231716, http://memoria.bn.br/DocReader/DocReader.aspx?bib=030015_11\&PagFis=231928, http://memoria.bn.br/DocReader/DocReader.aspx?bib=030015_11\&PagFis=232144, http://memoria.bn.br/DocReader/DocReader.aspx?bib=030015_11\&PagFis=232145, http://memoria.bn.br/DocReader/DocReader.aspx?bib=030015 11\&PagFis $=232206$, http://memoria.bn.br/DocReader/DocReader.aspx?bib=154083_05\&PagFis=47797. Consultados em 02/05/2016.
} 
legitimidade com o Sergio Motta e o grupo de lá é um grupo difícil, que tem ideias próprias e eu não tenho outro nome para o BNDES" [...]. O Luiz Carlos Mendonça de Barros me entregou uma carta que eu escrevi pra ele quando o Sergio Motta tinha morrido, dizendo sobre a vida pública, sobre a importância e tal. [E ele disse:] "Olha! Você não pode fugir dessa responsabilidade" [...]. Então falei. "ah, ok. Não vai ser tão oneroso", Ledo engano! (Entrevista de André Lara Resende à autora, 2012).

Vendo-se como "mandato tampão", já que Mendonça lhe dizia que tinha vontade de voltar para o Banco, Lara Resende não fez alterações na diretoria, só trocou a chefe de gabinete. Ajudava o fato de que conhecia parte da equipe, visto que Pio era seu amigo de longa data, Sergio havia sido seu aluno e José Mauro circulava no mesmo universo social e profissional. Mantém, ademais, as linhas de condução do Banco, empenhando-se, sobretudo, na conclusão do processo de privatização do sistema de telecomunicações.

Em novembro de 1998, a equipe econômica e o governo de Fernando Henrique sofrem enorme abalo quando vêm a público gravações nas quais André Lara Resende, Luiz Carlos Mendonça de Barros e outros membros do governo conversam sobre a montagem dos consórcios que concorreriam nos leilões da telefonia. Os trechos liberados dos grampos ${ }^{552}$, tal qual apresentados na época, sugeriam que poderia haver tentativa de favorecimento do consórcio do qual participava o Banco Opportunity, de Daniel Dantas, no qual Persio Arida trabalhava. A liberação do conteúdo total das fitas poderia, por outro lado, sugerir que o governo pressionara para a formação de diversos consórcios com o objetivo de tornar mais lucrativo o leilão. A trama é complexa pois advogava-se, ainda, que os responsáveis pela liberação do grampo eram membros de um dos consórcios, interessados em desestruturar os concorrentes ${ }^{553}$.

\footnotetext{
${ }^{552}$ As investigações feitas na época indicavam que antigos funcionários do Serviço Nacional de Informações (SNI), que controlava todos os órgãos públicos durante o governo militar, mantiveram após a redemocratização grampos em diversos órgãos do governo, inclusive no BNDES, vendendo informações aos empresários interessados em obter informações privilegiadas, incluindo sobre todos os processos de privatização. Ver: http://memoria.bn.br/DocReader/DocReader.aspx?bib=030015_11\&PagFis=251341, http://memoria.bn.br/DocReader/DocReader.aspx?bib=030015_11\&PagFis=251408 consultados em 09/05/2016 ${ }^{553}$ Ver: http://memoria.bn.br/DocReader/DocReader.aspx?bib=154083 05\&PagFis $=51084$,
} http://memoria.bn.br/DocReader/DocReader.aspx?bib=154083 05\&PagFis=51167, http://memoria.bn.br/DocReader/DocReader.aspx?bib=030015_11\&PagFis=251132 http://memoria.bn.br/DocReader/DocReader.aspx?bib=030015_11\&PagFis=251144 http://memoria.bn.br/DocReader/DocReader.aspx?bib=030015_11\&PagFis $=251235$ http://memoria.bn.br/DocReader/DocReader.aspx?bib=030015_11\&PagFis $=251340$ http://memoria.bn.br/DocReader/DocReader.aspx?bib=030015_11\&PagFis $=251412$ http://memoria.bn.br/DocReader/DocReader.aspx?bib=030015_11\&PagFis=251583 http://memoria.bn.br/DocReader/DocReader.aspx?bib=030015_11\&PagFis=251586, 09/05/2016. 
O episódio aumentou o desequilíbrio entre as frações neoliberal e liberaldesenvolvimentista da equipe econômica, já que afastou do governo, de uma vez, os dois Mendonça de Barros, que pertenciam ao grupo mais preocupado com as políticas de crescimento e com a mediação com os estados e municípios, e André Lara Resende, que transitava bem nos dois segmentos. O grupo da AP já estava enfraquecido pois Motta falecera e José Serra transferira o Ministério do Planejamento para as mãos de Antônio Kandir, em 1996, pois Mario Covas pressionara-o para, no último momento, deixar o governo e concorrer à prefeitura de São Paulo ${ }^{554}$, eleição que perdeu para Celso Pitta. Persuadido por seu amigo desde a época no Chile, Vilmar Faria, Serra retornou ao governo federal, no início de 1998, como ministro da saúde, levando para sua equipe outro colega daqueles tempos, Cláudio Salm (SERRA, 2001). Nesta posição podia ter influência, mas não fazia mais parte da cúpula da gestão econômica. Consequentemente, ao final de 1998, o grupo que pressionava por uma política mais assertiva de desenvolvimento fora praticamente dizimado, criando um desequilíbrio na balança de poder que FHC havia cultivado ao longo do primeiro mandato.

O efeito foi ainda maior pois o Presidente planejava, para o segundo mandato, alterações que levariam, ao que tudo indica, ao fortalecimento do grupo liberaldesenvolvimentista, com o objetivo de responder a distúrbios como desemprego, quebra de companhias e deterioração da balança comercial, que se avolumaram após a irrupção da crise econômica asiática de 1997. A ideia seria reforçar um ministério para encarregarse da produção e de todas as tarefas ligadas ao crescimento, incluindo o comércio exterior e as indústrias, sendo Luiz Carlos, José Roberto e Lara Resende prováveis peças do novo arranjo ministerial (Entrevista de André Lara Resende à autora, 2012; BARROS, 1999). A desmontagem do grupo abalou o plano de criar um Ministério da Produção. Em compensação, tentou-se fortalecer o Ministério da Indústria, Comércio e Turismo que no primeiro governo FHC havia sido ocupado por Dorothea Werneck, sucedida por Francisco Neves Dornelles (item 5.4). No início do segundo mandato, o órgão passou a chamar-se Ministério do Desenvolvimento, Indústria e Comércio Exterior (MDIC), incialmente comandado por Celso Lafer, que passou a abrigar o BNDES. Críticas à lenta evolução da pasta fizeram com que ele permanecesse apenas 6 meses no cargo, que foi

\footnotetext{
${ }^{554}$ Ver: http://memoria.bn.br/DocReader/DocReader.aspx?bib=030015 11\&PagFis=169414 
transferido a Clóvis Carvalho, um dos poucos remanescentes do grupo da AP e um dos principais articuladores do governo no primeiro mandato.

Uma das primeiras medidas de Clóvis foi trocar o presidente do BNDES. Com a saída abrupta de André Lara Resende, o vice-presidente José Pio Borges permaneceu interinamente no cargo, apesar de ter apresentado carta de renúncia junto com seu amigo. O período de interinidade durou dos últimos dias novembro de 1998 até janeiro de 1999, quando foi confirmado no cargo e tornou-se o segundo funcionário de carreira a ocupar a presidência do BNDES 555 . O primeiro havia sido Jayme Magrassi de Sá, três décadas antes. Nos sete meses que permaneceu na presidência, as linhas de ação do Banco foram mantidas: o mesmo perfil de desembolsos, o mesmo volume de apoio à exportação, a progressiva retomada do apoio à indústria etc. A equipe também foi pouco alterada, com apenas duas mudanças. A primeira decorreu da necessidade de convocar alguém para seu próprio posto de diretor e a segunda foi consequência da saída de Sergio Besserman, convidado, no início de 1999, para ocupar a presidência do IBGE, até então a cargo do sociólogo Simon Schwartzman (item 3.1).

O intermediário que ajudou Besserman a assumir o IBGE foi o também carioca David Zylbersztajn (1955), engenheiro com graduação e mestrado na PUC-RJ e doutorado pelo Institut d'Économie et de Politique de l'Énergie da Université de Grenoble. Zylbersztajn, que havia sido secretário de energia do governo de Mario Covas e era então o diretor-geral da Agência Nacional de Petróleo, Gás Natural e Biocombustíveis, era amigo antigo de Besserman e, até então, genro de FHC ${ }^{556}$. Sergio comenta que quis migrar para o IBGE, apesar da redução de salário que acarretaria, porque a sua "visão de mundo sugeria que, vencida a inflação, a questão social brasileira, especificamente a desigualdade, iria aparecer na agenda porque ela, como realidade, já era muito obviamente pesada e a questão central do Brasil, mas, por conta da necessidade de vencer a inflação, ela na agenda não tinha emergido" e lhe interessaria trabalhar nessa temática (Entrevista de Sergio Besserman à autora, 2012).

\footnotetext{
${ }^{555}$ Ver: http://memoria.bn.br/DocReader/DocReader.aspx?bib=030015_11\&PagFis=255418. Consultado em $10 / 05 / 2016$.

${ }^{556}$ Zylbersztajn e Besserman eram amigos há décadas. Os dois estudaram no Colégio de Aplicação da UFRJ, ambos haviam sido comunistas na juventude e frequentado o Kinderland, que segundo Besserman era "uma colônia de férias que existe até hoje, em Morro Azul, criada por judias de esquerda que vieram para o Brasil e fundaram a associação feminina israelita brasileira e que tinham essa colônia de férias cujo mote era desenvolver o pensamento crítico". Ele explica que era uma "zona, aquela mistura de movimento hippie, anos 70, esquerda e Partido Comunista recrutando gente e elas judias, já velhinhas, de esquerda, que achavam aquilo o máximo" (Entrevista de Sergio Besserman à autora, 2012).
} 
Quando Pio assumiu a Presidência do Banco, deslocou José Mauro de volta para a vice-presidência e convidou o engenheiro civil com pós-graduação em engenheira de transportes feita em Stanford, José Luís Osório (1951) (item 5.6), e Darlan Dórea para preencher as vagas remanescentes. Osório conta que já vinha sendo sondado por André Lara Resende para ocupar uma vaga na diretoria: "Eu conhecia ele do Garantia [...]. Ele me conhecia e perguntou se eu queria ir. Aí teve aquele escândalo [...] das conversas deles querendo vender a Telemar. Ele caiu e eu desisti. Aí o Zé Pio Borges virou presidente. Me ligou. Eu estava presidindo, na época, a Lehman Brothers no Brasil [...]. Ele falou: você quer vir tocar a privatização? Eu aceitei”. José Luís Osório até então havia tido pouco contato com Pio Borges. Interagiram apenas uma vez, quando convidou-o para fazer uma palestra em um banco de investimentos no qual trabalhava, razão pela qual imagina que André tenha sido o intermediário da extensão, à gestão de Pio, do convite que ele mesmo havia feito para que Osório viesse para o BNDES (Entrevista de José Luís Osório à autora, 2012).

Darlan Dórea (1942), por sua vez, era economista formado na Universidade Federal da Bahia, com experiência no Banco de Desenvolvimento da Bahia e no Banco Regional de Desenvolvimento do Extremo-Sul, e trabalhava no BNDES desde 1983. Jorge Lins Freire, que era seu chefe no Banco de Desenvolvimento da Bahia, ao assumir a presidência do BNDES, convidou-o a ocupar a diretoria de operações da FINAME. Lins Freire deixou o Banco, mas Darlan continuou na FINAME por muitos anos, trabalhando com José Pio e José Mauro, que se tornaram grandes amigos. No início de 1999, ao vagar o cargo de Besserman, decidiram deslocá-lo da direção da FINAME para a do BNDES (Entrevista de Darlan Dórea à autora, 2012).

\subsection{O segundo governo FHC e a aliança do BNDES com o mercado de capitais}

Andrea Sandro Calabi, que havia sido secretário do Planejamento com Serra e ocupava a presidência do Banco do Brasil desde o início do segundo mandato, foi o escolhido por Clóvis Carvalho para a presidência do BNDES. Calabi entrou no BNDES bem afinado com Clóvis, exaltando a necessidade de promover o crescimento. Seu discurso de posse cita o presidente Fernando Henrique: "sem estabilidade o crescimento não dura, mas também a estabilidade, se não tiver o desenvolvimento, não cria raízes". 
Calabi argumenta que "agora, em parte por causa dos avanços na estabilização, conseguimos alongar o horizonte de planejamento e melhorar ações de governo voltadas ao desenvolvimento econômico [...]. É justamente um plano de desenvolvimento claro, bem formulado e compatível com o equilíbrio fiscal que representa um instrumento para a consolidação da estabilização" (CALABI, 1999 [DVD]).

Tendo sido duas vezes secretário-geral do Ministério do Planejamento e presidente do IPEA, Calabi trazia de volta à pauta o planejamento para o desenvolvimento econômico, que fora abafado durante a década de 1990. Explica que, "evidentemente", as ações do governo, as melhorias na infraestrutura, os projetos e programas deveriam ser "as bases para o estímulo a investimentos privados" e não estatais, como outrora. $\mathrm{Na}$ mesma linha, menciona a necessidade de dar continuidade ao processo de privatização, agora pensando, especificamente, em um modelo de concessões para os serviços de utilidade pública. Como seus antecessores, Calabi discursa em prol uma política de “promoção e expansão comercial de nossas exportações”, fala em pequenas e médias empresas, retoma a ideia de um BNDES social, que tem compromissos com os trabalhadores, fonte dos fundos operados pelo Banco, e proclama ser o BNDES o grande financiador do investimento, ou seja, alinha-se ao trajeto que o Banco seguia desde a gestão Mendonça de Barros, deixando explícito que pretendia planejar em direção ao desenvolvimento, o que os liberais-desenvolvimentistas reivindicaram durante todo o primeiro mandato (CALABI, 1999, [DVD]).

Calabi manteve, inicialmente, a mesma equipe de seu antecessor. Alguns meses depois, começou a organizar mudanças na diretoria e pensava em contratar uma consultoria externa para "chacoalhar sistemas e processos" (Entrevista de Andrea Calabi à autora, 2012), mas não teve tempo de implementar seus planos, já que, rapidamente, ele e Clóvis Carvalho foram destituídos de seus cargos. Carvalho havia assumido publicamente o apoio a políticas voltadas ao crescimento e ao desenvolvimento. Em setembro de 1999, em pronunciamento em seminário do PSDB, criticou o governo por ter dado excessiva primazia à estabilização. Explicitando sua visão da divisão na gestão econômica, afirmou: "de um lado, o que temos é uma equipe que prioriza o ajuste macroeconômico. De outro, aqueles que consideram que a modernização das atividades produtivas exige a indução do Estado”. Ao grupo da estabilização alertou: “o excesso de cautela, a essas alturas, será o outro nome para covardia". Segundo ele, "nos últimos meses vimos que sem crescimento 
teremos instabilidade política. E essa instabilidade política terminará por contaminar a própria estabilidade econômica. Sendo assim, precisamos ousar mais, arriscar mais, arriscar até o limite da responsabilidade". Era um ataque frontal à equipe de Pedro Malan e às gestões de Gustavo Franco e Armínio Fraga no Banco Central (Clóvis Carvalho apud FRANCO, 1999) ${ }^{557}$. Malan, constrangido e ofendido, teria respondido dizendo que eles não eram mercadores de ilusões e deviam fugir dos discursos fáceis (FRANCO, 1999).

Fernando Henrique demitiu Clóvis e designou, para o MDIC, Alcides Lopes Tápias (1942), proveniente de Santo Anastácio, no Estado de São Paulo, administrador formado pelo Mackenzie e advogado pelas Faculdades Metropolitanas Unidas, que havia feito carreira no Bradesco, começando como contínuo e chegando à vice-presidência. De 1991 a 1994, Tápias presidiu a Federação Brasileira de Bancos (FEBRABAN) e, de 1996 a 1999, a construtora Camargo Correia. Ao escolhê-lo, FHC mantinha o cargo com São Paulo, com alguém dissociado das lutas internas de seu governo, além de agraciar os empresários, alvo principal das políticas do MDIC558 (DHBB, verbete Alcides Tápias).

O BNDES, subordinado ao MDIC desde o início do segundo mandato, estava naquele momento nas mãos de Calabi. Seus estilos, alegava Tápias, não eram compatíveis. De fato, a migração do BNDES para o MDIC criou um conflito institucional estrutural. O BNDES era um órgão com grande poder e prestígio, que passou a estar subordinado a um Ministério que FHC não conseguiu fortalecer como pretendera, o que gerou desequilíbrio no organograma. Conflitos entre o BNDES e o titular do MDIC repetir-seiam nos anos seguintes.

No final de 1999, Tápias trocou o secretário da Carteira de Comércio Exterior do Banco do Brasil (CACEX), tirando o representante do Itamaraty e trazendo para o posto o empresário Roberto Giannetti da Fonseca, que havia sido parte da Cotia Trading. Em fevereiro Tápias exigiu que o presidente derrubasse Calabi, ceifando do governo um dos poucos remanescentes do grupo liberal-desenvolvimentista de São Paulo. Tão logo o presidente consentiu fazer a substituição, Alcides apresentou um nome para o posto: o de

\footnotetext{
${ }^{557}$ Ver: http://memoria.bn.br/DocReader/DocReader.aspx?bib=030015 11\&PagFis=273230. Consultado em 03/05/2016. E http://memoria.bn.br/DocReader/DocReader.aspx?bib=030015 11\&PagFis=273330 http://memoria.bn.br/DocReader/DocReader.aspx?bib=030015 11\&PagFis=273229. Consultados em 09/05/2016.

${ }^{558}$ Ver: http://memoria.bn.br/DocReader/DocReader.aspx?bib=030015_11\&PagFis=273606. Consultados em $09 / 05 / 2016$.
} 
Francisco Gros, um amigo de décadas e, como ele, um homem do mercado de capitais ${ }^{559}$. O pouco que sobrou do grupo da AP tinha influência muito marginal. José Serra fora deslocado para a Saúde. O economista cearense Martus Tavares, que assumiu o Ministério do Planejamento, havia trabalhado com Serra e Kandir desde o início dos anos 1990, mas não tinha grande influência na equipe econômica. O equilíbrio de poder do primeiro mandato não foi, portanto, renovado (DHBB, verbete Martus Tavares).

Treze anos depois de deixar a diretoria de mercado de capitais do BNDES para assumir a presidência do Banco Central, Gros voltava à casa. Nesse meio tempo fora presidente do $\mathrm{BCB}$ duas vezes, encerrara suas atividades no Banco particular que fundara, o BFC, e aceitara convite para chefiar a área de América Latina do Banco Morgan Stanley, em Nova York. Ao entrar no BNDES, Gros encontra um processo de transição em curso. Andrea Calabi acabara de fazer convites para a diretoria. Darlan, José Mauro e Beatriz haviam sido mantidos e permaneceram em suas posições. Os convocados por Calabi foram Aluysio da Motta Asti, Isac Roffé Zagury e Eleazar de Carvalho Filho, que substituiriam Eduardo Rath Fingerl, Fernando Perrone, que assumiu a Empresa Brasileira de Infraestrutura Aeroportuária (INFRAERO), e José Luís Osório, convidado para presidir a Comissão de Valores Mobiliários (CVM). Asti e Zagury eram funcionários de carreira do BNDES. Zagury (1951) fez graduação em economia na PUC-RJ e mestrado em administração na mesma universidade, com a dissertação Sistemas de custos industriais: aplicação ao processo petroquímico (1975). Trabalhou na Petrobrás e depois ingressou no Banco, onde fez toda a carreira na área financeira, começando no departamento de captação de recursos e chegando à superintendência. Concomitantemente, lecionou finanças internacionais no Instituto Brasileiro de Mercado de capitais (IBMEC), de 1988 até 1998. Na metade de 1999, havia sido cedido pelo Banco para trabalhar como Secretário Adjunto do Tesouro Nacional, encarregado da gestão da dívida pública

\footnotetext{
${ }^{559}$ Ver:

http://memoria.bn.br/DocReader/DocReader.aspx?bib=030015 12\&PagFis $=4064$ http://memoria.bn.br/DocReader/DocReader.aspx?bib=154083_06\&PagFis=878 http://memoria.bn.br/DocReader/DocReader.aspx?bib=154083_06\&PagFis $=893$ http://memoria.bn.br/DocReader/DocReader.aspx?bib=100439 14\&PagFis=1601 http://memoria.bn.br/DocReader/DocReader.aspx?bib=154083_06\&PagFis=875 http://memoria.bn.br/DocReader/DocReader.aspx?bib=030015 12\&PagFis $=3997$ http://memoria.bn.br/DocReader/DocReader.aspx?bib=030015_12\&PagFis $=4015$ http://memoria.bn.br/DocReader/DocReader.aspx?bib $=030015 \quad 12 \&$ PagFis $=4046$ http://memoria.bn.br/DocReader/DocReader.aspx?bib=030015_12\&PagFis $=4054$ http://memoria.bn.br/DocReader/DocReader.aspx?bib=030015_12\&PagFis $=4065$ http://memoria.bn.br/DocReader/DocReader.aspx?bib=030015_12\&PagFis=4069 Consultados em 04/05/2016.
} 
brasileira, interna e externa. Calabi convidou-o para voltar para o BNDES no início de 2000 e Francisco Gros manteve o convite. Zagury foi diretor até o fim do governo FHC, passando a ocupar a vice-presidência em 2002 (Entrevista de Isac Zagury à autora, 2012).

Aluysio (1948) é graduado em direito e economia pela Federal do Rio Grande do Sul (UFRGS), onde também fez o mestrado em economia, pensando em seguir para o doutorado em Vanderbilt, do qual desistiu quando aprovado no concurso para o BNDES, em 1975. Aluysio foi alocado no departamento de indústrias de bens de capital e produtos tradicionais, onde permaneceu até a criação da área social em 1982, na qual trabalhou durante quase todo o período em que Carlos Lessa a dirigiu. No final de 1988, foi deslocado para o departamento de estudos econômicos do DEPLAN e na sequência para a área de energia. Segundo ele, integrava o grupo que se opunha veementemente à destruição da área social, razão pela qual teria sido afastado na era Collor. Em 1996, foi convidado por José Serra para o Ministério do Planejamento, para trabalhar com a parte de infraestrutura do programa Brasil em Ação, que pretendia identificar projetos e investimentos que o governo deveria priorizar (Entrevista de Aluysio Asti à autora, 2012), dando origem ao Avança Brasil, o programa do segundo governo de Fernando Henrique.

Asti não conhecia Serra nem Kandir. Foi indicado por José Silveira, funcionário de carreira da Petrobrás, que havia trabalhado na elaboração de cenários do BNDES e se aproximara de Vellozo Lucas, sendo nomeado secretário de tecnologia do Ministério de Ciência e Tecnologia de José Goldemberg, no início do governo Collor. Silveira discutiu com diretores do Banco, chegando ao nome de Aluysio. No Ministério, Asti ficou encarregado da definição de projetos urgentes e estratégicos nas áreas social e de infraestrutura. Ao retornar ao Banco, em março de 1998, integrou-se à recriada área social, sendo convidado por Azeredo para ser o superintendente (SILVEIRA, 2009a; Entrevista de Aluysio Asti à autora, 2012; Yolanda Maria Melo Ramalho in: BNDES, 2012, p. 99). Gros aceitou sua nomeação. Conhecia Asti da primeira passagem que teve pelo Banco no governo Sarney. Asti explica que nunca foram do mesmo grupo, porque "eu era desenvolvimentista e ele era um banqueiro [...], conservador, muito conservador, queria tudo para o lado do risco", de modo que Asti ficou só um ano na diretoria (Entrevista de Aluysio Asti à autora, 2012).

Eleazar de Carvalho relata, em seu depoimento ao Projeto Memória de 2002, que “no começo de 2000, quando o Francisco Gros ingressou no banco, ele me fez um 
convite, deve ter sido por volta de março de 2000, para entrar no BNDES, como diretorsuperintendente da BNDESPAR e como diretor do Banco responsável pela área de desestatização" (CARVALHO FILHO, 2002, [DVD]). Em entrevista declara que conhecia Francisco Gros da época em que trabalhavam em grupos financeiros concorrentes "que tinham sido consorciados para trabalhar na privatização das empresas elétricas em São Paulo. O Gros pelo Morgan Stanley e eu pelo que veio a ser UBS [...]. Nós interagimos muito durante o processo de privatização" (Entrevista de Eleazar de Carvalho à autora, 2012).

Eleazar afirma que a intervenção de Armínio Fraga, que ligou e disse que "chegou a hora de você fazer o serviço militar", foi importante para que aceitasse o convite. Os dois eram amigos há anos, conheceram-se "jogando bola [...] na porta do cinema Miramar no Leblon e os pais e avós conheciam os meus pais. O Armínio joga golfe muito bem. Eu não jogo golfe, eu brinco, mas eu me lembro de ter feito aulas de golfe, no Intanhangá [Golf Club], que o meu pai era sócio, quando ele começou a jogar. Então o Armínio eu conheci, não intimamente, mas conheci enquanto garoto”, depois estabeleceram contatos profissionais (Entrevista de Eleazar de Carvalho Filho à autora, 2012).

Eleazar de Carvalho Filho (1957) era neto, por parte de pai, de um capitão da polícia militar cearense e, por parte de mãe, de advogado e fazendeiro paranaense, casado com escritora, integrante da Academia Paranaense de Letras, filha de general e neta de engenheiro de pontes francês, que veio para o Brasil construir a estrada de ferro CuritibaParanaguá. Seus pais eram personalidades do mundo musical: a pianista e compositora curitibana Jocy de Oliveira, que estudou no conservatório de Paris com a pianista Marguerite Long e fez mestrado na Washington University em Saint-Louis, e o regente Eleazar de Carvalho, nascido em Iguatu, no Ceará. Seu pai deslocou-se para o Rio de Janeiro, no início da década de 1920, com 11 anos de idade, para integrar a Marinha e acabou mais interessado na Banda dos Fuzileiros Navais do que na carreira naval. Fez graduação em música na Universidade do Brasil, onde estudou composição e regência. Tornou-se músico do Teatro Municipal do Rio de Janeiro e, em 1946, partiu para os Estados Unidos, onde estudou com o regente russo Sergey Koussevitzky, ao mesmo tempo que Leonard Bernstein, e fez o doutorado na Washington University. Regeu diversas orquestras no Brasil e no exterior e lecionou em diversas universidades norteamericanas, tendo alunos que se tornaram conhecidos regentes e compositores como 
Claudio Abbado, Zubin Mehta, Seiji Ozawa, Gustav Meier, David Wooldridge, Harold Faberman e Charles Dutoit. Finalmente, do início dos anos 1970, até seu falecimento, em 1996, foi maestro titular da Orquestra Sinfônica do Estado de São Paulo ${ }^{560}$ (Entrevista de Eleazar de Carvalho Filho à autora, 2012).

Eleazar de Carvalho Filho nasceu São Paulo, mas deslocou-se sucessivamente durante a infância, para acompanhar os pais que alteravam com frequência as cidades nas quais regiam e tocavam. De São Paulo, os pais transferiram-se para o bairro do Leblon, no Rio de Janeiro, onde Eleazar Filho viveu até os 5 anos de idade. Fez o pré-primário na Escola Americana, mudando-se em seguida para os Estados Unidos, pois seu pai tornouse regente da orquestra de Saint-Louis em Missouri. No final dos anos 1960, voltou para o Rio e cursou o ginásio e o colegial no Colégio Padre Antônio Vieira, onde aprendeu francês. Voltou para os EUA, em 1975, onde estudou economia e literatura brasileira na New York University (NYU). Na sequência, fez mestrado em relações internacionais na Johns Hopkins. Lá foi aluno e assistente do brasilianista Riordan Roett, que havia tido numerosas estadias de pesquisa no Brasil e sido aluno de Gilberto Freyre, sob a supervisão de quem escreveu um doutorado sobre a influência da Agência NorteAmericana para o Desenvolvimento Internacional (USAID) no nordeste. Roett fora, ademais, professor na universidade de Vanderbilt, influenciando os inúmeros brasileiros e brasilianistas que passaram por lá561 (Entrevista de Eleazar de Carvalho Filho à autora, 2012).

Neste período, Eleazar de Carvalho Filho teve suas primeiras experiências no mundo das finanças. Foi analista de crédito do Banco do Estado de São Paulo (BANESPA), em uma de suas férias, e estagiou um verão no Citibank e, durante todo o segundo do ano do mestrado, trabalhou no Banco Mundial, que considerou muito grande e burocrático. De volta ao Brasil, foi funcionário no Crefisul, do grupo Citibank. Em seguida, atuou como tesoureiro e diretor da área financeira do grupo industrial Alcoa, onde teve bastante contato com Armínio Fraga, então no Garantia. Tinha interações frequentes também com o cunhado de Armínio, José Luís Osório que, como visto no

\footnotetext{
${ }^{560}$ Ver: http://www.osesp.art.br/paginadinamica.aspx?pagina=orquestra e http://www.unicamp.br/unicamp/unicamp_hoje/ju/agosto2008/ju403pag9.html e http://acervo.estadao.com.br/noticias/personalidades, eleazar-de-carvalho, $936,0 . \mathrm{htm}$. Consultados em $05 / 05 / 2016$.

${ }^{561}$ Ver: https://familysearch.org/ark:/61903/3:1:33S7-95B3-926N?mode $=$ g\&i=89\&wc=QS6B$\mathrm{N} 3 \mathrm{~K} \% 3 \mathrm{~A} 1019549001 \% 2 \mathrm{C} 1019962401 \% 3 \mathrm{Fcc} \% 3 \mathrm{D} 1932363 \& \mathrm{cc}=1932363 \mathrm{e}$ http://library.brown.edu/wecannotremainsilent/wp-content/uploads/2014/04/Riordan-Roett-interview-3-5-04.pdf. Consultados em 05/05/2016.
} 
capítulo anterior, foi quem levou Eleazar para ser entrevistado por Jorge Paulo Lemann e sua equipe no Banco Garantia. Mudou-se então para o Rio de Janeiro, voltando ao universo dos bancos de investimento. Permaneceu no Garantia seis anos e depois trabalhou no banco "UBS Warburg, que é um banco de investimento inglês de origem suíça”. Foi nesse período que interagiu mais largamente com Francisco Gros, por conta do processo de privatização (CARVALHO FILHO, 2002. [DVD]; Entrevista de Eleazar de Carvalho Filho à autora, 2012).

Diferentemente de Aluysio Asti e de Isac Zagury, Eleazar era uma pessoa que Gros conhecia de fora do BNDES e que tinha, como ele, longa trajetória no mercado de capitais, sendo, pois, aliado importante no projeto da central da gestão de Gros que consistia em aumentar a interação do Banco com o mercado financeiro, usando o mercado para complementar os investimentos do BNDES e, simultaneamente, o próprio BNDES para alavancar o mercado (Alcides Tápias in: BNDES, 2002, p. 130). Ao assumir a presidência do Banco, em fevereiro de 2002, Francisco engajou-se no planejamento estratégico para o período 2000-2005. Ele argumentava que teria chegado ao final do ciclo que se iniciara com as privatizações do governo Collor e que era preciso avaliar, uma vez mais, "qual era a missão do Banco, quais eram os seus objetivos, quais eram as suas prioridades e eu acho que isso foi fundamental para o Banco encontrar o seu caminho. Para encontrar clareza naquilo que ele faz e naquilo que ele não faz (GROS, 2002, [DVD]). Segundo Gros o processo envolveu

\begin{abstract}
mais de cem dirigentes e executivos, os grupos de trabalho, formados a partir das dimensões estratégicas fixadas pelo Plano [Avança Brasil, do governo FHC II], encarregaram-se dos desdobramentos e do desenvolvimento das medidas e ações necessárias à implementação da agenda de mudanças. Em paralelo, começou um processo de reorganização interna para adaptar e ajustar as equipes técnicas à nova filosofia de gestão e às novas ênfases com as quais doravante trabalharemos. Desse processo de planejamento estratégico emergirá, certamente, um BNDES reestruturado, mais moderno e mais eficiente. O plano estratégico redefiniu os princípios de atuação do BNDES, estabelecendo que o Banco trabalhará em sete dimensões prioritárias: modernização dos setores produtivos; infraestrutura; apoio às exportações; desenvolvimento social; micro, pequenas e médias empresas; redução dos desequilíbrios regionais; e privatização. $O$ desenvolvimento do mercado de capitais é um fator-chave para a realização das metas estabelecidas pelo plano (BNDES, 2000, p. 7).
\end{abstract}

Diferentemente do planejamento estratégico do início dos anos 1980, agora tratava-se de uma reestruturação de cima para baixo, liderada pelos dirigentes e executivos (COSTA, 2011, pp. 222-223). O relatório de atividades do BNDES de 2000 apresenta sete áreas unidas por um círculo que representa o mercado de capitais, dimensão que 
uniria todas elas (Figura II). No que concerne às áreas prioritárias elencadas, não há novidade; nova, efetivamente, era a ênfase atribuída ao mercado de capitais, visto pela nova gestão como elemento crucial para que se pudessem realizar os projetos do Banco e aprimorar o capitalismo brasileiro.

\section{Planejamento Estratégico 2000-2005}

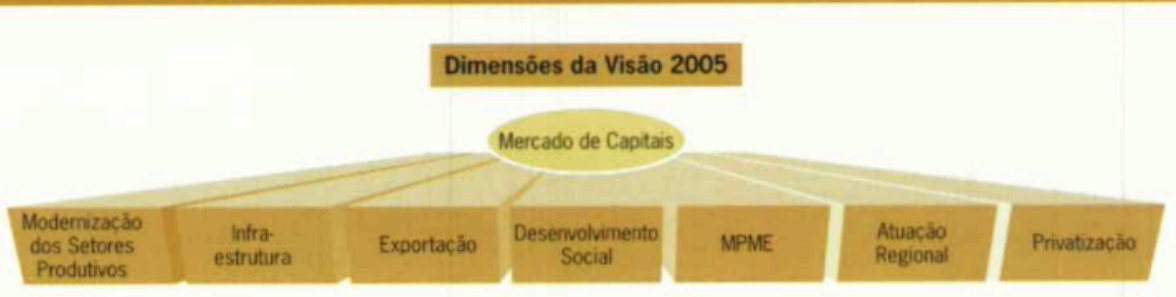

\section{As Dimensões da Visã̃o 2005}

Figura II: As dimensões da visão 2005. Fonte: BNDES, 2000, p. 18.

Segundo Francisco Gros, em seu depoimento para o projeto memória de 2002:

O que me frustra no Brasil de hoje é que quando eu olho o nosso cenário, nós não temos uma única empresa pública, no sentido internacional da palavra, ou seja, uma empresa com gestão profissionalizada e capital pulverizado, ou seja, sem dono. Quem é o dono da GM? Quem é o dono da IBM? Quem é o dono da Kodak? Não tem dono. É o mercado. Ninguém tem mais do que meio por cento do capital dessa empresas. São corporações públicas. Não existe uma única no Brasil. Toda empresa no Brasil tem dono, ou é o governo ou é uma pessoa ou uma família. Isso impõe limitações muito claras. Limitações na capacidade de crescimento dessas empresas, pelas limitações financeiras do seu dono. Limitação da capacidade de crescimento dos profissionais, na medida em que quem manda é o dono; quem tem juízo obedece, quer dizer, é um problema cultural. Nós ainda, em termos empresariais, somos um país colonial, de feitores e escravos. E não é assim que se constrói uma economia competitiva. Então a minha frustração é que eu acho que nós estamos no limiar de criar grandes corporações públicas, mas não conseguimos ainda. Não se muda automaticamente. Eu acho que se muda isso abrindo a economia. No fundo, é uma longa discussão mas no Brasil nós [nãp] criamos um capitalismo que separou a propriedade do poder de mando [...]. O seu Bill Gates comanda a Microsoft, mas tem 5\% ou 6\% do capital, não é dono. Se ele não for bem sucedido ele amanha será posto no olho da rua. Aqui não. Você não tem a menor condição de demitir um dono e o que a gente verifica no Brasil é que os donos quebram com as suas empresas, mas não são demitidos. Você não tem como tomar o comando de uma empresa do seu dono e isso tem implicações absolutamente fundamentais na nossa estrutura capitalista [...]. Aqueles que quiserem crescer, vão ter que acessar capital de terceiros. Vão ter que acessar capital de mercado. Vão ter que compartilhar poder. Vão ter que abrir mão do controle absoluto ou não vão crescer. Para mim, o grande desafio da economia brasileira hoje ainda é este. Como é que nós conseguimos construir grandes empresas de porte global; competitivas a nível global e a única maneira é pulverizando capital. A época dos donos passou, na 
minha opinião, no resto do mundo há dois séculos atrás. Eu acho que está na hora que essa era termine no Brasil (GROS, 2002, [DVD]).

Considerando que a debilidade do mercado de capitais estava no âmago do caráter amador do capitalismo nacional, Francisco começou a operar o próprio BNDES em prol da dinamização do capital financeiro. Quando diretor da área de mercado de capitais, na década de 1980, ele já havia feito grande lançamento de ações da Petrobrás que eram parte da carteira do BNDES. O valor arrecadado foi “da ordem de 300 milhões de dólares. $\mathrm{Na}$ época, de longe foi a maior operação de mercado de capitais que já foi realizada no Brasil, que envolveu mais de uma centena da instituições financeiras. Foi uma operação que marcou muito todos que participaram dela pelo seu tamanho, pelo seu pioneirismo e pelo seu sucesso" (GROS, 2002, [DVD]). De volta ao Banco, em 2000, com o amigo Tápias no MDIC, voltou a promover grandes pulverizações da carteira da BNDESPAR, incluindo nova rodada de venda de ações da Petrobrás: "180 milhões de ações ordinárias, representativas de $28,3 \%$ do capital votante da Petrobras, foram vendidas por 7,2 bilhões de reais. As ações vendidas faziam parte do excedente da participação acionária do Governo Federal [...]. Foi a maior oferta pública já realizada na América Latina e a terceira maior operação de mercado de capitais de países considerados emergentes" (BNDES, 2012, p. 144).

O relatório de 2000 indica que houve, naquele ano, tanto crescimento da carteira de créditos e valores mobiliários do Banco quanto "as alienações de ativos, que têm como fundamento o giro e a reciclagem da carteira de participações, além da formação de funding para novos investimentos, alcançaram R \$ 5,2 bilhões. Predominaram desinvestimentos de participações mantidas em companhias concessionárias de energia elétrica”. Concomitantemente, passaram a apoiar o desenvolvimento de fundos de investimento, com o "propósito de estimular a adoção de boas práticas de governança corporativa, a transparência, a comunicação e o bom relacionamento com os acionistas minoritários, bem como desenvolver administradores com competência de gestão de fundos de capital de risco" e criaram programa de apoio ao investimento de capital de risco em pequenas e médias empresas, visando fazer convergir dois objetivos do planejamento, o "apoio às pequenas e médias empresas e o desenvolvimento do mercado de capitais" (BNDES, 2000).

Nesse registro, a ideia não era apenas fazer com que as atividades praticadas pelo BNDES impulsionassem as finanças privadas, mas estruturar o próprio Banco como um 
gestor de crédito de mercado. Para tanto, contrataram uma consultoria e decidiram alterar a forma, a cultura e os procedimentos de operação do BNDES (Entrevistas à autora, 2012-2015). Um entrevistado declara que “o Francisco acabou com o negócio de salinha e fez um andar aberto, que os diretores de carreira estranharam um pouco no início, mas para a comunicação não tinha nada melhor. Era uma sala única para toda a diretoria, aos moldes do Bradesco. Porque o Bradescão funciona assim”. Segundo outro diretor, eles criaram "área de produto, área de cliente... tinha uma coisa de até quebrar mesmo o procedimento do Banco" 562 . Gros efetuou ainda uma reforma na gestão dos recursos humanos, que redefiniu a carreira, as regras de movimentação interna de funcionários e criou uma área de aperfeiçoamento de pessoal e uma universidade coorporativa, para promover cursos e treinamentos (Entrevistas à autora, 2012-2015; BNDES, 2001; CARVALHO FILHO, 2003, [DVD]).

Em 2000 e 2001, os desembolsos do Banco voltaram a crescer, depois de leve declínio em 1999, mas não alcançaram o patamar de 1997 e 1998 (Gráfico V1). A distribuição setorial dos recursos permanece semelhante, havendo incremento na agropecuária, que de 1999 a 2002 dobra sua participação, declínio na infraestrutura e estancamento da parcela atribuída à indústria. Os investimentos em infraestrutura tiveram que ser retomados após a irrupção, em 2001, da crise energética que ficou conhecida como "Apagão". Na ocasião, houve incremento de quase 50\% nos recursos do Banco, pois o governo injetou 9,5 bilhões de reais do Tesouro e o Banco captou 4,5 bilhões em organismos internacionais para tentar acelerar os investimentos no setor. "O Banco adaptou suas linhas de crédito para o setor elétrico, modificando as condições financeiras de modo a estimular os investimentos em geração e transmissão de eletricidade" (BNDES, 2001). A urgência fez com que Gros tivesse que dar um passo atrás em seu projeto de não promover o dirigismo e não privilegiar setores.

Ao escolher o substituto de Aluysio Asti na área de infraestrutura, no início de 2001, Gros convidou outra pessoa ligada ao mercado financeiro, o paulistano Octávio Castello Branco (1958). Engenheiro formado na Escola Politécnica da USP, havia trabalhado no Banco Chase, no Interatlântico, no JP Morgan do Brasil e feito um ano de

\footnotetext{
${ }^{562}$ Sobre a lógica da divisão em área de cliente (que incluía Setores Produtivos 1, Setores Produtivos 2, Infraestrutura Urbana - Desenvolvimento Social, Energia Logística, Telecomunicações e Complexo Eletrônico) e área de produtos (que incluía os segmentos de Desestatização e Reestruturação, Renda Fixa, Renda Variável, Exportação, Produtos Automáticos, Desenvolvimento Regional, Relacionamento com Instituições Financeiras e Desenvolvimento de Novos Produtos) e as mudanças no organograma e procedimentos de administração do período, ver: COSTA, 2011, pp. 243-248.
} 
treinamento no JP Morgan dos EUA. Quando o JP Morgan fundiu com o Chase, Castello Branco tornou-se responsável por toda área de Investment Banking e co-presidente do grupo no Brasil. Como Eleazar, Octávio teve, no meio de sua carreira, experiência como responsável financeiro em uma grande empresa privada, a mineradora Caemi chegando a presidir, por dois anos, a Caemi Internacional, com sede em Haia, na Holanda (Entrevista de Octávio Castello Branco à autora, 2012). Segundo ele,

o conselho de administração do grupo [Caemi] tinha um cara chamado Gerald Hess, que tinha sido da CVM e era um dos caras de referência do mercado de capitais brasileiro, já falecido. Tinha o Alain Belda, que foi presidente da Alcoa durante muitos anos no Brasil e fora do Brasil [...]. O Jorge Hilário Gouvêa Vieira, que tinha sido presidente da CVM. Ele era o sócio principal do que, na época, era um dos dois ou três principais escritórios de advocacia do Rio, chamado Gouvêa Vieira Advogados, e tinha sido presidente do BANERJ e secretário das finanças do Rio. Era um dos caras influentes da comunidade de negócios do Rio de Janeiro. O Francisco Gros, que já tinha sido presidente do Banco Central [...], tinha uma proximidade muito grande com o grupo Caemi e era um banqueiro de confiança da família dos Antunes [donos da Caemi]. Eu, moleque, vinte e nove anos, obviamente me apoiei muito no Geraldo Hess, no Jorge Hilário e no Francisco Gros. Foram três pessoas importantes para mim no desafio que eu tinha de conquistar a minha credibilidade dentro do grupo, montar a área [financeira] e tocar a companhia. Acabei fazendo nos três grandes amigos. O Francisco, por conta dessa amizade, cinco anos depois me convidou para ser diretor do BNDES (Entrevista de Octávio Castello Branco à autora, 2012).

Castello Branco relata os contatos iniciais do convite:

Em viagem a Nova York, no avião eu encontrei o Francisco Gros. Foi em janeiro de 2001 [...]. Ele já era o presidente do BNDES na época, e falou: "que tal trabalhar no governo?" E aquilo foi... "eu nunca pensei nisso, Francisco". Ele falou: "então pensa, porque eu estou atrás de uma pessoa para a posição de diretoria de infraestrutura e pode ser interessante para você". "Pô, Francisco, só faltam dois anos para o final do governo Fernando Henrique, será que vale a pena?". [...]. Ele falou: "olha, o Fernando Henrique está determinado a governar até o último dia e eu estou precisando dar uma dinamizada na área de infraestrutura. Tem uma agenda pesada e além disso. Tem um problema de racionamento de energia chegando. É possível que o Banco tenha um papel importante na solução disso". E eu respondi: "Francisco eu não sei. Eu preciso pensar. Não estava na minha agenda trabalhar no governo". Aí ele falou: "faz o seguinte. Vamos marcar algumas conversas para você. Pensa sobre o assunto e eu marco, vem bater um papo com algumas pessoas". Aí ele marcou uma conversa com o Alcides Tápias [...], com o Pedro Malan, com o Armínio Fraga. O Tápias, eu já conhecia, porque o Tápias tinha vindo do Bradesco, então eu conheci no mercado financeiro [...]. Aí fui falar com os três e os três foram muito unânimes em descrever o que depois eu conheci na medida em que trabalhei lá. Foi o seguinte: "olha, o BNDES é um dos poucos lugares do governo que tem a capacidade e a autonomia de fazer. Porque tem dinheiro e tem time e mais do que isso tem autonomia. A diretoria do Banco é autônoma. Ela não precisa pedir permissão a ninguém [...]. Então a tua capacidade de realmente atuar no banco para fazer aquilo que você acredita, a política, a missão do banco de desenvolver, de emprestar e de fazer a economia girar. No Banco você é capaz de fazer isso". Segundo ponto que eles falaram, que depois também eu vim a conhecer, é sobre a qualidade do time. "Olha, o BNDES é uma ilha de excelência dentro do 
governo, uma das poucas áreas onde tem alguma uniformidade de competência. Porque tem uma história de 50 anos, tem um plano de carreira e soube se manter razoavelmente blindado de influências políticas". Falaram que, obviamente, você tem que, sempre que você vai para o governo, [deve] avaliar as pessoas com quem você vai estar (Entrevista de Octávio Castello Branco à autora, 2012).

Além de Francisco e Tápias, Castello Branco conhecia Eleazar: "ele trabalhou um tempo no Garantia e depois trabalhou no UBS. Nós chegamos a fazer alguns negócios juntos. Projetos onde a gente se associava para buscar um cliente comum. Então era um amigo, conhecido [...]. Também teve uma importante influência. Foi uma das pessoas que o Francisco recomendou que eu falasse sobre ir ou não ir [para o BNDES], para tomar a decisão [...]. Obviamente, me entusiasmou a ir". Castello Branco explica que "tinha um sincronismo muito grande tanto com o Francisco quanto com o Eleazar [...]. Entre eu, ele e o Francisco, quer dizer, o background é mais ou menos parecido e isso deu muito o tom do Banco" (Entrevista de Octávio Castello Branco à autora, 2012).

Os três homens do mercado de capitais foram aos poucos reforçando o time ligado às finanças, facilitando a aproximação com o BNDES.

\begin{tabular}{|l|r|r|r|}
\hline & $\begin{array}{l}\text { Estado (nacional ou } \\
\text { internacional) } \\
\text { (anos/percentual) }\end{array}$ & $\begin{array}{l}\text { Mercado } \\
\text { (anos/percentual) }\end{array}$ & $\begin{array}{l}\text { Academia } \\
\text { (anos/percentual) }\end{array}$ \\
\hline Persio Arida & $44,4 \%$ & $12,2 \%$ & $43,4 \%$ \\
\hline Edmar Bacha & $43,7 \%$ & $20,0 \%$ & $36,3 \%$ \\
\hline $\begin{array}{l}\text { Luiz Carlos Mendonça de } \\
\text { Barros }\end{array}$ & $54,8 \%$ & $21,1 \%$ & $24,1 \%$ \\
\hline André Lara Resende & $55,6 \%$ & $18,7 \%$ & $25,7 \%$ \\
\hline José Pio Borges & $60,0 \%$ & $21,4 \%$ & $18,6 \%$ \\
\hline Andrea Calabi & $58,3 \%$ & $22,9 \%$ & $18,9 \%$ \\
\hline Francisco Gros & $57,0 \%$ & $28,9 \%$ & $14,1 \%$ \\
\hline Eleazar de Carvalho Filho & $49,8 \%$ & $36,1 \%$ & $14,1 \%$ \\
\hline FHC (ministro da \\
fazenda + presidente)
\end{tabular}

Tabela VII: Percentual da trajetória profissional dos diretores de cada gestão dividida entre vínculos com o Estado (política, administração pública no país ou fora do país), o mercado e a academia $^{563}$. Fonte: entrevistas à autora 2012-2015. Elaboração: própria. Legenda: em verde destacadas as gestões com maior incidência de cada tipo de vínculo em cada governo.

\footnotetext{
${ }^{563} \mathrm{O}$ cálculo do tipo de trajetória é feito somando-se o número de anos que o dirigente esteve ocupado em cada um dos setores entre o momento de conclusão da graduação e a entrada na diretoria, extraindo-se o percentual correspondente a cada tipo de vinculação. Se a pessoa teve vínculos concomitantes o ano será somado a mais de um setor.
} 
A diretoria foi uma das portas de entrada para os profissionais com conhecimento de mercado, mas não a única. Em 2001 e 2002 foram feitos dois processo seletivos para o Banco no qual recrutaram 53 contadores, 59 advogados, 74 economistas e 250 engenheiros, dando sequência ao processo de reversão da escassez de profissionais (Gráfico 1). No concurso de 1997 a ênfase da bibliografia recomendada aos economistas era nos temas de história econômica, macroeconomia e economia monetária. No caso dos engenheiros, organização industrial e economia do desenvolvimento, inovação, mudança tecnológica e crescimento eram os tópicos que dominavam o conteúdo requerido. Nos concursos de 2001 e 2002 há predomínio da área de economia financeira, tanto para economistas quanto para engenheiros. O segundo tema de maior incidência foi economia internacional, nos exames para economistas, e administração, marketing, contabilidade e gestão para os engenheiros. 


\begin{tabular}{|c|c|c|c|c|c|c|c|c|c|c|}
\hline $\begin{array}{l}\text { Índice JEL de classificação } \\
\text { da produção em Ciência } \\
\text { Econômica }\end{array}$ & $\begin{array}{l}\text { Eco } \\
1997\end{array}$ & $\begin{array}{l}\text { Eco } \\
2002 \\
\end{array}$ & $\begin{array}{l}\text { Eco } \\
2005\end{array}$ & $\begin{array}{l}\text { Eco } \\
2007\end{array}$ & $\begin{array}{l}\text { Eco } \\
2009\end{array}$ & $\begin{array}{c}\text { Eco } \\
\text { Total } \\
\end{array}$ & $\begin{array}{l}\text { Eng } \\
1997\end{array}$ & $\begin{array}{l}\text { Eng } \\
2001\end{array}$ & $\begin{array}{l}\text { Eng } \\
2008\end{array}$ & $\begin{array}{l}\text { Eng } \\
\text { Total }\end{array}$ \\
\hline $\begin{array}{l}\text { (A) Ciência Econômica } \\
\text { Geral e Ensino de Economia }\end{array}$ & & $3,1 \%$ & & & & $0,6 \%$ & & $6 \%$ & & $1 \%$ \\
\hline $\begin{array}{l}\text { (B) História do } \\
\text { Pensamento Econômico, } \\
\text { Metodologia e Abordagens } \\
\text { Heterodoxas }\end{array}$ & & & & & & & & & & \\
\hline $\begin{array}{l}\text { (C) Métodos Quantitativos } \\
\text { e Matemáticos }\end{array}$ & $8,3 \%$ & $6,3 \%$ & $5,3 \%$ & $6,1 \%$ & $11,5 \%$ & $6,4 \%$ & $11 \%$ & $6 \%$ & $7 \%$ & $8 \%$ \\
\hline (D) Microeconomia & $8,3 \%$ & $3,1 \%$ & $2,6 \%$ & $4,1 \%$ & $7,7 \%$ & $7,0 \%$ & & & $4 \%$ & $1 \%$ \\
\hline $\begin{array}{l}\text { (E) Macroeconomia e } \\
\text { Economia Monetária }\end{array}$ & $16,7 \%$ & $3,1 \%$ & $7,9 \%$ & $6,1 \%$ & $3,8 \%$ & $7,0 \%$ & & & $4 \%$ & $1 \%$ \\
\hline $\begin{array}{l}\text { (F) Economia } \\
\text { Internacional }\end{array}$ & $8,3 \%$ & $15,6 \%$ & $5,3 \%$ & $4,1 \%$ & $3,8 \%$ & $7,0 \%$ & & & & \\
\hline (G) Economia Financeira & $8,3 \%$ & $34,4 \%$ & $7,9 \%$ & $10,2 \%$ & $15,4 \%$ & $14,5 \%$ & $14 \%$ & $17 \%$ & $11 \%$ & $14 \%$ \\
\hline $\begin{array}{l}(\mathrm{H}) \text { Economia do Setor } \\
\text { Público }\end{array}$ & & $9,4 \%$ & $15,8 \%$ & $18,4 \%$ & $11,5 \%$ & $12,2 \%$ & $4 \%$ & $11 \%$ & $4 \%$ & $4 \%$ \\
\hline $\begin{array}{l}\text { (I) Saúde, Educação e } \\
\text { Renda }\end{array}$ & & & $5,3 \%$ & $4,1 \%$ & $7,7 \%$ & $3,5 \%$ & & & & \\
\hline $\begin{array}{l}\text { (J) Economia do Trabalho } \\
\text { e da Demografia }\end{array}$ & & & $2,6 \%$ & & & $0,6 \%$ & & & & \\
\hline \multicolumn{11}{|l|}{ (K) Direito e Economia } \\
\hline (L) Organização Industrial & $8,3 \%$ & $3,1 \%$ & $7,9 \%$ & $8,2 \%$ & $7,7 \%$ & $7,0 \%$ & $25 \%$ & $11 \%$ & $11 \%$ & $15 \%$ \\
\hline \begin{tabular}{l}
\multicolumn{1}{c}{ (M) Administração de } \\
Negócios e Economia de \\
Negócios: Marketing, \\
Contabilidade e Economia \\
da Gestão de Pessoal \\
\end{tabular} & $8,3 \%$ & $3,1 \%$ & $2,6 \%$ & $2,0 \%$ & & $2,9 \%$ & $14 \%$ & $17 \%$ & $26 \%$ & $18 \%$ \\
\hline (N) História Econômica & $25,0 \%$ & $6,3 \%$ & $5,3 \%$ & $8,2 \%$ & $7,7 \%$ & $9,3 \%$ & & & $4 \%$ & $1 \%$ \\
\hline $\begin{array}{l}\text { (O) Economia do } \\
\text { Desenvolvimento, Inovação, } \\
\text { Mudança Tecnológica e } \\
\text { Crescimento }\end{array}$ & $8,3 \%$ & $6,3 \%$ & $18,4 \%$ & $10,2 \%$ & $3,8 \%$ & $9,9 \%$ & $18 \%$ & $11 \%$ & $11 \%$ & $13 \%$ \\
\hline \multicolumn{11}{|l|}{ (P) Sistemas Econômicos } \\
\hline $\begin{array}{l}\text { (Q) Economia da } \\
\text { Agricultura e dos Recursos } \\
\text { Naturais, Economia da } \\
\text { Ecologia e Meio Ambiente }\end{array}$ & & & $2,6 \%$ & $2,0 \%$ & $3,8 \%$ & $1,7 \%$ & & $6 \%$ & $7 \%$ & $4 \%$ \\
\hline $\begin{array}{l}\text { (R) Economia Urbana, } \\
\text { Rural, Regional, Imobiliária } \\
\text { e dos Meios de Transporte }\end{array}$ & & & $5,3 \%$ & $4,1 \%$ & $3,8 \%$ & $2,9 \%$ & $4 \%$ & $11 \%$ & & $4 \%$ \\
\hline \multicolumn{11}{|l|}{ (Y) Categorias Mistas } \\
\hline $\begin{array}{l}\text { (Z) Outros tópicos } \\
\text { (decretos e publicações } \\
\text { governamentais) }\end{array}$ & & $6,3 \%$ & $5,3 \%$ & $12,2 \%$ & $11,5 \%$ & $7,6 \%$ & & $6 \%$ & $11 \%$ & $14 \%$ \\
\hline 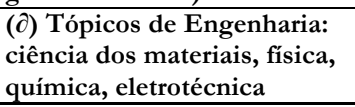 & & & & & & & $11 \%$ & & & $4 \%$ \\
\hline Total & $100 \%$ & $100 \%$ & $100 \%$ & $100 \%$ & $100 \%$ & $100 \%$ & $100 \%$ & $100 \%$ & $100 \%$ & $100 \%$ \\
\hline
\end{tabular}

Tabela VIII: Bibliografia dos concursos para o BNDES 1997-2008. Fonte: editais de seleção e listas de admissão para o BNDE(S) de 1997 a 2009, fornecidos pelo Serviço de Informação ao Cidadão do BNDES. Elaboração: classificação (de acordo com as categorias do AJL index: American Economic Association: https://www.aeaweb.org/econlit/jelCodes.php?view=jel), tradução do índice e elaboração da tabela própria ${ }^{564}$. Legenda: Azul: tema mais presente no ano. Roxo: segundo tema mais presente.

${ }^{564}$ Lista com os títulos recomendados nos editais divididos por ano e por categoria, explicitando as escolhas feitas no processo de classificação utilizado para a construção da Tabela. Economistas: (A) 2002: Sen. (C) 1997: Wonnacot. 2002: Puccini, Wonnacot. 2005: Puccini, Wonnacot. 2007: Guajarati, Puccini, Wonnacot. 2009: Bussab, Guajarati, Puccini. (D) 1997: Ferguson. 2002: Varian. 2005: Varian. 2007: Pindyck, Varian. 2009: Pindyck, Varian. (E) 1997: Dornbush, Simonsen. 2002: Dornbush. 2005: Dornbush, Pereira, Blanchard. 2007: Blanchard, Dornbush, Pereira. 2009: Blanchard. (F) 1997: Williamson. 2002: Gonçalves, Krugman, Gonçalves [2], Kasznar, Aronovich. 2005: Gonçalves, Krugman. 2007: Gonçalves, Krugman. 2009: Gonçalves. (G) 1997: Ayres 1997. 2002: Fabozzi, Fortuna, Brealey, Damodaran, Lethbridge, Sifert, Borges, Altman, 
A prioridade dada às finanças reinaria até o final do segundo governo FHC. Quando Francisco Gros deixou o Banco para substituir Philippe Reichstul, que estivera à frente da Petrobrás de abril 1999 a ao final de 2001, Eleazar foi alçado à presidência. Para preencher a própria vaga na diretoria foi convidado outro profissional do mercado de capitais, Eduardo Bunker Gentil (1955). Tal qual Eleazar, Gros e Octávio, Gentil, além de ser um homem do mercado, havia tido experiências profissionais nos Estados Unidos. Depois de fazer graduação em história e economia em Princeton e um MBA na NYU, trabalhou no JP Morgan de Nova York e na sede brasileira do banco, totalizando onze anos. Na sequência foi trabalhar para o Goldman Sachs, um ano em Nova York e sete no Brasil (Entrevista de Eduardo Gentil à autora, 2013). Ele relata que:

o Eleazar eu tinha conhecido uns 15 anos antes, porque ele também era casado,
na época, com uma americana e morava em São Paulo então, socialmente, os
filhos nas mesmas escolas... a gente conhecia. Além disso, o Eleazar, antes de ir
para o Garantia, foi diretor financeiro da Alcoa e eu seguia a conta da Alcoa no
JP Morgan. Então a gente se conheceu profissionalmente [...]. O Eleazar me
ligou e falou: "olha, vai surgir uma oportunidade aqui no Banco porque o Gros
vai para a Petrobrás e eu vou para a presidência e eu preciso de alguém para
ocupar a vaga que eu tinha na BNDESPAR". E aí foi muito rápido [...]. Todo
mundo tinha me falado antes: "olha, se algum dia você tiver a chance de
trabalhar no governo, seja no Banco Central ou no BNDES, que são duas
organizações muito profissionalizadas, dentro do governo... relativamente
profissionalizadas... você deveria aceitar". E aí eu fui. Foi uma opção muito
rápida. E também eu sabia que era por um período possivelmente curto, porque
o Fernando Henrique já estava no segundo mandato, então eu atuei como diretor
do BNDES por um período muito curto, de janeiro/fevereiro de 2002 até
janeiro/fevereiro de 2003 , quando o Lula assumiu e todos os diretores indicados
entregam o cargo (Entrevista de Eduardo Gentil à autora, 2013).

Arcoverde, Jorion, Silva. 2005: Fortuna, Brealey, Carvalho. 2007: Brealey, Carvalho, Fortuna, Lima, Ross. 2009: Carvalho, Damodaran, Lima, Ross. (H) 2002: Além, Finnerty, Pires. 2005: Além, Bononi, Finnerty, Rezende, BNDES/BID/MRE, Pasin, Nascimento. 2007: Além, Bononi, Brito, Clemente, Finnerty, Nascimento, Pinto, Rezende, Teixeira. 2009: Além, Ferreira, Finnerty. (I) 2005: Dedecca, Rocha. 2007: Rocha, Singer. 2009: Barros, Rocha. (J) 2005: Ross. (L) 1997: Sherer. 2002: Porter. 2005: Kupfer, Coutinho, Porter. 2007: Coutinho, Kupfer, Laplane, Porter. 2009: Ferraz, Kupfer. (M) 1997: Iudibicus. 2002: Iudibicus. 2005: Iudibicus. 2007 Iudibicus. (N) 1997: Abreu, Velloso, Faro. 2002: Abreu, Giambiagi. 2005: Abreu, Giambiagi. 2007: Abreu, Castro, Giambiagi, Tavares. 2009: Abreu, Giambiagi. (O) 1997: Melnick. 2002: Woiler, Sen. 2005: Woiler, Medeiros, Stiglitz, Belluzzo, Alves, Lall, Ocampo. 2007: Belluzzo, Lall, Medeiros, Ocampo, Stiglitz. 2009: Tigre. (Q) 2005: May. 2007: May. 2009: May. (R) 2005: Diniz, Cano. 2007: Cano, Diniz. 2009: Diniz. (Z) 2002: Bacen, Bacen [2]. 2005: Bacen, MIDC. 2007: MIDC, Ministério do Planejamento, Bacen, Pintec, BNDES, PAC. 2009: MCT, PDP, PAC. Engenheiros: 2001: Sen. (C) 1997: Faro, Wonnacot, Polya. 2001: Wonnacot. 2008: Morettin, Puccini. (D) 2008: Varian. (E) 2008: Mankiew. (G) 1997: Eliseu, Gitman, IBMEC, Hess. 2001: Fontoura, Gitman, Matarazzo. 2008: Fortuna, Gitman, Matarazzo. (H) 1997: Contador. 2001: Finnerty, Contador. 2008: Contador. (L) Porter, Porter [2]. Woodwaed, Lerner, OCDE, Araújo, GEIPOT. 2001: Eliseu, Porter. 2008: Davenport, Ghemawat, Porter. (M) 1997: Ansoff, Eliseu, Hampton, Florentino. 2001: Horngren, Lambert, Mintzberg. 2008: Copeland, Gianesi, Horngren, Kotler, Eliseu, Mintzberg, Nonaka. (N) 2008: Furtado. (O) 1997: Neves, Hess, Buffa, Hollanda, Simonsen. 2001: Matus, Slack. 2008: Ballou, Mattos, Slack. (Q) 2001: Jannuzzi. 2008: Barbieri, Protocolo de Kyoto. (R) 1997: Mello. 2001: Vasconcellos, Villaça. (Z) 2001: Revista BNDES. 2008: Revista BNDES, PPP, PAC. (d) 1997: Vlack, Valmulack, Resende. 
Também o "Otávio Castello Branco eu conhecia muito bem, porque nós trabalhamos juntos no Morgan uns três quatro anos”. Com Eleazar tinha vários elos. Como relata Eleazar: "Quando ele foi fazer mestrado na NYU, ele trabalhava como stringer para o Wall Street Journal e a minha ex-mulher pegou exatamente essa função dele [...]. Ele estudou história em Princeton, aliás o Gros fez Princeton undergraduate também. Então tem esses elos indiretos. Mas daí ele foi fazer um MBA na NYU e aí começou a trabalhar no JP Morgan com o Otávio. Daí trabalhou na Goldman, e o Garantia e a Goldman tinham muita ligação, faziam muita coisa em conjunto, então tinha muita relação profissional" (Entrevista de Eleazar de Carvalho à autora, 2012).

Com a equipe, formada por três profissionais do mercado financeiro, um funcionário de carreira da área financeira, Zagury, além de Darlan, Beatriz e José Mauro que estavam há anos na diretoria, o Banco operou até a metade de 2002. Ao final da gestão, José Mauro e Octávio deixaram o Banco, sendo substituídos, na diretoria, pela a superintendente da área jurídica, a advogada Mariza Giannini e Wallim Vasconcelos, colega de Armínio e Elena no Santo Inácio e economista formado na PUC-RJ. Wallim conta que ele e Eleazar conheciam-se há algum tempo pois ele, representando a BNDESPAR, teve "bons contatos com ele por conta de operações em que ele estava no setor privado, não no Garantia, mas acho que depois no UBS. A gente tinha alguns conhecimentos, algumas reuniões etc. Aí depois ele foi morar lá em São Conrado, na rua do meu pai. A gente estreitou um pouco mais o relacionamento, aí o Gros chamou ele para ir para o Banco e ele foi ser meu chefe" na diretoria da BNDESPar, posição que Wallim, que fez sua carreira inteira na subsidiária, ocupava desde 2000 (Entrevista de Wallim Vasconcelos à autora, 2012).

A gestão de Eleazar dá continuidade ao trabalho iniciado por Gros. Fala-se mais em sustentabilidade, em fundos tecnológicos e em experimentos com um cartão de crédito que aceleraria a tomada de empréstimos para pequenos e médios empresários, que se tornaria um instrumento essencial da política do Banco no governo seguinte, mas até então três diretrizes seguem incipientes e pouco operacionalizadas. Ao despedir-se do BNDES, no início de 2003, Eleazar reforça a continuidade entre sua gestão e a de seu antecessor, fundada na centralidade conferida ao mercado de capitais.

Tem sido fundamental para o Banco manter abertos e desenvolver novos mecanismos de captação de mercado. A política de riscos de crédito desta instituição nos últimos anos, tem sido a de conciliar prazos e taxas, além de adequar as provisões para garantir a sustentabilidade e retorno das operações. 
Retorno este compatível com outras instituições semelhantes no mundo. Preservar a qualidade do crédito e o rating do BNDES é aumentar a sua capacidade de apoio às prioridades do Banco. O Banco tem preparado uma emissão de debentures no mercado local, um título a ser negociado em bolsa atrelado ao índice Bovespa. O objetivo de estimular emissões padronizadas é o de reduzir o custo de transação, desenvolver o mercado secundário, aumentando a sua liquidez. A securitização de recebíveis no mercado doméstico também é parte de uma ampla agenda visando criar ativos para fomentar a poupança interna de longo prazo. As vendas pulverizada de ações de Petrobrás e Vale do Rio Doce serviram para atrair um grande contingente de trabalhadores ao mercado acionário, mostrando que se deve estimular a oferta de novos valores mobiliários no Brasil (CARVALHO FILHO, 2003, [DVD]).

A vitória da perspectiva segundo a qual o BNDES deveria estar umbilicalmente ligado ao mercado de capitais pode ser lida como efeito do domínio, no topo do Governo Federal, da vertente neoliberal, majoritariamente carioca, que buscava implementar um capitalismo cuja modernidade residia na pulverização financeira, em contraste com a perspectiva liberal-desenvolvimentista, de raiz fundamentalmente paulista, que lutava por uma política industrial modernizante, voltada à competitividade e à exportação e atrelada à base produtiva. Vitória favorecida pela sucessiva queda de membros da vertente desenvolvimentista, paulatinamente substituídos no governo por especialistas com trajetórias predominantemente percorridas no mercado financeiro. É em oposição à centralidade que as finanças conquistaram no governo Fernando Henrique que se colocará o primeiro presidente do Banco da era Lula, Carlos Lessa (item 1.5).

\subsection{A transição para o governo Lula: invertendo o sinal}

Ao vencer as eleições para a Presidência da República em 2002, Lula monta sua equipe de governo recrutando pessoas de pontos do espaço dos economistas, via de regra, afastados daqueles em que apareciam os economistas que trabalharam no governo FHC, principalmente do grupo ligado à finanças. Ao longo de suas gestões na presidência, Lula trará para o centro do poder economistas que tiveram vínculos com a CEPAL, como Carlos Lessa, Antônio Barros de Castro e João Carlos Ferraz (1953); pessoas ligadas ao antigo MDB que haviam participado do governo Sarney, como Carlos Lessa e Luciano Coutinho; intelectuais próximos ao Partido dos Trabalhadores (PT) desde a fundação, como o grupo que integrou o shadow cabinet que montou após a derrota de 1989 e 
militantes do Em Tempo, tais como Paul Singer, Guido Mantega e Maurício Borges Lemos (item 5.3).

Carlos Lessa foi o primeiro presidente do Banco no governo Lula, tendo recebido apoio de Celso Furtado, de Maria da Conceição Tavares, de Pedro Simon, político de quem era próximo dos tempos do MDB de Ulysses Guimarães, e do governador do Paraná, Roberto Requião. Lessa conta que:

quando o Lula conversou comigo, eu disse: "olha Presidente, na minha avaliação o BNDES foi inteiramente distorcido das suas funções. Ao invés de ser um Banco de desenvolvimento virou uma agência de corretagem de negócios, na verdade de venda de empresas públicas, um operador do mercado de capitais, deixou de ser aquela instituição espetacular de que o Brasil dispunha. Segundo, eu acho que é fácil recuperar, não acho que seja difícil não, Presidente. Agora, eu só posso aceitar do senhor com duas regras. A primeira regra é obviamente o senhor vai ter que pedir ao conselho universitário para me liberar da eleição que eu ganhei [para reitor da UFRJ] e a segunda é: eu indico todos os diretores. A diretoria é toda minha. Não tem nenhuma partilha política, partidária na diretoria". Aí o Lula disse assim: "Lessa!". "Sabe por que, Presidente? Você está me dando um depósito de esqueletos. Tem esqueletos por todos os lados esqueleto é dívida de um sujeito poderosíssimo que não é paga - e o Banco está desmoralizado completamente. Eu não posso ter que administrar questões políticas internas. Eu preciso ter uma diretoria coesa comigo". Ele disse: "Lessa, um diretor eu quero fazer". Eu disse: "depende, Presidente, quem é?" "Paul Singer". "Aceito. Eu sou muito amigo dele, gosto muito dele [...]. Eu inclusive fiz parte da banca dele de doutorado. Ele estava em bancas que eu fazia parte. Eu não tenho nenhum problema com ele". Aí o Lula pouco tempo depois me ligou: "Lessa, o Singer vai ficar com a economia solidária. Você tem alguma objeção que seja fulano de tal?". Fulano de tal era um ex-aluno meu de Campinas, Maurício [Borges Lemos]. Disse: "aceito, sem problema". O Lula queria um observador dele dentro da diretoria. Eu acho natural. Mas todos os outros presidentes [sic diretores] eram meus. O vice, tudo. Eu escolhi gente do Banco, do BNDES. De fora eu trouxe uma pessoa só, do Banco Central, [Luiz Eduardo] Melin, porque o Melin é de esquerda, o Melin é nosso (LESSA, 2003, [DVD]).

Além de Maurício Borges Lemos, economista e quadro do PT que havia sido indicado por Lula e de Luiz Eduardo Melin (1962), muito próximo do grupo de Lessa da UFRJ, tendo sido, inclusive, assessor de Maria da Conceição Tavares quando ela foi deputada federal, Lessa trouxe para a diretoria Fábio Erber, concursado da casa que também lecionava na UFRJ e havia integrado a diretoria de Antônio Barros de Castro, e funcionários de carreira do Banco, como o discípulo de Ignácio Rangel, Marcio Henrique Monteiro de Castro, Darc Antônio Luz da Costa e Roberto Timóteo da Costa, todos contratados nos anos 1970 e que fora parte do grupo deslocado para posições periféricas quando Eduardo Modiano assumiu a presidência do Banco, em 1990. O início da gestão de Lessa adota procedimento de tomada de poder semelhante ao empregado por Modiano, com o sinal ideológico invertido. Como na transição ocorrida no início do 
governo Collor, foram alterados quase todos os superintendentes e outros altos quadros do Banco, operando a lógica segundo a qual é difícil fazer uma inflexão substantiva quando os altos escalões, já enraizados, são portadores de outro projeto. O processo foi duramente criticado por muitos dos que integraram as gestões anteriores, assim como o início dos anos 1990 é repudiado pelos altos quadros dos anos 1980 que se viram deslocados nos anos Collor e Fernando Henrique. Lessa explica que:

\begin{abstract}
nós, eu e a minha diretoria, tomamos a seguinte decisão, demitimos todos os superintendentes e todos os chefes de departamento. Não sobrou um chefão. Cortamos quase todos os contratos de assessoria que havia. Havia contratos vergonhosos, pessoas que não faziam nada, ganhavam 40 mil por mês. Bom, promovemos uma turma relativamente jovem que nós sabíamos que era séria, de militância contra a ditadura, de bons alunos que nós tínhamos [...]. Aí, minha cara, a primeira coisa que nós fizemos foi voltar a dar o formato do BNDES clássico. O BNDES era a maior fonte de saber sobre a estrutura industrial brasileira. Sabia tudo sobre indústria. Sabia até o nome da amante do contador. Porque o problema é o seguinte. Todas as empresas de alguma maneira estavam ligadas ao Banco, por pedido de financiamento e o Banco conhecia os planos estratégicos de expansão, conhecia os problemas, conhecia as soluções, o Banco tinha uma radiografia absolutamente espantosa sobre o funcionamento da indústria no Brasil. Eles tinham acabado com isso, com a ideia de mercado de capitais. Parei as operações de mercado de capitais. Não fiz nenhuma durante dois anos. Minto, fiz uma, comprei o controle das ações da Vale do Rio Doce [bufa]. Então o primeiro esforço nosso foi repor o Banco nas suas funções de órgão de planejamento da industrialização e do desenvolvimento brasileiro. Enfrentávamos problemas terríveis, por exemplo, eu enfrentava dois problemas complicadíssimos. O primeiro é a tal definição de empresa de capital nacional. Bastava ser uma empresa instalada no Brasil que tinha capital nacional, então isso é horrível, porque, por exemplo, uma empresa pode ter lucro no Brasil, manda para fora, pega como empréstimo e aplica no mercado financeiro [...]. O segundo problema que eu tinha é que nós tínhamos perdido a cultura do desenvolvimento. Então eu montei um programa de treinamento para toda a jovem guarda, estudo a sério sobre todas as teorias de desenvolvimento e sobre as experiências de desenvolvimento nacionais (Entrevista de Carlos Lessa à autora, 2012).
\end{abstract}

A inversão ideológica indicava, assim, o retorno ao desenvolvimentismo, à indústria, ao nacional, à militância, ao controle de ações de companhias estratégicas como a Vale do Rio Doce e a Petrobrás, renegando o BNDES que se envolvera com o mercado de capitais e que pretendia funcionar como um "Bradescão".

Ao tomar posse, Lessa faz ver que o BNDE dos primórdios era a referência que tinha em mente. Ele menciona ter sido, enquanto estudante universitário, "iluminado pela obra do mestre Celso Furtado, Formação econômica do Brasil', sendo simbolo do projeto almejado a presença na mesa oficial da posse, em lugar de honra, do próprio Furtado. Lessa rememora o grupo misto CEPAL/BNDE e o Plano de Metas de JK ao dizer que: 
“o desenvolvimento brasileiro como projeto nacional e atuação do BNDE eram conceitos que se irmanavam no meu sonho de juventude". Entre os "grandes nomes" do Banco, cita os desenvolvimentistas nacionalistas Juvenal Osório Gomes, Ignácio Rangel, José Pelúcio Ferreira e Lúcio Meira. Lembra o ideal vigente nos anos de fundação do BNDE, quando pensava-se em "remover os pontos de estrangulamento ao desenvolvimento das forças produtivas, elevar a produtividade geral da economia, fazer a oferta de energia crescer à frente da demanda, como foi uma recomendação clássica do Presidente Getúlio Vargas quando aprovou o fundo de eletrificação... seria tão bom se se lembrassem das sentenças clássicas... fazer a oferta de energia crescer à frente da demanda, plasmar um sistema de transportes, que situasse o motor a explosão interna no coração da logística", fazendo, assim, crítica frontal à crise energética deflagrada no governo de Fernando Henrique (LESSA, 2003, [DVD]).

Segundo ele:

No início dos anos 1990 foi proposta uma missão que desviaria o BNDES de sua cultura. Acreditou-se que o mundo poderia ser cooperativo e, para melhor inserir-se nele, no Brasil deveria ser incentivada a competitividade interna. Como projeto nacional, houve a opção pelo neoliberalismo. Os ventos liberais sustentaram a ideia de uma reforma de Estado baseada em transmutações e fracionamentos patrimoniais. Surgiu uma frente de negócio de transferência de ativos de empresas públicas para mãos privadas. Até aquela década, o BNDES havia principalizado o desenvolvimento de nova capacidade produtiva; agora, deveria presidir e modelar o negócio das transmutações patrimoniais. Há uma dimensão positiva nisso: alguns setores industriais maduros e solidamente instalados no Brasil podem ser retirados da tutela do Estado. Porém, desmantelar setores estratégicos em nome de uma ideologia liberal cria situações de risco crescente - o Apagão é uma evidência forte neste sentido [muitos aplausos] (LESSA, 2003, [DVD]).

Lessa não discorda da privatização em si; tal como Rangel, acha que em setores maduros e sólidos ela poderia ser aplicada, mas rejeita a desestatização vista simplesmente como uma reconfiguração patrimonial, pleiteada pelo que caracteriza como ideologia neoliberal. Rejeita também a visão do Banco como um agente do mercado de capitais:

Como banco de desenvolvimento, as prioridades nacionais superam a visão estritamente bancária de risco. O Banco, comprometido com o que é novo, não se subordina ao jogo de mercado. Não pode ter atitude passiva em relação aos sinais de mercado. Obviamente, não pode desconhecer as realidades que contingenciam o presente; porém, estrategicamente, tem que se mover mais além do mercado, superando os condicionamentos... contingenciamentos. $\mathrm{O}$ banco de desenvolvimento é uma instituição vital para um país periférico que sonha superar o atraso. É literalmente um construtor de mercados e articulações produtivas. Contrasta com o banco de investimento que assume o risco como critério dominante [aplausos]. Para o banco de investimento, o negócio bom para uma empresa com alta classificação de segurança é bom para o banco, logo bom 
para a nação. Este é um singelo silogismo de uma criatura institucional de uma sociedade plenamente satisfeita com sua configuração estrutural. $\mathrm{O}$ banco de desenvolvimento inclui, numa missão muito mais ampla e complexa, as recomendações típicas de um banco de investimento; porém, se delas se tornar serventuário, cancela seus propósitos maiores. Para mim banco de desenvolvimento não é banco de investimento [aplausos] (LESSA, 2003, [DVD]).

Em lugar do BNDES da privatização e do mercado de capitais, clama por um Banco que retome a cultura de análise de projetos, que tenha uma visão da economia como conjunto de cadeias produtivas, que seja "formulador de políticas industriais microeconômicas, que se implementa a partir do conhecimento da organização setorial, suas cadeias produtivas, pontos fortes, pontos fracos”. Para ele é preciso retomar o BNDES como agente da industrialização, "concebida como processo central de transformação econômica e social para a superação do atraso", ajudando a desenvolver setores como a "siderurgia, a química pesada, o papel e a celulose, o cimento e a cerâmica branca, a metalurgia dos não-ferrosos, a petroquímica, a mecânica [que] se expandem ou nascem com o apoio deste Banco", avançando em direção aos bens de capital e "em direção às micro, pequenas e médias empresas, bem como ter uma inserção regional e uma difusão espacial mais significativas e sistêmicas” (LESSA, 2003, [DVD]).

Faz, não obstante, a seguinte ressalva:

Não leiam neste discurso qualquer retorno sebastianista. Ninguém no BNDES irá preconizar a busca de perdidas ilusões. Ninguém desconhece as realidades decorrentes das transformações do mundo e do país. Ninguém desconhece a perda de atratividade de projetos de longo prazo de maturação em cenários de grande incerteza. Todos sabemos da importância da logística para a redução do custo Brasil e para o aumento da competitividade externa brasileira, bem como das condições internas de execução dos programas de inclusão social. Todos sabemos que é necessário ir além de programas setoriais e da construção de políticas industriais cuja referência conceitual são as cadeias produtivas. Estamos advertidos de que a indústria no Brasil modernizou-se, porém pouco avançou em capacidade de inovar. Ninguém no Banco esquece a diferença essencial entre a capacidade de produzir e de inovar. Apesar do natural orgulho de pertencer a uma corporação pública, de tal essencialidade e excelência, não se praticará nem a arrogância nem o isolamento. Somos um instrumento do Estado nacional brasileiro, sob o comando de um governo democraticamente eleito, que enuncia, de forma muito clara, nossa missão: apoiar uma estratégia de desenvolvimento nacional que tenha a inclusão social e a redução das desigualdades como eixo organizador, que amplie a produtividade geral da economia brasileira e que atenue sua vulnerabilidade a desequilíbrios externos (LESSA, 2003, [DVD]).

Retornam, assim, temas presentes nas gestões anteriores, com inflexões na formulação das questões. Por exemplo, a competitividade deve ser acompanhada de um adensamento das cadeias produtivas internas, da inovação, da estruturação de setores fragmentados e montagem de "clusters" de pequenas e médias empresas para exportação, 
indicando que deveria haver uma política industrial governamental ativa na organização da produção. Em relação à inserção externa, o Banco pretendia seguir a diretriz federal para o estabelecimento de parcerias Sul-Sul, em especial com países latino-americanos. "Tais parcerias podem vir a consubstanciar sistemas integrados de transporte e de energia. A ligação continental terrestre entre o Atlântico e o Pacífico, que fez a glória e o dinamismo dos Estados Unidos da América do Norte, deve ser perseguida, para um fenômeno equivalente no continente sul [aplausos]”' (LESSA, 2003, [DVD]).

Tendo sido diretor da área social nos anos 1980, e em consonância com o discurso com o qual o PT chegava ao poder, Carlos Lessa enfatiza sobremaneira a atuação do Banco e do governo nesse segmento, argumentando que o direcionamento para o social representaria uma "uma mudança radical no padrão de desenvolvimento. No passado, o social foi concebido como subproduto da industrialização. Agora, o propósito civilizatório da inclusão social, será o motor da re-dinamização brasileira”. Deveria a inclusão social estar no centro do próprio projeto de desenvolvimento, não como um elemento complementar ao crescimento, mas seu fulcro, abraçando justamente o ponto que era o núcleo das críticas que a esquerda sustentou contra o regime militar por duas décadas: “a inclusão social não é um programa. É o centro de uma determinada concepção de desenvolvimento, a que esse Banco será instrumento e fiel executor" (LESSA, 2003, [DVD]).

A ideia de um BNDES social, voltado à integração latino-americana, à inovação, ao encadeamento da produção nacional e à promoção da infraestrutura é contraposta ao projeto neoliberal daqueles que ele identifica como a favor do fim do Estado:

À época, houve quem anunciasse o fim da história. A economia de mercado, pela globalização, determinaria, inexoravelmente, a convergência de todas as sociedades a um único padrão, afastando definitivamente os Cavaleiros do Apocalipse. Estaríamos no umbral do mundo em paz, próspero e com a progressiva abolição das distâncias entre os países. Projetos nacionais seriam inócuos e anacrônicos, e politicamente... políticas industriais próprias não teriam sentido. Na verdade este discurso ampliou a exposição do Brasil às turbulências geopolíticas e financeiras. Desconheceu pontos tão elementares quanto que as vantagens comparativas relativas dependem da interação entre o Estado e as empresas. Nenhum país no mundo conseguiu construir vantagens comparativas relativas sem essa virtuosa interconexão, que o liberalismo, em princípio, abomina e execra. Porém, não é só isso [respira fundo]. Esqueceu também que a presença no comércio exterior expressa, em boa medida, o tamanho e dinamismo dos mercados internos respectivos. No limite, o discurso neoliberal abriria mão da vontade de futuro e encerraria cada nação no seu presente medíocre. $\mathrm{Na}$ verdade, no limite, desaparece a esperança [...]. É evidente que o Brasil não pode depositar suas esperanças de vir a ser uma sociedade com desigualdades sociais atenuadas e conferindo níveis de vida dignos a cada brasileiro a partir de 
resultados de uma inserção passiva na fantasia neoliberal. A fantasia neoliberal não nos conduz a lugar nenhum [aplausos] (LESSA, 2003, [DVD]).

A breve exposição de alguns trechos da entrevista realizada com Carlos Lessa e de seu discurso de posse no Banco mostra que havia, no momento da transição governamental, uma disposição ao enfrentamento da perspectiva das gestões anteriores, retratadas como expressão do predomínio da lógica neoliberal, havendo um clamor pelo resgate de um BNDES desenvolvimentista. Como nos anos 1990, inicia-se o novo governo com disposição para uma radical transformação, que implica reestruturação interna e adoção de um impactante discurso de combate ao modelo precedente. Ao longo da década, em um e outro caso, há uma matização dos posicionamentos, perdendo o tom de ruptura radical, para avançar em direção à construção de um modelo que tem elementos de síntese com o passado. As gestões de Guido Mantega, Demian Fiocca (1968) e Luciano Coutinho representarão, nos anos 2000, avanço no desenvolvimento aliado a um projeto de inclusão social, mas a crítica direta ao modelo precedente, ao mercado de capitais e à privatização desaparecerá, dando espaço, em alguma medida, a uma combinação das orientações teórico-políticas divergentes.

Ainda que não se alcance por hora a análise detida dessas gestões, há elementos que indicam caminhos para futuras caracterizações do período. O crescimento acentuado dos desembolsos na segunda metade dos anos 2000 indica a disposição para retomada da função de indutor do desenvolvimento por parte do Estado, especialmente em meio à crise econômica de 2008, que poderia repercutir no país e ameaçar a estrutura produtiva (Gráfico VI). A mudança na distribuição setorial, com contínuo crescimento da proporção destinada às áreas de comércio e serviços pode ser associada à redução das desigualdades e ao aumento dos investimentos para suprir a demanda gerada pela inclusão no universo do consumo. O cartão BNDES, que facilita o investimento nesses segmentos, também teria impacto na alteração da distribuição setorial dos desembolsos do Banco (Gráfico V).

Contudo, outros elementos sugerem uma acomodação das pautas, conciliando-se preocupações específicas do governo Lula, como a integração Sul-Sul e a expansão dos investimentos em outros países periféricos, com temas que caracterizaram as gestões do governo anterior, como a estruturação de grupos com poder de competição externa e iniciativas dirigidas à expansão das exportações. O próprio mercado de capitais reconquista espaço ao longo do tempo, como revela a distribuição das temáticas presentes 
nos exames de seleção para o Banco, havendo um retorno aos tópicos do universo das finanças e da administração, depois de uma breve inflexão em direção a conteúdos na área de economia do desenvolvimento. A distribuição da bibliografia dos últimos concursos (Tabela VIII) apresenta evidências de que se teria chegado a um modelo de conciliação, no qual organização industrial, desenvolvimento e inovação aparecem ao lado dos tópicos relativos às finanças e à administração privada, indicando uma síntese entre modelos de BNDES apresentados, nos momentos de inflexão, como contraditórios.

Quanto à composição da diretoria, manteve-se a prática de conciliar quadros internos com diretores trazidos de fora da instituição, observada ao longo de toda a década de 1990. Observa-se na gestão Lessa a maior incidência de diretores com perfil acadêmico e a menor taxa de pessoas que tiveram passagem pelo setor privado (Tabela VII). Também na direção da acomodação das pautas percebe-se que ao longo do governo Lula haverá um aumento do número de diretores com experiência no mercado, ainda que o percentual médio de tempo das trajetórias no setor siga sendo inferior ao dos governos Fernando Henrique Cardoso. No que concerne à formação acadêmica dos dirigentes, se há maior incidência de pessoas ligadas à UNICAMP e à UFRJ, não é somente efeito das inflexões nas diretrizes mas, igualmente, da própria mudança do ponto do espaço social do qual partem as indicações para cargos de confiança de alunos e colegas. Ainda que não seja feita aqui uma análise das diretorias do período, a primeira diretoria do governo Lula e alguns dos diretores dos anos seguintes aparecem representados na rede, sendo possível observar de que pontos do espaço são provenientes.

\begin{tabular}{|c|c|c|c|c|}
\hline Personagem & Cronologia & Local de nascimento & Formação & Filiação \\
\hline Alexis Stepanenko & 1938 & São Paulo - SP & $\begin{array}{l}\text { Graduação em ciências } \\
\text { sociais (FFCL/PUC-RJ). } \\
\text { Especialização r em } \\
\text { finanças (Universidad de } \\
\text { Madrid). }\end{array}$ & $\begin{array}{l}\text { Pai russo, engenheiro } \\
\text { químico que foi major e } \\
\text { participou da política russa ao } \\
\text { lado do imperador, deixando } \\
\text { o país na sequência. Mãe } \\
\text { francesa. }\end{array}$ \\
\hline Darlan Dórea & 1942 & Ipirá - Bahia & $\begin{array}{l}\text { Graduação em economia } \\
\text { (UFBA) }\end{array}$ & $\begin{array}{l}\text { Avô paterno negociante de } \\
\text { estiva. Avô materno tabelião } \\
\text { e escrivão. Pai comerciante e } \\
\text { mãe professora primária. }\end{array}$ \\
\hline Júlio Mourão & 1944 & Belo Horizonte - MG & $\begin{array}{lr}\text { Graduação em economia } \\
\text { (FACE-UFMG). } \\
\text { Mestrado em engenharia } \\
\text { de produção } & \text { (COPPE- } \\
\text { UFRJ). } & \text { Doutorado } \\
\text { incompleto } & \text { em } \\
\text { economia } & \text { (IE- } \\
\text { UNICAMP). } & \end{array}$ & $\begin{array}{l}\text { Pai engenheiro fora } \\
\text { secretário do departamento } \\
\text { de viação área da Secretaria } \\
\text { de Viação e Obras Públicas. }\end{array}$ \\
\hline $\begin{array}{l}\text { Marcio João } \\
\text { Andrade Fortes }\end{array}$ & 1944 & Belo Horizonte - MG & $\begin{array}{lrr}\begin{array}{l}\text { Graduação } \\
\text { engenharia }\end{array} & \text { civil } & \text { (PUC- } \\
\end{array}$ & $\begin{array}{l}\text { Família de militares. Avô } \\
\text { paterno, o Tenente-coronel }\end{array}$ \\
\hline
\end{tabular}




\begin{tabular}{|c|c|c|c|c|}
\hline & & & $\begin{array}{l}\text { RJ). Especialização em } \\
\text { engenharia econômica } \\
\text { (UFRJ). Especialização } \\
\text { em elaboração e análise } \\
\text { de projetos habitacionais } \\
\text { (FGV). }\end{array}$ & $\begin{array}{l}\text { Enéas de Carvalho Fortes, } \\
\text { era engenheiro militar e } \\
\text { pertencia ao Estado Maior do } \\
\text { Exército Brasileiro. Avó } \\
\text { paterna Didia Machado } \\
\text { Fortes era professora } \\
\text { primária. Pai João Machado } \\
\text { Fortes, impossibilitado de } \\
\text { seguir carreira militar, cursou } \\
\text { a Faculdade Nacional de } \\
\text { Engenharia e fundou a João } \\
\text { Fortes Engenharia, uma das } \\
\text { maiores construtoras do país. } \\
\text { Mãe Maria Augusta de } \\
\text { Andrade Fortes é professora. }\end{array}$ \\
\hline Ibrahim Eris & 1945 & Bafra - Turquia & $\begin{array}{l}\text { Graduação em economia } \\
\text { (Middle East Technical } \\
\text { University }- \text { Acara). } \\
\text { Doutorado em economia } \\
\text { (Vanderbilt) }\end{array}$ & s.d. \\
\hline $\begin{array}{l}\text { Roberto Timóteo da } \\
\text { Costa }\end{array}$ & 1945 & Niterói - RJ & $\begin{array}{lr}\text { Graduação } & \text { em } \\
\text { Engenharia } & \text { Civil } \\
\text { (Nacional } & \text { de } \\
\text { Engenharia). } & \text { Pós- } \\
\text { graduação } & \text { em } \\
\text { Engenharia } & \text { Econômica } \\
\text { (PUC-RJ). } \\
\text { Especialização em } \\
\text { Administração (London } \\
\text { Business School). }\end{array}$ & $\begin{array}{l}\text { Bisavô paterno, Manuel } \\
\text { Timoteo da Costa, foi } \\
\text { professor catedrático na } \\
\text { Escola Nacional de } \\
\text { Engenharia, e da escola de } \\
\text { Minas e Ouro Preto, e } \\
\text { deputado federal. Avô } \\
\text { paterno. Manuel Timoteo da } \\
\text { Costa Jr era estatístico, } \\
\text { funcionário Ministério da } \\
\text { Fazenda. Pai estudou direito } \\
\text { em Niterói, era estatístico } \\
\text { trabalhou no IBGE e Rede } \\
\text { Ferroviária Federal. Avô } \\
\text { materno fazendeiro de café } \\
\text { no interior do RJ, } \\
\text { posteriormente tornou-se } \\
\text { dono de uma leiteria em } \\
\text { Niterói. Mãe era carioca e } \\
\text { costureira. }\end{array}$ \\
\hline $\begin{array}{ll}\text { José } & \text { Henrique } \\
\text { Couceiro } & \end{array}$ & s.d.-1998 & s.d. & Engenharia (s.d.). & $\begin{array}{l}\text { Pai, médico e dirigente do } \\
\text { CNPQ Antônio Moreira } \\
\text { Couceiro. Mãe Maria Violeta } \\
\text { Carneiro da Cunha, que era } \\
\text { filha do industrial e ex- } \\
\text { governador do Pernambuco } \\
\text { José Henrique Carneiro da } \\
\text { Cunha. }\end{array}$ \\
\hline $\begin{array}{lll}\text { Luís Carlos } & \text { Delben } \\
\text { Leite } & & \end{array}$ & 1945 & Araras - SP & $\begin{array}{l}\text { Graduação em economia } \\
\text { (PUC-SP). }\end{array}$ & $\begin{array}{l}\text { Pai empresário do setor } \\
\text { gráfico. }\end{array}$ \\
\hline Fernando Perrone & 1947 & Rio de Janeiro - RJ & $\begin{array}{l}\text { Graduação em direito } \\
\text { (UFF). Pós-graduação } \\
\text { em economia (FGV-RJ). }\end{array}$ & $\begin{array}{l}\text { Avô paterno da italiano da } \\
\text { Calábria, era alfaiate e a avó } \\
\text { paterna era italiana da } \\
\text { Lucânia. Pai nascido no } \\
\text { interior de São Paulo era } \\
\text { médico formado na } \\
\text { Universidade do Brasil e } \\
\text { professor. Avó materna } \\
\text { portuguesa do Porto e avô } \\
\text { materno brasileiro, } \\
\text { farmacêutico. Mãe carioca, } \\
\text { funcionária federal } \\
\text { concursada. }\end{array}$ \\
\hline $\begin{array}{l}\text { Ney Fontes de Mello } \\
\text { Távora }\end{array}$ & 1947 & Salvador - BA & $\begin{array}{lr}\text { Graduação } & \text { em } \\
\text { engenharia civil } & \text { (PUC- } \\
\text { RJ). Mestrado em } \\
\text { transportes } \\
\text { (Northwestern). }\end{array}$ & $\begin{array}{l}\text { Pai, Edison José de Melo } \\
\text { Távora, era também } \\
\text { engenheiro, fora secretário de } \\
\text { Viação e Obras no Ceará, sua } \\
\text { terra natal, elegendo-se } \\
\text { Deputado Federal sucessivas } \\
\text { vezes e depois diretor da }\end{array}$ \\
\hline
\end{tabular}




\begin{tabular}{|c|c|c|c|c|}
\hline & & & & Petrobrás. \\
\hline Aluysio Asti & 1948 & Rio Grande - RS & $\begin{array}{l}\text { Graduação em direito e } \\
\text { economia (UFRGS). } \\
\text { Pós-graduação } \quad \text { em } \\
\text { economia (UFRGS). }\end{array}$ & $\begin{array}{l}\text { Avôs paterno e materno e pai } \\
\text { gaúchos e comerciantes. Mãe } \\
\text { gaúcha, professora primária. }\end{array}$ \\
\hline Darc Luz da Costa & 1948 & Rio de Janeiro - RJ & $\begin{array}{l}\text { Graduação } \\
\text { Engenharia Civil } \text { (PUC- } \\
\text { RJ). Mestrado em } \\
\text { Engenharia Industrial } \\
\text { (PUC-RJ). Doutorado } \\
\text { em Engenharia de } \\
\text { Produção (UFRJ) }\end{array}$ & $\begin{array}{l}\text { Avô paterno carioca, } \\
\text { vendedor de café. Pai carioca, } \\
\text { engenheiro civil formado na } \\
\text { Escola Nacional de } \\
\text { Engenharia. Dono de } \\
\text { empresas de engenharia. Avô } \\
\text { materno mineiro, advogado, } \\
\text { foi deputado estadual. Mãe } \\
\text { nasceu em Belo Horizonte e } \\
\text { trabalhou como secretária em } \\
\text { empresa privada. }\end{array}$ \\
\hline José Pio Borges & 1948 & Rio de Janeiro - RJ & $\begin{array}{l}\text { Graduação } \\
\text { engenharia civil (PUC- } \\
\text { RJ). Especialização em } \\
\text { engenharia industrial } \\
\text { (PUC-RJ). Mestrado em } \\
\text { economia (New School } \\
\text { Social } \\
\text { Doutorado incompleto } \\
\text { (New School Social } \\
\text { Research). }\end{array}$ & $\begin{array}{l}\text { Pai general e engenheiro e } \\
\text { professor na escola militar. } \\
\text { Avô paterno comerciante, } \\
\text { representante da Lloyds no } \\
\text { Ceará. Descendia do Padre } \\
\text { Amaro, secretário geral da } \\
\text { Confederação do Equador. } \\
\text { Mãe carioca professora com } \\
\text { formação superior. Avô } \\
\text { materno funcionário público. }\end{array}$ \\
\hline Nildemar Secches & 1948 & General Salgado - SP & $\begin{array}{lr}\begin{array}{l}\text { Graduação } \\
\text { engenharia } \\
\text { (EESC-USP)). }\end{array} & \text { em } \\
\text { Especialização } & \text { em } \\
\text { finanças } & \text { (PUC-RJ). } \\
\text { Doutorado incompleto } \\
\text { em economia (IE- } \\
\text { UNICAMP). }\end{array}$ & s.d. \\
\hline Helio Blak & 1949 & Rio de Janeiro - RJ & $\begin{array}{l}\text { Graduação em geologia } \\
\text { (UFRJ). Especialização } \\
\text { em economia dos } \\
\text { recursos Minerais (FGV- } \\
\text { RJ). }\end{array}$ & $\begin{array}{l}\text { Avós paternos imigrantes } \\
\text { ucranianos. Avô trabalhador } \\
\text { rural caseiro, administrava } \\
\text { uma propriedade e tinha } \\
\text { direto de cultivar a terra. } \\
\text { Avós maternos vieram da } \\
\text { Bessarábia. Avô pequeno } \\
\text { comerciante na Bessarábia. } \\
\text { Avó tinha uma pensão no } \\
\text { Rio de Janeiro. Pai nasceu na } \\
\text { Ucrânia, no Brasil tornou-se } \\
\text { comerciante, tinha loja de } \\
\text { móveis. }\end{array}$ \\
\hline $\begin{array}{l}\text { José Mauro Mettrau } \\
\text { Carneiro da Cunha }\end{array}$ & 1949 & Rio de Janeiro - RJ & $\begin{array}{lr}\text { Graduação } & \text { em } \\
\text { engenharia mecânica } \\
\text { (UC Petropolis) } \\
\text { Pós-graduação } \\
\text { engenharia industrial } \\
\text { (UFRJ). Especialização } \\
\text { em } & \text { administração } \\
\text { (UCLA). } & \end{array}$ & $\begin{array}{l}\text { Avô paterno, provavelmente } \\
\text { advogado, de família de } \\
\text { usineiros pernambucanos. Pai } \\
\text { advogado do Ministério da } \\
\text { Aeronáutica. Família da } \\
\text { materna de Nova Friburgo, } \\
\text { avô comerciante. }\end{array}$ \\
\hline $\begin{array}{l}\text { Luiz Aranha Corrêa do } \\
\text { Lago }\end{array}$ & 1950 & s.d. & $\begin{array}{l}\text { Graduação em economia } \\
\text { (IEI-UFRJ). Mestrado } \\
\text { em economia (Duke). } \\
\text { Doutorado em economia } \\
\text { (Harvard). }\end{array}$ & $\begin{array}{l}\text { Pai diplomata Antônio } \\
\text { Correa do Lago. Avô } \\
\text { materno, Ministro da } \\
\text { Fazenda e diplomata Osvaldo } \\
\text { Aranha. Avô paterno major e } \\
\text { adido militar do Brasil na } \\
\text { Bélgica Manoel Corrêa do } \\
\text { Lago }\end{array}$ \\
\hline Sergio Zendron & $1950-2005$ & Blumenau - SC & $\begin{array}{l}\text { Graduação } \\
\text { engenharia civil (UFSC). }\end{array}$ & s.d. \\
\hline Isac Roffé Zagury & 1951 & Rio de Janeiro - RJ & $\begin{array}{l}\text { Graduação em economia } \\
\text { (PUC-RJ). Mestrado em } \\
\text { administração (PUC-RJ). }\end{array}$ & $\begin{array}{l}\text { Avós vieram do Marrocos e } \\
\text { se estabeleceram em Macapá. } \\
\text { Avô paterno comerciante de }\end{array}$ \\
\hline
\end{tabular}




\begin{tabular}{|c|c|c|c|c|}
\hline & & & & $\begin{array}{l}\text { Guaraná e proprietário de } \\
\text { uma concessionária Ford. Pai } \\
\text { nasceu em Macapá, fez } \\
\text { Medicina na Universidade } \\
\text { Federal Fluminense, atuou } \\
\text { como pediatra. }\end{array}$ \\
\hline José Luís Osório & 1951 & Rio de Janeiro - RJ & $\begin{array}{l}\text { Graduação } r \\
\text { engenharia civil (PUC- } \\
\text { RJ). Pós-graduação em } \\
\text { engenharia de } \\
\text { transportes (Stanford). }\end{array}$ & $\begin{array}{l}\text { Avo paterno português, } \\
\text { tornou-se caixeiro viajante na } \\
\text { região de Minas. Avó paterna } \\
\text { mineira da família do } \\
\text { Presidente Afonso Pena. } \\
\text { Avós maternos mineiros. O } \\
\text { avô foi dono da maior } \\
\text { empresa de Engenharia que o } \\
\text { Brasil teve nos anos } 30 \text {. Pai } \\
\text { mineiro, dentista formado na } \\
\text { UFRJ. }\end{array}$ \\
\hline $\begin{array}{ll}\text { Mauricio } & \text { Borges } \\
\text { Lemos } & \end{array}$ & 1951 & Cássia - MG & $\begin{array}{l}\text { Graduação em economia } \\
\text { (UFMG). Mestrado em } \\
\text { economia (UNICAMP). } \\
\text { Doutorado em economia } \\
\text { (UNICAMP) }\end{array}$ & $\begin{array}{l}\text { Avós paternos de famílias de } \\
\text { fazendeiros e criadores de } \\
\text { gado. Pai nasceu em Minas, } \\
\text { era fazendeiro, foi chefe do } \\
\text { INCRA e tardiamente } \\
\text { estudou direito em Goiânia. } \\
\text { Avô materno médico } \\
\text { paraibano, formado na } \\
\text { Universidade do Brasil. Avó } \\
\text { materna filha de fazendeiros } \\
\text { mineiros. Mãe mineira, } \\
\text { regente do coral da Igreja de } \\
\text { Santa Rita. }\end{array}$ \\
\hline $\begin{array}{ll}\text { Eduardo } & \text { Marco } \\
\text { Modiano } & \end{array}$ & 1952 & Rio de Janeiro - RJ & 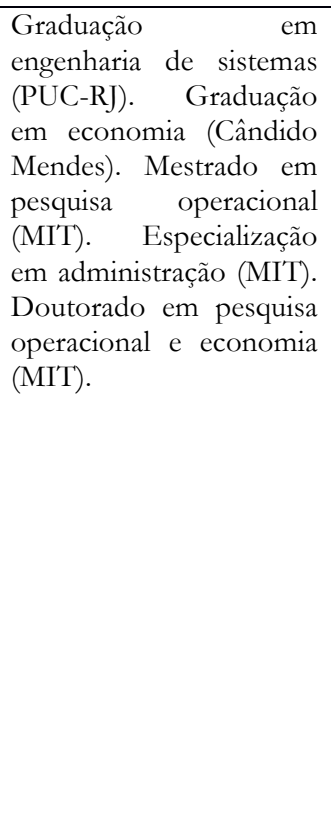 & $\begin{array}{l}\text { Pai Umberto Modiano, } \\
\text { italiano nascido na França, } \\
\text { chegou ao Brasil, em } 1947 \text { e } \\
\text { passou a trabalhar com } \\
\text { exportação e importação de } \\
\text { alimentos e café. Nos anos } \\
\text { 1960, foi dono companhia da } \\
\text { Ouro Fino, que tornou-se a } \\
\text { maior exportadora de café. } \\
\text { Dos anos } 1970 \text { aos } 1990 \text {, } \\
\text { instaurou } 22 \text { processos } \\
\text { contra o governo, no maior } \\
\text { deles chegou a receber } 50 \\
\text { milhões de dólares de uma só } \\
\text { vez. Simultaneamente, } \\
\text { engajou-se em } \\
\text { empreendimentos região de } \\
\text { imobiliários na ran } \\
\text { Búzios, conduzidos por sua a } \\
\text { empresa Rural e Colonização. } \\
\text { Mãe, Liliane, era médica } \\
\text { diretora da empresa } \\
\text { farmacêutica Labonobel. }\end{array}$ \\
\hline $\begin{array}{ll}\text { Gustavo } & \text { Jorge } \\
\text { Laboissière Loyola }\end{array}$ & 1952 & Goiânia - GO & $\begin{array}{l}\text { Graduação em economia } \\
\text { (UNB). Doutorado em } \\
\text { economia (EPGE). }\end{array}$ & $\begin{array}{l}\text { Pai advogado Cleomar de } \\
\text { Barros Loyola, que foi } \\
\text { procurador-geral do Estado, } \\
\text { e presidiu a OAB de Goiás. } \\
\text { Gustavo é sobrinho do } \\
\text { desembargador Clenon de } \\
\text { Barros Loyola, ex-presidente } \\
\text { do Tribunal de Justiça de } \\
\text { Goiânia. }\end{array}$ \\
\hline Eduardo Rath Fingerl & 1953 & Rio de Janeiro - RJ & $\begin{array}{l}\text { Graduação em } \\
\text { engenharia de produção } \\
\text { (UFRJ). Mestrado em } \\
\text { engenharia de produção } \\
\text { (UFRJ). }\end{array}$ & $\begin{array}{l}\text { Avô paterno nascido no } \\
\text { Leste Europeu, rabino, Avó } \\
\text { paterna da Bessarábia. Avós } \\
\text { maternos poloneses. Avô } \\
\text { tinha indústria de chapéus e } \\
\text { bonés no Rio de Janeiro. Pai } \\
\text { austríaco, nascido em Viena. } \\
\text { Veio para Recife, formou-se }\end{array}$ \\
\hline
\end{tabular}




\begin{tabular}{|c|c|c|c|c|}
\hline & & & & $\begin{array}{l}\text { engenheiro na Federal de } \\
\text { Pernambuco e trabalhava } \\
\text { com cálculo estrutural. }\end{array}$ \\
\hline $\begin{array}{l}\text { Zélia Maria Cardoso } \\
\text { de Mello }\end{array}$ & 1953 & São Paulo - SP & $\begin{array}{l}\text { Graduação em economia } \\
\text { (FEA-USP). Doutorado } \\
\text { em economia (FEA- } \\
\text { USP). }\end{array}$ & $\begin{array}{l}\text { A família de Zélia Cardoso } \\
\text { de Mello faz parte da elite } \\
\text { jurídica e política paulista. } \\
\text { Avô paterno, depois de } \\
\text { bacharelar-se em Direito, } \\
\text { advogou em Jaboticabal e } \\
\text { São Paulo e foi Pretor e Juiz } \\
\text { de Órfãos no Distrito } \\
\text { Federal. Casou-se com Maria } \\
\text { Suzana Machado, irmã de } \\
\text { José Alcântara Machado, } \\
\text { escritor e jurista e filha de } \\
\text { Brasílio Augusto Machado de } \\
\text { Oliveira, também advogado, } \\
\text { professor de direito e político } \\
\text { que ocupou a presidência da } \\
\text { província do Paraná. O pai } \\
\text { de Zélia, Emiliano Cardoso } \\
\text { de Mello, era advogado e } \\
\text { fizera carreira na polícia, } \\
\text { tornando-se delegado do } \\
\text { DOPS. Casou-se com uma } \\
\text { italiana. }\end{array}$ \\
\hline Luiz Orenstein & 1954 & Rio de Janeiro - RJ & $\begin{array}{l}\text { Graduação em } \\
\text { engenharia de produção } \\
\text { (UFRJ). Mestrado em } \\
\text { economia de produção } \\
\text { (UFRJ). Doutorado em } \\
\text { ciência politica e relações } \\
\text { internacionais } \\
\text { (IUPERJ/UCSD). }\end{array}$ & $\begin{array}{l}\text { Avós poloneses. Avô } \\
\text { materno teve empregos } \\
\text { esporádicos no comércio. } \\
\text { Avó materna costureira. Avô } \\
\text { paterno trabalhava na } \\
\text { construção civil. Pai carioca, } \\
\text { vendedor em lojas de móveis. } \\
\text { Mãe carioca, foi secretária em } \\
\text { empresas privadas. }\end{array}$ \\
\hline Eduardo Bunker & 1955 & São Paulo - SP & $\begin{array}{l}\text { Graduação em história e } \\
\text { economia (Princeton). } \\
\text { Especialização em } \\
\text { administração (NYU). }\end{array}$ & $\begin{array}{l}\text { Avô paterno homem de } \\
\text { negócios em Fortaleza, } \\
\text { estudou na Europa. Mãe } \\
\text { americana, fez secretariado. } \\
\text { Pai cearense, médico } \\
\text { cirurgião formado na } \\
\text { Universidade do Brasil, com } \\
\text { residência em Nova York. } \\
\text { Avô materno de nova } \\
\text { iorquino, economista } \\
\text { formado em Yale, empresário } \\
\text { do setor de açúcar e álcool e } \\
\text { embaixador. Avó materna } \\
\text { nova iorquina, fez } \\
\text { universidade para mulheres } \\
\text { na costa leste. }\end{array}$ \\
\hline Beatriz Azeredo & 1956 & Rio de Janeiro - RJ & $\begin{array}{l}\text { Graduação em economia } \\
\text { (UCM). Mestrado em } \\
\text { economia (IEI-UFRJ). } \\
\text { Doutorado em economia } \\
\text { na (IEI-UFRJ). }\end{array}$ & $\begin{array}{l}\text { Avô materno fluminense, } \\
\text { trabalhava comerciante em } \\
\text { Macaé, Niterói, Campos. Avô } \\
\text { paterno médico do Exército. } \\
\text { Pai nasceu em Campo } \\
\text { Grande, era militar, foi da } \\
\text { academia de Agulhas Negras } \\
\text { e comandante do forte São } \\
\text { João. Mãe carioca, professora } \\
\text { de educação física. }\end{array}$ \\
\hline Gustavo Franco & 1956 & Rio de Janeiro - RJ & $\begin{array}{l}\text { Graduação em economia } \\
\text { (PUC-RJ). Mestrado em } \\
\text { economia (PUC-RJ). } \\
\text { Doutorado em economia } \\
\text { (Harvard). }\end{array}$ & $\begin{array}{l}\text { Pai Guilherme Arinos Lima } \\
\text { Verde de Barroso Franco, } \\
\text { nascido no interior do } \\
\text { Amazonas. Avô paterno } \\
\text { faleceu precocemente. Avó } \\
\text { paterna trabalhava como } \\
\text { professora primária. No } \\
\text { início dos anos 1930, }\end{array}$ \\
\hline
\end{tabular}




\begin{tabular}{|c|c|c|c|c|}
\hline & & & & $\begin{array}{l}\text { Guilherme Arinos tornou-se } \\
\text { funcionário concursado do } \\
\text { Banco do Brasil. } \\
\text { Especializou-se na área } \\
\text { cambial e foi convidado para } \\
\text { ser chefe-de-gabinete dos } \\
\text { Ministros da Fazenda Gastão } \\
\text { Vidigal e Horácio Lafer. } \\
\text { Ademais, tornou-se assessor } \\
\text { direto do Presidente Vargas e } \\
\text { foi indicado para o primeiro } \\
\text { Conselho de Administração } \\
\text { do BNDES. Depois da } \\
\text { morte de Vargas, Guilherme } \\
\text { Barroso Franco foi diretor do } \\
\text { grupo industrial Monteiro } \\
\text { Aranha e sócio de Jorge } \\
\text { Paulo Lemann na compra da } \\
\text { corretora Garantia, que deu } \\
\text { origem, em 1976, ao Banco } \\
\text { Garantia. Deste modo } \\
\text { acumulou considerável } \\
\text { patrimônio financeiro ao } \\
\text { longo de sua vida. A mãe de } \\
\text { Gustavo era Maria Isabel } \\
\text { Ottoni Guedes Barbosa, } \\
\text { descendente de prestigiosas } \\
\text { famílias Mineiras. }\end{array}$ \\
\hline Edward Amadeo & 1956 & Rio de Janeiro - RJ & $\begin{array}{l}\text { Graduação em economia } \\
\text { (PUC-RJ). Mestrado em } \\
\text { economia (IEI-UFRJ). } \\
\text { Doutorado em economia } \\
\text { (Harvard). }\end{array}$ & $\begin{array}{l}\text { Mãe belga. Pai, Joaquin } \\
\text { Jacinto Amadeo era } \\
\text { americano nascido em } \\
\text { Guantánamo. Na época em } \\
\text { que chegou ao Brasil era } \\
\text { guarda-livros. Anos depois } \\
\text { fundou a primeira fábrica de } \\
\text { bebidas Bacardi do Brasil, } \\
\text { localizada em Recife. }\end{array}$ \\
\hline $\begin{array}{lll}\text { Luiz } & \text { Paulo } & \text { Vellozo } \\
\text { Lucas } & & \end{array}$ & 1956 & Vitória - ES & $\begin{array}{lr}\text { Graduação } & \text { em } \\
\text { engenharia } & \text { (UFRJ). } \\
\text { Especialização } & \text { em } \\
\text { engenharia } & \text { industrial } \\
\text { (UFRJ). } & \end{array}$ & $\begin{array}{l}\text { Pai dentista formado em } \\
\text { ortodontia e direito na } \\
\text { Federal do Espirito Santos, } \\
\text { foi professor universitário e } \\
\text { atuou no hospital dos } \\
\text { funcionários públicos. Mãe } \\
\text { administradora de empresas e } \\
\text { foi funcionaria do IAPI e do } \\
\text { INSS antes de entrar na } \\
\text { política. Começou chefiando } \\
\text { a Casa Civil e a Secretaria de } \\
\text { Educação e Cultura do } \\
\text { governo do Espírito Santo } \\
\text { nos anos } 1970 \text {. De } 1979 \text { a } \\
\text { 2000 fez parte do Tribunal de } \\
\text { Contas do Espírito Santo. Na } \\
\text { sequencia Ingressou no } \\
\text { PSDB e foi eleita Deputada } \\
\text { Federal. }\end{array}$ \\
\hline $\begin{array}{ll}\text { Maria Silvia } & \text { Bastos } \\
\text { Marques } & \end{array}$ & 1956 & $\begin{array}{lr}\text { Bom Jesus } & \text { de } \\
\text { Itabapoana - RJ }\end{array}$ & $\begin{array}{lr}\text { Graduação } & \text { em } \\
\text { administração (EBAP- } \\
\text { FGV). Mestrado em } \\
\text { economia (FGV-RJ). } \\
\text { Doutorado em economia } \\
\text { (FGV-RJ). }\end{array}$ & $\begin{array}{l}\text { Pai médico no interior. Mãe } \\
\text { pianista. }\end{array}$ \\
\hline Sergio Werlang & 1956 & Rio de Janeiro - RJ & $\begin{array}{lr}\begin{array}{lr}\text { Graduação } \\
\text { engenharia }\end{array} & \mathrm{em} \\
\text { Especialização } & (\mathrm{UFRJ}) . \\
\text { economia } & \mathrm{em} \\
\text { Pós-graduação } & \text { (FGV-RJ). } \\
\text { matemática } & \text { (IMPA). } \\
\begin{array}{l}\text { Doutorado em } \\
\text { (Princeton). }\end{array} & \text { economia } \\
\end{array}$ & s.d. \\
\hline
\end{tabular}




\begin{tabular}{|c|c|c|c|c|}
\hline Armínio Fraga Neto & 1957 & Rio de Janeiro - RJ & $\begin{array}{l}\text { Graduação em economia } \\
\text { (PUC-RJ). Mestrado em } \\
\text { economia (PUC-RJ). } \\
\text { Doutorado em economia } \\
\text { (Princeton). }\end{array}$ & $\begin{array}{l}\text { Os avós paternos } \\
\text { nordestinos. Avô paterno, } \\
\text { Armínio Fraga, era um } \\
\text { médico baiano que recebeu } \\
\text { uma bolsa da Fundação } \\
\text { Rockefeller para fazer uma } \\
\text { especialização nos Estados } \\
\text { Unidos e tornou-se } \\
\text { conhecido dermatologista e } \\
\text { professor da Faculdade de } \\
\text { Medicina da Universidade do } \\
\text { Brasil (UB). Casou-se com } \\
\text { Leopoldina de Souza Leão } \\
\text { Fraga, neta de Antônio de } \\
\text { Souza Leão, o Barão de } \\
\text { Morenos, de uma larga } \\
\text { família proprietária de } \\
\text { engenhos em Pernambuco. } \\
\text { O pai, Sylvio Fraga, formou- } \\
\text { se em medicina na UB. Fez a } \\
\text { residência na Filadélfia, onde } \\
\text { especializou-se erem } \\
\text { dermatologia, e tornou-se } \\
\text { livre-docente da UFRJ e } \\
\text { depois da PUC-RJ. Nos } \\
\text { Estados Unidos, conheceu e } \\
\text { casou-se com Margareth Ann } \\
\text { Breslin, enfermeira e e } \\
\text { professora de enfermagem } \\
\text { que era descendente de } \\
\text { irlandeses. }\end{array}$ \\
\hline $\begin{array}{l}\text { Carlos Ivan Simonsen } \\
\text { Leal }\end{array}$ & 1957 & Rio de Janeiro - RJ & $\begin{array}{lr}\begin{array}{lr}\text { Graduação } \\
\text { engenharia }\end{array} & \text { em } \\
\text { Especialização } & \text { (UFRJ). } \\
\text { economia } & \text { (FGV-RJ). } \\
\text { Pós-graduação } & \mathrm{em} \\
\text { matemática } & \text { (IMPA). } \\
\begin{array}{l}\text { Doutorado em } \\
\text { (Princeton). }\end{array}\end{array}$ & $\begin{array}{l}\text { Pai advogado. Sobrinho de } \\
\text { Mário Henrique Simonsen. }\end{array}$ \\
\hline $\begin{array}{l}\text { Eleazar de Carvalho } \\
\text { Filho }\end{array}$ & 1957 & São Paulo - SP & $\begin{array}{lr}\text { Graduação } & \text { em } \\
\text { Economia } & \text { (NYU). } \\
\text { Mestrado em } & \text { Relações } \\
\text { Internacionais } & \text { (Johns } \\
\text { Hopkins). } & \end{array}$ & $\begin{array}{l}\text { Avô paterno capitão da } \\
\text { polícia militar cearense. Avô } \\
\text { materno advogado e } \\
\text { fazendeiro } \\
\text { casado com } \text { paranaense, } \\
\text { integrante da Acritora, } \\
\text { Paranaense de Letras. Mãe } \\
\text { pianista e compositora } \\
\text { curitibana Jocy de Oliveira, } \\
\text { que estudou no conservatório } \\
\text { de Paris e fez mestrado na } \\
\text { Washington University em } \\
\text { Saint-Louis. Pai regente } \\
\text { Eleazar de Carvalho, fez } \\
\text { graduação em música na } \\
\text { Universidade do Brasil e } \\
\text { doutorado na Washington } \\
\text { University. Regeu diversas } \\
\text { orquestras no Brasil e no } \\
\text { exterior e lecionou em } \\
\text { diversas universidades norte- } \\
\text { americanas. }\end{array}$ \\
\hline Paulo Hartung & 1957 & Guaçuí - ES & $\begin{array}{l}\text { Graduação em economia } \\
\text { (UFES). }\end{array}$ & $\begin{array}{l}\text { Avós paternos pequenos } \\
\text { produtores rurais no Espírito } \\
\text { Santo. Avô materno de } \\
\text { família gaúcha, foi operário } \\
\text { da CSN. Pai capixaba, } \\
\text { estudou contabilidade na } \\
\text { escola de comércio e teve loja } \\
\text { e fábrica de móveis e } \\
\text { colchões, depois teve uma }\end{array}$ \\
\hline
\end{tabular}




\begin{tabular}{|c|c|c|c|c|}
\hline & & & & pequena construtora. \\
\hline Sergio Besserman & 1957 & Rio de Janeiro - RJ & $\begin{array}{l}\text { Graduação em economia } \\
\text { (PUC-RJ). Mestrado em } \\
\text { economia (PUC-RJ) }\end{array}$ & $\begin{array}{l}\text { Bisavô, coronel } \text { Alziro } \\
\text { Vianna, foi primeiro diretor } \\
\text { de contabilidade e depois } \\
\text { secretário principal da } \\
\text { Secretaria das Finanças de } \\
\text { Vitória, tornando-se uma } \\
\text { figura proeminente da } \\
\text { política do Espírito Santo. } \\
\text { Avô Ary de Siqueira, } \\
\text { começou a trabalhar como } \\
\text { caixeiro viajante e depois } \\
\text { tornou-se contador e } \\
\text { funcionário público. Foi feito } \\
\text { inspetor geral da Fazenda, } \\
\text { depois diretor da Receita } \\
\text { Pública e diretor-geral dos } \\
\text { departamentos das } \\
\text { Municipalidades e do Serviço } \\
\text { Público do Espírito Santo. } \\
\text { Em 1944, foi nomeado por } \\
\text { Getúlio Vargas prefeito de } \\
\text { Cachoeiro do Itapemirim, a } \\
\text { segunda maior cidade do } \\
\text { Espírito Santo, e na } \\
\text { sequência foi eleito } \\
\text { Deputado Federal e depois } \\
\text { Senador pelo PSD. Pai } \\
\text { médico formado na } \\
\text { Universidade do Brasil, irmão } \\
\text { de Marcos Pereira Vianna, } \\
\text { presidente do BNDES nos } \\
\text { anos 1970. Avô materno de } \\
\text { Krasnik, Polônia, } \\
\text { comerciante, de tapetes, } \\
\text { bolsas e joias. Avó materna } \\
\text { alemã. Mãe médica formada } \\
\text { na Universidade do Brasil e } \\
\text { psicanalista. }\end{array}$ \\
\hline Elena Landau & 1958 & Rio de Janeiro - RJ & $\begin{array}{l}\text { Graduação em economia } \\
\text { (PUC-RJ). Mestrado em } \\
\text { economia (PUC-RJ). } \\
\text { Doutorado incompleto } \\
\text { em economia (MIT). }\end{array}$ & $\begin{array}{l}\text { O pai e os avós paternos } \\
\text { eram judeus romenos de } \\
\text { Bucareste que vieram para o } \\
\text { Brasil em 1939. O avô havia } \\
\text { sido industrial na Romênia. } \\
\text { O pai seguiu, no Brasil, o } \\
\text { mesmo caminho. Estudou } \\
\text { engenharia em Itajubá e } \\
\text { passou a atuar em grandes } \\
\text { obras no siderúrgico tendo, } \\
\text { trabalhado na Vale do Rio } \\
\text { Doce e na Metropolitana } \\
\text { Engenharia. A família } \\
\text { materna de Elena era } \\
\text { brasileira, o avô um militar de } \\
\text { alta patente nascido no Rio } \\
\text { de Janeiro. A avó } \\
\text { maranhense. Sua mãe, antes } \\
\text { de tornar-se estilista, havia } \\
\text { iniciado a faculdade de } \\
\text { Matemática. }\end{array}$ \\
\hline $\begin{array}{ll}\text { Octavio } & \text { Castello } \\
\text { Branco } & \end{array}$ & 1958 & São Paulo - SP & $\begin{array}{l}\text { Graduação } \\
\text { engenharia de produção } \\
\text { (POLI-USP) }\end{array}$ & $\begin{array}{l}\text { Avô paterno cearense, } \\
\text { advogado, estabeleceu-se em } \\
\text { Limeira, cidade da qual foi } \\
\text { prefeito. Avó paterna família } \\
\text { tradicional do Vale do } \\
\text { Paraíba, os Moreira Cesar. } \\
\text { Pai nascido em Limeira, } \\
\text { advogado formado na FD- } \\
\text { USP, foi prefeito, deputado }\end{array}$ \\
\hline
\end{tabular}




\begin{tabular}{|c|c|c|c|c|}
\hline & & & & $\begin{array}{l}\text { estadual e trabalhou no } \\
\text { mercado financeiro. Avô } \\
\text { materno advogado gaúcho. } \\
\text { Avó materna paulistana filha } \\
\text { do jurista Waldemar Ferreira } \\
\text { que foi ministro da justiça. }\end{array}$ \\
\hline Wallim Vasconcelos & 1958 & Rio de Janeiro - RJ & 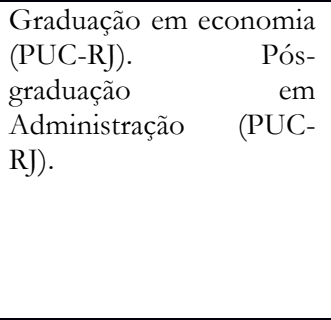 & $\begin{array}{l}\text { Avô paterno amazonense. } \\
\text { Bisavô materno primeiro } \\
\text { reitor da UFMG. Pai militar e } \\
\text { industrial do setor de pisos e } \\
\text { revestimentos, nascido em } \\
\text { Manaus. Avô materno } \\
\text { advogado mineiro, Álvaro } \\
\text { Mendes Pimentel. Mãe } \\
\text { mineira formada em letras. }\end{array}$ \\
\hline Laura Passos & 1959 & Rio de Janeiro - RJ & $\begin{array}{l}\text { Graduação em economia } \\
\text { (PUC-RJ). Mestrado em } \\
\text { economia (PUC-RJ) }\end{array}$ & $\begin{array}{l}\text { Avós paternos portugueses, } \\
\text { avó tinha um restaurante no } \\
\text { centro do Rio. Avô materno } \\
\text { baiano, era militar. Avó } \\
\text { materna trabalhava nos } \\
\text { Correios. Mãe baiana e pai } \\
\text { carioca, trabalhavam na IBM. }\end{array}$ \\
\hline Luiz Eduardo Melin & 1962 & Rio de Janeiro - RJ & $\begin{array}{l}\text { Graduação em economia } \\
\text { (PUC-RJ). Mestrado em } \\
\text { direito e relações } \\
\text { internacionais (PUC-RJ). } \\
\text { Doutorado em economia } \\
\text { (Essex) }\end{array}$ & $\begin{array}{l}\text { Avô paterno brasileiro, } \\
\text { nascido em Rezende, em } \\
\text { família de cafeicultores, } \\
\text { advogado pela Universidade } \\
\text { do Brasil, proprietário de } \\
\text { terras, vereador, prefeito, } \\
\text { deputado. Avô materno } \\
\text { nascido em Belém, jornalista } \\
\text { e publicitário. Bisavô } \\
\text { materno francês, vendedor } \\
\text { de artigos femininos } \\
\text { franceses. Avó materna } \\
\text { francesa, licenciada em } \\
\text { história, foi professora nos } \\
\text { colégios Pedro II e Sion. Pai } \\
\text { nasceu em Niterói, foi oficial } \\
\text { da Marinha, professor da } \\
\text { escola naval, adido naval em } \\
\text { Londres, fez mestrado em } \\
\text { matemática e lecionou na } \\
\text { UFRJ. Mãe carioca, } \\
\text { normalista. }\end{array}$ \\
\hline
\end{tabular}

Tabela XIX: Trajetórias das principais personagens do Quarto Movimento. Elaboração: própria.

\subsection{Rede do Quarto Movimento}

A rede do Quarto Movimento refere-se ao período 1990-2003, sendo nela contemplados os governos Fernando Collor, Itamar Franco, Fernando Henrique Cardoso I e II e o início do governo Luiz Inácio Lula da Silva. Como o capítulo, a rede é centrada no BNDES, sendo destacadas as conexões que dão origem a cada uma das presidências do Banco no período. A análise da rede centra-se, portanto, na descrição e caracterização das posições no espaço de cada um dos governos, assinalados por circunferências, e gestões, destacadas por retângulos. 
A forma final da rede espelha, em linhas gerais, a estrutura de polarizações entre correntes de pensamento econômico e escolas de economia encontradas ao final do Terceiro Movimento, sendo utilizada como guia a mesma escala da rede anterior. Ela percorre o eixo que vai da ortodoxia matematizada da Fundação Getúlio Vargas, embaixo, que passa a contar em seus quadros, inclusive, com pessoas formadas em matemática e especialistas em teoria dos jogos, passando sequencialmente pela UNB, PUC-RJ, FACE-UFMG, FEA-USP, PUC-SP e IEI-UFRJ até chegar à UNICAMP no topo da escala. Em apenas dois casos invertem-se as posições: a PUC-SP troca de lugar com a UFRJ e a UNB move-se para baixo da PUC-RJ. A EAESP perde destaque, visto ter a maior parte dos seus professores afastada da gestão pública nesse momento. Desaparecem da rede, nesse momento, tanto o antigo monetarismo da Fundação Getúlio Vagas quanto o desenvolvimentismo nacionalista, originalmente associado à Assessoria Vargas e ao Clube dos Economistas, não sendo mais tais classificações centrais para descrever a rede no período. Em seu lugar, são identificadas aglomerações de "Liberaisdesenvolvimentistas", "Neoliberais" e "Não liberais-desenvolvimentistas", delineando um triângulo no espaço.

Seguindo a cronologia, verifica-se que o governo Collor aparece muito próximo à FEA-USP, na parte do plano em que se encontra o núcleo paulista, visto ter sido a maior parte da equipe de Zélia Cardoso de Mello recrutada entre seus antigos colegas de faculdade, diversos dos quais vinculados também à UNICAMP e à PUC-SP. Os elos com essas escolas, que estão na parte superior do plano, são contrabalanceados por vínculos com economistas das escolas cariocas mais próximas da ortodoxia, tais como Maria Silvia Bastos Marques, Sergio Werlang e Eduardo Marco Modiano, presidente do BNDES durante todo o governo Collor. Dos presidentes do Banco, Modiano é o que aparece mais próximo ao extremo inferior do espaço e à FGV-RJ, estando entre a ortodoxia matematizada e a heterodoxia matematizada, ponto do plano caracterizado como neoliberal e área na qual figura a maior parte daqueles que estudaram em universidades estadunidenses.

O governo seguinte, de Itamar Franco, guarda características semelhantes àquelas da gestão de José Sarney, representada na rede anterior, estando posicionado ao centro, em meio a economistas advindos das várias regiões do país, com destaque para Minas Gerais, seu estado de origem e principal ponto de apoio no governo. A gestão aparece 
também em posição intermediária no que concerne à orientação econômica, expressão da participação nas equipes governamentais de membros das três diferentes correntes representadas no plano. O primeiro presidente do BNDES em seu governo, Antonio Barros de Castro, figura ao centro do núcleo não-liberal-desenvolvimentista, próximo da UFRJ e da UNICAMP e, no exterior, da Inglaterra, país no qual ele e vários daqueles que lhe eram próximos circularam. O segundo presidente do Banco no governo Itamar, Delben Leite, é o ponto de menor destaque na rede, visto não ter laços com o universo acadêmico. Persio Arida, ainda que tenha sido presidente durante o governo Itamar, aparece na rede como parte do grupo de colaboradores de Fernando Henrique Cardoso, figurando entre aqueles que compõem o grupo neoliberal e estando próximo da área que concentra os que tiveram trajetórias marcadas pela circulação entre o Estado, a academia e o mercado financeiro. A diretoria, em sua gestão, foi composta por funcionários de carreira do BNDES com trajetórias concentradas no Estado e por acadêmicos, quase todos ligados à PUC-RJ, escola na qual Arida lecionou e da qual aparece mais próximo na rede.

O governo Fernando Henrique Cardoso aparece, conforme exposto ao longo do capítulo, em meio a duas correntes, os liberais-desenvolvimentistas, centrados na JUC/AP, grupo predominantemente paulista e localizado entre a FEA-USP e a UNICAMP; e os neoliberais, grupo predominantemente carioca e próximo à PUC-RJ.

Edmar Bacha, o primeiro presidente do BNDES no governo FHC, faz parte do grupo neoliberal, figurando na metade inferior do espaço, entre Eduardo Modiano e Persio Arida, e próximo aos cariocas com circulação pelos EUA e pela PUC-RJ, escola onde também ele lecionou. Ainda que não tenha laços com o mercado financeiro, Bacha conserva grande multiposicionalidade, graças ao número de conexões com escolas de economia e com economistas mais jovens, com os quais interagiu seja em Cambridge nos EUA, seja na UNB, seja na PUC-RJ. A estrutura de trajetórias dos membros de sua diretoria (Tabela VII) é semelhante à de Arida, reduzindo-se um pouco o número de acadêmicos e elevando-se a proporção dos que tiveram passagem pelo setor privado.

Seu sucessor, Luiz Carlos Mendonça de Barros, aparece em posição oposta, na metade superior do plano, no fulcro do nucleo liberal-desenvolvimentista, em meio aos paulistas, tendo conexões com a JUC/AP, com a UNICAMP, com professores da FEAUSP e com o grupo de exilados. Luiz Carlos mantinha, igualmente, laços com o mercado 
financeiro, no qual trabalhou por muitos anos. Sua diretoria (Tabela VII), em contrapartida, não era, como ele, especialmente ligada ao setor privado, prevalecendo nitidamente aqueles que tiveram trajetórias no Estado, grupo que cresceu em detrimento dos que passaram mais tempo na academia.

André Lara Resende, por sua vez, é um dos economistas com maior número de conexões na rede pela multiplicidade de seus laços, facilitada por ter uma trajetória que combina passagens pelo Estado, pelo mercado e pela academia e por sua circulação entre São Paulo e Rio de Janeiro. Ele figura em meio aos cariocas, entre o grupo acadêmico ligado à PUC-RJ e os profissionais do mercado financeiro, estando mais próximo ao funcionalismo de carreira do Banco do que seus antecessores. Sua diretoria (Tabela VII) espelha essa aproximação, sendo aquela na qual há maior incidência de pessoas com trajetórias de Estado e declinando uma vez mais o número de anos das trajetórias dos diretores passados na academia.

O sucessor, José Pio Borges, foi o segundo funcionário de carreira do BNDES que conquista a presidência do órgão. Ele figura entre os cariocas, em posição intermediária entre o Banco e o mercado financeiro, do qual se aproximou devido aos vínculos forjados nos anos em que esteve afastado do BNDES para trabalhar na iniciativa privada. Sua gestão (Tabela VII) tem uma composição similar àquela de André Lara Resende, mormente por ser uma continuidade e terem sido mantidos quase todos os dirigentes do período anterior, , havendo, não obstante, uma redução na quantidade de diretores ligados à academia.

O segundo governo de Fernando Henrique Cardoso ensaia fortalecer o grupo liberal-desenvolvimentista, trazendo para o MDIC Clóvis Carvalho, que figura próximo de José Serra e Mendonça de Barros na rede. Andrea Calabi, também situado no polo liberal-desenvolvimentista, foi escolhido por Carvalho para o BNDES. Quando Alcídes Tápias, que está no grupo oposto, próximo ao mercado financeiro e aos cariocas, torna-se ministro, opta por substituir Calabi por um amigo financista, Francisco Gros. As gestões de Gros e de seu sucessor Eleazar de Carvalho, também ligado ao mercado de capitais, recrutam cada vez maior proporção das trajetórias percorridas na iniciativa privada (Tabela VII), notavelmente nas finanças, área do Banco que pretendiam fortalecer, estando a maior parte dos diretores de suas gestões na parte inferior da rede, na qual está presente o 
mercado financeiro, o neoliberalismo e as conexões com os Estados Unidos, visíveis em muitas das trajetórias dos dirigentes do período.

Finalmente, a transição para o governo de Luiz Inácio Lula da Silva distancia o BNDES da rivalidade entre liberais-desenvolvimentistas e neoliberais, posicionando-o na área oposta, a dos não-liberais-desenvolvimentistas, em ponto próximo à UNICAMP, à UFRJ e à circulação pela América Latina e Inglaterra, com maior parcela das trajetórias dos dirigentes sendo percorridas nos universos da academia e do serviço público do que do mercado (Tabela VII). Conforme sugerido ao final do Quarto Movimento, nas gestões seguintes do governo Lula, será possível encontrar uma síntese dos modelos precedentes (Tabela VII), com uma mescla mais equitativa entre os tipos de trajetórias, ainda que com menor proporção daqueles que fizeram suas carreiras no setor privado. Já as escolas às quais os dirigentes estão ligados e os países pelos quais circularam internacionalmente permanecem os mesmos, sendo acrescidos laços com a FEA-USP e a PUC-SP, aumentando a incidência de paulistas na diretoria. Finalmente, as gestões do BNDES no governo Lula residem todas na área ocupada pelos não-liberais-desenvolvimentistas, diferenciando-se, em termos de afinidades teóricas e políticas e de vínculos sociais, dos dois agrupamentos visíveis nos governos Fernando Henrique. 


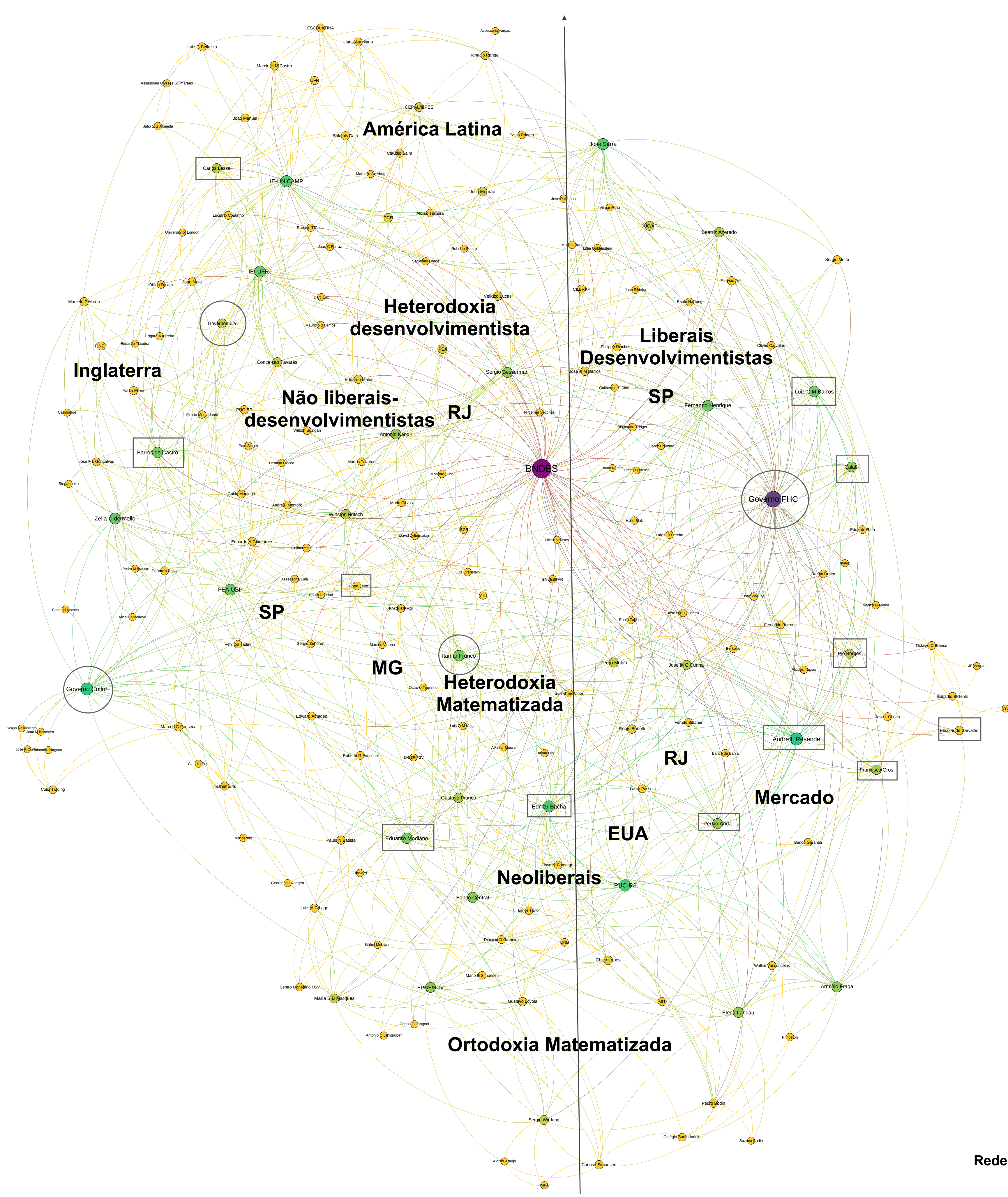




\section{FINALE ${ }^{565}$}

Ao longo dos capítulos foram apresentados dados proposopográficos elementares, data e cidade de nascimento, gênero, origem social e formação escolar dos principais agentes abordados na tese, que são organizados de maneira sintética na tabela abaixo. Trata-se, nesta seção final do trabalho, de sintetizar as transições geracionais e os fracionamentos nas propriedades sociais observáveis a cada momento e, em seguida, de apresentar as disposições sociais que estão na origem da coesão social que forma o substrato comum do espaço dos economistas no país.

A geração dos economistas práticos (LOUREIRO, 1997a) era proveniente, via de regra, de famílias brasileiras de elite, descendentes de políticos, profissionais liberais de prestígio, estancieiros, donos de grandes negócios de importação e exportação e militares de alta extração, entre os quais, por exemplo, Francisco Antunes Maciel, Octavio Bulhões, Luiz Simões Lopes, Lucas Lopes, Miguel Osório de Almeida e Octavio Dias Carneiro. As famílias estrangeiras do período, casos de Eugênio Gudin, Roberto Simonsen, Casimiro Ribeiro e Alexandre Kafka, eram, via de regra, abastadas, cultivadas e cosmopolitas.

Os primeiros especialistas em economia pertenciam ainda ao universo das elites socializadas à moda do velho continente - requerida em um período no qual as elites brasileiras buscavam construir-se à imagem e semelhança europeia, educando os filhos em colégios dirigidos por estrangeiros, como o Aldridge ou o Des Oiseaux, e importando as referências culturais com as quais tinham contato nas viagens internacionais - e educada nas primeiras grandes faculdades de direito e engenharia, ambientes seletivos onde conviviam em meio aos pares e adquiriam o título de bacharel, que passa a funcionar como instrumento de legitimação da reprodução da posição social familiar. Na conquista das posições dirigentes, o diploma combinava-se às insígnias cosmopolitas da educação à europeia e ao capital social que os conectava aos detentores do poder de nomear seus escolhidos para os altos postos de direção. Assim, o título de bacharel em si era antes uma insígnia de posição social do que um indicador de competência técnica (MARTINS, 1987, pp. 65-87; HOLANDA, 2006, pp. 17-31, 172; MICELI, 2001, pp. 79, 114-115 ; PINÇON

\footnotetext{
${ }^{565}$ A expressão é sobretudo empregada no teatro lírico, onde designa não apenas a última cena da obra, mas dá ao conjunto um caráter amplo, revestindo-o de modo brilhante (VIGNAL, 1999, p. 318).
} 
e PINÇON-CHARLOT, 1989, pp. 141-146; 2006 p. 115; BOURDIEU, 1989; DEZALAY \& MADSEN 2008 p. 12 ; CARVALHO 2013, pp. 21, 65-79; NEEDELL 1993, pp. 84-86).

Além dos membros das famílias de elite, sobretudo gaúchas e cariocas, que mantinham laços com aqueles que detinham o poder político e econômico, encontra-se nessa geração um conjunto de pessoas que ascenderam aos postos públicos de destaque por meio do serviço público, em vias de modernização com a criação de órgãos, como o Departamento Administrativo do Serviço Público (DASP), que visavam regulamentar o recrutamento das burocracias do Estado e melhorar o nível técnico de seus funcionários. Entre aqueles que ascenderam via funcionalismo, encontra-se um conjunto de advogados nordestinos, como Ignácio Rangel, Celso Furtado, Rômulo de Almeida, Ewaldo Correa Lima e Cleantho de Paiva Leite. Eles representam uma geração de famílias nordestinas abastadas que, face ao declínio experimentado pela região, decorrente da derrocada da agricultura açucareira acompanhada do deslocamento do centro político e cultural para o Sudeste, diversificou suas estratégias de reprodução social, com algumas de suas frações tornando-se profissionais liberais e migrando em busca de oportunidades no serviço público da capital do país (FURTADO, 1997; PEREIRA, 2008, pp. 50-51).

Além do nordestino Jeusus Soares Pereira, de procedência social modesta e ausência de formação superior, que ascende por seus vínculos com os positivistas, e de Roberto Campos, matogrossense e órfão que adquiriu seu capital cultural no seminário católico, aqueles de origem menos estabelecida concentram-se em São Paulo, correspondendo, em sua maioria, aos primeiros nomes de classe média baixa a projetar-se no meio dos especialistas em economia, por intermédio da Universidade de São Paulo. São os casos de Dorival Teixeira, Luiz Freitas Bueno e Alice Canabrava, a única mulher a integrar a coorte, produto da abertura da Faculdade de Filosofia às professoras primárias, de carreira restrita à academia.

Os poucos personagens com formação em economia no período inicial, os diplomatas Roberto Campos, Miguel Osório de Almeida, Octavio Dias Carneiro e João Baptista Pinheiro, e os funcionários públicos Celso Furtado, Cleantho de Paiva, Octavio Gouvêa de Bulhões, José Garrido Torres, Ignácio Rangel e Alexandre Kafka, formaramse em economia no exterior, financiados por recursos próprios, por serem membros do corpo diplomático ou por pertencer a órgãos do serviço público em vias de 
modernização, que começaram a promover a circulação internacional de seus funcionários. Eles serão os primeiros burocratas que, unindo a alta cultura e os vínculos sociais às competências científicas e técnicas, passam a contestar os critérios "políticos" de escolha dos dirigentes da área econômica, em trabalho simbólico de valorização de sua formação especializada, como requisito indispensável para a condução do país conforme a moderna racionalidade econômica (MICELI, 2001, pp. 77-79, 197-199; LOUREIRO, 1997a; GOMES 1994; FAORO, 1975, p. 743).

$\mathrm{Na}$ segunda geração, que abarca aqueles que nasceram entre os anos 1920 e o início dos 1940, há indivíduos com sólidos laços com a elite tradicional da primeira geração, dentre os quais José Carlos Perdigão Medeiros da Fonseca, Ruy Aguiar da Silva Leme, Julian Alfonso Magalhães Chacel, Paulo Hortênsio Pereira Lira, Plínio de Arruda Sampaio, Fernando Henrique Cardoso, Francisco Neves Dornelles, Mario Henrique Simonsen, Marcos Vianna, Arthur Candal, Fernão Bracher, Luiz Carlos Bresser Pereira e Carlos Lessa. Poucos dentre eles cursaram economia e outras ciências sociais na graduação. A maior parte frequentou as faculdades de engenharia e direito, que seguiam sendo as instituições educacionais de maior prestígio. Depois transitaram para a economia, por meio de cursos de pós-graduação, do exercício da função de docente em faculdades de economia, ou atuando profissionalmente como especialistas em economia.

Ao lado do grupo pertencente à elite nacional centrada no Rio de Janeiro, multiplicam-se aqueles que ascendem através do investimento escolar, viabilizado pela diversificação do recrutamento social decorrente da abertura de novos cursos e universidades, algumas das quais oferecem cursos noturnos e aceitam alunos com formação média técnica. É o caso das faculdades de economia da Universidade de São Paulo (USP), onde estudaram Antonio Delfim Netto, Akihiro Ikeda, Paulo Yokota, Paul Singer e Walter Barelli, e da Universidade do Estado da Guanabara, frequentada por João Paulo Reis Velloso e Pelúcio Ferreira, de famílias brasileiras modestas, que eram funcionários públicos em busca de qualificações para progredir em suas carreiras. Os imigrantes e filhos de imigrantes - notavelmente italianos, japoneses e judeus, das ondas migratórias do início do século XX, que se deslocavam para o Brasil em busca de melhores condições materiais e/ou fugindo das guerras e perseguições religiosas presentes na USP, bem como casos análogos em outras regiões do país, como Isaac Kerstenetzky no Rio e Simon Schwartzman em Minas Gerais, pertenciam a famílias que 
se instalaram nas grandes cidades e extraíam sua renda de pequenas atividades comerciais e da venda da força de trabalho. A primeira economista de destaque no Brasil, Maria da Conceição Tavares, é matemática e portuguesa. Ser estrangeira e já ter chegado ao país portando qualificação especializada valorizada afastam-na do destino doméstico da maioria das mulheres brasileiras de sua geração e extração social.

Dentre os primeiros economistas formados no Brasil, há diversos sobre o quais há pouca ou nenhuma informação disponível relativa às origens sociais. Via de regra é mais difícil encontrar informações sobre aqueles que não pertencem às elites, cuja história é preservada nos jornais, dicionários biográficos, livros de memórias, obras genealógicas, em intenso trabalho de cristalização da posição social na memória coletiva, trunfo na luta pela perenidade do nome familiar (PINÇON e PINÇON-CHARLOT, 2006; CANÊDO, 2011, pp. 56-57; BOURDIEU, 1989). O aumento do número de casos não enraizados na elite tradicional implica também a diversificação das vias de aquisição do cosmopolitismo e do capital cultural. Às amizades internacionais dos primeiros especialistas em economia somam-se os primeiros programas de cooperação técnico-científica dos órgãos voltados à racionalização administrativa e ao ensino de economia, novas portas para o espaço internacional. Em um período no qual decresce o volume daqueles que não frequentaram colégios dirigidos por estrangeiros e não tiveram professores particulares de idiomas, vemos a Fundação Getúlio Vargas oferecer reading knowledge para os estudantes que pretende enviar para o exterior, visto que até esse momento, prevalecem ainda aqueles que frequentaram especializações e mestrados no exterior, sendo raros os brasileiros com PhD em economia.

$\mathrm{Na}$ terceira geração, dos nascidos a partir do início dos anos 1940, continuam presentes aqueles pertencentes a elites enraizadas, como João Manuel e Zélia Cardoso de Mello, os irmãos Giannetti, André Lara Resende, Luciano Coutinho, Francisco Lopes, Gilda Portugal Gouvêa, Francisco Gros, Eduardo Suplicy e Carlos Ivan Simonsen Leal. Eles apresentam similaridades com as elites dos períodos antecessores no que concerne à formação em colégios de prestígio, ao aprendizado precoce de idiomas e à socialização cosmopolita. Diferem delas, entretanto, pela formação em economia desde a graduação, o que indica a legitimação social da profissão, que começa a aparecer como destino desejável para membros de grupos dominantes. 
Paralelamente, há membros de famílias imigrantes já estabelecidas, tendo os pais e avós acumulado capital econômico no Brasil, a maior parte deles através de atividades comerciais e industriais, permitindo que os filhos investissem plenamente nos estudos. Casos, por exemplo, de Andrea Calabi, Persio Arida, Renata Rosenthal, Frederico Mazzucchelli, Eduardo Modiano e Guido Mantega. Ao contrário dos descendentes de imigrantes da geração anterior, não passaram pelo ensino técnico e raramente conciliaram estudo e trabalho por necessidade. A chegada à universidade não aparece mais como conquista individual de uns poucos desviantes, mas como destino naturalizado, amplamente reconhecido pelos grupos familiares como investimento necessário para a manutenção de sua inserção social, embora com sentidos distintos. Em vários casos, a expectativa dos pais era que o filho diplomado assumisse os negócios da família, o que acaba por ser feito, muitas vezes, por outro filho. Assim, a divisão de trabalho entre irmãos dá a essas famílias duas vias de reprodução, uma na direção do negócio familiar, outra no âmbito da carreira acadêmica, cujos frutos vindouros não eram sempre claramente previsíveis para os pais.

Aqueles provenientes de famílias de proventos médios e baixa escolarização fizeram, em geral, carreira no serviço público, casos de Helio Blak, Darlan Dórea, Aluysio Asti e Luiz Orenstein. O baixo número de pessoas com esse perfil na última geração pode decorrer do recuo do ciclo de democratização do acesso a novos cursos superiores e universidades, ocorrido nos anos 1950 e 1960, e da crescente seletividade nas instituições de ensino superior de prestígio, com aumento da concorrência para o curso de economia, cada vez mais consagrado como carreira pertinente à elite.

Observa-se, no período, grande concentração no Rio de Janeiro e em São Paulo, com alguma presença residual de mineiros. Há também aumento do número de mulheres no quadro. Várias delas tiveram sucesso na carreira acadêmica, concluindo doutorados, pós-doutorados, lecionando no exterior e ocupando cargos de direção nas associações de pesquisa. Ainda que aumente o número de mulheres com trajetórias acadêmicas e profissionais tão completas e prestigiosas quanto as de seus colegas, companheiros e cônjuges, poucas ocuparam cargos de diretoria nos órgãos de Estado. No período todo contemplado pela pesquisa, temos, na diretoria do BNDES, somente Elena Landau, Laura Domingues, Beatriz Azeredo, Mariza Giannini e Maria Silvia Bastos Marques; nos 
cargos máximos da área econômica, apenas Zélia Cardoso de Mello, Dorothea Werneck, Aspásia Camargo e Yeda Crusius.

A terceira geração foi a principal beneficiada pela multiplicação dos convênios internacionais ampliados ao longo dos anos 1960, notavelmente como efeito da intensificação dos programas de cooperação científica norte-americanos durante a Guerra Fria. Os membros dessa geração formam o primeiro grupo a frequentar sistematicamente doutorados no exterior, tornando-se os agentes da transferência para o Brasil do desenho institucional dos departamentos de economia das universidades norte-americanas e da economia matematizada que conquistava posição dominante no espaço global dos economistas.

Além de uma identidade profissional e da valorização das ferramentas técnicas especializadas, forjadas nos espaços acadêmicos e profissionais nos quais os economistas se socializam e se aproximam, há um conjunto geral de disposições sociais partilhado pelas três gerações, notavelmente a perspectiva missionária, a adaptabilidade e a multiposicionalidade.

Declarações como "nós tínhamos todo um país por construir" (GROS, 2002, [DVD]), "era a obrigação que eu tinha com o país. [...]. Não tinha isso de saber se aceitava ou não aceitava" (Entrevista de Luiz Carlos Bresser Pereira à autora, 2012) ou "éramos poucos, os economistas brasileiros, e tudo estava por ser feito no país" (Octavio Bulhões apud FURTADO, 2014, pp. 55-56), revelam um caráter missionário e um sentido de dever subjacentes ao engajamento na gestão do Estado desses homens, legitimados pela capacidade de manusear as ferramentas, cada vez mais abstratas, da racionalidade econômica, na busca pelo que cada um deles julga ser o bem comum. O desenrolar da narrativa revela que, no contexto brasileiro, a adaptabilidade é capacidade requerida para o exercício missionário em meio à lógica da política nacional. Os economistas no poder reafirmam constantemente a universalidade de seus critérios racionais especializados, contrapondo-os à lógica dos interesses políticos parciais, mas mostram-se capazes de diversos arranjos entre as duas lógicas, incluindo a disposição para trabalhar em governos com ideários políticos divergentes dos seus. Os depoimentos revelam que esses agentes não veem nisso uma incoerência, justificando-a em dois registros. Por um lado, como disposição a novas e grandes experiências, quando referem-se ao exercício do poder político como uma aventura ou desafio pessoal; por outro lado, na perspectiva da 
autoconfiança e segurança da própria realização, quando classificam a convocação para postos de governo como oportunidade excepcional para implementar suas ideias no país.

Finalmente distinguem-se pela multiposicionalidade devida a incessante circulação entre o Estado, o mercado e a academia, entre o nacional e o internacional e entre as cidades politicamente centrais do país, configurando uma elite definida como um número restrito de indivíduos ocupando número elevado de posições de poder e prestígio (BOLTANSKI, 1973, p. 24). Essa multiposicionalidade permitiu aos economistas concentrar, em suas mãos, poderes públicos e privados e o poder simbólico da fala legítima, decorrente da crença na economia como ciência, academicamente avalizada, multiplicando e fortificando seu domínio sobre o campo do poder (LEBARON, 2000).

As circulações nacionais e internacionais constantes ajudam, ademais, a criar um grupo que se conhece, reconhece, e tem identidades sociais e psicológicas similares, forjadas em experiências comuns, partilhadas ao longo do tempo. Malgrado a existência de fracionamentos calcados em divergências teóricas e/ou políticas e em disputas em torno da delimitação dos critérios para poder exercer autoridade especializada (DENORD, YMONET, THINE, 2011, p. 26; BOURDIEU, 2011, pp. 126-127; BOURDIEU, 1989, p. 216; LEBARON, 2000), nota-se a existência de um conjunto vasto e estreito de laços que une economistas das diversas frações, favorecendo a articulação e a coesão para estabelecer, sem rupturas, os parâmetros no interior dos quais o desacordo é possível, definindo as fronteiras que separam os aptos a ter posições acerca da condução da economia dos demais (MILLS, 2012; BOLTANSKI, 1973, pp. 24-25).

A rede que une os especialistas em economia é formada pela conjunção de camadas de vínculos familiares, matrimoniais, amizades de infância e de universidade e camadas de vínculos profissionais nas quais o capital social revela-se recurso central. O oximoro meritocracia de laços indica que o aumento da qualificação especializada daqueles que se ocupam da gestão econômica do Estado não se dissocia do pertencimento originário ou conquistado a um universo de reconhecimento mútuo, com disposições subjetivas partilhadas e afinidades, criadas ao longo do tempo na frequentação de um mesmo mundo, que colaboram para a manutenção das posições dominantes. 


\section{REFERÊNCIAS}

ABREU, Alzira Alvez de e LAMARÃO, Sérgio (org.). Personalidades da Política Externa Brasileira. Brasília: Fundação Alexandre Gusmão, 2007.

ABREU, Marcelo de Paiva. The Ford Foundation and the department of Economics of PUC-Rio, 1977-1992. In: MICELI, Sérgio (org.). A Fundação Ford no Brasil. São Paulo: Editora Sumaré, 1993.

ABREU, Marcelo de Paiva. A Missão Niemeyer. Revista Administração de Empresas, v. 14, n. 4, 1974, pp. 7-28.

ABREU, Marcelo de Paiva (org.). A Ordem do Progresso: cem anos de política econômica republicana 1889-1990. Rio de Janeiro: Elsevier, 1990.

ACAYABA, Marlene Milan. Residências em São Paulo 1947-1975. São Paulo: Romano Guerra Editora, 2011.

ADELMAN, Jeremy. Worldly Philosopher: The Odyssey of Albert O. Hirschman. Princeton: Princeton University Press, 2013.

AFONSO, Carlos Alberto. O Amigo-Irmão. In: NAKANO, Maria e ROITMAN, Ari (org.). Estreitos nós: lembranças de um semeador de utopias. Rio de Janeiro: Garamond, 2001.

AGGIO, Alberto. Democracia e Socialismo: a experiência chilena. São Paulo: Editora Unesp, 1993.

AGGIO, Alberto. Brasileiros de esquerda no Chile de Allende: protagonismos, divergências, lições. Política Democrática - Revista de Política e Cultura Fundação Astrojildo Pereira, n. 19, 2007, pp. 114-122.

ALBERTI, Verena; SARMENTO, Carlos Eduardo e ROCHA, Dora (org.). Mario Henrique Simonsen: um homem e seu tempo. Rio de Janeiro: Editora da Fundação Getúlio Vargas, 2002.

ALBUQUERQUE, José Augusto Guilhon (org.). O Legado de Franco Montoro. São Paulo: Imprensa Oficial do Estado de São Paulo, 2008.

ALMEIDA, Ana de. O assalto à educação pelos economistas. Tempo Social, Revista de Sociologia da USP, v. 20, n. 1, 2008, pp. 163-178.

ALMEIDA, Maria Hermínia Tavares de. Tributo a Gilberto Dupas. Política Externa, v. 18, n. 1, 2009a, pp. 119-121. 
ALMEIDA, Maria Hermínia Tavares de. Tomando Partido, Formando Opinião: cientistas sociais, imprensa e política. São Paulo: Editora Sumaré, 1992.

ALMEIDA, Rômulo. Romulo Almeida (depoimento, Projeto Memória da Petrobrás). Rio de Janeiro: CPDOC/FGV - SERCOM/Petrobrás, 1988.

ALMEIDA, Miguel Ozorio de. Miguel Ororio de Almeida: um depoimento. Rio de Janeiro: Centro de História e Documentação Diplomática; Brasília: Fundação Alexandre de Gusmão, 2009b.

ALVES, Cosette. Ao vencedor, as batatas. Folha de São Paulo, 24 de novembro de 1996. Disponível em: http://www1.folha.uol.com.br/fsp/1996/11/24/revista_da_folha/3.html. Consultado em 24/05/2016.

ANDRADA, Alexandre; BOIANOVSKY Mauro e CABELLO, Andrea. O Clube dos Economistas e a Revista Econômica Brasileira (1955-1962): um episódio na história do desenvolvimentismo nacionalista do Brasil. ANPEC, 2015. Disponível em: http://www.anpec.org.br/encontro/2015/submissao/files_I/i1c104a501614cd5d1c65f7315055b3137.pdf. Consultado em 17/01/2015.

ANGELO, Vitor Amorim de. A trajetória da Democracia Socialista: da fundação ao PT. Dissertação apresentada ao Programa de Pós-Graduação em Ciências Sociais da Universidade Federal de São Carlos. São Carlos: UFSCAR, 2007.

ANHEIER, Helmut; GERHARDS, Jurgen e ROMO, Frank. Forms of Capital and Social Structure in Cultural Fields: Examining Bourdieu's Social Topography. American Journal of Sociology, v. 100, n. 4, 1995, pp. 859-903.

ARANTES, Paulo Eduardo. Um Departamento Francês de Ultramar. Rio de Janeiro: Paz e Terra, 1994.

ARANTES, Paulo Eduardo. Um depoimento sobre o Padre Vaz. Sintese - Revista de Filosofia, v. 32, n. 102, 2005, pp. 5-24.

ARAÚJO, Alcione. Betinho o Travesso. In: NAKANO, Maria e ROITMAN, Ari (org.). Estreitos nós: lembranças de um semeador de utopias. Rio de Janeiro: Garamond, 2001.

ARAÚJO, Anna Paula Moreira de. Francisco Weffort e o papel da Intelligentsia Nacional: considerações sobre uma trajetória. Dissertação apresentada ao Programa de Mestrado da Faculdade de Ciências e Letras da Universidade Estadual Paulista Júlio de Mesquita Filho. Araraquara: UNESP, 2012. 
ARIDA, Persio. Neutralizar a inflação: uma ideia promissora. In: REGO, José Marcio (org.). Inflação Inercial, Teorias sobre Inflação e o Plano Cruz̧ado. Rio de Janeiro: Paz e Terra, 1986.

ARIDA, Persio. Discurso de posse na presidência do BNDES [DVD]. Rio de Janeiro: Arquivo do BNDES, 1993.

ARIDA, Persio. Discurso de transmissão da presidência do BNDES [DVD]. Rio de Janeiro: Arquivo do BNDES, 1995.

ARIDA, Persio. Entrevista com Pérsio Arida. In: BIDERMAN, Ciro; COZAC, Luis Felipe L. e REGO, José Marcio. Conversas com Economistas Brasileiros. São Paulo: Editora 34, 1996.

ARIDA, Persio. RAKUDIANAI: A política, a prisão, o encontro com o crocodilo, o julgamento e meu pai: lembranças de quarenta anos atrás. Piauí, n. 55, 2011. Disponível em: http://revistapiaui.estadao.com.br/materia/rakudianai/. Consultado em 13/05/2016. ARRUDA, Maria Arminda do Nascimento. A Modernidade Possível: Cientistas e Ciências Sociais em Minas Gerais. In: MICELI, Sérgio (org.). História das Ciências Sociais no Brasil v. 1. São Paulo: Edições Vértice/IDESP, 1989.

AULER, Marcelo. O Todo-Poderoso de Búzios. Jornal do Brasil, 3 de março de 1990.

AZEVEDO, Aroldo de. Cochranes do Brasil: a vida e obra de Thomas Cocharane e Ignácio Cochrane. São Paulo: Companhia Editora Nacional, 1965.

AZEVEDO, Carlos. Jornal Movimento: uma reportagem. Belo Horizonte: Editora Manifesto, 2011.

BABB, Sarah. Proyecto: México, los economistas del neoliberalismo. DF, México: Fondo de Cultura Económica, 2003.

BACHA, Edmar Lisboa. Discurso de posse na presidência do BNDES [DVD]. Rio de Janeiro: Arquivo do BNDES, 1995.

BACHA, Edmar Lisboa. Discurso de transmissão da presidência do BNDES [DVD]. Rio de Janeiro: Arquivo do BNDES, 1995a.

BACHA, Edmar Lisboa. Entrevista com Edmar Lisboa Bacha. In: BIDERMAN, Ciro; COZAC, Luis Felipe L. e REGO, José Marcio. Conversas com Economistas Brasileiros. São Paulo: Editora 34, 1996.

BACHA, Edmar Lisboa. Memória Acadêmica. Economia Aplicada, v. 2, n. 1, 1998, pp. 197210. 
BACHA, Edmar Lisboa. Memória IBGE, Edmar Bacha. Entrevista projeto história oral IBGE, 13 de julho de 2006. Disponível em:

https://www.youtube.com/watch? ${ }_{\mathrm{v}}=\mathrm{cCyff2} \mathrm{dMOBE} \&$ feature=youtu.be. Consultado em $27 / 05 / 2016$.

BACHA, Edmar Lisboa. A “inflaflução": os preços no reino de Lisarb. In: BACHA, Edmar Lisboa. Belíndia 2.0: fábulas e ensaios sobre o país dos contrastes. Rio de Janeiro: Editora Civilização Brasileira, 2012.

BACHA, Edmar Lisboa. Prefácio. In: CUNHA, Luiz Roberto; LEOPOLDI, Maria Antonieta e RAPOSO, Eduardo. Dionísio Dias Carneiro, um humanista cético: uma história da formação de jovens economistas. Rio de Janeiro: Editora PUC-Rio/LTC, 2014.

BACIC, Miguel Juan e SOUZA, Maria Carolina de Azevedo Ferreira de. Introdução. In:

BACIC Miguel Juan e SOUZA, Maria Carolina de Azevedo Ferreira de (org.). Casos e Conceitos em Gestão de Pequenas e Médias Empresas Industriais, edição no1. Campinas: IEUNICAMP, 2006.

BAER, Werner. Explorando o mundo real. Economia Aplicada, v. 2, n. 4, 1998, pp. 767770.

BAER, Werner e VILLELA, Anníbal. The Changing Nature of Development Banking in Brazil. Journal of Interamerican Studies and World Affairs, v. 22, n. 4, 1980, pp. 423-440.

BAIARDI, Amilcar. Tamás Szmrecsányi, uma grande perda para o mundo acadêmico. Caderno CRH - Salvador, v. 22, n. 55, 2009, pp. 205-210.

BALTAR, Antônio Bezerra. Depoimento Antônio Bezerra Baltar. In: MONTENEGRO, Antônio Torres; SIQUEIRA, Antônio Jorge e AGUIAR, Antônio Carlos. Engenheiros do Tempo: Memórias da Escola de Engenharia de Pernambuco. Recife: Editora Universitária da UFPE, 1995.

BAMBIRRA, Vânia. Memorial Vânia Bambirra. Brasília: Fundação UNB, 1991.

BAMBIRRA, Vânia. Meu melhor amigo! In: TRASPADINI, Roberta e STEDILE, João Pedro (org.). Ruy Mauro Marini vida e obra. São Paulo: Expressão Popular, 2011.

BARBOSA, Alexandre de Freitas. Rômulo de Almeida. In: PERICÁS, Luiz Bernardo e SECCO, Lincoln (org.). Interpretes do Brasil: clássicos, rebeldes e renegados. São Paulo: Boitempo, 2014. 
BARBOSA, Alexandre de Freitas e KOURY, Ana Paula. Rômulo de Almeida e o Brasil desenvolvimentista (1946-1964): ensaio de reinterpretação. Economia e Sociedade, v. 21, n. especial, 2012, pp. 1075-1113.

BARBOSA, Francisco de Assis (org.). João Pinheiro: documentário sobre a sua vida. Belo Horizonte: Publicações do Arquivo Público Mineiro nº 1, 1966.

BARBOSA, Wilson. IPEA (Instituto de Pesquisa Econômica Aplicada) - Planejamento e Reproducão do Capital (1964 a 2004). Tese apresentada ao Programa de Pós-graduação em História da Universidade Federal de Goiás. Goiânia: UFG, 2012.

BARELLI, Walter. Depoimento Walter Barelli. São Paulo: Centro de Memória Sindical, 2006. Disponível em: http://www.memoriasindical.com.br/lermais_materias.php?cd_materias=318. Consultado em 15/05/2016.

BARRAL, Welber e BOHER, Carolina Pancotto. A integração latino-americana em foco: 50 anos $A L A L C / A L A D I$. Brasília: FUNAG, 2010.

BARRALES, Daniel. (Re)conociendo la enseñanza económica en Chile: materiales para una historia. Estudios Nueva Economía, n. 5, 2015, pp. 25-38.

BARROS, Luiz Carlos Mendonça de. Discurso de posse na presidência do BNDES [DVD]. Rio de Janeiro: Arquivo do BNDES, 1995.

BARROS, Luiz Carlos Mendonça de. Brasil em 2000 - entrevista à Cosette Alves. Folha de São Paulo, 26 de dezembro de 1999.

BASTOS, Pedro Paulo Zahluth. O presidente desiludido: a campanha liberal e o pêndulo de política econômica do governo Dutra (1942- 1948). História econômica \& história de empresa, v. 7, n. 1, 2004, pp. 99-135.

BASTOS, Pedro Paulo Zahluth. Liberal Esclarecido ou Aliado Fiel? Sobre a Natureza da Política Econômica Externa Brasileira no Governo Dutra (1946-1951). EconomiA, Revista da ANPEC, v. 11, n. 4, 2010, pp. 285-320.

BASTOS, Pedro Paulo Zahluth. Restrição Externa e desenvolvimentismo no Brasil: sobre o Segundo Governo Vargas (1951-1954). Texto para Discussão IEI/UNICAMP, n. 202, 2012, pp. 1-21.

BECA, Carlos Eugênio; RICHARDS, Cecilia e BIANCHETTI, Lucídio. Ennani Maria Fiori: un professor brasileño en tierras chilenas - testimonios. Educação e Realidade, v. 38, n. 3, 2013, pp. 1021-1034. 
BEIGEL, Fernanda. La FLACSO chilena y la regionalización de las ciencias sociales en América Latina (1957-1973). Revista Mexicana de Sociología, v. 71, n. 2, 2009, pp. 319-349.

BELLUZZO, Luiz Gonzaga. Entrevista com Luiz Gonzaga Belluzzo. In: BIDERMAN, Ciro; COZAC, Luis Felipe L. e REGO, José Marcio. Conversas com Economistas Brasileiros. São Paulo: Editora 34, 1996.

BELLUZZO, Luiz Gonzaga. Luiz Gonzaga Belluzzo por Ricardo Ismael, Rosa Freire D’Aguiar, Alexandre de Freitas Barbosa e Bernardo Ricupero. Cadernos do Desenvolvimento, v. 6, n. 9, 2011, pp. 420-441.

BENEVIDES, Maria Victoria de Mesquita. O Governo Kubitschek: Desenvolvimento Econômico e Estabilidade Política 1956-1961. Rio de Janeiro: Paz e Terra, 1976.

BERLINCK, Manoel Tosta. Marginalidade Social e relações de classes em São Paulo. São Paulo: Vozes, 1975. Ver:

http://www.fundamentalpsychopathology.org/uploads/files/teses/berlinck_marginalida desocial.pdf. Consultado em 09/04/2016.

BERLINCK, Manoel Tosta. Elogio da Universidade. In: KANTOR, Iris; MACIEL, Débora e SIMÕES, Júlio Assis. A Escola Livre de Sociologia e Política: anos de formação 19331953: depoimentos. São Paulo: Escuta, 2001.

BERNIS G. Destanne de. François Perroux. In: ARESTIS, Philip e SAWYER, Malcom. A Biographical Dictionary of Dissenting Economists, Second Edition. Cheltenham: Edward Elgar Publishing, 2000.

BERGDOLL, Barry. Duhart y la arquitectura transcontinental de las Naciones Unidas. In: PLAUT, Jannette e SAROVIC, Marcelo. CEPAL 1962-1966 United Nations Building Emilio Dubart Arquitecto. Santiago: Constructo, 2012.

BERQUÓ, Elza. Entrevista com Elza Berquó. In: MONTERO, Paula e MOURA, Flávio (org.). Retrato de Grupo - 40 anos do CEBRAP. São Paulo: Cosac Naify, 2009.

BETTENCOURT, João; BETTENCOURT, Luiz Alberto e FARO, Luiz Cesar. Marcos Vianna: memórias de uma revolução industrial. Rio de Janeiro: Pensar Planejamento e Operação de Comunicação Social e Insight Engenharia de Comunicação e Marketing, 2010.

BETTO, Frei. Betinho militante da utopia. Folha de São Paulo, 11 de agosto de 1997. Disponível em: http://www1.folha.uol.com.br/fsp/brasil/fc110811.htm. Consultado $22 / 11 / 2015$. 
BETTO, Frei. Perfil Amigo de um conspirador do bem. In: NAKANO, Maria e ROITMAN, Ari (org.). Estreitos nós: lembranças de um semeador de utopias. Rio de Janeiro: Garamond, 2001.

BIAZO, Glauber Cícero Ferreira. Entre a ditadura e a democracia: história oral de vida acadêmica (FFLCH-USP) v.2: entrevistas. Tese apresentada ao Programa de Pós-graduação em História Social da Faculdade de Filosofia Letras e Ciências Humanas da Universidade de São Paulo. São Paulo: USP, 2014.

BIAZO, Glauber Cícero Ferreira. Entre a ditadura e a democracia: história oral de vida acadêmica (FFLCH-USP) v.1. Tese apresentada ao Programa de Pós-graduação em História Social da Faculdade de Filosofia Letras e Ciências Humanas da Universidade de São Paulo. São Paulo: USP, 2014a.

BIELSCHOWSKY, Ricardo. Ideologia e Desenvolvimento: Brasil, 1930-1964. In: LOUREIRO, Maria Rita (org.). 50 anos de Ciência Econômica no Brasil: pensamentos instituições, depoimentos. Petrópolis: Vozes, 1997.

BIELSCHOWSKY, Ricardo (org.). Cinqüenta anos de pensamento na CEPAL. Rio de Janeiro: Editora Record, 2000.

BIELSCHOWSKY, Ricardo. Pensamento Econômico Brasileiro: o ciclo ideológico do desenvolvimentismo. Rio de Janeiro: Contraponto, 2000a.

BIGLAISER, Glen. The internationalization of Chicago's Economics in Latin America. Economic Development and Cultural Change, v. 50, n. 2, 2002, pp. 269-286.

BLANCO, Alejandro. Ciências sociais no Cone Sul e a gênese de uma elite intelectual (1940-1965). Tempo Social, revista de sociologia da USP, v. 19, n. 1, 2007, pp. 89-114.

BLAY, Eva Alterman. Mulheres na USP: Horizontes que se abrem. São Paulo: Humanitas, 2004.

BNDE. Exposição sobre o programa de reaparelhamento econômico, exercício de 1952. Rio de Janeiro: BNDE, 1953.

BNDE. Exposição sobre o programa de reaparelhamento econômico, exercício de 1954. Rio de Janeiro: BNDE, 1954.

BNDE. Portaria No 9/1955, de 28 de julho de 1955. Regula o concurso para provimento de cargos da classe inicial da carreira de Economista do Banco Nacional de Desenvolvimento Econômico. Rio de Janeiro, BNDE, 1955. 
BNDE. Exposição sobre o programa de reaparelhamento econômico, exercício de 1957. Rio de Janeiro: BNDE, 1957.

BNDE. Exposição sobre o programa de reaparelhamento econômico, exercício de 1961. Rio de Janeiro: BNDE, 1961.

BNDE. Exposição sobre o programa de reaparelhamento econômico, exercício de 1962. Rio de Janeiro: BNDE, 1962.

BNDE. Exposição sobre o programa de reaparelhamento econômico, exercício de 1963. Rio de Janeiro: BNDE, 1963.

BNDE. Exposição sobre o programa de reaparelhamento econômico, exercício de 1964. Rio de Janeiro: BNDE, 1964.

BNDE. Exposição sobre o programa de reaparelhamento econômico, exercício de 1965. Rio de Janeiro: BNDE, 1965.

BNDE. Exposição sobre o programa de reaparelhamento econômico, exercício de 1966. Rio de Janeiro: BNDE, 1966.

BNDE. Exposição sobre o programa de reaparelhamento econômico, exercício de 1967. Rio de Janeiro: BNDE, 1967.

BNDES. Relatório de Atividades do Sistema BNDES, 1983. Rio de Janeiro: BNDES, 1983.

BNDES. Relatório de Atividades do Sistema BNDES, 1990. Rio de Janeiro: BNDES, 1990.

BNDES. Relatório de Atividades do Sistema BNDES, 1991. Rio de Janeiro: BNDES, 1991.

BNDES. Relatório de Atividades, 1994. Disponível em:

http://www.bndes.gov.br/SiteBNDES/export/sites/default/bndes_pt/Galerias/Arquiv os/empresa/RelAnual/relatorio_anual1994.pdf

BNDES. Relatório de Atividades 1995. Rio de Janeiro: BNDES, 1995. Disponível em: http://www.bndes.gov.br/SiteBNDES/export/sites/default/bndes_pt/Galerias/Arquiv os/empresa/RelAnual/relatorio_anual1995.pdf

BNDES. Relatório de Atividades 1996. Rio de Janeiro: BNDES, 1996. Disponível em: http://www.bndes.gov.br/SiteBNDES/export/sites/default/bndes_pt/Galerias/Arquiv os/empresa/RelAnual/relatorio_anual1996.pdf

BNDES. Relatório de Atividades 1997. Rio de Janeiro: BNDES, 1997. Disponível em: http://www.bndes.gov.br/SiteBNDES/export/sites/default/bndes_pt/Galerias/Arquiv os/empresa/RelAnual/relatorio_anual1997.pdf

BNDES. Relatório Anual 2000. Rio de Janeiro: BNDES, 2000. Disponível em: 
http://www.bndes.gov.br/SiteBNDES/bndes/bndes_pt/Institucional/Relacao_Com_In vestidores/Relatorio_Anual/RelAnual2000.html

BNDES. Relatório Anual 2001. Rio de Janeiro: BNDES, 2001. Disponível em: http://www.bndes.gov.br/SiteBNDES/bndes/bndes_pt/Institucional/Relacao_Com_In vestidores/Relatorio_Anual/RelAnual2001.html

BNDES. BNDES 50 Anos de Desenvolvimento. São Paulo: DBA Artes Gráficas, 2002.

BNDES. Relatório Anual 2002. Rio de Janeiro: BNDES, 2002ª. Disponível em: http://www.bndes.gov.br/SiteBNDES/bndes/bndes_pt/Institucional/Relacao_Com_In vestidores/Relatorio_Anual/RelAnual2002.html

BNDES. Relatório Anual 2003. Rio de Janeiro: BNDES, 2003. Disponível em: http://www.bndes.gov.br/SiteBNDES/bndes/bndes_pt/Institucional/Relacao_Com_In vestidores/Relatorio_Anual/RelAnual2003.html

BNDES. Relatório Anual 2004. Rio de Janeiro: BNDES, 2004. Disponível em: http://www.bndes.gov.br/SiteBNDES/bndes/bndes_pt/Institucional/Relacao_Com_In vestidores/Relatorio_Anual/RelAnual2004.html

BNDES. Relatório Anual 2005. Rio de Janeiro: BNDES, 2005. Disponível em: http://www.bndes.gov.br/SiteBNDES/bndes/bndes_pt/Institucional/Relacao_Com_In vestidores/Relatorio_Anual/RelAnual2005.html

BNDES. Relatório Anual BNDES 2006. Rio de Janeiro: BNDES, 2006. Disponível em: http://www.bndes.gov.br/SiteBNDES/bndes/bndes_pt/Institucional/Relacao_Com_In vestidores/Relatorio_Anual/RelAnual2006.html

BNDES. Relatório Anual 2007. Rio de Janeiro: BNDES, 2007. Disponível em: http://www.bndes.gov.br/SiteBNDES/bndes/bndes_pt/Institucional/Relacao_Com_In vestidores/Relatorio_Anual/RelAnual2007.html

BNDES. Relatório Anual 2008. Rio de Janeiro: BNDES, 2008. Disponível em: http://www.bndes.gov.br/SiteBNDES/bndes/bndes_pt/Institucional/Relacao_Com_In vestidores/Relatorio_Anual/RelAnual2008.html

BNDES. Relatório Anual 2009. Rio de Janeiro: BNDES, 2009. Disponível em: http://www.bndes.gov.br/SiteBNDES/bndes/bndes_pt/Institucional/Relacao_Com_In vestidores/Relatorio_Anual/RelAnual2009.html

BNDES. Relatório Anual 2010. Rio de Janeiro: BNDES, 2010. Disponível em: 
http://www.bndes.gov.br/SiteBNDES/bndes/bndes_pt/Institucional/Relacao_Com_In vestidores/Relatorio_Anual/RelAnual2010.html

BNDES. Relatório Anual 2011. Rio de Janeiro: BNDES, 2011. Disponível em: http://www.bndes.gov.br/SiteBNDES/bndes/bndes_pt/Institucional/Relacao_Com_In vestidores/Relatorio_Anual/RelAnual2011.html

BNDES. BNDES: um banco de história e do futuro, texto Márcia de Paiva. São Paulo: Museu da Pessoa, 2012.

BNDES. Relatório Anual 2012. Rio de Janeiro: BNDES, 2012a. Disponível em: https://web.bndes.gov.br/bib/jspui/handle/1408/931

BNDES. Relatório Anual 2013. Rio de Janeiro: BNDES, 2013. Disponível em: https://web.bndes.gov.br/bib/jspui/bitstream/1408/1802/1/RA_2013_final.pdf

BNDES. Relatório Anual 2014. Rio de Janeiro: BNDES, 2014. Disponível em: https://web.bndes.gov.br/bib/jspui/handle/1408/5342

BOLTANKI, Luc. L'espace positionnel: multiplicité des positions institutionnelles et habitus de classe. Revue Française de Sociologie, v. 14, n. 1, 1973, pp. 3-26.

BORGES, Maria Angélica; MELlO, Cristina Helena P.; GALVANI, Claudemir e GOMES, Waldir Pereira. Memória do Departamento de Economia: a fala de alguns de seus chefes. São Paulo: EDUC, 1998.

BOURDIEU, Pierre. Bourdieu Pierre. Genèse et structure du champ religieux. Revue française de Sociologie, v. 12, n. 3, 1971, pp. 295-334.

BOURDIEU, Pierre. Questões de Sociologia. Rio de Janeiro : Editora Marco Zero, 1983.

BOURDIEU, Pierre. L'illusion Biographique. Actes de la Recherche en Sciences Sociales, v. 6263, 1986, pp. 69-72.

BOURDIEU, Pierre. La Noblesse D’État: grandes écoles et esprit de corps. Paris: Les Éditions de Minuit, 1989.

BOURDIEU, Pierre. Raisons Pratiques: sur la théorie de l'action. Paris: Éditions du Sueil, 1994. BOURDIEU, Pierre. Sociologia. In: ORTIZ, Renato (org.). São Paulo: Ática, 1994a.

BOURDIEU, Pierre. Méditations Pascaliennes. Paris: Éditions du Sueil, 1997.

BOURDIEU, Pierre. Les Structures Sociales de l'Économie. Paris: Éditions du Seuil, 2000.

BOURDIEU, Pierre. Os Usos Sociais da Ciência: por uma sociologia clínica do campo científico. São Paulo: Editora Unesp, 2003. 
BOURDIEU, Pierre. Reprodução Cultural e Reprodução Social. A Economia das Trocas Simbólicas. São Paulo: Perspectiva, 2005.

BOURDIEU, Pierre. A Distinção: crítica social do julgamento. São Paulo: Zouk/Edusp, 2008.

BOURDIEU, Pierre. Homo academicus. Buenos Aires: Siglo XXI Editores, 2008a.

BOURDIEU, Pierre. Champ du pouvoir et division du travail de domination. Texte manuscrit inédit ayant servi de support de cours au Collège de France, 1985-1986. Actes de la Recherche en Sciences Sociales, n. 190, 2011.

BOURDIEU, Pierre e SAINT-MARTIN, Monique de. Anatomie du goût. Actes de la Recherche en Sciences Sociales, v. 2, n. 5, 1976. pp. 2-81.

BOURDIEU, Pierre e SAINT-MARTIN, Monique de. Le patronat. Actes de la Recherche en Sciences Sociales, v. 20-21, 1978, pp. 3-82.

BRACHER, Fernão. Entrevista com Fernão Bracher. In: NAKANO, Yoshiaki, REGO, José Marcio e FURQUIM, Lilian (org.). Em Busca do Novo: o Brasil e o Desenvolvimento na obra de Bresser Pereira. Rio de Janeiro: Editora FGV, 2004.

BRAGA, Roberto Saturnino. In : TAVARES, Maria da Conceição (org.) Centro Internacional Celso Furtado de Políticas para o Desenvolvimento - Memórias do Desenvolvimento, v. 4, n. 4, 2010.

BRANDÃO, Inácio Loyola de. Ruth Cardoso: fragmentos de uma vida. São Paulo: Globo, 2010.

BRASIL. I Plano Nacional de Desenvolvimento (I PND) - 1972/1974. Brasília: texto publicado no suplemento ao Diário Oficial em 17 de dezembro de 1971.

BRASIL. II PND: II Plano Nacional de Desenvolvimento (1975-1979). Brasília: texto publicado no Diário Oficial de 6 de dezembro de 1974.

BRASIL. Primeiro Plano Nacional de Desenvolvimento da Nova República. Brasília, 1986. Disponível em: http://legis.senado.gov.br/legislacao/ListaPublicacoes.action?id=130255. Consultado em 28/03/16.

BRIGNOLI, Héctor Pérez. Los 50 años de la FLACSO y el desarrollo de las Ciencias Sociales en América Latina. San José: Editorial Juricentro, 2008.

BRITO, Angela Xavier de. Um saldo positivo: as elites femininas brasileiras e o modelo de cultura escolar católica de tradição francesa. Revista Eletrônica de Educação, v. 3, n. 1, 2009, pp. 39-57. 
BRITO, Angela Xavier de. L’influence française dans la socialisation des élites féminines brésiliennes : le collège Notre Dame de Sion à Rio de Janeiro. Paris : L'Harmattan, 2010.

BROOKE, Nigel e WITOSHYNSKY, Mary (org.). Os 40 anos da Fundação Ford no Brasil: uma parceria para a mudança social. São Paulo : EDUSP/Fundação Ford, 2002.

BRUNA, Paulo. Restauro e ampliação no edifício da Cepal em Santiago do Chile: Uma intervenção controvertida Santiago do Chile, 2010/2011. Vitruvius v. 11, 2011. Disponível em http://www.vitruvius.com.br/revistas/read/projetos/11.125/3863

BUENO, Luiz de Freitas. Métodos quantitativos na FEA-USP, minha realização profissional. Economia Aplicada, v. 1, n. 2, 1997, pp. 333-339.

BULHÕES, Octavio Gouvêa de. O Ministro Eugênio Gudin. In: CARNEIRO, Paulo E. Berredo (org.). Eugênio Gudin visto por seus contemporâneos. Rio de Janeiro: Editora da Fundação Getúlio Vargas, 1979.

BULHÕES, Octavio Gouvêa de. Depoimento Octavio Gouvêa de Bulhões. Brasília: Divisão de Impressão e Publicações do Departamento de Administração de Recursos Materiais do Banco Central do Brasil, 1990.

CABRIA, Juan Vicente Bachiller. El BNDES y las estrategias de desarrollo económico en Brasil. Banca pública de desarrollo, instituciones gubernamentales y trayectorias de intervención estatal (19522010). Tese de doutorado apresentada ao departamento de Ciência Política da Universidad de Salamanca, 2012.

CALABI, Andrea. Discurso de posse na presidência do BNDES [DVD]. Rio de Janeiro: Arquivo do BNDES, 1999.

CALLON, Michel. The embeddedness of economic markets in economics. In: Michel Callon (org.) The Laws of the markets. Oxford: Blackwell, 1998.

CAMPOS, Eudes. Nos caminhos da Luz, antigos palacetes da elite paulistana. Anais do Museu Paulista, v. 13. n. 1, 2005, pp. 11-57.

CAMPOS, Roberto de Oliveira. Economia, planejamento e nacionalismo. Rio de Janeiro: Editora APEC, 1963.

CAMPOS, Roberto de Oliveira. Entrevista Roda Viva, TV Cultura, 1991. Disponível em http://www.rodaviva.fapesp.br/materia/648/entrevistados/roberto_campos_1991.htm. Consultado em 29/05/2016.

CAMPOS, Roberto de Oliveira. A Lanterna na Popa. Rio de Janeiro: Topbooks, 1994. 
CAMPOS, Roberto de Oliveira. Entrevista com Roberto Oliveira Campos. In: BIDERMAN, Ciro; COZAC, Luis Felipe L. e REGO, José Marcio. Conversas com Economistas Brasileiros. São Paulo: Editora 34, 1996.

CAMPOS, Roberto de Oliveira. Entrevista com presidentes do BNDE: Roberto Campos, concedida a Ângela Coronel, Euclydes Pereira, Aloísio Barbosa de Araújo e Roberto Rodrigues, em 27 de março de 1982. Memórias do Desenvolvimento - Centro Internacional Celso Furtado de Políticas para o Desenvolvimento Econômico, v. 3, n. 3, 2009, pp. 41-64.

CANABRAVA, Alice Piffer. As Condições Sociais, Econômicas e Políticas da Fundação. In: CANABRAVA, Alice Piffer (org.). História da Faculdade de Economia e Administração da Universidade de São Paulo (1946-1981) v.1. São Paulo: FEA-USP, 1984.

CANABRAVA, Alice Piffer (org.). História da Faculdade de Economia e Administração da Universidade de São Paulo (1946-1981) v2. São Paulo: FEA-USP, 1984a.

CANABRAVA, Alice Piffer. Minhas reminiscências. Economia Aplicada, v. 1, n. 2, 1997, pp. $157-163$.

CANÊDO, Letícia Bicalho. Héritage en politique, ou comment acquérir les dispositions et compétences nécessaires aux fonctions de représentation politique (1945-1964). Cabiers du Brésil Contemporain, n. 47/48, 2002, pp. 71-119.

CANÊDO, Letícia Bicalho. Les boursiers de la Fondation Ford et la recomposition des sciences sociales brésiliennes: le cas de la science politique. In: GARCIA, Afrânio e MUÑOZ, Marie Claude (org.). Mobilité universitaire et circulation internationale des idées: Le Brésil et la mondialisation des savoirs. Cahiers de la recherche sur l'éducation et les savoirs Revue internationale de sciences sociales, Hors Série, n. 2, 2009, pp. 33-55.

CANÊDO, Letícia Bicalho. Um capital político multiplicado no trabalho genealógico. Revista Pós Ciências Sociais, v. 8, n. 15, 2011, pp. 55-76.

CANO, Wilson. Wilson Cano por Ricardo Ismael, José Carlos Braga e Rosa Freire D’Aguiar. Cadernos do Desenvolvimento, v. 8, n. 13, 2013, pp. 292-308.

CARCANHOLO, Reinaldo. Pluralismo e ensino de Economia no Chile de Allende (Antecedentes do movimento contra a ciência econômica autista). O Olho da História, n. 18, 2012. Disponível em:

http://oolhodahistoria.org/n18/artigos/carcanholo.pdf. Consultado em 28/05/2016.

CARDOSO, Fernando Henrique. Empresário industrial e desenvolvimento econômico no Brasil. São Paulo: DIFEL, 1964. 
CARDOSO, Fernando Henrique. Prefácio. In: TOLIPAN, Ricardo e TINELLI, Arthur Carlos. A controvérsia sobre distribuição de renda e desenvolvimento. Rio de Janeiro: Zahar Editores, 1975.

CARDOSO, Fernando Henrique. Procópio: Depoimento. Novos Estudos CEBRAP, n. 17, 1987, pp. 26-28.

CARDOSO, Fernando Henrique. Conferência do Presidente da República, Fernando Henrique Cardoso, na sede da CEPAL, em Santiago, 3 de março de 1995. Resenha de Política Exterior do Brasil, n. 76, 1995, pp. 82-88.

CARDOSO, Fernando Henrique. O Presidente segundo o Sociólogo: Entrevista de Fernando Henrique Cardoso a Roberto Pompeu de Toledo. São Paulo: Companhia das Letras, 1998.

CARDOSO, Fernando Henrique. O discreto charme da competência. Novos Estudos, n. 62, 2002, pp. 5-7.

CARDOSO, Fernando Henrique. Entrevista de Fernando Henrique Cardoso. In: BASTOS, Elide Rugai et al., (org.). Conversas com Sociólogos Brasileiros. São Paulo: Editora 34, 2006.

CARDOSO, Fernando Henrique. Entrevista de Fernando Henrique Cardoso concedida à Daniel Cantinelli Sevillano. Informe: informativo da Faculdade de Filosofia, Letras e Ciências Humanas da USP, edição especial, 2006a, pp. 95-101.

CARDOSO, Fernando Henrique. Fernando Henrique Cardoso: The acidental presidente of Brazil - a memoir with Brian Winter. New York: PublicAffairs, 2006b.

CARDOSO, Fernando Henrique. A Arte da Política: a bistória que vivi. Rio de Janeiro: Civilização Brasileira, 2006c.

CARDOSO, Fernando Henrique. Entrevista com Fernando Henrique Cardoso. In: MONTERO, Paula e MOURA, Flávio (org.). Retrato de Grupo - 40 anos do CEBRAP. São Paulo: Cosac Naify, 2009.

CARDOSO, Fernando Henrique. Montoro por Fernando Henrique Cardoso - entrevista concedida a Jorge Cunha Lima. In: LIMA, Jorge Cunha (org.). Franco Montoro - perfis parlamentares, n. 54. Brasília: Câmara dos Deputados, 2009a.

CARDOSO, Fernando Henrique. Entrevista com Fernando Henrique Cardoso concedida à Angela Randolpho Paiva, Ricardo Ismael, Santuza Cambraia Naves e Clara Lugão. Desigualdade \& Diversidade - Revista de Ciências Sociais da PUC-Rio, n. 9, 2011, pp. 11-30. 
CARDOSO, Fernando Henrique. Fernando Henrique Cardoso (depoimento, 2011). Rio de Janeiro: CPDOC/FGV; LAU/IFCS/UFRJ; ISCTE/IUL, 2012.

CARDOSO, Fernando Henrique. A Soma e o Resto: um olhar sobre a vida aos 80 anos, entrevista de Fernando Henrique Cardoso a Miguel Darcy. Rio de Janeiro: Civilização Brasileira, 2012a.

CARDOSO, Fernando Henrique. A ousadia da formação: discurso de agradecimento na ocasião de recebimento do prêmio John W. Kluge. Novos Estudos CEBRAP, v. 94, 2012b, pp. 199-205.

CARDOSO, Fernando Henrique. Depoimento de Fernando Henrique Cardoso à Comissão Nacional da Verdade, em São Paulo, 26 de novembro de 2014. Disponível em: https:/ /www.youtube.com/watch?v=DpTT19wIQeY. Consultado em 24/05/2016.

CARDOSO, Fernando Henrique e FALETTO, Enzo. Dependência e Desenvolvimento na América Latina: ensaio de interpretação sociológica. Rio de Janeiro: Zahar Editores, 1970.

CARICATURA FAUSTO RODRIGUES TAVARES. Caricaturas da Rádio Nacional. Produtor Fernando Lobo, Narrador Roberto Faissal e Celso Guimarães. Rio de Janeiro: Rádio Nacional, 7 de outubro de 1949. Programa de Rádio.

CARIELlO, Rafael. Vultos da República: o Chefe. Revista Piauí, n. 96, 2014. Disponível em: http://revistapiaui.estadao.com.br/materia/o-chefe/. Consultado em 07/02/2016.

CARIELLO, Rafael. Vultos da Economia: o Palestrante Cético. Revista Piauí, n. 100, 2015. Disponível em: http://revistapiaui.estadao.com.br/materia/o-palestrante-cetico/. Consultado em 26/03/2016.

CARLOTTO, Maria Caramez. Ciência como instituição e como prática: A mudança do regime disciplinar/estatal de produção e difusão do conbecimento científico no Brasil vista a partir do Laboratório Nacional de Lu₹ Sincrotron. Dissertação de mestrado apresentada ao Programa de Pós-graduação em Sociologia da Universidade de São Paulo, 2008.

CARLOTTO, Maria Caramez. Universitas semper reformanda? A bistória da Universidade de São Paulo e o discurso da gestão à luz da estrutura social. Tese de doutorado apresentada ao Programa de Pós-graduação em Sociologia da Universidade de São Paulo, 2014.

CARNEIRO, Dionísio Dias. Crise e Esperança 1974-1980. In: ABREU, Marcelo de Paiva (org.). A Ordem do Progresso: cem anos de politica econômica republicana 1889-1990. Rio de Janeiro: Elsevier, 1990.

CARNEIRO, Dionísio Dias. Dionisio Dias Cameiro (depoimento, 2000). Rio de Janeiro: CPDOC, 2003. 
CARNEIRO, Paulo E. Berredo. O exemplo e a lição de Eugênio Gudin - traços de sua personalidade. In: CARNEIRO, Paulo E. Berredo (org.). Eugênio Gudin visto por seus contemporâneos. Rio de Janeiro: Editora da Fundação Getúlio Vargas, 1979.

CARneIRO, Teresa Dias. Personalidades da Política Externa da República: Octávio Augusto Dias Carneiro, um pioneiro da diplomacia econômica. Brasília: FUNAG, 2005. Disponível em: http:// funag.gov.br/loja/download/336-

Personalidades_da_PolItica_Externa_da_RepUblica.pdf. Consultado em 13/05/2016.

CARONE, Edgard. Roberto C. Simonsen e sua obra. Revista de Administração de Empresas, v. 11, n. 4, 1971, pp. 23-28.

CARRION, Raul. Raul Carrion: 50 anos de militância política e revolucionária, 2013.

Disponível em: http://www.raulcarrion.com.br/publicacoes/carrion_bio_2013.pdf. Consultado em 05/02/2016.

CARVALHO FILHO, Eleazar de. Entrevista de Francisco Gros para o projeto memória BNDES 50 anos [DVD]. Rio de Janeiro: Arquivo do BNDES, 2002.

CARVALHO FILHO, Eleazar de. Discurso de transmissão da presidência do BNDES [DVD]. Rio de Janeiro: Arquivo do BNDES, 1993.

CARVALHO, José Murilo de. Entrevista com José Murilo de Carvalho, concedida em 9 de outubro de 1998 a Lucia Lippi Oliveira, Marieta de Moraes Ferreira e Celso Castro. Estudos Históricos, n. 22, 1998, pp. 357-377.

CARVAlHO, José Murilo de. A Construção da Ordem: a elite política imperial. Teatro de Sombras: a política imperial, Rio de Janeiro, Civilização Brasileira, 2013.

CARVALHO, Luiz Maklouf. O Ortodoxo: do exílio ao patrocínio oficial, o trajeto de Emir Sader, intelectual orgânico do petismo. Piauí, dezembro de 2006. Disponível em: http://revistapiaui.estadao.com.br/materia/o-ortodoxo/. Consultado em 23/12/2015. CARVALHO, Luiz Maklouf. O Planeta Guido: a vida, as ideias e as angústias do ministro de maior longevidade nos governos PT. Revista Época-Tempo, 13 de janeiro de 2012. Disponível em: http://revistaepoca.globo.com/tempo/noticia/2012/01/o-planetaguido.html. Consultado em 16/03/16.

CASTILHO, Fausto. Entrevista Pública concedida por Fausto Castilho. Educação e Filosofia Uberlândia, v. 27, n. 53, 2013, pp. 17-72.

CASTRO, Adelina Barros de. Outrora... e Sempre. Rio de Janeiro: Cia Brasileira de Artes Gráficas, 1978. 
CASTRO, Ana Maria; COSTA, Evandro Fernandes e BORSOI, Zilda Maria Ferrão. A Criatividade e a Informação em um Processo Decisório Contínuo e Participativo. In: MONTEIRO, Dulce Corrêa e MODESINI, Rui Lyrio (org.). BNDES, um banco de idéias: 50 anos refletindo o Brasil. Rio de Janeiro: BNDES, 2002.

CASTRO, Antonio Barros de e LESSA, Carlos. Introdução à Economia: uma abordagem estruturalista. Rio de Janeiro: Forense-Universitária, 1977.

CASTRO, Antonio Barros de. Discurso de posse na presidência do BNDES [DVD]. Rio de Janeiro: Arquivo do BNDES, 1992a.

CASTRO, Antonio Barros de. Entrevista com Antonio Barros de Castro. In: MANTEGA, Guido e REGO, José Marcio. Conversas com Economistas Brasileiros II. São Paulo: Editora 34, 1999.

CASTRO, Antonio Barros de. Antonio Barros de Castro: a solidão do corredor de longa distância. Economia Aplicada, v. 4, n. 4, 2000, pp. 823-839.

CASTRO, Claudio de Moura. O PET visto por seu criador, s/d. Disponível em: http://claudiomouracastro.com.br/, consultado em 2/10/2015.

CASTRO, Claudio de Moura. Investimento em Educação no Brasil: comparação de três estudos. Pesquisa e Planejamento, v. 1, n. 1, 1971, pp. 141-152.

CASTRO, Claudio de Moura. Investimento em Educação no Brasil: uma réplica. Pesquisa e Planejamento, v. 1, n. 2, 1971a, pp. 393-401.

CASTRO, Juan Cristobal Cárdenas. Una historia sepultada: el Centro de Estudios Socioeconómicos de la Universidad de Chile, 1965-1973 (a 50 años de su fundación). De Raíz Diversa, v. 2, n. 3, 2015, pp. 121-140.

CASTRO, Lavinia Barros de. A bistória precoce das ideias do Plano Real. Dissertacao de mestrado apresentada ao Departamento de Economia da Faculdade de Administração, Economia e Contabilidade da Universidade Federal do Rio de Janeiro. Rio de Janeiro: UFRJ, $1999 \mathrm{~b}$.

CASTRO, Nivalde José de. As Origens da Faculdade Nacional de Ciências Econômicas da Universidade do Brasil. Rio de Janeiro: UFRJ/ FEA, 1991.

CASTRO, Nivalde José de. O economista: a história da profissão no Brasil. Rio de Janeiro: COFECON; CORECON-RJ; CORECON-SP, 2001. 
CASTRO, Sérgio de. Prólogo. In: CENTRO DE ESTUDIOS PÚBLICOS. "El Ladrillo”: Bases de la Politica Económica del Gobierno Militar Chileno. Santiago: Centro de Estudios Públicos, 1992.

CATE, Thomas (org.) An Encyclopedia of Keynesian Economics, Second Edition. Northampton: Edward Elgar Publishing, 2013.

CATERMOL, Fabrício. BNDES-Exim: 15 Anos de Apoio às Exportações Brasileiras. Revista do BNDES, v. 12, n. 24, 2005, pp. 3-30.

CELLARD, André. A análise documental. In: POUPART, Jean. Pesquisa Qualitativa: Enfoques Epistemológicos e Metodológicos. Petrópolis: Vozes, 2008.

CENTRO INTERNACIONAL CELSO FURTADO DE POLÍTICAS PARA O DESENVOLVIMENTO. Apresentação. Memórias do Desenvolvimento - Centro Internacional Celso Furtado de Políticas para o Desenvolvimento, v. 2, n. 2, 2008, pp. 7-12.

CENTRO INTERNACIONAL CELSO FURTADO DE POLÍTICAS PARA O DESENVOLVIMENTO. Apresentação. Memórias do Desenvolvimento - Centro Internacional Celso Furtado de Políticas para o Desenvolvimento, v. 3, n. 3, 2009.

CENTRO INTERNACIONAL CELSO FURTADO DE POLÍTICAS PARA O DESENVOLVIMENTO. As origens do Banco Nacional de Desenvolvimento Econômico (BNDE) 1952-1955. In: TAVARES, Maria da Conceição (org.). Memórias do Desenvolvimento - Centro Internacional Celso Furtado de Politicas para o Desenvolvimento, v. 4, n. 4, 2010, pp. 13-44.

CEPAL. Problemas de la Industria Siderúrgica y de Transformación de Hiero y Acero en América Latina. Ciudad del México: CEPAL, 1960.

CEPAL. Informe Provisional del Seminario de Programación industrial. Mar del Plata: CEPAL, 1963.

CEPAL. El Empresario Industrial en América Latina. Estudio preparado por el Consultor de la Secretaría, Profesor Fernando Henrique Cardoso, de la Universidad de São Paulo. Mar del Plata: CEPAL, 1963a.

CEPÊDA, Vera Alves. Roberto Simonsen e a formação da ideologia industrial no Brasil - limites e impasses. Tese de doutorado apresentada ao Departamento de Ciência Política da Universidade de São Paulo. São Paulo: USP, 2003. 
CHACEL, Julian. Eugênio Gudin - o professor. In: CARNEIRO, Paulo E. Berredo (org.). Eugênio Gudin visto por seus contemporâneos. Rio de Janeiro: Editora da Fundação Getúlio Vargas, 1979.

CHACEL, Julian. Entrevista com Julian Chacel. In: LOUREIRO, Maria Rita (org.). 50 anos de Ciência Econômica no Brasil: pensamentos instituições, depoimentos. Petrópolis: Vozes, 1997.

CHACEL, Julian. Da crise à recessão: entrevista de Julian Chacel à Betholdo de Castro. Conjuntura Econômica, 2012, pp. 20-24.

CHARLE, Christophe. Le pantouflage en France (vers 1880 - vers 1980). Annales. Économies, Sociétés, Civilisations, v. 42, n. 5, 1987, pp. 1115-1137.

CHARLE, Christophe. Prosopography (Collective Biography). In: SMELSER, N. J. e BALTES, B. (org.). International Encyclopedia of the Social \& Behavioral Sciences. Oxford: Elsevier Science, 2001.

CHAVES, Miriam Waidenfeld. O céu é o limite: a educação escolar da elite carioca nos anos 1950. GT-14: Sociologia da Educação, 31ª ANPED, 2008, pp. 1-19.

CHAVES, Miriam Waidenfeld. Estratégias de socialização da igreja: o papel dos colégios católicos masculinos nos anos 1920-1950. Educação em foco, v. 15, n. 2, 2010/2011, pp. 135-152.

CILAS. Center for Iberian and Latin American Studies (CILAS) Newsletter Fall/Winter 1997-98, 1997, pp. 1-12.

CMBEU. Relatório da Comissão Mista Brasil-Estados Unidos. Memórias do Desenvolvimento - Centro Internacional Celso Furtado de Políticas para o Desenvolvimento, v. 2, n. 2, 2008, pp. 279336.

COELHO, Francisco da Silva. Antonio Delfim Netto: Formação e Influência de suas Análises sobre o Crescimento e o Desenvolvimento Econômico. In: SZMRECSÁNYI, Tamás e COELHO, Francisco da Silva (org.). Ensaios de História do Pensamento Econômico no Brasil Contemporâneo. São Paulo: Atlas, 2007.

COFECON. Conselho Federal de Economia: sessenta anos de História da Regulamentação da Profissão de Economista. São Paulo: Editora Narrativa Um, 2012.

COLANDER, David e KLAMER, Arjo. The Making of an Economist. Journal of Economic Perspectives, v. 1, n. 2, 1987, pp. 95-111. 
COLISTETE, Renato Perim. O desenvolvimentismo Cepalino: Problemas Teóricos e Influências no Brasil. In: SZMRECSÁNYI, Tamás e COELHO, Francisco da Silva (org.). Ensaios de História do Pensamento Econômico no Brasil Contemporâneo. São Paulo: Atlas, 2007. CONTI, Mario Sergio. Para a alma mater : até poltrona de Delfim fica com a USP. Piauí, n. 55, 2011. Disponível em: http://revistapiaui.estadao.com.br/materia/para-a-alma-mater/. Consultado em 07/02/2016.

CORREA, Aline Fernandes e LEMOS, Celina Borges. PET: a gênese do programa de educação tutorial, s.d. Disponível em:

http://www.enapet.ufsc.br/anais/PET_A_genese_do_Programa_de_educacao_tutorial.p df, consultado em 02/10/2015.

CORRÊA, Ingrid da Silva Mendonça. Ulysses Guimarães: trajetória política de um liberaldemocrata na luta contra a ditadura militar (1971 - 1984). Dissertação apresentada ao Departamento de História Social pela Universidade Federal Fluminense. Niterói: UFF, 2011.

CORRÊA, Maria Letícia. Um estudo sobre o debate desenvolvimentista nas páginas de $O$ Observador Econômico e Financeiro (1936-1954). Anais do XXVI Simpósio Nacional de HistóriaANPUH, São Paulo, 2011a, pp. 1-10.

CORTEZ, Lucini Grangeiro. O Drama Barroco dos Exilados do Nordeste. Tese de doutorado apresentada ao Programa de Pós-Graduação em História da Universidade Federal de Pernambuco. Recife: UFPE, 2003.

COSTA, Iraci del Nero e NOZOE, Hideiki. O departamento de Economia. In: CANABRAVA, Alice Piffer (org.). História da Faculdade de Economia e Administração da Universidade de São Paulo (1946-1981). São Paulo: FEA-USP, 1984.

COSTA, Karen Fernandes da. Metamorfoses: o papel do BNDES na reordenação da economia brasileira. Tese de doutorado em Ciência Política. Campinas: UNICAMP, 2011.

COUTINHO, Maurício Domingues. Depoimento Maurício Domingues Coutinho. In: MONTENEGRO, Antônio Torres; SIQUEIRA, Antônio Jorge e AGUIAR, Antônio Carlos. Engenheiros do Tempo: Memórias da Escola de Engenharia de Pernambuco. Recife: Editora Universitária da UFPE, 1995.

CRUZ, Aníbal Pinto Santa. Introdução. In: CASTRO, Antonio Barros de e LESSA, Carlos. Introdução à Economia: uma abordagem estruturalista. Rio de Janeiro: ForenseUniversitária, 1977. 
CRUZ, Fábio Lucas da. Frente Brasileño de Informaciones e Campanha: Os jornais de brasileiros exilados no Chile e na França (1968-1979). Dissertação apresentada ao Programa de PósGraduação em História Social do Departamento de História da Faculdade de Filosofia, Letras e Ciências Humanas da Universidade de São Paulo. São Paulo: USP, 2010.

CRUZ, Hérnan Santa. Una página de la historia de las Naciones Unidas en sus primeros años: recuerdos sobre el nacimiento de la CEPAL. Santiago: CEPAL, 1966.

CRUZ, Hérnan Santa. Recuerdos de la Creación de la CEPAL, a guisa de introducción. Antecedentes sobre la Creación de la CEPAL. Santiago: CEPAL/ILPES, 1988.

CRUZ, Rodrigo Santa. Homenaje de CEPAL a Hernán Santa Crur, Presentación de Rodrigo Santa Crur, 18 de diciembre de 2008. Disponível em: http://www.cepal.org/prensa/noticias/comunicados/7/34887/DiscursoRodrigoSantaCr uz.pdf. Consultado em 10/11/2015.

CUNHA, Luiz Roberto; LEOPOLDI, Maria Antonieta e RAPOSO, Eduardo. Dionísio Dias Carneiro, um humanista cético: uma história da formação de jovens economistas. Rio de Janeiro: Editora PUC-Rio/LTC, 2014.

CUNHA, Márcia Pereira. Do Planejamento à ação focalizada IPEA e a construção de uma abordagem de tipo econômico da pobreza. Tese apresentada ao Programa de Pós-Graduação em Sociologia da Universidade de São Paulo. São Paulo: Universidade de São Paulo, 2012.

D’ARAÚJO, Maria Celina Soares. O segundo governo Vargas 1951-1954: democracia, partidos e crise politica. São Paulo: Ática, 1992.

D’ARAÚJO, Maria Celina (org.). Fundação Getúlio Vargas: concretização de um ideal. Rio de Janeiro: Editora Fundação Getúlio Vargas, 1999.

D’ARAÚJO, Maria Celina e CASTRO Celso (org.). Tempos modernos: João Paulo Reis Velloso, Memórias do Desenvolvimento. Rio de Janeiro: Editora FGV, 2004.

D’ARAÚJO, Maria Celina; FARIAS, Ignez Cordeiro de; HIPPOLITO, Lucia (org.). IPE A 40 anos apontando caminhos: depoimentos ao CPDOC. Brasília: IPEA, 2005.

DAWIDOFF, Nicholas. The fly Swatter: how my grandfather made his way in the world. New York: Vintage Books, 2003.

DEDECCA, Paula Gorenstein. Sociabilidade, critica e posição: o meio arquitetônico, as revistas especializadas e o debate do moderno em São Paulo (1945-1965). Dissertação apresentada a Faculdade de Arquitetura e Urbanismo da Universidade de São Paulo. São Paulo: USP, 2012. 
DELFIM NETTO, Antonio. As Oportunidades, os Problemas e a Estratégia para Melhorar no Brasil o Treinamento Universitário em Economia. Revista Brasileira de Economia, v. 20, n. 4, 1966, pp. 9-18.

DELFIM NETTTO, Antonio. Prefácio. In: LANGONI, Carlos Geraldo. Distribuição da Renda e Desenvolvimento Econômico do Brasil. Rio de Janeiro: Expressão e Cultura, 1973.

DELFIM NETTO, Antonio. Entrevista com Antônio Delfim Netto. In: BIDERMAN, Ciro; COZAC, Luis Felipe L. e REGO, José Marcio. Conversas com Economistas Brasileiros. São Paulo: Editora 34, 1996.

DELFIM NETTO, Antonio. Arqueologia Econômica. Economia Aplicada, v. 1, n. 4, 1997, pp. 731-739.

DELFIM NETTO, Antonio. Luiz de Freitas Bueno. Folha de São Paulo, caderno Opinião, 22 de março de 2006. Disponível em:

http://www1.folha.uol.com.br/fsp/opiniao/fz2203200607.htm. Consultado em 08/02/2016.

DELFIM NETTO, Antonio; PASTORE, Affonso; CARVALHO, Eduardo Pereira de; CIPPOLARI, Pedro. Estudos ANPES 1: Alguns Aspectos da Inflação Brasileira. São Paulo: Editora Piratininga, 1965.

DENORD, François; LAGNEAU-YMONET, Paul e THINE, Sylvain. Le champ du pouvoir en France. Actes de la recherche en sciences sociales, n. 190, 2011, pp. 24-57.

DENORD, François. Genèse et institutionnalisation du néo-libéralisme en France (années 1930 années 1950). Thèse pour obtenir le grade de Docteur de l'EHESS en Sociologie. Paris: EHESS, 2003.

DENORD, François. Néo-libéralisme version Française. Histoire d'une idéologie politique. Paris: Éditions Demopolis, 2007.

DENORD, François. Géométrie des réseaux sociaux. In: LEBARON, Frédéric e LE ROUX, Brigitte. La Métodologie de Pierre Bourdieu en Action: espace culturel, espace social et analyse de données. Paris: Dunod, 2015.

DEZALAY, Yves. Les courtiers de l'international: Héritiers cosmopolites, mercenaires de l'impérialisme et missionnaires de l'universel. Actes de la recherche en sciences sociales, v. 151152, 2004, pp. 4-35. 
DEZALAY, Yves et MADSEN, Mikael Rask. Espaces de pouvoirs nationaux, espaces de pouvoirs internationaux : Stratégies cosmopolites et reproduction des hiérarchies sociales. Comunication Colóquio Internacional Saber e Poder, Campinas, 2008.

DEZALAY, Yves e GARTH, Bryant. La Mondialisation des Guerres de Palais: la restructuration du pouvoir d'État en Amérique Latine, entre notables du droit et "Chicago boys". Paris: Éditions du Seuil, 2002.

DIAS, José Luciano. O BNDES e o Plano de Metas 1956-1961. In: BNDES. O BNDES e o Plano de Metas. Rio de Janeiro: Departamento de Relações Institucionais do BNDES, 1996.

DIEGUEZ, Consuelo. O formulador emotivo. Piauí, março de 2009. Disponível em: http://revistapiaui.estadao.com.br/materia/marco-aurelio-garcia/. Consultado em $23 / 12 / 2105$.

DINIZ, Adriana Nascimento. BNDES de Agente desenvolvimentista a gestor da privatização 1952-2002. Dissertação de Mestrado apresentada ao Instituto de Economia da UNICAMP. Campinas: UNICAMP, 2004.

DÓREA, Célia Sodré. Memória viva: Madre Cristina. Psicologia ciência e profissão, v. 4, n. 2 , 1984, pp. 40-43.

DÓREA, Célia Sodré. Entrevista de Célia Sodré Dórea, Madre Cristina a Maria Rita Khel e Paulo Vannuchi. Teoria e Debate, n. 9, 1989, pp. 1-17. Disponível em:

http://www.teoriaedebate.org.br/materias/sociedade/madre-cristina. Consultado em $22 / 11 / 2015$.

DOSMAN, Edgar J. Raúl Prebisch (1901-1986): a construção da América Latina e do terceiro mundo. Rio de Janeiro: Contraponto, 2011.

DOSMAN, Edgar J. e POLLOCK, David H. Raúl Prebisch 1901-1971: la búsqueda constante. In: IGLESIAS, Enrique (org.). El legado de Raúl Prebisch. Washington: BID, 1993.

DRAKE, Paul W. Introduction: The Political Economy of Foreign Advisers and Lenders in Latin America. In: DRAKE, Paul W (org.). Money Doctors, Foreign Debts, and Economic Reforms in Latin America from the 1890s to the present. Wilmington: Jaguar books on Latin America, 1994.

DUARTE, Betinho. Rua Viva o Desenho da Utopia. Belo Horizonte: Rona, 2004. 
DUPAS, Gilberto. História de vida Gilberto Dupas. São Paulo: Museu da Pessoa, 2009. Disponível em: http://dualtec.museudapessoa.net/_index.php/historia/9220-historia-devida/texto. Consultado em 22/11/2015.

DURÃO, Vera Saavedra e TOTTI, Paulo. O descanso da Guerreira. Valor Econômico, 17 de agosto de 2012. Disponível em: http://www.valor.com.br/cultura/2792488/odescanso-da-guerreira. Consultado em 03/12/2105.

EKERMAN, Raul. A comunidade de economistas do Brasil: dos anos 50 aos dias de hoje. Revista Brasileira de Economia, v. 43, n. 2, 1989, pp. 113-138.

EICHENGREEN, Barry. A Globalização do Capital: uma história do Sistema Monetário Internacional. São Paulo: Editora 34, 2000.

ELIAS, Norbert. Mozart: sociologia de um gênio. Rio de Janeiro: Jorge Zahar Ed., 1995.

ELLIS, Howard (org.). The Economy of Brazil. Berkeley: University of California Press, 1969.

EMIRBAYER, Mustafa. Manifesto for a Relational Sociology. The American Journal of Sociology, v. 103, n. 2, 1997, pp. 281-317.

ESCAMILLA, Ramon Martinez e MANRIQUE, Irma. Juan F. Noyola: Vida, Pensamiento y obra. D.F. México: Instituto Politécnico Nacional, 1991.

ESPINA, Delia Beatriz. Valentim F. Bouças e a chegada da IBM no Brasil (1917), sua trajetória até hoje 1994. Interciência, v. 23, n. 1, 1998, pp. 45-50.

EVANS, Peter. Embedded autonomy: states and industrial transformation. New Jersey: Princeton University Press, 1995.

FALCOFF, Mark. Eduardo Frei Montalva (1911-1982). The Review of Politics, v. 44, n. 3, 1982, pp. 323-327.

FALETTO, Enzo. Faletto, o amigo independente: entrevista de Enzo Faletto a Vinicius Torres Freire. Folha de São Paulo, 28 de maio de 1995. Disponível em: http://www1.folha.uol.com.br/fsp/1995/5/28/mais!/12.html. Consultado em 12/05/2016.

FALETT'T, Enzo. Entrevista com Enzo Faletto, por José Marcio Rego. Tempo Social Tempo Social: revista de sociologia da USP, v. 19, n. 1, 2007, pp. 189-213.

FAORO, Raymundo. Os donos do poder: formação do patronato politico brasileiro. São Paulo: Globo, 2001. 
FAORO, Raymundo. Os donos do poder: formação do patronato politico brasileiro. São Paulo: EDUSP, 1975.

FARIA, Lina e COSTA, Maria Conceição da. Cooperação Científica Internacional: Estilos de Atuação da Fundação Rockefeller e da Fundação Ford. DADOS - Revista de Ciências Sociais, v. 49, n. 1, 2006, pp. 159-191.

FARIAS, Rogério de Souza. Industriais, economistas e diplomatas: o Brasil e as negociações comerciais multilaterais (1946-1967). Tese de doutorado apresentada ao Instituto de Relações Internacionais da Universidade de Brasília. Brasília: UNB, 2012.

FARO, Clóvis. Isaac Kerstenetzky: o reconhecimento da RBE. Revista Brasileira de Economia, n. 45, v. 3, 1991, pp. 333-334.

FARO, Luiz Cesar e GATTO, Coriolano. Mario. Rio de Janeiro: Insight Comunicação/SulAmérica Seguros, 1994.

FARO, Luiz Cesar e SINELLI, Mônica. Ignácio Rangel: elogio à ousadia. Rio de Janeiro: Insight Comunicação, 2014.

FARIA JÚNIOR, Carlos. O Pensamento Econômico de José da Silva Lisboa, Visconde de Cairu. Tese de Doutorado apresentada ao Programa de Pós-Graduação em História Econômica do Departamento de História da Universidade de São Paulo. São Paulo: USP, 2008.

FAUSTO, Ayrton. Introdução: Vilmar Faria: o melhor de uma geração. In: FAUSTO, Ayrton (org.). Desenvolvimento e integração na américa latina e no caribe: a contribuição das ciências sociais. Brasília : IPRI/FUNAG/FLACSO, 2002.

FAUSTO, Ruy. Entrevista com Ruy Fausto. In: NOBRE, Marcos e REGO, José Marcio (org.). Conversas com filósofos brasileiros. São Paulo: Editora 34, 2000.

FAUSTO, Ruy. Os piores anos de nossa vida: histórias - 'suspiros poéticos e saudades'. Brasília: Fundação Astrojildo pereira, 2008.

FÁVERO, Maria Lourdes de Albuquerque; PEIXOTO, Maria do Carmo de Lacerda e SILVA, Ana Elisa Gerbasi da. Professores estrangeiros na Faculdade Nacional de Filosofia, RJ (1939-1951). Cadernos de Pesquisa São Paulo, n. 78, 1991, pp. 59-71.

FELDHUES, Paulo Raphael Pires. A Confederação Nacional da Indústria e o Nordeste Brasileiro: o desenvolvimentismo nas páginas de Desenvolvimento \& Conjuntura (1957-1964). Tese apresentada ao Programa de Pós-Graduação em História da Universidade de Brasília como requisito final à obtenção do grau de Doutor em História. Brasília: 2014. 
FERNANDES, Arissane Dâmaso. Ignácio Rangel: História, Política e Tecnocracia no Brasil (1930-1960). Tese apresentada ao Programa de Pós-Graduação em História da Universidade de Federal Goiás. Goiânia: UFG, 2011.

FERNÁNDEZ, Ramón García e SUPRINYAK, Carlos Eduardo. Creating academic economics in Brazil: the Ford Foundation and the beginnings of ANPEC. Belo Horizonte: UFMG/CEDEPLAR, 2015.

FERRARI, Amílcar Figueira. José Pelúcio Ferreira e a pós-graduação no Brasil. Brasília: Paralelo 15/Coordenação de Aperfeiçoamento de Pessoal de Nível Superior, 2001.

FERRARI, Amílcar Figueira. O Fundo Nacional de Desenvolvimento Científico e Tecnológico - FNDCT e a Financiadora de Estudos e Projetos - FINEP. Revista Brasileira de Inovação, v. 1, 2002, pp. 151-188.

FERREIRA, Marieta de Moraes. História do tempo presente: desafios. Cultura Vozes, v. 94, n. 3, 2000, pp. 111-124.

FERREIRA, Fábio Vizeu. Management no Brasil em perspectiva histórica: o projeto do IDORT nas décadas de 1930 e 1940. Tese apresentada ao Programa Doutorado em Administração de Empresas da Escola de Administração de Empresas de São Paulo da Fundação Getúlio Vargas. São Paulo: EAESP/FGV, 2008.

FERREIRA, Francisco Whitaker. Itinéraire: Francisco Whitaker Ferreira. Revue Projet, v. 3, n. 271, 2002, pp. 8-17.

FERREIRA, Francisco Whitaker. Perfil Francisco Whitaker. Revista do Instituto Humanitas Unisinos, v. 9, n. 360, 2011. Disponível em:

http:/ /www.ihuonline.unisinos.br/index.php?option $=$ com_content\&view $=$ article\&id $=38$ 41\&secao $=360$. Consultado em 20/01/2015.

FIORI, José Luís. Visão de Mundo: José Luís Fiori. Pepianos: Publicação dos estudantes do Programa de Pós-Graduação em Economia Política Internacional da UFRJ, v. 2, 2015, pp. 23-41.

FISHLOW, Albert. Brazilian Size Distribution of Income. The American Economic Review, v. 62, n. 1/2, 1972, pp. 391-402.

FISHLOW, Albert. O desenvolvimento como tema. Economia Aplicada, v. 7, n. 3, 2003, pp. 657-669.

FIUZA, Guilherme. 3000 dias no bunker: um plano na cabeça e um país na mão. Rio de Janeiro: Editora Record, 2008. 
FLÔRES, Jorge Oscar de Mello. Jorge Oscar de Mello Flores II (depoimento, 1996/1997). Rio de Janeiro: CPDOC, 1998.

FOLHA de São Paulo. Sentimento do Mundo: Presidente recebe condecoração em Lisboa e diz que já quis ser poeta. Folba de São Paulo, 12 de novembro de 2002.

FONSECA, Justo Pinheiro da. Entrevista de Justo Pinheiro da Fonseca à Lígia Maria Leite Pereira. Projeto Memória e História: Visões de Minas, parte I. Belo Horizonte UFMG, 1990.

FONSECA, Justo Pinheiro da. Entrevista de Justo Pinheiro da Fonseca à Lígia Maria Leite Pereira. Projeto Memória e História: Visões de Minas, parte II. Belo Horizonte UFMG, 1990a.

FONSECA, Roberto Giannetti da. Memórias de um trader: a história vivida do comércio exterior brasileiro nos anos 70 e 80. São Paulo: IOB, 2002.

FOURCADE, Marion. Economists and Societies: discipline and profession in the United States, Britain and France 1890s to 1990s. Princeton: Princeton University Press, 2009.

FOURCADE, Marion. The United States: an economist's economy. In: MONTECINOS, Venrónica e MARKOFF, John (org.). Economists in the Americas. Massachusetts: Edward Elgar, 2009a.

FRANCO, Gustavo Henrique Barroso. O Plano Real e outros ensaios. Rio de Janeiro: Francisco Alves, 1995.

FRANCO, Gustavo Henrique Barroso. Entrevista com Gustavo Franco. In: MANTEGA, Guido e REGO, José Marcio. Conversas com Economistas Brasileiros II. São Paulo: Editora 34, 1999.

FRANCO, Gustavo Henrique Barroso. Economia na PUC-Rio: Notas de uma Testemunha. In: SZMRECSÁNYI, Tamás e COELHO, Francisco da Silva (org.). Ensaios de História do Pensamento Econômico no Brasil Contemporâneo. São Paulo: Atlas, 2007a.

FRANCO, Gustavo Henrique Barroso. A negociação da dívida, depoimento de Gustavo Franco. FERREIRA, Marieta Moraes e SARMENTO, Carlos Eduardo (org.). Mario Covas: a ação conforme a pregação: uma revolução ética em São Paulo. São Paulo: Editora Fundação Mario Covas, 2003.

FRANCO, Gustavo Henrique Barroso. Cartas a um Jovem Economista: Conselhos para seus planos econômicos. Rio de Janeiro: Elsevier, 2011. 
FRANCO, Ilimar. Carvalho faz duras críticas a Malan. Jornal do Brasil, 3 de setembro de 1999.

FRANCO, Rolando. La FLACSO Clásica (1957 - 1973): vicisitudes de las ciencias sociales latinoamericanas. Santiago: Catalonia, 2007.

FRANCO, Rolando. La invención del ILPES. Santiago: Publicación de las Naciones Unidas, 2013.

FRANK, André Gunder. Capitalism and Underdevelopment in Latin America. New York: Montly Review Press, 1967.

FRANK, André Gunder. Economic Genocide in Chile: Open Letter to Milton Friedman and Arnold Harberger. Economic and Political Weekly, v. 11, n. 24, 1976, pp. 880-888.

FRANK, André Gunder. The cold war and me, 1998. Disponível em: http://rrojasdatabank.info/agfrank/syfrank.htm. Consultado em 23/12/2015.

FREIRE, Ana Maria Araújo. A voz da esposa: a trajetória de Paulo Freire. In: GADOTTI, Moacir (org.). Paulo Freire: uma biobibliografia. São Paulo: Cortez Editora, 1996.

FREIRE, Paulo. Ernani Fiori: um intelectual apaixonado, entrevista a Tomaz Tadeu da Silva. Educação e Realidade, v. 11, n. 1, 1986, pp. 11-18.

FREITAS, Marcos Cezar de. Álvaro Vieira Pinto: a personagem histórica em sua trama. São Paulo: Editora Cortez, 1998.

FRENKEL, Jacob. Professor Jacob Frenkel, entrevista. IE em Foco, v. 2, 2013, pp. 7-8.

FREYRE, Gilberto. Sobrados e Mucamos: decadência do patriarcado rural e desenvolvimento urbano. São Paulo: Editora Global, 2003.

FRIEDMAN, Milton. Capitalismo e Liberdade. São Paulo: Nova Cultural, 1985.

FRIEDMAN, Milton. Bases para un desarrollo económico, conferencia en el Edificio Diego Portales de Santiago, el 26 de marzo de 1975. In: SOTO, Angel (org.). Un Legado de Libertad: Milton Friedman en Chile [Kindle]. Instituto Democracia y Mercado/Atlas Economic Research Foundation/ Fundación para el Progresso, 2012.

FRIEDMAN, Milton. Carta de Milton Friedman al Gral. Augusto Pinochet, 21 de abril de 1975. In: SOTO, Angel (org.). Un Legado de Libertad: Milton Friedman en Chile [Kindle]. Instituto Democracia y Mercado/Atlas Economic Research Foundation/ Fundación para el Progresso, 2012a.

FRITSCH, Winston. Política Industrial do Novo Governo: Um Passo à Frente, Dois Para Trás?. Revista Brasileira de Economia, v. 45 (especial), 1991, pp. 344-348. 
FRITSCH, Winston. Torneira Viciada. Isto é Senhor, 18 de julho de 1990.

FURLAS, Héllen Aparecida. Conde e Condessa do Pinhal e seus descendentes. Casa do Pinhal, 2016, pp. 1-37. Disponível em http://casadopinhal.com.br/img/pdfs/CondeCondessa-Pinhal-Descendentes3.pdf. Consultado em 08/04/2016.

FURTADO, Bernardino e FRIEDLANDER, David. Serra. Revista Época, 21 de outubro de 2002. Disponível em: http://revistaepoca.globo.com/Epoca/0,6993,EPT4198662011-1,00.html Consultado em 20/01/2015.

FURTADO, Celso. Desenvolvimento e Subdesenvolvimento. Rio de Janeiro: Editora Fundo de Cultura, 1961.

FURTADO, Celso. Dialética do Desenvolvimento. Rio de Janeiro: Editora Fundo de Cultura, 1964.

FURTADO, Celso. Subdesenvolvimento e Estagnação na América Latina. Rio de Janeiro: Civilização Brasileira, 1968.

FURTADO, Celso. Aventuras de um economista Brasileiro. In: FURTADO, Celso. Obra autobiográfica de Celso Furtado, Tomo II. Rio de Janeiro: Paz e Terra, 1997.

FURTADO, Celso. Obra autobiográfica de Celso Furtado, Tomo I. Rio de Janeiro: Paz e Terra, $1997 \mathrm{a}$.

FURTADO, Celso. Entrevista com funcionários do BNDE: Celso Furtado, concedida a

Nora Lanari, Ângela Coronel, Rui Modenesi, Aloísio Barbosa e Roberto Rodrigues em 22 de junho de 1982. Memórias do Desenvolvimento - Centro Internacional Celso Furtado de Políticas para o Desenvolvimento, v. 3, n. 3, 2009, pp. 101-122.

FURTADO, Celso. Obra autobiográfica: A Fantasia Organizada, A Fantasia Desfeita, Os Ares do Mundo. São Paulo: Companhia das Letras, 2014.

GALVÊAS, Ennane. Ernane Galvêas I (depoimento, 1989). Rio de Janeiro: CPDOC/BANCO CENTRAL DO BRASIL, 1990.

GARCIA, Afrânio. La construction interrompue. Actes de la Recherche en Sciences Sociales, v. 121-122, 1998, pp. 52-61.

GARCIA, Afrânio. A dependência da política: Fernando Henrique Cardoso e a sociologia no Brasil. Tempo Social: revista de sociologia da USP, v. 16, n. 1, 2004, pp. 285-300.

GARCIA, Afrânio. Circulation internationale et formation d'une "école de pensée" latinoamericaine (1945-2000). Information sur les sciences sociales, v. 44, n. 2/3, 2005, pp. 521-555. 
GARCIA, Marco Aurélio. Memória: Eder Sader - O Futuro sem este Homem. Teoria e Debate, n. 4, 1988. Disponível em:

http://www.teoriaedebate.org.br/index.php?q=materias/nacional/eder-sader-o-futurosem-este-homem\&page $=0,0$. Consultado em 23/12/2015.

GARCIA, Miliandre. A questão da cultura popular: as políticas culturais do Centro Popular de Cultura (CPC) da União Nacional dos Estudantes (UNE). Revista Brasileira de História, v. 24, n. 47, 2004a, pp. 127-62.

GARCIA, Sylvia Gemignani. Destino Ímpar: sobre a formação de Florestan Fernandes. São Paulo: Editora 34, 2002.

GAROFÁLO, Gílson de Lima e RIZZIERI, Juarez Alexandre Baldini. O Departamento de Economia da FEA/USP e o Pensamento Econômico Brasileiro. In: SZMRECSÁNYI, Tamás e COELHO, Francisco da Silva (org.). Ensaios de História do Pensamento Econômico no Brasil Contemporâneo. São Paulo: Atlas, 2007.

GAVIÃO, Fábio Pires. A "esquerda católica" e a Ação Popular (AP) na luta pelas reformas sociais (1960-1965). Dissertação apresentada ao Departamento de História do Instituto de Filosofia e Ciências Humanas da Universidade Estadual de Campinas. Campinas: UNICAMP, 2007.

GEDDES, Barbara. Building "State" Autonomy in Brazil. Comparative Politics, v. 22, n. 2, 1990, pp. 217-235.

GIANNOTTI, José Arthur. Entrevista com José Arthur Giannotti. In: MONTERO, Paula e MOURA, Flávio (org.). Retrato de Grupo - 40 anos do CEBRAP. São Paulo: Cosac Naify, 2009.

GOMES, Eustáquio. O Mandarim: história da infância da UNICAMP. Campinas: Editora da UNICAMP, 2007.

GONÇALVES, Luiz Eduardo Fonseca de Carvalho. As Relações Brasil-CEPAL (19471964). Brasília: Fundação Alexandre Gusmão, 2011.

GONTIJO, Ricardo. Sem vergonha da Utopia: conversas com Betinho. Petrópolis: Vozes, 1988. GORDON, Lincoln. O Progresso pela Aliança. Rio de Janeiro: Distribuidora Record, 1962. GOUVÊA, Gilda Portugal. Burocracia e Elites Burocráticas no Brasil. São Paulo: Paulicéia, 1994. 
GOUVÊA, Gilda Portugal. Entrevista com Gilda Figueiredo Portugal Gouvêa: Lecionar coloca o envelhecimento em seu devido lugar. Portal do Envelhecimento, 2014. Disponível em:

http://portaldoenvelhecimento.org.br/index.php/item/230-gilda-figueiredo-portugalgouvea- $\%$ E2\%80\%9Clecionar-coloca-o-envelhecimento-em-seu-devidolugar $\% \mathrm{E} 2 \% 80 \% 9 \mathrm{D}$. . Consultado em 04/03/16.

GOUVEIA, Oserias. Os (des)caminhos da Utopia: glória e derrocada do comunismo na memória política de militantes dos anos sessenta. Recife: Editora Universitária da UFPE, 2003

GRANOVETTER, Mark. The strenght of weak ties. American Journal of Sociology, v. 78, n. 6, 1973, pp. 1360-1380.

GRANOVETTER, Mark. Ação Econômica e Estrutura Social: o Problema da Imersão. RAE-Eletrônica, v. 6, n. 1, 2007.

GREY, Richard; GROSS, Ruth; GOEBEL, Rolf; KOELB, Clayton. A Franz Kafka Encyclopedia. Westport: Greenwood Press, 2005.

GREEN, James e JONES, Abigail. Reinventando a história: Lincoln Gordon e as suas múltiplas versões de 1964. Revista Brasileira de História, v. 29, n. 57, 2009, pp. 67-89.

GROS, Francisco. Entrevista de Francisco Gros para o projeto memória BNDES 50 anos [DVD]. Rio de Janeiro: Arquivo do BNDES, 2002.

GUDIN, Eugênio. A Mística do Planejamento. Correio da Manhã, 29 de maio, 2, 6, 9 e 11 de junho de 1953.

GUDIN, Eugênio. Carta ao Ministro Gustavo Capanema, 21 de agosto de 1944. In: CARNEIRO, Paulo E. Berredo (org.). Eugênio Gudin visto por seus contemporâneos. Rio de Janeiro: Editora da Fundação Getúlio Vargas, 1979.

GUDIN, Eugênio. Eugênio Gudin depoimento, 1979. Rio de Janeiro: FGV/CPDOC-História Oral, 1980.

GUDIN, Eugênio. Rumos de Política Econômica. In: GUDIN, Eugênio e SIMONSEN, Roberto Cochrane. A controvérsia do planejamento na economia brasileira; coletânea da polêmica Simonsen $x$ Gudin, desencadeada com as primeiras propostas formais de planejamento da economia brasileira ao final do Estado Novo. Brasília: IPEA, 2010.

HADDAD, Paulo Roberto. Discurso do ministro do planejamento na posse de Antonio Barros de Castro na presidência do BNDES [DVD]. Rio de Janeiro: Arquivo do BNDES, 1992. 
HADDAD, Paulo Roberto. Itaipava 30 anos depois: Seminário da USP - Cinquenta Anos de Ciência Econômica no Brasil. FEA-USP, agosto de 1996. In: LOUREIRO, Maria Rita (org.). 50 Anos de Ciência Econômica no Brasil: pensamento, instituições e depoimentos. Petrópolis: Editora Vozes, 1997.

HADDAD, Paulo Roberto. A Associação Nacional de Centros de Pós-Graduação em Economia. Revista ANPEC, v. 4, 1998, pp. 185-190.

HARBERGER, Arnold. An interview with the dean of the "Chicago Boys", by David Levy from the Federal Reserve Bank of Minneapolis, march 1999. Disponível em: https://www.mpls.frb.org/publications/the-region/interview-with-arnold-harberger.

Consultado em 12/09/2015.

HARBERGER, Arnold. Commanding Heights: the battle for the world economy on PBS. Amold "Al" Harberger, 2000. Disponível em:

http://www.pbs.org/wgbh/commandingheights/shared/minitextlo/int_alharberger.html , Consultado em 13/09/2015.

HARBERGER, Arnold. Interview with Arnold C. Harberger by Catherine MansellCarstens. Economia Mexicana: Nueva Época, v. 12, n. 2, 2003.

HARTUNG, Paulo. Entrevista com Paulo Hartung. In: MOREIRA, Renato Heitor Santoro. O movimento estudantil na Universidade Federal do Espirito Santo: a trajetória de um grupo ao poder (1976 - 1981). Dissertação apresentada ao Programa de Pós-graduação em História Social das Relações Políticas, da Universidade Federal do Espírito Santo. Vitória: UFES, 2008.

HILTON, Ronald. Who's Who in Latin America: Part VI: Brazil. Stanford: Stanford University Press, 1948.

HODARA, Joseph. Prebisch y Urquidi: vidas paralelas. Araucaria. Revista Iberoamericana de Filosofía, Politica y Humanidades, n. 19, 2008, pp. 46-63.

HOFE, Harold von. German Literature in Exile: Leonhard Frank. The German Quarterly, v. 20, n. 2, 1947, pp. 122-128.

HOLANDA, Sérgio Buarque de. Raízes do Brasil. São Paulo: Companhia das Letras, 2006. HOLANDA, Bartolomeu Buarque de. Buarque uma família Brasileira: ensaio genealógico. Rio de Janeiro: Casa da Palavra, 2007

IBGE. Isaac Kerstenetzkey: legado e perfil. Rio de Janeiro: IBGE, Centro de Documentação e Disseminação de Informações, 2006. 
IPEA/CEPAL. A cooperação técnica da CEPAL nos 40 anos de IPEA. Brasília: IPEA, 2004.

JAGUARIBE, Helio. O ISEB e o Desenvolvimento Nacional. In: TOLEDO, Caio Navarro (org). Intelectuais e politica no Brasil: a experiência do ISEB. Rio de Janeiro: Revan, 2005.

JAY, Martin. A Imaginação Dialética: história da Escola de Frankfurt e do Instituto de Pesquisas Sociais 1923-1950. Rio de Janeiro: Contraponto, 2008.

JORNALISMO: GUY DE ALMEIDA. Memória e Poder. Minas Gerais: TV Assembleia de Minas, 29 de agosto de 2002.

Disponível

em

http://www.almg.gov.br/acompanhe/tv_assembleia/videos/index.html?idVideo $=64559$ 0\&cat $=87$. Consultado em 24/05/2016.

JUILLARD, Etienne. Études rurales: des économistes aux géographes. Annales. Économies, Sociétés, Civilisations, v. 14, n. 4, 1959, pp. 766-776.

KAFKA, Alexandre. Dr. Gudin e o Instituto Brasileiro de Economia da Fundação Getúlio Vargas. In: CARNEIRO, Paulo E. Berredo (org.). Eugênio Gudin visto por seus contemporâneos. Rio de Janeiro: Editora da Fundação Getúlio Vargas, 1979.

KAFKA, Alexandre. Depoimento Alexandre Kafkea. Brasília, Secretaria de Relações Institucionais do Banco Central do Brasil, 1998.

KEINERT, Fábio Cardoso. Cientistas Sociais entre Ciência e Política (Brasil, 1968-1985). Tese de doutorado apresentada ao Programa de Pós-Graduação em Sociologia da Universidade de São Paulo. São Paulo: USP, 2011.

KERSTENETZKY, Isaac e CHACEL, Julian M. Reflexões em torno dos Problemas da Investigação Econômica no Brasil. Revista Brasileira de Economia, v. 20, n. 4, 1966, pp. 4760.

KHAN, Rahman Shamus. Privilege: the making of an adolescent elite at St. Paul's School. Princeton: Princeton University Press, 2011.

KINZO, Maria d'Alva Gil. Oposição e autoritarismo: gênese e trajetória do MDB 1996-1979. São Paulo: Vértice, 1988.

KLÜGER, Elisa. Técnicos e políticos nos primeiros anos do BNDE. Cadernos do Desenvolvimento, v. 9, n. 14, 2014, pp. 59-81. 
KLÜGER, Elisa. Le cosmopolitisme tourné vers l'intérieur: une stratégie de distinction d'élites brésiliennes. Working Paper Centre Européen de Sociologie et de Science Politique, n. 3, 2015a, pp. 1-13.

KLÜGER, Elisa. A contraposição das noções de técnica e política nos discursos de uma elite burocrática. Revista Sociologia e Política v. 23, n. 55, 2015b, pp. 75-96.

KLÜGER, Elisa. Construindo uma burocracia econômica de excelência: concursos de seleção para o Banco Nacional de Desenvolvimento Econômico e Social (BNDES), de 1955 a 2012. Plural Revista de Ciências Sociais Programa de Pós Graduação em Sociologia da Universidade de São Paulo, v. 22, n. 2, 2015c, pp. 81-114.

KOWARICK, Lúcio. Entrevista com Lúcio Kowarick. In: MONTERO, Paula e MOURA, Flávio (org.). Retrato de Grupo - 40 anos do CEBRAP. São Paulo: Cosac Naify, 2009.

KUBITSCHEK, Juscelino. Discurso de Juscelino Kubitschek na inauguração de curso de treinamento sobre problemas de desenvolvimento econômico, patrocinado pelo Governo Federal e pela Comissão Econômica para a América Latina, no Ministério da Fazenda. Rio de Janeiro: Biblioteca da Presidência da República, 18 de setembro de 1956.

KUCINSKI, Bernardo. Jornalistas e revolucionários nos tempos da imprensa alternativa. São Paulo: EDUSP, 2003.

KUGELMAS, Eduardo. Entrevista com Eduardo Kugelmas concedida à Hélgio Trindade em outubro de 2001. In: TRINDADE, Hélgio. Ciências Sociais no Brasil: Diálogos com mestres e discipulos. Brasília: ANPOCS; Liber Livro Editora, 2012.

KUSHNIR, Beatriz. Cães de Guarda - Jornalistas e Censores do AI-5 à constituição de 1988. São Paulo: Boitempo, 2004.

LAFER, Celso. O Planejamento no Brasil: observações sobre o Plano de Metas (19561961). In: LAFER, Betty Mindlin. Planejamento no Brasil. São Paulo: Editora Perspectiva, 1975.

LAFER, Celso. Experiência, Ação e Narrativa: Reflexões sobre um curso de Hannah Arendt. Estudos Avançados, v. 21, n. 60, 2007, pp. 289-304.

LAFER, Celso. Uma Aproximação Pertinente. Comentário ao livro: A Duas Vozes Hannah Arendt e Octavio Paz, de Eduardo Jardim. REVISTA USP, n. 76, 2007-2008, pp. $168-171$. 
LAGO, Luiz Aranha Corrêa do. A retomada do crescimento e as distorções do "milagre". In: ABREU, Marcelo de Paiva (org.). A Ordem do Progresso: cem anos de política econômica republicana 1889-1990. Rio de Janeiro: Elsevier, 1990.

LAGO, Pedro Aranha Corrêa do. A SUMOC como embrião do Banco Central: sua influência na condução da política econômica, 1946-1965. Dissertação de mestrado apresentada ao Departamento de Economia da Pontifícia Universidade Católica do Rio de Janeiro. Rio de Janeiro: PUC-RJ, 1982.

LAHUERTA, Milton. Intelectuais e Resistência Democrática: Vida Acadêmica, Marxismo e Política no Brasil. Cadernos AEL, v. 8, n. 14-15, 2001, pp. 55-94.

LAMOUNIER, Bolívar. Bolivar Lamounier (depoimento, 2012). São Paulo: CPDOC/FGV; LAU/IFCS/UFRJ; ISCTE/IUL; IIAM, 2013.

LANGONI, Carlos Geraldo. A study in economic growth: the Brazilian case. Tese de doutorado apresentada ao departamento de economia da University of Chicago. Illinois: University of Chicago, 1970.

LANGONI, Carlos Geraldo. Investimento em Educação no Brasil: um comentário. Pesquisa e Planejamento, v. 1, n. 2, 1971, pp. 381-392.

LANGONI, Carlos Geraldo. Distribuição da Renda e Desenvolvimento Econômico do Brasil. Rio de Janeiro: Expressão e Cultura, 1973.

LANGONI, Carlos Geraldo. Distribuição da Renda: uma versão para a minoria. Revista Pesquisa e Planejamento Econômico, v. 4, n. 1, 1974, pp. 167-180.

LAZEGA, Emmanuel. Que sais-je? Réseaux sociaux et structures relationnelles. Paris: Presses Universitaires de France, 1998.

LEBARON, Frédéric. La dénégation du pouvoir. Actes de la recherche en sciences sociales, v. 119, 1997, pp. 3-26.

LEBARON, Frédéric. La Croyance Économique: les économistes entre science et politique. Paris: Éditions du Seuil, 2000.

LEBARON, Frédéric. L'Enquête Quantitative en Sciences Sociales: recueil et analyse de données. Paris: Dunod, 2006.

LEBARON, Frédéric. "Nobel" economists as public intellectuals: the circulation of symbolic capital. International Journal of Contemporary Sociology, v. 43, n. 1, 2006a, pp. 87-101. LEBARON, Frédéric. Central bankers in the contemporary global field of power: a 'social space' approach. The Editorial Board of the Sociological Review, 2008, pp. 121-144. 
LEBARON, Frédéric. L’analyse géométrique des données dans un programme de recherche sociologique: Le cas de la sociologie de Bourdieu. Revue MODULAD, n. 42, 2010, pp. 102-109.

LEFEBVRE, Jean-Paul. Les professeurs français des missions universitaires au Brésil (1934-1944). Cahiers du Brésil Contemporain, n. 12, 1990.

LEITE, Cleantho de Paiva. O Assessoramento da presidência da República. Rio de Janeiro: Fundação Getúlio Vargas, 1959.

LEMOS, Chélen Fischer (org.). Ações premiadas no 50 Concurso de Inovações na Gestão Pública Federal. Brasília: ENAP, 2000.

LEO, Sergio. Um Liberal Heterodoxo. Valor Econômico, à mesa com Valor, 13, 14 e 15 de abril de 2012.

LEONI, Brigitte Hersant. Fernando Henrique Cardoso: o Brasil do Possivel: um perfil biográfico. Rio de Janeiro: Nova Fronteira, 1997.

LEOPOLDI, Maria Antonieta. Burocracia, empresariado e arenas decisórias estratégicas: trajetórias o neocorporativismo no Brasil (1939 a 1955). Ciências Sociais Hoje. São Paulo: ANPOCS, 1992.

LESSA, Carlos. Entrevista com o economista Carlos Lessa realizada por Nelson Castan, Rubens Soares de Lima e Enéas Costa de Souza em outubro de 1981. Ensaios FEE, v. 2, n. 1, 1981, pp. 165-174.

LESSA, Carlos. Conferência sobre o pensamento de Aníbal Pinto. Revista de Economia Contemporânea, n. 3, 1998, pp. 5-11.

LESSA, Carlos. Discurso de posse na presidência do BNDES [DVD]. Rio de Janeiro: Arquivo do BNDES, 2003.

LESSA, Carlos. Entrevista com o economista Carlos Lessa realizada por Graziela Wolfart, Greyce Vargas e Rafaela Kley. Revista do Instituto Humanitas Unisinos, v. 10, n. 344, 2010, Disponível em:

http:/ / www.ihuonline.unisinos.br/index.php?option=com_content\&view $=$ article\&id $=35$ $\underline{29 \& s e c a o=344}$. Consultado em 15/11/2015.

LEVI, Giovanni. Les usages de la biographie. Annales. Économies, Sociétés, Civilisations, v. 44, n. 6, 1989, pp. 1325-1336.

LEVY, Clayton. A Economia bem temperada de Wilson Cano. Jornal da UNICAMP, n. 396, 2008. Disponível em: 
https://www.unicamp.br/unicamp/unicamp_hoje/ju/maio2008/ju396pag3.html.

Consultado em 06/03/16.

LIMA, Jorge Cunha (org.). Franco Montoro - perfis parlamentares n. 54. Brasília: Câmara dos Deputados, 2009.

LIMA, Jorge Cunha. Memórias dos Brasileiros: Jorge da Cunha Lima. São Paulo: Museu da pessoa, 2011. Disponível em:

http://www.museudapessoa.net/pt/conteudo/historia/jorge-da-cunha-lima-44778.

Consultado em 23/05/2016.

LIMA, Marco Antonio Albuquerque de Araujo. O Desenvolvimento Inacabado do Brasil: $O$ BNDE e a Convenção do Crescimento de 1952 a 1978. Dissertação de Mestrado em Desenvolvimento, Agricultura e Sociedade. Seropédica: UFRRJ, 2006.

LIMA, Marcos Costa (org.). Os Boêmios Civicos: a Assessoria econômico-política de V argas (19511954). Rio de Janeiro: Centro Internacional Celso Furtado de Políticas para o Desenvolvimento, 2013.

LIMA, Haroldo e ARANTES, Aldo. História da Ação Popular da JUC ao PC do B. São Paulo: Editora Alfa-Omega, 1984.

LIRA, Paulo Hortêncio Pereira. Paulo Lira I (depoimento, 1989). Rio de Janeiro: CPDOC/BANCO CENTRAL DO BRASIL, 1990.

LOPES, Francisco Lafaiete. O Choque Heterodoxo: combate à inflação e reforma monetária. Rio de Janeiro: Campus, 1986.

LOPES, Francisco Lafaiete. Entrevista com Francisco Lopes. In: MANTEGA, Guido e REGO, José Marcio. Conversas com Economistas Brasileiros II. São Paulo: Editora 34, 1999.

LOPES, José Sérgio Leite. Sobre o debate da distribuição de renda: leitura crítica de um artigo de Fishlow. Revista de Administração de Empresas, v. 13, n. 3, 1973, pp. 47-61.

LOPES, Juarez Brandão. Entrevista de Juarez Brandão Lopes. In: BASTOS, Elide Rugai et al., (org.). Conversas com Sociólogos Brasileiros. São Paulo: Editora 34, 2006 a.

LOPES, Lucas. Entrevista com presidentes do BNDE: Lucas Lopes, concedida a Ângela Coronel, Ricardo Weiss, Marcelo Averbug e Iolanda, 8 de março de 1982. Memórias do Desenvolvimento - Centro Internacional Celso Furtado de Politicas para o Desenvolvimento, v. 3, n. 3, 2009, pp. 9-40.

LOPES, Lucas. Memórias do desenvolvimento. Rio de Janeiro: Centro da Memória da Eletricidade no Brasil, 1991. 
LOPES, Luís Simões. Luís Simões Lopes II (depoimento, 1990). Rio de Janeiro: CPDOC, 2003.

LOPES, Rodrigo. Sonbo e Razãa: Lucas Lopes, o Planejador de JK. São Paulo, ARX, 2006.

LOPES, Rosalba. Luzes à esquerda: partidos e organizações marxistas no Brasil e a democracia nos anos 1970. Revista Democracia Socialista, n. 1, 2013, pp. 101-128.

LÓPEZ, Manuel Fernández. Raúl Prebisch y su Alma Máter. Universidad de Buenos Aires Facultad de Ciencias Económicas: II Congreso Internacional de Economía y Gestión, 2008, pp. $1-24$.

LOUREIRO, Felipe. Aliança contra ou a favor do progresso? Os acordos financeiros de maio de 1961 entre Brasil e Estados Unidos. XVI Encontro Nacional da Sociedade Brasileira de Economia Política (SEP), 2011.

LOUREIRO, Maria Rita. Economistas e elites dirigentes no Brasil. Revista Brasileira de Ciências Sociais, n. 20, v. 7, 1992, pp. 47-69.

LOUREIRO, Maria Rita (org.). 50 anos de Ciência Econômica no Brasil: pensamentos instituições, depoimentos. Petrópolis: Vozes, 1997.

LOUREIRO, Maria Rita. Os Economistas no Governo: gestão econômica e democracia. Rio de Janeiro: Editora Fundação Getulio Vargas, 1997a.

LOVATTO, Angélica. Maria Augusta Tibiriçá Miranda e Helga Hoffmann: presença feminina nos Cadernos do Povo Brasileiro nos anos 1960. Meditações - revista de ciências sociais, v. 14, n. 2, 2009, pp. 178-197.

LOVE, Joseph. Economic Ideas and Ideologies in Latin America Since 1930. In: BETHELL, Leslie (org.). Ideas and Ideologies in Twentieth Century Latin America. Cambridge: Cambridge University Press, 1996.

LÖWY, Michel. Um intelectual marxista: entrevista com Michael Löwy. Entrevista a Ângela de Castro Gomes e Daniel Aarão Reis. Tempo, v. 1, n. 2, 1996, pp. 166-183.

LYRA, Flávio Tavares de. Eu e meus tempos: recortes de memória. Brasília: Tesaurus Editora, 2007.

MACARINI, José Pedro. A política econômica da ditadura militar no limiar do "milagre" brasileiro: 1967/69. Texto para Discussão. IE/UNICAMP, n. 99, 2000, pp. 1-34.

MACARINI, José Pedro. A política econômica do governo Médici. Nova Economia - Belo Horizonte, v. 15, n. 3, 2005, pp. 53-92. 
MACARINI, José Pedro. Governo Geisel: transição político-econômica? Um ensaio de revisão. Texto para Discussão - IE/UNICAMP, n. 142, 2008, pp. 1-29.

MACARINI, José Pedro. A política econômica do Governo Sarney: os Planos Cruzado (1986) e Bresser (1987). Texto para Discussão. IE/UNICAMP, n. 157, 2009, pp. 1-63.

MACEDO, Roberto Brás Matos Macedo. A Projeção da Entidade e de seus Institutos e Fundações no Quadro Científico e Profissional. In: CANABRAVA, Alice Piffer (org.). História da Faculdade de Economia e Administração da Universidade de São Paulo (1946-1981). São Paulo: FEA-USP, 1984.

MACEDO, Roberto Brás Matos Macedo. Figuras Representativas: Antonio Delfim Netto. Estudos Avançados, v. 15, n. 43, 2001, pp. 375-388.

MACH, André; DAVID, Thomas e BÜHLMANN, Felix. La fragilité des liens nationaux: la reconfiguration de l'élite du pouvoir en Suisse, 1980-2010. Actes de la Recherche en Sciences Sociales, n. 190, 2011, pp. 78-107.

MACHADO, Rogério Marcondes. Flávio império e a montagem de Os Fuzis da Senhora Carrar (1968). Revista Sala Preta PPGAC-USP, v. 14, n. 1, 2014, pp. 113-124.

MAGALHÃES, Heloísa. Com o dom para decidir. Valor Econômico, à mesa com Valor, 2 de abril de 2015 .

MALAN, Pedro. Ainda sobre a Distribuição da Renda. Revista de Administração de Empresa, v. 14, n. 2, 1974, pp. 116-123.

MALAN, Pedro. Relações econômicas internacionais do Brasil (1945-1964). In: FAUSTO, Boris (org.). História Geral da Civilização Brasileira, Tomo III: O Brasil Republicano, Volume IV: Economia e Cultura. São Paulo: Diefel, 1984.

MALAN, Pedro, ABREU, Marcelo, BONELli, Régis, PEREIRA, José Eduardo de Carvalho. Política econômica externa e industrialização no Brasil 1939/1952. Rio de Janeiro: IPEA/INPES, 1980.

MALAN, Pedro e WELLS, John. Distribuição de renda e desenvolvimento econômico do Brasil. In: TOLIPAN, Ricardo e TINELLI, Arthur Carlos. A controvérsia sobre distribuição de renda e desenvolvimento. Rio de Janeiro: Zahar Editores, 1975.

MALINVAUD, Edmond. An interview with Edmond Malinvaud, by Alan B. Krueger. Journal of Economic Perspectives, v. 17, n. 1, 2003, pp. 181-198.

MALTA, Maria Mello de. Interpretar e transformar o mundo: o propósito De Aloísio Teixeira. Revista Economia Contemporânea, v. 16, n. 3, 2012, pp. 385-392. 
MANCINI, Francine Trevisan. Sajous architecto : presença e atuação profissional 1930-1959. Dissertação de Mestrado apresentada ao Programa de Pós-Graduação da Faculdade de Arquitetura e Urbanismo da Universidade São Paulo, 2013.

MANESCHI, Andrea. Mihail Manoilescu: an appreciation and a critique. Romanian Journal of Economic Forecasting, n. 1, 2008, pp. 130-133.

MANOÏLESCO, Mihail. Teoria do Protecionismo e da permuta internacional. Rio de Janeiro, Capax Dei, 2011.

MARCOVITCH, Jacques. O Centro Acadêmico Visconde de Cairu. In: CANABRAVA, Alice Piffer (org.). História da Faculdade de Economia e Administração da Universidade de São Paulo (1946-1981). São Paulo: FEA-USP, 1984.

MARCOVITCH, Jacques. Pioneiros e empreendedores: a saga do desenvolvimento do Brasil v. 1. São Paulo: Edusp, 2007.

MARCUSE, Herbert. Cultura e Sociedade v. 2. São Paulo: Editora Paz e Terra, 1998.

MARINI, Ruy Mauro. Memoria por Ruy Mauro Marini. In: TRASPADINI, Roberta e STEDILE, João Pedro (org.). Ruy Mauro Marini vida e obra. São Paulo: Expressão Popular, 2011.

MARINI, Ruy Mauro. Dialética da Dependência. In: TRASPADINI, Roberta e STEDILE, João Pedro (org.). Ruy Mauro Marini vida e obra. São Paulo: Expressão Popular, 2011a.

MARQUES, Eduardo Cesar. Os Mecanismos Relacionais. Revista Brasileira de Ciências Sociais, v. 22, n. 64, 2007, pp. 157-161.

MARQUES, Eduardo. Prospec: Modelo de Geração de Cenários em Planejamento Estratégico. In: MONTEIRO, Dulce Corrêa e MODESINI, Rui Lyrio (org.). BNDES, um banco de idéias: 50 anos refletindo o Brasil. Rio de Janeiro: BNDES, 2002.

MARQUES, Maria Silva Bastos. Maria Silvia Bastos Marques I (depoimento, 1999). Rio de Janeiro, CPDOC/FUNDAÇÃO CSN, 2008.

MARTÍN, Juan Jesus Morales. José Medina Echavarría. Un clásico de la sociología mexicana. Desacatos, n. 33, 2010, pp. 133-150.

MARTINS, Carlos Estevam. Entrevista com Carlos Estevam Martins concedida à Hélgio Trindade em julho de 2002. In: TRINDADE, Hélgio. Ciências Sociais no Brasil: Diálogos com mestres e discipulos. Brasília: ANPOCS; Liber Livro Editora, 2012. 
MARTINS, Eliseu; SILVA, Amado Francisco da; RICARDINO, Álvaro. Escola Politécnica: possivelmente o primeiro curso formal de contabilidade do Estado de São Paulo. Revista Contabilidade \& Finanças USP, n. 42, 2006, pp. 113-122.

MARTINS, Luciano. Pouvoir et développement économique: formation et évolution des structures politiques au Brésil. Paris: Editions Anthropos, 1976.

MARTINS, Luciano. A Gênese de uma Intelligentsia: os intelectuais e a política no Brasil 1920 a 1940. Revista Brasileira de Ciências Sociais, v. 2, n. 4, 1987, pp. 1-25.

MARTINS, Paulo Egydio. Paulo Egydio: depoimento ao CPDOC / FGV / Organização Verena Alberti, Ignez Cordeiro de Farias, Dora Rocha. São Paulo: Imprensa Oficial do Estado de São Paulo, 2007.

MARTINS, Thais Joi. Desejo, necessidade e realidade: os marcadores culturais e econômicos e suas implicações ocupacionais para o grupo profissional de engenheiros de produção no Brasil. Tese de doutorado em Ciência Política. São Carlos: UFSCAR, 2015.

MATONTI, Frédérique e POUPEAU, Franck. Le capital militant. Essai de définition. Actes de la recherche en sciences sociales, n. 155, 2004, pp. 4-11.

MATTEDI-RAUD, Cécile. Análise crítica da Sociologia Econômica de Mark Granovetter: os limites de uma leitura do mercado em termos de redes e imbricação. Politica e Sociedade: Revista de Sociologia Politica, n. 6, 2005, pp. 59-82.

MAZA, Fábio. O idealismo prático de Roberto Simonsen: ciência, tecnologia e indústria na construção da nação. São Paulo: Instituto Roberto Simonsen, 2004.

MEDEIROS, Benicio. Otto Lara Resende: a poeira da Glória. Rio de Janeiro: Relume Dumará/Prefeitura, 1998.

MEDEIROS, Jane Maria. O Instituto de Economia/UFRJ: memória e representação nos discursos e narrativas dos seus professores - 1979-1996. Dissertação apresentada à Universidade Federal do Estado do Rio de Janeiro. Rio de Janeiro: UNIRIO, 2005.

MELHEM, Célia Soibelmann. Política de Botinas Amarelas: o MDB-PMDB Paulista de 1965 a 1988. São Paulo: Editora HUITEC/Departamento de Ciência Política da USP, 1998. MELO, Hildete Pereira de. Conceição Tavares: uma mulher política. In: PRADO, Luiz Carlos Delorme (org.). Desenvolvimento econômico e crise: ensaios em comemoração aos 80 anos de Maria da Conceição Tavares. Rio de Janeiro: Contraponto/Centro Internacional Celso Furtado, 2012. 
MELO, Maria Mituoso de. Um pouco de minha vida. Rio de Janeiro: Civilização Brasileira, 1983.

MELLO, João Manoel. Entrevista com João Manoel Cardoso de Mello. In: REGO, José Marcio. Duas Teorias Econômicas: "Consumo" e "Retórica" Subsídios para o Estudo do Campo Científico da Economia no Brasil. Tese de doutoramento apresentada à EAESP-FGV. São Paulo: EAESP-FGV, 1998.

MELLO, João Manoel. Entrevista com João Manoel Cardoso de Mello. In: MANTEGA, Guido e REGO, José Marcio. Conversas com Economistas Brasileiros II. São Paulo: Editora 34, 1999.

MELlO, Zélia Cardoso de. Metamorfoses da Riqueza - contribuição ao Estudo da Passagem da Economia Mercantil Escravista à Economia Exportadora Capitalista. Tese de doutorado apresentada ao departamento de Economia da Faculdade de Economia e Administração da Universidade de São Paulo. São Paulo: USP, 1981.

MEYER, Victor. Acerca do autor e sua obra: Ernesto Martins, Eric Czaczkes Sachs. In: SACHS, Eric. Qual a Herança da revolução russa e outros textos. Belo Horizonte: SEGRAC Editora, 1988.

MICELI, Sérgio. A aposta numa comunidade científica emergente: a Fundação Ford e os cientistas sociais no Brasil. MICELI, Sérgio (org.). A Fundação Ford no Brasil. São Paulo: Editora Sumaré, 1993.

MICELI, Sérgio. Intelectuais à Brasileira. São Paulo: Companhia das Letras, 2001.

MIGLIOLI, Jorge. O ISEB e a Encruzilhada Nacional. In: TOLEDO, Caio Navarro (org). Intelectuais e politica no Brasil: a experiência do ISEB. Rio de Janeiro: Revan, 2005.

MILLS, C. Wright. L'Élite au Pouvoir. Marseille: Agone, 2012

MINISTÉRIO DO PLANEJAMENTO. Diretrizes de governo: Programa Estratégico de Desenvolvimento. Brasília: Ministério do Planejamento, 1967.

MISSÃO COOKE NO BRASIL. Rio de Janeiro: FGV, 1949.

MODIANO, Eduardo Marco. A ópera dos três cruzados 1985-1989. In: ABREU, Marcelo de Paiva (org.). A Ordem do Progresso: cem anos de politica econômica republicana 18891990. Rio de Janeiro: Elsevier, 1990.

MODIANO, Eduardo Marco. Discurso de transmissão da presidência do BNDES [DVD]. Rio de Janeiro: Arquivo do BNDES, 1992. 
MODIANO, Eduardo Marco. Entrevista de Eduardo Modiano para o projeto memória BNDES 50 anos [DVD]. Rio de Janeiro: Arquivo do BNDES, 2002.

MODIANO, Eduardo Marco e CARNEIRO, Dionísio Dias. A mágica do novo cruzeiro e a geração da inflação. In: MODIANO, Eduardo. Inflação: inércia e conflito. Rio de Janeiro: Campus/INPES/IPEA, 1988.

MODIANO, Eduardo e LOPES, Francisco. Inflação: análise do impacto de mudanças na política salarial. In: MODIANO, Eduardo. Inflação: inércia e conflito. Rio de Janeiro: Campus/INPES/IPEA, 1988.

MONTECINOS, Venrónica. Economics: the Chilean Story. In: MONTECINOS, Venrónica e MARKOFF, John (org.). Economists in the Americas. Massachusetts: Edward Elgar, 2009.

MONTES, Leonidas. Friedman's two visits to Chile in context. Mimeo, 2015, pp. 1-34. Disponível em: http://jepson.richmond.edu/conferences/summerinstitute/papers2015/LMontesSIPaper.pdf. Consultado em 26/02/2016.

MOREIRA, Marcílio Marques. Diplomacia, Política e Finanças, entrevista à Fundação Getúlio Vargas. Rio de Janeiro: Objetiva, 2001.

MOTTA, Marly Silva da. Economistas: intelectuais, burocratas e "mágicos". In: GOMES, Ângela de Castro (org.). Engenheiros e Economistas: novas elites burocráticas. Rio de Janeiro: Editora Fundação Getúlio Vargas, 1994.

MOTTA, Marly Silva da. Os "boêmios cívicos” da Assessoria Econômica: saber técnico e decisão política no governo Vargas (1951-54). In: HISTÓRIA Oral: história, cultura e poder, 2005. Disponível em: http://cpdoc.fgv.br/producao_intelectual/arq/1675.pdf. Consultado em 11/05/2016.

MOTTA, Marly Silva da e ROCHA, Dora (org.). Memórias do IBRE - Instituto Brasileiro de Economia: depoimentos ao CPDOC. Rio de Janeiro: Editora da Fundação Getúlio Vargas, 2008.

MOURÃO, Julio Olimpio Fusaro. A Integração Competitiva e o Planejamento Estratégico no Sistema BNDES. Revista do BNDES, v. 1 n. 2. pp. 3-26, 1994.

MUNIZ, José de Souza. A magia do quadrado mágico: a formação de uma editora no eixo Rio-São Paulo e as reconfigurações do campo editorial brasileiro na década de 1990. XVI Congresso Brasileiro de Sociologia, Grupo de Trabalho: Sociologia da Cultura, Salvador, 2013. 
NAJBERG, Sheila. Transformação do Sistema BNDES em Financiador do Setor Privado Nacional. In: MONTEIRO, Dulce Corrêa e MODESINI, Rui Lyrio (org.). BNDES, um banco de idéias: 50 anos refletindo o Brasil. Rio de Janeiro: BNDES, 2002.

NAKANO, Maria e ROITMAN, Ari (org.). Estreitos nós: lembranças de um semeador de utopias. Rio de Janeiro: Garamond, 2001.

NAKANO, Yoshiaki. Entrevista com Yoshiaki Nakano. In: MANTEGA, Guido e REGO, José Marcio. Conversas com Economistas Brasileiros II. São Paulo: Editora 34, 1999.

NASSIF, Luís. O último guerreiro de Vargas. Folha de São Paulo, 19 de junho de 2005.

NASSIF, Luís. Os Cabeças-de-Planilha: como o pensamento econômico da era FHC repetiu os equivocos de Rui Barbosa. Rio de Janeiro: Ediouro, 2007.

NEEDELL Jeffrey. Belle Époque Tropical : sociedade e cultura de elite no Rio de Janeiro da virada do século. São Paulo: Companhia das Letras, 1993.

NEIBURG, Frederico. Economistas e culturas econômicas no Brasil e na Argentina: notas para uma comparação das heterodoxias. Tempo Social: Revista de Sociologia da USP, v. 16, n. 2, 2004, pp. 177-202.

NUNES, Edson de Oliveira. Bureaucratic insulation and clientelism in contemporary Brazil: uneven state-building and the taming of modernity. Tese de doutorado. Berkeley: University of California, Berkeley, 1984.

NOBRE, Aloysio Argollo. Uma ausência no livro da história da dermatologia no Brasil: professor Sylvio Fraga. Anais Brasileiros de Dermatologia, v. 78, n. 2, 2003, pp. 239-245.

NOGUEIRA, Rafael Pires. Mudança Institucional, Ideários e Burocracia: uma perspectiva sobre a ação do BNDES no governo Collor. Dissertação de Mestrado em políticas públicas, estratégias e desenvolvimento. Rio de Janeiro: UFRJ/PPED, 2010.

NOOY, Wouter. Fields and networks: correspondence analysis and social network analysis in the framework of field theory. Poetics, v. 31, 2003, pp. 305-327.

O LONGO AMANHECER - CINEBIOGRAFIA DE CELSO FURTADO. José Mariani. Documentário, 2007.

OLIVEIRA, Francisco de. A Economia Brasileira: Crítica à Razão Dualista. Estudos CEBRAP, n. 2, 1972, pp. 4-82.

OLIVEIRA, Francisco de. Entrevista com Francisco de Oliveira. In: MANTEGA, Guido e REGO, José Marcio. Conversas com Economistas Brasileiros II. São Paulo: Editora 34, 1999. 
OLIVEIRA, Francisco de. Entrevista com Francisco de Oliveira. In: MONTERO, Paula e MOURA, Flávio (org.). Retrato de Grupo - 40 anos do CEBRAP. São Paulo: Cosac Naify, 2009.

OLIVEIRA, Irene Rodrigues de. Missão Cooke, Estado Novo e implementação da CSN. Rio de Janeiro: E-Papers Serviços Editoriais, 2003.

OLIVIERI, Cecília. A política de nomeação do alto escalão do Banco Central do Brasil (19852000). Dissertação de Mestrado em Ciência Política apresentada ao Departamento de Ciência Política da Universidade de São Paulo. São Paulo: USP, 2001.

ORELlANA, César Ross. Hernán Santa Cruz: del pensamiento a la acción. Horizontes Latino Americanos - Revista de Humanidades e Ciências Sociais do Mercosul Educacional, v. 2, n. 1, 2014, pp. 79-92.

OSÓRIO, Juvenal., 2009. Entrevista com Funcionários do BNDE: Juvenal Osório, concedida a Ângela Coronel e Luiz Carlos em 10 de fevereiro de 1982. Memórias do Desenvolvimento - Centro Internacional Celso Furtado de Políticas para o Desenvolvimento, v. 3, n. 3, 2009, pp. 137-160.

OYARZÚN, Fernando Pérez. Emilio Duhart y el edificio de las Naciones Unidas en Santiago. In: PLAUT, Jannette e SAROVIC, Marcelo. CEPAL 1962-1966 United Nations Building Emilio Duhart Arquitecto. Santiago: Constructo, 2012.

PAGNANI, Éolo Marques. Da concepção à extinção do Centro Técnico de Assessoria Empresarial no processo de consolidação do Instituto de Economia da UNICAMP. In: BACIC Miguel Juan e SOUZA, Maria Carolina de Azevedo Ferreira de. Casos e Conceitos em Gestão de Pequenas e Médias Empresas Industriais, edição nº1. Campinas: IE-UNICAMP, 2006. Disponível em:

https://www3.eco.unicamp.br/neit/images/stories/CTAE_CD2/da_concepcao_a_extin cao_ctae_ie_unicamp.pdf. Consultado em 24/05/2016.

PAIM, Gilberto. Ignácio Rangel: um intérprete original da realidade brasileira. In: MAMIGONIAN, Armen; REGO, José Marcio (org.). O pensamento de Ignácio Rangel. São Paulo: Editora 34, 1998.

PASTORE, Affonso Celso. Entrevista com Affonso Celso Pastore. In: BIDERMAN, Ciro; COZAC, Luis Felipe L. e REGO, José Marcio. Conversas com Economistas Brasileiros. São Paulo: Editora 34, 1996. 
PARMAR, Inderjeet. Foundations of the American Century: the Ford, Carnegie \&o Rockefeller foundations in the rise of American power. New York: Columbia University Press, 2012.

PAULA, João Antonio de. O ensino e a pesquisa em economia na Universidade Federal de Minas Gerais. Análise - Revista de Administração da PUCRS, v. 17, n. 2, pp. 329-344, 2006.

PAULO NETTO, José. Breve nota sobre um marxista convicto e confesso. In: BRAZ,

Marcelo. Carlos Nelson Coutinho e a renovação do marxismo no Brasil. São Paulo: Expressão Popular, 2012.

PAULANI, Leda. O Heterodoxo e o Pós-Moderno. Rio de Janeiro. Editora Paz e Terra, 1987.

PÉCAUT, Daniel. Entre le peuple et la nation: les intellectuels et la politique au Brésil. Paris: Maison des sciences de l'homme, 1989.

PEREIRA, Alexsandro Eugenio. Organização, Estrutura e Trajetória do ISEB. In: TOLEDO, Caio Navarro (org). Intelectuais e política no Brasil: a experiência do ISEB. Rio de Janeiro: Revan, 2005.

PEREIRA, Luiz Carlos Bresser. Mobilidade e carreira dos dirigentes das empresas paulistas. Tese de Doutorado apresentada ao Departamento de Economia da Faculdade de Economia e Administração da Universidade de São Paulo. São Paulo: USP, 1972.

PEREIRA, Luiz Carlos Bresser. Uma experiência de governo: depoimento de sua gestão como Ministro de Estado da Fazenda, de abril a dezembro de 1987. Conferência proferida no IUPERJ em 16 de setembro de 1988.

PEREIRA, Luiz Carlos Bresser. Entrevista com Luiz Carlos Bresser Pereira. In: BIDERMAN, Ciro; COZAC, Luis Felipe L. e REGO, José Marcio. Conversas com Economistas Brasileiros. São Paulo: Editora 34, 1996.

PEREIRA, Luiz Carlos Bresser. Interpretações sobre o Brasil. In: LOUREIRO, Maria Rita (org.). 50 anos de Ciência Econômica no Brasil: pensamentos instituições, depoimentos. Petrópolis: Vozes, 1997.

PEREIRA, Luiz Carlos Bresser. Luiz Carlos Bresser Gonçalves Pereira - janeiro a julho de 1999. In: MOTOYAMA, Shozo. 50 anos do CNPQ contados pelos seus presidentes. São Paulo: FAPESP, 2002.

PEREIRA, Luiz Carlos Bresser. Burocracia pública na construção do Brasil, 2008, pp. 1-129. Disponível em: http://www.bresserpereira.org.br/Books/LivroBurocraciaConstru\%E7\%E3oBrasil.6.pdf. Consultado em 16/01/2016. 
PEREIRA, Luiz Carlos Bresser. O caminho com meu irmão. Discurso na solenidade de homenagem do Instituto Cultural Lourenço Castanho a meu irmão, Sylvio Luiz. Bresser-Pereira e de criação da bolsa de estudos com sen nome. São Paulo, 27 de fevereiro de 2012. Disponível em: http://www.bresserpereira.org.br/view.asp?cod=4877. Consultado em 02/03/2016.

PERLOFF, Harvey. Alliance for Progress: A social invention in the making. Baltimore: The Johns Hopkins University Press, 1969.

PEROSA, Graziela Serroni. Grupos familiares, investimentos educacionais e o mercado escolar de São Paulo em 1930. Pro-posições, v. 15, n. 2, 2004, pp. 61-76.

PERRUSO, Marco Antonio. Em busca do "novo": intelectuais brasileiros e movimentos populares nos anos 1970/80. Tese de Doutorado apresentada ao Programa de Pós-graduação em Sociologia e Antropologia do Instituto de Filosofia e Ciências Sociais da Universidade Federal do Rio de Janeiro. Rio de Janeiro: UFRJ, 2008.

PEZZONIA, Rodrigo. Revolução em DEBATE: O grupo DEBATE, o exílio e a luta armada no Brasil (1970 - 1974). Dissertação de mestrado apresentada ao programa de pósgraduação em Sociologia do Instituto de Filosofia e Ciências Humanas da Universidade Estadual de Campinas. Campinas: UNICAMP, 2011.

PHELP, Cristopher. A socialist magazine in the American century. Monthly Review, v. 51, n. 1, 1999. Disponível em http://monthlyreview.org/1999/05/01/introduction/. Consultado em 29/01/2016.

PINÇON, Michel e PINÇON-CHARLOT, Monique. Dans les Beaux Quartiers. Paris: Éditions du Seuil, 1989.

PINÇON, Michel e PINÇON-CHARLOT, Monique. Grandes Fortunes: Dynasties Familiales et formes de richesse en France. Paris: Éditions Payot \& Rivages, 2006.

PINHEIRO, Daniela. Serra na hora da decisão. Piauí, v. 37, 2009.

PINHO, Benevides Diva. O Departamento de Ciências Econômicas. In: CANABRAVA, Alice Piffer (org.). História da Faculdade de Economia e Administração da Universidade de São Paulo (1946-1981). São Paulo: FEA-USP, 1984.

PINHO, Demosthenes Madureira de. A estratégia brasileira em perspectiva internacional. In: BNDES. O BNDES e o Plano de Metas. Rio de Janeiro: Departamento de Relações Institucionais do BNDES, 1996.

PINTO, José Nêumanne. O que eu sei de Lula. Rio de Janeiro: Topbooks, 2011. 
PINTO, Mario da Silva. Mario da Silva Pinto depoimento de 1987. Rio de Janeiro: CPDOC/FGV - SERCOM/Petrobrás, 1988.

PINTOR, Rafael López. Los partidos de centro y la alternativa autoritaria: él caso de la DC en chile. Papers, Revista de Sociología, n. 7, 1977, pp. 113-139.

PIO, Carlos. A estabilização heterodoxa no Brasil: idéias e redes políticas. Revista Brasileira de Ciências Sociais, v. 16, n. 46, 2001, pp. 29-54.

PIO, Carlos. A construção política da Economia de Mercado no Brasil: estabilização e abertura comercial (1985-1995). Tese de doutorado em Ciência Política apresentada ao Instituto Universitário de Pesquisas do Rio de Janeiro. Rio de Janeiro: IUPERJ, 2001a.

POLLAK, Michael. Memória e identidade social. Estudos Históricos, v. 5, n. 10, 1992, pp. 200-212.

POLLOCK, David. Some changes in the United States attitudes towards CEPAL over the past 30 years. CEPAL Review, n. 2, 1978, pp. 57-80.

PONT, Raul. Entrevista com Raul Pont. Muitos Caminhos, uma estrela: memórias de militantes do PT, v. 1. São Paulo: Editora Fundação Perseu Abramo, 2008.

PONTES, Heloísa. Modas e modos: uma leitura enviesada de O espírito das roupas. Cadernos Pagu, v. 22, 2004, pp. 13-46.

PONTUAL, Virgínia. O engenheiro Antônio Bezerra Baltar prática urbanística, CEPUR e SAGMACS. Revista Brasileira de estudos urbanos e regionais, v. 13, n. 1, 2011, pp. 151-169.

PRADO, Eleutério. A Ortodoxia Neoclássica. In: SZMRECSÁNYI, Tamás e COELHO, Francisco da Silva (org.). Ensaios de História do Pensamento Econômico no Brasil Contemporâneo. São Paulo: Atlas, 2007.

PRADO, Maria Clara do. A real história do Real. Rio de Janeiro: Record, 2005.

PRATA, Aluízio. Necrológio Amaury Domingos Coutinho. Revista da Sociedade Brasileira de Medicina Tropical, v. 28, n. 4, 1995, p. 433.

PRATA, José; BEIRÃO, Nirlando e TOMIOKA, Teiji (org.). Sérgio Motta: o trator em ação. São Paulo: Geração Editorial, 1999.

PREBISCH, Raúl. O desenvolvimento econômico da América Latina e alguns de seus problemas principais. Revista Brasileira de Economia, v. 3, n. 3, 1949, pp. 47-11.

PREBISCH, Raúl. A Mística do Equilíbrio Espontâneo da Economia. Santiago: CEPAL, 9 de Setembro de 1953. 
PREBISCH, Raúl. Exposición del dr. Raúl Prebisch, director principal a cargo de la secretaria ejecutiva de la comisión, el 14 de febrero de 1962, en la primera sesión de trabajo. Comisión Económica para América Latina. Comité Plenario. Octavo período de sesiones. Documento informativo $\mathrm{n}^{\circ}$ 7. Santiago de Chile: 14 a 16 de febrero de 1962.

PREBISCH, Raúl. Entrevista inédita a Prebisch: logros y deficiencias de la CEPAL, realizada por David Pollock, Daniel Kerner y Joseph L. Love. Revista de la CEPAL, v. 75, 2001, pp. 9-23.

PREBISCH, Raúl. Aquellos viejos tiempos: la formación teórica y practica de Raúl Prebisch en la Argentina. Una entrevista realizada por David Pollock, editada por David Pollock, Joseph Love e Daniel Kerner. Desarrollo Económico: revista de ciencias sociales, v. 41, 2002, pp. 531-553.

PREBISCH, Raúl. O desenvolvimento econômico da América Latina e alguns de seus problemas principais. In: GURRIERI, Adolfo. O Manifesto Latino-Americano e outros ensaios. Rio de Janeiro: Contraponto, 2011.

PROCHNIK, Marta. Fontes de Recursos do BNDES. Revista do BNDES, v. 2 n. 4, 1995, pp. 143-180.

PULICI, Carolina. Entre sociólogos: versões conflitantes da "condição de sociólogo" na USP dos anos 1950-1960. São Paulo: EDUSP/FAPESP, 2008.

QUEIROZ, Marcelina Silveira. Trajetórias Interrompidas: um estudo de caso sobre exilados politicos de Minas Gerais (1964-2004). Dissertação Apresentada ao Curso de Mestrado em História da Universidade Federal de Juiz de Fora. Juiz de Fora: UFJF, 2007a.

QUEIROZ, Rodrigo Cristiano. Oscar Niemeyer e Le Corbusier: Encontros. Tese de doutorado apresentada ao programa de pós-graduação em arquitetura para obtenção do título de doutor. São Paulo: USP, 2007.

RABÊLO, José Maria e RABÊLO, Thereza. Diáspora: os longos caminhos do exílio. São Paulo: Geração Editorial, 2001.

RAFAEL, Tiago. Ex-ministro acredita na reeleição de Dilma Rousseff e na intensificação de protestos com a aproximação da Copa do Mundo: entrevista com Alexis Stepanenko. Raízes Diário, 25 de fevereiro de 2014.

RAMÍREZ, Hernán Ramiro. Os Institutos de Estudos Econômicos de Organizạções Empresariais e sua Relação com o Estado em Perspectiva Comparada: Argentina e Brasil (1961-1996). Tese apresentada ao Programa de Pós-Graduação em História do Instituto de Filosofia e 
Ciências Humanas da Universidade Federal do Rio Grande do Sul. Porto Alegre: UFRGS, 2005.

RAMOS, Bárbara Oliveira. A Cooperação Internacional e os Debates Teóricos: um estudo de caso sobre a atuação da Agência Norte-Americana para o Desenvolvimento Internacional (USAID) no Brasil. Dissertação apresentada ao Programa de Pós-Graduação em Relações Internacionais da Universidade de Brasília, 2006.

RANGEL, Ignácio. O outro lado da privatização. Folha de São Paulo, 21 de maio de 1988.

RANGEL, Ignácio. Introdução ao desenvolvimento econômico brasileiro. São Paulo: Editora Bienal, 1990.

RANGEL, Ignácio. Entrevista com o professor Ignácio de Mourão Rangel concedida a Armen Mamigonian, Maria Dolores Buss, Raquel Fontes do Amaral Pereira, Everton Vieira Machado e Jose Messias Bastos em 1987. Geosul, n. 12/13, v. 6, 1991-1992, pp. 113-139.

RANGEL, Ignácio. Entrevista com funcionários do BNDE: Ignácio Rangel, concedida a Ângela Coronel, Francisco Marcelo, José Eduardo e Carlos Telles Menezes, em 1982. Memórias do Desenvolvimento - Centro Internacional Celso Furtado de Políticas para o Desenvolvimento, n. 3, v. 3, 2009, pp. 123-137.

RANGEL, Inácio. Obras reunidas v. 1. Rio de Janeiro: Contraponto e Centro Internacional Celso Furtado de Políticas para o Desenvolvimento, 2012.

RAPOSO, Eduardo. Banco Central do Brasil: o Leviatã Ibérico, uma interpretação do Brasil contemporâneo. Rio de Janeiro: Editora PUC-Rio, 2011.

RAUD, Cécile. Bourdieu e a Nova Sociologia Econômica. Tempo Social, revista de sociologia da USP, v. 19, n. 2, 2007, pp. 203-232.

REIS, Elisa Pereira. A construção intelectual e a política das Ciências Sociais brasileiras: a experiência do IUPERJ. In: MICELI, Sérgio (org.). A Fundação Ford no Brasil. São Paulo: Editora Sumaré, 1993.

REIS, Elisa Pereira. Memorial de Elisa P. Reis. Rio de Janeiro, 1998. Disponível em: http://cpdoc.fgv.br/sites/default/files/cientistas_sociais/elisa_reis/ElisaReisMemorial.p df. Consultado em 3/12/2015.

REIS, Elisa Pereira. Elisa Maria da Conceição Pereira Reis (depoimento, 2008). Rio de Janeiro: CPDOC/FGV; LAU/IFCS/UFRJ; ISCTE/IUL, 2010. 
REIS, Eliana Tavares dos. Contestação, engajamento e militantismo: da "luta contra a ditadura" à diversificação das modalidades de intervenção política no Rio Grande do Sul. Tese apresentada ao Departamento de Ciência Política da Universidade Federal do Rio Grande do Sul. Porto Alegre: UFRGS, 2007.

RESENDE, André Lara. A moeda indexada: uma proposta para eliminar a inflação inercial. In: REGO, José Marcio (org.). Inflação Inercial, Teorias sobre Inflação e o Plano Cruzado. Rio de Janeiro: Paz e Terra, 1986.

RESENDE, André Lara. Estabilização e Reforma: 1964-1967. In: ABREU, Marcelo de Paiva (org.). A Ordem do Progresso: cem anos de política econômica republicana 1889-1989. Rio de Janeiro: Elsevier, 1990.

RESENDE, André Lara. Entrevista com André Lara Resende. In: BIDERMAN, Ciro; COZAC, Luis Felipe L. e REGO, José Marcio. Conversas com Economistas Brasileiros. São Paulo: Editora 34, 1996.

RESENDE, Otto Lara. O Rio é tão Longe: cartas a Fernando Sabino. São Paulo: Companhia das Letras, 2011.

RETRATOS DO SERRA - UMA BIOGRAFIA EM FILMES. Guilherme Coelho e Pedro Cezar. Documentário, 2010. Disponível em:

http://www.retratosdoserra.com.br/downloads/. Consultado em 24/05/2016.

RBE. Editorial. Revista Brasileira de Economia, v. 20, n. 4, 1966, pp. 3-6.

RIBEIRO, Alex. Cirurgião das Finanças. Valor Econômico, à mesa com Valor, 24 de maio de 2013.

RIBEIRO, Casimiro Antônio. Casimiro Ribeiro I (depoimento, 1975/1979). Rio de Janeiro: CPDOC, 1981.

RIBEIRO, Casimiro Antonio. Casimiro Ribeiro II (depoimento, 1989). Rio de Janeiro: CPDOC. BANCO CENTRAL DO BRASIL, 1990.

RIBEIRO, Darcy. Confissões: Darcy Ribeiro. São Paulo: Companhia das Letras, 1997.

RIBEIRO, Ricardo Alaggio. A Aliança para o Progresso e as relações Brasil-EUA. Tese de doutorado em Ciência Política apresentada ao Instituto de Filosofia e Ciências Humanas da Universidade Estadual de Campinas, 2006.

RICIOPPO, Plauto. Ensino Superior e formação de Professores em Uberaba/MG (1881-1938): uma trajetória de avanços e retrocessos. Dissertação apresentada ao Programa de Pós- 
Graduação em Educação da Universidade de Uberaba para a obtenção do título de mestre. Uberaba: UNIUBE, 2007.

RIDENTI, Marcelo. O romantismo revolucionário da Ação Popular: do cristianismo ao maoísmo. Meeting of the Latin American Studies Association, 1998, pp. 1-25. Disponível em: http://lasa.international.pitt.edu/LASA98/Ridenti.pdf. Consultado em 22/11/2015.

RIDENTI, Marcelo. O Fantasma da Revolução Brasileira. São Paulo: Editora UNESP, 2010.

RIDENTI, Marcelo. Em Busca do Povo Brasileiro: artistas da revolução, do CPC à era da TV, 2a edição revista e ampliada. São Paulo: Editora UNESP, 2014.

ROCCA, Carlos Antônio; CEOTTO, Eny Elza e RIZZIERI, Juarez Alexandre Baldini. O Instituto de Pesquisas Econômicas (IPE) e a Fundação Instituto de Pesquisas Econômicas (FIPE). In: CANABRAVA, Alice Piffer (org.). História da Faculdade de Economia e Administração da Universidade de São Paulo (1946-1981). São Paulo: FEA-USP, 1984.

RODRIGUES, Lidiane Soares. A Produção Social do Marxismo Universitário em São Paulo: Mestres, Discípulos e 'Um Seminário' (1958-1978). Tese de doutorado apresentada ao Programa de Pós-Graduação em História Social da Universidade de São Paulo. São Paulo: USP, 2011.

ROLDAN, Hector Gutierrez. La población de Chile. Committee for International Cooperation in National Research in Demography, 1975.

ROLLEMBERG, Denise. Exilio: entre raízes e radares. Rio de Janeiro: Editora Record, 1999.

ROMA, Celso. A institucionalização do PSDB entre 1988 e 1999. Revista Brasileira de Ciências Sociais, v. 17, n. 49, 2002, pp. 71-92.

ROMA, Sandro Luiz Costa. Desafios do sucesso no longo praz̧o em estratégias de reestruturação: o caso da $A M B E V$. Dissertação de Mestrado apresentada ao Programa de Pós-Graduação em Administração do Instituto COPPEAD-UFRJ, 2011.

ROMÃO, Wagner de Melo. Sociologia e Política acadêmica nos anos 1960: a experiência do CESIT. São Paulo: Associação Editorial Humanitas, 2006.

ROSATTI, Camila Gui. O projeto modernizador de Vilanova Artigas: prática profissional e clientela nos anos 1940. Encontro Anual da ANPOCS 36, GT 27 - Pensamento Social no Brasil, 2012, pp. 1-27. 
ROSATTI, Camila Gui. Moderno sob encomenda: produtores e clientes do mobiliário paulistano na década de 1950. Encontro Anual da ANPOCS 38, SPG 8 - Gosto, hierarquias simbólicas e legitimidades culturais, 2014, pp. 1-32.

ROSENTHAL, Gert. ECLAC: A Commitment to a Latin American Way Toward Development. In: BERTHELOT, Yves. Unity and Diversity in Development Ideas: perspectives from the UN Regional Commissions. Indiana: Indiana University Press, 2004.

ROSTOW, Walt Whitman. As etapas do desenvolvimento econômico: um manifesto não comunista. Rio de Janeiro: Zahar Editores, 1978.

SABINO, Fernando. Zélia, uma paixão. Rio de Janeiro: Record, 1991.

SACHS, Ignacy. Experiências internacionais de um cientista inquieto: Entrevista com Ignacy Sachs. Estudos Avançados, v. 18, n. 52, 2004, pp. 353-372.

SADER, Emir Simão. Nós que amávamos tanto o capital - fragmentos para a história de uma geração. Sociologias, n. 14, 2005, pp. 150-177.

SADER, Emir Simão. Entrevista : Emir Sader por Juarez Guimarães. Revista democracia Socialista, n. 1, 2013, pp. 7-46.

SAES, Flávio Azevedo Marques de. A obra de Alice Canabrava na historiografia brasileira. História econômica e história de empresas, v. 2, n. 2, 1999, pp. 41-61.

SÁEZ, Hugo Enrique. La fundación de la CEPAL en México: desde los orígenes hasta 1960. CEPAL, Serie Estudios y Perspectivas, v. 113, 2009, pp. 1-38.

SAFATLE, Claudia. O homem que se reinventou. Valor Econômico, à mesa com Valor, 10 de fevereiro de 2012. Disponível em: http://www.valor.com.br/cultura/2525158/ohomem-que-se-reinventou. Consultado em 07/02/2016.

SAINT-MARTIN, Monique. Da reprodução às recomposições das elites: as elites administrativas, econômicas e políticas na França. TOMO, Revista do núcleo de pós-graduação e pesquisa em ciências sociais, n. 13, 2008, pp. 43-74.

SALLUM JR, Brasílio. "O Brasil sob Cardoso: neoliberalismo e desenvolvimentismo". Tempo Social: Revista de Sociologia da USP, v. 11, n. 2, 1999, pp. 23-47.

SALM, Cláudio Leopoldo. O debate sobre a tendência à estagnação. In: MALTA, Maria Mello de (org.). Ecos do Desenvolvimento: uma história do pensamento econômico brasileiro. Rio de Janeiro: IPEA/Centro Internacional Celso Furtado de Políticas para o Desenvolvimento, 2011. 
SAMPAIO, Plínio de Arruda. Ciência e política na origem da FAPESP: Plínio de Arruda Sampaio. In: HAMBURGER, Amélia Império (org.). FAPESP 40 anos abrindo fronteiras. São Paulo: EDUSP, 2004.

SANGLARD, Gisele e FERREIRA, Luiz Otávio. Médicos e filantropos: a institucionalização do ensino da pediatria e da assistência à infância no Rio de Janeiro da Primeira República. Varia hist., v. 26, n. 44, 2010, pp.437-459.

SANTOS, Aurora Almada. A ONU e as Resoluções da Assembleia Geral de Dezembro de 1960. Relações Internacionais, n. 30, 2011b, pp. 61-69.

SANTOS, Theotônio dos. Entrevista com Theotônio dos Santos. Ciência e Luta de Classes, n. 4, 2009. Disponível em:

http://www.ceppes.org.br/revista/versao-impressa/4/entrevista-com-theotonio-dossantos. Consultado em 23/12/2015.

SANTOS, Theotônio dos. The Structure of Dependence. The American Economic Review, v. 60, n. 2, (Papers and Proceedings of the Eighty-second Annual Meeting of the American Economic Association), 1970, pp. 231-236.

SANTOS, Vivian Machado dos. Por dentro do FAT. Revista do BNDES, v. 13, n. 26, 2006, pp. 3-14.

SANTOS, Wanderley Guilherme dos. Wanderley Guilherme dos Santos (depoimento, 2011). Rio de Janeiro: CPDOC/FGV; LAU/IFCS/UFRJ; ISCTE/IUL, 29p., 2011.

SANTOS, Wanderley Guilherme dos. Wanderley Guilherme dos Santos - II (depoimento, 2011). Rio de Janeiro: CPDOC/FGV; LAU/IFCS/UFRJ; ISCTE/IUL, 37p., 2011a.

SAPIRO, Gisèle. Réseaux, institutions et champ. In: MARNEFFE, Daphné de et DENIS, Benoît (éd.), Les réseaux littéraires, Bruxelles, Le Cri / CIEL, 2006.

SARDENBERG, Carlos Alberto. Aventura e Agonia nos Bastidores do Cruzado. São Paulo: Editora Companhia das Letras, 1987.

SARETTA, Fausto. Octavio Gouvêa de Bulhões (1906-1990). In: SZMRECSÁNYI, Tamás e COELHO, Francisco da Silva (org.). Ensaios de História do Pensamento Econômico no Brasil Contemporâneo. São Paulo: Atlas, 2007.

SAWYER, Malcom. Gunnar Myrdal. In: ARESTIS, Philip e SAWYER, Malcom. A Biographical Dictionary of Dissenting Economists, Second Edition. Cheltenham: Edward Elgar Publishing, 2000. 
SAYAD, João. Entrevista com João Sayad. In: REGO, José Marcio. Duas Teorias Econômicas: "Consumo" e "Retórica" Subsídios para o Estudo do Campo Científico da Economia no Brasil. Tese de doutoramento apresentada à EAESP-FGV. São Paulo: EAESP-FGV, 1998.

SCALERCIO, Mário e ALMEIDA, Rodrigo de. Eugênio Gudin: inventário de flores e espinhos: um liberal em estado puro. Rio de Janeiro: Insight, 2012.

SCHLESINGER, Arthur. Mil dias John F. Kenedy na Casa Branca. Rio de Janeiro: Editora Civilização Brasileira, 1966.

SCHNEIDER, Ben Ross. Politics within the state: elite burocrats and industrial policy in authoritarian Brazil. Pittsburgh: University of Pittsburgh Press, 1991.

SCHNEIDER, Ben Ross. A privatização no governo Collor: triunfo do liberalismo ou colapso do estado desenvolvimentista?. Revista de Economia Política, v. 12, n. 1, 1992, pp. 518.

SCHUMAHER, Schuma e BRAZIL, Érico Vital (org.). Dicionário Mulheres do Brasil. Rio de Janeiro: Jorge Zahar Editor, 2000.

SCHWARZ, Roberto. Ao Vencedor as Batatas : forma literária e processo social nos inícios do romance brasileiro, São Paulo, Livraria Duas Cidades, 1992.

SCHWARTZMAN, Simon. Simon Schwartzman (depoimento, 2009). Rio de Janeiro: CPDOC/FGV; LAU/IFCS/UFRJ; ISCTE/IUL, 2010.

SCHWARTZMAN, Simon. Simon Schwartzman, crítico virtuoso, uma história de perseverança e sucesso na Sociologia brasileira. Ciência Hoje, revista de divulgação científica da SBPC, n. 313, v. 53, 2014, pp. 46-53.

SERRA, José. A reconcentração da renda: justificações, explicações, dúvidas. In: TOLIPAN, Ricardo e TINELLI, Arthur Carlos. A controvérsia sobre distribuição de renda e desenvolvimento. Rio de Janeiro: Zahar Editores, 1975.

SERRA, José. Aníbal Pinto e o desenvolvimento latino-americano. Economia e Sociedade, v. 10, 1998, pp. 1-18.

SERRA, José. Entrevista com José Serra. In: REGO, José Marcio. Duas Teorias Econômicas: "Consumo" e "Retórica" Subsídios para o Estudo do Campo Cientifico da Economia no Brasil. Tese de doutoramento apresentada à EAESP-FGV. São Paulo: EAESP-FGV, 1998a. 
SERRA, José. Vilmar Faria: sociólogo e militante. Folha de São Paulo, 29 de novembro de 2001. Disponível em: http://www1.folha.uol.com.br/fsp/opiniao/fz2911200110.htm. Consultado em 15/01/2016.

SERRA, José. O sonhador que faz: a vida, a trajetória politica e as ideias de José Serra, entrevista a Teodomiro Braga. Rio de Janeiro: Record, 2002.

SERRA, José. Homenagem à Sergio Motta: dez anos de morte do ex-Ministro da Comunicação do governo FHC. Portal do governo do Estado de São Paulo, 2 de junho de 2008. Disponível em: http://saopaulo.sp.gov.br/spnoticias/lenoticia.php?id=95798\&c=201. Consultado em 22/11/2015.

SERRA, José. Tributo a Gilberto Dupas. Politica Externa, v. 18, n. 1, 2009, pp. 119-121.

SERRA, José. Maria e Eu. O Globo, 24 de abril de 2010. Disponível em: http://serraescreve.blogspot.com.br/2010/04/maria-e-eu.html. Consultado em $15 / 11 / 15$.

SERRA, José. Cinquenta anos esta noite: o golpe, a ditadura e o exilio. Rio de Janeiro: Editora Record, 2014.

SEVCENKO, Nicolau. Orfeu extático na metrópole: São Paulo sociedade e cultura nos frementes anos 20, São Paulo, Companhia das Letras, 1992.

SILVA, Alexandra de Mello e. A política externa de JK: Operação Pan-Americana. Rio de Janeiro: CPDOC, 1992.

SILVA, Luiz Inácio Lula da. Depoimento de Luiz Inácio Lula da Silva à Comissão Nacional da Verdade, em São Paulo, 8 de dezembro de 2014. Disponível em: https://www.youtube.com/watch?v=Cvcv3RP1qCc. Consultado em 25/05/2016.

SILVA, Patricio. Tecnócratas y política en Chile: de los Chicago Boys a los Monjes de Cieplan. In: ARIZTÍA, Tomás (org.). Produciendo lo social: usos de las ciencias sociales en el Chile reciente. Santiago: Ediciones Universidad Diego Portales, 2012.

SILVA, Ana Paula Barcelos Ribeiro. Um olhar sobre a história: medo, angústia e morte no pensamento de Fidelino de Figueiredo. RCL/Convergência Lusíada, n. 30, 2013, pp. 132148.

SILVEIRA, José Paulo. História de vida José Paulo Silveira. São Paulo: Museu da Pessoa, 2009a. Disponível em: http://www.museudapessoa.net/pt/conteudo/historia/josepaulo-silveira-49965. Consultado em 04/05/2016. 
SILVEIRA, Pedro Braum Azevedo da. O estado da ciência e a ciência do Estado: a Fundação Getúlio Vargas e a configuração do campo das ciências econômicas no Brasil. Dissertação de mestrado apresentada ao Departamento de Antropologia Social da Universidade Federal do Rio de Janeiro. Rio de Janeiro: UFRJ, 2009.

SILVEIRA, Pelópidas. Pelópidas Silveira (depoimento, 1978). Rio de Janeiro: CPDOC, 2005.

SIMÃO, Azis. Entrevista de Azis Simão concedida a José Albertino Rodrigues e Vera Rita da Costa. Ciência Hoje, maio 1989. Disponível em:

http://www.canalciencia.ibict.br/notaveis/livros/azis_simao_19.html. Consultado em $23 / 12 / 2015$.

SIMONSEN, Mario Henrique. O Ensino de Economia em nível de Pós-Graduação no Brasil. Revista Brasileira de Economia, v. 20, n. 4, 1966, pp. 19-30.

SIMONSEN, Mario Henrique. Entrevista com Mario Henrique Simonsen. In: BIDERMAN, Ciro; COZAC, Luis Felipe L. e REGO, José Marcio. Conversas com Economistas Brasileiros. São Paulo: Editora 34, 1996.

SIMONSEN, Roberto Cochrane. A Planificação da Economia Brasileira. In: GUDIN, Eugênio e SIMONSEN, Roberto Cochrane. A controvérsia do planejamento na economia brasileira; coletânea da polêmica Simonsen $\times$ Gudin, desencadeada com as primeiras propostas formais de planejamento da economia brasileira ao final do Estado Novo. Brasília: IPEA, 2010.

SINGER, Paul. Entrevista com Paul Singer. In: MONTERO, Paula e MOURA, Flávio (org.). Retrato de Grupo - 40 anos do CEBRAP. São Paulo: Cosac Naify, 2009.

SINGER, Paul. Entrevista com Paul Singer. In: MANTEGA, Guido e REGO, José Marcio. Conversas com Economistas Brasileiros II. São Paulo: Editora 34, 1999.

SIRKIS, Alfredo. Roleta Chilena. Rio de Janeiro: Record, 1982.

SMITH, Tony. The Alliance for Progress: The 1960s. In: LOWENTHAL, Abraham (org.). Exporting Democracy: the United States and Latina America - Themes and Issues. Baltimore: The Johns Hopkins University Press, 1993.

SMITH-DOERR, Laurel e POWELL, Walter W. Networks and Economic Life. In: SMELSER, Neil e Swedberg, Richard (org.). Handbook of Economic Sociology, second edition. Princeton: Princeton University Press, 2005, pp. 379-402.

SOARES, Gláucio Ary Dillon. Homenagem a Vilmar Faria. BIB - Revista Brasileira de Informação Bibliográfica, n. 53, 2002, pp. 5-6. 
SOARES, Sebastião José Martins. Entrevista com funcionários do BNDE, Sebastião José Martins Soares, concedida a Ângela Coronel e Salo Coifman em 6 de maio de 1982. Centro Internacional Celso Furtado de Politicas para o Desenvolvimento - Memórias do Desenvolvimento, v. 3 n. 3, 2009, pp. 209-241.

SOARES, Weber. A Emigração de Valadarenses à Luz dos Fundamentos Teóricos da Análise das Redes Sociais. In: MARTES, Ana Cristina e FLEISCHER, Soraya. Fronteiras Cruzadas: Etnicidade, Gênero e Redes Sociais. São Paulo: Paz e Terra, 2003.

SOLA, Lourdes. Limites políticos ao choque heterodoxo no Brasil - Técnicos, políticos, democracia. Revista Brasileira de Ciências Sociais, v. 9, 1989. Disponível em: http://www.anpocs.org.br/portal/publicacoes/rbcs_00_09/rbcs09_04.htm. Consultado em 13/04/2016.

SOLA, Lourdes. Ideias econômicas, decisões politicas: desenvolvimento, estabilidade e populismo. São Paulo: Editora da Universidade de São Paulo/Fapesp, 1998.

SOLNIK, Alex. Os Pais do Cruzado Contam Por Que Não Deu Certo. Porto Alegre: L\&PM Editores, 1987.

SORJ, Bernardo. A construção intelectual do Brasil contemporâneo: da resistência à ditadura ao governo FHC. Rio de Janeiro: Jorge Zahar Editor, 2001.

SPIGOLON, Nima Imaculada. Pedagogia da convivência: Elza Freire - uma vida que faz. educação. Tese de mestrado em educação apresentada ao Programa de Pós-Graduação em Educação da Universidade Estadual de Campinas. Campinas: UNICAMP, 2009.

SOUZA, Herbert José de. Betinho (Herbert José de Souza). In: CAVALCANTI, Pedro Celso Uchôa e RAMOS, Jovelino. Memórias do Exílio. São Paulo: Editora Livramento, 1976.

SOUZA, Luiz Alberto Gómez de. A JUC: os estudantes católicos e a política. Petrópolis: Vozes, 1984.

SOUZA, Luiz Alberto Gómez de. Ernani Fiori: um pensamento fértil na consciência latinoamericana. Sintese, n. 34, 1985, pp. 27-43.

SOUZA, Luiz Alberto Gómez de. A geração de Betinho. In: NAKANO, Maria e ROITMAN, Ari (org.). Estreitos nós: lembranças de um semeador de utopias. Rio de Janeiro: Garamond, 2001. 
SPIRANDELLI, Claudinei Carlos. Trajetórias intelectuais: professoras do Curso de Ciências Sociais da FFCL-USP (1934-1969). Tese de doutorado apresentada ao Programa de PósGraduação em Sociologia da Universidade de São Paulo. São Paulo: USP, 2008.

STEPAN, Alfred. The Military in Politics. New Jersey: Princeton University Press, 1974.

SUNKEL, Osvaldo. Algunos recuerdos cepalinos. Economia Aplicada, v. 2, n. 2, 1998, pp. 183-195.

SUNKEL, Osvaldo. Conversación con Osvaldo Sunkel, Jesus A. Teviño, 16 de maio de 2006. Disponível em:

http://www.insumisos.com/lecturasinsumisas/Platica $\% 20$ con $\% 20$ Oswaldo $\% 20$ Sunkel.p df. Consultado em 15/12/2015.

STONE, Lawrence. Prosopografia. Revista Sociologia e Política, v. 19, n. 39, 2011, pp. 115137.

SUPLICY, Marta. Entrevista Marta Suplicy. PSI, Jornal de Psicologia, CRP-SP, v. 17, n. 112, 1998.

SUZIGAN, Wilson. O Plano de Estabilização e a Política Industrial. Revista Brasileira de Economia, v. 45 (especial), 1991, pp. 339-343.

SZMRECSÁNYI, Tamás e COELHO, Francisco da Silva (org.). Ensaios de História do Pensamento Econômico no Brasil Contemporâneo. São Paulo: Atlas, 2007.

TAVARES, Maria da Conceição. Entrevista de Maria da Conceição Tavares concedida a Isaac Kerstenetzky, Raul Ekerman, José Murilo de Carvalho, Alberto Passos Guimarães Filho, Otávio Velho e César Benjamin, 1986. Disponível em:

http://www.canalciencia.ibict.br/notaveis/livros/maria_da_conceicao_tavares_34.html. Consultado em 15/11/2015.

TAVARES, Maria da Conceição. Entrevista com Maria da Conceição Tavares. In: BIDERMAN, Ciro; COZAC, Luis Felipe e REGO, José Marcio. Conversas com Economistas Brasileiros. São Paulo: Editora 34, 1996.

TAVARES, Maria da Conceição. Entrevista com a Professora Maria da Conceição Tavares. In: LOUREIRO, Maria Rita (org.). 50 anos de Ciência Econômica no Brasil: pensamentos instituições, depoimentos. Petrópolis: Vozes, 1997.

TAVARES, Maria da Conceição. Maria da Conceição Tavares: da fronda ao front. Praga revista de estudos marxistas, n. 2, 1997a, pp. 5-21. 
TAVARES, Maria da Conceição. Memórias Sem Costura. In: NAKANO, Maria e ROITMAN, Ari (org.). Estreitos nós: lembranças de um semeador de utopias. Rio de Janeiro: Garamond, 2001.

TAVARES, Maria da Conceição. Entrevista Maria da Conceição Tavares. Margem Esquerda: ensaios marxistas, v. 11, 2008, pp. 13-23.

TAVARES, Maria da Conceição. Entrevista com funcionários do BNDE: Maria da Conceição Tavares, concedida a Nora Lanari, Ângela Coronel, Salo Coifman, Rui Modenesi, José Eduardo Pereira de Carvalho e Marcelo Averbug, em 6 de maio de 1982. Centro Internacional Celso Furtado de Políticas para o Desenvolvimento Econômico - Memórias do Desenvolvimento, v. 3, n. 3, 2009, pp. 161-192.

TAVARES, Maria da Conceição. Entrevista de Maria da Conceição Tavares a Juarez Guimarães. Carta Capital, 9 de setembro de 2010. Disponível em:

http://www.cartacapital.com.br/economia/80-anos-de-reflexoes. Consultado em $26 / 11 / 2015$.

TAVARES, Maria da Conceição (org.) Centro Internacional Celso Furtado de Políticas para o Desenvolvimento - Memórias do Desenvolvimento, v. 4 n. 4, 2010a.

TAVARES, Maria da Conceição e BELLUZZO, Luiz Gonzaga. Uma reflexão sobre a natureza da inflação contemporânea. In: REGO, José Marcio (org.). Inflação Inercial, Teorias sobre Inflação e o Plano Cruz̧ado. Rio de Janeiro: Paz e Terra, 1986.

TAVARES, Maria da Conceição e SERRA, José. Além da Estagnação: uma discussão sobre o estilo de desenvolvimento recente do Brasil. In: SERRA, José (org.). América Latina: ensaios de interpretação econômica. Rio de Janeiro: Paz e Terra, 1976.

TCE-SP. Tribunal de Contas do Estado de São Paulo: Edição Histórica 85 anos, n. 123, 2009.

Disponível em http://www4.tce.sp.gov.br/sites/tcesp/files/downloads/rtce-123.pdf. Consultado em 03/03/2016.

TEIXEIRA, Aloisio; MARINGONI, Gilberto e GENTIL, Denise Lobato. Desenvolvimento: o debate pioneiro de 1944-1945. Brasília: IPEA, 2010.

TOBIN, James e BRAINARD, William. Financial Intermediaries and the Effectiveness of Monetary Controls. The American Economic Review, v. 53, n. 2, 1963, pp. 383-400.

TOTTI, Paulo. O Quixote da Renda Mínima. Valor Econômico, 22 de fevereiro de 2013.

TOURINHO, Irene. Encontros com Koellreutter: sobre suas histórias e seus mundos. Estudos Avançados, v. 13, n. 35, 1999, pp. 209-223. 
UNZELTE, Celso (org.). A familia Bresser na História de São Paulo. São Paulo: Saraiva, 2003.

URQUIDI, Victor. José Medina Echevarría, un recuerdo. Estudios sociológicos, n. 4, v. 10, 1986, pp. 5-10.

URQUIDI, Víctor. Incidentes de integración en Centroamérica y Panamá, 1952-1958. Revista de la CEPAL, Número Extraordinario, 1998. Disponível em:

http://www.cepal.org/publicaciones/xml/5/19385/urquidi.htm. Consultado em $17 / 12 / 2015$.

VALDÉS, Juan Gabriel. Pinochet's economists: the Chicago School in Chile. Cambridge: Cambridge University Press, 1995.

VARGAS, Milton. A Tecnologia no Brasil. In: FERRI, Mário Guimarães e MOTOYAMA, Shozo. História das Ciências no Brasil v. 1. São Paulo: EPU, Editora da Universidade de São Paulo, 1979.

VASCONCELOS Maria Celi Chaves A educação doméstica no Brasil de oitocentos. Revista Educação em Questão, v. 28, n. 14, 2007, pp. 24-41.

VAZ, Henrique Cláudio de Lima. Leonel França e a cultura católica no Brasil. Sintese Nova Fase, v. 25, n. 82, 1998, pp. 317-328.

VELASCO JUNIOR, Licínio. Documento histórico: A privatização no Sistema BNDES. Revista do BNDES, v. 33, 2010, pp. 307-382.

VERSIANI, Flávio Rabelo. Intercâmbio, Verbas e Pluralismo: a ANPEC na evolução do ensino e da pesquisa em economia no Brasil. In: SZMRECSÁNYI, Tamás e COELHO, Francisco da Silva (org.). Ensaios de História do Pensamento Econômico no Brasil Contemporâneo. São Paulo: Atlas, 2007.

VERSIANI, Flávio Rabelo. A ANPEC aos 25 Anos: Passado e Futuro. Revista ANPEC, v. 1, 1997, pp. 219-259.

VIANA Filho, Luiz. Homenagem a Rômulo de Almeida. Brasília: discurso no Senado Federal em 24 de novembro de 1988.

VIANA, Ana Luiza D’Ávila. O BNDE e a industrialização brasileira 1952-1961. Dissertação de mestrado apresentada ao Instituto de Filosofia e Ciências Humanas da UNICAMP. Campinas: UNICAMP, 1981.

VIANNA, Marcos Pereira. Entrevista de Marcio Vianna para o projeto memória BNDES 50 anos [DVD]. Rio de Janeiro: Arquivo do BNDES, 2002. 
VIANNA, Marcos Pereira. Entrevista com presidentes do BNDES: Marcos Vianna, concedida a Ângela Coronel, Ricardo Weiss e Marcelo Aveburg em 18 de fevereiro de 1982. Centro Internacional Celso Furtado de Politicas para o Desenvolvimento - Memórias do Desenvolvimento, v. 3, n. 3, 2009, pp. 65-98.

VIANNA, Marcos Pereira. Conversas Informais. In: TAVARES, Maria da Conceição (org.) Centro Internacional Celso Furtado de Politicas para o Desenvolvimento - Memórias do Desenvolvimento, v. 4, n. 4, 2010, pp. 293-307.

VIANNA, Sergio Besserman. A Política Econômica no Segundo Governo Vargas (19511954). Rio de Janeiro: BNDES, 1987.

VIEIRA, Dorival Teixeira. A História da Ciência Econômica no Brasil. In: FERRI, Mário Guimarães e MOTOYAMA, Shozo. História das Ciências no Brasil v. 3. São Paulo: EPU, Editora da Universidade de São Paulo, 1981.

VIGNAL, Marc (org.). Larousse Dictionnaire de la musique. Larousse-Bordas, 1999.

WAGNER, Anne-Catherine. La bourgeoisie face à la mondialisation. Mouvements, v. 26, 2003, pp. 33-34.

WAGNER, Anne-Catherine. Les classes sociales dans la mondialisation. Paris: Éditions la découverte, 2007.

WANDERLEY, Sérgio E. P. V. Desenvolviment(ism)o, Descolonialidade e a Geo-História da Administração no Brasil: a atuação da CEPAL e Do ISEB como instituições de ensino e pesquisa em nivel de pós-graduação. Tese de Doutorado apresentada à Escola Brasileira de Administração Pública e de Empresas da Fundação Getúlio Vargas-RJ. Rio de Janeiro: FGV, 2015.

WATTS, Duncan J. Networks, Dynamics, and the Small-World Phenomenon. AJS, v. 105, n. 2, 1999, pp. 493-527.

WEBER, Max. Ciência e Política: duas vocações. São Paulo: Editora Pensamento-Cultrix, 2011.

WIARDA, Howard. Did the Alliance "Lose Its Way" or Were Its Assumptions All Wrong from the Beginning and Are Those Assumptions Still with Us? In: SCHEMAN, Ronald (org.). The Alliance for Progress: a Retrospective. New York: Praeger, 1988.

YOKOTA, Paulo. Alguns Traços de ADN (de office boy a Czar da economia, mestre em política, com muita ironia, que é sinal de fina inteligência). Esboços preliminares. In: DELFIM NETTOO, Antônio. Antônio Delfim Netto: o professor, compilado por Antônio Delfim Netto. Mimeo, 2009. 
DHBB. Dicionário Histórico Biográfico Brasileiro Eletrônico do Centro de Pesquisa e Documentação de História Contemporânea no Brasil. Verbetes: Affonso Pastore, Alcides Tápias, Aldo Arantes, Alexis Stepanenko, Alfredo Malan d'Angrogne, Alfredo Souto Malan, Almino Afonso, Amaral de Souza, André Franco Montoro, Antônio Bezerra Baltar, Antônio Carlos Lemgruber, Antônio Corrêa do Lago, Antônio Perosa, Armínio Fraga, Ary de Siqueira Vianna, Ary Torres, Augusto Inácio do Espírito Santo Cardoso, Carlos Alberto Carvalho Pinto, Carlos Simonsen Leal, Celso Lafer, Celso Peçanha, Ciro do Espírito Santo Cardoso, Cleantho de Paiva Leite, Clóvis Carvalho, Dênio Nogueira, Dílson Funaro, Dorothea Werneck, Edison José de Melo Távora, Eduardo Modiano, Edward Amadeo, Ernane Galvêas, Eugênio Gudin, Fernando Milliet, Francisco Antunes Maciel, Francisco Leivas de Otero, Francisco Neves Dornelles, Garrido Torres, Genival Santos, Glycon de Paiva Teixeira, Guilherme Gomes Dias, Gustavo Loyola, Hélio Beltrão, Horácio Lafer, Hugo Napoleão, IPÊS, Israel Pinheiro, Ivan Ramos Ribeiro, Ivandro Cunha Lima, Jayme Magrassi de Sá, Jesus Soares Pereira, João Batista Pinheiro, João de Almeida Lisboa, Jorge Lins Freire, José Carlos Perdigão Medeiros da Fonseca, José Domingues da Silva, José Joaquim Mello Neto, José Maria Alkmin, José Pereira Lira, José Soares Maciel Filho, Leocárdio Antunes, Leônidas Fernandes Cardoso, Lima Sobrinho, Lincoln Gordon, Lucio Meira, Luís Carlos Delben Leite, Luiz Inácio Lula da Silva, Luiz Sande de Oliveira, Luiz Simões Lopes, Marcio Fortes, Marta Suplicy, Martus Tavares, Miguel Colasuonno, Ney Fontes de Mello Távora, Octávio Dias Carneiro, Octavio Gouvêa de Bulhões, Paulo de Tarso Santos, Paulo Hortênsio Pereira Lira, Paulo Renato Costa Souza, Paulo Roberto Haddad, Pedro Malan, Plínio de Arruda Sampaio, Rômulo de Almeida, Ruy Leme, Ulysses Guimarães, Válder Sarmanho, Valentim Bouças, Vicente Faria Lima, Vinicius Caldeira Brant, Waldir Pires, Walter Barelli, Zeferino Vaz. 